Millennium-Studien

Millennium Studies

\title{
Post-Roman Towns,
}

Trade and Settlement in Europe and Byzantium

Vol. 2

Byzantium, Pliska, and the Balkans

Edited by

Joachim Henning

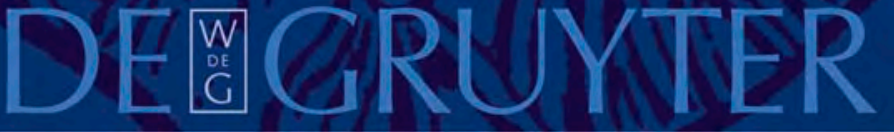


Post-Roman Towns,

Trade and Settlement in Europe and Byzantium

Vol. 2

W
DE
$G$ 


\section{Millennium-Studien}

zu Kultur und Geschichte des ersten Jahrtausends n. Chr.

\section{Millennium Studies}

in the culture and history of the first millennium C.E.

Herausgegeben von / Edited by

Wolfram Brandes, Alexander Demandt, Helmut Krasser, Hartmut Leppin, Peter von Möllendorff

Volume $5 / 2$

Walter de Gruyter · Berlin · New York 


\title{
Post-Roman Towns, \\ Trade and Settlement in Europe and Byzantium
}

\author{
Vol. 2 \\ Byzantium, Pliska, and the Balkans
}

Edited by

Joachim Henning

Walter de Gruyter · Berlin · New York 
Diese Publikation wurde im Rahmen des Fördervorhabens 16TOA021 - Reihentransformation für die Altertumswissenschaften („Millennium-Studien“) mit Mitteln des Bundesministeriums für Bildung und Forschung im Open Access bereitgestellt. Das Fördervorhaben wird in Kooperation mit dem DFG-geförderten Fachinformationsdienst Altertumswissenschaften - Propylaeum an der Bayerischen Staatsbibliothek durchgeführt.

\title{
(c) BY-NC-ND
}

Dieses Werk ist lizenziert unter der Creative Commons Attribution-NonCommercial-NoDerivatives 4.0 International Lizenz. Weitere Informationen finden Sie unter http://creativecommons.org/licenses/by-nc-nd/4.0/.

Die Bedingungen der Creative-Commons-Lizenz gelten nur für Originalmaterial. Die Wiederverwenung von Material aus anderen Quellen (gekennzeichnet mit Quellenangabe) wie z.B. Schaubilder, Abbildungen, Fotos und Textauszüge erfordert ggf. weitere Nutzungsgenehmigungen durch den jeweiligen Rechteinhaber.

$@$ Printed on acid-free paper which falls within the guidelines of the ANSI to ensure permanence and durability.

ISBN 978-3-11-018358-0

ISSN 1862-1139

\author{
Library of Congress Cataloging-in-Publication Data
}

A CIP catalogue record for this book is available from the Library of Congress.

Bibliographic information published by the Deutsche Nationalbibliothek

The Deutsche Nationalbibliothek lists this publication in the Deutsche Nationalbibliografie; detailed bibliographic data are available in the Internet at http://dnb.d-nb.de.

(C) Copyright 2007 by Walter de Gruyter GmbH \& Co. KG, D-10785 Berlin All rights reserved, including those of translation into foreign languages. No part of this book may be reproduced or transmitted in any form or by any means, electronic or mechanical, including photocopy, recording or any information storage and retrieval system, without permission in writing from the publisher.

Printed in Germany

Cover design: Christopher Schneider, Berlin 


\section{Preface}

The second volume of the collection "Post-Roman Towns, Trade and Settlement" is devoted to the early medieval world of Byzantium, and to the territories of southeastern Europe and the Near East, which were either Byzantine provinces or were conquered by the steppe-nomadic Turco-Bulgars or the Arabs. Byzantine influence, if not direct political control, was always present in these areas, even after the Balkans were "paganized" by cults that originated in the Middle East or Islam established itself along the new eastern borders of the empire. This volume therefore contains all the contributions from the international Bad Homburg conference (October 30 - November 3, 2004) relating to these areas. Contributions covering regions that were formerly parts of the Western Roman Empire are to be found in the first volume. At the conference a separate section also was organized to present the results of a German-Bulgarian research program that ran from 1997 to 2003 and focused on Europe's largest early medieval fortified settlement, Aboba-Pliska, an agglomeration that more often than not is called a city, or even a metropolis. Without doubt the work at this unique site of European importance deserved to be discussed by the scholarly community that met in Bad Homburg, and the papers from this section dominate the second part of the volume. During the course of the work of the project on the early medieval Pliska basin in Northeastern Bulgaria, with its important power centers, a smaller working conference entitled "Zwischen Byzanz und Abendland: Pliska, der östliche Balkanraum und Europa im Spiegel der Frühmittelalterarchäologie“ was held at the medieval castle of Ebernburg near Bad Münster am Stein in the Palatinate from November 15-18, 1999 (Figs 1-2). Since some of the contributions to this conference represented valuable overviews of the archaeological situation in or around these centers in the Pliska basin, or dealt with questions related to them, they were also included in this volume. Résumés of the papers presented at Ebernburg were published ahead of the conference. ${ }^{1}$ Finally, individual articles are to be found in this collection that were produced by our Bulgarian partners so that they could be published in a suitable framework, and this volume seemed to be ideal.

In order to further knowledge of the early medieval antiquities of the Old Bulgarian power centers on the part of an interested German and Bulgarian public, the joint German-Bulgarian research program promoted two impressive exhibitions, prepared with

1 Henning 1999. 


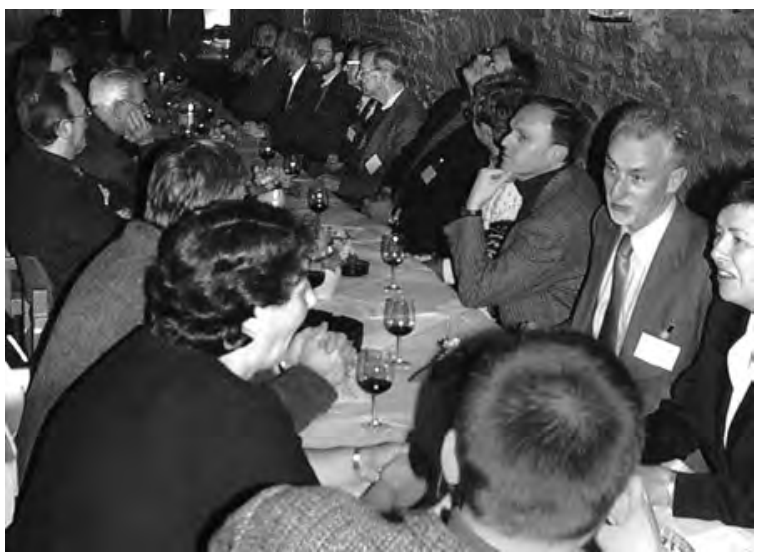

Fig. 1 Participants of the Ebernburg meeting at the evening lecture

the support of both Frankfurt University and the Archaeological Institute and Museum in Sofia. These were staged at the Kulturhistorisches Museum of Magdeburg (August December 2001) and the Archaeological Museum in Sofia (November 1999 - March 2000). The archaeological items displayed on these occasions are reproduced in the exhibition catalogues edited by the Magdeburg Museum and Frankfurt University with the kind support of many Bulgarian museums and institutions. ${ }^{2}$ Since the catalogue of the Sofia exhibition appeared in Bulgarian and in a limited black-and-white edition, it was translated and appended to this volume in a revised, technically improved form.

At the Ebernburg conference we had the great pleasure of enjoying a presentation of the immense scholarly work which Vladimir I. Kozlov from the St Petersburg branch of the Archaeological Institute of the Russian Academy of Science had realized over several decades in the territories of modern Moldavia and Ukraine, areas which in early medieval times were part of the Bulgarian realm. Nobody could foresee then that this would be one of his last appearances in a remarkable scholarly career. He passed away not long after returning home from the conference, and soon after having submitted his manuscript to us. This now appears here as testimony to his scholarly work.

2 For the exhibits from Bulgaria see: Puhle 2001, "Bulgarien” pp. 482-496; Henning/ DončevaPetkova 1999. 


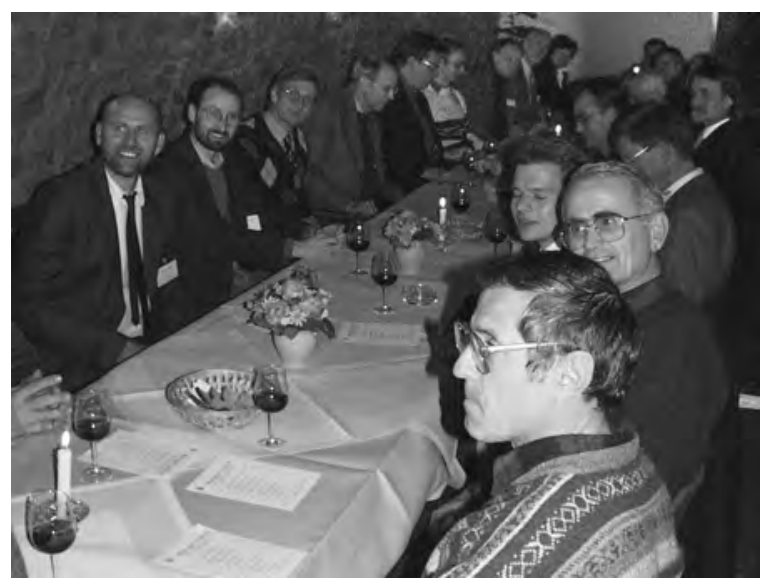

Fig. 2 Participants of the Ebernburg meeting at the evening lecture

\section{Bibliography}

Henning 1999: Joachim Henning (Ed.) Zwischen Byzanz und Abendland: Pliska, der östliche Balkanraum und Europa im Spiegel der Frühmittelalterarchäologie, Internationales Kolloquium auf der Ebernburg (Ebernburg, Bad Münster am Stein) 15. bis 18. November 1999, Kurzfassungen der Referate, dt./bulg., Frankfurt am Main 1999.

Henning/Dončeva-Petkova 1999: Йоахим Хеннинг/Людмила Дончева-Петкова (Eds), Първопрестолна Плиска: 100 години археологически разкопки, introduction and catalogue of the Sofia exhibition November 1999-March 2000, Frankfurt am Main 1999.

Puhle 2001: Matthias Puhle (Ed.), Otto der Grosse, Magdeburg und Europa: vol. 2 - Katalog, Mainz 2001. 



\section{Acknowledgements}

The international Bad Homburg conference would not have been possible without the support of the many institutions, private persons and enterprises who sponsored the event. They were mentioned in the foreword to the first volume. As regards the section of the meeting devoted to the German-Bulgarian research program in the Pliska basin, we are especially grateful to the Volkswagen foundation, which covered the traveling costs of the Bulgarian participants within the framework of a separate cooperation program. Frankfurt University offered invaluable support in many ways in order to make the Ebernburg conference possible.

Furthermore we wish to express our gratitude to the Univerity's sponsoring organization, "Vereinigung von Freunden und Förderern der J. W. Goethe Universität e.V.", which offered substantial funding for the development of the German-Bulgarian cooperation. A number of younger scholars participating in this program received stipends and travel awards to realize $\mathrm{PhD}$ theses directly or indirectly related to the German-Bulgarian research program. We are indebted the Deutsche Forschungsgemeinschaft (1997-2001) and the Volkswagen Foundation (2002-2005) for their generous support to Vassilena Petrova, Tchavdar Kirilov, Peter Milo, Norbert Schleifer, Marco Hartlaub, Thorsten Westphal, Eyub F. Eyub and Jürgen Bigalke.

I owe a debt of thanks to all my colleagues at Frankfurt University who invested so much effort in the preparation of the print manuscript of this volume: Katja Rösler M.A., Petra Hanauska M.A., Thorsten Sonnemann M.A., Angela Ehrlich, Antje Faustmann M.A. and Dr. Andreas Vogel for their manifold assistance in the editorial process (text revisions, layout preparation, digital enhancement etc.). I also thank John F. Romano (Cambridge MA), David Toalster (Frankfurt), Dr. David Wigg-Wolf (Academy of Science and Literature, Mainz), Dr. Conrad Leyser and Dr. Hannah Williams (University of Manchester) for carrying out the revision of English texts written by non-native speakers. Finally my thanks are due to Dr. Sabine Vogt of De Gruyter Verlag and Prof. Dr. Wolfram Brandes, member of the editorial board of the Millennium Studies, for supporting and advising the editorial team.

It would be going too far to mention all the people who were involved in the practical archaeological fieldwork that was carried out by the German-Bulgarian expedition over seven years of campaigns. The staff consisted of up to 45 persons. I wish to thank them all individually for their contributions, regardless of their nature, whether support in the direction of the program or in employing a trowel during the excavations. All these contributions were equally important for the realisation of the project, the success of which is documented in this volume. 



\section{Contributors}

Stefka Angelova, Университет Св. Климент Охридски / St Kliment Ohridski-University, Sofia, Bulgaria

Charalambos Bakirtzis, Ninth Ephoreia of Byzantine Antiquities, Salonica, Greece

Todor Balabanov, Археологически институт и музей на БАН / Archaeological Institute and Museum of the Bulgarian Academy of Sciences, Shumen branch, Bulgaria

Ivan Buchvarov, Исторически музей Силистра / Museum of History, Silistra, Bulgaria

Janko Dimitrov, Археологически институт и музей на БАН / Archaeological Institute and Museum of the Bulgarian Academy of Sciences, Shumen branch, Bulgaria

Ljudmila Dončeva-Petkova, Археологически институтимузейна БАН/Archaeological Institute and Museum of the Bulgarian Academy of Sciences, Sofia, Bulgaria

Eyup F. Eyup, Institut für Archäologische Wissenschaften, Johann Wolfgang GoetheUniversität Frankfurt am Main, Germany

Uwe Fiedler, Landesamt für Denkmalpflege und Archäologie Sachsen-Anhalt, Halle/ Saale, Germany

Joachim Henning, Institut für Archäologische Wissenschaften, Johann Wolfgang Goethe-Universität Frankfurt am Main, Germany

Yizhar Hirschfeld, Institute of Archaeology, The Hebrew University of Jerusalem, Israel

Pavel Georgiev, Археологически институт и музей на БАН / Archaeological Institute and Museum of the Bulgarian Academy of Sciences, Shumen branch, Bulgaria

Eric Ivison, Department of History, City University of New York, USA

Thomas Kind, Institut für Archäologische Wissenschaften, Johann Wolfgang GoetheUniversität Frankfurt am Main, Germany

Chavdar Kirilov, Университет Св. Климент Охридски / St Kliment Ohridski-University, Sofia, Bulgaria

Rumjana Koleva, Университет Св. Климент Охридски / St Kliment Ohridski-University, Sofia, Bulgaria 
Vladimir I. Kozlov, Отдел археологии Центральной Азии и Кавказа, Институт истории материальной культуры, Российская академия наук / Department of the Archaeology of Middle East and Caucasus, Institute of the History of Material Culture, Russian Academy of Sciences, St Petersburg, Russia

Zofia Kurnatowska, Instytut Archeologii i Etnologii PAN, oddział w Poznaniu / Institute of Archaeology and Ethnology, Polish Academy of Sciences, Poznań Branch, Poland

Irene Marzolff, Institut für Physische Geographie, Johann Wolfgang Goethe-Universität Frankfurt am Main, Germany

Henryk Mamzer, Instytut Archeologii i Etnologii PAN, oddział w Poznaniu / Institute of Archaeology and Ethnology, Polish Academy of Sciences, Poznań Branch, Poland

Mihailo Milinković, Одељење за археологију, Универзитет у Београду / Department of Archaeology, University of Belgrade, Serbia

Peter Milo, Ústav archeologie a muzeologie Masarykova univerzita v Brně / Institute of Archaeology and Museology, Masaryk University in Brno, Czechia

Philipp Niewöhner, Deutsches Archäologisches Institut, Istanbul, Turkey/Germany

Günter Prinzing, Abteilung Byzantinistik, Historisches Seminar, Johannes GutenbergUniversität Mainz, Germany

Vassilena Petrova, Institut für Archäologische Wissenschaften, Johann Wolfgang Goethe-Universität Frankfurt am Main, Germany

Rašo Rašev, Археологически институт и музей на БАН / Archaeological Institute and Museum of the Bulgarian Academy of Sciences, Sofia, Bulgaria

Norbert Schleifer, Petrophysical Laboratory, Wintershall Holding AG, Barnstorf, Germany

Radoslav Vasilev, Археологически институт и музей на БАН / Archaeological Institute and Museum of the Bulgarian Academy of Sciences, Sofia, Bulgaria

Stojan Vitljanov, Факултет по хуманитарни науки, Шуменски Университет "Епископ Константин Преславски" / Faculty of the Humanities, Bishop Konstantin Preslavsky University, Shumen, Bulgaria

Karl Hans Wedepohl, Institut für Anorganische Chemie, Georg-August-Universität Göttingen, Germany

Michael Wendel, Institut für Prähistorische Archäologie, Martin-Luther Universität Halle-Wittenberg, Germany

Daniel Ziemann, Historisches Seminar, Universität zu Köln, Germany 


\section{Contents}

\section{Vol. 2 - Byzantium, Pliska, and the Balkans}

Preface
Acknownledgements
Contributors of volume 2

\section{Chapter IV. Byzantium}

The reduction of the fortified city area in late antiquity: some reflections on the end of the 'antique city' in the lands of the Eastern Roman Empire

ChaVdar Kirilov

Amorium in the Byzantine Dark Ages (seventh to ninth centuries)

ERIC A. IVISON

Durostorum in late antiquity (fourth to seventh centuries) 61

Stefka Angelova \& Ivan Buchvarov

Imports, exports and autarky in Byzantine Thessalonike from the seventh to the tenth century

Charalambos Bakirtzis

Archäologie und die „Dunklen Jahrhunderte“ im byzantinischen Anatolien

PHILIPP NIEWÖHNER

Stadt oder „Stadt“: Frühbyzantinische Siedlungsstrukturen im nördlichen Illyricum

Mihailo Milinković

Post-Roman Tiberias: between East and West 193 YIZHAR HiRSCHFELD 


\section{Chapter V. Pliska - Town and Hinterland}

The Metropolis of Pliska or, how large does an early medieval settlement have to be in order to be called a city?

JoACHIM HENNING

Pliska in the view of Protobulgarian inscriptions and Byzantine written sources

GÜNTER PRINZING

Zur historischen Topographie Pliskas einhundert Jahre nach den ersten

Ausgrabungen

JANKO DiMITROV

Eine Hauptstadt ohne Gräber? Pliska und das heidnische Bulgarenreich an der unteren Donau im Lichte der Grabfunde

UwE FIEDLER

Eighth- and ninth-century pottery from the industrial quarter of Pliska, capital of the early medieval Bulgarian kingdom

LuUdmila DončEva-PetKova

The early medieval yellow pottery from Pliska, Bulgaria:

the question of its provenance and the problem of its origin

Vassilena Petrova

Geophysical prospecting in Pliska (Bulgaria): applied methods and results

Norbert SCHLEIFER

Soda-Kalk-Glas des 8. und 9. Jahrhunderts vom Asar-dere in Pliska

(Bulgarien) im Vergleich mit frühmittelalterlichem Glas in Westeuropa

Karl Hans WedePohl

Periodisierung und Chronologie der Besiedlung und des Baugeschehens im Gebiet um die Große Basilika von Pliska 361 Pavel Georgiev

Ergänzende Angaben zur frühmittelalterlichen Siedlung auf dem Gebiet der Großen Basilika 
Ein Herrenhof des 10.-11. Jahrhunderts in der Äußeren Stadt von Pliska 383 Stojan Vitluanov

Ein Hortfund mit Eisengegenständen aus Pliska und das Problem der frühmittelalterlichen Agrartechnik in Bulgarien 393

Stojan VitLJanov

Ein früher Haustypus in der Siedlung südöstlich der Inneren Stadt von

Pliska

Stanislav Stanilov \& Janko Dimitrov

A virtual view of Pliska: Integrating remote sensing, geophysical and archaeological survey data into a geographical information system 417 Irene MarzolfF \& JoAChim HenNing

Kabiyuk: another Pliska?

JoAChim HenNing \& Eyup F. Eyup

Khan Omurtag's stone palace of AD 822: a "modernized" eighth century timber fort 433

Joachim Henning, Todor Balabanov, Peter Milo \& Daniel Ziemann

The early medieval boyar courtyard of Strumba near Shumen 441 Joachim Henning \& Peter Milo

\section{Chapter VI. Pliska and the Balkans}

Der Beginn von Pliska und der bulgarischen Landnahmezeit 449 RAŠO RAŠEV

Zur Siedlungsstruktur der Nordostprovinz des Ersten Bulgarenreiches 463 Vladimir I. Kozlov

Archäologische Zeugnisse frühslawischer Besiedlung in Bulgarien 481

Stefka Angelova \& Rumjana Koleva

Die Ausgrabungen in Iatrus und Karasura: Zu einigen Aspekten der Frühmittelalterforschung in Bulgarien 509 Michael Wendel 
Ergebnisse und Erfahrungen aus den polnischen Untersuchungen in

Stărmen und Odărci

Zofia Kurnatowska \& Henryk Mamzer

Westliche Einflüsse auf der östlichen Balkanhalbinsel im Spiegel der früh- und hochmittelalterlichen Reitausrüstung 543

THOMAS KIND

The rebellion of the nobles against the baptism of Khan Boris (865-866) 613

DANIEl ZiEMANN

Die Ausgrabungen in der Kirche Nr. 2 des Erzbischofsitzes von

Drăstăr (1993-1999)

StefKa Angelova

Zur ethnischen Zugehörigkeit einiger Nekropolen des 11. Jahrhunderts in

Bulgarien 643

Ljudmila DončEva-Petkova

Catalogue of archaeological finds from Pliska: Introduction /

Katalog archäologischer Funde aus Pliska: Einführung 661

JOACHIM HENNING

Katalog (Ljudmila Dončeva-Petkova, Joachim Henning, Vassilena Petrova \& Angela Ehrlich)

Picture credits 705

Plates 709 


\section{Vol. 1 - The Heirs of the Roman West}

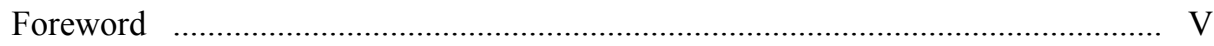

Acknowledgements …………………................................................. IX

Contributors of volume 1 ........................................................................ XV

\section{Chapter I. The Franks, Italy and Spain}

Early European towns: The way of the economy in the Frankish area between dynamism and deceleration 500-1000 AD

JOACHIM HENNING

Where do trading towns come from? Early medieval Venice and the northern emporia

Michael McCormick

Provenancing Merovingian garnets by PIXE and $\mu$-Raman spectrometry

Patrick Périn, Thomas Calligaro, Franç̧oise Vallet, Jean-Paul Poirot

\& Dominique Bagault

Flourishing places in North-Eastern Italy: towns and emporia between

late antiquity and the Carolingian age

SAURo GeLichi

Rome in the ninth century: the economic system

Paolo Delogu

Production and circulation of silver and secondary products (lead and glass) from Frankish royal silver mines at Melle (eighth to tenth century)

Florian TEREYGEOL

The hinterlands of early medieval towns: the transformation of the countryside in Tuscany

RicCARdo Francovich

Where is the eighth century in the towns of the Meuse valley?

Frans Theuws 
Towns and rivers, river towns: environmental archaeology and the archaeological evaluation of urban activities and trade 165

JoËLLE BURNOUF

The royal foundation of Recópolis and the urban renewal in Iberia during the second half of the sixth century

Lauro Olmo EnCiso

\section{Chapter II. Emporia of the North and the Carolingian East}

Recent archaeological research in Haithabu

Claus von Carnap-Bornheim \& Volker Hilberg

Agrarian production and the emporia of mid Saxon England, ca. AD 650-850 ... 219 Helena Hamerow

Urbanisation in Northern and Eastern Europe, ca. AD 700-1100

JOHAN CALLMER

Urban archaeology in Magdeburg: results and prospects 271

THOMAS WeBER

Micromorphology and post-Roman town research: the examples of

London and Magdeburg 303

Richard I. Macphail, John Crowther \& JiLl Cruise

Karlburg am Main (Bavaria) and its role as a local centre in the late Merovingian and Ottonian periods

Peter EtTel

Some remarks on the topography of Franconofurd

EGON WAMERS

Marburg Castle: the cradle of the province Hesse, from Carolingian to

Ottonian times

Christa Meiborg 
Das karolingerzeitliche Kloster Fulda - ein „monasterium in solitudine“.

Seine Strukturen und Handwerksproduktion nach den seit 1898 gewonnenen archäologischen Daten

Thomas Kind

New findings of the excavations in Mosaburg/Zalavár (Western Hungary)

BÉla Miklós SzÖKE

\section{Chapter III. Eastern Central Europe}

"Tribal" societies and the rise of early medieval trade: archaeological

evidence from Polish territories (eighth-tenth centuries)

AndRzej Buko

Counted and weighed silver: the fragmentation of coins in early medieval

East Central Europe

Sebastian Brather

Early medieval centre in Pohansko near Břeclav/Lundeburg:

munitio, emporium or palatium of the rulers of Moravia?

JIŘí MACHÁČEK

Ninth-century Mikulčice: the "market of the Moravians"?

The archaeological evidence of trade in Great Moravia

LuMír PolÁČEK

Ein frühmittelalterliches Grubenhaus von Bielovce (Slowakei):

Befund und Rekonstruktion

Gabriel Fusek

On "Orient-preference" in archaeological research on the Avars, proto-Bulgarians and conquering Hungarians

CSANÁD BÁLINT

Picture credits

Plates 

Chapter IV

BYZANTIUM 



\title{
The reduction of the fortified city area in late antiquity: some reflections on the end of the 'antique city' in the lands of the Eastern Roman Empire
}

\author{
Chavdar Kirilov
}

The controversy about the character of the transition between late antiquity and the early Middle Ages goes back quite a long time. Most of the scholars still accept the old idea that the period of late antiquity to the early Middle Ages represents an epoch of decline in the history of European civilisation - an opinion, which has to be attributed to Gibbon's well known work The Decline and Fall of the Roman Empire. One of the essential points in this debate is the one about the fate of the so-called 'antique city'. A starting point of the discussion was the publication of the famous work of A. Kazhdan concerning the fate of the Byzantine towns and cities in the so-called 'Dark Ages', followed by critical remarks of various Russian ${ }^{2}$ and European scholars and, first of all, of G. Ostrogorsky ${ }^{3}$. The excellent papers of E. Kirsten ${ }^{4}$ and F. Dölger ${ }^{5}$ present clear evidence for the growing attention in regarding the problems of late antique and early medieval towns of the Eastern Roman Empire in the decade after the Second World War. Since that time, thousands of articles and dozens of books and anthologies have been published. A recent article contained a detailed list of the most important contributions to the subject. ${ }^{6}$

It is believed that one of the symptoms of the decline of the cities and towns of the later Roman Empire during the transition period and later in the Dark Ages is the reduction of their wall circuits. The adepts on this subject point to various reasons for the decline. According to most of them, the main reason was the irreversible weakening process of the city councils after the fourth century and the crisis of the municipal finances. ${ }^{7}$ Furthermore, the cities suffered from barbar-

1 Kazhdan 1954.

2 For example Siuziumov 1956.

3 Ostrogorsky 1959.

4 Kirsten 1958.

5 Dölger 1961.

6 Lavan 2001a.

7 Vittinghoff 1958; Kurbatov 1971; idem 1973; Liebeschuetz 1959; idem 1987; idem 1996; idem 2001a. 
ian invasions, ${ }^{8}$ famines and pest epidemics, ${ }^{9}$ together with natural disasters such as earthquakes etc. ${ }^{10}$ The effect of all these misfortunes was, according to this point of view, a disastrous financial, cultural and demographic collapse which led to the definitive decline and even to the disappearance of the institution 'city' in the territories of the former Roman Empire for more than two or even three hundred years. This 'catastrophe theory' was developed in the last decades mostly by scholars such as Wolfgang Müller-Wiener ${ }^{11}$, Clive Foss ${ }^{12}$ and Wolfram Brandes ${ }^{13}$ and was described as 'a transition from polis to kastron'.${ }^{14}$ Some scholars believe that the new, much shorter walls even represented the actual border of the settlement. ${ }^{15}$ In these small fortresses, according to this point of view, a small number of representatives of the civilian, ecclesiastical and military administration took refuge.

In this paper I am not attempting to argue to what extent it is justifiable to use the term decline concerning the development of the cities and towns in this period. ${ }^{16}$ Recently this old problem was discussed once more in the Journal of Roman Archaeology ${ }^{17}$ and in several volumes of the series 'The Transformation of the Roman World'.$^{18} \mathrm{I}$ am simply aiming at getting the answer to one main question: To what extent should the reduction of the fortified area be interpreted as a sign of decline of the Roman cities? To find a solution to this main problem, the following questions have to be answered: Was the entire city area densely populated in classical antiquity? Were the living spaces in Classical and late antiquity one and the same? Did the city walls in late antiquity represent the real settlement borders?

\section{Question No. 1: Was the entire town area densely populated in classical antiquity?}

Situated in the bizarre mountains of South Lycia, the earliest settlement of Arykanda (Fig. 1) was the residence of a local ruler, demonstrated by the keep on the rocks above the small town dated to between the sixth and fourth century BC. The town grew considerably during the last pre-Christian centuries, but remained unfortified. An intensive

\footnotetext{
8 Foss 1975.

9 Allen 1979; Leven 1987; Durliat 1989; see also the remarks in Brandes 1999.

10 Mango 1980, 60-87.

11 Müller-Wiener 1961; idem 1967; idem 1986.

12 Foss 1975; 1977.

13 Brandes 1989.

14 See Poulter 1996 and Dunn 1994 for the situation on the Balkans.

15 Russel 1958, 7-8, 71-88.

16 I for myself prefer the expression transformation.

17 Liebeschuetz 2001b; Cameron 2001; Ward-Perkins 2001; Whittow 2001.

18 Brogiolo/Ward-Perkins 1999; idem 2000.
} 


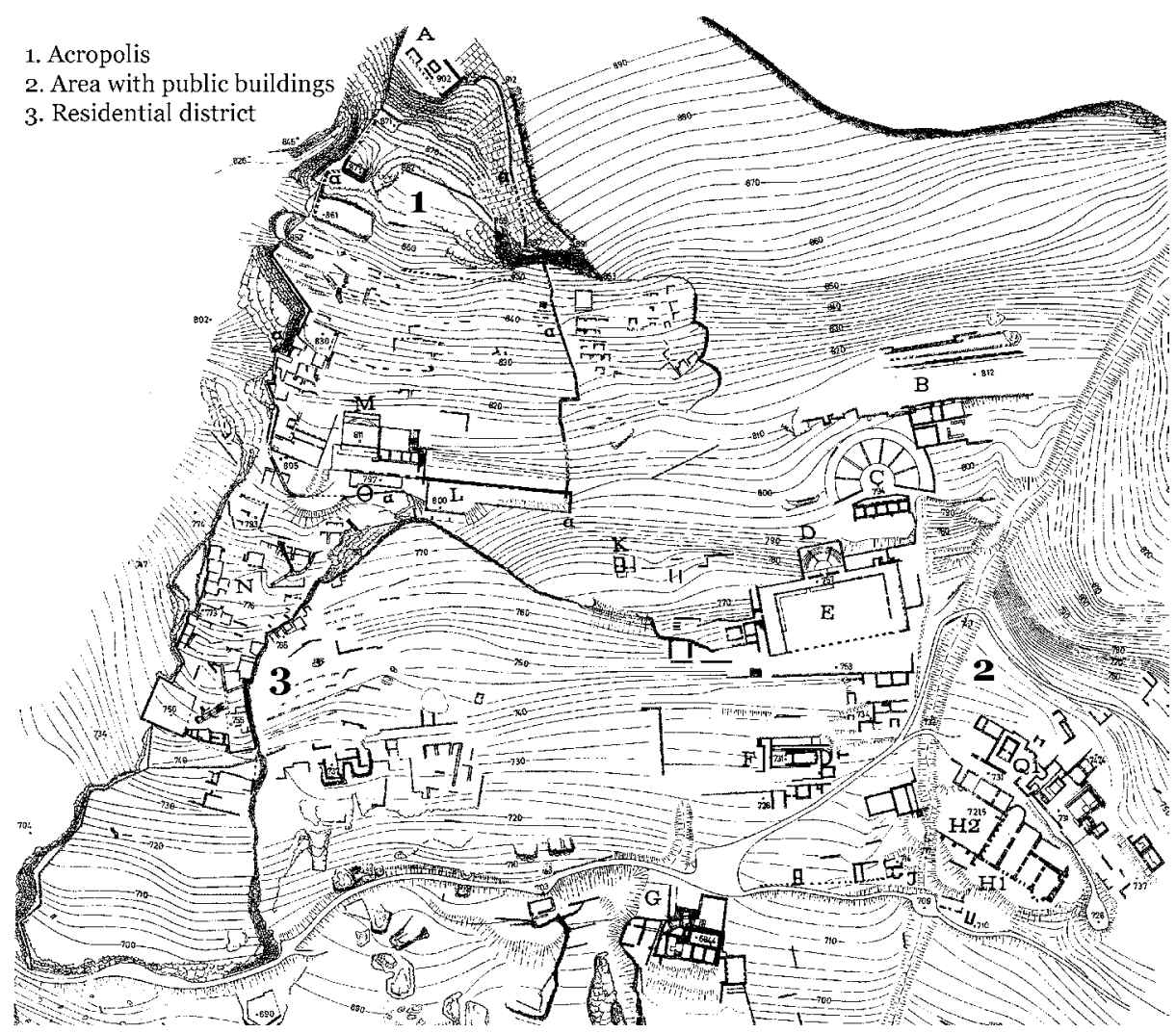

Fig. 1. Map of Arykanda: the town in the Hellenistic and Roman ages

building programme was realised in the Roman age (second century AD). As a result, the significantly greater part of the built-up town area was occupied by public buildings. ${ }^{19}$ Residencies were discovered only in the western part, on the steep slopes below the old acropolis.

Similar to Arykanda, the town of Pinara was founded in the sixth century BC. The populated area was extended considerably during the Roman age. A clear subdivision of the town area into private and public areas can be recognised: the palace district, the agora with the adjacent public buildings, the temples north to the palace, a residential district west towards the temples and a necropolis in the south-western parts of the town. In late antiquity, the built-up area was restricted to the borders of the old Lycian town and the fortification of the town was strengthened. ${ }^{20}$

19 Knoblauch/Witschel 1993.

20 Wurster/Wörrle 1978. 


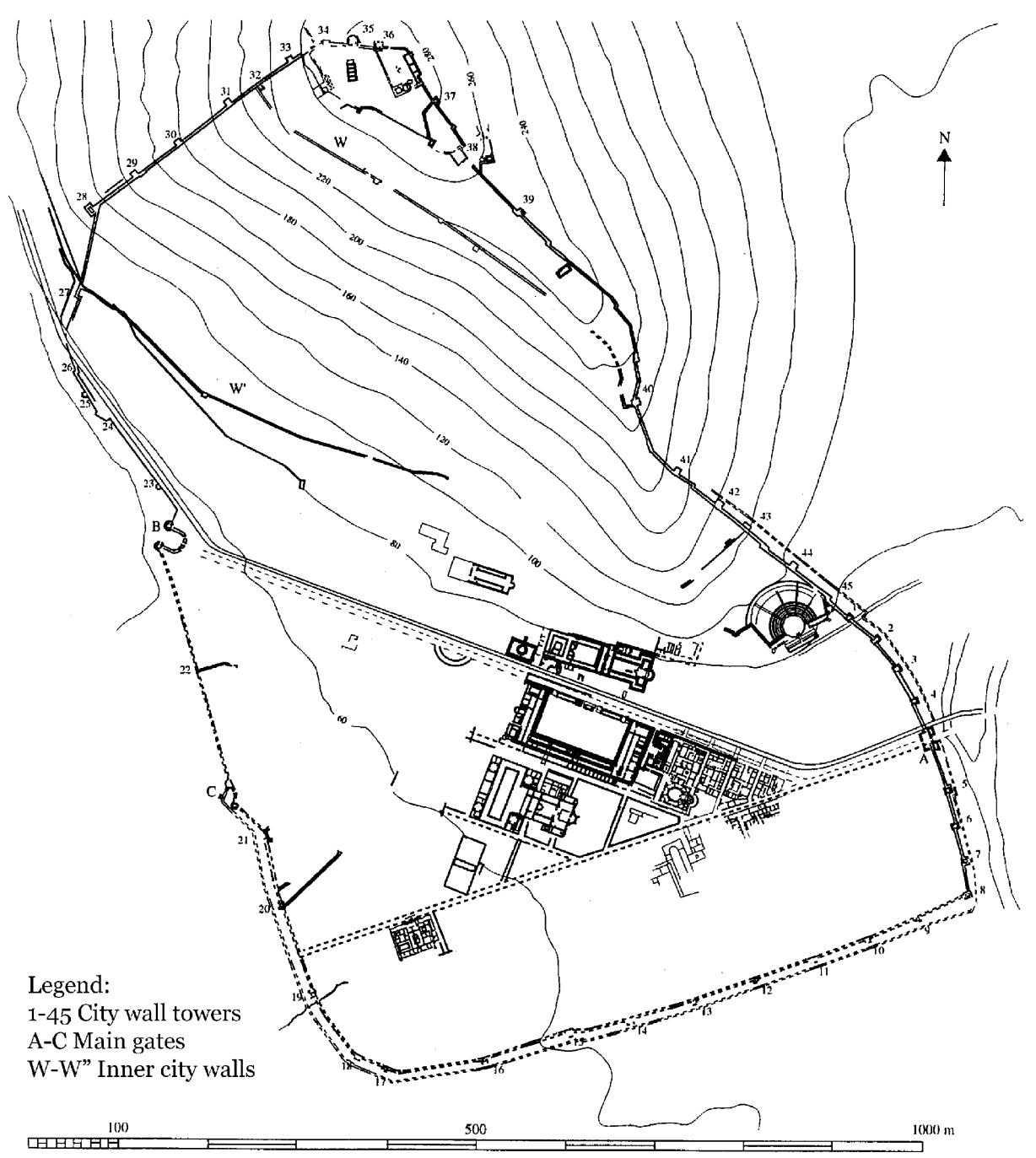

Fig. 2. Map of Philippi in the Hellenistic and Roman ages

The length of the Hellenistic and Roman age walls of Philippi (Fig. 2) amounted to $3,500 \mathrm{~m}$; the fortified area covering nearly 70 ha. Only the low, flat parts of the town were built-up and populated; the steep slopes of the hill, crowned by the acropolis remained unsettled. ${ }^{21}$ In Taracco, about one third of the fortified town area was occupied by a quarter with exclusively public functions, including the so-called 'cult district', a representative square and a circus. Numerous buildings with public

21 Provost 2001. 


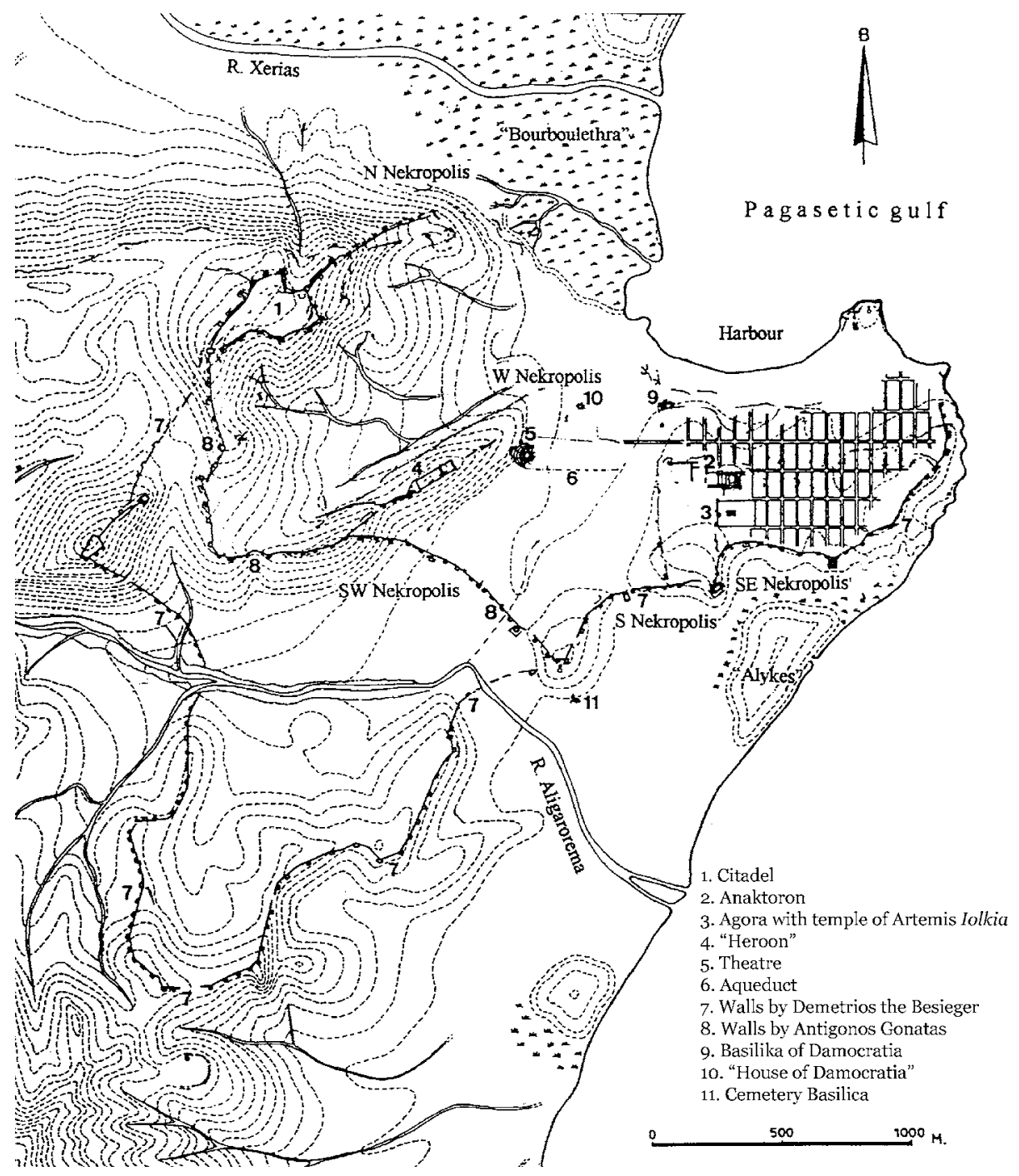

Fig. 3. Map of Demetrias in the Hellenistic and Roman ages

character were situated within the residential district, which occupied the lower parts of the town area. ${ }^{22}$

The town Demetrias (Fig. 3) was founded in 294 BC by Demetrios Poliorketes (the Besieger), who brought together all the neighbouring settlements behind mighty walls; with the area surrounded by the walls originally covering about 440 ha. During

22 Panzram 2002, 28-92. 
the reign of Antigonos Gonatas, an inner wall was built dividing the fortified area into two sectors. The town itself was situated in the district around the harbour and was surrounded by a wall, whose length amounted to more than $8,000 \mathrm{~m}$. The zones outside the walls of Gonatas (the fertile valley of the river Aligarorema) served as the first line of defence and probably also for agricultural purposes. ${ }^{23}$

The wall circuit of the ancient town Priene measured about 2,500 m. Inside the wall, several non built-up areas are apparent: the rocky plateau of the acropolis, the terraces below the acropolis and a wide strip along the southern wall. ${ }^{24}$

It is obvious that the entire town area was not identical with the actually populated area. This assertion can be made by means of some additional cases. For example, the fortification of the city of Antioch illustrates the aspiration of the Hellenistic architects and builders with the erection of majestic walls, surrounding even rocky and uninhabited peaks regardless of the factual requirements for the defence of the city and the extent of the populated area. ${ }^{25}$ The walls of the city of Athens in classical times were quite impressive as well, ${ }^{26}$ and the fortified area in Corinth in the pre-Roman age surrounded more than 700 ha. The case of Teltepe (Diana Veteranorum) in North Africa is very instructive. In the beginning, the scholars expected that the populated town area would cover more than 400 or even 500 ha, but later, owing to the weight of the evidence, it had to be reduced to only $50-100$ ha. $^{27}$

\section{Question No. 2: the size of the dwellings space}

Roman Volubilis was a successor of an old Phoenician settlement, probably a colony of Carthage. In the so-called 'north-eastern district' of the Roman town, altogether 25 dwelling units were excavated. Apart from private rooms, open (i.e. unroofed) and representative rooms, storerooms, workshops, accommodations for guests etc. were found. ${ }^{28}$ The floorage in Priene (Fig. 4) amounted to an average of 210 sqm; about 75 sqm of which were roofed. The size of the private rooms amounted only to between 25-30 sqm, with the storerooms often being larger. ${ }^{29}$

The archaeological-ethnographical approach to the analysis of private houses in Pompeii $^{30}$ illustrates how complicated it is to specify which of the numerous rooms

23 Karagiorgou 2001.

24 Dontas 2000, 174-177.

25 Kondoleon 2000, 17.

26 Thompson et al. 1943.

27 Duncan-Jones 1974, 265, n. 2.

28 Risse 2001.

29 Dontas 2000, 178.

30 Allison 1997. 


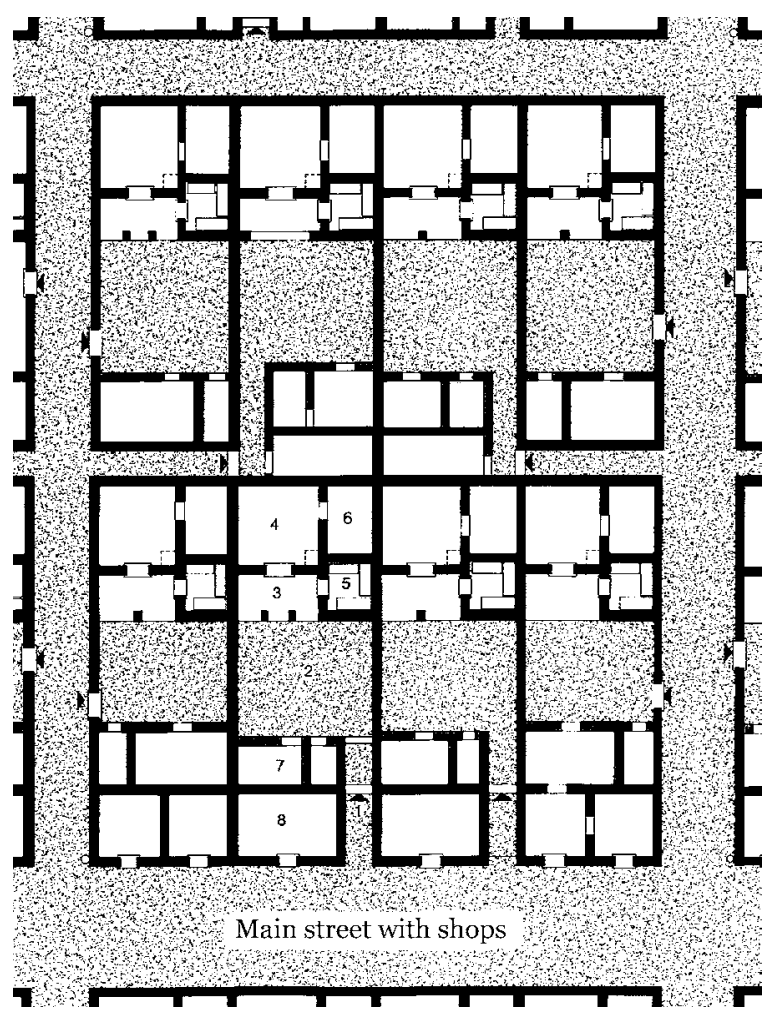

Fig. 4. Houses in Priene

within the wealthy Roman residence had explicit dwelling functions. The problem is connected with the specific role of large Roman houses as a places of public life. ${ }^{31} \mathrm{On}$ the other hand, it was shown that large areas within the Roman town were covered with public structures such as temples, baths, theatres, market squares, palestrae and stadia. A good model in this respect is Xanthen, where public buildings dominate most of the excavated areas. ${ }^{32}$

This situation will not seem all that strange to us, if we take into account how Roman towns were planned. In his well-known book, the famous Roman architect Vitruvius enacted exact norms for urban planning. First of all, he wrote, the course of the future town wall must be chosen, and in this case the special features of the topography and the surrounding landscape have to be taken into consideration, not the size of the (potentially) populated area. ${ }^{33}$ Then, the road network has to be laid out,$^{34}$ followed by the choice of the position for the public buildings - forum, temples,

31 Lavan 2001b.

32 Precht/Rüger1978.

33 Vitruvius, De Architectura, Liber I.V.

34 Vitruvius, De Architectura, Liber I.VI. 


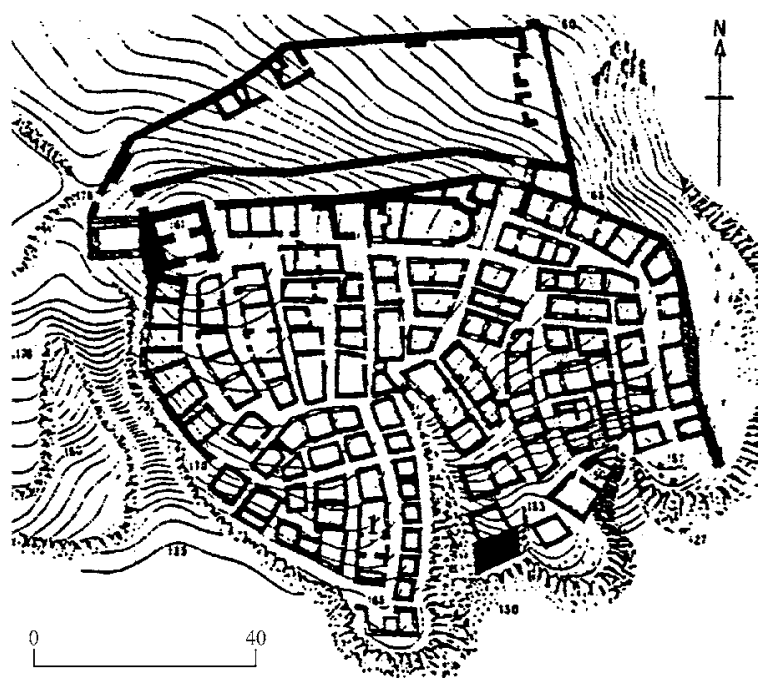

Fig. 5. Map of Golemanovo Kale

baths etc. ${ }^{35}$ Not until these decisions had been made were the dwelling areas plotted out. On the other side, the public areas were jealously guarded by imperial legislation and were not liable to building activities. ${ }^{36}$ Attempts at using public spaces for private purposes were to be opportunely neutralised. Although there is evidence that the central government and the local officers tried to enforce these laws as late as in the age of Justinian, the scholars rightfully are in doubt about the use of the efforts undertaken. ${ }^{37}$ The archaeological evidence has also shown that a significant change occurred in late antiquity.

The change in late antiquity

In Heraclea Lyncestis ${ }^{38}$ in the Republic of Macedonia, numerous small-room-houses above and near the ancient theatre were excavated and dated to the sixth century AD. ${ }^{39}$ Such small and narrow houses, closely situated to each other were also found in late antique fortified settlements in North Bulgaria, such as Shumen and Golemanovo Kale (Fig. 5). ${ }^{40}$

35 Vitruvius, De Architectura, Liber I.VII.

36 Kennedy 1985, 21.

37 Claude 1969, 54-55.

38 Confer Milinković in this volume fig. 2.

39 Janakiewski 1977.

40 Dintchev 1997a. 
At the turn of the fifth to the sixth century, the former public buildings adjacent to the round square in Caričin Grad were divided into numerous small rooms and served as private houses of "newcomers" ${ }^{41}$ All these examples demonstrate that the late antique citizen required considerably less living space than his ancestors in the period of the classical antiquity. In other words, in this period much more people could live within a much smaller area compared to earlier times.

A similar situation was given in Arykanda after 500 AD (Fig. 6). Although the town did not suffer from barbarian invasions, the population of the Roman age-settlement for some reason withdrew to the old Lycian acropolis. However, the so-called Byzantine Lower Town was founded approximately one mile away from the old settlement. There were virtually no public areas and squares in this Lower Town. It was surrounded by mighty walls and obviously densely populated. About thirteen percent of the built-up area was occupied by the bishop's residence, in addition, some parts of the old populated areas below the acropolis were still occupied - for example some of the baths. ${ }^{42}$

\section{Question No. 3: Did the walls represent the real settlement borders in late antiquity?}

A small fortress was erected on the hill Jolkos close to the town Demetrias in the sixth century $\mathrm{AD}$, the areas surrounding the harbour were nevertheless further on populated. ${ }^{43}$ Obviously the new fortress only served the inhabitants of Demetrias as a refuge in dangerous times.

Athens (Fig. 7) was originally surrounded by long walls, erected in the fifth century $\mathrm{BC}$, the so-called Themistoclean Walls. During the Roman age, they had considerably fallen into decay. In the middle of the third century AD - during the reign of the Emperor Valerian - the fortified area extended eastward. ${ }^{44}$ In 267 AD, Athens became victim of the Herules and their disastrous attack, ${ }^{45}$ the citizens were not able to defend their city effectively because of the enormous length of the walls, which did not correspond to the number of the inhabitants. They learnt a lesson and in the last third of the third century AD, the shorter late Roman wall was built. ${ }^{46}$ In 395 AD, the Goths under Alaric could not capture the city because of the strength of this new fortification ${ }^{47}$ and

41 Popovič 1982.

42 Knoblauch/Witschel 1993.

43 Karagiorgou 2001.

44 Thompson//Scranton1943, 372.

45 Thompson 1959, 61.

46 Frantz 1988, 5-6.

47 Zosimos $V$, 6.1-2. 


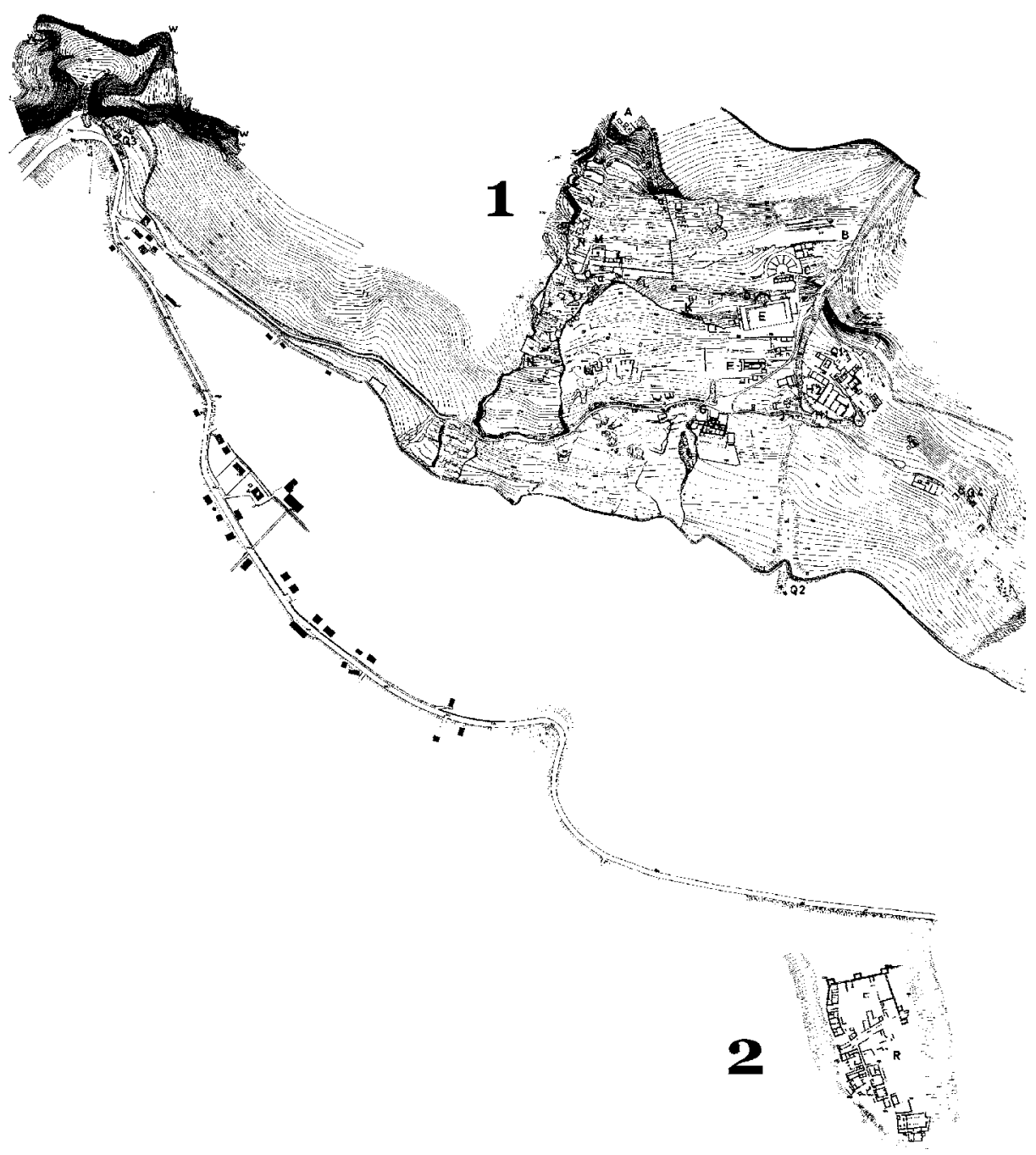

Fig. 6. Arykanda after $500 \mathrm{AD}$

were only able to burn parts of the city outside the late Roman walls. ${ }^{48}$ Excavations of many years' duration in the area of the ancient ('Greek') agora, which lay to the west of the newly fortified area, and in other districts to the east of the late Roman wall had shown traces of active settlement life during the period between the fourth and sixth centuries $\mathrm{AD} .{ }^{49}$

48 Frantz 1988, pp. 52-56

49 Idem 1979; idem 1988; Thompson 1988. 


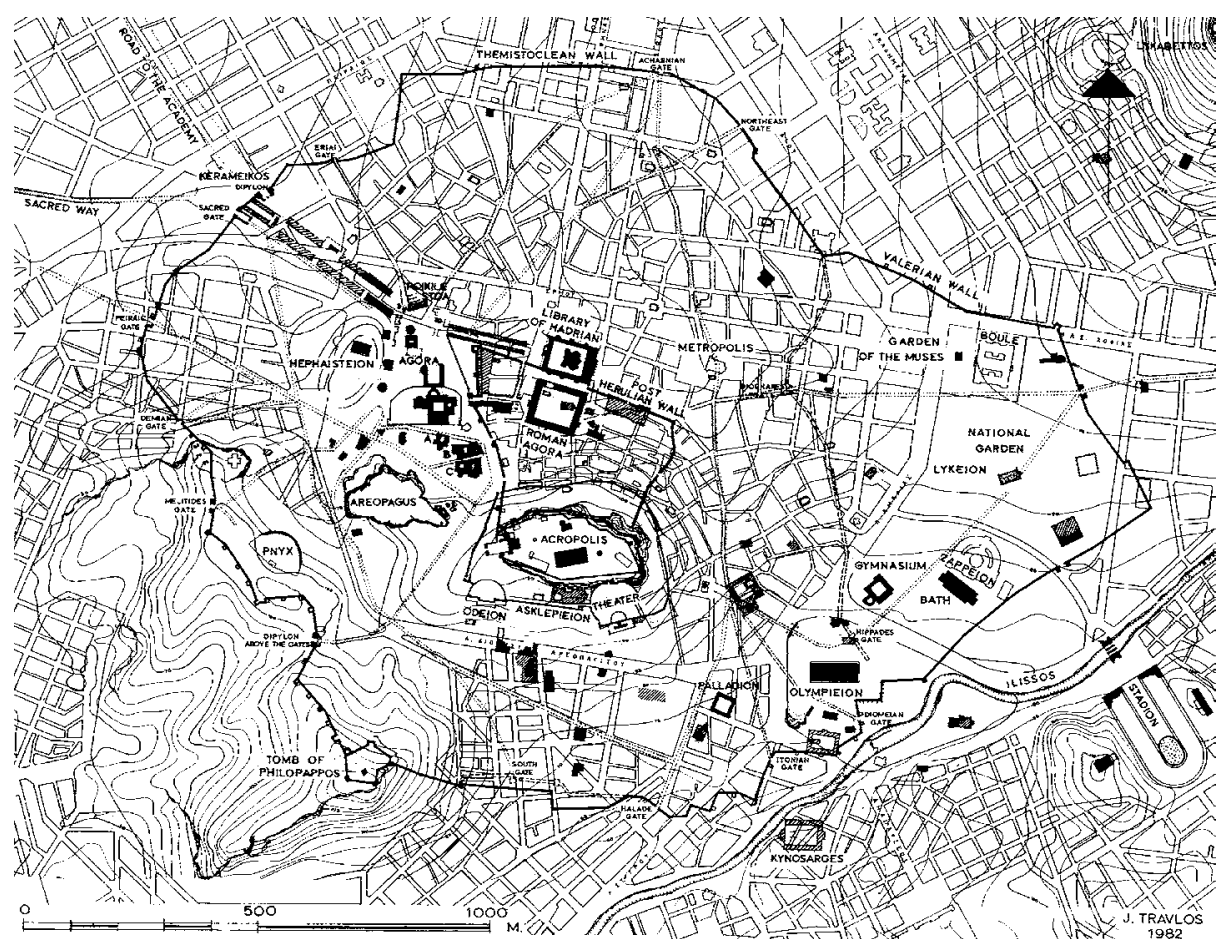

Fig. 7. Map of Athens in classical, Roman and late Roman ages

The giant ancient walls of Corinth (the area surrounded by walls covered about $700 \mathrm{ha}$ ) were destroyed after the conquest of the city by Romans in $146 \mathrm{BC}$. In $396 \mathrm{AD}$, the city was destroyed by the Goths. According to the contemporary sources, the city was taken easily because of the absence of walls, ${ }^{50}$ but even if they had been present, it is questionable to what extent they should have been able to protect the people, as the case of Athens has shown. Immediately after this disaster had occurred, a new, shorter wall was built. ${ }^{51}$ The inhabitants overcame the barbarian invasion and its effects relatively quickly and within the newly fortified area new building programmes were realised. In addition, traces of intensive life were detected outside the walls. ${ }^{52}$

The area surrounded by walls in the town Pautalia amounted to about 30 ha. The walls were built during the reign of the Emperor Marcus Aurelius. Towards the end of the fourth century AD, a hill-fort immediately to the south of the town was built. There is evidence of intensive life within the old town areas in the period between the fourth and the sixth century AD, confirmed by findings and coins. The most recent coin dates

50 Zosimos $V, 6.4$.

51 Gregory 1979, 269.

52 Rothaus 2000, 21-31. 


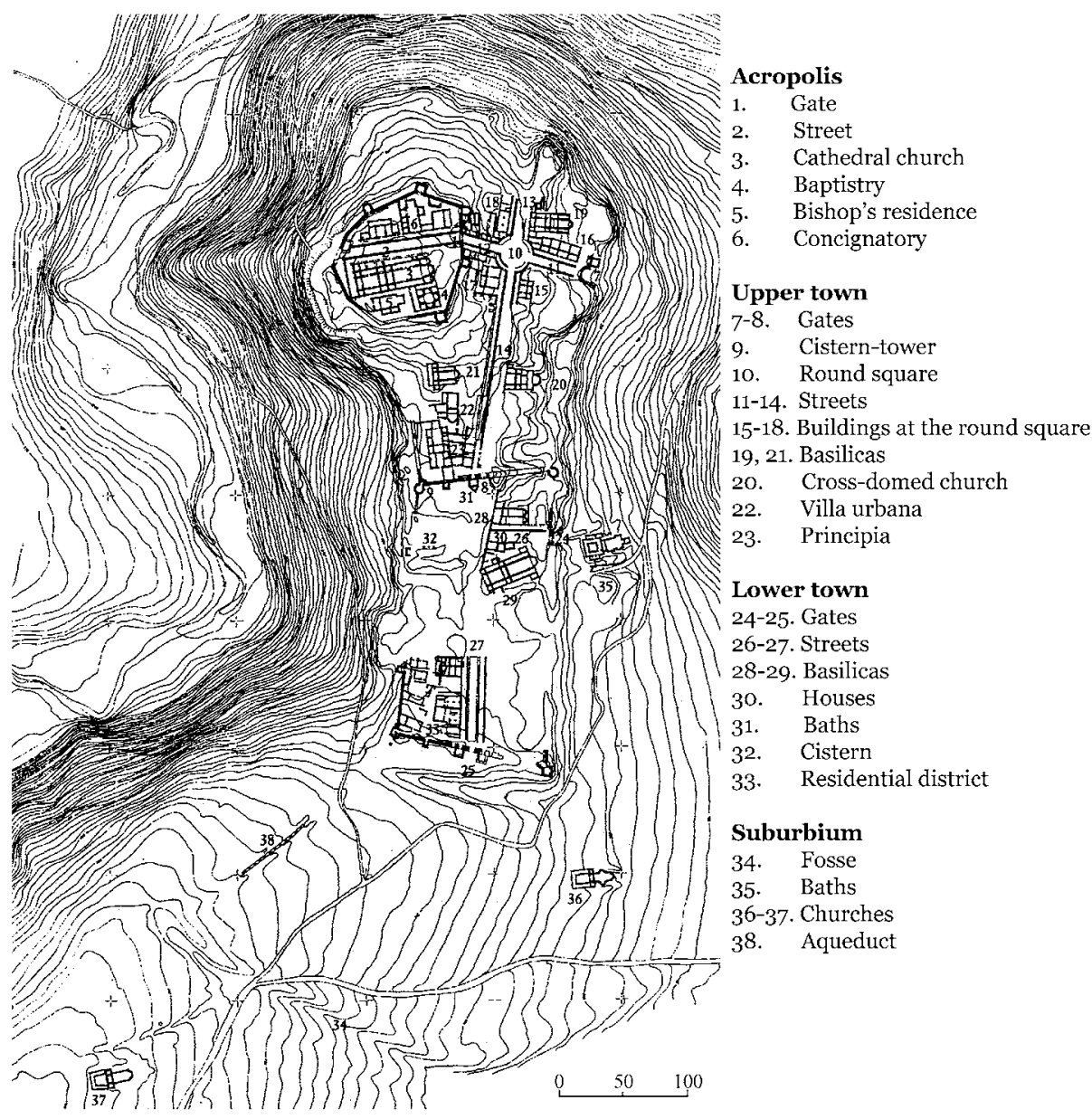

Fig. 8. Map of Caričin grad/Justiniana Prima

to $585 \mathrm{AD} .{ }^{53} \mathrm{Also}$, a partitioning wall was discovered in the lower town, which unfortunately could not be dated precisely. All that is known is that it was erected between the fifth and ninth centuries AD. ${ }^{54}$ According to the latest investigations, in late antiquity the populated areas were located only to its west. In that case, we have to wait for the final evaluation.

The total built-up area of Caričin grad (Fig. 8), identified as Justinian's foundation Justiniana Prima, amounted to almost 8 ha (according to other scholars to more than $10 \mathrm{ha}$ ). The town was founded around or after $535 \mathrm{AD}$, near the birth-place of

53 Slokoska/Stajkova-Alexandrova/Spassov 2002.

54 Spassov/Fărkov/Stajkova-Alexandrova 1991. 
Emperor Justinian, far from the main routes of the region. On the acropolis, the bishop's residence and the cathedral church were situated, below lay the so-called upper town where various public buildings and squares, churches, a principia and a villa urbana were discovered. The excavations in the areas of the so-called lower town brought to light several public buildings, churches, a reservoir and a small residential district in the south-west corner of the fortress. The suburb was unfortified with the exception of a single fosse. Here numerous houses, workshops and churches were excavated. ${ }^{55}$

The ancient ruins near the modern village Viranşehir in Turkey (Fig. 9) were identified as the late antique Mokisos which was also founded by Justinian. Its entire populated area amounted to about 50 ha, with a number of more than 1,000 buildings being identified. The town was unfortified with the exception of the small acropolis $(120 \times 30 / 50 \mathrm{~m})$ and of the small fort in the central parts of the town $(18 \times 26 \mathrm{~m})$. The bishop's residence lay outside these areas, surrounded by walls. ${ }^{56}$

The late antique town on the hill of Tsarevets (Fig. 10), identified as the late antique bishop's see Zikideva, could be interpreted as a successor of the Roman town Nicopolis ad Istrum. It flourished in the decades after the end of the late antique settlement next to Roman Nicopolis (dated to around 500 AD). The inhabited area was a densely populated rocky plateau in an outstanding, naturally defendable position. Like as Justiniana Prima, the town at Tsarevets just represents an emblematic example of the late antique town-planning concept on the Balkans. Traces of settlement life were also found on the slopes below the plateau, as well as on the hills in the vicinity of Tsarevets - Trapesitza and Momina krepost/Devin Grad. The settlement at Momina krepost was also fortified. The entire populated area of the agglomeration amounted to almost 30 ha. $^{57}$

It is obvious that the populated and the fortified areas in the late antique period are not one and the same. A great number of inhabitants lived outside the new, much shorter town walls. Therefore, the reduction of the fortified area was not (in most cases at least) caused by a demographic catastrophe or by an imaginary 'general decline' of the institution 'city'. Despite their shorter walls, the towns and the cities remained in many cases significant centres of their territories and also within the imperial economic and administrative structure. In addition, these new walls were in several cases an insuperable obstacle for the invading barbarians and could guarantee the safety of the citizens.

55 Bavant/Ivaniševič 2003.

56 Berger 1998.

57 Dintchev 1997b. 


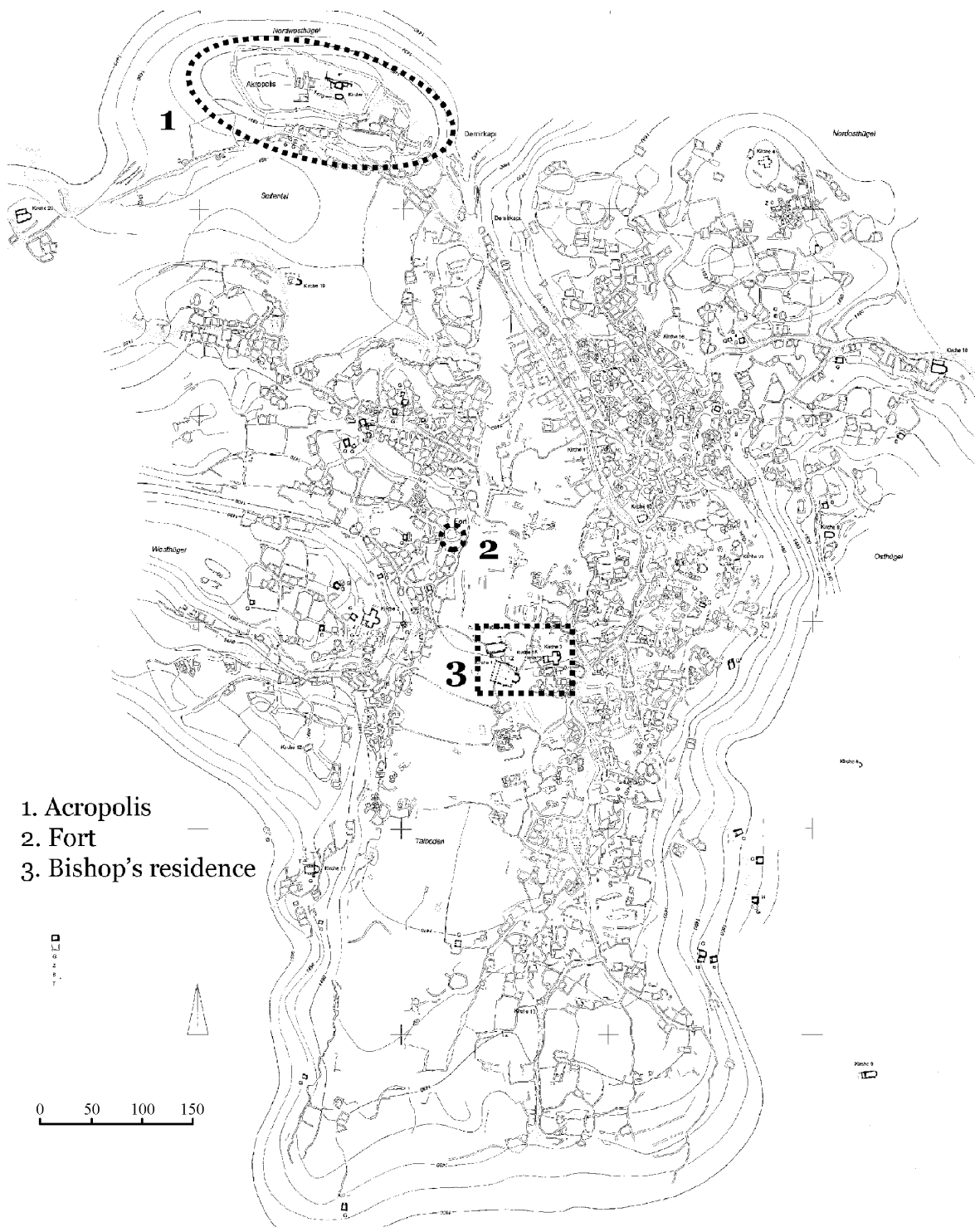

Fig. 9. Map of Viranşehir/Mokisos 


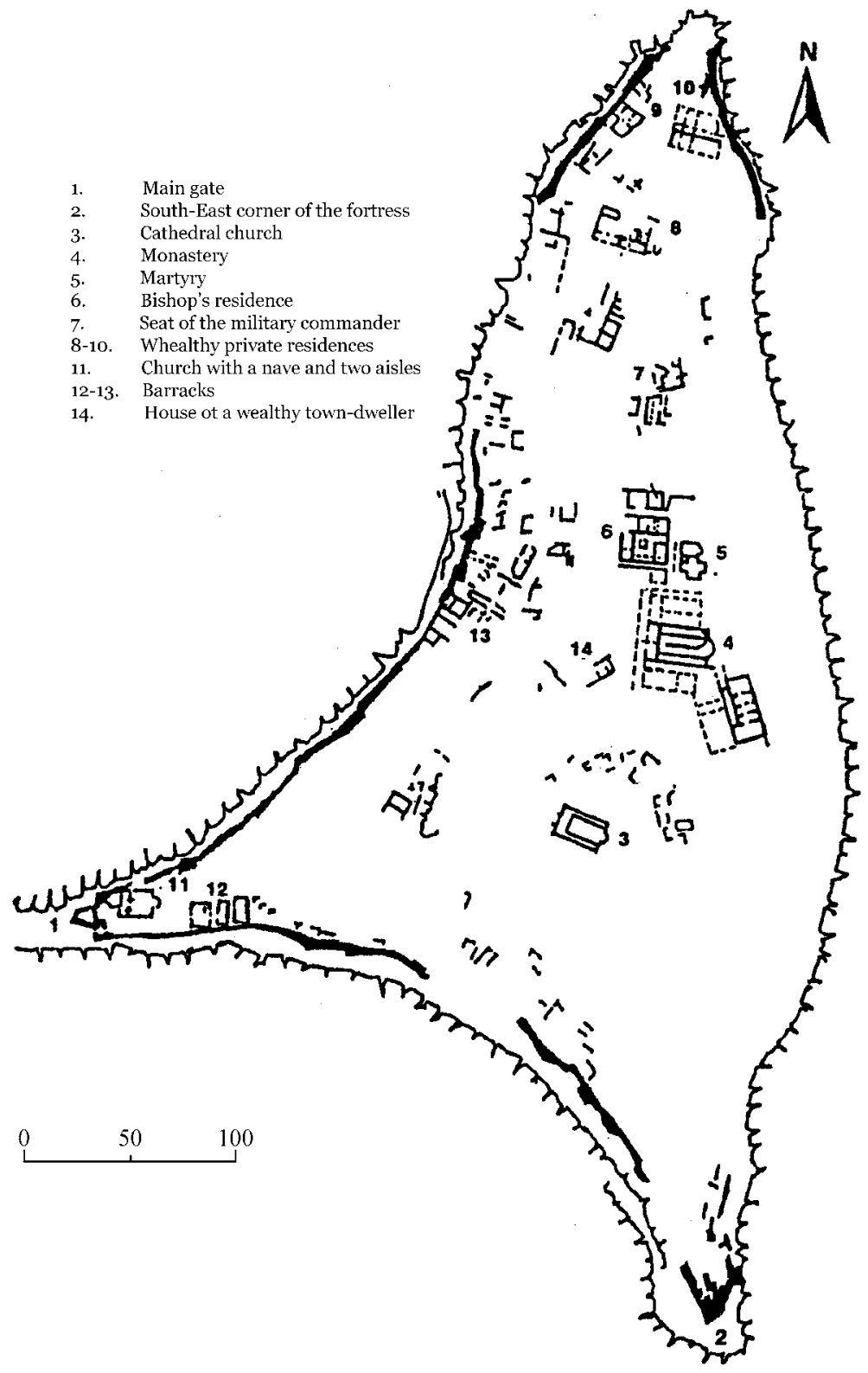

Fig. 10: Map of Tsarevets/Zikideva 


\section{What made the people in late antiquity reduce the city walls?}

In the first three centuries $\mathrm{AD}$, a new religion - Christianity -quickly conquered the hearts and souls of a considerable number of the Roman people. In most towns and cities of the Roman Empire, Christian communities were founded. The Christians could participate relatively easy in the town's public and economic life (with some exceptions concerning pagan cult practice and especially the cult of the Emperor). In other words, the early Christian was not a revolutionary. He wanted to save his soul and not to change the existing world order.

In the time after the Edict of Milan, things changed drastically. The discontent of the church and its representatives with a number of municipal institutions grew. The devil and his actions could be recognised practically everywhere. One of the most important deeds of the devil were the theatrical performances which were considered 'immoral' and a 'waste of time'. The theatre absorbed large sums of money and the flock was still more attracted to it than to the church. According to the church fathers, gladiatorial contests were cruel, brutal and represented a superfluous pagan tradition; the fathers also condemning fights with wild animals. The public baths were denounced as anti-spiritual - Christians should rather take care of their souls. The agora was also regarded as a pagan place and a place of intercourse with young women. ${ }^{58}$ In short, the Christian church denounced most of the old city symbols which were the sites of public life; in this way denouncing public life itself. Christians were rather to live within their own family, not in the streets of the city. That is why the physical change of the city during the period of Christianisation is not only connected with the destruction of pagan temples ${ }^{59}$ and the erection of churches, but with a total transformation of the urban pattern. The victory of Christianity is therefore the main reason for the disappearance of the public aspects in the life of the city and its inhabitants. ${ }^{60}$

However, the Church cannot take responsibility for the reduction of the town walls. The merit of the Christian religion was to make the people accept the idea of living without public spaces; the immediate reasons being the barbarian invasions and their consequences.

In the course of the period of migration, the inability of the central government to guarantee the security of the frontiers of the empire became more and more evident. The limes was no longer an obstacle for the invading barbarians. $420 \mathrm{AD}$, the Emperors Honorius and Theodosius permitted the fortification of private estates. ${ }^{61}$ As a result of this edict, not only a great number of villae were surrounded by walls, but in rural regions numerous fortresses and fortified settlements were erected which had to

58 Saradi-Mendelovici 1988, 365-401.

59 Spieser 1976; idem 1986; Saradi-Mendelovici 1990.

60 See an obverse opinion in Brands 2003.

61 Codex Iustinianus VIII, 10.10. 
protect the life of the people in the countryside. ${ }^{62}$ The town inhabitants also had to act on their own account. The central government was unable to station troops in every city and town of the Empire, for which reason only a small number of places had garrisons within their walls. Even in important cities such as Antioch, military units were either not present or inadequately small. In the town Chalkis in Syria, the citizens were forced to hide the soldiers in their houses to protect them from the Persian conquerors. ${ }^{63}$ In many cases it has been reported that for this reason town militias were founded. ${ }^{64}$ The participation of civilian citizens in war efforts and the defence of their own towns or cities were a common phenomenon already in the sixth century, wherefore it was recommended by the highest military command. ${ }^{65}$

However, neither the citizens nor the insufficient military garrisons could successfully defend extremely long wall circuits, leading to the central government's decision to drastically reduce the size of the enormous walls. Although Procopius tried to convince us of the crucial role played by the Emperor Justinian in this development, his ancestors and successors doubtlessly had a share in these processes. Of course, most of the evidence belongs to Justinian's age.

Thus, Justinian for example ordered his commander Belisarius to curtail the walls of the towns and fortresses at the North African frontier in case he should find that the hitherto existing walls were too long and could not be defended successfully by their inhabitants. The emperor's orders were obviously executed immediately: Lepcis Magna is a demonstrative case ${ }^{66}$ The length of the ramparts of Antioch ${ }^{67}$ and Caesarea in Kappadokia ${ }^{68}$ were reduced as well and for the same reasons - too long walls rather represented a risk for the citizens than an obstacle for their enemies. In other words, the reduction of the area surrounded by walls was a preventive measure and did not represent a sign of decline of the cities, but, on the contrary, of their vitality. In many cases, 'reduction' was a synonym for 'survival'. If we must describe the motivation for the reduction with only one word, it would have to be 'prudence'.

\section{The instructive case of Androna}

Not only legislation and other contemporary written sources allow us to understand the motivation of the citizens in late antiquity to reduce the walls of their towns and cities -

62 See for example Popov 1982, and the contribution of M. Milinkovič in this volume.

63 Procopius, De bello persico II, 12.2.

64 Claude 1969, 130-131.

65 Mauricii Strategicon X.3.

66 Procopius, De aedificiis VI, 4.2-3; Goodchild/Ward-Perkins 1953.

67 Procopius, De aedificiis II, 10.2-5, 9-14.

68 Procopius, De aedificiis V, 4.7-14. 
there is archaeological evidence as well. I would like to outline the results of the recent investigations of the ancient town Androna in Syria, known today as al-Andarin. The town was surrounded by two (inner and outer) wall circuits. The excavations revealed many superior buildings: public buildings, altogether eleven churches, public baths etc. The prime of the town is dated by ceramic finds to the fifth and sixth centuries. The most significant building within the wall circuits of the town is the so-called castrum, a fortress situated almost in the town centre. This is a nearly square building with about $80 \mathrm{~m}$ side length, with a small church in the centre of the inner yard. On the gate in the middle of the west side of the castrum, an inscription in Greek was found. It reports that a wealthy inhabitant of Androna, a certain Thomas, donated this fortress. Construction work began May 558. Inscriptions on the doors of the church in the inner yard mention another person, a certain John, likewise an inhabitant of the town, as donator of the castrum. Thus, the town castle was donated by one or more private persons. The most important fact is that they financed the erection of the castle being private persons and citizens, and not by order of the central civil or military government. This was a luxurious refuge in cases of emergency. The case of Androna demonstrates once more that every town and every city able to afford it had to take care of its own safety.

\section{Bibliography}

Allen 1979: Pauline Allen, “The ,Justinianic' Plague”, in: Byzantion 49, 1979, pp. 5-20.

Allison 1997: Penelope M. Allison, "Roman Households: an archaeological perspective", in: Helen M. Parkins (Ed.), Roman Urbanism: beyond the Consumer City, London-New York 1997, pp. 112-146.

Bavant/Ivaniševič 2003: Bernard Bavant/Vujadin Ivaniševič, Iustiniana Prima-Caričin Grad, Beograd 2003

Berger 1998:Albrecht Berger, "Viranşehir(Mokisos), eine byzantinische Stadt in Kappadokien", in: Istanbuler Mitteilungen 48, 1988, pp. 349-429.

Brandes 1989: Wolfram Brandes, Die Städte Kleinasiens im 7. und 8. Jahrhundert (=Berliner Byzantinistische Arbeiten 56), Berlin 1989.

Brandes 1999: Wolfram Brandes, "Byzantine Cities in the Seventh and Eighth Centuries - Different Sources, Different Histories? Some Methodological Observations on the Relationship between Written, Numismatic, Sigillographic and Archaeological Sources Used in Research into Byzantine Urbanism in the Seventh and Eighth Centuries", in: Gian P. Brogiolo/Bryan Ward-Perkins (Eds), The Idea and Ideal of the Town Between Late Antiquity and the Early Middle Ages (=The Transformation of the Roman World 4), Leiden-Boston-Köln 1999, pp. 21-57.

Brands 2003: Gunnar Brands, "Die spätantike Stadt und ihre Christianisierung", in: Gunnar Brands/Hans-Georg Severin (Eds), Die spätantike Stadt und ihre Christianisierung. Symposion vom 14. bis 16. Februar 2000 in Halle/Saale (=Spätantike - Frühes Christentum - Byzanz. Kunst im ersten Jahrtausend, Reihe B: Studien und Perspektiven 11), Wiesbaden 2003, pp. 1-26. 
Brogiolo/Ward-Perkins 1999: Gian P. Brogiolo/Bryan Ward-Perkins (Eds), The Idea and Ideal of the Town between Late Antiquity and the Early Middle Ages (=The Transformation of the Roman World 4), Leiden-Boston-Köln 1999.

Brogiolo/Gauthier/Christie 2000: Gian P. Brogiolo/Nancy Gauthier/Neil Christie (Eds.), Towns and their Territories between Late Antiquity and the Early Middle Ages (=The Transformation of the Roman World 9), Leiden-Boston-Köln 2000.

Cameron 2001: Averil Cameron, "A Response”, in: Luke Lavan (Ed.), Recent Research in Late Antique Urbanism (=Journal of Roman Archaeology Supplementary Series 42), Porthmouth-Rhode Island 2001, pp. 238-239.

Claude 1969: Dietrich Claude, "Die byzantinische Stadt im 6. Jahrhundert" (=Byzantinisches Archiv 13), München 1969.

Codex Iustinianus: Paul Krüger (Ed.), Codex Iustinianus. Nachdruck der Ausgabe Berlin 1877 (100 Jahre Bürgerliches Gesetzbuch: Pandektenrecht 62), Goldbach 1998.

Dintchev 1997a: Ventzislav Dintchev, "Household Substructure of the Early-Byzantine Fortified Settlements on the Present Bulgarian Territory”, in: Archaeologia Bulgarica 1/1, 1997, pp. 47-63.

Dintchev 1997b: Ventzislav Dintchev, "Zikideva - an Example of Early-Byzantine Urbanism in the Balkans", in: Archaeologia Bulgarica 1/3, 1997, pp. 54-77.

Dölger 1961: Franz Dölger, "Die byzantinische und byzantinisch beeinflusste Stadt (V.-VIII. Jahrhundert)", in: Franz Dölger, ПАРАГПОРА: 30 Aufsätze zur Geschichte, Kultur und Sprache des byzantinischen Reiches, Ettal 1961, pp. 65-100.

Dontas 2000: Nikos A. Dontas (Ed.), Priene, Athens 2000.

Duncan-Jones 1974: Richard Duncan-Jones, The Economy of the Roman Empire: Quantitative Studies, Cambridge 1974.

Dunn 1994: Archibald Dunn 1994, "The Transition from Polis to Kastron in the Balkans (III-VII cc.): general and regional perspectives", in: Byzantine and Modern Greek Studies 18, 1994, pp. 60-80.

Durliat 1989: Jean Durliat, "La peste du VI ${ }^{\mathrm{e}}$ siècle: pour un nouvel examen de sources byzantines", in: Hommes et richesses dans l'empire byzantin, Tome I. IV -VII siècles (=Réalités Byzantines 1), Paris 1989, pp. 107-125.

Foss 1975: Clive Foss, "The Persians in Asia Minor and the End of Antiquity", in: The English Historical Review 90, 1975, pp. 721-747.

Foss 1977: Clive Foss, "Archaeology and the "Twenty Cities" of Byzantine Asia", in: American Journal of Archaeology 81, 1977, pp. 469-486.

Frantz 1979: Alison Frantz, "A Public Building of Late Antiquity in Athens (IG II', 5205)”, in: Hesperia 48/2, 1979, pp. 194-203.

Frantz 1988: Alison Frantz, Late Antiquity: A.D. 267-700 (=The Athenian Agora 24), Princeton 1988 .

Goodchild/Ward-Perkins 1953: Richard G. Goodchild/John Bryan Ward-Perkins, The Roman and Byzantine Defences of Lepcis Magna, in: Papers of the British School of Rome 21, N.S. 8, 1953, pp. 42-37.

Gregory 1979: Timothy E. Gregory, “The Late Roman Wall at Corinth”, in: Hesperia 48/3, 1979, pp. 264-280.

Ward Perkins 1953: John Bryan Ward-Perkins, "The Roman and Byzantine Defences of Lepcis Magna", in: Papers of the British School of Rome 21, N.S. 8, 1953, pp. 42-37.

Janakievski 1977: Томе Јанакиевски, “Доцноантичка микростамбена целина врз римскиот театар во Heraclea Lyncestis”, in: Macedoniae Acta Archaeologica 3, 1977, pp. 81-102. 
Kazhdan 1954: Александр П. Каждан, Византийские города в VII-XI веках, in: Советская Археология 21, 1954, pp. 164-183.

Karagiorgou 2001: Olga Karagiorgou, "Demetrias and Thebes: the Fortunes and Misfortunes of two Thessalian Port Cities in Late Antiquity", in: Luke Lavan (Ed.) Recent Research in Late Antique Urbanism (=Journal of Roman Archaeology, Supplementary Series 42), Porthmouth-Rhode Island 2001, pp. 183-215.

Kennedy 1985: Hugh Kennedy, "From Polis to Madina: Urban Change in Late Antique and Early Islamic Syria", in: Past and Present 106, 1985, pp. 3-27.

Kirsten 1958: Ernst Kirsten, "Die byzantinische Stadt", in: Berichte zum XI. Internationalen Byzantinisten-Kongress (München 1958), München 1958, pp. 1-48.

Knoblauch/Witschel 1993: Paul Knoblauch/Christian Witschel, "Arykanda in Lykien: eine topographische Aufnahme”, in: Archäologischer Anzeiger, 1993/2, pp. 229-262.

Kondoleon 2000: Christine Kondoleon, Antioch: the lost ancient city, Princeton 2000.

Kurbatov 1971: Георгий Л. Курбатов, Основные проблемы внутреннего развития византийского города, Ленинград 1971.

Kurbatov 1973: Георгий Л. Курбатов, Разложение античной городской собственности в Византии IV-VII вв., in: Византийский Временник 35, 1973, pp.19-32.

Lavan 2001a: Luke Lavan, "The Late Antique City: a bibliographic essay", in: Luke Lavan (Ed.), Recent Research in Late Antique Urbanism (= Journal of Roman Archaeology Supplementary Series 42), Porthmouth-Rhode Island 2001, pp. 9-26.

Lavan 2001b: Luke Lavan, "The Praetoria of Civil Governors in Late Antiquity", in: Luke Lavan (Ed.), Recent Research in Late Antique Urbanism (=Journal of Roman Archaeology Supplementary Series 42), Porthmouth-Rhode Island 2001, pp. 39-56.

Leven 1987: Karl-Hainz Leven, "Die justinianische Pest", in: Jahrbuch des Instituts für Geschichte der Medizin der Robert-Bosch-Stiftung 6, Stuttgart 1987, pp. 137-161.

Liebeschütz 1959: John H. W. G. Liebeschuetz, "The Finances of Antioch in the Fourth Century A. D.", in: Byzantinische Zeitschrift 52, 1959, pp. 344-356.

Liebeschuetz 1987: John H. W. G. Liebeschuetz, "Government and Administration in the Late Empire (to A. D. 476)", in: John Wacher (Ed.), The Roman World 1, London 1987, pp. 455-469.

Liebeschuetz 1996: John H. W. G. Liebeschuetz 1996, "The End of The Ancient City”, in: John Rich (Ed.), The City in Late Antiquity (=Leicester-Nottingham Studies in Ancient History 3), London-New York ${ }^{2}$ 1996, pp. 1-49.

Liebeschuetz 2001a: John H. W. G. Liebeschuetz, Decline and Fall of the Roman City, Oxford 2001.

Liebeschuetz 2001b: John H. W. G. Liebeschuetz, "The Uses and Abuses of the Concept of 'decline' in Later Roman History, or Was Gibbon Politically Incorrect?”, in: Luke Lavan (Ed.), Recent Research in Late Antique Urbanism (= Journal of Roman Archaeology Supplementary Series 42), Porthmouth-Rhode Island 2001, pp. 233-238.

Mango 1980: Cyril Mango, Byzantium: the Empire of New Rome, London 1980.

Mauricii Strategicon: Das Strategikon des Maurikios. Einführung, Edition und Indices von George T. Dennis. Übersetzung von Emil Gamillscheg (Corpus Fontium Historiae Byzantinae 17), Wien 1981.

Müller-Wiener 1961: Wolfgang Müller-Wiener, "Mittelalterliche Befestigungen im südlichen Jonien”, in: Istanbuler Mitteilungen 11, 1961, pp. 5-122.

Müller-Wiener 1967: Wolfgang Müller-Wiener, "Das Theaterkastell von Milet”, in: Istanbuler Mitteilungen 17, 1967, pp. 279-290.

Müller-Wiener 1986: Wolfgang Müller-Wiener, "Von der Polis zum Kastron: Wandlungen der Stadt im Ägäischen Raum von der Antike zum Mittelalter”, in: Gymnasium 93, 1986, pp. 435-475. 
Ostrogorsky 1959: George Ostrogorsky, "Byzantine Cities in the Early Middle Ages", in: Dumbarton Oaks Papers 13, 1959, pp. 47-66.

Panzram 2002: Sabine Panzram, "Stadtbild und Elite: Tarraco, Corduba und Augusta Emerita zwischen Republik und Spätantik" (=Historia Einzelschriften 161), Stuttgart 2002.

Popov 1982: Атанас Попов, Крепостни и укрепителни съоръжения в Крънската средновековна област, София 1982.

Popovič 1982: Vladislav Popovič, "Desintegration und Ruralisation der Stadt im Ost-Illyricum vom 5. bis 7. Jahrhundert n. Chr.”, in: Dietrich Papenfuss/Volker Michael Strocka (Eds), Palast und Hütte: Beiträge zum Bauen und Wohnen im Altertum von Archaeologen, Vor- und Fruehgeschichtlern. Tagungsbeiträge eines Symposiums der Alexander von Humboldt-Stiftung, Bonn-Bad Godesberg, veranstaltet vom 25. - 30. November 1979 in Berlin, (Internationale Fachgespräche/Alexander-von-Humboldt-Stiftung), Mainz 1982, pp. 545-566.

Poulter 1996: Andrew Poulter, "The use and abuse of urbanism in the Danubian provinces during the Later Roman Empire", in: John Rich (Ed.) The City in Late Antiquity (=Leicester-Nottingham Studies in Ancient History 3), London ${ }^{2} 1996$, pp. 99-135.

Precht/Rüger 1978: Gundolf Precht/Christoph B. Rüger (Eds.), Archäologischer Stadtplan Colonia Ulpia Traiana (Xanthen, Kreis Wesel): archäologisch gesicherter Bestand des 2.- 3. Jahrhunderts n. Chr, Köln 1978.

Procopius, De aedificiis: Prokop. Bauten. Griechisch-deutsch ed. Otto Veh (=Prokop Werke 5), München 1977.

Procopius, De bello persico: Prokop. Perserkriege. Griechisch-deutsch ed. Otto Veh (=Prokop Werke 3), München 1970.

Provost 2001: Samuel Provost, "City Wall and Urban Area in Philippi”, in: Luke Lavan (Ed.) Recent Research in Late Antique Urbanism (=Journal of Roman Archaeology Supplementary Series 42), Porthmouth-Rhode Island 2001, pp. 123-135.

Risse 2001: Martina Risse (Ed.), Volubilis: Eine römische Stadt in Marokko von der Frühzeit bis in die islamische Periode (=Sonderbände zur Antiken Welt/Zaberns Bildbände zur Archäologie), Mainz 2001.

Rothaus 2000: Richard M. Rothaus, "Corinth: The First City of Greece: an Urban History of Late Antique Cult and Religion (=Religions in the Graeco-Roman World 13), LeidenBoston-Köln 2000.

Russel 1958: Josiah C. Russel, "Late Ancient and Medieval Population”, in: Transactions of the American Philosophical Society 48/3, Philadelphia 1958.

Saradi-Mendelovici 1988: Helen Saradi-Mendelovici, "The Demise of the Ancient City and the Emergence of the Mediaeval City in the Eastern Roman Empire", in: Echos du Monde Classique/Classical Views 32, N. S. 7, 1988, pp. 365-401.

Saradi-Mendelovici 1990: Helen Saradi-Mendelovici, "Christian Attitudes toward Pagan Monuments in Late Antiquity and Their Legacy in Later Byzantine Centuries", in: Dumbarton Oaks Papers 44, 1990, pp. 47-61.

Slokoska/Stajkova-Alexandrova/Spasov2002:ЛюдмилаСлокоска/ЛидияСтайкова-Александрова/ Румен Спасов, "Пауталия", in: Rumen Ivanov (Ed.), Roman and Early Byzantine Cities in Bulgaria (=Studies in Memory of Prof. Teofil Ivanov 1), Sofia 2002, pp. 251-266.

Spasov/Fărkov/Stajkova-Alexandrova 1991: Румен Спасов/Юри Фърков/Лидия СтайковаАлександрова, "Новооткрита крепостна стена в националния архитектурен и археологически резерват «Пауталия - Велбъжд - Кюстендил»", in: Известия на Исторически музей Кюстендил 3, 1991, pp. 39-48. 
Spieser 1976: Jean-Michel Spieser, "La christianisation des sanctuaries païens en Grèce", in: Ulf Jantzen (Ed.), Neue Forschungen in griechischen Heiligtümern. Internationales Symposion in Olympia vom 10. bis 12. Oktober 1974, Tübingen 1976, pp. 309-320.

Spieser 1986: Jean-Michel Spieser, "La christianisation de la ville dans l'Antiquité tardive", in: Ktèma 11, 1986, pp. 49-55.

Sjuzjumov 1956: Михаил Я. Сюзюмов, Роль городов-емпориев в истории Византии, in: Византийский Временник 8, 1956, pp. 26-41.

Thompson 1959: Homer A. Thompson, “Athenian Twilight: A.D. 267-600”, in: The Journal of Roman Studies 49/1-2, 1959, pp. 61-72.

Thompson 1988: Homer A. Thompson, "The Palace of the Giants", in: Allison Frantz, Late Antiquity: A.D. 267-700 (=The Athenian Agora 24), Princeton 1988, pp. 95-116.

Thompson/Scranton 1943: Homer A. Thompson/Robert L. Scranton, "Stoas and City Walls on the Pnyx", in: Hesperia 12/4, 1943, pp. 269-383.

Vitruvius, De Architectura: Vitruvius. Ten books on architecture. Translated by Ingrid D. Rowland. Commentary and illustrations by Thomas Noble Howe, Cambridge 2002.

Vittinghoff 1958: Friedrich Vittinghoff, "Zur Verfassung der spätantiken „Stadt"”, in: Studien zu den Anfängen des europäischen Städtewesens (=Vorträge und Forschungen 4), Sigmaringen 1958, pp. 11-40.

Ward-Perkins 2001: Bryan Ward-Perkins, "A Brief Comment”, in: Luke Lavan (Ed.), Recent Research in Late Antique Urbanism (=Journal of Roman Archaeology Supplementary Series 2), Porthmouth-Rhode Island 2001, pp. 239-241.

Whittow 2001: Mark Whittow, "Was Gibbon politically incorrect, or just wrong?", in: Luke Lavan (Ed.), Recent Research in Late Antique Urbanism (=Journal of Roman Archaeology Supplementary Series 42), Porthmouth-Rhode Island 2001, pp. 241-243.

Wurster/Wörrle 1978: Wolfgang W. Wurster/Michael Wörrle, "Die Stadt Pinara", in: Archäologischer Anzeiger 1978, 1, pp. 74-101.

Zosimos: Zosimos. Neue Geschichte. Übersetzt und eingeleitet von Otto Veh. Durchgesehen und erläutert von Stefan Rebenich (=Bibliothek der griechischen Literatur 31), Stuttgart 1990. 


\title{
Amorium in the Byzantine Dark Ages (seventh to ninth centuries)
}

\author{
ERIC A. IVISON
}

In a pioneering article published in 1959, the great Byzantinist George Ostrogorsky remarked that, "[a]mong the fundamental problems of Byzantine history it would be hard to name one that has been studied less than has that of the cities"1. Scholarship since 1959 has not neglected the subject of the Byzantine city and has access to considerably more sources. Nonetheless, the nature of urban life in medieval Byzantium remains a topic of controversy in Byzantine studies. This is especially true when considering the Byzantine cities of Asia Minor during the so-called 'Dark Ages' of the seventh to ninth centuries. The pioneering works of Clive Foss were the first to document much new evidence and combined the study of texts, historical geography and archaeology to produce histories of individual cities. ${ }^{2}$ Other historians such as Cyril Mango, Michael Angold, Wolfram Brandes, and John F. Haldon have created broader historical syntheses, seeking to use archaeological data with a more nuanced study of Byzantine texts. Key questions raised by these studies include the functions of cities, the causes of growth and decline, the urban economy and the nature of daily life, and even whether some settlements can be regarded as 'urban' or 'cities' at all. ${ }^{3}$ Given the continuing paucity of written sources it is to archaeological fieldwork, and specifically excavation, that future scholars must turn to expand the base of Byzantine urban history.

This paper is a contribution to this debate and will discuss aspects of the development and economy of the Anatolian city of Amorium during the period of the so-called Byzantine Dark Ages (seventh to ninth centuries). The Byzantine site of Amorium is located in the ancient region of Phrygia in Central Western Turkey, some $168 \mathrm{~km}$ south west of the modern capital of Ankara (Fig. 1). Historical sources attest that medieval Amorium was a major military and administrative center during this period, becoming

1 Ostrogorsky 1959, 47.

2 Foss 1976; idem 1977a, 27-87; idem 1989. For Foss' thesis concerning the role of the Persians in the collapse of the cities in the early seventh century, see Foss 1975, 721-47; idem 1977b, 469-86. For a critique of Foss' thesis, see Russell 2001, 41-71; see also Whittow 1996, 89-95 and notes.

3 Mango 1980, 60-87; Angold 1985, 1-37; Brandes 1989; idem 1999, 25-57; Haldon 1997, 93 124, 459-61; idem 1999, 1-23. See also: Dunn 1994, 60-80; Trombley 1997, 429-449. 


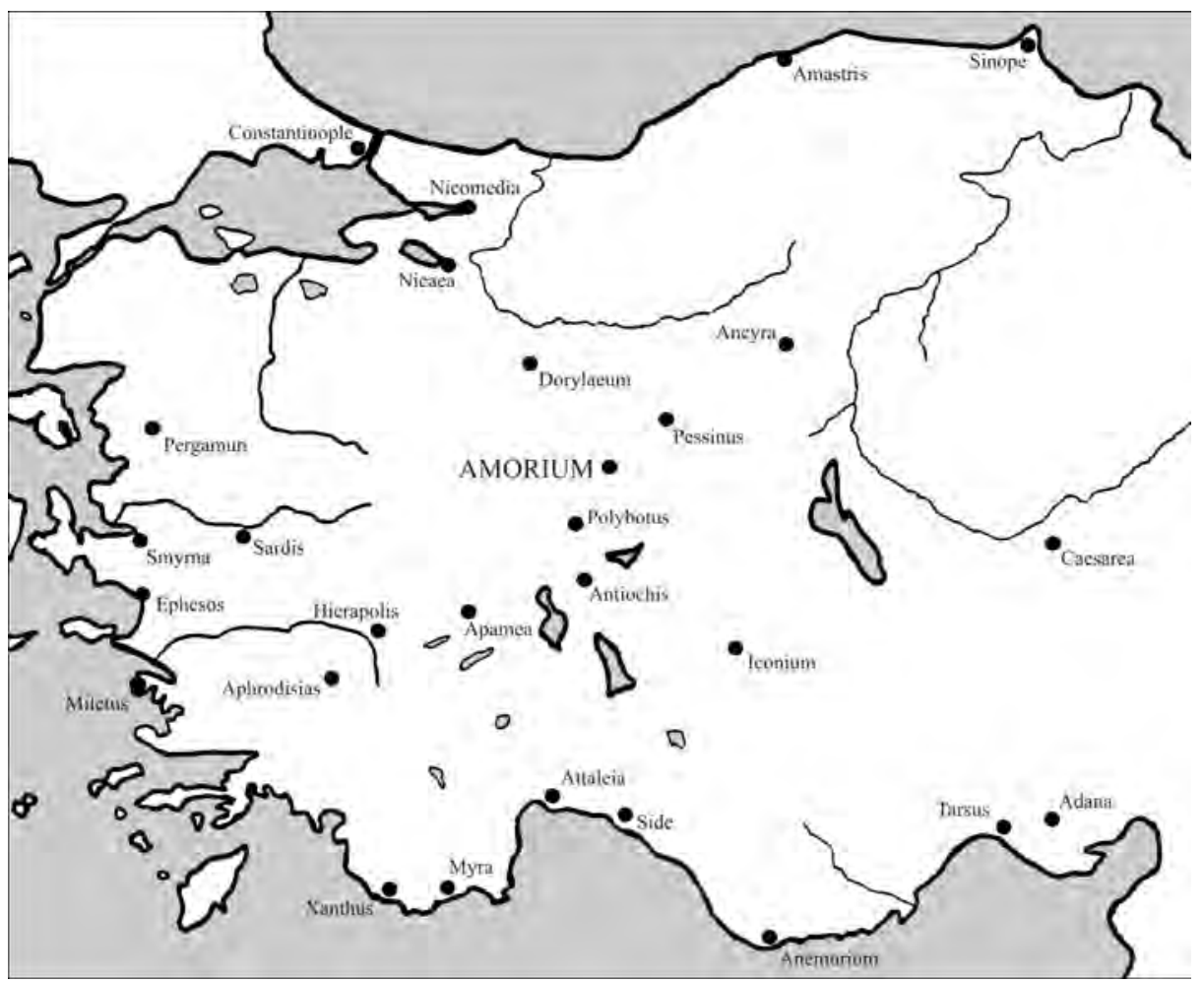

Fig. 1. Map of Asia Minor showing the location of Amorium

the headquarters of the military district or theme of Anatolikon in the mid seventh century. Amorium thus played an important role in the events of the Dark Ages and was fortunate in its associations with a number of emperors. Two strategoi launched their successful bids for the throne from Amorium - Leo III in 717 and Leo V the Armenian in 813. A native of Amorium was emperor Michael II (820-829) who founded the Amorian dynasty (820-867). Constantine V sought refuge at Amorium from the usurpation of Artavasdus (742-743) where he drew upon the dynastic loyalty of troops based there to recapture the imperial throne. Anatolikon was also the flash point for a number of army revolts in the course of the seventh and eighth centuries. Due to its importance the city was the object of repeated Arab invasions and raids, notably for the years 644, 646, 666/667, 669/670, 707, 715/716, 779, and 796. The history of Dark Age Amorium came to an end with the sack and destruction of the city on August 12, 838 by the armies of the Abbasid Caliph al-Mu tasim after a siege of twelve days. ${ }^{4}$ This was not

4 Brandes 1989, 133-135 with notes. Historical data on Amorium has been summarized by Belke/Restle 1984, 122-125, and by Lightfoot/Ivison 2002, 1-3. 
the end of Byzantine Amorium, however, since a new city was to rise upon the ruins of its predecessor during the middle Byzantine period.

The first European traveler to visit and identify Amorium was William J. Hamilton in 1836, who later described the site as a ruin-field strewn with "fallen buildings" and substantial ruins, one of which he identified as a church. ${ }^{5}$ The founding of the village of Hisarköy in 1892 considerably speeded the robbing of these remains for construction, and consequently few significant ruins stand above ground today. But despite these modern deprivations, the outlines of buildings and streets are visible on the surface, and the medieval archaeology beneath remains well preserved to a depth of several meters. Unlike other important Byzantine sites, most of Amorium is not buried beneath modern occupation. The modern village of Hisarköy occupies only a small portion at the center of the site, which now has legally protected status as an archaeological reserve. Amorium therefore is one of the few places in Turkey where systematic excavations can be conducted to explore a thematic capital, thus making it a key site for the study of Byzantine urbanism. It was with these specific goals that excavations and survey began in 1987, 2004 being the seventeenth season at Amorium. ${ }^{6}$

Before discussing the archaeological evidence from Amorium one must acknowledge that the excavations are ongoing and therefore new discoveries can and no doubt will change our current understanding. Indeed, part of the discussion below is based upon the most recent discoveries of the 2001-2004 seasons, the publication of which is still forthcoming. One must echo the cautious words of Wolfram Brandes that “... experience shows that data are often received and accepted too hastily, and without critical appraisal of what superficially looks like clear evidence" "T This is especially true of the use of preliminary reports, which by their very nature trace the evolving knowledge of a site season by season. Historians can be all too eager to mine provisional data from such publications, despite the fact that later reports may offer radically revised interpretations. As this essay will show, scholarly understanding of Dark Age Amorium itself is a case in point. One must also appreciate that Amorium is a large site - the so-called Lower City alone comprises some 75 hectares. Under such circumstances a sampling strategy was adopted to target promising and representative areas considered critical for the history of the site. Thus although the excavations constitute only portions of the entire urban area, these strategic interventions, combined with intensive field survey, do

5 Hamilton 1842, 448-455.

6 I am grateful to my colleague, Dr. Christopher S. Lightfoot, the Director of the Amorium Excavations Project, for the opportunity to publish this paper and for the many fascinating years we have spent contemplating the ruins of Amorium. We would also like to thank the Turkish authorities for supporting the Amorium Project and in particular, to acknowledge an enormous debt of gratitude to the Directorate of Antiquities in Ankara and the staff of the Afyon Museum.

7 Brandes 1999, 37-38. 
permit interesting observations on patterns of urban development between the seventh and ninth centuries. ${ }^{8}$ The Amorium Excavations Project has been publishing preliminary reports and scholarly articles since 1988 , and two volumes of the final publication have recently appeared (2002 and 2003). ${ }^{9}$ Such publications will make more materials available to the scholarly community and will inevitably continue to shape our understanding of medieval Amorium. Thus although this paper cannot represent the final word on Dark Age Amorium, it can at least serve as a prolegomenon for discussion. This essay therefore presents an overview of relevant findings to date (2004) and proposes a conceptual framework through which to view Dark Age Amorium, so that its development can be related to the other cities of the Byzantine world. To these ends, I will focus on three aspects that I propose characterize the development of Amorium during the Dark Ages. First, I will examine continuity in the form of the late antique/ early Byzantine fabric of the city; I will then turn to processes of change, adaptation, and urban evolution; finally I will discuss evidence of discontinuity. Throughout my paper I will emphasize the importance of the imperial government in preserving and stimulating urban life. Let us now consider the historical and social context of Dark Age Amorium before turning to the archaeological evidence.

\section{State and society at Dark Age Amorium}

The contraction of the imperial frontiers to the Taurus and Anti-Taurus ranges and the exposure of Anatolia to Arab invasion had a profound impact upon the life and development of Dark Age Amorium. The most important consequence was the withdrawal of the field army of the magister militum per Orientem from northern Syria and Mesopotamia and its settlement in Southern Central Anatolia. In Greek speaking Asia Minor this army of Oriens was translated into that of Anatolikon, and the Greek term thema (army) was soon applied to the entire region where it was based. The exact year when Amorium became the headquarters of the Anatolic thema remains unknown, but it must have occurred in the mid seventh century, following the withdrawal of the armies to Anatolia in the late $630 \mathrm{~s}$ and the $640 \mathrm{~s} .{ }^{10}$ Amorium's new role as a significant base of operations appears to be implied by the importance attached to its capture by Arab

8 Lightfoot/Ivison 2002, v, 5-6 (the history of the Project, sampling strategies, and methods of excavation and recording).

9 Lightfoot/Ivison 2002, with pages v-vi, 29-31 for Amorium publications. Preliminary reports have appeared in the journals Anatolian Studies (vols 38-46, 1988-1996), Dumbarton Oaks Papers (vol. 51, 1997- ) and in the archaeology symposium series published by the Turkish Ministry of Culture, Kazı Sonuçları Toplantısı (vol. 11, 1990- ). The second volume in the Amorium Monograph Series was published in 2003 (Lightfoot 2003). Further final reports are in preparation.

10 Haldon 1999b, 73-77; idem 1997, 113, 216. 
armies, who began targeting the city in $644 .^{11}$ The first clear reference to a formalized command structure of Anatolikon dates to $669 / 670 .{ }^{12}$

Recent scholarship has emphasized the crucial role of the state in the survival and development of cities during the upheavals of the Dark Ages, and Amorium was no exception. ${ }^{13}$ In the late sixth and early seventh centuries Amorium appears to have been a civilian settlement with a social profile typical of many cities in Western Asia Minor. When St Theodore of Sykeon visited Amorium around 600 the most important persons were the illustri or landed 'notables' (local aristocrats who dominated the city's public affairs) and the bishop. Theodore stayed at the suburban residence of the illustris Anastasius outside the city, where the saint healed the son of the illustris John in a private chapel of the Theotokos. Theodore was escorted into Amorium by a religious procession of the clergy and people and was invited to celebrate the liturgy in the cathedral by the bishop. ${ }^{14}$ The arrival of imperial administrators and the military commander or strategos and his staff in the mid. seventh century must have transformed the existing social hierarchy of the city, a process that was accelerated by the events of the Dark Ages. The repeated invasions and instability of the seventh and eighth centuries favored the militarization of provincial governance and by the later eighth century the civilian administration was being absorbed into the military command structure. By the mid ninth century, the strategos had assumed the powers of a military governor in charge of civil defense and administration and overseeing tax collecting and juridical matters, who was responsible only to the emperor himself. The strategos was assisted in this work by three senior officers or tourmarchai (sing. tourmaches) who commanded the three tourmai (sing. tourma) or army divisions of the thema. A lower tier of junior officers called drouggarioi led smaller subdivisions within each tourma termed drouggoi. ${ }^{15}$ It was 42 of these senior officers, the patrikioi, who were taken for ransom and later martyred following the fall of Amorium to the Arabs in 838. Accounts of the fall of the city and the Acta of the 42 Martyrs name some of the most notable, namely the strategos Aëtius, Theodore Krateros, Bassoes, Theophilos the patrikios and Constantine the drouggarios. ${ }^{16}$

By reason of their positions and powers these patrikioi must have dominated the life of Amorium. One should expect that buildings were constructed or adapted for the use of the thematic administration in Amorium, although no such structures have yet been

11 Brandes 1989, 53-54, 133-34.

12 Haldon 1999b, 86.

13 For example Haldon/Kennedy 1980, 92-94; Ivison 2000, 1-46.

14 Vie de Théodore de Sykeon, $\$ 107$ and No. 16. On the roles of the 'notables' in the cities of the sixth and early seventh centuries, see Liebeschuetz 2001, 110-120.

15 Haldon 1999b, 112-114. On the debate over the origins, organization and development of the themes, see also Haldon 1997, 208-253; idem 1993 1-67, esp. 2-11, and Whittow 1996, 96-133.

16 Theophanes Continuatus, 126; Acta martyr. Amor. 202-219; see also the discussion in Bury 1912, 267, No. 3, and 271, No. 3. 
identified. Building inscriptions from other Byzantine sites make it clear that the construction and maintenance of city fortifications were one of the chief responsibilities of a thematic strategos and his senior staff. These building works would be carried out by troops or by imposing a corvée on the local population. ${ }^{17}$ Neglect of these responsibilities by the patrikios and strategos Aëtius in the summer of 838 was a major factor in the fall of Amorium to the Arabs. ${ }^{18}$ An inscription from nearby Sivrihisar, located some $50 \mathrm{~km}$ to the north of Amorium, shows that thematic patrikioi also acted as private patrons in the region. The inscription records the embellishment of a church of the Theotokos by one "Aëtius, the protospatharios and strategos of the Anatolics and his wife Ampelia ...", who has been identified with the strategos who conducted the unsuccessful defense of Amorium in $838 .{ }^{19}$ In this regard, Aëtius was following the pious example of the imperial family and other members of the ruling élite throughout the Empire. ${ }^{20}$ The actions of military officers and other thematic officials towards private patronage and the acquisition of landed property at Amorium should therefore not be excluded. ${ }^{21}$

Members of the clergy, led by the bishop, would have constituted the other influential group in Dark Age Amorium. Amorium was a bishopric, rising in status from a suffragan see of Pessinus at the start of the seventh century to an autokephalos archbishopric by the early ninth century. ${ }^{22}$ Although never rivaling imperial officials in terms of power, Byzantine bishops were notable figures in urban society, promoting the imperial establishment and serving as local representatives. ${ }^{23}$ During the 838 siege, for example, the chronicler Michael the Syrian (twelfth century) records that the strategos Aëtius sent the bishop with three military officers on an embassy to Caliph al-Mu'tasim to negotiate for the safety of the inhabitants of Amorium if the city surrendered. ${ }^{24}$ In addition to pastoral work and politics one should expect that the bishopric also played a role in the local economy through its properties. ${ }^{25}$

To date, at least four major churches have been identified at Amorium: the socalled Lower City Church, which is discussed below, and three unexcaveted churches: two in the Lower City, and another church on the Upper City. It is yet uncertain whether any of these buildings can be conclusively identified as the cathedral, and further churches and chapels may yet await discovery. The pedestal of a monumental column discovered at the site of the Lower City Church bears an inscription dated to the sixth century that sheds

17 Ivison 2000, 8-14.

18 Ivison 2000, 13-14; al-Tabari 108-109 [1245-46]; Theophanes Continuatus, 130.

19 CIG IV, xl: Inscriptiones christianae, No. 8682.

20 Ivison 2000, 22-23.

21 Haldon 1999a, 19-22.

22 For the history of the bishopric of Amorium and known bishops from seals and documentary sources, see Belke/Restle 1984, 123-124.

23 Whittow 1996, 129-133; Ivison 2000, 19; Liebeschuetz 2001, 145-55.

24 Michael the Syrian, 98-99.

25 Dagron 1977, 10, 21-23. 
further light upon ecclesiastical arrangements at Amorium. The monument was dedicated to the martyr saint Konon and mentions a bishop Markos (presumably of Amorium) and one Christophoros, the hegoumenos or abbot of a monastery. This monastery was presumably located at or near Amorium although we have no indication of its location or dedication. ${ }^{26}$

Soldiers would have been a familiar sight in the streets of Amorium, and must have made up a significant portion of the population. Although originally these soldiers had come from Northern Syria and Mesopotamia, in the course of the eighth century thematic troops became increasingly localized as soldiers put down roots and came to be recruited locally. By the ninth century thematic forces had evolved into two major categories. The best trained thematic forces were salaried, standing troops that probably served as garrisons in forts and cities throughout the theme. The larger category consisted of part-time militia recruited locally that would muster for campaigns and were supplied largely in kind. ${ }^{27}$ The number of soldiers that formed the permanent garrison at Amorium itself must remain speculative, but according to Theophanes Confessor the future emperor Leo III defended the city against an Arab attack in 715/716 with only 800 troops. It remains open to question whether such purported numbers could adequately defend the $3 \mathrm{~km}$ of the Lower City Walls. ${ }^{28}$ Seasonal fluctuations of troop numbers should also be expected in response to the campaigning season and Arab attacks. From the mid eighth century élite tagmatic forces would accompany the emperor on campaign, and during the crisis of 838 three tagmatic regiments helped to defend the city. ${ }^{29}$ The presence of large numbers of troops would have served as a strong stimulus to the local economy in terms of goods and services requisitioned locally and by soldiers spending their pay. ${ }^{30}$ The billeting of troops may also have prompted the construction of military facilities such as barracks, stables, armories, and storehouses.

Less is known about the civilian population of Amorium during the Dark Ages, and numerical estimates in medieval sources must be treated with extreme caution. The Byzantine source Theophanes Continuatus, writing in the tenth century, reported that 70,000 were killed in the sack of Amorium in 838, whereas the Arab chronicler Mas'udi (c 896-956) reported that 30,000 perished. The Arab historian al-Tabari (838923) informs us that 6,000 male captives were killed on the return march to Samarra. ${ }^{31}$ Although these figures give some idea of the magnitude of the event in the minds of

26 Anatolian Studies 42, 1992, 211, pl. XLVIII (a). To date, two other hegoumenoi of Amorium are known, suggesting that the monastery continued to function through the Dark Ages. See Prosopography of the Byzantine Empire I: entries for Elias 29 (seventh century) and Theodoros 96 (dated 787).

27 Haldon 1999b, 122-123; idem 1993.

28 Brandes 1989, 66-67; Lightfoot 1998b, 61.

29 Haldon 1999b, 77-78; Lightfoot 1998b, 61-62.

30 Haldon 1993, 66; Ivison 2000, 25.

31 Theophanes Continuatus, 130; al-Mas 'udi, 119 [1255]. Treadgold 1988, 444-45, No. 415, proposed a population for Amorium of 30,000 based upon these figures. 
these authors, such numbers are inevitably prone to exaggeration and no great reliance should be placed upon them. One should also consider that the city's population could fluctuate during Arab raids, either because the inhabitants of the locality sought refuge at Amorium, or due to the evacuation of non-combatants, as during the siege of 715/716. ${ }^{32}$ Whatever its true size, the civilian population of Amorium was certainly diverse enough to support a significant Jewish community and Christian heretical groups. Jews were apparently well established in the city, but we know little of the life of the community and no archaeological traces have yet come to light. ${ }^{33}$ Orthodox Christian writers closely associated the Amorium Jews with the heretical movement of the Athinganoi, the latter being regarded as the most notorious inhabitants of the region. The actual practices of the Athinganoi are difficult to reconstruct due to the deliberate conflation of their practices with other heresies by Orthodox authors. They were portrayed as a Judaizing group who adopted levitical codes of purity, kept a dual Sabbath and practiced astral magic. Emperor Nicephorus I (802-811) who came from Phrygia, and the Amorian emperor Michael II (820-829), were accused by hostile historians of being pro-Jewish or even crypto-Athinganoi by reason of their origins. ${ }^{34}$ Due to his provincial roots, Michael II was also depicted as an illiterate peasant unfit for the imperial office. According to Theophanes Continuatus:

However, Michael [II] was well versed in his own pursuits: that is to say, he could tell of a litter of pigs which would grow up healthy and strong, and vice versa. He knew how to stand up close to a kicking horse, and to get out of the way of the heels of a kicking donkey. He was an excellent judge of a mule, and could tell you which was the better for a baggage-animal and which for a rider. He could distinguish between speed and stamina in a war-horse, and say which of your cows and sheep would be best for breeding or supplying milk .... Such were the tastes of his youth and age, and on these he prided himself in no small degree. ${ }^{35}$

Such ad hominem attacks should be treated with skepticism, but they do suggest that Amorium enjoyed the popular reputation at Constantinople of a city that produced either spiritual deviants or country bumpkins. In fact, as the quotation of Theophanes Continuatus suggests, it seems likely that many of the inhabitants of Amorium were employed in supplying the thematic forces with livestock and agricultural produce, although archaeological evidence discussed below also indicates the presence of smallscale manufacturing.

32 Theophanes Confessor, 538-540, No. 386-391

33 Sharf 1971, 72-76, 86; Starr 1970, 30, 46, 48, 98, 109.

34 Starr 1936, 93-106; Gouillard 1965, 307-312; Sharf 1971, 72-74.

35 Theophanes Continuatus, 43-44; English translation in Jenkins 1966, 140. 


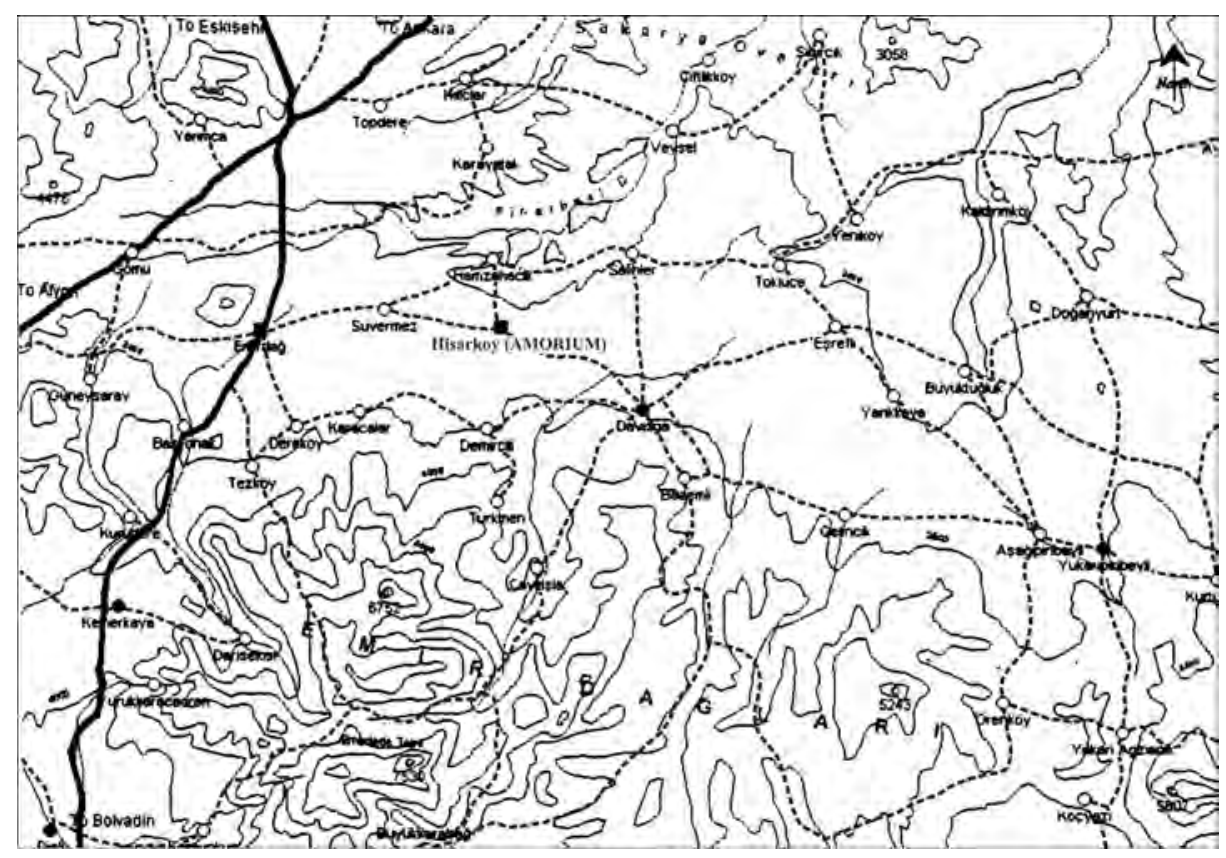

Fig. 2. Contour map of the region around Amorium

\section{Rise to thematic capital: Amorium's advantages}

The historical record does not document the reasons for Amorium's selection as a thematic headquarters, but like other sites, the answers must derive in part from the advantages offered by the city's location and facilities. In terms of communications, Amorium was located at a strategic nexus of highways; the road to the northwest leads to Dorylaeum (modern Eskişehir), Nicaea (İznik), and so on to Constantinople; it continued in a south-easterly direction to Iconium (Konya) and thence to the Cilician Gates. Another road connected Amorium with Pessinus (Ballihisar) and Ancyra (Ankara), and so on to Cappadocia and the east, while other routes led to Akroinon (Afyon) and thence to the Aegean coastal cities (Fig. 1). ${ }^{36}$ The location of Amorium astride these roads, especially those connecting the imperial capital with the new frontiers of the Caliphate along the Taurus mountains, can hardly have escaped the attention of military planners, and this fact is reflected in the documented movements of Arab armies and imperial forces. The landscape around Amorium also offered strategic advantages for its defenders (Fig. 2). The vicinity is characterized by low, rolling hills, cut by streams feeding the ancient Sangarius (modern Sakarya). As any modern visitor can attest, this

36 Belke/Restle 1984, 122-125; Lightfoot/Ivison 2002, 1; Anatolian Studies 38, 1988, 175. 
topography serves to conceal Amorium, the site of which only becomes visible within the last few kilometers. Conversely, the site of Amorium affords excellent views of the surrounding countryside in all directions, and on clear days up to a distance of $50 \mathrm{~km}$ away. The mountain range of the Emirdağları to the south also served to shield the city. Field surveys have discovered the ruins of small Byzantine towers in the mountains that could have served as advance warning stations for the city in the plain below. The Emirdağları mountains also served as a occasional refuge for the city's inhabitants: Theophanes Confessor records that in 715/716 the strategos Leo (later emperor Leo III) sent non-combatants (largely women and children) together with the bishop to the mountains for safety during an Arab siege. ${ }^{37} \mathrm{~A}$ good water-supply and stockpiles of food and other materials were essential for a successful defense during such Arab attacks, and for the needs of the thematic troops. Byzantine Amorium was blessed with plentiful supplies of fresh water drawn from a water table some $8.50 \mathrm{~m}$ beneath the modern ground surface. Excavation shows that wells supplied the city's needs during the medieval period. ${ }^{38}$ The inhabitants also had easy access to good food supplies from the fertile fields of the surrounding countryside. Amorium is situated at an elevation of c 925-945 m above sea level, and so shares the same climate and temperature as the rest of the Anatolian plateau, with cold, snowy winters and hot, arid summers. Floral and faunal remains excavated at the site reveal the presence of cereal crops such as barley, together with vegetables and fruits, as well as livestock such as cattle, sheep, goats, and other animals..$^{39}$ Archaeological data and contemporary practice at modern Hisarköy suggest that conditions at Byzantine Amorium must have resembled those described by bishop Leo, metropolitan of Synnada, writing in the late tenth century:

You see, we do not produce olive oil; this is something we have in common with all the residents of the Anatolikon theme. Our land does not yield wine because of the high altitude and the short growing season. Instead of wood, we use zarzakon, which is really dung that has been processed, a thoroughly disgusting and smelly business. All the other requisites for the healthy or infirm we solicit from the Thrakesion theme, from Attaleia, and from the capital itself. ${ }^{40}$

Beyond the advantages endowed by nature, another major factor in the rise of Amorium must have been the impressive legacy of constructions that had expanded the city in Late Antiquity. Until the upheavals of the seventh century, Amorium does not appear to have been an imperial administrative center of much consequence. Ancient Amorium probably

37 Theophanes Confessor, 538-540, No. 386-391; on Byzantine towers discovered during survey in the Emirdağları, see 17 Kazı Sonuçları Toplantısı, II (Ankara 1996), 367 and Res. 8.

38 Lightfoot/Ivison 2002, 1, 9.

39 Anatolian Studies 43, 1993, 152-153; Anatolian Studies 45, 1995, 124-127; Lightfoot/Ivison 2002, 1.

40 Leo Correspondence, 68-71, No. 43. 


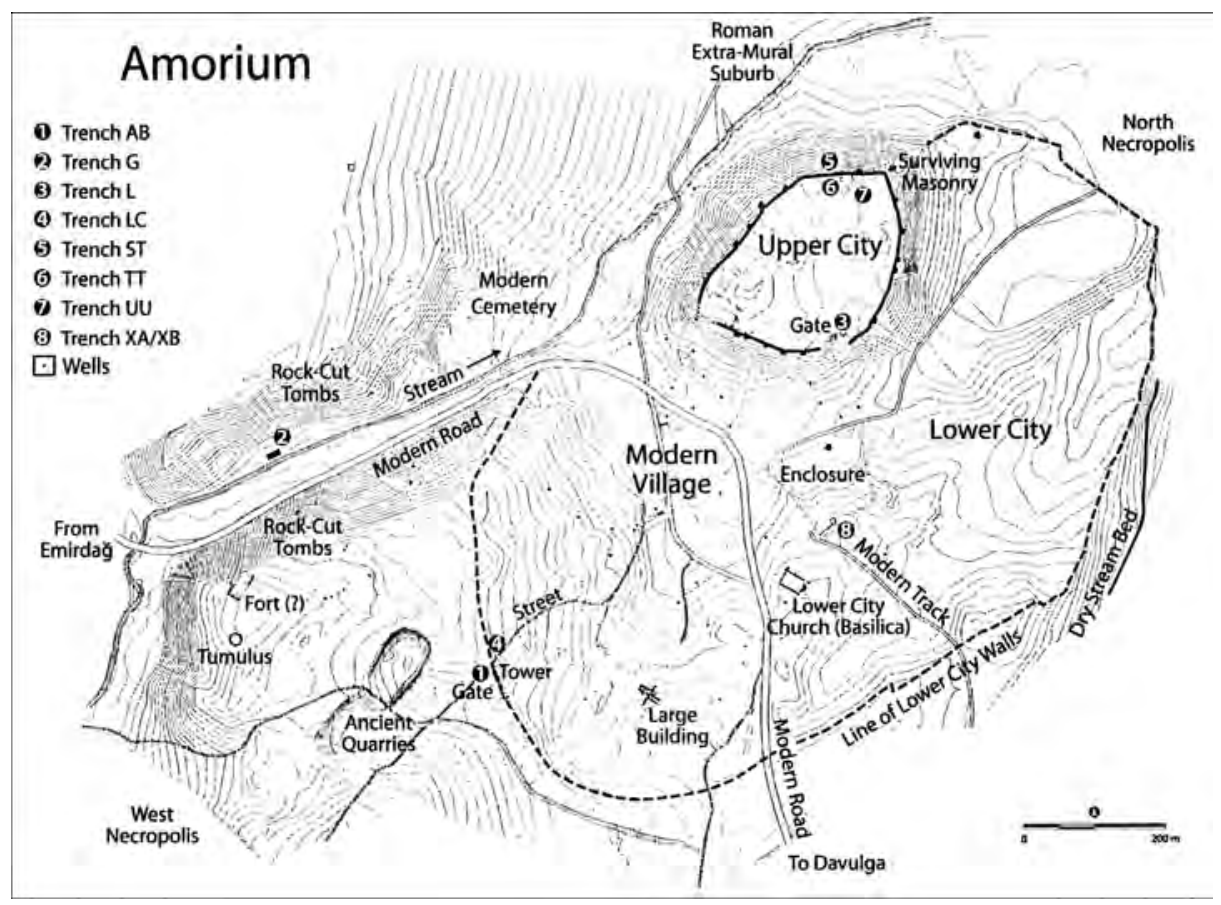

Fig. 3. Topographical site plan of Amorium (2001)

lies beneath the mound or hüyük now designated the Upper City, which stands testimony to centuries of human occupation (Fig. 3). Recent survey suggests that the civic center of the Roman city may have stood at the foot of the southern slope of the mound in the area termed the Lower City, on the saddle where the modern village of Hisarköy now stands. Fragments of architecture indicate the existence of classical public buildings and civic shrines under the early Empire, as well as the growth of an extensive extramural necropolis. A major change in Amorium's fortunes occurred in the later fifth and sixth centuries however, when the city was greatly extended and endowed with new public buildings. Excavations at the so-called Lower City Walls, the Lower City Church, the Large Building, a bathhouse and its surrounding district beneath the middle Byzantine structure termed the Enclosure have revealed evidence for this expansion (Fig. 3). These discoveries lend weight to the word of the later Byzantine historian Kedrenos, who states that Amorium was 'built' ( $\varepsilon \kappa \tau i ́ \sigma \theta \eta)$ by the emperor Zeno (474-491). Interestingly, an Arab tradition ascribes its construction to his successor the emperor Anastasius I (491-518). ${ }^{41}$ Archaeological evidence discussed below further demonstrates that all of these structures were maintained through the Dark Ages into the early ninth century.

41 Kedrenos I, 615. For the Arab sources, see Belke/Restle 1984, 123, and No. 9-11. 


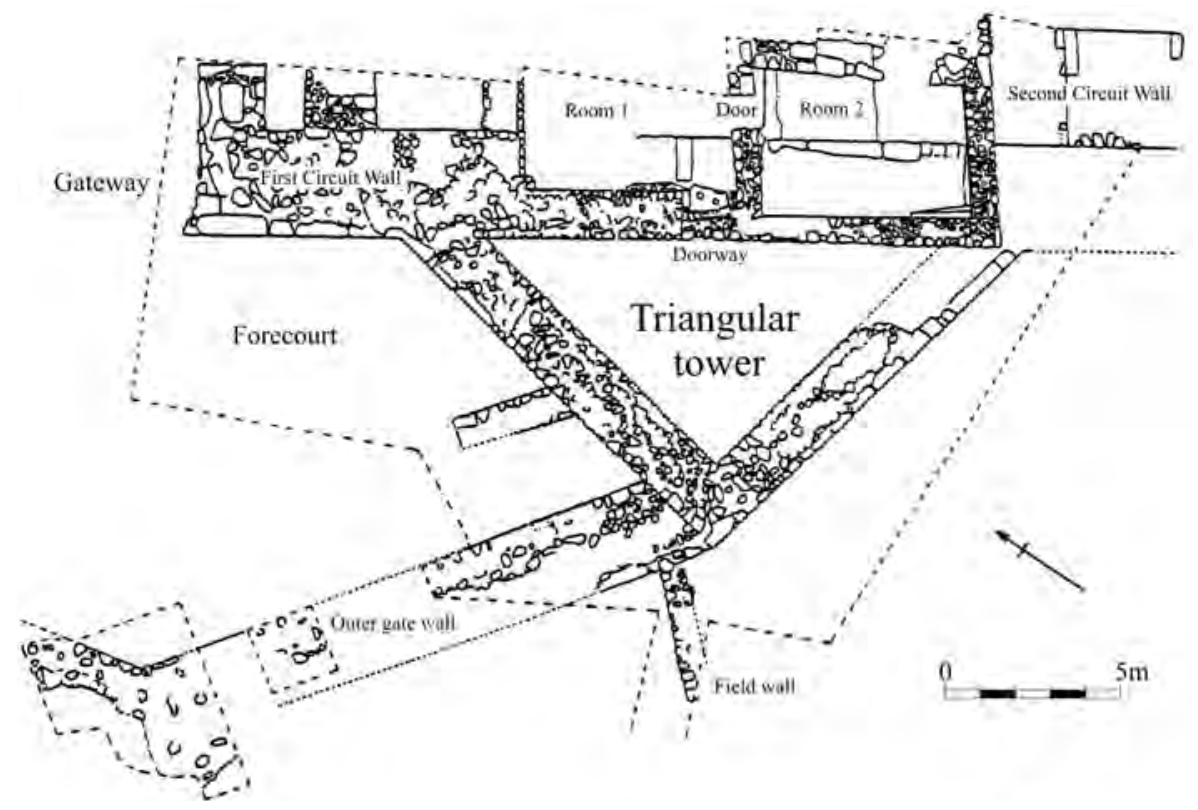

Fig. 4. Plan of the Lower City Walls, Trench AB, 1990

A new set of defensive walls, the Lower City Walls, were constructed to the south and east of the Upper City and the old Roman city, thus increasing the size of the so-called Lower City to 75 hectares (Fig. 3). Within this circuit a new street system must also have been laid out or extended, along with entire new quarters of the city. The construction of these new fortifications was a massive undertaking, running for some $3 \mathrm{~km}$ and built de novo. The builders shrewdly took advantage of the topography, siting the defensive wall itself in the more defensible position on the crests of the low hills surrounding the Lower City, and utilizing seasonal wadis and earth dug ditches as a fosse below the walls. The wall was strengthened by circular and polygonal towers (remains of over 20 have been located by survey so far), and was pierced by at least four major gates flanked by towers. Excavations in Trench AB on the southern stretch of the circuit have revealed one of the city gates flanked by triangular towers (Figs. 3.1 and 4). At its footings, the mortared rubble core of the Wall was faced with courses of massive limestone blocks. Smaller courses of brick and stone blocks alternated above (Fig. 5). Dendrochronological evidence from Trench AB on the Lower City Walls provides a terminus post quem for construction of $487 \mathrm{CE}$, while comparable fortifications in the Roman East suggest a date in the later fifth to early sixth centuries. ${ }^{42}$ These rela-

42 Lightfoot/Ivison 2002, 8-9, 11-12; Lightfoot 1998b, 60-62; Anatolian Studies 38, 1988, 176 179, fig. 2. For the dendrochronology, see Kuniholm 1995, 35 and Anatolian Studies 44, 1994, 127-128. 


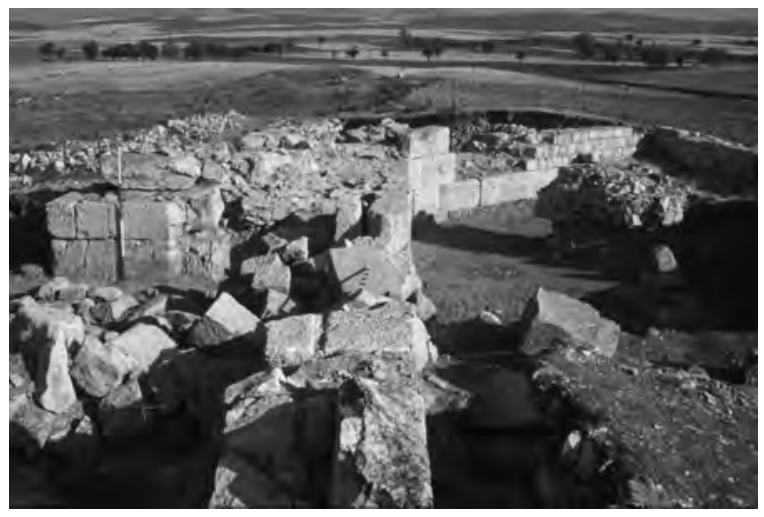

Fig. 5. View from the north of Trench $\mathrm{AB}$ on the Lower City Walls showing the gateway and flanking triangular tower to the south

tively new and state-of-the-art defenses must have been a decisive factor in the choice of Amorium as a thematic headquarters.

A similar date can also be proposed for the construction of the Christian basilica designated the Lower City Church (Figs. 3 and 6). The basilica was built in the same manner as the Lower City Walls, utilizing large ashlars for the lower courses, above which were courses of smaller stone blocks probably alternating with bands of brick. Recent study shows that the basilica and a connected ecclesiastical complex were initially built in one phase ('Phase I'). Pottery from the foundations, the plan, and the interior decorations of the basilica indicate a construction date in the later fifth and early sixth centuries. ${ }^{43} \mathrm{~A}$ similar construction technique and dating has also been proposed for the so-called Large Building in the south sector of the Lower City. Only a small part of this structure has been excavated, and although its function remains unclear, it seems likely that it formed part of a more extensive complex, possibly of a public or official nature. ${ }^{44}$

Since 2000 excavations beneath the middle Byzantine fortification termed the Enclosure has revealed a bathhouse and its surrounding district (Fig. 3). The bathhouse was built in one phase, consisting of a polygonal entrance hall or apodyterium (designated Structure 3, Fig. 7A) that led to a rectangular block (Structure 1) containing the bathing chambers (Fig. 7). The architecture and pottery from the foundation levels indicate a date in the sixth century for its construction, and attest to the splendor of its original form. The apodyterium was vaulted, with half domes over the recessed niches flanking a barrel-vaulted ambulatory. Six marble columns with basket capitals probably supported a shallow dome at center. The interior walls were sheathed with marble revetment, some of which was imported from Greece, including Thessalian

43 Lightfoot/Ivison 2002, 14; Anatolian Studies 43, 1993, 155, 156-159.

44 Lightfoot/Ivison 2002, 11, figs D-E; Anatolian Studies 39, 1989, 171-172 and pls XLVI (ab) and XLVIII (a) showing a sixth century Ionic impost capital. 


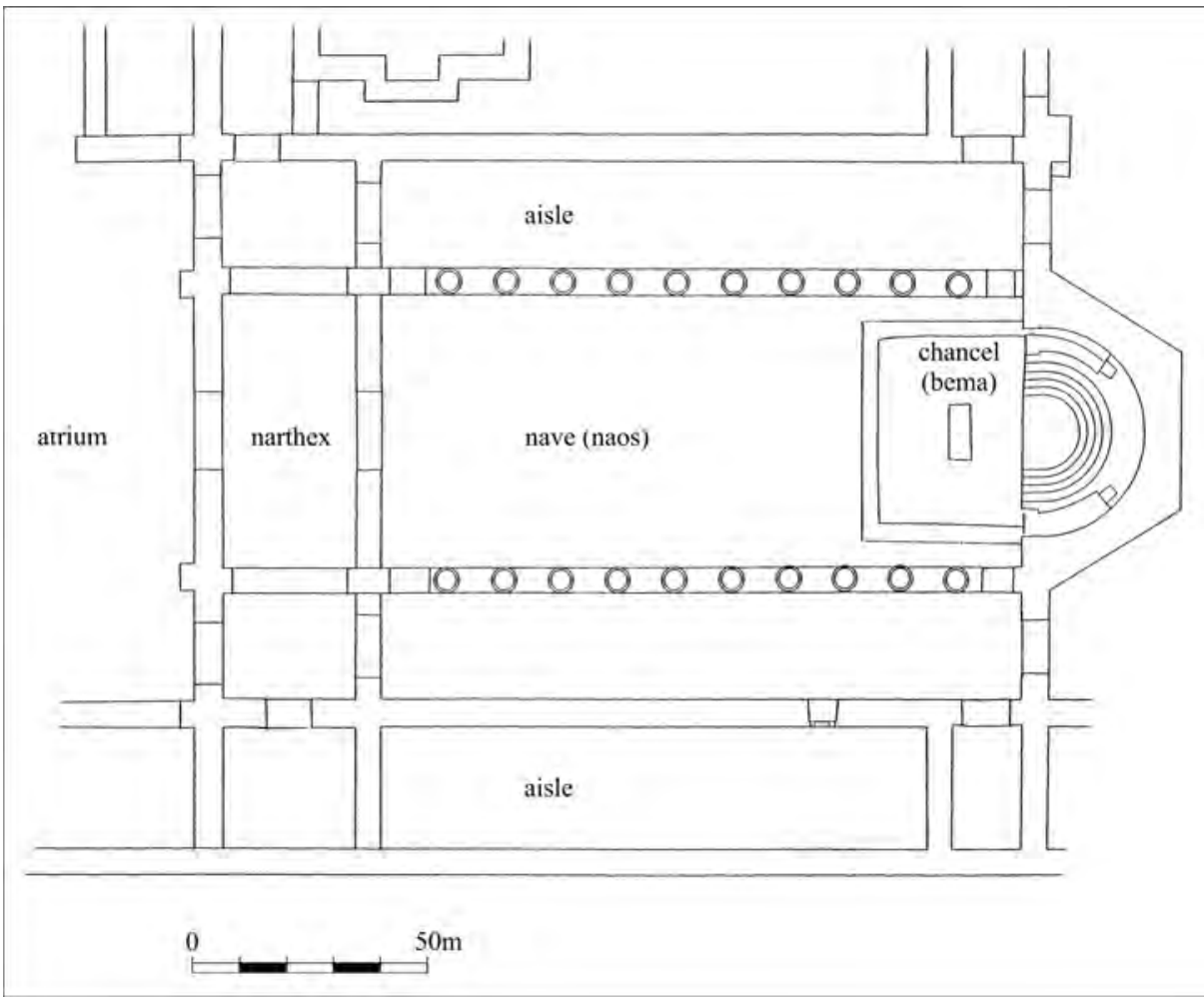

Fig. 6. Reconstructed plan of the Christian basilica (phase 1) at the Lower City Church site

verde antico and marmor lacedaimonium from Laconia. The rooms of the bathhouse proper were similarly decorated, although as we shall see, these decorations were subject to extensive renovation during the eighth century. Given the urban context of the Amorium bathhouse there seems little reason to doubt that it was a public establishment. Although of small size compared with the great public thermae of earlier centuries, the Amorium bathhouse compares well with our knowledge of the smaller public baths of the sixth century. ${ }^{45}$

The late antique framework of public buildings, streets, and public and private spaces formed the grid within which the Dark Age city developed. In this respect Amorium follows a pattern observed at other cities of comparable rank and size

45 On the bathhouse excavations (Trench XC), see: Dumbarton Oaks Papers 55, 2001, 381-394; Dumbarton Oaks Papers 58, 2004, 356-363 (forthcoming); Dumbarton Oaks Papers 59, 2005, forthcoming for the 2002 season. See also the brief summaries in 24 Kazı Sonuçları Toplantısı, 1 (Ankara 2003), 521-523, Res. 1-5, and 25 Kazı Sonuçları Toplantısı, 1 (Ankara 2004), 1-3, Çizim 1, Res. 1-5. For a small bathhouse of similar date, see Sanders 1999. 


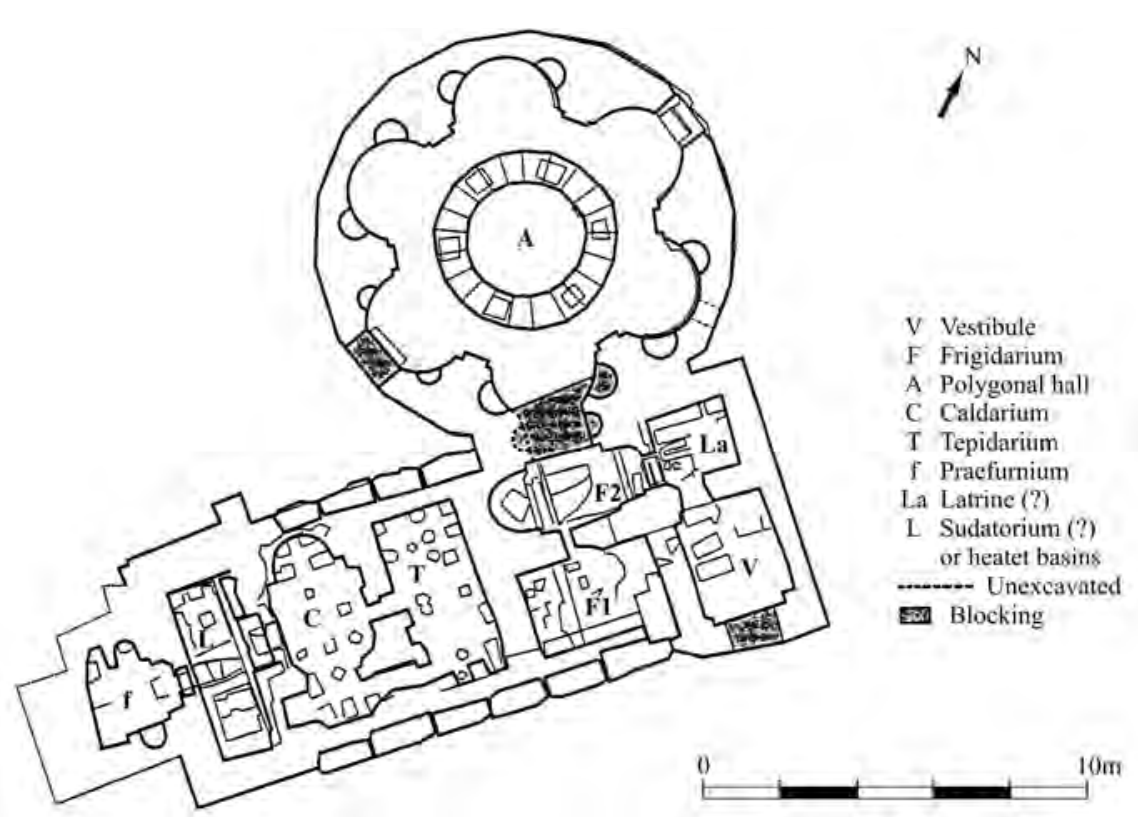

Fig. 7. Plan of the early Byzantine and Dark Age bath complex

during the Dark Ages. For example, the late antique city walls of Thessaloniki, its Roman grid and public spaces, and the city's great Christian basilicas, such as those of Saint Demetrius and the Mother of God (modern Acheiropoïtos), remained a dominating presence, shaping the development of the medieval city. ${ }^{46}$ Nicaea became the thematic capital of Opsikion, no doubt in part because of its inheritance of mighty city walls. ${ }^{47}$ And like Nicaea and Constantinople, the city walls of Amorium were clearly not deemed too extensive to be defended. In this light, perhaps we should consider that the large spaces such cities enclosed offered positive advantages for the imperial authorities and the inhabitants. Only portions of the Lower City at Amorium have been excavated so far, and so one cannot yet say whether all the area was intensively occupied. The model of Constantinople may offer a working hypothesis, however, by suggesting that unoccupied areas in Amorium, especially near the city walls, could have been utilized for market gardens, water storage, and cemeteries. ${ }^{48}$

46 On medieval Thessaloniki, see the essay by Charalambos Bakirtzis in this volume; for the city walls, see Gounaris 1982, 13-15; for the basilica of Saint Demetrius, see Bakirtzis 1988.

47 Foss/Winfield 1986, 80, 100-102, 113.

48 Mango 1980, 76, and Mango 1990, 56-60. 


\section{The urban fabric in the Dark Ages: repairs, recycling and adaptation}

The maintenance of older structures such as city walls and churches was of vital concern to the imperial authorities during the Dark Ages. These buildings were crucial bulwarks, defending against the enemy, be it the Arabs or demonic forces. These structures helped to preserve the state and its inhabitants, but also served ideological purposes, reminding the emperor's subjects and his enemies of the power and majesty of the Empire. ${ }^{49}$ Excavations at Amorium have found evidence for the maintenance of such critical structures in the forms of the Lower City Walls, and the basilica of the Lower City Church.

The excavations at Trench $\mathrm{AB}$ prove that the Lower City Walls were in use and maintained through the Dark Ages up into the ninth century. This evidence lends new credibility to the Arab accounts of Amorium which emphasize the strength of the fortifications. ${ }^{50}$ The ninth century Arab geographer Ibn-Khordādhbeh specifically mentions the height of the circuit wall, 44 towers and the presence of a moat, features that approximate to the Lower City Walls. ${ }^{51}$ Trench AB on the western stretch of the Lower City Walls exposed a gateway and associated street, with flanking triangular towers, as well as Dark Age occupation adjacent to the curtain wall later buried beneath domestic structures of the late tenth and eleventh centuries (Figs. 4 and 5). Excavation revealed that the massive curtain wall at Trench $\mathrm{AB}$ had been strengthened sometime between the sixth and ninth centuries with the addition of an inner skin and the construction of an forecourt to shield the gateway from attack. Occupation layers excavated within the basement of the south triangular tower also offer insights on the uses of such towers during the Dark Ages. The lowest occupation layers show that the basement was used as a refuse dump and latrine by the defenders. Large numbers of rodent skeletons were found in this organic layer, together with pottery of the sixth and first half of the seventh centuries. After this date, the basement was made serviceable by laying a fresh earth floor which was then strewn with straw. ${ }^{52}$ Despite such efforts to keep the walls in repair, the Arab historian al-Tabari records that erosion of the elements and poor maintenance were to blame for the weakness of a stretch of the walls targeted during the 838 siege. The wall failed and Amorium fell, suggesting that decrepitude and neglect were also characteristics of even vital structures of the Dark Age city. ${ }^{53}$

The Lower City Basilica was a major monument of the city, forming part of a larger complex of rooms and buildings that extend to the north and south (Fig. 6). The western part of the complex appears to be supported by an artificial terrace, while the

49 Ivison 2000.

50 Contra the comments by Brandes 1999, 38-40.

51 Ibn-Khordâdhbeh, vi, 77-80.

52 Lightfoot/Ivison 2002, 12-13; Anatolian Studies 44, 1994, 110-111.

53 Ivison 2000, 13-14; al-Tabari, 108-109 [1245-46]; Theophanes Continuatus, 130. 
site commands an elevated position in the Lower City. This basilica was in use for over 300 years through the Dark Ages until its complete destruction by fire. During the Dark Age period efforts were made to keep the structure in repair. At both western and eastern ends of the nave arcades buttresses were constructed, artfully inserted between the pilasters and the adjacent column. Unlike the original walls, these buttresses were built of spolia, bonded with brick courses and timber lacing. As a result, painted wall plaster was sandwiched behind these constructions. These buttresses must have served to strengthen the arcades at their weakest points, a fact that is suggestive of ravages of old age. The persistence of such older church buildings through the Byzantine centuries, which were often subject to alteration and addition, links Amorium with Hagia Sophia at Nicaea, the basilicas of Thessaloniki, and the Cuman'ın Camii at Attaleia (Antalya), and the many churches of Constantinople. ${ }^{54}$

It would appear that the events of the seventh century did lead to some reorganization of urban space at Amorium however. Two of the most profound transformations were the fortification of the ancient mound, creating an inner citadel or Upper City, and the destruction and abandonment of the Roman extramural cemeteries. At present one can only speculate on the nature of occupation on the ancient mound of the Upper City before the seventh century (Fig. 3). Perhaps pagan shrines were located on this high place, but in any case, such cults must have been suppressed in the Christian Amorium of the fifth and sixth centuries. The surface remains of a late antique basilica on the Upper City would appear to confirm this supposition. ${ }^{55}$ At the southern foot of the mound the walls and massive vaults of a major early Roman structure are visible, most probably of a civic complex. ${ }^{56}$ The function and appearance of the Upper City was drastically altered by the construction of a new fortification encircling the top of the mound. Excavations in Trenches L and ST revealed remnants of this defensive wall containing large quantities of Roman spolia, particularly pagan funerary stelai. The spolia foundations of this wall can also be traced around the edges of the mound where erosion has exposed the blocks. Only the lowest courses of this first fortification have survived since the rest had been robbed away and backfilled before the construction of a later, middle Byzantine enceinte of quite different character. ${ }^{57}$ Excavations in Trench L also revealed some structures ('Phase 2') associated with these spolia fortifications. A paved street east of the spolia wall has been assigned to the same general period, together with two rooms flanking a passage leading to a courtyard (Fig. 8). These structures also made extensive use of spolia gravestones. The fortification of the mound thus divided

54 Ivison 2000, 8, 19, 22-23 and No. 42-46; on Constantinople, see the Vita Basilii, 192-194 (Theophanes Continuatus, V, $321 \mathrm{ff}$.).

55 Lightfoot/Ivison 2002, 7-8. Roman cults attested from civic coins at Amorium include those of Zeus and Tyche (Anatolian Studies 40, 1990, 216 and No. 11).

56 Dumbarton Oaks Papers 53, 1999, 347, fig. 9.

57 Lightfoot 1998b, 63-66; Lightfoot/Ivison 2002, 15-17. 


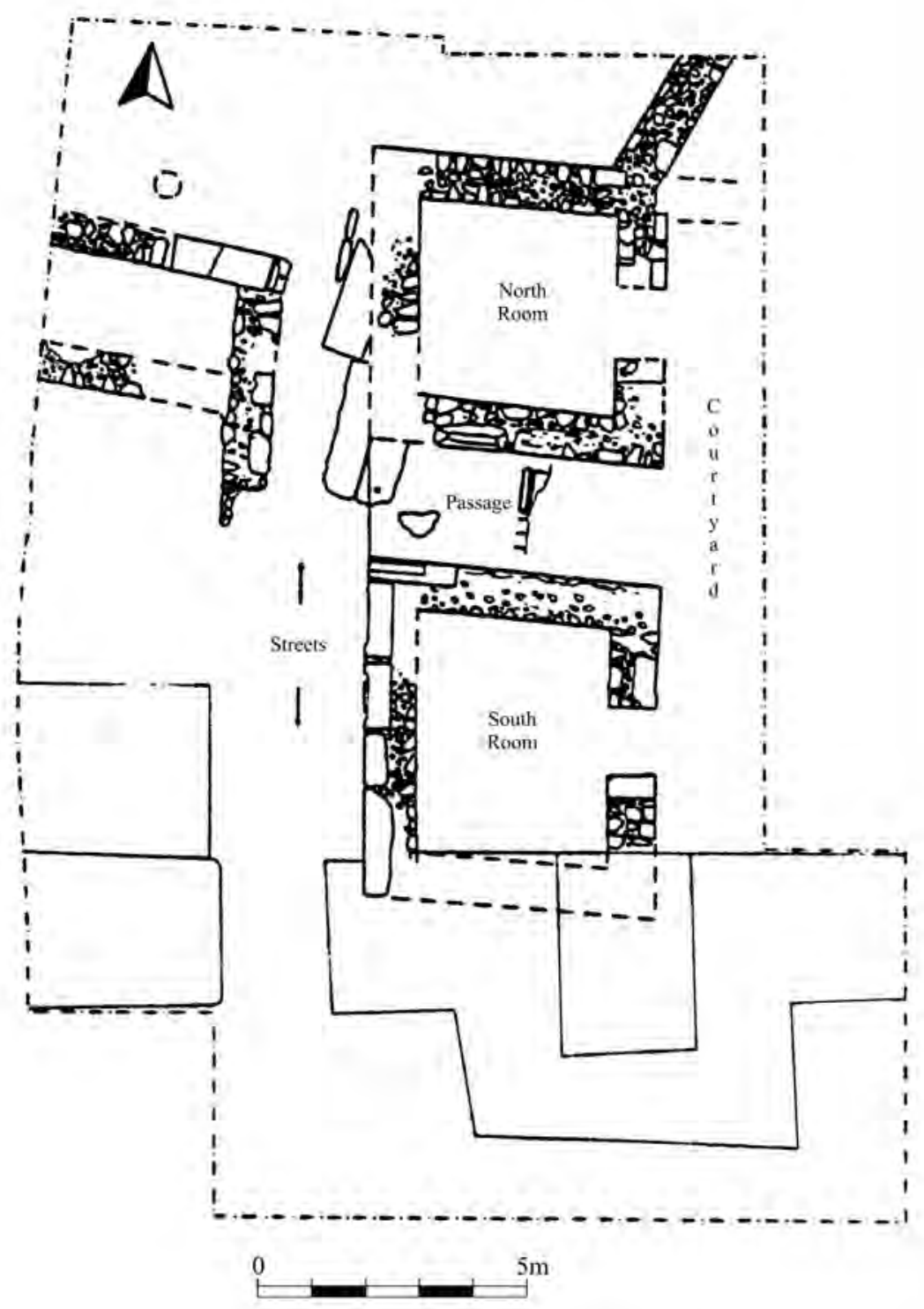

Fig. 8. Plan of Upper City Trench L, 1990, 'Phase 2' 
Amorium into two zones - an Upper City or inner citadel, and a Lower or residential City. The stratigraphic level of the spolia fortification and the buildings in Trench L places these features well below the middle Byzantine strata of the tenth and eleventh centuries that sealed its remains. Given this terminus ante quem, it seems reasonable to assign these structures to the Dark Ages of the seventh to ninth centuries. ${ }^{58}$ The extensive use of spolia in the Upper City fortification (which are not found in constructions of the fifth and sixth centuries at Amorium) may also be directly compared with those at Ancyra, Sardis, and Ayasoluk at Ephesus, all of which have been assigned to the seventh or eighth century. ${ }^{59}$ On this basis, C.S. Lightfoot plausibly proposed a Dark Age date and function for the new wall:

The use of spolia, however, is common to many Byzantine fortifications, and a date in the mid- $7^{\text {th }}$ century would not seem inappropriate for the construction of the first-phase all around the Upper City. Indeed, it may have been prompted not so much by the Persian raids in the 610-20s as by the new role that Amorium assumed as the headquarters of the magister militum per Orientem in the 640 s. So, while the civilian inhabitants, perhaps, continued to look to the Lower City walls for protection, the military may have established a secure base in the most suitable position, the Upper City. ${ }^{60}$

The division of a number of Byzantine thematic cities into an upper and lower city would certainly suggest the application of some kind of zoning, perhaps in response to the needs of government. Further excavation is needed to clarify the nature of the Dark Age occupation on the Upper City, and to determine whether this citadel had a special function within the city, such as sheltering the offices of the thematic administration.

To judge from the very broken state of the small number of Roman sculptures and inscriptions found in medieval levels at Amorium it would appear that little sentiment was attached to visible remnants of the pagan past. ${ }^{61}$ Pagan temples, defunct civic structures, and abandoned pagan cemeteries were demolished at many sites in the Byzantine world in order to furnish stone for churches and fortifications during the seventh to ninth centuries. At Nicaea, for example, the Roman theater was amongst the structures stripped of its stones to restore the walls after the damaging Arab attack of 727. The same is true of the citadel walls of Ancyra. ${ }^{62}$ Amorium would seem to fit this pattern of recycling the older, redundant structures of the city to repair and change the urban fabric. The reuse of pagan tomb stelai in the fortifications of the Upper City clearly indicates the abandonment of the extramural cemeteries and the retreat of activity within the Lower City Walls (Fig. 3). This deduction is confirmed by survey: the

58 Lightfoot/Ivison 2002, 15-16, fig. J.

59 Foss/Winfield 1986, 131-142, 288-290, figs 10-17.

60 Lightfoot 1998b, 64-65.

61 Anatolian Studies 44, 1994, 117-118.

62 Foss/Winfield 1986, 100, 133-37, 272, figs 28-29, 288-289, figs 11-12; Foss 2003, 252. 


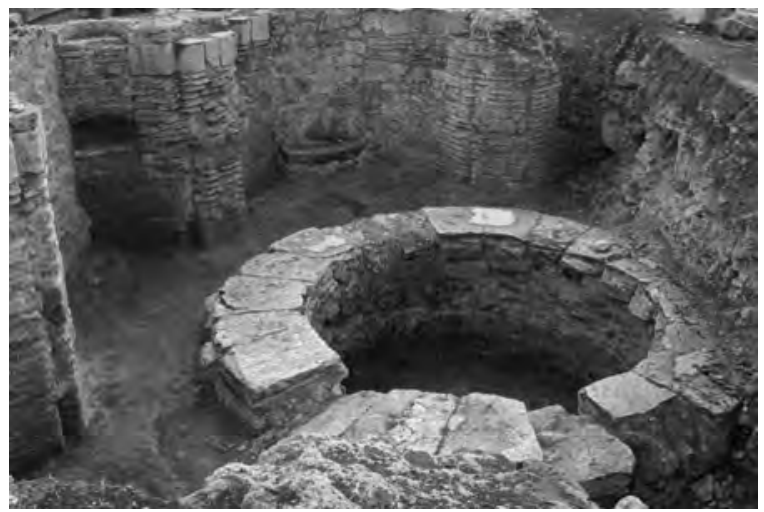

Fig. 9. The bath complex at Trench $\mathrm{XC}$ : View of the partially excavated apodyterium (room A) from north

latest material from extramural suburbs dates to the early seventh century. Even the Christian extramural cemeteries were abandoned: the latest object from a tomb outside the west gate was a 'Syracuse type' belt buckle dating to the early seventh century. ${ }^{63}$ No cemeteries of the Dark Age have yet been discovered at Amorium, but it seems likely that burial had become associated with intramural churches, as has been documented at many other sites.

A short distance from the Lower City Basilica complex is the excavation area here termed the bathhouse district, which has provided important evidence of continuity and change in Dark Age Amorium (Fig. 3). ${ }^{64}$ On the southern side of the bathhouse there appears to have been a large courtyard, flanked by large buildings of the fifth to sixth centuries to the west and south. A street may be postulated to the east, facing the main entrance on that side. The bathhouse itself (Trench XC) apparently functioned through the seventh and first half of the eighth century, but underwent major changes in the later eighth century (see Fig. 7 for plan showing designated rooms). Upon excavation, the apodyterium (room A) was found to have been stripped to the bare masonry of all its marble fittings, even to the removal of pavements and water basins (Fig. 9). The shell of the apodyterium was then made inaccessible by walling up the doorways from the outside, and the connecting doorway into the bathhouse proper (Fig. 7). The interior was then apparently abandoned to decay and eventual collapse; the columns were found fallen over the stripped floors, surrounded by accumulations of rubbish and rubble (Fig. 10). ${ }^{65}$ Below these deposits and at the very bottom of a robbed water basin

63 Lightfoot 1998a, 303-304; idem 1998b, 60; Lightfoot/Ivison 2002, 7, 18; Anatolian Studies 46, 1996, 97-102, figs 3-6.

64 On the bathhouse excavations (Trench XC), see: Dumbarton Oaks Papers 55, 2001, 381-94; Dumbarton Oaks Papers 58, 2004, 356-363 (forthcoming); Dumbarton Oaks Papers 59, 2005, Trench XC, forthcoming for the 2002 season.

65 Dumbarton Oaks Papers 58, 2004, 357-58, figs 1-4, forthcoming; Dumbarton Oaks Papers 59, 2005 forthcoming; 25 Kazı Sonuçları Toplantısı, 1 (Ankara 2004), 2, 10, Res. 3. 

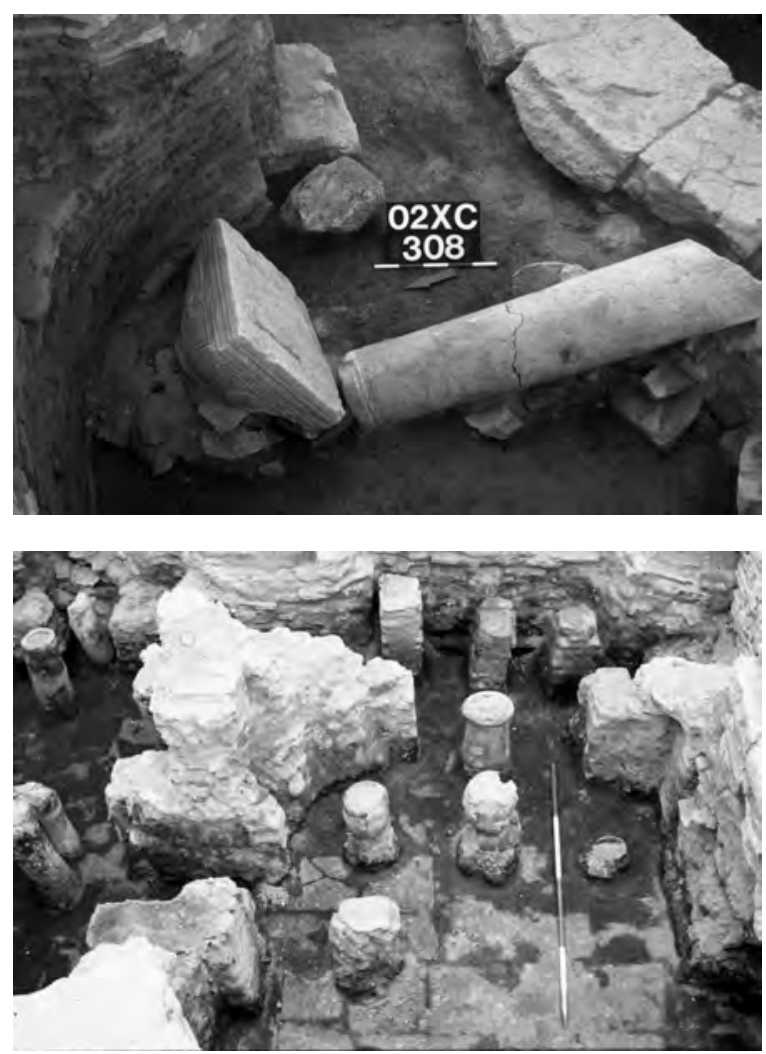

Fig. 10. The bath complex at Trench $\mathrm{XC}$ : fallen column and basket capital in situ in the apodyterium

Fig. 11. The bath complex at Trench $\mathrm{XC}$ : interior of the caldarium (room C) looking north showing the pilae

in the west niche were found a small group of coins, one of which could be identified as a class 2 follis of Leo IV, dated 778-780. ${ }^{66}$ This coin suggests a date for the robbing and abandonment of the apodyterium in the second half of the eighth century. The interior arrangement of the adjacent bathhouse rooms does not appear to have been altered during the seventh and eighth centuries. Instead, the rooms show careful repairs and adaptations. Some of the brick pilae of the hypocausts in the caldarium and tepidarium were supplemented and replaced by spolia blocks and reused terracotta waterpipes (Fig. 11). A replacement arch in the hot air flue between room L and the praefurnium was constructed of sixth century spolia, while further spolia were used to buttress the north-west corner of the building (Fig. 12). ${ }^{67}$ These repairs could have been piecemeal, implemented when necessary. Coins in the ash heaps of the praefur-

66 SF4500 identified by C.S. Lightfoot: AE follis, class 2 of Leo IV, dated 778-780; 24-22 mm; $4.40 \mathrm{~g}, 6 \mathrm{~h}$.

67 Dumbarton Oaks Papers 59, 2005, Trench XC and figs 3-6 of pilae and spolia (forthcoming); 25 Kazı Sonuçları Toplantısı, 1 (Ankara 2004), 2, 9, Res. 1-2, and 10-11, Res. 4-5. 


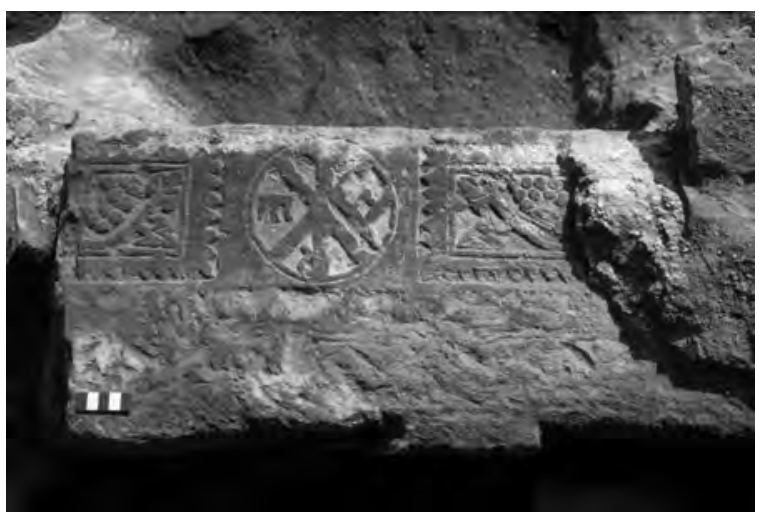

Fig. 12. The bath complex at Trench $\mathrm{XC}$ : Early Byzantine spolium reused in Dark Age alterations to bathhouse

nium (Constans II, dated c 651/2), and the interior rooms (Michael II, dated 821-29) indicate that the bathhouse operated from the seventh through early ninth centuries. ${ }^{68}$ A major renovation of the bathhouse appears to have taken place at the same time as the apodyterium was being stripped and abandoned in the late eighth century. This was proven by evidence that marble revetment slabs lining the interior of the bathhouse had originally decorated the apodyterium next door. A number of these revetment and floor slabs fitted settings preserved in the apodyterium and had clearly been carefully removed whilst still intact. Others had been cut down and sometimes reversed for use in the suspended pavements. ${ }^{69}$ The installations found in Room La suggest that it served as a latrine (Fig. 7). Like elsewhere in the Byzantine world, however, the Amorium bath was not supplied by piped water in this period. A well was found in the V(estibule) room and so water must have been dispensed in buckets (Fig. 7). It therefore appears that the Dark Age inhabitants of Amorium continued to bathe like their ancestors, a fact corroborated for other cities by written sources. ${ }^{70}$

The environs of the bathhouse were also the scene of considerable activity between the seventh to early ninth centuries. ${ }^{71}$ These contexts have been associated with a surprising number of coins from the period, including occupation layers excavated during the 2004 season containing copper alloy issues of Constans II (641-668) and Leo III (717-741). Excavation has shown that the open area to the south and west of the bathhouse was gradually filled in by smaller structures, constructed from spolia, cobble

68 Constans II, dated c. 651/2, SF4462 identified by C.S. Lightfoot: AE follis, type 5; 2518.5mm; 41.3 g; Michael II, dated 821-29, SF4182. Dumbarton Oaks Papers 58, 2004, 360 and No. 27, forthcoming.

69 Dumbarton Oaks Papers 58, 2004, 359-361; Dumbarton Oaks Papers 59, 2005 forthcoming.

70 Bouras 2002, 525-526 with references.

71 Dumbarton Oaks Papers 52, 1998, 328, and fig. 14; Dumbarton Oaks Papers 55, 2001, 381-86, 398-99, strata VII-IV, and figs 15-18; Dumbarton Oaks Papers 57, 2003, 288-292, fig. B, and figs 13-19. 

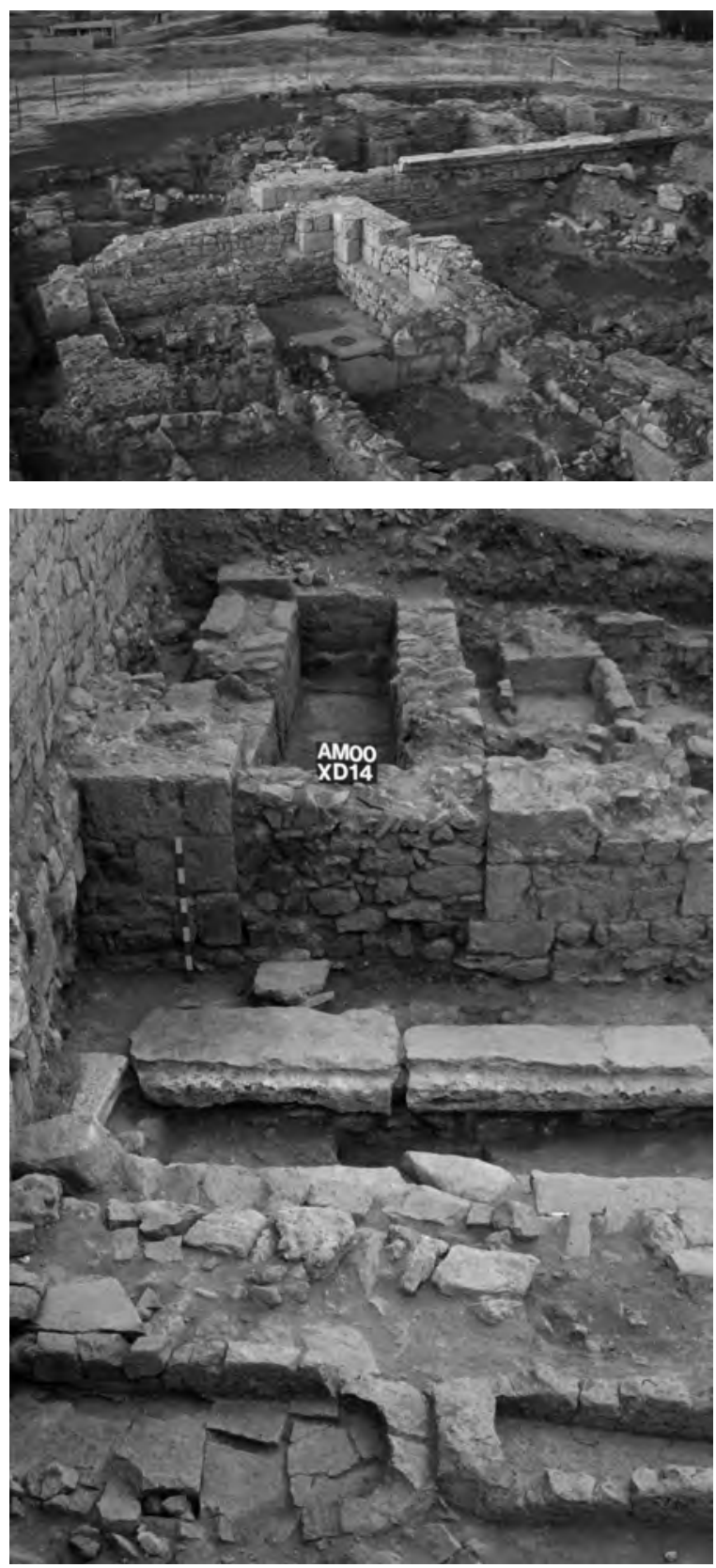

Fig. 13. The bathhouse district: view of Structure 2 (foreground) looking north to the bath complex beyond (Structures 1 and 3)

Fig. 14. The bathhouse district: view looking southwest of stone troughs standing against ruined wall (foreground) with drain and Structure 2 beyond. Note the Enclosure Wall (left) crossing the Dark Age remains 


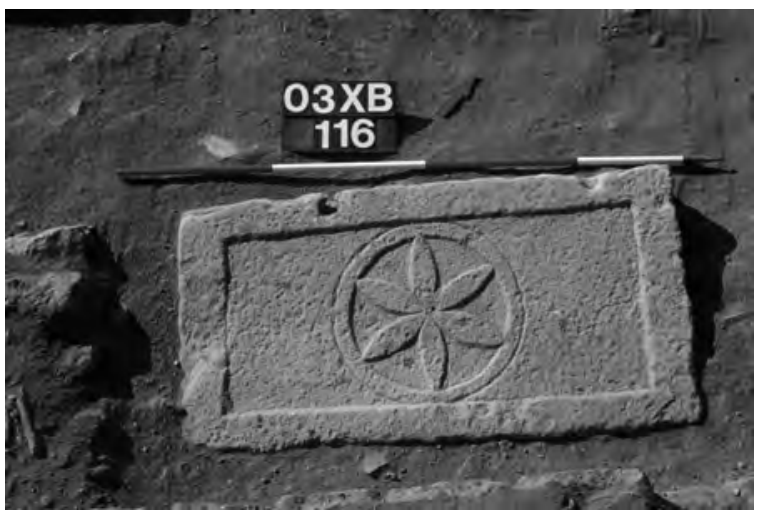

Fig. 15. The bathhouse district: stone trough

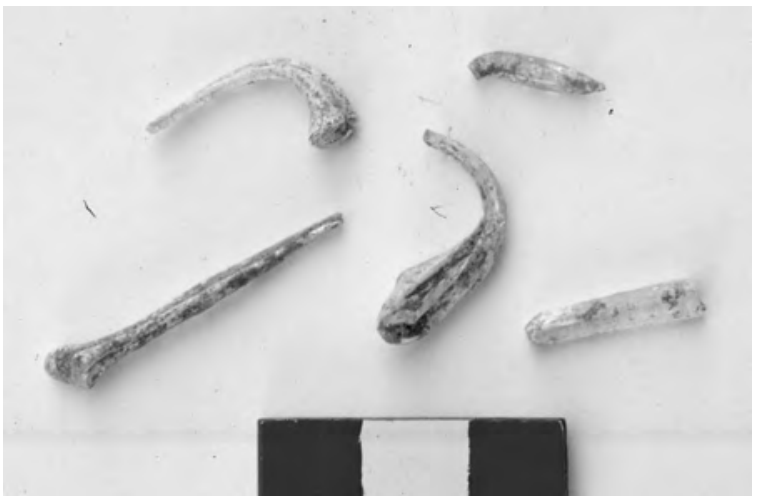

Fig. 16. The bathhouse district: glass working waste

stones, and mud brick, in marked contrast to the surrounding monumental architecture of Late Antiquity. Structure 2, the most substantial building to the south west of the bathhouse, was gradually subdivided with partition walls and floors and thresholds were raised over time (Fig. 13). More flimsy structures of cobble stones and mud brick were probably domestic housing and produced good quantities of plain and glazed tableware. The excellent stratigraphy of this area will make a notable contribution to the study of Byzantine pottery, currently being prepared by Prof. Dr. Beate Böhlendorf-Arslan (Onsekiz Mart University, Çanakkale, Turkey). A notable feature of the neighborhood is the presence of large numbers of shallow stone troughs, placed in lines beside walls, presumably fronting onto small courtyards and narrow alleys (Figs 14 and 15). These must have been supplied with water from wells discovered in the vicinity. Some units may have operated as small scale workshops. Fragments of glass cullet and waste indicate the presence nearby of a glass maker (Fig. 16). Overall then, the findings in the bathhouse district indicate a builtup urban environment supporting a range of public and private activities. It also suggests that occupation became denser over time, with the gradual filling in of older, monumental spaces, in favor of smaller subdivisions. Such activity raises questions of urban and demographic growth during the Dark Ages. 


\section{The end of Dark Age Amorium}

The uncovering of dramatic evidence for the end of Dark Age Amorium is one of the most significant discoveries, since it links the different excavation areas and offers a datable horizon for the study of material culture. The use of the Lower City Walls came to an end with a catastrophic destruction and collapse caused by fire. This was evident from the massive jumble of masonry and charred beams found inside the interior of the triangular tower at Trench AB (Fig. 17). Mixed with this debris were coins, pottery of the eighth and ninth centuries (including brown glazed fragments) charred textile fragments, and ironwork, including several iron points of arrows and spears (Figs 18 and 19). Samples of ash produced a ${ }^{14} \mathrm{C}$ date of c 800, while the latest coin (AE follis, SF1612) from the destruction dated to the years 829-830/831 of the emperor Theophilus. Excavation within the city immediately behind the curtain wall and tower in Trenches LC5-6 revealed similar fire-related destruction associated with coins of Nicephorus I (802-811) and Theophilus (dated 829/830). ${ }^{72}$ The same destruction contained an important assemblage of pottery, still largely intact. These included globular cooking vessels and peculiar multi-handled jars. The interiors of these jars were made up of an inner and outer skin, much like a thermos flask, and were pierced at base and mouth with narrow holes (Figs 20 and 21). Despite many ingenious suggestions the function of these jars remains a mystery at present. ${ }^{73}$

Destruction layers like those encountered at $\mathrm{AB}$ and LC have also been excavated in the bathhouse district and again in association with coins of Theophilus and his immediate predecessors. ${ }^{74}$ An extensive destruction by fire was found in structures excavated in 2003-2004 to the south and west of the bathhouse. The severity of these fires could be gauged by the thickness of the ash layers and the charred remains of earth floors and stonework (Fig. 22). Evidence for the latest use of the bathhouse also dates to the early ninth century (coin of Michael II, dated 821-829, see above). However, substantial deposits of ash found in the hypocaust basements are accumulations resulting from heating the bath rather than evidence of a destruction. These layers were buried beneath debris resulting from the collapse of the suspended floors and upper walls of the bath after its abandonment.

72 See the discussion in Lightfoot/Ivison 2002, 12-13; Lightfoot 1998b, 62; Anatolian Studies 44, 1994, 110-111, pl. XVIII (a).

73 Dumbarton Oaks Papers 55, 2001, 379-81, and figs 11-12.

74 Dumbarton Oaks Papers 59, 2005, "The Coins," by C.S. Lightfoot, forthcoming. Sixteen copper alloy coins of Theophilus (829-842) had been found during the excavations up to the 2004 season. Coins from Trench XC include: SF4427, a decanummium of Constantine IV (668-685); SF4382, a follis of Justinian II (dated 705/6); SF4394, a follis of Constantine V (dated 751-769); SF4441, a follis of Nicephorus I (802-811); SF4421 and SF4386, two folles of Leo V (813-20); SF4361, a follis of Michael II (dated 821). 


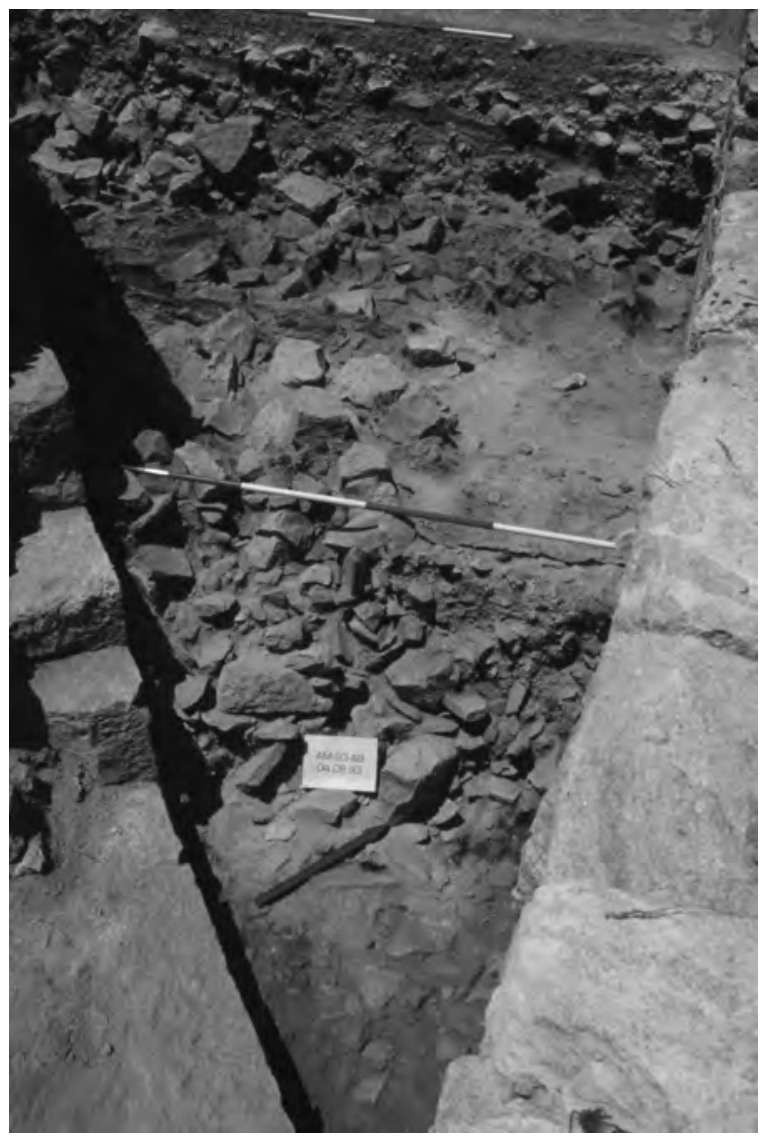

Fig. 17. Trench AB: destruction inside the triangular tower

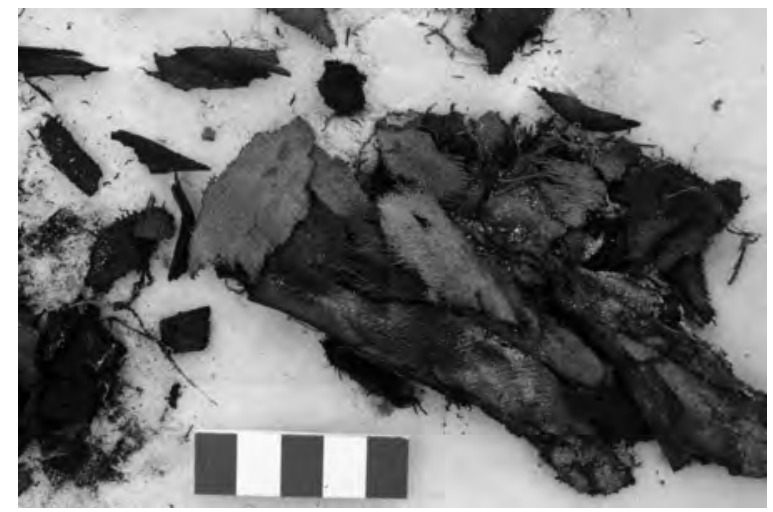

Fig. 18. Trench AB: charred textiles recovered from the destruction in the triangular tower 


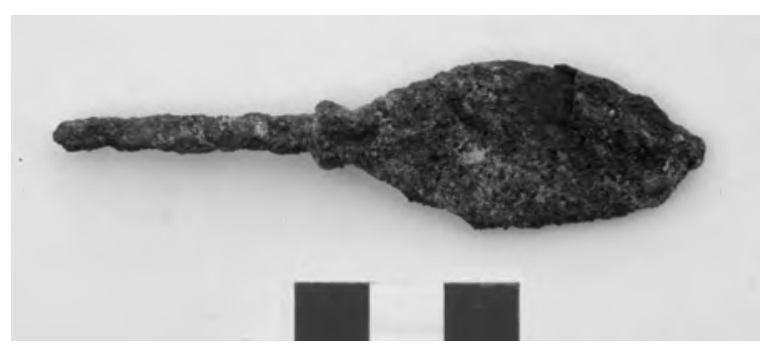

Fig. 19. Trench AB: iron arrow head recovered from the destruction in the triangular tower

Associated with the destruction layers excavated during the 2003 and 2004 seasons were considerable quantities of pottery, glassware, metalwork, and even human remains. The significance of these finds is considerable, given that little material culture of the early ninth century has been identified to date. Of exceptional interest was a copper alloy basin found in installations to the south of the bathhouse (Fig. 23). Also associated with the basin was a set of bone gaming pieces (Fig. 24). Another unusual find was a copper

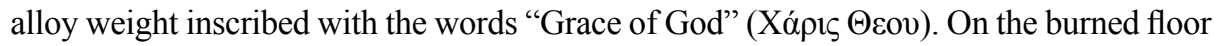
of one room were found fragments of a dichroic glass vessel, partially melted by fire. Several fragments of dichroic glass have already been found at Amorium, and it can now be identified as a previously unattested type of Byzantine glass. This glass appears as a dull, opaque red fabric, but when viewed against the light it turns blue and purple. ${ }^{75}$ The pottery from these destructions is still being studied, but a jug from the bathhouse bears an inscription from Psalm 29:3: “... the voice of God upon the waters” (+ $\varphi \omega v \eta ́$ K(vpío)v

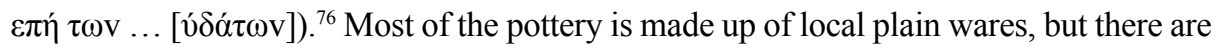
also local glazed wares and fragments of Constantinopolitan White Wares. Some scattered human remains were also found in these destruction layers, offering a gruesome insight on the magnitude of the disaster.

The Lower City Basilica was also destroyed by fire. Badly charred sections of the walls were later hidden behind new walls and painted plaster when the church was reconstructed. Many fragments of the original marble furnishings, such as marble revetment and closure slabs, show signs of burning. The same is true of the fragments of Corinthian capitals from the nave arcades. These pieces were incorporated into the walls and floor beds of the new church that arose within the shell of the old basilica. ${ }^{77}$ Due to the clearance of debris in the process of reconstruction, no destruction layer has been excavated at the church. A terminus ante quem in the late ninth to early tenth century is provided by the proposed date for the reconstruction of the basilica as a domed, vaulted church. A date for the destruction of the basilica earlier in the ninth century is therefore likely. ${ }^{78}$

75 Gill/Lightfoot 2002, 253-258.

76 Dumbarton Oaks Papers 58, 2004, 360, forthcoming.

77 Anatolian Studies 45, 1995, 119; Dumbarton Oaks Papers 51, 1997, 293-294, fig. 3; Lightfoot 1998a, 308; idem. 1998b, 67-68.

78 Dumbarton Oaks Papers 55, 2001, 372-379, 398; Ivison forthcoming. 


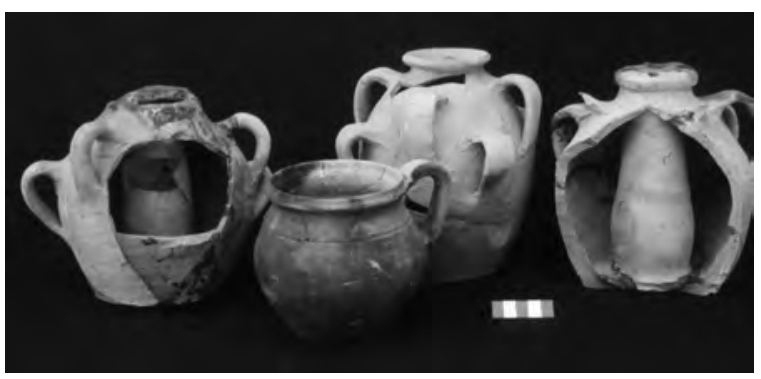

Fig. 20. Trench LC, Lower City Walls: pottery recovered from the destruction contexts

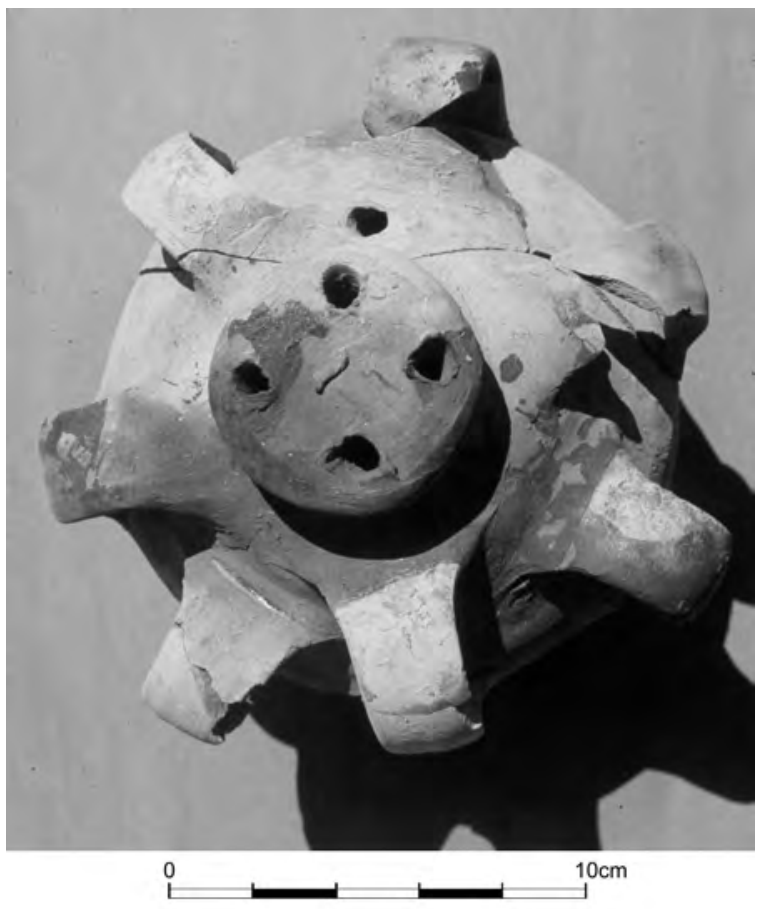

Fig. 21. Trench LC, Lower City Walls: top of a typical vessel recovered from the destruction contexts

All the areas I have discussed above experienced a definite dislocation following the end of the Dark Age period. The inhabitants of the tenth and eleventh centuries either had to undertake major reconstruction, as at the Lower City Basilica, or built their structures over the buried remains, often following a plan utterly contrary to that of the earlier urban layout. This is particularly evident in Trenches ST and L, where the later Middle Byzantine city wall buried Dark Age structures, ${ }^{79}$ and in the bathhouse district, where some of the earliest reoccupation can be associated with the reign of Nicephorus II Phokas (963-969). Here the huge trapezoidal fortification termed the Enclosure ran over

79 Ivison 2000, 13-18, 27; Lightfoot/Ivison 2002, 16-17. 


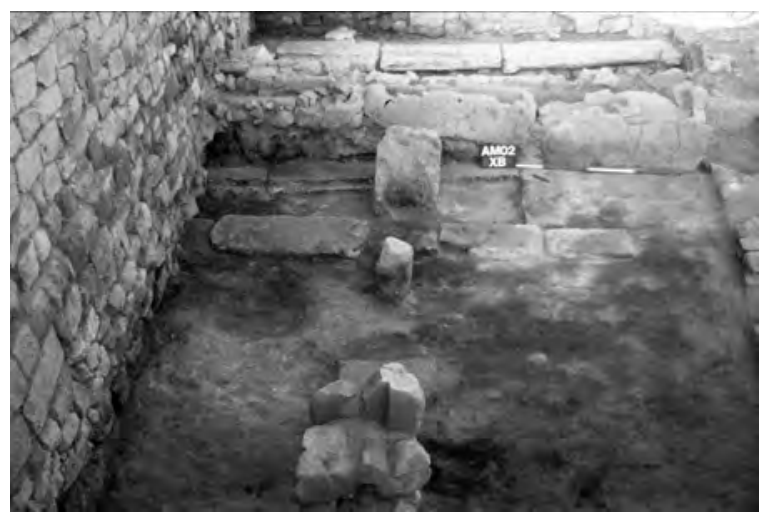

Fig. 22. The bathhouse District: view looking southwest of domestic structures showing destruction horizon. Note Enclosure Wall (left) crossing the Dark Age remains

the buried Dark Age remains (Figs. 14, 22). Coin evidence dates the construction of the Enclosure to c $1000 .{ }^{80}$ At Trench AB the Lower City Wall was left a burned out ruin. Limited occupation here resumed in the eleventh century, with the quarrying of the circuit wall and the construction of a residence over its leveled remains. ${ }^{81}$

One must always be careful in linking archaeological and historical events, especially evidence of destruction. ${ }^{82}$ But given the preponderance of dating evidence it does seems likely that some of these destructions represent the legacy of the sack of Amorium by the Arabs on August 12, 838, in the reign of the emperor Theophilus (829-842). The sack of Amorium is well recorded in Christian and Arab sources. Al-Tabari, writing some decades after the event, records the sack and burning of the city, including the burning of a church together with its defenders. ${ }^{83}$ Medieval Arab historians even record the tradition that doors from one of the city gates of Amorium were removed as spoils of war to Raqqa ${ }^{84}$ The general population suffered massacre, the survivors being enslaved and deported to a miserable death. A select number of the most important captives were taken back to Samarra where they were executed in 845, becoming the 42 Martyrs of Amorium. ${ }^{85}$

80 Lightfoot/Ivison 2002, 15; Dumbarton Oaks Papers 55, 2001, 382-392, 398-399. For the dating of the Enclosure Wall, see 24 Kazı Sonuçları Toplantısı, 1 (Ankara 2003), 525, Res. 9.

81 Lightfoot/Ivison 2002, 13; Anatolian Studies 41, 1991, 221-222; Anatolian Studies 43, 1993, 150-151; Dumbarton Oaks Papers 51, 1997, 297-298; Dumbarton Oaks Papers 55, 2001, 379-381.

82 Russell 2001, 41-71 offers a case in point.

83 al-Tabari, 115-117 [1252-1255]; see also the account of Michael the Syrian, 99-101.

84 Bosworth/van Donzel/Heinrichs/Lecomte 1995, VIII, 411. Dr. Christopher S. Lightfoot and I are grateful to Dr. Marilyn Jenkins-Madina for bringing this reference to our attention.

85 al-Tabari, 115-119 [1252-1256]; Michael the Syrian, 99-101. On the 42 Martyrs of Amorium, see Kazhdan 1991, 800-801, and Acta martyr. Amor., 202-219. 


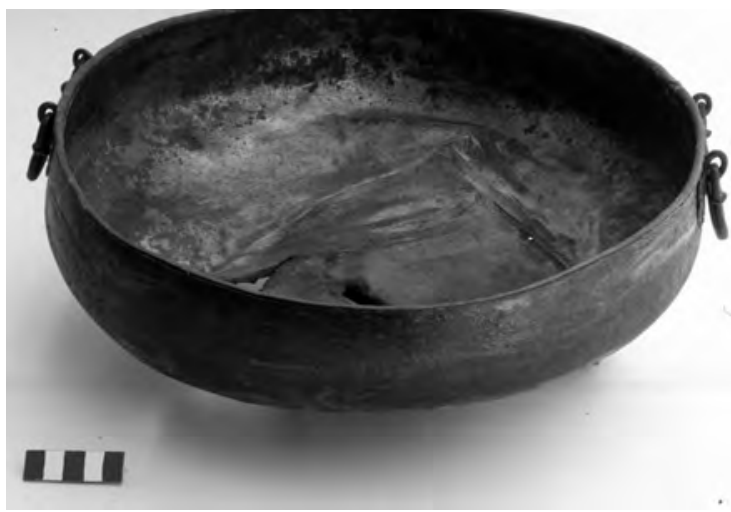

Fig. 23. The bathhouse District: copper alloy bowl from the destruction horizon

\section{Conclusions: Dark Age Amorium - continuity and change}

The Arab attacks on Amorium recorded for the years 644, 646, 666 and 707 appear to have left little if no trace in the archaeological record found to date. ${ }^{86}$ The same is true of a brief Arab occupation of the city that apparently lasted for a few months in the year 666/67. ${ }^{87}$ Amorium resisted successfully the Arab siege of 715/16 thanks to the leadership of the future emperor Leo III, then the strategos of the Anatolic theme. ${ }^{88}$ Two further brief sieges by the Arabs in 779 and 796 were also successfully repulsed. ${ }^{89}$ It would therefore appear that the disruptions caused by these attacks were short-lived and that the development of Amorium continued largely unbroken through the Dark Age. The archaeological evidence gathered so far suggests an evolutionary process characterized by a mix of trends: the maintenance of important structures, the dismantling of those no longer needed; the adaptation and renovation of others; the recycling of building materials; the continuing importance of the late antique urban framework; the redevelopment of formerly public space. This picture suggests evolution and transformation rather than discontinuity. Rather, it was the sack of 838 that marked the end of an era, bringing about large scale destruction and abandonment. No coins have yet been found at Amorium from the reign of Michael III, and there is historical evidence to suggest that the site was left in ruins for at least a generation. ${ }^{90}$ Large scale reconstruction took

86 Brandes 1989, 53-54, 58-59, 75-76 (table); Kaegi 1977, 19-22; Brooks 1899, 19-33; al-Balâdhuri 175 (trans. Hitti, 254).

87 Brandes 1989, 59-60 (assigned to the years 669/670); Theophanes Confessor 490, No. 351, 353 (assigned to $\mathrm{AD} 666 / 667)$.

88 Brandes, 1989, 66-67; Theophanes Confessor 538-540, No. 386-391.

89 Belke/Restle 1984, 123.

90 Lightfoot 1998b, 66. The thematic headquarters was temporarily transferred to Marj al-Shahm ("Meadow of Fatness"). This site has been identified either as Germia, located to the north of Amorium (Brooks 1899, 31 and note; Brooks 1901, 70; Haldon/Kennedy 1980, 95), or more convincingly, as nearby Polybotus, the modern Bolvadin (Treadgold 1988, 304 and 445, No. 418). 


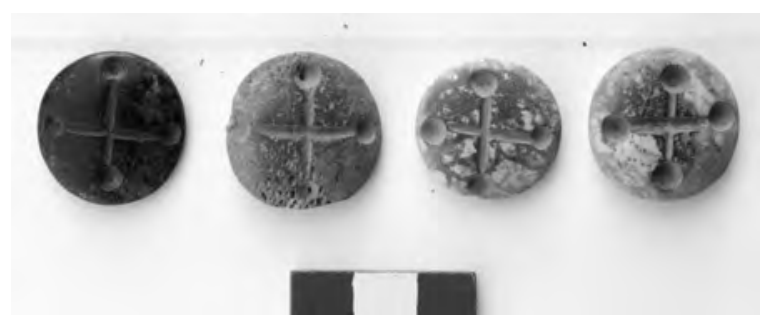

Fig. 24. The bathhouse District: bone gaming pieces

place only later. Apart from the reconstruction of ruined churches like the Lower City Church, the middle Byzantine reoccupation did not seek a total restoration. The new fortified city that rose above the buried ruins was confined only to the former citadel (Fig. 3). The return of the Byzantines to Amorium marked a break with the Dark Age past, the ruins of which were quarried, built over, and forgotten..$^{91}$

Perhaps the most important discovery at Amorium is the fact that the Lower City remained an integral part of the walled city until the Walls were breached in 838 (Fig. 3). In 1980 Cyril Mango, referring to the Upper City, wrote that the site of the Byzantine city of Amorium "was quite a small place" $"$. The evidence discussed in this essay corrects past assumptions about the extent of the fortified city of the Dark Ages. ${ }^{93}$ Dark Age Amorium was not confined solely to a kastron on the Upper City mound, but rather "[a]t little over 1 kilometer across, Amorium was a big city by medieval Byzantine standards" ${ }^{94}$. Another important realization is that Dark Age Amorium does share common trends of development with other cities of comparable rank, size and function. On this basis, I would contend that Dark Age Amorium should now be added to Wolfram Brandes' list of "Städte mit relativer Kontinuität", and be compared with cities such as Nicomedeia, Nicaea, Smyrna, Attaleia, Selge, and Trebizond. ${ }^{95}$ Future excavations at such sites should target not only civilian occupation, but also seek to identify structures with military and administrative uses. The adoption of a comparative method may permit us to discern better the local and national forces that were shaping the Byzantine city during the Dark Ages. By doing so, a better conceptualization of urbanism might emerge that would permit Byzantine cities to be more usefully compared with their Western European and Islamic counterparts.

91 Ivison 2000, 13-18, 27.

92 Mango 1980, 72.

93 Haldon 1999a, 14-15; Brandes 1999, 38-41.

94 Mango 2002, 200; Crow/Hill 1995, 263, fig. 3, showing the plan of Amorium compared at the same scale with those of Ancyra, Amaseia, and other thematic centers, although the shaded zone of occupation only encompasses the Upper City.

95 Brandes 1989, 124-131. 


\section{Bibliography}

Acta martyr. Amor:: Acta XLII martyrum Amoriensium, ed. Б. Васильиевский/П. Никитин; éd. V. Vasiljevskij/P. Nikitin (=Записки императорской Академий наук VII, 2; Mémoires de l'Academie des Sciences de St. Pétersbourg, VIIIe serie, VII, 2), Ст. Петербург; St. Pétersbourg 1905.

al-Baladhuri: The origins of the Islamic state: being a translation from the Arabic accompanied with annotations, geographic and historic notes of the Kitâb futûh al-buldân of al-Imâm abu-l 'Abbâs Ahmad ibn-Jâbir al-Balâdhuri, by Philip Khûri Hitti (=Studies in History, Economics and Public Law 68), New York 1916.

al-Mas 'udi: al-Mas 'udi, The Meadows of Gold, in: Aleksandr Aleksandrovich Vasiliev, Byzance et les Arabes I: la dynastie d'Amorium (820-867), ed. fr. H. Grégoire et M. Canard (=Corpus Bruxellense Historiae Byzantinae 1), Bruxelles 1935.

al-Tabari: al-Tabari, The History of al-Tabari, vol. XXXIII. Storm and Stress along the Northern Borders of the Abbasid Caliphate, translated and annotated by Clifford Edmund Bosworth, Albany 1991.

Angold 1985: Michael Angold, "The shaping of the Middle Byzantine City", in: Byzantinische Forschungen 10, 1985, pp. 1-37.

Bakirtzis 1988: Charalambos Bakirtzis, The Basilica of Saint Demetrius, Thessaloniki 1988.

Belke/Restle 1984: Klaus Belke/Marcell Restle, Tabula Imperii Byzantini IV, Galatien und Lykaonien, Wien 1984.

Bosworth/van Donzel/Heinrichs/Lecomte 1995: Clifford E. Bosworth/Emeri J. van Donzel/ Wolfhardt P. Heinrichs/Gérard Lecomte, The Encyclopaedia of Islam 8, Leiden, 1995.

Bouras 2002: Charalambos Bouras, "Aspects of the Byzantine City, Eighth-Fifteenth Centuries", in: Angeliki Laiou (Ed.), The Economic History of Byzantium, Washington D.C. 2002, pp. 497-528.

Brandes 1989: Wolfram Brandes, Die Städte Kleinasiens im 7. und 8. Jahrhundert (=Berliner Byzantinistische Arbeiten 56), Berlin 1989.

Brandes 1999: Wolfram Brandes, "Byzantine towns in the seventh and eighth century - different sources, different histories?", in: Gian P. Brogiolo/Bryan Ward-Perkins (Eds), The idea and ideal of the town between Late Antiquity and the early Middle Ages, Leiden-Boston-Köln 1999, pp. 25-57.

Brooks 1899: Ernest W. Brooks, “The Campaign of 716-718, from Arabic Sources”, in: Journal of Hellenic Studies 19, 1899, pp. 19-31.

Brooks 1901: Ernest W. Brooks, "Arabic Lists of the Byzantine Themes", Journal of Hellenic Studies 21, 1901, 67-77.

Bury 1912: J. B. Bury, A History of the Eastern Roman Empire from the Fall of Irene to the Accession of Basil I, London 1912.

CIG IV, xl: Inscriptiones christianae: Corpus Inscriptionum Graecarum IV, xl: Inscriptiones christianae; revised edition in: H. Grégoire, Recueil des inscriptions grecques-chrétiennes d'Asie mineure 1, Paris 1922; reprinted Amsterdam 1968.

Crow/Hill 1995: James Crow/Stephen Hill, "The Byzantine Fortifications of Amastris in Paphlagonia", in: Anatolian Studies 45, 1995, pp. 251-265.

Dagron 1977: Gilbert Dagron, "Le Christianisme dans la ville byzantine", in: Dumbarton Oaks Papers 31, 1977, pp. 1-25.

Dunn 1994: Archibald W. Dunn, "The transformation from polis to kastron in the Balkans (IIIVII cc.): general and regional perspectives”, in: Byzantine and Modern Greek Studies 18, 1994, pp. $60-80$. 
Foss 1975: Clive Foss, "The Persians in Asia Minor and the End of Antiquity", in: English Historical Review 1975, pp. 721-747.

Foss 1976: Clive Foss, Byzantine and Turkish Sardis, Cambridge, Mass. 1976.

Foss 1977a: Clive Foss, "Late Antique and Byzantine Ankara“, in: Dumbarton Oaks Papers 31, 1977, pp. 27-87.

Foss 1977b: Clive Foss, “Archaeology and the 'Twenty Cities' of Byzantine Asia”, in: American Journal of Archaeology 81, 1977, pp. 469-486.

Foss 1989: Clive Foss, Ephesus after Antiquity: a Late Antique, Byzantine and Turkish City, Cambridge 1989.

Foss/Winfield 1986: Clive Foss/David Winfield, Byzantine Fortifications: an Introduction, Pretoria 1986.

Foss 2003: Clive Foss, “The Walls of İznik 260-1330”, in: I. Akbaygil/H. İnalckk/ O. Aslanapa (Eds), Iznik Throughout History, Istanbul 2003, pp. 249-262.

Gill/Lightfoot 2002: Margaret A.V. Gill/Christopher S. Lightfoot, "The Dichroic Fragments", in: Margaret A.V. Gill, with contributions by Christopher S. Lightfoot, Eric A. Ivison, and Mark T. Wypyski, Amorium Reports 1. Finds I: the Glass (1987-1997) (=British Archaeological Reports International Series 1070), Oxford 2002, pp. 253-255.

Gouillard 1965: Jean Gouillard, "L'hérésie dans l'Empire byzantin des origines au XIIe siécle", in: Travaux et Mémoires 1, 1965, pp. 299-324.

Gounaris 1982: George Gounaris, The Walls of Thessaloniki, Thessaloniki 1982.

Haldon 1993: John F. Haldon, "Military service, military lands, and the status of soldiers: current problems and interpretations", in: Dumbarton Oaks Papers 47, 1993, pp. 1-67.

Haldon 1997: John F. Haldon, Byzantium in the Seventh Century: the Transformation of a Culture, Cambridge-New York 1997.

Haldon 1999a: John F. Haldon, "The idea and ideal of the town in the Byzantine Empire", in: Gian Pietro Brogiolo/Bryan Ward-Perkins (Eds), The idea and ideal of the town between Late Antiquity and the early Middle Ages, Leiden-Boston-Köln 1999, pp. 1-23.

Haldon 1999b: John F. Haldon, Warfare, State and Society in the Byzantine World, 565-1204, London 1999.

Haldon/Kennedy 1980: John F. Haldon/Hugh Kennedy, "The Arab-Byzantine frontier in the eighth and ninth centuries: military organization and society in the borderlands", in: Zbornik Radova 19, 1980, pp. 79-116.

Hamilton 1842: William J. Hamilton, Researches in Asia Minor, Pontus and Armenia 1, London 1842.

Ibn-Khordâdhbeh: Kitãb al-masãlik wa- 'l-mamãlik; Auctore Abu'l-Kâsim Obaidallah Ibn Abdallah Ibn Khordâdhbeh. Acc. excerpta e Kitâb al-Kharâdj, Auctore Kodâma Ibn Dja'far, ed. Michael Jan de Geoje (=Bibliotheca geographorum Arabicorum 6), Lugduni Batavorum 1889.

Ivison 2000: Eric A. Ivison, "Urban Renewal and Imperial Revival in Byzantium (730-1025)", in: Byzantinische Forschungen 26, 2000, pp. 1-46.

Ivison (forthcoming): Eric A. Ivison, "Middle Byzantine Sculptors at Work: evidence from the Lower City Church at Amorium", in: Charalambos Pennas/Vasso Pennas/C. Vanderheyde (Eds) La sculpture byzantin (VIIe-XIIe siècles) (=Actes du colloque internationale organize par l'Ecole française d'Athènes et l'Ephorie Byzantine des Cyclades-Golfe Saronique [6-10 septembre 2000], Supplément au Bulletin de Correspondance Hellénique) Paris (forthcoming).

Jenkins 1966: Romilly Jenkins, Byzantium: the Imperial Centuries A.D. 610-1071, New York 1966.

Kazhdan 1991: Alexander Kazhdan (Ed.), The Oxford Dictionary of Byzantium, Washington D. C. 1991. 
Kaegi 1977: Walter E. Kaegi, “The First Arab Expedition against Amorium”, in: Byzantine and Modern Greek Studies 3, 1977, pp. 19-22.

Kedrenos: Georgius Cedrenus, Compendium historiarum 1, ed. I. Bekker (=Corpus scriptorum historiae Byzantinae 32), Bonnae 1838.

Kuniholm 1995: Peter I. Kuniholm, "New Tree-Ring Dates for Byzantine Buildings", in: TwentyFirst Annual Byzantine Studies Conference. Abstracts of Papers, New York 1995, p. 35.

Leo Correspondence: The Correspondence of Leo, Metropolitan of Synada and Syncellus. Greek text, translation and commentary by Martha Pollard Vinson, Washington, D.C. 1985.

Liebeschuetz 2001: John H.W.G. Liebeschuetz, The Decline and Fall of the Roman City, Oxford 2001.

Lightfoot 1998a: Christopher S. Lightfoot, "The Public and Domestic Architecture of a Thematic

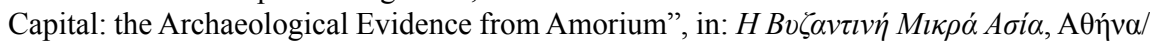
Athens 1998, pp. 303-320.

Lightfoot 1998b: Christopher S. Lightfoot "The Survival of Cities in Byzantine Anatolia, the Case of Amorium“, in: Byzantion 68, 1998, pp. 56-71.

Lightfoot 2003: Christopher S. Lightfoot(Ed.), Amorium Reports II: Research Papers and Technical Reports (=British Archaeological Reports, International Series 1170), Oxford 2003.

Lightfoot/Ivison 2002: Christopher S. Lightfoot/Eric A. Ivison, "Introduction", in: Margaret A.V. Gill with contributions by Christopher S. Lightfoot, Eric A. Ivison, and Mark T. Wypyski, Amorium Reports 1. Finds: the Glass (1987-1997) (=British Archaeological Reports, International Series 1070), Oxford 2002, pp. 1-31.

Mango 1980: Cyril Mango, Byzantium: the Empire of New Rome, London 1980.

Mango 1990: Cyril Mango, Le développement urbain de Constantinople (IVe-VIIe siècles), Paris ${ }^{2} 1990$.

Mango 2002: Cyril Mango (Ed.), The Oxford History of Byzantium, Oxford 2002.

Michael the Syrian: La Chronique de Michel le Syrien, patriarche Jacobite d'Antioche (11661199) éd. fr. Jean B. Chabot, 4 vols, Paris 1899-1924.

Ostrogorsky 1959: George Ostrogorsky, "Byzantine Cities in the Middle Ages", in: Dumbarton Oaks Papers 13, 1959, pp. 47-66.

Prosopography of the Byzantine Empire I: Prosopography of the Byzantine Empire I (641-867), ed. John R. Martindale (CD-ROM) Ashgate Publications 2001.

Theophanes Confessor: The Chronicle of Theophanes Confessor. Byzantine and Near Eastern History A.D. 284-813, translated with introduction and commentary by Cyril Mango and Roger Scott, Oxford 1997.

Russell 2001: James Russell, "The Persian Invasions of Syria/Palestine and Asia Minor in the Reign of Heraclius: Archaeological and Numismatic Evidence", in: Eleonora KontouraGalake (Ed.), The Dark Centuries of Byzantium ( $7^{\text {th }}-9^{\text {th }}$ C.), Athens 2001, pp. 41-71.

Sanders 1999: G.D.R. Sanders, “A Late Roman Bathhouse at Corinth”, in: Hesperia 68, 1999, pp. 441-480

Sharf 1971: Andrew Sharf, Byzantine Jewry from Justinian to the Fourth Crusade, London 1971.

Starr 1936: Joshua Starr, “An Eastern Christian Sect: the Athinganoi”, in: Harvard Theological Review 29, 1936, pp. 93-106.

Starr 1970: Joshua Starr, The Jews in the Byzantine Empire 641-1204, New York 1970 (reprint).

Theophanes Continuatus: Theophanes Continuatus, ed. Immanuel Bekker (=Corpus Scriptorum Historiae Byzantinae 31), Bonn-Leipzig 1838.

Vita Basilii: Vita Basilii translated by Cyril Mango, The Art of the Byzantine Empire, 312-1453: Sources and documents, Toronto-Buffalo-London 1986.

Treadgold 1988: Warren Treadgold, The Byzantine Revival 780-842, Stanford 1988. 
Trombley 1997: Frank R. Trombley, "Byzantine 'Dark Age' Cities in a comparative context”, in: To Ellinikon, Studies in honor of Speros Vryonis, Jnr I: Hellenic Antiquity and Byzantium, New York 1997, pp. 429-449.

Vie de Théodore de Sykeon: Vie de Théodore de Sykeon, ed. A-J. Festugière, 2 vols, (Subsidia hagiographica No. 48) Brussels 1970; English translation by E. Dawes and N.H. Baynes, Three Byzantine Saints: Contemporary Biographies of St. Daniel the Stylite, St. Theodore of Sykeon and St. John the Almsgiver, London 1948.

Whittow 1996: Mark Whittow, The Making of Byzantium, 600-1025, Berkeley-Los Angeles 1996.

Wypyski 2002: M.T. Wypyski, “The Amorium Dichroic Glass Fragments: Technical Analyses”, in: Margaret A.V. Gill with contributions by Christopher S. Lightfoot, Eric A. Ivison, and Mark T. Wypyski, Amorium Reports 1. Finds I: the Glass (1987-1997) (=British Archaeological Reports International Series 1070), Oxford 2002, pp. 256-258. 



\title{
Durostorum in late antiquity (fourth to seventh centuries)
}

\author{
Stefka Angelova \& Ivan Buchvarov
}

The history of the Roman city of Durostorum is well-known from the written and epigraphic sources, investigated mainly by Bulgarian and Romanian scholars. The scholarly debates surrounding the city focus on the topography of the antique city; and the statute (the category of the city) and chronology of the canabae, municipium and vicus, which are found in the epigraphical sources. Many of the controversial points were settled by rescue excavations carried out in the 1970 s. ${ }^{1}$ Recently R. Ivanov summarized the history of research, polemics, and some of the views of contemporary scholars. ${ }^{2}$ The long-term research of the ceramic workshops in Durostorum led by Romanian archaeologists has also been published. The workshops were located about 2.5-3 km away from Bulgaria's modern frontier with Romania, in the north-eastern sector of a settlement whose statute is not yet quite clear in relation to the rest of the city. Workshops for architectural ceramics and lamps have also been found. They are subject of future investigation. In any case, these are military and private workshops organized right after Legio XI Claudia settled there in 105-106. ${ }^{3}$ The production of various ceramic articles continued through the fourth century, probably until the Gothic War in 376-378. Some faint traces of continued settlement are distinguishable after it as well.

Durostorum in late antiquity has been the subject of both broad and more specific study, as based upon the wealth of written sources for this city. ${ }^{4}$ Many works touch on the archaeological data, though so far no study of a more general character exists. ${ }^{5}$ This contribution attempts to do just that.

According to the administrative division, Duostorum belonged to the province of Moesia Secunda in late antiquity. To a large extent, its political history related to the newly established province of Scythia Minor and reflected the events happening there.

1 Donevski 1988, 84-96.

2 Ivanov 2003, 75-86.

3 Museteanu 2003, 14-15, 131 sqq.

4 Velkov 1988, 25-31; idem 1984; Vulpe/Barnea 1968.

5 Angelova 1973, 3, 83-93; Donevski 1988, 84-96; Angelova 1988, 34 sqq.; Milosevic/ Donevski 1988/1999, 245-255; Angelova 2003, 245-251. 
In $\mathrm{AD} 250,70,000$ Goths lead by Cniva besieged the city but were repulsed. A severe raid followed in 267, when an army of 320,000 Goths, Herulae, Bastarnae, Gepids, Greutungae and Tervingae devastated the region. This time, they were driven back for more than hundred years. ${ }^{6}$ These events explain the traces of fire on the fortress walls of the camp, and are the basis for dating the military building activities that followed. Similar fires are also evidenced on the buildings of the canabae. The final period of massive building activities began directly afterwards. ${ }^{7}$

Two large coin hoards buried on the camp territory help us to understand these events. The latest coins belong to Emperor Volusianus (251-253). A building inscription from the very end of the third and the beginning of the fourth century contains information about the construction of a fortress and repairs of preexisting fortifications in Durostorum. ${ }^{8}$ The inscription reports the erection of praesidia. ${ }^{9}$

A hoard of 750 Roman silver denarii was discovered north-west of the camp. The latest coins belong also to Emperor Volusianus and provide more evidence that the Gothic raids did not spare the civilian population of Durostorum.

At the beginning of the fourth century a military reform established auxiliary troops - limitaneia - to support the legions in the defence of the Limes. They also lived in permanent camps. The troops were recruited from the local population, and the soldiers had the right to have families and estates. The mobile internal troops - comitatenses - were another branch of military service subjected directly to the central power. The written sources give extensive information on the fortification of the Limes. ${ }^{10}$

The growing significance of Durostorum for the defence of the Lower Danube Limes was revealed during the journey of Emperor Diocletian. He visited the city on 21-22 October 294 and on 8 June 303, and issued some edicts there. Milestones were erected along the road crossing the city. ${ }^{11}$

Emperor Valens stayed in Durostorum in 367 and also issued edicts there. In 376 when Goths - Tervingae - were transferred to the south of the Danube, they were settled in Durostorum. There is no information available of the city's fate during the Gothic War of 376-378. So far, there are no hoards known from that time, and the single coins found on the territory of the camp, canabae, and the late antique fortresses along the river bank date until the middle of the next century without any break. The coins on the territory of the camp and the canabae belong to the reign of Emperor Honorius (393423), and those from the late antique fortresses to the reign of Emperor Theodosius II (401-450). Obviously the city was not hit hard by this devastating war. Nevertheless,

6 Velkov 1984, 132-133.

7 Donevski 1988, 90 sqq.

8 Kolendo 1966, 148-149; Ivanov 2003, 83-84.

9 Torbatov 2002, 78-79.

10 Velkov 1984, 157-158.

11 Idem 1988, 28. 
the city did not escape so easily in 441-442, when the Huns swept its environs. We have no direct evidence that the Huns seized the city. The circulation of coins, however, stopped for about fifty years. We know the name of bishop Minofilus from some letters of the episcopal synod of Moesia Secunda, dating from 457-458, in the days of Emperor Leo - Minofilus episcopus civitatis Durostori. ${ }^{12}$ We do not know how the city looked at that time. Nor do we know if some of its citizens departed. Nevertheless, life went on in some way as coins of Emperor Anastasius (491-518) appeared again in some particular sectors of the city. That same emperor's coins seem to be the latest early Byzantine pieces known up to now from the camp and canabae territory.

From the late fourth century onwards we observe a gradual barbarization of the inhabitants of the provinces of Moesia Inferior and Scythia Minor. Scyri, Sadagari and Alans had already settled there by the mid-fifth century. ${ }^{13}$ The process intensified greatly during the sixth and seventh centuries due to ceaseless invasions of Slavs, and later of Avars.

For the first time Slavs under the name of Getae came along the Lower Danube in the days of Emperor Anastasius. They appeared under their proper name Anti in Emperor Justin's reign (518-527). One of the mightiest raids of the Slavs dates from 540, terminating in a treaty between the Anti and Emperor Justinian (527-565), according to which they would be settled as foederates. ${ }^{14}$ Yet the Slavs' invasion continued. In 578 the Byzantines transferred at Durostorum an Avar army of 60,000 men against the Slavonic settlements along the left bank of the Danube. The latest coins from a hoard of 56 follisi were struck in 574; the hoard was found by accident to the south of the early Byzantine fortress. A coin struck in 568-569 was discovered in the north-western sector of this fortress within a burnt layer. ${ }^{15}$ These coins likely reflect one of the Slavs' attacks not mentioned in the written sources. Theophylactos Symokathas reports on the Avars seizing Marcianopolis, Zaldapa, and Dorostol in 585. ${ }^{16}$

In 593 this frontier city became the starting point of the Byzantine army lead by Priscus for his campaign on the left bank of the Danube. ${ }^{17}$ This fact demonstrates a relative stability of the Byzantine rule there. These events repeated in 594-596, when Peter was commander of the army. ${ }^{18}$ The seals found in the city, as well as in the area enclosed by Silistra and Kalarat, also bear witness to the presence of the Byzantine administration and military units during the sixth to seventh century. We know this from eight seals. They belonged to private and official persons alike, stratilatus Theoktistos

12 Soustal 1997, 117.

13 Velkov 1984, 162.

14 Ibid., 163.

14 Angelova 2003, 246.

16 GIBI I, 299 (Theophylaktos).

17 Theophanos Confessor-GIBI VI, 246.

18 Mutafchiev 1973, 24. 
and a certain Peter, who bore the title of "consul and patrician". The latter has obviously carried on a correspondence with some officials in the city. ${ }^{19}$ The latest early Byzantine coins discovered during the excavations in the fortress on the Danube bank belong to Emperor Phocas (602-610). Two more coins of Emperors Heraclius (610-641) and Constantine IV Pogonatos (668-685) were found at the riverbank by accident. Two silver coins of the latter emperor were found among silver jewels hidden in one of the intercolumns of a basilica planned for construction north of the Roman camp. ${ }^{20}$

It is yet hard to describe what the city was like during the seventh century. The written sources cease for several decades. The archaeological data is rather scanty too. Dwellings and ceramics dating from the sixth to seventh century, unearthed over the ruins of a Roman bath north of the camp and on the early Byzantine fortress territory, show a permanent presence of Slavs. ${ }^{21}$ Nevertheless, in the early seventh century, some groups of the local population deserted to the south. Then the relics of the local saint Dasius were transferred to Italy, to the town of Ancona. ${ }^{22}$ The name of Durostorum is associated with the consolidation of Christianity along the Lower Danube. As early as the fourth century the city became an episcopal seat and held this rank until the end of antiquity. The names of several of its bishops are known. After Auxentius, disciple of the Gothic bishop Wulfila, bishop Jacob followed, who took part in the Oecumenical Council of 431. We have already mentioned the name of Minofilus, bishop from the second half of the fifth century. A tombstone from Odessos tells us the name of bishop Dulcissimus, who died and was buried in that city. ${ }^{23}$ The inscription dates between the fifth and sixth century. ${ }^{24}$ Bishop Johan took part in the Oecumenical Council of 553.

Archaeological excavations in Silistra had not been carried out for a long time. Ruins of this fortress wall rose in the Danube Park along the bank of the river; in 1960s they were described as remains of the medieval fortress of Drustur. Monuments of antique art, mainly sculptures, tombstones, and architectural decorative elements, had been accidentally found and were dispersed into various collections. Up to 1913 they were taken to Rousse and Sofia. In 1940 a considerable number of classical and late antique pieces of art were transported to Romania, later going to museum collections in Bucharest, Constanța, and Kãlaraşi. Intensive public and residence construction started in mid-1950s and especially during 1960s in the central and some parts of the south-western and south-eastern sectors of the modern town. The observations made meanwhile lie at the basis of the town archaeological record. The artefacts discovered launched today's archaeological collection of the Museum of History.

19 Barnea 1966, 2, No. 2; Vulpe 1968, 512, fig. 68; Jordanov 1987, 195, tab. III, 198, tab. IV.

20 Angelova/Penchev 1989, 40-41.

21 Angelova 2003, 246-248.

22 Velkov 1984, 165.

23 Besevliev 1964, 76, No. 107.

24 Ilski 1955. 
The rescue excavations of the fortress on the Danube bank began in 1969, but because of the important results they produced, they were transformed into regular research in 1976. The rescue excavations of some classical and late antique sites in the south-eastern and eastern sectors of Silistra are also of particular value. It was there where the legionary camp (Fig. 1.1) and canabae (Fig. 1.2) of Durostorum were located, and some significant observations on the topography, town-planning and architecture have been made. The spot of the municipium has not yet been fixed for certain. It was either beyond the north-north-western sector of the canabae or on the territory of the vicus, located east of the Bulgarian-Romanian frontier. ${ }^{25}$ A related find is a street revealed within a construction project at $43 \mathrm{~K}$. Arabadzyan Street. The disclosure is part of a street running north-south and is $6 \mathrm{~m}$ wide. The location is about $500 \mathrm{~m}$ north of the camp, and $100 \mathrm{~m}$ west and south-west of buildings defined as components of the canabae. The street is paved with large stone slabs, upon which wheel tracks can be seen. Storehouses of a precise construction are preserved to the east. A masonry drain runs under the pavement, in the middle of the street bed $(1.40 \mathrm{~m}$ deep, $0.60-0.40 \mathrm{~m}$ wide). The drain is paved with tegulae fastened with mortar. The artefacts found during the excavation show that the street was in use until the sixth century without any reconstruction. Streets similar in size and structure have not been found up to now in the canabae of Durostorum. The streets were up to $3.5 \mathrm{~m}$ wide, paved with small stones. These streets display three levels corresponding to the three construction periods of the buildings nearby. ${ }^{26}$

\section{The fortification system}

During late antiquity the fortress wall of the legionary camp was fortified in the sector investigated - the south-western corner with its adjacent curtain wall to the south and west. A new rectangular tower was constructed there, projecting entirely outside the curtain wall. Its measurements are $21.70 \times 12.80 \mathrm{~m}$. The upper floors rest upon the walls, as well as upon four pylons, arranged at a distance of 2.30-3 m from one another. All four pylons rest upon an earlier wall. A wall $2.60 \mathrm{~m}$ thick was uncovered south of the original inner tower. It was suggested that it might have belonged to another outer tower of two building periods, like similar ones found along the western and southern fortress walls. During the second period, in regard to the superstructure of the walls, the masonry is double-faced, made of quadrae 0.90-0.70 $\mathrm{m} \times 0.30-0.40 \mathrm{~m}$, arranged on their long or short side, well leveled, and bound by pink mortar. In-between both faces, the walls are made of mixed building materials, also bound by pink mortar. Various

25 Ivanov 2003, 83.

26 Donevski 1988, 89, 91. 


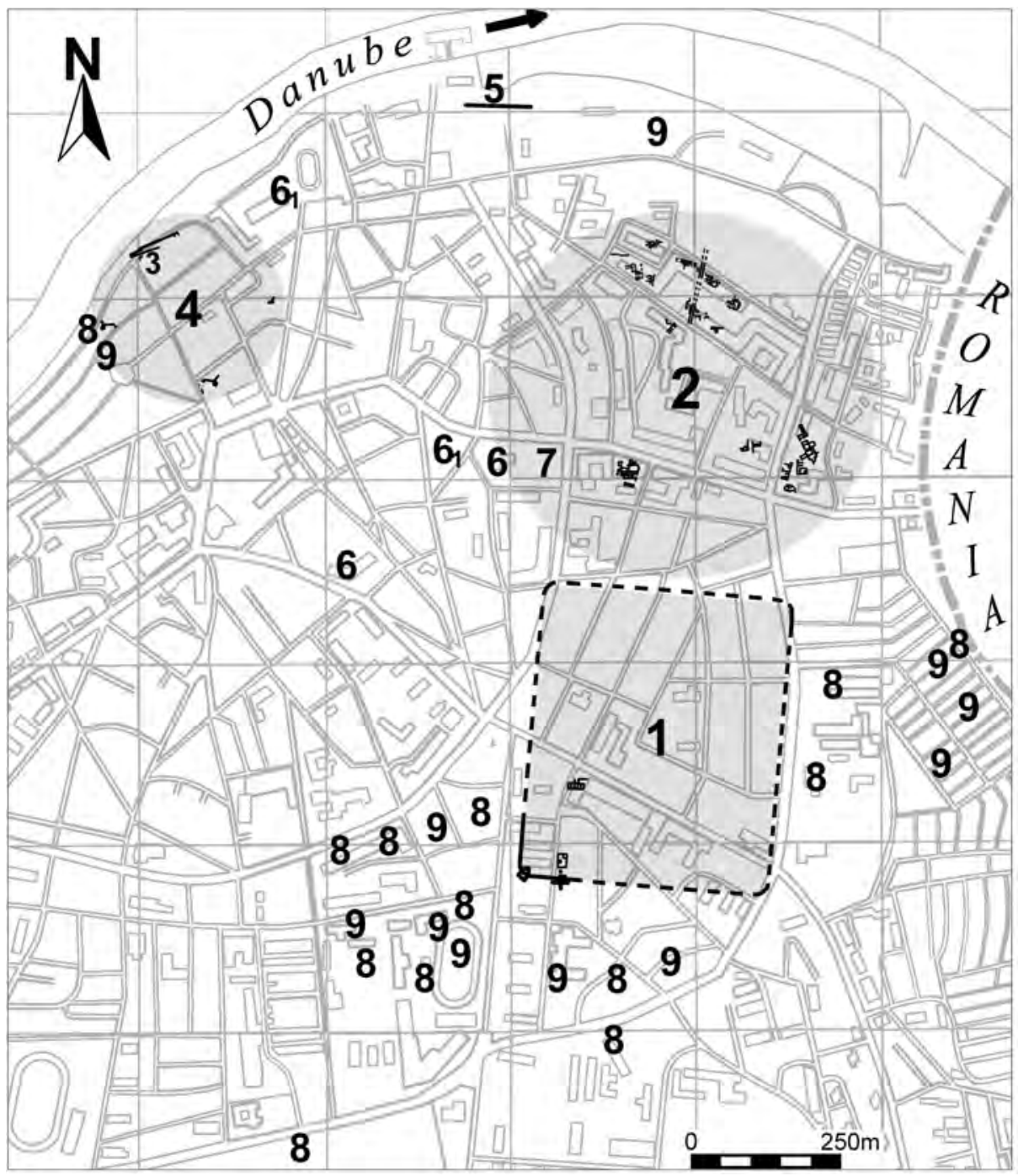

Fig. 1. Map of late antique sites. 1. Roman camp; 2. canabae; 3. late antique fortress; 4 . territory of the early Byzantine fortress; 5. early Byzantine wall; 6. pottery kiln for architectural ceramics; 6.1. utilitarian pottery kiln; 7. early Byzantine basilica; 8-9. late Roman and late antique burials and tombs

considerations lead us to assign the first repairs of the walls and the construction of new towers between the very end of the third and the beginning of the fourth century, and the following quadrae masonry between the late fifth and the early sixth century. ${ }^{27}$

27 Ibid., 85-86. 


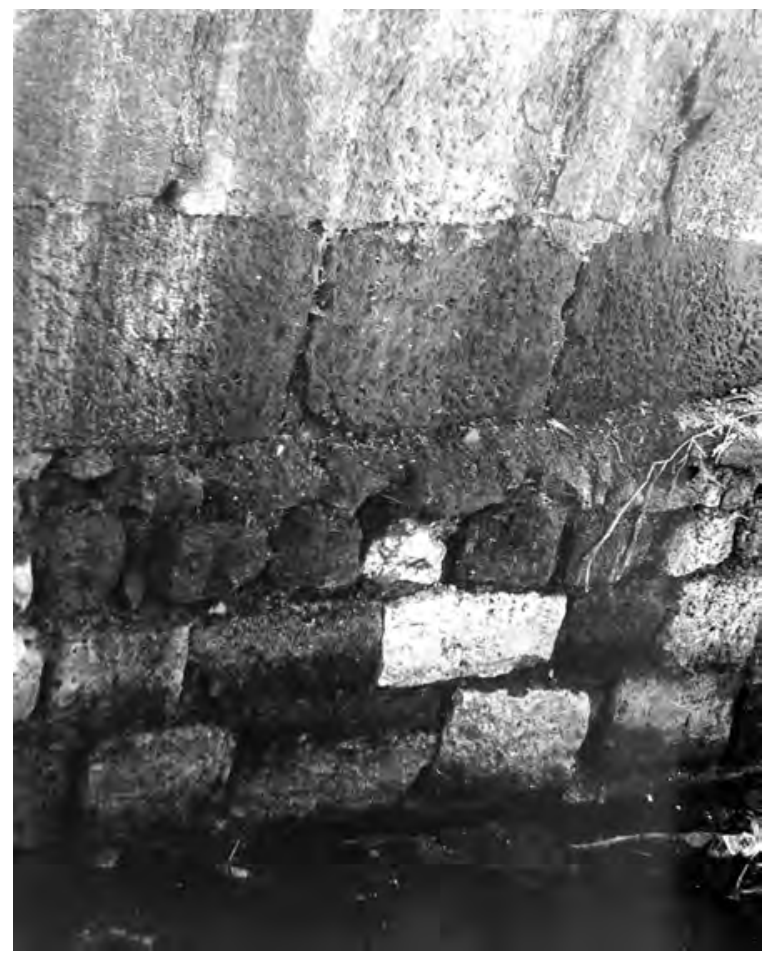

Fig. 2. Late antique wall as a basis for the early Byzantine one

At the same time, when the camp fortification was first reconstructed, a new fortress was erected (Fig. 1.3) above the first raised terrace on the bank of the Danube. For the present, the investigation revealed the north-western corner of the fortress; a fragment of the northern wall running northeast up to the spot it was reused as the foundation of a new wall in the sixth century; and most likely a fragment of the eastern wall was also reused as the foundation of an early Byzantine wall (Fig. 2). The wall sectors investigated are 700-800 m away to the north-north-west of the presumable north-western corner of the camp. The superstructure of the northern wall is preserved in 1-2 courses, and the eastern one in 4-5 courses. The whole wall is constructed of small, neatly dressed rectangular stone blocks $(0.35 \mathrm{~m}$ x $0.45 \mathrm{~m} ; 0.50 \mathrm{~m}$ x $0.30 \mathrm{~m}$; $0.60 \mathrm{~m} \times 0.40 \mathrm{~m} ; 0.70 \mathrm{~m} \times 0.50 \mathrm{~m}$ ) bound by pink mortar. It is $2.20-2.60 \mathrm{~m}$ thick. There is a gateway at the western end, probably shaped as an overarched passage. It is $2 \mathrm{~m}$ wide. The corner stones of the inner face of the passage are hewn in a special way. The foundations are $3.10 \mathrm{~m}$ deep, and begin with banquettes, $0.10-0.18 \mathrm{~m}$ wide. They are constructed of crushed stone bound by pink mortar.

We have only circumstantial evidence to date this wall fragment. It seems that it was demolished and leveled partly to match the terrain and partly to serve as the foundation for the construction of the new early Byzantine wall. If this is the same wall 


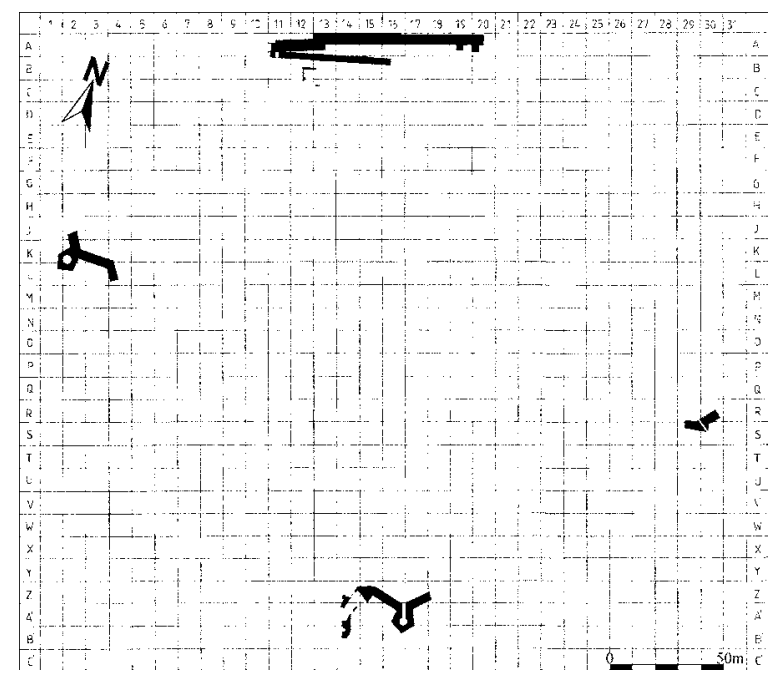

Fig. 3. Plan of late antique and early Byzantine fortress

at the eastern sector, then both fortresses' territory coincides at least to the north, and north-east to east. The arguments already expressed for dating the wall from the very end of third to the beginning of fourth century, ${ }^{28}$ are still on firm ground. The exact functions of this newly built fortress are yet another problem. Considering its date, it did not fortify the municipium. Moreover, there are no remains of a massive classical construction found on its territory up to now, despite the cultural layer containing artefacts and coins from the third to the fifth centuries. The northern wall was built above the classical wall at two spots. It seems reasonable to suggest that the fortress was nothing less than a military construction designed to reinforce the defence of the ford across the Danube River so often attacked by the Barbarians.

Durostorum was strengthened once again in the sixth century. Excavations have unearthed the north-western pentagonal corner tower, together with its adjoining parts of the curtain wall, fragments of the northern wall with a gateway, fragments of the eastern wall with a triangular tower, and a postern passing through this tower, as well as the southern wall together with two triangular, a pentagonal and a semicircular tower (Fig. 3). The building technique and the identity of the towers, as well as the stratigraphical data undoubtedly show that all belong to one and the same fortification. The new fortress lies on the first and second terraces over the Danube River. The displacement between the southern and northern walls is more than $2 \mathrm{~m}$. Some returns observed along all of the four investigated sectors make the fortress look like a polygon. The fortified area measures approximately 0.5 ha. All towers are situated at returns of the walls, thus projecting significantly in front of the face of the curtain wall.

28 Angelova 1973, 89. 
The central and eastern sections of the northern wall are preserved. The wall is $4.20 \mathrm{~m}$ thick. Great lengths of its western half up to the north-western corner tower are demolished and engulfed by the Danube. The wall foundation has not been traced because of the higher level of subterranean water. The superstructure begins with a twostepped footing made of quadrae, and continues upwards in three double-faced courses preserved, of quadrae measuring $1.0 \mathrm{~m} \times 0.50 \mathrm{~m} \times 0.42 \mathrm{~m} ; 0.90 \mathrm{~m} \times 0.70 \mathrm{~m} \times 0.58 \mathrm{~m}$. The quadrae are arranged in length and across, and they are leveled. Sometimes the stone blocks cling close to one another, sometimes there are gaps between them, 4-6 cm wide, and they are plastered up with a red hydrophobic coat. The emplecton is of a heterogeneous building material - stone and architectural ceramics - bound by mortar of a saturated red colour. Classical limestone and marble cornices, gravestones, etc. are also put in the construction. At some spots even the face quadrae, reused from some earlier constructions, are leveled by architectural ceramics, horizontally or vertically.

A gateway has been revealed in the eastern half of the northern wall. Most likely it was an overarched passage through the wall, flanked at the inner side, and probably from the outside by massive trapezium-planned engaged poles. The passage was about $2.20 \mathrm{~m}$ wide. At this very place the wall and the gate survived only in its substructure. A pentagonal tower was constructed at the north-western corner over a deep return to the south-east. There the wall is $3.60 \mathrm{~m}$ thick. The tower was erected upon a circular hollow basement. There is no evidence of a construction providing access to the upper floors. The maximum measurements of the tower are $10 \mathrm{~m} \times 9 \mathrm{~m}$, and the thickness of the wall reaches $2.50 \mathrm{~m}$. Both the wall and the tower foundations are made of trashed stone and fragmentary architectural ceramics fastened by red mortar. They rest upon banquettes $0.15-0.20 \mathrm{~m}$ wide. From the tower the wall runs south to south-east; its foundation is traced along $10 \mathrm{~m}$.

A section of the eastern fortress wall has been revealed among residences on Stoyan Zaimov Street (Figs 4.1 and 4.2). Its superstructure displays the same form of construction. At this spot an earlier wall had been reused as the foundation of the early Byzantine wall, expanded by masonry of trashed stone and red mortar, $1.20 \mathrm{~m}$ thick. The superstructure begins with a single over-ground plinth course of quadrae. It is $3.60 \mathrm{~m}$ thick. The wall return is shaped as a triangular tower, and a postern passes through it. The postern wall is well fashioned, and it is paved with stone slabs; even pieces with Latin inscriptions are among them. The measurements preserved are $6.20 \mathrm{~m}$ in length, $1.02 \mathrm{~m}$ $\mathrm{x} 0.95 \mathrm{~m}$ in width. The gate was closed from inside by a portcullis, grooves for which being specially made in the wall and in the pavement.

A section of $40 \mathrm{~m}$ of the southern wall and four towers of the early Byzantine fortress were investigated in 1986-1987 in the northern sector of Silistra's modern town square. Only the foundations survived from two of the towers - one circular and one triangular (Fig. 5.1). Both of the other towers - triangular and pentagonal ones - are of shapes and size identical to the towers known from other sectors of the fortress. The 


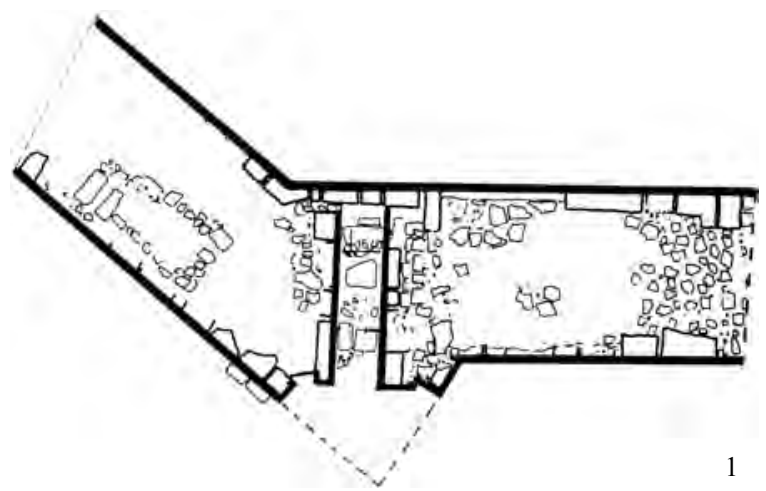

Fig. 4.1-2. Early Byzantine wall (East) with a poterna

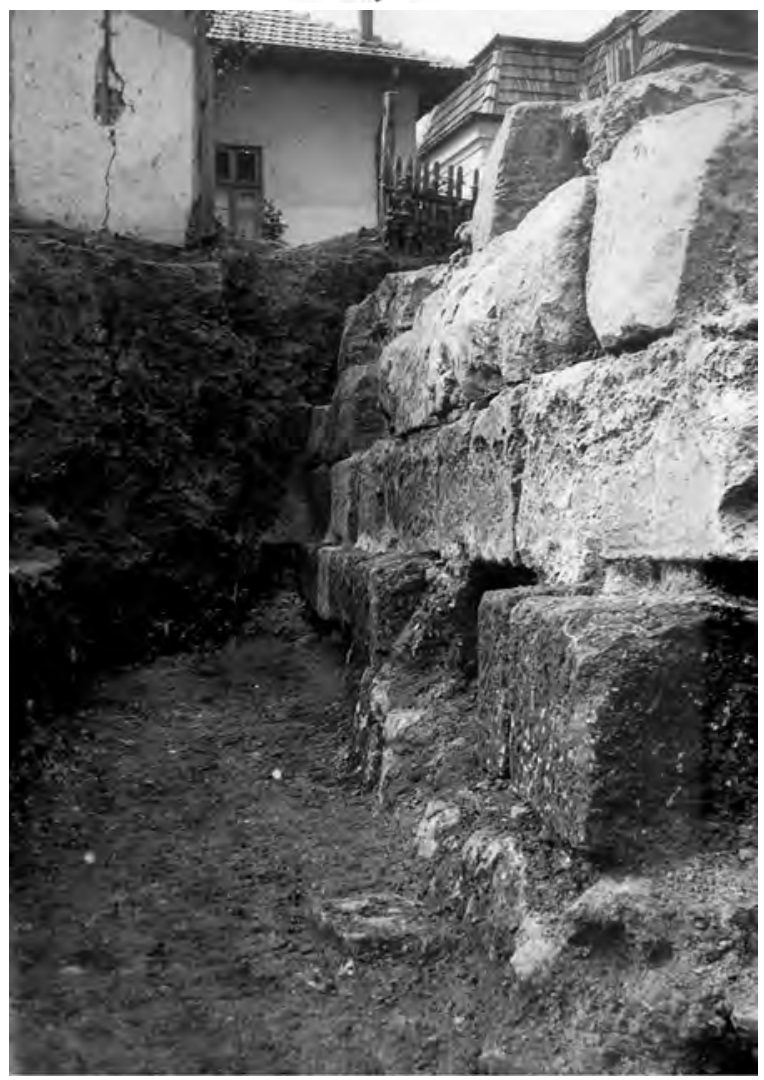

wall is $3.60 \mathrm{~m}$ thick. The foundation (3.80-3.90 $\mathrm{m}$ wide, and $3 \mathrm{~m}$ deep) is constructed of small and medium sized trashed or roughly dressed stones, leveled, and fastened by a solution of lime, coarse-grained river sand, and broken architectural ceramics. The terrain had not been specially stabilized before the masonry was built. The first 


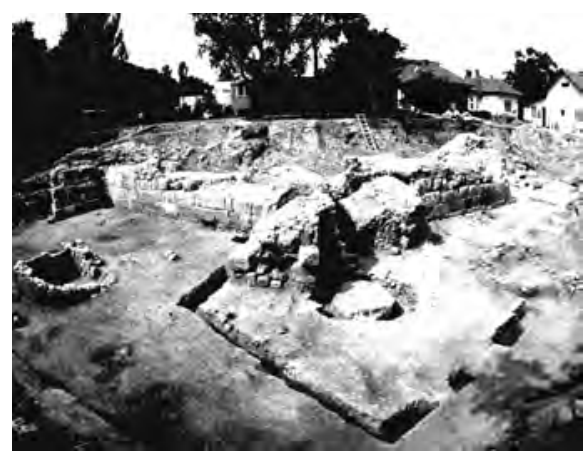

Fig. 5.1. Southern early Byzantine wall with a pentagonal tower - view from south-east

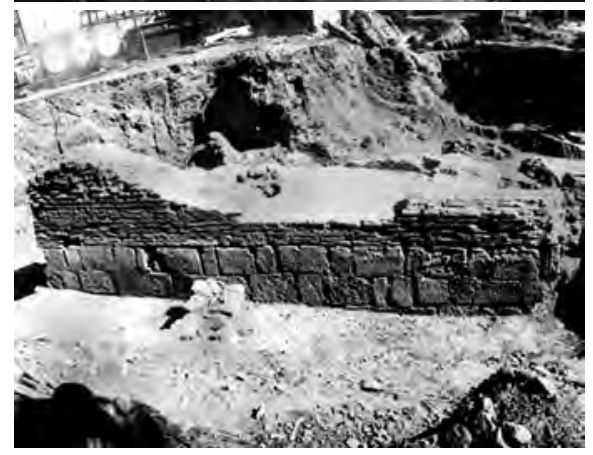

Fig. 5.2. Southern early Byzantine wall with a pentagonal tower - view from the north

overground course of the towers was formed as a plinth of quadrae, up to $1.90 \mathrm{~m}$ large, alternating lengthwise and across. Three courses follow, made of quadrae up to $1.20 \mathrm{~m}$ long. They are well leveled and are arranged in the same system. The wall between the two towers, except for the overground plinth course, is composed of the same masonry. Obviously many of the quadrae had been taken from some earlier constructions; therefore the horizontal and vertical gaps are of various widths $(2 \mathrm{~cm}, 4 \mathrm{~cm}, 6 \mathrm{~cm})$. At some points they were filled with fragments of architectural ceramics and red mortar. The preserved face plaster is of red mortar and brightly polished. Above this block masonry the wall, and likely the towers, were built double-faced of double brick courses and an emplecton of stone and bricks soaked in red mortar. At some points eighteen courses of the brick masonry survived (Fig. 5.2), i.e. this peculiar pseudo-brick masonry obviously reached up to the platform. The masonry is very solid though not rather precise, largely due to reused heterogeneous building materials taken from older buildings. There are no traces of brick masonry in the rest of the fortress, and yet more than one plinth and three following courses of superstructure survived nowhere else.

We can determine the date of the stone-brick wall construction relatively precisely. At two spots the wall is on top of the third to fourth century wall, which was in use at least until the fifth century. The artefacts and coins from the late antique cultural layer date to that same time. As we have mentioned before, coins from the second 
half of the fifth century are missing. The early Byzantine cultural layer is best preserved around the walls and towers. The coins coming from it date from the reign of Emperor Anastasius (491-518) to Emperor Phocas (602-610). Stone-brick masonry, groundwork, reuse of various building materials taken from earlier constructions, tower types, and gates flanked by elongated engaged poles are all elements characteristic of the early Byzantine style of building. The brick masonry has been imitated in a rather successful manner. The area of the fortress is comparatively small, though very efficacious. The intervals between the towers along the southern wall are not longer than 12-13 m. Probably the eastern and western walls looked the same. For the present, only the northern wall has revealed no towers. The fortress was planned and built as a military site either in the days of Emperor Anastasius, or, more likely, under Emperor Justinian (527-565). Procopius of Caesarea credits Emperor Justinian with the repairs of each of Dorostolon's fortifications. ${ }^{29}$

The last repair of the walls and towers of the legionary camp refers also to the same time or little a bit earlier. According to the observation of P. Donevski, since the end of sixth century the camp was inhabited by civilian population. It seems most likely that the military units were removed to the fortress at the riverbank, and stayed there until the end of Antiquity. Obviously the fortress wall of the camp and the fortresses at the River bank were in function at the same time, thus building up an extended depth of the defensive line.

In the summer of 1988 a large fragment of another wall (Fig. 1.5) was accidentally found $300 \mathrm{~m}$ east of the late antique and early Byzantine fortress. It is $60 \mathrm{~m}$ long and $2.10 \mathrm{~m}$ thick. The wall is double-faced, and the emplecton consists of heterogeneous building materials and pink mortar. The exterior face is made of large quadrae arranged lengthwise and across in turn. Stone blocks of various sizes compose the interior face. As many of them have been taken from some earlier buildings, the width of the gaps differs too. Pink mortar is employed as binding solution on both faces. The wall is constructed without a foundation. ${ }^{30}$ The cultural layer beneath the wall contains artefacts dating from the third century, and bears clear marks of fire. The wall might well have been erected upon the northernmost sector of the canabae that were not rebuilt after the fire. The wall imitates the masonry of the early Byzantine fortress, and most likely it was also constructed in the sixth century. It was made in a hurry, with material drawn out from antique buildings. All we can say for now is that the wall appears as one more element of the defence system of the early Byzantine city.

29 Procopius of Caesarea 1958, 169.

30 Donevski 1990, 244. 


\section{Town planning and architecture}

We only have scanty data of town-planning of fortresses on the fortress terrain during late antiquity. As it is well known, the early Byzantine fortress became the nucleus of the medieval town of Drustur. The terrain, at least the northern sector of the fortress, had been leveled prior to the compact overbuilding by the medieval town. Some water conduits, lying about $1 \mathrm{~m}$ beneath the level of the medieval ones, show that the fortresses were supplied with water (Fig. 6.1). A drain, built-up and covered with stone slabs, was discovered near the north-western corner of the late antique fortress (Fig. 6.2). A large two-spaced building was unearthed between the medieval basilica and the northern fortress wall. Its walls are $0.80 \mathrm{~m}$ thick, made of trashed stone and hewn stone blocks, small in size, and bound with pink mortar. The foundations are of the same material, though bound with mud. The building was covered with tiles. This may have something to do with the brick-and-tile housing levels surviving partially inside the central apse of the basilica and the eastern sector of its central nave. Its functions are not quite clear yet. Nevertheless, considering its size, as well as the archaeological data available, it does not seem to be an ordinary residence building. Its location close to the northern fortress wall supports the suggestion. The building disturbed a layer containing coins from the third to fifth centuries; and a layer with artefacts and coins from the sixth century was found above the wall banquettes. There is evidence of buildings with stone foundation and walls made of adobe, located in the north-eastern sector of the fortresses, as well as to the south, in front of the early Byzantine fortress' southern wall.

We have already mentioned that since the end of the sixth century, the camp territory was inhabited by civilian population. The architectural data, though, is scarce enough. The archaeologist exploring the camp published the plans of two late antique buildings without commenting upon them in the text. ${ }^{31}$ One of them is very large in size, twospaced and with a system of poles attached to the wall from inside. The other one is also divided into two rooms. Probably a street, about $5 \mathrm{~m}$ wide, runs between the buildings. Both buildings' walls are $0.60 \mathrm{~m}$ thick. They are described as civilian houses, and the objects found are for daily use.

There were significant building activities in the canabae of Durostorum during the first half of the sixth century. The planning designs of the rich private houses changed almost entirely. A building investigated $200 \mathrm{~m}$ north of the camp, in Patriarch Evtimi Street (Fig. 7), appears to be particularly illustrative of private construction in late antiquity. In the early fourth century an impressive house was erected upon at least two earlier buildings. Its orientation is north-south, with 12 degrees declination to the east, which seems to be usual for most of the buildings in the canabae. The entrance is on the east, shaped as a portico. A large hall with deep semi-circular exedra covers the house's eastern half.

31 Idem 1988, 93, tab. X. 


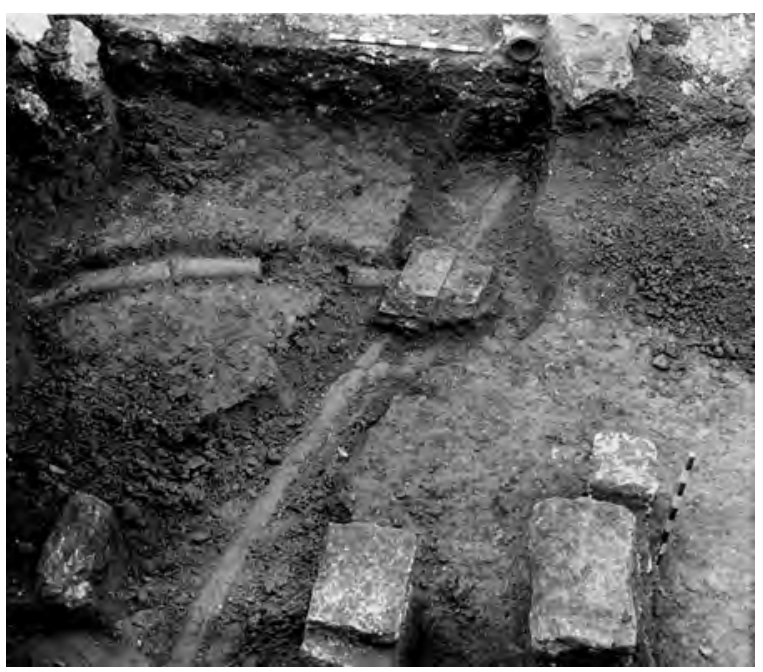

Fig. 6.1. Early Byzantine pipelines

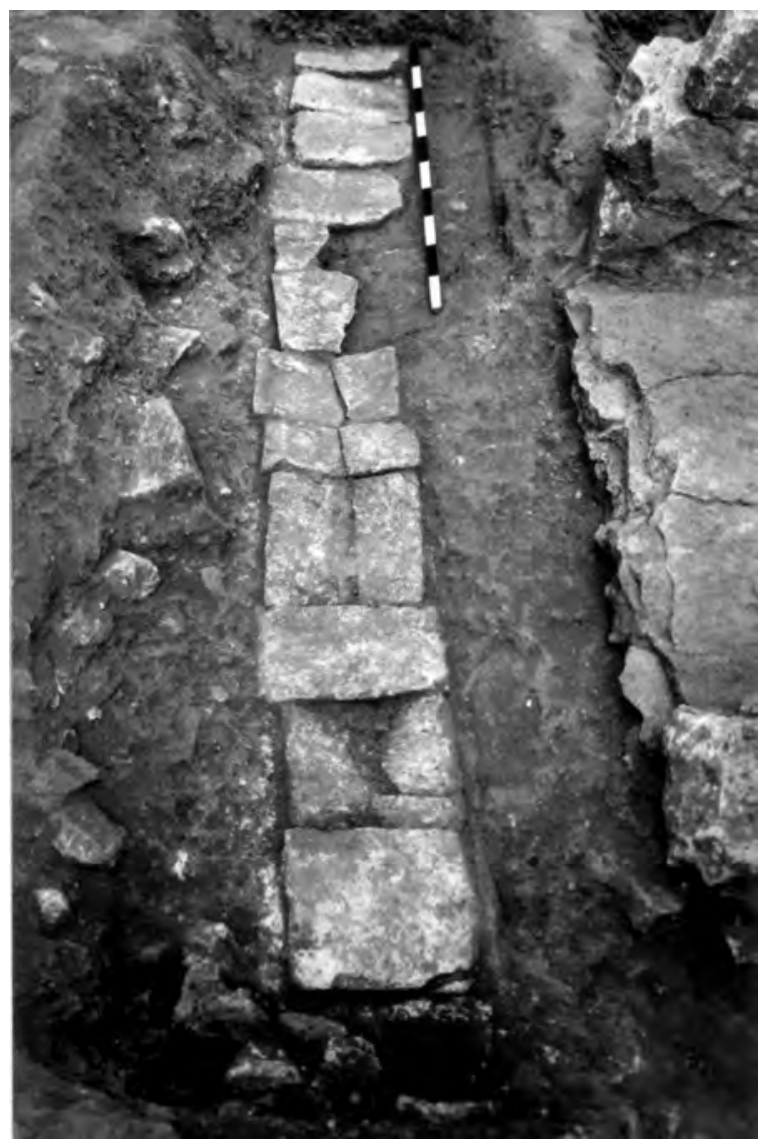

Fig. 6.2. Sewage system of the late antique fortress 


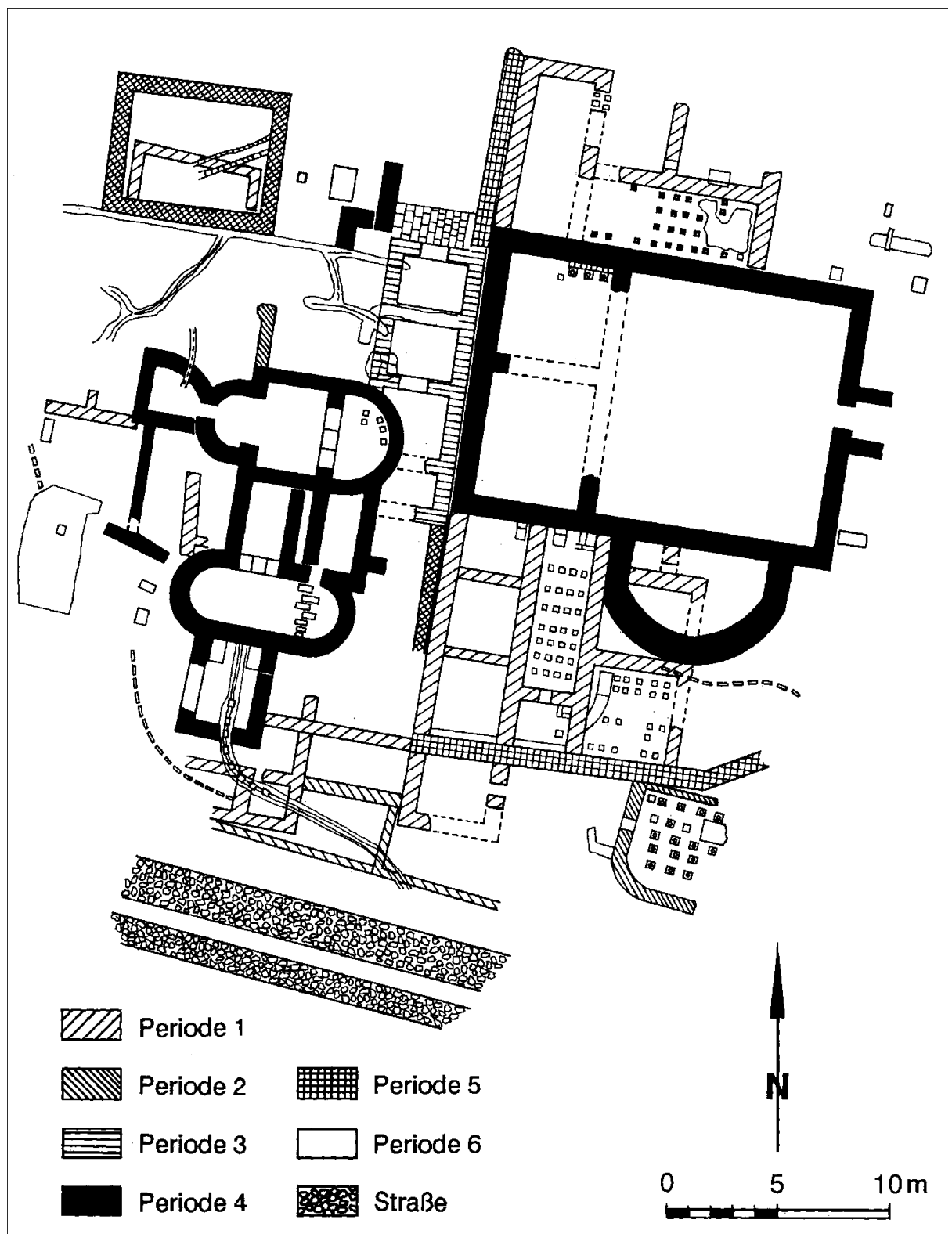

Fig. 7. A building from the canabae 
The western half is reconstructed as two-spaced. No other entrances were identified. The thickness of the walls up to $1 \mathrm{~m}$ suggests a second floor. The masonry is of stone and bricks. Most of the stones came from earlier constructions, and a Latin inscription was also walled in. Pink mortar was used to bind it. It is the same kind of masonry observed in the bath located to the west. There is a street, $3.5 \mathrm{~m}$ wide, running south of the house. As one may tell from this house plan, ${ }^{32}$ it lasted well to continue to function until the end of antiquity. Both of the latest building periods marked on the plan seem to be a kind of additional works to the south and west; however they did not affect its original design.

Many other private houses on the canabae territory went through the same building history. It is only known that they were rebuilt in the beginning of the fourth century and they were much more representative than the earlier ones. They were constructed according to an elaborate architectural plan, supplied with a hypocaust system, and connected to water main and sewer. The houses rose 7.50-12 m from one another on both sides of streets running north-south or east-west. The artefacts found during the excavations range from the second to the sixth century. ${ }^{33}$

The public buildings experienced a slightly different fate. A very elaborate bath has been investigated in Bogdan Voivoda Street, some $260 \mathrm{~m}$ north of the camp. Its latest reconstruction was in the first half of the fourth century. ${ }^{34}$ It is not known when the bath was abandoned. Most likely it happened after the middle of the fifth century. The coins found there date as late as the sixth century, and late antique lamps as late as the sixth to early seventh century. ${ }^{35}$ This circumstance means that life continued on the bath terrain even after the bath itself stopped working.

A series of problems confronts us in the attempt to sketch the inhabited territory of the late antique town due to the lack of complete publications of the sites investigated, and mostly due to the incomplete data obtained by rescue excavations. Considering the location of the fourth to sixth century necropolises (Fig. 1.8-9), the town territory remained unchanged. One only out of all eight vaulted tombs lays north-west of the camp, in the canabae area. ${ }^{36}$ early Byzantine graves have been found west of the stone-brick fortress, over a terrain undeveloped up to this time. Simultaneously, kilns for architectural ceramics and pottery appeared in the sixth century in areas containing third-century artefacts. Considering their position north and north-west of the camp, these areas might have belonged to the canabae (Fig. 1.6; 1.6.1). Upon a burnt layer of the same date, a wall was also built, $300 \mathrm{~m}$ east of the fortresses on the bank of the Danube. This data makes us think about certain changes in the function of some parts of the settlements around the camp. We have already commented on some changes of the nature of the camp territory.

32 Idem 1990, fig. 4.

33 Ibid., 239, fig. 3.

34 Idem 1988, 90, fig. 7.

35 Kuzmanov/Buchvarov 1986, 59.

36 Donevski/Miloshevic 2000, 41. 


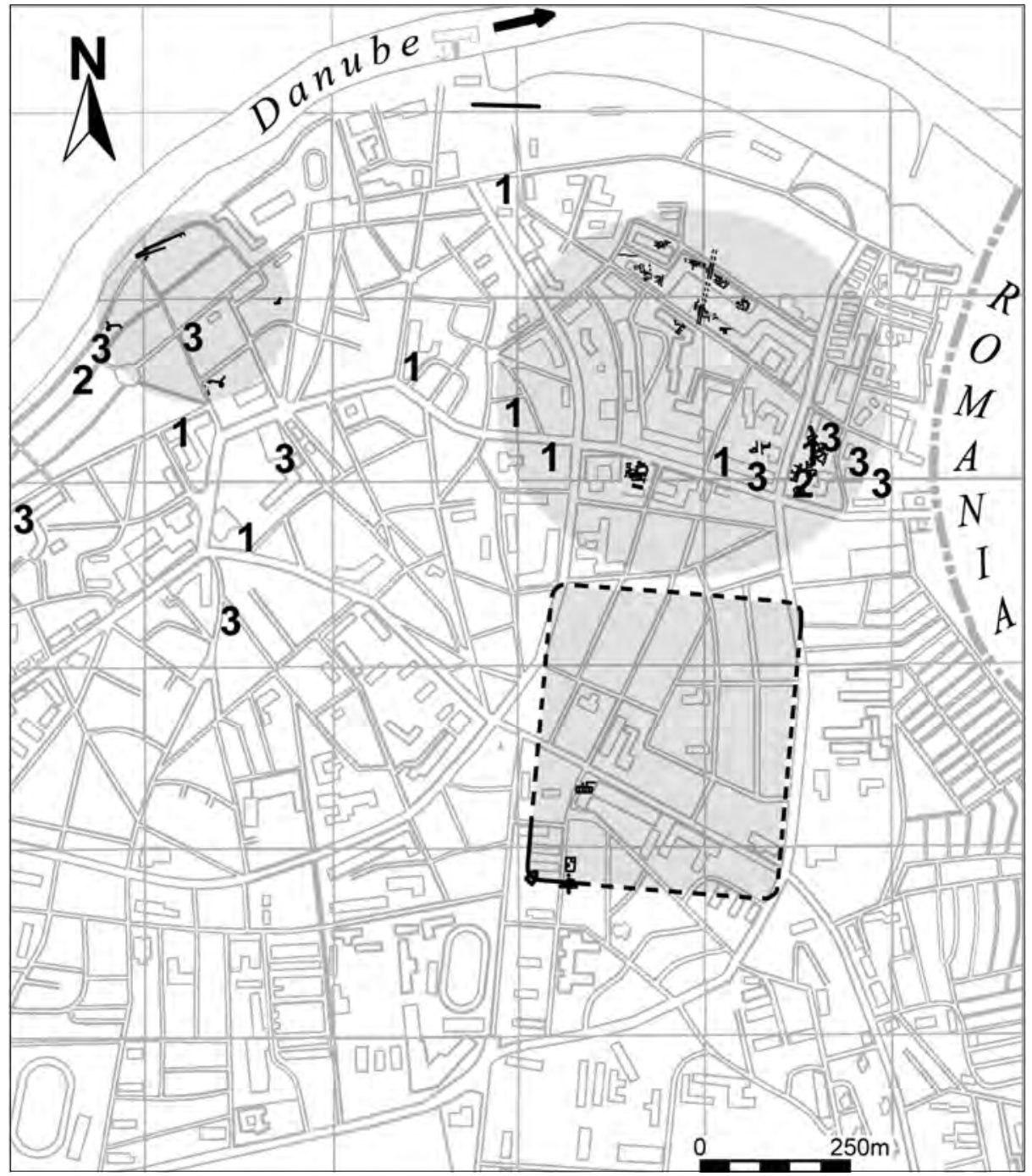

Fig. 8. Map of late antique lamps. 1. lamps 6-5th, fifth century; 2. lamps (fifth-sixth century); 3. lamps (sixth-seventh century) 
Plotting the late antique lamps found in Silistra on the archaeological report affords additional data. Lamps dating from the third to fourth or fourth to fifth centuries have been discovered during excavations or by accident on the canabae territory. ${ }^{37}$ Lamps from fifth to sixth and sixth to seventh centuries concentrate on the territory of the early Byzantine fortress (Fig. 8), or on neighbouring areas. Lamps of the same date have been found also during investigations of the Roman bath, $260 \mathrm{~m}$ north of the camp, and as an exception at other sites in the canabae region..$^{38}$

During late antiquity Durostorum was a seat of Christian culture. We should expect the construction of churches and one or more cathedrals. And in fact a church was found, but almost entirely destroyed during construction work on a new prosecutor's office in Makedonia Blvd (Fig. 1.7). One of the stylobates and part of the southern aisle survived. The intervals between the bases of the colonnade are $3 \mathrm{~m}$ long. The floor is paved with large bricks laid upon mortar bedding. The stylobate foundation is made of trashed stone.

Most likely the church was of a basilica type. It is part of a large architectural complex, but chain premises survived only on the north. It perished in fire, dated by means of a treasure hidden in the church. The treasure contains jewels and coins, the latest minted by Emperor Constantine IV Pogonatos (668-685).

In the course of the years, marble capitals, cornices, and slabs have been found at many places in Silistra. Their patterns are characteristic of church decoration dating from the fifth to sixth centuries. They suggest that some representative cult structures existed at that time (Fig. 9). We have to suppose that these kinds of buildings gradually became town-planning accents and thus imposed a new organization of the town space.

\section{Crafts and commerce}

The continuous building activities - military, cult or private - required the maintenance of high standards of stone-dressing and building trade in general. Stone-dressers' workshops have not yet been found, although they undoubtedly existed. Local kinds of rocks were used for the construction of new fortress walls and private residence buildings, mainly limestone of various types of hardness. The classical city was of course also a constant source of building materials. The building trade and artistic processing of stone in Durostorum followed traditions lasting several centuries. Now decorative carving, inspired by the spirit of the times, developed. Marble was imported and processed as well, mainly to decorate cult constructions.

37 Kuzmanov/Buchvarov 1986, 61-62.

38 Ibid., 57-59. 


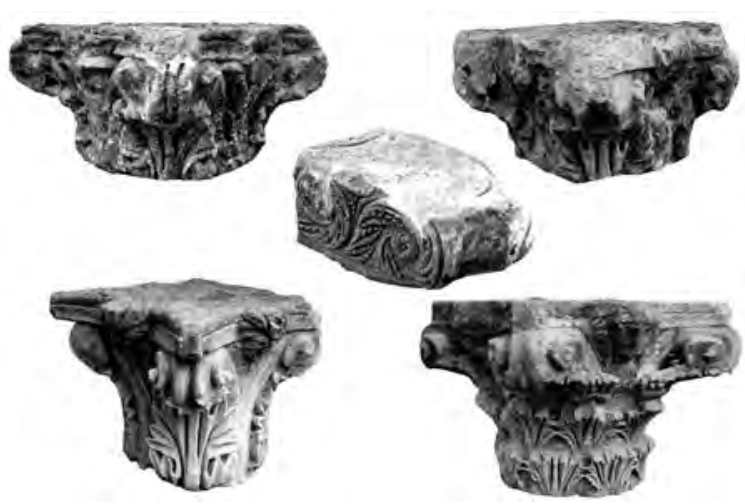

Fig. 9. Capitals

During Classical Antiquity, architectural ceramics were produced mostly in the figlinae of Legio XI Claudia, and in the officinae, located around Ostrov (in present day Romania). ${ }^{39}$ Bricks bearing the stamp of RVMORIDVS date to the fourth century; they were made in the workshops of a private producer, and are also known from other places along the Limes. ${ }^{40}$ All these workshops stopped their activities in the last decades of the fourth century. Two kilns for architectural ceramics have been accidentally discovered during construction work in the central zone of Silistra. One of them was destroyed during construction works on the terrain of the old Bobev Hotel, and the other one was found at the Silistra Municipality garage. They are located some 250 $\mathrm{m}$ away from one another, and at almost the same distance north-west of the camp and south-east of the early Byzantine fortress. The kilns were not documented. They were bicameral. Numerous fragments of bricks and tiles have been found around them. They are red in colour, decorated with low grooves on their forefront, and of shapes particular to early Byzantine architectural ceramics. The kilns' furnaces disturbed a third-century burnt layer. Three bells of copper alloy had been hidden inside one of the kilns. The kilns obviously belonged to workshops for architectural ceramics from the sixth century, which were owned by private producers. One cannot tell whether they were permanent or temporary structures, working for a particular construction site. In any case, there is no evidence of an earlier or contemporary construction nearby. This circumstance explains the occurrence of such inflammable structures in an area presumably overbuilt with civilian settlements.

Brick-making remained a permanent trade during the entire period of late antiquity. Thus standards for quantity and quality were maintained. Bricks, tiles, and water pipes were manufactured from store for private and public buildings, and impressive stone brick tombs. The construction of the early Byzantine wall also demanded large-scale

39 Museteanu 2003, 14-15.

40 Ivanov 2002, 125-148. 

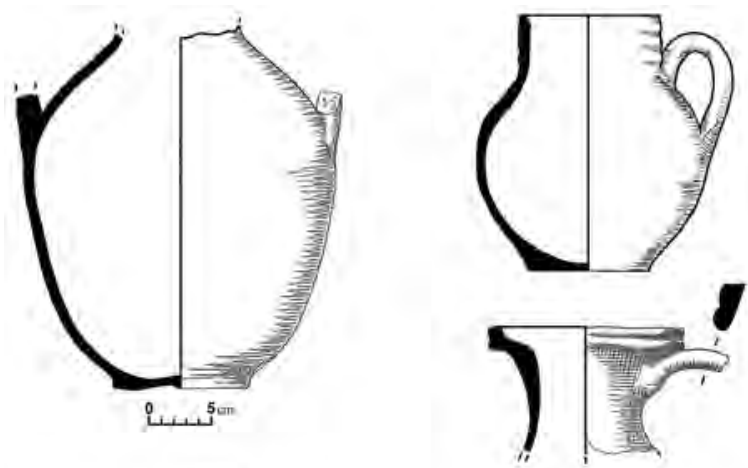

Fig. 10. Pottery and lamps from a kiln
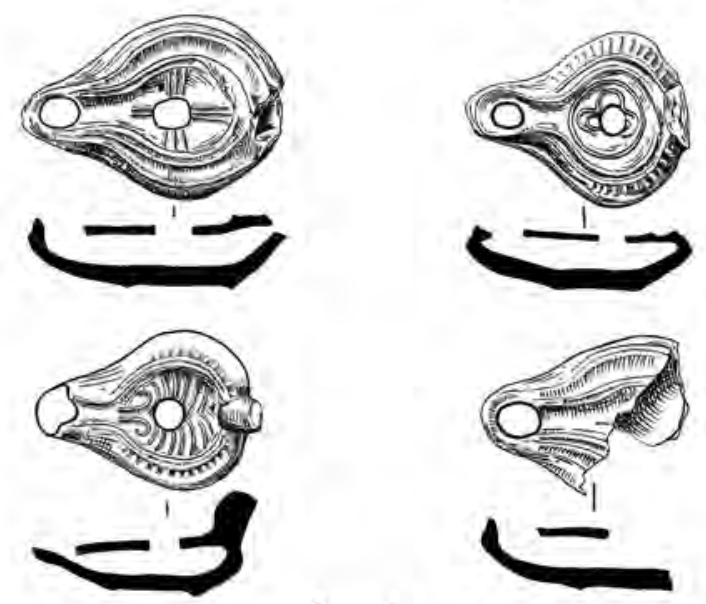

$\underbrace{0,3}, 3^{\mathrm{com}}$

production of bricks. Bricks contemporary of the wall were used for both of its faces. The bricks for the emplecton were taken from some older building deposits, or from demolished antique buildings. The forms documented are 28 in number, to begin with the bricks produced in Legio XI Claudia's workshops. The reason does not lie in the lack of production, but rather in the speed of the construction works demanding the employment even of decorative architectural pieces, tombstones, etc.

After the workshops for pottery and lamps, located in the vicinity of Ostrov, closed, the production of such articles moved to the outskirts of the city. Two kilns for pottery and lamps, and a pit containing waste products, obviously dug close to a kiln still undiscovered, date to the sixth century. One of the kilns was located outside of the city, however, very close to the eastern wall of the early Byzantine fortress. It contained grey pots and lids made of sandy clay, belonging to the category of everyday pottery. The kiln was accidentally revealed while working on the construction of the Danube town 


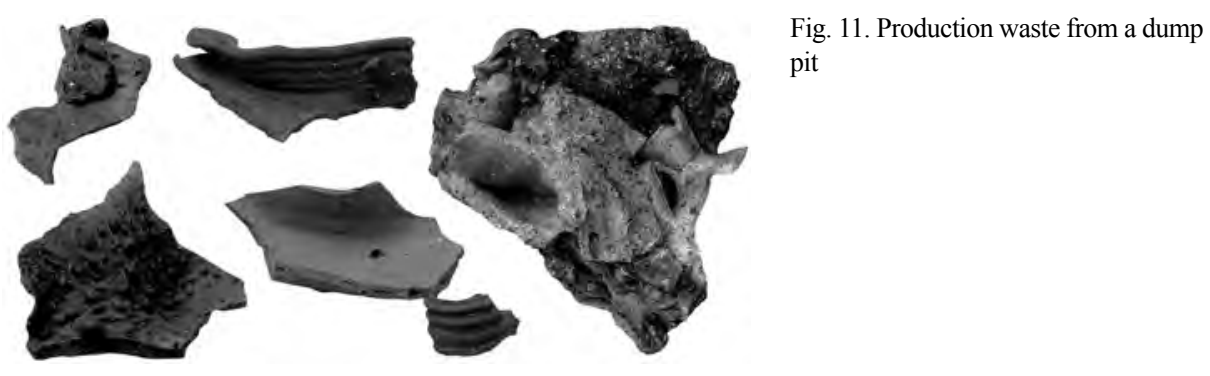

swimming pool. Some of the vessels found had been deformed during firing. There is no data available on kiln construction.

The second kiln was also outside the fortress wall, some $500 \mathrm{~m}$ away, south-east of the eastern wall with triangular tower and postern. It was revealed and demolished while building a post office (Fig. 10). Of its products some table earthenware, flat-bottomed amphorae for storage of liquids, and lamps have survived. ${ }^{41}$

The lamps are made of yellowish clay without any engobe. They were cast in moulds with an elongated shape, concave disc, enclosed within embossed rings, transforming into a groove over the wick. Embossed patterns develop around the opening of the oil reservoir. The bottoms are slightly concave. Two pieces have been cast in one and the same mould. Their parallels classify them among types wide-spread all over the Danube provinces between the fourth and seventh centuries. The lamps do not bear any traces of use, i.e. they belong to the still unsold products of a workshop. The authors assume that the same workshops also produced the amphorae and table ceramics of the same date, well known from the Isthros-Pontian zone. The variety of production and its high quality were characteristic of Durostorum, and lasted well until the close of antiquity.

The production waste coming from a pit near the eastern end of the northern fortress wall (Fig. 11) appears to be of great interest. The pit lies at the inner side of the wall. It is still hard to say if the workshop with the kiln was there. Among its products there are cooking pots, tableware, jugs and pitchers with two handles. The number of bowls and dishes with ochre-red and brown-red slip is very similar to the one of the late antique red firnis pottery.

On the basis of all this evidence, we could conclude that late antique Durostorum produced urban building and utilitarian pottery. The preservation of the local craftsmen's guilds, as well as the existence of large deposits of plastic clays around the city contributed to this.

In the early 1960s in Marin Drinov Street during sewer construction, a collective find of circa forty objects was found. These were vessels, candlesticks, copper alloy

41 Angelova/Buchvarov, in print. 


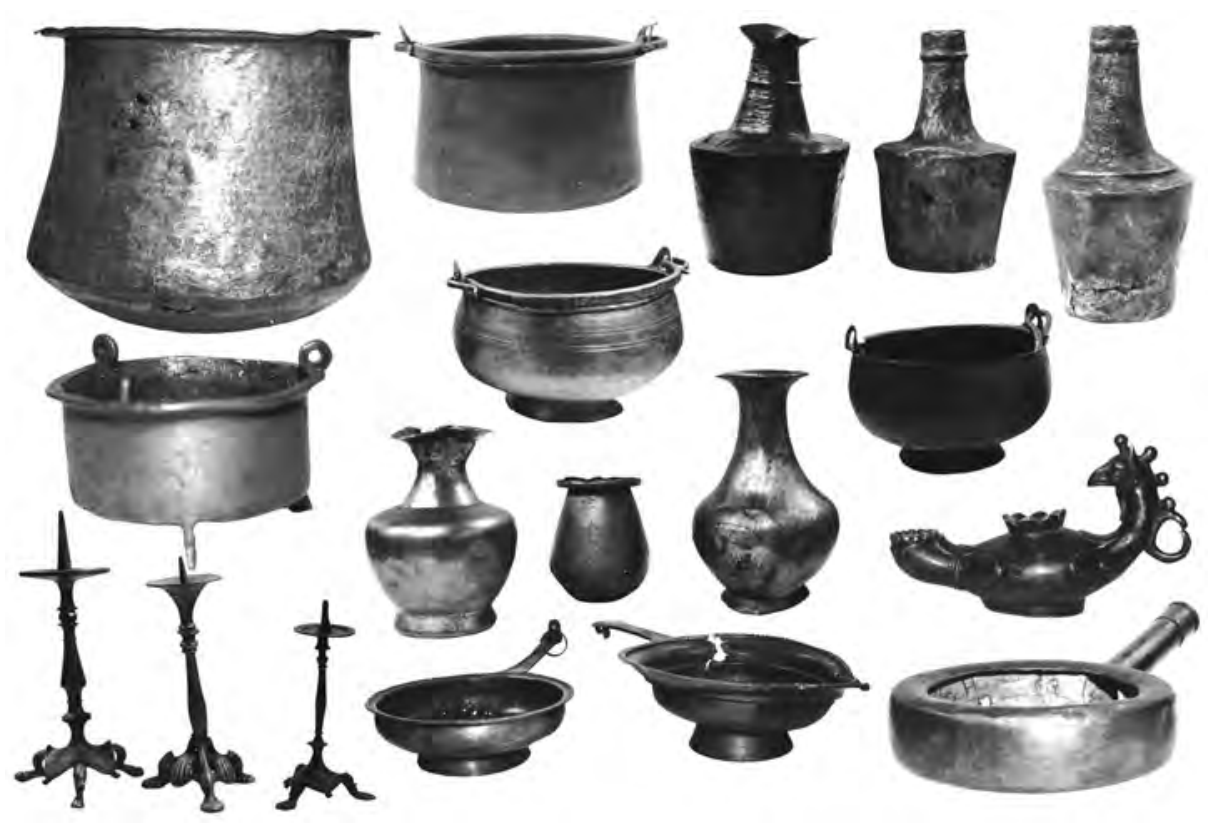

Fig. 12. Copper vessels from a collective find

lamps and a few iron objects (Fig. 12). This street slopes within the estimated north half of the Roman camp. The archaeological context of the find is not clear. Its collective character, the damage on the vessels and the different dating of the different objects, extending over 100 years, suggests rather that it was the private collection of a craftsman. There are similar finds from other places, e.g. Olympia ${ }^{42}$ and the famous find from Stara Zagora, ${ }^{43}$ the latest objects of which are dated to the mid- to late sixth century. The most probable reason for its burial in the ground seems to be the Avar invasion of 585 .

The find consists of one large cauldron, a few smaller pails, jugs, oinochoes, pateras, candlesticks and lamps. One of the lamps has a handle shaped like a griffin, another one like a cross. Most of the objects are wrought. The probably come from different provincial workshops, preserving the traditions of antique artistic metalwork.

The workshops of the late antique city probably produced the large number of metal pieces of the costume like fibulae, belt and shoe buckles, appliqués, etc., which were found by accident during excavations. The murals of the most well-known fourth century tomb from the city's necropolis illustrate best the costume of the well-off citizens of Durostorum and their servants. In the course of time, tastes changed and in the sixth century, the smaller metalwork was done in the Barbarian-Byzantine fashion

42 Völling 1995, 424-459.

43 Velkov 1959, 144-145. 
originating from the Lower Danube. Some smaller finds and pottery could be connected to the presence of a Germanic population from the early fifth century.

The finds from the church on Makedonia Street could be defined as a jeweller's hoard. The one-type earrings, uncleaned after production, are a direct evidence for this. The simple jewellery in Byzantine style is made of silver. Silver was obtained by melting Byzantine silver coins, three of which were found with the jewellery. The geographical spread of the jewellery led us to believe that it was traded to the Slavic population, whose presence in Durostorum at that time is a well-established fact. The latest of the coins belongs to Emperor Constantine IV (668-685). A series of similar hoards mark the movement of Bulgarians towards the Danube delta. The hiding of the silver hoard in the church most probably means that Asparouh took the city.

Apart from the crafts already mentioned, for which direct evidence exists, we should suppose also the production of tools for stone-cutting, copper-processing, fine jewellery etc., i.e. the existence of ironmonger workshops, in which utilitarian objects were made.

The connections of Durostorum in late antiquity with the fertile regions near it could not be traced. The only villa rustica studied so far is situated south-east of the camp. Like most villas of this kind in Scythia Minor and Moesia Inferior, it was used until the last decades of the sixth century.

The question of food provision for the late antique city needs its own study. The wealth of the citizens, demonstrated in the quality of the public and private buildings and in the brick-stone tombs excavated in the necropolis, suggests the existence of its own sources of income. It is hard to verify of what kind they were. The city's resources obviously decreased between the late fifth and early sixth century, when the maintenance of the big public baths was terminated. In the sixth century a wealthy class still remained, which continued to invest money in the construction of religious buildings and rich tombs. The private craftsmen were probably well-off too.

The circulation of Byzantine copper coins can be illustrated through a number of finds from the time of Constantine the Great (303-337) up to Justine II and Sophia (565-578). As we have already mentioned, there are no coins from the late fifth century and the emperors from the last quarter of the sixth and the early seventh centuries are represented by few specimens, discovered on the territory of the early Byzantine fortress. After Emperor Phocas (609-610) the already limited internal market completely collapsed.

The status of Durostorum as a customs point in late antiquity is a matter for speculation. Imports could be traced by the great amount of amphorae for importing foods, wine and oils. Luxury red firnis pottery was imported, as well as glassware, marble and marble decorations - i.e. capitals, cornices and slits. We have to assume that in Durostorum a distinct traders' class existed, which together with the craftsmen financed both military construction works and the church's building enterprises. 


\section{Necropolises}

Most of Durostorum's burial constructions were found by accident. The historical topography of the necropolises was clarified by the mapping of the former on the archaeological report. Late antique tombs and other burials are located south, south-east and south-west of the camp. Only a single tomb from the late third to early fourth century is situated in the north-west part of the canabae. ${ }^{44}$ Apart from the eight tombs published by these authors, there are two more in the yard of "Stomana" plant. They were single-chambered, with hemispheric vaults and of a stone-brick construction. A tomb with murals has been found and destroyed in the yard of the old brick factory. For all of them there is no documentation. Recently another tomb was found and documented in Dr. Anastas Yankov Street. It also dates to the fourth century and is single-chambered with a hemispheric vault. It is thoroughly painted from the inside with reddish lime solution.

All published tombs belong to the hypogaeus type, built of stone and bricks, the bricks being used in the vaults and as flooring. They are planned as single- or twochambered tombs with an antechamber. The smallest tomb has an area of $4-5 \mathrm{~m}^{2}$, while some of the biggest have $14-17.50 \mathrm{~m}^{2}$. They are painted with a reddish lime solution. Some contain traces of paint, i.e. they were decorated. N8 names the famous Silistra tomb with murals ${ }^{45}$ The tombs contained one to three burial places, although sarcopha$g i$ were not found. They were used many times, as the bone materials found show. They are differently oriented but the entrances - small openings, framed with stone - are always situated on a short side. At the entrance of tomb N3 there was an inscription in red paint that most likely related to the liturgy.

The only tomb different in planning and roof construction is the one documented as N7. Its plan is octagonal. Within the octagon a square, measuring $3.98 \mathrm{~m} \times 3.65 \mathrm{~m}$ and containing three archsolias in the shape of the three parts of a cross, was inserted. The three burial niches, intended for sarcophagi, are situated at the northern, southern and western sides. They are all vaulted, with the vaults rising to $1.80 \mathrm{~m}$ in height. The entrance is accessible by means of a prolonged corridor with steps, measuring $3.70 \mathrm{~m}$ $\mathrm{x} 1.20 \mathrm{~m}$. A stone frieze appears at $0.60 \mathrm{~m}$ above the floor. From the outside the tomb was built with stones, from the inside with bricks measuring $28 \mathrm{~cm} \times 28 \mathrm{~cm} \times 3.5 \mathrm{~cm}$, $29 \mathrm{~cm} \times 29 \mathrm{~cm} \times 4 \mathrm{~cm}, 30 \mathrm{~cm} \times 30 \mathrm{~cm} \times 4 \mathrm{~cm}$. The joints $-6 \mathrm{~cm}$ thick - between the bricks are of fine pink mortar. The thickness of the walls is up to $1 \mathrm{~m}$. P. Donevski and G. Miloshevich suggest, on the basis of numerous parallels, various ideas for the roof construction of the tomb - cross vaults or a dome on trumps. They also believe that the tomb was partly or entirely dug into the terrain, i.e. it could also be of the hypogaeus

44 Donevski/Miloshevich 2002, 41-54, tab. I-VI.

45 Ibid., 43. 
type. It was accessed by means of a long dromos - a corridor consisting of a vaulted ground and an underground part with an overall length of $9 \mathrm{~m}$. If the bigger part of the tomb could be reconstructed on the ground, it will be seen as a family mausoleum or a martyrium. ${ }^{46}$ The authors list accounts of the early Christians tortured to death and pronounced martyrs of the holy faith. Neglecting the presence of bones and pottery in the tomb, one scholar sees the monument as the martyrium of the martyr saints Maximus, Dada and Quintillianus. ${ }^{47}$

All these monuments serve as a good archaeological environment for the famous Silistra tomb with murals. It turned out to be situated among other similar constructions in the southern part of the late antique necropolis. It could be compared with the other vaulted single-chambered tombs with stone-brick masonry in terms of architectural type and building techniques. Its inner walls and vault are covered with murals, revealing a symmetrical composition around the central axis, which coincides with the lengthwise axis of the tomb. The main freeze on the walls consists of eleven framed rectangular spaces, reminiscent of the orthostats in the architecture. These are the frames, within which nine figural images and two chandeliers are situated. The human figures are a procession of servants carrying gifts to the masters, painted in the central field of the western wall. A magnificent "beam-construction" separates the murals on the walls from the ones on the lunettes and the vault and somehow defines them as a background. The background creates false perspective. The vault, which through the painted octagons resembles the antique paneled ceilings, includes four hunting scenes and scenes of nature in 63 fields. On the lunettes peacocks and pigeons reside among scattered flowers.

The murals of this tomb have been studied thoroughly and analysed a number of times. ${ }^{48}$ These studies are so well-known that they do not need to be presented here again. The iconography, the characteristics of the style, the data and so on are the basis for the dating of the murals to the era of Emperor Theodosius I (378-395). This dating places the monument at a somewhat special spot in the development of late antique painting. In it should be sought the signs of that new, to a great extent syncretic art that consumed the artistic traditions of antiquity. It serves as a source from which the emerging Christian art energetically sought inspiration.

The late antique tomb from the Durostorum necropolis contains a lot of realia, which have also been studied carefully. ${ }^{49}$ The artist has depicted real people - masters and servants - in their characteristic clothing and footwear. Tunicas, dalmaticas, trousers and cloaks, fibulae, belts and jewellery reveal the costume of the wealthy population

46 Ibid., 45.

47 Atanasov 2002, 55-65.

48 Dimitrov/Chichikova 1986.

49 Ibid., 56-61. 
of Durostorum and their domestic slaves in the last decades of the fourth century. The silver vessels and chandeliers are part and parcel of the rich household interiors.

There are other types of burial constructions known from the late antique necropolis of Durostorum. In the fourth century brick-laid graves still exist. In the fifth to sixth century burial pits predominate, floored and covered in the shape of eaves with tegulae. The burial gifts disappear completely.

\section{Bibliography}

Angelova 1973: Стефка Ангелова, “Крепостната стена на Дуросторум - Дръстър-Силистра. Предварително съобщение”, in: Археология 15/3, 1973, pp. 83-93;

Angelova 1988: Стефка Ангелова, “Археологическото проучване на средновековния Дръстьр (резултати и перспективи)”, in: Дуросторум - Дръстър-Силистра, Силистра 1988, pp. 32-52.

Angelova 2003: Стефка Ангелова, “Етническият състав на населението в ранновизантийския Доростол през VI-VII в.”, in: Сборник в памет на д-р Петър Горбанов 2 (=Годишник на Софийския Университет, Исторически факултет, кн. Археология; Studia Archaeologica, Supplementum 1), София 2003, pp. 245-251.

Angelova/Băčvarov (forthcoming): Елена Ангелова/Иван Бъчваров, “Керамичен производствен комплекс от VI в. от Дуросторум", in: Studia Archaeologica, Supplementum 3, София (forthcoming).

Angelova/Penčev 1989: Стефка Ангелова/Владимир Пенчев, “Сребърно съкровище от Силистра", in: Археология 31/2, 1989, pp. 40-41

Atanasov 2002: Георги Атанасов, “За късноантичния мавзолей - мартирий в Дуросторум - Силистра и доростолските мъченици Св. Св. Св. Максим, Дада и Квинтилиан”, in: Добруджа 20, 2002, pp. 55-65.

Barnea 1966: Ioan Barnea, "Noi sigile bizantine de la Dunarea de Jos", in: Studii şi cercetări de istorie veche 17/2, 1966, pp. 277-297.

Beševliev 1964: Veselin Beševliev, Spätgriechische und spätlateinische Inschriften aus Bulgarien, Berlin 1964.

Donevski 1990: Peti Donevski, “Zur Topographie von Durostorum“, in: Germania 68/1, 1990, pp. 236-245.

Dimitrov/Čičikova 1986: Димитьр П. Димитров/Мария Чичикова, Късноантичната гробница при Силистра, София 1986.

Donevski 1988: Пети Доневски, “Разкопки на лагера и канабето на XI Клавдиев легион”, in: Дуросторум-Дръстър-Силистра, Силистра 1988, pp. 84-96.

Donevski/Miloševič 2002: Пети Доневски/Гордана Милошевич, “Късноантични гробници от Силистра ( Дуросторум)”, in: Добруджа 20, 2002, pp. 41-54.

$\mathrm{GIBI}=$ Гръцки извори за българската история

Ivanov 2002: Румен Иванов, Строителна керамика от Долния Дунав, София 2002.

Ivanov 2003: Румен Иванов, “Дуросторум (Durostorum) през епохата на принципата”, in: Римски и ранновизантийски селища в България, София 2003, pp. 75-86.

Ilski 1997: Kazimierz Ilski, Biskupi Mezji i Scytii IV-VI (=Prosopographia Moesiaca 3, Moesia II et Scythia Minor 3), Poznań 1995 (cited after: P. Soustal, "Dorostolon - Silistra: Die 
Donaustadt im Lichte neuerer Forschung”, in: Miscellanea Bulgarica 11, Wien 1997, p. 118)

Jordanov 1988: Ivan Jordanov, "Dobrudza (491-1092) - selon les donnes de la numismatique et de la sphragistique", in: Dobrudža: Etudes ethno- culturelles, Sofija 1987, pp. 183-207.

Kolendo 1966: Jerzy Kolendo, "Une inscription inconnue de Sexaginta Prista et la fortification du Bas- Danube sous la Tetrarchie", in: Eirene 5, 1966, pp. 169-154.

Kuzmanov/ Băčvarov 1986: Георги Кузманов/Иван Бъчваров, “Колекцията от антични лампи в Силистренския музей”, in: Известия на народния музей Варна 27 (37), 1986, pp. 4-62.

Milošević/Donevski 1999: Gordana Milošević/Peti Donevski, "The Late Antique Tombs At Silistra (Durostorum )", in : Der Limes an der Unteren Donau von Diokletian bis Heraklios. Vorträge der internationalen Konferenz in Svištov (1.-5. September 1998), Sofia 1999, pp. 245-255;

Museteanu 2003: C. Museteanu, Ateliere ceramice romane de la Durostorum (=Monografie IV), Bucureşti 2003.

Mutafčiev 1973: Петър Мутафчиев, “Съдбините на средновековния Дръстър”, in: Петър Мутафчиев, Избрани произведения 2, София 1973, pp. 19-103.

Prokopios of Caesarea, De aedificiis = Прокопий Кесарийски, „За строежите“, превод и бележки Иван Дуйчев, in: Извори за българската история 2, Гръики извори за българската история 1, София 1958, pp. 154-178.

Soustal 1997: P. Soustal, "Dorostolon - Silistra: Die Donaustadt im Lichte neuerer Forschung", in: Miscellanea Bulgarica 11, Wien 1997, pp. 115-126.

Theophanes Confessor = Теофан Изповедник, превод Веселин Бешевлиев и Геновева Цанкова-Петкова, увод и бележки Геновева Цанкова-Петкова, in: Извориза българската история 6, Гръики извори за българската история 3, София 1960, pp. 226-289

Theophylaktos Simokattes = Теофилакт Симоката, увод и превод Веселин Бешевлиев, откъс 5 на с. 311 е преведен от Василка Тъпкова-Заимова, in: Извори за българската история 2, Гръики извори за българската история 1, София 1958, pp. 291-356

Torbatov 2002: Сергей Борисов Торбатов, Укрепителната система на провинция Скития (края на III-VII в.), Велико Търново 2002.

Velkov 1959: Велизар Велков, Градът в Тракия и Дакия през късната античност, София 1959.

Velkov 1984: Велизар Велков, “Добруджа през периода на римската владичество (I-III в.)”, in: История на Добруджа 1, София 1984, pp. 124-155.

Velkov 1984: Велизар Велков, “Добруджа през късната античност (IV-VI в.)”, in: История на Добруджа 1, София 1984, pp. 156-173.

Velkov 1988: Велизар Велков, Античният Дуросторум”, in: Дуросторум - Дръстър Силистра, Силистра 1988, pp. 25-31.

Völling 1995: Thomas Völling, "Ein frühbyzantinischer Hortfund aus Olympia", in: Mitteilungen des Deutschen Archäologischen Instituts, Athenische Abteilung 110, 1995, pp. 424-459.

Vulpe/Barnea 1968: Radu Vulpe/Ion Barnea, Românii la Dunărea de Jos (=Din istoria Dobrogei 2), Bucureşti 1968. 



\title{
Imports, exports and autarky in Byzantine Thessalonike from the seventh to the tenth century
}

\author{
Charalambos BaKirtzis
}

Byzantine Thessalonike from the seventh to the tenth century offers an example of the continuity of urban life between late antiquity and the Middle Ages. I use the term 'Byzantine' because I am not sure that 'Post-Roman', as per the title of the conference, covers all the different conditions and different processes prevailing in Western Europe, Byzantium and the Near East between the seventh and the tenth century.

My account is based on information gleaned from texts and on archaeological comments in their regard. The primary text is the Miracles of St Demetrios, which concerns events that took place in the second half of the sixth and the seventh century. I have also used John Kaminiates' account of the capture of Thessalonike by the Saracens in 904, together with eighth-, ninth- and tenth-century lives of saints connected with Thessalonike. ${ }^{1}$

These texts mention trade and commerce in Thessalonike in a somewhat indirect and spasmodic manner. Being written by churchmen accustomed to an ecclesiastical and monastic life, they are informed by a spirit of autarky, which seems to pervade

1 P. Lemerle's critical edition of the Miracles of St Demetrios (1979) was followed by two more annotated editions with a modern Greek translation (1994 and 1997). G. Böllig's critical edition and German translation of Kaminiates (1973 and 1975) was followed by an annotated modern Greek translation (1987) and a republication of the text with a translation into modern Greek (2000). However, it is matter of some debate whether and how far these texts describe a contemporary situation. Later revisions and additions have overlain the 'reality', which is thus viewed through a distorting glass. Speck 1993 and 1994 questioned the historicity of the Miracles of St Demetrios detecting various writers at various levels in the composition of these hagiological texts, and suggests that they were worked on for the last time in the ninth, not the seventh, century. Kazhdan 1978 posited that Kaminiates' text was composed in the late Byzantine period. Konstantakopoulou 1996, 45-94, discusses the debate and analyses the way in which Kaminiates perceived 'real' space. 
events and situations, though we do not know how far this autarky reflects reality. ${ }^{2}$ All the same, it is quite apparent in these same texts that the state, the church and private citizens did not refuse to import and export commodities, though the extent of these dealings escapes us. ${ }^{3}$

\section{The Miracles of Saint Demetrios}

Social organisation

The Miracles of St Demetrios depicts a civil society constructed on principles, rules and laws. The citizens were governed by the eparchs, who were not local men, but appointed by the basileus. Purely local administrative influence was wielded by the Archbishop of Thessalonike, who, unlike the eparchs, was favoured by the demos and the city's powerful families, who also took part in governance. ${ }^{4}$ One gathers that the eparchs were not liked by the people, nor yet by St Demetrios himself, because rather than the social justice ensured by the city's autarky in terms of commodities, they were more interested in lucrative free trade. ${ }^{5}$

Apart from the citizens, an important part in the economic life of Thessalonike was played by its foreign residents. The foreign refugees or emigrants who came flocking into the city at this time wanted to settle inside it and their presence created a housing crisis. Many of them squatted in the public baths. ${ }^{6}$ They were a source of cheap labour and would certainly have been involved in some of the city's major projects, such as the restoration of the Basilica of St Demetrios after the fire of ca 620 and the building of the Hagia Sophia in $688-690 .^{7}$ This is why I believe they were supported by the

2 Laiou 2001/2002, 13 and 15: 'As an ideological norm, autarky, or self-sufficiency, has its origins in classical times, and was subsequently reinforced by the normal teachings of Christianity. . The most interesting example of the relative role of ideology in the reality is to be found in the case of monasteries'. See also Laiou 2002d, 1123, 1125-1130. For the cities as monasteries, see 1999, 7.

3 Laiou 2002d, 1129.

4 Konstantakopoulou 1996, 23-27.

5 See note 39.

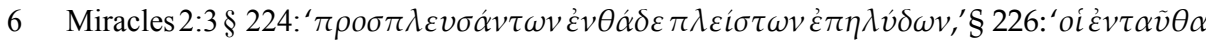

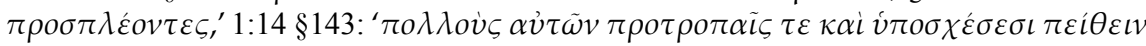

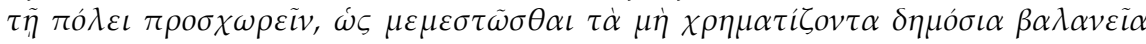

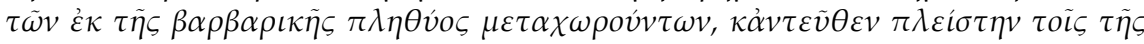

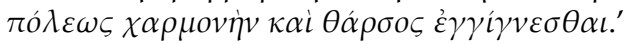

7 Opinions vary as to the dating of Hagia Sophia in Thessalonike. I have proposed a date of 688-690 (Bakirtzis 1982, 165-180). 
city's ruling class. ${ }^{8}$ In the votive inscription on a seventh-century mosaic in the Basilica of St Demetrios, the Church of Thessalonike actually prays for its citizens and its foreigners together, confirming that both these categories of inhabitants contributed to the development of the city: 'Most happy martyr of Christ, you who love the city, take care of both citizens and foreigners.'

However, the vast majority of the foreigners, who were of varied descent and were not allowed into the city, resided outside it and earned their living as farmers, stockbreeders and labourers, enhancing the city's self-sufficiency in terms of commodities. ${ }^{10}$ Their leaders (Chatzon, Perboundos, Kouber and Mauros) were taken care of and provided for, but also kept under observation by the city. When they were dissatisfied with what the city gave them, they stirred up the various population groups who then tried either to settle inside the city, or to seize the citizens' property. In an attempt to control their exploitation and not wishing to see more of them inside the city and, at the same time, keen to see a workforce settled in an agricultural area, the authorities organised the newcomers into a ghetto, first in the Keramesios kampos on the western plain near Thessalonike and later just outside the western wall. ${ }^{11}$ Refugees of Greek descent were allowed into the city and the eparchs sent them on to Constantinople to serve as manpower. $^{12}$

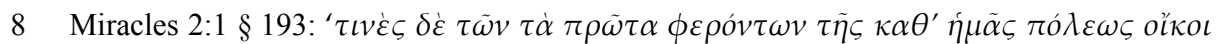
$\tau o \tilde{v} \tau o v$ [Chatzon, the leader of the foreigners living outside the city] $\kappa \alpha \tau \varepsilon \kappa \kappa v \tau \tau \tau o v$,

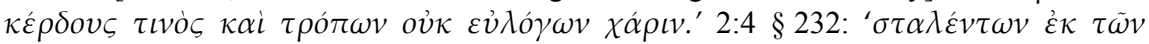

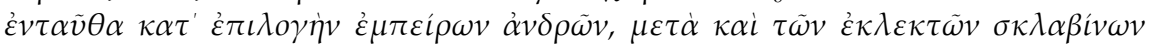

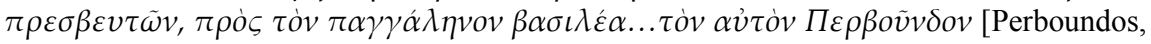

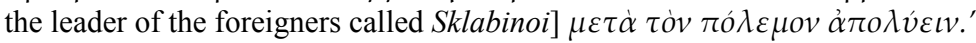

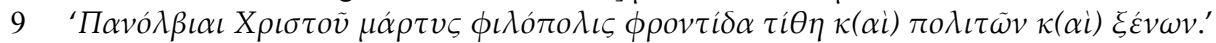

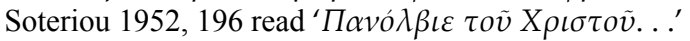

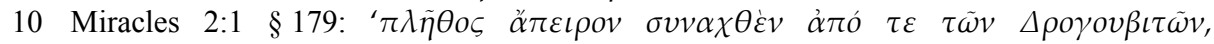

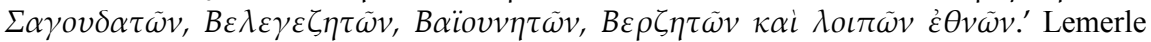
1981, 89-90; Theocharides 1980, 179-183.

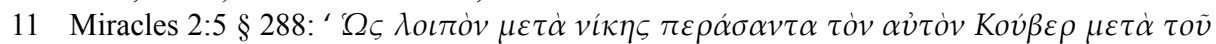

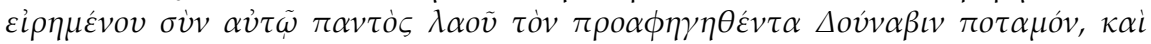

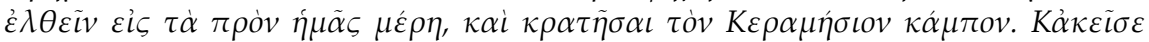

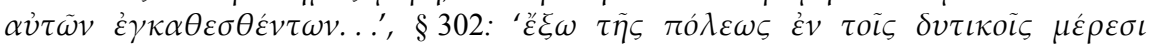

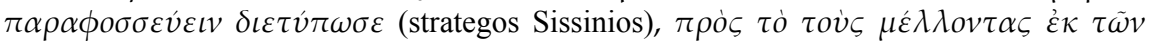

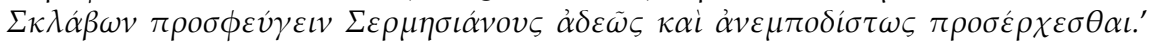
For the location of the Keramesios Kampos, see note 65.

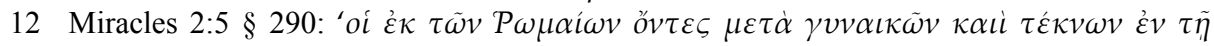

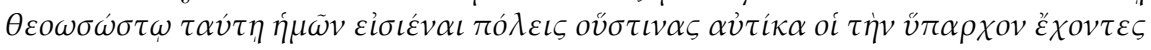

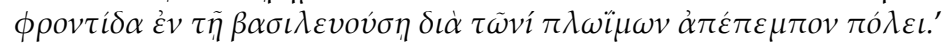




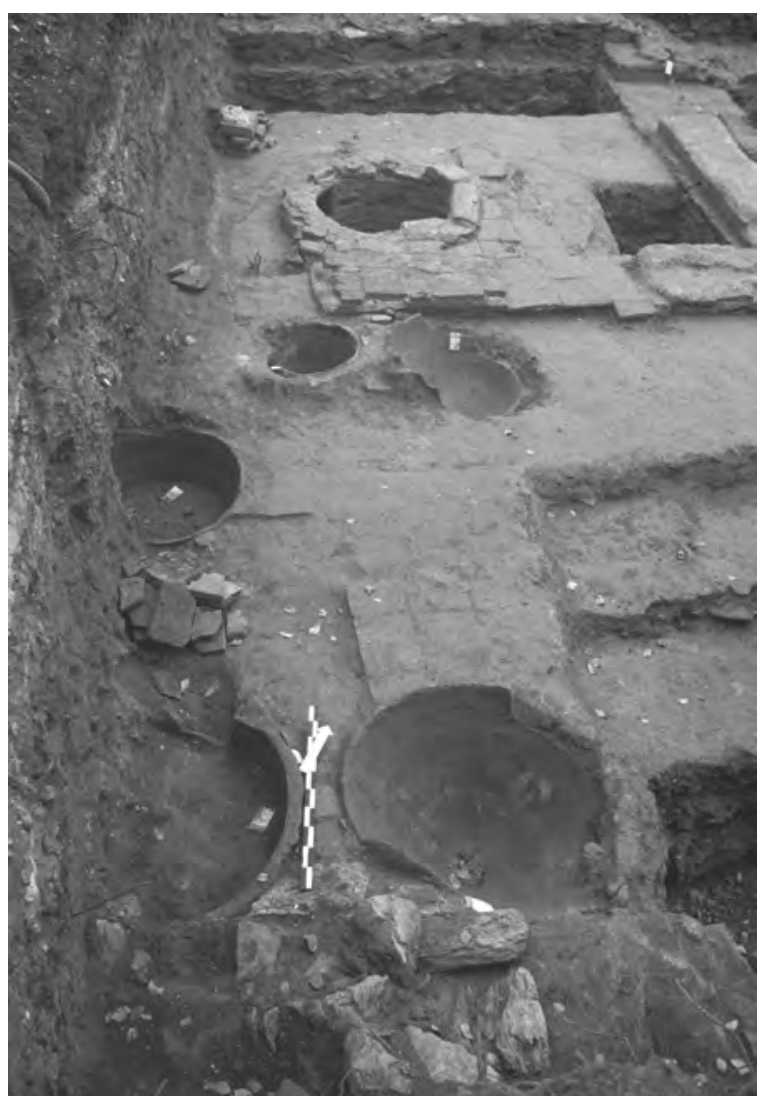

Fig. 1. Storage jars in situ

\section{Agriculture and stockbreeding}

There were vegetable gardens and olive trees for private use inside the city, in people's courtyards and on waste land near the walls. ${ }^{13}$ Grain and cereals, grapes and other agricultural products were systematically cultivated on the plain outside the walls and stored in situ, together with farming implements, in storehouses, alongside the harvests of the previous year. ${ }^{14}$ One such early Christian storehouse (from the fourth-seventh

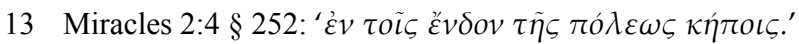

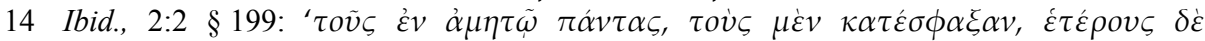

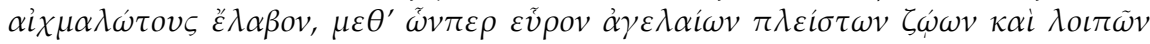

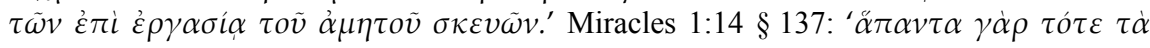

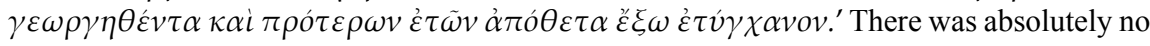
practical reason for farmers to keep agricultural produce from previous years in the storehouses. It is explained by I. Karayannopoulos's suggestion (1982, 961-970) that the state bound the rural population to the land in order to secure taxation. 


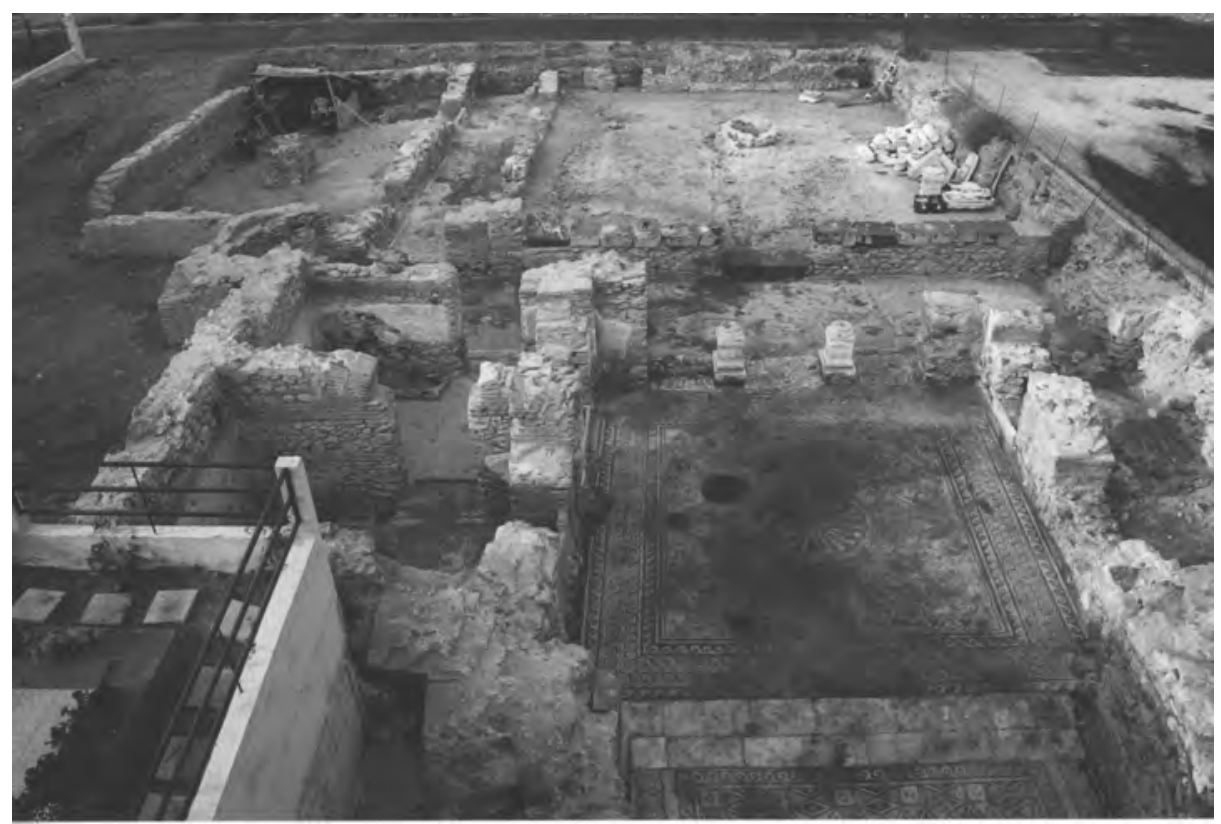

Fig. 2. Early Christian farmhouse with mosaic floor

century) with large storage jars in situ, wells for drinking water and water-storage cisterns in the rooms, has been found outside the east city walls, near the sea (Fig. 1). ${ }^{15}$

The agricultural work, the reaping and the harvesting of grapes were done by people who stayed in the suburbs and on the farmland. When danger threatened, if they were residents of the city they would take refuge within the walls and if they lived in the hilly areas to the north they would flee to the 'outer parts'. ${ }^{16}$ A luxurious early Christian farmhouse with a defensive wall has recently been excavated in the foothills outside the west city wall (Fig. 2). ${ }^{17}$ It had a beautiful mosaic floor with scenes from mythology, including the personification of the River Echedoros.

15 Toska et al. 1999, 419-423.

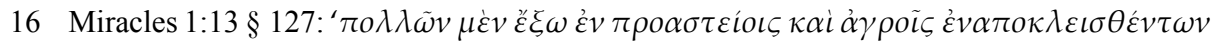

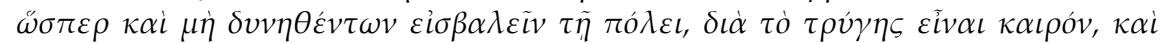

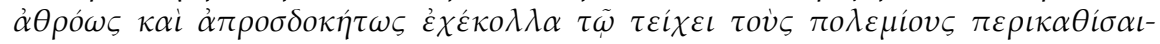

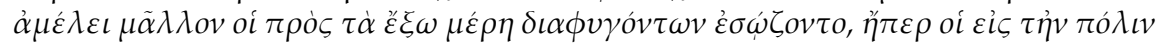

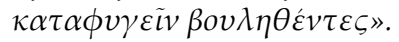

17 Thessaloniki Rescue Excavations 2002, 8-9; Marke-Akrivopoulou 2003, 283-298. 
There were also stockbreeders with their flocks and herds in the area outside the city. ${ }^{18}$ The men in charge of the siege engines ${ }^{19}$ and the men who rowed the dugouts ${ }^{20}$ protected themselves with ox- and camel-hides, which were also used for making footwear and belts. ${ }^{21}$

In the hills to the north of the city and around Lete were the Sklabinoi, who were self-sufficient as farmers and, in their semisubterranean houses, had all the commodities they needed (grain, pulses and other foodstuffs), utensils, receptacles and implements with which they tried to capture Thessalonike. ${ }^{22}$ The neighbouring Drougoubitai to the west who were also farmers, stored their produce in tents and received orders from the emperor to supply food to Kouber's refugees who, according to Lemerle, arrived on the plain of Thessalonike and settled in the Keramesios kampos in 682-684. ${ }^{23}$

The port

Ever since it was founded, Thessalonike has enjoyed the geopolitical advantages conferred by its position as a Balkan port communicating via the Aegean with the Black Sea and, especially, with the Levant. At this time, the main harbour was still the one created by Constantine the Great in the south-west corner of the city. ${ }^{24}$ It was the site of the dockyard, the state granaries and the customs services under the control of kom-

18 See note 14.

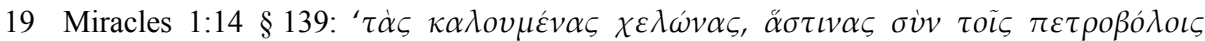

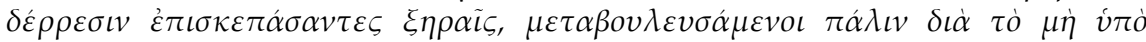

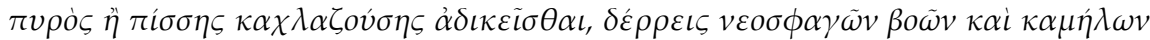

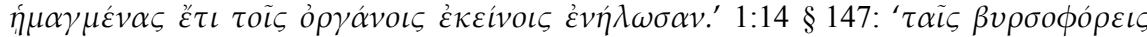

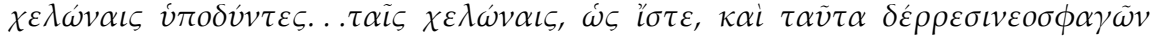

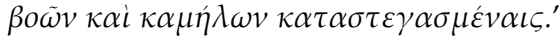

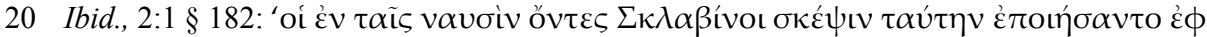

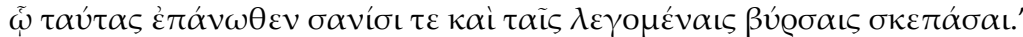

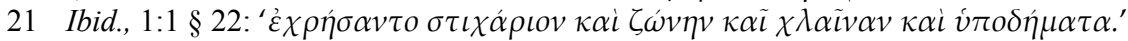

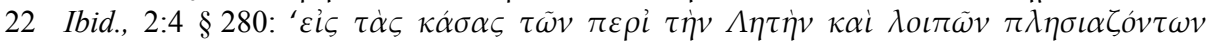

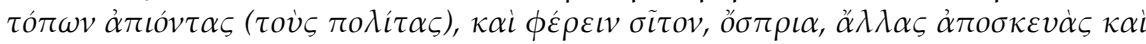

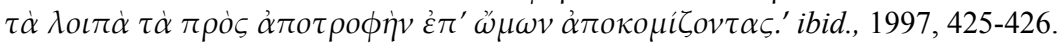

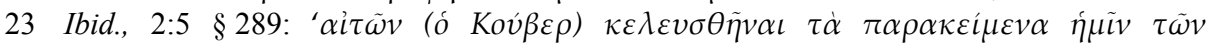

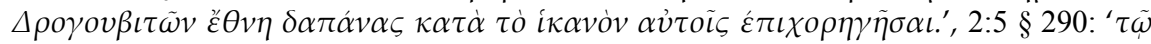

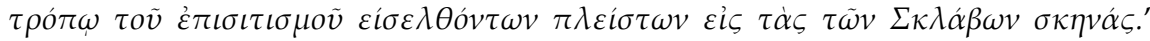
Lemerle 1981, 161.

24 Bakirtzis 1975, 315-20; Odorico 2003, 121-141. 
merkiarioi or abydikoi and was also a naval port, for which reason it was closed to some categories of ships and was surrounded by a fortifying wall, which prevented free movement. $^{25}$

Two other harbours were the Ekklesiastike skala (Ecclesiastical landing-place) and the Kellarion. ${ }^{26}$ The first was in the south-east corner of the city, on the site of the Roman harbour that had served the palace of Galerius. ${ }^{27}$ The fact that it was termed 'ecclesiastical' and was differentiated from the main harbour suggests that it was used exclusively by the Church of Thessalonike, probably exempt from the normal customs procedures. The second harbour was further to the east. ${ }^{28}$ On this side, the Gulf of Thessalonike formed a number of coves suitable for landing-stages for sailors and passengers, ship's planks for short-distance trade within the Gulf, fishing anchorages and market-places. ${ }^{29}$ It was at one of these, at Embolos (Megalo Karaburnu?), that Theodore of Stoudios and his brother Joseph landed in 797 and entered the city through the eastern, the so-called Kassandra Gate. ${ }^{30}$

\section{The city's food supply}

As long as Egypt was under Byzantine control (until 618/619) Thessalonike continued to receive, under the management of the state, a regular supply of grain to supplement the food its population cultivated locally. ${ }^{31}$ After the loss of Egypt (640-642), the state sought to increase local agricultural production by several mechanisms and by allowing refugees and immigrants of various provenance to settle in the area of Thessalonike. ${ }^{32}$

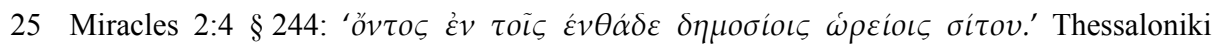
Rescue Excavations 2001, 9. For kommerkiarioi (712/713-eleventh century) or abydikoi (ninth century) see Oikonomidès 1991, 244-245.

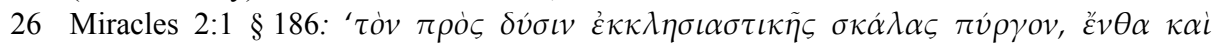

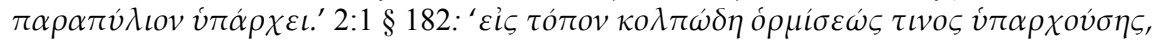

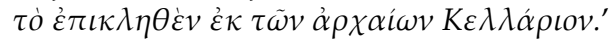

27 Bakirtzis 1975, 320-321; Spieser 1984, 34, thinks that the Ekklesiastike skala would have been inside Thessalonike's main harbour.

28 Bakirtzis 1975, 321-322: at Karabournaki; Toska et al., 426: in the bay to the east of the White Tower, see note 97.

29 Ancient Ports, 36-39.

30 Cheynet/Flusin 1990, 198.45-49 and 210. For Embolos, see Lefort 1982, 80-81 and Koder 198, 379-385. See note 49.

31 Hattersley-Smith 1996, 27-28.

32 The state mechanisms are described by Dagron 2002, 450-452. For the stocking of the countryside around Thessalkonike with an agrarian workforce of varied provenance in late sixth and

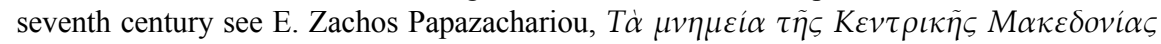
$\kappa \alpha i$ i $\pi \alpha \rho \alpha \gamma \omega \gamma \iota \kappa \eta \dot{\beta} \alpha \alpha \sigma \eta$, project "Central Macedonia: Image and Character" conducted by the Ephoreia of Byzantine Antiquities of Thessaloniki under the direction of Ch. Bakirtzis. 
The city (governors and citizens) also kept itself supplied with quantities of grain and pulses, which it obtained by sea from the Belegezitai, who were farmers in the area of Thebes and Demetrias in the Pagasitic Gulf. ${ }^{33}$ Expeditions to procure food from distant places, such as Sicily, were undertaken only at the instigation of the state, which also reserved itself the right to control them. ${ }^{34}$

When the public storehouses and private granaries were full, local production was sufficient to feed the city. ${ }^{35}$ The lowest permissible reserve of grain in the state granaries was deemed to be 5,000 measures (modius, equal to 17.0841 or $12.8 \mathrm{~kg}$ ). When it was impossible to obtain grain from anywhere and social unrest was feared, a state of famine was declared in the city. ${ }^{36}$ In these cases, at the request of the local authorities, ${ }^{37}$ the state would take the matter in hand and efficient state mechanisms and state action would supply the city with as much as 60,000 measures of grain. ${ }^{38} \mathrm{It}$ was brought on cargo-ships escorted by warships ${ }^{39}$ via Chios - which was a supply station for Constantinople and Thessalonike - under the supervision of the komes of Abydos. ${ }^{40}$ St Demetrios' intervention consisted in hastening the arrival of the aid by

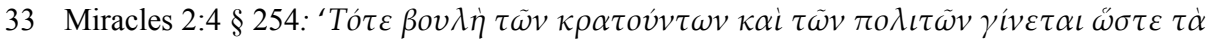

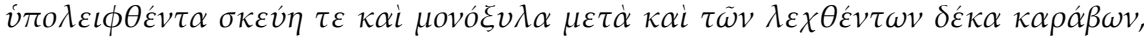

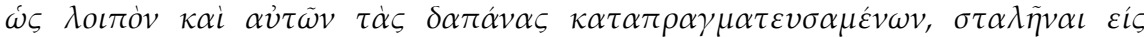

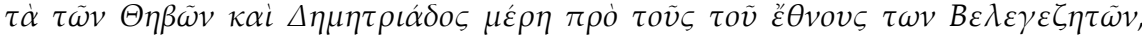

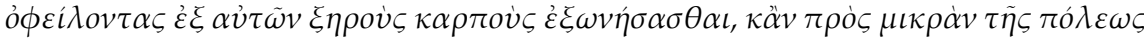

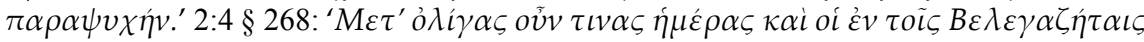

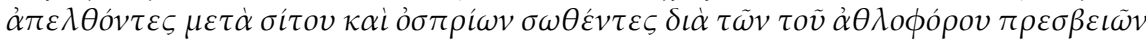
$\kappa \alpha \tau \dot{\varepsilon} \lambda \alpha \beta o v . '$

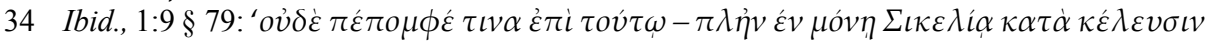
$\beta \alpha \sigma \iota \lambda \iota \kappa \eta \dot{v » .}$

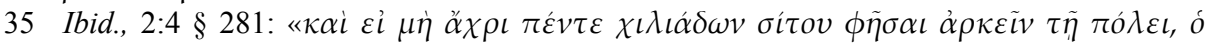

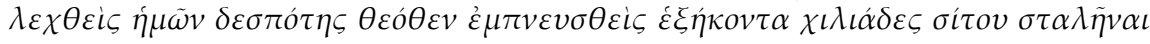
$\eta \mu \tilde{l} v \dot{\varepsilon} \kappa \varepsilon ́ \lambda \varepsilon v \sigma \varepsilon »$; Schilbach 1970, 279; Morrisson/Cheynet 2002, 817, t. 3.

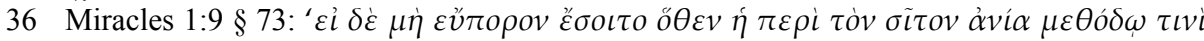

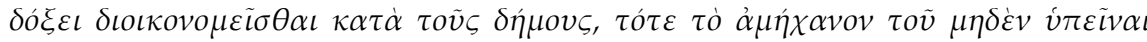

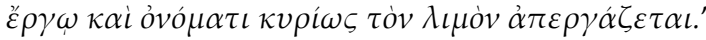

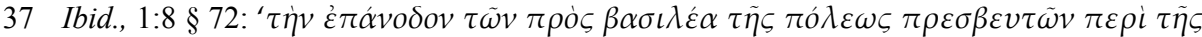

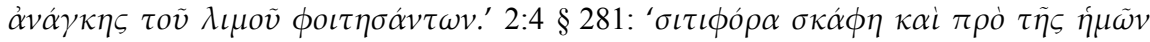

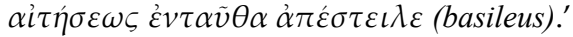

38 See note 35.

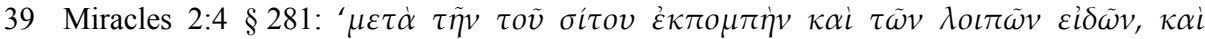

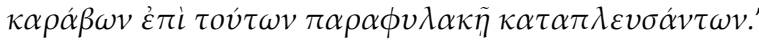

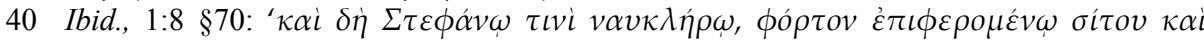

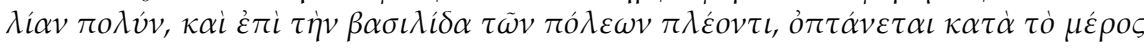

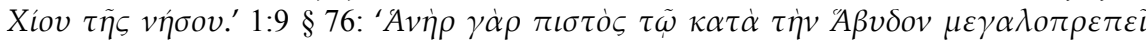

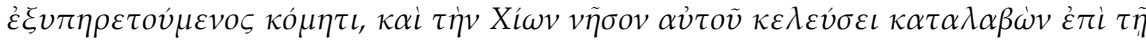

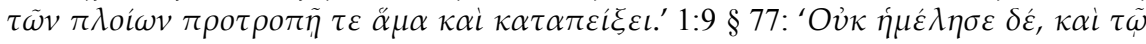

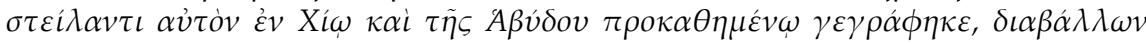

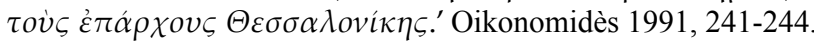


skirting administrative structures and bureaucratic processes; the captains of the cargoships "from many different regions" and the saint himself are presented as supporters of 'modernism' in the economy.

Saving and trade in the city

In $676^{41}$ the city governors made an irregular sale of grain from the public granaries to the ships' merchants for the special price of $1 / 7$ nomisma (gold coin) per modius (12.8 $\mathrm{kg}$ ) earning them 7,857 nomismata. ${ }^{42}$ It is conjectured that 55,000 modioi of grain, equal to 939,629 1 or $704 \mathrm{t}$, were sold out of the 60,000 modioi with which the emperor had filled the public granaries. ${ }^{43}$ That is 55,000 modioi $\mathrm{X}: 1 / 7$ gold coin $=7,857$ gold coins. This commercial transaction took place shortly before the city was besieged and the prescribed procedures were not observed. The Miracles regards it as a blow against the city's autarky. But there is no mention, neither of where the grain was transported, ${ }^{44}$ nor whether those responsible were ever censured by the government services. The grain was not sold cheaply of proteering by the city governors, as the Miracles implies. On the contrary, it was sold at very good price, at a time when the price of grain, from $1 / 15$ and $1 / 12$ of a gold coin per modius at the end of the sixth century, had risen to $1 / 3$ to $1 / 4$ gold coin per modius in 655 , owing to the loss of the very fertile province of Egypt. ${ }^{45}$ So in fact, with this commercial trasaction, the city governors secured a significant quantity of gold coins for the defence of the city (to pay soldiers' wages, buy ammunition and so forth). As for the city's self-sufficiency (autarky) in grain, they were not worried, but relied on receiving a supply by sea, as they were not expecting a blockade of the port.

41 According to Lemerle 1981, 132.

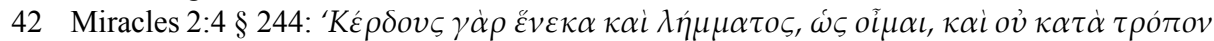

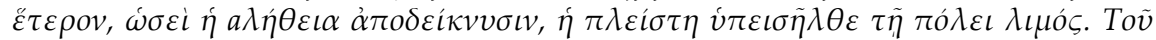

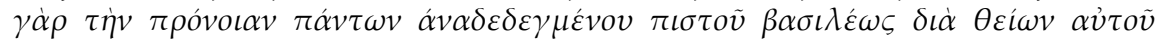

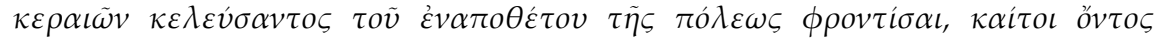

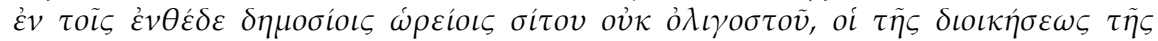

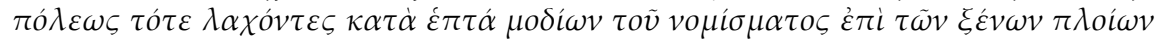

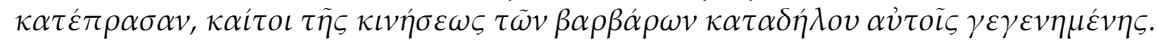

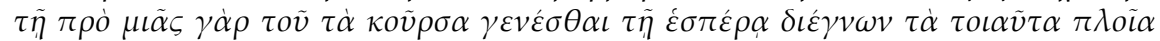

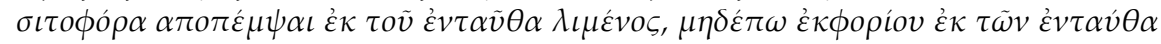

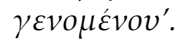

43 See note 35 . The annual demand of grain for 100,000 inhabitants should be 20,000 tons or a little more, explains Koder 2002, 116.

44 Constantinople? (Malingoudis 1997, 68-69).

45 Morrisson-Cheynet 2002, 822, t. 5 
However, eminent citizens, like the rentier Menas, the retired lawyer John and others, had no confidence in the currency and saved in gold and silver ${ }^{46}$ as did the eparch Marianos, whose salary was, of course, paid in cash. ${ }^{47}$

In times of famine, private individuals would buy food from sailors on the black market and exchange it for gold items, mattresses, clothing and women's earrings ${ }^{48}$ objects, that is, that had some value, were not easily available on the market and for which there was also a market outside Thessalonike. Also, in times of a siege, the city exchanged everyday utensils and equipment with the Belegezitai farmers for agricultural produce. ${ }^{49}$

Salt monopoly

In September 689, Justinian II gave the proceeds from the sale of salt from a government salt-works on the coast near Thessalonike to the Basilica of St Demetrios to help its running costs. ${ }^{50}$

\section{Household equipment}

In a time of war, the crenelles in the battlements were blocked with old pieces of cloth and discarded clothing that had been woven on the loom and with goat-hair banqueting mattresses. ${ }^{51}$ The infirmary of the Basilica of St Demetrios provided its patients with floor-mattresses. ${ }^{52}$ In the houses there were mattresses ${ }^{53}$ and formal attire in the form

46 See note 59.

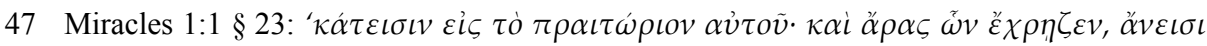

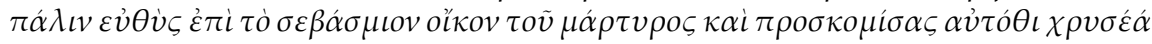

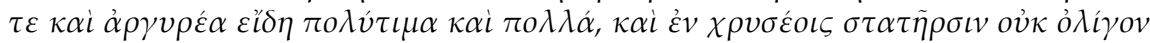
тобóv.'

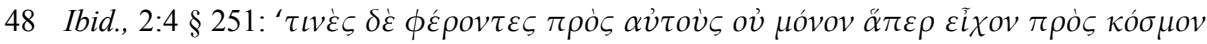

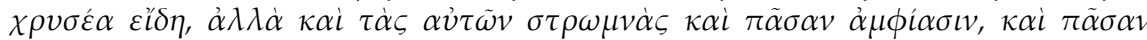
$\dot{\alpha} \mu \phi i \alpha \sigma \iota v, \kappa \alpha i \tau \dot{\alpha} \dot{\varepsilon} v \omega \dot{\tau} \tau \iota \alpha \tilde{\omega} v \gamma v v \alpha \iota \kappa \tilde{\omega} v \alpha \hat{v} \tau \tilde{\omega} v \dot{\varepsilon} \xi \varepsilon \lambda o ́ v \tau \varepsilon \varsigma \alpha \dot{\alpha} \pi \dot{\varepsilon} \delta o v \tau o . '$

49 See note 33. The meaning of this sentence is not clear. A. Sideri translates the term ' $\sigma \kappa \varepsilon v ́ \eta$ '

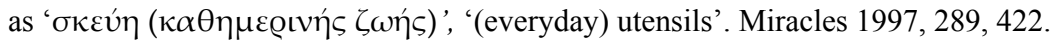

50 Spieser 1973, No. 8, pp. 156-159. There is an old salt-works operating today on the south shore of Megalos Embolos (Megalo Karaburnu). See note 30.

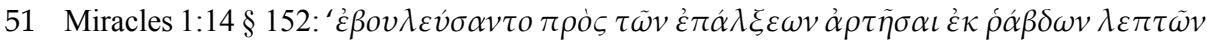

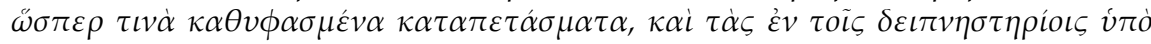

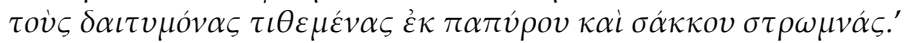

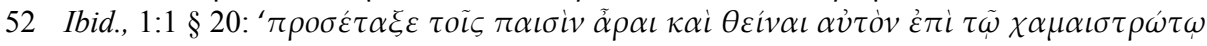

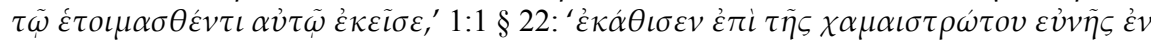

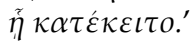

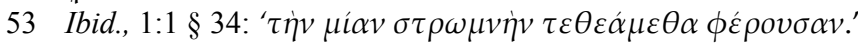


of sleeved tunics (sticharia) and woollen cloaks (chlainai). ${ }^{54}$ This offers evidence of weaving on a domestic or light industrial basis, as also of importation.

\section{Copper- and silver-smithing}

Coppersmithery is mentioned in the Passio altera of the St Demetrios legend. The saint is said to have preached the Christian faith in the western portico of the main agora (Megaloforos), where there were coppersmiths' shops. ${ }^{55}$

With his salary, the eparch Marianos bought many gold and silver objects in the Thessalonike agora, though, naturally, it is not specified which of these were imported. ${ }^{56}$ Certainly, Thessalonike had a long tradition of silversmithing, judging by the missorium of Theodosios I, made in Thessalonike in 388 and now in Madrid, the paten made by Pausilypos of Thessalonike, now in Augst and the silver reliquary (380-410) found at Nea Herakleia in Chalkidike, now in the Museum of Byzantine Culture in Thessalonike. ${ }^{57}$

In the middle of the nave of the Basilica of St Demetrios stood a hexagonal ciborium made of wood rivetted with silver. Within the ciborium was a silver pseudosarcophagus decorated with a repoussé figure of St Demetrios. ${ }^{58}$ One night the ciborium caught fire and the silver melted and, perhaps owing to theft, was reduced in quantity. ${ }^{59}$ The remaining silver was insufficient to re-cover the ciborium and the Archbishop of Thessalonike was minded to melt down the bishop's throne, which was also of wood

54 See note 21.

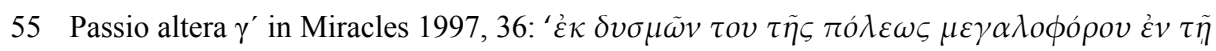
$\dot{\varepsilon} \kappa \varepsilon \tilde{\imath} \sigma \varepsilon X \alpha \lambda \kappa \varepsilon v \tau \iota \kappa \tilde{\eta} \lambda \varepsilon \gamma o \mu \varepsilon \dot{\varepsilon} v \eta \sigma \tau o \tilde{\alpha} . '$ There are coppersmiths' shops operating today on the same part of Thesalonike (Hadzi Ioannou 1880, 95).

56 See note 46.

57 For the connection of these works of minor art with Thessalonike, see Tsitouridou 1972, 187-196; Bakalakis 1968, 3-5; Buschausen 1971, 234-239, 7.

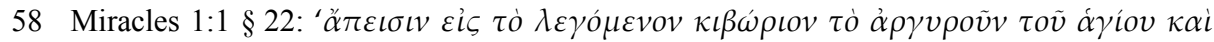

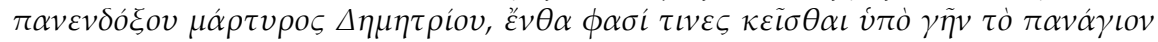

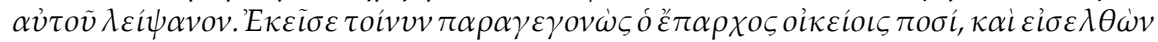

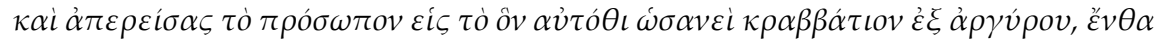

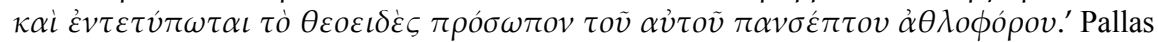
1979, 44-53.

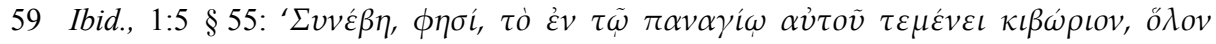

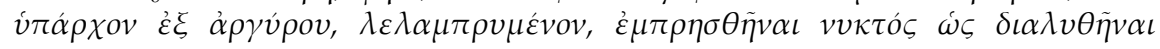

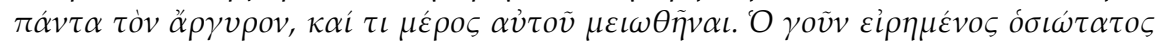

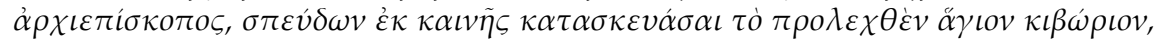

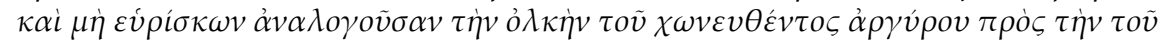

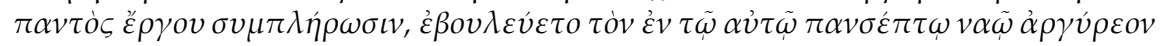
$\theta \rho o ́ v o v ~ \lambda \tilde{v} \sigma \alpha \iota . '$ 
rivetted with silver. St Demetrios did not agree with this plan to dispose of his property and due to his intervention it was not carried out; and when more than 115 litrai of silver had been collected from donations, a local silversmith undertook the task of making a new ciborium. ${ }^{60}$ Throughout this entire process, there is no mention of any state control over trade in precious metals, nor do we know whether the silversmith was paid with a quantity of silver or in cash. ${ }^{61}$

When the Church of Thessalonike adroitly avoided allowing St Demetrios's relics to be divided up, a quantity of fragrant earth from the traditional site of the tomb of Thessalonike's patron saint was taken to the sacristy of the metropolitan church. ${ }^{62}$ I believe that the reliquary containing the soil, like the reliquaries in which the Church of Thessalonike subsequently sent some of it to Justinian I and Maurice, were replicas of the ciborium and were made by local silversmiths. These gift-reliquaries were kept in the imperial treasury in Constantinople and the eleventh-century Moscow reliquary (1059-1067) is a copy of them. ${ }^{63}$

\section{Candlemaking}

The candles lit inside the ciborium were of three sizes and corresponding value: 'small' or 'slender', 'great' and 'greatest', the last being, I suppose, as tall as a person. ${ }^{64}$ Onesiphoros, the caretaker (paramonarios) of the ciborium, extinguished the candles before they were spent and sold the wax. He believed that this was also to the advantage of St Demetrios, presumably because the chandlery to which he sold the wax was owned by the Basilica of St Demetrios. ${ }^{65}$ The making of candles of course presupposes

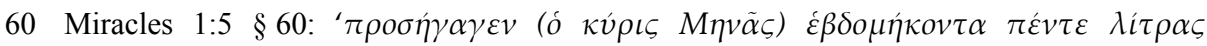

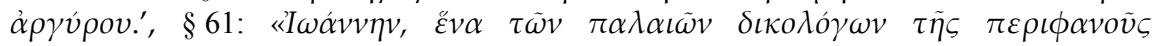

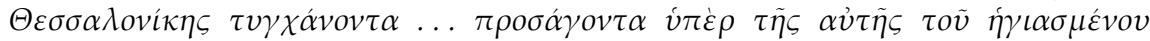

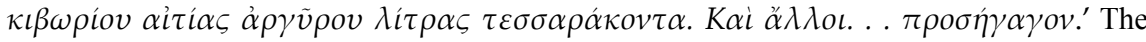
donations to St Demetrios' were meagre in comparison with those made to St Peter's in Rome in 625-638: revetments and chandeliers 9.224 pounds of silver, in 687-701 cross 20 pounds, silver dais weighing 120 pounds and six silver lamps weighing 170 pounds (Morrisson/Cheynet 2002, 856, t. 15).

61 Eparchenbuch § 2.1-11; Dagron 2002, 435-436.

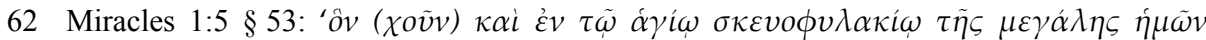

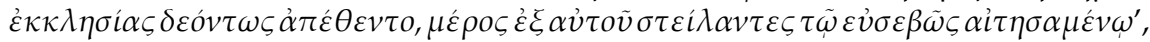

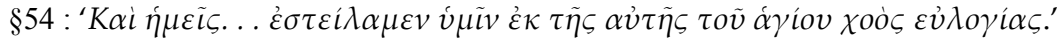

63 Bakirtzis 2002, 179.

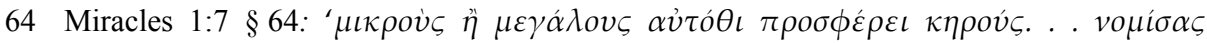

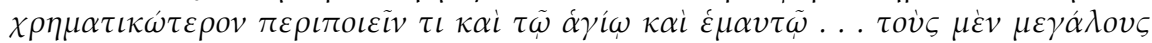

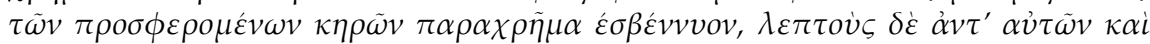

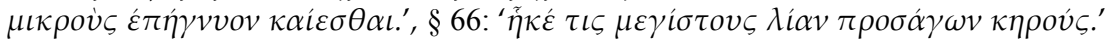

65 Hagia Sophia in Constantinople was owner of a chandlery (Eparchenbuch § 11.1). 
apiculture, which was practised by the local farmers who sold the honey in the market and the wax to the basilica's chandlery.

\section{Pottery}

Keramesios kampos (pottery plain) was the name given to an area just to the west of Thessalonike, where bricks and roof-tiles were manufactured to meet the city's consid-

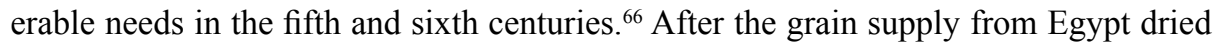
up and the Drougoubitai farmers were settled in this area in the seventh century for the purpose of increasing local agricultural production, the potteries ceased operating in the Keramesios kampos and were relocated closer to the city. ${ }^{67}$

As well as bricks and roof-tiles, the Thessalonike potteries also manufactured receptacles for special purposes, such as the water vessels that were used to extinguish the fire that broke out in the roof of the Basilica of St Demetrios when the ciborium was set alight. ${ }^{68}$ My own view is that these were specially constructed medium-sized amphoras with thin walls that made them light to carry and easy to smash and with two handles so that they could easily be passed from one person to another. Being disposable, they were not very well fired. These are the characteristics of the amphora-like vessels that were used to fill in the vaults over the north and south porticos and the apse of Hagia Sophia in Thessalonike (Fig. 3). Although they resemble amphoras, these were not transportation vessels because they have extremely thin walls, had not been used before and had been fired in large quantities in open, not closed kilns.

St Demetrios, who expressed the clerical views both of the local church, the ruling families and the demos, did not favour exports, but he did intervene on behalf of imports; albeit certainly not in order to aid the merchants in acquiring wealth, but in the case of the imports stabilising the city's autarky. This attitude towards the city's

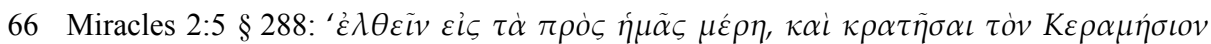

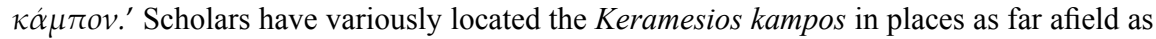
Prilep, Stobi, and Heraklea Lynkestis (see bibliographgy collected by Gregoriou-Ioannidou 1981,70, n. 4), as also in the area of the drained lake of Genitsa (Theocharides 1980, 182183 ), or on the site of the modern village of Paliokastro, between Skydra and Genitsa (Liakos $1965,145)$. If the potteries in the Keramesios kampos manufactured building materials for Thessalonike, as I believe they did, thus safeguarding the city's autarky, then they must have been located closer to the city.

67 See note 106.

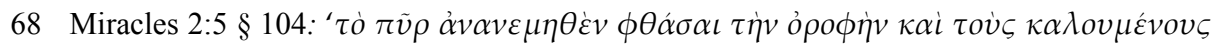

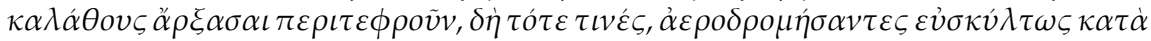

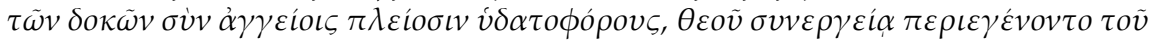
$\phi \lambda о \gamma \mu о \tilde{v} . '$ 


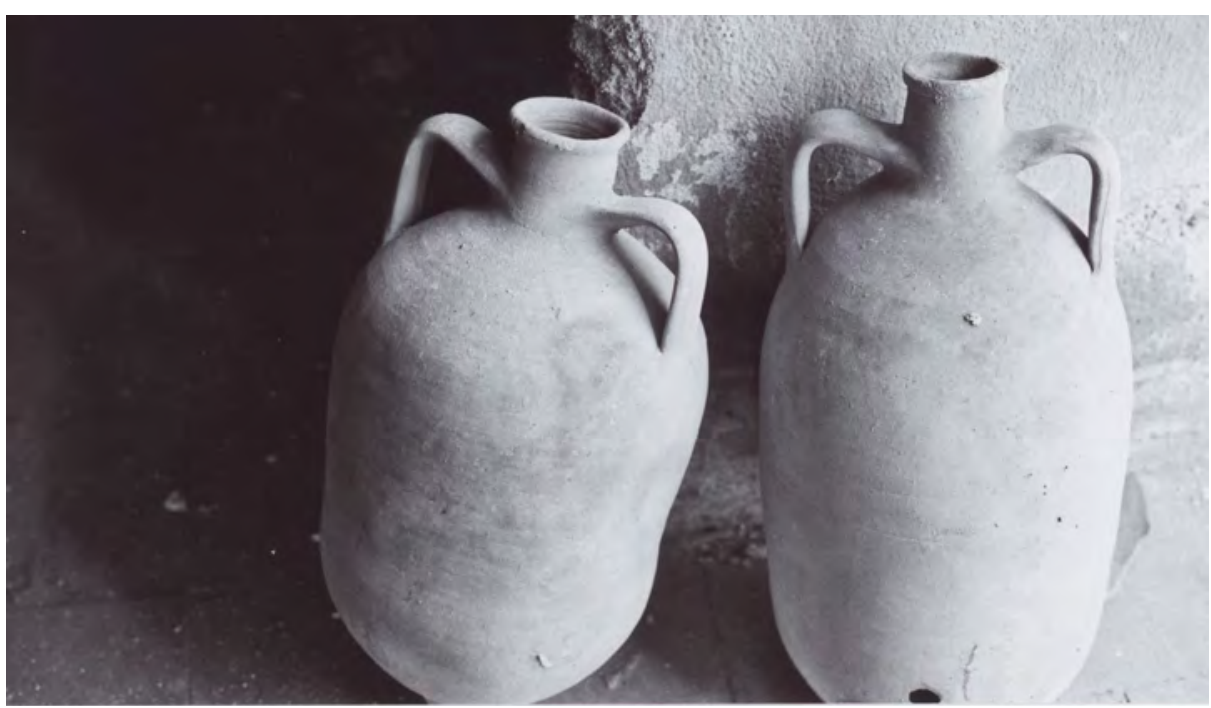

Fig. 3. Amphora-like vessels

economic affairs also accounts for his patriotism, i.e. as a support for Thessalonike's self-sufficiency in all sectors and at all levels.

Through the eparchs and the government services the state employed various processes that enhanced the measures implemented by the city to maintain its autarky and its survival. Unfortunately, the administrative acts by which the measures were implemented and the steps taken by the government, which lie behind the events recounted in the Miracles, are not preserved in any official record. The account of the events and the analysis of the situations in the Miracles is thus one-sided and slightly biased towards the church.

\section{Ioannes Kaminiates}

John Kaminiates' account of late ninth- and early tenth-century Thessalonike and its environs traces the development of maritime trade and agricultural production. The narrative begins in chapter four, with a description of the city from the sea and of the Thermaic Gulf, indicating the major role which the port and maritime communications played in the life of the city. ${ }^{69}$ Kaminiates attributes Thessalonike's progress to

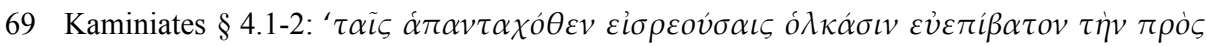

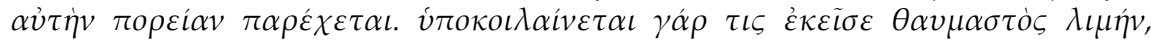
$\dot{\alpha} \sigma \phi \alpha \lambda \tilde{\omega} \varsigma \dot{v} \pi \tau \iota \dot{\alpha} \zeta \omega \nu \tau \sigma \tilde{\iota} \varsigma \pi \lambda \omega \tau \tilde{\eta} \rho \sigma \iota \tau \dot{\eta} v \varepsilon \grave{c} \sigma o \delta o v . '$ 
the development of agriculture on land and of trade by sea and ascribes this development to the peaceful conditions which prevailed after the Bulgars were converted to Christianity in $885 .{ }^{70}$

The countryside

Chapter five describes the area of Mount Chortiates and its foothills to the north and north-east of Thessalonike, inhabited by hermits. ${ }^{71}$ During this period, old churches were repaired and new monasteries were being built in the mountainous countryside to the east. ${ }^{72}$ The monks from this area visited Thessalonike not only to pray but also to shop for supplies.

There follows a description of lowland Kalamaria and the Mygdonian basin, with much praise for the local villagers' productive activities, which helped the city to be self-sufficient. The cultivation methods would not have been any different from those described in the Geoponika. The Thessalonian farmers' interest in diversified agriculture and higly marketable crops is demonstrated by the way they heeded the agricultural advice of their Metropolitan, Leo the Mathematician (840-843). ${ }^{73}$

Chapter six offers a description of the extensive alluvial plain to the west of the city, which Kaminiates divides into two parts. Vines, fruit-trees and gardens were cultivated in the part nearer the city which was studded with farmsteads and monasteries. In this area and also in the corresponding area to the east of the city, not very far from

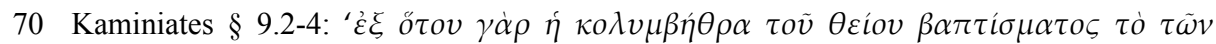

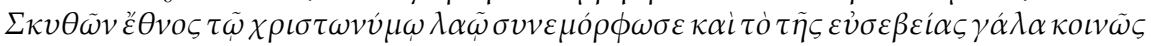

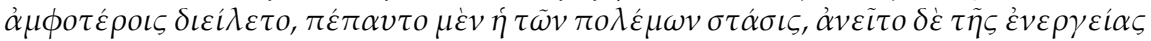
$\dot{\eta} \tau \dot{\alpha} \varsigma \sigma \phi \alpha \gamma \dot{\alpha} \varsigma \dot{\varepsilon} \pi \iota \tau \eta \delta \varepsilon \dot{v} \sigma v \sigma \alpha \mu \alpha \dot{\alpha} \chi \alpha \iota \rho \alpha, \kappa \alpha i \tau \dot{\alpha} \pi \rho \circ \varepsilon \chi \theta \dot{\varepsilon} v \tau \alpha \tau \tilde{\omega} \mu \varepsilon \gamma \alpha \lambda o \phi \omega v o \tau \alpha \dot{\tau} \omega$

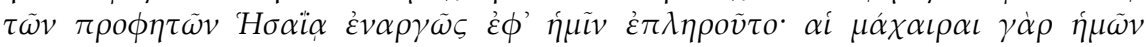

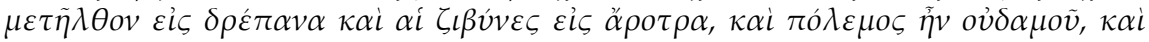

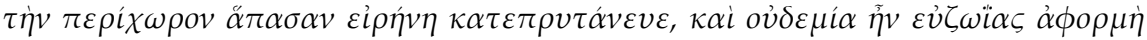

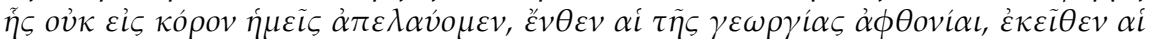

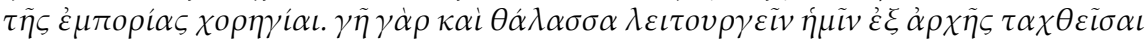

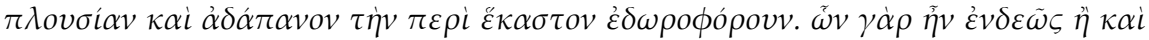

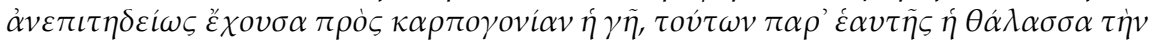

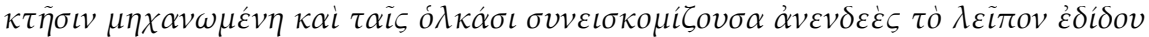

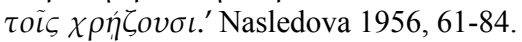

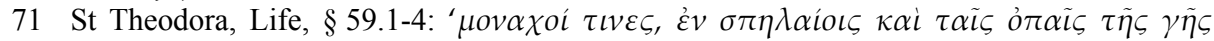

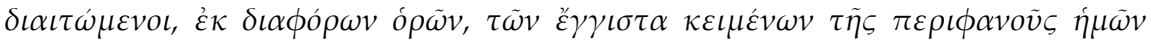

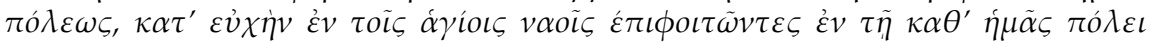

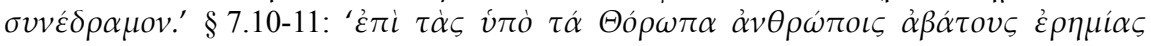
$\dot{\alpha} \pi \dot{\varepsilon} \delta \rho \alpha \mu \varepsilon .^{\prime}$

72 The Monastery of St Andreas at Peristera, Chortaites Monastery (Lefort 1982, s.w.).

73 Konstantakopoulou 1996, 68; for diversified agriculture, see Laiou 2002d, 1129. 
the city itself, independent growers held cheap markets, where the inhabitants of the city were able to shop for produce. ${ }^{74}$ As these markets became institutionalised and production increased, the Demetria international fair came into existence, described in the twelfth-century dialogue Timarion.

Beyond this area there was also a large expanse of scrubland suitable for growing all kinds of crops. This lowland area extended as far as the foothills of Upper Macedonia and the town of Berroia. ${ }^{75}$ It was cultivated by the inhabitants of various large villages, some of which had a mixed immigrant population of varied provenance, namely Drougoubitai and Sagoudatoi. ${ }^{76}$ Through the agency of such merchants as Staurakios and Kosmas, who exploited them, the inhabitants of some villages, mainly those near the Bulgarian border, exchanged goods from Thessalonike's workshops with the neighbouring Bulgars for products and raw materials from the Balkan hinterland, which they then sold to workshops in the city. ${ }^{77}$ Leo VI tried in vain to incorporate the resulting profits (which were not under state control) into the customs revenues by transferring the Bulgar merchants from Constantinople to Thessalonike in $894 .{ }^{78}$ Apart from irrigation and fishing, the rivers which crossed this plain to the west of Thessalonike, being navigable, were also used for maritime trade with the hinterland and the Balkan interior

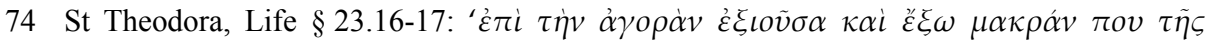
$\pi o ́ \lambda \varepsilon \omega \varsigma \delta \iota \dot{\alpha} \tau \dot{\eta} v \tau \tilde{\omega} v \omega \dot{v} \iota \dot{\omega} v \varepsilon \dot{v} \theta \eta v i ́ \alpha v{ }^{\prime}$

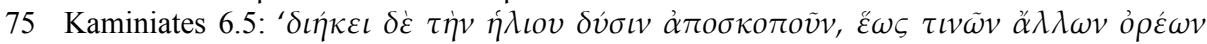

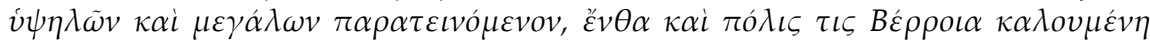
$\kappa \alpha \tau \omega \kappa \iota \sigma \tau \alpha \iota . '$

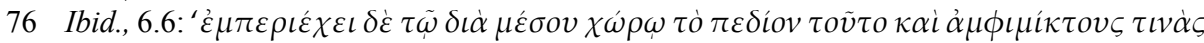

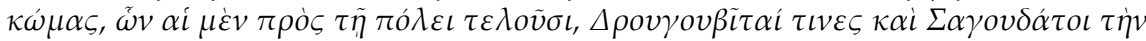

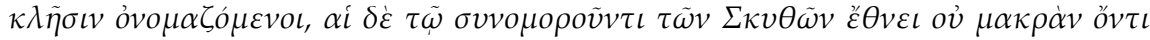

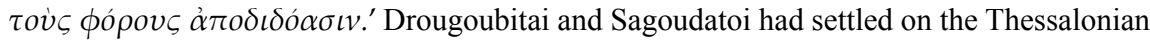
plain (Tsaras 1985, 182).

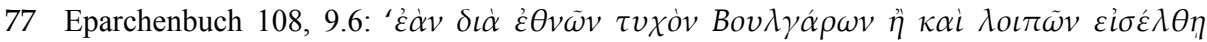

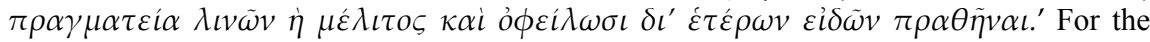
activity of Staurakios and Kosmas see Theophanes Continuatus, 357-358: "oít

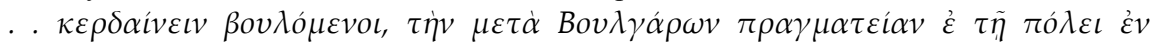

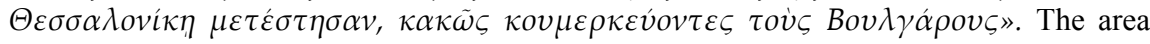
between 'Romaioi and Bulgaroi' where these exchanges were conducted is attested by a Protobulgarian inscription, which dates to the very early years of the tenth century, before Thessalonike was captured in 904 and was found $22 \mathrm{~km}$ to the north of Thessalonike (Oikonomidès 1995, 239-243).

78 Oikonomidès 1991, 246-247; Laiou 2002b, 695. 
under the control of a vardarios. ${ }^{79}$ The Thessalonike-Belgrade route is attested in the middle of the tenth century. ${ }^{80}$

The city

The early Christian fortifications of Thessalonike enclosed a large area. ${ }^{81}$ However, the city had shrunk in size in the flat, lowland part owing to the significant demographic decline that occurred in Byzantium and began in 541/542 until the ninth century. ${ }^{82}$ It was as densely populated 'as the sands of the sea' ${ }^{83}$ The upper city was uninhabited, occupied only by monasteries. ${ }^{84}$ The area between the modern Kassandrou and Olymbiados Streets, north of the Basilica of St Demetrios, with large late Roman and early Christian houses laid out on the Hippodamean grid system, ceased to be inhabited after the early Christian period and was not inhabited again until after Thessalonike fell to the Turks in 1430. ${ }^{84}$ After the early Christian dwellings were abandoned, their sites were taken over by churches with adjacent structures, probably monasteries. ${ }^{86}$ Poor neighbourhoods, refuse dumps and ruins of earlier buildings appeared on the edges of the lower city. ${ }^{87} \mathrm{~A}$ stylite is said to have lived atop a Roman or early Christian column in the west part of

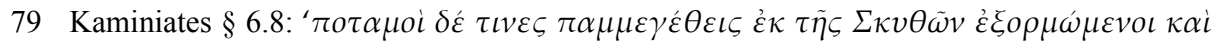

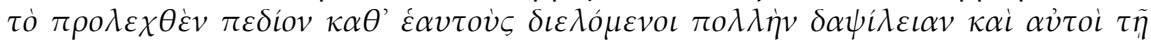

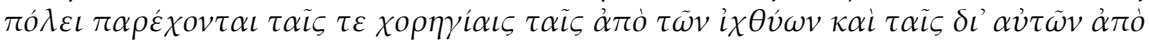

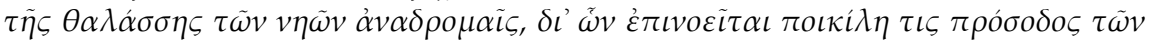

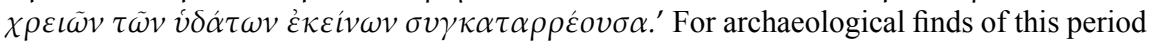
in the Upper Axios valley which attest this contact, see Mikulcic 1996 and Oncevska 2004, 82. For vardarios see Oikonomidès 1991, 246.

80 Constantine Porphyrogenitus De Administrando Imperii, 182, ch. 42, see vol. II, Commentary (S. Runciman) ed. R. J. H. Jenkins, London 1962; 153; Hattersley-Smith 1996, 192.

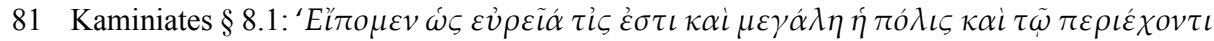

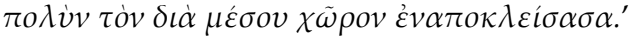

82 Laiou 2002a, 49-50.

83 Kaminiates § 9.7: '

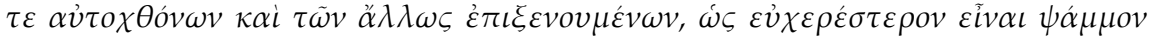

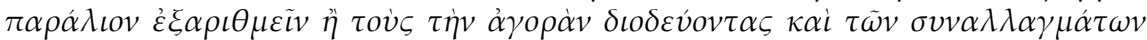

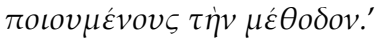

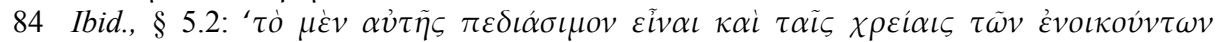

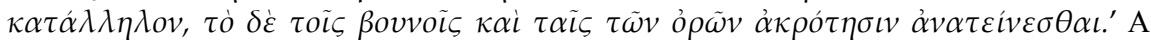
monastery functioning in this period in Thessalonike's upper town is Latomus, see Janin $1975,392$.

85 Karydas 2002, 342-344.

86 Idem 1998, 152-154, pl. 6; idem 1999, 249-255.

87 For a detailed description, see St Theodora, Life § 50.1-14. 
the city. ${ }^{88} \mathrm{~A}$ gift of three pigs for charitable purposes was no small offering and attests the existence of piggeries outside the densely populated city. ${ }^{89}$

Excavations within the city have ascertained that the main construction activity at this time consisted not so much in building as in adapting older structures to new purposes and dividing spaces up into smaller ones. The rooms of the former GraecoRoman-style houses were converted into separate households and their atria into shared courtyards. This type of conversion is clearly apparent in the extensive excavation in Diikitiriou Square, on the south side of the decumanus of what is now Ayiou Dimitriou Street. The rooms of a large house that was occupied in the late Roman and early Christian period were divided into smaller spaces by walls, some of which took up part of the atrium, which was converted into a courtyard. In the Life of St Gregory of Dekapolis (first half of ninth century) the word 'room' (domation) actually means 'house'. 90

The private houses needed modifications and some of them had upper storeys and several rooms, wine cellars and their own bathrooms, as did the monasteries. ${ }^{91}$ Fragile water-supply and drainage systems, wells in the courtyard of houses, water cisterns and rainwater pits found at all levels of rescue excavations in Thessalonike required frequent maintenance and repairs. Kaminiates mentions a large wastepipe that carried away the household waste and the water that had been brought into the city. It emptied into the sea and it is evident that the city was responsible for maintaining its regular function with special teams of workers. ${ }^{92}$

The three large non-parochial churches (the Basilica of St Demetrios, the Acheiropoietos and the Hagia Sophia) and the Rotunda of Asomatoi were in need of repair and conservation. ${ }^{93}$ This was specialised work, requiring special technical staff, labourers and large quantities of building materials.

88 St Gregory of Dekapolis 60.8-11.

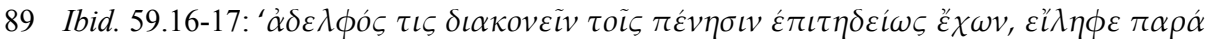

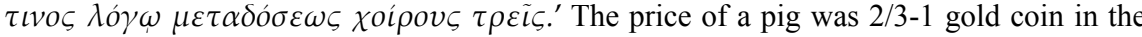
seventh-eighth century (Morrisson/Cheynet 2002, 840, t. 11).

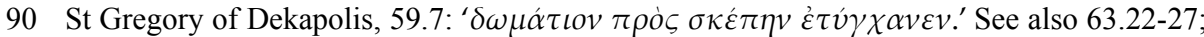

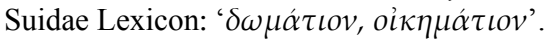

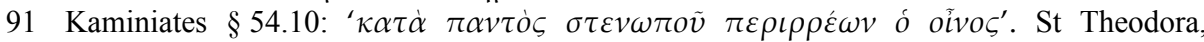

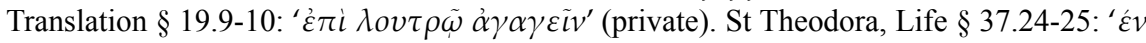
$\beta \alpha \lambda \alpha v \varepsilon i \omega \dot{\alpha} \pi \iota \tilde{v} \sigma \alpha v^{\prime}$ (in the nunnery of St Stephen).

92 Ibid., § 57.7.

93 Velenis 2003 
The city had nunneries ${ }^{94}$ like that of St Luke ${ }^{95}$ and St Stephen, where St Theodora was a nun, ${ }^{96}$ and men's monasteries founded by imperial and private benefactions; Constantine VII Porphyrogennetos, for instance, founded Pantokrator Monastery in Thessalonike in $946 .{ }^{97}$ On the north-western edge of the inhabited city, a certain Zacharias converted his property into a monastery of St Mark, in which each monk built his own cell. ${ }^{98}$

As far as building activity is concerned, people often constructed buildings themselves or offered their services for the purpose, though of course professional builders were essential for specialised work. A spirit of self-sufficiency led many people to do their own building work, using spolia and mud as construction materials, like, for instance, the neighbour of the monk Zacharias and Antonios' companion monks. ${ }^{99}$ Because of this voluntary work, Antonios himself suffered from chronic lumbago, a common complaint among builders. ${ }^{100}$

The material for building the walls and towers and monasteries in the city and in the countryside came from older buildings, like brick and stone spolia, and from quarries inside and outside the city, while manpower was supplied by the people. ${ }^{101}$ There were no large pine forests in the Thessalonike area. The area supplied the city with

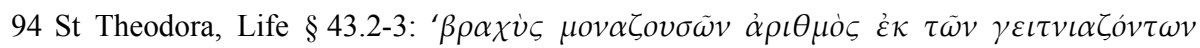
$\mu o v \alpha \sigma \tau \eta \rho i \omega v^{\prime}$.

95 Ibid., § 5.2-4.

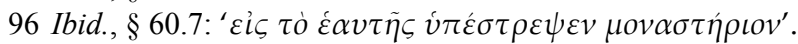

97 Theocharides 1978, 7-77.

98 St Gregory of Dekapolis 60.8-11. Mr I. Papangelos thinks that the existing metochion of St Charalambos in Thessalonike gives us an idea of what the Monastery of St Mark must have looked like: a courtyard with a church and a building on one side.

99 St Gregory of Dekapolis 59.7-14. St Theodora, Life § 59.20-23: 'ö $v$ [the monk Antonios]

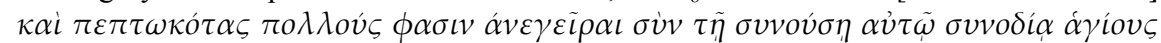

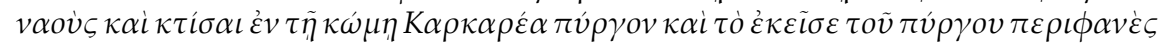
$\mu о v \alpha \sigma \tau \eta \dot{\rho} \iota v^{\prime}$.

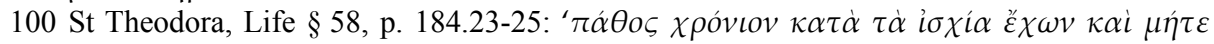

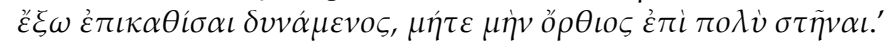

101 Ousterhout 1999, 140-145. The use of spolia was common after the seventh century (Sodini 2002, 138-142). Early Christian bricks were used to repair Acheiropoietos (Raptis 1999, 221-222) and Hagia Sophia (Theocharidou 1994, 172). In his account of Latomou Monastery in Thessalonike, Ignatios, the abbot, mentions old stone quarries inside the city: ' $\pi \varepsilon \rho i \tau \dot{\alpha}$

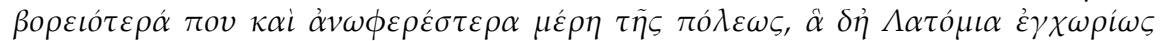

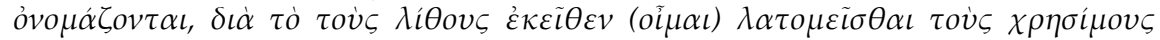

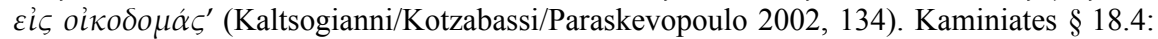

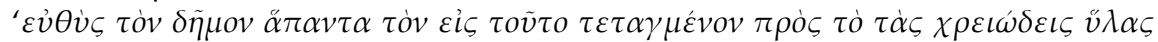

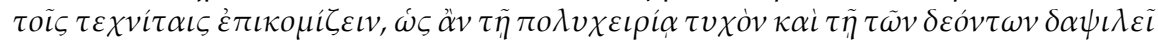

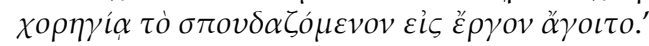


firewood for winter heating and for the many baths. ${ }^{102}$ This was why the Saracens did not construct their catapults on the spot, but used timber from Thasos (Thasian pine). ${ }^{103}$ Therefore, the massive timbers with which the Thessalonians built wooden towers must have come from older buildings. ${ }^{104}$

Specialised construction materials were rare and therefore expensive. A quantity of pitch, which provided effective insulation against the damp, was found by chance when the foundations were being dug for the 'room' of the monk Zacharias' neighbour. Having sought the advice of St Gregory of Dekapolis, she sold the pitch and with the money she got for it not only paid for her house to be built, but also easily kept herself fed. ${ }^{105}$

After the Keramesios kampos had been abandoned, the potteries moved closer to Thessalonike. Apart from everyday wares, they manufactured receptacles for special purposes, such as amphoras for extinguishing fires and incendiary clay grenades. ${ }^{106}$ Pottery workshops of this period and kilns for firing building materials have recently been excavated outside the east city wall, near the Kassandra Gate and the White Tower (Fig. 4) ${ }^{107}$ The subsoil here is argillaceous and a river flowed alongside the city's east wall, serving also as a moat. The building materials manufactured in the potteries were not only for the local market, but were probably also exported by sea, as we may gather from the fact that the workshops were situated at the head of a cove, which would also have served as a little harbour. The site was known as Kaminia (kilns) in 903. The potteries were private enterprises for a document relating to the sale of one of them (workshop for tiles) survives from 952. ${ }^{108}$

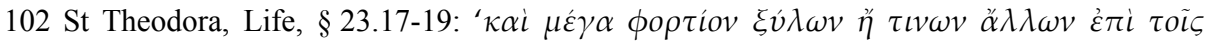

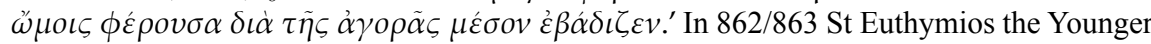
of Galatia brought his ailing spiritual father, Theodoros, from Olympus in Bithynia to Thessalonike because of the city's many baths (Kaltsogianni/Kotzabassi/Paraskevopoulo $2002,111)$ and because of its tolerance of bathing.

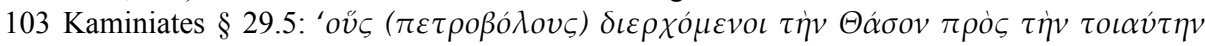

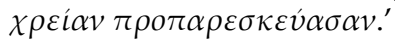

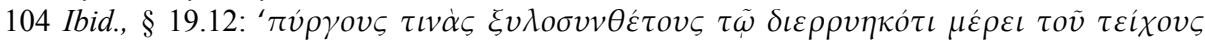
$\eta \mu \varepsilon \tilde{\iota} \varsigma \delta о \mu \eta \sigma \alpha \dot{\mu} \mu v o \iota \tau \varepsilon^{\prime}$. When dating old buildings, dendrochronologists should bear this practice in mind.

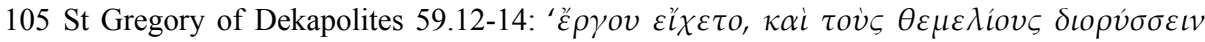

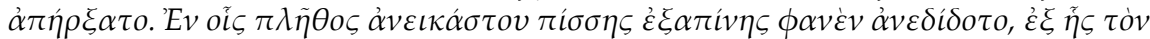

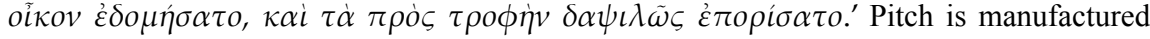
from resinous trees (Orlando/Travlos, Lexikon, p. 211), which flourish in Chalkidike. So it is very likely that that pitch was manufactured in Chalkidike.

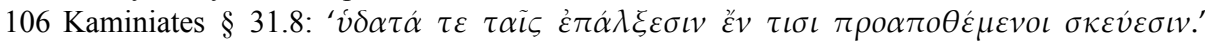

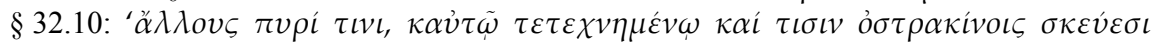

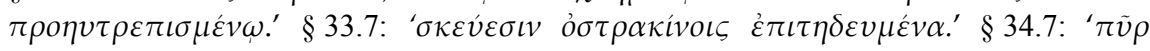

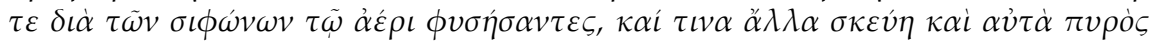
$\dot{\alpha} v \alpha \dot{\mu} \mu \varepsilon \sigma \tau \alpha \varepsilon \grave{l} \sigma \omega \tau \sigma \tilde{v} \tau \varepsilon \dot{\chi} \chi 0 v \varsigma \dot{\varepsilon} \xi \alpha \kappa o v \tau \iota \sigma \alpha v \tau \varepsilon \varsigma^{\prime}$.

107 Thessaloniki Rescue Excavations 2002, 11.

108 Actes de Lavra I, 101. I owe the information to Ms Styliane Sabanopoulou. 


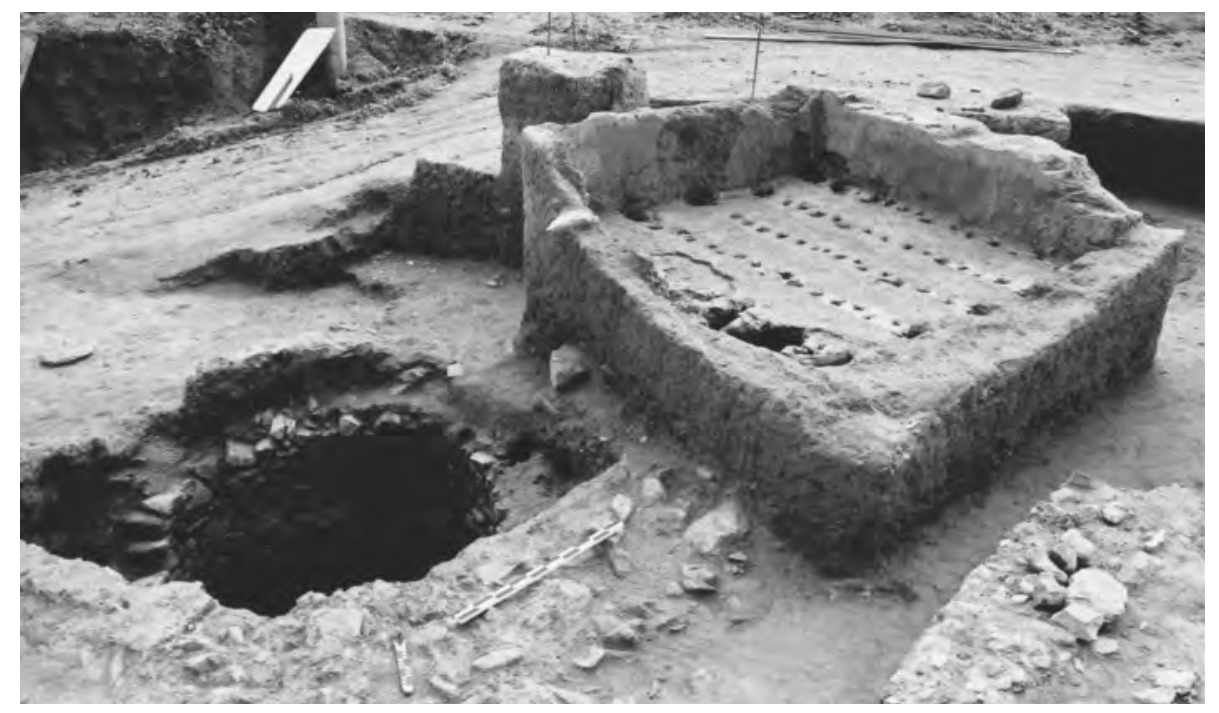

Fig. 4. Pottery workshops and kilns for firing building materials

The city had all it needed to live, voluntary labour, builders, stone and marble masons, ${ }^{109}$ local stone, ${ }^{110}$ and marble available from Roman monolithic sarcophagi in the cemeteries, though there is no mention of any trade in spolia. ${ }^{111}$ Judging by the war operations, which were also the most serious to date and undertaken in anticipation of the city's siege at the hands of the Saracens, the government mechanisms consisted in providing technical know-how and sending experts to help the city meet its needs. ${ }^{112}$

Import and export trade involved commodities that were not produced in or near Thessalonike and was carried out by merchants and foreign visitors, though it is not

109 Mention is made in 893 of the construction of a marble sarcophagus with decoration, in which

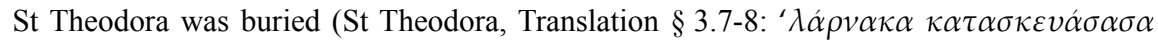

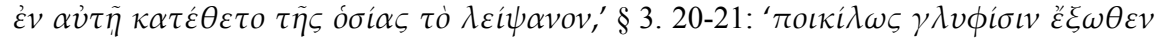
$\tau \alpha \dot{v} \tau \eta v \delta \iota \alpha \kappa o \sigma \mu \eta \dot{\sigma} \sigma \alpha \tau \varepsilon \varsigma^{\prime}$ ), and of a stone mason who was also a priest (St Theodora,

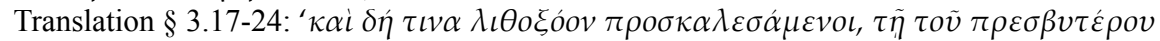
$\left.\tau \varepsilon \tau \iota \mu \eta \mu \varepsilon v^{\prime} v \alpha^{\alpha} \xi \alpha^{\prime}\right)$. St Hilarion of Iberia, too, was buried in Thessalonike in a marble sarcophagus ( $\uparrow 875$, Kaltsogianni/Kotzabassi/Paraskevopoulo 2002, 107). But it is not clear whether it was newly constructed or an old sarcophagus (see Ayios Nikolaos Orphanos, 121 (Styl. Vasileiadou) pl. 35).

110 See note 100 .

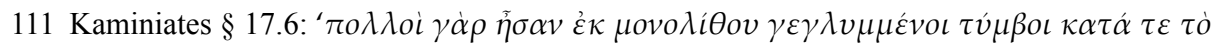

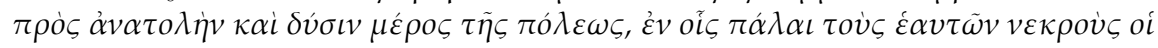

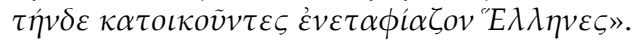

112 Ibid., $\S 16.2$ (messenger), $\$ 17.2$ (protospatharios Petronas), §18.2 (strategos Leo Chitzilakes, see also Spieser 1973, No. 12, p. 162), § 19.2 (strategos Niketas). 
always clear what was actually imported and exported. ${ }^{113}$ On the one hand grain was transported on short-distance ships loaned by the city to the merchants, ${ }^{114}$ but on the other we do not know what kind of trade occupied the Monemvasiots who came en masse to Thessalonike at the beginning of the tenth century. ${ }^{115}$

Refugees from other parts of Greece also came to Thessalonike, attracted by the city's seemingly impregnable position, conditions and peaceful way of life and they brought their goods and chattel with them. ${ }^{116}$ After Iconoclasm, pilgrims and monks travelled to and from Thessalonike by road or by sea because of the city's key position and large population. ${ }^{117}$ They brought new ideas, propaganda and money and influenced not only the city's ecclesiastical life, but its social and economic life as well. For instance, St Euthymios the Younger of Galatia came to Thessalonike in 862/863. He lived as a stylite on two occasions outside the city walls and built a men's and a women's monastery and a number of churches at Peristerai on the other side of Mount Chortiates. ${ }^{118}$

Gold and silver, precious stones, bronze, iron, tin, lead and glass, both silken, linen and woollen fabrics were bought and sold in the city. ${ }^{119}$ The main street, the Leophoros, was lined with workshops like the Mese in Constantinople. ${ }^{120}$ Kaminiates mentions an agora as the centre of the city's urban and commercial life, probably referring to the

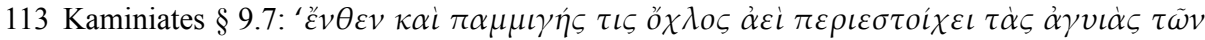

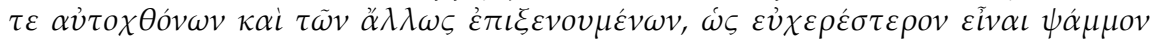

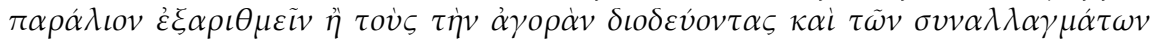

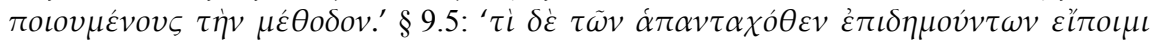

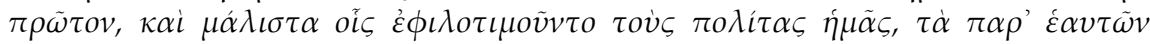
$\delta \iota \delta o ́ v \tau \varepsilon \varsigma \kappa \alpha i \tau \dot{\alpha} \tau \alpha \rho ' \eta \mu \tilde{\omega} v \dot{\alpha} v \tau \iota \lambda \alpha \mu \beta \alpha \dot{v o v} \tau \varepsilon \varsigma^{\prime}$.

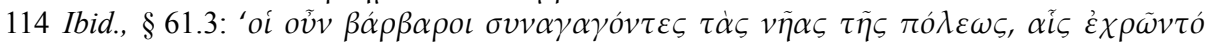

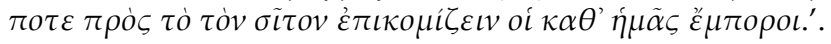

115 Kaltsogianni/Kotzabassi/Paraskevopoulo 2002, 128-129.

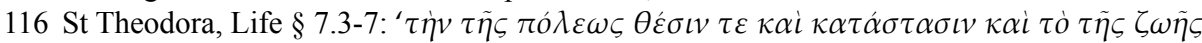

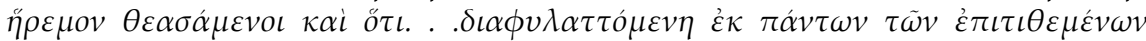
$\kappa \alpha \kappa \tilde{\omega} v \dot{\alpha} v \alpha \dot{\alpha} \lambda \omega \tau \sigma \varsigma \delta \varepsilon \dot{\imath} \kappa v v \tau \alpha \iota^{\prime}$.

117 Konstantakopoulou 1996, 62.

118 Kaltsogianni/Kotzabassi/Paraskevopoulo 2002, 111-114.

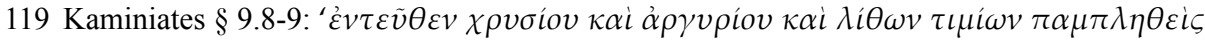

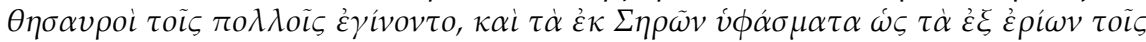

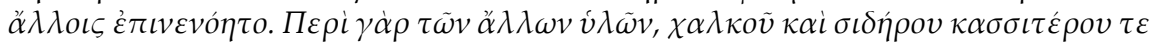

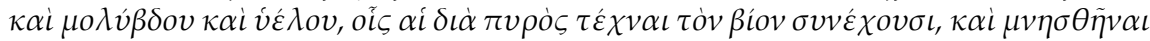

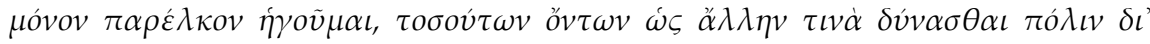

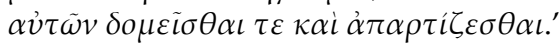

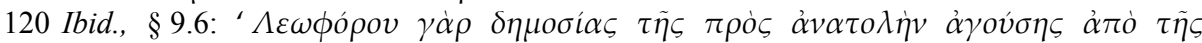

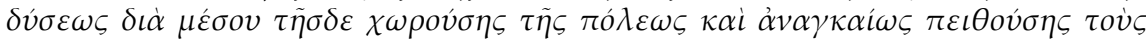

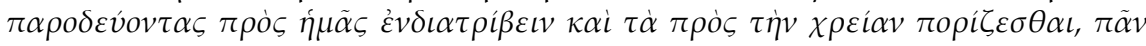

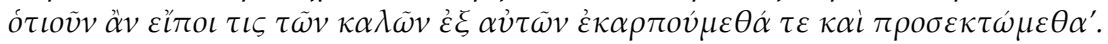


area of the Roman forum (Megaloforos) beside the main street. ${ }^{121}$ There was also an agora, in the sense of a fair rather than a market, for reasons of safety and practicality inside the Kassandra Gate at the west end of the main street. ${ }^{122}$ It was a place of local trade in agricultural products, raw materials and light industrial and commercial supplies between the inhabitants of Kalamaria and those of Thessalonike.

The workshops included chandleries in the monasteries or in the city, ${ }^{123}$ coppersmiths' workshops for hot-water boilers ${ }^{124}$ and those of basket-makers and tanners. ${ }^{125}$ There were also carpentry workshops making beds and couches, moreover carts for farmers and boats for fishermen, ${ }^{126}$ ironsmiths' workshops, which manufactured and repaired the ironclad timber doors of the city gates, ${ }^{127}$ weapons, which private citizens kept in their houses ${ }^{128}$ and fine locks. ${ }^{129}$ A ninth century glass-works has been excavated in Diikitiriou Square, in an area that showed signs of abandonment after the seventh century. ${ }^{130}$ In the monasteries, in keeping with the spirit of autarky, the monks and nuns used scraps of cloth to make bags and rag rugs, wove rush mats and baked bread in order not to have any need of a baker. ${ }^{131}$ The monastery of St Stephen probably had a

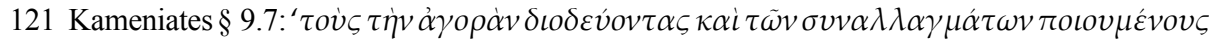

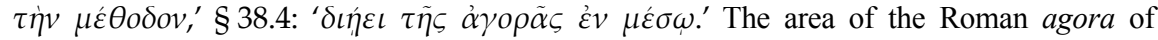
Thessalonike was an open square in the late Byzantine period, see Bakirtzis 2003, 57.

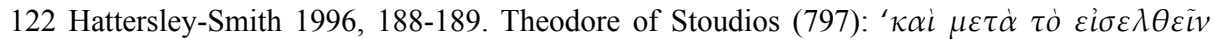
$\kappa \lambda \varepsilon i \sigma \alpha v \tau \varepsilon \varsigma \tau \dot{\alpha} \varsigma \quad \pi \hat{v} \lambda \alpha \varsigma$ [eastern] $\tilde{\eta} \gamma o v \delta \dot{\alpha} \tau \tilde{\eta} \varsigma \dot{\alpha} \gamma o \rho \tilde{\alpha} \varsigma^{\prime}$ (Kaltsogianni/Kotzabassi/

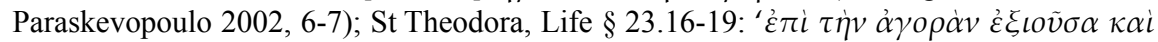
$\ddot{\varepsilon} \xi \omega \mu \alpha \kappa \rho \alpha \dot{v} \pi o v \tau \tilde{\eta} \varsigma \pi \hat{\lambda} \varepsilon \omega \varsigma \delta \iota \dot{\alpha} \tau \tilde{\omega} v \omega \dot{\omega} v i \omega v \varepsilon \dot{v} \theta \eta v i \alpha v^{\prime}$. Other examples (Rhodes) in Bouras 2002, 512-513. Markets and fairs in Laiou 2002c, 730-731.

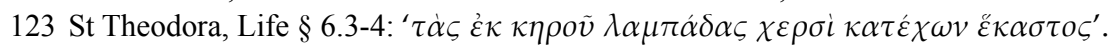

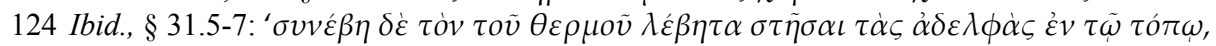

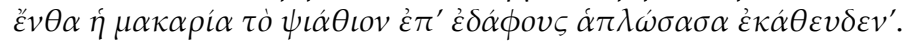

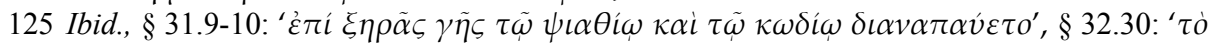
$\dot{\varepsilon} v \hat{\omega} \kappa \alpha \theta \varepsilon \dot{v} \delta \varepsilon \iota \varsigma \kappa \omega \dot{\delta} \delta \iota v^{\prime}$.

126 Kaminiates $\S 31.2:^{\prime} \alpha \mu \alpha \dot{\xi} \alpha \varsigma \dot{\varepsilon} \phi \varepsilon v \rho o ́ v \tau \varepsilon \varsigma \dot{\varepsilon} \pi \dot{\varepsilon} \theta \eta \kappa \alpha v \dot{\varepsilon} v \alpha \dot{v} \tau \alpha \tilde{i} \varsigma \pi \rho \eta v \varepsilon \tilde{i} \varsigma \tau \dot{\alpha} \varsigma \beta \rho \alpha \chi v \tau \alpha \dot{\alpha} \tau \varsigma \varsigma$

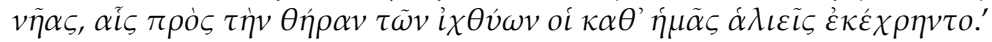

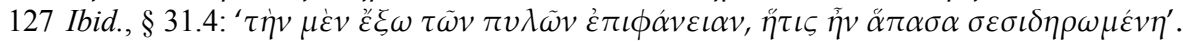

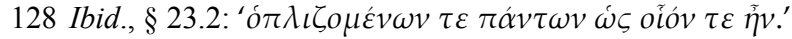

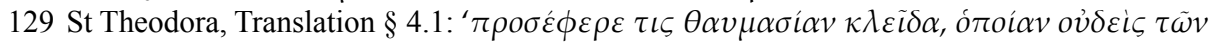

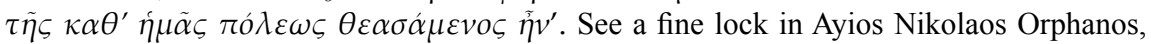
123-125 (St. Tzevreni), pl. 35.

130 Kanonidis 2002, 143-152.

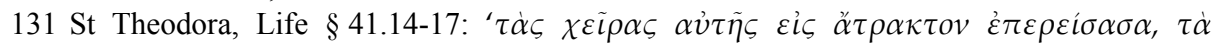

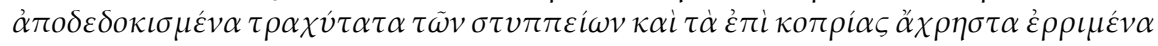

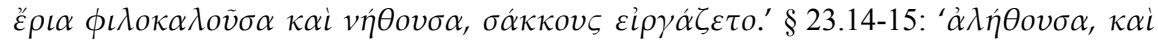

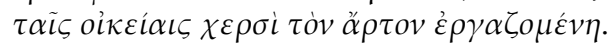


bakehouse, even though it was in the city centre and it was considered dangerous to operate ovens in densely populated districts. ${ }^{132}$

Judging by the Saracens' preferences, the various commodities were categorised as either luxury goods or cheap goods: the former included wares and jewellery of precious metals and silken and fine-woven linen fabrics; the latter included copper and iron wares and woollen fabrics, such as the blankets used in the monasteries. ${ }^{133}$ The citizens, however, took a different view and, corresponding to the spirit of autarky, hoarded luxurious and cheap objects indiscriminately - though not coins. ${ }^{134}$

Coins of this period are rarely reported among the finds from excavations in Thessalonike. An excavational trench dug along Ayiou Dimitriou Street in Thessaloniki's old town was investigated before a new water main was laid. ${ }^{135}$ It yielded 285 identified bronze coins, of which 15 were minted between the seventh and tenth centuries. The hoard discovered near the harbour in 1959 contained luxurious jewellery only of the ninth to the tenth century. ${ }^{136}$ Gold coins weighing two talents, which were brought from Constantinople by a special delegate to pay the salaries of an army on the Bulgarian frontier, were given to the Saracens to dissuade them from burning the city down. ${ }^{137}$ Coins are also mentioned among the assets of visitors to the city or refugees. Early in the ninth century, a young man who had come to study in Thessalonike lent a monk a gold coin. ${ }^{138}$ St Theodora, a refugee from the isle of Aegina in the Saronic Gulf,

132 Eparchenbuch §18.3; Dagron 2002, 453-454.

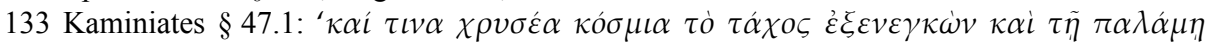

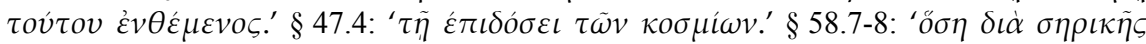

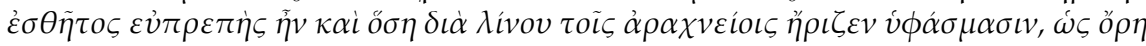

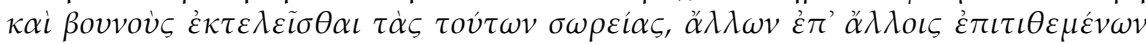

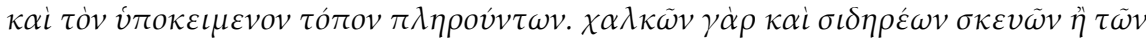

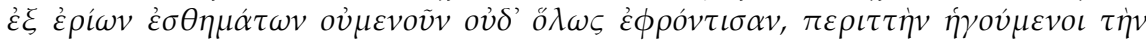

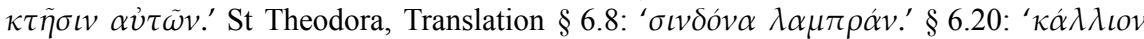

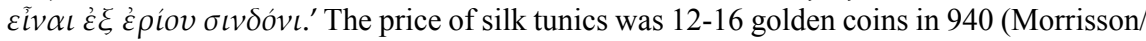
Cheynet 2002, 851, t. 15).

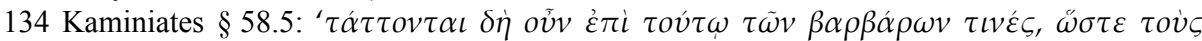

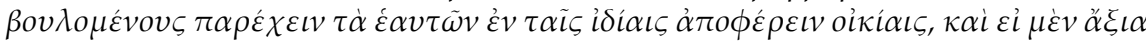

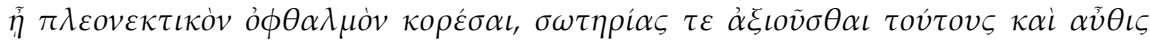

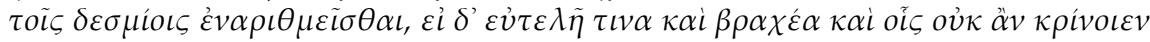

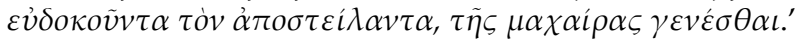

135 Public Works, 373-397.

136 Pelekanidis 1959; Everyday Life 411, No. 518.

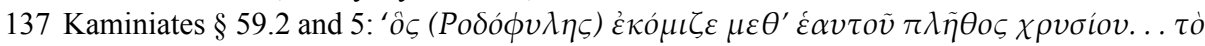

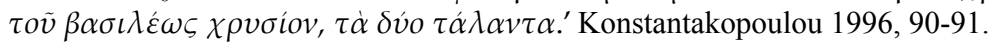

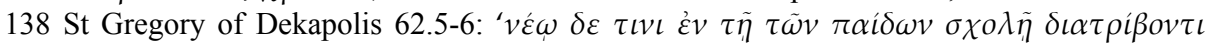

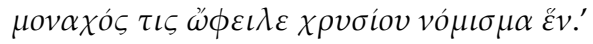


had a hundred gold coins among her assets. ${ }^{139}$ Later on, when the circulation of coins increased, we find hoards of coins, such as gold issues of the first half of the eleventh century, in the area of the harbour. ${ }^{140}$

If the ship loaded with grain that was sailing in the northern Sporades in August $904^{141}$ was making for Thessalonike, this means that food supplies to the city began immediately after the departure of the Saracens. Just a few months later, Metropolitan Plotinos described Thessalonike as a 'most fortunate metropolis', being blessed with abundance and much wealth. ${ }^{142}$ This means that despite reduced exports and imports owing to the war, the city continued to operate as a port and the productive sources of its autarky were not destroyed.

\section{Bibliography}

Actes de Lavra I: Paul Lemerle/André Guillou/Nicolas Svoronos/Denise Papachryssanthou, Actes de Lavra, I, Des origines a 1204, Archives de l'Athos V, Paris 1970.

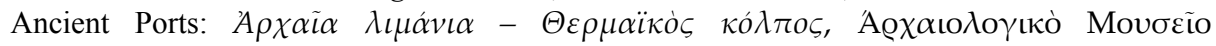

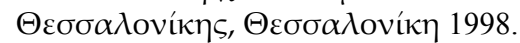

Ayios Nikolaos Orphanos: Charalambos Bakirtzis (Ed.), Ayios Nikolaos Orphanos: the Wall Paintings, Athens 2003.

Bakalakis Georgios 1968: Georgios Bakalakis, «ПАY $\Sigma \mathrm{I} \Lambda$ YПО $\Sigma$ von Thessalonike», in: E. Schmid/L. Berger/P. Burgin (Eds), PROVINCILIA, Festschrift fur Rudolf Laur-Belart, Basel-Stuttgart 1968, pp. 3-5.

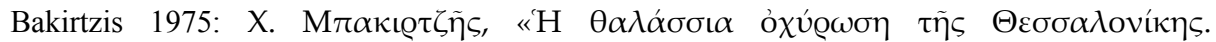
П

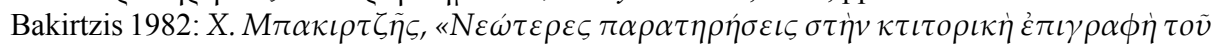

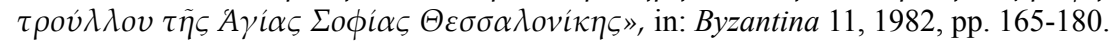

Bakirtzis 2002: Charalombos Bakirtzis, "Pilgrimage to Thessalonike: the Tomb of St Demetrios", in: Dumbarton Oaks Papers 56, 2002, pp. 175-192.

Bakirtzis 2003: Charalambos Bakirtzis, "The Urban Continuity and Size of Late Byzantine Thessalonike", in: Dumbarton Oaks Papers 57, 2003, pp. 35-64.

Bouras 2002: Charalambos Bouras, "Aspects of the Byzantine City, Eighth-Fifteenth Centuries", in: Angeliki E. Laiou (Ed-in-Chief), Economic History of Byzantium from Seventh through the Fifteenth Century 1-3, Washington, D.C. 2002, pp. 497-528.

Buschausen 1971: Helmut Buschausen, Die spatrömischen Metallscrinia und frühchristlichen Reliquiare (=Wiener Byzantinistische Studien IX), Wien 1971.

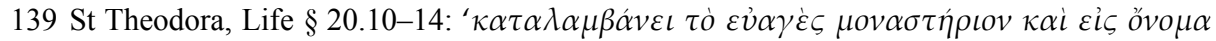

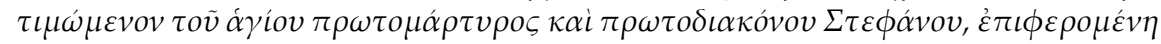

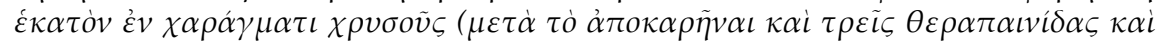

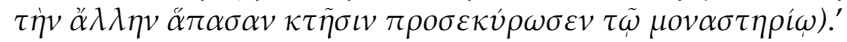

140 Touratsoglou 2003, 523-41.

141 Kaminiates $\S 67.8$.

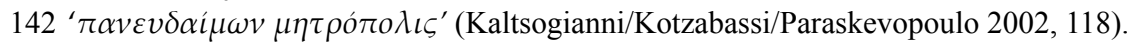


Cheynet/Flusin 1990: Jean-Claude Cheynet/Bernard Flusin, "Du monastère Ta Kathara a Thessalonique: Théodore Stoudite sur la route de l'exil”, in: Revue des Études Byzantins 48, 1990, pp. 193- 211.

Constantine Porphyrogenitus De Administrando Imperii: Gyula Moravcsik/Romilly James Heald Jenkins (Eds), Constantine Porphyrogenitus De Administrando Imperii, Washington, D.C. ${ }^{2} 1968$.

Dagron 2002: Gilbert Dagron, "The Urban Economy, Seventh-Twelfth Centuries", in: Angeliki E. Laiou (Ed-in-Chief), Economic History of Byzantium from Seventh through the Fifteenth Century 1-3, Washington, D.C. 2002, pp. 393-461.

Eparchenbuch: Johannes Koder, Das Eparchenbuch Leons des Weisen (=Corpus fontium historiae Byzantinae XXXIII), Wien 1991.

Everyday Life: Demetra Papanikola-Bakirtzi (Ed.), Everyday Life in Byzantium: Thessaloniki, White Tower, October 2001- January 2002 (=catalogue of the exhibition "Byzantine hours - works and days in Byzantium"), Athens 2002.

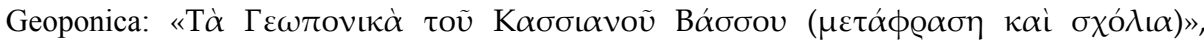

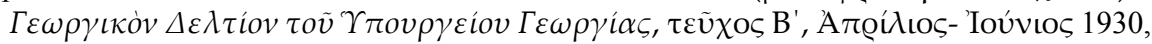
A $\theta \tilde{\eta} v \alpha \iota 1930$

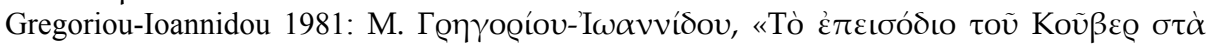

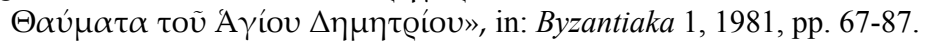

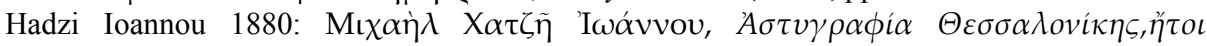

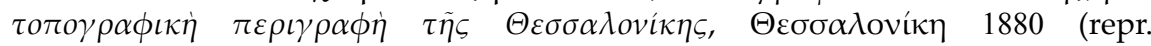

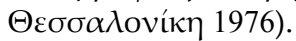

Hattersley-Smith 1996: Kara M. Hattersley-Smith, Byzantine Public Architecture between the Fourth and Early Eleventh Centuries AD, with Special Reference to the Towns of

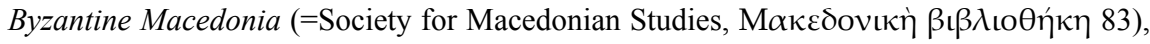
Thessaloniki 1996.

Janin 1975: Raymond Janin, Les églises et les monastères des grands centres byzantins (Bithynie, Hellespont, Latros, Galesios, Trébizonde, Athènes, Thessalonique), Paris 1975.

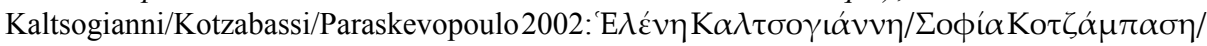

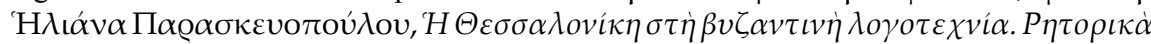

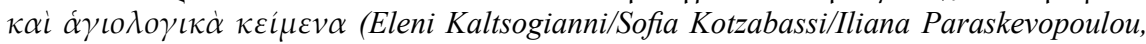
Thessaloniki in the Byzantine Literature. Rhetorical and Hagiographical Texts) (=Byzantine Recherche Centre, Byzantine Texts and Studies 32), Thessaloniki 2002.

Kaminiates: De expugnatione Thessalonicae (=Corpus fontium historiae Byzantinae IV) 1973; german Translation G. Bohlig, Die Einnahme Thessalonikes durch die Araber im Jahre 904, Graz-Wien-Köln 1975.

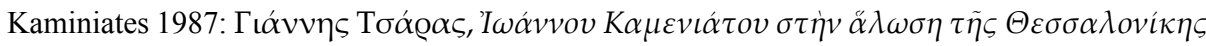

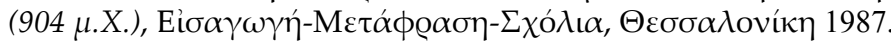

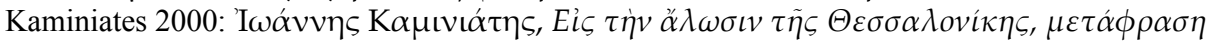

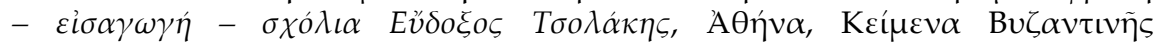

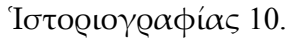

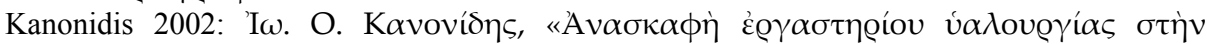

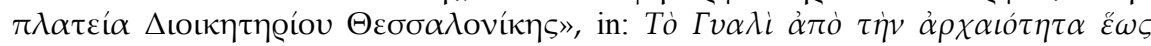

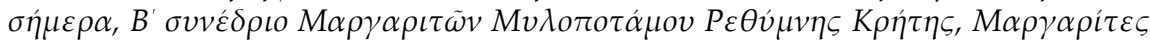

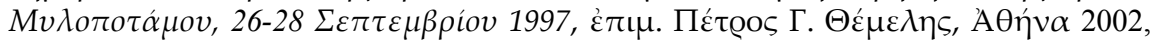
pp. 143-152.

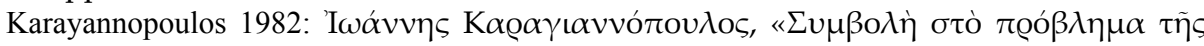

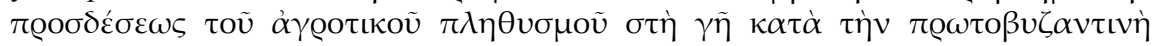




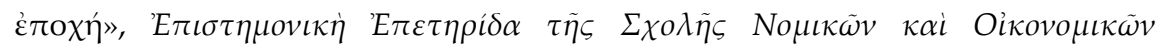

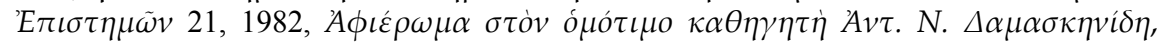
pp. 961-970.

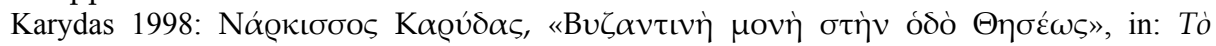

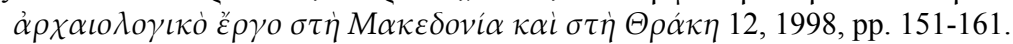

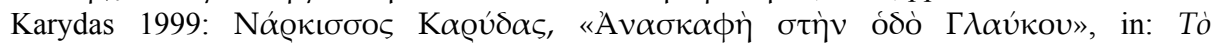

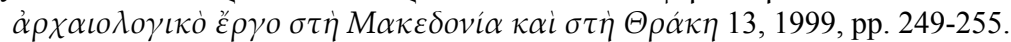

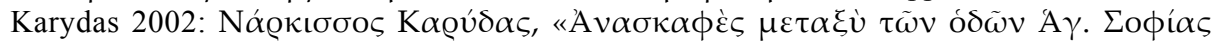

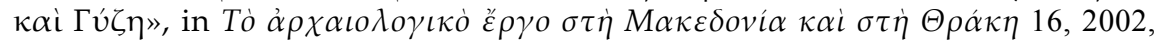
pp. 337-344.

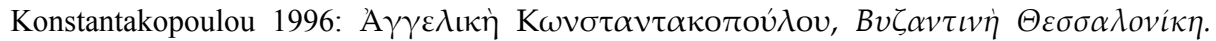

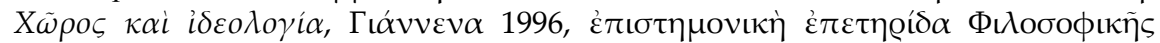
$\Sigma \chi 0 \lambda \tilde{\eta} \varsigma \Delta \omega \delta \omega \dot{\nu \eta, \pi \alpha \varrho \alpha ́ \varrho \tau \eta \mu \alpha ~} 62$.

Kazhdan 1978: Al. Kazhdan, "Some questions adressed to the scholars who believe in the authenticity of Kameniatis' 'Capture of Thessalonica' ”, in: Byzantinische Zeitschrift 71, 1978, pp. 301-314.

Koder 1998: Johannes Koder, "Embolos-Ekbolos" in: EYYYXIA, mélanges offerts a Hélène Ahrweiler II (=Byzantina Sorbonensia 16), Paris 1998, pp. 379-385.

Koder 2002: Johannes Koder, "Maritime trade and the food supply for Constantinople in the middle ages", in Ruth J. Macrides (Ed.), Travel in the Byzantine World: Papers from the Thirty-Fourth Spring Symposiun of Byzantine Studies, Birmingham, April 2000 (=Society for the Promotion of Byzantine Studies 10), Aldershot 2002, p. 109-124.

Laiou 2001/2002: Angeliki E. Laiou, "Methodological Questions Regarding the Economic History of Byzantium", in: Zbornik Radova Vizantoloskog Instituta 39, 2001/2002, pp. 9-22.

Laiou 2002a: Angeliki E. Laiou, "The Human Resources", in: Angeliki E. Laiou (Ed.-in-Chief), Economic History of Byzantium from Seventh through the Fifteenth Century 1-3, Washington, D.C. 2002, pp. 47-56.

Laiou 2002b: Angeliki E. Laiou, "Economic and Noneconomic Exchange", in: Angeliki E. Laiou (Ed.-in-Chief), Economic History of Byzantium from Seventh through the Fifteenth Century 1-3, Washington, D.C. 2002, pp. 681-696.

Laiou 2002c: Angeliki E. Laiou, "Exchange and Trade, Seventh-Twelfth Centuries", in: Angeliki E. Laiou (Ed.-in-Chief), Economic History of Byzantium from Seventh through the Fifteenth Century 1-3, Washington, D.C. 2002, pp. 697-770.

Laiou 2002d: Angeliki E. Laiou, "Economic Thought and Ideology”, in: Angeliki E. Laiou (Ed.in-Chief), Economic History of Byzantium from Seventh through the Fifteenth Century 1-3, Washington, D.C. 2002, pp. 1123-1144.

Lefort 1982: Jacques Lefort, Villages de Macédoine: notices historiques et topographiques sur la Macédoine orientale au Moyen Age. 1: La Chalcidique occidentale (=Travaux et Mémoires du Centre de Recherche d'Histoire et Civilisation de Byzance, Monographies 1), Paris 1982.

Lemerle1981: Paul Lemerle, Les plus anciens recueils des Miracles de Saint Demétrius et la pénétration des Slaves dans les Balkans II, Commentaire, Paris 1981.

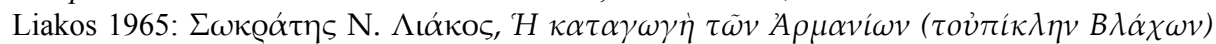

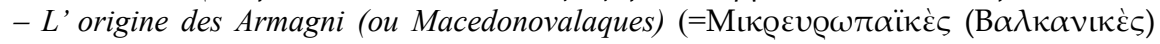

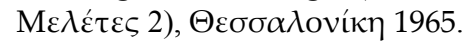

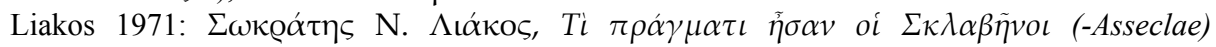

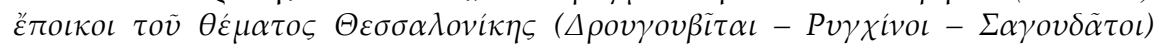

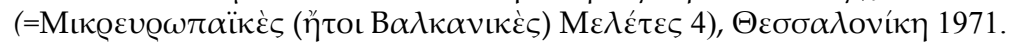




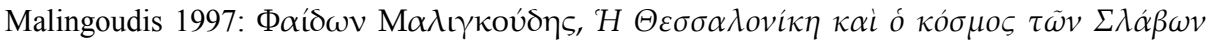

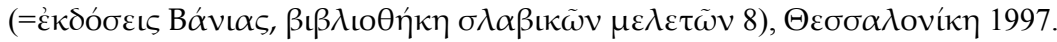

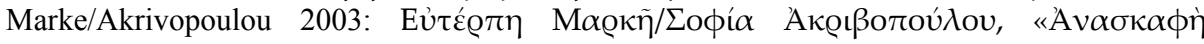

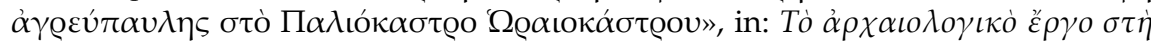

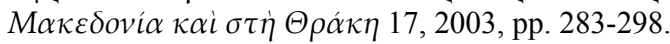

Milkucic 1996: Ivan Milkucic, Srednovekovni gradovi I tvrdini vo Makedonija (=Makroproekt Istorija na kulturata vo Makedonija 5), Skopje 1996.

Miracles: Paul Lemerle, Les plus anciens recueils des Miracles de Saint Demétrius et la pénétration des Slaves dans les Balkans I: le texte, Paris 1979.

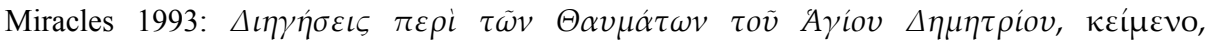

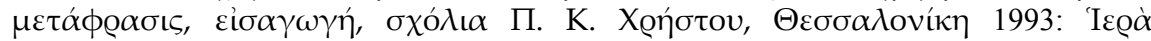

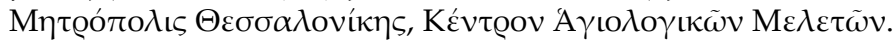

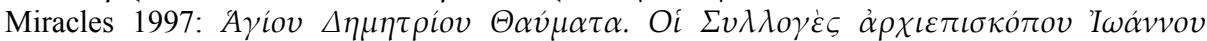

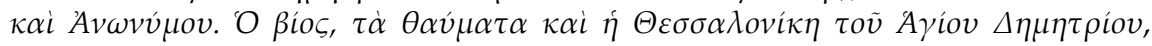

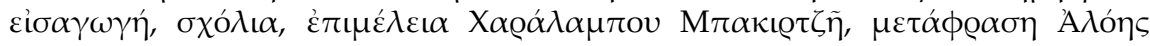

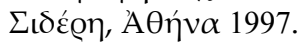

Morrisson/Cheynet 2002: Cecile Morrisson/Jean-Claude Cheynet, "Prices and Wages in the Byzantine World", in: Angeliki E. Laiou (Ed.-in-Chief), Economic History of Byzantium from Seventh through the Fifteenth Century 1-3, Washington, D.C. 2002, pp. 815-878.

Nasledova 1956: R. A. Nasledova, "Remeslo I torgovlja Fessaloniki v konca IX-nacala X v. po dannym Ioanna Kameniaty", in: Vizantiskij Vremennik 8, 1956, pp. 61- 84.

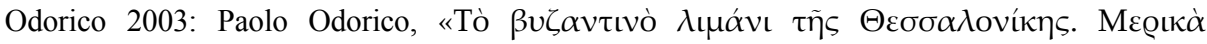

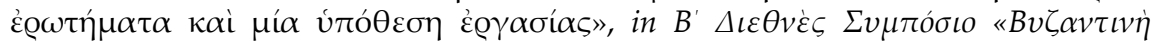

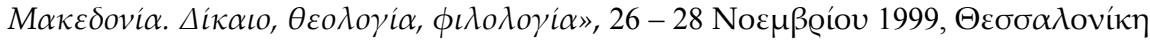

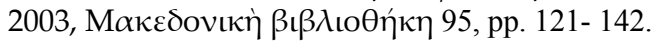

Oikonomidès 1991: Nicolas Oikonomidès, "Le Kommerkion d'Abydos: Thessalonique et le commerce bulgare au IXe siècle", in: Vassiliki Kravari/Jaques Lefort/Cécile Morrisson (Eds), Hommes et richesses dans l'empire byzantin, II, VIIIe - XVe siècle (=Réalités byzantines 3), Paris 1991, pp. 241-248.

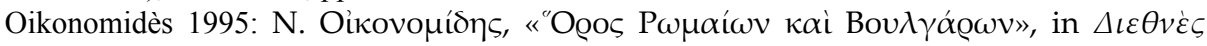

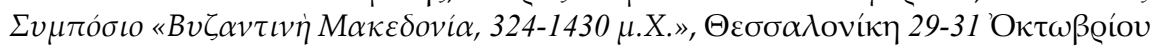

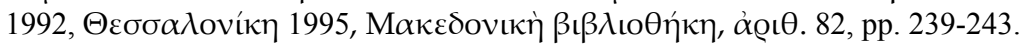

Oncevska 2004: Marina Onceska Todorovska, Docnoanticka Grncarija od Skupi (vtora polovina na IV-VI vek), Skopje 2004.

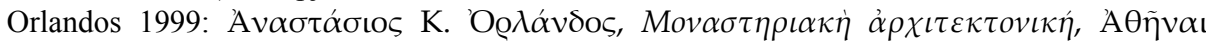

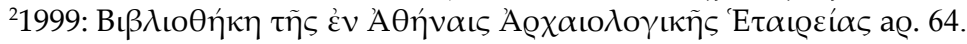

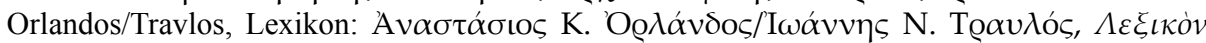

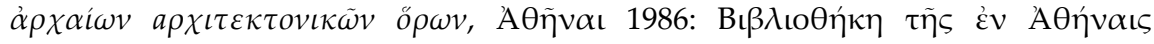

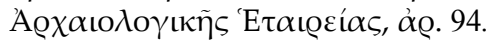

Ousterhout 1999: Robert Ousterhout, Master Builders of Byzantium, Princeton, N.J. 1999.

Pallas 1979: Demetrios I. Pallas, "Le ciborium hexagonal de saint Demetrios de Thessalonique", in: Zograf 10, 1979, pp. 44-58.

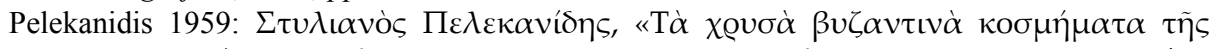

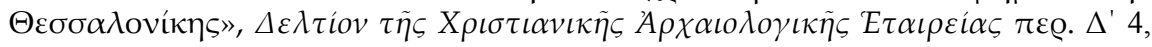
1959, pp. 55-71 (repr. Stylianos Pelekanidis, Studien zur frühchristlichen und byzantinischen Archäologie (=Institut for Balkan Studies 174), Thessaloniki 1977, pp. 243-260). 


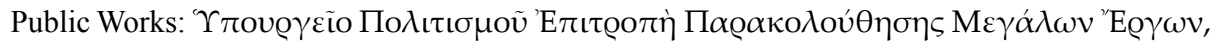

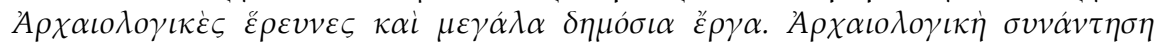

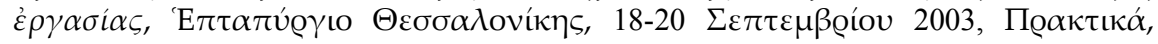

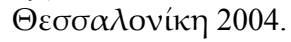

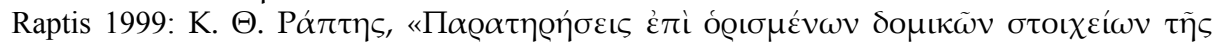

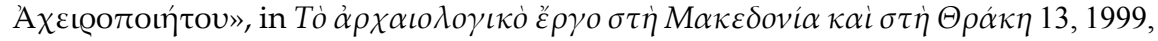
pp. 219-237.

Saint Gregoire le Decapolite : F. Dvornik, La vie de Saint Grégoire le Decapolite et le Slaves macédoniens au IX e siècle (=Travaux publies par l'Institut d'Etudes Slaves V), Paris 1926.

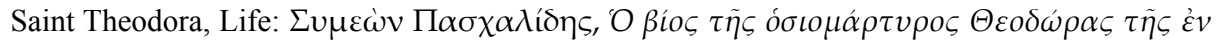

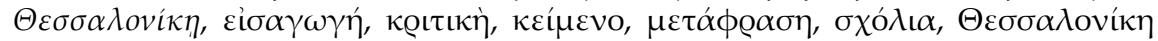

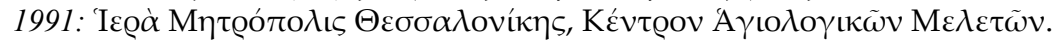

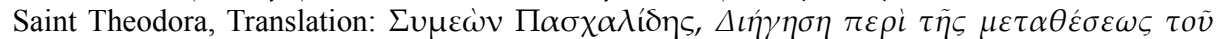

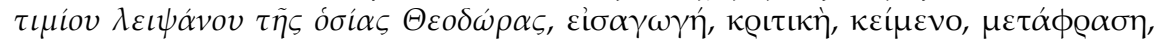

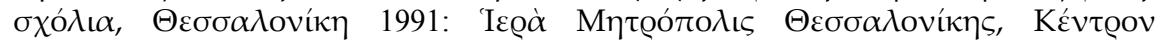

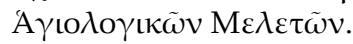

Schilbach 1970: Erich Schilbach, Byzantinische Metrologie (=Byzantinisches Handbuch XIV), München 1970.

Sodini 2002 : Jean-Pierre Sodini, "Marble and Stoneworking in Byzantium, Seventh -Fifteenth Centuries", in: Angeliki E. Laiou (Ed.-in-Chief), Economic History of Byzantium from Seventh through the Fifteenth Century 1-3, Washington, D.C. 2002, pp. 129-

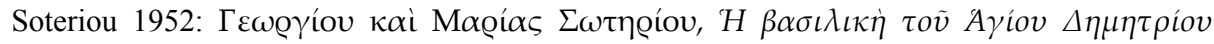

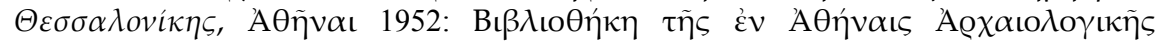

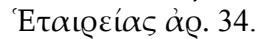

Speck 1993: Paul Speck, "De Miracula Sancti Demetrii, qui Thessalonicam profugus venit, oder Ketzerisches zu den Wundergeschichten des Heiligen Demetrios und zu seiner Basilica in

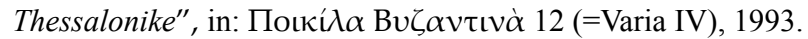

Speck 1994: Paul Speck, "Nochmals zu den Miracula Sancti Demetrii: die Version des Anastasius

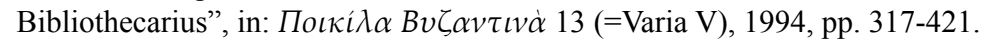

Spieser 1973: Jean-Michel Spieser, "Inventaires en vue d'un recueil des inscriptions historiques de Byzance. I: les inscriptions de Thessalonique", in: Travaux et Mémoires 5, 1973, pp. 145-180.

Spieser 1984: Jean-Michel Spieser, Thessalonique et ses monuments du IVe au Vie siècle: contribution a l'étude d'une ville paléochrétienne (=Bibliothèque des Écoles Françaises d'Athènes et de Rome 254), Athènes-Paris 1984.

Suidae Lexicon: Ada Adler (Ed.), Svidae Lexicon (=Lexicographie graeci).

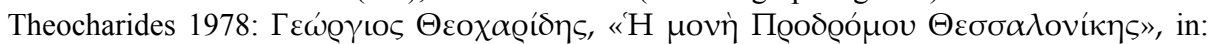
Makedonika 18, 1978, 7-26.

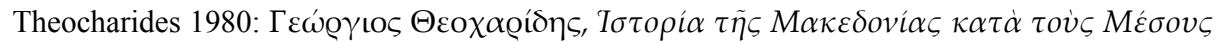

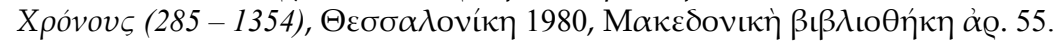

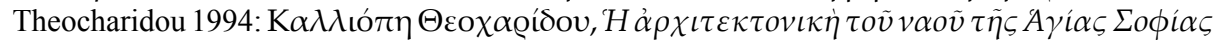

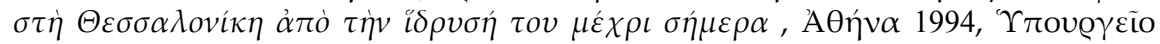

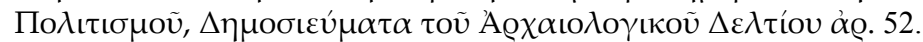

Theophanes Continuatus: Immanuel Bekker, Theophanes Continuatus, CB, Bonnae 1838.

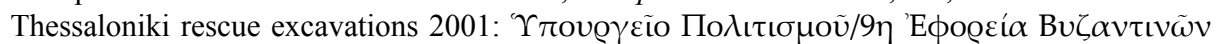

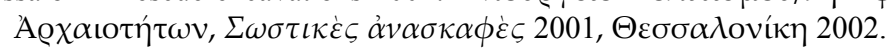

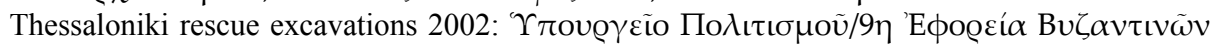

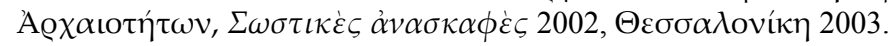




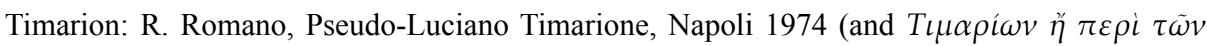

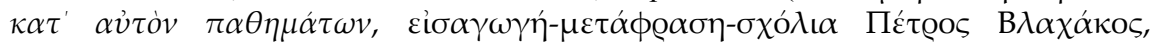
$\Theta \varepsilon \sigma \sigma \alpha \lambda$ ovíkך 2001).

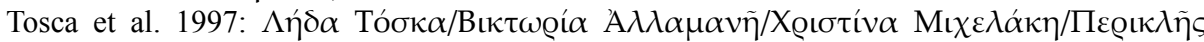

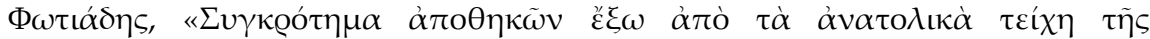

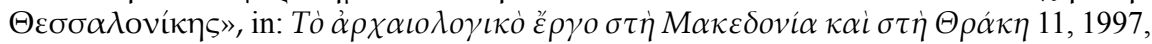
pp. 419-428.

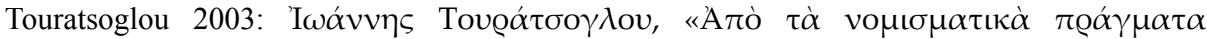

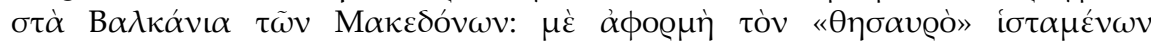

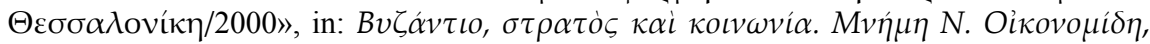

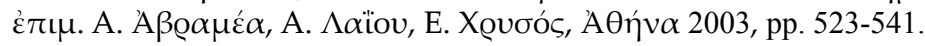

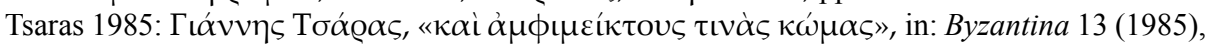

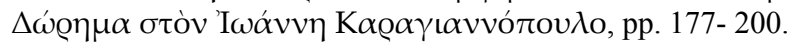

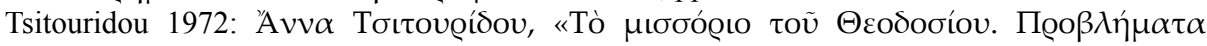

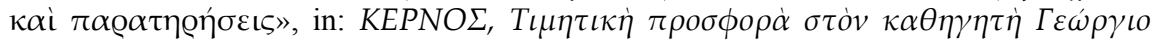

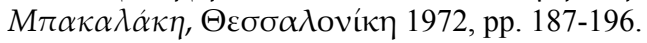

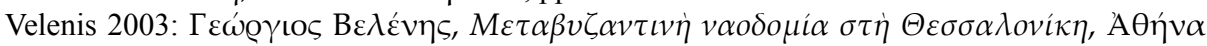

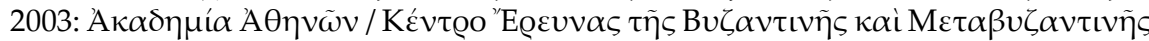

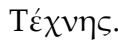




\title{
Archäologie und die „Dunklen Jahrhunderte“ im byzantinischen Anatolien
}

\author{
PHILIPP NIEWÖHNER
}

\section{Einleitung}

Vor einem Vierteljahrhundert hat C. Foss erstmals primär archäologische Befunde herangezogen, um den bis dato umstrittenen Charakter der sogenannten Dunklen Jahrhunderte im byzantinischen Anatolien zu klären. Es geht darum, ob die Zeit der Perserund Araberkriege - das 7. bis 9. Jahrhundert - mit einem abrupten Zusammenbruch des (spät)antiken städtischen Lebens verbunden war, das Mittelalter also durch eine Katastrophe eingeleitet wurde, oder die Städte fortbestanden und sich der Übergang von der Antike zum Mittelalter in einem allmählichen Wandel vollzog.

Anhand der schriftlichen Quellen, des epigraphischen und des numismatischen Befunds allein ist das nicht zu entscheiden; sie lassen sich so oder so interpretieren. ${ }^{1}$ Deshalb hat Foss den archäologischen Befund in die Diskussion eingeführt, weil er als ein unmittelbares Abbild der historischen Verhältnisse nur eine Interpretation zuzulassen schien. ${ }^{2}$ In einem ersten Aufsatz mit dem Titel „The Persians in Asia Minor and the end of antiquity ${ }^{63}$ hat Foss zu zeigen versucht, dass die Perser zu Anfang des 7. Jahrhunderts Sardis $^{4}$ und andere bis dahin blühende (spät)antike Städte vernichteten. Dem ist jedoch widersprochen worden, denn auch anhand des archäologischen Befunds lässt sich eine derartige Katastrophe im frühen 7. Jahrhundert wohl nicht beweisen. ${ }^{5}$

In einem zweiten Aufsatz ,Archaeology and the ,Twenty cities' of Byzantine Asia Minor $^{\text {"6 } 6}$ hat Foss dann auch davon abgesehen, seine These von einer Katastrophe des

1 Zur älteren Literatur, insbesondere der Kontroverse zwischen Ostrogorsky 1959, Weiß 1977 und Cutler/Každan 1982, siehe zusammenfassend Haldon 1985, 78, Anm. 4; Brandes 1989, 17-22, zum numismatischen Befund insb. 143-149.

2 So auch Brandes 1989, 81: „Ein eindeutigeres Bild der Siedlungsentwicklung der kleinasiatischen Städte vermittelt die archäologische Forschung“.

3 Foss 1975a.

4 Speziell zu Sardis auch ders. 1975b, ders. 1976, 53-55 und Foss/Scott 2002, 615.

5 Brandes 1982, 615-616; Trombley 1985, 75-81; Russel 1986; ders. 2001, 57-71.

6 Foss 1977b. 
anatolischen Städtewesens in den Dunklen Jahrhunderten dadurch angreifbar zu machen, dass er sie mit einzelnen historischen Ereignissen verbunden hätte. Vielmehr vergleicht er urbane Pracht und Größe sowie diverse öffentliche Gebäude der Spätantike mit verhältnismäßig einfachen und engen Kastra sowie Kirchen des Mittelalters und erklärt den Gegensatz dadurch, dass das städtische Leben zwischenzeitlich abgerissen sei und sich danach ex novo habe entwickeln müssen. Als Beleg wird ein Aussetzen des Befunds während der deshalb so genannten Dunklen Jahrhunderte angeführt, mit den Barbaren als Ursache. In dieser allgemeineren Form ist die „Katastrophentheorie“ ${ }^{“ 7}$ auf breite Akzeptanz gestoßen, der Gegensatz zwischen (Spät)antike und Mittelalter hat eine kontinuierliche, bruchlose Entwicklung durch Wandel scheinbar ausgeschlossen. ${ }^{8}$

Dieser Gegensatz beruht jedoch auf einer vereinfachenden Auffassung der Spätantike als einer einheitlichen urbanistischen Blütezeit. J. Haldon, W. Brandes und W. Liebeschuetz gehen inzwischen davon aus, dass ein Niedergang des traditionellen antiken Städtewesens schon während der Spätantike einsetzte. Daraus haben sie allerdings nur geschlossen, dass die Antike auch ohne das Einwirken der Barbaren zu Ende gegangen wäre, ${ }^{9}$ ohne deshalb an der vermeintlich archäologisch verbürgten Katastrophe für das anatolische Städtewesens in den Dunklen Jahrhunderten zu zweifeln.

Eine genauere Betrachtung des archäologischen Befunds zeigt aber, dass der anatolische Städtebau zuletzt um 400 florierte, um danach bereits im 5./6. Jahrhundert die Symptome zu entwickeln, anhand derer mittelalterliche von antiken Stadtbildern

7 Brandes 1982, 613.

8 Každan 1977; Bouras 1981, 615, 641 u. 653; Angold 1985, 4-5; Haldon 1985, 77-78; MüllerWiener 1986; Brandes 1989; Iacobini 1994, 38-43; Haldon 1997, 102-114; Brandes 1999; Haldon 1999, 1; Ivison 2000, 4; Bouras 2002, 501; Dagron 2002, 397-401. Dagegen schließt Trombley 1993, 429 ausgehend von einer minimalen Materialgrundlage darauf, „that many urban settlements did indeed survive during the so-called „Dark Age“ in Anatolia“.

Für den ländlichen Raum vergleichen Loos 1978, 9-12 und Kaplan 1992, 379, 382, 388, 447-449, 539-540 u. 575-576 die ländliche Besiedlung des 6., frühen 7. und späten 8. Jahrhunderts anhand der Viten der Heiligen Nikolaos von Sion, Theodor von Sykeon sowie Philaret und schließen daraus auf Siedlungskontinuität auch während der Dunklen Jahrhunderte. Treadgold 1988, 360-362, Lefort 1993, 104-107 und Lefort 2002, 267-275 gehen hingegen davon aus, dass Demographie und die Siedlungsstruktur während der Dunklen Jahrhunderte einbrachen und sich erst danach wieder erholten. Paläobotanische Untersuchungen bei Beyşehir im Südwesten der Zentralanatolischen Hochebene kommen zu dem Schluss, dass es im frühen Mittelalter einen größeren Waldbestand gab als in der Spätantike, d.h. es wurden weniger Flächen intensiv bewirtschaftet. Deshalb schließt man darauf, dass auch die frühmittelalterliche Bevölkerungsdichte hinter der spätantiken zurückblieb (Dunn 1992, 247-248; Bottema/Woldring 1995, 334-335; Waelkens 1997, 237-238; Vanhaverbeke/ Waelkens 2003, 315). Dagegen kommt M. Vermoere jüngst in derselben Gegend für Sagalassos und sein Umland zu dem Ergebnis, dass der Baumbestand seit dem 7. Jahrhundert weiter zurückging und führt das u.a. auf eine zunehmende Anzahl von Schafen und Ziegen zurück (Vermoere 2004).

9 Haldon 1997, 94; Liebeschuetz 2001, 404-405. 
unterschieden werden: Vernachlässigung von Repräsentationsarchitektur, städtischer Infrastruktur und öffentlichen Gebäuden mit Ausnahme von Kirchen, unregelmäßige Bebauung vormals öffentlichen Raums und - seltener nachzuweisen - eine Reduktion des Stadtgebiets. ${ }^{10}$ Eine lose Besiedlung und innerstädtische Freiflächen sind nicht nur für die bedeutendsten mittelalterlichen Städte wie Iznik/Nikaia, Trapezunt, Thessaloniki und Konstantinopel überliefert, ${ }^{11}$ sondern kamen auch bereits im 5./6. Jahrhundert vor. ${ }^{12}$ Zwischen dem anatolischen Städtebau des 5./6. Jahrhunderts und des Mittelalters bestand demnach kein prinzipieller Unterschied. ${ }^{13}$ Infolgedessen gibt es keinen Grund mehr, a priori von einem Bruch auszugehen und deshalb ex silentio auf eine Desurbanisierung Anatoliens während der Dunklen Jahrhunderte zu schließen.

Es kommt hinzu, dass das Fehlen von Fundmünzen aus jener Epoche, das Foss z.B. in Sardis noch als Indikator für das Ende wirtschaftlichen Lebens gegolten hat, ${ }^{14}$ heute vielmehr auf die Finanzpolitik der Zentralregierung zurückgeführt wird, ${ }^{15}$ so dass sich siedlungsgeschichtliche Schlussfolgerungen verbieten. ${ }^{16}$ Ähnlich gilt das für Keramik aus den Dunklen Jahrhunderten, von der Foss hat annehmen müssen, dass es sie nicht gab. Inzwischen hat man dieser Zeit z.B. in Limyra Siedlungsschichten zuweisen können, deren Keramik sich einer Datierung bislang entzogen hatte. ${ }^{17}$ Folglich muss man wohl auch andernorts damit rechnen, dass die Keramik der Dunklen Jahrhunderte unerkannt geblieben ist, und auch in dieser Beziehung verbietet sich ein argumentum ex silentio.

10 Zum archäologischen Befund siehe demnächst die Dissertation des Verfassers. Die wahrscheinliche Ursache der Entwicklung, das Kurialenproblem (Liebeschuetz 1959; Jones 1964, 737-757; Liebeschuetz 1972, 257-258; Laniado 2002, 1-129) und seine Folgen für das Städtewesen (Haldon 1985, 86-88; Saradi-Mendelovici 1988; Spieser 1989; Brandes 1995; 22-23; Haldon 1997, 95-98; Liebeschuetz 2001), ist schon länger bekannt.

11 Bryer 1986, 271. Zu Konstantinopel ergänzend Maguire 2000, 258-264 und Talbot 2002, 61-64; zu Thessaloniki Bakirtzis 2003; zu beiden Städten Constantinides 2002, 92-100.

12 z.B. Konstantinopel (Mango 1990, 47-50; Koder 1993, 69-70; Talbot 2002, 61-64). Siehe auch die unten zitierte Bemerkung des Anonymus Byzantinus, Kap. 11, Z. $28-29$ zu innerstädtischen Gärten, Parks und Wiesen.

13 So kommt bereits Bryer 1986, $273 \mathrm{zu}$ dem Ergebnis, ,the urban tissue of [...] both fifth- and fifteenth-century Constantinople was unexpectedly similar", und weist auch darauf hin, dass die Katastrophen-Theorie vom Gegenteil ausgeht, ohne daraus jedoch weitere Schlüsse zu ziehen.

14 Foss 1976, 60; ders. 1977b, 476.

15 Haldon 1985, 82-86; ders. 1997, 118-120; Hendy 1985, 640-645; Brubaker/Haldon 2001, 149; Morrisson 2001; Brandes 2002, 323-328; Morrisson 2002.

16 So auch Hebert 2002a, 196-197 zu Aphrodisia.

17 Vroom 2004, 288-306. Vgl. ähnliche Ergebnisse einer Nachuntersuchung im Umland von Sagalassos (Vanhaverbeke/Waelkens 2003, 305) und die ungeklärte Bedeutung von „large quantities of pottery and other artifacts among the ruins in some of the houses" von Aphrodisias (Herbert 2002a, 197). 
All das sei zum Anlass genommen, die Beweislast einmal umzukehren und versuchsweise von einer urbanistischen Tradition auch während der Dunklen Jahrhunderte auszugehen, solange nichts Gegenteiliges bekannt wird. Daraus ergibt sich eine Revision des Paradigmas von der Kontraktion der Poleis zu Kastra. Es kann nämlich nicht ausgeschlossen werden, dass die Städte neben den Kastra und ohne Befestigungen fortbestanden. Das lehrt ein Vergleich mit dem besser erforschten 5./6. Jahrhundert.

Außerdem erhalten vereinzelte Indizien für urbane Kontinuität, die Foss und andere gegenüber dem vermeintlich krassen Gegensatz zwischen spätantiker Monumentalität und mittelalterlicher Dürftigkeit vernachlässigen zu dürfen geglaubt oder auch (noch) nicht gekannt haben, nun angesichts der Rückschritte in der Stadtentwicklung schon während des 5./6. Jahrhunderts mehr Gewicht und sollen deshalb exemplarisch aufgezeigt werden. Dabei kommt den Kirchen besondere Bedeutung zu, weil sie neben den Befestigungsanlagen häufig die einzigen monumentalen Bauten darstellen, deren kontinuierliche Nutzung sich nachweisen lässt. Aus demselben Grund ist anhand der Festungs- und Kirchenbauten zu prüfen, ob sich die Dunklen Jahrhunderte auch gegenüber den nachfolgenden mittelbyzantinischen so kümmerlich ausnehmen, wie das die These vom Niedergang und der nachfolgenden Wiederbelebung des anatolischen Städtewesens erfordert.

\section{Städte und Kastra im 5./6. Jahrhundert}

Stadtmauern: Nachdem um 400 im Rahmen der letzten allgemeinen Ausbauphase der anatolischen Städte auch zahlreiche Mauerringe neu errichtet worden waren, ${ }^{18}$ schlief im 5./6. Jahrhundert mit dem Städte- auch der Mauerbau nahezu ein. Im 5. Jahrhundert wurde lediglich noch Limyra befestigt, ${ }^{19}$ unter Markian die Mauern von Myra wiederhergestellt ${ }^{20}$ und unter Zenon oder Anastasios diejenigen von Amorion erbaut. ${ }^{21}$

18 Eirenupolis im rauhen Kilikien zwischen 355 und 359 (TIB 5, Teil 1, 245), Aphrodisias (Roueché 1989, 42-45, Kat.-Nr. 22; Ratté 2001, 125-126) und Sardis (Hanfmann 1983, 143 144; Greenwalt 2001, 228) in der zweiten Hälfte des 4. Jahrhunderts, Mopsuestia spätestens in dieser Zeit (TIB 5, Teil 1, 356), Anemurion um 382 (Russel 1999), Kastabala im späten 4. Jahrhundert (TIB 5, Teil 1, 294), Smyrna/Izmir unter Arkadios (Müller-Wiener 1962, 62-63), Sagalassos (Depuydt/Loots/Waelkens 2000, 616-618), Hierapolis (Verzone 1971, Sp. 1223), wohl auch Anazarbos (TIB 5, Teil 1, 182) und Blaundos in Phrygien (Filges 2003, 47) um 400.

19 Keramik des 4. und 5. Jahrhunderts in der Fundamentierung der Tordurchfahrt nördlich des Ptolemaion liefern einen terminus post quem im 5. Jahrhundert (Borchhardt et al.2002, 307), der Anbau der Kirche südöstlich des Ptolemaions einen terminus ante quem im 6. Jahrhundert (Borchhardt et al. 2002, 305).

20 Anthologia Graeca 15, 2; Peschlow 2002, Sp. 810.

21 Keramik (Harrison 1991, 225-226) und Typologie eines dreieckigen Turms (Crow 2001, 102) ergeben einen terminus post quem um die Mitte des 5. Jahrhunderts, byzantinische Quellen eine Zuschreibung an Zenon, arabische eine an Anastasios (TIB 4, 123). 
Der Mauerring von Amorion reichte im Westen und Nordosten bis an die Nekropolen, im Norden sparte er jedoch eine Vorstadt aus, ${ }^{22}$ und im Südwesten fußt ein Mauerabschnitt auf älterem Gemäuer ${ }^{23}$ und wird somit das Stadtareal gleichfalls beschnitten haben. ${ }^{24}$

Für das 6. Jahrhundert führt Prokop nur die Stadtmauer von Kaisareia auf, dem bedeutendsten anatolischen Zentrum westlich der armenisch-persischen Grenze ${ }^{25}$, die damals neu befestigt wurde. In Kaisereia ließ Justinian einen älteren Mauerring verkürzen: Die alte Befestigung hatte entfernte Hügel mit einbezogen, damit diese nicht als Bollwerk gegen die Stadt verwendet werden konnten, und dabei Freiflächen umschlossen, die auch später nicht besiedelt worden waren. Deshalb war der alte Mauerring unverhältnismäßig lang und weder zu erhalten noch zu verteidigen gewesen. ${ }^{26}$

Die justinianische Verkürzungsstrategie entspricht der zeitgenössischen Empfehlung des Anonymus Byzantinus: Innerstädtische Gärten, Parks und Wiesen ${ }^{27}$ - gemeint sind die damit verbundenen ausgedehnten Mauerringe, wie sie in Anatolien noch um 400 üblich gewesen waren ${ }^{28}$ - wollte er allenfalls fern der Grenzen zulassen, wo mit Überraschungsangriffen nicht zu rechnen war. ${ }^{29}$ Vermutlich blieb dort im Bedrohungsfall Zeit genug, die zur Verteidigung langer Mauern nötigen Mannschaften zusammenzuziehen. Dementsprechend fielen Mauerringe in den damals von barbarischen Einfällen betroffenen Grenzregionen im Nahen Osten und auf dem Balkan ${ }^{30}$ sowie in Nordafrika ${ }^{31}$ bereits im 5./6. Jahrhundert verhältnismäßig eng aus. ${ }^{32}$

Unbefestigte Städte: West- und zentralanatolische Städte konnten hingegen weiterhin unbefestigt bleiben, wie das während der pax romana zur Regel geworden war, so z.B. in Phrygien, ${ }^{33}$ wo ,,abgesehen von der Ummauerung einiger größerer Städte noch in der frühesten byzantinischen Zeit [dem 4. Jahrhundert] der Bau bedeutenderer Festungsanlagen kaum nachzuweisen“" 34 ist. Offenbar waren im 5./6. Jahrhundert Stadtmauern in jener Binnenregion des Römischen Reichs fernab der Grenzen entbehrlich. ${ }^{35}$ Das

22 Lightfoot 1998b, 304 u. Abb. 1.

23 Ders. 1994, 111.

24 Ders. 1997, 297.

$25 \mathrm{Zu}$ jener siehe TIB 2, 128-129 und Trombley 1985, 77.

26 De aedificiis V, 4. Für einen archäologischen Kommentar siehe TIB 2, 130-131 u. 195.

27 Anonymus Byzantinus Kap. 11, Z. 28-29.

28 Siehe oben Anm. 18.

29 Anonymus Byzantinus Kap. 11, Z. 35-37.

30 Sinngemäß Zanini 2003, 215-217 mit Abb. 12 anhand der Beispiele Dara, Resafa, Zenobia und Justiniana Prima.

31 Pringle 1981, 119. Zu allen drei Regionen zusammenfassend auch Iacobini 1994, 33-38.

32 Vgl. Ch. Kirilov in diesem Band.

33 z.B. in Aizanoi: Rheidt 2003.

34 TIB 7, 161.

35 anders Claude 1969, 15. 
bestätigen nicht zuletzt einige der erst um 400 neu befestigten Städte, die ihre Verteidigungsanlagen nun wieder verfallen ließen: Der neue Mauerring von Sagalassos wurde wieder aufgegeben und diente nach einem Erdbeben 518 als Schutthalde ${ }^{36}$ Der Abriss eines Teils der um 382 errichteten Seemauer von Anemurion ${ }^{37}$ schuf Platz zum Bau einer Kirche des 5. Jahrhunderts..$^{38}$ Außen an die neue Stadtmauer von Hierapolis am Meander ${ }^{39}$ baute man im 5./6. Jahrhundert ein Bad $^{40}$ an diejenige von Limyra im 6. Jahrhundert eine Kirche an ${ }^{41}$ was die Verteidigungsfähigkeit beeinträchtigt haben muss und darauf schließen lässt, dass die Wehranlagen vernachlässigt wurden. Das wird auch daraus ersichtlich, dass man die Kirche später möglicherweise im Zug einer mittelalterlichen Instandsetzung der Befestigung planierte.

Kastra: Kastra dienten im Unterschied zu Stadtmauern nicht zur Verteidigung der zivilen Siedlungen, sondern lediglich zur Sicherung strategischer Positionen und zum Schutz von Statthalter und Bischof..$^{42}$ In manchen Fällen konnten sie darüber hinaus auch die Rolle von Fluchtburgen für die städtische Zivilbevölkerung spielen, in anderen war das offenbar nicht vorgesehen, da die Anlagen dafür zu klein waren. Ersteres wird beispielsweise schon für die sogenannte Valerianische Mauer von Athen angenommen, die im späten 3. Jahrhundert angelegt wurde, nachdem die Stadt zuvor von den Herulern eingenommen worden war. ${ }^{43}$ Oder für die Festung von Nikopolis ad Istrum, welche die Byzantiner in der zweiten Hälfte des 5. Jahrhunderts errichteten, als sie die Kontrolle über die Stadt von den Hunnen zurück erlangten. Das neue Kastron von Nikopolis umschloss neben der Bischofs(?)kirche verhältnismäßig große Freiflächen, auf denen sich die Bevölkerung der nach wie vor bewohnten Altstadt im Verteidigungsfall niedergelassen haben könnte. ${ }^{44}$

36 Depuydt/Loots/Waelkens 2000, 616-618.

37 Russel 1999.

38 Hill 1996, 92.

39 Verzone 1971, Sp. 1223.

40 Bernardi Ferrero 1995, 96-97; D’Andria 1998, 113.

41 Borchhardt et al. 2002, 305.

42 Man könnte sie deshalb als Burgen bezeichnen. Was das Byzantinische Reich angeht, ist dieser Begriff jedoch nur dann gebräuchlich, wenn kein Zusammenhang mit einer Stadt besteht (vgl. Hellenkemper 1991). Vgl. auch die ländlichen Befestigungen auf dem Balkan, bei denen es sich möglicherweise um zivile Siedlungen handelt, wie M. Milinković in diesem Band ausführt (siehe dazu auch Poulter 2004, 246-247; Dunn 2004, insb. 552-556).

43 Gregory 1982, 50-51 betont, dass die zivile Siedlung außerhalb des Kastron im alten Stadtgebiet fortbestand und von einer Reduktion der Stadt auf ein Kastron nicht die Rede sein kann. Kazanaki-Lappa 2002, 640.

44 Poulter 1995, 45-46 ; ders. 1999, 24, zur Siedlungskontinuität außerhalb des Kastron auch 47; ders. 2002, 246 f.; ders. 2000, 351-352. 
Die justinianische Zitadelle von Caričin Grad war hingegen offensichtlich zu klein, um die Stadtbevölkerung aufzunehmen. Dieses Kastron schütze nur die Bischofskirche und den Palast. Die umliegende Stadt verfügte hingegen über eigene Mauern, in die sich im Verteidigungsfall auch die Bevölkerung der Vorstädte geflüchtet haben wird. ${ }^{45}$ In den anatolischen Städten westlich der persischen Grenze waren derartige Kastra nicht üblich; sie sind typisch für die von barbarischen Einfällen betroffenen Grenzregionen auf dem Balkan, ${ }^{46}$ im Nahen Osten ${ }^{47}$ und in Nordafrika. ${ }^{48}$

\section{Die sogenannten Dunklen Jahrhunderte in Anatolien: Städte oder Kastra?}

Stadtmauern: Die mittelalterlichen Befestigungen in Anatolien unterscheiden sich von den spätantiken prinzipiell dadurch, dass man nun auch dort regelmäßig dem Rat des Anonymus Byzantinus zu folgen begann und dem militärischen Festungsbau gegenüber dem zivilen Städtebau Priorität einräumte. Am Mittelmeer wurde das spätestens dann nötig, als die Araber begannen, dort vom Meer her überraschend einzufallen. ${ }^{49}$ In solchen Fällen wird den Byzantinern nicht mehr genug Zeit geblieben sein, die zur Verteidigung langer Mauern nötigen Mannschaften zusammenzuziehen. Dementsprechend beschränkte man sich in Limyra jetzt auf eine Erneuerung der Weststadt-Mauern ${ }^{50}$ und legte wahrscheinlich in diesem Zusammenhang auch die Kirche vor den Mauern nach einem Brand vollständig nieder, so dass sie Angreifern keine Deckung mehr gegen die Geschosse der Verteidiger bot. ${ }^{51}$ Die andere Hälfte der spätantiken Stadtbefestigung um die Oststadt wurde damals hingegen nicht wieder instand gesetzt, ${ }^{52}$ obwohl auch sie weiterhin besiedelt war. ${ }^{53}$

In Izmir/Smyrna wurde unter Michael III. (842-867) ein neuer Mauerzug errichtet, um den Umfang der (spät)antiken Ringmauer zu reduzieren, ${ }^{54}$ wobei ein Zeustempel und eine Hallenstraße außen vor blieben. ${ }^{55}$ In derselben Epoche

45 Siehe zusammenfassend Sniveley 2001 und Bavant/Ivanišević 2003.

46 Poulter 1992, 123-131.

47 z.B. Halabiyya/Zenobia (Lauffray 1983-1991), das im 6. Jahrhundert zusätzlich zu einer Stadtmauer auch mit einer Zitadelle gesichert wurde.

$48 \mathrm{Zu}$ Kastra justinianischer Zeit in Nordafrika siehe zusammenfassend Pringle 1981, 119, der betont, dass die zivilen Siedlungen außerhalb der Kastra in den alten Stadtgebieten fortbestanden und von einer Reduktion der Städte auf Kastra nicht die Rede sein kann. Zu allen drei Regionen zusammenfassend auch Iacobini 1994, 33-38.

49 Ahrweiler 1962, 10-12.

50 Borchhardt et al. 2002, 308-309.

51 Ebd., 306.

52 Ebd., 308-309.

53 Vroom 2004, 288-306.

54 Müller-Wiener 1962, 63-64.

55 Naumann/Selâhattin 1950, 71-72 mit Abb. 1. 
dürften auch die neuen Mauerringe von Side, ${ }^{56}$ Patara, ${ }^{57}$ Milet,${ }^{58}$ Magnesia am Meander $^{59}$ und Ephesos ${ }^{60}$ gebaut worden sein. Auch dort wurde jetzt jeweils nur etwa die Hälfte des (spät)antiken Stadtgebiets befestigt, obwohl aus Side ${ }^{61}$ und

56 Foss 1977a; ders. 1996c, 43-44; anders Mansel 1963, 40 und Hild 1995, 386 bzw. TIB 8, 388-389, die den fraglichen Mauerzug für spätantik halten. Zu den in der TIB vorgebrachten Argumenten für eine Frühdatierung ist erstens zu bemerken, dass die Errichtung des Vespasians-Brunnens zwischen Tor und Theater keinen terminus ante quem für den Mauerbau bildet. Bei der Rückwand des Brunnens handelt es sich entgegen der TIB nämlich nicht um die zuvor neu errichtete Wehrmauer, sondern um eine ältere Wand mit dem Zweck, die von Osten kommende Hallenstraße zu blockieren und den Verkehr durch das Bogentor umzuleiten. Das machte ein im Westen hinter der Wand und in der Verlängerung der Straßenachse gelegener Dionysos-Tempel notwendig (Mansel 1978, Faltplan). Die Wand besteht im Unterschied zur Wehrmauer nicht aus zwei Schalen bunt zusammengewürfelter Spolien (Foss 1977a, 172; Mansel 1978, 29, Abb. 18 und 68-70, Abb. 69-71; Foss 1996c, 41-42, Abb. 6-8), sondern aus Läufern und Bindern, die sich in regelmäßigen Lagen abwechseln (Mansel 1978, 115, Abb. 124). Theaterseitig sind zwei übereinander liegende Öffnungen eingebunden, die es im Erd- und im Obergeschoss (?) erlaubten, von dem S-Portikus der Hallenstraße in Richtung Dionysos-Tempel zu passieren. Die Wand selbst enthält auf beiden Seiten, zur Hallenstraße und zum Dionysos-Tempel, hoch gelegene Nischen (Mansel 1978, 30-31, Abb. 19-20).

Zweitens spricht neben den von Foss vorgebrachten Argumenten wohl auch die Position der Philippus Attius-Inschrift dagegen, dass es sich um eine Mauerbauinschrift handelt. Die Inschrift sitzt nämlich so hoch, dass sie ohne ein Fernglas allenfalls zu erkennen, aber nicht zu lesen ist (Bereisung im Jahr 2001). Drittens umfassen die datierten spätrömischen und spätantiken Mauerringe jeweils das gesamte bewohnte Stadtgebiet, während der fragliche Mauerring Side halbiert.

57 Foss 1994, 15. Siehe auch Effenberger/Koch/Kunze 1993, 281 und Işı 2000, 106 u. Plan zur sogenannten „Stadtkirche“ des 6. Jahrhunderts außerhalb des Mauerrings als terminus post quem für dessen Errichtung.

58 Zum Verlauf der sogenannten byzantinischen Mauer siehe grundlegend Milet 2, 3, 114117, und ergänzend Müller-Wiener 1982, 16, der, ohne das zu erläutern, in einem ,älteren Bau“ (Milet 1, 6, 17 mit Abb. 19) am Löwenhafen unterhalb des Theaterhügels einen Turm erkennt und dort deshalb einen Mauerverlauf rekonstruiert, der vom Löwenhafen aus in gerader Linie zum Theater anstieg, so dass der nördliche Zipfel der milesischen Halbinsel außen vor blieb. Nach Foss 1972, 483, Anm. 55 und ders. 1977b, 478 ergibt sich die Zeitstellung des fraglichen Mauerrings daraus, dass dieser das Stadion über- und verbaut, letzteres aber noch bis ins 7. Jahrhundert Schauplatz von Wagenrennen gewesen sein muss, denn aus dieser Zeit stammen die letzten Inschriften der Zirkusparteien. Dagegen beziehen Milet 1, 7, 154-155 u. 303-304 und danach Milet 2, 3, 116, Cobet 1997, 274 und Milet 6, 1, 201, Kat.-Nr. 206 eine justinianische Torbauinschrift nicht wie Foss nur auf das ältere Markttor sondern auf die gesamte Mauer und datieren sie deshalb ins 6. Jahrhundert

59 Foss 1977b, 483; Bingöl 1998, 57-58.

60 Foss 1979a, 106-107; anders Karwiese 1995, 138-140. Eine Datierung anhand von Akklamationen auf einem älteren Türgewände, das beim Torbau am Theater wiederverwendet wurde, ist entgegen Thür 2003, 268-269 wohl nicht möglich, weil die Akklamationen von einer vorhergehenden Verwendung des Türgewändes herrühren könnten.

61 Ruggieri 1995b; Foss 1996c, 44-47. 
Ephesos $^{62}$ bekannt ist, dass die ausgeschlossenen Stadtteile nach wie vor bewohnt waren. In Iznik/Nikaia erfolgte denn auch eine aufwändige Verstärkung des gesamten spätrömischen Mauerrings. ${ }^{63}$ Auch die Mauern von Apollonia am Rhyndakos in Mysien ${ }^{64}$ und Strallk in Karien ${ }^{65}$ werden den Dunklen Jahrhunderten zugeschrieben und könnten die Siedlungen vollständig umfasst haben; es handelt sich um Halbinseln, die mit verhältnismäßig geringem Aufwand zu sichern waren, aber es ist wohl nicht auszuschließen, dass die (spät)antiken Orte sich auch über die Halbinseln und deren mittelalterliche Befestigungen hinaus auf das Festland ausgedehnt hatten. In Apollonia ist das anhand von Theater und Stadion extra muros zumindest für die Kaiserzeit nachgewiesen. ${ }^{66}$

Städte ohne neue Befestigungen: Weiter im Landesinneren sind hingegen keine Stadtmauern aus den Dunklen Jahrhunderten bekannt. ${ }^{67}$ Dort war man arabischen Überraschungsangriffen nicht in gleicher Weise ausgesetzt wie am Mittelmeer, weil die Araber einen weiten Überlandweg innerhalb byzantinischen Territoriums zurückzulegen hatten, bevor sie eine Stadt erreichen konnten. Das ließ den Byzantinern Zeit, etwa

62 Foss 1979a, 113 u. 134-135.

63 Ders. 1996a, 90-92; Bondoux 2003, 397; Möllers 2004, Sp. 984-985.

Auch das benachbarte Nikomedia könnte seinen ausgedehnten diokletianischen Mauerring beibehalten haben (Foss 1996d, 16), denn seine militärische Bedeutung in den Dunklen Jahrhunderten (siehe auch Bondoux 2003, 400-401) lässt auf die Existenz einer Festung schließen, und die hellenistische Akropolis scheint erst in komnenischer Zeit gegen die Türken erneuert worden zu sein (Foss 1996d, 31-41).

Die Wiederherstellung des hellenistischen Mauerrings von Selge in Pamphylien ist gleichfalls den Dunklen Jahrhunderten zugeschrieben worden (Machatschek/Schwarz 1981, 20). Die untere Agora und mehrere Kirchen liegen außerhalb der Mauern. Bei der Kirche in der Nekropole am Osthang handelt es sich wohl um eine Friedhofskirche (Machatschek/ Schwarz 1981, 115-116), aber diejenige im Nordtal lag vielleicht in einem Vorort. Diese ursprünglich dreischiffige Anlage wurde später durch Abmauerung der Seitenschiffe auf eine Halle in der Breite des Mittelschiffs reduziert (Machatschek/Schwarz 1981, 114-115 u. Taf. 25), wie das z.B. im benachbarten Lykien typischerweise im Mittelalter vorkam (Peschlow 1993, 61; TIB 8, 226-227). Trotz ihrer exponierten Lage scheint die Kirche also nicht aufgegeben worden zu sein.

Die späte Spolien-Mauer von Nysa am Meander umfasst das gesamte Stadtgebiet (Diest 1913, 51-52 u. Plan 2), wie das bei der sog. Gotenmauer aus dem 3. Jahrhundert im benachbarten Milet der Fall ist (Milet 2, 3, 81-84) und noch bis um 400 in anderen anatolischen Städten vorkam. Der Mauerring von Nysa dürfte deshalb in dieser früheren Zeit und nicht während der Dunklen Jahrhunderte entstanden sein, aus denen derartig ausgedehnte und aufwändige Stadtbefestigungen nicht bekannt sind.

64 Foss/Winfield 1986, 139.

65 Foss 1988, 169-170.

66 Hasluck 1910, 68-73 mit Abb. 2; Bondoux 2003, 382.

67 Zu Galatien und Lykaonien siehe TIB 4, 110-113; zu Phrygien und Pisidien TIB 7, 161. 
mit einer eigens dazu eingerichteten Feuerzeichenkette ${ }^{68}$ frühzeitigen Alarm auszulösen. ${ }^{69}$ Auf diese Weise meinte man anscheinend, mit älteren oder ohne Stadtmauern auskommen zu können. Ersteres war beispielsweise in Kaisareia ${ }^{70}$ und Amorion $^{71}$ der Fall, wo es offenbar die spätantiken Befestigungen waren, die 647 bzw. 838 gegen die Araber nicht gehalten werden konnten; letzteres z.B. im phrygischen Aizanoi, wo die Siedlungskontinuität im (spät)antiken Stadtgebiet auch ohne Mauerring nicht abgerissen zu sein scheint, so dass sich das kaiserzeitliche Straßenraster bis heute tradiert hat. ${ }^{72}$ Derselben Kategorie sind wohl all jene der nachfolgend aufgeführten Orte zuzurechnen, wo zwar Kastra, aber keine Stadtmauern gebaut wurden. Denn hier war bei entsprechend zeitigem Alarm die Möglichkeit gegeben, dass die Stadtbevölkerung in die Kastra flüchtete, um danach wieder in die Städte zurückzukehren, wie das z.B. aus Euchaita berichtet wird.

Kastra: Eines der bedeutendsten Kastra und Hauptquartier einer Armee war dasjenige oberhalb des (spät)antiken Stadtgebiets von Ankara/Ankyra. ${ }^{73}$ Es stammt möglicherweise aus dem 7. Jahrhundert, erlebte jedenfalls unter Michael III. 859 bereits eine zweite Bauphase. ${ }^{74}$ In der darunter liegenden Stadt wurde indessen die Klemenskirche gebaut, die typologisch mit der Koimesiskirche in Iznik/Nikaia in Zusammenhang gebracht und deshalb ins 7./8. Jahrhundert datiert wird. ${ }^{75}$ Später gab es An- und Umbauten, ${ }^{76}$ und schließlich scheinen die Türken den damals offenbar unversehrt erhaltenen Bau in eine Moschee umgewandelt zu haben. ${ }^{77}$ Von der türkischen Stadtmauer nimmt man an, dass sie dem Verlauf eines alten Mauerrings aus tetrarchischer Zeit folgte. ${ }^{78}$ Beides spricht für einen kontinuierlichen Fortbestand der Stadt, deren Bewohner sich nur im Fall akuter Bedrohung in das Kastron geflüchtet haben mögen.

68 TIB 7, 163 zu Zentralanatolien und mit Verweisen auf die grundlegende ältere Literatur.

69 Zur Taktik der Byzantiner, die Araber zu beobachten und sich im Fall eines Angriffs in Festungen zurückzuziehen, siehe grundlegend Lilie 1976, $92-93$ und ergänzend Haldon 1978, 228.

70 Trombley $1985,79-80$.

71 Ivison 2000, 14-15 und in diesem Band.

72 Rheidt 1997, 495 mit Abb. 32.

73 Foss $1977 \mathrm{c}, 73$.

74 Ebd., 74-79.

75 Krautheimer 1986, 288-295; zu dieser Datierung der Koimesiskirche siehe zuletzt Peschlow 2003, 205 und Barsanti 2003, 278-280; Russo 2002, 10-11 mit Anm. 48 vertritt hingegen eine frühere Datierung.

76 Jerphanion 1928, 122.

77 Ebd., 138-139.

78 Mamboury 1933, 71 u. 78-82; Foss 1977b, 62. 
In Kütahya/Kotyaeion in Phrygien liegt wohl ein ähnlicher Fall vor. Auch hier wurde ein Berg oberhalb der Stadt anscheinend in den Dunklen Jahrhunderten befestigt, ${ }^{79}$ während die zweifellos in der Ebene darunter gelegene ${ }^{80}$ (spät)antike Stadt offenbar fortbestand. Jedenfalls scheinen zahlreiche Kirchen dort noch in Funktion gewesen zu sein als das Kastron u.a. aus Spolien gebaut wurde, denn das liturgische Mobiliar der Kirchen wurde dabei noch nicht verwendet. Liturgisches Mobiliar taucht erstmals in komnenischen ${ }^{81}$ (oder späteren? ${ }^{82}$ ) Reparaturen des Kastron auf; der größere Teil ist jedoch bis zur türkischen Eroberung in der Ebene verblieben und dann dort wieder verwendet worden, ${ }^{83}$ wo im 13. Jahrhundert unmittelbar nach der türkischen Eroberung eine Moschee gebaut wurde. ${ }^{84}$

Auch in Sardis war es ein Berg oberhalb der (spät)antiken Stadt, der wohl unter Konstans II. befestigt wurde. ${ }^{85}$ Etwa gleichzeitig erneuerte man im Stadtgebiet darunter eine Haupt- und Durchgangsstraße, ${ }^{86}$ die auch unter den Osmanen noch einmal eine neue Pflasterung erfuhr und bis heute die Hauptstraße bildet. ${ }^{87}$ Und auch von der einzigen ausgegrabenen spätantiken Kirche am Ort ist bekannt, dass sie im Mittelalter immer wieder repariert wurde, ${ }^{88}$ bis man sie im 13. Jahrhundert durch einen kleineren Neubau an gleicher Stelle ersetzte, ${ }^{89}$ der schließlich von den Türken zu Wohn- und Wirtschaftszwecken genutzt wurde. ${ }^{90}$ Andernorts in der Stadt fehlen Belege für eine kontinuierliche Besiedlung während der Dunklen Jahrhunderte. Münzen und datierbare Keramik haben sich erst aus der Zeit danach wieder gefunden, ${ }^{91}$ aber das schließt eine Siedlungskontinuität wie gesagt nicht aus. ${ }^{92}$

Der archäologische Befund aus Pergamon ist diesbezüglich exemplarisch: Dort wurde die Bergspitze und antike Akropolis über der Stadt durch einen Mauerring gesichert. ${ }^{93}$ Das Innere des Kastron ist zum großen Teil bis auf antike Schichten herab ausgegraben worden. Trotzdem hat man nichts gefunden, was sich mit der Befestigung

79 Foss 1985, 12-85. Zur Frage der Datierung siehe auch Edwards 1987, 677-680 und TIB 7, 315.

80 Edwards 1987, 677-680; TIB 7, 314.

81 Foss 1985, 83-84.

82 Edwards 1987, 677-680. Siehe jedoch auch TIB 7, 315.

83 Verf., Frühbyzantinische Steinmetzarbeiten in Kütahya (Zentralanatolien), in Vorbereitung.

84 Foss 1985, 14.

85 Ders. 1976, 57-59; Foss/Scott 2002, 618.

86 Foss 1976, 57; Foss/Scott 2002, 617-618.

87 Crawford 1990, 3.

88 Foss 1976, 74; Foss/Scott 2002, 618.

89 Foss 1976, 84.

90 Ebd., 70-71.

91 Ebd., 66-89; Foss/Scott 2002, 618-621.

92 Sinngemäß auch Foss 1976, 60.

93 AvP 16, 1, 13-22. 
in einen chronologischen Zusammenhang bringen ließe. ${ }^{94}$ Offensichtlich stammt sie aus einer Zeit, deren materielle Hinterlassenschaften bislang übersehen worden sind. Das spricht für eine Datierung in die Dunklen Jahrhunderte, ${ }^{95}$ denn ein Kastron des alternativ erwogenen 6. Jahrhundert ${ }^{96}$ wäre den Archäologen sicherlich nicht entgangen, darauf lässt die reiche Befundsituation in den oben genannten Kastra des 5./6. Jahrhunderts schließen. Sind die Dunklen Jahrhunderte im verhältnismäßig gut untersuchten Kastron von Pergamon nicht nachzuweisen gewesen, kann das Fehlen entsprechender Befunde im heute dicht besiedelten und archäologisch kaum erforschten (spät)antiken Stadtgebiet ${ }^{97}$ ebenfalls nicht als Indiz für ein Abreissen der urbanistischen Tradition gelten. ${ }^{98}$ Eher wird die alte Stadt fortbestanden haben und von dort die Bevölkerung gekommen sein, die seit dem 11. Jahrhundert zunehmend in den Schutz des erneuerten Kastron ${ }^{99}$ umzog, ${ }^{100}$ wie das damals unter dem Druck der Türken auch in anderen anatolischen Städten geschah. ${ }^{101}$

Eine ähnliche Befundsituation bietet das pamphylische Syllaion. Aus der vielfältigen schriftlichen Überlieferung zur Stadtgeschichte in den Dunklen Jahrhunderten geht unter anderem hervor, dass die Metropolie von Perge im 9. Jahrhundert in Syllaion ansässig war, wohin sie wahrscheinlich in den Schutz der erneut befestigten Akropolis umgezogen war. ${ }^{102}$ Dementsprechend sind zwei kleine undatierte Kirchen ${ }^{103}$ und ein wohl spätmittelalterlicher Palast ${ }^{104}$ in einer undatierten Zitadelle ${ }^{105}$ als ,ecclesiastical

94 AvP 15, 2, 155-176

95 Dafür sprechen außerdem das Mauerwerk (Foss/Winfield 1986, 133) und die historischen Umstände (AvP 16, 1, 22-33).

96 AvP 5, 2, 171-171. Vor der mit dem Mauerbau verbundenen endgültigen Zerstörung des Pergamonaltars scheinen vielen Reliefs die Köpfe abgeschlagen worden zu sein. Letzteres könnte gegen das Heidentum gerichtet gewesen und folglich noch in die Spätantike zu datieren sein, ohne dass deshalb auch bereits der Altar abgetragen und das Kastron gebaut worden sein muss (Rheidt 2002, 624).

97 Dazu zusammenfassend Rheidt 2002, 623-624 u. Abb. 1.

98 anders AvP 15, 2, 186-197, 237 u. 245-246 und Rheidt 2002, 624 u. 626

99 AvP 16,1, 35-61

100 AvP 15, 2, 247; Rheidt 2002, 625

101 z.B. in Sardis (Foss 1976, 70) und in Aizanoi (Rheidt 2001, 249).

102 Nethercott/Ruggieri 1986; Foss 1996b, 1920.

103 Nethercott/Ruggieri 1986, 150-155.

104 Foss 1996c, 20-21, der selbst bemerkt, ,the building follows a plan familiar in later Byzantine palaces", um das Gebäude dessen ungeachtet im nächsten Absatz als ein für das 9. Jahrhundert überliefertes prätorium zu identifizieren. TIB 8, 400-401: „mittelbyzantinisch“.

105 Zur Datierung bemerkt Foss 1996c, 20: „The wall was faced with carefully arranged large spoils in a technique appropriate to the Dark Ages". Vergleicht man das Mauerwerk jedoch mit demjenigen der sogenannten Philippus Attius-Mauer im benachbarten Side, die Foss gleichfalls in die Dunklen Jahrhunderte datiert (siehe oben Anm. 56), fällt auf, dass die Bausteine in Syllaion im Gegensatz zu Side nicht in Lagen angeordnet sind, sondern 
centre“106 bzw. „praetorium“107 der Dunklen Jahrhunderte angesprochen worden. Weil sich sonst keine mittelalterlichen Gebäude auf der Akropolis erhalten haben, schließt C. Foss weiter, „the centre of the Byzantine city [...] was apparently far too small to fill it" und habe sich auf die Zitadelle beschränkt, räumt aber selbst ein: „The centre of the Roman and late antique city was in the plain below, where the remains have been obscured or destroyed by the modern village. If more were known of them, the general picture might be very different." ${ }^{108}$

Dafür spricht auch ein Vergleich mit Mastaura/Dereağzı, wohl dem nach der Metropolis Myra bedeutendsten mittelalterlichen Bischofssitz im benachbarten lykischen Hochland: ${ }^{109}$ Im 9. Jahrhundert wurde dort nicht nur die alte Bergfestung neu bewehrt, ${ }^{110}$ sondern gleichzeitig auch die darunter gelegene Talsiedlung ausgebaut, $u$. a. mit einer der größten und aufwändigsten Kirchen der Epoche, ${ }^{111}$ wahrscheinlich der neuen Kathedrale. Jedenfalls ist klar, dass die Erneuerung der Bergfestung nicht etwa mit einer Reduktion der Talsiedlung auf das Kastron in Zusammenhang stand, sondern mit deren Blüte einherging. ${ }^{12}$ Der Vergleich spricht dagegen, dass die Metropolie in Syllaion mit den kleinen Kirchen und der engen Zitadelle auf der Akropolis auskam. Eher wird sie im alten Stadtgebiet darunter angesiedelt gewesen sein und die Akropolis mit ihren Freiflächen nur als Fluchtburg genutzt haben.

Pessinus in Galatien, für das die Vita Theodors von Sykeon für die Zeit um 600 die Existenz einer Stadtmauer überliefert, ${ }^{113}$ erhielt ebenfalls ein Kastron auf einer Kuppe oberhalb der Stadt. ${ }^{114}$ Das Kastron wird von den Ausgräbern in justinianische Zeit datiert, ${ }^{115}$ weil es eine Nekropole überbaut, die im Lauf des 5. Jahrhunderts aufgegeben worden war, ${ }^{16}$ die Planierung der Nekropole zum Bau des Kastron Keramik

unregelmäßige Form und Größe aufweisen und dadurch kleinerer Zwickelsteine nötig machen, was Foss/Winfield 1986, 149 u. 294, Abb. 28 in Archangelos in Ionien und generell (ebd., 163) als Kriterium für eine spätere Datierung in die Zeit der Türkenkriege gilt. Sollte die Zitadelle demnach zusammen mit dem sogenannten prätorium erst lange nach den Dunklen Jahrhunderten entstanden sein? TIB 8, 400-401: „mittelbyzantinisch“.

106 Nethercott/Ruggieri 1986, 150.

107 Foss 1996c, 21; TIB 8, 400-401: ,mittelbyzantinisch“ und „Praitorion“.

108 Ebd., 20.

109 Hild 1996; ders. 2004, 3-4; TIB 8, 716-718.

110 Morganstern 1993.

111 Ders. 1983.

112 Ders. 1993, 164-165.

113 In Kap. 101 ist von einer Kirche extra muros die Rede (Vie de Théodore, Bd. 1, 18, Z. 40), also muss es Mauern gegeben haben. So auch TIB 4, 214 und Trombley 1985, 77. DeMulder/Devreker/Vermeulen 1998, 790-791 zweifeln die Überlieferung der Vita jedoch an, weil sich eine Stadtmauer archäologisch bislang nicht hat belegen lassen.

114 Devreker/Theon/Vermeulen 2003, 347-387.

115 Ebd., 383.

116 Zur Chronologie der Nekropole vgl. ebd., 132. 
des 6. Jahrhunderts enthält ${ }^{117}$ und die Befestigung den justinianischen Kastra auf dem Balkan gleiche. ${ }^{118}$

Auf den ersten Blick verwundert daran lediglich, dass nichts über Keramik berichtet wird, die oberhalb der Planierung und des Laufhorizonts gefunden worden wäre und sich der Nutzungszeit des Kastron zuschreiben ließe, ${ }^{119}$ obwohl z.B. Haus B noch mehrere Steinlagen über Fußbodenniveau erhalten ist und zahlreiche Pithoi in situ vorgefunden wurden. ${ }^{120}$ Das Fehlen datierbarer nutzungszeitlicher Keramik passt nicht in die Spätantike, sondern entspricht der aus Sardis und Pergamon bekannten Befundlücke während der Dunklen Jahrhunderte.

Dadurch sensibilisiert, fallen bei genauerem Hinsehen weitere Ungereimtheiten in der justinianischen Datierung des Kastron von Pessinus auf: So kommt in den Gräbern der älteren Nekropole bzw. der Planierung und Fundamentierung für das Kastron auch Keramik des späteren 6./frühen $7 .{ }^{121}$ und des 7. Jahrhunderts ${ }^{122}$ vor und legt einen nachjustinianischen terminus post quem für den Bau des Kastron nahe. Dem entsprechen zwei sicherlich spätantike Doppelhalbsäulen, von denen die eine als Türgewände von Haus $\mathrm{C}$ wiederverwendet wurde, ${ }^{123}$ das zusammen mit der Wehrmauer in der ersten Bauphase des Kastron errichtet worden sein soll. ${ }^{124}$ Die Spolierung der Doppelhalbsäulen verweist auf eine nachantike Bauzeit, denn während der Spätantike wurde zwar gleichfalls spoliert, aber typischerweise ältere, inzwischen funktionslos gewordene Gebäude, nicht die eben erst errichteten Kirchen oder Häuser der eigenen Epoche, in denen die Doppelhalbsäulen ursprünglich verwendet gewesen sein werden. ${ }^{125}$

Des weiteren unterscheidet sich das Kastron durch seine strategische Höhenlage, eine Zitadelle, zahlreiche Türme und eine Mauerstärke von 2-2,3 m aus bis zu 1,6 m breiten Blöcken ${ }^{126}$ von vergleichbar kleinen Befestigungen, die andernorts in Anatolien westlich des persischen Grenzgebiets während der Spätantike häufig in ebenem Gelände ohne Zitadelle, mit weniger Türmen und längeren, schmalen Kurtinen aus

117 Zur Chronologie der Keramik vgl. Devreker/Theon/Vermeulen 2003, 74-84.

118 Ebd., 383 mit Anm. 220.

119 Zur Stratifizierung der Keramik siehe ebd., 364-366.

120 Ebd., 356-358 mit Abb. 205-208.

121 Ebd., 74, Grab 1.44a. Das Grab wurde von Mauer 8 überschnitten (ebd., 33, Abb. 26) und wahrscheinlich im Zug des Mauerbaus ausgeraubt (ebd., 159), wobei auch die Keramik des späteren 6./frühen 7. Jahrhunderts in das Grab gelangt sein wird (ebd., 160). Demnach ergibt sich für den Bau von Mauer 8 ein nachjustinianischer terminus post quem.

122 Ebd., 83.

123 Ebd., 359, Abb. 210. Zu der anderen Doppelhalbsäule siehe ebd., 361, Abb. 215.

124 Ebd., 356.

125 Zur Funktion und Verwendung von Doppelhalbsäulen siehe Orlandos 1952-1954/2, 425-428.

126 Devreker/Theon/Vermeulen 2003, 349-354. 
handlichen Quadern errichtet wurden. ${ }^{127}$ Letztere umfriedeten kleinere Siedlungen und wurden auch noch im 5./6. Jahrhundert neu gebaut, als viele größere Städte ihre Befestigungen vernachlässigten (siehe oben) und ländliche Siedlungen meist noch ohne Mauern auskamen. ${ }^{128}$ Offenbar rechnete man in Anatolien während des 5./6. Jahrhunderts noch nicht mit feindlichen Belagerungen, wie sie das vergleichsweise stark befestigte Kastron von Pessinus zu antizipieren scheint. Es passt demnach besser in die Dunklen Jahrhunderte, als man sich auch in Zentralanatolien so zu verteidigen hatte, wie das in justinianischer Zeit nur an den Reichsgrenzen auf dem Balkan, im Nahen Osten und in Nordafrika der Fall war.

Weitere Kastra der besprochenen Art sind mit den Stadtgebieten von Bursa, ${ }^{129}$ Amasra/Amastris, Sagalassos ${ }^{130}$ und Apollonia/Sozopolis in Pisidien sowie Poimanenon am Hellespont gleichgesetzt worden. An den beiden erstgenannten Orten wurde jedoch wie so häufig nur jeweils eine hellenistische Akropolis neu befestigt, in Amasra/Amastris wahrscheinlich in erster Linie wegen der Bedeutung des Flottenhafens, aber wohl auch, um der in der Ebene darunter gelegenen Stadt ${ }^{131}$ als Fluchtburg zu dienen. ${ }^{132}$ Aus Apollonia/Sozopolis, wo das Kastron auf einem Felskegel oberhalb des (spät)antiken Stadtgebiets liegt, ${ }^{133}$ ist nichts von einer älteren Befestigung bekannt, aus Poimanenon ${ }^{134}$ auch nichts über die Lokalisierung des Stadtgebiets im Verhältnis zum Burgberg.

Als Zitadelle innerhalb einer bestehenden Stadtmauer hat das Kastron von Amorion zu gelten, solange der spätantike Mauerring funktionierte. ${ }^{135}$ Nach der Eroberung

127 TIB 8, 236-237. Vgl. die Schutzmauern der kilikischen Kome Korasion, gegründet 367375 (TIB 5, 311) sowie von Panormos (grundlegend Hattersley-Smith/Ruggieri 1990 und TIB 8, 776-779. Siehe auch Lohmann 1999a, 69-71, der in Unkenntnis der vorgenannten an einer älteren Identifizierung mit Prepia festhält, sich aber 2001, 218 korrigiert), Aperlai (Foss 1994, 17 u. Abb. 25 u. 32), Andriake (Foss 1994, 32 u. Abb. 41, der allerdings mittelalterlich datiert. Zur spätantiken Datierung und einem Plan siehe Peschlow 2002, Sp. 831 u. Abb. 8 in Sp. 825-826) und Arif in Lykien (Harrison 2001, 41), letztere wohl wie der ganze Ort erst im 5./6. Jahrhundert entstanden (ebd., 46).

128 Siehe Beispiele in Kilikien (Eyice 1981; Wulf 2003), Lykien (Grossmann/Severin 2003, 2022; Marksteiner/Niewöhner 2004, 22, Abb. 2), Karien (Ruggieri 2003, 153-223; Zäh 2003) und Ionien (Lohmann 1997, 304-305).

129 Grundlegend Gabriel 1958, 23-28, ergänzend Grélois/Pralong 2003, 139-141. Zur Datierung in die Dunklen Jahrhunderte Foss/Winfield 1986, 138-139. Zur damaligen Bedeutung der Stadt als kaiserliches Bad Bondoux 2003, 385.

130 Martens/Poblome/Waelkens/Vanhaverbeke 2004, 271.

131 TIB 9, 165-166.

132 Crow/Hill 1995.

133 TIB 7, 388, wo allerdings noch die spätere Datierung in die Zeit der Türkenkriege referiert wird, die Foss 1985, 153-157 vertrat, obwohl sich Foss/Winfield 1986, 139-140 inzwischen korrigiert haben und von einer Enstehungszeit während der Dunklen Jahrhunderte ausgehen.

134 Belke 2002, Sp. 858-859.

135 Lightfoot 1998a, 64-65 und E. Ivison in diesem Band. 
Amorions durch die Araber 838 wurde allein das Kastron wieder aufgebaut, ${ }^{136}$ ohne dass man die umliegende Stadt deshalb aufgab. Das bezeugen Häuser ${ }^{137}$ und der mittelalterliche Neubau einer zerstörten spätantiken Kirche ${ }^{138}$ dort. Auch in Amasya/Amaseia war es möglicherweise nur das Kastron, das während der Dunklen Jahrhunderte wieder instand gesetzt wurde, als der Ort wie Amorion als Hauptstadt eines Themas diente und deshalb besondere militärische Bedeutung hatte. ${ }^{139}$

Eine ähnliche Situation wird für Euchaita erschlossen, wo man die spätantike Stadtmauer gegen die Perser hatte verteidigen können, sich vor den Arabern aber in Fluchtburgen zurückgezogen haben soll, um erst nach deren Abzug wieder in die nach wie vor funktionierende Stadt zurückzukehren. ${ }^{140}$ Und auch das Kaston auf der sogenannten lykischen Akropolis von Xanthos entstand möglicherweise als Zitadelle innerhalb eines äußeren Mauerrings, ${ }^{141}$ falls eine frühmittelalterliche Instandsetzung der hellenistischen Stadtmauern tatsächlich etwa in die gleiche Zeit datiert. ${ }^{142}$

Zusammenfassung: Im 5./6. Jahrhundert wurden in Anatolien westlich der persischen Grenze kaum mehr Stadtmauern gebaut. Zahlreiche Städte kamen ohne solche aus und ließen nur wenig ältere Verteidigungsanlagen aus der Zeit um 400 wieder verfallen. Kastra kamen in diesen Städten nicht vor. Das änderte sich in den Dunklen Jahrhunderten, als Anatolien erstmals wieder zu einer umkämpften Grenzregion wurde: Jetzt unterwarf man auch den anatolischen Städtebau fortifikatorischen Prinzipien, wie sie aus dem 5./6. Jahrhundert von den damaligen Grenzregionen auf dem Balkan, im Nahen Osten

136 Ivison 2000, 14-18 und in diesem Band.

137 Lightfoot 1998b, 306-307.

138 Ders. 1998a, 67-68 und E. Ivison in diesem Band.

139 Foss/Winfield 1986, 17-19.

140 Trombley 1985, 55-62; Zuckerman 1988, 196-199; Trombley 1993, 431; Crow 1996, 26-31. Siehe jedoch auch Kazhdan 1988 und danach Haldon 1997, 109-110, Anm. 40 zu einer abweichenden Interpretation, sowie Brandes 1999, 47-49 zu Zweifeln an der Zuverlässigkeit der entsprechenden Überlieferung in der Vita Theodors von Sykeon.

141 Zur Datierung des Kastron siehe Manière-Lévêque 2002, 235, Anm. 6: „La construction de cet ouvrage est actuellement datée entre le milieu de 6 e et le début de 7e ap. J.-C. d'après de matériel céramique mis au jour dans les sondage".

$142 \mathrm{Zu}$ einem ,prekären terminus ante quem [...] des 6./7. Jahrhunderts“ für die frühmittelalterliche Instandsetzung des hellenistischen Mauerrings siehe Marksteiner 2002, 210. Ob auch das Kastron von Milet und dasjenige auf dem Ayasoluk-Hügel bei Ephesos bereits aus einer Zeit stammen, als die frühmittelalterlichen Mauerringe jener Städte noch bestanden und verteidigt wurden, ist nicht klar. Zum Kastron von Milet siehe grundlegend Müller-Wiener 1967. Foss 1977b, 478 zieht in Erwägung, dass das Kastron als Ersatz für die Stadtmauer gebaut worden sein könnte. Müller-Wiener 1999, Sp. 374 zufolge ist „nach Notizen in den Grabungstagebüchern anzunehmen“, dass das Stadtgebiet unterhalb des Kastron während des Mittelalters besiedelt blieb. Für die Befestigung des Ayasoluk-Hügels bei Ephesos nimmt Müller-Wiener 1961, 85-112 eine spätantike, Foss 1979a, 107 eine Enstehungszeit in den Dunklen Jahrhunderten an. 
und in Nordafrika bekannt sind: Am Mittelmeer wurden zahlreiche Städte erneut mit Mauern umgeben, wobei man nicht selten nur etwa die Hälfte des (spät)antiken Stadtgebiets befestigte. Grund dafür werden die arabischen Piraten gewesen sein, mit denen man dort ständig rechnen musste, so dass die Befestigungen ununterbrochen besetzt zu halten waren, wofür die ausgedehnten (spät)antiken Mauerringe zu große Mannschaften erfordert hätten.

Anders verhielt es sich in Zentralanatolien, wohin die Araber einen weiten Weg zurückzulegen hatten, so dass die Städte vor ihrem Eintreffen gewarnt werden konnten. Dort wurden offenbar deshalb keine neuen, engen Mauerringe angelegt, weil Zeit genug blieb, entweder die ausgedehnten (spät)antiken zu besetzen oder sich in die Kastra zurückzuziehen, die damals vielerorts neu oder wiedererrichtet wurden. Waren die Araber abgezogen und die Gefahr vorüber, kehrte man in die Städte zurück und erneuerte oder ersetzte dort auch die alten Kirchen.

\section{Städte und Kastra in mittelbyzantinischer Zeit}

Stadtmauern: Als Maßstab für die Entwicklung der anatolischen Städte während der Friedenszeit, die unter der makedonischen Dynastie auf die Dunklen Jahrhunderte folgte, mögen die Befestigungen dienen, die unter den Komnenen und später errichtet wurden, als man sich gegen die Türken zu verteidigen hatte. ${ }^{143}$ Ein erneuter urbanistischer Aufschwung, wie ihn die Katastrophentheorie vom vorhergehenden Niedergang des anatolischen Städtewesens während der Dunklen Jahrhunderte erfordert, könnte an größeren Festungsanlagen abzulesen sein. Den alten fortifikatorischen Prinzipien zufolge wären nun - anders als noch während der Dunklen Jahrhunderte - nämlich auch in Zentralanatolien Stadtmauern angebracht gewesen, weil die Türken dort ständig präsent und deshalb zu Überraschungsangriffen in der Lage waren, die der Stadtbevölkerung keine Zeit ließen, sich in Kastra in Sicherheit zu bringen, wie das zuvor die weiten Wege der Araber ermöglicht hatten.

Dennoch scheinen Stadtmauern nur noch ausnahmsweise erneuert worden $\mathrm{zu}$ sein, z.B. in Iznik/Nikaia, ${ }^{144}$ danach in Magnesia am Sipylos ${ }^{145}$ und später noch einmal in Trapezunt, ${ }^{146}$ als jene Orte zu Hauptstädten wurden bzw. Magnesia diese Rolle für den im benachbarten Nymphaion residierenden Johannes Vatatzes spielte. Außerdem besfestigte man Antalya/Attaleia ${ }^{147}$ neben Trapezunt die wichtigste Hafenstadt

143 Sinngemäß Foss 1977b, 480 zu Pergamon: „A new wall recognised the growth and recovery which took place under the Macedonian and Comnenian dynastie".

144 Foss 1996a, 93-95; Bondoux 2003, 398; Möllers 2004, Sp. 985.

145 Foss 1979b, 307. Und in Alaşehir/Philadelphia (Pralong 1984)?

146 Bryer/Winfield 1985, 182-190.

147 Sabbides 1989, 129-130; Foss 1996c, 12. 
Anatoliens, ${ }^{148}$ und - mit einer verhältnismäßig kurzen Mauer - Karabika/Pegai, eine privilegierte Hafenstadt am Marmarameer. ${ }^{149}$

Kastra: Andernorts deutet der Festungsbau darauf hin, dass Städte zur Zeit der Türkenkriege preisgegeben wurden: ${ }^{150}$ In Milet,${ }^{151}$ Pergamon, ${ }^{152}$ Sardis,${ }^{153}$ Aphrodisias ${ }^{154}$ und Aizanoi $^{155}$ baute oder erneuerte man damals Kastra, deren Inneres nicht die für die älteren Fluchtburgen charakteristischen Freiflächen aufwiesen, sondern zunehmend dicht besiedelt wurden. Offenbar begann zumindest ein Teil der Stadtbevölkerung wegen der permanenten Türkengefahr und der fehlenden Stadtmauern ständig in den Kastra zu wohnen. Die Städte wurden deshalb nicht aufgegeben, schon allein weil die Stadtbevölkerung in der Regel nicht vollständig in den verhältnismäßig kleinen Kastra Platz gefunden haben wird. In Sardis, ${ }^{156}$ Aphrodisias $^{157}$ und Aizanoi ${ }^{158}$ lässt der archäologische Befund darauf

148 Oikonomides 1998; Foss 1996c, 8-9.

149 Müller-Wiener 1989; Belke 2002, Sp. 863-865.

150 Während nach wie vor zahlreiche außerstädtische Burgen errichtet wurden, die nach Glykatzi-Ahrweiler 1960, 186, Foss 1982, 152 u. passim, ders. 1987, 100, ders. 1996d, 44-70 und Giros 2003, 213-224 weniger zur Sicherung einzelner Orte als zur Verteidigung des gesamten Territoriums dienten, ähnlich den Burgensystemen, die in den Dunklen Jahrhunderten die Taurus-Grenze (TIB 2, 129 u. 131-132) oder im 5./6. Jahrhundert den Nahen Osten (grundlegend Mouterde/Poidebard 1945), den Balkan (Biernacka-Lubańska 1982, 56-62 u. 217-219) und Nordafrika (Pringle 1981) sicherten.

In anderen türkenzeitlichen Festungen erkennt Giros 2003, 209 u. 213-214 hingegen primär Fluchtburgen oder klassifiziert sie aufgrund der schriftlichen Überlieferung als neu gegründete Städte, ohne dass sie sich nach Form oder Lage von den erstgenannten Burgen unterscheiden ließen. Vgl. dazu auch die spätantike Situation im Nahen Osten, für den Liebeschuetz 1977, 490-494 entgegen Mouterde/Poidebard 1945 die Auffassung vertritt, die fraglichen Befestigungen seien weniger auf militärische als auf private Initiative hin entstanden und hätten vorrangig als Fluchtburgen gedient. Das gleiche wird auch für spätantike ländliche Befestigungen auf dem Balkan geltend gemacht, siehe die oben in Anm. 42 genannte Literatur.

151 Das Kastron nahm das Plateau des Theaterhügels ein und bestand aus der sogenannten komnenischen Stadtmauer und dem Theaterkastell als Zitadelle. Zu ersterer siehe Müller-Wiener 1982, 15-17, zu letzterem außerdem Müller-Wiener 1967, zur dichten Besiedlung ebd., 285 mit Anm. 10.

152 Zum Kastron siehe AvP 16,1, 35-61, zu seiner zunehmend dichten Besiedlung AvP 15, 2, 247 und Rheidt 2002, 625.

153 Foss 1976, 70; Foss/Scott 2002, 618-619.

154 Zur Datierung des Kastron siehe grundlegend Erim 1973, 64-65 und danach Brandes 1989, 94, Hebert 2002a, 205-206 und ders. 2002b, zu den Häusern, die innerhalb des Kastron gebaut wurden, ebd.

155 Zum Kastron siehe Naumann 1985, zu seiner zunehmend dichten Besiedlung Rheidt 2001, 249.

156 Foss 1976, 72-75; Foss/Scott 2002, 619-621.

157 Hebert 2002a, 201-205 u. 207-208; ders. 2002b.

158 Siehe demnächst die Dissertation des Verfassers. 
schließen, dass auch die alten Stadtgebiete weiterhin bewohnt blieben. Dennoch zeichnet sich nun erstmals der vielzitierte Wandel von Poleis zu Kastra ${ }^{159} \mathrm{ab}$, den man für die Dunklen Jahrhunderte bislang vergeblich nachzuweisen versucht hat. Typischerweise beschränkte man sich jetzt auch dort, wo man in den Dunklen Jahrhunderten noch bemüht gewesen war, mehr oder minder große Teile ziviler Siedlungen durch Stadtmauern gegen die Araber zu sichern, auf den Bau oder die Neubefestigung von Kastra, so etwa in Patara, ${ }^{160}$ Milet, ${ }^{161}$ Ephesos, ${ }^{162} \mathrm{Izmir} /$ Smyrna ${ }^{163}$ und Dorylaion. ${ }^{164}$ Offenbar waren diese Städte seit den Dunklen Jahrhunderten eher geschwächt als gestärkt worden.

Kirchen: Ein ähnlich ernüchterndes Bild der mittelbyzantinischen Epoche in Anatolien bietet auch der Kirchenbau im Vergleich sowohl zu den vorhergegangenen sogenannten Dunklen Jahrhunderten als auch zu gleichzeitigen Bauaktivitäten in der Hauptstadt ${ }^{165}$ und auf der Balkan-Halbinsel. ${ }^{166}$ In den Dunklen Jahrhunderten waren in Anatolien aller Widrigkeiten der Perser- und Araberkriege zum Trotz oder möglicherweise als Ersatz für damals zerstörte Bausubstanz ${ }^{167}$ bedeutende Kirchen in wohl größerer Zahl errichtet worden, als im gesamten übrigen Byzantinischen Reich. ${ }^{168}$

„If we trace the further development [...] we face the enigma that [...] Asia Minor seems to have had only a minor, and possibly an insignificant place in the construction of major monuments. [...] We look in vain for the dozens of monastic and village churches [...] which we know from Greece, and good examples [...] such as those of Constantinople are all but unknown there [in Anatolien]. Moreover, the splendid later development [...] has apparently not left a single trace on the mainland of Asia Minor. This lacuna cannot be attributed to the late eleventh century depravations in Asia Minor, because many of the best examples

159 Kirsten 1958; Müller-Wiener 1986.

160 Foss 1994, 15.

161 Siehe oben Anm. 151.

162 Müller-Wiener 1961, 85-112.

163 Ders. 1962, 65-66, 82 u. 84.

164 Eine Stadtmauer, die während der Dunklen Jahrhunderte neu errichtet (Foss 1996b, 53-54) oder erhalten (TIB 7, 241) und jedenfalls verschiedentlich verteidigt worden war, ersetzte man nun durch ein kleineres Kastron, so jedenfalls die Schriftquellen (TIB 7, 239-240; Foss 1996b, 46-48). Siehe dagegen jedoch auch Foss 1996b, 53-54 zu der Hypothese, bei dem neuen Kastron könne es sich entgegen der schriftlichen Überlieferung um eine Erneuerung der älteren Stadtmauer handeln. Auch in Nikomedia deutet alles darauf hin, dass die Stadtmauer in komnenischer Zeit von einem Kastron abgelöst wurde (siehe oben Anm. 63).

165 Zusammenfassend Restle 1990, Sp. 480-513.

166 Zusammenfassend Krautheimer 1986, 369-395.

167 Buchwald 1984, 228.

168 ebd., 225-227. Vgl. die Kataloge bei Ruggieri 1995a, 62-176 und Ousterhout 2001, 8-15. 
[...] in Greece and the capital were built before the battle of Manzikert opened the way for the Seljuk invasions. Nor do I believe that the lack of evidence is due entirely to the loss of significant monuments [...], because so many buildings constructed in other Byzantine styles have survived." 169

Zusammenfassung: Den Türken scheinen die anatolischen Städte weniger entgegenzusetzen gehabt zu haben als den Arabern: Obwohl das nun auch in Zentralanatolien angemessen gewesen wäre, wurde nicht nur kaum ein neuer Mauerring gebaut, sondern auch die alten allerorten aufgegeben. Erstmals gibt es archäologische Hinweise auf den sogenannten Wandel von Poleis zu Kastra. Im Vergleich zu den Dunklen Jahrhunderten erscheinen die anatolischen Städte demnach eher geschwächt als gestärkt.

Das gleiche Bild ergibt der anatolische Kirchenbau, der während der mittelbyzantinischen Epoche hinter dem zurückblieb, was zuvor während der sogenannten Dunklen Jahrhunderten gebaut worden war. So gesehen brachten es die anatolischen Städte in mittelbyzantinischer Zeit zu kaum mehr als einer oberflächlichen Instandsetzung. Eine substantielle Erneuerung des Städtewesens lässt der archäologische Befund nicht erkennen.

\section{Schlussfolgerungen}

Die engen Mauerringe und Kastra, die an der Mittelmeerküste bzw. im Landesinneren von Anatolien während der Dunklen Jahrhunderte gebaut wurden, lassen sich mit fortifikatorischen Prinzipien erklären, die aus den Grenzregionen des 5./6. Jahrhunderts bekannt sind. Sie sind also kein Grund, a priori eine Katastrophe der anatolischen Städte und ihre Reduktion auf Kastra anzunehmen, denn das war auch in den archäologisch besser erforschten Grenzregionen des 5./6. Jahrhunderts nicht der Fall. Außerdem ist für Mastaura/Dereağzı belegt, dass dort der Bau der Akropolis-Befestigung im 9. Jahrhundert nicht mit dem Niedergang, sondern mit einer Blüte der zivilen Tal-Siedlung in Zusammenhang stand.

Andernorts im Anatolien der Dunklen Jahrhunderte sind bislang vielleicht nur deshalb verhältnismäßig wenig Hinweise auf urbanistische Kontinuität gefunden worden, ${ }^{170}$ weil sich die Keramik dieser Epoche noch nicht identifizieren lässt. Gemessen an der Monumentalarchitektur der Zeit - Festungen und Kirchen - erweisen sich die Dunklen Jahrhunderte der nachfolgenden mittelbyzantinischen Epoche jedenfalls als

169 Buchwald 1984, 227-228. Sinngemäß auch Krautheimer 1986, 395.

170 Siehe jedoch Bondoux 2003, 408, der für bithynische Städte zu dem Schluss kommt: „La permanence [...] est remarquable, par comparison avec d'autres provinces de l'Empire.“ Allerdings ist diese Einschätzung in erster Linie auf die schriftliche Überlieferung gegründet, die in der Regel keine Aussagen über Form und Größe der Städte während der Dunklen Jahrhunderte zulässt. 
überlegen. Folglich kann von einem Tiefpunkt, geschweige denn von einer Katastrophe des anatolischen Städtewesens während der Dunklen Jahrhunderte keine Rede sein.

Möglicherweise wurde die Entwicklung der anatolischen Städte demnach auch im Mittelalter weniger durch äußere Faktoren wie Kriege und Epidemien geprägt als durch sozio-politische Veränderungen im Byzantinischen Reich: Die Städte hatten nämlich seit dem 5./6. Jahrhundert kontinuierlich an Bedeutung verloren, erst im Zusammenhang mit dem sogenannten Kurialenproblem, dann vielleicht durch eine fortschreitende „Feudalisierung“ der Gesellschaft, ${ }^{171}$ bis die Unterscheidung zwischen Stadt und Kastron mittelbyzantinischen Schriftquellen zufolge schließlich irrelevant wurde. ${ }^{172}$

Für derartige Schlussfolgerungen ist es jedoch wohl noch zu früh, denn das hier entwickelte Szenario relativer urbanistischer Kontinuität ist auf denselben Sand gebaut wie Foss' Katastrophentheorie. Für viele Orte sind seine Pionierarbeiten nach wie vor grundlegend. Klare Konturen werden die Dunklen Jahrhunderte wohl erst annehmen, wenn das Keramik-Problem einmal gelöst sein wird. Vorläufig gilt, womit P. Schreiner seinen „Beitrag zur Erforschung der Region von Milet“ beschlossen hat: „Vielleicht ist alles ganz anders gewesen." 173

171 Allgemein: Angold 1984. Mit Bezug auf das Städtewesen: ders. 1985, 21: „In Anatolia [...] a great many, if not the majority of cities, came under the control of a lord. [...] Every city needed a protector, even in some cases faute mieux a Turkish chieftain, or some foreign adventurer.” Für konkrete Beispiele siehe Bryer 1969/70, 175, Anm. 44 und ergänzend Bryer/Dunn/Nesbitt 2003, 58-60, zu Atra der Gabraden, Patlagean 1987, 570-571, zu Çavuşin der Phokaden in Kappadokien und Crow 1994 zu Kastamon der Komnenen in Paphlagonien. Zusammenfassend: Haldon 1999, 19-20. Siehe auch Bouras 1981, 650 zu mittelalterlichen Kastra als Wohnort städtischer Aristokratie und Oikonomides 1966, 416 sowie Trojanos 1969, 55-56 zur Vergabe mittelalterlicher Kastra an Privatpersonen. Dagegen stellt Whittow 1995, 69 im Vergleich mit europäischen Adelsburgen fest, „the Byzantines clearly regarded most kastra as essentially imperial or public fortresses“, lässt dabei allerdings die Feudalisierung der kaiserlichen Beamtenschaft unberücksichtigt. Vielleicht war letztere ein Grund für den Schwund an gesellschaftlicher Solidarität, den Trombley 1998, 139 dafür mitverantwortlich macht, dass die Türken nicht mehr wie einst die Araber zurückgeschlagen wurden.

172 Brandes 1989, 40-43 und danach Haldon 1999, 14-17 datieren diese Entwicklung nach den schriftlichen Quellen ins 10. Jahrhundert, um dann jeweils hinzuzufügen, dass der tatsächliche Wandel von Poleis zu Kastra wohl schon in den Dunklen Jahrhunderten stattgefunden habe. In den byzantinischen Quellen habe sich das mit einer Zeitverzögerung von einigen Jahrhunderten niedergeschlagen, während arabische Quellen zuverlässiger seien. Dagegen siehe jedoch Kaegi 2003, 274-279, demzufolge die frühen muslimischen Historiker nur sporadisch und oberflächlich über Anatolien berichten. Nimmt man stattdessen die byzantinische Überlieferung beim Wort, passt sie gut zu dem Szenario relativer urbanistischer Kontinuität während der Dunklen Jahrhunderte.

173 Schreiner 1998, 616. 


\section{Summary}

Some 25 years ago C. Foss published an essay entitled „Archaeology and the ,Twenty cities' of Byzantine Asia Minor". He for the first time referred mainly to archaeological evidence in order to determine the disputed character of the so-called Dark Ages in Byzantine Anatolia. The argument evolved around the question whether the Persian and Arab incursions from the seventh to the ninth century caused a sudden disruption of ancient urbanism and a catastrophic beginning of the Middle Ages. Alternatively towns might have continued to exist and their change from ancient to medieval appearance came about by gradual transformation. Written sources, epigraphic, and numismatic evidence alone have not been conclusive. This is why Foss brought the archaeological evidence in the discussion: As a one-to-one image of the historical situation, archaeological evidence seemed less likely to cause disagreement about its interpretation.

Foss contrasts urban splendour and size as well as diverse public buildings of late antiquity with comparably simple and small kastra and churches of the Middle Ages. He explains the disparity by a disruption of urban life. According to Foss the Dark Ages cut off all ancient traditions and thereby cleared the way for a new start of an independent medieval development. As proof Foss refers to a lacuna in the archaeological record during the Dark Ages and as a reason he gives the barbarian incursions. This catastrophic scenario has been generally accepted. The apparent contrast between late antiquity and the Middle Ages seemed to rule out a continuous, uninterrupted development through transformation.

That contrast however is but the result of a simplistic image of late antiquity as a homogenous period of urban growth and prosperity. Under closer scrutiny the archaeological evidence reveals that the last major urban building campaigns in Anatolia took place around A.D. 400. By the fifth/sixth century a transformation to what is generally associated with a medieval townscape was well under way: prestigious architecture, urban infrastructure, and public buildings were neglected - churches being the only general exception to the rule. Private dwellings irregularly invaded formerly public spaces and some towns can even be shown to have shrunken in size. There was therefore no fundamental difference between urban construction of the fifth/sixth century and that of the Middle Ages. Accordingly there is no reason to assume a priori that urban development was disrupted in the intervening period, and to conclude ex silentio that Anatolia witnessed a de-urbanisation during the Dark Ages.

Furthermore the lack of coins from that period, which Foss has taken to indicate economic discontinuity, is nowadays explained by a change in monetary policy and may not be used as evidence against urban continuity. The same holds true for ceramics from the Dark Ages: A quarter of a century ago Foss had to believe such ceramics did not exist. By now thick strata rich in ceramics that used to be ignored as not datable have been identified with the period in question, for example in Limyra. It seems more 
than likely that ceramics of the Dark Ages exist elsewhere as well, but have so far not been recognised as such. Accordingly their lack does not lend itself to an argument ex silentio against urban continuity.

All this seems reason enough to try to turn Foss' argument upside down and for once assume urban continuity during the Dark Ages, wherever the opposite is not proven beyond reasonable doubt. This leads to a revision of the paradigm of contraction from polis to kastron. The alternative scenario can not be ruled out: Towns may have continued to exist outside the fortifications, as had happened earlier on in late antiquity: Chavdar Kirilov in his contribution to this volume makes this point with respect to late antique town walls. Late antique kastra, as opposed to town walls, were not intended to defend civilian settlements. Their purpose was limited to securing strategic positions and maybe the governor's or the bishop's residence. In some cases they might also have served as a safe haven for the civilian population, for example in Nikopolis ad Istrum: Here the Byzantines built a new kastron after re-conquering the place from the Huns in the second half of the fifth century. Next to a church, possibly the cathedral, the kastron enclosed much free space, where the civilian population might have assembled in case of an attack, as Andrew Poulter suggests. In contrast the Justinianic citadel of Caričin Grad was obviously too small to host the urban population. It only secured the cathedral and the palace. The surrounding town had its own circuit of walls, and the suburban population fled there to seek shelter from violence.

A wider circuit that included the loosely settled suburbs would have defied the advice of a contemporary manual on strategy, the so called Anonymus Byzantinus: gardens, parks, and lawns inside the walls that resulted in long circuits were - according to the Anonymus - to be admitted only far away from the border, where the enemy could not launch a sudden and surprising attack. Otherwise there would probably not have been enough time to assemble the troops necessary for the defence of extended fortifications. Justinian acted accordingly when he restored the walls of Cappadocian Caesarea in the hinterland of the Persian border. As Procopius informs us, the old fortification had enclosed distant hills in order to prevent them from serving an aggressor as bastions against the town. These hills and much free space within the walls had at no time been populated. Procopius considers such an extended circuit as unreasonably long for both maintenance and defence, and Justinian had it shortened. The same happened in many North African towns that were liable to rapid barbarian attacks from across the border.

In Central and Western Anatolia life was comparably peaceful in late antiquity and no such kastra and reduced circuits were built. After the erection of numerous extended town walls during the last urban building boom around 400, wall building died down almost completely in the fifth/sixth century. Some towns even allowed their newly acquired fortifications to fall into disrepair: The late fourth-century circuit of Sagalassus in Pisidia was given up and used for dumping debris after the earthquake of 518. 
The walls of Anemurium in Cilicia that had been built around 382 were partly pulled down again to make space for a fifth-century church. In Hierapolis upon Meandrus a bath was built against the outer face of the town wall in the fifth/sixth century. In Lycian Limyra the same happened with a church in the sixth century. In both cases the defensive function of the recently erected fortifications was affected and therefore must have been considered negligible.

All this changed radically in the Dark Ages, when from the seventh century onwards Anatolia came first under Persian and then under Arab attack. The new situation can be compared to what the Balkans, the Near East, and North Africa were facing two centuries earlier, and the same kind of defences were built: The Mediterranean coast now lay open to sudden Arab raids from the sea. These razzias will have left the towns close to the shore with no time to gather troops and men along the walls. Accordingly Limyra had its western circuit of walls renewed and the before-mentioned church was pulled down again, but the eastern circuit seems to have been given up, although people continued to live in that part of the town as well. Other examples are Side, Patara, Miletus, and Ephesus, where new or newly shortened circuits enclosed only half or less of the ancient town. According to Foss they all date to the Dark Ages.

In inland Anatolia the situation was somewhat different and no town walls of the Dark Ages are known. The high plateau was not exposed to surprise Arab attacks in the same way as the Mediterranean coast. The enemy had to advance a long way within Byzantine territory. There he was shadowed by the Byzantines, and they designed an early warning system to notify towns prior to any attack. Thus, the towns seem to have felt confident that they would be able to either defend the full extend of their ancient circuits or do without any town walls at all. Euchaita in Pontus is for example reported to have successfully defended her ancient circuit against the Persians, but when the Arabs were advancing the inhabitants are said to have chosen a different strategy: Instead of defending their town they took shelter in some kastra on the hills above. Not for long though, because as soon as the enemy had left, they returned to the plain and moved into their old town again. Amorium suffered a comparable fate as Erik Ivison explains elsewhere in this volume: There the late antique town wall was taken and destroyed by the Arabs in 838 . It was never rebuilt, and only a small kastron was refortified. As in Euchaita, the limitation of the defences to a kastron did not mean that the town was given up and deserted. Excavations have unearthed houses and an ancient church that were built or restored after 838 .

The same can be demonstrated elsewhere: The kastron high above Ancyra was a very important one. It served as headquarters of an army. It may date back to the seventh century and in any case was in need of restoration by 859 , when Michael III. had it remodelled. In the meantime the church of St Clemens had been built in the town below. The domed basilica was preserved and must have remained in use all through the Middle Ages until the Turks finally turned it into a mosque. Furthermore the Turkish 
town wall was observed to follow and be based on an older circuit dating back to the times of the tetrarchs. Both the tradition of the house of prayer and the town wall may indicate continuous habitation. Only in case of emergency might the townspeople have fled to the kastron for temporary shelter.

Mastaura/Dereağzı, the second ranking bishopric of Lycia, had its acropolis refortified in the ninth century. At the same time one of the biggest and most sumptuous churches of the age was built in the plain below. It was a domed basilica built with bricks just like St Clement in Ankyra. The new church of Mastaura/Dereağzı probably served as a cathedral. It testifies that the fortification works on the acropolis had nothing to do with a contraction from town to kastron.

In Sardis a similar position on a hill above the town was fortified in the seventh century. At about the same time the main street and thoroughfare of the town below was newly paved, as happened again in Ottoman times. Elsewhere in town the only excavated late antique church was repaired again and again during the Middle Ages, until it was replaced by a new building in the thirteenth century that the Turks in their turn transformed into living spaces and workshops. Other indicators for continuous habitation during the Dark Ages are lacking. Coins and ceramics have only been recorded for later centuries. This, however, proves nothing, as has already been pointed out and as becomes most obvious in Pergamum.

In Pergamum it is once more the peak of the acropolis high above the town that was walled in. The interior of the fortification has been excavated down to ancient levels, but no finds have been recorded from the kastron itself. It clearly dates to a period with inconspicuous material remains that the archaeologists have overlooked. This speaks in favour of a date in the Dark Ages, because a kastron of the sixth century, as has alternatively been suggested, would hardly have escaped notice to judge by the plentiful findings in any of the before mentioned sixth-century fortifications. If the Dark Ages have been overlooked in the extensively excavated kastron of Pergamum, the same is likely in the town below that is mostly built up with modern houses which limit exploration to a few ancient monuments. The lack of Dark Age findings there can thus not be accepted as proof for the collapse of urban life. More likely the town will have continued to exist and been the home of the substantial population that moved up to the kastron in the eleventh century.

This leads to the last period to be considered in this context: According to Foss' catastrophic scenario Anatolian urbanism should have regained momentum once the Dark Ages were over and times became more peaceful again under the Macedonian dynasty. To test this hypothesis one can look at the churches built during the Middle Byzantine period and compare them with those of the Dark Ages: During the Dark Ages more major churches were built in Anatolia than in all other parts of the Byzantine Empire combined. Later on Anatolia seems to have had only a minor and possibly an insignificant position in the construction of major monuments. As far as church 
building is concerned there is therefore no sign of any urban revival during the Middle Byzantine period.

Another aspect of the post Dark Age development of Anatolian towns are the fortifications built from the eleventh century onwards, when the towns had to defend themselves again, this time against the Turks. A previous urban revival under the Macedonian dynasty should have enabled the towns to afford more extensive fortifications than during the Dark Ages. Furthermore, according to the above-said principles of defence, one would now expect town walls in inland Anatolia as well: The permanent Turkish presence there enabled the enemy to launch sudden attacks that would leave the townspeople with no time to take shelter in a kastron. In spite of all this the erection or even restoration of a town wall to defend themselves against the Turks was an exception. It happened in Nicaia and in Magnesia ad Sipylus, when those towns were temporarily functioning as capitals after Constantinople had been lost in the fourth crusade. Other examples are Trabzon and Attaleia, then the most important harbours of Anatolia.

Elsewhere the fortifications built against the Turks seem to indicate that the fate of the towns was no longer taken into consideration. In Miletus, Pergamum, Sardis, Aphrodisias and Aizanoi kastra were built or restored that did not contain any free space for the townspeople to assemble in case of attack, as had been the custom in earlier times. Instead ordinary houses ever more densely occupied the later kastra. A growing part of the urban population seems to have moved to the kastra permanently, as towns without walls did not offer sufficient protection against the Turks. It looks as if the centre of the civilian settlement had now shifted from the loosely inhabited town to the densely occupied kastron. This development finally goes with the much-quoted shift from polis to kastron that had originally been attributed to the Dark Ages. Towns that in those times still tried to defend a more or less extended circuit of walls against the Arabs now characteristically made do with a kastron, as happened all over Anatolia, for example in Patara, Ephesus, Smyrna and Dorylaium. Since the Dark Ages these towns seem to have lost rather than gained in strength.

To conclude: The reduced circuits and kastra that were built along the Mediterranean coast and in inland Anatolia during the Dark Ages are comparable to late antique fortifications in the borderlands. The same principles of defence may explain them both. And as towns continued to exist in the borderlands during late antiquity, there is no reason to assume a priori that they did not do so in Anatolia during the Dark Ages. Moreover a case like Mastaura/Dereağzı proves that the building of a kastron on an acropolis may coincide with affluence rather than decline in the civilian settlement below. Elsewhere in Dark Age-Anatolia the paucity of archaeological evidence for continuous urban habitation might be accounted for by the inability to identify ceramics of the period.

To judge by the monumental architecture of the time that consists mainly of fortifications and churches, the Anatolian Dark Ages look superior to the subsequent mid- 
dle Byzantine period. According to these parameters at least it does not make sense to speak of a catastrophic collapse or even a low of Anatolian urbanism during the Dark Ages. More likely Anatolian towns will have declined continuously due to socio-political changes within the Byzantine Empire. This has been the case during the fifth/sixth century, triggered as it seems by what has become known as the flight of the curials and the rise of the notables in their stead. During the Middle Ages the so-called feudalisation of Byzantine society might have contributed to a further erosion of urbanism. Only when the Turks took over did towns start to thrive again.

It must be pointed out, however, that this scenario of relative urban continuity during the Dark Ages is based on much of the same archaeological evidence as Foss' hypothesis about a catastrophic collapse. For many Anatolian towns and kastra Foss' pioneering research still forms the basic work of reference. The understanding of the Dark Ages will probably only come to a break through once ceramics of the period can be identified. Until then any interpretation is bound to end with about the same words: Maybe it all happened quite differently.

\section{Bibliographie}

Ahrweiler 1962: Hélène Ahrweiler, „L'Asie Mineure et les invasions arabes (7e-9e siècles)“, in: Revue historique 227, 1962, S. 1-32.

Angold 1984: Michael Angold, „Introduction“, in: Michael Angold (Hrsg.), The Byzantine aristocracy: $9^{\text {th }}$ to $13^{\text {th }}$ centuries (=British Archaeological Reports, international series 221), Oxford 1984, S. 1-9.

Angold 1985: Michael Angold, „The shaping of the medieval Byzantine 'city'“, in: Byzantinische Forschungen 10, 1985, S. 1-37.

Anonymus Byzantinus: George T. Dennis (Hrsg.), Three Byzantine military treatises: Text, translation, and notes (=Corpus fontium historiae Byzantinae 25), Washington, DC 1985, S. 1-136.

AvP 15, 2: Klaus Rheidt, Die byzantinische Wohnstadt (=Altertümer von Pergamon 15, 2), Berlin 1991.

AvP 16, 1: Manfred Klinkott, Die byzantinischen Befestigungsanlagen von Pergamon mit ihrer Wehr- und Baugeschichte (=Altertümer von Pergamon 16, 1), Berlin 2001.

Bakirtzis 2003: Charalambos Bakirtzis, „The urban continuity and size of late Byzantine Thessaloniki“, in: Dumbarton Oaks Papers 57, 2003, S. 35-64.

Barsanti 2003: Claudia Barsanti, „The Iznik - Nicea's archaeological museum: in search of a catalogue“, in: Isil Akbaygil/Oktay Aslanapa/Halil Inalc1k (Hrsg.), Iznik throughout history, Kolloquium Iznik 2000, Istanbul 2003, S. 267-300.

Belke 2002: Klaus Belke, „Mysien und Hellespont“, in: Reallexikon zur byzantinischen Kunst 6 , Lieferung 46, Stuttgart 2002, Sp. 839-868.

Bernardi Ferrero 1995: Daria de Bernardi Ferrero, „Excavations and restorations during 1994 in Hierapolis of Phrygia“, in: Kazı sonuçları toplantısı 17/2, 1995, S. 95-105.

Biernacka-Lubańska 1982: Malgorzata Biernacka-Lubańska, The Roman and early Byzantine fortifications of Lower Moesia and northern Thrace (= Bibliotheca antiqua 17), Wroclaw 1982. 
Bingöl 1998: Orhan Bingöl, Magnesia am Mäander, Ankara 1998.

Bondoux 2003: René Bondoux, „Les villes“, in: Bernard Geyer/Jacques Lefort (Hrsg.), La Bithynie au Moyen Âge (=Réalités byzantines 9), Paris 2003, S. 377-409.

Borchhardt et. al. 2002: Jürgen Borchhardt et al., „Bericht der Grabungskampagne in Limyra 2001“, in: Kazı sonuçları toplantısı 24/2, 2002, S. 303-314.

Bottema/Woldring 1995: Sytze Bottema/H. Woldring, „The environment of classical Sagalassos“, in: Jeroen Poblom/Marc Waelkens (Hrsg.), Sagalassos 3: report on the fourth excavation campaign of 1993 (= Acta archaeologica Lovaniensia, monographiae 7), Leuven 1995, S. 327-340.

Bouras 1981: Charalambos Bouras, „City and village: urban design and architecture“, in: 16. Internationaler Byzantinistenkongreß, Wien 1981, Teil 1, Teilband 2 (=Jahrbuch der Österreichischen Byzantinistik 31/2), Wien 1981, S. 611-653.

Bouras 2002: Charalampos Bouras, „Aspects of the Byzantine city, eighth-fifteenth centuries", in: Angeliki E. Laiou (Hrsg.), The economic history of Byzantium from the seventh through the fifteenth century 2 (=Dumbarton Oaks studies 39/2), Washington, D.C. 2002, S. 497-537.

Brandes 1982: Wolfgang Brandes, „Ephesos in byzantinischer Zeit. ,Rezension zu Clive Foss, Ephesus after antiquity: a late antique, Byzantine and Turkish city’, Cambridge 1979“, in: Klio 64, 1982, S. 611-622.

Brandes 1989: Wolfgang Brandes, Die Städte Kleinasiens im 7. und 8. Jahrhundert (=Berliner byzantinistische Arbeiten 56), Berlin 1989.

Brandes 1995: Wolfgang Brandes, „Die Entwicklung des byzantinischen Städtewesens von der Spätantike bis zum 9. Jahrhundert“, in: Klaus-Peter Matschke (Hrsg.), Die byzantinische Stadt im Rahmen der allgemeinen Stadtentwicklung, Kolloquium Leipzig 1990, Leipzig 1995, S. 9-26.

Brandes 1999: Wolfgang Brandes, „Byzantine cities in the seventh and eighth centuries - different sources, different histories?", in: Gian Pietro Brogiolo/Bryan Ward-Perkins (Hrsg.), The idea and ideal of the town between late antiquity and the early Middle Ages (=The transformation of the Roman world 4), Leiden-Boston-Köln 1999, S. 25-57.

Brandes 2002: Wolfgang Brandes, Finanzverwaltung in Krisenzeiten: Untersuchungen zur byzantinischen Administration im 6.-9. Jahrhundert (=Forschungen zur byzantinischen Rechtsgeschichte 25), Frankfurt am Main 2002.

Brubaker/Haldon 2001: Leslie Brubaker/John Haldon, Byzantium in the iconoclast era (ca 680850): the sources (=Birmingham Byzantine and Ottoman monographs 7), Aldershot 2001.

Bryer 1969/70: Anthony Bryer, „A Byzantine family: the Gabrades c. 979-1653“, in: University of Birmingham historical journal 12, 1969/70, S. 164-187. Reprint in: ders., The empire of Trebizond and the Pontos, London 1980.

Bryer 1986: Anthony Bryer, „The structure of the late Byzantine town: dioikismos and the mesoi“, in: Anthony Bryer/Heath Lowry (Hrsg.), Continuity and change in late Byzantine and early Ottoman society, Birmingham 1986, S. 263-279. Reprint in: ders., Peoples and settlement in Anatolia and the Caucasus, 800-1900 10, London 1988.

Bryer/Dunn/Nesbitt 2003: Anthony Bryer/Archibald Dunn/John W. Nesbitt, „Theodore Gabras, duke of Chaldia († 1098) and the Gabrades: portraits, sites and seals“, in: Anna Avramea/ Euangelos Chrysos/Angeliki Laiou (Hrsg.), Byzantium: state and society. In memory of Nikos Oikonomides, Athen 2003, S. 51-70.

Bryer/Winfield 1985: Anthony Bryer/David Winfield, The Byzantine monuments and topography of the Pontos (=Dumbarton Oaks studies 20), Washington, D.C. 1985. 
Buchwald 1984: Hans Buchwald, „Western Asia Minor as a generator of architectural forms in the Byzantine period, provincial back-wash or dynamic center of production?"“, in: Jahrbuch der Österreichischen Byzantinistik 34, 1984, S. 199-234. Reprint in: ders., Form, style and meaning in Byzantine architecture 5, London 1999.

Claude 1969: Dietrich Claude, Die byzantinische Stadt im 6. Jahrhundert (=Byzantinisches Archiv 13), München 1969.

Cobet 1997: Justus Cobet, „Milet 1994-1995. Die Mauern sind die Stadt: zur Stadtbefestigung des antiken Milet", in: Archäologischer Anzeiger 1997, S. 249-284.

Constantinides 2002: Costas N. Constantinides, „Byzantine gardens and horticulture in the late Byzantine period, 1204-1453: the secular sources“, in: Antony Robert Littlewood/Henry Maguire/Joachim Wolschke-Bulmahn (Hrsg.), Byzantine garden culture, Washington, D.C. 2002, S. 87-103.

Crawford 1990: John Stephens Crawford, The Byzantine shops at Sardis (=Archaeological exploration of Sardis monographs 9), Cambridge, MA 1990.

Crow 1996: James Crow, „Alexios Komnenos and Kastamon: castles and settlement in middle Byzantine Paphlagonia“, in: Margart Mullett/Dion Smythe (Hrsg.), Alexios I Komnenos, Kolloquium Belfast 1989, 1 (=Belfast Byzantine texts and translations 4/1), Belfast 1996, S. 12-36.

Crow 2001: James Crow, „Fortifications and urbanism in late antiquity: Thessaloniki and other cities“, in: Luke Lavan (Hrsg.), Recent research in late-antique urbanism, Kolloquia Nottingham, Birmingham u. Oxford 1997-1999 (=Journal of Roman Archaeology, Ergänzungsband 42), Portsmouth, R.I. 2001, S. 89-105.

Crow/Hill 1995: James Crow/Stephen Hill, „The Byzantine fortifications of Amastris in Paphlagonia“, in: Anatolian studies 45, 1995, S. 251-265.

Cutler/Každan 1982: Anthony Cutler/Alexander P. Každan, „Continuity and discontinuity in Byzantine history“, in: Byzantion 52, 1982, S. 429-478.

Dagron 2002: Gilbert Dagron, „The urban economy, seventh-twelfth centuries“, in: Angeliki E. Laiou (Hrsg.), The economic history of Byzantium from the seventh through the fifteenth century 2 (=Dumbarton Oaks studies 39/2), Washington, D.C. 2002, S. 393-461.

D'Andria 1998: Francesco D'Andria, „The evolution of Hierapolis of Phrygia“, in: David Parrish (Hrsg.), Urbanism in western Asia Minor: new studies on Aphrodisias, Ephesos, Hierapolis, Pergamon, Perge and Xanthos, Kolloquium Washington, D.C. (=Journal of Roman Archaeology, Supplement 45), Portsmouth 1998, S. 94-115.

DeMulder/Devreker/Vermeulen 1998: Guy DeMulder/John Devreker/Frank Vermeulen, „Urban development in early Byzantine Pessinus (Asia Minor)“, in: Acta 13 Congressus internationalis archaeologiae christianae, Kolloquium Split u. Poreč 1994, 3 (=Vjesnik za arheologiju i historiju dalmatinsku, Ergänzungsband 89; Studi di antichità cristiana 54/3), SplitCittà del Vaticano 1998, S. 787- 796.

Depuydt/Loots/Waelkens 2000: Frans Depuydt/Lieven Loots/Marc Waelkens, „,The city fortifications of Sagalassos from the Hellenistic to the late Roman period“, in: Lieven Loots/Marc Waelkens (Hrsg.), Sagalassos 5: report on the survey and excavation campaigns 1996 and 19972 (=Acta archaeologica Lovaniensia, Monographiae 11 B), Leuven 2000, S. 595-634.

Devreker/Thoen/Vermeulen 2003: John Devreker/Hugo Thoen/Frank Vermeulen, Excavations in Pessinus: the so-called Acropolis. From Hellenistic and Roman cemetery to Byzantine castle (=Archaeological reports Ghent university 1), Gent 2003.

Diest 1913: Walther von Diest, Nysa ad Maeandrum: nach Forschungen und Aufnahmen in den Jahren 1907 und 1909 (=Jahrbuch des Deutschen Archäologischen Instituts, Ergänzungsband 10), Berlin 1913. 
Dunn 1992: Archibald Dunn, „The exploitation and control of woodland and scrubland in the Byzantine world“, in: Byzantine and modern Greek studies 16, 1992, S. 235-298.

Dunn 2004: Archibald Dunn, „Continuity and change in the Macedonian countryside from Gallienus to Justinian“, in: William Boden/Luke Lavan/Carlos Machado (Hrsg.), Recent research on the late antique countryside (=Late antique archaeology 2), Leiden 2004, S. 535-586.

Effenberger/Koch/Kunze 1993: Arne Effenberger/Guntram Koch/M. Kunze, „Bizans çağ1 araştırmaları", in: Kazı sonuçları toplantısı 15/2, 1993, S. 281-282.

Erim 1973: Kenan Erim, „1971 excavations at Aphrodisias in Caria“, in: Türk arkeoloji dergisi 20, 1973, S. 63-87.

Eyice 1981: Semavi Eyice, „Einige byzantinische Kleinstädte im Rauhen Kilikien“, in: 150 Jahre Deutsches Archäologisches Institut 1829-1979, Kolloquium Berlin 1979, Mainz 1981, S. 204-209.

Filges 2003: Axel Filges, „Stadtentwicklung im Gebiet des oberen Mäander: die lydisch-phrygische Grenzregion am Beispiel von Blaundos“, in: Elmar Schwertheim/Engelbert Winter (Hrsg.), Stadt und Stadtentwicklung in Kleinasien (=Asia Minor Studien 50), Bonn 2003, S. 35-50.

Foss 1972: Clive Foss, Byzantine cities of western Asia Minor, Diss. Harvard Univ. 1972.

Foss 1975a: Clive Foss, „The Persians in Asia Minor and the end of antiquity“, in: English historical review 90, 1975, S. 721-743. Reprint in: ders., History and archeology of Byzantine Asia Minor 1, London 1990.

Foss 1975b: Clive Foss, „The fall of Sardis in 616 and the value of evidence“, in: Jahrbuch der Österreichischen Byzantinistik 24, 1975, S. 11-22.

Foss 1976: Clive Foss, Byzantine and Turkish Sardis (=Archaeological exploration of Sardis, monograph 4), Cambridge, MA 1976.

Foss 1977a: Clive Foss, „Attius Philippus and the walls of Side“, in: Zeitschrift für Papyrologie und Epigraphik 26, 1977, S. 172-180. Reprint in: ders., History and archeology of Byzantine Asia Minor 8, London 1990.

Foss 1977b: Clive Foss, „Archaeology and the ,twenty cities' of Byzantine Asia Minor", in: American Journal of Archaeology 81, 1977, S. 469-486. Reprint in: ders., History and archeology of Byzantine Asia Minor 2, London 1990.

Foss 1977c: Clive Foss, „Late antique and Byzantine Ankara“, in: Dumbarton Oaks Papers 31, 1977, S. 29-87. Reprint in: ders., History and archeology of Byzantine Asia Minor 6, London 1990.

Foss 1979a: Clive Foss, Ephesus after antiquity: a late antique, Byzantine and Turkish city, Cambridge 1979.

Foss 1979b: Clive Foss, „Late Byzantine fortifications in Lydia“, in: Jahrbuch der Österreichischen Byzantinistik 28, 1979, S. 297-320. Reprint in: ders., Cities, fortresses and villages of Byzantine Asia Minor 6, London 1996.

Foss 1982: Clive Foss, „The defences of Asia Minor against the Turks“, in: Greek orthodox theological review 27, 1982, S. 145-205. Reprint in: ders., Cities, fortresses and villages of Byzantine Asia Minor 5, London 1996.

Foss 1985: Clive Foss, Survey of medieval castles of Anatolia: 1. Kütahya (=British Archaeological Reports, International Series 261), Oxford 1985.

Foss 1987: Clive Foss, „Sites and strongholds of northern Lydia“, in: Anatolian studies 37, 1987, S. 81-101. Repr. in: ders., History and archeology of Byzantine Asia Minor 11, London 1990.

Foss 1988: Clive Foss, „Strobilos and related sites“, in: Anatolian studies 38, 1988, S. 147-174. Reprint in: ders., History and archeology of Byzantine Asia Minor 12, London 1990. 
Foss 1994: Clive Foss, „The Lycian coast in the Byzantine age“, in: Dumbarton Oaks Papers 48, 1994, S. 1-52. Reprint in: ders., Cities, fortresses and villages of Byzantine Asia Minor 2, London 1996.

Foss 1996a: Clive Foss, Nicaea: a Byzantine capital and its praises (=Archbishop Iakovos library of ecclesiastical and historical sources 21), Brookline, MA 1996.

Foss 1996b: Clive Foss, „Dorylaion: bulwark of the Byzantine frontier“, in: Greek orthodox theological review 41, 1996, S. 39-55.

Foss 1996c: Clive Foss, „The cities of Pamphylia in the Byzantine age“, in: ders., Cities, fortresses and villages of Byzantine Asia Minor 3, London 1996.

Foss 1996d: Clive Foss, Survey of medieval castles of Anatolia 2: Nicomedia (=British institute of archaeology at Ankara monograph 21), Oxford 1996.

Foss/Scott 2002: Clive Foss/Jane Ayer Scott, „Sardis“, in: Angeliki E. Laiou (Hrsg.), The economic history of Byzantium from the seventh through the fifteenth century (=Dumbarton Oaks studies 39/2), Washington, D.C. 2002, S. 615-622.

Foss/Winfield 1986: Clive Foss/David Winfield, Byzantine fortifications: an introduction, Pretoria 1986.

Gabriel 1958: Albert Gabriel, Une capitale turque: Brousse, Bursa-Paris 1958.

Giros 2003: Christophe Giros, „Les fortifications médiévales“, in: Bernard Geyer/Jacques Lefort (Hrsg.), La Bithynie au Moyen Âge (=Réalités byzantines 9), Paris 2003, S. 209-224.

Glykatzi-Ahrweiler 1960: Hélène Glykatzi-Ahrweiler, „Les forteresses construites en Asie Mineure face à l'invasion seldjoucide“, in: Franz Dölger/Hans-Georg Beck (Hrsg.), Akten des 11. internationalen Byzantinistenkongresses München 1958, München 1960, S. 182-189.

Greenwalt 2001: Crawford H. Greenwalt, „Sardis: archaeological research and conservation projects in 2000", in: Kazı sonuçları toplantısı 23/2, 2001, S. 227-234.

Gregory 1982: Timothy E. Gregory, „Fortification and urban design in early Byzantine Greece“, in: Robert L. Hohlfelder (Hrsg.), City, town and countryside in the early Byzantine era, Boulder, Col. 1982, S. 43-64.

Grélois/Pralong 2003: Jean-Pierre Grélois/Annie Pralong, „Les monuments byzantins de la ville haute de Brousse“, in: Bernard Geyer/Jacques Lefort (Hrsg.), La Bithynie au Moyen Âge (=Réalités byzantines 9), Paris 2003, S. 139-149.

Grossmann/Severin 2003: Peter Grossmann/Hans-Georg Severin, Frühchristliche und byzantinische Bauten im südöstlichen Lykien: Ergebnisse zweier Surveys (=Istanbuler Forschungen 46), Tübingen 2003.

Haldon 1978: John F. Haldon, „Rezension zu Ralf-Johannes Lilie, Die byzantinische Reaktion auf die Ausbreitung der Araber: Studien zum Strukturwandel des byzantinischen Staates im 7. und 8. Jahrhundert' (=Miscellanea byzantina monacensia 22), München 1976“, in: Byzantinoslavica 39, 1978, S. 227-229.

Haldon 1985: John Haldon, „Some considerations on Byzantine society and economy in the seventh century“, in: Byzantinische Forschungen 10, 1985, S. 75-112.

Haldon 1997: John Haldon, Byzantium in the seventh century: the transformation of a culture, Cambridge ${ }^{2} 1997$.

Haldon 1999: John Haldon, „The idea of the town in the Byzantine empire“, in: Gian Pietro Brogiolo/Bryan Ward-Perkins (Hrsg.), The idea and ideal of the town between late antiquity and the early Middle Ages (=The transformation of the Roman world 4), Leiden-BostonKöln 1999, S. 1-24.

Hanfmann 1983: George M. A. Hanfmann, Sardis from prehistoric to Roman times, Cambridge, MA 1983. 
Harrison 1991: Martin R. Harrison, „Amorium excavations 1990: the third preliminary report“, in: Anatolian studies 41, 1991, S. 215-229.

Harrison 2001: Martin R. Harrison (Wendy Young, Hrsg.), Mountain and plain: from the Lycian coast to the Phrygian plateau in the late Roman and early Byzantine period, Ann Arbor 2001.

Hasluck 1910: Frederick W. Hasluck, Cyzicus: being some account of the history and antiquities of that city, and of the district adjacent to it, with the towns of Apollonia ad Rhyndacum, Miletupolis, Hadrianutherae, Priapus, Zeleia, etc., Cambridge 1910.

Hattersley-Smith/Ruggieri 1990: Kara M. Hattersley-Smith/Vincenzo Ruggieri, „A Byzantine city near Osmaniye (Dalaman) in Turkey: a preliminary report“, in: Orientalia Christiana Periodica 56, 1990, S. 135-164.

Hebert 2002a: Laura A. Hebert, The temple-church at Aphrodisias, Diss. New York Univ. 2000, Ann Arbor 2002.

Hebert 2002b: Laura A. Hebert, „Middle Byzantine Aphrodisias“, in: Twenty-eighth annual Byzantine studies conference, October 2002, Abstracts of papers, College Park, Md. 2002, S. 10-11.

Hellenkemper 1991: Hansgerd Hellenkemper, „Kastron: 2. Burg“, in: Lexikon des Mittelalters 5, 1991, Sp. 1052-1053.

Hendy 1985: Michael F. Hendy, Studies in the Byzantine monetary economy c. 300-1450, Cambridge 1985 .

Hild 1995: Friedrich Hild, „Rezension zu Clive Foss, ,History and archaeology of Byzantine Asia Minor‘, London 1990“, in: Jahrbuch der Österreichischen Byzantinistik 45, 1995, S. 385-387.

Hild 1996: Friedrich Hild, „Rezension zu James Morganstern (Hrsg.), ,The fort at Dereağz1 and other material remains in its vicinity: from antiquity to the Middle Ages' (=Istanbuler Forschungen 40), Tübingen 1993“, in: Jahrbuch der Österreichischen Byzantinistik 46, 1996, S. 483-484.

Hild 2004: Friedrich Hild, „Lykien in den Notitiae episcopatuum“, in: Jahrbuch der Österreichischen Byzantinistik 54, 2004, S. 1-17.

Hill 1996: Stephen Hill, The early Byzantine churches of Cilicia and Isauria (=Birmingham Byzantine and Ottoman monographs 1), Aldershot 1996.

Iacobini 1994: Antonio Iacobini, „Città: area bizantina“, in: Enciclopedia dell'arte medievale 5, 1994, S. 33-48.

Işık 2000: Fahri Işık, Patara: the history and ruins of the capital city of Lycian league, Antalya 2000.

Ivison 2000: Eric A. Ivison, „Urban renewal and imperial revival in Byzantium (730-1025)“, in: Byzantinische Forschungen 26, 2000, S. 1-46.

Jerphanion 1928: Guillaume de Jerphanion, Mélanges d'archéologie anatolienne: monuments préhelléniques, gréco-romains, byzantins et musulmans de Pont, de Cappadoce et de Galatie (=Mélanges de 1'Université Saint-Joseph 13/1), Beirut 1928.

Jones 1964: Arnold H. M. Jones, The later Roman Empire 284-602, Oxford 1964.

Kaegi 2003: Walter Emil Kaegi, „, The earliest Muslim penetrations into Anatolia“, in: Anna Avramea/Euangelos Chrysos/Angeliki Laiou (Hrsg.), Byzantium: state and society. In memory of Nikos Oikonomides, Athen 2003, S. 269-282.

Kaplan 1992: Michel Kaplan, Les hommes et la terre à Byzance du $6^{e}$ au $11^{e}$ siècle: propriété et exploration du sol (=Byzantina Sorbonensia 10), Paris 1992.

Karwiese 1995: Stefan Karwiese, Groß ist die Artemis von Ephesos: die Geschichte einer der großen Städte der antiken Welt, Wien 1995. 
Kazanaki-Lappa 2002: Maria Kazanaki-Lappa, „Medieval Athens“, in: Angeliki E. Laiou (Hrsg.), The economic history of Byzantium from the seventh through the fifteenth century 2 (=Dumbarton Oaks studies 39/2), Washington, D.C. 2002, S. 639-646.

Každan 1977: Alexander Každan, „Rezension zu Clive Foss, ,Byzantine and Turkish Sardis“ (=Archaeological exploration of Sardis monographs 4), Cambridge, Mass. 1976“, in: Byzantina 9, 1977, S. 478-484.

Kazhdan 1988: Alexander Kazhdan, „The flourishing city of Euchaita?“, in: Fourteenth annual Byzantine studies conference, Houston 1988, Abstracts of papers, Washington, D.C. 1988, S. 4.

Kirsten 1958: Ernst Kirsten, Die byzantinische Stadt (=Berichte zum 11. internationalen Byzantinisten-Kongreß 5,3, München 1958), München 1958.

Koder 1993: Johannes Koder, Gemüse in Byzanz: die Versorgung Konstantinopels mit Frischgemüse im Lichte der Geoponika (=Byzantinische Geschichtsschreiber, Ergänzungsband 3), Wien 1993.

Krautheimer 1986: Richard Krautheimer, Early Christian and Byzantine architecture, 4. Aufl., durchgesehen von dems. u. S. Ćurčić, London 1986.

Laniado 2002: Avshalom Laniado, Recherches sur les notables municipaux dans l'empire protobyzantin (=Travaux et mémoires monographies 13), Paris 2002.

Lauffray 1983-1991: Jean Lauffray, Halabiyya-Zenobia: place forte du limes oriental et la HautMésopotamie au $\sigma^{e}$ siècle (=Bibliothèque archéologique et historique $119 \mathrm{u}$. 138), Paris 1983-1991.

Lefort 1993: Jacques Lefort, „Rural economy and social relations in the countryside“, in: Dumbarton Oaks Papers 47, 1993, S. 101-113.

Lefort 2002: Jacques Lefort, „The rural economy, seventh-twelfth centuries“, in: Angeliki E. Laiou (Hrsg.), The economic history of Byzantium from the seventh through the fifteenth century 1 (=Dumbarton Oaks studies 39/1), Washington, D.C. 2002, S. 231-310.

Liebeschuetz 1959: Wolf Liebeschuetz, ,The finances of Antioch in the fourth century AD“, in: Byzantinische Zeitschrift 52, 1959, S. 344-356. Reprint in: ders., From Diocletian to the Arab conquest: change in the late Roman Empire 12, London 1990.

Liebeschuetz 1972: John H. W. G. Liebeschuetz, Antioch: city and imperial administration in the later Roman Empire, Oxford 1972.

Liebeschuetz 1977: Wolf Liebeschuetz, „The defences of Syria in the sixth century“, in: D. Haupt (Hrsg.), Studien zu den Militärgrenzen Roms 2, Vorträge des 10. internationalen Limeskongresses in der Germania inferior, Xanten 1974 (=Bonner Jahrbücher, Beiheft 38), Köln 1977, S. 487-499. Reprint in: ders., From Diocletian to the Arab conquest: change in the late Roman Empire 20, London 1990.

Liebeschuetz 2001: John H. W. G. Liebeschuetz, Decline and fall of the Roman city, Oxford 2001.

Lightfoot 1994: Christopher S. Lightfoot, „Amorium excavations 1993: the sixth preliminary report“, in: Anatolian studies 44, 1994, S. 105-126.

Lightfoot 1997: Christopher S. Lightfoot, „The Amorium project: the 1995 excavation season“, in: Dumbarton Oaks Papers 51, 1997, S. 291-300.

Lightfoot 1998a: Christopher S. Lightfoot, „The survival of the cities in Byzantine Anatolia: the case of Amorium“, in: Byzantion 68, 1998, S. 56-71.

Lightfoot 1998b: Christopher S. Lightfoot, „,The public and domestic architecture of a thematic capital: the archaeological evidence from Amorion“, in: Byzantine Asia Minor $\left(6^{\text {th }}-12^{\text {th }}\right.$ cent. $)$ (=The Speros Basil Vryonis centre for the study of Hellenism, Hellenism: ancient, medieval, modern 27; Institute for Byzantine research, international symposium 6), Athen 1998, S. 303-320. 
Lilie 1976: Ralf-Johannes Lilie, Die byzantinische Reaktion auf die Ausbreitung der Araber: Studien zum Strukturwandel des byzantinischen Staates im 7. und 8. Jahrhundert (=Miscellanea Byzantina Monacensia 22), München 1976.

Lohmann 1997: Hans Lohmann, „Survey in der Chora von Milet: Vorbericht über die Kampagnen der Jahre 1994 und 1995“, in: Archäologischer Anzeiger 1997, S. 285-311.

Lohmann 1999: Hans Lohmann, „Zwischen Kaunos und Telmessos: Reisenotizen aus dem karisch-lykischen Grenzgebiet", in: Orbis terrarum 5, 1999, S. 43-83.

Lohmann 2001: Hans Lohmann, „Zwischen Kaunos und Telmessos: Addenda et Corrigenda“, in: Orbis terrarum 7, 2001, S. 217-222.

Loos 1978: Milan Loos, „Quelques remarques sur les communautés rurales et la grande propriété terrienne à Byzance ( $7^{\mathrm{e}}-11^{\mathrm{e}}$ siècles)“, in: Byzantinoslavica 39, 1978, S. 3-18.

Machatschek/Schwarz 1981: Alois Machatschek/Mario Schwarz, Bauforschungen in Selge (=Österreichische Akademie der Wissenschaften, philosophisch-historische Klasse, Denkschriften 152; Tituli Asiae Minoris, Ergänzungsband 9), Wien 1981.

Maguire 2000: Henry Maguire, „Gardens and parks in Constantinople“, in: Dumbarton Oaks Papers 54, 2000, S. 251-264.

Mamboury 1933: Ernest Mamboury, Ankara: guide touristique, Ankara 1933.

Mango 1990: Cyril Mango, Le développement urbain de Constantinople (4e - $7^{e}$ siècles) (=Travaux et mémoires monographies 2), Paris ${ }^{2} 1990$.

Manière-Lévêque 2002: Anne-Marie Manière-Lévêque, „La maison de l'acropole lycienne à Xanthos", in: Anatolia antiqua 10, 2002, S. 235-243.

Mansel 1963: Arif Müfid Mansel, Die Ruinen von Side, Berlin 1963.

Mansel 1978: Arif Müfid Mansel, Side: 1947-1966 yılları kazıları ve araştırmalarının sonuçları (=Türk tarih kurumu yayınları 5/33; Antalya bölgesinde araştırmalar 10), Ankara 1978.

Marksteiner 2002: Thomas Marksteiner, „Untersuchungen an den westlichen Stadtmauern von Xanthos“, in: Anatolia antiqua 10, 2002, S. 197-216.

Marksteiner/Niewöhner 2004: Thomas Marksteiner/Philipp Niewöhner, „Die Kirche von Istlada in Lykien“, in: Mitteilungen zur Christlichen Archäologie 10, 2004, S. 21-51.

Martens/Poblome/Waelkens/Vanhaverbeke 2004: Femke Martens/Jeroen Poblome/Marc Waelkens/Hannelore Vanhaverbeke, „Late antiquity in the territory of Sagalassos“, in: William Boden/Luke Lavan/Carlos Machado (Hrsg.), Recent research on the late antique countrysi$d e$ (=Late antique archaeology 2), Leiden 2004, S. 247-279.

Milet 1, 6: Armin v. Gerkan, Der Nordmarkt und der Hafen an der Löwenbucht (=Milet 1, 6), Berlin 1922.

Milet 1, 7: Hubert Knackfuss, Der Südmarkt und die benachbarten Bauten (=Milet 1, 7), Berlin 1924 .

Milet 2, 3: Armin v. Gerkan, Die Stadtmauern (=Milet 2, 3), Berlin 1935.

Milet 6: Volkmar v. Graeve (Hrsg.), Inschriften von Milet (=Milet 6, 1 u. 2), Berlin 1997-1998.

Möllers 2004: Sabine Möllers, „Nikaia“, in: Reallexikon zur byzantinischen Kunst 6, Lieferung 47, 2004, Sp. 976-1013.

Morganstern 1983: James Morganstern, The Byzantine church at Dereağzı and its decoration (=Istanbuler Mitteilungen, Beiheft 29), Tübingen 1983.

Morganstern 1993: James Morganstern (Hrsg.), The fort at Dereağzı and other material remains in its vicinity: from antiquity to the Middle Ages (=Istanbuler Forschungen 40), Tübingen 1993. 
Morrisson 2001: Cécile Morrisson, „Survivance de l'économie monétaire à Byzance ( $7^{\mathrm{e}}-9^{\mathrm{e}}$ siècle)“, in: Eleonora Kontoura-Galake (Hrsg.), The dark centuries of Byzantium ( $7^{\text {th }} 9^{\text {th }} c$ c.), Kolloquium Athen 1999 (The national Hellenic research foundation, Institute for Byzantine research, international symposium 9), Athen 2001, S. 377-397.

Morrisson 2002: Cécile Morrisson, „Byzantine money: its production and circulation“, in: Angeliki E. Laiou (Hrsg.), The economic history of Byzantium from the seventh through the fifteenth century (=Dumbarton Oaks studies 39/3), Washington, D.C. 2002, S. 909-966.

Mouterde/Poidebard 1945: René Mouterde/Antoine Poidebard, Le limes des Chalcis: organisation de la steppe en haute Syrie Romaine (=Bibliothèque archéologique et historique 38), Paris 1945.

Müller-Wiener 1961: Wolfgang Müller-Wiener, „Mittelalterliche Befestigungen im südlichen Jonien“, in: Istanbuler Mitteilungen 11, 1961, S. 5-122.

Müller-Wiener 1962: Wolfgang Müller-Wiener, „Die Stadtbefestigungen von Izmir, Siğacık und Çandarlı: Bemerkungen zur mittelalterlichen Topographie des nördlichen Jonien“, in: Istanbuler Mitteilungen 12, 1962, S. 59-114.

Müller-Wiener 1967: Wolfgang Müller-Wiener, „Das Theaterkastell von Milet“, in: Istanbuler Mitteilungen 17, 1967, S. 279-290.

Müller-Wiener 1982: Wolfgang Müller-Wiener, „Milet 1981“, in: Istanbuler Mitteilungen 32, 1982, S. 5-29.

Müller-Wiener 1986: Wolfgang Müller-Wiener, „Von der Polis zum Kastron: Wandlung der Städte im ägäischen Raum von der Antike zum Mittelalter“, in: Gymnasium 93, 1986, S. 435-475.

Müller-Wiener 1989: Wolfgang Müller-Wiener, „Pegai-Karabiga, eine mittelalterliche Stadt“, in: Nezih Başgelen/Mihin Lugal (Hrsg.), Festschrift für Jale Inan armağanı, Istanbul 1989, S. 169-176, Taf. 71-76.

Müller-Wiener 1999: Wolfgang Müller-Wiener, „Milet“, in: Reallexikon zur byzantinischen Kunst 6, Lieferung 43, 1999, Sp. 362-377.

Naumann 1985: Claudia Naumann, „Die mittelalterliche Festung von Aizanoi-Çavdarhisar“, in: Istanbuler Mitteilungen 35, 1985, S. 275-294.

Naumann/Selâhattin 1950: Rudolf Naumann/Kantar Selâhattin, „Die Agora von Smyrna: Bericht über die in den Jahren 1932-1941 auf dem Friedhof Namazgâh zu Izmir von der Museumsleitung in Verbindung mit der türkischen Geschichtskommission durchgeführten Ausgrabungen“, in: Kleinasien und Byzanz: Gesammelte Aufsätze zur Altertumskunde und Kunstgeschichte (=Istanbuler Forschungen 17), Berlin 1950, S. 69-114.

Nethercott/Ruggieri 1986: F. Nethercott/Vincenzo Ruggieri, „The metropolitan city of Syllaion and its churches“, in: Jahrbuch der Österreichischen Byzantinistik 36, 1986, S. 133-156.

Oikonomides 1966: Nikolas Oikonomides, „The donations of castles in the last quarter of the $11^{\text {th }}$ century“, in: Peter Wirth (Hrsg.), Polychronion, Festschrift Franz Dölger zum 75. Geburtstag (=Forschungen zur griechischen Diplomatik und Geschichte 1), Heidelberg 1966, S. 413-417.

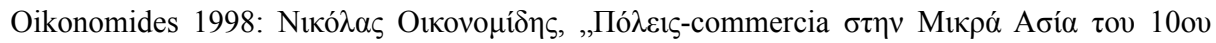
alóva“, in: Byzantine Asia Minor ( $6^{\text {th }}-12^{\text {th }}$ cent.) (=The Speros Basil Vryonis centre for the study of Hellenism, Hellenism, ancient, medieval, modern 27; Institute for Byzantine research, international symposium 6), Athen 1998, S. 67-72.

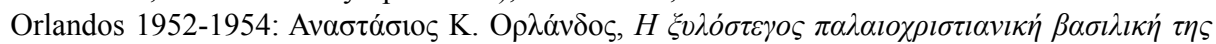

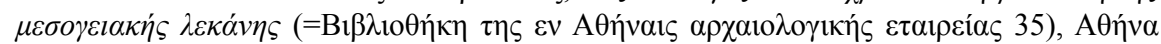
1952-1954. 
Ostrogorsky 1959: Georgije Ostrogorsky, „Byzantine cities in the early Middle Ages“, in: Dumbarton Oaks Papers 13, 1959, S. 45-66.

Ousterhout 2001: Robert Ousterhout, "The architecture of iconoclasm: the buildings", in: Leslie Brubaker/John Haldon, Byzantium in the iconoclast era (ca 680-850): the sources (=Birmingham Byzantine and Ottoman monographs 7), Aldershot 2001, S. 3-19.

Patlagean 1987: Évelyne Patlagean, „Byzantium in the tenth and eleventh centuries“, in: Paul Veyne (Hrsg.), A history of private life 1: from pagan Rome to Byzantium, Cambridge, MA 1987, S. 551-641.

Peschlow 1993: Urs Peschlow, „Spuren des byzantinischen Mittelalters in Lykien“, in: Jürgen Borchhardt/Gerhard Dobesch (Hrsg.), Akten des 2. internationalen Lykien-Symposions, Wien 1990, 2 (=Österreichische Akademie der Wissenschaften, philosophisch-historischen Klasse, Denkschriften 235; Tituli Asiae Minoris, Ergänzungsband 18), Wien 1993, S. 59-67.

Peschlow 2002: Urs Peschlow, „Myra“, in: Reallexikon zur byzantinischen Kunst 6, Lieferung 46, 2002, Sp. 806-839.

Peschlow 2003: Urs Peschlow, „The churches of Nicaea/Iznik“, in: Isil Akbaygil/Oktay Aslanapa/Halil Inalc1k (Hrsg.), Iznik throughout history, Kolloquium Iznik 2000, Istanbul 2003, S. 201-218.

Poulter 1992: Andrew Poulter, „The use and abuse of urbanism in the Danubian provinces during the late Roman Empire“, in: John Rich (Hrsg.), The city in late antiquity (=Leicester-Nottingham studies in ancient society 3), London 1992, S. 99-135.

Poulter 1995: Andrew G. Poulter, Nicopolis ad Istrum: a Roman, late Roman and early Byzantine city. Excavations 1985-1992 (=The Journal of Roman Studies monographs 8), London 1995.

Poulter 1999: Andrew G. Poulter, Nicopolis ad Istrum: a Roman to early Byzantine city. The pottery and glass (=Reports of the Research Committee of the Society of Antiquaries of London 57), London 1999.

Poulter 2000: Andrew G. Poulter, „The Roman to Byzantine transition in the Balkans: preliminary results in Nicopolis and its hinterland“, in: Journal of Roman Archaeology 13, 2000, S. 346-358.

Poulter 2002: Andrew G. Poulter, „Economic collapse in the countryside and the consequent transformation of city into fortress in late antiquity“, in: Lukas de Blois/John Rich (Hrsg.), The transformation of economic life under the Roman empire. Proceedings of the second workshop of the international network Impact of empire (Roman Empire, c. 200 B.C. - A.D. 476), Nottingham 2001, Amsterdam 2002, S. 244-266.

Poulter 2004: Andrew G. Poulter, „Cataclysm on the lower Danube: the destrucion of a complex Roman landscape“, in: Neil Christie (Hrsg.), Landscapes of change: rural evolution in late antiquity and the early Middle Ages, Aldershot 2004, S. 223-253.

Pralong 1984: Annie Pralong, „Les remparts de Philadelphie“, in: Philadelphie et autres études (=Byzantina Sorbonensia 4), Paris 1984, S. 101-126.

Pringle 1981: Denys Pringle, The defence of Byzantine Africa from Justinian to the Arab conquest: an account of the military history and archaeology of the African provinces in the sixth and seventh centuries (=British Archaeological Reports, International Series 99), Oxford 1981.

Ratté 2001: Christopher Ratté, „The urban development of Aphrodisias in late antiquity“, in: David Parrish (Hrsg.), Urbanism in western Asia Minor: new studies on Aphrodisias, Ephesos, Hierapolis, Pergamon, Perge and Xanthos, Kolloquium Washington, D.C. 1998 (=Journal of Roman Archaeology, Ergänzungsband 45), Portsmouth, R. I. 2001, S. 116-147.

Restle 1990: Marcel Restle, „Konstantinopel“, in: Reallexikon zur byzantinischen Kunst 4, 1990, Sp. 366-737. 
Rheidt 1997: Klaus Rheidt, „Römischer Luxus - anatolisches Erbe: Aizanoi in Phrygien - Entdeckung, Ausgrabung und neue Forschungsergebnisse“, in: Antike Welt 28, 1997, S. 479-499.

Rheidt 2001: Klaus Rheidt, „Aizanoi: die Ausgrabungen und Forschungen 1997 bis 2000“, in: Archäologischer Anzeiger 2001, S. 241-267.

Rheidt 2002: Klaus Rheidt, „The urban economy of Pergamon“, in: Angeliki E. Laiou (Hrsg.), The economic history of Byzantium from the seventh through the fifteenth century 2 (=Dumbarton Oaks studies 39/2), Washington, D.C. 2002, S. 623-629.

Rheidt 2003: Klaus Rheidt, „Archäologie und Spätantike in Anatolien: Methoden, Ergebnisse und Probleme der Ausgrabungen in Aizanoi“, in: Gunnar Brands/Hans-Georg Severin (Hrsg.), Die spätantike Stadt und ihre Christianisierung, Kolloquium Halle 2000 (=Spätantike - frühes Christentum - Byzanz: Kunst im ersten Jahrtausend, Reihe B: Studien und Perspektiven 11), Wiesbaden 2003, S. 239-247.

Roueché 1989: Charlotte Roueché, Aphrodisias in late antiquity: the late Roman and Byzantine inscriptions including texts from the excavations at Aphrodisias conducted by Kenan T. Erim (=The Journal of Roman Studies, monographs 5), London 1989.

Ruggieri 1995a: Vincenzo Ruggieri, L'architettura religiosa nell'impero Bizantino (fine 6-9 secolo) (=Accademia angelica costantiniana, Saggi studi testi 2), Soveria Mannelli 1995.

Ruggieri 1995b: Vincenzo Ruggieri, „Appunti sulla continuità urbana di Side in Panfilia“, in: Orientalia Christiana Periodica 61, 1995, S. 95-116.

Ruggieri 2003: Vincenzo Ruggieri, Il golfo di Keramos: dal tardo-antico al medioevo bizantino, Soveria Mannelli 2003.

Russel 1986: James Russel, „Transformations in early Byzantine urban life: the contributions and limitations of archaeological evidence", in: The $17^{\text {th }}$ international Byzantine congress, Washington, D.C. 1986, major papers, New Rochelle NY 1986, S. 137-154.

Russel 1999: James Russel, „The military garrison of Anemurium during the reign of Arcadius“, in: Atti del 11 congresso internazionale di epigrafia greca e latina, Roma 1997 1, Rom 1999, S. 721-728.

Russel 2001: James Russel, „The Persian invasions of Syria/Palestine and Asia Minor in the reign of Heraclius: archaeological and numismatic evidence", in: Eleonora Kountoura-Galake (Hrsg.), The dark centuries of Byzantium $\left(7^{\text {th }} 9^{\text {th }}\right.$ c.), Kolloquium Athen 1999 (The national Hellenic research foundation, Institute for Byzantine research, international symposium 9), Athen 2001, S. 41-71.

Russo 2002: Eugenio Russo, „Considérations sur la sculpture architecturale et décorative à Nicée à l'époque paléochrétienne“ in: Bizantinistica. Rivista di studi bizantini e slavi Ser. 2, Bd. 4, 2002, S. 1-11.

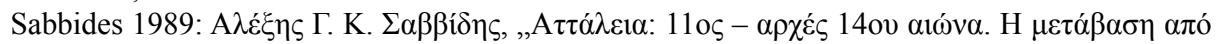

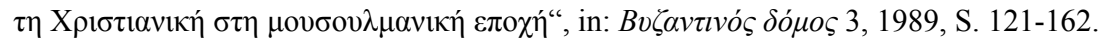

Saradi-Mendelovici 1988: Hélène Saradi-Mendelovici, „The demise of the ancient city and the emergence of the mediaeval city in the eastern Roman Empire", in: Echos du monde classique/Classical views 32, N.S. 7, 1988, S. 365-401.

Schreiner 1998: Peter Schreiner, „Eine Schlacht bei Mylasa im Jahre 1079/1080? Ein Beitrag zur Erforschung der Region von Milet", in: Evwvxía. Mélanges offerts à Hélène Ahrweiler (=Byzantina Sorbonensia 16), Paris 1998, S. 611-617.

Snively 2001: Carolyn S. Snively, „Iustiniana Prima (Caričin Grad)“, in: Reallexikon für Antike und Christentum 19, 2001, S. 638-668.

Spieser 1989: Jean-Michel Spieser, „L'évolution de la ville byzantine de l'époque paléochrétienne à l'iconoclasme“, in: Pièrre Zech (Hrsg.), Hommes et richesses dans l'empire byzantin 1: $4^{e}-7^{e}$ siècle, Paris 1989, S. 97-106. 
Talbot 2002: Alice-Mary Talbot, „Byzantine monastic horticulture: the textual evidence“, in: Antony Littlewood/Henry Maguire/Joachim Wolschke-Bulmahn (Hrsg.), Byzantine garden culture, Washington, D.C. 2002, S. 37-67.

Thür 2003: Hilke Thür, „Das spätantike Ephesos: Aspekte zur Frage der Christianisierung des Stadtbilds“, in: Gunnar Brands/Hans-Georg Severin (Hrsg.), Die spätantike Stadt und ihre Christianisierung, Kolloquium Hall 2000 (Spätantike - frühes Christentum - Byzanz: Kunst im ersten Jahrtausend, Reihe B: Studien und Perspektiven 11), Wiesbaden 2003, S. 259-273.

TIB 2: Friedrich Hild/Marcel Restle, Tabula Imperii Byzantini 2: Kappadokien (=Österreichische Akademie der Wissenschaften, philosophisch-historische Klasse, Denkschriften 149), Wien 1981.

TIB 4: Klaus Belke, Tabula Imperii Byzantini 4: Galatien und Lykaonien (=Österreichische Akademie der Wissenschaften, philosophisch-historische Klasse, Denkschriften 172), Wien 1984.

TIB 5: Hansgerd Hellenkemper/Friedrich Hild, Tabula Imperii Byzantini 5: Kilikien und Isaurien (=Österreichische Akademie der Wissenschaften, philosophisch-historische Klasse, Denkschriften 215), Wien 1990.

TIB 7: Klaus Belke/Norbert Mersich, Tabula Imperii Byzantini 7: Phrygien und Pisidien (=Österreichische Akademie der Wissenschaften, philosophisch-historische Klasse, Denkschriften 211), Wien 1990.

TIB 8: Hansgerd Hellenkemper/Friedrich Hild, Tabula Imperii Byzantini 8: Lykien und Pamphylien (=Österreichische Akademie der Wissenschaften, philosophisch-historische Klasse, Denkschriften 320), Wien 2004.

TIB 9: Klaus Belke, Tabula Imperii Byzantini 9: Paphlagonien und Honorias (=Österreichische Akademie der Wissenschaften, philosophisch-historische Klasse, Denkschriften 249), Wien 1996.

Treadgold 1988: Warren Treadgold, The Byzantine revival 780-842, Stanford, Cal. 1988.

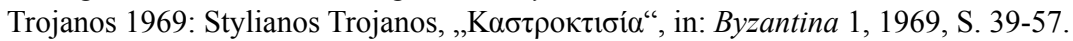

Trombley 1985: Frank R. Trombley, „The decline of the seventh-century town: the exception of Euchaita", in: Speros Vryonis (Hrsg.), Byzantine studies in honor of Milton V. Anastos (=Byzantina kai metabyzantina 4), Kastoria 1985, S. 65-90.

Trombley 1993: Frank R. Trombley, „Byzantine ,Dark age' cities in comparative context”, in:

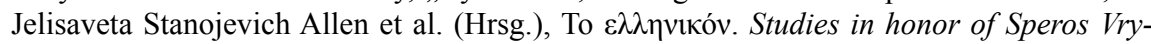
onis 1: Hellenic antiquity and Byzantium, New Rochelle NY 1993, S. 429-449.

Trombley 1998: Frank R. Trombley, „War, society and popular religion in Byzantine Anatolia $\left(6^{\text {th }}-13^{\text {th }}\right.$ centuries)", in: Byzantine Asia Minor ( $6^{\text {th }}-12^{\text {th }}$ cent. $)$ (=The Speros Basil Vryonis centre for the study of Hellenism, Hellenism: ancient, medieval, modern 27; Institute for Byzantine research, international symposium 6), Athen 1998, S. 97-139.

Vanhaverbeke/Waelkens 2003: Hannelore Vanhaverbeke/Marc Waelkens, The chora of Sagalassos: the evolution of the settlement pattern from prehistoric until recent times (=Studies in eastern Mediterranean archaeology 5), Turnhout 2003.

Vermoere 2004: Marleen Vermoere, Holocene vegetation history in the territory of Sagalassos (southwest Turkey): a palynological approach (=Studies in eastern Mediterranean archaeology 6), Turnhout 2004.

Verzone 1971: Paolo Verzone, „Hierapolis“, in: Reallexikon zur byzantinischen Kunst 2, 1971, Sp. 1203-1223.

Vie de Théodore: André-Jean Festugière (Hrsg.), Vie de Théodore de Sykéôn (=Subsidia hagiographica 48), Bruxelles 1970. 
Vroom 2004: Joanita Vroom, „Late antique pottery, settlement and trade in the eastern Mediterranean: a preliminary comparison of ceramics from Limyra (Lycia) and Boetia”, in: William Boden/Luke Lavan/Carlos Machado (Hrsg.), Recent research on the late antique countryside (=Late antique archaeology 2), Leiden 2004, S. 281-331.

Weiß 1977: Günter Weiß, „Antike und Byzanz: die Kontinuität der Gesellschaftsstruktur“, in: Historische Zeitschrift 224, 1977, S. 529-560.

Whittow 1995: Marc Whittow, „Rural fortifications in western Europe and Byzantium, tenth to twelfth century", in: Byzantinische Forschungen 21, 1995, S. 57-74.

Wulf 2003: Ulrike Wulf, „Akören: zur Stadtplanung und Wohnarchitektur zweier Siedlungen in Kilikien“, in: Gunnar Brands/Hans-Gerd Severin (Hrsg.), Die spätantike Stadt und ihre Christianisierung, Kolloquium Halle 2000 (=Spätantike - frühes Christentum - Byzanz, Kunst im ersten Jahrtausend, Reihe B: Studien und Perspektiven 11), Wiesbaden 2003, S. 299-307.

Zäh 2003: Alexander Zäh, „Anastasioúpolis? Der Ruinenort in der Bucht von Ala Kilise in Karien - eine spätantike Hafenstadt“", in: Antike Welt 34/1, 2003, S. 43-48.

Zanini 2003: Enrico Zanini, „The urban ideal and urban planning in Byzantine new cities of the sixth century AD“, in: William Bowden/Luke Lavan (Hrsg.), Theory and practice in late antique archaeology (=Late antique archaeology 1), Leiden 2003, S. 196-223.

Zuckerman 1988: Constantin Zuckerman, „The reign of Constantine V in the miracles of St. Theodore the recruit (BHG 1764)“, in: Revue des études byzantines 46, 1988, S. 191-210. 



\title{
Stadt oder „Stadt“: Frühbyzantinische Siedlungsstrukturen im nördlichen Illyricum
}

\author{
Mihailo MilinKović
}

\section{Einführung}

Das hier zu behandelnde Gebiet (Serbien, Bosnien und Herzegowina, Mazedonien) ist Teil der nördlichen, zentralen und westlichen Balkanhalbinsel und gehörte in frühbyzantinischer Zeit zu Illyricum (Provinzen Moesia I, Dacia Ripensis, Dacia Mediterranea, Dardania, Dalmatia, Praevalis, Macedonia I und Macedonia II). Die Vorgänge, von denen hier die Rede sein soll, beziehen sich auf die Zeit vom Beginn der Völkerwanderung um 375 bis zum Anfang des 7. Jahrhunderts, vor allem aber auf den chronologischen Rahmen vom Ende der ersten Hälfte des 5. Jahrhunderts bzw. von der durch die Hunneneinfälle verursachten Zäsur 441-447 bis zum Anfang des 7. Jahrhunderts, als nach der slawischen Landnahme in den genannten Gebieten das byzantinisch/romäische Staatssystem für einige Jahrhunderte zusammenbrach, was in Zerstörungshorizonten auf den Ausgrabungsstätten, in einer Unterbrechung des Münzumlaufs und der Distribution von Produkten und in anderem mehr seinen Niederschlag fand.

Zur Einführung soll ein Blick auf die Vorgänge in vorrömischer und römischer Zeit geworfen werden. ${ }^{1}$ Das vorrömische ethnische Substrat bildeten in den genannten Gebieten illyrische, thrakische, keltische, paeonische und mazedonische Stämme. Aufgrund ihrer Lage kamen Küstenregionen wie diejenigen an der Adria durch die griechische Kolonisation im 4. Jahrhundert v.Chr. und der späteren römischen Expansion schon früh in Kontakt mit den mediterranen Zivilisationen. Im Inneren des Balkans waren es nur die höher gestellten Persönlichkeiten, die sich mit griechischen Importgütern umgaben. An der Wende vom 3. zum 2. vorchristlichen Jahrhundert kamen die Römer durch die Dardaner zum ersten Mal in Berührung mit Stämmen aus dem zentralen Balkangebiet. Die einheimische Bevölkerung lebte zu diesem Zeitpunkt in Dörfern und nutzte Befestigungen. Aus dem Gebiet nördlich von Mazedonien sind mit Ausnah-

1 Für Angaben zur geographischen und historischen Einführung vgl. neben anderen angeführten Werken Milinković 2005. 
me vielleicht der Siedlungsräume der Dardaner noch keine „Städte“ überliefert. ${ }^{2}$ Zum Unterschied von den an das Mittelmeer anlehnenden Zonen in Mazedonien und an der Adria kam es im tieferen kontinentalen Hinterland zu umfangreicheren Kontakten mit der griechischen oder römischen Welt erst später, um Christi Geburt, als die Legionen an die Donau stiessen. Von diesem Moment an setzt in den genannten Gegenden ein Romanisierungsprozess ein, der mit Unterbrechungen und Schwankungen etwa 600 Jahre bis zur slawischen Landnahme andauerte und wie es scheint an den meisten Orten Erfolg hatte. In den südlichen und nordöstlichen Teilen der Balkanhalbinsel, unterhalb der sogenannten Jireček-Linie, kann demgegenüber von einem Hellenisierungsprozess gesprochen werden, da in diesen Gebieten das Griechische die Kultursprache war. Anscheinend haben die „Ureinwohner“ des Balkans innerhalb bestimmter Sprachinseln ihr Idiom bis zum Ende der Römerherrschaft bewahren können, was gegen eine zu strikt aufgefasste römisch-griechische Sprachgrenze spricht. ${ }^{3}$

In antiker Zeit waren die ökonomischen Grundlagen dieser Reichsgebiete der Ackerbau und die Viehwirtschaft sowie als örtliches Charakteristikum der Bergbau, da Serbien über die Jahrtausende eine terra metallica war, was auch für Bosnien und Mazedonien gilt. Die Landwirtschaft ermöglichte zeitweise Exporte wie z.B. von Getreide aus Moesien. ${ }^{4}$ Der sich seit dem 2. Jahrhundert entwickelnde Großgrundbesitz gehörte zum Teil dem Kaiser und Angehörigen des Senatorenstandes. Die Bergbauaktivitäten sind an einigen Beispielen erforscht, vor allem in Zentral- und Ostserbien, obwohl sie auch in West- und Südserbien sowie in Bosnien von überregionaler Bedeutung waren. Es wurden Silber, Blei, Zink, Kupfer, Eisen und Gold gefördert. ${ }^{5}$ Daneben sind aus der späten Kaiserzeit auch Steinbrüche überliefert. Einige davon sind aus christlichen Heiligenlegenden erschließbar wie jener über die Vier Gekrönten, die Quattuor Coronati. ${ }^{6}$ An einigen Orten wie in Ćuprija/Horreum Margi oder in Niš/Naissus befanden sich Werkstätten. Gleiches gilt für Sremski Petrovci/Bassianae in der Pannonia Syrmiensis. In Sirmium, Horreum Margi und Naissus dienten diese zur Herstellung von Waffen und Militärzubehör (fabricae), in Naissus auch von Silbergeschirr und in Bassianae von Textilien.

2 Die allgemeine ökonomische Grundlage in der römischen Zeit zusammengefasst bei Mirković 1981, 77-88.

3 Als Beispiel für eine unvollendete Romanisierung, zumindest in sprachlicher Hinsicht, kann man die an der Wende des 4. zum 5. Jahrhundert thrakisch sprechenden Bessen im heutigen serbisch-bulgarischen Grenzgebiet nennen. Vgl. Fiedler 1992, 44-45.; Schramm 1999, 70-74.

4 Mirković 1981, 85.

5 Beleg für landwirtschaftliche Villen und Bergbau bei Dušanić 1995, 219-225; vgl. auch die Beiträge von V. Kondić, P. Petrović, M. Tomović im selben Sammelband (Jovanović 1995).

6 Vgl. Mijović 1967, 53-60; Seeliger 2001, 780-781. 
Abgesehen von legendenhaften Überlieferungen, stammen die ersten ausführlicheren Zeugnisse des Christentums aus der Zeit der diokletianischen Verfolgungen, denen manche kirchliche Oberhäupter aus Illyricum wie der Bischof von Sirmium und viele andere zum Opfer fielen. ${ }^{7}$

Im Allgemeinen ist davon auszugehen, dass die Randzonen des hier zu behandelnden Gebietes besser romanisiert bzw. hellenisiert waren als das Binnenland. Zu den Randzonen ist auch die Limeslinie entlang der Donau zu rechnen, wo der Romanisierungsprozess ebenfalls intensiver als im Hinterland ablief.

\section{Die Zäsur der Hunnenzeit und das Forschungsproblem der zweiten Hälfte des 5. Jahrhunderts}

Die erste Zäsur in dieser Entwicklung, die weit reichende Folgen hatte, wurde durch die verheerenden Vorstöße der Hunnen in den Jahren 441/442 bzw. 447 bewirkt. Sie stießen zu dieser Zeit bis zu den Thermophylen vor. Dutzende von Städten und Befestigungen wurden eingenommen und in einem nie zuvor gekannten Ausmaß zerstört. Priskos' bildhafte Beschreibung der Ruinen von Naissus und der unbegrabenen Toten kurz nach dem Sturm, ${ }^{8}$ legt neben einem Hiatus in der archäologischen Stratigraphie mancher Fundorte Zeugnis ab für die verheerenden Auswirkungen dieser Raubzüge, nach denen das Kaiserreich allem Anschein nach für einige Jahrzehnte die volle Kontrolle über Nordillyricum verlor. ${ }^{9}$ Nicht umsonst verlangte Attila, dass die Reichsgrenze mit den Markt- bzw. Handelsplätzen von der Donaustrecke zwischen Belgrad/Singidunum und Svištov/Novae im heutigen Bulgarien um fünf Tagesmärsche nach Süden verschoben werden solle. Es bleibt unklar, inwieweit diese Forderung erfüllt wurde, da Attila im nächsten Jahr wieder die Donaulinie als Grenze vorschlug. ${ }^{10}$ Kaiser Leo I hatte im Jahre 458 auf seiner Adressenliste jedenfalls keine Bischöfe in Moesia Prima und Dacia Ripensis mehr, denen er die Beschlüsse des Konzils von Chalkedon von 451 hätte verkünden können. ${ }^{11}$ Dies scheint zu belegen, dass trotz des Zerfalls des Hunnenreiches nach 454 das Imperium noch über Jahre und Jahrzehnte hinweg nicht imstande war, diese nördlichen Gebiete unter ständiger und direkter Kontrolle zu halten. Etwa in dieser Zeit oder etwas früher könnte auch der Beginn der ostgermanischen Nekropole „Burdelj“ im Stadtgebiet von Viminatium liegen, die dann während der zweiten Hälfte des 5. Jahrhunderts weiterbelegt wurde. Es stellt sich die Frage, wer diese Gruppe von

\footnotetext{
7 Popović 2003, 259-264.

8 Fontes 1955, 13.

9 Vgl. Poulter 1992, 123-124.

10 Fontes 1955, 13, Anm. 11.

11 Ferjančić 1974, 107.
} 
Barbaren auf Reichsgebiet angesiedelt hat..$^{12}$ Als die Goten um 473 von Pannonien auf den Balkan vordrangen, beobachteten zwar kaiserliche Truppen zusammen mit ihren sarmatischen Föderaten den Vorgang, schritten aber nicht ein, was auf eine - wenn auch fragwürdige - Präsenz des Imperiums im Nordillyricum hindeutet. ${ }^{13}$ Seit dem Beginn der Romanisierung in Inneren des Balkans scheint der Hunnensturm der stärkste Einschnitt gewesen zu sein. Nach ihm war jedoch eine Erholung und Weiterentwicklung immer noch möglich, wenn auch in neuer Form. Einige Siedlungen wie diejenige in Pazarište bei Novi Pazar in Südwestserbien sollen - zumindest nach M. Popović - ihre Kontinuität bewahrt haben. ${ }^{14}$ Wie das Verhältnis von zerstörten zu intakt gebliebenen Ansiedlungen aussah, bleibt als Desiderat künftiger Forschung vorbehalten.

Siedlungsunterbrechungen, die sich auf das Ende des 4. sowie auf den Anfang und die erste Hälfte des 5. Jahrhunderts beziehen, sind bei Ausgrabungen von Landvillen, Städten und anderen römischen Fundstellen in Serbien und Mazedonien beobachtet worden, so z.B. am Limes, in Singidunum und Sirmium, in Čačak und dessen Umland im westlichen Zentralserbien sowie in Stobi und Heracleia Lyncestis. ${ }^{15}$ Obwohl die genaue chronologische Bestimmung dieser Zerstörungshorizonte noch der Prüfung bedarf, endet die Laufzeit vieler Siedlungen in den Tallagen etwa am Beginn bzw. in der ersten Hälfte des 5. Jahrhunderts. Dies wird durch Münzfunde belegt, und soweit dies an einzelnen Orten feststellbar war, kann man im 5. Jahrhundert in den Tallagen weder von einer Erneuerung noch von einer reduzierten Fortdauer der Besiedlung sprechen. Eine Wiederbelebung und daher mittelbare Kontinuität der autochtonen, lateinisch sprechenden, christlichen Bevölkerung des Nord- und Zentralillyricums und wohl auch Dalmatiens sollte nach heutigem Forschungsstand mit einem anderen zeitlichen und historischen Umfeld in Verbindung gebracht werden, und zwar vor allem mit dem 6. Jahrhundert und der spätestens nach 530 einsetzenden justinianischen Erneuerung. ${ }^{16}$ Diese war es, die vor allem in den neu gewählten Höhenpositionen und Berglagen ein Weiterbestehen der ursprünglich an die Mittelmeerzivilisation gebundenen Lebensweise für einige weitere Jahrzehnte, manchmal für fast ein Jahrhundert bewirkte. Das schließt gewisse vorangehende Entwicklungen gegen Ende des 5. Jahrhunderts nicht

12 Über Burdelj siehe Zotović 1981, 95-115. Lj. Zotović hat das gesamte Material aus der Nekropole in das späte 5. Jahrhundert datiert und mit den Ostgoten in Verbindung gebracht. Abgesehen von der unsicheren ethnischen Deutung kann der Beginn des Gräberfeldes „Burdelj“ etwa in die Mitte des 5. Jahrhunderts oder etwas davor gesetzt werden. Die Bestatteten könnte man am ehesten unter ostgermanischen Gruppierungen suchen, die bereits Akkulturisationsprozessen ausgesetzt waren.

13 Wolfram 1990, 268.

14 Popović 1999, 294.

15 Vgl. Vasić 1993, 15.

16 Für den Beginn der großen Bauaktion vgl. Angaben aus der Novelle XI, wo von Iustiniana Prima und erneuerten Befestigungen beidseits der Donau gesprochen wird. Kondić-Popović $1977,371$. 
aus. Besiedlungshinweise aus der zweiten Hälfte des 5. Jahrhunderts sind jedoch zurzeit in Serbien archäologisch kaum fassbar. Dies könnte verschiedene Ursachen haben. Neben möglichen methodologischen Forschungsproblemen käme in Betracht, dass die verbliebene, zerstreute romanische bzw. romäische Bevölkerung bereits auf geschützten Bergpositionen lebte, ohne dass diese Orte anfangs fest ummauert waren. Beim jetzigen Forschungsstand muss dies aber eine Hypothese bleiben. Nach ersten Resultaten von Probegrabungen, scheint ein guter Teil der befestigten Höhenanlagen einphasig zu sein, mit einer Entstehungs- und Nutzungszeit im 6. und eventuell zu Beginn des 7. Jahrhunderts, meist ohne Vorgängerphasen und Überlagerungen älterer Besiedlung. Nur an einigen wenigen Orten wurden Befestigungen aus dem 4. Jahrhundert erneuert. An anderen wiederum ging das Leben nach einem Hiatus im frühen Mittelalter weiter. Die vorgeschichtlichen Vorgängerphasen werden hier außer Acht gelassen.

\section{Das Siedlungsmuster in den zentralen, nördlichen und nordwestlichen Balkangebieten im 6. Jahrhundert}

\section{Forschungsgeschichte}

Das Siedlungsmuster des 6. Jahrhunderts im Inneren des Balkans ist vor allem durch die Feldforschung bereits besser bekannt geworden, obwohl die meisten Objekte nur durch Prospektion und kleinere Grabungen untersucht wurden. Daneben gibt es einige Fundstätten, auf denen durch großflächige Ausgrabungen wichtige Teile von Stadtoder Befestigungsstrukturen aufgedeckt wurden. Beispiele sind Gradsko/Stobi (Abb. 1) und Bitola/Heracleia Lyncestis in Mazedonien (Abb. 2), Mogorjelo in der Herzegowina (Abb. 3), Gamzigrad/Romuliana in Nordostserbien (Abb. 4, Abb. 5) und Caričin Grad/Iustiniana Prima? in Südserbien ${ }^{17}$. Dabei muss bemerkt werden, dass sich die großflächigen Ausgrabungen meistens auf größere Siedlungen, Städte und Residenzen beschränkten. Die kleineren und entlegenen Höhenanlagen, ausgenommen Vrsenice in Südwest-Serbien, blieben von größeren Untersuchungen weitgehend unberührt. Ohne dass dies bei Grabungsbeginn bereits absehbar war, wurde Gamzigrad dank der hier erschlossenen tetrarchischen Phase (Palast des Galerius, Abb. 5) eine der am besten erforschten frühbyzantinischen Fundstätten in Serbien.

Forschungsgeschichtlich betrachtet ist die Fundsituation bezogen auf die Überreste der spätantiken und frühbyzantinischen Befestigungen vielfach besser als vor 20 bis 25 Jahren. Damals waren solche Fundstätten noch sehr wenig erforscht, was besonders für die Höhenanlagen gilt. Nicht selten wurden sie vor Aufnahme der Ausgrabungen wegen ihres unregelmäßigen Grundrisses für mittelalterlich gehalten, was sich später

17 Vgl. Kirilov in diesem Band, Abb. 8. 


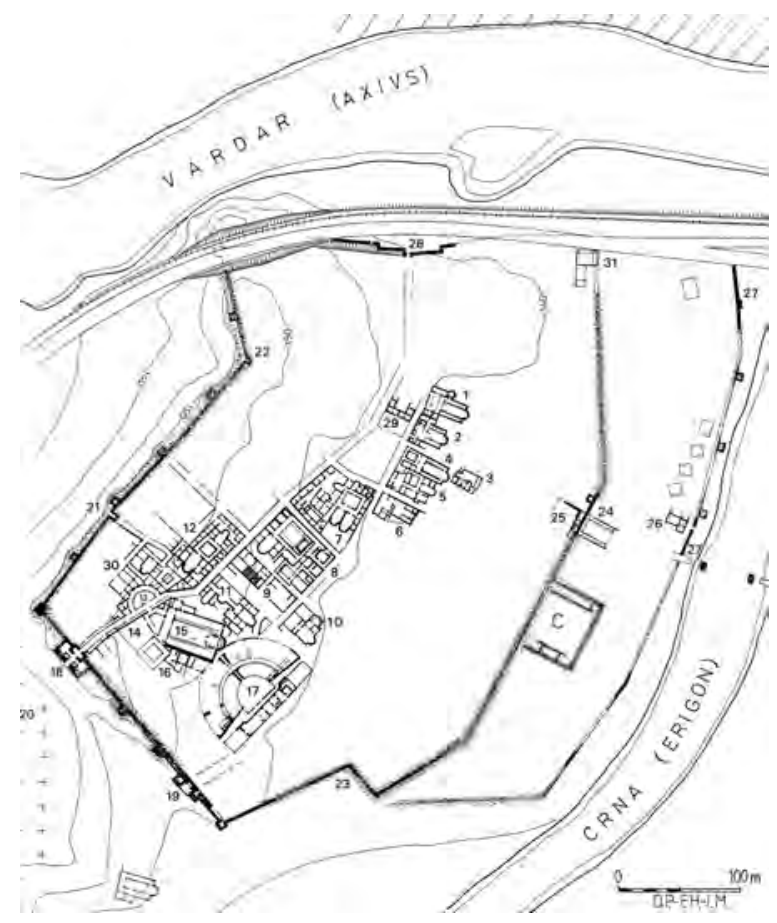

Abb. 1. Grundriss von Stobi

nicht oder nur in Einzelfällen bestätigt fand. ${ }^{18}$ Ende der 70er und in den 80er Jahren des 20. Jahrhunderts kam es zu merklichen Fortschritten, als man in Serbien begann, erste Grabungen auf Höhenanlagen wie jenen um Novi Pazar im Südwesten des Landes zu organisieren und als I. Mikulčić in Mazedonien die Resultate seiner umfangreichen Feldforschungen (vornehmlich Prospektionen) veröffentlichte. ${ }^{19}$ Angaben zu einigen wenigen spätantiken Befestigungen in Bosnien und in der Herzegowina wurden 1972 von Đ. Basler bekannt gemacht. ${ }^{20}$ In der Region um den serbischen mittelalterlichen Hauptortes Ras, nahe der heutigen Stadt Novi Pazar, wurden seit Ende der 70er und zu Beginn der 80er Jahre des 20. Jahrhunderts viele befestigte Höhenanlagen überwiegend durch zahlreiche kleine Probeschnitte sowie in drei Fällen auch durch größere Grabungen untersucht. Im Ergebnis dieser Arbeiten ergab sich schließlich, dass 20 spätantiken und frühbyzantinischen Objekten nur noch fünf Anlagen gegenüber standen, die vollständig in das Mittelalter gehörten oder aber wenigstens eine oder mehrere mittelalterliche Entwicklungsphasen aufzuweisen hatten. Diese Entwicklung führte

18 Vgl. die Aufnahme der Gradina auf der Jelica in die Liste der mittelalterlichen Burgen bei Deroko 1950, 114, Abb. 160.

19 Mikulčić 1982.

20 Basler 1972, 47-61; vgl. auch die neuere Ausgabe bei dems. 1993, 30-40. 


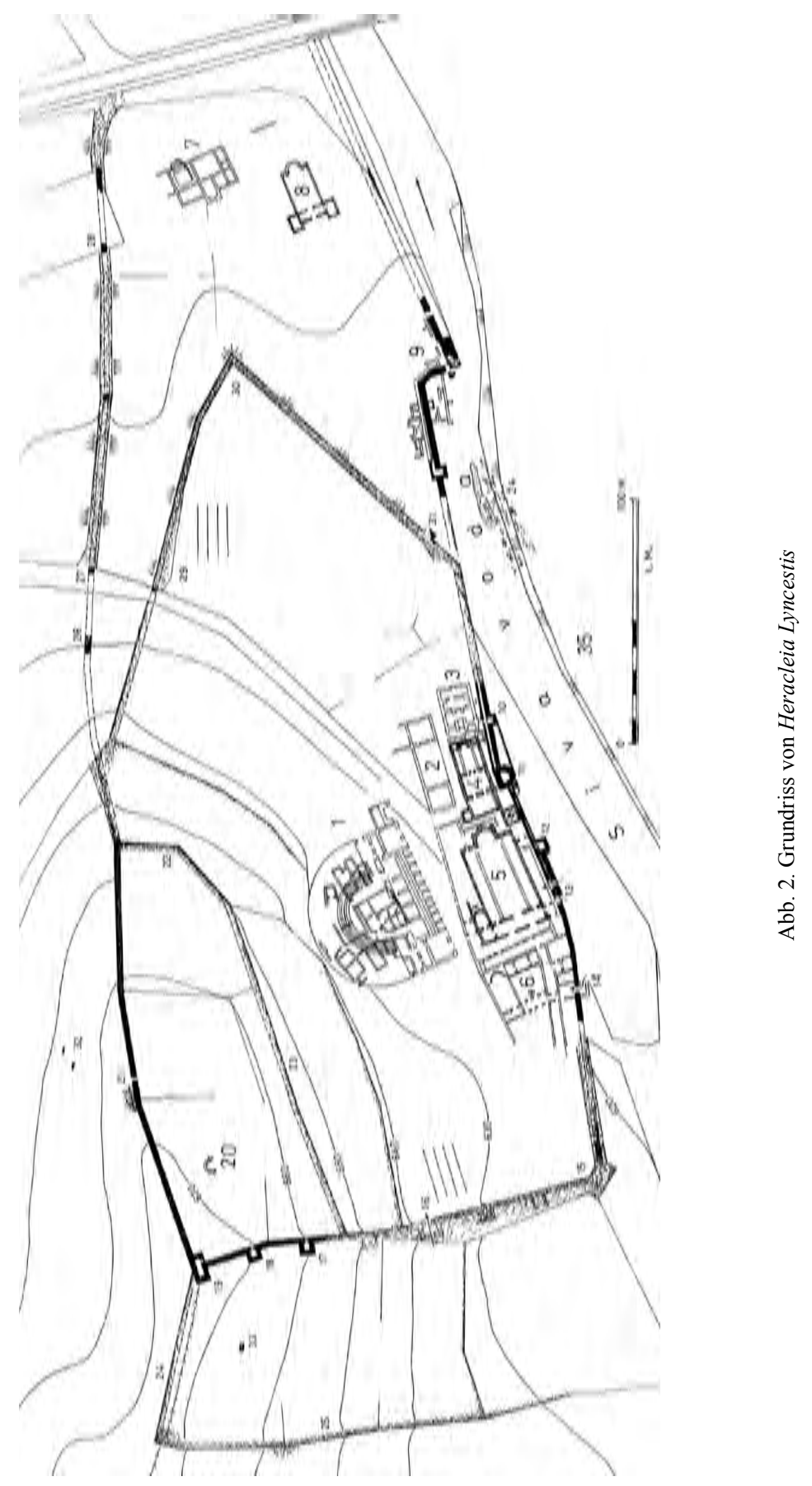


schnell zu einer Umbewertung der Höhenanlagen, zumal solche Objekte in verhältnismäßig dichter Konzentration auch aus anderen Teilen Serbiens bekannt waren, so um Čačak in Zentralwestserbien ${ }^{21}$, um Kruševac ${ }^{22}$, um Prokuplje in Südserbien ${ }^{23}$ und im Hinterland des Limes am Eisernen Tor $^{24}$. Diese Neubewertungen sind oft der intensiven Feldforschung, vor allem den Prospektionen und Probegrabungen der lokalen musealen oder Denkmalschutzinstitutionen zu verdanken (Abb. 6). ${ }^{25}$ Als klar wurde, dass von einer deutlich größeren Zahl frühbyzantinischer befestigter Höhenanlagen auszugehen ist, kamen Zweifel auf, ob man solche Objekte nur als Refugien deuten könne, die in entlegenen und schwer zugänglichen Bergregionen errichtet wurden. Auch wenn Prospektionen und Grabungen in den 90er Jahren des letzten Jahrhunderts und zu Beginn des 21. Jahrhunderts nur in einem nicht allzu großen Umfang fortgeführt werden konnten, haben doch die ergrabenen Baureste und die Deutungen des Kleinfundmaterials ergeben, dass es sich hier nicht oder zumindest nicht nur um Refugien gehandelt haben kann.

Im Ergebnis dieser forschungsgeschichtlichen Übersicht kann somit festgehalten werden, dass sich in den zentralen und westlichen Balkangebieten in den letzten Jahrzehnten kaum eine andere Fundortkategorie so profiliert hat, wie die der spätantiken und frühbyzantinischen Befestigungen. Eine ähnliche Entwicklung ist auch anderswo zu beobachten wie z.B. in Slowenien, wo die Erforschung der spätantiken Höhenanlagen vor allem dank der Bemühungen von S. Ciglenečki zum „Rennpferd“ der dortigen Archäologie geworden ist. ${ }^{26}$

\section{Die Höhenanlagen - befestigte Dörfer?}

Das neue Siedlungsmuster der spätantik-frühbyzantinischen Zeit wird vorrangig durch Objekte in Höhenlagen der Bergregionen bestimmt (Abb. 6), obwohl daneben auch Ansiedlungen in den Ebenen des Tieflands bekannt sind wie z.B. Niš/Naissus ${ }^{27}$ oder Gamzigrad/Romuliana ${ }^{28}$ Das genaue Zahlenverhältniss zwischen den Tal- und Höhenanlagen ist unbekannt. Es ist jedoch nach momentanem Forschungsstand anzunehmen, dass hauptsächlich die Berggebiete besiedelt waren. Außerhalb der Höhenlagen gab es

21 Milinković 2002, 129-130.

22 Rašković 2002, 29-73.

23 Milinković 1999, 87-90, Abb. 1.

24 Janković 1981.

25 Für die Verbreitungskarte der Befestigungen wurden u.a. Angaben von Z. Gunjača (Dalmatien), I. Mikulčić (Mazedonien) und P. Špehar (Bosnien und Herzegowina) verwendet. I. Nešić und P. Špehar schulde ich Dank für die Kartierungshilfe, die sich auf Bosnien und die Herzegowina wie auch Dalmatien bezog.

26 Ciglenečki 1999, 292-293, mit älterer Literatur.

27 Petrović 1999, 21-24.

28 Živić 2003, 10. 


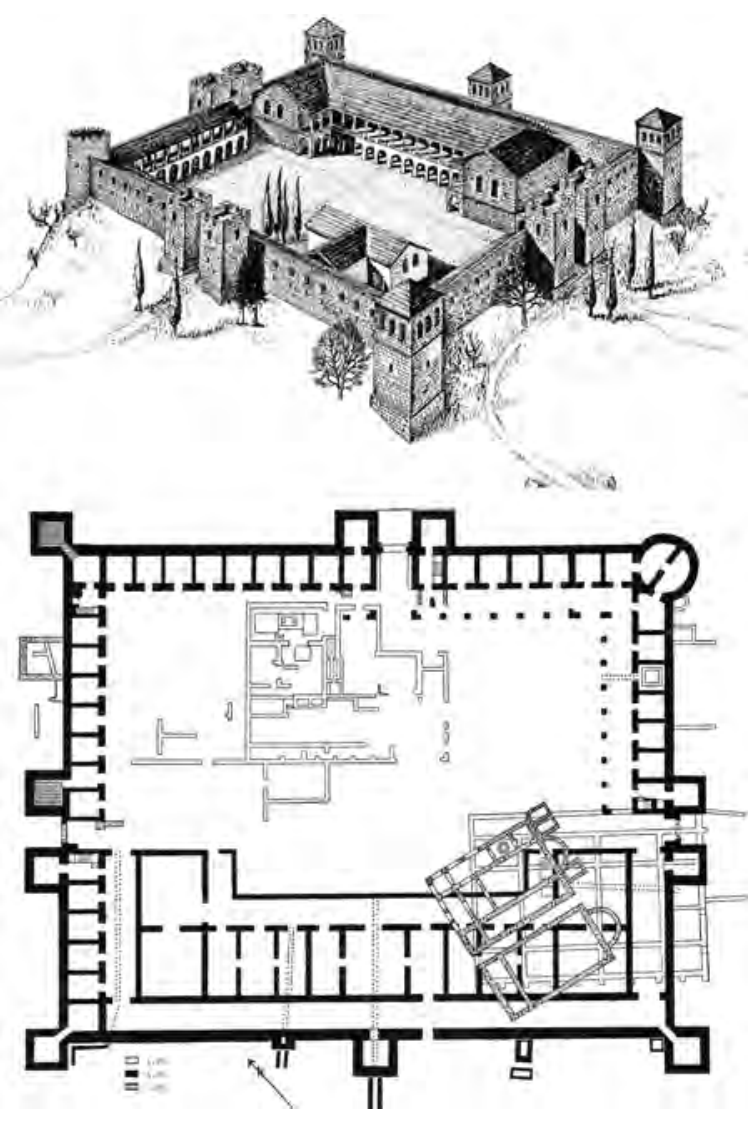

Abb. 3. Rekonstruktion und Grundriss von Mogorjelo

noch die instand gesetzten Befestigungen an der Donaulinie des Limes, deren Entstehung und Erneuerung militärisch und überregional gesteuert wurde. Von den mehr als 170 bekannten frühbyzantinischen Befestigungen in Serbien, deren wirkliche Anzahl erheblich größer sein wird, entfallen etwa 140 auf Höhenanlagen. ${ }^{29}$ Die Zahl der bekannten Höhenfesten steigt ständig. In Bosnien sind etwa 60 solcher Anlagen bekannt, ${ }^{30}$ in Mazedonien insgesamt ca. 500, wovon nach I. Mikulčić 400 auf das 6. Jahrhundert entfallen. ${ }^{31}$ Es ist deutlich erkennbar und wird durch die weitere Forschung immer wieder bestätigt, dass die geschützten Höhenpositionen - meistens in Höhen von über 500 m, oft auch über 1000, 1500 oder um $1800 \mathrm{~m}$ - zur Regel wurden. Obwohl sich im westlichen, zentralen und nördlichen Balkangebiet das Siedlungsmuster erst in frühbyzantinischer Zeit von Grund auf änderte und damit aus Gründen der Bodenbe-

29 Milinković, im Druck (a).

30 Špehar, im Druck.

31 Mikulčić 2002, 119-120. 


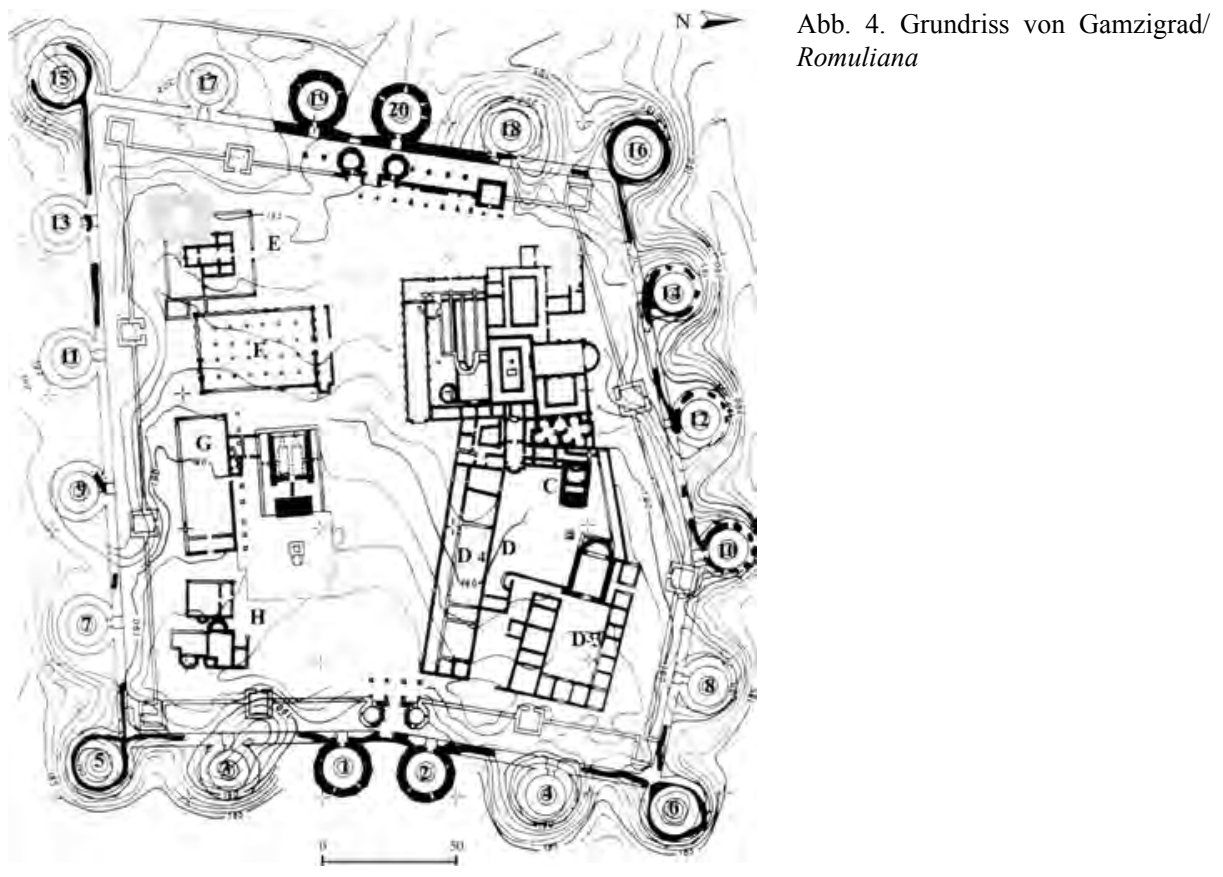

schaffenheit und des Klimas auch Modifizierungen der wirtschaftliche Basis der in den Befestigungen lebenden Bevölkerung in Richtung einer stärkeren Viehzuchtkomponente bewirkte, werden bereits frühere Ansätze dieses Prozesses greifbar. Wie auch in einigen anderen Teilen Europas kam es auch in unseren Gebieten bereits im 3. Jahrhundert dazu, dass bequeme Talpositionen mit schwer zugänglichen, aber geschützten Lagen im Gebirge getauscht, alte vorgeschichtliche Burgen und oppida wiederbenutzt und auch neue Befestigungen angelegt wurden. Dafür zeugen solche Beispiele aus Südwest- und Nordost-Serbien wie die Höhenanlage Trojan auf der Pešter-Hochebene (Abb. 7). Obwohl diese frühen und bisher nur in kleinerer Anzahl nachgewiesenen Befestigungen in der Literatur oft als Benefiziarstationen im Inneren des Reiches gedeutet wurden ${ }^{32}$ soll hervorgehoben werden, dass ihre Entstehungszeit etwa in die Periode der großen Barbareneinfälle zu setzen ist. In diesem Teil des Reiches waren es vor allem die Goten, die für Unsicherheit sorgten und die 269 von Claudius II bei Niš/Naissus geschlagen wurden. ${ }^{33} \mathrm{Im}$ 4. Jahrhundert scheinen die Gründe für eine stellenweise Besetzung der Höhen weiter bestanden zu haben. Aber die Anzahl dieser Anlagen blieb solange gering, bis im 6. Jahrhundert ein offensichtlich groß angelegtes Bauvorhaben dieser Entwicklung den

32 Kritisch dazu Milinković, im Druck (a).

33 Petrović 1999, 35. 


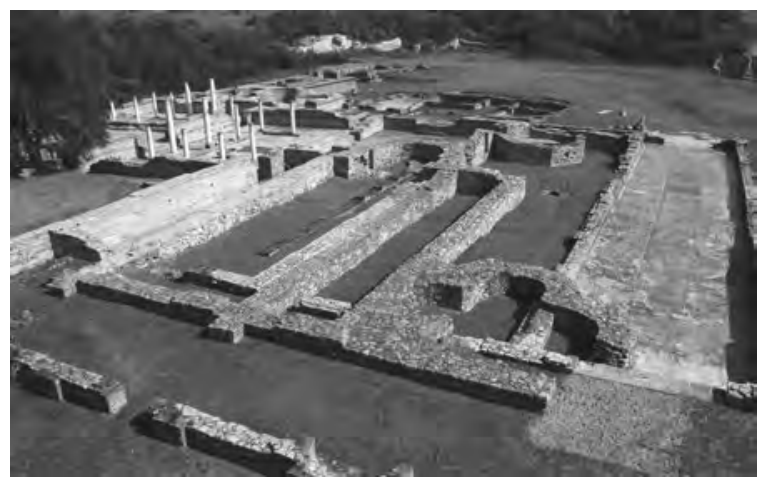

Abb. 5. Gamzigrad, Basilika und Palast des Galerius

entscheidenden Auftrieb gab. Es handelt sich um jenen Vorgang, den Prokop in seinem Werk De aedificiis beschrieben hat. ${ }^{34}$

An anderem Ort ist bereits der Versuch unternommen worden, die Anlagen als befestigte Dörfer zu deuten. ${ }^{35}$ Diese Annahme ist durch verschiedene Argumente begründet, die hier in Kürze wiederholt werden sollen. Unter anderem spricht dafür die Anzahl dieser oft in entlegenen Berggebieten und, soweit bekannt, zumeist ohne Verbindung zum Straßennetz angelegten Befestigungen, die bedeutend größer ist, als die der 654 Kastelle, die Prokop für den Balkan erwähnt (Abb. 6). ${ }^{36}$ Prokop hat also mit seiner Beschreibung der justinianischen Bautätigkeit auf der Balkanhalbinsel nicht übertrieben, sondern sogar einen wesentlichen Teil, man könnte fast sagen, eine ganze Kategorie von Monumenten ausgelassen. Es stellt sich die Frage, warum dies geschah, denn Prokop wird sicher über diese Entwicklungen informiert gewesen sein. Wichtig für die Lösung dieser Frage ist der vielfach beobachtete Umstand, dass die Bauweise solcher befestigter Höhenanlagen im Inneren des Balkan zwar einfach, aber sehr effektiv und durchdacht ausgeführt war, was ein zentral koordiniertes, gemeinsames Vorgehen lokaler Baukräfte wahrscheinlich macht. Diese hatten wohl auch für die Beschaffung des Materials zu sorgen. Es kann das Wirken romäischer Militäringenieure vermutet werden. Als Beispiel eines justinianischen Militärarchitekten ist der auf Inschriften mehrfach bezeugte Victorinos zu nennen, für den angeführt wird, dass er in Illyricum, Moesien und anderswo Befestigungen gebaut habe. ${ }^{37}$ Bereits die Auswahl des Platzes für eine solche Befestigung war gekonnt. An möglichst vielen Seiten wurde der Zutritt für den Feind z.B. durch Felsen und Steilhänge, an denen keine Abwehrmauern gebaut werden mussten, fast unmöglich gemacht oder erheblich erschwert (Abb. 8, Abb. 9). So konnte man mit weniger Aufwand und schneller eine größere Anzahl von Festen errichten.

34 Prokop.

35 Milinković, im Druck (a).

36 Beševliev 1970, 74.

37 Feissel 1988, 136-146. 


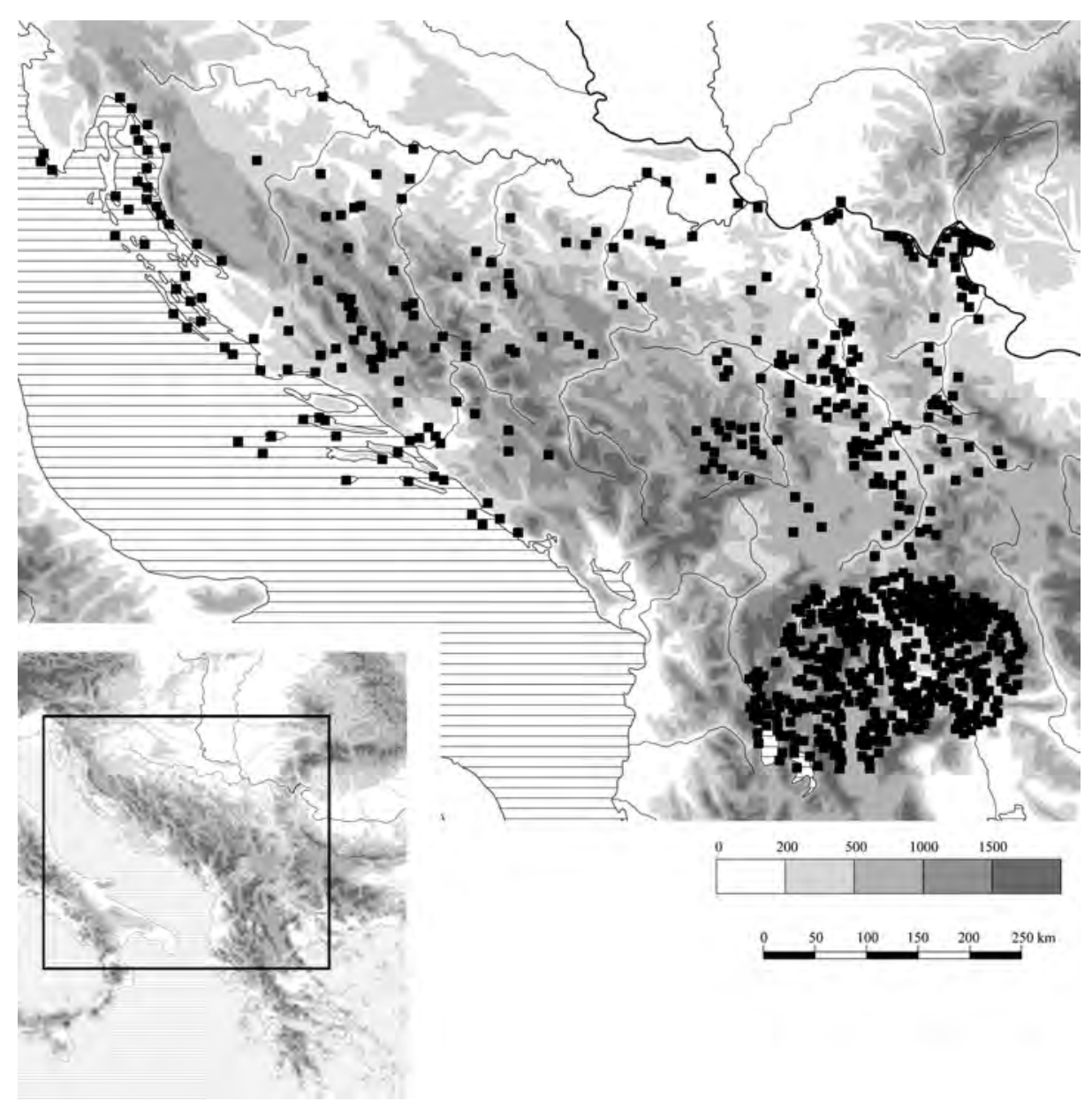

Abb. 6. Verbreitungskarte der spätantiken und frühbyzantinischen Befestigungen in Dalmatien, Bosnien und der Herzegowina, Serbien und Mazedonien

Die Grundrisse der Höhenanlagen waren strikt dem Gelände angepasst und deswegen unregelmäßig, womit die Befestigungen in ihrem Aussehen bereits teilweise das mittelalterliche Konzept vorweg nahmen. Dies auch wegen der dominanten Stellung des Kirchgebäudes innerhalb der Mauern sowohl größerer wie auch kleinerer Anlagen. Beispiele dafür sind aus Caričin $\operatorname{Grad}^{38}$ (Abb. 19), Bregovina ${ }^{39}$ (Abb. 10), von der Jelica ${ }^{40}$

38 Bavant-Ivanišević 2003, Abbildungen auf den Seiten 11, 13, 19; Kirilov in diesem Band, Abb. 8.

39 Jeremić-Milinković 1995, 210-212.

40 Milinković 2002, 92. 


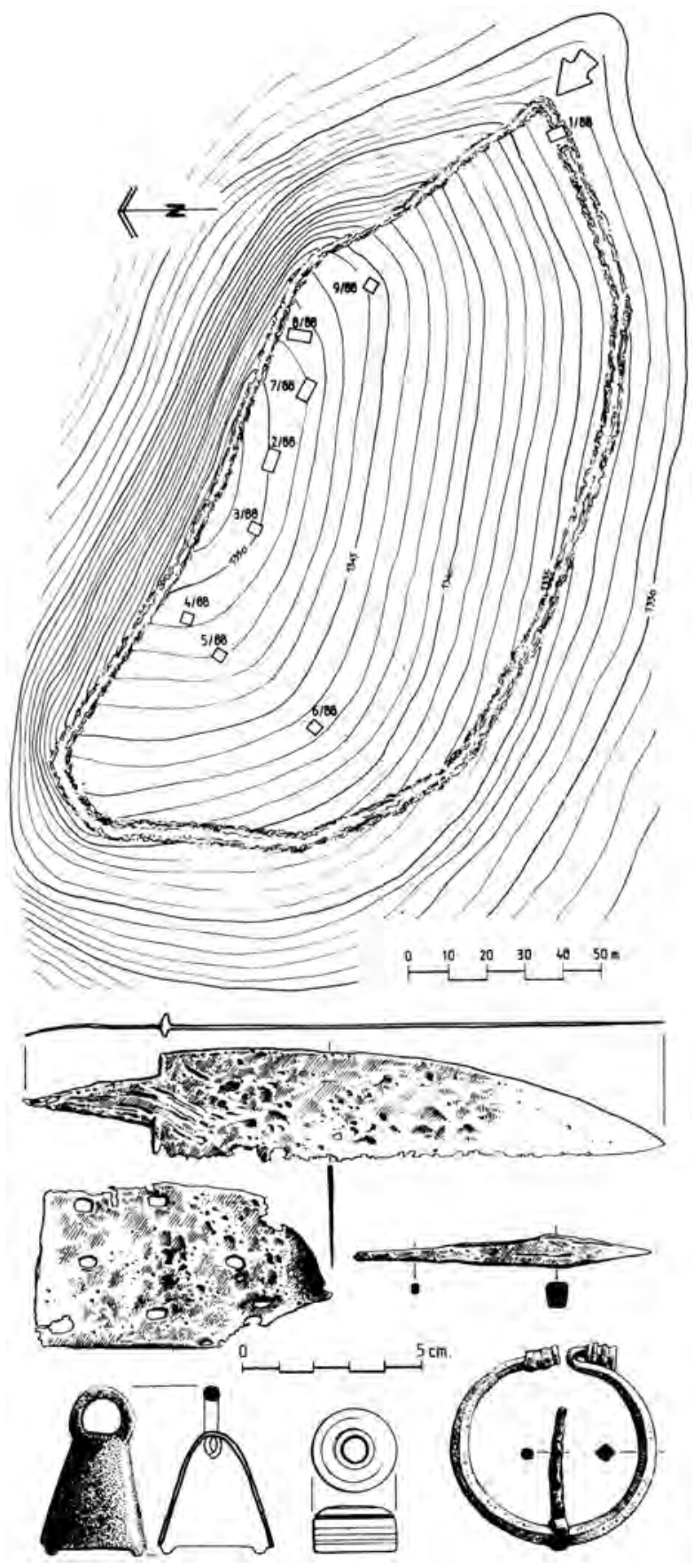

Abb. 7. Trojan. Grundriss und Kleinfunde 


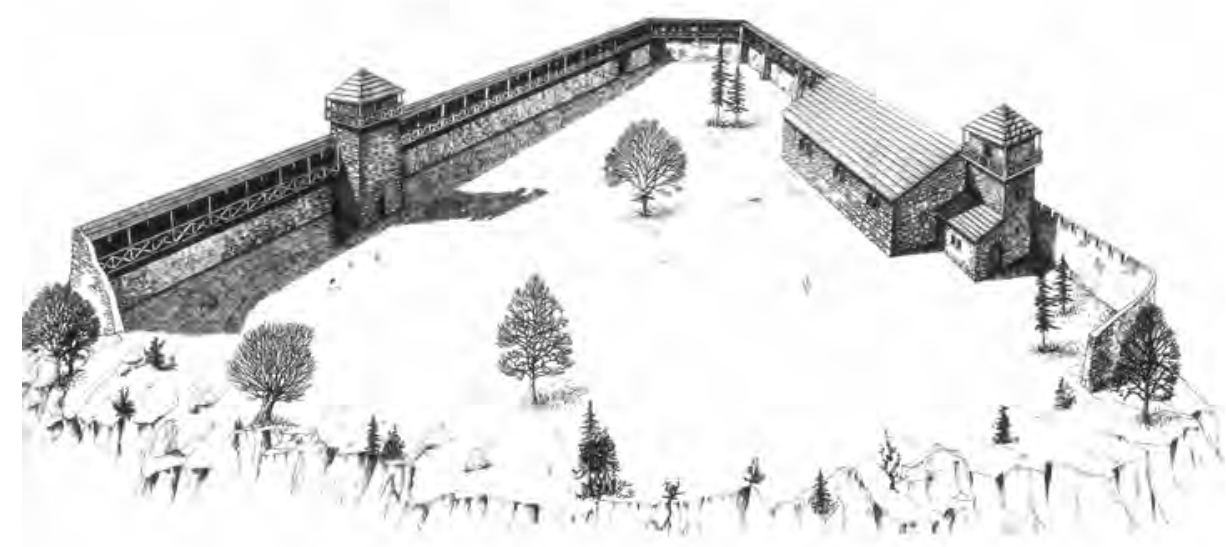

Abb. 8. Vrbljani. Rekonstruktion

(Abb. 11), aus Gamzigrad ${ }^{41}$ (Abb. 4), Davina-Čučer ${ }^{42}$ in Mazedonien, oder Lepenica ${ }^{43}$ in Bosnien (Abb. 12) bekannt. Gerade die dominante Positionierung der Kirchen innerhalb der Siedlungsstruktur ist einer der wichtigsten Bestandteile des neuen Konzepts, welches hier nach dem Einschnitt des Hunneneinfalls und der damit einher gehenden unsicheren Zeit ausgeprägt wurde. Demnach hatte offensichtlich der christliche Tempel monumental, erhaben und von weitem sichtbar zu erscheinen. Gerade diese zentrale Position der Kirchgebäude zeigt, dass die beschriebenen Siedlungsmuster wirkliche Neubildungen waren, von Anfang an den veränderten Vorstellungen jener Zeit entsprachen und sich nicht wegen etwa schon bestehender Objekte oder aus anderen Gründen mit einer Lage an der Peripherie der Siedlungen zufrieden geben mussten. Die klassische Antike war trotz aller Restaurationsversuche für immer vorbei. Durch die oben beschriebene neue Art der Befestigungsbauweise ließen sich die massenhaft erfolgenden Bauaktionen in der Summe mit bedeutend geringeren Aufwendungen als früher realisieren. Andererseits waren diese Befestigungen häufig nicht sehr massiv und solide gebaut und daher nicht mit jenen an der Limeslinie oder denen der großen Zentren im Süden wie z.B. Caričin Grad, Zlata oder Vodno in Südserbien und Mazedonien vergleichbar. Man gewinnt mancherorts wegen der oft geringen Mauerbreite den Eindruck, dass die Anlagen nur angesichts einer sporadischen Bedrohungssituation durch Barbaren erbaut wurden und nicht für länger andauernde Belagerungen gedacht waren. ${ }^{44}$ Dies scheint im Einklang mit der Tatsache zu stehen, dass die Barbarenheere allein schon wegen logistischer Probleme oft keine

41 Živić 2003, 45.

42 Mikulčić 2002,157, Abb. 45.

43 Skarić 1932, Abb. 4.

44 Vgl. Wozniak 1982, 200. 

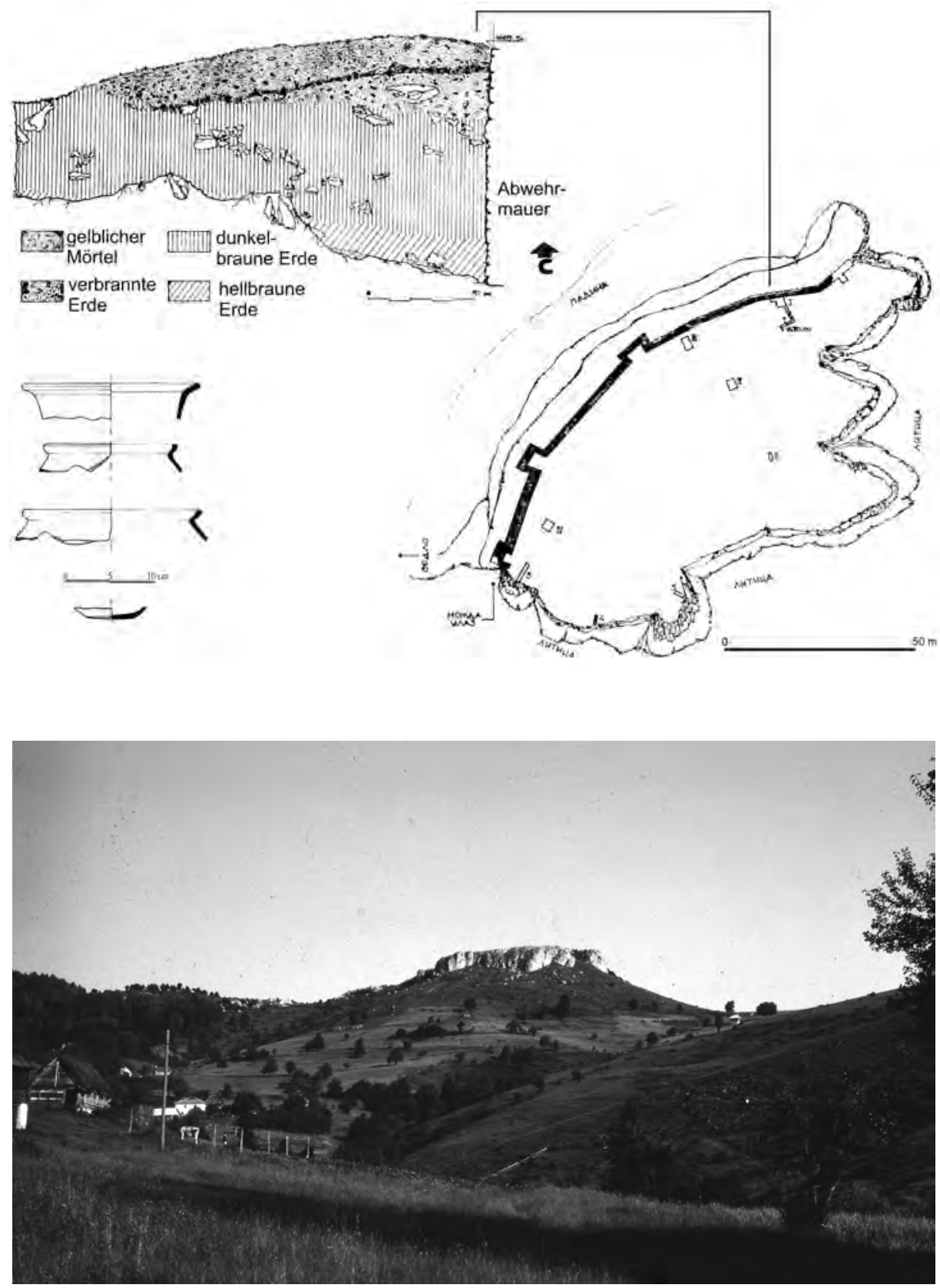

Abb. 9. Đerekare. Grundrissskizze, Profil, Keramik und topographische Lage 


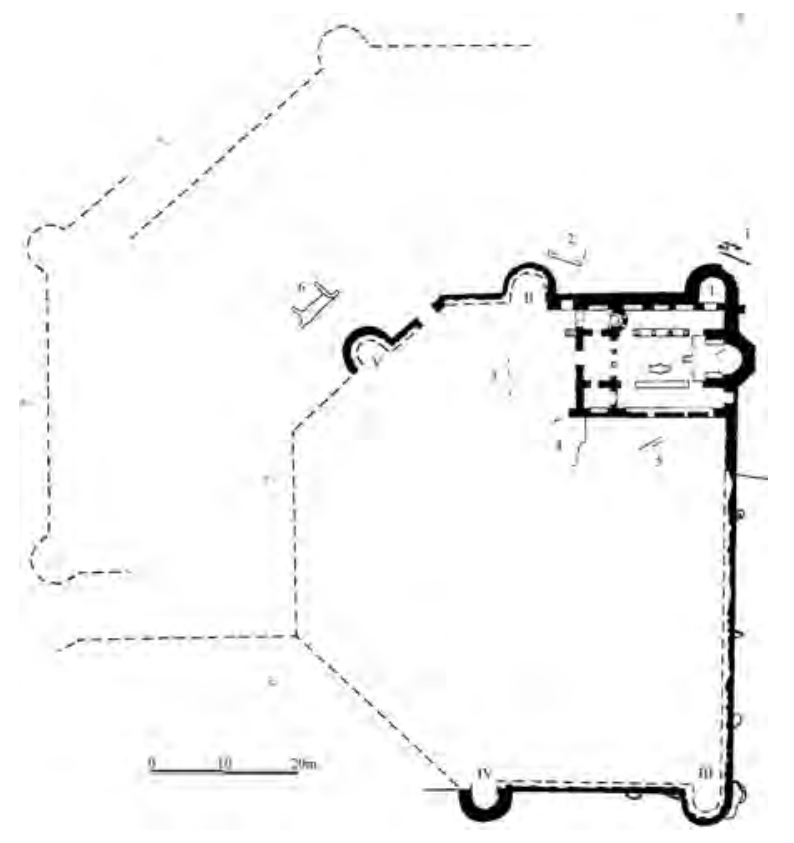

Abb. 10. Bregovina. Grundrissskizze

langen Belagerungen durchführen konnten. Auch dürfte das Reich nicht im Mindesten über die nötige Zahl von Soldaten verfügt haben, um die nach Hunderten, wenn nicht Tausenden zählenden Befestigungen auf dem Balkan effektiv zu besetzen (Abb. 6). Einen der entscheidenden Hinweise auf den ländlichen Charakter dieser Anlagen liefert aber das Kleinfundrepertoire, welches unter anderem Werkzeuge und Geräte für die Landwirtschaft, Viehzucht und für die Verrichtung bestimmter handwerklicher Tätigkeiten, vor allem für die Bearbeitung von Holz, enthält. ${ }^{45}$ Viehglocken, Sicheln, Hacken und anderes Kleingerät, das für die Bewirtschaftung von Kleinparzellen im Bergland geeignet war, sprechen von der wirtschaftlichen Tätigkeit derjenigen, die intra muros lebten (Abb. 13, Abb. 14). Die wenigen anthropologischen Untersuchungen wie diejenigen, die von $\breve{\text {. }}$ Mikić (Philosophische Fakultät der Universität Belgrad) auf der Jelica in Zentralwestserbien durchgeführt wurden, sprechen bei einem Anteil von ca. 37,23\% Kinder- und Frauengräbern ${ }^{46}$ deutlich gegen eine Interpretation als Militärstützpunkt wie auch gegen die Annahme, es handle sich um Refugien, die nur vorübergehend besiedelt waren. Dies erscheint auch aus anderen Gründen wenig wahrscheinlich, da durch Grabungen

45 Vgl. Popović 1995, 69.

46 Milinković 1995, 246. 


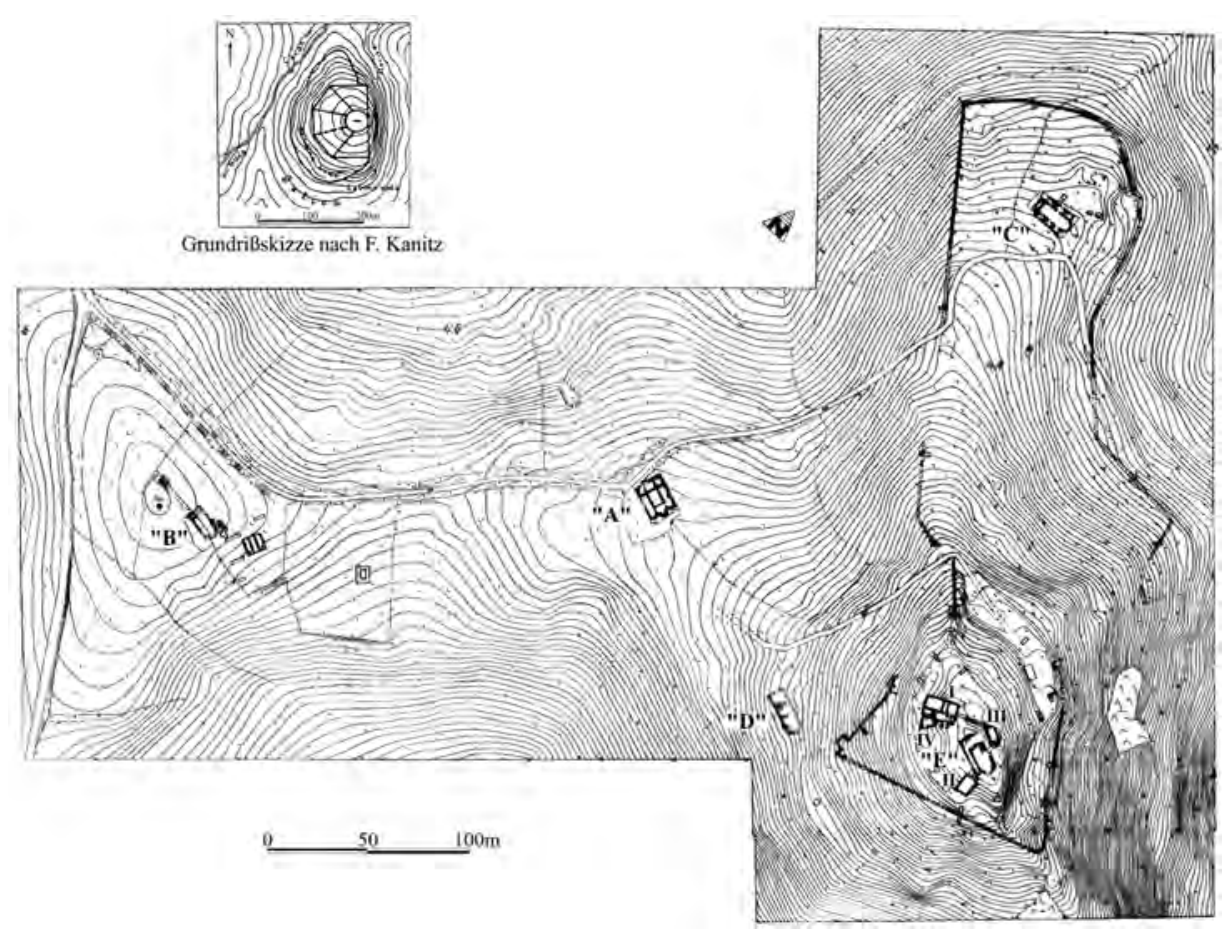

Abb. 11. Jelica-Gradina. Grundriss

an verschiedenen Fundstellen Überreste von Gebäuden und Kirchen ${ }^{47}$ wie auch Hausinventar zum Vorschein gekommen sind, was wohl mit einer Funktion als reines Refugium nicht in Einklang stehen dürfte. Zwar scheint die Ausbildung solcher Siedlungsschichten prinzipiell auch durch eine nur zeitweise Benutzung der Anlagen möglich, allerdings wahrscheinlich nicht in der Konzentration, wie sie durch die Grabungen deutlich wurde. Es bleibt eigentlich kaum eine andere Möglichkeit, als die befestigten Anlagen als mehr oder weniger ständig bewohnte Dörfer zu deuten. Nach Prokop wurde auch Taurision, das Dorf in welchem Iustinian I geboren wurde, nachträglich befestigt. ${ }^{48}$ Auch wenn Prokop diesen Befestigungsbau mit dem besonderen Charakter des Platzes als Geburtsort des Kaisers in Verbindung bringt, ist kaum anzunehmen, dass sich die Gründe für den Bau der Befestigung sonderlich von denen unterschieden, die das neue ländliche Siedlungsbild

47 So z.B. in der Höhenanlage (1055m ü.M.) Zlatni Kamen bei Novi Pazar in Südwest-Serbien, vgl. Ivanišević 1990, 7-17, Abb. 1-4, oder in der Anlage in Babotinac in Südserbien, wo zwei Kirchen entdeckt wurden, vgl. Kuzmanović-Cvetković 1986, 213-218. In diesen wie in noch einigen anderen Fällen sind die Kirchen kleiner und weniger sorgfältig gebaut, waren aber, wie das Beispiel von Zlatni Kamen aufzeigt, mit Kirchmobiliar ausgestattet. 


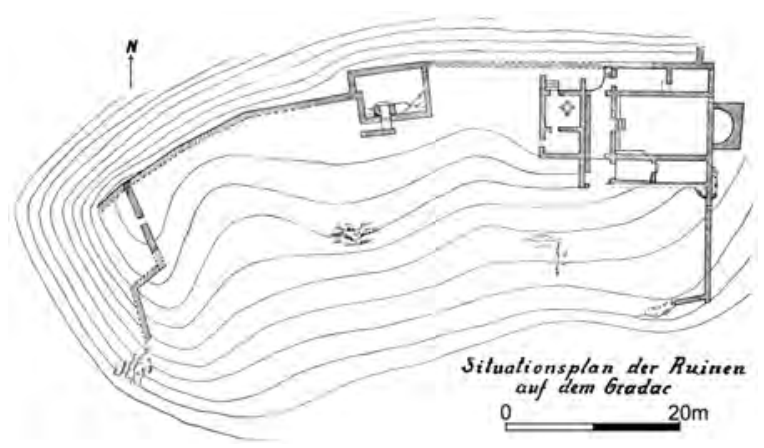

Abb. 12. Lepenica. Grundriss

hervorbrachten. So hat das Reich zwei scheinbare Gegensätze miteinander vereinigt: die Fortifikation, die eigentlich entweder für Militäranlagen oder für Siedlungen städtischen Charakters typisch ist, mit einer vorwiegend von Landwirtschaft lebenden Bevölkerung.

In manchen Höhenanlagen ist Schlacke gefunden worden, was auf bergmännische Aktivitäten hindeutet. Dies verwundert nicht, denn viele Befestigungen sind in entsprechenden Rohstoffrevieren angesiedelt wie jenem bei Novi Pazar in SüdwestSerbien. In der Befestigung von Babrež, südwestlich von Novi Pazar, wurde in einem Turm ein Schmelzofen für Metallverarbeitung gefunden. ${ }^{49}$ Dass die Montanaktivitäten in spätantiker Zeit einen Aufschwung erlebten, zeigt das Beispiel von Mazedonien (hauptsächlich das Territorium der ehemaligen Provinz Macedonia II), wo nach I. Mikulčić in 180 Kleinregionen Eisenlagerstätten zu verzeichnen sind und wo neben Kupferschlacken und Barren auch Spuren der Blei- und Silbergewinnung bzw. Verarbeitung von Chrom-Erz vorliegen. In Mazedonien sind an 170 spätantik-frühbyzantinischen Befestigungen metallurgische Tätigkeiten nachgewiesen, was zwischen einem Drittel und einem Viertel der von dort bekannten Gesamtzahl ausmacht. ${ }^{50}$ Die mit der Verarbeitung von Metall verbundenen Tätigkeiten sind auch in größeren, zentralen Anlagen nachgewiesen wie in Caričin Grad, wo Gussformen für die Herstellung von Gürtelbeschlägen und anderem Zubehör sowie Schmuck ausgegraben wurden, ${ }^{51}$ oder auf der Jelica, wo man im Objekt III eine metallurgische Werkstatt (Schmelzofen) entdeckt hat. ${ }^{52}$ Schlackenfunde gehören auch in Serbien zum üblichen Fundrepertoire der frühbyzantinischen Befestigungen, doch eine genaue chemische Analyse steht hier noch aus. Die Ansiedlung mit Eisenwerk in Japra bei Blagaj im pannonischen Teil Bosniens scheint nach $Đ$. Basler die spätantike Zeit nicht mehr erlebt zu haben. ${ }^{53}$ Alle

49 Premović-Aleksić 1989, 21, Abb. 3.

50 Mikulčić 2002, 119.

51 Kondić-Popović 1977, 391; Bavant-Ivanišević 2003, 69.

52 Milinković 2002, 87.

53 Basler 1993, 21-22. 


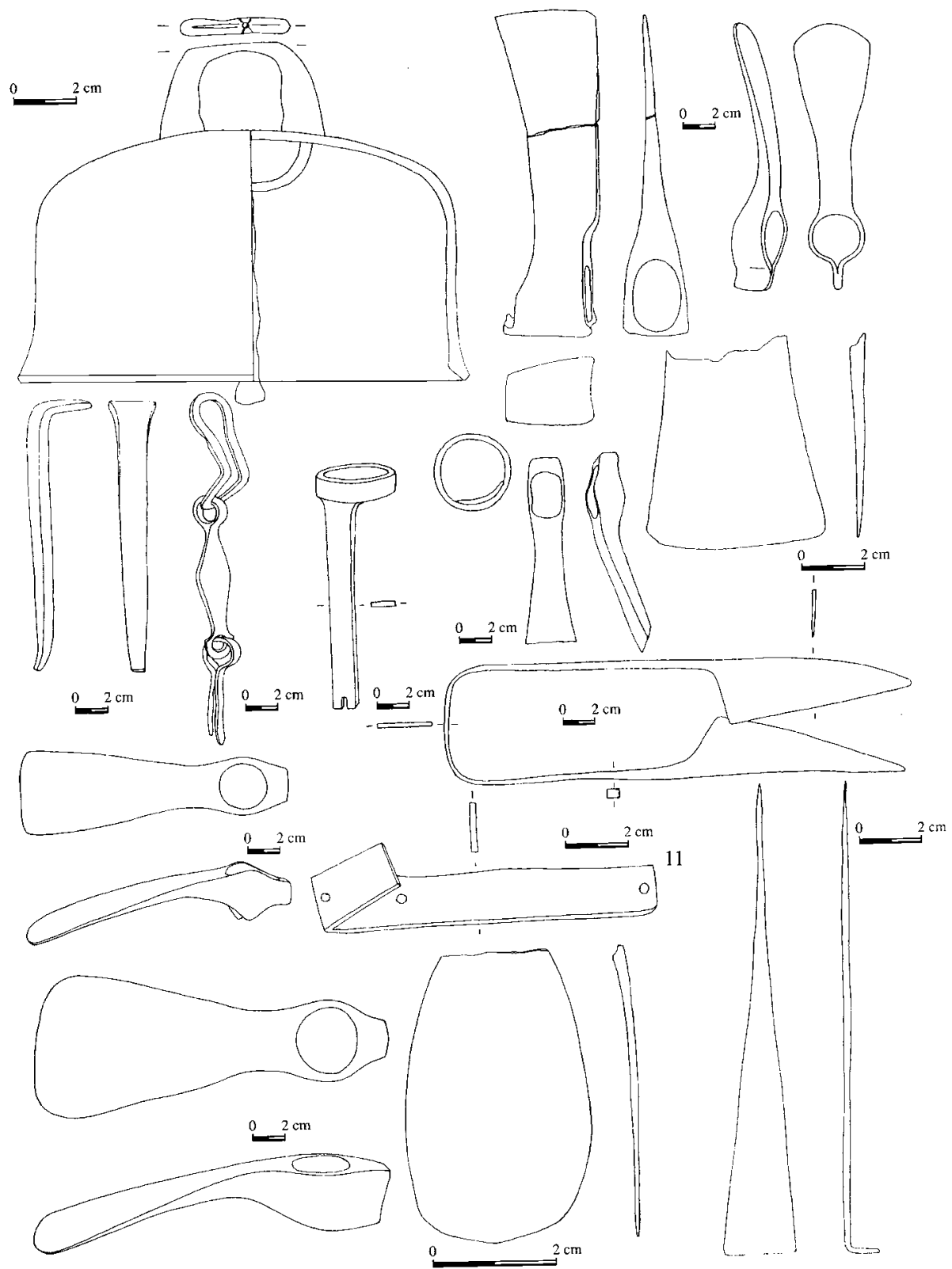

Abb. 13. Jelica-Gradina. Werkzeug- und andere Depotfunde 


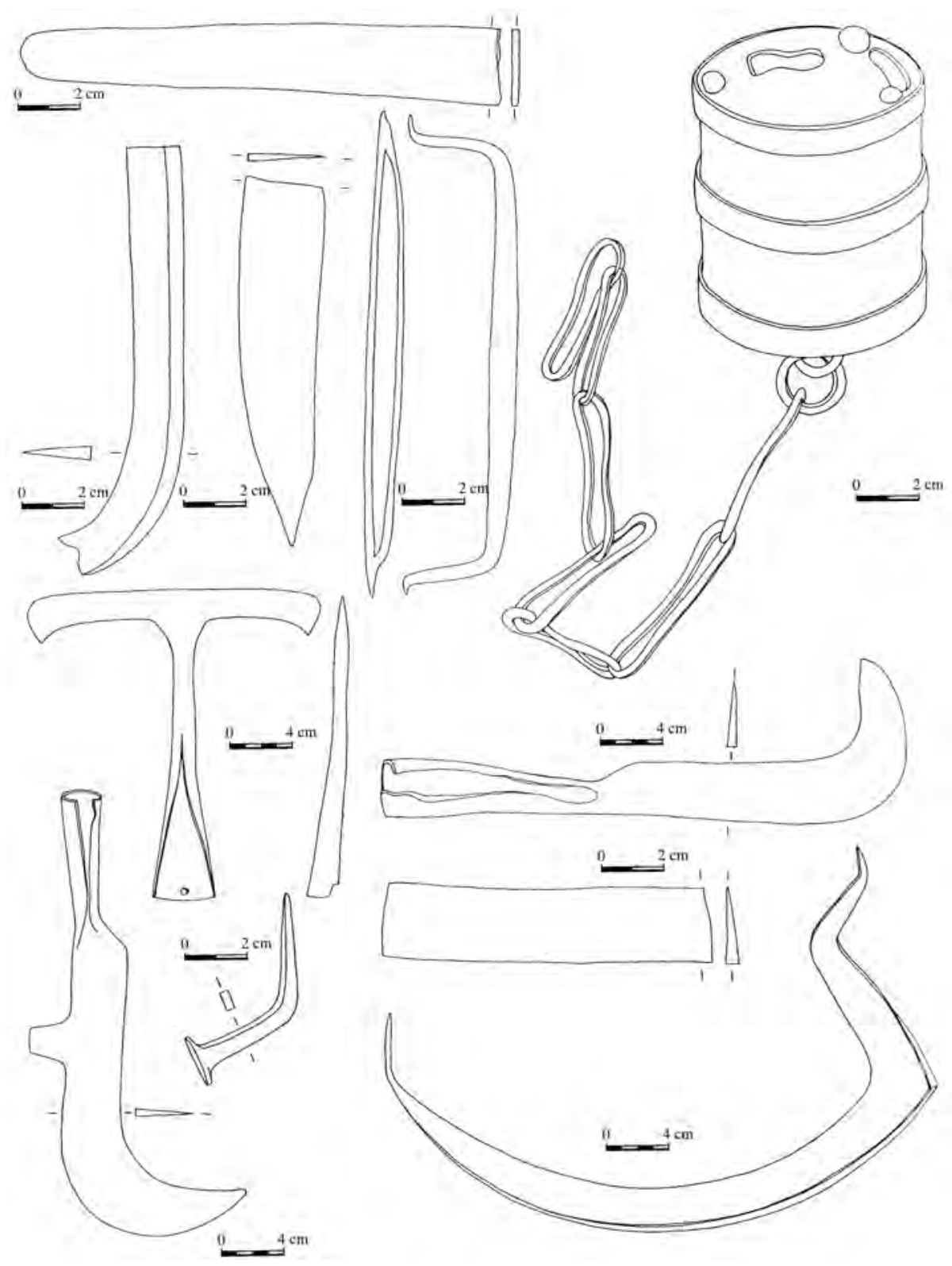

Abb. 14. Jelica-Gradina. Werkzeug- und andere Depotfunde 
diese Aktivitäten lehnen sich wahrscheinlich an den spätrömischen Bergbau und an die Metallverarbeitung im Illyricum an. ${ }^{54}$

\section{Städte und stadtähnliche Siedlungen}

Was eine Stadt ausmacht und welche Elemente dazu unentbehrlich sind, ist seit langem Gegenstand der Diskussion. Diese kann nur davon profitieren, wenn die Suche nach einer geeigneten Definition der Stadt auch die Situation in der Spätantike und in den ersten Jahrhunderten des Oströmischen Reiches berücksichtigt. Aus dieser Sicht sollte eine Stadt sowohl quantitativ als auch qualitativ bestimmt werden. Im quantitativen Sinne benötigt sie eine Fläche, die in der Regel größer als diejenige ist, die von einem Dorf oder einer kleineren Befestigung eingenommen wird, sowie auch eine im Vergleich zu jenen größere Anzahl von Einwohnern, die sich wenigstens überwiegend nicht von der Landwirtschaft ernähren. Eine Stadt sollte sich darüber hinaus durch bestimmte urbanistisch-architektonische Faktoren hervorheben. Dazu zählen Formen der Stadtplanung, eine bestimmte Bausubstanz sowie das erkennbare Wirken von Bauvorschriften. Der städtische Siedlungsort sollte sich also durch eine entsprechende räumliche Organisation und den Bau von privaten und öffentlichen Gebäuden (Villen, Kirchen, Getreidespeicher, Stauseen, Aquaedukte, Zisternen, Thermen etc.), die Errichtung und Instandhaltung einer Befestigungsanlage eingeschlossen, abheben. Als Bestandteil städtischen Lebens ist in gewisser Weise auch der rechtliche Status des Ortes als einer juristischen Person aufzufassen. So ist erwiesen, dass die frühbyzantinischen urbanen Zentren Stadtrecht besitzen konnten, auch wenn dieses Recht nur ein schwacher Abglanz der Situation in den vorhergehenden Jahrhunderten gewesen sein mag. ${ }^{55}$ Es würde den Rahmen dieser Abhandlung sprengen, sämtliche denkbaren Elemente und Möglichkeiten einer Stadtdefinition aufzulisten, die eine Rolle der Stadt als wirtschaftliches, kirchliches, politisches, administratives und kulturelles Zentrum bestimmen. Wenigstens die wichtigsten Charakteristika sollen hier aber noch einmal genannt werden, da der Stadtbegriff auch den beträchtlichen strukturellen Änderungen Rechnung tragen muss, die in der hier zu behandelnden Zeit auftraten. Über diese Vorgänge ist bereits viel geschrieben worden, so dass es ausreicht, unter den zahlreichen Details nur die Wichtigsten zu erwähnen. Dazu gehört, dass sich in den meisten Fällen die Stadtfläche reduziert, die Rolle des kirchlichen Oberhauptes, des Bischofs, auch in zivilen Angelegenheiten vorherrschend wird und die Bevölkerung Prozessen einer ,Verländlichung“ ausgesetzt ist. Wie im Weiteren gezeigt wird, ändert sich das Stadtbild auch im urbanistisch-architektonischen Sinne. Diese „Desintegration und Ruralisation“, wie

54 Dušanić 1995, 219-225.

55 Claude 1969, 151. 
es Vladislav Popović genannt hat, ${ }^{56}$ konnte örtlich verschieden stark ausgeprägt sein. Jedenfalls ist jener Vorgang sowohl in den Schriftquellen als auch in den materiellen Hinterlassenschaften klar erkennbar: Die Einwohner von Singidunum werden nach Theophylactus Simocatta 584 von den Awaren beim Einbringen der Ernte vor den Stadtmauern überrascht (angeblich sogar der „Großteil" der Stadtbewohner von $\Sigma i \gamma \gamma \eta \delta o ́ v) .{ }^{57}$ Den Miracula s. Demetrii I folgend widerfuhr ein ähnliches Schicksal auch den Bürgern der großen und bedeutenden Stadt Thessaloniki. ${ }^{58}$ Man muss sich fragen, was das für Stadtbewohner waren, die vor den Stadtmauern mit eigenen Händen die Ernte einholten? Diese wichtigen Indizien aus den Schriftquellen werden von zahlreichen archäologischen Funden intra muros unterstützt: von landwitschaftlichem Gerät, von Viehglocken und ähnlichen Gegenständen, die auf eine Bevölkerung hindeuten, deren Lebensgrundlage in der Landwirtschaft verankert war. Auch andere Befunde sprechen ganz eindeutig davon, dass in den Städten eine Bevölkerung ansässig wurde, die mit den Kunstwerken, Mosaiken und großzügig konzipierten Wohnanlagen der früheren Zeit offenbar wenig anzufangen wusste. Es wurden diese älteren Elemente hervorgehobenen städtischen Lebens in einem so großen Umfang von schlichten Wohnanlagen überbaut, dass die ältere Forschergeneration anfangs annahm, mit dieser späten Phase der frühbyzantinischen Siedlungsaktivitäten die Zeugnisse der slawischen Landnahme entdeckt zu haben. ${ }^{59}$ Was die ländliche Bevölkerung vor allem in der zweiten Hälfte des 6. Jahrhunderts bewog, massenweise in die Städte und Siedlungen mit zentralörtlicher Funktion zu ziehen, waren selbstverständlich nicht die urbanen Lebensformen, sondern viel eher der Schutz der mächtigen Mauern, hinter die man sich begeben konnte, um sich der Gefahr der Barbarenangriffe zu entziehen.

Angesichts des beschriebenen Forschungsstandes ist es nicht immer einfach zu bestimmen, ob eine Ansiedlung als Stadt, Städtchen (,polychnia“), befestigtes Dorf mit gewissen zentralörtlichen Funktionen oder etwas anderes anzusehen ist. Versuche, wie sie von I. Mikulčić unternommen wurden, eine feste Kategorisierung zur Anwendung zu bringen, scheinen noch immer verfrüht und somit unsicher zu sein. ${ }^{60}$ Es stellt sich außerdem die Frage, ob sie überhaupt einen Sinn haben, denn es scheint, dass - zumindest in den Augen der Zeitgenossen - oftmals fast kein Unterschied zwischen einem Kastell und einer Stadt bestanden hat. Großstädte sind hier zwar auszunehmen, doch zeigt das Beispiel von Thessaloniki, dass auch hier Vorsicht geboten ist. Die Übergänge zwischen den Sied-

56 Popović 1982, 545-566.

57 Fontes 1955, 106.

58 Ebd., 179.

59 Kondić-Popović 1977, 373. Dies wurde allerdings durch Funde der sogenannten slawischen Fibeln in Caričin Grad unterstützt wie durch einige andere Funde, z.B. die der schlechter hergestellten Keramik am selben Fundort.

60 Vgl. Mikulčić 1986, 105ff. Mikulčić hat auch in seinem neueren Schrifttum die Kategorisierung beibehalten, obwohl der Forschungsstand immer noch ungenügend ist. 
lungsformen waren fließend. So wird z.B. Meridio, ein Bischofssitz in Dacia Ripensis, als phrourion, also als Kastell bezeichnet, während Prokop einige Kastelle als polychnia, Kleinstädte, einstuft. ${ }^{61}$ Wenn die Zeitgenossen nicht imstande oder daran interessiert waren, eine strikte Einteilung der Siedlungen und Befestigungen durchzuführen, so sollte man bei Versuchen, dies aus heutiger Sicht und vor allem vor dem Hintergrund eines noch unzureichenden Forschungsstandes zu tun, solange vorsichtig sein, bis großflächige Ausgrabungen neue Einsichten ermöglichen. Und selbst dann wird diese Typologisierung nicht leicht sein.

Die Frage ist, ob in den Gebieten mit den beschriebenen befestigten Höhenanlagen, die hier primär als Dörfer mit vielleicht gelegentlichen Funktionen auch im Bergbau oder für das Militär angesprochen werden, noch andere Siedlungsformen existierten. Sofern man überhaupt von einer Einbindung einzelner Siedlungen in geschützter Lage in das Straßennetz sprechen kann, da diese Orte oft nur in einer gewissen Nähe zu Straßenzügen lagen, sind die bekannten Fälle dieser Art leider nur ungenügend erforscht. ${ }^{2}$ Man kann auch nicht unbedingt davon ausgehen, dass das antike Straßennetz intakt geblieben ist. Es ist daher nur zu vermuten, dass wenigstens an wichtigen Straßenkreuzungspunkten wie z.B. in Niš/Naissus Siedlungsformen bestanden, die man als stadtähnlich, wenn nicht gar als Städte bezeichnen kann. Ein wirklicher Beweis jedoch fällt schwer, und die Vermutung liegt eher nahe, dass es solche Städte kaum in großer Zahl gegeben hat. Leider verfügt man im Fall von Niš/Naissus nahezu über keine aussagekräftigen Daten, die das Stadtbild im 6. Jahrhundert erleuchten könnten. Einzig die große, noch unpublizierte Nekropole von Jagodin-Mala mit ihren fünf Kirchen und zahlreichen Grabkammern, darunter auch solchen mit frühchristlicher Freskenmalerei, vermittelt eine gewisse Vorstellung. In der dardanischen Metropole Scupi, an der wichtigen Verkehrsader entlang des Morava-Vardar-Tales gelegen, konnten für das 6. Jahrhundert aus der Zeit nach dem Erdbeben von $518^{63}$ zwei Erneuerungsphasen der Straßen nachgewiesen werden. Dies lässt immerhin auf eine Weiternutzung und Instandhaltung von städtischen Strukturen schließen. Doch muss dies nicht der Normalfall gewesen sein, besonders nicht im Norden des Illyricums. Es ist kaum zu übersehen, dass sich das ,Stadtbild“ im 6. Jahrhundert von dem des 4. Jahrhunderts unterschied, und das nicht nur wegen der Verlagerung der Siedlungen aus den Niederungslagen in die Bergregionen. Beispiele aus Belgrad/Singidunum ${ }^{64}$ und Stari Kostolac/Viminatium ${ }^{65}$ sprechen nämlich dafür, dass es

61 Mikulčić 2002, 52.

62 Z.B. Glašinačko Kale/Castrum Herculis auf der Strecke Naissus-Lissus, vgl. Milinković, im Druck (b).

63 Lilčić 2004, 182-183. Anders Mikulčić, welcher die Behauptung äußert, das Erdbeben von 518 hätte die Stadt zerstört, vgl. Mikulčić 2002, 56-58. Mikulčić denkt zugleich, dass gerade in Scupi, heute an der nordwestlichen Peripherie von Skoplje, Iustiniana Prima lokalisiert sei, eine Idee, die nicht viel Anerkennung gefunden hat.

64 Ivanišević-Kazanski 2002, 124-125.

65 Popović 1988, 31-37. 
auch in den Tälern oder tiefen Lagen zu einer Abkehr von alten Siedlungsmustern kam. Ehemals bebaute Teile von Städten wurden nun von neu angelegten Gräbern und Gräberfeldern, manchmal mit germanischem Charakter, oder von kleinen, neu erbauten Ansiedlungen überdeckt (Abb. 15). Solche Erscheinungen lassen die Verdrängung des homogenen Stadtgefüges durch das spätantike „Konzept“ verstreut liegender kleinerer Wohnbauten, konstruiert aus leichterem Material (vgl. Lokalität „Svetinja“ bei Viminatium) sowie eine Reduktion der Siedlungsflächen erkennen. Dasselbe Phänomen ist auch in Mazedonien beobachtet worden, wo es in Städten mit Jahrhunderte alten urbanen Traditionen und selbst im ruhigeren und reicheren Süden fassbar wird. So hat man z.B. in frühbyzantinischer Zeit in Bitola/Heracleia Lyncestis (Südmazedonien) Skulpturen der einstigen Ehrenbürger der Stadt als BaumaterialSpolien im Siedlungsgebiet oberhalb der zugeschütteten Überreste des Theaters für primitive Überbauungen genutzt (Abb. 2,16.17). ${ }^{66}$

Ein besonders wichtiges Beispiel stellt die justinianische Neugründung auf Caričin Grad dar, die von den meisten Forschern mit Iustiniana Prima gleichgesetzt wird ${ }^{67}$ Mit ihrer relativ kleinen Fläche von ca. 10 ha kann diese Zentralanlage keine große Stadt mit vielen Einwohnern gewesen sein. Allerdings verbieten sich diesbezüglich endgültige Aussagen, da hier und an anderen Fundstätten wie z.B. in Gamzigrad/Romuliana die wirkliche Siedlungsausdehnung immer noch unbekannt ist. Sie wird größer als bisher angenommen gewesen sein, da es in beiden Fällen eine Bebauung extra muros und eventuell auch eine Umwallung gab. ${ }^{68}$ Während Gamzigrad/Romuliana im 6. Jahrhundert aufgrund der bisherigen Grabungsergebnisse eher als eine Kombination aus kirchlichem Zentrum und Dorf anzusehen ist, bei der nur die alten tetrarchischen Verteidigungsmauern und die Basilika mit dem Baptisterium solide gebaut waren (Abb. 5) - was gewissermaßen an Mogorjelo in der Herzegowina ${ }^{69}$ (Abb. 3) und an Krivina/Iatrus in Bulgarien erinnert ${ }^{70}$ (Abb. 18) - ist der Charakter der Siedlung in Caričin Grad nicht so leicht zu bestimmen. Man ist versucht, sich an ein Phänomen der neueren Geschichte zu erinnern, nämlich an die sogenannten Potemkinischen Dörfer, die ihre Existenz Propagandazwecken, genauer gesagt dem Bedürfnis nach Blendwerk zu verdanken haben (Abb. 19). Dieser Vergleich sollte allerdings nicht allzu wörtlich verstanden werden.

66 Popović 1982, 562, Janakievski 1977, 81-101.

67 Vgl. Kirilov in diesem Band, Abb. 8.

68 Für Caričin Grad vgl. Bavant-Ivanišević 2003, 17. Für Gamzigrad schulde ich dem Bauforscher Dr. Čedomir Vasić, Denkmalschutzamt in Niš, Dank für die freundliche Mitteilung. Seit 2004 ist die extra muros-Zone in Gamzigrad Gegenstand eines gemeinsamen serbisch-deutschen Forschungsunternehmens (geophysikalische und Sondageprospektion), vgl. Wulf-Rheidt 2004. Ältere Resultate der Erforschung extra muros in: Gamzigrad 1983, 13-14. Vor kurzem sind von der Philosophischen Fakultät in Belgrad Prospektionen der Umgebung von Gamzigrad unternommen worden, bei denen eine größere Anzahl von Fundstellen aufgenommen wurde.

69 Basler 1993, 25, 62-64.

70 von Bülow 1995, 61-66. 


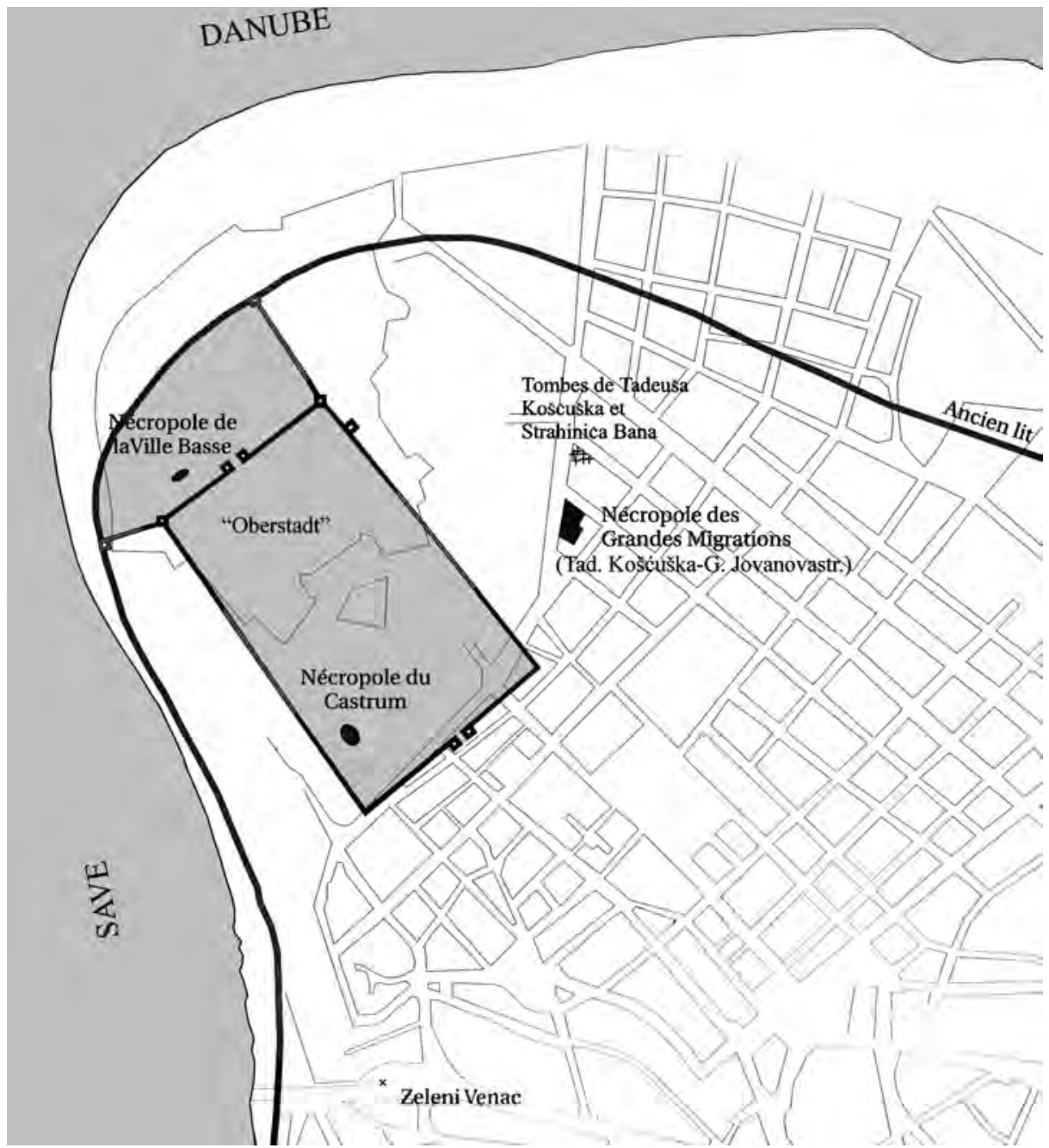

Abb. 15. Verbreitung der völkerwanderungszeitlichen Nekropolen auf dem Stadtgebiet von Singidunum 

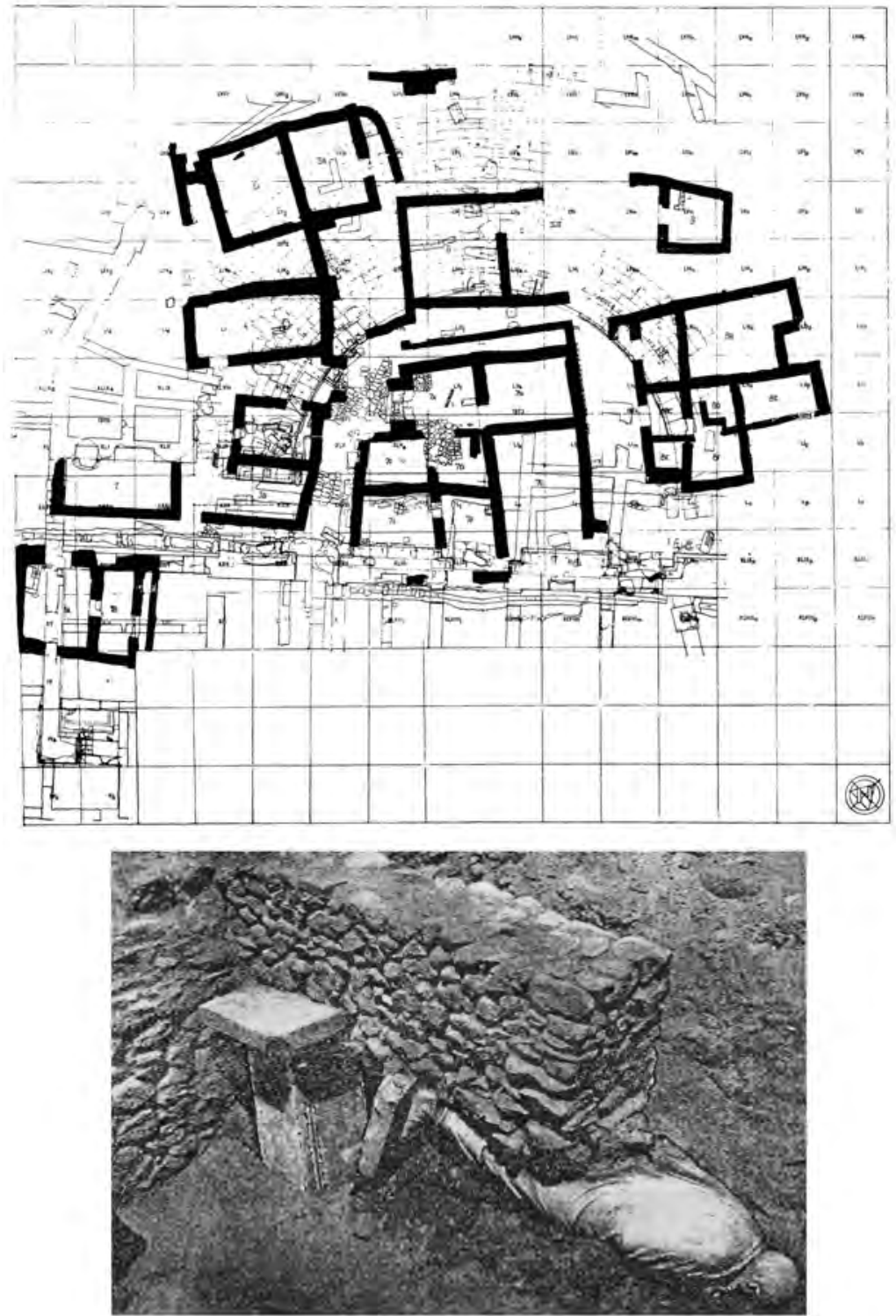

Abb. 16. Habitat auf dem Theater von Heracleia Lyncestis und Spolie 


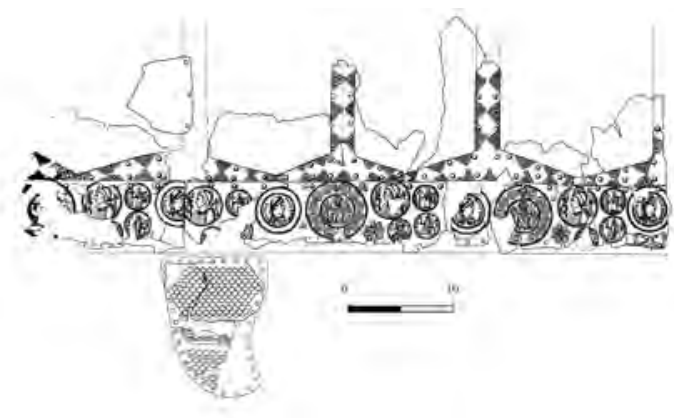

Abb. 17. Kleinfunde aus Heracleia Lyncestis

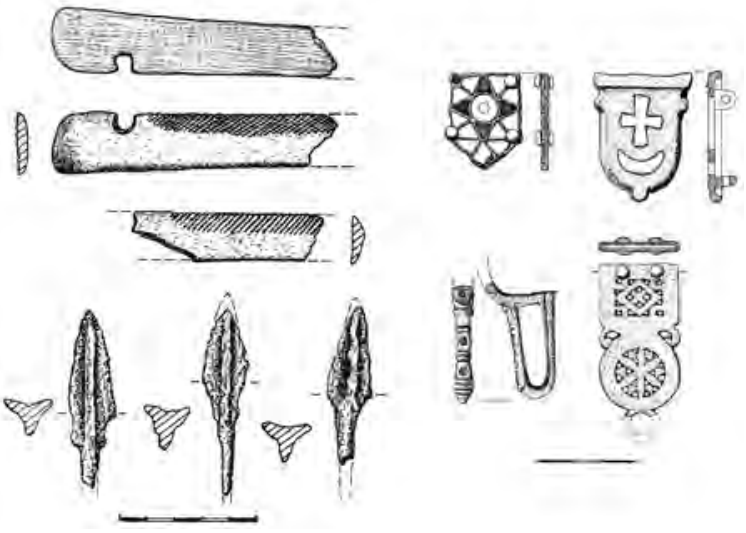

Gebaut wurde schnell und in beeindruckenden Ausmaßen, als ob man zeigen wollte, dass das mächtige Imperium wieder präsent ist. Dieser kurzlebige, aber notwendige Effekt scheint ebenso wichtig gewesen zu sein wie die solide Fundamentierung der Bauwerke, die man an manchen anderen Orten nur zu oft vernachlässigt hat. ${ }^{71}$ Die zahlenmäßig eher kleine Bevölkerung von Caričin Grad dürfte zumindest in den ersten Jahrzehnten des Bestehens des Ortes noch eine „urbane“ Zusammensetzung aus Beamten, Würdenträgern, Klerikern, Offizieren, Handwerkern, Kaufleuten etc. aufgewiesen haben. Gegen Ende der Besiedlung trat ein immer stärker landwirtschaftliches Gepräge in den Vordergrund, und bedingt durch die Anwesenheit von verschiedenen Barbaren intra muros traten auch ethnische Veränderungen in der Zusammensetzung der Bevölkerung ein - ein Prozess, von dem zwischen dem 5. und dem 7. Jahrhundert manche Stadt und Befestigung im

71 So wurden die Fundamente der Westmauer der Kirche "C" auf der Jelica nicht horizontal in den Hang eingegraben, sondern folgten der Neigung auf lehmigem Untergrund, was zu statischen Problemen und zu nachträglichen Ausbesserungen führte. Teile der Kirche „E“ wurden ohne oder mit nur sehr wenig Mörtel errichtet. Ähnliche Beispiele sind auch von anderen Fundstellen zu berichten, sogar von Befestigungen - wenn auch in keiner großen Anzahl - deren Mauerzüge teilweise ohne Mörtel gebaut waren. 


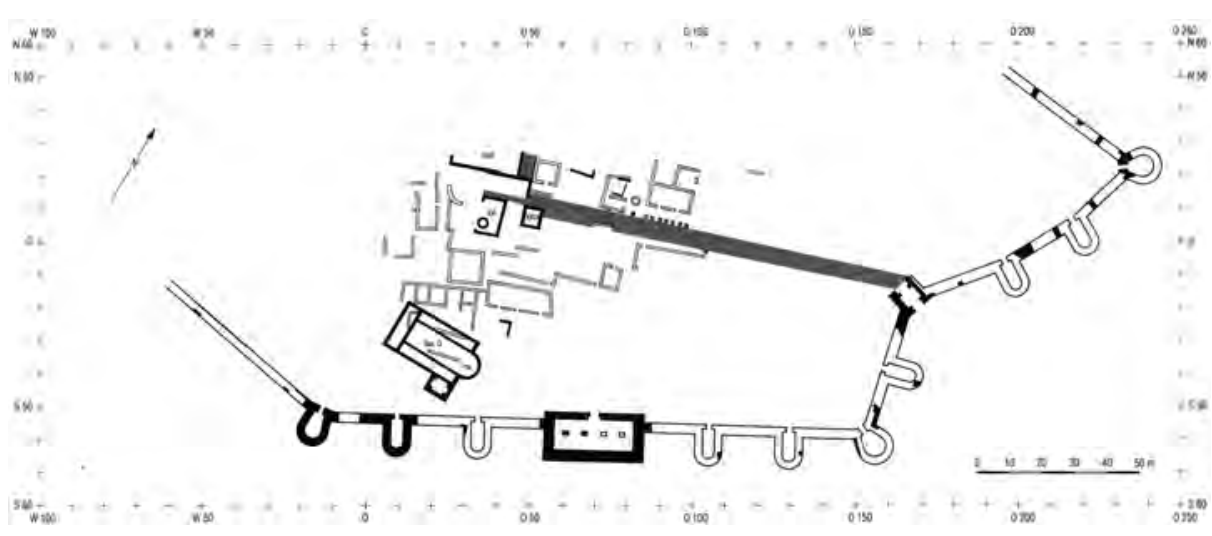

Abb. 18. Krivina/Iatrus Grundriss der Siedlungsperiode D2

Illyricum betroffen war. Immerhin unterhielt diese ethnisch nicht ganz homogene Bevölkerung Handelsbeziehungen zum Mittelmeer, die durch entsprechende Amphorenfunde und andere keramische Produkte bezeugt sind. Solche Beispiele kann man auch von der Jelica anführen, wo Amphoren- und Spatheiafunde überregionale Handelskontakte belegen. Bekanntlich wurden Amphoren zum Transport verschiedener Lebensmittel, Getränke und Saucen verwendet, darunter Wein und Olivenöl, was mit der Fortdauer mediterraner Lebensgewohnheiten in Verbindung stehen dürfte. Die Versorgung der kaiserlichen Truppen am Limes entlang der Donau wird hier als eine militärisch-logistische Angelegenheit außer Acht gelassen. Wie der Binnenhandel bzw. der regionale Handel ausgeprägt war, kann zurzeit nur vermutet oder in groben Konturen erkannt werden. Solche Austauschaktivitäten scheinen sich auf Erzeugnisse wie Tafelgeschirr, Glas, bestimmte Werkzeuge und anderes Alltagsgerät beschränkt zu haben, das nicht am Ort hergestellt werden konnte. Allem Anschein nach wurde ein guter Teil des Bedarfs der Bevölkerung durch lokale oder Eigenproduktion gedeckt, was gewissermassen auf eine ökonomische Autarkie hindeutet. Nachgewiesen sind Textil- und Lederverarbeitung, Verarbeitung von Knochen und Horn, die Töpferei usw. Diese Autarkie wird in den Dörfern stärker ausgeprägt gewesen sein als in den Städten.

Bei Aussagen zur Mobilität von Erzeugnissen und Personen müssen jedoch auch solche Aspekte wie die Möglichkeit wandernder Handwerker und die Wirkungen von Pilgerreisen zu Wallfahrtsorten und Heiligtümern in Betracht gezogen werden. Es kann nicht ausgeschlossen werden, dass zentrale Orte mit verhältnismäßig vielen Kirchen wie die Gradina auf der Jelica auch Pilger angezogen haben. Dass es auch im Illyricum Gläubige gab, die weite Pilgerfahrten unternahmen, ist durch solche sporadischen Funde wie dem einer Ampulle aus Caričin Grad bezeugt. ${ }^{72}$

72 Metzger 1984, 158-160. 


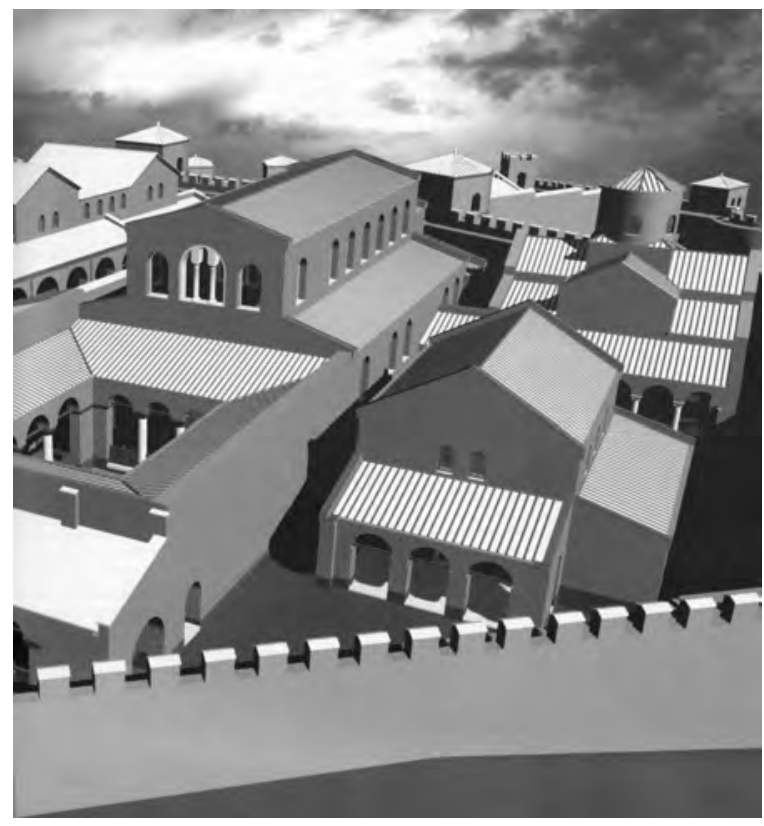

Abb. 19. Caričin Grad, Akropolis.

Rekonstruktion

Zusammenfassend muss nochmals hervorgehoben werden, dass im kontinentalen Hinterland des zentralen, nördlichen und westlichen Illyricum nur sehr zurückhaltend von einem ausgeprägten Städtewesen gesprochen werden kann, da die Übergänge zwischen Stadt, Kleinstadt, Dorf und Kastell, also zwischen Siedlungs- und Befestigungsformen (civitates, oppida, vci murati, pagi murati, refugia etc...) fließend sind. Welches funktionale Element für die einzelnen Siedlungen jeweils entscheidend ist, kann nur durch Fallstudien untersucht werden. Generalisierungen sind angesichts der jetzigen Forschungslage nicht hilfreich. Diese erlaubt allenfalls die Feststellung, dass es in den unruhigen Zeiten des 5.-7. Jahrhunderts von den genannten Gebieten generell jene im Süden waren, die bessere Voraussetzungen für das Weiterleben urbaner Formen und von Siedlungen dieser Art boten. Ein Blick auf die Verbreitungskarte der frühbyzantinischen Befestigungen in Dalmatien, Bosnien, Serbien und Mazedonien, die hier zusammengestellt wurde (Abb. 6), lässt bereits auf gewisse Trends schließen. Dies gilt ungeachtet der Tatsache, dass größere geographische Kartierungslücken durch den Forschungsstand und nicht durch ein wirkliches Fehlen von befestigten Anlagen erklärbar sind. ${ }^{73}$ Offenbar war der Süden des hier behandelten Gebietes (Mazedonien) verhältnismäßig dicht besiedelt. Es ist jedoch kaum anzunehmen, dass z.B. in Dardanien, dem heutigen

73 Außer vielleicht in der Region Mačva südlich der Save in Nordost-Serbien (Flachland), wo nach umfassender Prospektion keine Befestigungen gefunden wurden - handelt es sich um ein aufgegebenes Territorium mit befestigten Orten erst in der angrenzenden Bergzone? 
Kosovo und der Metohija nur sehr wenige Befestigungen vorhanden waren, besonders wenn man die Angaben von Prokop in Rechnung stellt. Umso beeindruckender wirkt die Verbreitungskarte für Mazedonien, die vor allem dank der ständigen Bemühungen von I. Mikulčić entstanden ist. Bei näherer Betrachtung der Gebiete in Serbien, die auch hier besser erforscht sind als jene um Caričin Grad, Novi Pazar, Čačak oder um Kruševac, entsteht immerhin der Eindruck, dass die Anlagen hier doch etwas weniger dicht verteilt sind. $\mathrm{Ob}$ diese Annahme in die richtige Richtung weist, müssen künftige Forschungen zeigen.

Durch die Ergebnisse archäologischer Forschungen, die sich in den hier betrachteten Gebieten nicht immer leicht realisieren ließen, ist es in den letzten Jahrzehnten gelungen, ein neues und um ein Vielfaches klareres Siedlungsbild des Balkans im 5., 6. und im beginnenden 7. Jahrhundert zu entwerfen. Eine auf bestimmte ausgewählte Fundorte konzentrierte, großflächige weitere Erforschung und eine weiträumig und gezielt durchgeführte Prospektion durch Sondageuntersuchungen, beispielsweise im anscheinend fundleeren Montenegro, würde bald zu neuen, tieferen und besser fundierten Einsichten führen.

\section{Bibliographie}

Basler 1972: Đuro Basler, Die Architektur der spätantiken Zeit in Bosnien und der Herzwgowina, Sarajevo 1972 [Serbisch mit deutscher Zusammenfassung].

Basler 1993: Đuro Basler, Spätantike und frühchristliche Architektur in Bosnien und der Herzegovina, Wien 1993.

Bavant/Ivanišević 2003: Bernard Bavant/Vujadin Ivanišević, Ivstiniana Prima: Caričin Grad, Beograd 2003.

Beševliev 1970: Veselin Beševliev, Zur Deutung der Kastellnamen in Prokops Werk „De Aedificiis “, Amsterdam 1970.

von Bülow 1995: Gerda von Bülow, „Die Siedlungsperiode D2 in Iatrus“, in: Iatrus-Krivina 5: Studien zur Geschichte des Kastells Iatrus, Berlin 1995, S. 61-66.

Ciglenečki 1999: Slavko Ciglenečki, „Results and Problems in the Archaeology of the Late Antiquity in Slovenia“, in: Arheološki vestnik 50, 1999, S. 287-309.

Claude 1969: Dietrich Claude, Die byzantinische Stadt im 6. Jahrhundert, München 1969.

Deroko 1950: Aleksandar Deroko, Les chateaux forts medievaux sur le territoire de la Serbie, Crna Gora et Macèdoine, Beograd 1950 [Serbisch mit franz. Zusammenfassung].

Dušanić 1995: Slobodan Dušanić, „Late Roman Mining in Illyricum: historical observations“, in: Borislav Jovanović (Hrsg.), Ancient Mining and Metallurgy in Southeast Europe, International Symposium, Donji Milanovac 20.-25.05.1990, Belgrade-Bor 1995, S. 219-225.

Feissel 1988: Denis Feissel, „L'architecte Viktôrinos et les fortifications de Justinien dans les provinces balkaniques“, in: Bulletin de la société nationale des antiquaries de France 1988, S. 136-146.

Fontes: Fontes historiae populorum Iugoslaviae spectantes 1, Beograd 1955.

Ferdančić1974: Божидар Ферјанчић, „Београд од почетка сеобе народа до досељења Словена (375-602)“, in: Историја Београда I, Београд 1974, S. 105-112. 
Fiedler 1992: Uwe Fiedler, Studien zu Gräberfeldern des 6. bis 9. Jahrhunderts an der unteren Donau 1, Bonn 1992.

Gamzigrad: Gamzigrad: An Imperial Palace of the Late Classical Times (Ausstellungskatalog), Beograd 1983.

Ivanišević 1990: Vujadin Ivanišević, „La forteresse de Zlatni Kamen“, in: Novopazarski Zbornik (Novi Pazar) 14, 1990, S. 7-17 [Serbisch mit franz. Zusammenfassung].

Ivanišević/Kazanski 2002: Vujadin Ivanišević/Michael Kazanski, „La nécropole de l'époque des Grandes Migrations à Singidunum“, in: Marko Popovic (Hrsg.), Singidunum 3, Beograd 2002, S. 101-145.

Janakievski 1977: Tome Janakievski, „Late Antique micro dwelling entity found above the Theatre in Heraclea Lyncestis“, in: Macedoniae Acta Archaeologica 3, 1977, S. 81-101 [Mazedonisch mit engl. Zusammenfassung].

Janković 1981: Đorđe Janković, La partie danubienne de la région d'Aquis au VIe et au début du VIIe siècle, Beograd 1981 [Serbisch mit franz. Zusammenfassung].

Jeremić/Milinković 1995: Miroslav Jeremić/Mihailo Milinković, „Die byzantinische Festung von Bregovina“, in: Antiquité Tardive 3, 1995, S. 209-225.

Jovanović 1995: Borislav Jovanović (Hrsg.), Ancient Mining and Metallurgy in Southeast Europe, International Symposium, Donji Milanovac 20.-25.05.1990, Beograd-Bor 1995.

Kondić/Popović 1977: Vladimir Kondić/Vladislav Popović, Caričin Grad: Site fortifié dans l'Illyricum byzantin, Beograd 1977.

Kuzmanović-Cvetković 1986: Julka Kuzmanović-Cvetković, „Early Byzantine Fortress at Babotinac“, in: Гласник Српског Археолошког Друштва 3, 1986, S. 213-218 [Serbisch mit engl. Zusammenfassung].

Lilčić 2004: Viktor Lilčić, „Early Byzantine Castels and small Fortresses in the Northern Part of the Skopje-Kumanovo Region“, in: Niš and Byzantium 2, Second Symposium-Niš 2003, Niš 2004, S. 177-184 [Serbisch mit engl. Zusammenfassung].

Metzger 1984: Catherine Metzger; „Une 'ampoule à eulogie' du type d'Asie Mineure“, in: Noël Duval/Vladislav Popović (Hrsg.), Caričin Grad 1, Beograd 1984, S. 158-160.

Mijović 1967: Pavle Mijović, „Quattuor Coronati: sculpteurs et tailleurs de Pierre de Sirmium“, in: Starinar 17/1966, 1967, S. 53-60 [Serbisch mit franz. Zusammenfasung].

Mikulčić 1982: Ivan Mikulčić, Skopje und umgebende Festungen in der Antike und dem Mittelalter, Skopje 1982 [Mazedonisch mit deut. Zusammenfassung].

Mikulčić 1986: Ivan Mikulčić, ,Spätantike Festungen in der SR Makedonien“, in: Verteidigungssysteme in der Vorgeschichte und Antike im Gebiet von Jugoslawien, Referati XII Kongresa arheologa Jugoslavije Novi Sad 1984, Novi Sad 1986, S. 101-123 [Serbisch mit deut. Zusammenfassung].

Mikulčić 2002: Ivan Mikulčić, Spätantike und frühbyzantinische Befestigungen in Nordmakedonien: Städte-Vici-Refugien-Kastelle (=Münchner Beiträge zur Vor- und Frühgeschichte 54), München 2002.

Milinković 1995: Mihailo Milinković, „Die Gradina auf dem Jelica-Gebirge und die frühbyzantinischen Befestigungen in der Umgebung von Čačak, Westserbien“, in: Antiquité tardive 3, 1995, S. 227-250.

Milinković 1999: Mihailo Milinković, „Die frühbyzantinische Befestigung bei Bregovina“, in: Miloje Vasić/Dragoslav Marinković (Hrsg.), Prokuplje in Prehistory, Antiquity and Middle Ages, Beograd-Prokuplje 1999, S. 87-116 [Serbisch mit deut. Zusammenfassung].

Milinković 2002: Mihailo Milinković, „Die byzantinische Höhenanlage auf der Jelica in Serbien - ein Beispiel aus dem nördlichen Illyricum des 6. Jahrhunderts“, in: Starinar 51/2001, 2002, S. 71-130. 
Milinković, im Druck (a): Mihailo Milinković, „Die spätantik-frühbyzantinischen befestigten Höhenanlagen in Serbien“, in: Internationales Symposium „Höhensiedlungen zwischen Antike und Mittelalter von den Ardennen bis zur Adria ", Freiburg i.Br. (im Druck).

Milinković, im Druck (b): Mihailo Milinković, Einige Bemerkungen zu frühbyzantinschen Befestigungen im Süden Serbiens, in: Symposium Niš i Vizantija III, Niš 2004, (im Druck) [Serbisch mit deutscher Zusammenfassung].

Milinković 2005: Mihailo Milinković, s.v. „Serbien“, in: Reallexikon der Germanischen Altertumskunde 28, Berlin 2005.

Mirković 1981: Мирослава Мирковић, „Економско-социјални развој у II и III веку“, in: Историја Српског народа 1, Београд 1981, S. 77-88.

Petrović 1999: Petar Petrović, Niš in Ancient Times, Niš 1999 [Serbisch mit engl. Zusammenfassung]

Popović 1995: Ivana Popović, „Les particularités de l'outilage protobyzantin dans les Balkans du Nord“, in: Starinar 45-46/1994-1995, 1995, 67-75.

Popović 1987: Marko Popović, „Svetinja - Contribution to the Study of the Early Byzantine Viminacium“, in: Starinar XXXVIII/1987, 1988, S. 1-37 [Serbisch mit engl. Zusammenfassung]

Popović 1999: Marko Popović, The Fortress of Ras, Beograd 1999 [Serbisch mit engl. Zusammenfassung].

Popović 1982: Vladislav Popović, „Desintegration und Ruralisation der Stadt im Ost-Illyricum vom 5. bis 7. Jahrhundert n.Chr.", in: Dietrich Papenfuss/Volker M. Strocka (Hrsg.), Palast und Hütte: Beiträge zum Bauen und Wohnen im Altertum, Symposium Berlin 1979, Mainz 1982, S. 545-566.

Popović 2003: Владислав Поповић, „Блажени Иринеј, први епископ Сирмијума“, in: Владислав Поповић (Hrsg.), Sirmium: Град иарева и мученика (сабрани радови о археологији и историји Сирмијума), Сремска Митровица 2003, S. 259-264.

Poulter 1992: Andrew Poulter, „The use and abuse of urbanism in the Danubian provinces during the Later Roman Empire“, in: John Rich (Hrsg.), The City in Late Antiquity, London 1992, S. 99-135.

Premović-Aleksić 1989: Dragica Premović-Aleksić, „The Late-Antiquity Fort in Babrez near Novi Pazar“, in: Novopazarski Zbornik 13, 1989, S. 17-29 [Serbisch mit engl. Zusammenfassung].

Prokop: Otto Veh (Hrsg.), Procopius. Werke. Teil 5: Bauten, München 1977.

Rašković 2000: Dragan Rašković, „Early Byzantine Archaeological Sites and Roads in the Environs of Kruševac“, in: Papers of the Third Yugoslav Byzantine Studies Conference, Kruševac 2000, Beograd-Kruševac 2002, S. 29-73 [Serbisch mit engl. Zusammenfassung].

Schramm 1999: Gottfried Schramm, Anfänge des albanischen Christentums: Die frühe Bekehrung der Bessen und ihre langen Folgen, Freiburg i.Br. 1999.

R. Seeliger, s.v. „Vier Gekrönte“, in: Lexikon für Theologie und Kirche 10, Freiburg-Basel-RomWien 2001, S. 780-781.

Skarić 1932: Vladislav Skarić, „Altertümer von Gradac in der Lepenica (Bosnien)“, in: Glasnik Zemlajskog muzeja u Bosni i Hercegovini 44, 1932, S. 1-20.

Špehar, im Druck: Perica Špehar, „Late antique and early Byzantine fortifications in Bosnia and Herzegovina (Hinterland of the province of Dalmatia)", in: Internationales Symposium „Höhensiedlungen zwischen Antike und Mittelalter von den Ardennen bis zur Adria“, Freiburg i.Br. (im Druck).

Vasić 1993: Miloje Vasić, „Sites archéologiques de la basse antiquité à Tscatschak et dans ses environs“, in: Богородица Градачка у историји српског народа. Научни скуп поводом 800 
година Богородице Градачке и града Чачка, нов. 1992, Чачак 1993, S. 9-17 [Serbisch mit franz. Zusammenfassung].

Wolfram 1990: Herwig Wolfram, Die Goten: Von den Anfängen bis zur Mitte des sechsten Jahrhunderts: Entwurf einer historischen Ethnographie, München 1990.

Wozniak 1982: Frank Wozniak, „,The Justinianic Fortification of interior Illyricum“, in: Robert L. Hohlfelder (Hrsg.), City, Town and Countryside in the Early Byzantine Era, Boulder 1982, S. $199-209$.

Wulf-Rheidt 2004: Ulrike Wulf-Rheidt, Der Palast des Kaisers Galerius Felix Romuliana: Eine serbisch-deutsche Kooperation, Berlin 2004.

Zotović 1981: Ljubica Zotović, „Nécropole du territoire municipal de Viminatium de la période des migrations des peuples“, in: Starinar 31/1980, 1981, S. 95-115 [Serbisch mit franz. Zusammenfassung].

Živić 2003: Maja Živić, Felix Romuliana: 50 years of solving, Zaječar 2003. 



\title{
Post-Roman Tiberias: between East and West
}

\author{
YIZHAR HiRSCHFELD
}

\section{Introduction}

Tiberias was founded in $19 \mathrm{CE}$ as the capital of the realm of Herod Antipas, son of Herod the Great, and was named in honour of the emperor Tiberius. ${ }^{1}$ The Roman town was located in the area of the plain to the south of modern Tiberias and to the north of the thermal springs known as Hammat Tiberias. It was bounded on the western side by Mount Berenice, which rises to a height of ca. $200 \mathrm{~m}$ above the Sea of Galilee, and on the eastern side by the lake itself (Figs 1and 2).

The town was situated on an international trade route - the Via Maris, which in antiquity linked Egypt and Syria. This route extended from Egypt along the coastal plain to Beth Shean in the Jordan Valley. From Beth Shean it ascended northward to Tiberias and then ran along the River Jordan in the direction of Damascus. The main street of Tiberias - the Cardo Maximus - which crosses the town from south to north, was actually built along the course of the Via Maris (Figs. 3 and 4). Tiberias' location on the main trade route of the Syria-Palestine gave it one of its most notable advantages.

Like all other Roman towns in the Israel, Tiberias had many public buildings, either for purposes of government and administration or for cultic, entertainment and leisure purposes. Listed in the sources are the town's gates, the council building (bouleterion), thirteen synagogues, several batei midrash (houses of study), urban markets, a stadium, a bathhouse, lavatories, elaborate tomb structures, etc. Alongside all these were the residential quarters of the town's inhabitants and various industrial areas, i.e., for the production of glass and ceramics. ${ }^{2}$ To the south of the town, in the area close to the thermal springs, Hammat Tiberias was erected, an urban suburb intended to serve the multitudes who came to the hot baths. ${ }^{3}$

1 For the history of the town of Tiberias, see Schürer 1979, 178-183; Miller 1993, 358-359; Goodman 1983; Avissar 1973, 74-95.

2 On the remains of the various structures that existed in Tiberias, see Hirschfeld 1992; idem 1993; idem 2004; Avissar 1973, 35-42; Stacey 2004.

3 On Hammat Tiberias and the remains of a synagogue found there, see Dothan 2000. 


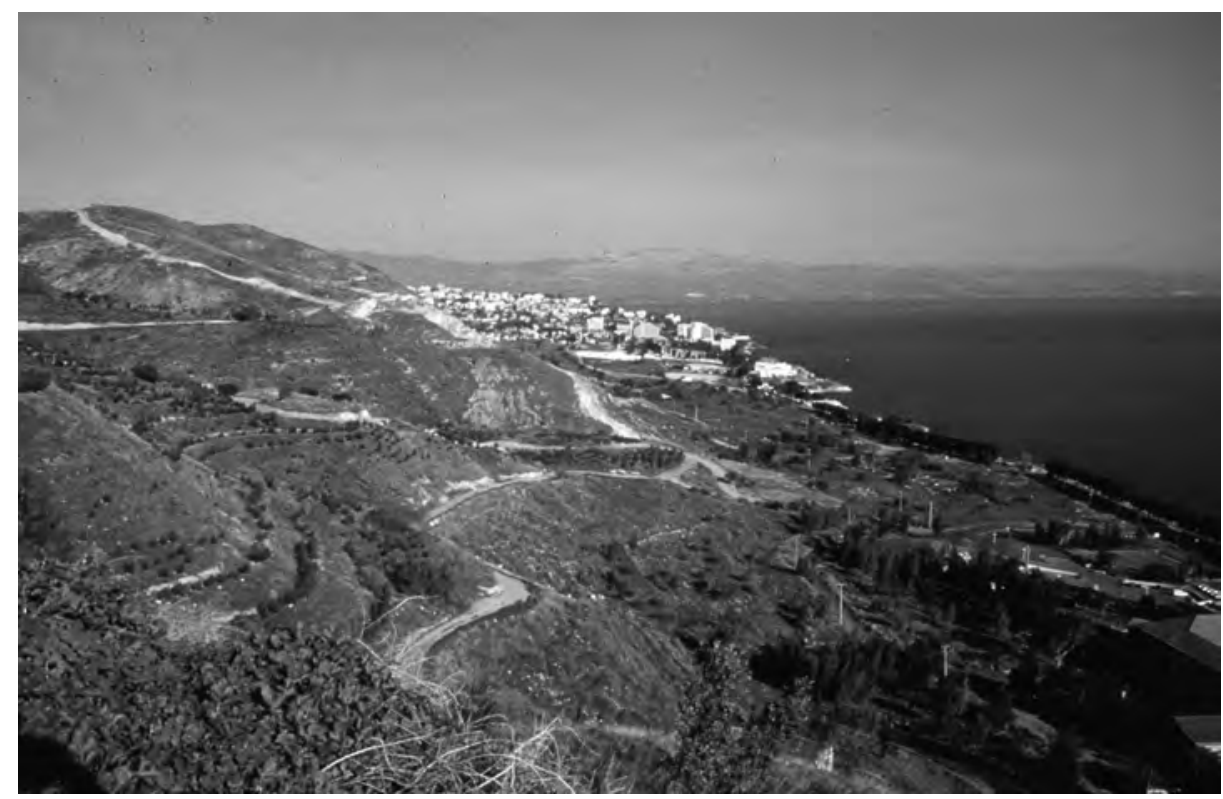

Fig. 1. Tiberias, general view of the site, looking north

On account of its location next to the Sea of Galilee, Tiberias became a pilgrimage site for the thousands who came to visit the Holy Land during the Byzantine period. Emperor Justinian (527-565), for propagandistic reasons, built a thick wall (2 m) with towers around the town. The wall ascended to the top of Mount Berenice, on the summit of which was erected a splendid, large church (Fig. 5). A monastery and a hostel for pilgrims were built next to the church. The church complex and the monastery were in continuous use for ca. 700 years, up to the Crusader period. ${ }^{4}$

\section{Tiberias during the early Muslim period}

Tiberias (el-Tabarīya) surrendered without a battle to the Muslim army under the command of Shurahhīl ibn Hasana in $636 .^{5}$ The Umayyad caliphs, whose seat was in Damascus, made Tiberias the capital of the northern region of Israel, known as Jund al-Urdunn (the "Jordan region"). This region was known to the Arabs on account of its proximity to the trade routes in Hauran and Syria. The Umayyad rulers developed the region and built palaces and amusement parks at Khirbet el-Minyeh to the north of Ti-

4 On the Christian complex on the summit of Mount Berenice, see Hirschfeld 1994; idem 2004.

5 On the Muslim conquest of Tiberias, see Hitti 1916, 178-179; Harrison 1992. 


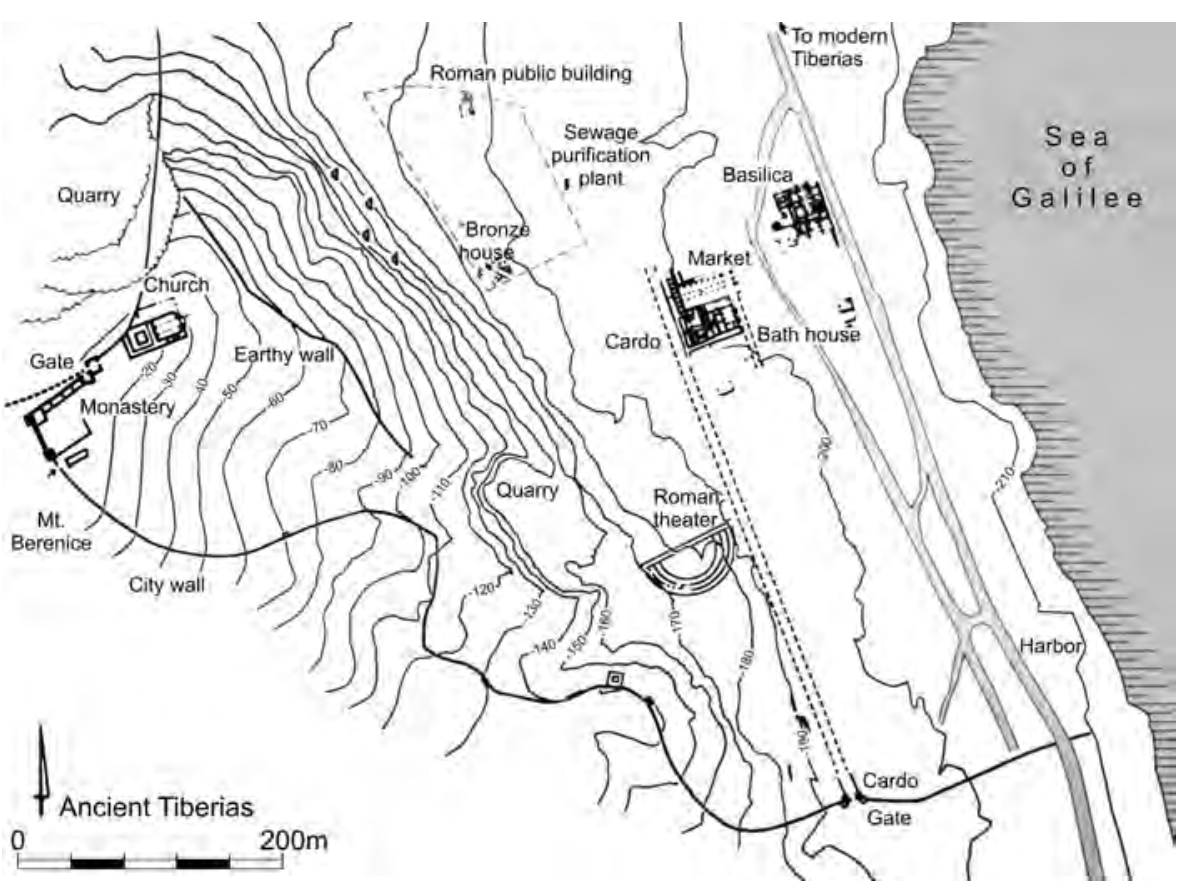

Fig. 2. Plan of the town of Tiberias

berias and at Beth Yerah to its south. ${ }^{6}$ A dedicatory inscription of the caliph Mu'awiya, found in the hot baths of Hammat Gader, refers to the renovation of the structure. ${ }^{7}$

The geographical location of Tiberias on the road between Damascus and Cairo boosted its trade, particularly with regard to the products of agriculture and small industry. Shops from this period were revealed in the area of the southern gate, ${ }^{8}$ as well as a large market in the center of the town (Fig. 6). The numismatic evidence is indicative of intensive trade between Tiberias and its neighbors, Gerash and Damascus, during the Umayyad period. ${ }^{9}$

During the early Arab period, Tiberias developed as a town with a mixed population of Jews, Christians, and Muslims. St Willibald, who visited Tiberias in 724, found "a large

6 On the remains of the Umayyad palace at Khirbet el-Minyeh, see Graber/Perrot/Ravani/ Rosen 1960. On the Umayyad remains at Beth Yerah, see Bar Adon, 1956. On the remains from early periods at the site, see Tepper 1999.

7 On the inscription of Mu'awiya in the baths of Hammat Gader, see Di Segni 1997, 237-240 (inscription 54).

8 On the shops and markets of Tiberias, see Stacey 2004, 2.

9 On the trade between Pella, Gerasa, Damascus and Tiberias according to the numismatic evidence, see Walmsley 1987, 147-150. 


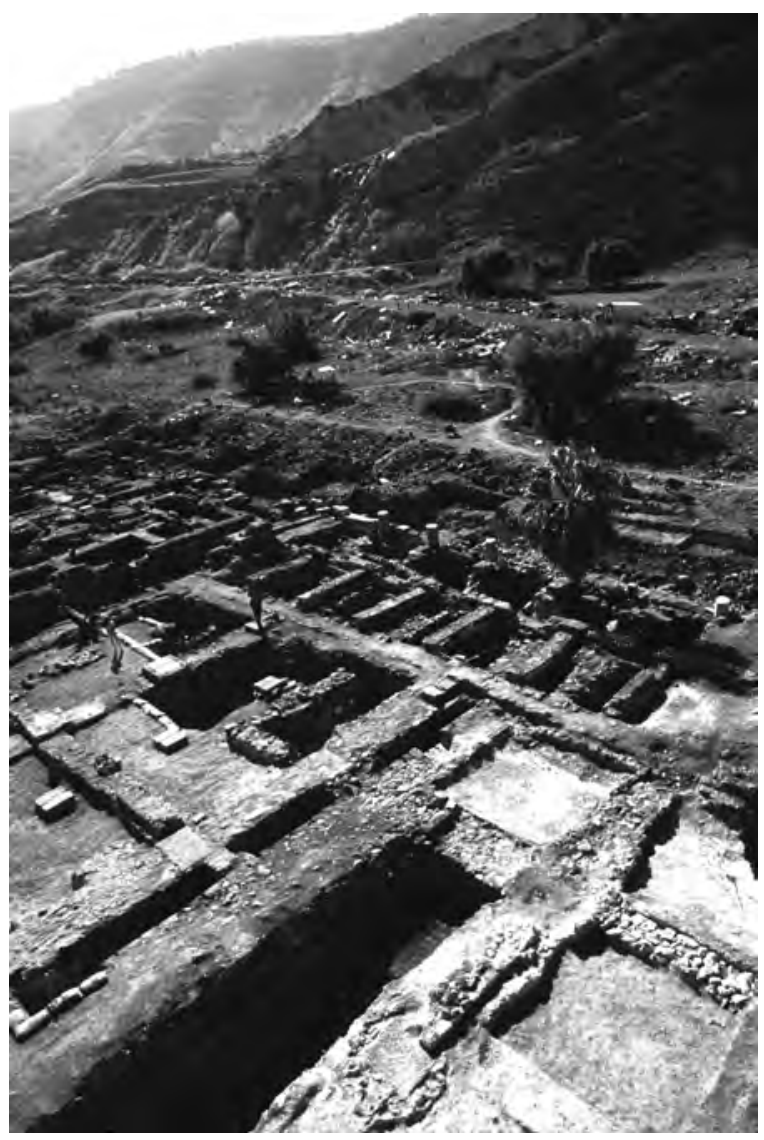

Fig. 3. Remains of the Cardo Maximus in Tiberias, looking south

number of churches and Jewish synagogues." ${ }^{10}$ A list of churches and monasteries in Palestine, compiled in the year 808 , includes five churches and one convent in Tiberias. ${ }^{11}$

The Muslim quarter developed in the southern part of the town while the Jewish quarter was located in its northern part, close to the cemetery. ${ }^{12}$ The Jews were granted a large measure of freedom in their religious practices. Jewish scholarship continued to develop around the Academy (Yeshiva) of Eretz Israel, which was located in Tiberias. The Tiberias vocalization and piyyut (poetry) were invented there in the seventh to eighth centuries. ${ }^{13}$ The Muslim traveler el-Muqadasi (ca. 985) mentions the Great Mosque which stood in the market of Tiberias. Another mosque in the western part

10 The evidence of St Willibald is presented in Wilkinson 1977, 128.

11 Ibid., 138.

12 On the division of Tiberias into residential quarters, see Stacey 2001, 247.

13 On the literary activity in Tiberias during the Early Muslim period, see Assaf/Meyer 1944, 14; Gil 1992, para. 465. 


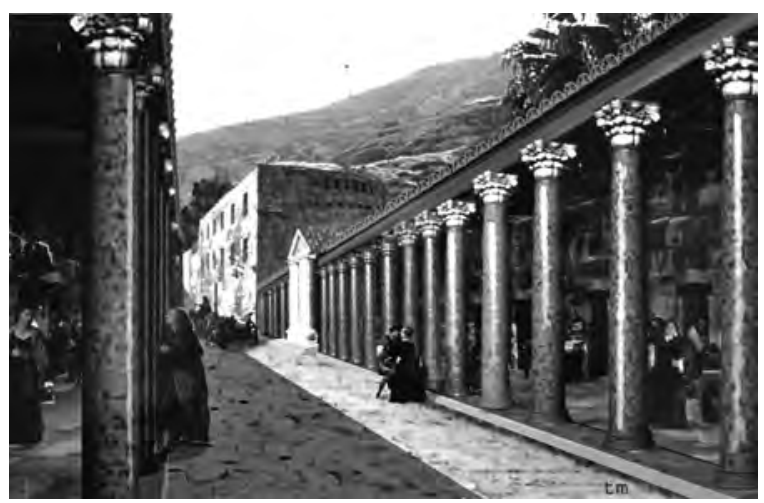

Fig. 4. Proposed reconstruction of the Cardo

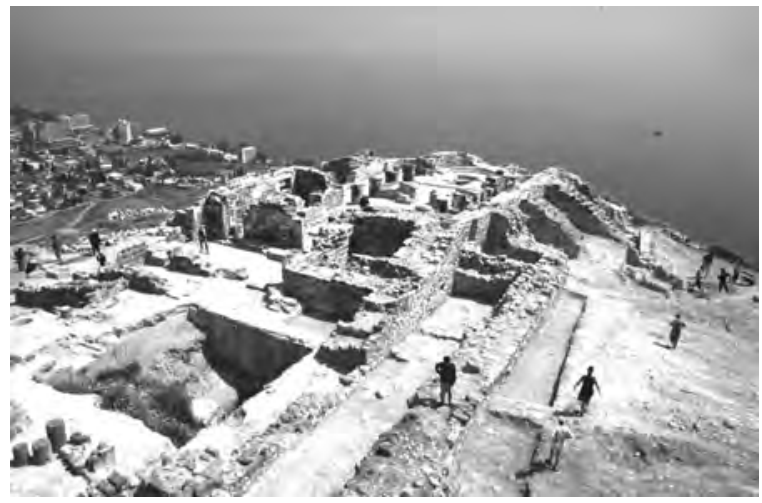

Fig. 5. The church on the summit of Mount Berenice, looking northeast

of the town was called the Jasmine Mosque because it was surrounded on all sides by jasmine shrubs. ${ }^{14}$

During the Muslim period, Tiberias retained its status as an important commercial town. In the days of Ibn Tulun, ruler of Egypt in the second half of the ninth century, commercial ties with Cairo were developed. These ties find expression in the archaeological finds. Products imported from Egypt, such as lusterware glass, as well as glazed pottery, were found during the excavations in Tiberias (Fig. 7). ${ }^{15}$ These splendid vessels were brought from Cairo, in contrast to the simpler ceramic vessels that were made locally. ${ }^{16}$

At the beginning of the tenth century, Tiberias suffered from incursions of the army of the Qarmatis (a radical Shi'ite movement), which wrought havoc and destruction. During this period, the Academy of Eretz Israel - the great Jewish center - moved from

14 On the mosques of Tiberias, see Harrison 1992, 53.

15 See, for example, the paper by Lester $(2004,204)$ on the glass vessels found at Tiberias.

16 On the pottery imported from Egypt, see Stacey 2004, 116; Amir 2004, 41. On the status of Tiberias as an important commercial town, see Whitcomb 1995, 493-494. 


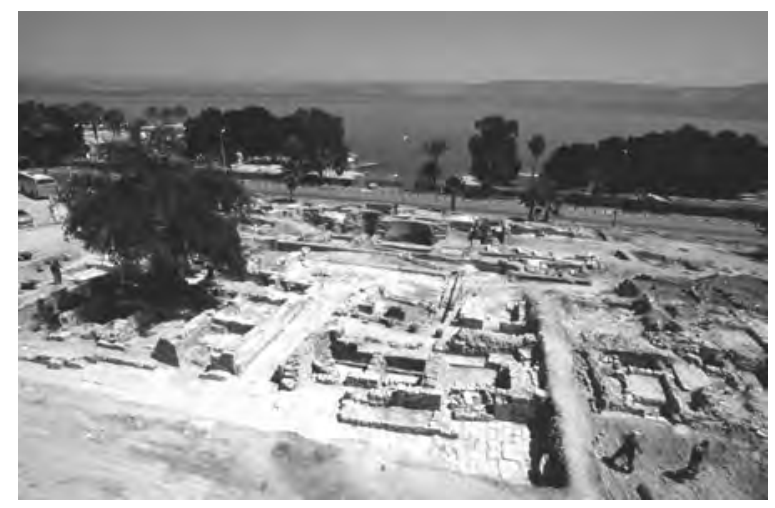

Fig. 6. The market of Tiberias, looking east

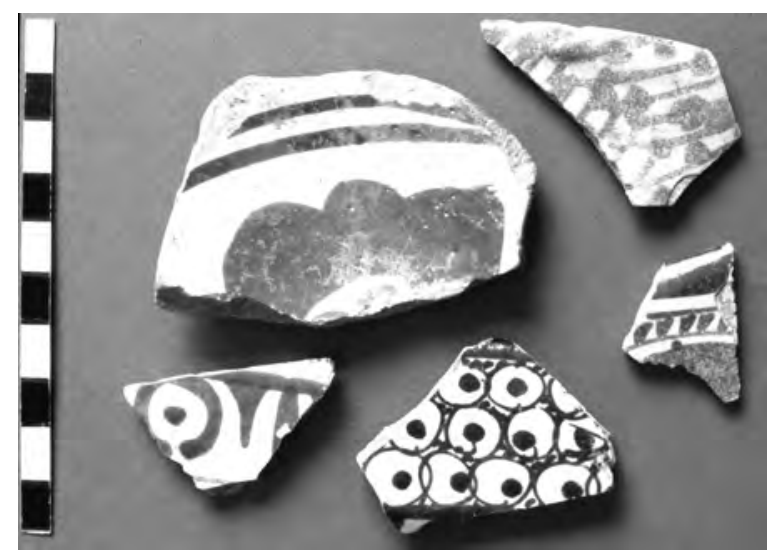

Fig. 7. Imported glazed ceramic vessels found in Tiberias

Tiberias to Jerusalem. ${ }^{17}$ In the second half of that century, the Fatimid rulers from Egypt gained control of Israel and Syria.

Tiberias, located between Cairo and Damascus, then enjoyed its last period of prosperity. Large hoards of gold, silver, and vessels made of bronze from this period were found there. ${ }^{18}$ Dwelling houses revealed in Tiberias testify to the wealth of the town's socially elite families. ${ }^{19}$

The export products of Tiberias - wine, oil, and dried fruits - reached Cairo by way of the Via Maris. The town was well known for its mat industry, which furnished products for export. ${ }^{20}$ In 1033 Tiberias was struck by a strong earthquake but the inhabitants were

17 Gil 1992, paras. 491-501; Stacey 2004, 3-4.

18 See, for example, the hoard of eleventh-century jewelry revealed in the excavations in the southern part of the town; Foerster 1993, 1472.

19 Stacey 2004, 5.

20 On the mats of Tiberias, see Avissar 1973, 32. A Tiberias mat is on display in the Benaki Museum in Athens. 


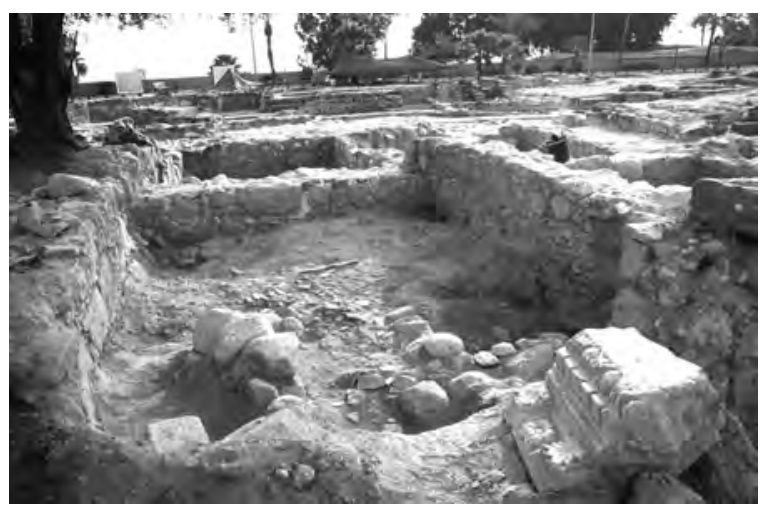

Fig. 8. Rubble resulting from the earthquake of 1068

sufficiently well established to rebuild the ruined town. The Persian traveler Nasir-i Khosrau, who visited Tiberias in 1047, describes it as a flourishing town with splendid houses built along the shore of the lake. ${ }^{21}$

Tiberias was damaged once again by the earthquake of 1068. During my recent excavations in Tiberias (2005) stone rubble resulting from this earthquake was revealed (Fig. 8). Ten years later, in 1078, the armies of the Seljuks invaded the town and massacred its population. The Crusaders, who reached Tiberias in the final year of the eleventh century, found it in a state of semi-ruin, without any inhabitants. As a result, they decided to rebuild the town in the level area to the north of the old town. The Crusader town became the nucleus from which modern Tiberias has grown.

\section{Tiberias as a town of international commerce}

Tiberias' location on the eastern edge of the Fatimid Empire made it an important commercial junction between East and West (Fig. 9). There were close commercial ties among the Islamic countries extending from Spain in the West to Iran and Turkey in the East. The archaeological finds indicate the direct and indirect contacts between the people of Tiberias and the Islamic countries. Moreover, from some of the finds we learn of their connections with Constantinople via merchants and/or pilgrims who continued to visit the holy places in Palestine.

In the excavation that I conduced in Tiberias together with Oren Gutfeld in 1998, a huge hoard of bronze vessels and objects from the Fatimid period were revealed. ${ }^{22}$ This

21 Stacey 2004, 6.

22 On the Tiberias hoard of bronze artifacts, see Hirschfeld/Gutfeld/Khamis/Amir 2000; Hirschfeld/Gutfeld 1999; Khamis/Amir 1999. 


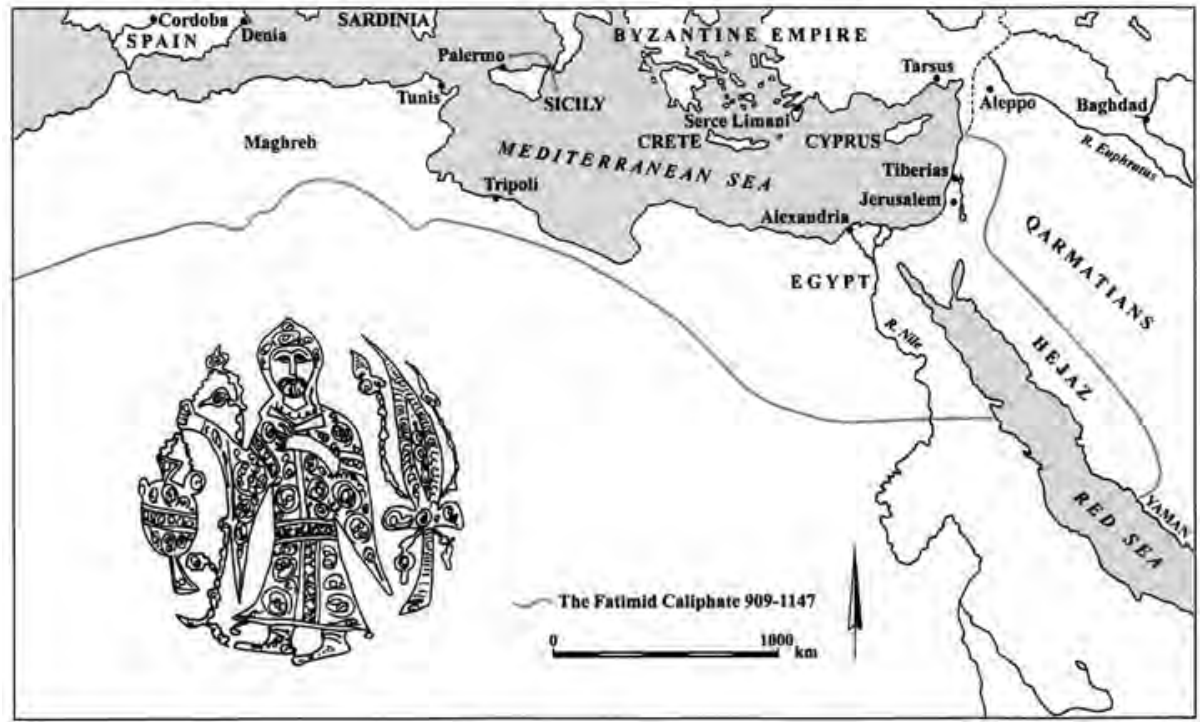

Fig. 9. Map of the Fatimid Caliphate in the tenth-eleventh century

hoard was discovered in three large pithoi concealed below the floors of a structure that served as a metalwork shop (Figs 10 and 11). The three pithoi were found to contain ca. 1,000 bronze vessels and objects of various kinds, many of them intact, thousands of pieces of metal scrap, and eighty coins. In addition to the hoard, the excavation also exposed architectural remains from the Fatimid period (969-1099), which testify to the town's prosperity at that time.

Prominent among the coins in the hoard is a group of 55 of the type termed anonymous Folles (Fig. 12). These coins were minted in Constantinople between the years 976 and $1060 .^{23}$ The anonymous Folles are also popularly known as "Jesus coins" because on one side the image of Jesus appears instead of the image of the emperor and on the other side there is a religious inscription with two similar formulations: "Jesus the Messiah, King of Kings" and "Jesus the Messiah is Victorious" (Fig. 13). Such coins are mostly found in the areas of Greece, the Balkans, Asia Minor, and Syria that came under Byzantine influence. They are very rare coins in Israel and this is the first time that they have been found here in an archaeological excavation. In the excavations that I am presently conducting in Tiberias (2005), another four coins of the anonymous Folles type were revealed, this time in the context of shops in the center of the town (Fig. 14). From the discovery of distinctly Christian coins in Tiberias we learn of the commercial ties and the movement of pilgrims between it and the Byzantine Empire.

23 On the coins from the Tiberias excavation, see Bijovsky 1999. 

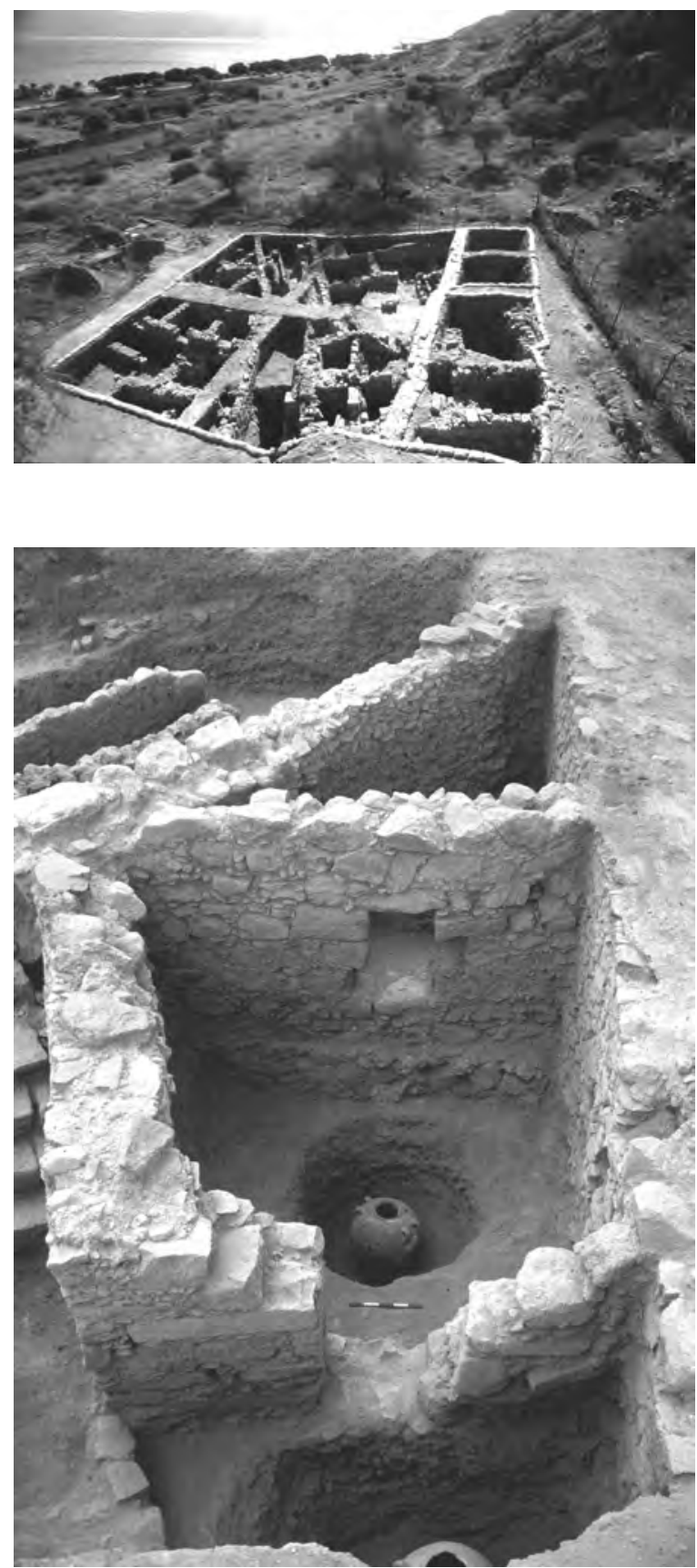

Fig. 10. General view of the excavation area in which the hoard of bronze artifacts were found, looking southeast

Fig. 11. Two of the pithoi in which the hoard was revealed 


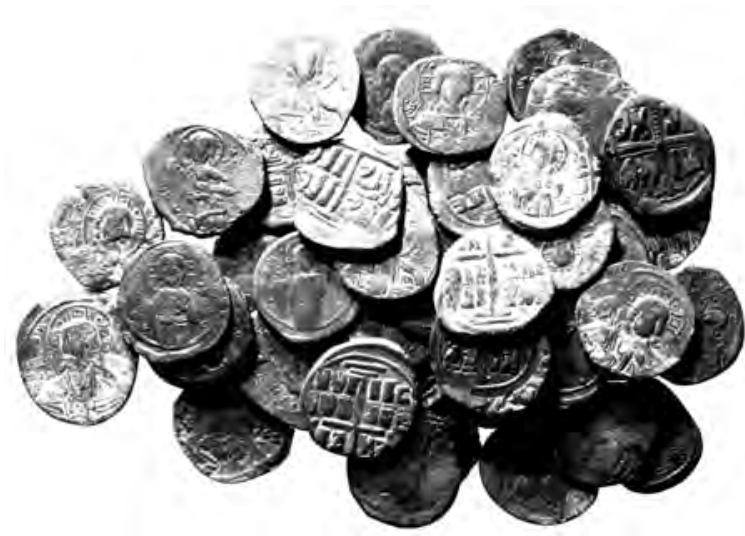

Fig. 12. Coins of the anonymous Folles type ("Jesus coins") found in the excavation

The bronze vessels and objects discovered in the hoard represent the broad scale of contacts between the people of Tiberias and various sites in the Muslim world. Prominent among them is a large group of ca. fifty lamp stands. These lamp stands consist of three parts: a tripod, a cylindrical column, and a round, flat tray on which the lamps were placed (Pl. 20.1). This shape was characteristic of Fatimid Egypt but was also known in Iran up to the thirteenth century. ${ }^{24}$

Another type of vessels found in the hoard is small bowls with a long spout, which served for filling oil lamps (Pl. 20.3). Similar bowls have been found at various sites in Egypt, Syria, Turkey, and Iran. Striking among the vessels in the large hoard is an elaborate incense burner with a cylindrical body and a domed lid (Pl. 20.2). Its closest parallels are from Coptic Egypt of the eighth to ninth century. From a chemical analysis carried out by Matthew Ponting, it became evident that the incense burner was produced in Egypt but it contains lead originating from Iran or Turkey. ${ }^{25}$ This phenomenon was also noted from other bronze objects that were examined (a total of 153 samples was taken); thus leading to the conclusion that the metal used in the local industry in Tiberias came from Iran or Turkey.

Prominent among the bronze artifacts of Tiberias are fairly elaborate objects such as the grille of a mosque lamp (Pl. 20.4). These objects were produced at known metalwork centers of the Fatimid period, such as Nishapur and Khurasan in eastern Iran, Damascus, and Cairo. ${ }^{26}$ The simpler artifacts were made in Tiberias. The hoard of bronze artifacts contained, inter alia, a piece of a lamp tripod bearing the name of its maker, 'Abbas. ${ }^{27}$

24 Khamis/Amir 1999, 109

25 On the metallurgical analysis of the Tiberias bronze artifacts, see Ponting 2003.

26 On the Fatimid metalwork industry, see Allan 1982.

27 Khamis/Amir 1999, 109. 


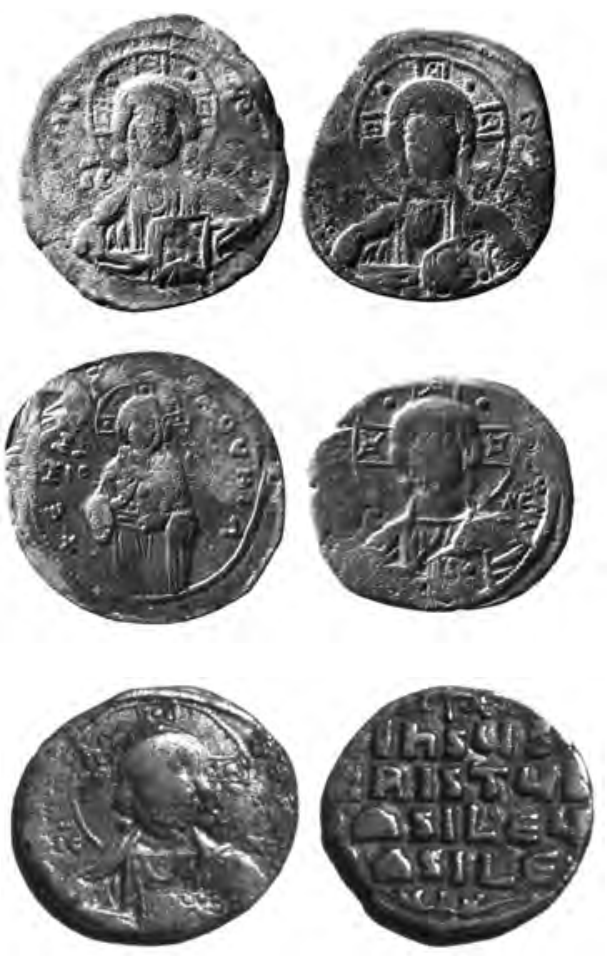

Fig. 13. Anonymous Folles coins from the hoard

Fig. 14. An anonymous Follis from the excavation of the shops at the center of the town

In a similar hoard of bronze vessels revealed in Caesarea we found the same name of the maker - once again 'Abbas, and the place of production - Caesarea. From this it follows that the relatively simple bronze artifacts were made at local workshops.

Parallel to the Tiberias hoard, hoards of bronze artifacts were found at three other sites. One of them - Caesarea - was mentioned above. At this site a hoard of 118 bronze artifacts very similar to those in Tiberias was discovered. ${ }^{28}$ Denia in southeastern Spain is another site in which Fatimid bronze artifacts were revealed. It was an important Fatimid harbour and administrative center in Andalusia. According to assessments, the 150 bronze vessels and objects found there, in large ceramic jars of the Tiberias type, came from Egypt. ${ }^{29}$

The third and most interesting site is a shipwreck at the site of Serce Liman in southern Turkey. ${ }^{30}$ The sunken ship had belonged to a Byzantine merchant and was on its way from Fatimid Syria to Constantinople. According to other objects found on board, it appears that the merchant was either of Bulgarian origin or maintained strong

28 On the hoard from Caesarea, see Lester 1999.

29 On the yet unpublished hoard from Denia, see Ponting 2003, 86.

30 On the bronze artifacts of the Serce Liman site, see Allan 2003. 


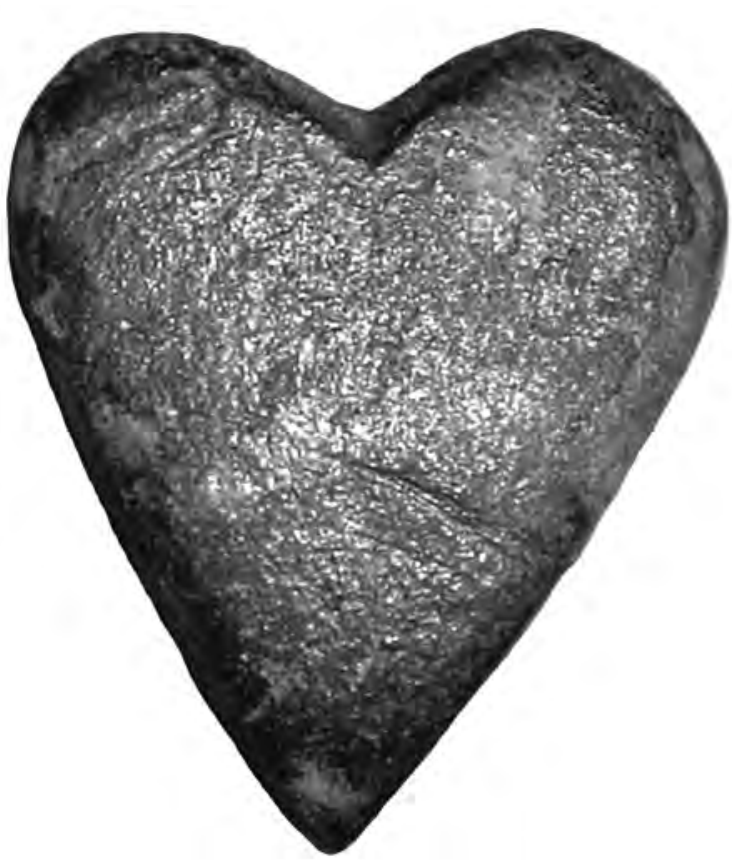

Fig. 15. Heart-shaped bronze object

ties with Bulgaria. Inter alia, a heart-shaped bronze object was found, the purpose of which is unknown. According to an isotopic analysis of the lead, it was determined that this object originated from Bulgaria. ${ }^{31}$ A similar heart-shaped bronze object was recently found (2004) in the excavations at Tiberias (Fig. 15). It possibly served as a weight for commercial purposes or as an ingot for the metal industry. Its discovery, together with that of the "Jesus coins," serves as evidence of the trade connections between Tiberias and the Byzantine world.

\section{Summary}

The archaeological finds at Tiberias point to the strong commercial ties that once existed between the town's inhabitants and Muslim countries such as Egypt, Syria, and Iran, as well as more distant countries such as Byzantium and Bulgaria. International trade connections were characteristic of the early Muslim period (638-1099). Tiberias' location between Damascus and Cairo led to its economic prosperity. Most of the archaeological finds exposed to date in Tiberias are from this period. It can be assumed that the excavations that are now fully under way there will yield many finds that will broaden our knowledge of post-Roman Tiberias and of its ties with the neighbouring countries.

31 Ponting 2003, 86-87. 


\section{Bibliography}

Allan 1982: James W. Allan, Nishapur: metalwork of the Early Islamic Period, New York 1982. Allan 2003: James W. Allan, "Metal Vessels", in: George F. Bass/James W. Allan/William C. Peel (Eds), Serce Liman: an eleventh-century shipwreck, College Station 2003.

Amir 2004: Roni Amir, "Pottery and Small Finds," in: Yizhar Hirschfeld, Excavations at Tiberias, 1989-1994 (=Israel Antiquities Authority Reports 22), Jerusalem 2004, pp. 31-56.

Assaf/Meyer 1944: S. Assaf/L. Meyer (Eds), Sefer Ha-Yishuv II, Jerusalem 1944 (Hebrew).

Avissar 1973: Oded Avissar, Sefer Teveriyya (Tiberias Book), Tel Aviv 1973 (Hebrew).

Bar Adon 1956: Pesach Bar Adon, "Sinnabra and Beth Yerah in the Light of the Sources and Archaeological Finds", in: Eretz Israel 4, 1956, pp. 50-55 (Hebrew).

Bijovsky 1999: Gabriella Bijovsky, "A Hoard of Bronze Objects and Coins from Tiberias in Israel", in: International Numismatic Newsletter 34, 1999, p. 34.

Di Segni 1997: Leah Di Segni, “The Greek Inscriptions of Hammat Gader”, in: Yizhar Hirschfeld (Ed.), The Roman Baths of Hammat Gader, Jerusalem 1997, pp. 185-266.

Dothan 2000: Moshe Dothan, Hammath Tiberias I-II, Jerusalem 2000.

Foerster 1993: Gideon Foerster, "Tiberias," in: Ephraim Stern (Ed.), New Encyclopedia of Archaeological Excavations in the Holy Land 4, Jerusalem 1993, pp. 1470-1473.

Gil 1992: Moshe Gil, A History of Palestine 634-1099, Cambridge 1992.

Goodman 1983: Martin Goodman, State and Society in Roman Galilee, A.D. 132-212, London 1983.

Graber/Perrot/Ravani/Rosen 1960: Oleg Grabar/J. Perrot/B. Ravani/M. Rosen, "Sondages à Khirbet el-Minyeh," in: Israel Exploration Journal 10, 1960, pp. 226-243.

Harrison 1992: Timothy P. Harrison, "The Early Umayyad Settlement at Tabariyah: a Case of Yet Another Misr?", in: Journal of Near Eastern Studies 51, 1992, pp. 51-59.

Hirschfeld 1992: Yizhar Hirschfeld, A Guide to Antiquity Sites in Tiberias, Jerusalem 1992.

Hirschfeld 1993: Yizhar Hirschfeld, "Tiberias," in: Ephraim Stern (Ed.), New Encyclopedia of Archaeological Excavations in the Holy Land 4, Jerusalem 1993, pp. 1464-1470.

Hirschfeld 1994: Yizhar Hirschfeld, "The Anchor Church at the Summit of Mt. Berenice, Tiberias," in: Biblical Archaeologist 57, 1994, pp. 122-134.

Hirschfeld 2004: Yizhar Hirschfeld, Excavations at Tiberias, 1989-1994 (=Israel Antiquities Authority Reports 22), Jerusalem 2004.

Hirschfeld/Gutfeld/Khamis/Amir 2000: Yizhar Hirschfeld/Oren Gutfeld/Elias Khamis/Roni Amir, "A Hoard of Fatimid Bronze Vessels from Tiberias", in: Al- 'Usur al-Wusta 12, 2000, pp. 1-7.

Hirschfeld/Gutfeld 1999: Yizhar Hirschfeld/Oren Gutfeld, "Discovery of a Fatimid Period Bronze Vessel Hoard at Tiberias", in: Qadmoniot 32, 1999, pp. 102-108 (Hebrew).

Hitti 1916: Philip Khuri Hitti, The Origins of the Islamic State, New York 1916.

Khamis/Amir 1999: Elias Khamis/Roni Amir, "The Fatimid Period Bronze Vessel Hoard," in: Qadmoniot 32, 1999, pp. 108-114 (Hebrew).

Lester 1999: Ayala Lester, "The Metal Hoard of Caesarea," in: Avner Raban (Ed.), The Richness of Islamic Caesarea, Haifa 1999, pp. 36-41.

Lester 2004: Ayala Lester, "The Glass," in: David Stacey, Excavations at Tiberias, 1973-1974: The Early Islamic Period (=Israel Antiquities Authority Reports 21), Jerusalem 2004, pp. 167-220.

Millar 1993: Fergus Millar, The Roman Near East 31 BC-AD 337, Cambridge, Mass.-London 1993.

Ponting 2003: Matthew J. Ponting, "From Damascus to Denia: the scientific analysis of three groups of Fatimid period metalwork", in: Historical Metallurgy 37, 2003, pp. 85-105.

Schürer 1979: Emil Schürer, The History of the Jewish People in the Age of Jesus Christ II, Edinburgh 1979. 
Stacey 2004: David Stacey, Excavations at Tiberias, 1973-1974: the Early Islamic Period (=Israel Antiquities Authority Reports 21), Jerusalem 2004.

Tepper 1999: Yotam Tepper, "A Basilica at Beth Yerah? Beth Yerah Revisited”, in: Tel Aviv 26, 1999, pp. 271-282.

Walmsley 1987: Allen G. Walmsley, The Administrative Structure and Urban Geography of the Jund of Filastin and the Jund of al-Urdunn (Ph. D. dissertation), Sidney 1987.

Whitcomb 1995: Donald Whitcomb, "Islam and the Socio-Cultural Transition of Palestine Early Islamic Period (638-1099 CE)", in: Thomas Evan Levy (Ed.), The Archaeology of Society in the Holy Land, London 1995, pp. 488-501.

Wilkinson 1977: John Wilkinson, Jerusalem Pilgrims before the Crusades, Jerusalem 1977. 


\section{CHAPTER V}

$$
\text { Pliska - Town ANd Hinterland }
$$





\title{
The Metropolis of Pliska or, how large does an early medieval settlement have to be in order to be called a city?
}

\author{
JoACHIM HenNing
}

\section{Introduction}

Who would hesitate to call early medieval Constantinople, the mega center of its day and capital of the Byzantine Empire, a city? And who would doubt that this city, embedded in a general urban culture of Byzantium, was not therefore the ultimate expression of that culture? According to Sozomen, a late antique historian of the Christian church, the enlargement of the city's fortified territory to an area of more than $12 \mathrm{~km}^{2}$ under the fifth-century rule of emperor Theodosius II would have made Constantinople the largest city in the Roman Empire. Thus Rome, the Eternal City, found itself in second place. And while the impact of pandemic plague brought a considerable loss for the city in terms of population, which had been estimated at a height of 400,000 for the middle of the sixth century, the territory of Constantinople never experienced any noteworthy reduction until the crusaders' conquest of AD 1204 . $^{1}$

And yet in the eastern half of early medieval Europe, namely in the Balkans in modern-day northeastern Bulgaria, and not too far from Constantinople, there stood another fortified center even bigger than this supposedly greatest of cities. But while it possessed dozens of stone monuments, such as palaces, sanctuaries and churches, stone fortifications with towers and gates, it perhaps remains doubtful as to whether we might call it a city comparable with the Byzantine urban model. Here I refer to the huge settlement complex situated in the vicinity of the former Turkish village named Aboba in northeastern Bulgaria, which was first brought under archaeological investigation at the end of the nineteenth century. Already before excavations started in 1899, the fortified site was hypothetically equated with the center of Pliskoba/Pliska, the assumed first "capital" of early medieval Bulgaria. ${ }^{2}$

Between 1997 and 2003 a series of joint German-Bulgarian archaeological field campaigns were realized in multiple early medieval fortifications in the basin of the

1 Koder 1984, 114-118.

2 For the background to the written record, see the article of Günter Prinzing in this volume. 
modern-day Pliska plain in northeastern Bulgaria; special attention was given to Aboba-Pliska, in an effort to explore in greater depth the chronology, structure, and economic traits of all these fortifications. The following essay will discuss some of the results of this fieldwork, focusing on the question of a possible urban characterization of that unique settlement complex.

The Bulgarian kingdom developed following the immigration of the Bulgars into the former Byzantine territories of Scytia minor and parts of Thracia in the year 681 AD. This realm dominated most areas of Southeastern Europe over the following centuries, and more then once Bulgarian armies stood before the city walls of Constantinople, ready to raise their own king to the throne of this "second Rome". A huge fortified settlement agglomeration, a "metropolis of the Balkans", grew up in the approximate topographical center of the early Bulgarian kingdom. As for the extension of the fortified occupation territory, it toppled both Roman capitals from their pedestals. The modern discoverers and first excavators called it the "fortification of Aboba", after the Turkish village that occupied a smaller part of the site. ${ }^{3}$ This early medieval settlement complex extends over a huge area of $21.8 \mathrm{~km}^{2}$, one third bigger than the city of Constantinople. And yet, surprisingly, the site remains very little known beyond the scholarly community, at least in Western Europe (Fig. 1). Scholarly speculation has long suggested that the site is indeed that of Pliska, supposedly the power center of the Bulgarian realm. The most recent German-Bulgarian research has, however, caused some of the older doubts to resurface concerning the occupation history of the site, the dating of its development stages, and its early roots. Also in question is its role following the Byzantine re-conquest in AD 971/972 of the eastern half of the Balkan Peninsula under John I

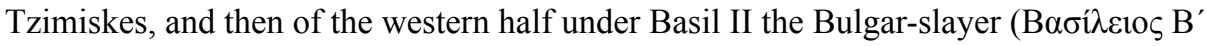

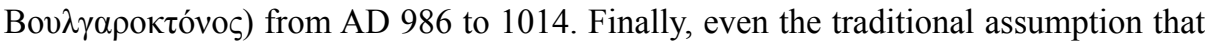
the Aboba fortification might be the only or the "true" Pliska was called into question after the German-Bulgarian team's surprising discovery of the unique occupation structures in the large Kabiyuk fortification, $8 \mathrm{~km}$ west of that of Aboba. ${ }^{4}$

For a detailed description of the Aboba-Pliska fortification we may consult the study of Janko Dimitrov, ${ }^{5}$ who has worked tirelessly to up-date the inventory of monuments first produced by Karel Škorpil ${ }^{6}$ and later revised by Krăstju Mijatev. As for the century-long research history of the Aboba-Pliska fortification, the compilation of Ljudmila Dončeva-Petkova provides a complete overview. Beginning with the first campaigns financed by the Russian Archaeological Institute in Constantinople in 1899 and directed jointly by Karel Škorpil, doyen of Bulgarian archaeology, and the institute's director Fjodor Ivanovič Uspenskij, specialist in Byzantine studies, the review is

3 Aboba-Pliska 1905.

4 See the article of Henning \& Eyup in this volume.

5 See his article in this volume with detailed references.

6 Škorpil 1905. 


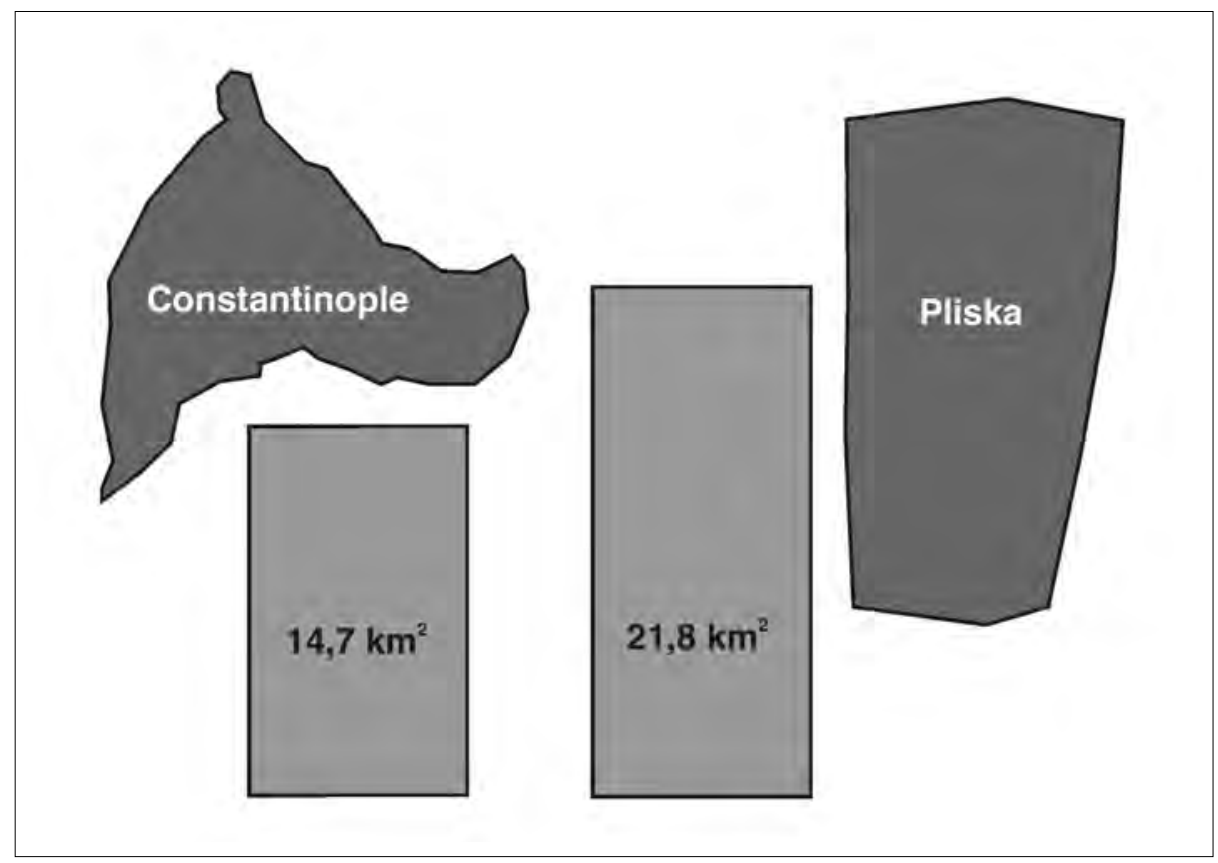

Fig. 1. Comparison between the fortified occupation areas of Constantinople (fourth-thirteenth centuries) and the Aboba fortification held to be Pliska, the capital of early medieval Bulgaria (c. eighth-tenth centuries)

then brought up to date with the German-Bulgarian campaigns financed by the University of Frankfurt am Main in 1997-2003. ${ }^{7}$

\section{The German-Bulgarian archaeological research campaigns in the Aboba fortification and in the Pliska plain (1997-2003)}

Two basic methodological challenges may be identified for archaeological research in the old Bulgarian ruling centers of the Pliska plain: First, the astonishing lack of modern methods of archaeological surveying and analysis applied in the Aboba-Pliska complex prior to $1997 .{ }^{8}$ This situation was especially regrettable in view of the great importance these sites have for Bulgarian and European history. Techniques such as

7 Dončeva-Petkova 2000. For more recent excavations in the Aboba fortification see: http:// aim.sofianet.net/main.php?lang=BG and reviews in: Archeologija (Sofia) 44/4, 3003, 64-65; 45/3-4, 2004, 105-116.

8 For a description of the new scientific strategies applied since 1997, see: Henning 2000; idem 2006. 
aerial photographs had been used sporadically since 1992, but very few basic applications of scientific analysis were realized. ${ }^{9}$ No consistent geodetic survey system relating to the entire territory of the site was ever installed ${ }^{10}$ and excavations too often were still organized in the style of nineteenth century Near-east large-scale diggings, with hundreds of workers and very few well-trained specialists. The second challenge lay in the enormous extension of the sites, especially of the Aboba fortification $\left(21.8 \mathrm{~km}^{2}\right.$; c. $6.5 \mathrm{~km}$ long and c. $3.9 \mathrm{~km}$ broad) and the Kabiyuk fortification $\left(3.7 \mathrm{~km}^{2}\right.$; side lengths of $2.0-1.2-1.98-2.36 \mathrm{~km})$ as well as the sites of Omurtag's palace (aulē) near to the village of Khan Krum ( 22.5 ha; c. $550 \mathrm{~m}$ x c. $450 \mathrm{~m}$ ) and the Strumba locality near to the town of Shumen (c. 4 ha). For German-Bulgarian surveying teams, there were considerable challenges in applying large scale prospecting by geophysics, systematic analysis of aerial photos and GIS application. With the exception of trench No. 21, and of a geophysical survey area in the southeastern corner of the Inner Town, all exploration activities in the Aboba-Pliska fortification were focused upon the extended areas of the Outer Town, especially on the Asar-dere area (Fig. 2).

In five 4-week-campaigns from 1997 to 2001 a total area of 53.35 ha (131.83 acres) was explored on the territory of the Aboba-Pliska fortification by geomagnetic measuring and corresponding mapping. Further sites were investigated in 2002 and 2003 in the same way outside the Aboba-Pliska fortification on a surface of another 29.2 ha (72.15 acres). The total of the explored area in the Pliska plain is 82.55 ha (203.98 acres). In order to verify structures that had been detected by geophysics, 40 archaeological trenches (31 trenches in Aboba-Pliska: Pls 24-a and 25, Fig. 3 and 9 trenches in the aule of Omurtag: Pl. 36) were positioned in the most target-oriented way, as directed by the geophysical results. Aerial orthophotos and topographical maps covering the whole extension of the explored fortifications (Aboba, Kabiyuk, Omurtag's aule etc.) were acquired, digitalized and then used for selecting and positioning suitable research areas and trenches and for displaying the results of structure detection. Geoelectric measurements were carried out in Aboba-Pliska for detecting production installations (trench No. 16), stone structures (trench No. 13) and the precise position of a secret passage in the Inner Town (trench No. 21; Pl. 29). ${ }^{11}$ The complex stratigraphy observed in the main trench (No. 4-10) was used for separating ceramic finds according to the pattern of strata and consequent analyzing of development trends of the ceramic material. ${ }^{12}$ Charcoal found in the secret passage (trench No. 21) was used for a first attempt at

9 Petrova 1992 and the article of Dimitrov (fig. 3) in this volume.

10 Personal experiences that were kindly confirmed by Professor Stefka Angelova (Sofia University). The German-Bulgarian team therefore used GPS, the Aamerican Global Navigation Satellite System (GNSS).

11 See the contribution of Norbert Schleifer in this volume.

12 See the first attempt at evaluating the ceramic materials by Ljudmila Dončeva-Petkova and the analysis of yellow pottery by Vassilena Petrova, both in this volume. 


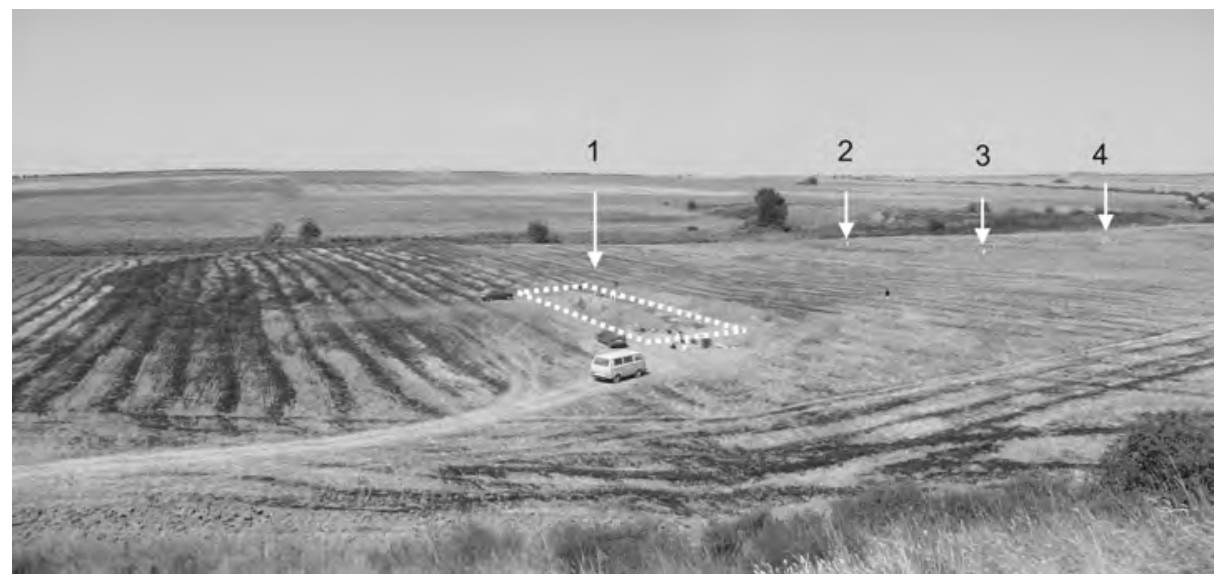

Fig. 2. The area of the German-Bulgarian field exploration at the Asar-dere creek valley (line of bushes in the background) in Aboba-Pliska's Outer Town surrounded by the earthen rampart (identical with the horizon line) viewed from the mound No. XXXIV (see Pl. 23). 1 - main trench (No. 4-10); 2 - trench No. 14; 3 - trench No. 13; 4 - trench No. 12

dendrochronological dating. A detailed report of the results is currently in preparation in monograph form. ${ }^{13}$

What follows is a discussion of some of the archaeological observations, which are especially relevant for the question of urban developments and the historical situation in the Pliska plain.

\section{A nomadic camp and rural beginnings?}

The extended rectangular earthen rampart enclosure that surrounds the Outer Town of the Aboba-Pliska complex (Pl. 22, graphic symbol No. 1) is commonly thought to be one of the first constructions built shortly after the first settlement of the nomadic Bulgars in the Pliska plain, which must have happened somewhat after 681 AD. According to that view, the inner territory of the camp-like enclosure would have been covered by loosely scattered rural settlement complexes consisting of modest cottage dwellings of the sunken floor type (grubenhäuser). ${ }^{14}$ This settlement area is called the Outer Town

\section{Henning (in prep.)}

14 This conceptual picture of an early Aboba-Pliska camp with grubenhäuser settlement structures was drawn especially by R. Rašev $(1995,16)$ who refers on the one hand to the research results of Michajlov, Milčev, Georgiev etc. in the Outer Town, and on the other hand ascribes all non-stone-built structures including the great number of grubenhäuser found in the Inner Town to a homogenous first archaic "timber-built Pliska". 


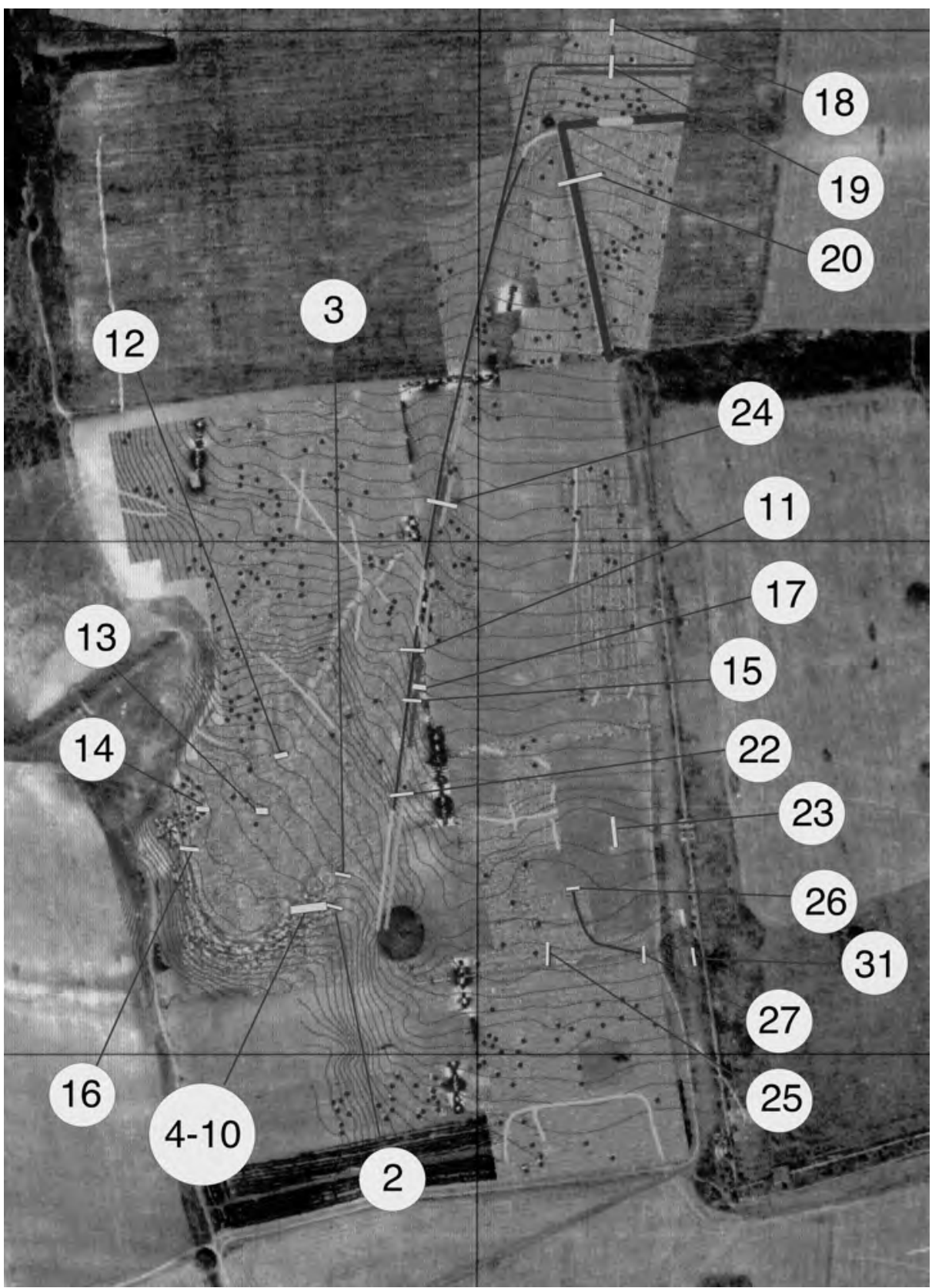

Fig. 3. Archaeological trenches of the German-Bulgarian research team (1997-2000) in the broader Asar-dere area of Aboba-Pliska (see also Pl. 24a and for trenches in the Poluostrov area, Pl. 25) 
as distinct from the Inner Town, which consists of the palace center and aristocratic building complexes encircled by a stone fortification ( $\mathrm{Pl}$. 22, graphic symbol No. 2). The two best explored examples of such supposedly primordial rural settlement structures of the Outer Town were those excavated by Atanas Milčev in the late1950s and early 1960s. These excavations took place in the Asar-dere area (parts of which are also called "Hadžaklăjuk"), which is an extended territory west of the Inner Town's stone fortification named after the nearby creek valley (Pls 23 and 24). ${ }^{15}$ Comparable excavations were carried out in the territory of the Great Basilica's building complex northeast of the Inner Town (Pl. 30). Parts of the latter excavation were undertaken, and results published, by Pavel Georgiev in the late 1970s, and these excavations were later completed by Radoslav Vasilev in the 1980s. ${ }^{16}$ Milčev's Asare-dere and Georgiev's Great Basilica settlements may be regarded as the two main pillars of Pliska's urbanization hypothesis. These two settlements were thought to have been associated with the very early first socio-economic development stage of the Aboba-Pliska complex in the period from the late seventh to the eighth centuries (Michajlov, Milčev) or in the eighth and first half of the ninth century (Georgiev). Supposedly they would attest a substantial rural population located around the ruler's residence, living in grubenhäuser in the large area surrounded by the earthen rampart and serving in the khan's army. The Asar-dere settlement in particular was labeled by A. Milčev as "Slavic" and was held to confirm the assumed original "Slavic character" of the first Bulgarian capital, a view that was clearly favored at that time by the state and party leaders of Bulgaria. ${ }^{17}$ Georgiev's assumption of a Slavic-Bulgarian character as regards the "pagan" settlement in the Great Basilica area holds a middle position in recent discussions. The population that lived in those two settlement complexes would have dealt predominantly with animal husbandry and to a certain extent with farming. An enormous nomadic, semi-nomadic or at least rural fortified camp with the khan's palace at the center thus seemed to provide an adequate label for that complex, which would be the starting point for further developments.

Four clay-made furnaces, which were interpreted as pottery kilns for producing glazed ceramic vessels were also uncovered in the Asar-dere area and were related to the next socio-economic development stage of Pliska in the later ninth to tenth centu-

15 Milčev 1960 (two grubenhäuser excavated in 1959). According to Milčev (1964, 29), five years later he had uncovered a total of 12 grubenhäuser spread over the entire Asar-dere area and all would have delivered the same pottery material datable to the eighth century. For such an early dating, see already: Michajlov/Milčev 1959, 288 with reference to the badly preserved (or excavated) grubenhäuser in the area of the building complex No. 31.

16 Georgiev 1981; idem 1993; Vasilev 1987; idem 1995. See also the articles of both authors in this volume.

17 See the conceptual article of Milčev 1964, and for the so-called "first Slavic capital", see: Michajlov 1959. The "Slavic" character of the early development stages of Aboba-Pliska still plays a role in the conceptual view of Dimitrov 1994b. 
ries. This would have been marked by the existence of professional and highly specialized craft working and other elements of an urban economy. ${ }^{18}$ The chronological basis for relating the many craft activities attested by Atanas Milčev in the Asar-dere area to this more advanced later development phase of Pliska - that is, the period after its supposedly stepwise transformation into a true large town - came as a result of the until now broadly and certainly correctly accepted dating of the first occurrence of glazed ceramic ware, namely not until the later ninth, or more likely even until the tenth or eleventh centuries. Similar conclusions were drawn from the situation observed at the Great Basilica where glazed ceramic supposedly never occurred in sunken floor dwellings of the grubenhaus settlement that was uncovered there. Consequently, that cottage agglomeration should have preceded the construction of the Christian church complex and was dated to the eighth and earlier ninth centuries and thus to the pagan period. After prince Boris/Michael had adopted Christianity in the year $864 \mathrm{AD}$ the former settlement area would already have been cleared and used immediately for constructing the Great Basilica.

Over subsequent years numerous similar assumptions and further observations made in Aboba-Pliska were more or less automatically incorporated into this conceptual view of a stepwise urbanization of the early medieval Bulgarian society out of ingenuous roots. ${ }^{19}$ It has thus been seen as a society comparable or equal-ranking with those of Byzantium and Western Europe or, perhaps, as an even stronger and more dynamic society since "Pliska" was in fact so incredibly large. ${ }^{20}$

\section{The dubious eighth century "Slavic" grubenhaus occupation in the} Asar-dere area

So far so good. However, as a result of the extended and complex investigation work that the German-Bulgarian team has realized in the Asar-dere area, it has become clear that the assumed stages of Aboba-Pliska's socio-economic evolution actually took place exactly in reverse order. It was not the case that a predominantly agricultural style of living opened the way to a stepwise growth in craft activities, but rather a situation of fully developed and highly specialized artisan production was followed later by a process of broad ruralization.

In its very first occupation phase large parts of the Asar-dere area comprised a huge waste disposal site, accompanied by numerous installations such as hearths and kiln-like features attesting several craft activities that created the extended layers of

18 Milčev 1960b esp. for the urban consequences pp. 54-55.

19 Balabanov 1980; Rašev 1994; Vitljanov 2000.

20 For a most curious demonstration of Pliska's superiority when comparing it with eighth/ ninth centuries' Paris, see: Milenov 2005. 


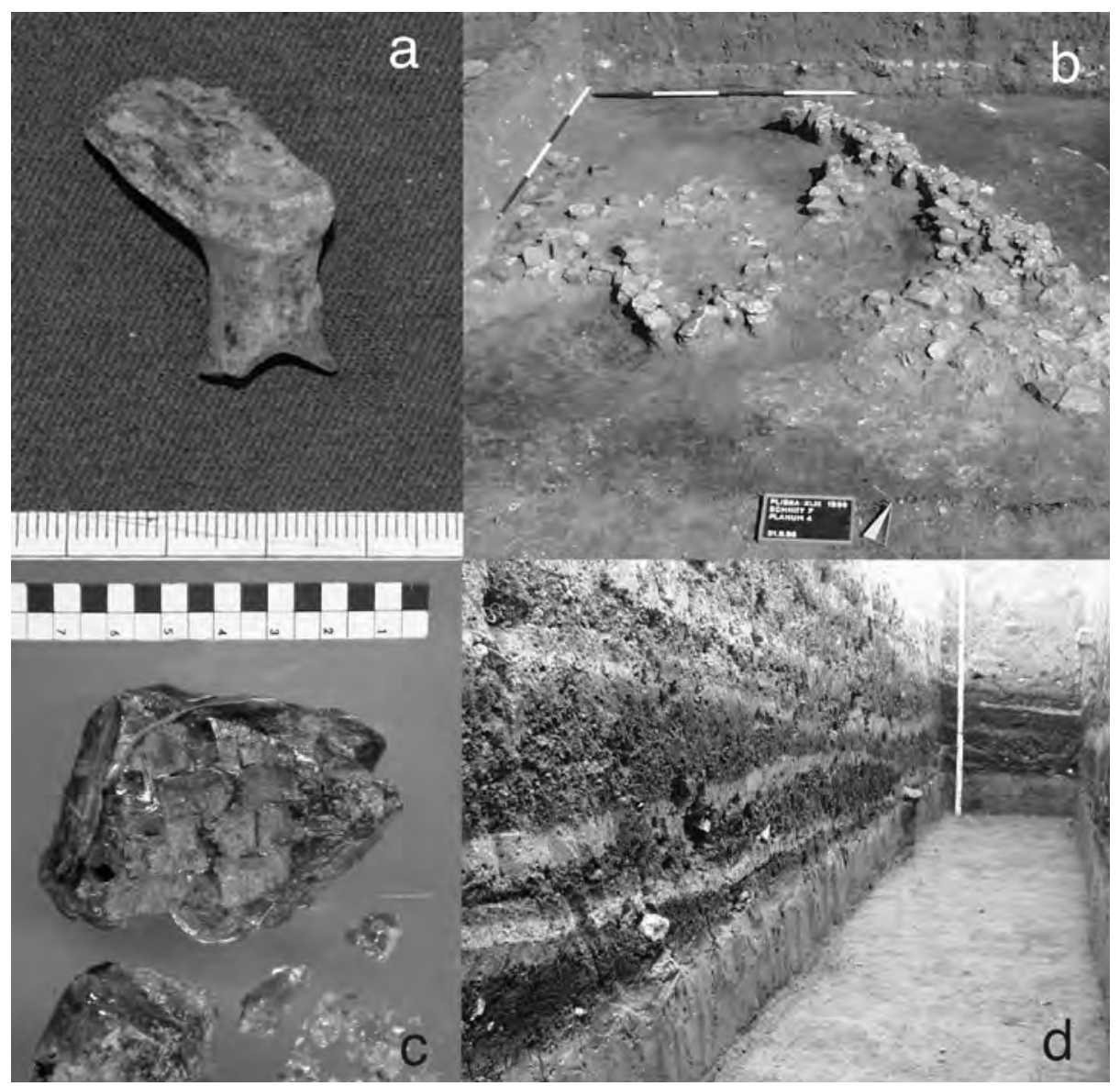

Fig. 4. Asar-dere artisan quarter (eighth/ninth centuries) in the Outer Town of Aboba-Pliska: a - fragmented glass vessel, b - stone hearth in the production area (main trench No. 4-10), c - production waste of glassmaking, $\mathrm{d}$ - multiple layers of production waste positioned on the original natural surface of the Asar-dere area (trench No. 14)

garbage (Fig. 4). Some of the hearths may have belonged to dwelling constructions at ground level. However, not a single sunken floor grubenhaus was found that was attributable to this early stage. The accompanying ceramic material dates these production and occupation activities to a time span between the eighth and earlier ninth centuries. Iron and non-ferrous pieces of slag, elements of casting moulds, waste from making glass vessels and window glass, spoiled ceramic fragments attesting pottery production, enormous amounts of charcoal and ashes have created the thick and most colorful layers that cover the leveled original natural soil surface of this area (Fig. 4-d).

The materials once uncovered in Milčev's Asar-dere excavation, namely the ceramic pieces found inside the heating chambers of the production installations held 
to be pottery kilns for glazed ceramic, are still preserved in the Sofia University today. ${ }^{21}$ Their re-evaluation brought to light that no artisan glazed pottery had been produced. Surprisingly, however, it was found that advanced glassmaking can be attested by many elements of broken ceramic fragments with glazed incrustations. Thus a number of these fragments were relicts of crucibles or melting pots misinterpreted as glazed pottery. Consequently there is no reason per se to date activities connected with these finds to later periods when glazed pottery occurred. The attribution, however, of the production installations, which were undoubtedly glass ovens and not pottery kilns, ${ }^{22}$ to the surrounding production garbage of the Asar-dere, which contains production waste of glassmaking and emerged in the eighth to earlier ninth centuries, is compelling. ${ }^{23}$ An extraordinary extended craft-working center characterized by highly professional and advanced craft working was installed on site in an early stage of the Aboba-Pliska complex. And this establishment of a craftsmen colony was a greenfield development.

The German-Bulgarian excavations in the Asar-dere area have uncovered many grubenhaus structures (Pls 23, 26, 27). Not a single one belongs to the earlier craft-working occupation phase of the eighth/ninth centuries. After the production activities had stopped, for whatever reason, the whole production area was covered by considerable amounts of erosion material (colluvium). Coming from higher parts of the area near to the Inner Town's fortification it traveled downhill and spread over the former craftworking zone (Pl. 24-b). The question as to why these erosion processes took place and exactly how long they lasted is difficult to answer. Their locally different intensity was reconstructed by physical-geographical studies. However, approximately at the end of these soil creep events cottage dwellings of the grubenhaus type were constructed in great numbers by digging them either into the erosion layer that had developed in the meantime or, if this layer was locally unimportant or even absent, directly into the older garbage layers of the abandoned craft-working quarter. This stratigraphical observation is valid for all grubenhäuser that have been discovered by the GermanBulgarian team. Grubenhäuser No. 10 and 20 were dug directly into the production garbage layers (Pl. 26) whereas No. 12, 13 and 14 were dug just into the upper erosion material covering the garbage (Pl. 27, especially clear is the case of grubenhaus No. 32). Photographs documenting the finding situation of most of the 12 grubenhäuser

21 I owe sincere thanks to Stefka Angelova (Sofia University) for making these materials available to me.

22 Such a characterization also corresponds with the unique construction of these objects, which are absolutely unusual for pottery kilns, see: Henning 1977, 178, cat. No. 153. Although pointing at the uniqueness of these kilns, I still followed then Milčev's characterization.

23 Nonetheless, the Asar-dere ovens still play a decisive role in conceptual synthesizes constructing a flourishing pottery production in Pliska's urban development stage: see Vitljanov 2000, 88 . 


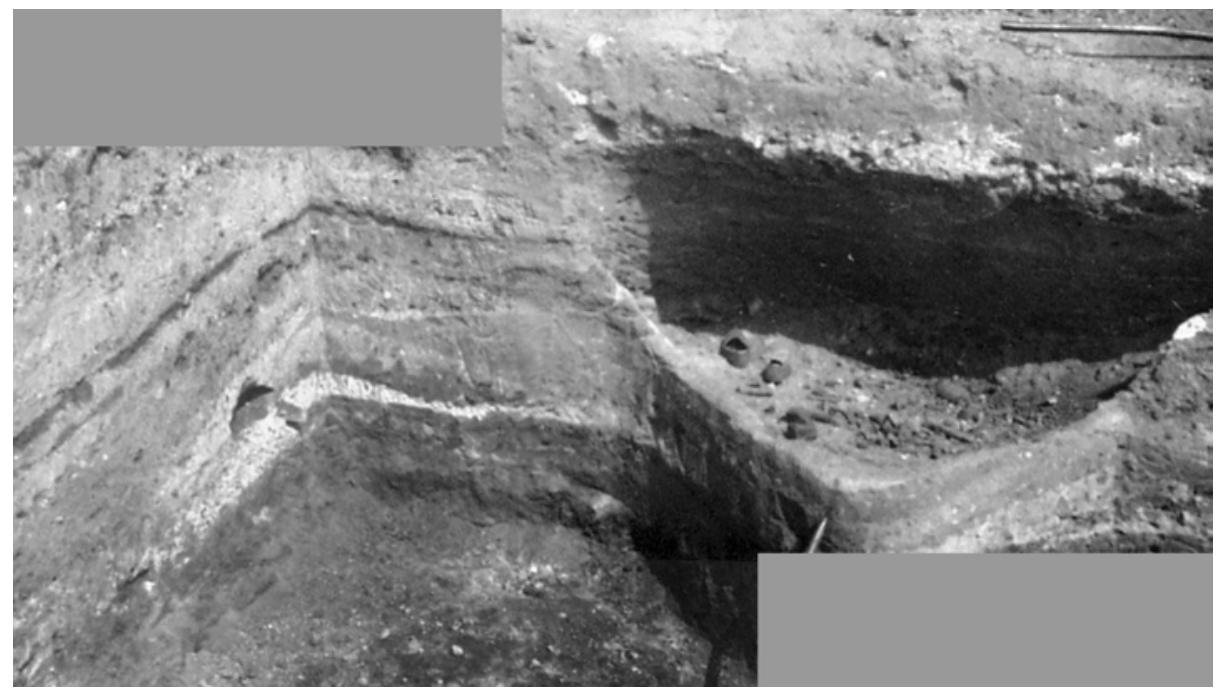

Fig. 5. Grubenhaus excavated in 1961 by Atanas Milčev in the Asar-dere area of Aboba-Pliska. An uncovered corner of this sunken feature is visible cutting into layers of production garbage

excavated by A. Milčev in the Asar-dere area are still preserved in the archive of the Sofia University. ${ }^{24}$ Except for the first two, which were published in $1960,{ }^{25}$ the remaining ten have never been published but all 12 were dated to the eighth century by the excavator since supposedly they would all have delivered the same spectrum of pottery finds. ${ }^{26}$ The description of the discovery situation of Milčev's grubenhaus No. 2 clearly attests that these dwellings were dug into a dark grey (most probably erosion) layer. ${ }^{27}$ A direct and unquestionable analogy to our observations is offered by another one of Milčev's Asar-dere grubenhäuser, visible on the photo documentation (Fig. 5). The pit of this grubenhaus was clearly dug into production garbage layers, which reveal multiple colorful strata.

24 I wish to address my sincere thanks to Vassilena Petrova for calling my attention to the existing documentation and to Stefka Angelova for making it available to me.

25 Milčev 1960a.

26 Idem 1964, 29.

27 Idem 1960a, 34. Since grubenhaus No. 2 was detected in a construction trench the complete profile was preserved. Grubenhaus No. 1, however, became visible only after bulldozers had removed the complete plow soil and probably the lower layer of old erosion materials as well. The excavator therefore correctly notices that he was unable to determine the exact level where the deepening of the pit of grubenhaus No.1 once had started. 
Thus Milčev's evaluation needs to be revised fundamentally. ${ }^{28}$ According to the careful analysis conducted by Ljudmila Dončeva-Petkova on the pottery materials excavated by the German-Bulgarian team, ${ }^{29}$ the ceramic finds from the fillings of the grubenhäuser in the Asar-dere region belong exclusively to the period after Christianization of the Bulgarian realm. Dating therefore has to be looked for between the late ninth and tenth/eleventh centuries, that is, some hundred years after Milčev's determination. ${ }^{30}$

\section{A "pagan" grubenhaus occupation below the Great Basilica?}

The second pillar of the supposed early rural beginnings of Aboba-Pliska, the grubenhaus settlement uncovered in the area of the stone building complex attached to the Great Basilica, is no less problematic (Pl. 30). When the present author arrived at the excavations of the area around the Great Basilica in 1976, as a newly minted archaeologist and well trained by the late Paul Grimm in excavating Central European grubenhäuser, ${ }^{31}$ a number of freshly uncovered, supposedly "free-standing" small stone ovens caught his attention. They were scattered over the territory of the excavated stone structures attached to the Great Basilica, which was just beginning to be extensively excavated by an enormous number of workers in preparation for the then forthcoming 1300 year jubilee of the Bulgarian state. Since the preliminary interpretation of these ovens as being part of "the monastery's open cooking area" seemed rather obvious, he asked for permission to excavate a separate section of the area more carefully. ${ }^{32}$ As a result, the first complete sunken floor feature clearly of the typical eastern European

28 We have nevertheless to stress here the great merit of A. Milčev having saved and perfectly documented for the time a number of very important non-stone-built monuments. This was achieved in a period of terrible devastations for the Outer Town areas in the 1950s and 1960s when the monstrous idea of constructing a reservoir dam in the Asar-dere valley was realized. I cannot exclude that after having discovered the last grubenhäuser of his campaigns, which in their stratigraphical situations were so clearly late but for unknown reasons have never been published, this well-trained excavator might have understood that his early dating of the Asar-dere settlement was wrong. It was, however, not the right time to revise the assumption of the Slavic roots of Bulgaria's first capital".

29 See the article of Dončeva-Petkova in this volume on the ceramic materials from the Asardere excavations.

30 Milčev 1964.

31 By 1972 I had spent more that six months on Grimm's excavation of the Ottonian Aula Regis (Pfalz) of Tilleda in eastern Germany and was especially responsible for excavating and documenting the dozens of Slavic influenced grubenhäuser in the palace's suburb, which regularly possessed stone ovens in one of their corners. For the results, see: Grimm 1990.

32 I am most grateful to Totju Totev, then director of the Shumen branch of the Archaeological Intitute, for giving me the permission for participating in the excavations and to Pavel Georgiev and Stojan Vitljanov for the close cooperation on site. 
grubenhaus type with a stone oven in its northeastern corner was excavated at this site (Fig. 6). ${ }^{33}$ And thus it was demonstrated that all the many stone ovens uncovered earlier in the area were the relicts of non-recognized grubenhäuser. ${ }^{34}$ Identification of these structures was in fact not easy for the archaeologist more familiar with excavating stone structures. They were dug into an older grey and uniform looking cultural layer, additionally superimposed by a cover of erosion sediments, which together were of a considerable thickness. As an element of exactly that older occupation layer the author succeeded in uncovering yet another different kind of dwelling feature, which had no stone oven but a flat stone hearth in one of its corners creating a platform of c. $80 \mathrm{~cm}$ diameter covered with clay that was burnt and, unlike the grubenhäuser, was not dug into the ground. ${ }^{35}$ This structure, named dwelling No. 3 (Pl. 30), was clearly associated with pottery of the earlier occupation stage of the Aboba-Pliska settlement complex and had to be dated therefore approximately to the eighth or first half of the ninth century. This pottery spectrum was widely identical with that of the occupation layer into which grubenhaus No. 4 was dug (Fig. 7). Both spectra were characterized by a high proportion (more than $50 \%$ ) of fine grey ware, often decorated with polished stripes and of the appearance of red-slipped fine ware (Pl. 30-b). These ceramic finds resemble those excavated in the earthen mound XXXIII (Fig. 8, P1. 4: 41-46, Pl. 5: 4749). Ceramic fragments discovered on the sunken floor of grubenhaus No. 4 , however, were unquestionably much later and typical for a period between the end of the ninth and the eleventh centuries. The pottery spectrum from that grubenhaus floor contained fine brownish or greenish glazed pottery typical for this later period, the portion of fine grey ware was strongly reduced and red-slipped fine ware was absent (P1. 30-c). A fairly similar spectrum occurred in the grubenhäuser excavated by the German-Bulgarian team in the Asar-dere area mentioned above. Since the position of all grubenhäuser in the Great Basilica area apparently respected a layout approximately in a grid pattern, and consequently not a single superposition was observed ( $\mathrm{Pl}$. 30-a), a chronological uniformity had to be assumed. ${ }^{36}$ Cultural distinctions between the two chronological phases, that of the older occupation layer with dwellings built at ground level and that

33 This sunken floor dwelling feature was first described in an article for a broader public (Henning 1980, 26, fig. 6) and later counted as "zhilishte (grubenhaus) No. 4" (following "zhilishte No. 3"). This was after one had understood that another two badly preserved (or badly recognized) structures that were excavated earlier represent relicts of sunken floor dwellings as well.

34 Unfortunately details of these many "free-standing" ovens have never been published, although a monographic publication describing the Great Basilica building complex has appeared in the meantime: Georgiev/Vitljanov 2001.

35 For a representation of this dwelling drawn by the author and counted as "zhilishte No. 3", see: Georgiev 1993, 17, fig. 8, who does not mention who the excavator was. Whether or not this relict once belonged to a yurt-like construction, as Georgiev assumes, is difficult to say. Vasilev $(1995,33)$ therefore suggests a "uniform planning" of the settlement. 


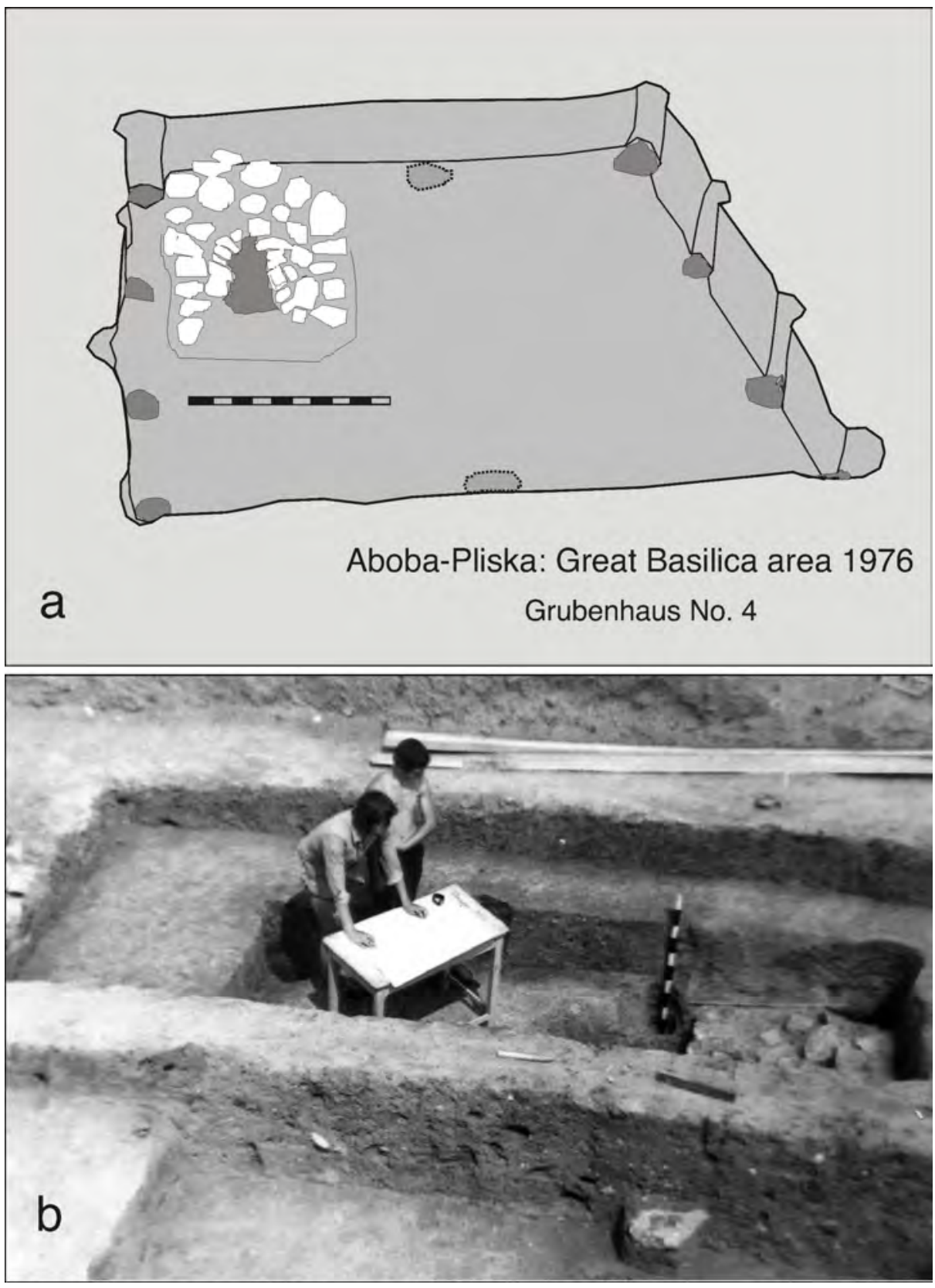

Fig. 6. Grubenhaus No. 4 in the area of the stone building compound around the Great Basilica of AbobaPliska. a - perspective representation, $\mathrm{b}$ - excavation photo 

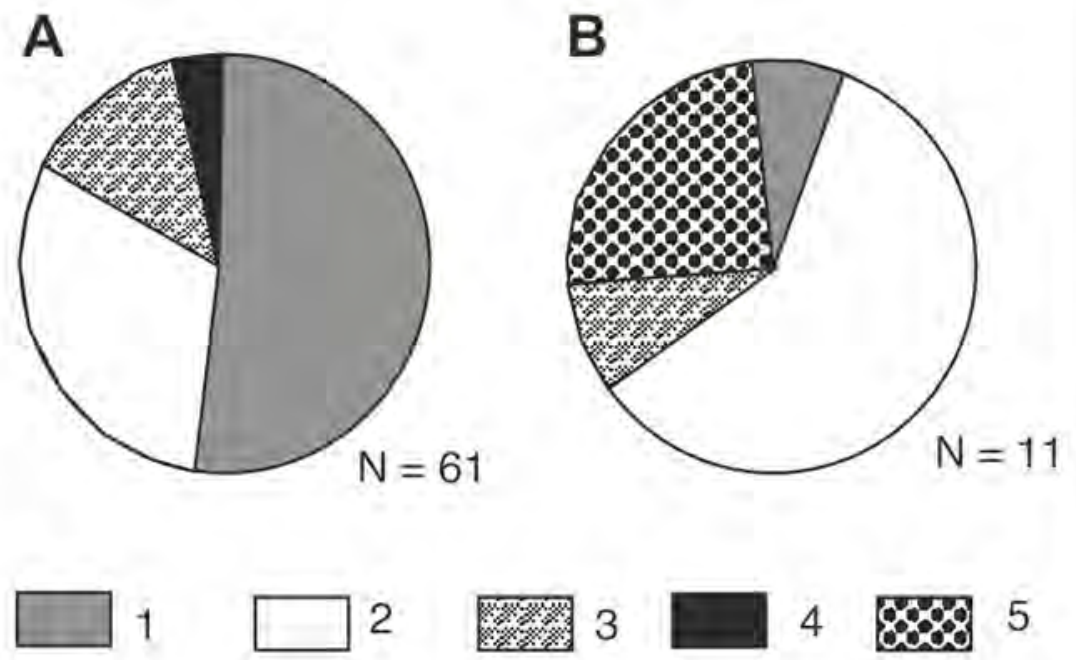

Fig. 7. Pottery fragments found in and around grubenhaus No. 4 in the Great Basilica's area of Aboba-Pliska: A - Pottery spectrum of the stratigraphically older occupation layer in which the sunken floor feature/grubenhaus No. 4 was dug; B - Pottery spectrum from the floor of grubenhaus No. 4. Key: 1 - grey fine ware, 2 - red coarse ware, 3 - red and yellow fine ware, 4 - red slipped fine ware, 5 - green and brown glazed fine ware

of the later grubenhaus settlement, could not be clearer and there was reason to assume a significant difference in time between the two phases, if not a hiatus. After grubenhaus No. 4 had been uncovered excavation of further grubenhäuser were completed in the following years in the Great Basilica's area and further to the east, with efforts now being made as far as possible to apply more careful excavation methods. The results were better but still insufficient, as must be derived from excavation documentation from areas not very far to the east of the Great Basilica. Apparently the true margins of grubenhäuser pits were not always recognized with certainty (Fig. 9). And the possible result of this is chronological confusion. ${ }^{37}$

However, the stratigraphical and chronological evaluations derived from observations of the grubenhaus No. 4 and dwelling No. 3 excavations were accepted by all specialists participating in the 1976 campaign at the Great Basilica while the author was present on site. And seemingly they were still held to be valid as the next three

37 Vasilev $(1987,402)$ does not question a late dating of at least some of these features to the transition from tenth to eleventh centuries since glazed pottery was uncovered from the grubenhaus pits. 


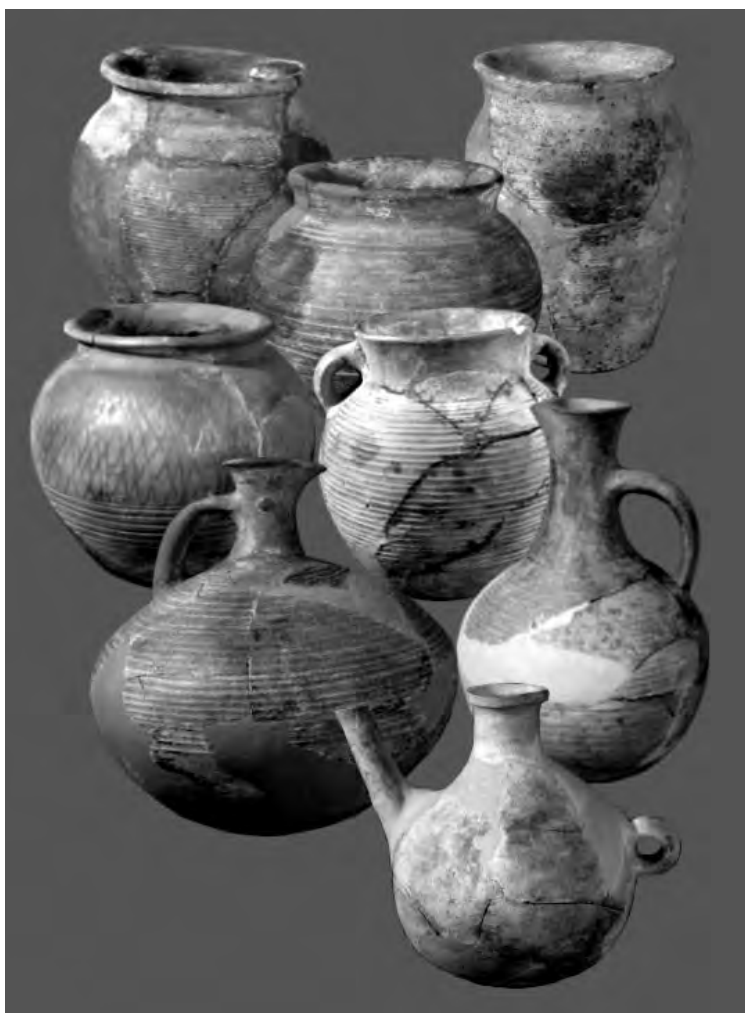

Fig. 8. Ceramic vessels found in the fill layers of the earthen mound XXXIII of Aboba-Pliska

grubenhäuser (No. 5-7) were uncovered in the few remaining areas not destroyed by earlier excavation campaigns.

When grubenhaus No. 8 was uncovered, however, a sharp conceptual turn occurred and a curious re-evaluation and re-interpretation of the entire settlement situation started. Except for grubenhaus No. 4, which the author had excavated and which was perfectly documented, all other sunken floor dwellings were now re-dated to the earliest occupation period of Aboba-Pliska. ${ }^{38}$ The existence of the thick occupation layer that had delivered the early materials was no longer mentioned. Ceramic mate-

38 This re-interpretation may be traced back to Pavel Georgiev (1981, 194-197), who dated the sunken floor features of the settlement to the eighth and first half of the ninth century without mentioning the clearly later dating of grubenhaus No. 4. Radoslav Vasilev $(1987,402)$ followed him as well without mentioning the "grubenhaus No. 4 problem". It was not until 18 years after its uncovering that Georgiev $(1993,16)$ for the first time mentioned grubenhaus No. 4 and named a possible dating at the earliest in the second half of the ninth century (or later). And it was not stated until 26 years after the excavation that, according to the materials found on its floor, a dating of grubenhaus No. 4 even in the tenth century seemed possible (Georgiev/Vitljanov 2001, 15 - introduction written by P. Georgiev). 

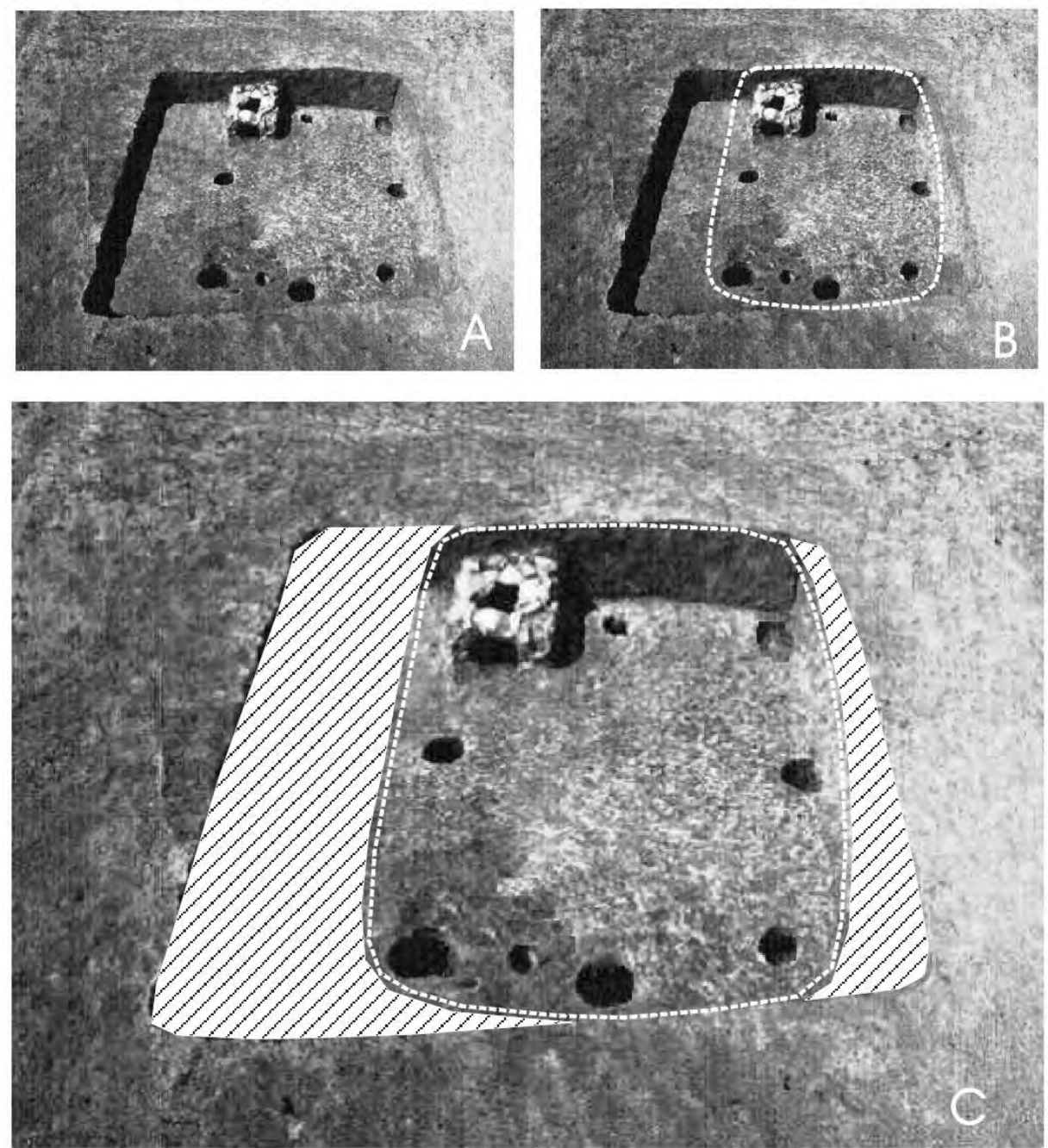

Fig. 9. Grubenhaus excavated east of the Great Basilica in the Outer Town of Aboba-Pliska, dug into older dark-grey erosion sediments or occupation layers. The true margin of the grubenhaus pit is difficult to recognize in such a case: a - photo showing the excavated deepening said to represent the grubenhaus extension and containing a stone oven and post-holes, which are in fact elements of a grubenhaus; b - probable true margin of the grubenhaus pit deduced from the excavated elements of the dwelling feature; $\mathrm{c}$ - mistakenly excavated areas surrounding the true grubenhaus pit, which when they deliver older finds can being about a false chronological interpretation of the grubenhaus feature

rials that undoubtedly relate to that older cultural layer were now attributed without discussion to the grubenhaus features, which as a result appeared to be contemporaneous with the non-sunken features built at ground level from the eighth and early ninth centuries. Not only was an early settlement of mixed Slavic and nomadic inhabitants 
"constructed" in this way, but another more fatal question was also settled. The willful grubenhaus No. $8 \mathrm{did}$ not - as was certainly expected - superimpose the stone structures of the annex buildings of the Great Basilica but was itself superimposed by these stone structures (Pl. 30-a). Considering the late dating exemplified in the case of grubenhaus No. 4 the building complex attached to the Great Basilica, which was held to be the first Bulgarian archbishop's monastery supposedly built by AD 864, was now in danger of being dated to a much later period, perhaps even to that of Byzantium's re-conquest of Bulgaria in the later tenth century. Such a dating of the buildings attached to the Great Basilica, which is one of the most important monuments of Aboba-Pliska and correspondingly played an essential role in the conceptual view of that place, seemed to be completely unacceptable and not at all desirable. ${ }^{39}$

\section{The late diffusion of grubenhäuser structures in the Pliska plain}

Whatever the details of the circumstances or causes for this re-interpretation, it is nonetheless true that the stratigraphical situations both in the Asar-dere and in the Great Basilica areas were in principle largely identical. In both cases an early occupation can be attested, which consisted of habitations and domestic or craft-working secondary buildings constructed exclusively at ground level. ${ }^{40}$ The thickness of the occupation layers that had established in both areas is considerable. And in both cases these layers were additionally superimposed by erosion material before a new style of occupation developed with grubenhäuser dug into these layers.

In the areas of geophysical investigations west and northwest of the Inner Town, which stretched over a surface of approximately 34 ha, a number of 288 dot-like anomalies were detected (Pl. 23, symbol 1a). Three of these anomalies were selected for archaeological investigations by trial trenches (No. 12, 13 and 14) and in all of these cases grubenhaus features (No. 25, 26, and 32) with heating or firing installations such as hearths or ovens were uncovered (Pl. 27). Undoubtedly it was exactly these burnt elements that produced the geophysical dot anomalies. We can therefore assume that most if not all of the discovered dot-like anomalies represent with relatively high probability grubenhäuser with heating or firing installations. In all likelihood many

39 In the corresponding publications one refers to Milčev's Asar-dere results (e.g. Georgiev 1993a, 10, fig. 1) and it is needless to say the author cannot accept both conceptions in the light of the new excavation results and of the insights that come equally from that and from older documentation and observations.

40 Two crucibles for non-ferrous metal casting were found and attributed to the older occupation layer in the Great Basilica area. A connection, however, to the structures of the grubenhäuser No. 1 und 2 as was assumed by Georgiev $(1993,34)$ is most doubtful since both features were nearly completely destroyed either by early medieval constructing activities or by the excavations of 1976 . 
more grubenhäuser may have existed in the area, but these may be invisible in the geomagnetic record because they either did not possess such burnt installations or these were damaged or badly preserved. Speaking in favor of such an assumption are another four grubenhäuser, which came to light in trenches which were not especially positioned for searching for such features (trenches No. 4, 7, 15, and 25). We are therefore certainly entitled to assume a very dense and numerous distribution of such habitations all over the Outer Town's territory or, a "sea of cottages" that filled the huge area of the Outer Town. And as long as really well observed and documented early examples of such features are missing in the territories encircled by the great earthen rampart of AbobaPliska, we have to assume that this distribution was related predominantly or probably even exclusively to the period from the late ninth to eleventh centuries, thus to the time following Christianization.

This picture of a massive "infiltration" of grubenhäuser into Aboba-Pliska's original settlement pattern after Christianization finds additional support in geomagnetic prospecting results at church No. 5, northeast of the Inner Town, where the distribution of dot-like anomalies around that religious building suggests the contemporaneous existence of a grubenhaus settlement (Pl. 31-a). ${ }^{41}$ This picture is very much comparable in principle with that of the fourteenth-century church of Vinica near Preslav with numerous cottages of the sunken floor type surrounding that building. The complex was excavated by Totju Totev and modeled in the Historical Museum of Shumen (Pl. 31-b). ${ }^{42}$

A number of further archaeological discoveries confirm the assumption of a late dating of the massive spread of the grubenhaus dwelling type in Aboba-Pliska and in the Pliska plain. Thus geomagnetic dot anomalies detected around the Strumba stone building complex - probably a noble boyar courtyard - near to the town of Shumen with its incorporated church structure seem to relate to a scattered distribution of grubenhäuser in the immediate surroundings of this complex datable to the time after Christianization. According to surface pottery finds, the time difference between the stone building compound and the grubenhaus structures must have been at most unimportant if there was any at all (Pl. 35-a-c). The $14 \mathrm{C}$ result also does not exclude a dating of the complex after Christianization. ${ }^{43}$

The same is true for the building complex No. 31 excavated east of the Great Basilica by Stamen Michajlov, which consists of stone structures representing a church and buildings probably of a boyar courtyard superimposing a number of grubenhäuser. ${ }^{44}$ These dwellings certainly emerged in the post-Christianization period, as has to be

41 Geophysical prospecting was carried out by Daniel Ziemann and students of the Shumen university.

42 Totev 1996.

43 Calibrated AMS 14-C date (2 sigma 93.1\%): cal. 773 AD-981 AD (Erlangen). See the article of Henning/Milo in this volume.

44 Michajlov 1949; Michajlov/Milčev 1959; Michajlov 1963. 
derived from a recent re-evaluation of the pottery finds from that post-war excavation (1945-1961). Thanks to Janko Dimitrov's detailed analysis and complete presentation of the ceramic finds from that excavation, published in $2003,{ }^{45}$ a considerable number of fragments of glazed pottery and similar developed types of pottery were uncovered not only in the fillings of several grubenhäuser in general but also with certainty on the floors of these dwellings. The published original excavation reports present only a small selection of "old-looking" pottery fragments from these dwellings, probably in order to make the suggested earlier dating of the grubenhäuser to the eighth and early ninth centuries more plausible. ${ }^{46}$ On the other hand there is no reason yet to call into question the consecutiveness of stratigraphically older grubenhaus structures and later stone-built structures, which is sufficiently well documented in the excavation reports. Therefore questions arise as to Dimitrov's unexplained revision of the ground plan of the excavated area. For example grubenhaus No. 6 delivered glazed pottery but, according to the original description and the primary ground plan, was nevertheless clearly superimposed by the stone building complex (Fig. 10-A). ${ }^{47}$ However, in Dimitrov's new ground plan - a point perhaps recognizable only to the insider - it appears no longer to be interfered with by the stone walls but rather added to them from outside suggesting at least synchronism with the stone structures if not a later dating (Fig. 10-B). ${ }^{48}$ Since no convincing explanation for this revision is given we are well advised to figure on exactly the same situation that likewise existed in the area of the stone building complex 31 and in the area of the stone buildings attached to the Great Basilica: Grubenhaus features in both cases belong to the post-Christianization period of Aboba-Pliska (somewhere between the late ninth and the eleventh centuries) but are regularly superimposed by stone buildings. Stone-built complexes such as the so-called archbishop's monastery and the boyar courtyard (complex No. 31) consequently relate to a more advanced, later part of this period and their existence, if not emergence, in the Byzantine period of Aboba-Pliska (after AD 972) is not improbable.

45 Dimitrov 2003.

46 Michajlov 1949, 214-222, figs 42-47 (selection from the complex No. 31 without further differentiation), Michajlov/Milčev 1959, 281-283, fig. 21 (selection from the so-called lower occupation level) and Michajlov 1963, 12-20, figs 10-15 (selection from grubenhäuser No. 6 and 7).

47 Michajlov 1963, 6 fig. 1.

48 It is not grubenhaus No. 6 that is depicted by Dimitrov $(2003,182$ fig. 1$)$ but the borders of the excavated area around that dwelling (see: Michajlov 1963, 7 fig. 2). It is also remarkable that in Dimitrov's revised drawing grubenhaus No. 6 has lost its stone oven. According to Michajlov (1963, 13 fig. 9) this stone oven clearly represented the type dug into the dwelling floor and thus was identical with that of grubenhaus No. 4 of the Great Basilica area excavated by the author (fig. 6) and with those stone ovens of the two published grubenhäuser excavated in 1959 in the Asar-dere area (see: Milčev 1960a, 34 fig. 5, 37 fig. 9). Dimitrov still seems to favor a very early dating for that type of oven and it is a matter of speculation why that stone oven had to be erased from the original ground plan. 


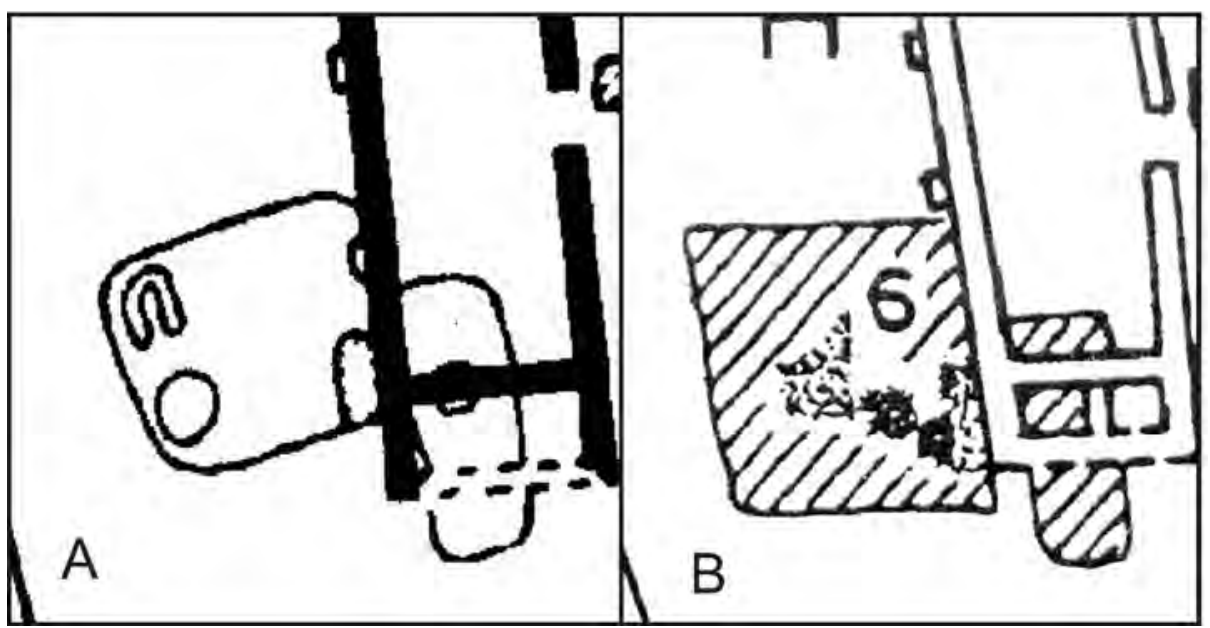

Fig. 10. Grubenhaus No. 6 in the area of the stone building complex No. 31 in Aboba-Pliska. A - detail of the original publication of the ground plan (Michajlov 1963); B - the same detail in the recent publication of the ground plan (Dimitrov 2003). The sunken floor dwelling originally clearly recognizable by its shape and the stone oven in one corner as a standard eastern European grubenhaus, which is interfered with by later stone structures (A) and in the course of 55 years changed its appearance considerably, mutated into a kind of annex building of the stone-built complex and lost its typical stone oven. This mysterious transformation occurred after glazed pottery was attributed to the grubenhaus. As a result of this helpful metamorphosis the stone structures are no longer in danger of being attributed to the late tenth-eleventh century Byzantine period of Aboba-Pliska

Grubenhäuser excavated in a locality of the Outer Town called "selishte", southeast of the Inner Town's stone fortification in the immediate vicinity of the church No. 11, have to be attributed with great probability to the post-Christianization period as well. It is likely that they belong approximately to the time when this religious stone building was constructed nearby, although the excavators tend to relate at most some of these sunken floor dwellings to a system of palisade lines forming court-like structures datable by a coin find to the early ninth century. ${ }^{49}$ Such enclosure lines have actually been attributed to the earlier development stages of Aboba-Pliska of the eighth/ninth centuries. Some of the grubenhäuser of the "selishte" locality clearly superimpose these older palisade structures and in some cases have delivered glazed pottery (e.g. grubenhaus No. 26). Moreover the geophysical measurement results of the German-Bulgarian team make clear that the extension of the grubenhaus occupation area exceeds considerably the area of the palisade enclosures. ${ }^{50}$ The numerous cases of the sunken type stone ovens, which are known from grubenhäuser of this site, can hardly attest the early

49 Stanilov/Dimitrov/Jankulov 1991, 135.

50 See the geophysical mapping in the article of Stanilov \& Dimitrov (fig. 11) in this volume. 
dating that was proposed by the excavators. ${ }^{51}$ The Russian research team, which was allowed to excavate for a limited period in the Inner Town of Aboba-Pliska (1977-1980, 1983), has dated grubenhäuser with sunken stone ovens exclusively to a more advanced occupation period (from the late ninth to eleventh century) ${ }^{52}$ and this is in accordance with our observations from the Great Basilica area (grubenhaus No. 4 with glazed pottery and a sunken type stone oven) mentioned above. A general chronological succession of clay furnaces, sunken stone ovens and stone ovens constructed at floor level ${ }^{53}$ is improbable since our grubenhaus No. 25 from the Asar-dere area with its clay furnace (Pl. 27) is clearly in a stratigraphically late position (dug into the erosion layer covering the early production site) and has delivered an advanced pottery spectrum. ${ }^{54}$

A great number of grubenhäuser excavated by Todor Balabanov west of the recent rural settlement of Pliska (the former Aboba village) but still on the territory of the Outer Town were also dated to the later ninth to tenth/eleventh centuries according to the finds they have delivered. ${ }^{55}$ Finally we have to assume that the many grubenhäuser detected in the Omurtag fortification ${ }^{56}$ have to be connected with a time period when the khan's palace fortification, built in stone in the year $822 \mathrm{AD}$, had already lost its original function. ${ }^{57}$ The small early medieval church that was built close to this grubenhaus settlement most probably was just one element of it.

51 Ibid. Grubenhaus No. 26, which contained glazed pottery, possessed a stone oven of the sunken type.

52 Pletnjova 1992, 54. These results are questioned from the Bulgarian side (Dimitrov 2004, and the article of Stanilov \& Dimitrov in this volume) stressing the traditional view of a strong Slavic character of Aboba-Pliska long before Christianization started. Especially for this aspect, see: Dimitrov 1994b.

53 For the attempt to construct such a succession, see the article of Stanilov \& Dimitrov in this volume.

54 A chronological succession of these oven types has already been excluded as a result of extended settlement analyses in the Middle Danube regions (see: Ruttkay 2002). The deep differences of opinions between Pletnjova's Russian team and the Bulgarian side about such issues is reflected in the criticism of the Russian results published in the Bulgarian Academy of Sciences' series "Pliska-Preslav" (Dimitrov 1994b).

55 Balabanov 2004b.

56 See the article of Henning/Balabanov/Milo/Ziemann in this volume.

57 The assumption of Antonova/Dremsizova-Nelčinova 1981 of an "early Slavic" dating of the earliest sunken floor dwellings in the Omurtag fortification was recently called in question by Balabanov 2004a, 125 . 


\section{Aboba-Pliska and the Hungarian incursions (AD 895-965)}

As a result of these many observations we can exclude with high probability that a huge camp-like rampart fortification filled with rural settlements of the grubenhaus dwelling type was created in the late seventh or eighth centuries when the Bulgars arrived and settled in the Pliska plain. With the exception of a few single areas within the later Outer Town's territory, an obvious "camp" would have been largely empty until the late ninth century. A few areas were probably inhabited or used by people who had to fulfill service tasks for the palace center such as craftsmen using the water resources of the Asar-dere creek or, people living in the area where the so-called archbishop's monastery was later built and dealing at least in part as well with craft production. Thus no plausible reason can be named as to why such an incredibly large rampart-and-ditch fortification should have been constructed in the early centuries of the Aboba-Pliska complex.

The situation between the late ninth and the eleventh centuries, however, was quite different since a large population now settled in the shadow of the fortified center that may have offered protection in times of insecurity or incursions. Because of the known difficulties connected with pottery dating it is impossible to decide if the area-wide occupation of the Outer Town's large territories, which was bound to the emergence of grubenhaus agglomerations, resulted from a gradual process that started in the late ninth century and stretched at least over the following decades or, alternatively, was connected with a short-term development or even with a relatively sudden event.

The impressive uniformity of the huge rectangular rampart fortification and the exhaustive and dense occupation, which seem strictly to respect the borderline marked by the earthen rampart defense, makes a planned process, such as a planned concentration of rural population around the stonewall-protected administrative center, seem more likely. The political events of the late ninth and the first half of the tenth centuries on the other hand obviously deliver the perfect background for deciphering the circumstances that may have caused the emergence of that unique fortified settlement complex.

In the year $895 \mathrm{AD}$, after a centuries-long period of stability interrupted only by the accidental two-week-campaign of Byzantine emperor Nikephoros I in the year 811 AD, the Bulgarian countryside for the first time experienced terrible devastation and the abduction of large numbers of captives at the hands of Hungarian invaders. Only some fortified places resisted, such as Drastar/Durostorum (Silistra) or Mundraga (Madara or Shumen), which provided shelter to the defeated Bulgarian ruler Simeon I, and probably the fortified Preslav. ${ }^{58}$ But this was just a foretaste of what would follow forty years later. In the next year (896 AD) a turnaround took place when the Pechenegs, probably supported by the Bulgarians, succeeded in completely defeating the Hungarians in their heartlands of the Southern Bug region (Etelköz). The Hungarian occupation of

58 Zlatarski [1927] 1971, 289-297; Runciman 1930, 146. 
the Carpathian basin and decades of Hungarian raids into Western Europe followed. Subsequent to their defeat at the hands of Henry the Fowler in AD 933, however, the Hungarians avoided the west and turned their attention once again to Bulgaria in AD 935. And in the course of the next 30 years, during the reign of Tsar Peter I, there were repeated attacks. After Peter called in vain to the western emperor Otto I in $965 \mathrm{AD}$ for help against the Hungarians, this difficult period ended with the conclusion of a peace treaty between Peter and the Hungarians in the same year. ${ }^{59}$

The heavy impact of these events can be determined from the many cases of nonfortified settlements in the northeastern Bulgarian countryside, especially along the Danube's right riverbank, which were destroyed or damaged in approximately these times. Destruction layers containing finds of a kind of arrowhead, usually identified in central and western Europe as "Hungarian", ${ }^{60}$ help to underline this picture. ${ }^{61}$ Michael Wendel has argued that after the disastrous events of AD 895 the damaged settlement of Krivina at the Danube was rebuilt and transformed into a sort of military garrison for defending the Danube border. ${ }^{62}$ Unfortunately the modern village of Krivina covers most parts of the ancient site and thus makes a clear judgment impossible as to whether or not Krivina had been fortified in this period. Exactly this can be proven, however, for the inland settlement of Stărmen just a few kilometers south of Krivina, this being in a similar strategic position on the same river course and overlooking the important traffic route leading south to the Balkans. The extended Polish excavations in Stărmen have proven that a rectangular earthen fortification was not built until the late ninth century and at that time encircled the central part of the former open settlement. Thus the rampart is superimposing many early medieval grubenhaus structures of the preceding large open settlement that had existed here continuously since the seventh century. And its transformation into a fortification coincides exactly with the period of the Hungarian incursions. ${ }^{63}$ Similar examples of rectangular rampart fortifications superimposing preceding early medieval grubenhaus features have been observed in multiple sites at the Danube's right riverbank as for example in Nova Černa ${ }^{64}$ and in Popina, ${ }^{65}$ both in

59 For a more detailed description of these historical events, see: Ziemann (forthcoming).

60 Schulze-Dörrlamm 2002.

61 Two well explored, non-fortified early medieval settlements at the Danube River course can be named here, which must have experienced considerable destructions especially by the unexpected attack of AD 869. Both settlements have delivered Hungarian arrowheads and correspondingly rich archaeological finding situations: Krivina, district of Ruse, on top of the former early Byzantine fortification of Iatrus (see: Wendel 1986, 197-198) with multiple hoards of iron tools and coins and Garvan, district of Silistra, near to the traditional Danube crossing (Văžarova 1986, 52 fig. 49).

62 See his article in this volume.

63 Hensel 1980, 139 fig. 44 and the article of Kurnatowska \& Mamzer in this volume.

64 Milčev/Angelova 1971, 17-23.

65 Văžarova 1956, 58 fig. 45. 
the district of Silistra. These rectangular rampart fortifications are archaeologically attested all along the Bulgarian Danube riverbank. And there are many positioned along the inland traffic routes as for example the rampart fortification of Chuma, in the district of Razgrad, which must have been attacked heavily or was destroyed even in this period of unrest as large numbers of Hungarian arrowheads suggest. ${ }^{66}$ There is no room for the curious assumption that these fortifications would have been starting points for town developments as was suggested by Stamen Michajlov, who did not exclude a dating even to the seventh century. ${ }^{67}$ And in no way whatsoever could they have worked as early forts against the sixth/seventh-century Slavic incursions into the Balkan Peninsula as the interpretations of the Nova Černa excavations might suggest. ${ }^{68}$ Nor were they elements of a gigantic early defense system, settled in the late seventh century by Bulgars in an area south of the Danube for the protection of their "state territory" against the Byzantines, through which Rašo Rašev has sought to explain the mysterious rectangular standard fortifications in northeastern Bulgaria. ${ }^{69}$ Archaeological analysis of the construction situations of some well-explored fortified sites of that type, and the datable finds from these fortifications, clearly indicate that most probably we are dealing here with the "Bulgarian solution" to problems caused by the Hungarian incursions into Europe. And this solution was not so different from those, which were found contemporaneously in western and central Europe: Fortified refuges for the rural population, which also served as military fortresses manned by peasant-soldiers, sprang up everywhere in the eastern parts of the Frankish empire and a new elite cavalry force was created. Widukind of Corvey described in detail the rapid emergence of this western system between the Rhine and Elbe rivers. ${ }^{70}$ Developments in the bordering Slavic lands looked quite similar in principle but differ in some details as a result of particular traits in society. ${ }^{71}$

When the Hungarians appeared for the first time, suddenly and unexpectedly, south of the Lower Danube in AD 896, the countryside was certainly easy prey for them. However, when they returned forty years later they might have found a better armed and well-protected country.

It seems impossible to imagine that the ruling center in the Pliska plain was not affected by these important developments. We know that the Hungarians coming from the Bug River area must have crossed the Danube River somewhere in the surroundings of the old Durostorum (modern-day Silistra) and when continuing their raid in the direction of Preslav they necessarily must have passed through the Pliska plain.

\footnotetext{
66 Rašev/Stanilov 1987, 150 pl. 49.

67 Michajlov 1982; idem 1967, 140.

68 Milčev/Angelova 1971.

69 Rašev 1982.

70 Widukind $\mathrm{I} / 38$.

71 Henning 1997.
} 
Hungarian arrowheads found in Aboba-Pliska suggest that the fortified complex was at least attacked if not actually seized. ${ }^{72}$ Some of these finds even come from the area inside the stone fortification of the Inner Town and we have therefore to assume that the stone fortress of Aboba-Pliska itself was certainly attacked. ${ }^{73}$ Did Aboba-Pliska consist until this time only of that inner stone fortification that encircled the palace compound? Was a strong and possibly strategic concentration of people in the area surrounding the old palace and ruling center, which was still at least an important religious place, just one of the conclusions drawn from the first experiences with the Hungarians in the year AD 895? And was another consequence the encirclement of the Outer Town area with the huge rectangular rampart-and-ditch fortification, which in principle represents the same solution, but on a much bigger scale, as it was adopted in Stărmen exactly at the same time and certainly in many more places? Archaeological trenches through the outer rampart line of Aboba-Pliska have delivered early medieval pottery materials from the bottom of this earthwork, which testifies to an earlier occupation. ${ }^{74}$ This is an observation very similar to the situation found in Stărmen and in other places that were fortified in this period. Such an archaeological picture would fit well with the information from the written sources about the defeated Bulgarian ruler Simeon I who did not seek shelter in the flatland places of the Pliska plain in $895 \mathrm{AD}$ but in better protected fortresses (Silistra, Mudraga). The best explanation for all these circumstances is the assumption of a much later emergence of the typical outlook of the "megapolis" of Aboba-Pliska than formerly assumed: There are many reasons, therefore, for interpreting the huge earthen rampart fortification, and thus the emergence of the Outer Town of Aboba-Pliska, as the central element of a country-wide military and defense build-up in the first half of the tenth century, intended to protect these southeastern European territories against the Hungarian incursions. Needless to say, this fortification process was centrally stimulated and conducted.

\section{Aboba-Pliska: A palace island in a cottage sea (Conclusions)}

Taking into account that the huge dimension of the Aboba-Pliska rampart fortification was very probably not the result of an economic development, but rather a military and strategic answer to heavy political problems with which a strongly centralized society

72 Vitljanov 1993, 122 pl. 1; idem 1996, pl. 3.

73 See the Pliska catalog in this volume, No. 11 (Hungarian arrowhead from the Inner Town near to the southern fortress wall); Michajlov 1949, 213 fig. 41, No. 12 (Hungarian arrowhead from the Inner Town c. $100 \mathrm{~m}$ west of the palace centre).

74 Rašev 1982, 97; idem 1985a, 10. 
was more or less suddenly confronted, we are certainly entitled to ask if the AbobaPliska complex as a whole may be considered a true city.

Although serious evidence is largely missing for economic exchange relations between the predominantly agricultural population of the Outer Town and craft working in the vicinity of the palace center, we should nonetheless characterize the core structure of Aboba-Pliska as a city. However, it was a sort of planned palace city not comparable in principle with the dynamic town developments in contemporaneous Western Europe.

The location of that palace city was initially chosen irrespective of the ancient network of roads, being placed in the middle of a large plain without access to any river or major traffic route. Thus long distance trade cannot be seen as a decisive factor for the establishment of the palace compound, although it may have played a certain role in its further history, e.g. at the end of the ninth century when quarrels are reported over the status of the Bulgarian traders in Constantinople, which triggered a military conflict with Byzantium and the first fatal Hungarian incursion of AD 895. Finds of scales both for coins and commodities and of lead weights from Aboba-Pliska, which attest trading and exchange activities, have to be dated to this period after Christianization. ${ }^{75}$

In the eighth to earlier ninth centuries the Asar-dere production area in particular was oriented first of all towards the raised standard of living in the palace center of the Inner Town. This craft production, dependent upon the residence of rulers and predominantly serving their needs, continued to exist inside the Inner Town after the Asar-dere production area was abandoned.

The German-Bulgarian research campaigns in the Outer Town have uncovered several new defense lines, consisting of earthen rampart or stonewall lines with ditches in front of these lines (Pls 23 and 28) or with ditches alone (Pl. 25). These results shall be discussed in more detail elsewhere. The exact dating and a determination as to the function of the ditch lines uncovered in the so-called Poluostrov area (Pl. 25) are still open to debate. However, a correlation between the newly discovered defense lines north and east of the Inner Town's stone fortification (Pls 23 and 28) and the fate of the Asar-dere production area on the one hand, and the stone fortification of the Inner Town on the other, may be described as follows: The broad ditch visible in trench No. 20 (green line) must have been created first of all in addition to the northern front of the stone fortification, which was already existent (blue line). As a next step the fortification line sectioned in trench No. 19 (yellow line) was created, and finally the rampart-ditch line sectioned in trench 15 (red line) was built. The erosion model of the Asar-dere area (Pl. 24b) demonstrates that very probably this line (red line) provided a channel for the colluvium materials to flow over the Asar-dere production area. In other words the defense building activities (green, yellow and red line), in addition to the stone fortification already in existence, took place when the Asar-dere production activities were declining or had already ended. The final development stage in this suc-

75 Vitljanov 1992 (scales); Dončeva-Petkova 1981 (lead weights). 
cession is represented by grubenhaus No. 30 (P1. 28, section 15), which was established when the defense line (red line) had lost its function. This seems to be the period when a much bigger solution for the defense of the Aboba-Pliska complex was developed: the construction of the earthen rampart of the Outer Town. In this period at the latest several workshops or craft quarters consisting of glassmaking installations and smithies emerged in the Inner Town or were transferred to this better protected area. The unusual displacement of many kinds of firing installations into the protected territory of the Inner Town, which happened until the late ninth century and would have caused extreme danger for living quarters, has certainly to be explained in light of the political events described above. ${ }^{76}$ This was just a small transformation of the palace town in continuous existence in the center of the Aboba-Pliska fortification.

The huge and densely occupied Outer Town, however, which developed most probably in the tenth century, was nothing but a monstrous strategic defense enclosure created in order to protect the ruling and religious center of the Bulgarian realm and to give shelter to the rural population of the northeastern Bulgarian countryside in times of unrest and incursions.

Caption for Plate 28 (see Plates at the end of this volume)

Pliska: fortification and ditch system enclosing the Inner Town.

Key: 1 - natural loess, 2 - plough zone, 3 - humous ditch filling, 4 - lime quarry stones, 5 - earthen mound No. XXXIII, completely destroyed by excavations, 6 - small ditch in front of a dry stone wall probably facing an earthen rampart, 7 - large ditch probably in front of an earthen rampart enclosing two earthen mounds (probably keeps), 8 - ditch in front of a earthen rampart with facing dry stone walls on both sides, the outer facing of the rampart built out of demolition stone and reddish mortar material, 9 - solid stone fortification wall built out of large stone blocks and reddish mortar (investigated by K. Škorpil), 10 - earthen rampart with two facing dry stone walls on both sides (excavated by S. Pletneva), 11 - earthen mounds (probably keeps)

\section{Bibliography}

Aboba-Pliska 1905 / Абоба-Плиска 1905: Абоба-Плиска: Материаль для болгарских древностей, 2 vol. (1: text, 2: Альбом / Plates) (Известия Русского археологического института в Константинополе 10), София 1905.

Antonova/Dremsizova-Nelčinova 1981: Вера Антонова/Цветана Дремсизова-Нелчинова, Аульт на хан Омуртаг при с. Чаталар, София 1981.

Balabanov 1980: Тодор Балабанов, “Занаяантчийсти производства и сооружения в Плиска през IX-X в.”, in: Средновековният български град, София 1980, pp. 91-98.

76 For craft working inside the Inner Town in continuation of the Asar-Dere center, see: Dončeva-Petkova 1980 and idem 1996 (iron working), Dončeva-Petkova/Zlatinova 1978 (glassmaking); Balabanov 1980 and idem 1981 (bronze working). 
Balabanov 1981: Тодор Балабанов, “Железарска и медникарска работилница в Плиска”, in: Музеи и паметници на културата 21/4, 1981, pp. 34-39

Balabanov 2004a: Тодор Балабанов, “Нови проучвания в аула на хан Омуртаг предварително съобщение”, in: Известия на Инсторичестия Музей - Шумен 12, 2004, pp. 126-137.

Balabanov 2004b: Тодор Балабанов, “Селище в югозападната част на Външния град на Плиска”, in: Плиска-Преслав 10, Шумен 2004, pp. 101-168.

Dimitrov 1994a: Янко Димитров, “Стратиграфията на Плиска и проучването на руската експедиция през 1977-1989 г.”, in: Археология 36/3-4, 1994, S. 37-51.

Dimitrov 1994b: Янко Димитров, “За славянските археологически паметници в Плиска”, in: Епископ-Константинови четения 1, 1994, S. 17-34.

Dimitrov 2003: Янко Димитров, "Наблюдения върху битовата керамика от обект 31 в Плиска", in: Плиска-Преслав 9, Шумен 2003, pp. 181-221.

Dimitrov 2004: Янко Димитров, “Керамиката от разкопките на руската експедиция (19771980, 1983 г.) в Плиска”, in: Плиска-Преслав 10, Шумен 2004, pp. 169-187

Dončeva-Petkova 1980:ЛюдмилаДончева-Петкова,“'Заметалодобиваиметалообработването в Плиска", in: Археология 22/4, 1980, pp. 27-36.

Dončeva-Petkova 1981: Людмила Дончева-Петкова, “Оловни тежести от Плиска”, in: Нумизматика 15/3, 1981, pp. 22-28.

Dončeva-Petkova 1995: Людмила Дончева-Петкова, "Пещи за добиване на желязо край западната крепостна стена на Плиска”, in: Плиска-Преслав 7, Шумен 1995, pp. 34-41.

Dončeva-Petkova 1999: Людмила Дончева-Петкова, "Карел Шкорпил и историята на проучванията на Плиска”/“Karel Škorpil und die Geschichte der Pliska-Forschungen”, in: Henning 1999, pp. 7-12.

Dončeva-Petkova 2000: Людмила Дончева-Петкова, “100 години археологически разкопки в Плиска”, in: Плиска-Преслав 8, Шумен 2000, pp. 9-18.

Dončeva-Petkova/Zlatinova 1978: Людмила Дончева-Петкова/Жечка Златинова, “Стькларска работилница край западната крепостна стена в Плиска”, in: Археология 20/4, 1978, pp. $37-48$.

Georgiev 1981: Павел Георгиев, “Ранносредновековно селище в района на Голямата базилика в Плиска”, in: Плиска-Преслав 2, София 1981, pp. 190-197.

Georgiev 1993: Павел Георгиев, Мартириумът в Плиска и началото на християнството в България, София 1993.

Georgiev/Vitljanov 2001: Павел Георгиев/Стоян Витлянов, Архиепископията-манастир в Плиска, София 2001.

Grimm 1990: Paul Grimm, Tilleda: Eine Königspfalz am Kyffhäuser. Vol. 2. Die Vorburg und Zusammenfassung (Schriften zur Ur- und Frühgeschichte 40), Berlin 1990.

Henning 1977: Joachim Henning, "Entwicklungstendenzen der Keramikproduktion an der mittleren und unteren Donau im 1. Jahrtausend u. Z.”, in: Zeitschrift für Archäologie 11, 1977, pp. 181-206.

Henning 1980: Joachim Henning, "Pliska - monumentales Zeugnis vom Beginn der Geschichte des bulgarischen Staates", in: Das Altertum 26/1, 1980, pp. 18-26.

Henning 1997: Joachim Henning, "Ringwallburgen und Reiterkrieger: Zum Wandel der Militärstrategie im ostsächsisch-slawischen Raum an der Wende vom 9. zum 10. Jahrhundert", in: Frans Verhaeghe/Guy De Boe (Eds), Papers of the "Medieval Europe Brugge 1997" Conference, vol. 11: Military Studies, Zellik 1997, pp. 21-31.

Henning 1999: Joachim Henning (Ed.), Zwischen Byzanz und Abendland: Pliska, der östliche Balkanraum und Europa im Spiegel der Frühmittelalterarchäologie, Internationales Kol- 
loquium auf der Ebernburg, Bad Münster am Stein, 15. bis 18. November 1999 (Kurzfassungen der Referate, dt./bulg), Frankfurt am Main 1999.

Henning 2000: Joachim Henning, "Pliska - Machtzentrum zwischen Byzanz und Abendland: Neue Wege der Archäologie", in: Forschung Frankfurt 2, 2000, pp. 6-15.

Henning 2006: Йоахим Хеннинг, “Нова светлина върху ранната история на Европа: Археологическият резерват Плиска - обект на интердисциплинарно университетско изледване”, in: Историкии: Юбилеен сборник / Десет години специалност история в Шуменския университет “Епископ Константин Преславски” vol. 1, Шумен 2006, pp. 219-223.

Henning (in prep.), Joachim Henning (Ed.), "Pliska - Machtzentrum zwischen Byzanz und Abendland, vol. 1: Deutsch-bulgarische archäologische Forschungen (1997-2003), Geschichte der Forschungen seit 1899 und die Diskussionen zur Geschichte Südosteuropas im Frühmittelalter", Bonn (in preparation).

Hensel 1980: Witold Hensel (Ed.), Styrmen nad Jantra (Butgaria). Badania archeologiczne w latach 1961-1964 i 1967-1968, Wrocław-Warszawa-Kraków-Gdańsk 1980.

Koder 1984: Johannes Koder, Der Lebensraum der Byzantiner. Historisch-geographischer Abriß ihres mittelalterlichen Staates im östlichen Mittelmeerraum (Byzantinische Geschichtsschreiber, Ergänzungsband 1), Graz/Wien/Köln 1984.

Michajlov 1949: Стамен Михайлов, “Разкопки в Плиска през 1945-1947 година”, in: Разкопки и проучвания 3, София 1949, pp. 171-225.

Michajlov 1959: Стамен Михайлов, “Първата славянска столица, Плиска, в светлината на последните археологически разкопки", in: Slavia Antiqua 6, 1959, pp. 325-360.

Michajlov 1963: Стамен Михайлов, “Разкопки в Плиска през 1959-1961 г.”, in: Известия на Археологическия институт 26, 1963, pp. 5-46.

Michajlov 1982: Стамен Михайлов, “Общ поглед върху укрепеното селище при Стърмен и мястото, което то заема в развитието на ранносредновековния български град”, in: Ранносредновековно селище при с. Стърмен (Разкопки и проучвания 7), София 1982, pp. 118-143.

Michajlov/Milčev 1959: Стамен Михайлов/Атанас Милчев, “Разкопки в Плиска през 1955 г.”, in: Известия на Археологическия институт 22, 1959, pp. 263-291.

Milčev 1960а: Атанас Милчев, “Разкопки в Плиска, западно от Вътрешния град през 1959 г.“, in: Археология 2/3, 1960, pp. 30-43.

Milčev 1960b: Атанас Милчев, “Археологически разкопки и проучвания в местността Асардере, Плиска през 1959 г.”, in: Годишник на Софийския университет, Философскоисторически факултет 53/2, 1960, pp. 33-66.

Milčev 1964: Атанас Милчев, “Проучвания на раннославянската култура в България и на Плиска през последните двадесет години”, in: Археология 6/3, 1964, pp. 23-35.

Milčev/Angelova 1971: Атанас Милчев/Стефка Ангелова, “Археологически разкопки и проучвания в местността Калето при с. Нова Черна, Силистренски окр. През 1967-1969 г.", in: Годишник на Софийския Университет, Историко-филологически факултет 63/3, История 1971, pp. 1-113.

Milenov 2005: Кристиян Миленов, Сравнителен архитектурен аналис между Първото Българско Царство, Франска империя и Византия, София 2005.

Milo/Henning 2005: Peter Milo/Joachim Henning, "Magnetic survey of an early medieval building compound in «Strumba» near Shumen, Bulgaria", in: Salvatore Piro (Ed.), $6^{\text {th }}$ International Conference on Archaeological Prospection, Rome September 14-17, 2005 (Proceedings/Extended abstracts), Rome 2005, pp. 352-356. 
Petrova 1992: Павлина Петрова, “Към въпроса за историко-археологическата топография на Външния град на Плиска по данни на аерометода”, in: Плиска-Преслав 5, Шумен 1992, pp. 64-76.

Petrova, 1993: Павлина Петрова, “Постройка от ранносредновековно имение край Шумен”, Известия на историческия музей Шумен 8, 1993, pp. 234-242.

Pletneva 1992: Светлана Александровна Плетнева, “Стратиграфические исследования Плиски (работы Советского отряда 1977-1980 гг.)”, in: Плиска-Преслав 5, Шумен 1992, pp. 35-63.

Rašev 1982: Рашо Рашев, Старобългарски укрепления на Долния Дунав (VII-XI в.), Варна 1982.

Rašev 1985: Рашо Рашев, “Земленотото укрепление на Плиска”, in: Плиска-Преслав 4, София 1985, pp. 7-15.

Rašev 1994: Рашо Рашев, “Аул и град в България през VIII-IX в.”, in: Сборник в чест на акад. Димитър Ангелов, София 1994, pp. 170-176.

Rašev 1995: Рашо Рашев, “Плисковският аул“, in: Плиска-Преслав 7, Шумен 1995, pp. 10-21.

Rašev/Stanilov 1987: Рашо Рашев/Станислав Станилов, Старобългарското укрепено селище при с. Хума, Разградски окръг (Разкопки и проучвания 17), София 1987.

Runciman 1930: Steven Runciman, A history of the First Bulgarian Empire, London 1930.

Ruttkay 2002: Matej Ruttkay, "Ländliche Siedlungen des 9. bis 11. Jahrhunderts im Mitteldonaugebiet", in: Joachim Henning (Ed.), Europa im 10. Jahrhundert. Archäologie einer Aufbruchszeit, Mainz 2002, pp. 267-282.

Schulze-Dörrlamm 2002: Mechthild Schulze-Dörrlamm, "Die Ungarneinfälle des 10. Jahrhunderts im Spiegel archäologischer Funde", in: Joachim Henning (Ed.), Europa im 10. Jahrhundert. Archäologie einer Aufbruchszeit, Mainz 2002, pp. 109-122.

Škorpil 1905: Карел Шкорпил, “Постройки в Абобском укреплении”, in: Абоба-Плиска 1905, pp. 62-152.

Stanilov/Dimitrov/Jankulov 1991: Станислав Станилов/Янко Димитров/Игор Янкулов, “Проучване на селището, югоизточно от Вътрешния град на Плиска", in: Проблеми на прабългарската история и култура 2, Шумен 1991, pp. 124-137.

Totev 1996: Тотю Тотев, Средновековна Виница, Шумен 1996.

Vasilev 1987: Радослав Василев, “Ранносредновековни селища VIII-X в. в района на Плиска", in: Българските земи в древността. България през средновековието. Втори международен конгрес по българистика vol. 6, София 1987, pp. 400-406.

Vasilev 1995: Радослав Василев, “Нови данни за ранносредновековното селище в района на Голямата базилика", in: Плиска-Преслав 7, Шумен 1995, pp. 27-33.

Văžarova 1956: Живка Въжарова, Славяно-българското селище край село Попина, Силистренско, София 1956.

Văžarova 1986: Живка Важарова, Средновековното селище с. Гарван, Силистренски окръг VI-XI в., София 1986.

Vitljanov 1993: Стоян Витлянов, “Накрайници за стрели от Плиска, Мадара и Преслав”, in: Плиска-Преслав 6, Шумен 1993, pp. 121-127.

Vitljanov 1996: Стоян Витлянов, “Старобългарското въоръжение. По археологически данни от Плиска, Мадара и Велики Преслав”, София 1996.

Vitljanov 2000: Стоян Витлянов, “Археологически данни за икономическия облик на Плиска”, in: Плиска-Преслав (Шумен) 8, 2000, pp. 87-92.

Wendel 1986: Michael Wendel, "Die mittelalterlichen Siedlungen", in: Iatrus-Krivina, Berlin 1986, pp. 24-210. 
Widukind: Widukind of Corvey, Res gestae Saxonicae. Albert Bauer/Reinhold Rau (Eds), Die Sachsengeschichte des Widukind von Korvei (lat./dt.), in: Quellen zur Geschichte der sächsischen Kaiserzeit (Freiherr-vom-Stein-Gedächtnisausgabe vol. 8), 5th ed., Darmstadt 2002, pp. 1-183.

Ziemann (forthcoming): Daniel Ziemann, Vom Wandervolk zur Großmacht: Die Entstehung Bulgariens im Frühmittelalter, Köln (forthcoming).

Zlatarski [1927] 1971: Васил Златарски, История на Българската държава през средните векове, vol. 1: История на Първото българско иарство, part 2: От славянизация на държавата до падането на Първото иарство (852 - 1018) [1927], София 1971. 


\title{
Pliska in the view of Protobulgarian inscriptions and Byzantine written sources
}

\author{
GÜNTER PRINZING
}

In the middle of the eighth century, in the territories on the Lower Danube, formerly under Roman-Byzantine dominance, over which the so-called Proto-Bulgars (the early medieaval, pre-Christian Bulgars) had been able to maintain authority from 681 on, a change in ruling dynasties took place: leadership switched from the house of Dulo to that of the Vokil/Ukil under khan Kormisos (737 until 754). This change also meant a relocation of the centre of administration from the Onglos-encampment (actually campus, field; near Nikulicel, district of Tulča) ${ }^{1}$ in Northern Dobrudža to Pliska, the seat of the new ruling clan. The name Pliska is of Slavic origin, related to the word pleso (lake or swamp), ${ }^{2}$ a term allowing certain conclusions as to the nature of the landscape. Pliska, according to Gyuzelev "one of the three great military-nomadic encampments on the vast plain extending from Novi-Pazar to Šumen and from Madara to Voivoda," lies near the village Aboba/Pliska: a site nearly exactly north (about $85 \mathrm{~km} \mathrm{NNE}$ ) of the stronghold of Durostorum/Silistra on the Danube and again nearly exactly south (about $10 \mathrm{~km} \mathrm{SSW}$ ) of the fortress Madara, also presenting easy access to the Bulgarian passes over the Balkan Mountains. Archaeological evidence for buildings/constructions on the $23 \mathrm{~km}^{2}$-large site of the outer city, surrounded by a rampart, suggests four distinct settlements, grouped in turn around the inner area of the khan's residence. Protected by an own surrounding inner wall made up out of a double row of wooden posts with a clay filling, this consisted of several wooden buildings, together with the so-called khan's yurt, with a diameter of $14 \mathrm{~m} .^{3}$

From the turn of the eighth to the ninth century, Pliska saw the construction of its first stone buildings, e.g. the so-called palace of khan Krum (802 until 814), with an oblong layout of $72.5 \times 59.5 \mathrm{~m}$, encompassing an area of some $4213.05 \mathrm{~m}^{2}$. Remains

1 See Gjuzelev 1991, 84 (with further references). On Pliska in general: Prinzing 1995 and partially also Panova 1996; Panova 1995, esp. 26-28, 33-35, 49-68 and 71-90; Dimitrov 1995, 247-263 and Nikolova 2003. However, results of the most recent archaeological research should also be taken into account (viz. relevant publications in this volume!).

2 See Beševliev 1981, 459; see also my related review: Prinzing 1984.

3 Gjuzelev 1991, 84, for the quote. 
of its fundament were found underneath the still visible ruins of the so-called throne room (also known as the aula regia). Together with the so-called small palatium and the slightly removed temple (court basilica), this area, newly constructed after 811 and encompassing $0.5 \mathrm{~km}^{2}$, forms the inner city, functioning as the khan's residence, now surrounded by a stone rampart replacing the former wooden wall. Archaeological incendiary evidence would seem to prove a burning of the aforementioned palace of Krum, and probably also other parts of the site, through withdrawing Byzantine troops who had seized Pliska in 811 under Nicephoros I. ${ }^{4}$

Looking towards the earliest Byzantine written sources concerning the history of Pliska, foremost mention goes to the records of emperor Nicephoros' I (802-811) campaign of 811, i.e. mainly the anonymous report contained in Cod. Vat. gr. 2014 (saec. XIII), fol. 119v-122v about "emperor Nicephoros and how he left his bones in Bulgaria." A text first edited in 1935 with many more following, whose authoritative edition, with translation and commentary, we owe to Ivan Dujčev. ${ }^{5}$ It must be mentioned though that the source, beginning with a description of the Bulgarian campaign in the ninth year of the emperor's rule, with no word mentions Pliska itself. Still, the sequence of events in the report is unambiguously clear:

First, the emperor and his army overpowered the kleisurai (military blockades) in the mountains, setting the Bulgars to flight. Advancing further, "he pitched his camp 'at the court' (as in the following passages, the actual residence is meant, G.P.) of the prince of Bulgaria, called Krum" (eis ten aulén tu protu tes Bulgarías, onómati Krúmu/

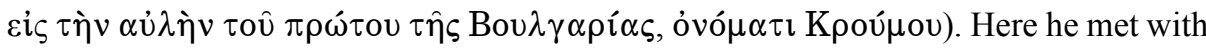
12,000 choice troops guarding the place, i.e. the Pliska garrison. In the ensuing battle all the Bulgars were killed, as were a (alleged) further 50,000 marching against the emperor. According to the source, the emperor, inflated with pride over his victory, before the eyes of his entourage accredited the victory to his own benevolent deeds, uttering the words: "See what justice can bring about!", after which he entered the

4 Beševliev 1984, 240-243 and 462-464, who 239 in my opinion rightly states that Nicephoros' announcement in 809 of the taking of the aule of khan Krum (in reaction to the latter's strike against Serdika) cannot refer to Pliska, but only to Krum's encampment. If indeed Pliska was meant, then this account is to be regarded as part of a propagandistically falsified war report by the emperor; see also Shepard 1995, 235 note 158 and below, note 5, moreover: Gjuzelev 1991, 85.

5 Dujčev 1965; reprint in: Dujčev 1968. On the source, see also Karayannopulos / Weiss 1982, 342 No. 207, Prosopographie der mittelbyzantinischen Zeit. Prolegoma 1998, 27-28 and Markopoulos 1999. On the campaign of Nicephoros I most recently Niavis 1987, but with no reference to Beševliev 1981, 240-246, and Treadgold 1988, 170-174, also with no reference to Beševliev's interpretation regarding the supposed taking of Pliska in 809; moreover, I would also like to point out that T.'s chronological considerations on p. 411 note 231 - without this having been documented - refer directly to my review of Beševliev's work, mentioned above (note 2), see Prinzing 1984, 64; see also Treadgold 1997, 428-429. 
residence proper and inspected the coffers, discovering an immense quantity of treasure. The booty, copper coins, clothing and several other valuables were portioned out to the army according to rank. He also had the wine cellars opened and large amounts of wine distributed among his troops. Arriving in the back alleys (ta ámphoda/ $\tilde{\alpha} \alpha \ddot{\alpha} \mu \varphi \circ \delta \alpha$ ) of the residence, he took to the balconies (or patios) of the houses (eis ta heliaká ton

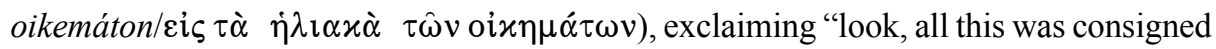
to me by God, and here I shall construct a new town of my own name that I may be known to all future generations." A few days later he supposedly left the residence of Godless Krum and, "on leaving, had all buildings, together with the enclosure made of joined pieces of wood set on fire". ${ }^{6}$

As we have seen, the anonymous report on emperor Nicephoros' I campaign contains valuable information on the layout of the khan's residence in the central area of the town. The small amount of other Byzantine sources regarding the campaign of the emperor contains nothing remotely comparable to this account. ${ }^{7}$ Therefore, we can record an inner or central area, surrounded and protected by a wooden (palisade) wall, divided by a number of small alleys and probably consisting mainly of the large unearthed palace itself, together with several annexes (oikémata/oix $\mu \alpha \tau \alpha$ ). The question of the location of treasure vaults or chambers and wine cellars and of which buildings possessed balconies remains as yet unanswered. In all probability it was this inner residence area, mainly consisting of the large palace that burnt down in 811 and, together with a new encompassing stone rampart, was later replaced with stone buildings by Krum's successors. ${ }^{8}$ A reconstruction of the town on the territory of Pliska in an imperial Greco-Roman manner and to be named after himself, envisaged, according to our source, by Nicephoros I, did not actually take place due to the disastrous defeat of the Byzantine troops and the death of Nicephoros on their withdrawal.

As far as Byzantine literary sources make any further mention of Pliska after 811, no actual substantial information on the history of the town is conveyed, as only the name itself is noted in historiographical works: the most important of these being mentions in the works of Leon Diakonos, Ioannes Skylitzes, Anna Komnene and Ioannes Zonaras. In his report on emperor Ioannes I Tzimiskes' campaign against the Rus', who under prince Svyatoslav had in 969 occupied Bulgaria and from there had begun to move against Byzantium, Leon Diakonos incidentally mentions a regain of

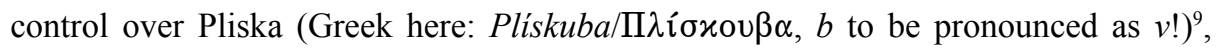

6 Dujčev 1965, 432,11-434,30, also the commentary 440-461, see also Gjuzelev 1991, 85, and Brandes 2002, 295.

7 Theophanes Confessor 490,8-491,17; see the commented translation by C. Mango and R. Scott 1997, 672-673.

8 Beševliev 1981, 462-465; see now Rašev 1995.

9 Leo Diaconus 138,24-139,2, translated into German by F. Loretto 1961, 128. On the 971 campaign, see most recently Treadgold (1997) as in note 5, 508-509. 


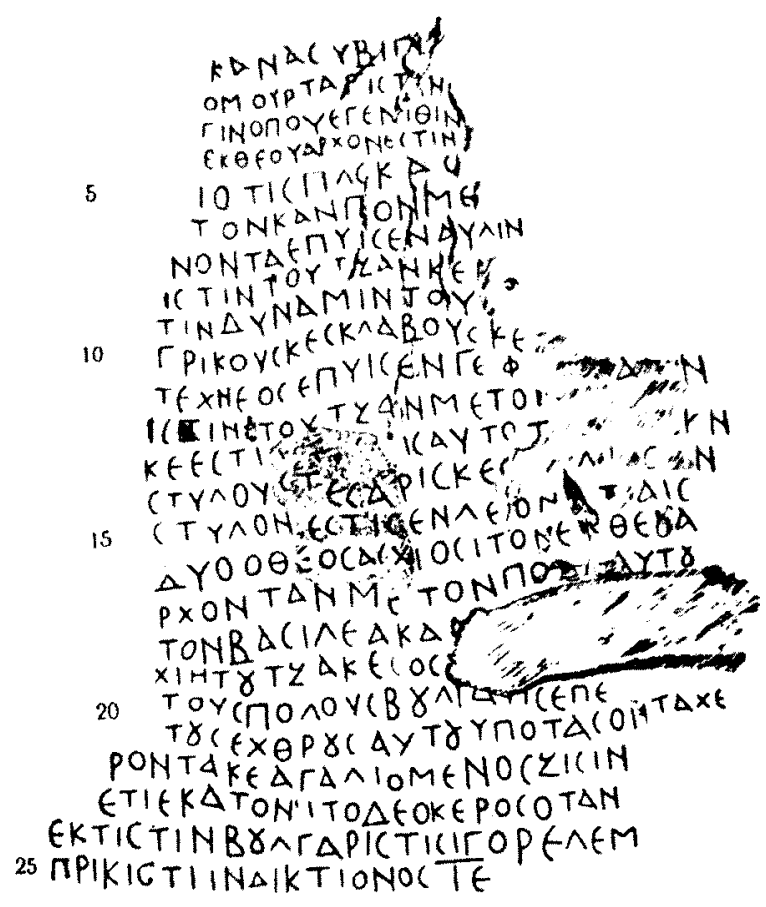

Fig. 1

while evidence from Skylitzes and Zonaras merely relate to the recorded fact of the

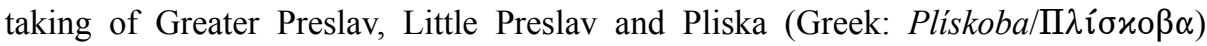
during the 999 campaign of emperor Basileios II against an uprising of the Bulgars. ${ }^{10}$ The mention from Anna Komnene, on the other hand, refers to a military campaign of emperor Alexios I against the Pechenegs in the year 1087, which amongst other things saw one early morning sojourn of the emperor in Pliska (Greek here again Plískoba), before moving on towards a hilltop called "Symeon's Knoll"."

Besides these few, relatively unspecific mentions of Pliska in Byzantine literary sources there also exists one indirect mention of Pliska resp. the khan's residence (which can be equated to Pliska), however meriting no further consideration, as it renders no actually utilisable information on the history of the town: it is a passage, already known to research from the so-called "Letter of the Three Patriarchs of the East" dating from 836 , containing a prophecy stating the emperor would subjugate the Bulgars and "affix

10 Ioannes Skylitzes 343-344 § 26, moreover loannis Zonaras 559, 8-9; German translation by E. Trapp 1986, 55.

11 Anne Comnène 94,9-12; Anna Comnena 209,72-74; comp. also the German translation by D.R. Reinsch: Anna Komnene, Alexias, 240. 
his broad (or possibly golden) sword to the brazen barn floor in the centre of their

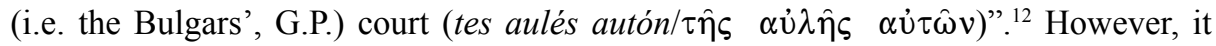
seems to me that further research into a clarification of the origin of this image that also emphasises the capture of the actual seat of authority in its description, is needed. ${ }^{13}$

Now all that remains to be scrutinised is to what extent our evidence can be supplemented with archaeological findings of (lead) seals. As far as these are concerned, although a number of Byzantine seals were indeed found in Pliska, ${ }^{14}$ the seal collections, as far as I am able to see, contain hardly any inscriptions mentioning the name of Pliska itself or any other place-names allowing for any undisputed identification with the town. Only recently has one scholar believed it to be possible to attribute a seal dating from the eleventh century to a Byzantine clerk/official holding an office related to Pliska (here, as above, referred to as Pliskoba). ${ }^{15}$

As far as the Protobulgarian inscriptions are concerned, this group of sources contains only a single, albeit comparatively early mentioning of Pliska. It is a building inscription of khan Omurtag, dating from 822, No. 56/57 in the corpus of Protobulgarian inscriptions edited by V. Beševliev (Fig. 1). Omurtag had it cut and set up to commemorate the construction of a new palace on the Tiča. This inscription, being the only one in the whole corpus displaying a genuine Protobulgarian dating, also gives the year of indiction, according to Byzantine custom. As the Byzantine sources mentioned above are all of a later date, or saw a later recording, this source represents the earliest written reference to the history of Pliska. The complete text of the inscription (the following text is based on the German translation by Beševliev, with minor alterations according to his new Bulgarian translation) is as follows:

12 Text in: Gauer 1994, 108,25-29 and (German) 110; resp. 143,14-144,1; now also in a new English edition: Munitiz/Chrysostomides/Harvalia-Crook/Dendrinos 1997, 114/115,25-26 and 180/182/181,25-183,1 (both editions with further references). See also Beševliev 1981, 467 and for the text of the source itself most recently: Prosopographie der mittelbyzantinischen Zeit, Prolegomena 1998, 41 No. 5.4.

13 Comparible, from a structural point of view, passages of "Ein Speerwurf vor der Schlacht" in: Tschižewskij 1968, 15-18.

14 Comp. Jordanov 1993, 29 nos 2-7, 43 nos 61, 54-55 nos 83-86, 170-171 nos 356-357, and 186 nos 388 (though none actually naming Pliska). Maybe the seals of a Katakalos, basilikos spatharios kai strategos Iliupoleos existed, but due to the bad state of conservation of the three seals that were found, the reading remains uncertain. This could also have been: Ioannupoleos $=$ Dristra, see also, 135-135 no. 252-256 (there, in footnote 1 Jordanov proposes - in the case of his reading „Iliupoleos“ being confirmed by a parallel fragment - to identify ,Iliupolis“" with the town of Pliska).

15 Comp. Jordanov 2003, 143 no. 62 (the seal of a certain Philotheos Phrangopoulos, "epi tu Chrysotriklinu kai strategos Pliskoba", eleventh century). Here, the place-name being in the nominative is irritating with this reading - all the more so, as Jordanov offers no further comment on the fact. 


\begin{abstract}
"Khan Š̈̈bigi Omurtag, through God archon in this land, in which he was born. Residing in Pliska, he built a small palace on the Tiča (near Car Krum = Čatalar, in Šumen district), whither he relocated his army against the Greeks and Slavs. Simultaneously, he artfully constructed a bridge over the Tiča with the palace, in which he had four pillars erected, on which he placed two lions. May God see fit to deem the God-appointed archon for worthy of placing his foot on the nape of the emperor's neck, as long as the Tiča may flow, and as long as ... and by ruling over the many Bulgars and by vanquishing his enemies, may he merrily and happily live for 100 years. The time, of the building was in Bulgarian sigora elem, in Greek the $15^{\text {th }}$ indiction". ${ }^{16}$
\end{abstract}

The translation "residing in Pliska" does not directly confer the actual wording of this passage. Originally, the inscription here states that the khan "remaining (dwelling,

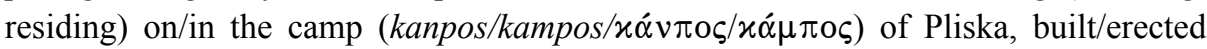
a small palace/court (aúlin/aú̉ıv) on the Tutza (= Tiča) ..." In other words: this inscription assigns to Pliska the term of kampos (from the Latin campus), making our source therefore literally speak of the "military camp/encampment of Pliska". As far as its interpretation is concerned, Beševliev concurringly quotes Bury's opinion that "doubtless kampos designates not the whole pedion of Aboba, but the fortified enclosure of Pliska". ${ }^{17}$ That this mention of a fortified military camp allows us to conclude the existence of a residence of the khan in Pliska, is confirmed by a closer look at the probably slightly older inscription No. 55 (56 in the Bulgarian edition) of the corpus (Fig. 2): it also deals with a new palace which the khan was having himself built on the Danube "while he was staying (i.e. living) in his old house" (is ton paleón ýkon autú

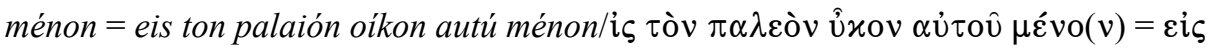

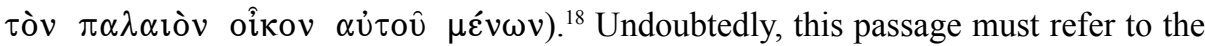
palace (or residence) of the khan in Pliska, especially since the same inscription, only a short space later, speaks of it as "ten aulín mu tén archéan"/

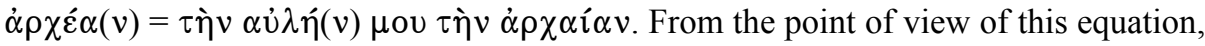
further supported by the strikingly similar wording of the passage, there is no objection to Beševliev's translation of the lines from No. 56 (57), quoted above.

16 Beševliev 1963, text (Greek/German): 260-261 (No. 56), commentary 262-277; idem 1979, text (Greek/Bulgarian) 200-201 (No. 57), commentary 201-209. Comp. also idem 1981, 283, 402, 462 and 467-468 and Gjuzelev 1991, 86 (with evidence for further "auxilliary residences" of the khans).

17 Beševliev 1963, 266 (German edition), idem 1979, 202 (Bulgarian edition). Comp. here also for reference to the initial passage.

18 Idem 1963, text: 247-248 (German edition) and 252 (commentary), resp. idem 1979: text 192 (Bulgarian edition) and 194-195 (commentary). Comp. also idem 1981, 402 and 466467, further Gjuzelev 1991, 84 "Um die Mitte des 8. Jh. wurde Pliska vom campus in sedes principalis umgestaltet."(Around the middle of the eighth century, Pliska was reorganised, from campus to sedes principalis); see also Nikolov 2005, 77, 111. 
Pliska in the view of Protobulgarian inscriptions

247

Fromtot

THWOMO

MOPTATi

CTONTA^E

5 ONYKONA

YTYMENO

ETYHCENYT

EP

10 HKANAANOB

TOANAMECO

TONTAN $\phi V$

MOKATAMETPH

CACICTIMMECIN:

15 NVICATYMBANKE

AMOTHNAY THECH

TFCTYMBACEOC THAAT

MrTHAPPXEDTCIHOPTHE

MYPIAAEC:B: KenITONA

20 ANORINICHNOPTIECMY PIA $\triangle \in C: B: T O \triangle \in A T O T Y B T$ TCTIMANQVMÖBMETPICÁ TECTINRINETYISTARPAMA

25 TATATAOAHOKO NOCKK ANdZ HATOONICKIREAN OCTENATEKEINAOECXATONLH CBETETONDAOEOPONYIOMNI

30

NOMATOY YTCANTAAYTOTOAE

MOPTAR KANXONTOCECTHH

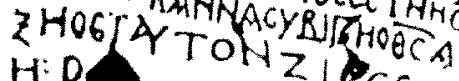

H:P. TI EET

Fig. 2 


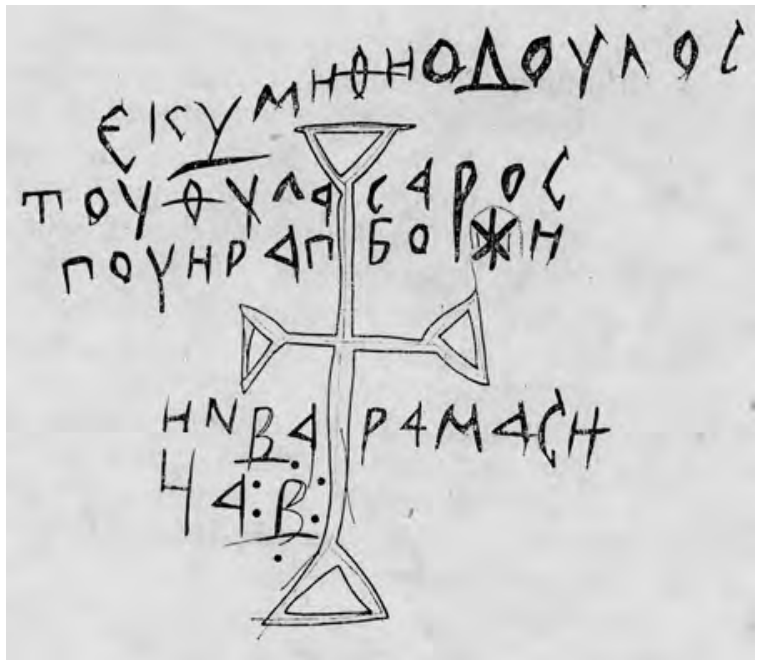

Fig. 3

When regarding both terms (kampos und palaios oikos / aule archaia) as indicators of a development of Pliska, then, under consideration of both inscriptions, one can cautiously come to following conclusions: by the year 822 the site was transformed from a (probably centrally situated) fortified military encampment to the (ancient) residence of the khan. Moreover, even before 822 one must have begun the construction of further, albeit possibly smaller forts or palaces in other strategically important locations as alternative residences.

At the end of this overview of Pliska in Byzantine and Protobulgarian written sources, one fact remains to be noted: with the exception of a very small number, all Protobulgarian inscriptions were actually found in or around Pliska itself - firm argument for the site's central importance. ${ }^{19}$ Therefore, I would here like to point out a bilingual, i.e Slavic/Old Bulgarian and Greek, inscription, also discovered in Pliska "on a grave of the necropole of the monastery near the Great Basilika" (Georgiev), but dating from after the introduction of Christianity, probably from the ninth or tenth century (Fig. 3). Although the actual name of the town appears neither directly nor indirectly, it would seem legitimate to also mention it here, as - apart from the Slavisation - it records in an impressive fashion, how the population of Bulgaria, and therefore also of Pliska, became subject to change due to the introduction of Christianity. The text of the inscription, one of the oldest of its kind (only two further bilingual inscriptions are known to exist on Bulgarian monuments), is as follows:

19 Beševliev 1963, 14 (German edition), idem 1979, 30 (Bulgarian edition). 


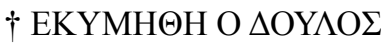 TOY $\overline{\Theta Y} \Lambda \mathrm{A} \Sigma \mathrm{APO \Sigma}$ \\ ПОЧИ РАП БОЖИ \\ ИНВАРА МАСИ \\ ЦА : В :}

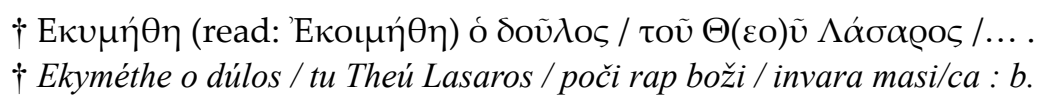

$\dagger$ Passed away has the servant / of God, Lasaros / deceased is the servant of God / month January / day $2 .^{20}$

(translation: David Toalster)

\section{Bibliography}

Anne Comnène: Anne Comnène, Alexiade, ed. by B. Leib II, Paris 1967 (with a synopt. French transl.); Anna Comnena: Annae Comnenae Alexias, rec. Diether R. Reinsch et Athanasios Kambylis, I, Prolegomena et textus (=Corpus Fontium Historiae Byzantinae 40/1), Berlin-New York 2001; Anna Komnene, Alexias. Übersetzt, eingeleitet und mit Anmerkungen versehen von Diether R. Reinsch, Köln 1996.

Beševliev 1963: Veselin Beševliev (Ed.), Die Protobulgarischen Inschriften (=Berliner Byzantinistische Arbeiten 23) Berlin 1963.

Beševliev 1979: Веселин Бешевлиев (Ed.), Първобългарски надписи, София 1979.

Beševliev 1981: Veselin Beševliev, Die protobulgarische Periode der bulgarischen Geschichte, Amsterdam 1981.

Brandes 2002: Wolfram Brandes, Finanzverwaltung in Krisenzeiten: Untersuchungen zur byzantinischen Administration im 6.-9. Jahrhundert (=Forschungen zur Byzantinischen Rechtsgeschichte 25), Frankfurt am Main.

Dimitrov 1995: Янко Димитров, “Плиска", in: Материали за средновековната българска държава (територията на днешна Североизточна България), ed. Рашо Рашев, in: Плиска-Преслав 7, Шумен 1995, pp. 157-332.

Dujčev 1965: Ivan Dujčev, "La chronique byzantine de l'an 811”, in: Travaux et Mémoires. Centre de Recherche d'Histoire et Civilisation Byzantines 1, 1965, pp. 205-264, reprinted in: idem, Medioevo bizantino-slavo 2: Saggi di storia letteraria, Rome 1968 (=Storia e letteratura. Raccolta di Studi e Testi 113), pp. 425-489 (with bibliographical addenda: pp. 618-621).

Gauer 1994: Heinz Gauer, Texte zum byzantinischen Bilderstreit: Der Synodalbrief der drei Patriarchen des Ostens von 836 und seine Verwandlung in sieben Jahrhunderten (=Studien und Texte zur Byzantinistik 1), Frankfurt am Main-Berlin etc. 1994.

20 Georgiev 1978, 33 (text of the inscription, where Georgiev overlooked the horizontal stroke above the letters $\Theta \mathrm{Y}$ as a mark of the contracted nomen sacrum), and 32-43 (commentary). 
Georgiev 1978: Pavel Georgiev, „Eine zweisprachige Grabinschrift aus Pliska“, in: Palaeobulgarica $2 / 3,1978$, pp. 32-43.

Gjuzelev 1991: Vasil Gjuzelev, „Hauptstädte, Residenzen und Hofkultur im mittelalterlichen Bulgarien 7.-14. Jh: vom Nomadencampus bis zum Zarenhof", in: Études Balkaniques 27/2, 1991, pp. 82-105.

Ioannes Skylitzes: Ioannis Skylitzae Synopsis Historiarum, ed. by Ioannes Thurn (=Corpus Fontium Historiae Byzantinae 5), Berlin-New York 1972.

loannes Zonaras: loannis Zonarae Epitomae Historiarum, ed. by Theodor Büttner-Wobst, Bonn 1897; Militärs und Höflinge im Ringen um das Kaisertum. Byzantinische Geschichte von 969 bis 1118 nach der Chronik des Johannes Zonaras, translated, explained and with a preface by Erich Trapp (=Byzantinische Geschichtsschreiber 16), Graz-Wien-Köln 1986.

Jordanov 1993: Иван Йорданов, Печатите от стратегията в Преслав (971-1088) (=Monumenta slavico-byzantina et mediaevalia 2), София 1993.

Jordanov 2003: Ivan Jordanov, Corpus of Byzantine Seals from Bulgaria 1: Byzantine Seals with Geographical Names, Sofia 2003.

Karayannopulos/Weiss 1982: Johannes Karayannopulos/Günter Weiss, Quellenkunde zur Geschichte von Byzanz (324-1453), $2^{\text {nd }}$ semi-volume, Wiesbaden 1982.

Leo Diaconus: Leonis Diaconi Caloensis Historiae, ed. by Karl Benedict Hase, Bonn 1828; Nikephoros Phokas, “der bleiche Tod der Sarazenen” and Johannes Tzimiskes. Die Zeit von 959 bis 976 in der Darstellung des Leon Diakonos, translated by F. Loretto (=Byzantinische Geschichtsschreiber 10), Graz-Wien-Köln 1961.

Markopoulos 1999: Athanasios Markopoulos, „La chronique de l'an 811 et le Scriptor incertus de Leone Armenio: problèmes des relations entre l'hagiographie et l'histoire“, in: Revue des études byzantines 57,1999 , pp. 255-262.

Munitiz/Chrysostomides/Harvalia-Crook/Dendrinos 1997: The Letter of the Three Patriarchs to Emperor Theophilos and Related Texts, ed. by Joseph A. Munitiz/J. Chrysostomides/ E. Harvalia-Crook/ Ch. Dendrinos, Camberley, Surrey 1997 (Engl./Greek. synopt.).

Niavis 1987: Pavlos Niavis, The Reign of the Byzantine Emperor Nicephoros I (AD 802-811), Athens 1987.

Nikolov 2005: Георги Н. Николов, Централизъм и регионализъм в ранносредновековна България (края на VII- началото на XI в.) София 2005.

Nikolova 2003: Светлана Николова, “Плиска”, in: Кирило-Методиевска енциклопедия 3, София 2003, pp. 148-156.

Panova 1995: Росица Панова, Столичният град в културата на средновековната България, София 1995.

Panova 1996: Rositza Panova, „The Capital City in the Medieval Bulgarian Culture“, in: Jahrbuch der Österreichischen Byzantinistik 46, 1996, pp. 437-440.

Prinzing 1984: Günter Prinzing, review of Beševliev 1981: Byzantinische Zeitschrift 77, 1984, pp. 61-64.

Prinzing 1995: Günter Prinzing, s.v. „Pliska“, in: Lexikon des Mittelalters 7, 1995, col. 22-23.

Prosopographie der mittelbyzantinischen Zeit. Prolegomena: Prosopographie der mittelbyzantinischen Zeit: 1. Abteilung (641-867), Prolegomena, compiled after the preliminary research of Friedhelm Winkelmann by Ralph-Johannes Lilie (et al.), Berlin-New York 1998.

Rašev 1995: Рашо Рашев, “Плисковият аул”, in: Плиска-Преслав 7, Шумен 1995, pp. 10-22.

Shepard 1995: Jonathan Shepard, „Slavs and Bulgars“, in: Rosamond McKitterick (Ed.), The New Cambridge Medieval History II c. 700-c.900, Cambridge 1995, pp. 228-248. 
Theophanes Confessor: Theophanis Chronographia 1, ed. by Carl de Boor, Hildesheim 1964 (reprint); The Chronicle of Theophanes Confessor: Byzantine and Near Eastern History AD 284-813, translated by Cyril Mango and Roger Scott, Oxford 1997.

Treadgold 1988: Warren T. Treadgold, The Byzantine Revival 780-842, Stanford 1988.

Treadgold 1997: Warren T. Treadgold, A History of the Byzantine State and Society, Stanford 1997.

Tschižewskij 1968: Dmitrij Tschižewskij, Abriss der altrussischen Literaturgeschichte (=Forum slavicum 9), München 1968. 



\title{
Zur historischen Topographie Pliskas einhundert Jahre nach den ersten Ausgrabungen
}

\author{
JANKO DiMITROV
}

Nachdem bei den Feldforschungen vergangener Jahre in Pliska, der ersten altbulgarischen Hauptstadt, verschiedene archäologische Einzelfragen und Probleme verfolgt wurden, ist es jetzt nach 100 Jahren Ausgrabungen an der Zeit, auch übergreifende Analysen zur historischen Topographie der Siedlungsanlage in Angriff zu nehmen. ${ }^{1}$ Dieser Zeitpunkt erklärt sich daraus, dass die Erhebung entsprechender Daten natürlich ganz entscheidend vom Umfang und den Fortschritten der archäologischen Feldarbeiten abhängt.

Einen ersten wichtigen Schritt in diese Richtung stellt die genaue Analyse des zeitlichen Nacheinanders der archäologischen Denkmäler auf dem ausgedehnten Siedlungsgebiet Pliskas $\left(23,3 \mathrm{~km}^{2}\right)$ dar. Dies betrifft besonders die großen Baukomplexe, wie z.B. das Palastzentrum und die anderen monumentalen Bauten der Inneren und Äußeren Stadt. Für die Erarbeitung einer modellhaften, städtebaulichen und topographisch-sozialen Charakteristik der Siedlungsanlage und das Verfolgen seiner Entwicklung durch die Zeit, ist es erforderlich, die Einzelstratigraphien in einen Gesamtzusammenhang zu bringen.

Die Rekonstruktion der historischen Topographie von Pliska erfolgt also in drei Schritten: 1. allgemeine Erfassung, Kartierung und funktional-typologische Gruppierung der Denkmäler, 2. chronologische Differenzierung der baulichen Objekte einerseits und die der drei Teile des besiedelten Territoriums andererseits, 3. Herausarbeitung der grundlegenden Tendenzen der Siedlungsentwicklung.

Die von L. Dončeva-Petkova jüngst vorgelegte Übersicht zur hundertjährigen Forschungstätigkeit in Pliska gibt mir die Möglichkeit, den Blick auf die Forschungsgeschichte abzukürzen. ${ }^{2}$ Um den Gang der Forschungen aufzuzeigen, die für die Bestimmung der Topographie Pliskas besonders wichtig waren, sollen hier vor allem die bisher zu Pliska erstellten Übersichtskartierungen angesprochen werden.

1 Dimitrov 1998a; ders. 1999.

2 Dončeva-Petkova 2000. 
Die erste umfassende archäologische Karte Pliskas ist das Werk K. Škorpils (Abb. 1). Auf ihr sind die bei Feldbegehungen und Grabungen zwischen 1899 und 1900 entdeckten Objekte in den einzelnen Siedlungsarealen eingetragen worden. Der Plan des Palastzentrums zeigt die Umfassungsmauer der Zitadelle mit den in ihrem nordwestlichen Teil nachgewiesenen Bauten und Anlagen sowie die Gebäude des sogenannten Großen Palastes und der Palastbasilika. ${ }^{3}$ Der Plan der Inneren Stadt zeigt den genauen Verlauf der Festungsmauer mit ihren Toren und Türmen. ${ }^{4}$ Außer den Gebäuden des Palastkomplexes sind keine weiteren archäologischen Objekte eingetragen. Im vom Erdwall umgrenzten Gebiet der Äußeren Stadt und in der näheren Umgebung dieses Walles, sind von Škorpil verschiedene Bodendenkmäler kartiert worden. Für diese Darstellung wurde eine topographische Grundkarte gewählt, die das Relief, die Hydrographie und die Toponyme zeigt. ${ }^{5}$ Die Karte enthält die drei Hügel (Nr. XXXIIXXXIV) und 19 Fundstellen mit Resten von Steinbauten, von denen sechs (Nr. 1, 4, 11, $12,16,18)$ als Kirchen bezeichnet werden. Neben diesen Steinbauten sind außerdem die Große Basilika, der steingepflasterte Prozessionsweg und vier weitere Hauptwege sowie der Verlauf des Walles nördlich von Hügel XXXIII verzeichnet.

Dieser Plan Škorpils diente jahrzehntelang als Grundlage für die Kartierung aller neuentdeckten Denkmäler innerhalb des befestigten Areals. Die von ihm eingeführten Namen und die Nummerierung der Gebäude sind bis auf den heutigen Tag beibehalten worden.

Etwa 30 Jahre später wurde der Plan der Inneren Stadt und des Palastzentrums durch die von Kr. Mijatev und P. Karasimenov nachgewiesenen Gebäude ergänzt. ${ }^{6}$ Neben den Beobachtungen zu baulichen und architektonischen Besonderheiten an verschiedenen Gebäuden und zu ihrer stratigraphischen Lage, konnte erstmals eine Periodisierung der Objekte des Palastzentrums vorgelegt werden. ${ }^{7}$ Darüber hinaus wurde versucht, die relative Chronologie der Denkmäler auf die wichtigsten Ereignissen der Geschichte Pliskas zu beziehen.

Eine weitere archäologische Karte wurde 1955 von St. Michajlov und At. Milčev publiziert (Abb. 2). ${ }^{8}$ Tatsächlich hat man dabei aber nur den Plan Škorpils durch neuere Ergebnisse der Grabungen in der Inneren Stadt zwischen 1945 und 1948 ergänzt. 20 neue Objekte, differenziert nach kirchlichen und städtischen Bauten, wurden in das Gebiet der Inneren Stadt eingetragen und in Anlehnung an Škorpil mit den arabischen Ziffern 20 bis 39 bezeichnet. Hinzu kamen 25 weitere Objekte, die ohne genauere Ansprache ihres Charakters auf der Karte verzeichnet wurden. Ein Mangel dieser Karte ist das Fehlen einiger

\footnotetext{
3 Aboba-Pliska 1905, Taf. 4,2.

4 Ebd., Taf. 4,4.

5 Ebd., Taf. 1.

6 Mijatev 1943, 89 Abb. 157; Karasimeonoff 1943, Abb. 236.

7 Karasimeonoff 1943, 165-167 Abb. 235, Abb. 236.

8 Michajlov 1949, 172 Abb. 1; ders., 1955, Abb. 1.
} 


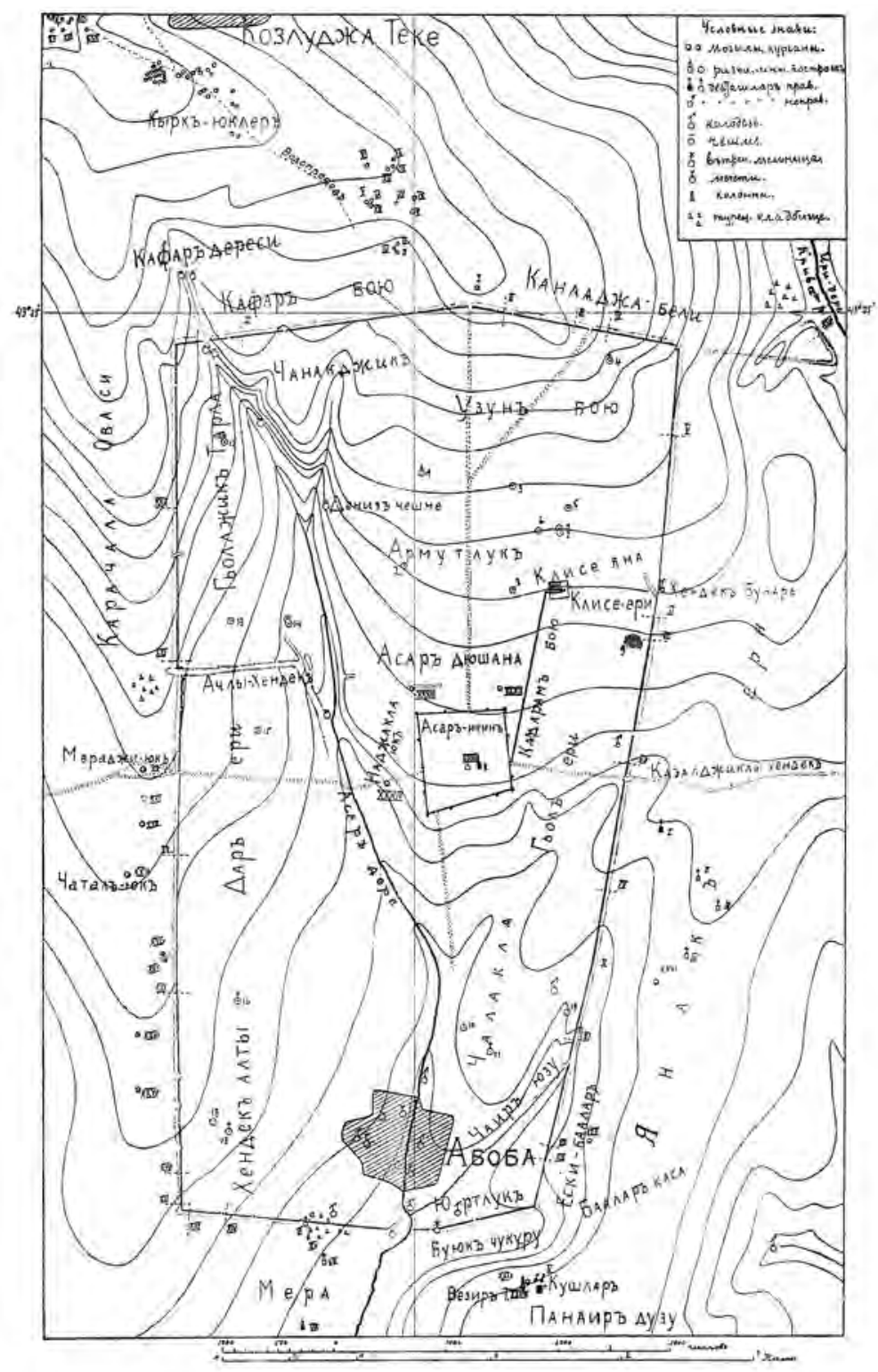

Abb. 1. Archäologische Karte von Pliska von K. Škorpil (1905) 


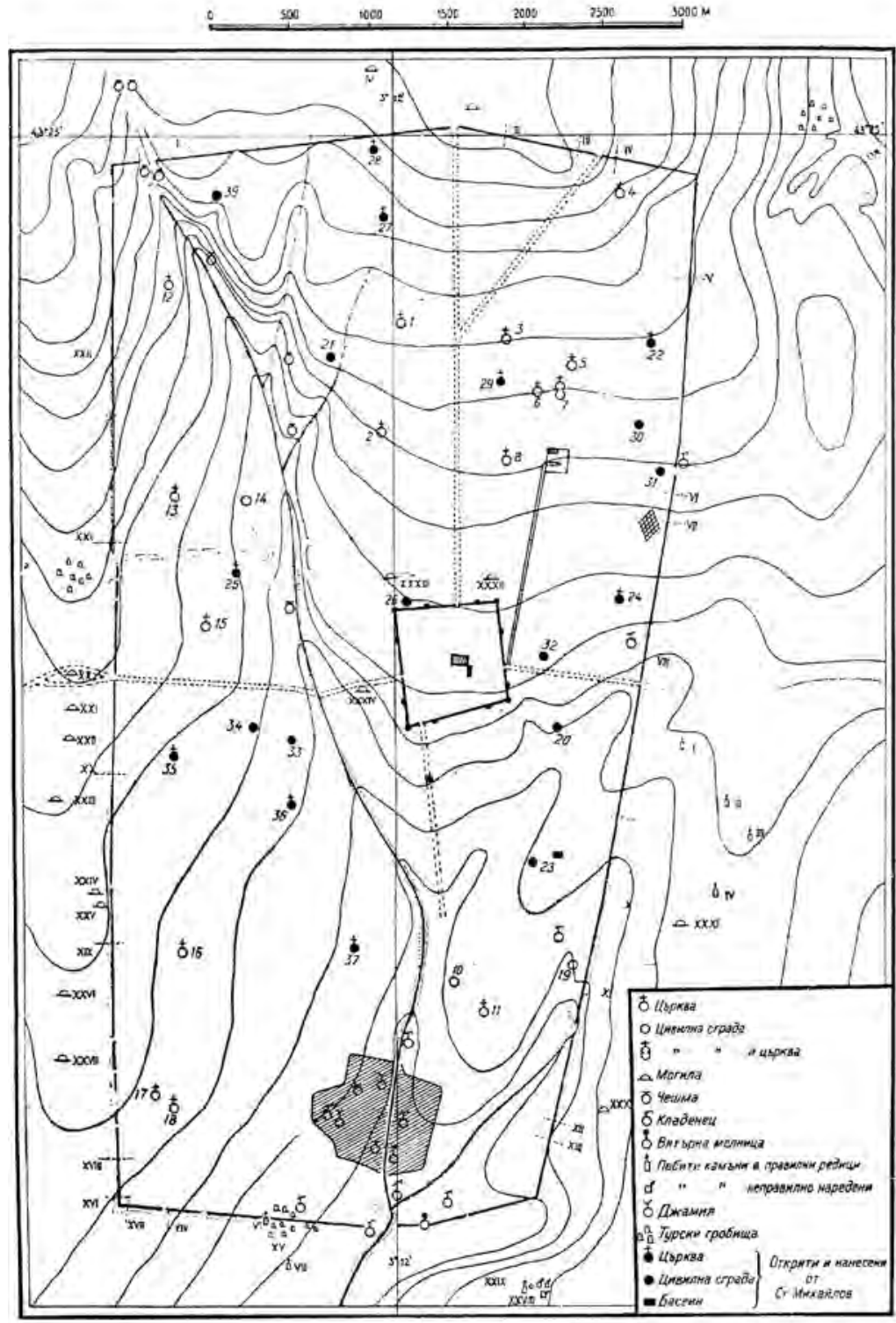

Abb. 2. Archäologische Karte von Pliska von St. Michajlov (1955) 
bereits in früheren Jahren entdeckter Objekte, wie etwa der Siedlung und der Produktionsbereiche in der Flur Asar-dere sowie der Steinmauer nördlich der Inneren Stadt. ${ }^{9}$

Im Anschluss an Škorpil und Michajlov/Milčev veröffentlichte P. Petrova 1984 eine Karte des gesamten befestigten Siedlungsareals von Pliska (Abb. 3). ${ }^{10}$ Sie nahm erstmals eine dreidimensionale Einmessung der Objekte vor. Neben den bereits bekannten Denkmälern enthält die Karte einige neue architektonische Befunde, die aus Luftbildern gewonnen wurden. So ist zum Beispiel die Mauer nördlich der Festung und die in demselben Areal vermutete Erdwallanlage eingetragen worden, die später auch durch Grabungen erfasst wurde. ${ }^{11}$ Außer den Gebäudekomplexen der Inneren Stadt zeigt die Karte elf neue Architekturobjekte in der Äußeren Stadt. Die als hofartige Wohnkomplexe bezeichneten Anlagen wurden nach Škorpils System von 40 bis 50 durchnumeriert.

Die kartierten Luftbildbefunde fanden später durch Grabungen in zwei dieser Komplexe Bestätigung. ${ }^{12}$ Ebenfalls eingetragen sind das so genannte Handelsgebäude und 15 weitere, in der Gegend der südlichen Festungsmauer und an der östlichen Linie des Walles gelegene Hofareale mit Steingebäuden, ${ }^{13}$ die jedoch nicht nummeriert wurden.

Zum Zeitpunkt vor 20 Jahren bildete die Karte von P. Petrova die genaueste Darstellung der Architekturdenkmäler in der Äußeren Stadt von Pliska. Wie bei den älteren Karten sind aber auch in diese Karte keine Punkte aufgenommen worden, an denen flächenhafte Befunde wie Grubenhaussiedlungen, Wasserleitungen und Nekropolen zum Vorschein kamen. In diesem Zusammenhang ist der von R. Rašev publizierten Plan Pliskas hervorzuheben, der die kulturellen Niederschläge auf dem Gesamtgebiet innerhalb der Wallbefestigung zeigt. ${ }^{14}$ Die besondere Bedeutung dieser Karte für die Erforschung der historischen Topographie Pliskas liegt darin, dass erstmals versucht wurde, die intensiver besiedelten Gebiete in ihren verschiedenen Entwicklungsetappen hervorzuheben.

Aus diesem kleinen Überblick dürfte deutlich geworden sein, dass die Erfassung und Darstellung von Daten zur Siedlungsstruktur von Pliska nicht nur das Resultat der Arbeit von vier Archäologengenerationen ist, sondern dass dieser sich immer noch fortsetzende Prozess nur in sehr langsamen Schritten zu einer gewissen Fortentwicklung des bereits nach den ersten Grabungen um die Jahrhundertwende entworfenen

9 Zur Siedlung und zu den Keramikwerkstätten vgl. Milčev 1960, 31-64; ders. 1969, 30-43, Abb. 1. Zur Einfassungsmauer nördlich der Inneren Stadt vgl. Michajlov 1955, 63; Milčev 1964, 31 Abb. 8.

10 Petrova 1984, 53 Abb. 1; dies. 1992, 65 Abb. 1.

11 Dies. 1992, 66 Abb. 2; dies. 1988, 135. Ein Schnitt durch die Befestigungslinie wurde auch von der deutsch-bulgarischen Pliska-Expedition angelegt (Grabungsergebnisse 1999).

$12 \mathrm{Zu}$ den Ausgrabungen in dem als Objekt Nr. 40 bezeichneten Komplex vgl. Petrova/Aladžov 1986, 37-48; Aladžov 1993, 85-93. Zum Objekt Nr. 41 vgl. den Beitrag von St. Vitljanov, Ein Herrenhof des 10.-11. Jahrunderts in der Äußeren Stadt von Pliska, in diesem Band.

13 Vgl. dazu: Aladžov 1959, 30; ders. 1992, 206-210, Abb. 35.

14 Rašev 1990, 70 Abb. 1. 
topographischen Bildes geführt hat. Geringe Fortschritte sind besonders für das Gebiet der Äußeren Stadt zu verzeichnen, da es sich hier um ein Gebiet der Siedlungsagglomeration von enormer Größe mit nur geringen Grabungsaktivitäten handelt.

Einige Lücken in unseren Kenntnissen über die Topographie von Pliska konnten durch ausgedehnte Feldbeobachtungen in den Jahren 1989 bis 1991 geschlossen werden. Damals hat man auf dem Gebiet der Äußeren Stadt für den Bau landwirtschaftlicher Bewässerungsleitungen umfangreiche Kanalausschachtungen ausgeführt. Das System dieser Baugräben war insgesamt $44 \mathrm{~km}$ lang und betraf etwa 1500 ha der im Frühmittelalter besiedelten Fläche Pliskas zwischen der steinernen Festung und dem äußeren Erdwall (Abb. 4). Die Bauarbeiten wurden archäologisch begleitet. ${ }^{15}$ Der überwiegende Teil dieser Wasserleitungsgräben hatte eine Breite von $0,5 \mathrm{~m}$ und eine Tiefe von 0,91,1 m. Einzelne Abschnitte aber waren mit Breiten bis zu $2 \mathrm{~m}$ und Tiefen von 2,2-2,5 m bedeutend größer. Die meist senkrechten Grabenwände und die ebenen Grabensohlen wurden an Stellen mit Siedlungs- oder Gräberbefunden archäologisch aufgearbeitet und je nach Bedarf und sich bietenden technischen Möglichkeiten zeichnerische und fotografisch dokumentiert. Die Erdeingriffe wurden genutzt, um erstmals großflächige Daten über Nutzungsintensität und -form eines großen Teils der Siedlungsfläche von Pliska zu gewinnen. Es ergab sich, dass auf diese Weise zahlreiche Objekte ans Tageslicht kamen, die zuvor weder durch Flurbegehungen noch durch Luftbildauswertungen erfasst worden sind. Die auf dem Trassenverlauf der Wasserleitungsgräben beobachteten Befunde sind nach bestem Vermögen vermessen und in einen Katasterplan eingetragen worden. Etliche hundert Keramikscherben und Kleinfunde konnten genutzt werden um einige der Objekte einer ungefähren Datierung näher zu bringen.

Die zwischen den Leitungsgräben liegenden Flächen und das gesamte südliche Drittel der Äußeren Stadt wurden nach Oberflächenfunden abgesucht. Auch die dabei gemachten Funde und Befunde wurden kartographisch registriert. Außer der archäologischen Begleitung der Baggerarbeiten und Feldbegehungen sind auch einzelne archäologische Aufdeckungen gefundener Objekte durchgeführt worden, die den Erkenntnisgewinn zur Topographie Pliskas abgerundet haben. ${ }^{16}$

Folgende Objekte, gegliedert nach funktionalen Merkmalen und der Art ihrer Erfassung, wurden nachgewiesen:

1. Steingebäude: 23 durch Sondagen erfasste und genau lokalisierte; 34 durch Feldbegehungen erfasste, annähernd lokalisierte

2. Siedlungen: 29 Plätze mit insgesamt 233 Grubenhäusern

3. Bestattungen: fünf Befunde

4. Wasserleitungen: fünf Teilabschnitte

15 Zu den Ergebnissen dieser Untersuchungen s. Dimitrov 1992, 58-67; ders. 1998a.

16 Dimitrov 1995, 42-70. 


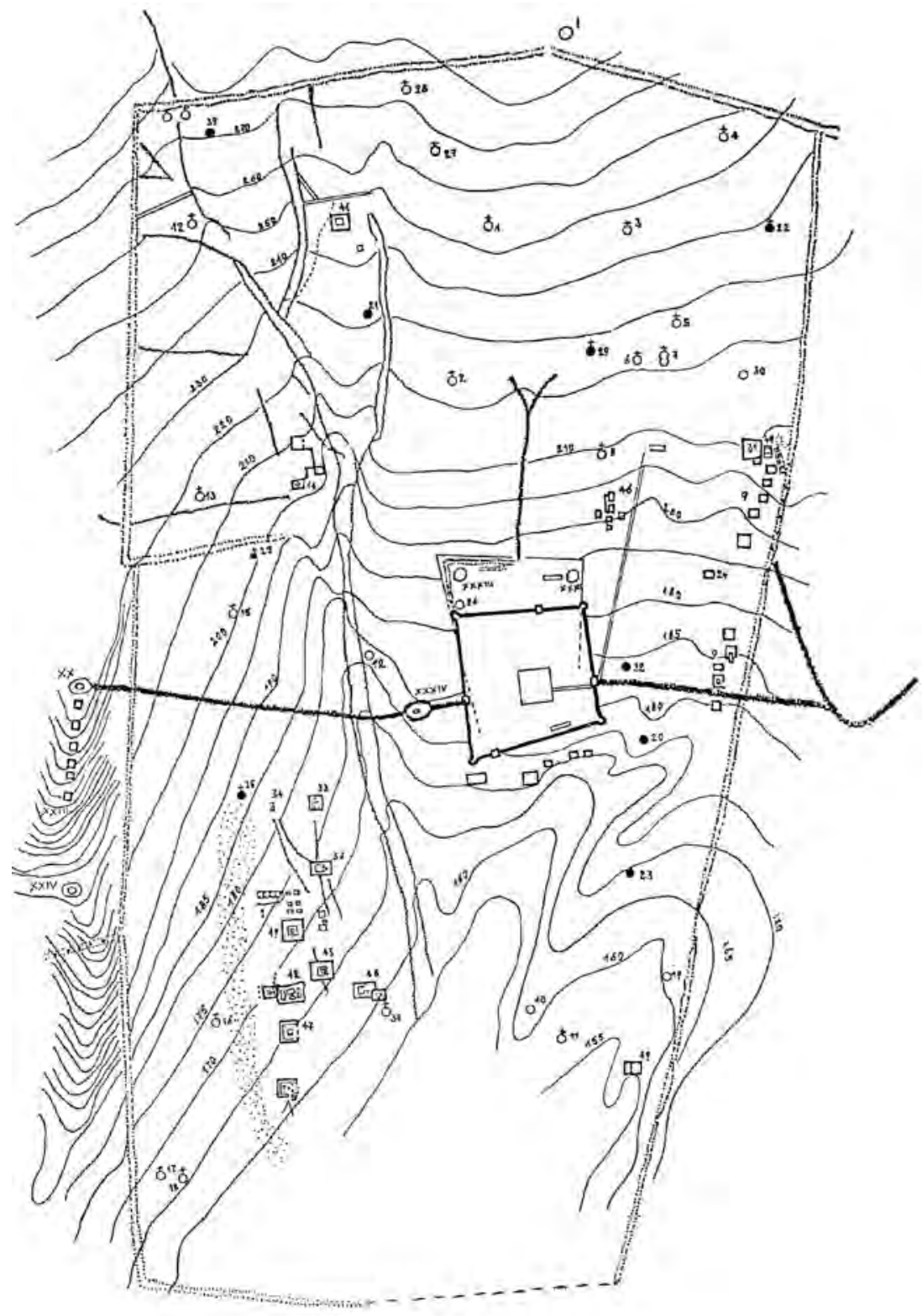

Abb. 3. Archäologische Karte von Pliska von P. Petrova (1992) 


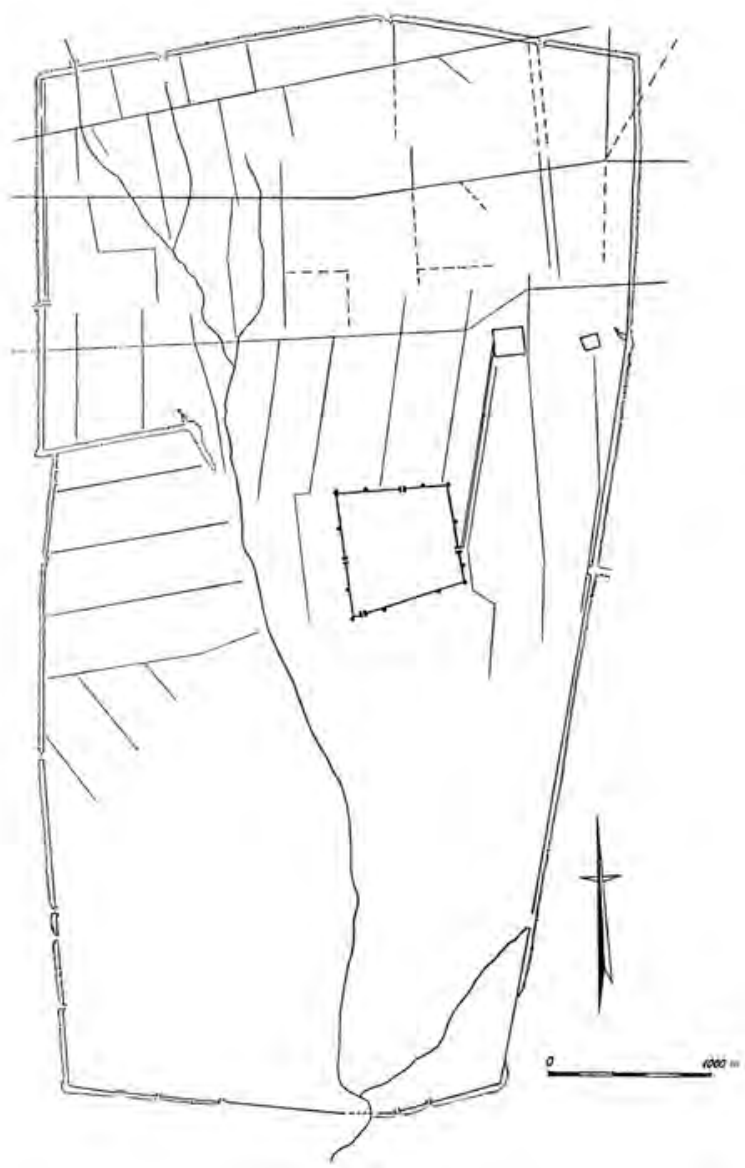

Abb. 4. Lage des Grabennetzes für die Bewässerungsanlagen

Diese neu erschlossenen Befunde gaben Anlass, eine aktualisierte Fassung der archäologischen Karte von Pliska zu erarbeiten. In diese wurden alle bisher innerhalb des Befestigungswalles gefundenen Architekturobjekte aufgenommen. Um eine genauere Darstellung zu erreichen, besteht diese Kartierung aus drei getrennten Plänen von Äußerer und Innerer Stadt sowie dem Palastzentrum. ${ }^{17}$ Auf dem Plan der Äußeren Stadt, der aus Gründen der Übersichtlichkeit keine Höhenlinien zeigt, sind alle Denkmäler mit einem Symbol markiert und durchnumeriert (Abb. 5). Der Plan der Inneren Stadt (Abb. 6), der 1992 mit modernen vermessungstechnischen Methoden erstellt wurde, gibt die genaue Position eines Teils der steinernen Bauten an. Allerdings konnten die in früheren Jahren ausgegrabenen Objekte, die nicht dreidimensional eingemessen worden waren, nur durch Symbole dargestellt werden. Das System der Nummerierung

17 Vollständige Publikation der Karte und des Katalogs bei Rašev/Dimitrov 1999, 51-101. 
behält die traditionellen Angaben für die bekannten Objekte bei. In gleicher Weise wurden auch alle die Objekte dargestellt, die nicht oberirdisch erkennbar sind.

Die wenigen im Verhältnis zur Gesamtfläche Pliskas ausgegrabenen Flächen (etwa 8,3\% innerhalb der Festungsmauer und etwa $0,5 \%$ in der Äußeren Stadt), erlauben noch keine detaillierte Rekonstruktion des historischen Bildes und des städtebaulichen Gesamtgrundrisses. Dennoch wird eine systematische Erfassung und Bewertung des Bekannten die ungefähre Bestimmung von Lage, Funktion und Ausdehnung einzelner Siedlungsareale erlauben. Ein tieferes Eindringen in die chronologische Situation wird darüber hinaus weitere Angaben zum Charakter und zur Entwicklungsdynamik einzelner Siedlungsbereiche ermöglichen.

Eine relativchronologische Bewertung der einzelnen Gebäudeanlagen lässt drei zeitliche Etappen der Siedlungsentwicklung erkennbar werden. Diese umfassen erstens die Zeit vom Ende des 7. Jahrhunderts bis zur Mitte des 9. Jahrhunderts (Abb. 7), zweitens die Zeit vom dritten Viertel des 9. Jahrhunderts bis zum dritten Viertel des 10. Jahrhunderts (Abb. 8) und drittens die Zeit vom Ende des 10. Jahrhunderts bis zur zweiten Hälfte des 11. Jahrhunderts (Abb. 9). ${ }^{18}$

Die drei Zeitperioden werden dem Modell der Siedlungsentwicklung zugrunde gelegt und führen unter Berücksichtigung der Schriftquellendaten zu dem im Folgenden erläuterten Gesamtbild der Stadtgeschichte Pliskas:

\section{Heidnische Phase der Hauptstadt (Ende des 7. Jahrhunderts - 864)}

Obwohl die Nachrichten der Schriftquellen eher spärlich sind, scheinen diese sowie vor allem alle bisherigen archäologischen Beobachtungen die These entschieden zu stützen, wonach Pliska erst nach der Bildung des Bulgarenreiches im Jahr 681 entstanden ist. Dafür spricht vor allem das Fehlen jeglicher älterer Spuren antiker oder frühslawischer Siedlungen auf dem wallumgrenzten Territorium Pliskas, die man auf einen Vorläufer der ältesten bulgarischen Hauptstadt beziehen könnte. ${ }^{19}$

Die Entstehung Pliskas wird man wohl als einen Vorgang auffassen müssen, der sehr schnell und im Gefolge der Umgestaltung eines Teils der heutigen Pliska-Ebene in ein Heerlager und eine Siedlung für die von Khan Asparuch angeführten (proto-) bulgarischen Gruppe erfolgt ist. Die im Zentrum des wallumgrenzten Territoriums errichtete

18 Die Argumentation zum hier vorgestellten Periodisierungsschema findet sich ausführlich bei Dimitrov 1998.

19 Diese Aussage wird ganz eindeutig durch die zwischen 1989 und 1990 im Bereich der Äußeren Stadt durchgeführten systematischen Beobachtungen im Zusammenhang mit der Anlage eines Wasserleitungssystems bestätigt. Das enge Netz der hierzu ausgehobenen Gräben schließt die Möglichkeit nahezu vollständig aus, dass auf diesem Gebiet Reste bislang unbekannter antiker oder frühslawischer Besiedlung übersehen worden wären. 


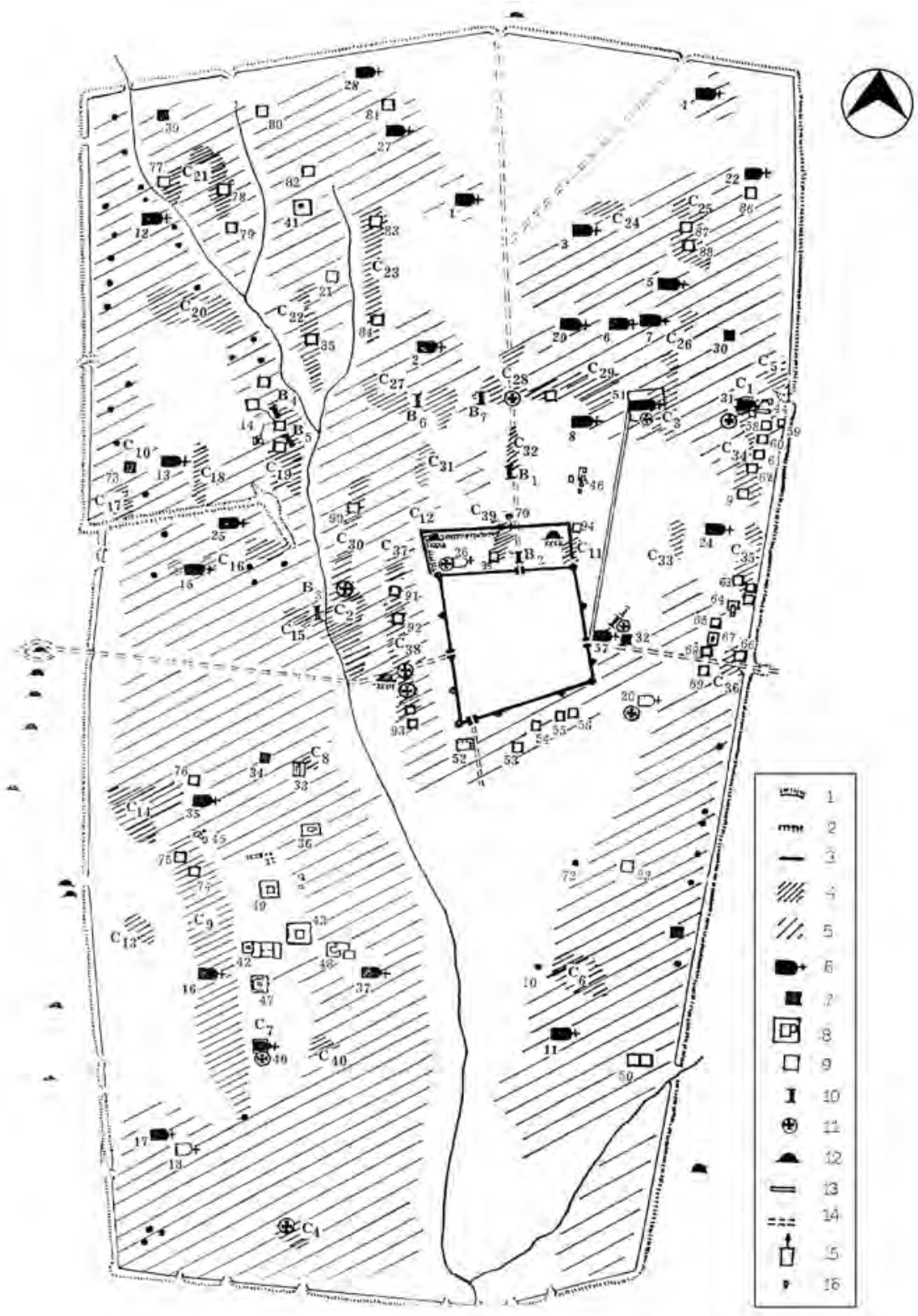

Legende: 1. Wall, 2. Graben, 3. steinerne Mauer, 4. Siedlungssektor, 5. besiedelte Region, 6. Kirche (erforscht), 7. Steingebäude (erforscht), 8. Komplex von Steinbauten in einem Hof, 9. Steingebäude (unerforscht), 10. Wasserleitung, 11. Nekropole, 12. Hügel, 13. steingepflasterter Weg, 14. Weg, 15. Devtašlari (Monolithe), 16. unbestimmte Bauten aus Stein

Abb. 5. Archäologische Karte von Pliska: Äußere Stadt 
Residenz des Khans gewinnt rasch den Charakter eines Nukleus, um den herum sich schon bald ein Kranz verschiedener Siedlungen bildet. Aus siedlungstopographischer Sicht ist der Umstand besonders erwähnenswert, dass keine dieser Siedlungen die Begrenzung des Erdwalles überschritten hat. So entwickelte die erste Hauptstadt der bulgarischen Herrscher gleich zu Beginn ihres Bestehens eine besondere Struktur, die am besten mit dem Begriff der Siedlungsagglomeration umschrieben werden kann. In ihrem Territorium umschließt sie zwei aus soziokultureller Sicht unterschiedlich geartete Siedlungssysteme: Die Aul-Residenz des Khans (die heute als Innere Stadt bezeichnet wird) und den sie umgebenden Ring aus Satellitensiedlungen (die sogenannte Äußere Stadt).

Die Erforschung von vier dieser Siedlungen in der Äußeren Stadt hat gezeigt, dass der gebräuchlichste Haustyp das rechtwinklige Grubenhaus mit einem in einer Ecke gelegenen steinernen Ofen ist. ${ }^{20}$ Die Ballung der Häuser an einigen Stellen sowie die rechteckige Umgrenzung zweier Siedlungen mit einer hölzernen Palisade, scheint anzudeuten, dass die im Gebiet der Äußeren Stadt siedelnde Bevölkerung in Geschlechterverbänden organisiert war. ${ }^{21}$

Im Bereich der Äußeren Stadt entstehen in dieser Phase zwei Sonderareale. Zum einen eine Memorialzone, bestehend aus drei großen Hügeln unmittelbar neben der Residenz des Khans, ${ }^{22}$ und entlang des Flusslaufes ein großes Handwerkszentrum für die Verarbeitung von Eisen und Buntmetallen. ${ }^{23}$

Die Siedlungen der einfachen Bevölkerung verändern ihr Aussehen im Laufe der Zeit nur hinsichtlich ihrer Ausdehnung (Zunahme der Zahl der Grubenhäuser), während ihr allgemeines Erscheinungsbild, insbesondere ihre Hausbauweise und ihre materielle Kultur, im Prinzip durchgängig gleich bleibt. Dagegen erfolgen im Bereich der Residenz des Khans deutliche qualitative Veränderungen. So werden die hier ursprünglich mehrheitlich aus Holz errichteten Gebäude und Wallmauern nach und nach „monumentalisiert““. ${ }^{24}$ An die Stelle der hölzernen Wohn- und Palastbauten treten

20 Allgemein zur Erforschung von Siedlungen im Gebiet der Äußeren Stadt siehe Vasilev 1987, 400-406 mit weiterer Literatur; zu neueren Grabungsergebnissen vgl. die Beiträge von S. Stanilov, Ja. Dimitrov, P. Georgiev und R. Vasilev in diesem Band.

21 Stanilov/Dimitrov/Jankulov 1991, 133-136 sowie die Beiträge von S. Stanilov und Ja. Dimitrov in diesem Band.

22 Zur Erforschung der drei Hügel um die Innere Stadt: Škorpil 1905, 326-332; Fehér 1940, 95, 106; Georgieva 1955, 11-41. Zum Charakter des Hügels Nr. XXXIV als Gedenkbau vgl. die Vorberichte der Grabungsequipe (S. Stanilov, L. Dončeva-Petkova, P. Georgiev und R. Vasilev) über die Ergebnisse neuerer Grabungen zwischen 1994 und 1997 (in der Reihe „Археологически открития и разкопки“ unter den entsprechenden Jahren).

23 Übersicht zu den älteren Handwerksnachweisen am Bachlauf des Asar-dere: Balabanov 1983. $\mathrm{Zu}$ den neuesten Forschungsergebnissen in diesem Teil der Äußeren Stadt vgl. Henning 2000.

$24 \mathrm{Zu}$ der sogenannten Holzbauperiode der Residenz von Pliska und seine „Monumentalisierung“ am Anfang des 9. Jahrhunderts vgl. Rašev 1993, 252-262; ders. 1995, 15-21, Abb. 2, Abb. 9. 


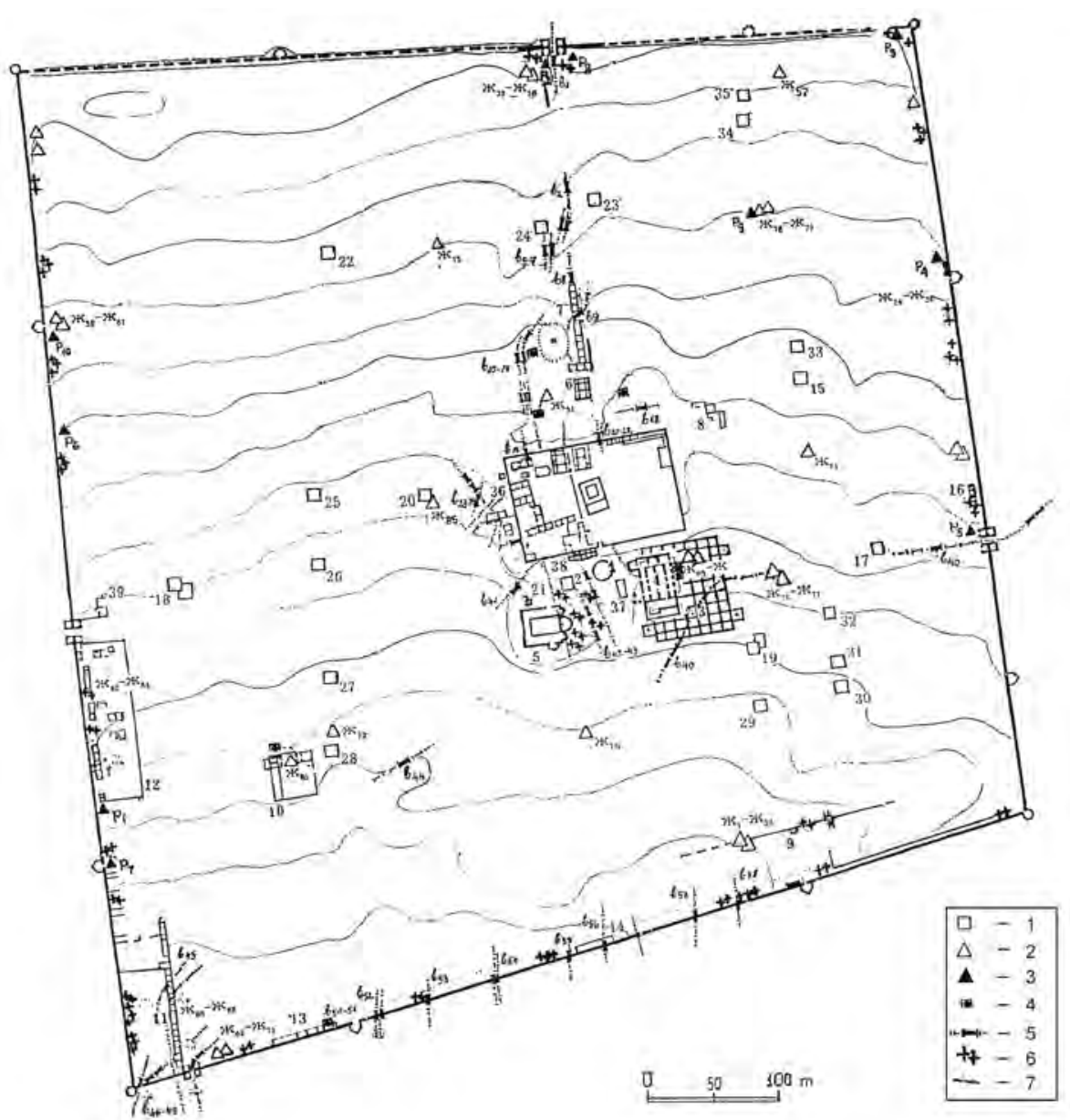

Legende: 1. Steingebäude, 2. Grubenhäuser, 3. Werkstatt, 4. Produktionsofen, 5. Wasserleitung/Kanal, 6. Nekropole, 7. unterirdischer Gang

Abb. 6. Archäologische Karte von Pliska: Innere Stadt

Stein- bzw. Ziegelkonstruktionen, und nach dem Brand im Jahr 811 wird auch der aus Holz errichtete Befestigungswall, der die Residenz umfasst, durch eine Mauer aus Steinquadern ersetzt. Schließlich entsteht mit dem Bau einer Ziegelmauer ein dritter, innerer Befestigungsring, der den Wohn- vom Repräsentationstrakt des Palastes trennt. ${ }^{25}$

25 Zur Gesamtperiodisierung und Chronologie der Stein-Ziegel-Bauten im Palastzentrum vgl. Stančev 1961, 101-109; Vaklinov 1977, 87-90, 106-111. 


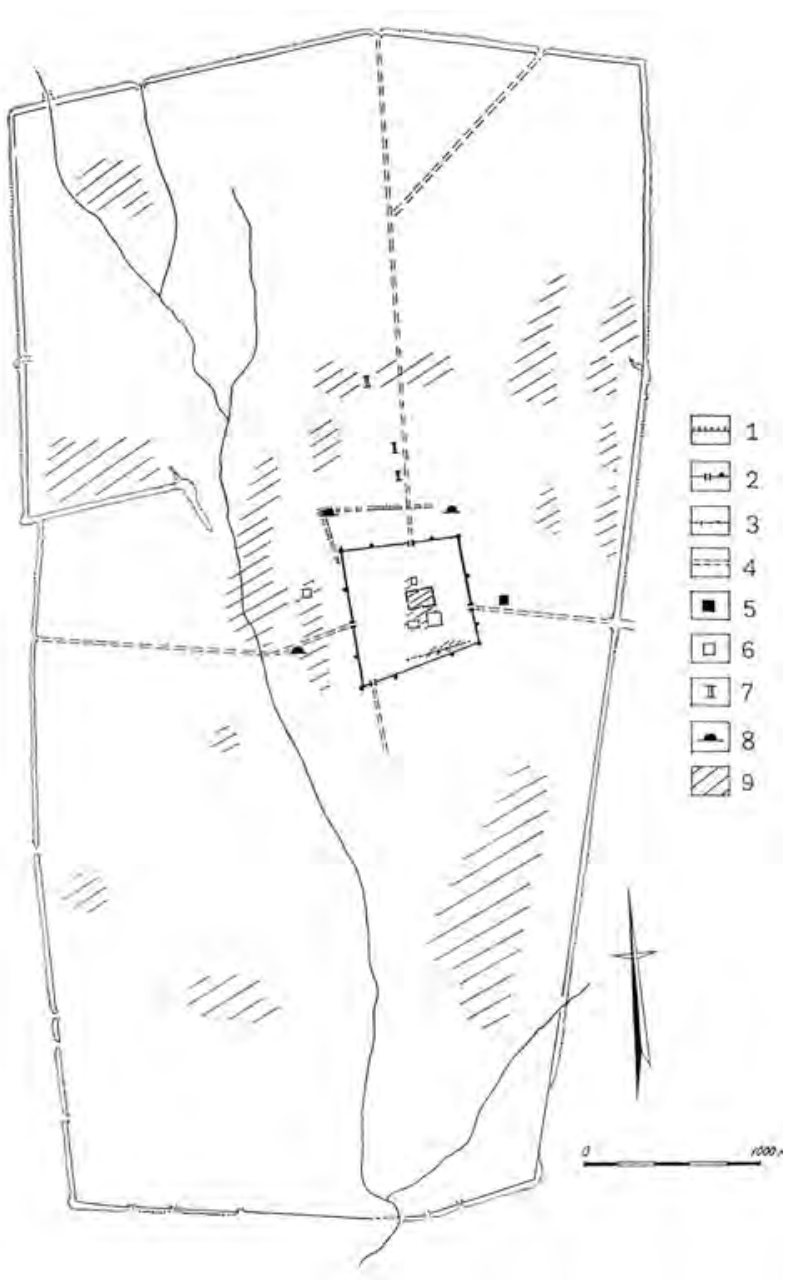

Abb. 7. Topographie von Pliska vom Ende des 7. bis Mitte des 9. Jahrhunderts

Legende: 1. Graben und Wall, 2. steinerne Befestigung, 3. Holzmauer, 4. Weg, 5. Steingebäude (erforscht), 6. Steingebäude (unerforscht), 7. Wasserleitung, 8. Hügel, 9. Siedlung mit Grubenhäusern

Nach der Errichtung der Festungsmauer aus Stein bleibt das Gebiet, das sie großräumig umschließt, bis auf die Residenzbauten und ihre unmittelbare Umgebung lange Zeit nahezu unbesiedelt. Es scheint, dass die ummauerte Residenz des Khans (der Aul) nicht nur das Administrations- und Heereszentrum war, sondern auch als heiliger Bezirk (medno gumno) galt.

Es bleibt also festzuhalten, dass bereits in der heidnischen Periode eine klare Trennung zwischen Residenz und Siedlung, Zentrum und Peripherie sowie sakralen und profanen Bezirken vorliegt. 


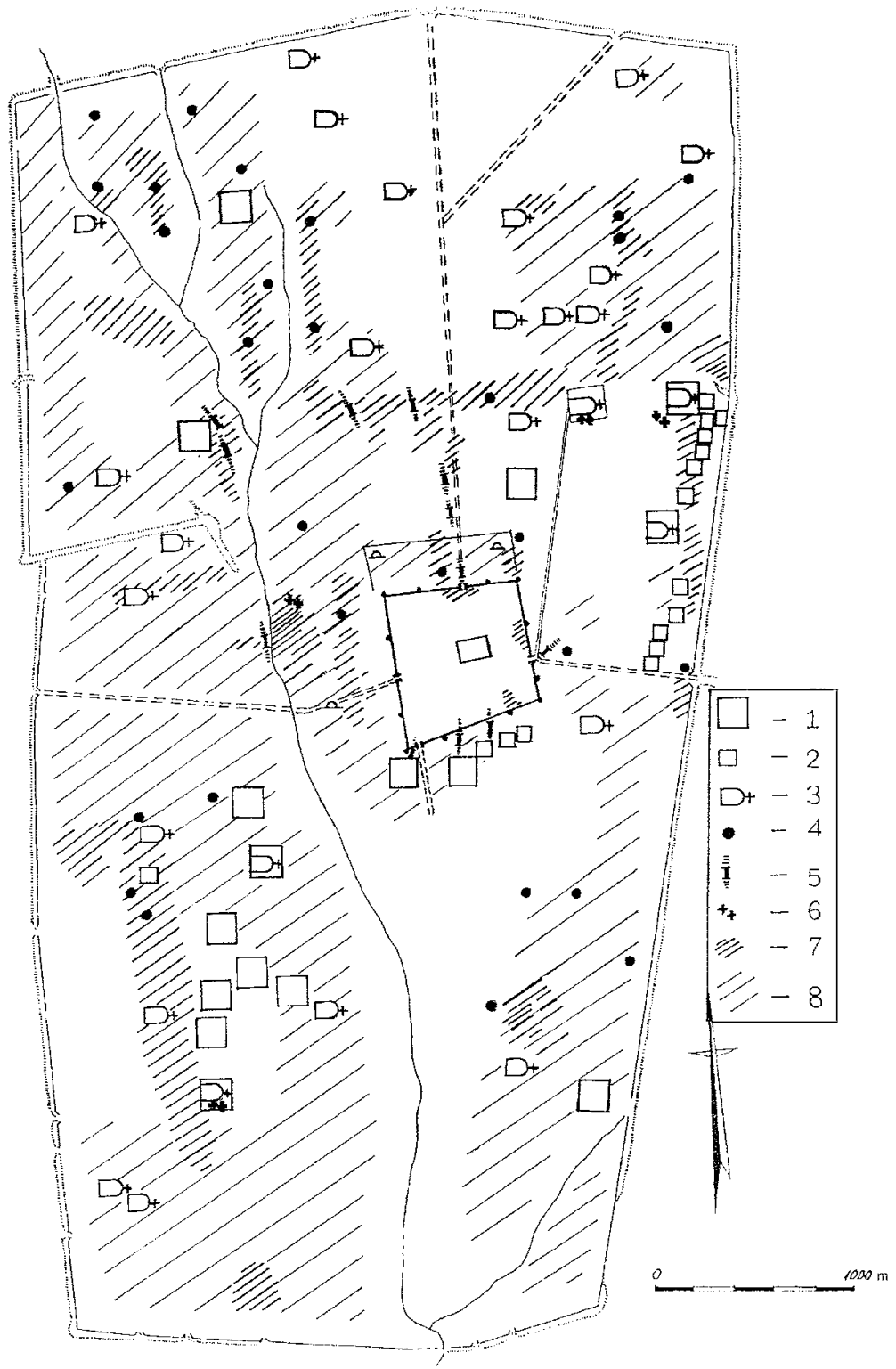

Legende: 1. großer Komplex aus Steinbauten mit Hofareal, 2. kleiner Komplex aus Steinbauten mit Hofareal, 3. Kirche, 4. Steingebäude, 5. Wasserleitung, 6. Nekropole, 7. Siedlungssektor, 8. besiedeltes Areal

Abb. 8. Topographie von Pliska vom dritten Viertel des 9. bis dritten Viertel des 10. Jahrhunderts 


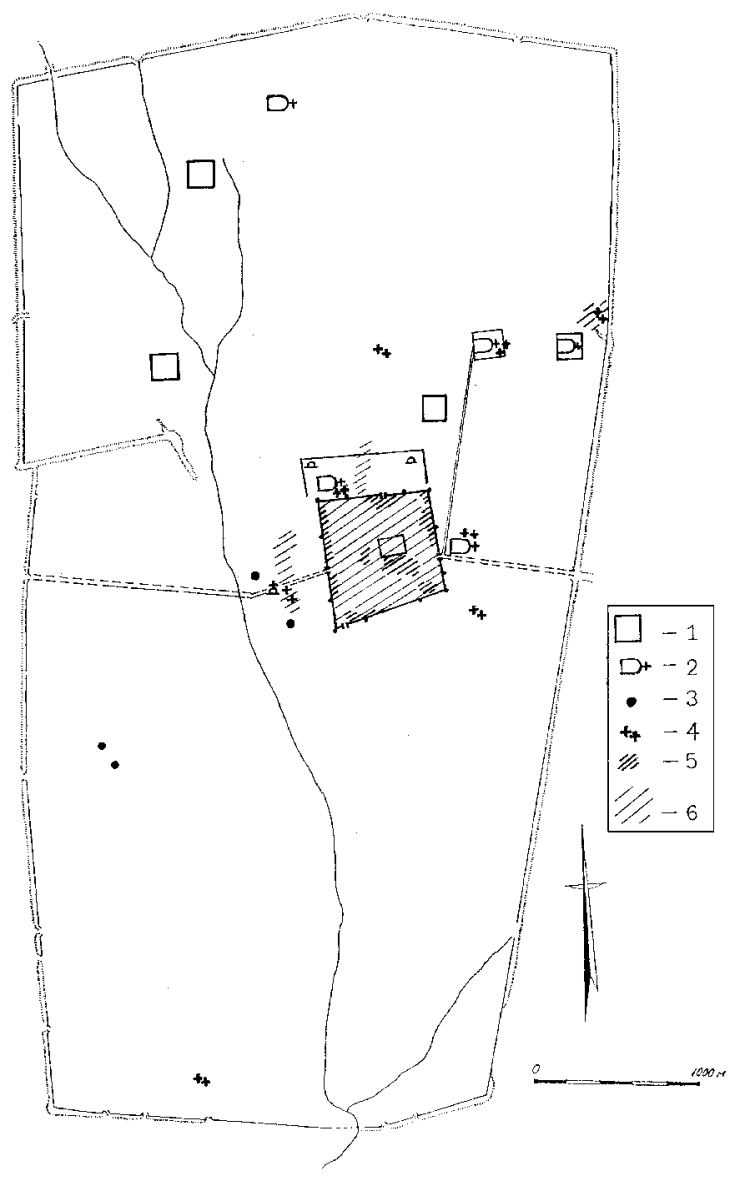

Abb. 9. Topographie von Pliska vom Ende des 10. bis zweite Hälfte des 11. Jahrhunderts

Legende: 1. Gebäudekomplex mit Hof, 2. Kirche, 3. Steingebäude, 4. Nekropole, 5. Siedlungssektor, 6. besiedeltes Areal

\section{Christliche Phase der Hauptstadt (864-893)}

Mit dem Wirken des Fürsten Boris-Michail beginnt die Zeit der Christianisierung, die vor allem durch die Errichtungen der ersten Kirchen- und Klosterbauten geprägt ist. ${ }^{26}$ Die Eingrenzung dieser kurzen Periode ist aufgrund genauer Untersuchungen baulicher Relationen möglich. In dieser Zeit wurde in der Inneren Stadt die Palastbasilika errichtet, während in der Äußeren Stadt die Große Basilika mit dem erzbischöflichen Hofkomplex, dem ersten bulgarischen Kloster und dem Didaskalon entstand. In diese Phase gehört auch zumindest ein Teil der so genannten kurzen Basiliken vom Typ Pliska, die in allen Bereichen der Äußeren Stadt zu finden sind. Offenbar sind diese

26 Zur Frage der Baugeschichte und der Chronologie der Kirchen- und Klosterbauten in Pliska vgl. Georgiev 1987, 63-75 mit weiterer Literatur; ders. 1993, 49-68 mit weiterer Literatur; vgl. auch den Beitrag von P. Georgiev in diesem Band. 
Kirchenbauten in die Bereiche vorher bestehender Siedlungskonzentrationen gesetzt worden, und sie markieren so für uns deren Lage.

Es ist davon auszugehen, dass diese Siedlungsstrukturen bis 893, dem Jahr der Verlegung der Hauptstadt nach Preslav, fortbestanden haben.

\section{Nachhauptstädtische Phase (893-971)}

Diese Periode ist durch entscheidende Veränderungen gekennzeichnet. In der Inneren Stadt, die offensichtlich ihren repräsentativen und sakralen Charakter verloren hat, werden die freien Flächen entlang der Innenseite der Festungsmauern besiedelt; es entstehen Grubenhäuser ${ }^{27}$ und Werkstätten zur Bearbeitung von Eisen, Glas und Buntmetallen. ${ }^{28} \mathrm{Im}$ Gebiet zwischen der Festungsmauer und den Palästen werden kleinere Hofkomplexe errichtet, ${ }^{29}$ die aber auch in der Äußeren Stadt entstehen und zum Teil schon aus der vorangegangenen Periode bekannt sind. ${ }^{30}$ Sie können als hofartige Wohnund Wirtschaftskomplexe reicher Boljaren angesehen werden, die sich den ehemaligen Grundbesitz des Khans angeeignet haben.

Offensichtlich zog in dieser Zeit Bevölkerung, die ursprünglich außerhalb der Steinfestung gesiedelt hatte, in das städtische Zentrum, denn Grubenhäuser lassen sich in wachsender Zahl jetzt auch innerhalb der Steinmauern nachweisen. Ein bedeutender Bevölkerungsteil scheint dabei seine ackerbauliche Tätigkeit aufgegeben und zu einer handwerklichen gewechselt zu haben. Nur der Bereich innerhalb der Ziegelsteinmauer blieb weiterhin einer weiteren Besiedlung verschlossen.

\section{Byzantinische Periode (971 - 2. Hälfte 11. Jahrhundert)}

Das deutlichste Kennzeichen für diese Phase in der Geschichte Pliskas ist das massive Auftreten von byzantinischen Münzen, die während der Herrschaft der Kaiser Johannes Tzimiskes und Basileios II. geprägt wurden. ${ }^{31}$ Die durch Schriftquellen bezeugte by-

27 Balabanov 1992, 146-167.

28 Gesamtüberblick zu den entlang der Festungsmauer entdeckten Werkstätten und Produktionseinrichtungen bei Balabanov 1983. Unzureichend begründet ist die Annahme, dass ein Teil dieser Anlagen bereits in der ersten Hälfte des 9. Jahrhunderts entstanden sei. Zu den neuesten Untersuchungsergebnissen vgl. Dončeva-Petkova 1995, 34-41.

29 Beispiel für eine solche Hofanlage ist der als Objekt $Z$ bezeichnete Architekturkomplex; vgl. Džingov 1992, 105-122, Abb. 6,I.

$30 \mathrm{Zu}$ den durch Grabungen erschlossenen Boljarenhöfen in der Äußeren Stadt vgl. Anm. 12 sowie Michajlov 1963, 5-46; Aladžov 1997, 102-104.

31 Jordanov 1980, 33-34. 
zantinische Eroberung Pliskas im Jahre 971 (und endgültig im Jahre 1000) brachte neue städtebauliche Veränderungen mit sich. Die sogenannte Zitadelle konnte ihre repräsentative Funktion offenbar dadurch bewahren, dass sie zunächst Aufgaben als Residenz für den örtlichen byzantinischen Stadthalter erfüllte. Die Wohnviertel um sie herum wuchsen schnell bis dicht an sie heran. Außerdem entstanden Produktionsanlagen, die sich nun sogar auf den ehemals sakralen Kernbereich der alten Hauptstadt, den Palasthof, ausdehnten. ${ }^{32}$ Um den Beginn des 11. Jahrhunderts dienten dann auch die noch erhaltenen Überreste der monumentalen Bauten der Zitadelle als Wohnhäuser für die allgemeine Bevölkerung. Die freien Flächen wurden mit traditionellen Grubenhäusern bebaut. ${ }^{33} \mathrm{Im}$ Vergleich zur vorangegangenen Phase scheint die Äußere Stadt ungewöhnlich dünn besiedelt gewesen zu sein. Klar erkennbare Siedlungsschichten des 10. und 11. Jahrhunderts wurden nur im Kloster der Großen Basilika und in einigen Bojarenhöfen nachgewiesen. Die Innere Stadt nahm jetzt fast die gesamte Bevölkerung auf. In der Äußeren Stadt wurden zu dieser Zeit Nekropolen angelegt, deren Gräber aus kleinen Grüften bestanden. ${ }^{34}$

Die Endphase dieser Entwicklungstendenzen wurde schließlich in der Zeit der späten Nomadeneinfälle (Petschenegen und Usen) in den Jahrzehnten nach der Mitte des 11. Jahrhunderts erreicht. ${ }^{35}$ In dieser Spätzeit seiner mittelalterlichen Geschichte hatte sich die sozial-topographische Struktur Pliskas in genau das Gegenteil dessen verwandelt, mit dem die Entwicklung einmal begonnen hatte.

\section{Bibliographie}

Aboba-Pliska 1905: Абоба-Плиска: Альбом (=Известия Русского археологического института в Константинополе 10), Варна 1905.

Aladžov 1992: Живко Аладжов, „Разкопки около южната порта и югозападната крьгла кула във Вътрешния град на Плиска“, in: Плиска-Преслав 5, Шумен 1992, S. 206-210.

Aladžov 1993: Живко Аладжов, „Некропол край църквата на Обект 40 (Комплекс “А”) във Външния град на Плиска“, in: Плиска-Преслав 6, Шумен 1993, S. 85-93.

Aladžov 1997: Живко Аладжов, „За облика и характера на комплексите от Външния град на Плиска“, in: Известия на исторически музей Шумен 9, 1997, S. 102-104.

32 Michajlova 1992, 169-184.

$33 \mathrm{Zu}$ den spätesten Besiedlungshinweisen aus dem Gebiet der sogenannten Zitadelle vgl. Stančev 1960, 62. Zwei Horizonte mit Grubenhäusern aus der ersten Hälfte des 11. Jahrhunderts sind während Grabungen durch R. Rašev und Ja. Dimitrov festgestellt worden (unpubliziert).

34 Dimitrov 1995; ders. 1998b, 69-80.

$35 \mathrm{Zu}$ den archäologischen Belegen für die zerstörerischen Einfälle sogenannten „später Nomaden“ und ihre Ansiedlung in und um Pliska vgl. Rašev 1992, 242-253; Dončeva-Petkova 1992, 144; dies. 1993, 260. 
Balabanov 1983: Тодор Балабанов, Занаятчийски производства в Плиска (VIII-XI в.), София 1983 (unpublizierte Dissertation).

Balabanov 1992: Тодор Балабанов, „Жилища покрай северната и източната крепостна стена в Плиска“, in: Плиска-Преслав 5, Шумен 1992, S. 146-167.

Dimitrov 1992: Янко Димитров, „Нови данни за археологическата карта на Плиска“, in: Приноси към българската археология 1, София 1992, S. 58-67.

Dimitrov 1995: Янко Димитров, „Църква и некропол във Външния град на Плиска (края на X-XI в.)“, in: Плиска-Преслав 7, Шумен 1995, S. 42-70.

Dimitrov 1998a: Янко Димитров, Историческа топография на Плиска, София 1998 (unpublizierte Dissertation).

Dimitrov 1998b: Янко Димитров, „Два некропола във Външния град на Плиска (края на X-XI в.)“, in: Трудове на катедрите по история и богословие в Шуменския университет 2, Шумен 1998, S. 69-80.

Dimitrov 1999: Янко Димитров, Историческа топография на Плиска, София 1999 (Zusammenfassung der Dissertation).

Dončeva-Petkova 1992: Людмила Дончева-Петкова, „Сгради при южния сектор на западната крепостна стена на Плиска“, in: Плиска-Преслав 6, Шумен 1992, S. 124-145.

Dončeva-Petkova 1993: Людмила Дончева-Петкова, „Глинени съдове от ХІ в. от Плиска“, in: Преслав 4, София 1993, S. 250-262.

Dončeva-Petkova 2000: Людмила Дончева-Петкова, “100 години археологически разкопки в Плиска", in: Плиска-Преслав 8, Шумен 2000, S. 9-13.

Dončeva-Petkova 1995: Людмила Дончева-Петкова, „Пещи за добиване на желязо край западната крепостна стена на Плиска“, in: Плиска-Преслав 7, Шумен 1995, S. 34-41.

Džingov 1992: Георги Джингов, „Археологически проучвания във Вътрешния град на Плиска“, in: Плиска-Преслав 5, Шумен 1992, S. 105-122.

Fehér 1940: Гезер Фехер, Ролята и културата на прабългарите. Значението на прабългарската и старомаджарската култура в изграждането на иивилизацията на Източна Европа, София 1940.

Georgiev 1987: Павел Георгиев, „Церковное строительство в Болгарии во второй половине IX века“, in: Tруды V-ого международного конгресса славянской археологии 3/2a, Москва 1987, S. 63-75.

Georgiev 1993: Павел Георгиев, „Разкопки в Голямата базилика през 1978-1979 г.“, in: Плиска-Преслав 6, Шумен 1993, S. 49-68.

Georgieva 1955: Соня Георгиева, „Разкопки на могили XXXIII и XXXII в Плиска“, in: Известия на Археологическия институт 20, 1955, S. 11-41.

Henning 2000: Joachim Henning, „Pliska - Machtzentrum zwischen Byzanz und Abendland: Neue Wege der Archäologie“, in: Forschung Frankfurt 2, 2000, S. 6-15.

Jordanov 1980: Иван Йорданов, „Монетная циркуляция средневековой Плиски“, in: IV Международный конгресс славянской археологии: Тезисы докладов болгарской делегачии, София 1980, S. 33-34.

Karasimeonoff 1943: Peter Karasimeonoff, „Neue Ausgrabungen in der Residenz von Pliska“, in: Известия на Българския археологически институт 14 (1940-42), 1943, S. 136-168.

Michajlov 1949: Стамен Михайлов, „Разкопки в Плиска през 1945-1947 г.“, in: Разкопки и проучвания 3, София 1949, S. 171-225.

Michajlov 1955: Стамен Михайлов, „Археологически материали от Плиска (1948-1951 г.)“, in: Известия на Археологическия институт 20, 1955, S. 49-181.

Michajlov 1963: Стамен Михайлов, „Разкопки в Плиска през 1959-1961 г.“, in: Известия на Археологическия институт 26, 1963, S. 5-46. 
Michajlova 1992: Тонка Михайлова, „Сгради и съоръжения на запад от Тронната палата в Плиска“, in: Плиска-Преслав 5, Шумен 1992, S. 169-184.

Mijatev 1943: Кръстю Миятев, „Крумовият дворец и други новооткрити постройки в Плиска“, Известия на Българския археологически институт 14 (1940-42), 1943, 71-135.

Milčev 1960: Атанас Милчев, „Археологически разкопки в местността Асардере в Плиска“, in: Годишник на Софийския университет: Историко-филологически факултет 53, 1960, S. 33-66.

Milčev 1964: Атанас Милчев, „Проучвания на раннославянската култура и на Плиска през последните двадесет години“, in: Археология 6, 1964, No. 3, S. 23-35.

Milčev 1969: Атанас Милчев, „Разкопки в Плиска западно от Вътрешния град: 1959 г.“, in: Археология 11/3, 1969, S. 30-43.

Petrova 1984: Павлина Петрова, „Археологическо проучване на архитектурни комплекси от IX-X в.“, in: Археология 25/1, 1984, S. 52-56.

Petrova 1988: Павлина Петрова, „Вътрешно землено укрепление в Плиска“, in: Археологически открития и разкопки за 1987 г., Благоевград 1988.

Petrova 1992: Павлина Петрова, „Към въпроса за историко-археологическата топография на Външния град на Плиска по данни на аерометода“, in: Плиска-Преслав 5, Шумен 1992 , S. 64-76.

Petrova/Aladžov 1986: Павлина Петрова/Живко Аладжов, „Археологически проучвания на Комплекс “А” (Обект 40) във Външния град на Плиска“, in: Годишник на музеите om Северна България 12, 1986, S. 37-48.

Rašev 1990: Рашо Рашев, „Към топографията на Плиска и Преслав“, in: Векове 5, 1990, S. 69-73.

Rašev 1992: Рашо Рашев, „Късни номади в Плисковското поле“, in: Преслав 3, София 1983, S. 242-253.

Rašev 1993: Рашо Рашев, „Най-старият строителен период в центьра на Плиска“, in: Известия на исторически музей Шумен 8, 1993, S. 252-262.

Rašev 1995: Рашо Рашев, „Плисковският аул“, in: Плиска-Преслав 7, Шумен 1995, S. 15-21.

Rašev/Dimitrov 1999: Рашо Рашев/Янко Димитров, Плиска: 100 години археологически разкопки, Шумен 1999.

Škorpil 1905: Карел Шкорпил, „Курганы““, in: Aboba-Pliska 1905, S. 326-332.

Stanilov/Dimitrov/Jankulov 1991: Станислав Станилов/Янко Димитров/Игор Янкулов, „Проучване на селището югоизточно от Вътрешния град на Плиска“, in: Проблеми на прабългарската история и култура 2, София 1991, S. 133-136.

Stančev 1960: Станчо Станчев, „Материали от Дворцовия център в Плиска“, in: Известия на Археологическия институт 23, 1960, S. 23-65.

Stančev 1961: Станчо Станчев, „За периодизацията на Плисковския дворцов център“, in: Изследвания в памет на Карел Шкорпил, София 1961, S. 101-109.

Vaklinov 1977: Станчо Ваклинов, Формиране на старобългарската култура VI-XI в., София 1977.

Vasilev 1987: Радослав Василев, „Ранносредновековни селища VIII-X в. в района на Плиска“, in: Втори международен конгрес по българистика, Доклади 6: Българските земи в древността: България през Средновековието, София 1987, S. 400-406. 



\title{
Eine Hauptstadt ohne Gräber? Pliska und das heidnische Bulgarenreich an der unteren Donau im Lichte der Grabfunde*
}

\author{
UwE FIEDLER
}

Die frühmittelalterlichen Grabfunde in Nordostbulgarien sind von vielen Autoren behandelt worden, namentlich von St. Vaklinov (bzw. Stančev; 1921-1978), ${ }^{1}$ D. I. Dimitrov $(1927-1988),{ }^{2}$ Ž . Văžarova (1916-1990) ${ }^{3}$ und zuletzt von mir in meiner 1992 publizierten Dissertation. ${ }^{4}$ In letzterer habe ich einen Kriterienkatalog zur Unterscheidung der slawischen von den protobulgarischen Friedhöfen der heidnischen Zeit aufgestellt, der auf den Arbeiten der genannten Autoren fußt, jedoch einige Modifikationen und Ergänzungen enthält. Hier seien die Kriterien nochmals kurz wiederholt:

Slawische Gräberfelder des fortgeschrittenen 7. bis späten 9. Jahrhunderts sind Brandgräberfelder mit der Beisetzung des Leichenbrands in Keramikgefäßen (Urnen). Urnenlose Bestattungen machen in der Regel nur einen geringen Prozentsatz aus. Nur gelegentlich sind Kinder auch unverbrannt bestattet worden. ${ }^{5}$ Die Beigaben/ Trachtbestandteile sind spärlich und oft durch das Scheiterhaufenfeuer deformiert (Abb. 1 mit einem der reichsten Inventare). Unter dem menschlichen Leichenbrand

* Aktualisierte Fassung des am 17.11.1999 auf der Ebernburg, Bad Münster am Stein, im Rahmen des Kolloquiums „Zwischen Byzanz und Abendland. Pliska, der östliche Balkanraum und Europa im Spiegel der Frühmittelarchäologie“ gehaltenen Vortrages.

1 Stančev/Ivanov 1958.

2 Zahlreiche Aufsätze zu seinen Gräberfeldgrabungen mündeten in seine unpublizierte Dissertation ein (Dimitrov, D. I. 1975). Hervorgehoben werden sollen hier: ders. 1974; ders. 1977.

3 Văžarova 1976.

4 Fiedler 1992. - Rezensionen: Sâmpetru 1993; Diaconu 1994; ders. 1996 (französische Fassung); Dimitrov, Ch. 1994; Sarnovski 1994; Sedov 1995; Stanilov/Aladžov 1994; Cândea 1995, 36-59; Pohl 1995; Harhoiu 1997; Angelova 1997a; dies. 1998 (deutsche Fassung); Bóna 1999. - Danach sind noch weitere zusammenfassende Abhandlungen zu dieser Thematik erschienen: Melamed 1995; Madgearu 1997, 120-130; 152-160; Daskalov 1997-1999; Luca/Măndescu 2001. Sie blieben jedoch oberflächlich oder bedienten sich einer fragwürdigen Methodik und konnten so den Erkenntnisstand nicht weiter vertiefen.

5 Wolska 1999, bes. 337, 342, 345. 


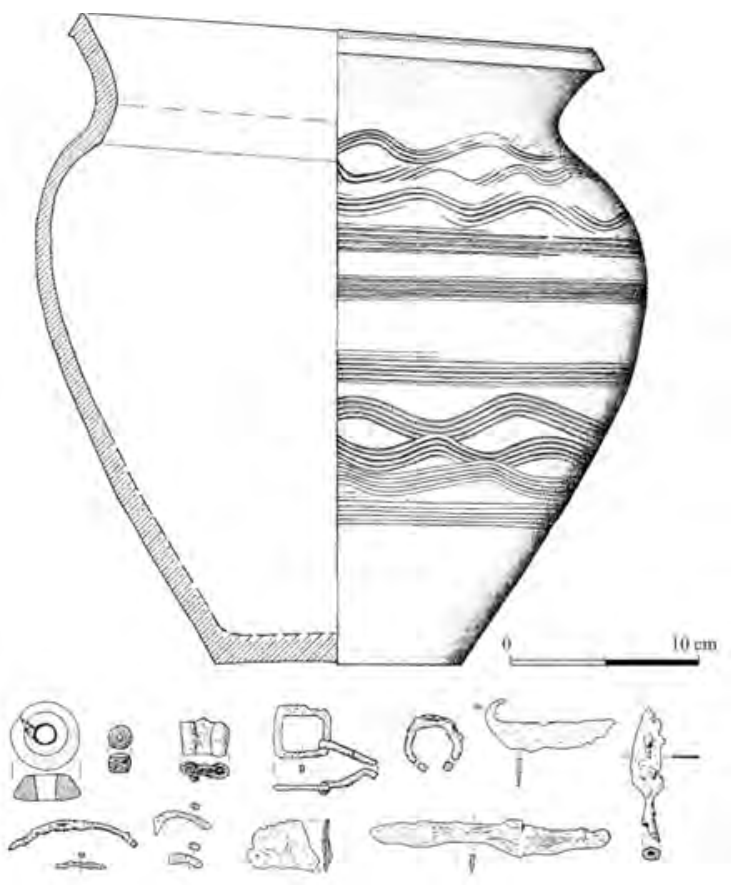

Abb. 1. Razdelna (Region Varna), Grab 170. Inventar eines slawischen Urnengrabes (Doppelgrab?) aus der zweiten Hälfte des 8. Jahrhunderts

sind verschiedentlich auch Tierknochen festgestellt worden, die in der Regel kalziniert sind. ${ }^{6}$ Die Tiere oder Fleischstücke sind also mit dem Toten zusammen verbrannt worden. Im Zentrum des slawischen Bestattungsrituals stand die Verbrennung an sich, die wohl für den Übertritt des Toten in eine andere Welt stand. Die Beisetzung des Leichenbrands war augenscheinlich nur von sekundärer Bedeutung. So sind auch Keramikgefäße neben den Urnen und andere Beigaben selten anzutreffen.

Die Friedhöfe der Protobulgaren sind birituell, d.h. die Protobulgaren haben sowohl die Brand- wie auch die Körperbestattung praktiziert. Bei der Brandbestattung gibt es deutliche Abweichungen von den slawischen Urnengräbern. Die Protobulgaren haben den Leichenbrand ihrer Toten nur in Ausnahmefällen in größeren Urnen beigesetzt. Verschiedentlich nahmen kleine Töpfe einen Teil der Asche auf, zumeist wurde sie aber in Beuteln deponiert oder einfach in der Erde bestattet. Dem Toten gab man kleine Töpfe, Kannen und etwas später auch amphorenartigen Krüge als Beigabe mit. Sie dürften Speise und Trank für den Toten enthalten haben. Auch Tierknochen oder ganze

6 Wolska 1999, auch neu publizierte abweichende Befunde ändern nicht den Eindruck der Regelhaftigkeit: bes. 334-335. 
Tiere treten relativ häufig auf. Die Knochen sind in der Regel nicht kalziniert, ${ }^{7}$ d.h. die Fleischbeigaben erfolgten erst bei der Grablege. Dieser Akt war anscheinend von größerer Bedeutung als die Totenverbrennung, auf jeden Fall haben die Protobulgaren mehr Wert auf diesen gelegt als die Slawen.

Die protobulgarischen Körpergräber weisen die gleichen Merkmale wie die Brandgräber auf. Während Trachtgegenstände und Waffenbeigaben sehr selten sind, weisen sie vielfach die gleichen Keramikgefäße und Fleischbeigaben sowie ganze Tiere auf. In Nordostbulgarien lassen sich die Körpergräber aus heidnischer Zeit leicht identifizieren. Sie sind nordsüdlich ausgerichtet (Abb. 2). Nördlich der Donau sind sie allerdings wie in christlicher Zeit westöstlich orientiert.

Die Grabausrichtung ist von entscheidender Bedeutung für die Ansprache der nordostbulgarischen Grabfunde. Nach der Christianisierung glichen Slawen und Protobulgaren ihren Bestattungsbrauch an. Fortan wurde nur noch die Körperbestattung mit dem Kopf im Westen praktiziert. Einige heidnische Friedhöfe sind trotz des Glaubenswechsels weiter belegt worden. Wenn neben heidnischen Urnengräbern christliche Körpergräber gefunden worden sind, so sollte man dennoch nicht von einem birituellen Friedhof reden, wie dies Văžarova getan hat. Es handelt sich dabei nur um zwei Zeitschichten mit unterschiedlichem Bestattungsbrauch, der für die ganze Gemeinschaft verbindlich war. Für die protobulgarischen Friedhöfe ist bezeichnend, dass beide Bestattungsarten gleichzeitig praktiziert wurden, wobei völlig unklar bleibt, welche Kriterien ausschlaggebend für die Wahl der Bestattungsart waren. ${ }^{8}$

Slawen und Protobulgaren haben in der Regel ihre Toten auf getrennten Friedhöfen bestattet und wahrscheinlich auch in getrennten Siedlungsgemeinschaften gewohnt. Es gibt allerdings eine Reihe von mehr oder weniger gesicherten Ausnahmefällen (Istria-

7 Durch neue Untersuchungen des Leichenbrandes von Topola wird diese Beobachtung allerdings in Frage gestellt. Kalzinierte Tierknochen konnten hier sowohl L. Ninov (Sofia) (Angelova/ Dončeva-Petkova/Daskalov 1997, 145) wie auch B. Heußner (Berlin; laut Vorstellung ihrer Untersuchungsergebnisse durch J. Henning im Anschluss an meinen Vortrag) feststellen. Leider liegen mir keine Informationen dazu vor, ob die betreffenden Gräber zu den in Topola recht zahlreichen Urnengräbern gehören. Beide Ausgräberinnen rechnen mit der Anwesenheit von Slawen in Topola, so dass hier ein sowohl von Slawen als auch von Protobulgaren belegter Friedhof vorliegen könnte. Anderenfalls wären auch auf den Scheiterhaufen der Protobulgaren Tiere bzw. Fleischbeigaben verbrannt worden. Sie unterscheiden sich dann aber immer noch durch die bei der Grablege erfolgte Fleischbeigabe von den slawischen Brandgräbern.

8 Ein voreiliger Schluss ist sicherlich, daraus gleich auf ethnisch unterschiedliche Gruppen innerhalb des protobulgarischen Stammesverbandes zu schließen, wie dies K. Melamed getan hat (Melamed 1995, 35). Sie schreibt unter Verweis auf die byzantinischen Chronisten auch das Urnengräberfeld von Razdelna den Protobulgaren zu. Damit bedeutet dieser Aufsatz eindeutig einen Rückschritt gegenüber den Arbeiten der obengenannten Autoren und meiner Dissertation, die von der Autorin nachträglich in die Fußnoten aufgenommen wurde. 


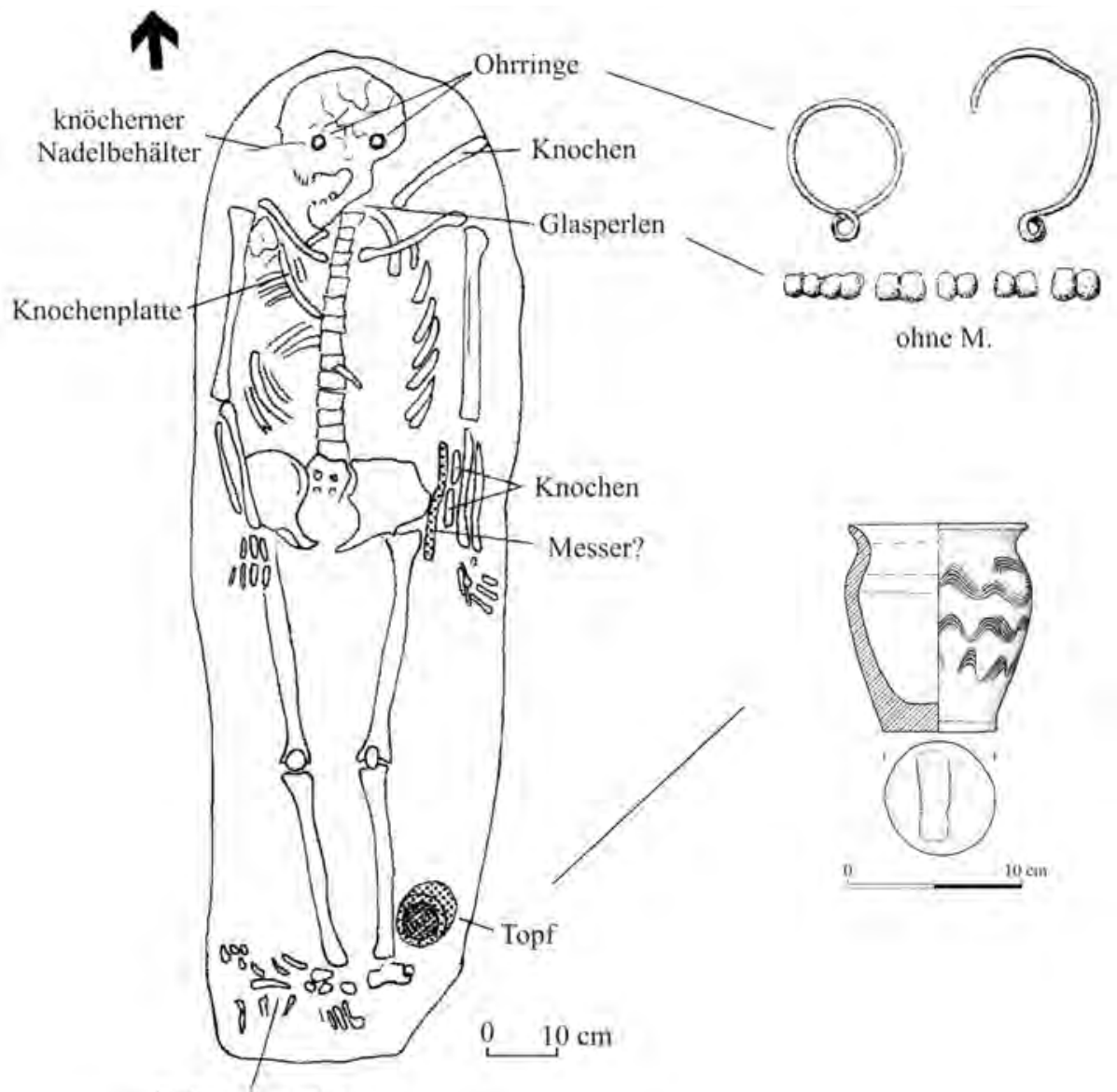

Geflügelknochen

Abb. 2. Kjulevča (Region Šumen), Grab 70. Protobulgarisches Mädchengrab des späten 8. Jahrhunderts

Capul Viilor, Sultana, Topola sowie - nach der Publikation - auch Chitovo-2 und -3), ${ }^{9}$ wo Slawen und Protobulgaren zusammen gelebt und gemeinsam bestattet haben.

Wenig beachtet worden ist von der Forschung, dass meine revidierte ethnische Unterscheidung der frühmittelalterlichen Grabfunde an der unteren Donau eine Absicherung durch die unterschiedliche räumliche Verteilung der beiden Friedhofstypen gefunden hat. Diese sollen hiermit noch auf den aktuellen Stand gebracht werden.

9 Jotov 1997; vgl. Jotov/Botov 1991, 18 Nr. 3, Taf. 3; Fiedler 1992, 516, Taf. 117,1. 
Gleichzeitig oder kurz nach Erscheinen meiner Dissertation sind zwei kleinere Fundvorlagen erschienen. Einerseits veröffentlichten M. und Ch. Mănucu-Adameşteanu die von mir bereits berücksichtigten Streufunde von 6-Martie, jetzt Sălcioara (jud. Tulcea). ${ }^{10}$ Zum anderen erfolgte durch V. Jotov und K. Botov die Vorlage einer Reihe von Gefäßen aus den Museen Dobrič, Balčik und Šabla, die Streufunden darstellen oder aus einzelnen beobachteten Bestattungen stammen. Auch hier ist eine Reihe von Funden bereits von L. Bobčeva oder mir publiziert worden, vier Fundorte von Gräbern oder mutmaßlichen Grabstellen sind aber durch diesen Aufsatz hinzugetreten. ${ }^{11}$ Fünf Kannen aus dem Museum Šumen, die jüngst von Ch. Stojanova vorgestellt worden sind, können die Fundstellenanzahl nicht erweitern. ${ }^{12}$ Vier oder fünf mutmaßliche Urnengräber, die bereits 1979 in einer spätantiken Grabkammer im Stadtteil Bela voda von Pernik, $33 \mathrm{~km}$ westsüdwestlich vom Zentrum Sofias, geborgen worden waren, wurden erst

10 Mănucu-Adameşteanu 1996, 105, 111 Abb. 4 (vgl. Fiedler 1992, 452, Taf. 41,6-7). Nachzutragen sind zwei Ausstellungskataloge. Der eine enthält erstmals Fotos der Urnen des Gräber 83 von Sihleanu und 16 von Tichileşti (beide jud. Brăila): Exposiţia 1995/1996, 168 Nr. 749 und 751, Taf. 33 (die Nr. 750 und 752 sind entgegen den Angaben des Kataloges bei Fiedler 1992, Taf. 6,6, Taf. 8,4 abgebildet). Im anderen findet sich eine qualitätvolle Farbabbildung der Kanne aus Şaring a (Fiedler 1992, Taf. 41,5) unter Angabe des Nachbarortes Pietroasele: Mamalaucă 2000, 40 Nr. 56.

11 Zumindest teilweise bekannt waren: Balčik (2 Gefäße): Jotov/Botov 1991, 21 Nr. 8, Taf. 4,7-9; von L. Bobčeva bereits 1982 publiziert; vgl. Fiedler 1992, 118 Nr. 36. - Chitovo-1 (Streufunde vom Gräberfeldareal): Jotov/Botov 1991, 18 Nr. 3, Taf. 3; vgl. Fiedler 1992, 516, Taf. 117,1. - Dobrič (ehem. Tolbuchin; Körpergrab): Jotov/Botov 1991, 18 Nr. 1, Taf. 2,2; vgl. Fiedler 1992, 516, Taf. 116,3. - Krasen (Kanne): Jotov/Botov 1991, 21 Nr. 11, Taf. 5,5; schon 1972 durch L. Bobčeva vorgelegt; vgl. Fiedler 1992, 119 Nr. 69. - Rosenovo (7 Körper- und 2 Brandgrubengräber sowie 2 Einzelfunde): Jotov/ Botov 1991, 18 Nr. 2, Taf. 2,5-6; vgl. Fiedler 1992, 516, Taf. 116,4. - Šabla (2 Gefäße): Jotov/Botov 1991, 21 Nr. 9, Taf. 4,9; von L. Bobčeva bereits 1982 publiziert; vgl. Fiedler 1992, 120 Nr. 4a. - Neu zu verzeichnen sind: Bălgarevo (Kanne): Jotov/Botov 1991, 21 Nr. 12, Taf. 5,6. - Dobrič (kleiner Topf bei dessen Fundort kurz vor Erscheinen der Publikation ein heidnisches Körpergrab entdeckt wurde): ebd., 21 Nr. 6, Taf. 4,4. Ljuljakovo (Streufunde eines mutmaßlich birituellen Gräberfeldes: ebd., 21 Nr. 5, Taf. 4,1-3. - Lozenec (Kanne; Grabfund?): ebd., 21 Nr. 7, Taf. 4,5-6.

12 Stojanova 1997. Sie stellt zwei Kannen aus Cărkvica vor, wovon mir eine andere Kanne im Museum Šumen bekannt war (Fiedler 1992, Taf. 116,1). In Vărbjane ist nach dem Kannenfund von R. Rašev gegraben worden (Rašev 1995a). Die Kanne von Riš kann schließlich nicht als Grabfund gewertet werden. 
2004 publiziert. ${ }^{13}$ Umfängliches Gräberfeldmaterial ist nach meiner Dissertation aber nicht mehr vorgelegt worden. ${ }^{14}$ Hervorheben möchte ich aber eine kürzlich erschienene teilweise Veröffentlichung der Ergebnisse der anthropologischen Bearbeitung von vier Urnengräberfeldern in Südostrumänien (Sihleanu, Tichileşti, Chiscani und Canlia), die eine Reihe von zusätzlichen Erkenntnissen zum slawischen Bestattungsritual bietet. ${ }^{15}$ Auf bulgarischer Seite sind weitere anthropologische Untersuchungen zu birituellen Gräberfeldern erschienen. ${ }^{16}$

Mit Ausnahme von Kozloduj sind keine neueren Befunde oder Fundstoff bildlich publiziert worden. Zusätzliche Informationen lassen sich aber Kurzberichten entnehmen. Sehr nützlich ist hier ein 1995 erschienenes Fundortkataster des frühmittelalterlichen Nordostbulgariens, also des Kernraums des Ersten Bulgarenreichs. ${ }^{17}$ Weiter ermöglichen die in kleiner Auflage erschienenen Druckfassungen der Jahreskonferenzen einen Überblick über die neueren Grabungsaktivitäten in Bulgarien, eine dreijährige Lücke gibt es hier allerdings von 1996 bis $1998 .{ }^{18}$ Solche Berichtsbände über die aktuellen Ausgrabungen gibt es auch für Rumänien. ${ }^{19}$ Jüngst ist überdies eine Studie zu den Bestattungssitten der frühmittelalterlichen Grabfunde südlich und östlich der Karpaten mit einem ausführlichen Katalogteil aus der Feder zweier junger Forscher erschienen. ${ }^{20}$ Zudem konnten zwei Hinweise bezüglich der Ukraine verwertet werden. Alle Informationen zusammen haben die hier wiedergegebenen revidierten Kartierungen ermöglicht (Abb. 3-4). ${ }^{21}$

13 Dončeva-Petkova/Ljubenova 2004. Da der Leichenbrand zu einem Kalziumphosphat abgebaut worden sein soll, ließ sich die Ansprache der Gefäße als Urnen nicht mehr verifizieren. Bei der vielfältigen, zur Datierung herangezogenen Literatur ist unverkennbar, dass die Autorinnen meine Dissertation bewusst nicht zitiert haben. Hier sei deshalb die Zuweisung nach meiner Typengliederung nachgeholt. Die ganzen Gefäße gehören zu meinen Typen B V (Nr. 1-2), B I/3 (Nr. 3) und B VII/2 (Nr. 4). Entgegen der Datierung der Autorinnnen in das 7. Jahrhundert, gehören die Gefäße damit wahrscheinlich erst in die zweite Hälfte des 8. oder die erste Hälfte des 9. Jahrhunderts.

14 Erwähnt werden kann hier die Neubearbeitung der Keramik aus B a bo vo: Koleva/Daskalov 1993. Auch die Keramik aus der Umgebung von Varna wird anscheinend weiter analysiert: Aladžov, A. 2002.

15 Wolska 1999, bes. 337, 342, 345 .

16 Jordanov/Dimitrova 1997; Čolakov 1998.

17 Rašev 1995a.

18 Археологически открития и разкопки. Национална археологическа конференция.

19 Cronica cercetărilor arheologice din România (Bukarest). Der Band Campania 2002 (2003) war mir nicht zugänglich.

20 Luca/Măndescu 2001, 79-88.

21 Als neuer gesicherter biritueller Friedhof ist nur bekannt geworden: Vărbjane (obšt. Kaspičan, obl. Varna): Stojanova 1997, 331-332, 336 Abb. 1,3; Rašev 1995a, 195 Nr. 257; Археологически открития и разкопки 1995, 91-92; Rašev 1997. - Als unsichere birituelle Friedhöfe wurden nachgetragen: In Rumänien: 


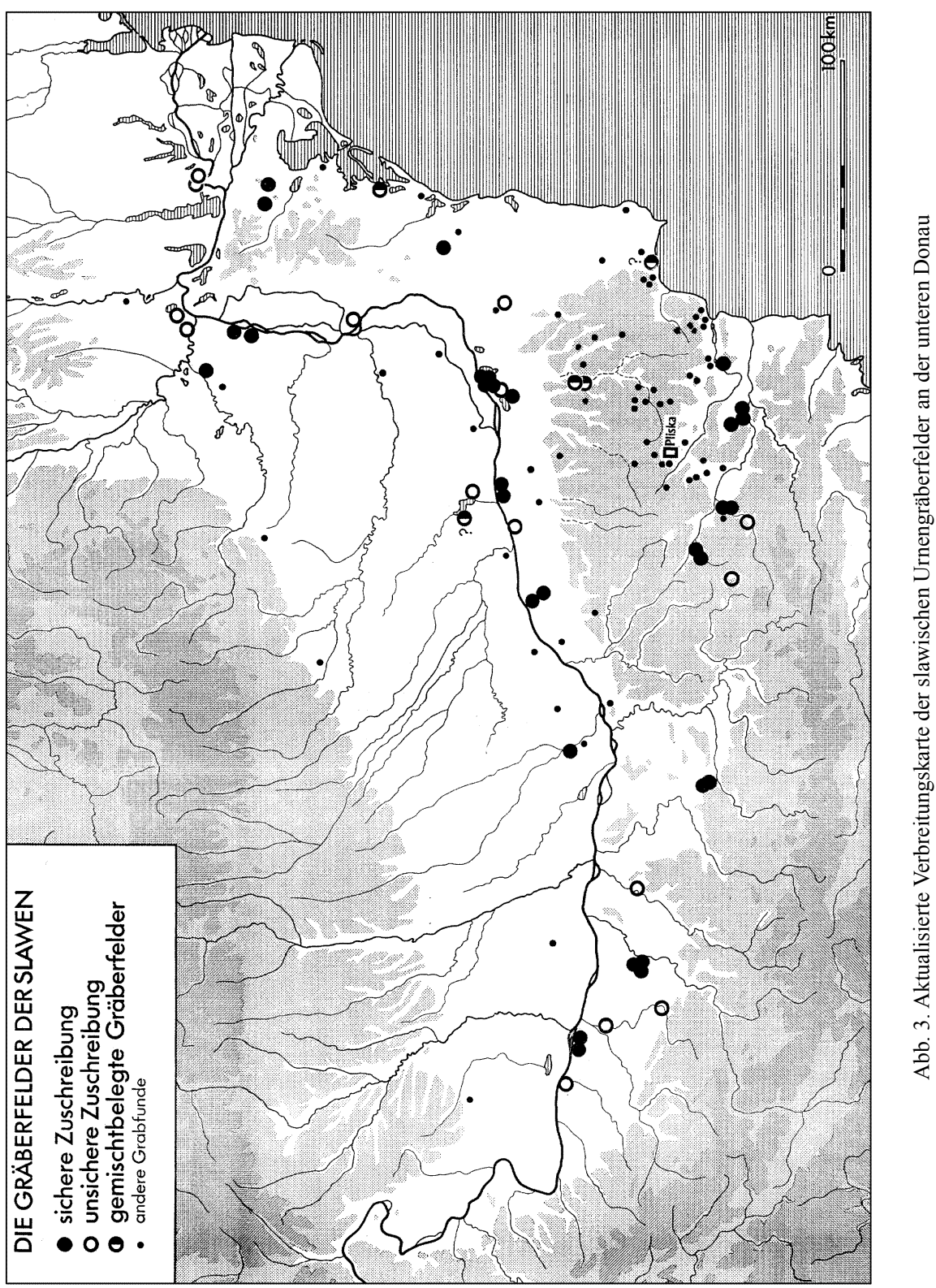




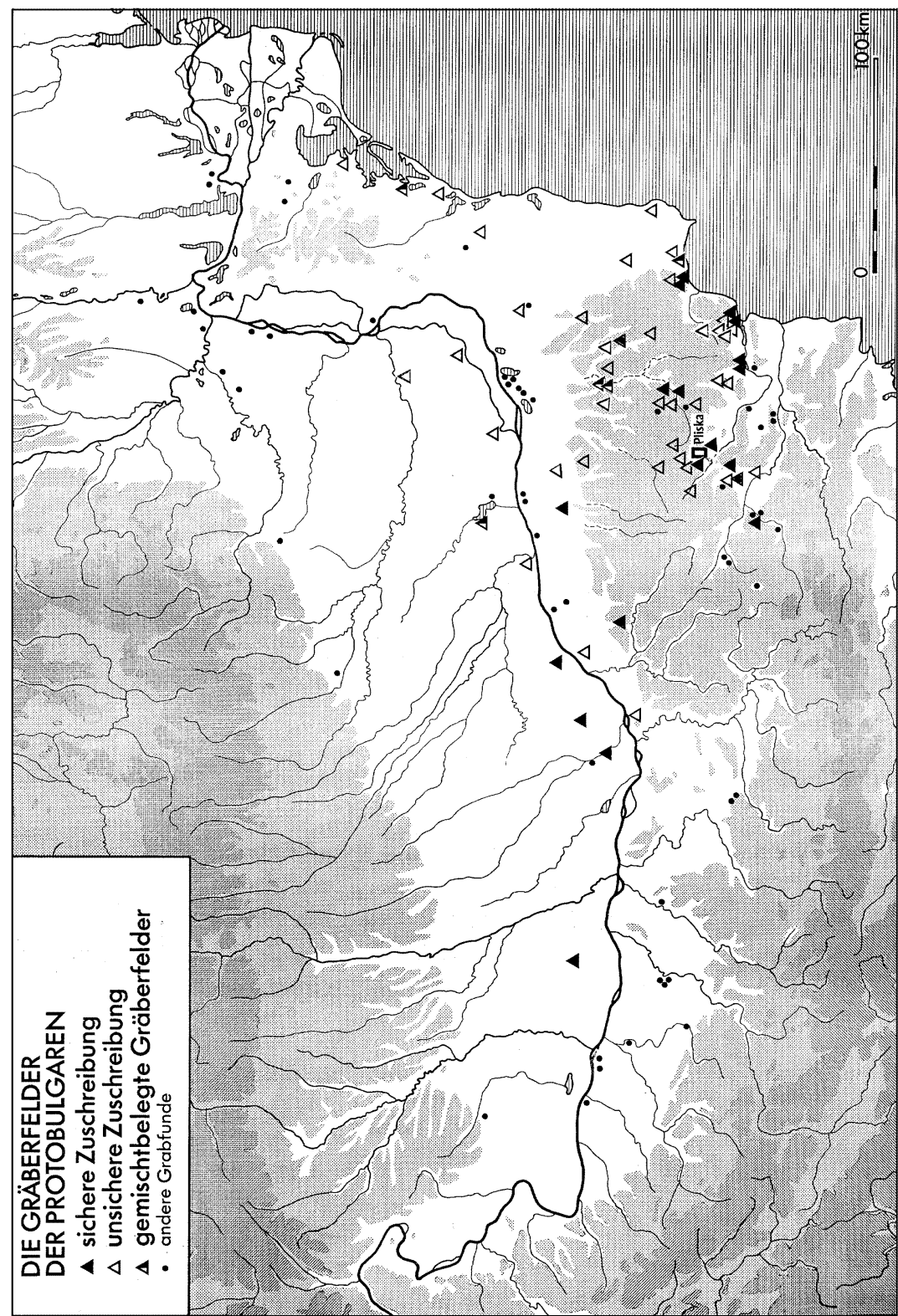

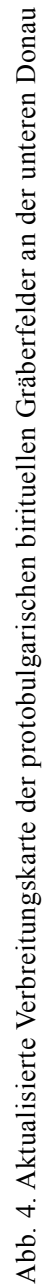


Bevor ich näher auf diese eingehe, möchte ich aber noch einige Bemerkungen zum Stand der frühmittelalterlichen Gräberforschung beiderseits der unteren Donau machen. Es fällt auf, dass sowohl in Bulgarien als auch in Rumänien offenbar kein Interesse an der Untersuchung von slawischen Urnengräberfeldern besteht. Auch die Publikation der Altgrabungen in Rumänien (Satu Nou-1 und -2, Păuleasca, Sihleanu, Tichileşti) hat sich anscheinend niemand zum Ziel gesetzt. Die meisten Urnengräberfelder sind vor 30 oder mehr Jahren untersucht worden. Im Süden Rumäniens ist seit 1971 (Tichileşti) kein Urnengräberfeld mehr gegraben worden. Die erst jüngst bekannt gewordene Bergung von ca. 15 Urnengräbern aus Hagieni (com. Mihail Kogălniceanu, jud. Ialomiţa) vermag diesen Eindruck nicht wesentlich zu mindern. In Bulgarien sind an neueren

Platoneşti (com. Săveni; jud. Ialomița): Harhoiu 1997, 499; Luca/Măndescu 2001, 85; Cronica cercetărilor arheologice din România 1999 (2000), 75-76; 2000 (2001), 168; 2001 (2002), 238-239. - In Bulgarien: Aksakovo (obšt. Aksakovo; obl. Varna): Rašev 1995a, 159 Nr. 6 (in der Originalpublikation allerdings Siedlung! nach der Keramik sicher kein Urnengräberfeld); Bradvari (obšt. Silistra; obl. Ruse): Rašev 1995a, 169 Nr. 89; Jarebična (obšt. Aksakovo, obl. Varna): Rašev 1995a, 296 Nr. 1176; Lozenec (obšt. Krušari, obl. Varna): Jotov/Botov 1991, 21 Taf. 4,5; Rašev 1995a, 227 Nr. 567 (nur Kanne); Novakovo (obšt. Aksakovo, obl. Varna): Rašev 1995a, 236 Nr. 653; Tervel (obšt. Tervel, obl. Varna): Jotov/Botov 1991, 21 Taf. 5,3-4; Rašev 1995a, 283 Nr. 1043 (nur Kanne). - Zwei neue gesicherte Urnengräberfelder des 8.-9. Jahrhunderts sind aus Kozloduj bekannt geworden: St. Angelova, in: Археологически открития и разкопки 1985 (1986), 184; Angelova/Koleva 1992; Angelova 1997b, Nr. 2-4, Taf. 7 (Die frühslawischen Gräber wurden im Zentrum, die späteren Brandgräber in den Fluren "Krušov Bair" und 3 km [nord]westlich der Stadt im Weinberg des Spasenko Vladimir gefunden. Den Berg nennt man Kalifera). - Als neue, nicht gesicherte Urnengräberfelder sind bekannt geworden: Hagieni (com. Mihail Kogălniceanu, jud. Ialomița): Luca/Măndescu 2001, 83 Nr. 17; Saf'jany/Sofian (Kr. Izmaila/Ismail; obl. Odessa; Ukraine): bei landwirtschaftlichen Arbeiten 1992 gemachte Urnenfunde laut brieflicher Mitteilung von V.I. Kozlov vom 25.5.1996, der die Fundstelle 1993 rekognosziert hat; Izmaila/Ismail (obl. Odessa; Ukraine): gesicherte Urnenfunde laut mündlicher Mitteilung von demselben während der Tagung auf der Ebernburg. - Omurtag (obšt. Omurtag, obl. Ruse): Rašev 1995a, 241 Nr. 703. - $\mathrm{Zu}$ den birituellen Gräberfeldern mit Urnengräbern müssen nunmehr nicht nur Istria-Capul Viilor und Sultana, sondern auch Topola (?) sowie Chitovo2 und -3 (Angelova/Dončeva-Petkova/Daskalov 1997; Jotov 1997) gerechnet werden. - Nicht aufgenommen wurden: Ilija R. Blăskov (Rašev 1995a, 213 Nr. 413), da es sich um einen christlichen Friedhof handeln könnte, Ljuljakovo (Jotov/Botov 1991, 21 Taf. 4,1-3; Rašev 1995a, 228 Nr. 577), da er vielleicht identisch mit den von Văžarova unter Velikovo genannten Streufunden ist (zumal letzterer Fundort bei Rašev 1995a nicht erscheint), das zweite, östlich der Stadt gelegene Gräberfeld von Novi Pazar (Balabanov 2003, 90 Nr. 24), da die beiden Körpergräber westöstlich ausgerichtet waren, und - trotz der NordsüdGräber - Zaičino oreše (ebd., 92 Nr. 47), da datierende Funde fehlen. - Der unter Černa in die Literatur eingegangene Friedhof gehört zum Dorf Kragulevo (vgl. Rašev 1995a, 221 Nr. 498 mit Anm. 1). Selce habe ich in meiner Dissertation fälschlich als Selče und 6 Martie fälschlich als 6 Marție publiziert. Letzteres trägt jetzt wieder den Namen Sălcioara. 
Untersuchungen nur die 1985-1986 sondierten frühslawischen Gräber und die beiden Gräberfeldreste des 8.-9. Jahrhunderts in Kozloduj sowie die bei landwirtschaftlichen Arbeiten beobachteten Gräber von Omurtag (ohne Jahresangabe) zu verzeichnen. Dabei wären neue, gut dokumentierte Befunde von Urnengräbern zur weiteren Beleuchtung des slawischen Bestattungsbrauches notwendig.

Die aktualisierte Karte der slawischen Gräberfelder (Abb. 3) ist somit nur um sechs Punkte bereichert worden (2x Kozloduj, Omurtag, Hagieni, Saf'jany/Sofian und Izmaila/Ismail). Die fraglichen Urnenfunde von Pernik-Bela voda am südwestlichen Rand des Kartenausschnitts konnten nicht mehr berücksichtigt werden. Die Häufungen der slawischen Gräberfelder in den Randzonen des Bulgarenreiches wird mit diesen aber noch deutlicher.

Fehlende Finanzmittel können nicht die einzige Ursache für dieForschungsabstinenz bezüglich der slawischen Urnengräberfelder sein, denn Grabungen an birituellen, sprich protobulgarischen Gräberfeldern sind in Nordostbulgarien weitergelaufen. Neu hinzugekommen ist ein kleiner 1995 untersuchter Friedhof bei Vărbjane unmittelbar neben Pliska. In Dibič, nunmehr Debič geschrieben (obšt. Šumen), wo bislang nur drei Körpergräber beim Kanalbau angeschnitten worden waren, haben systematische Ausgrabungen 41 Bestattungen erfasst. ${ }^{22}$ Auch an bekannten Friedhöfen sind die Ausgrabungen weitergegangen, so hat man in Balčik-3 51 neue Gräber, ${ }^{23}$ in Topola bis einschließlich 1994 gar 105 neue Gräber aufgedeckt (die Ausgrabungen sind hier in den Folgejahren fortgesetzt worden). ${ }^{24}$ In Rumänien ist nur eine Untersuchung eines birituellen Friedhofs zu verzeichnen, nämlich Platoneşti, wo seit 1990 insgesamt 627 Gräber (davon 98 Körpergräber) aufgedeckt wurden. ${ }^{24 a}$ Es handelt sich damit um das größte Gräberfeld des Arbeitsgebiets. Die Anzahl der mutmaßlichen birituellen Gräberfelder ist auch dadurch angestiegen, dass die oben genannten beiden neueren Materialpublikationen ${ }^{25}$ fast ausnahmslos Funde aus birituellen Friedhöfen betreffen.

Die meisten der acht neu hinzugekommenen Fundpunkte (Aksakovo, Bradvari, Jarebična, Lozenec, Novakovo, Platoneşti, Tervel, Vărbjane) betreffen nur Streufunde, die mutmaßlich von birituellen Gräberfeldern stammen, wenngleich auch manchmal Menschenknochen bemerkt worden sind. Sie liegen aber ausnahmslos in den bisher bekannten Verbreitungsschwerpunkten der birituellen Gräberfelder (Abb. 4). Drei Friedhöfe, die aufgrund von Streufunden in meiner Dissertation noch als ungesichert galten, können jetzt als gesichert angesehen werden, nämlich der erwähnte von

22 Археологически открития и разкопки 1992/93 (1994), 121 (und 124); ebd., 1994 (1995), 133-134; Čolakov 1998.

23 Археологически открития и разкопки 1994 (1995), 136; ebd., 1995 (1996), 92-93.

24 Археологически открития и разкопки 1992/93 (1994), 120 f.; ebd., 1994 (1995), 134-135; Angelova/Dončeva-Petkova/Daskalov 1997.

24a Auskunft des Anthropologen N. Sultana durch freundliche Vermittlung von M. Constantinescu.

25 Jotov/Botov 1991; Mănucu-Adameşteanu 1996. 
Dibič/Debič sowie die von Rosenovo und Šumen-Divdjadovo, wo 2004 ein Körpergrab mit einer Gürtelgarnitur vom Typ Vrap-Velino geborgen worden ist ${ }^{26}$.

Dafür habe ich zwei, 1992 noch vermeintlich sichere protobulgarische Gräber streichen müssen. Einmal handelt es sich um das Grab 5 im Hügel III von Madara. Wie ich 1996 in einem Tagungsbeitrag erläutert habe, ist das Grab vor der protobulgarischen Landnahme einzuordnen, nämlich in die Zeit um 600 oder das erste Drittel des 7. Jahrhunderts, und ist einem Oguren zuzuweisen. ${ }^{27}$

Ebenfalls musste Pliska-7, der Friedhof hinter der Großen Basilika, gestrichen werden. Schon in meiner Dissertation hatte ich die Vermutung geäußert, dass die beiden von Văžarova ausgegrabenen „Brandgräber“ (25 u. 26) missinterpretierte Siedlungsreste gewesen sein könnten. ${ }^{28} \mathrm{Zu}$ einem solchen Schluss ist auch P. Georgiev bei seiner neuen Analyse der Grabfunde gekommen. Ihm zufolge erwecken diese Ziegelkonstruktionen am Ostrand des Friedhofs vielmehr den Eindruck von Grubenhausöfen. ${ }^{29}$ Den von Văžarova und anderen Autoren postulierten heidnischen Charakter des reich ausgestatteten Grabes im Sarkophag 4 verwirft er ebenfalls, so dass dieser kleine Friedhof der protobulgarischen Aristokratie erst in die Zeit nach der Christianisierung gehört und nicht in eine Kartierung der heidnischen Grabfunde.

Die aktualisierte Kartierung (Abb. 4) ergibt nach wie vor eine protobulgarische Siedlungskonzentration zwischen der Schwarzmeerküste von Balčik bis Varna und der Gegend um Šumen bzw. vom Nordrand des Plateaus von Ludogorie (Ludogorsko plateau) im Norden und dem Plateau von Provadija (Provadijsko plateau) sowie den Varnaer Seen im Süden. Pliska liegt im westlichen Zentrum dieses Gebietes. Der erste publizierte und immer noch bekannteste protobulgarische Friedhof, Novi Pazar wurde nur ca. 5 km westlich der Umwallung Pliskas ausgegraben. Kjulevča liegt keine $10 \mathrm{~km}$ südlich von Pliska. Die Grabfunde von Pravenci, Vojvoda und Cărkvica sind 2-5 km vom Nordende der Umwallung Pliskas entfernt, nur $1 \mathrm{~km}$ westlich davon befindet sich der neugegrabene Friedhof von Vărbjane. Pliska wird also von heidnischen Grabfunden fast umringt, bleibt selbst jedoch ausgenommen.

Da in Pliska (Abb. 5) der Khan mit seinem Gefolge residiert hatte, stellt sich insbesondere die Frage nach den Grabstellen der heidnischen Oberschicht und der Khane selbst. Georgiev macht darauf aufmerksam, dass in der Großen Basilika auch drei heidnische Grabinschriften verbaut worden seien und für den christlichen Sarkophag 3 hinter der Basilika eine Abdeckung mit heidnischer Gedenkinschrift für einen Würdenträger (namens Oturdacis/Oturdač) aus der Zeit Omurtags verwendet worden sei. Alle könnten

26 Briefliche Mitteilung von Stanislav Stanilov (Sofia). Dies konnte nicht mehr in Abb. 4 berücksichtigt werden.

27 Fiedler 1997. - Die neue Datierung ist allerdings bei den bulgarischen Kollegen auf Skepsis gestoßen: vgl. Dimitrov, Ja. 1998a, 104; Stanilov 2005, 32-69 bes. 35-36.

28 Fiedler 1992, 313.

29 Georgiev 1993, 65-75, bes. 66-67. 
von dem heidnischen Friedhof Pliskas stammen. ${ }^{30}$ Diese Gedenk- oder Ehreninschriften müssen aber nicht am Grabe der Geehrten gestanden haben, selbst dann nicht, wenn diese innerhalb der Wälle von Pliska verstorben sind. Wahrscheinlich standen sie wie die Triumphinschriften an einem Platz, wo sie von vielen gesehen werden konnten und dem Ruhme der Khane dienlich waren, also nahe dem Palast.

Die von mir geäußerte Vermutung, dass die drei Hügel vor der inneren Stadt (sowie die beiden Hügel im Aul des Omurtag bei Čatalar) Bestandteile des Grabkultes der protobulgarischen Khane gewesen sein könnten ${ }^{31}$ ist nicht weiter bestätigt worden. Die neuere Grabungen des Hügels XXXIV ergaben nur angeschüttetes Siedlungsmaterial, ${ }^{32}$ so dass doch eher an einen fortifikatorischen Zweck dieser Hügel zu denken ist, zumal sich diese Hügel hinter bzw. an den inneren Ecken von Befestigungslinien befanden. ${ }^{33}$

Neueste Forschungen haben sich mit gleicher Zielrichtung den prähistorischen Grabhügeln westlich des äußeren Walles zugewendet. Die Grabungen seit 1997 haben darin tief eingegrabene frühmittelalterliche Schächte mit Tieropfern nachgewiesen. Sie werden mit dem Totenkult der protobulgarischen Elite, insbesondere der Khane selbst, verbunden ${ }^{34}$ Einen Verstorbenen hat man darin noch nicht nachweisen können. Auch wenn man der Interpretation der Ausgräber folgte, ist damit die Grableere innerhalb des Umfassungswalles von Pliska nicht beseitigt.

Nach der Christianisierung hat man in Pliska dagegen an vielen Stellen bestattet. Die reichen Gräber hinter der Großen Basilika bzw. ihrem kreuzförmigen Vorgängerbau wurden bereits erwähnt. $\mathrm{Zu}$ den 43 Gräbern kommen noch zehn Gräber eines Mönchsfriedhofs und einige weitere Grabreste. ${ }^{35} \mathrm{Um}$ die Palastkirche hat man mehr als 174 Gräber aufgedeckt, ${ }^{36}$ um die Kirche an der südlichen Festungsmauer 20 Gräber $^{37}$. 18 Gräber wurden verstreut im inneren Stadtgebiet aufgedeckt. ${ }^{38}$ An der Innenseite der Mauer der Inneren Stadt, die erst in der ersten Hälfte des 10. Jahrhundert errichtet wur-

30 Georgiev 1993, 74-75.

31 Fiedler 1989, 145-146. - Auch noch bei Rašev/Dimitrov 1999, 35 wird die Asche auf der Spitze des Hügels XXXIII auf eine herrschaftliche Brandbestattung zurückgeführt.

32 Археологически открития и разкопки 1994 (1995), 129-130 (L. Dončeva-Petkova/ St. Stanilov/P. Georgiev/R. Vasilev); ebd., 1995 (1996), 86-87 (P. Georgiev).

33 Petrova 1992, bes. Abb. 2-5; Rašev 1995b, bes. 14-15; ders. 1995a, 257; Henning 2000, 8 Abb. 6.

34 Rašev/Stanilov 1998.

35 Michajlov 1979; Văžarova 1979; Georgiev 1993, 65-75; Vitljanov 1997; Rašev 1995a, 855$856 \mathrm{Nr} .803$.

36 Rašev 1995, 248 Nr. 766; Rašev/Dimitrov 1999, 83 Nr. 148 (angeblich 200 Gräber); Michajlova 2003, 265 Anm. 11 spricht nur von 170 Gräbern.

37 Pletneva 1992, 38 Abb. 3; 58-59 mit Abb. 31; 61 Abb. 32; Dimitrov, Ja. 1994, 40-41 Abb. 5-6; 46; 48; Rašev 1995a, 253-254 Nr. 793; Rašev/Dimitrov 1999, 83 Nr. 149.

38 Rašev/Dimitrov 1999, 85 Nr. 151.

39 Dimitrov 1994, 48. 


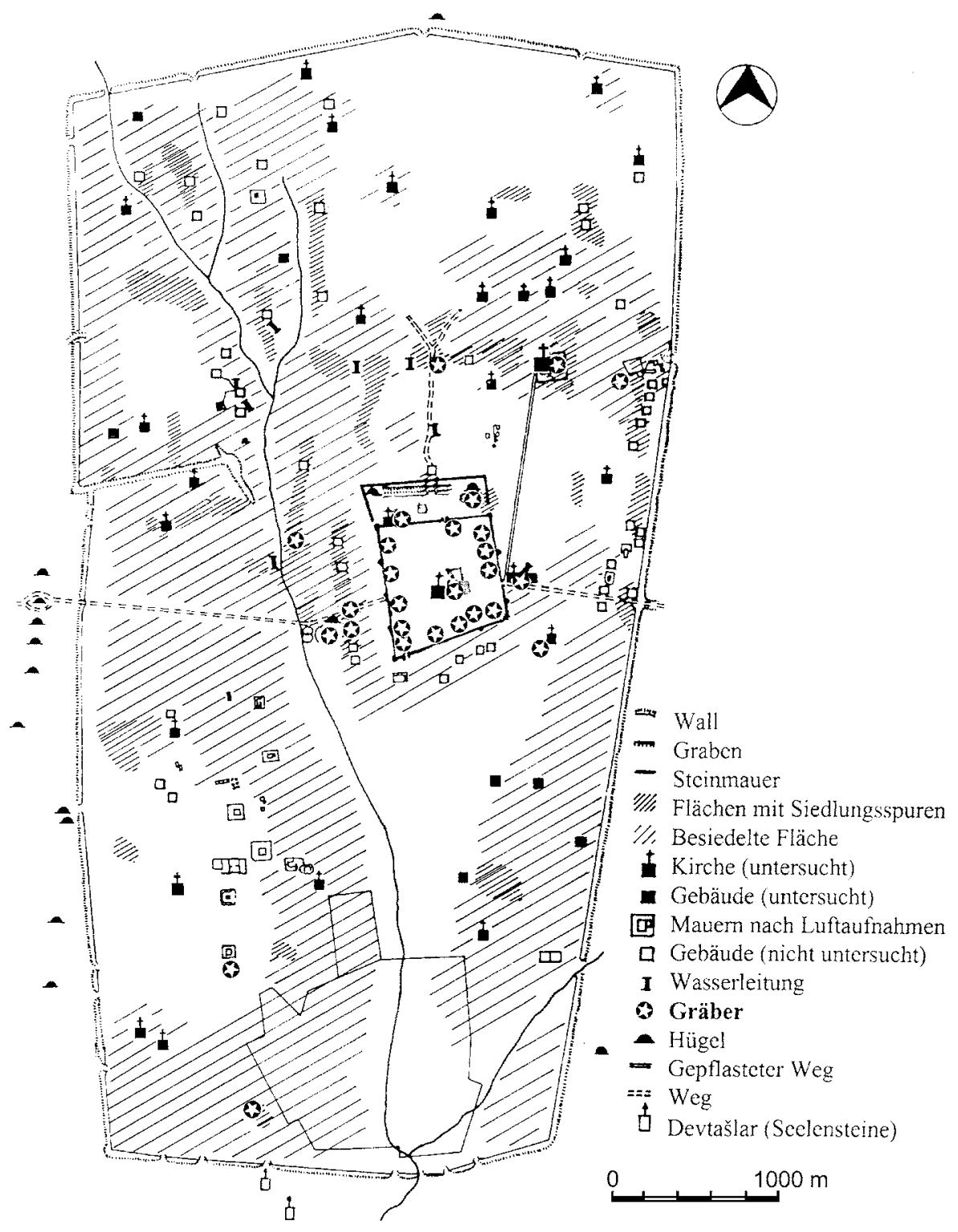

Abb. 5. Pliska. Plan mit den Grabfunden aus christlicher Zeit 
de, ${ }^{39}$ hat man dem Anschein nach überall bestattet. Bei Ausgrabungen sind 186 Gräber aufgedeckt worden. ${ }^{40}$ Davon werden sechs - nach meiner Rechnung acht - als heidnisch bezeichnet. Beginnen wir mit den beiden heidnischen Gräbern an der Südmauer. Das eine (Grab 10) war auf dem Steinboden des im 10. Jahrhundert erbauten Turmes 1 angelegt worden, weshalb der Kopf nach Süden wies. Das andere Grab (20) war südost-nordwestlich ausgerichtet und enthielt Pferdegeschirr als Beigabe. Rašev hat beide späten Nomaden zugewiesen, sie gehören auf jeden Fall schon in byzantinische Zeit. ${ }^{41}$ - Im Schnitt der russischen Expedition wurde unweit der Südmauer in der Verfüllung des Grubenhauses 3 eine genordete Bestattung (Grab 1) aufgedeckt, die gemäß der Ausrichtung noch in die heidnische Zeit gewiesen wurde. Wie Dimitrov herausgearbeitet hat, gehört besagtes Grubenhaus aber schon in das letzte Viertel des 10. Jahrhunderts, also ebenfalls in die byzantinische Zeit. Die Bestattung ist damit nur als regelwidrig einzuordnen. ${ }^{42}$ - Diese Regelwidrigkeit lässt sich auch bei anderen Bestattungen feststellen, so bei dem Grab 11, das unter den 41 von 1973 bis 1975 an der Westmauer aufgedeckten Gräbern des 11. (-12.?) Jahrhunderts als einziges eine Nord-Süd Ausrichtung aufwies und zudem ein Hocker darstellte, ${ }^{43}$ bei den vier nord-südlich ausgerichteten Gräbern innerhalb einer Grabgruppe gleicher Zeitstellung am Nordtor ${ }^{44}$ sowie bei drei Bestattungen, die isoliert von dem Friedhof um die Palastkirche in Siedlungsgruben bzw. einem Ofen aufgefunden wurden und nicht vor dem 10. Jahrhundert datiert werden können. ${ }^{45}$ Auch bei letzteren waren die Beine angezogen. Deswegen gelten sie als petschenegische Bestattungen. Egal, wie man zu dieser ethnischen Ansprache steht, festzuhalten bleibt, dass alle Gräber mit Sicherheit in die Zeit nach der Christianisierung der Protobulgaren gehören und den spätesten Bestattungshorizont in Pliska darstellen.

Groß ist auch die Anzahl der Gräberfunde in der Äußeren Stadt. In die erwähnten Erdhügel wurden erst in christlicher Zeit Gräber eingetieft: Zwei in den Hügel $\mathrm{XXXII}^{46}$ und 36 in den Hügel XXXIV. Westlich und östlich von letzterem sind weitere 54 Bestattungen aufgedeckt worden, wobei Dutzende von in den 1980er Jahren gestör-

40 Rašev 1995a, 249; 254 Nr. 799 (mit Literatur); Rašev/Dimitrov 1999, 83 Nr. 150; Balabanov 2000.

41 Zachariev 1979, 134 Abb. 46, 136 Abb. 47, 137; Rašev 1983, 48-50; Abb. 2-4.

42 Pletneva 1992, 49; Dimitrov, Ja. 1994, 39 Abb. 4, 42, 48-50 mit Tab. 1.

43 Antonova/Vitljanov 1985, 66-67, 70, Taf. 8.

44 Balabanov 1985, 120-121.

45 Michajlova 2003. - Sie gehören wohl zu den 18 bei Rašev/Dimitrov 1999, 85 Nr. 151 aufgeführten Einzelgräbern, worunter sich allerdings acht Bestattungen später Nomaden befinden sollen.

46 Rašev 1995a, 262 Nr. 864. 
ten Gräbern nicht berücksichtigt werden. ${ }^{47}$ Drei Gräber wurden nördlich der Inneren Stadt freigelegt. ${ }^{48}$ Vor dem Osttor der Inneren Stadt hat man in der Umgebung einer kleinen Kirche („Objekt 57“) bis 2003 insgesamt 290 Gräber eines sicherlich größeren Friedhofs erfasst. ${ }^{49}$ Gräberfunde sind auch um verschiedene weitere Kirchen oder mutmaßliche Kirchen überliefert: „,Objekt 7“ einige Gräber ${ }^{50}$, „Objekt 20“ sieben Gräber, ${ }^{51}$ „,Objekt 26“ mindestens sechs Gräber, ${ }^{52}$ „,Objekt 31 “ 15 Gräber, ${ }^{53}$ „,Objekt 40 “ 24 Gräber, ${ }^{54}$ „Kirche 3“ eine Vierfachbestattung ${ }^{55}$, „Kirche 12“ mehrere Gräber ${ }^{56}$, „Kirche 13“ mehrere Grabreste ${ }^{57}$, „Kirche 25 “ drei Gräber ${ }^{58}$ und „Kirche 29“ ein Grab ${ }^{59}$. Weiter überlagerte eine kleine Gruppe von fünf Gräbern teilweise ein Grubenhaus des 9./10 Jahrhunderts des „Objektes Cecha“ am Südrand der Äußeren Stadt. ${ }^{60}$ Die Zahl der im Siedlungsgebiet am linken Ufer des Asar-dere aufgedeckten Bestattungen ist leider unbekannt. ${ }^{61}$

Die aufgeführten Zahlen summieren sich zu 398 Gräbern aus der Inneren und mindestens 509 Gräbern aus der Äußeren Stadt, also zusammen auf 907 Gräber, wobei mit weiteren nicht zahlenmäßig übermittelten Grabfunden zu rechnen ist. Diese Bestattungen gehören teilweise auch in die byzantinische Zeit, die obere Grenze wird nicht definiert, kann um die Mitte des 11. Jahrhunderts angenommen werden (nur vereinzelt wird auch noch das frühe 12. Jahrhundert mit einbezogen). Somit verteilen

47 Rašev 1995a, 262 Nr. 866 und 862; Dimitrov, Ja. 1998b, 69; Rašev/Dimitrov 1999, 69 Nr. 91; Археологически открития и разкопки 1992/93 (1994), 98; ebd. 1994 (1995), 129-130; ebd. 1995 (1996), 86; ebd. 2002 (2003), 123 (die Zahlenangaben sind leider widersprüchlich).

48 Rašev/Dimitrov 1999, 69 Nr. 93.

49 Dimitrov, Ja. 1995, 45; Rašev 1995a, 261 Nr. 857; Археологически открития и разкопки 1999-2000 (2001), 126; ebd. 2001 (2002), 115-116; ebd. 2002 (2003), 121-122; ebd. 2003 (2004), 174-175.

50 Rašev/Dimitrov 1999, 55-56 Nr. 12A.

51 Rašev 1995a, 259 Nr. 823; 262 Nr. 862,4; Dimitrov, Ja. 1995, 69-70; Rašev/Dimitrov 1999, 63-64 Nr. 60 und 69 Nr. 92.

52 Rašev 1995a, 259 Nr. 829; Rašev/Dimitrov 1999, 59 Nr. 31.

53 Археологически отрития и разкопки 1991 (1992), 97; Rašev 1995a, 259-260 Nr. 834, 262 Nr. 862,1; Rašev/Dimitrov 1999, 59-60 Nr. 36, 69 Nr. 89.

54 Археологически открития и разкопки 1991 (1992), 97; Aladžov, Ž. 1993; Rašev 1995a, 259-260 Nr. 834 und 262 Nr. 862,1; Rašev/Dimitrov 1999, 61 Nr. 45; Aladžov/Dončeva 2000, 204-210.

55 Rašev/Dimitrov 1999, 55 Nr. 8.

56 Ebd., 56-57 Nr. 17.

57 Ebd., $57 \mathrm{Nr} .18$.

58 Ebd., 58 Nr. 30.

59 Ebd., 59 Nr. 34.

60 Rašev 1995a, 262 Nr. 862,2; Rašev/Dimitrov 1999, 69 Nr. 94 (7 Gräber); Balabanov 2004, 122 Abb. 18 und 132 (5 Gräber).

61 Rašev 1995a, 262 Nr. 862,5; Rašev/Dimitrov 1999, 69 Nr. 90. 
sich die Grabfunde auf nicht einmal zwei Jahrhunderte - also auf einen fast so langen Zeitraum wie den heidnischen Abschnitt (680/1-864/5). Auch wenn man P. Georgiev folgt und den Beginn der Residenz erst um die Mitte des 8 . Jh. veranschlagt ${ }^{62}$ und man darüber hinaus auch mit einem erheblichen Bevölkerungswachstum in christlicher Zeit rechnet, hat man immer noch mehrere hundert heidnische Gräber zu erwarten. Wie gesagt, gibt es aber kein einziges. Zwischen Steinmauer und äußerer Umwallung sind mindestens fünf Siedlungsstellen des 8.-9. Jahrhunderts nachgewiesen. ${ }^{63}$ Wenn es Gräberfelder zu diesen Siedlungen gegeben hätte, sollten sie den Archäologen aufgrund der Keramikbeigaben aufgefallen sein. Der Forschungsstand in Pliska ist doch recht gut, schließlich gräbt man dort seit über einem Jahrhundert. ${ }^{64}$

Die Entstehung der 19,6 km langen, äußeren Umwallung einschließlich ihrer Gräben ist jüngst von P. Georgiev neu beleuchtet worden. Er hat auch auf ihre Funktion bei der Wasserversorgung hingewiesen und die These eines älteren Kerns in der Nordwestecke aufgestellt. Diese erste Wallanlage habe größenmäßig zwischen den Lagern von Stan und Novi Pazar gelegen. ${ }^{65}$ In ihrer endgültigen Form, als die Umwallung ein über $23 \mathrm{~km}{ }^{2}$ großes Gebiet mitsamt der Khansresidenz einschloss, hatte sie sicherlich weniger die Funktion einer Befestigung als die der Markierung eines ausgesonderten Bezirkes zu erfüllen, in dem besondere Vorschriften galten. Als Erklärung des oben umrissenen, offenbar niemals thematisierten Phänomens möchte ich die Vermutung aussprechen, dass eine dieser Sondervorschriften ein allgemeines Bestattungsverbot gewesen sein könnte. Die Gründe dafür wären in der religiösen Sphäre zu suchen, denn gleich nach der Christianisierung verlor es seine Gültigkeit, wie es die frühen Gräber hinter der Großen Basilika beweisen.

Unser heutiges Wissen über Pliska wird weitgehend durch die Architektur aus christlicher Zeit geprägt. Die Diskussion über die Datierung der Architekturbefunde muss sicherlich noch weiter geführt werden. Es wäre aber zu begrüßen, wenn auch alle Befunde der heidnischen Zeit neu zusammengestellt und ausgewertet würden ${ }^{66}$. Vielleicht gibt es dann größere Klarheit über die Funktionen dieser sicherlich noch nicht städtischen Anlage vor 864/5: saisonales Heerlager, Khansresidenz und religiöses Zentrum mit mehreren Siedlungsagglomerationen agrarischen oder gewerblichen Charakters?

62 Georgiev 2000b, 20; 27; ders. 2003, 180-181.

63 Ders. 1993, 10-14 mit Abb. 1; ders. 2000b, 21 Abb. 3; Rašev 1995b, 30 Abb. 1.

64 Anders sieht dies Georgiev 2003, 177. Er führt das Fehlen von heidnischen Grabfunden auf den ungenügenden Kenntnisstand der frühen Siedlungsstrukturen zurück.

65 Georgiev 2000a; ders. 2000b und 2003. Plan der ersten Anlage: Georgiev 2000a, 26 Abb. 5. Zu den Lagern von Stan und Novi Pazar vgl. Плиска-Преслав 9, 2003, 163 Abb. 1.

66 Diese Forderung hat auch Georgiev 2003, 178 aufgestellt, der in seinen jüngeren Arbeiten schon Wesentliches für eine zeitliche Differenzierung des Siedlungsbildes getan hat. 


\section{Bibliographie}

Aladžov, A. 2002: A[ndrej] Aladzhov [Aladžov], „Origin of the so called ,Pastyrska pottery“ from Varna necropolis“, in: Археологія та етнологія Східної Свропи: матеріали $i$ дослідження 3, 2002, S. 157-158.

Aladžov, Ž. 1993: Живко Аладжов, „Некропол край църквата на обект 40 (комплекс „А“) във Външния град на Плиска“, in: Плиска-Преслав 6, 1993, S. 85-92.

Aladžov/Dončeva 2004: Живко Аладжов/Стела Дончева, „Ракопки на обект № 40 (комплекс „А“) и тяхното значение за археологическото проучване на Плиска“, in: Плиска-Преслав 10, 2004, S. 198-211.

Angelova 1997a: Стефка Ангелова, (Rezension zu Fiedler 1992), in: Годишник на Софийския университет: Исторически факултет - Специалност археология 1, 1994 (1997), S. 205-213.

Angelova 1997b: Стефка Ангелова, „Ранносредновековна керамика от Козлудуй“, in: Годишник на Софийския университет: Исторически факултет - Специилност археология 1, 1994 (1997), S. 129-147.

Angelova 1998: Stefka Angelova, (Rezension zu Fiedler 1992), in: Archaeologia Bulgarica 2/2, 1998, S. 88-95.

Angelova/Dončeva-Petkova/Daskalov 1997: Стефка Ангелова/Людмила Дончева-Петкова/ Методи Даскалов, „Двуобредният некропол край село Топола, Каварненска община“, in: Проблеми на прабългарската история и култура 3, Шумен 1996, S. 141-154.

Angelova/Koleva 1992: Стефка Ангелова/Румяна Колева, „За някой особености на раннославянската керамика от северозападна България“, Приноси към Българската археология 1 (Gedenkschrift für Stančo Vaklinov), София 1992, S. 173-179.

Antonova/Vitljanov 1985: Вера Антонова/Стоян Витлянов, „Плиска. Западна крепостна стена / сектор север (Археологически разкопки 1973-1975 г.)“, in: Плиска-Преслав 4, 1985, S. 44-78.

Balabanov 1985: Тодор Балабанов, „Разкопки на северната и източна крепостна стена в Плиска (1977-1978)“, in: Плиска-Преслав 4, 1985, S. 117-131.

Balabanov 2000: Тодор Балабанов, „Некропольт при северната порта и източната крепостна стена на Плиска“", in: Плиска-Преслав 8, 2000, S. 93-102.

Balabanov 2003: Тодор Балабанов, „Археологически свидетелства за поселищния живот в Новопазарска община (праистория и средновековие)“, in: Плиска-Преслав 9, 2003, S. 81-103.

Balabanov 2004: Тодор Балабанов, „Селище в югозападната част на Външния град на Плиска“, in: Плиска-Преслав 10, 2004, S. 101-168.

Bóna 1999: Istvan Bóna, (Rezension zu Fiedler 1992), in: Acta Archaeologica Academiae Scientiarum Hungaricae 49, 1997 (1999) S. 481-486.

Cândea 1995: Ionel Cândea, Brăila. Origini şi evoluție până la jumătatea secolului al XVI-lea, Brăila 1995.

Čolakov 1998: Славчо Чолаков, „Антропологично проучбане на ранносредновековите некропол при с. Дибич, Шуменско“, in: Археология 39/3-4, 1998, S. 83-93.

Daskalov 1997-1999: Методи Даскалов, „Към хронологията на ранносредновековите езически некрополи в Североизточна България и Добруджа“, in: Добруджа 14-16, 1997-1999, S. 137-154.

Diaconu 1994: Petre Diaconu, (Rezension zu Fiedler 1992), in: Recenzii şi discuții arheologice 1 (= Culture et civilisation au Bas Danube 12), 1994, S. 121-135. 
Diaconu 1996: Petre Diaconu, „Sur les nécropoles danubiennes (VIe-XIe siècles)“, in: Dacia N.S. 37, 1993 (1996) S. 291-300.

Dimitrov, Chr. 1994: Христо Димитров, (Rezension zu Fiedler 1992), in: Bulgarian Historical Review 23, 1994, S. 136-137.

Dimitrov, D. I. 1974: Димитър Ил. Димитров, „Погребалният обред при раннобългарските некрополи във Варненско (VIII-X v.)“, in: Известия на Археологическия институт 34, 1974, S. 51-94.

Dimitrov, D. I. 1975: Димитьр Ил. Димитров, Раннобългарски некрополи във Варненско, София 1975 (unpublizierte Dissertation).

Dimitrov, Ja. 1994: Янко Димитров, „Стратиграфията на Плиска и проучването на руската експедиция през 1977-1980 г.“, in: Археология 36/3-4, 1994, S. 37-51.

Dimitrov, Ja. 1995: Янко Димитров, „Цьрква и некропол във Външния град на Плиска (края на X-X I в.)“, in: Плиска-Преслав 7, 1995, S. 42-70.

Dimitrov, Ja. 1998а: Янко Димитров, (Tagungsbericht Šumen), in: Археология 39/1-2, 1998, S. 104.

Dimitrov, Ja. 1998b: Янко Димитров, „Два некропола във Външния град на Плиска (края на IX-XI в.)“, in: Трудове на катедрите по история и богословие в Шуменския университет 2, Шумен 1998, S. 69-80.

Dončeva-Petkova/Ljubenova 2004: Ljudmila Dončeva-Petkova/Venezia Ljubenova, „Slawische Urnen in einer spätantiken Grabstätte bei der Stadt Pernik“, in: Gabriel Fusek (Hrsg.), Zborník na počest’ Dariny Bialekovej [Festschrift D. Bialeková] (=Archaeologica Slovaca Monographiae 7), Nitra 2004, S. 60-74.

Exposiția 1995/1996: Eugen Marius Constantinescu (Hrsg.), „Rădăcini ale civilizației străromâneşti in Muntenia de răsărit, Moldova de Sud şi centrală în secolele III-XI d. Ch. “ (=Ausstellungskatalog), Buzău 1995/1996.

Fiedler 1989: Uwe Fiedler, „Die Grablegen der Protobulgaren an der unteren Donau“, in: Проблеми на прабългарската история и култура (1), Šumen 1989, S. 143-158.

Fiedler 1992: Uwe Fiedler, Studien zu Gräberfeldern des 6. bis 9. Jahrhunderts an der unteren Donau (=Universitätsforschungen zur Prähistorischen Archäologie 11), Bonn 1992.

Fiedler 1997: Uwe Fiedler, „Nochmals zur Datierung von Grab 5 in Hügel III von Madara“, in: Проблеми на прабългарската история и култура 3, Šumen 1997, S. 125-140.

Georgiev 1993: Павел Георгиев, Мартириумът в Плиска и началото на християнство в България, София 1993.

Georgiev 2000а: Павел Георгиев, „Землените укрепления на Абоба - Плиска“, in: ПлискаПреслав 8, 2000, S. 19-30.

Georgiev 2000b: Павел Георгиев, „Селищната структура на Абоба-Плиска“, in: Археология 41/3-4, 2000, S. 16-30.

Georgiev 2003: Павел Георгиев, „Началото на Абоба - Плиска“, in: Studia protobulgarica et mediaevalia europensia в чест на проф. Веселин Бешевлиев (Konferenz Veliko Tărnovo 2000), София 2003, S. 175-182.

Harhoiu 1997: Radu Harhoiu, (Rezension zu Fiedler 1992), in: Dacia N.S. 38-39, 1994/95 (1997), S. 495-499.

Henning 2000: Joachim Henning, „Pliska - Machtzentrum zwischen Byzanz und Abendland. Neue Wege der Archäologie“" in: Forschung Frankfurt, Wissenschaftsmagazin der Johann Wolfgang Goethe-Universität Frankfurt am Main 2000/2, S. 6-15.

Jordanov/Dimitrova 1997: Йордан Йорданов/Бранимира Димитрова, „Ритуални действия върху кости от ранносредновекожни некрополи в България“, in: Проблеми на прабългарската история и култура 3, Шумен 1997, S. 172-177. 
Jotov 1997: Валери Йотов, „Ранносредновековните некрополи в с. Хитово и нови данни“, in: Проблеми на прабългарската история и култура 3, Шумен 1997, S. 155-171.

Jotov/Botov 1991: Валери Йотов/Кирил Ботов, „Някой непубликувани ранносредновековни археологически материали от Южна Добруджа“, in: Добруджа 8, 1991, S. 18-27.

Koleva/Daskalov 1993: Румяна Колева/Методи Даскалов, „Керамиката от ранносредновековния некропол край с. Бабово, Русенско“, in: Приноси към Българската археология 2 (=Gedenkschrift Krăstju Mijatev), София 1993, S. 159-165.

Luca/Măndescu 2001: Cristian Luca/Dragoş Măndescu, Rituri şi ritualuri funerare în spațiul extracarpatic în secolele VIII-X, Brăila 2001.

Madgearu 1997: Alexandru Madgearu, Continuitate şi discontinuitate culturală la Dunărea de Jos în secolele VII-VIII, Bucureşti 1997.

Mamalaucă 2000: Mircea Mamalaucă (Hrsg.), Două milenii de creştinism / Deux millenaires de christianisme (Ausstellungskatalog), Bârlad 2000.

Mănucu-Adameşteanu 1996: Mihaela \& Gheorge Mănucu-Adameşteanu, „Contribuții la topografia antică a Dobrogei“, in: Peuce 12, 1996, S. 103-112.

Melamed 1995: Катя Меламед, „Характеристики на ранносредновековите некрополи по Българското крайбрежие“, in: Археология 37/1, 1995, S. 33-40.

Michajlov 1979: Стамен Михайлов, „Камените саркофази до Голямата базилика в Плиска“, in: Плиска-Преслав 1, 1979, S. $44-59$ (-68).

Michajlova 2003: Тонка Михайлова, „Къснономадски гробове в дворцовия център на Плиска“, in: Плиска-Преслав 9, 2003, S. 259-266.

Petrova 1992: Павлина Петрова, „Към въпроса за историко-археологическата топография на Външния град на Плиска по данни на аерометода“, in: Плиска-Преслав 5, 1992 , S. 64-76.

Pletneva 1992: Светлана Александровна Плетнева, „Стратиграфические исследования Плиски“, in: Плиска-Преслав 5, 1992, S. 35-63.

Pohl 1995: Walter Pohl, (Rezension zu Fiedler 1992), in: Bonner Jahrbücher 195, 1995, S. 854-855.

Rašev 1983: Рашо Рашев, „Късни номади в Плисковското поле“, in: Преслав 3, 1983 (=Gedenkschrift Krăstju Mijatev), S. 242-252.

Rašev 1995a: Рашо Рашев, „Материали за картата на средновековната българска държава (територията на днешна Североизточна България)““, in: Плиска-Преслав 7, 1995, S. 155-332.

Rašev 1995b: Рашо Рашев, „Плисковският аул“, in: Плиска -Преслав 7, 1995, S. 10-22.

Rašev 1997: Рашо Рашев, „Пръстенът от Върбяне“, in: Проблеми на прабългарската история и култура 3, Шумен 1997, S. 180-185.

Rašev/Dimitrov 1999: Рашо Рашев/Янко Димитров, Плиска. 100 години археологически разкопки, Шумен 1999.

Rašev/Stanilov 1998: Rašo Rašev/Stanislav Stanilov, „Kenotaph für einen Herrscher bei der ersten bulgarischen Hauptstadt Pliska“, in: Das Altertum 44, 1998, S. 67-72.

Sâmpetru 1993: Mihai Sâmpetru, (Rezension zu Fiedler 1992), in: Thraco-Dacica 14, 1993, S. 181-188.

Sarnovski 1994: Tadeusz Sarnovski, (Rezension zu Fiedler 1992), in: Archeologia (Warszawa) 45, 1994, S. 118-119.

Sedov 1995: Валентин Василевич Седов, (Rezension zu Fiedler 1992), in: Российская археология 1995/2, S. 245-249

Stančev/Ivanov1958: Станчо Станчев/Йордан Иванов, Некрополът до Нови Пазар, София 1958. 
Stanilov 2005: Станислав Станилов/Stanislav Stanilov, Художествен метал на Българското ханство на Дунав (7-9 век) / Die Metallkunst des Bulgarenkhanats an der Donau (7.-9. Jh.), София / Sofia 2005.

Stanilov/Aladžov 1994: Станислав Станилов/Живко Аладжов, (Rezension zu Fiedler 1992), in: Археология 36/1-2, 1994, S. 83-85.

Stojanova 1997: Христина Стоянова, „Глинени съдове от VIII-IX век от фонда на Исторически музей Шумен“, in: Проблеми на прабългарската история и култура 3, Шумен 1997, S. 330-336.

Văžarova 1976: Живка Въжарова, Славяни и Прабългари по данни на некрополите от VIХІ в. на територията на България, София 1976.

Văžarova 1979: Живка Въжарова, „Некропольт до Голямата базилика в Плиска“, in: Плиска-Преслав 1, 1979, S. 69-80.

Vitljanov 1997: Стоян Витлянов, „Манастирски некропол при Голямата базилика в Плиска“, in: Векове 8/8, 1997, S. 62-65.

Wolska 1999: Wanda Wolska, „Die biologische Dynamik der Bevölkerungen des 8.-10. Jhs. auf dem Gebiet des heutigen Rumänien“, in: Nikolaus Boroffka/Tudor Soroceanu (Hrsg.), Tanssilvanica. Gedenkschrift für Kurt Horedt (=Internationale Archäologie, Studia Honoraria 7), Rahden/Westf. 1999, S. 331-351.

Zachariev 1979: И. Захариев, „Южната крепостна стена на Плиска и некропольт до нея (разкопки през 1971-1974 г.)“, in: Плиска-Преслав 1, 1979, S. 108-138. 


\title{
Eighth- and ninth-century pottery from the industrial quarter of Pliska, capital of the early medieval Bulgarian kingdom
}

\author{
LuUdmila Dončeva-PetKova
}

From 1997 to 2001 a Bulgarian-German team of archaeologists and natural scientists worked in the Outer City of the first Bulgarian capital, Pliska. The subject of the exploration was the huge area to the west and northwest of the stone fortress, reaching down to the dry bed of the Asar dere River. Taking into account the evidence from the preliminary geophysical prospecting, thirty trenches were chosen for excavation on such places where the most distinct magnetic anomalies had been registered (Fig. 1). The most interesting results were delivered by two trenches. The first one is situated 66 $\mathrm{m}$ to the west of Mound XXXIV. It is $35 \mathrm{~m}$ long and $5 \mathrm{~m}$ wide and consists of sections 4 to 10 . The second one, No. 14, is approximately $200 \mathrm{~m}$ to the northwest of the same mound and is $10 \mathrm{~m}$ long and $1 \mathrm{~m}$ wide (Fig. 2). The explored area is of great scientific interest as far as handicraft activities are concerned. In the 1940s, Nikola Mavrodinov ${ }^{1}$ and Stamen Michajlov ${ }^{2}$ registered numerous traces of metallurgic production; at the end of the 1960s Atanas Milčev excavated four pottery kilns . ${ }^{3}$ By field surveys recently conducted by the author, ceramic fragments in large quantities were collected, these being especially numerous in the area to the west and southwest of the mound and close to the river bed. They date from the so-called pagan period, the time from the establishment of the Bulgarian State until the adoption of Christianity (i.e. the end of the seventh to the 60 s of the ninth century). The excavations of the Bulgarian-German team proved that the region between the fortified city and the Asar dere River had been inhabited during two main periods - from the eighth until the beginning of the ninth century and from the late tenth until the first half of the eleventh century.

In the first period an intensive handicraft activity took place here. From a depth of $0.30 \mathrm{~m}$ up to $1.70 \mathrm{~m}$ below today's surface, both of the mentioned trenches revealed multiple layers of production waste which occupy a rather vast area and are either clearly distinguishable, being separated by sterile packages of yellow loess, or are admixed with the same material. These layers contain artefacts verifying the execution

1 Mavrodinov 1948, 163-165.

2 Michajlov 1955, 63.

3 Milčev 1960, 35-55. 


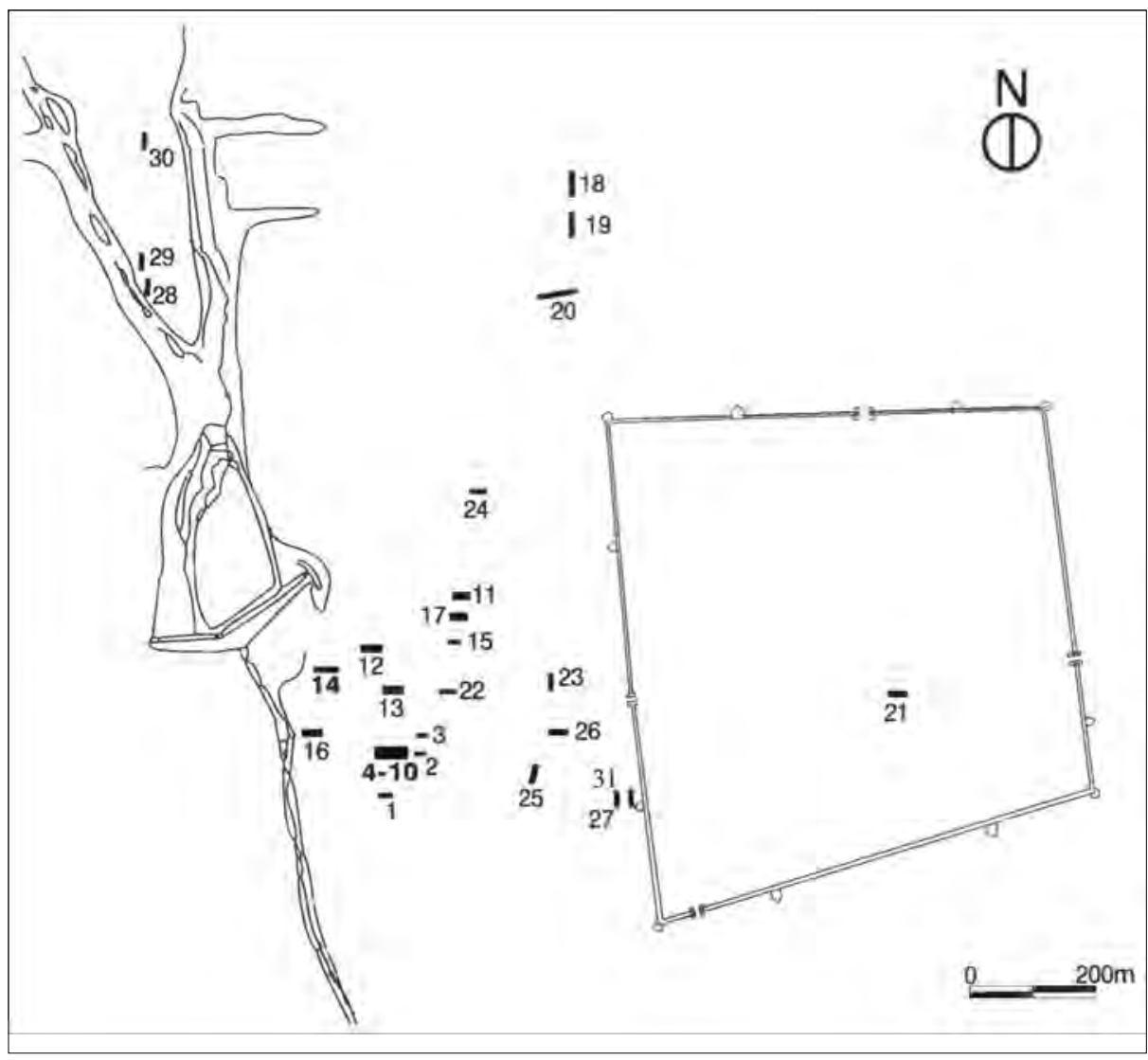

Fig. 1. Trenches in the Outer City of Pliska excavated from 1997-2001 by the Bulgarian-German archaeological team

of different production activities. Most numerous are the finds connected with iron processing - large amounts of slag, charcoal, ash, bellows and pig iron. There are also sherds of melting pots, drops, slag and damaged adornments, etc., probably stemming from the casting of non-ferrous metals. Fragments of glass vessels, drops of glass and molten amorphous glass residue on the other hand point to glassmaking. The animal bones found in large quantities could also have been further processed for different purposes. As usual, the ceramic material is most numerous, with some of the potsherds surely belonging to vessels spoiled during the firing. This is evidence for the existence of pottery workshops in the area.

Several dwellings (or parts of them) were also discovered in both trenches - No. 10 in section 4; No. 20 in sections 6 and 7 and No. 32 in trench 14 (Fig. 2). They were dug in the earlier cultural layers, thereby destroying them, and date in the second period. The present paper focuses on the pottery of the first period (eighth-ninth century). 


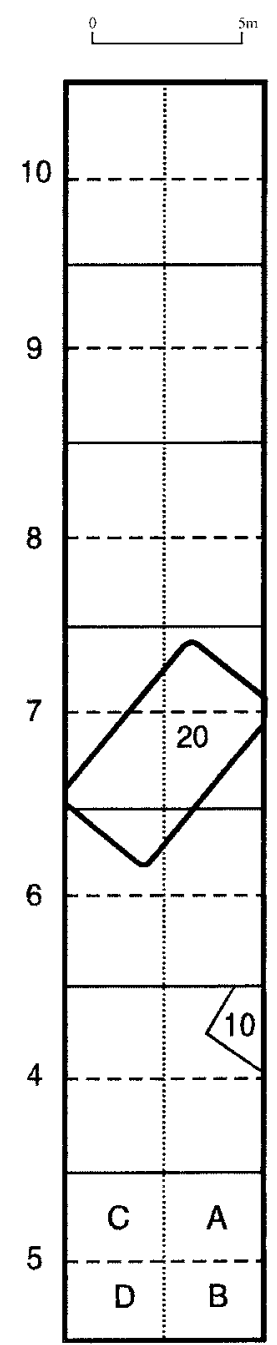

$\stackrel{N}{1}$

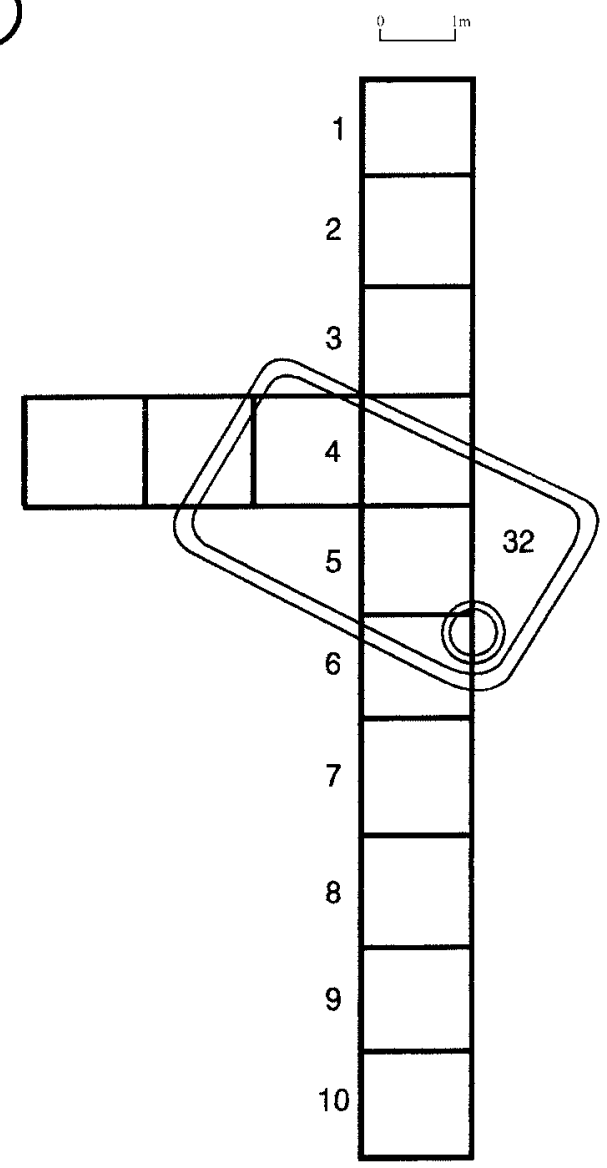

Trench 14

Trenches 4-10

Fig. 2. Plan of sections No 4-10 and trench No 14 


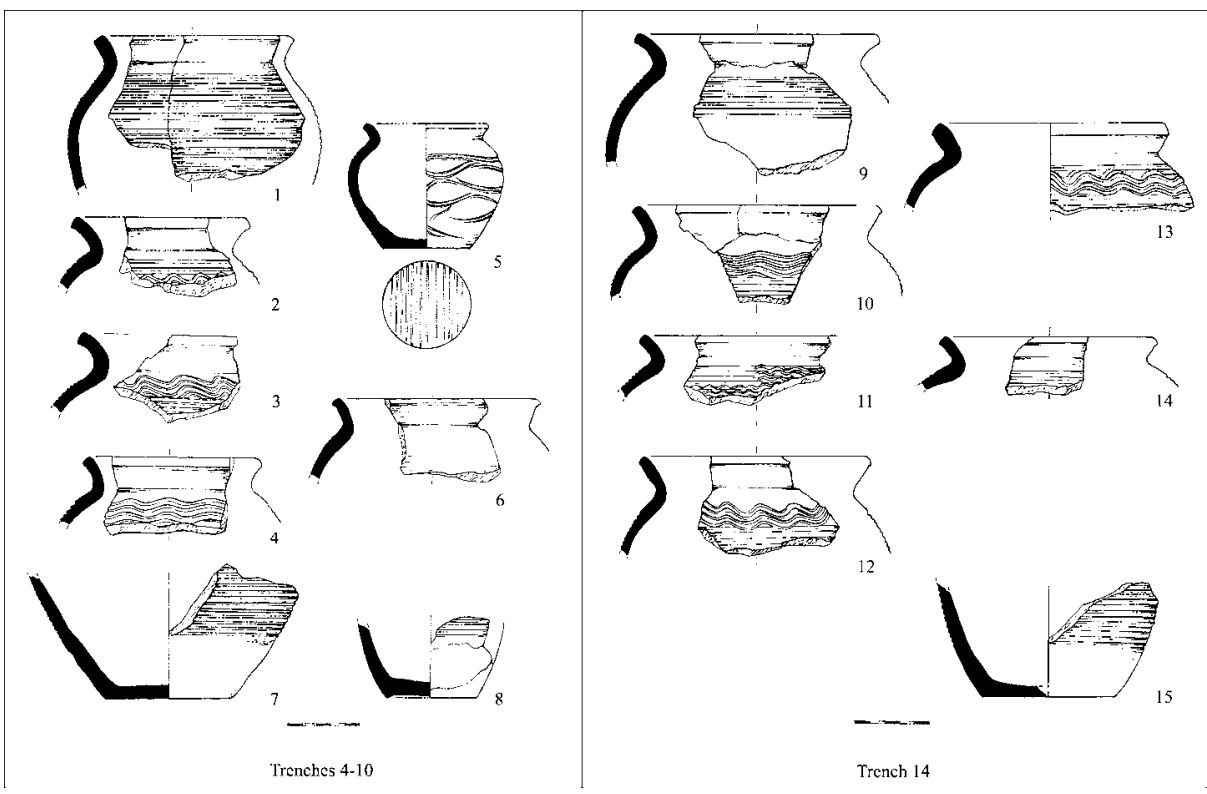

Fig. 3. Fragments of pots made of sand-tempered clay and decorated with incised lines. Trenches No 4-10 and trench No 14

Almost all finds belong to early medieval ceramic groups well documented for Bulgaria. According to their purpose in the household, cooking, table and storage ware can be distinguished. Parts of the vessels, decorated with incised patterns, are made of clay containing numerous sand inclusions and were fired in an oxidising atmosphere. Others, decorated by polishing, are made of pure clay and were fired in a reducing atmosphere. It is worth mentioning that within certain sections and layers, pure clay-pottery is in considerable amount, sometimes even prevailing. Due to long-term contact with iron objects and the impact of moisture many potsherds now bear rusty brown spots.

\section{Cooking ware}

Contrary to its quantitative abundance, its assortment is limited to only one form - pots. The material is very fragmentary - only rim, wall and bottom pieces have reached us. In most cases the bad state of preservation gives no clear idea of the pots' actual shape.

The sand-tempered pots do not display a great variety in either shape or ornamentation (Fig. 3). Seemingly, most of them possessed an ovoid body, a narrow neck with a mouth turned outward and a rounded or obliquely cut lip. The rim diameters vary between 7 and $16 \mathrm{~cm}$, with the majority measuring $12-14 \mathrm{~cm}$. The bottoms are 


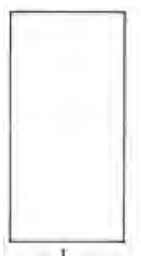

I

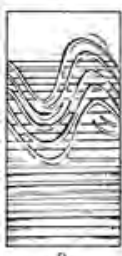

9

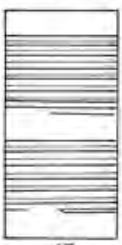

17

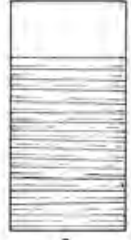

2

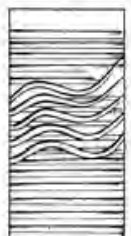

10

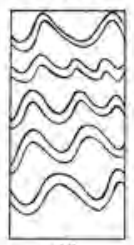

18

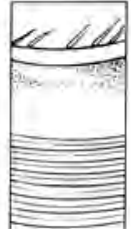

3
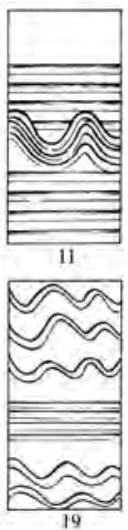

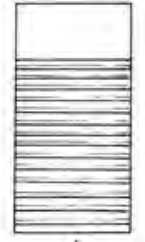

4

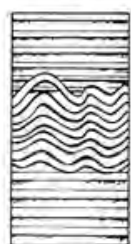

12

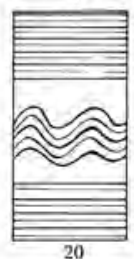

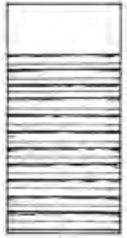

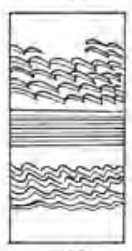

13

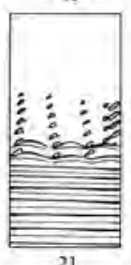

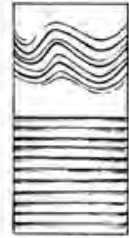

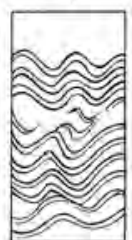

14

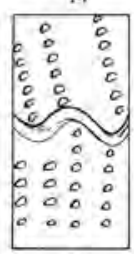

22
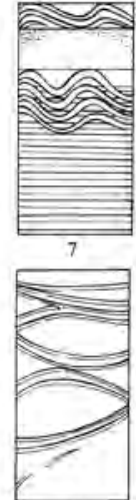

15

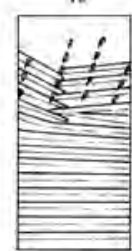

23

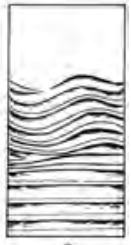

8

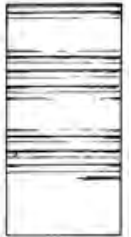

16

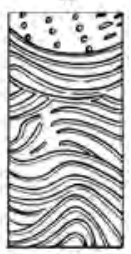

24

Fig. 4. Incised ornaments on vessels (pots and storing jars) made of sand-tempered clay. Trenches No 4-10

flat and have a diameter from 7-8 $\mathrm{cm}$ to $10-12 \mathrm{~cm}$. Although fragments without any decoration are occasionally found in different layers, the decorated ones prevail. The most characteristic ornament consists of straight lines, shallowly, or, most often, deeply incised by means of a comb, covering almost the entire body. Sometimes beneath the mouth of the vessels, above, over, or between these straight lines there is a band of 4-8 wave lines, made with the same combs (Fig. 4.6-12, Fig. 5.3, 6-10); single wave lines or their various combinations with grooves are rare (Fig. 4.3, 21-24, Fig. 5.11).

Most of the pots were thrown on a slow potter's wheel, rotated by hand. Some of them are rather heavy and plump; single coils are visible on the inner side of their walls, immediately above the bottoms. Small imprints from fallen off grains of sand are to be seen on the bottoms. Some of the bottoms also have relief rims on the periphery and/or potters' marks, with a circle or a cross in a circle being the most frequent types of marks. There is one mark which was cut before firing. The other vessels bear regular concentric lines on the inner side of the walls. They were obviously made on a more improved wheel, closer to the fast potter's wheel.

Quartz sand, limestone or feldspar are admixed to the clay as tempering materials. The colour of the vessels after firing is yellow-brown, orange-red or brick red, with the cross section of the walls revealing a grey or grey-black core. Some potsherds show traces of secondary contact with smoke, possibly due to their discarding in such a milieu, 

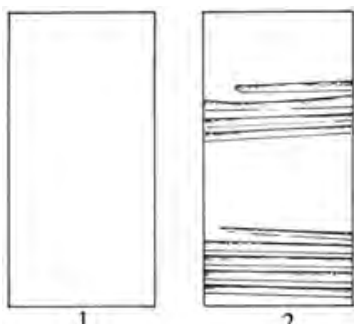

2

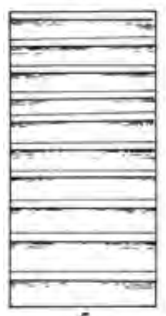

5

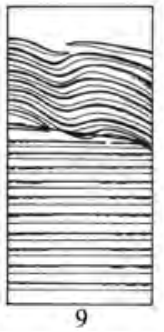

6

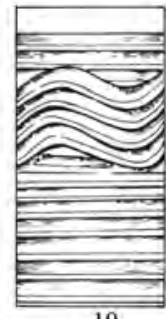

10
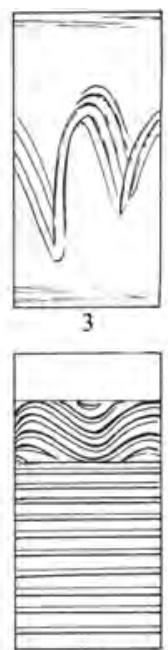

7

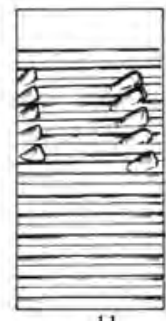

11

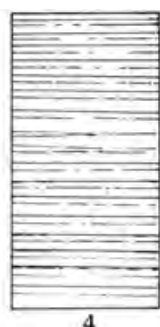

Fig. 5. Incised ornaments on vessels (pots and storing jars) made of sandtempered clay. Trench No 14

e.g. among burning or smouldering materials. It is interesting to notice that the inside of the pots sometimes feature a very thin grey-blackish layer. It resembles a manganese varnish which could have been intentionally applied in order to prevent leakage.

Only one small pot could be completely restored (Fig. 3.5 and 6.1). This pot, as well as the rim fragments with wide rounded shoulders, belong to Type III or XIII, Variant $A$ and $\mathrm{B}$ according to the classification of Bulgarian house pottery. ${ }^{4}$ Similar intact or restored vessels are known from other sites in or not far from Pliska (Fig. 6.4-8), e.g. Mound XXXIII, ${ }^{5}$ the bi-ritual cemetery near the village Kjulevča and the cemetery of the neighbouring village Vojvoda. ${ }^{6}$

The fragments from pots made of pure clay are considerable in quantity, amounting to one third of the ceramic finds from layers 9 to 15 in trench 14 and in the last layer 15 even prevailing. The most frequently measured diameters of the rim fragments are 12 and $14 \mathrm{~cm}$. Some of them have high (2.5-4 cm) and almost conic necks (Fig. 7.1-3),

4 Dončeva-Petkova 1977, 51-53, 60-61.

5 ibid., Cat. No. 126-130, 172-175.

6 Văžarova 1976, 94, 102, 105-106, 125, 141, fig. 48.5, 50.2, 57.3, 59.2, 62.2, 74.7, 87.2. 

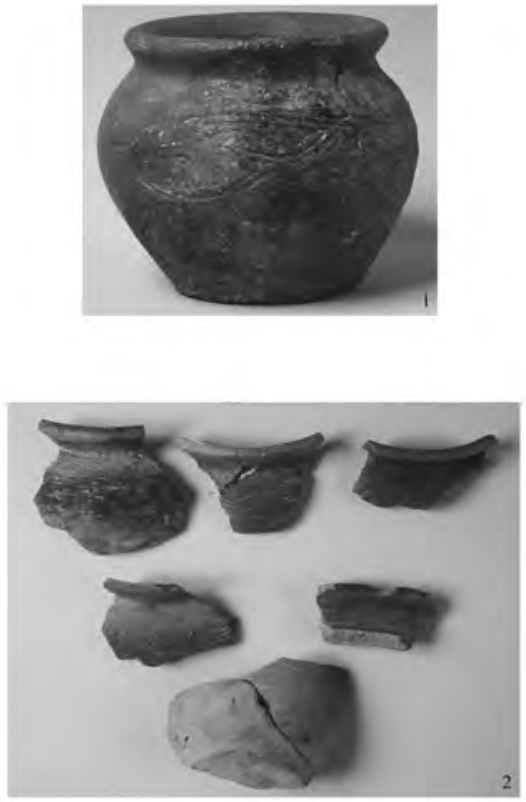
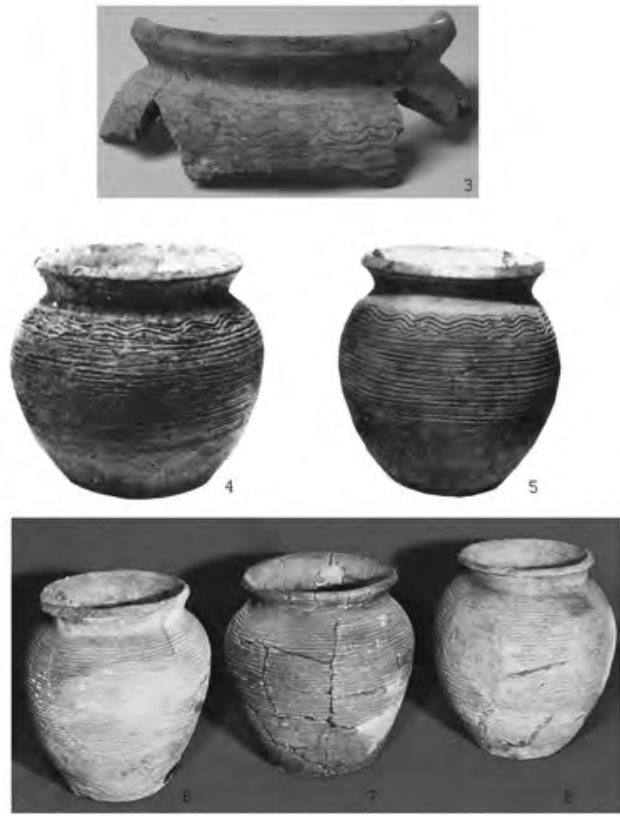

Fig. 6. Pots made of sand-tempered clay with incised decoration. 1. trench $4 b ; 2$. trenches 4-10; 3. trench 14; 4. pot from the cemetery at Kjulevča village, Šhumen district; 5. pot from the cemetery at Vojvoda village, Šhumen district; 6-8. vessels from Mound XXXIII in Pliska

while others have rather short ones (Fig. 7.4-6). The lip is rounded, either broad or narrow and only rarely thickened. As several fragments show, some of the pots had handles; unfortunately, the exact vessel shape remains unclear.

The pots are made of pure clay containing tiny glimmer pieces; small quartz grains or limestone pieces are more than rare. The colour of the vessels is grey, grey-black, grey-brown, yellow-brown or reddish-orange. The inner or outer surface layer is most often grey, the core being black. There are also yellow or reddish-orange sherds with an evenly coloured cross section.

The decoration shows a greater variety than the incised ornaments of the sand-tempered pots. Apart from the well-polished shiny surface (Fig.8.12, 25), different combinations from horizontal, vertical or diagonal polished lines are to be seen, e.g. the quite typical grid pattern (Fig. 8.2-4, 25-32). Sometimes the polished lines are combined with incised horizontal lines (Fig. 8.5-12, 39). The walls of the pots with pale colour are not always even, sometimes being wavy and/or having flutes (Fig. 8.35-36, 40). All of them were thrown on a slow potter's wheel. Relief marks are rare, obviously because after forming the vessel, the potters smoothened the bottoms. Some sherds of this group also show traces of smoke on the inner and outer surface. The available 


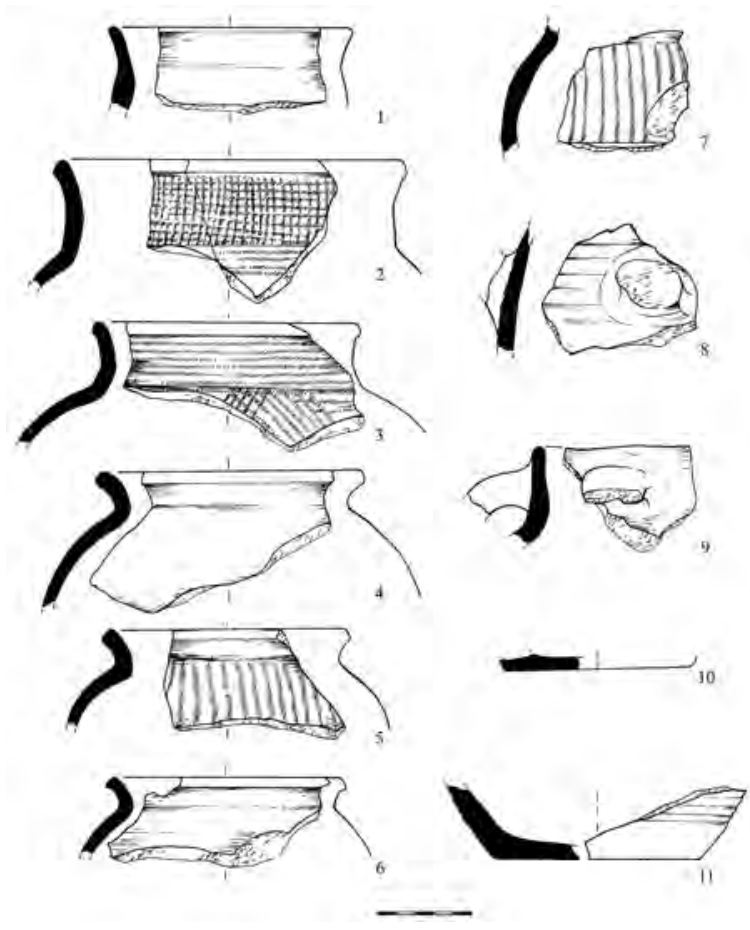

Fig. 7. Fragments from pots made of pure clay and decorated by polishing. Trenches No 4-10 and trench No 14

vessel parts belong most probably to pots with ovoid bodies, as known from Mound XXXIII in Pliska, ${ }^{7}$ the cemeteries near Novi Pazar $^{8}$ and Kjulevča, ${ }^{9}$ as well as from other bi-ritual cemeteries (Fig. 9).

\section{Table ware}

Table ware is represented by jugs, double-handled flagons and dishes. The jug form is maybe the most interesting one, attested by rim, wall and handle fragments (Figs 10-12). The rims vary in form. Some of them are threefold (Fig. 10.1-4, 12.1-4) and belong to large vessels; while others are funnel-like and belong rather to small jugs. Some of the necks are modelled very carefully, but in the prevailing part of the fragments the single coils are still well visible on the inside (Fig. 10.1-3, 5, 7, Fig. 12.2-3). This part of the vessel demands the greatest skilfulness: because of the narrow opening, the potter has not always managed to remove the traces from coiling. The same technical feature is

7 Dončeva-Petkova 1977, 56, Cat. No. 152-156.

8 Stančev/Ivanov 1958, table XV.

9 Văžarova 1976, 96, fig. 50.5, 105, fig. 59.1, 106, fig. 62.3. 


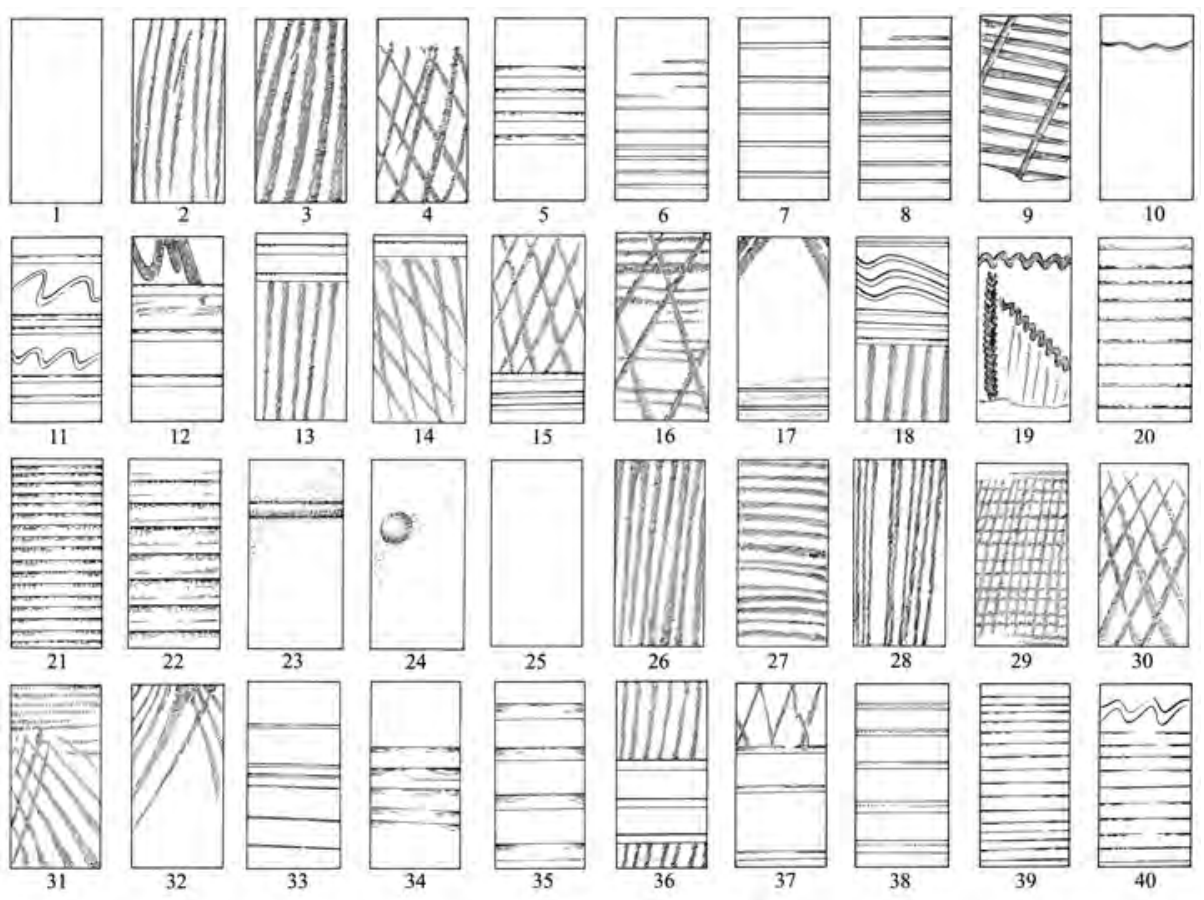

Fig. 8. Ornaments made by polishing on pots, jugs, amphora-like flagons, dishes and storing jars.

1-24. trenches no $4-10 ; 25-40$. trench no 14

visible at the upper parts of the walls of certain specimens (Fig. 10.15-18, 20-23). These vessels were also crafted on a slow potter's wheel. Their colour is mostly grey, but also pale or dark yellow.

Polishing is the most typical decoration, as it is the case for the pots made of pure clay (Fig. 8.1-4, 13-16, 21-22, 25-32). Some additionally attached relief elements are also present - small lumps or strips (Fig. 8.23-24, Fig. 10.24-25), as well as small pseudo-handles (Fig. 10.21-23). The jugs from Mound XXXIII, the north junction of the secret passage at the so-called Krum palace, ${ }^{10}$ the cemeteries near Novi Pazar, Kjulevča and Bdinci, etc. feature the same elements (Fig. 13). ${ }^{11}$

Among the numerous ceramic material only four fragments belong most probably to double-handled flagons (Fig. 14). The rims are funnel-like and possess horizontally cut lips. The clay material is without any inclusions and the vessels have become grey, grey-brown or pale brown after firing. Reproduced in various techniques, with different

10 Henning/Dončeva-Petkova 1999, Cat. No. 117.

11 Stančev/Ivanov 1958, table XVI1; Văzharova, 1976, 99, fig. 53.10, 101, fig. 54.2a, 116, fig. $69.2,123$, fig. $73.1,125$, fig. 75.2 . 

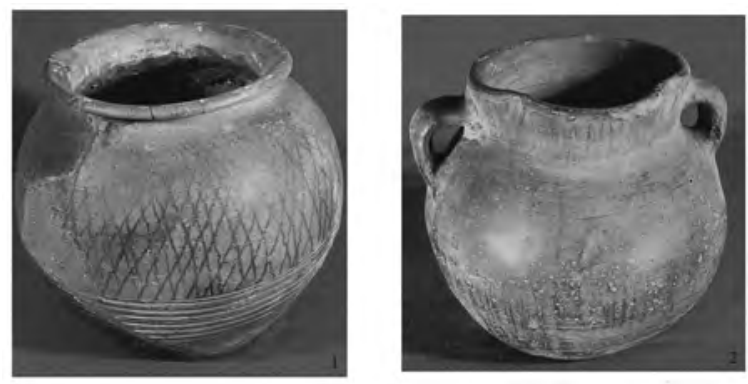

Fig. 9. Pots made of pure clay and decorated by polishing. 1. Mound XXXIII; 2. cemetery at Novi Pazar; 3-4. cemetery at Kjulevča
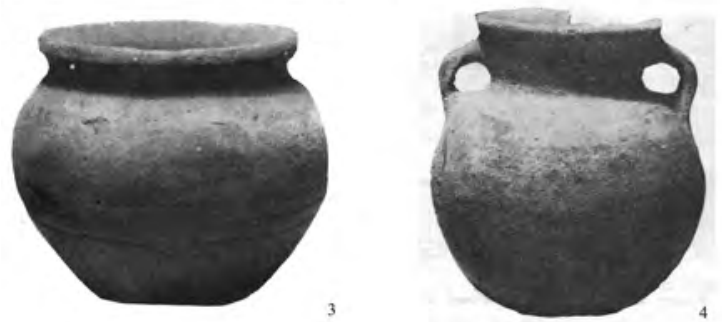

colour and decoration, the form of the double-handled flagons (known also as amphora-like flagons) is widespread in early medieval Bulgaria during the pagan period. ${ }^{12}$

Of special interest are eight rims (Fig. 15.1-8), two bottoms, one handle and more than 80 wall pieces belonging to single- or double-handled flagons; as well as two spout pieces (Fig. 15.9-10) belonging to "teapots". They could be classified in a particular group of luxurious vessels, very carefully modelled from pure clay and displaying a pale yellow colour. Some of the wall sherds bear traces of red slip, the spout fragments and one wall piece of yellow-green glaze. Such vessels, 36 being completely restored (Fig. 16.1-6), were found 25 years ago in the south junction of the secret passage, which supposedly burnt down together with the so-called Krum palace. ${ }^{13}$ One "teapot" is also known from Mound XXXIII (Fig. 16.7). Other wall, handle and bottom fragments also belonging to single- and double-handled flagons were found in both trenches. These vessels were also crafted on a fast wheel, also display a pale yellow colour in different nuances and are covered with red slip. Such pottery is characteristic for the lowest cultural layers of the earliest buildings and along the stone walls of Pliska. ${ }^{14}$

Sections 4 to 10 delivered 15 fragments of dishes (Fig. 17.1-7, 9, 11-13), trench 14 only two (Fig. 17.8, 10). Two vessels are represented by more than one fragment. Because of the wide-opened and low body, the exact shape of these vessels could

12 Dončeva-Petkova 1977, 78-82.

13 Rašev 1985, 42; idem 2004, 61-100; Bălgarite 2004, Cat. No. 13.

14 Dončeva-Petkova 1973, 14-16; idem 1979, 91, fig. 23; idem 1992, 496, fig. 1-3; Henning/ Dončeva-Petkova 1999, Cat. No. 118-119; Milčev 1985, 34; Georgiev/Vitljanov 2001, 114, fig. 47.1-3, 5-6; Dimitrov 2003, 201-202, table I.27. 

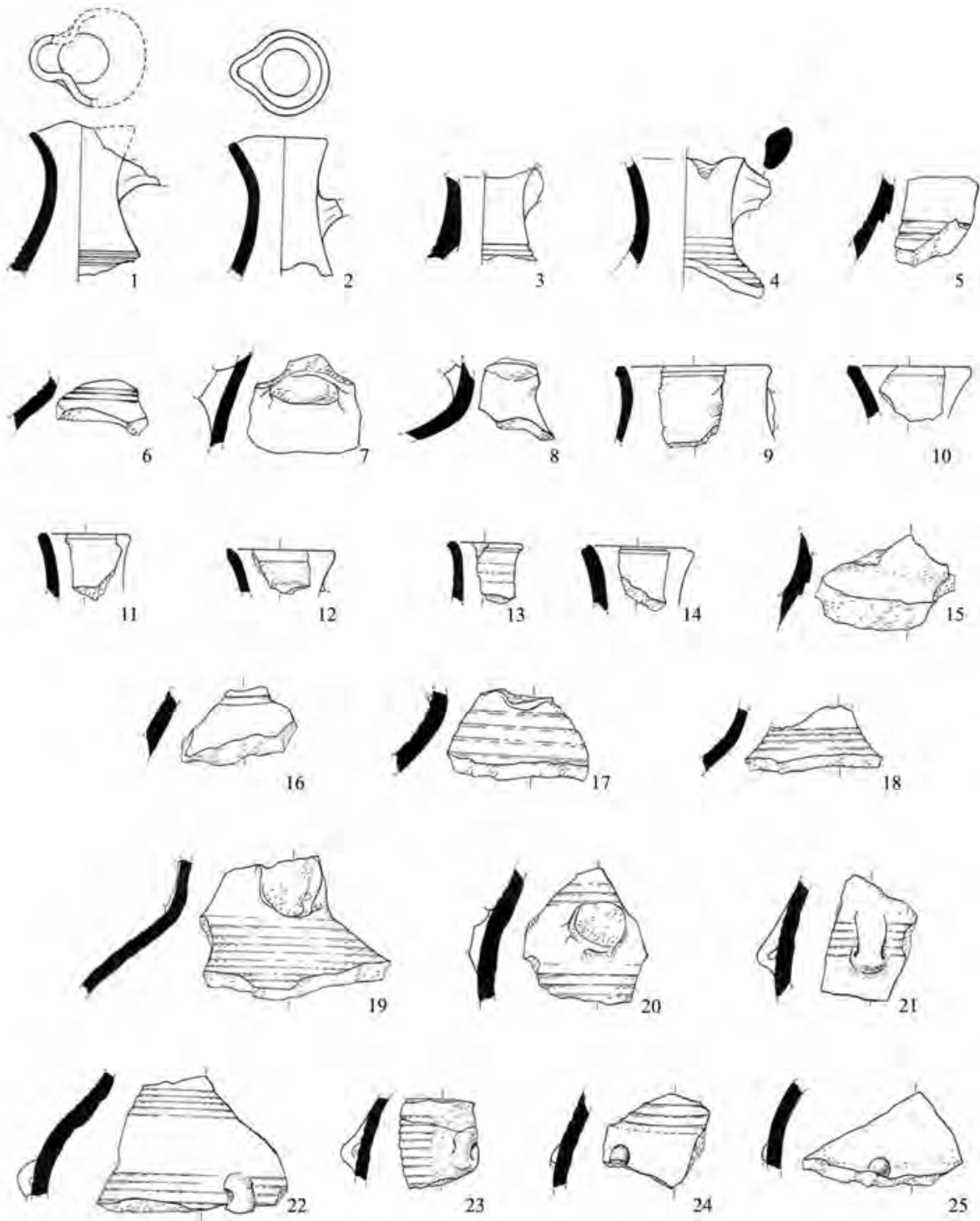

Fig. 10. Fragments belonging to grey jugs 

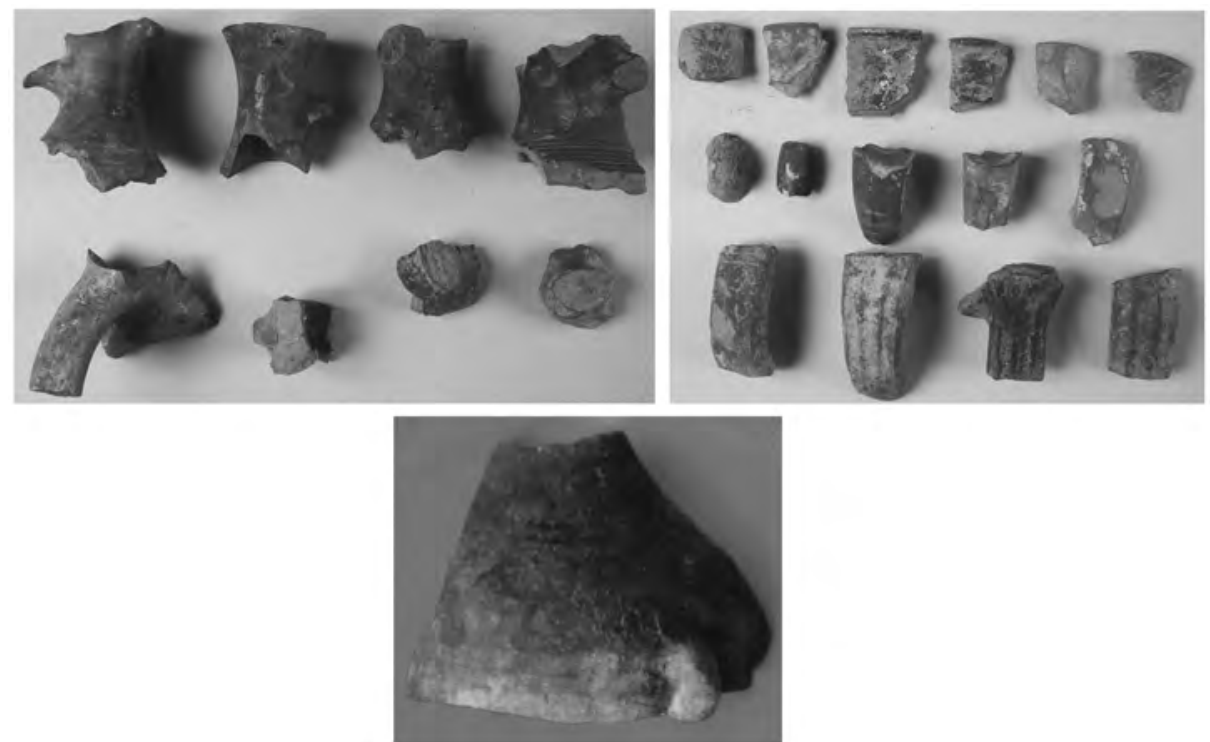

Fig. 11. Fragments belonging to grey jugs
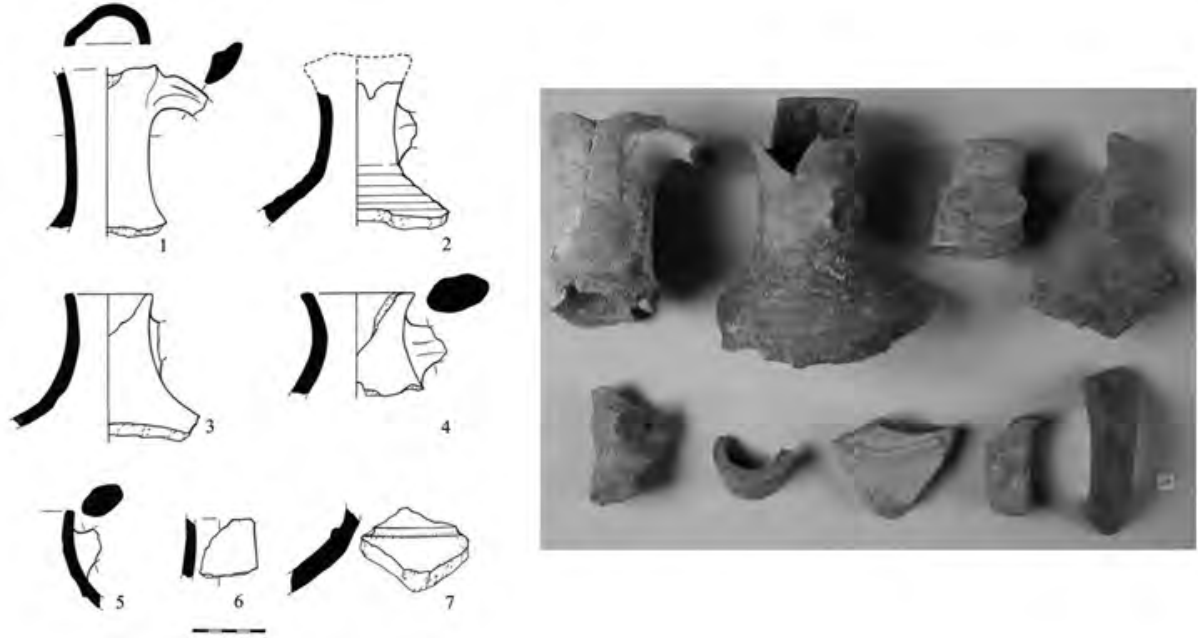

Fig. 12. Fragments belonging to yellow jugs 

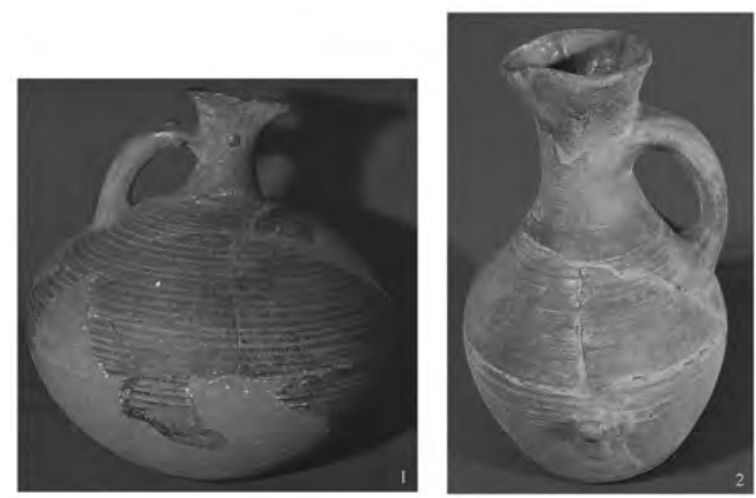

Fig. 13. Jugs. 1. Mound XXXIII in Pliska; 2. cemetery at Novi Pazar; 3-4. cemetery at Kjulevča
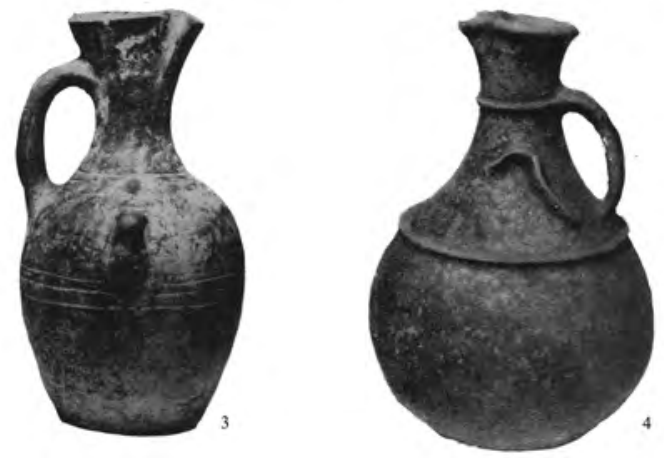

be established more precisely and, though few in number, three different types may be distinguished. The dishes of the first type have a spherical body and according to the rim shape could be further divided into five variants. The shoulders of the second type are bigger in diameter than the rim and their body narrows abruptly towards the bottom. The dishes of the third type are characterised by their bi-conical body. The vessels are of grey or grey-black colour, these of Type II dark yellow and ochre.

\section{Storage ware}

Storage ware can be divided into storage jars and amphorae. The storage jars look exactly like the cooking pots, only being bigger in size. The fragments of such vessels are numerous; coming in a considerable number from the fifth layer of the large trench (sections 4-10). It seems possible that they were ordered if required or were used in the nearby smithies.

The storage jars of the first group are made of clay mixed with sand or other tempering materials. The rim diameter measures from $18-24 \mathrm{~cm}$ and the wall thickness 


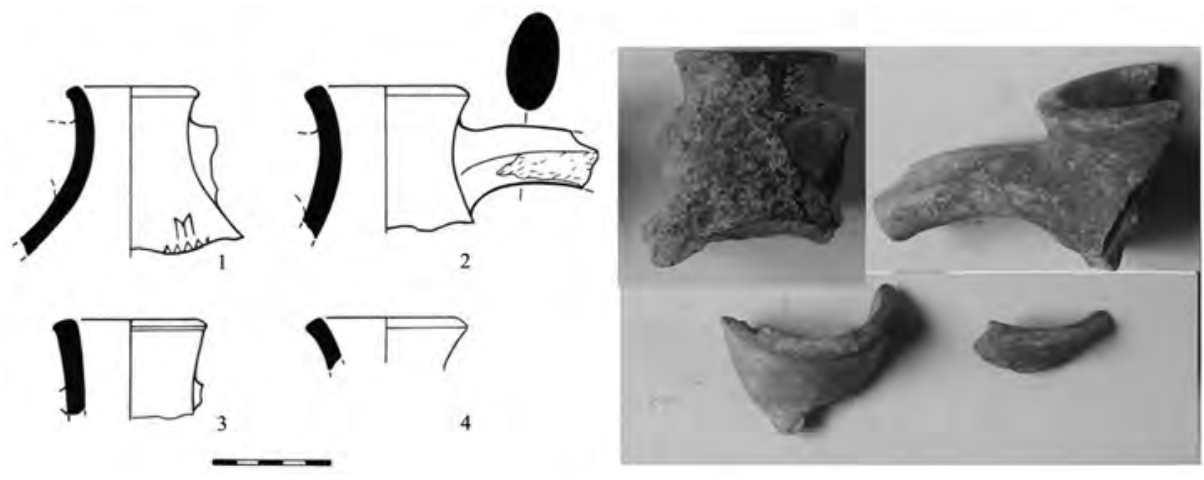

Fig. 14. Fragments belonging to amphora-like flagons

from 1.2-1.4 cm (Fig. 18.1-5). A number of fragments coming from different sections and depths may be distinguished - they are characterised by the good quality of firing, a yellowish to light brown colour and, above all, by the presence of a large quantity of feldspar inclusions in the clay. The great amount of tempering material most likely had the purpose of preventing any deformation of the vessels during modelling and firing.

The storage jars of the second group prevail (Fig. 18.6-14, Fig. 19). They are made of pure clay and were fired in a reducing atmosphere. Most of them are excellently formed on an improved potter's wheel, turned by hand or even by foot. One bottom piece with yellow-brown colour bears a relief mark in form of a circle on the outside; at the same time four concentric circles (traces from the potter's fingers) are to be seen on the inside (Fig. 19.2), which are a result of the high rotation speed of the wheel. Such specimen are of great importance because they illustrate in a good way the transition from the slow, hand-rotated potter's wheel, towards the fast, foot-rotated one. The decoration consists of various ornaments (Fig. 8.1-4, 6-22, 29-40). The firing quality is very good - the colour of the fragments is even on the surface and in the cross section. Apart from grey storage jars there are also those of yellow or yellow-brown colour. In some cases even the shape of the vessels could be restored. There are jars resembling the three complete specimens from Mound XXXIII (Fig. 21.1), with others having two handles and rounded bottoms (Fig. 18.11-12). It is to be noted that there are also defect pieces which are a product of bad preparation of the clay or failure during the firing process.

The fragments of amphorae are of a considerable number (Fig. 20) and either of dark (grey, grey-black) or light colour (yellow, yellow-brown, brick red). There are parts of walls, rounded bottoms and handles. One bottom is narrow, massive and conical in shape. Two pieces belonging to one and the same vessel were found at different depths (layers 6 and 7) in section 7d. The lip and part of one handle were broken, but the neck and the other handle remained intact; on these parts some signs were incised after firing 

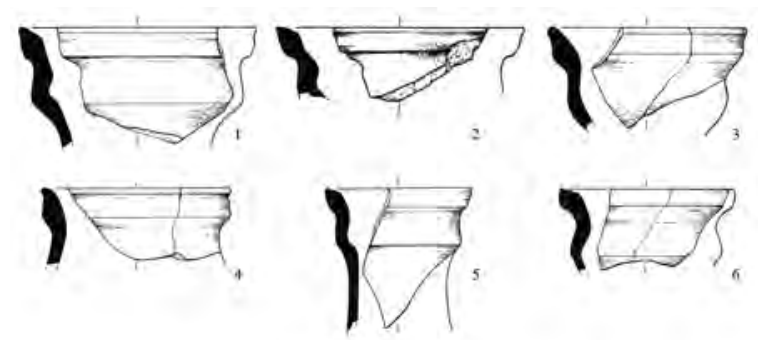

Fig. 15. Luxurious pottery. 1-8. rims belonging to one- or double-handled flagons; 9-10. spout fragments belonging to spouted vessels
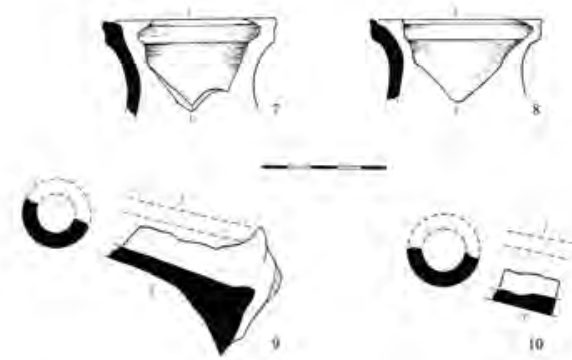

(Fig. 20.1, Fig. 21.3). The surface of this vessel was smoothened; the resulting specimen closely resembling a restored amphora from the secret passage at the so-called Krum palace, $42 \mathrm{~cm}$ in height. ${ }^{15}$ Another specimen coming from layer 10 in trench 14 looks very much like the amphorae from Mound XXXIII - it displays the same short neck, funnel-like rim and colour. ${ }^{16}$

The various ceramic materials from both trenches is quite fragmentary and was probably discarded there as waste. Nevertheless, this pottery gives important information about the techniques applied by the potters and the usage of these vessels in the household. As usual it also presents good material for dating. As such it shows similarities to the material from other excavation sites in Pliska, e.g. the secret passage at the so-called Krum palace, the earliest buildings in the city centre, the lowest layers along the stone fortress, Mounds XXXIII and XXXIV, as well as from cemeteries of the pagan period, found not far away from Pliska.

The clay material yielded from different outcrops in the vicinity: A large number of fragments, with pale yellow, dark yellow or brown-yellow colour, are made of local high-quality clayey. The same is valid for the luxurious pottery from the secret passage and for the pottery covered with red slip; this material also contains tiny glimmer pieces. A great part of the pots and the storage jars are made from clays of lower quality mixed with sand. Other tempering material like feldspar was also used for a group of pots and storage jars with a yellow-brown colour.

15 Rašev 2004, 80, fig. 21.

16 Henning/Dončeva-Petkova 1999, Cat. No. 50. 


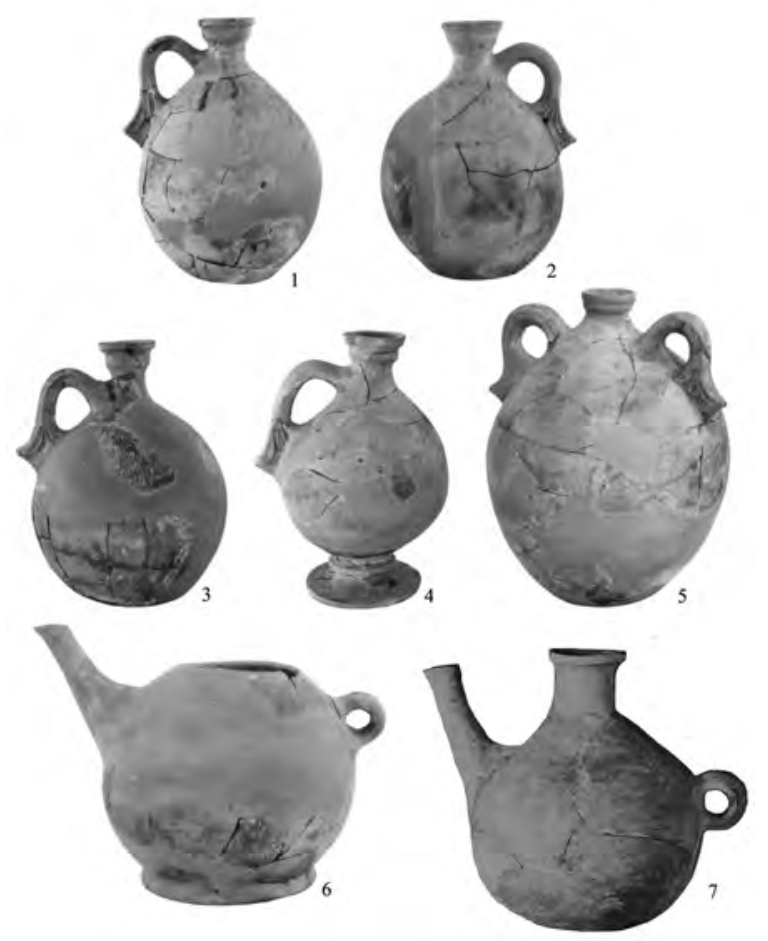

Fig. 16. Luxurious pottery. 1-4. onehandled flagons; 5. amphora-like flagon; 6-7. spouted vessels. 1-6. secret passage at the so-called Krum palace; 7. Mound XXXIII

The vessels made of pure clay and decorated by polishing (pots, jugs, amphora-like flagons, dishes and storage jars) are considerable in number. According to this criterion that kind of pottery from the "industrial quarter" of Pliska shows certain similarities to the material from the settlement and the relevant cemetery near Topola village, Kavarna district and to the bi-ritual cemeteries at Novi Pazar, Kjulevča, Balčik (cemetery 3), Devnja (cemeteries 1 and 3), etc. The vessels are usually grey in colour, but there are also yellow ones - mainly jugs, dishes, storage jars and amphorae.

As it was already pointed out, the prevailing part of the vessels were crafted by means of a slow potter's wheel, rotated by hand. This is primarily indicated by the relief marks and the peripheral rims on the bottoms; further by the hardly visible coils or simply cracks in the walls on the contact points between them or by the inevitable stacking of coils on the inside of jugs' and flagons' necks; finally by the traces from smoothing on the inside and outside surface. The discussed bottom piece (Fig. 19.2) is an example for the usage of an improved potter's wheel, which must have achieved a higher rotation speed. The above mentioned 8 rims, 2 spouts and more than 80 wall pieces, identical with the superior vessels from the secret passage at the so-called Krum palace, are a product of other craftsmen using a fast potter's wheel, rotated by foot. The fact that these fragments were found in such an area outside the fortress walls, where different production activities took place, shows that the workshop, where these vessels were 

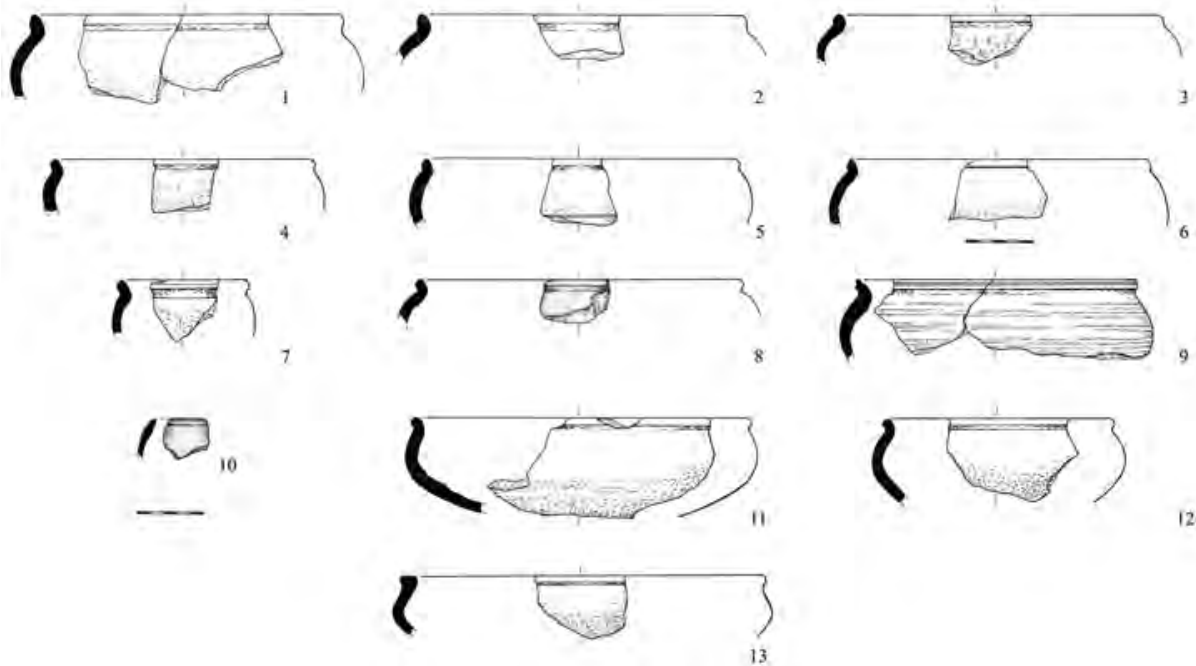

Fig. 17. Fragments belonging to dishes. 1-7, 9, 11-13. from trenches no 4-10; 8, 10. from trench no 14
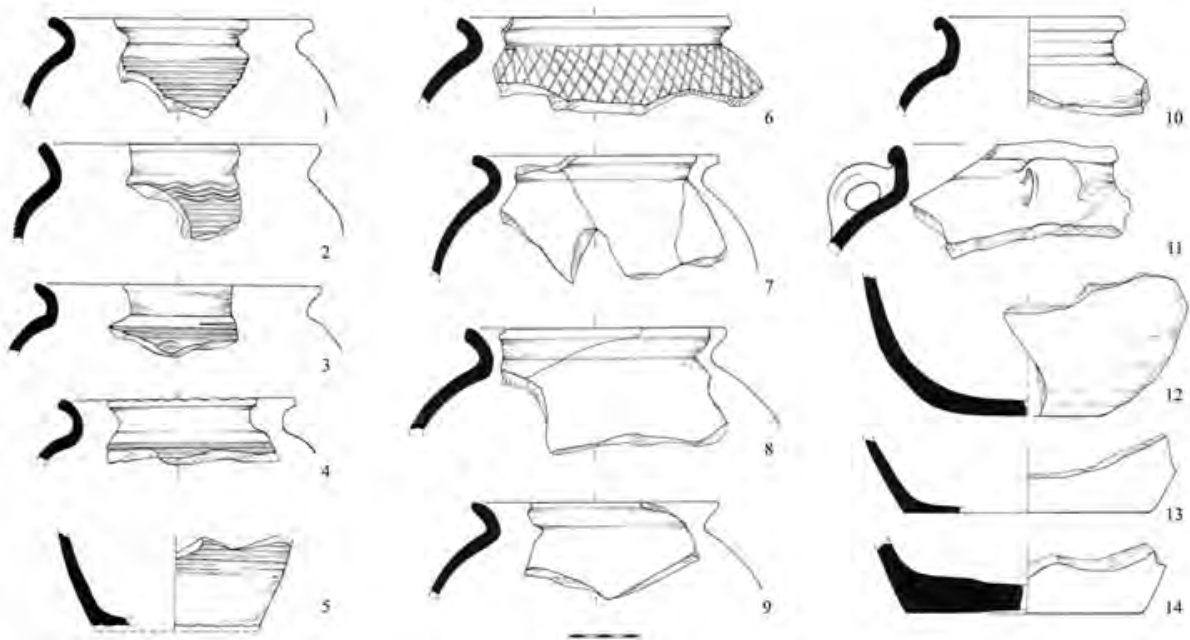

Fig. 18. Fragments belonging to storage jars. 1-5. fragment made of sand-tempered clay; 7-14. fragments made of pure clay and decorated by polishing 

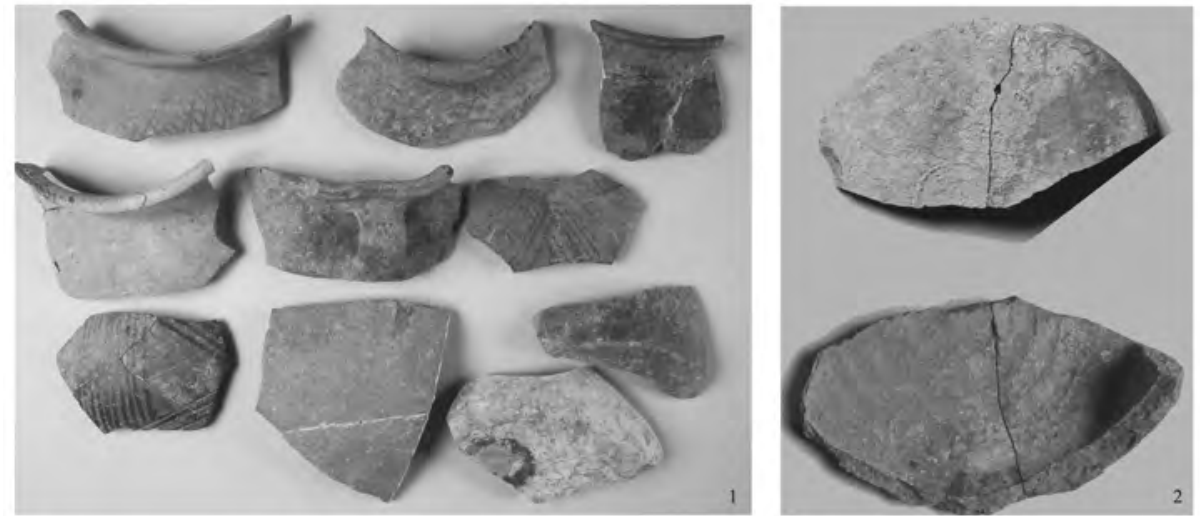

Fig. 19. 1. Fragments belonging to storage. 1. fragments made of pure clay; 2 . bottom piece with a relief mark made on an improved hand-rotated potter's wheel
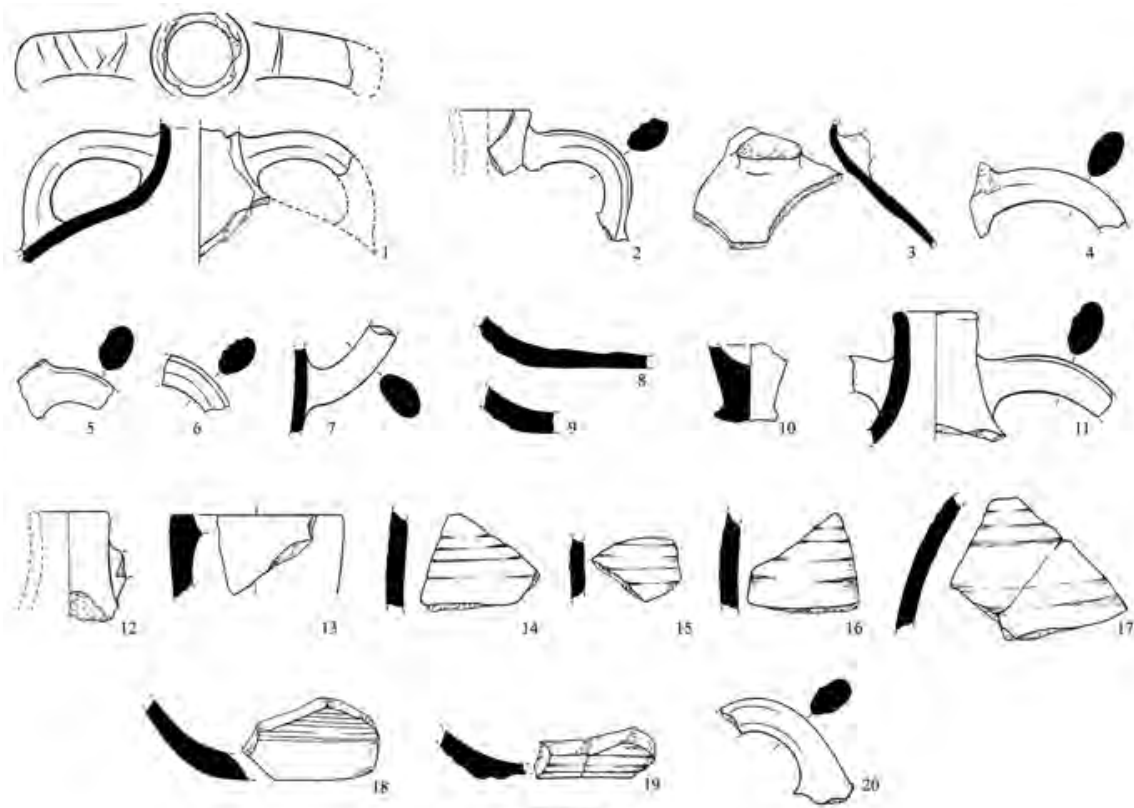

Fig. 20. Fragments belonging to amphorae. 1-10. from trenches no 4-10; 11-20. from trench no 14 


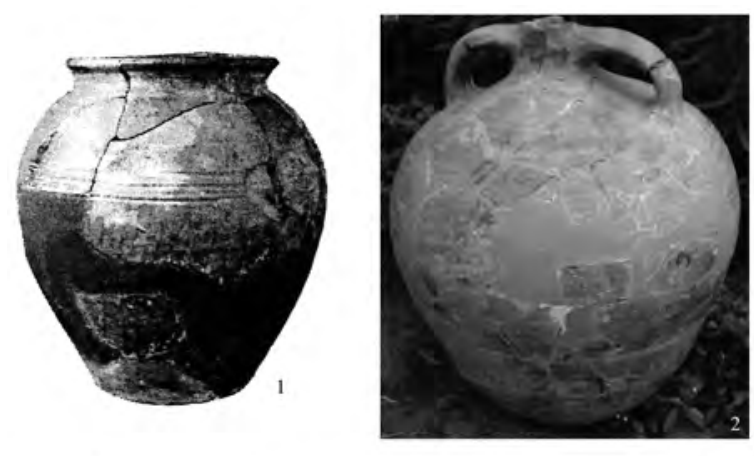

Fig. 21. 1. storage jar from Mound XXXIII; 2. amphora from Mound XXXIV; 3. fragments belonging to amphorae from trenches no 4-10 and trench no 14

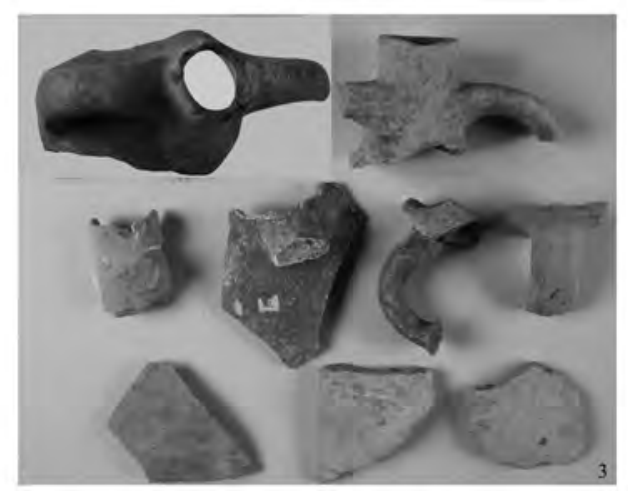

made, was also situated here, on the bank of the Asar dere River. These potters chose and processed the clay material very carefully. Moreover, they excellently mastered the firing process and were familiar with the techniques of glazing and slip covering. In the same or in nearby workshops potters must have worked, making the red slipcovered vessels, which were also thrown on a fast wheel but are more massive and rough in their outside appearance. Apart from this group of pottery there are other vessels crafted on a fast wheel. They were made of pure clay and display a yellow, light brown, ochre red or grey-black colour after firing. The large storage jars and the amphorae also required a high measure of skill; they were tastefully decorated and in most cases also very well fired. Nevertheless, there are also fragments with defects. The production waste is due to bad clay preparation or, mainly, to an unsuccessful firing procedure - resulting in irregular colouring, surface peeling, cracking or crater building (Fig. 22). Such sherds could be described as production waste; they were undoubtedly dumped as being useless.

Undisputedly, most of the clay vessels were locally produced, as it is the case in the settlement at Topola, where the relevant pottery workshop has been excavated. ${ }^{17}$ According to their shape, the vessels from our excavations show a great similarity to

17 Bobčeva 1981, 198-199. 

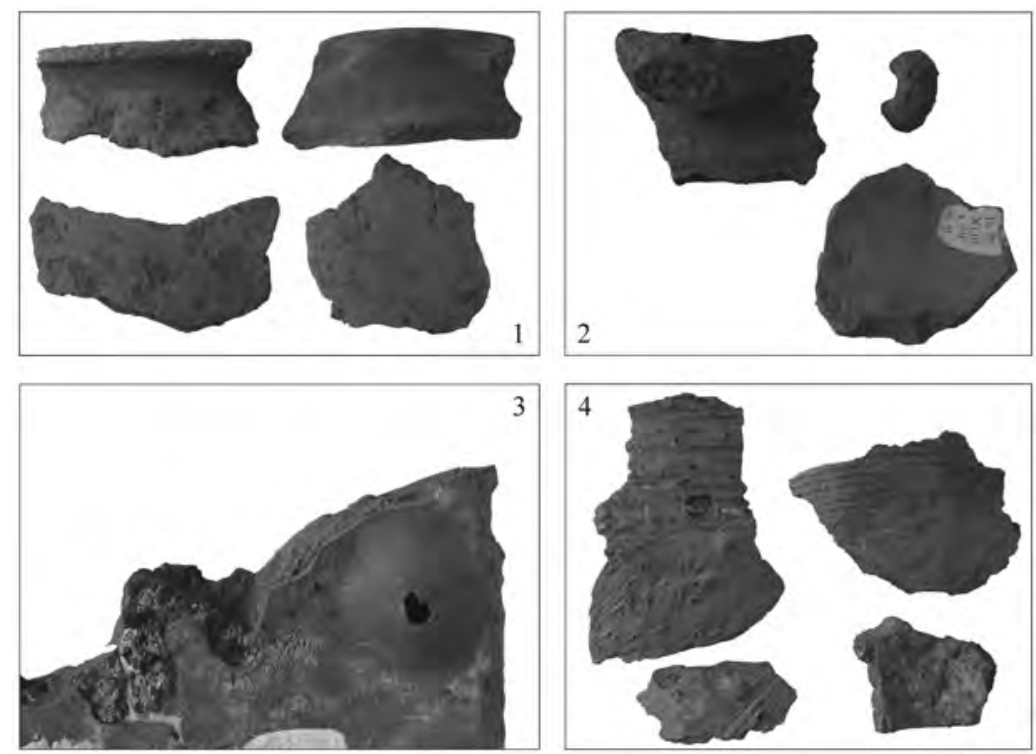

Fig. 23. Production waste

the vessels from the bi-ritual cemeteries of the pagan period. Especially close morphological and decorative relationship exists with the pottery from the nearby cemetery at Kjulevča, possibly indicating further distribution of the ware produced in the workshops in the Asar dere area within the neighbouring region. The intact vessels from this and other cemeteries give us an idea about the shapes of our often fragmentary material. On the other hand, it is sure that the pottery from our excavations was produced for use in everyday life and not as a grave good. Otherwise, storage ware (jars and amphorae), normally not found in cemeteries, couldn't be present here. The luxurious flagons, amphora-like flagons and spouted vessels, which are imitations of metal specimen, were ordered especially and only for the court of the Khan. The problem of the origin of the potters producing them remains difficult because this group of vessels combines different elements. Some of them stay close to the pottery production of neighbouring Byzantium, others to the Late Avar yellow pottery of Middle Europe. However, the features typical for the so-called "new style", which was current in Middle Asia during the seventh and eighth centuries, apparently prevail.

The unearthed ceramics were produced in the same period when intensive smithing activities were practised in this region. Here, to the west of the stone fortress and along the Asar dere River the "metallurgical factory" of Pliska was placed. It is without doubt that the armour for Krum's army "completely dressed in iron" was manufactured here. The vessels from the secret passage are also dated to this period. It was most probably 
burnt down during the campaign of emperor Nikephoros I in $811 .{ }^{18}$ Other dating materials were found in sections 4 and 10, e.g. a bone needle container in section 4a, layer 6 and a fingering with loose ends in section 10a, layer 5. Similar containers are known only from the early pagan cemeteries.

Another observation also deserves our attention. Searching for suitable parallels, it became clear that a lot of the fragments find their exact matches among the vessels from Mound XXXIII, situated not far away and to the northeast of the fortress. The same is true for the fragmentary material found in the core of Mound XXXIV, two amphorae whose lowest parts have been completely restored. These observations could only mean that the materials discovered from 1997 until 2001 were accumulated simultaneously with the erection of this mound. This is covered with a mighty layer of yellow loess, $4 \mathrm{~m}$ thick at its uppermost point. The same sediment was also found in our trenches, within or between the layers of burning. This material is present everywhere on the territory of the former medieval capital, some $0.80-1 \mathrm{~m}$ below the plough horizon. It is quite possible that the earth dug for the foundations of the stone fortress, built just after the demolishing fire in 811, was accumulated on top of Mound XXXIV or was scattered where we found it in our trenches.

(translation: Vasilena Petrova)

\section{Bibliography}

Bobčeva 1981: Любка Бобчева, „Прабългарско селище при с. Топола, Толбухински окръг“, in: Плиска - Преслав 2, София 1981, pp. 198-201.

Dimitrov 2003: Янко Димитров, „Наблюдения върху битовата керамика на обект 31 в Плиска“, in: Плиска - Преслав 9, Шумен 2003, pp. 181-221.

Dončeva-Petkova 1973: Людмила Дончева-Петкова, "Ранносредновековни ангобирани съдове“, in: Археология 15/3, 1973, pp. 14-20.

Dončeva-Petkova 1977: Людмила Дончева-Петкова, Българска битова керамика през ранното средновековие (втората половина на VII - края на Х в.), София 1977.

Dončeva-Petkova 1979: Людмила Дончева-Петкова, „Западната крепостна стена в Плиска (проучвания на южния сектор през 1973 и 1974 г.)“, in: Плиска - Преслав, 1, София 1979 pp. 81-97.

Dončeva-Petkova 1992: Людмила Дончева-Петкова, „Региональные варианты древнеболгарской керамики“, in: Четвърти международен конгрес по славянска археология: Доклади и съобщения 1, София 1992, pp. 496-517.

Henning/Dončeva-Petkova 1999: Йоахим Хеннинг/Людмила Дончева-Петкова (Eds), Първопрестолна Плиска: 100 години археологически проучвания, Франкфурт на Майн 1999.

Georgiev/Vitljanov 2001: Павел Георгиев/Стоян Витлянов, Архиепископията -манастир 6 Плиска, София 2001.

18 Mijatev 1943, 117, 129. 
Mavrodinov 1948: Никола Мавродинов, „Разкопки и проучвания в Плиска“, in: Разкопки и проучвания 3, 1948, pp. 159-170.

Mihajlov 1955: Стамен Михайлов, „Археологически материали от Плиска (1948-1951)“, in: Известия на Археологическия институт 20, 1955, pp. 49-181.

Mijatev 1943: Кръстю Миятев, „Крумовият дворец и други новооткрити постройки в Плиска“, in: Известия на Археологическия институт 14 (1940-1942), 1943, pp. 71 135.

Milčev 1960: Атанас Милчев, „Археологически разкопки и проучвания в местността Асардере - Плиска, през 1959 г.“, in: Годишник на Софийския университет. Философско-исторически факултет 53, 1960, pр. 33-66.

Milčev 1985: Атанас Милчев, „Разкопки и проучвания на южната порта в Плиска“, in: Плиска - Преслав 4, София 1985, pp. 16-43.

Rašev 1985: Рашо Рашев, Плиска: Пътеводител, Шумен 1985.

Rašev 2004: Рашо Рашев, „Керамични съдове от подземния ходник на Крумовия дворец в Плиска“, in: Плиска - Преслав 10, Шумен 2004, pp. 61-100.

Stančev/Ivanov 1958: Станчо Станчев/Стефан Иванов, Некрополът до Нови пазар, София 1948.

Bălgarite 2004: Българите и техните съседи през $V-X$ в. Каталог към изложба, Варна 2004.

Văžarova 1976: Живка Въжарова, Славяни и прабългари по данни на некрополите от края на VI-XI в. на територията на България, София 1976. 


\title{
The early medieval yellow pottery from Pliska, Bulgaria: the question of its provenance and the problem of its origin
}

\author{
Vassilena Petrova
}

Recently undertaken archaeometric study of the early medieval yellow pottery from Pliska ${ }^{1}$ gave reasons to revise the question of its provenance and called for a new elaboration on the problem of its origin. To begin with, a clear differentiation, missing in most of the publications on the topic, between the terms in use is needed. The question of provenance - was it locally produced or not? - has only one possible answer; whereas the problem of origin - where did the tradition come from? - is more complex. It could even have no clear answer or be a combination of several answers.

In the present contribution the already formulated ideas and theories about the provenance and origin of the yellow pottery from Pliska will be discussed, trying to apprise the plausible ones. The main task will not be to give new answers, but, above all, to try to properly formulate the question(s) and to give the correct direction of research. The notes on terminology, which go through the whole analysis, are not only a secondary issue, but also an unavoidable requirement for a right starting point.

\section{The 'secret passage' group}

Translated into different languages - 'sárga kerámia' (Hu), 'žlatá keramika' (Sk), 'gelbe Keramik' (G), 'жута керамика' (Sr), 'la céramique jaune' (Fr) - the term 'yellow pottery' has become current in specialised literature for naming a certain early medieval fast-wheel pottery, which was spread in the Carpathian Basin in the late Avar Period. ${ }^{2}$ Jovan Kovačević criticised the term with the argument that not all vessels indeed were actually yellow. ${ }^{3}$ However, the expression could not be considered as inadequate, provided that it is regarded as a terminus technicus combining a wide spectrum of shared characteristics, e.g. composition of the clay, technique, form, decoration, function,

1 The project is being realised as a $\mathrm{PhD}$ work at the J. W. Goethe-University of Frankfurt/ Main (Petrova, forthcoming); some preliminary information in Petrova/Brey 2005.

2 Bialeková 1967; Garam 1969a; Vida 1999, 83.

3 Kovačević 1977, 183. 
distribution, dating and origin. Although none of these should be underestimated, the technological features always play the leading role in the relevant modern classifications. $^{4}$

Drawing parallels to the late Avar yellow pottery, some $\operatorname{archaeologists}^{5}$ call in the same way the spouted jar found by Geza Fehér in Mound XXXIII ${ }^{6}$, to the north-west of the stone fortress of Pliska and the flagons ${ }^{7}$ and spouted jars (Fig. 1, left) that came to light in 1979 during Rašo Rašev's excavations of the 'secret underground passage' connected with the so-called Krum palace ${ }^{8}$, to the south of the citadel. If it is further necessary to differentiate them they will be referred to as 'secret passage' vessels.

Preferring on good grounds the description 'ceramic set' instead of 'collective find', R. Rašev regards these specimens as a new constituent of the tableware, as a separate ceramic group marked by a uniform technology, typology and decoration ${ }^{9}-\mathrm{a}$ classification act, which I here intend to argue against. Later on, an attempt will be made at convincing the reader of its tenability.

G. Fehér only gives a drawing of the spouted jar from Mound XXXIII next to a well-matching find from the cemetery by Györ, Hungary, without further commenting this relationship. ${ }^{10}$ In 1948, Stančo Stančev supplied the first scientific description of the vessel. ${ }^{11}$ Although the form looked strange to him, he classified it as belonging to the group of grey pottery with polished decoration. The author points out that in Hungarian archaeology this form is considered as Avar by origin, but he is convinced that the vessel from Pliska, similar to grey pottery, is a product of the Proto-Bulgarian ${ }^{12}$ ceramic tradition.

4 Vida 1999, 26-27; Dimitrov 2003, 183.

5 Angelova 1984, 93; Balabanov 1983, 71-73; Stanilov 1997, 210; Fiedler 1999, 156.

6 Dončeva-Petkova in this volume, fig. 16.7; Catalogue of finds from Pliska, in this volume, Cat. No. 48, pl. V.48.

7 Here a differentiation between 'flagon' - high and closed form with round mouth and one or two handles - and 'jug' - one-handled vessel with spouted mouth - is made. In Bulgarian archaeological literature, the word for jug ('кана') is often used for the 'secret passage' flagons, which is terminologically not precise. R. Rašev shares the same opinion albeit clinging to ethnographical definitions: Rašev 2004, 69.

8 Rašev 2004; Dončeva-Petkova in this volume, fig. 16.1-6; Catalogue of finds from Pliska, in this volume, Cat. No. 5, pl. I.5.

9 Rašev 2004, 61, 65.

10 Fehér 1940, 106, fig. 73. The strong cultural impact of the Proto-Bulgarians upon the Hungarians (Magyars) is a leitmotif of this and other works of his and reflects the pre-war scientific tendencies.

11 Stančev 1948, 232-233, fig. 2.14.

12 'Proto-Bulgarians' is a strongly criticised scientific invention, which should differ between the Bulgarians of Asparuch and the later formed Bulgarian nation. 

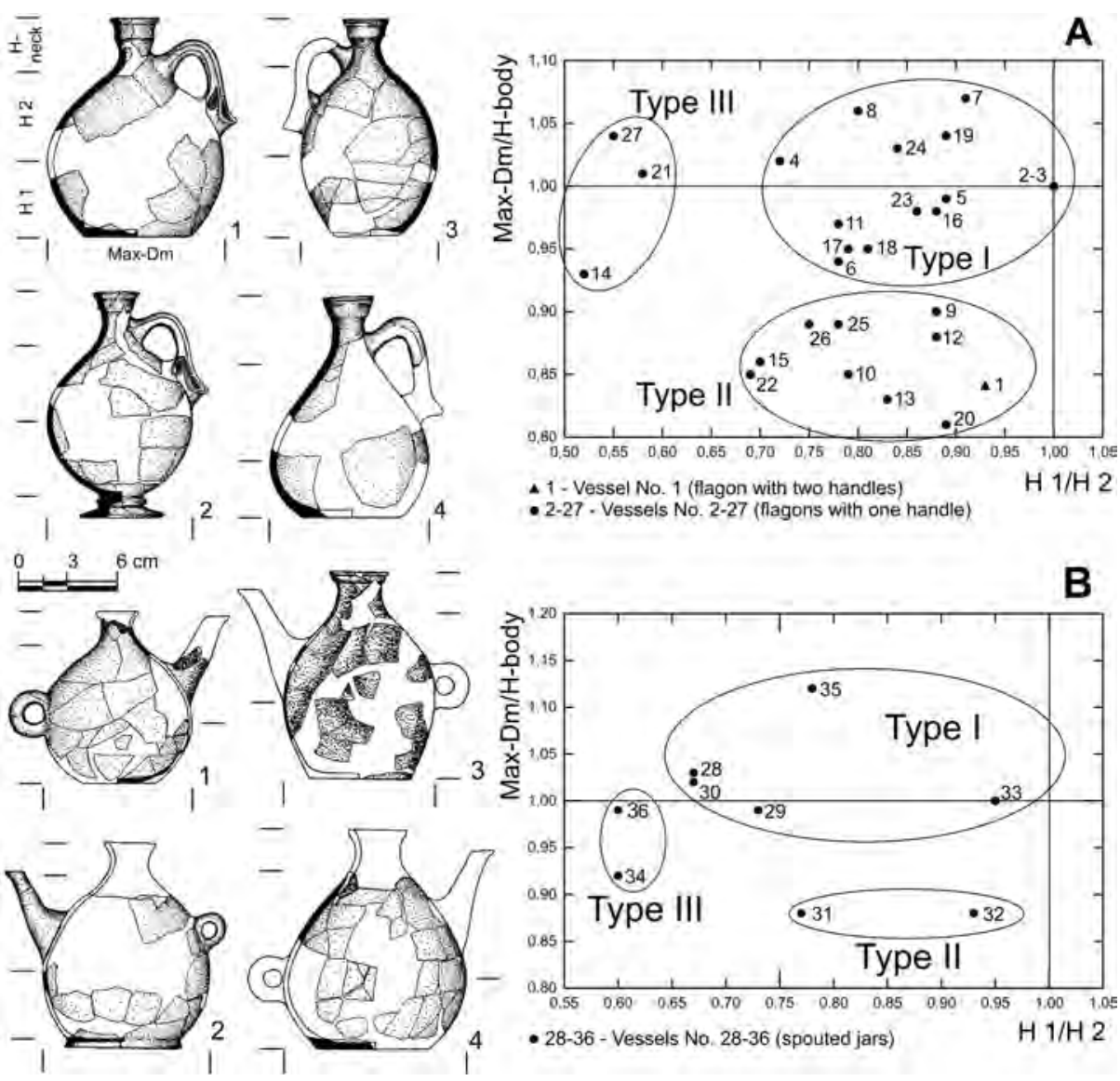

Fig. 1. Typology of the yellow pottery: the vessels from the 'secret passage'. A - Correlation between the main body parameters of the flagons. 1. Type I (vessel No. 7; 2). Type I with pedestal foot (vessel No. 2 ); 3. Type II (vessel No. 20); 4. Type III (vessel No. 21); B - Correlation between the main body parameters of the spouted vessels. 1. Type I (vessel No. 28); 2. Type I with ring base (vessel No. 30); 3. Type II (vessel No. 31); 4. Type III (vessel No. 36); H1 - lower part of the body; H2 - upper part of the body; $\mathrm{H}$ - height of the body without the neck; Max-Dm - maximal diameter

In her classification of the early medieval household pottery from Bulgaria, Ljudmila Dončeva-Petkova attributes the jar to the group of the tableware,,$^{13}$ comparing it further to the spouted vessels from Transylvania ${ }^{14}$ and the cemetery at Nové Zámky (graves No. 176 and 236). Later on she includes the vessel in her compilation work on

13 Dončeva-Petkova 1977, 77 and 178, Cat. No. 247, fig. 20.247 and pl. XVIII.247.

14 Fig. 7 in the publication of Moreşti in Studii şi Cercetări de Istorie Veche, 1-2, 1954, p. 214, to which L. Dončeva refers, shows fourth to sixth century grey pottery and no spouted vessel. 
Proto-Bulgarian ceramics in Bulgaria, ${ }^{15}$ manifesting in this way her opinion about its ethnical affiliation. As a source for comparable but formally and technologically not absolutely identical parallels from the territory of Hungary and Slovakia, one of the publications on the yellow pottery in the Carpathian Basin available since $1967^{16}$ is here already taken into consideration, but erroneously together with a work on the so-called grey pottery from the early Avar cemeteries. The spouted jars belonging to the latter ${ }^{17}$ are by no means relevant for this problem.

At this early stage of research the opinion on the Proto-Bulgarian origin of this single spouted jar dominates for different reasons. The relationship to the late Avar yellow pottery is more or less correctly established, but the comparison failed to go any deeper. How did this relationship look for the Avar specialists?

In the course of the 1960s, É. Garam (Hungary) and D. Bialeková (Slovakia) worked almost simultaneously and independently of each other on the problems of the technology, typology, distribution, production and origin of the yellow pottery in the Carpathian Basin. Searching for parallels, É. Garam finds technologically similar yellow vessels in the publications of the cemetery at Novi Pazar, some $5 \mathrm{~km}$ to the east of Pliska. ${ }^{18}$ For her the yellow vessels from Bulgaria remain strange in their surrounding milieu, in the same way as those in the Carpathian Basin. According to her, the existing similarity between both groups goes back to their common Asian origin.

É. Garam and D. Bialeková made a critical revue of the hitherto quite contradictory theories on the origin of the yellow pottery. ${ }^{19}$ They deny its local evolution rooting on still existing Roman traditions in the former province of Pannonia, as well as its origin in the Caucasus area, and searched for the place of its development within the frontiers of the West-Turk Khaganate, in the Semirechye. According to them, the know-how was brought to the Middle (and Lower) Danube as a result of migration caused by the fatal crisis for the existence of the Khaganate in the last third of the seventh century.

15 Dončeva-Petkova 1990,86 , note 40 , pl. 6.2. This contribution is only a slightly updated German translation of a work from 1981, published in Pliska-Preslav 2, 160-169; both of them strictly follow the structure of her 1977 monograph. This gave me reasons to regard it as belonging to this research phase.

16 Bialeková 1967.

17 Bialeková 1968b, 205-208.

18 Garam 1969b, 160 and note 7; Garam 1969a, 240 and note 109. Before then, Ilona Kovrig drew the same comparison: Kovrig 1963, 240 and notes 1035-1036. It was rather the general outlook than the technical characteristic of the vessels, which might have struck them: While the spouted jar from Mound XXXIII (Stančev/Ivanov 1958, fig. 9.4) is technically comparable, the bowl from Madara (Stančev/Ivanov 1958, 72 and fig. 15.3) belongs to the grey pottery with polished decoration and only formally resembles the specimens from Szebény (Gold der Awaren 2002, 95, fig. 19B) and Jánoshida (Bialeková 1967, 20, fig. 17.4) Tibor Horváth $(1935,79)$ makes a similar mistake when drawing parallels to the glazed cups with ring handles found in Pliska (Škorpil 1905, 305 and pl. LXc.1-3).

19 Bialeková 1967, 40-41; idem 1968a, 27-28; Garam 1969b, 160-162, see also Bóna 1971, 323. 
Only the number of the newcomers is appraised differently - either simply a group of crafts- or tradesmen, ${ }^{20}$ or a larger migration wave. ${ }^{21}$ The discrepancy is noteworthy, ${ }^{22}$ but, in my opinion, not significant enough concerning the mechanism of this historical process. ${ }^{23}$ To understand their argumentation we have to pay attention to the scientific tendencies at that time: É. Garam and D. Bialeková were equally convinced that the answer to this highly controversial question was immediately connected to the general issue of the sudden (sic!) change of the material culture in the Carpathian Basin, which found its outmost manifestation in the displacement of pressed-bronze manufacture by cast-bronze production. They followed the understandable logic that a simultaneous appearance of two or more phenomena should correspond to a common 'land of birth'. The establishment of the three-stage subdivision of the Avar era (early, middle and late Periods) has led to the theory of a third migration wave at the end of the middle Avar Period, dated from around the middle until the end of the seventh century. Here it shall suffice to mention that the Central Asia-idea was only one of the proposed theories. ${ }^{24}$

In Bulgaria, the interest towards this special kind of pottery awoke anew after the discovery of the vessels from the secret passage. Apart from exhibition catalogues and tourist guides, until recently only two author's works threw more light on them. ${ }^{25}$ For our purpose it is necessary to repeat Rašev's most important conclusions:

- The vessels were hidden there in a moment of danger, most probably just before the devastating assault of Byzantine emperor Nicephorus I (802-811) against the residence of Khan Krum in 811.

- The extraordinary good quality of this ceramic set makes R. Rašev believe that it was in possession of the Bulgarian Khan Krum (802-814) or one of his predecessors and was used for official occasions at the court.

- The set could only have been imported from a central Byzantine (Constantinopolitan) atelier specialised in the production of non-standardised ceramics, therefore it was very expensive and affordable only to a limited number of consumers. Only the lack of suitable Byzantine parallels fails to allow R. Rašev to be absolutely sure. He further

20 Bialeková 1968a, 30.

21 Garam 1969b, 162.

22 Bóna 1971, 323.

23 In a later work, D. Bialeková writes about tribes or groups from Central Asia, which presumes the arrival of more than only several employers: Bialeková 1973, 326. As István Bóna hints, this must surely go back to differences between the Hungarian and the Slovakian archaeological schools: Bóna 1971, 323.

24 Summary by Pohl 2002, 283 and endnotes 20-25; Bálint 1989, 149-150.

25 The first one (Rašev 1981, 2) is a short report in a regional newspaper with only a very limited distribution. The second one (Rašev 1983, 261 and 263, pl. 3.5) is a contribution to the International Symposium on the Ancient History and Archaeology of Bulgaria at the University of Nottingham, organised in 1981 by Andrew Poulter but the information therein is quite sparse. 
mentions the similarity of Pliska's flagons to the golden vessels from the Nagyszentmiklós Treasure (Sînnicolaul Mare, Romania) under the presumption that such metal works very often served as models for the potters.

Stefka Angelova opposed his theor ${ }^{26}$ with the following arguments: the production of the Byzantine ateliers in this and in earlier periods was highly standardised and the few exceptions had a rather regional area of distribution; there are no parallels among Byzantine pottery, neither for the feet and the extended lower ends of the handles of the flagons, nor for the spouted vessels. She returned to the relationship between the late Avar yellow pottery and the 'secret passage' vessels and, using the 1967 work of D. Bialeková, analysed their similarities and their differences. According to S. Angelova, there are two possible scenarios for the appearance of this kind of pottery in Pliska:

- At the end of the seventh century, a group of Central Asian craftsmen settled on the Lower Danube together with the Proto-Bulgarians. They - or more likely their successors - worked according to the so-called "new style ${ }^{27}$ of pottery making, the main characteristic of which is the imitation of metal ware. The strong impact of the local tradition led to deviations from the initial models, to innovations in the form range and the decoration and hence to differences between the yellow pottery at the Lower and Middle Danube.

- Native potters - belonging to the local Byzantine population - made the set from the secret passage. They will have worked by order and probably used metal vessels as models. This may explain their uniqueness, the lack of standardisation in size and decoration, as well as the singular act of their production.

Reading her lines one feels that S. Angelova's sympathises with the second version, nevertheless she does not express this directly, preferring to leave this difficult decision to the time after the scientific publication of the material.

For a second time the theory of R. Rašev was opposed by Todor Balabanov. ${ }^{28} \mathrm{He}$ was not able to find a plausible explanation why this pottery, provided that it has been an item of import, disappeared after the demolition of the passage. It seems hardly believable to him, if still produced outside the borders of Bulgaria, that the succeeding Khans would have done without such a luxurious product. T. Balabanov follows the idea of D. Bialeková and hence, the first variant of S. Angelova.

26 Angelova 1984, 91-94.

27 The expression was used by B. Maršak (Maršak 1961, 178). It stands for the sudden change, which the spectrum, surface treatment and decoration of the tableware in Central Asia (Sogd, Semirechye, North Tokharistan, etc.) underwent at the end of the seventh century, continuing until the beginning of the ninth century. It emerged on the basis of well-developed short- and long-distance trade and the existence of an urban culture with a wealthy aristocracy (Maršak 1961, 200; Srednjaja Asia 1999, 72).

28 Balabanov 1983, 71-73. 
Meanwhile our knowledge of the material culture of the Avar Khaganate has been dramatically improved. While there are still protagonists of the migration theory - among these the later É. Garam and D. Bialeková - modern studies strongly doubt the existence of the already-mentioned third wave. ${ }^{29}$ According to Walter Pohl movements on their own account of a smaller or larger number of people, which can never be excluded, could have influenced the process of exactly this cultural change but could not have been the actual reason for it. However, nobody denies the similarities between the late Avar culture and the Central and Middle Asian materials, including the yellow pottery; the explanation for them seems to be more complicated than simply a migration of people (e.g. economic developments, fashion trends, trade, presents, etc.). For my particular approach the dynamic system of connections between distant parts of the world at that time is of great importance. The Bialeková/Garam-theory of the origin of the yellow pottery should be revised in the light of the new scientific information, but this is only possible within an exhaustive analysis of the late Avar ceramic material, like the one currently being prepared by T. Vida. I personally share the opinion that Central Asian parallels are not sufficient proof and that not more than stimuli for the production could have been drawn from somewhere else. ${ }^{30}$

Being familiar with the publications of É. Garam (1969a) and D. Bialeková (1967), Stanislav Stanilov also thinks that the yellow pottery at the Lower and Middle Danube is of Asiatic origin. In contrast to R. Rašev, S. Angelova and T. Balabanov, he elaborated on a different possibility, that is to say that without doubt, the yellow pottery was not produced on the Lower Danube but was rather brought from the Avar Khaganate by means of peaceful contacts, or even sporadic penetrations of the Avar population, than by military conflict. ${ }^{31}$

The hypothesis of Atanas Milčev that the vessels from the secret passage are late antique materials dating from the fourth to sixth century should only serve to complete the picture. ${ }^{32}$

To recapitulate: After Rašev's discovery, three different places of provenance for the secret passage vessels were suspected - Constantinople/Byzantium, Pliska/Bulgaria and the Avar Khaganate. The arguments for the second location seemed quite plausible (S. Angelova), only the absence of exact parallels either in Byzantium or the Avar Khaganate providing a satisfactory argument. However, the lack of direct evidences

29 Bóna 1985, 15-18; Bálint 1989, 168-175; Tomka 1989; Pohl 2002, 282-287 with literature; Daim 2002, 307-321.

30 "Höchstens Anregungen zur Produktion mögen von außerhalb gekommen sein": Fiedler $1992,156$.

31 Stanilov 1997, 209-210.

32 Milčev 1990, 81. A. Milčev was a strong protagonist of the idea that some of the buildings in Pliska were constructed in the Late Roman Period. His assertions are strongly criticised and do not find support anymore: Rašev 1995, 10-11 with literature. 
(waste and/or pottery kilns) for on-place manufacture left the question open. The main task of the mentioned archaeometric study was, therefore, to search for such evidence while comparing ceramic samples to clay deposits from the vicinity of Pliska. The results of the chemical and mineralogical analysis showed that the 'secret passage' vessels were imported neither from Byzantium, nor from the Carpathian Basin, but had been locally produced.

Working independently from each other on the ceramics from the Bulgarian-German excavations (1997-2001) in the Asar dere area, to the east of the stone fortress of Pliska, L. Dončeva-Petkova and I have sorted out such fragments which are visually identical to those found by R. Rašev. ${ }^{33}$ They came mostly from trenches No. 4-10, situated near Mound XXXIV, one sherd was from trench No. 14. Among these there are pieces of grey, grey-black or black colour, exactly like the fragments from the secret passage, which were found there only due to the fact that the passage was abruptly burnt down, collapsing over the fragile vessels. Nevertheless, the studied fragments cannot be categorically determined as products of unsuccessful firing, as L. Dončeva-Petkova believes: They were disposed as useless waste, but are themselves not necessarily production wasters.

The answer to the question "under what circumstances did such fragments come to this place?" depends on the interpretation of the archaeological situation in the Asar dere area. According to Joachim Henning and L. Dončeva-Petkova, a large industrial quarter was situated there in the eighth and ninth centuries where a variety of highly specialised handcrafts were practised. ${ }^{34}$ J. Henning was the first to suppose that the 'secret passage' vessels were produced somewhere in the vicinity. ${ }^{35}$ The archaeological circumstances and the results from the chemical analysis gave L. Dončeva-Petkova even better reasons to believe that the workshops for these ceramics were situated along the Asar dere River, and only the enormous changes in the landscape ${ }^{36}$ and the limited scale of the opened trenches make the task of discovering them rather difficult. No doubt could be cast upon the existence of vivid production activities there - the various production wastes verify it - but it the possibility should be kept in mind that the vast area around these only indirectly predictable ateliers - during the excavations not

33 L. Dončeva-Petkova has prepared a special report on the material: Dončeva-Petkova, in print. I would like to thank her for discussing with me her observations and allowing me to use the manuscript. See also the brief remarks about this in her contribution in this volume, fig. 1 and 15 .

34 Henning 2000a, 75-77; Henning 2000b, 10-11; Dončeva-Petkova in this volume.

35 Henning 2000b, 11.

36 Intensive erosion processes resulted in the accumulation of one immense colluvial stratum, which overlays the earlier layers: Henning 2000a, 77, fig. 2C; at the end of the 1950s an irrigation dam was built on this place, destroying numerous archaeological structures: Milčev 1960a, 30 and idem, 1960b, 33-35. 
even one relevant production facility from the period was revealed - might well have been used as a rubbish dump. ${ }^{37}$ The idea that destruction materials and wastes from the city centre could have been disposed somewhere at this location had been supposed earlier by Stamen Michajlov in connection with his excavation of an analogous context to the west of Mound XXXIV and near the river. ${ }^{38}$ The unearthing of fragments of this rare ceramic ware, especially of pieces belonging visually to one and the same vessel at different depths means that the layers were accumulated simultaneously, probably at the same time. ${ }^{39}$ Leaving aside the uncertainties about the absolute dating of the monumental buildings in Pliska, including the stone wall, after a destructive fire the ruins were cleared away and renewed construction began. In the trenches along Asar dere we find presumably indirect indications for this process. ${ }^{40}$ The vessels to which the discussed fragments belonged could well have been located in one of the representative buildings, only being removed after its destruction (by fire) to the find site. This may explain why even the pieces, which visually belong to one and the same vessel, do not fit together. ${ }^{41}$

The question where exactly the workshops were situated remains a task for future surveys; it could be only taken for sure that the vessels from the 'secret passage' were locally produced, somewhere in or around Pliska. The archaeometric studies, however, cannot solve the riddle where the tradition comes from. In a later work, R. Rašev managed to express the quintessence of the problem with only one sentence. How to give a precise answer when the flagons with pedestal feet resemble and imitate the form of metal vessels of Sasanian type, the spouted vessels have analogies in the socalled late Avar yellow pottery and the amphora resembles seventh-century Byzantine examples? ${ }^{42}$ In her still unpublished report, L. Dončeva-Petkova declares that no definite answer can be given to this question. Even a renewed perusal of the specialised literature on the triangle of Central Europe-Central Asia-Byzantium ${ }^{43}$ was of no avail. According to her, a not particularly promising solution may be found if we suppose that two separate groups of Central Asiatic potters, using a similar technology, reached the

37 The geophysical anomaly, at the end of which lie the trenches No. 4-10 and No. 14, indicates as much. It has the form of a wide opened semi-circle and occupies the sloping side of a positive relief form with level difference of about $5 \mathrm{~m}$. See the contribution of N. Schleifer in this volume, fig. 3; J. Henning, in this volume, pl. \#\#\#.

38 Michajlov 1955, 63-66.

39 Dončeva-Petkova, in print.

40 See the idea of L. Dončeva-Petkova in this volume on the origin of the loess layers.

41 I am aware of the fact that this is only a further hypothesis requiring more trustworthy evidence. So does the statement of J. Henning and L. Dončeva-Petkova, even if it seems quite logical. The problem deserves discussion and hopefully the publication of the results of the Bulgarian-German excavations will bring to light more facts.

42 Rašev 2003, 158.

43 Dončeva-Petkova, in print, notes 21-29. 
Carpathian Basin and the Lower Danube; this could explain the dissimilarities between the two regions. Yet even to her this hypothesis does not seem completely convincing.

As seen, shortly before the publication of the material from the 'secret passage' the Bulgarian archaeologists could not decide between two possibilities: Asian potters or native, in broader sense Byzantine, craftsmen.

The systematic and diverse information provided by R. Rašev in his newest work on the set is an important step towards a correct solution. He analyses the forms, the morphological elements, the decoration and finally deals with the origin of the production and the cultural tradition as well as with the cultural and historical meaning of the ceramic set. At this place only R. Rašev's general conclusions will be mentioned. $\mathrm{He}$ is very well acquainted with the so-called 'new style' of the ceramic production in Central Asia, but for him it is just another example for the old and widespread practice of imitating metal vessels in clay. ${ }^{44} \mathrm{He}$ drew comparisons with the Carpathian yellow pottery but this led him to the final conclusion that the latter is geographically and ethno-culturally a clearly definable group and offers just single common features, which rather separates than connects it to the vessels from the secret passage. ${ }^{45}$ In this way the vessels from Pliska appear to be completely isolated and cut off from the surrounding world. In my opinion one should always register the differences, but also search for an explanation for the striking similarities, which cannot appear almost at one and the same time in three geographically remote regions without any contacts existing between them. Further on R. Rašev disagrees with the migration model of D. Bialeková and shares the scepticism of those scientists who accept that the yellow pottery is rather a result of evolution and transformation of the local ceramic tradition. ${ }^{46}$ Finally, R. Rašev decides in favour of the second scenario of S. Angelova, and of the idea that the 'secret passage' set is one of the expressions of the 'antique' influence on the Bulgarian early medieval pottery, or more precisely, of the seventh- to ninth-century Byzantine ceramics, which have preserved and continued to develop forms and technologies from previous times. $^{47}$

44 Rašev 2004, 73.

45 Ibid., 76.

46 Ibid., 81. R. Rašev does not name these authors, but the example which he gives on fig. 13.2 reveals his use of a publication by Zdeněk Klanica (Klanica 1986, 69-71, fig. 15.1). The Czechoslovakian author has quite a broad understanding of the yellow pottery: neither the vessels on his fig. 15.1-3,5-7 (see the catalogues of D. Bialeková and É. Garam) nor those on fig. 17 (Vida 1999, 83-88, group IE) are considered as such. This could explain why he insists on the direct Late Antique roots of (parts of) the yellow pottery.

47 Rašev 2004, 82. 


\section{'Ceramics with (red) slip'/'light-coloured ceramics made on a fast wheel'}

In connection with the three ring-handled cups from the cemetery of Sultana (Romania), Uwe Fiedler briefly discussed the phenomenon of 'yellow pottery'. ${ }^{48} \mathrm{He}$ regards as 'gelbe Keramik' not only the vessels from the secret passage in Pliska, but also a jug and a water bottle from the cemetery at Hitovo, in north-east Bulgaria, and finds suitable parallels in the cemeteries Nožarevo (Grave No. 15) and Varna-2 (grave No. 342). Probably misled by the surface colour, he has made the same mistake as D. Bialeková and, many years ago, Tibor Horváth, ${ }^{49}$ who placed pieces of different technology and tradition in one classification group: Apart from the water bottle, all these vessels are jugs made on a slow potter's wheel. ${ }^{50}$ In grave No. 16 from the cemetery at Nožarevo, however, a double-handled flagon was found, ${ }^{51}$ which belongs to a group of tableware known from only few archaeological sites in Bulgaria besides Pliska.

In Bulgarian archaeological literature two interchangeable expressions are used for it. The first one - 'ceramics with (red) slip' or '(червено)ангобирана керамика' - appeared first, as far as I was able to discern, in an article of L. Dončeva-Petkova about early medieval vessels with slip, ${ }^{52}$ in which the then known vessels (Novi Pazar near Pliska, the Great water reservoir in the Citadel of Pliska) and fragments are a constituent of group 1. It combines vessels differing in their technology and chronology, whose entire body is covered with slip. In publications concerning the special ceramic group discussed here, the expression is often followed by additional details regarding the technique (fast wheel), the form (flagons with one or two handles with extended lower ends), or the place of unearthing (Pliska), ${ }^{53}$ distinguishing it from any other pottery group. Nevertheless, I consider it as unsuitable: It is well known that not all of the vessels belonging to it have been covered with slip.

The second current expression - 'light-coloured ceramics made on a fast wheel' or 'светлоглинена керамика на бързо колело' - is preferred in some recent works on pottery classification from Pliska. It is correct, nevertheless long and descriptive. On

48 Fiedler 1992, 155-156.

49 Horváth 1935, 75-83.

50 S. Stanilov has already noticed the incorrectness - Stanilov 1997, 210.

51 Rašev/Stanilov 1989, 218. The vessel is exhibited in the museum of Silistra; the material is not published.

52 Dončeva-Petkova 1973, 15, 17-18.

53 Idem 1979, 91, 95; idem, in print; Angelova 1984, 94; Angelova/Koleva/Angelova/Ivanova 1997, 68; Balabanov, 1983, 70-73. 
the basis of the presence or absence of surface coating, the latter has been divided either into two subgroups ${ }^{54}$ or even into two separate groups within the tableware. ${ }^{55}$ Leaving apart that such division might cause classification problems, it does not reflect such an outmost significance, which may be combined with other deviating features in order to plausibly explain a meaningful difference.

Already the earliest excavations in Pliska delivered fragments of this special kind of ceramics. K. Škorpil calls them amphorae and classified them to his second group - vessels with good quality, which according to him are 'foreign', i.e. imported. Precisely for the piece in question he added that such vessels decorated with ochre are found among the ruins of Roman cities like Tegris, Appiaria, Dimus. ${ }^{56}$

The almost intact flagon found in the empty space between graves No. 10, 23 and 24 of the cemetery at Novi Pazar is well-known. ${ }^{57} \mathrm{~S}$. Michajlov reported about the unearthing in 1948 of similar fragments (handles with extended lower ends) in a trench situated at the left side of Asar dere River. ${ }^{58}$ Later on, excavating the so-called Site 31 to the north-east of the Inner City, he even classified such kinds of handles with red slip into a separate group..$^{59}$ His wrong interpretation of the cultural horizon, to which the cemetery at Novi Pazar and the sunken houses under the stone buildings in Site 31 belong, namely that it dates from the third to fifth centuries and belonged to some local Thracian or Sarmatian tribes,$^{60}$ was later revised. ${ }^{61}$ However, A. Milčev and S. Michajlov consider the ceramics with 'red ochre' even in recent times to be late Roman/ early Byzantine material, which was only secondarily used in the Medieval Period. ${ }^{62}$ We only have to remember the above-mentioned statement of A. Milčev regarding the vessels from the secret passage.

54 Vitlianov/Dimitrov 1996, 245, group III; Dimitrov 2003, 183, group III.

55 Stanilov/Dimitrov/Jankulov 1991, 130-132, groups II.2. Ceramics from fine light(ochre)coloured clay made on a fast wheel - 'yellow pottery' (sic!) and II.3. Ceramics with red slip; Dimitrov 2004, 185-186, 188, groups IV.2. Light-coloured ceramics covered with red slip and V. Light-coloured ceramics on a fast wheel. This methodical behaviour is hardly understandable: In the publications it is stressed that both subgroups/groups are technologically and morphologically identical. Moreover, the bad state of preservation of the slip, caused by unfavourable soil conditions or by cleaning the shards using a brush, may greatly mislead the archaeologist.

56 Škorpil 1905, 301, 305, pl. LXc.1.

57 Stančev/Ivanov 1958, 50, Cat. No. 18, pl. XIII, Находки извън гробовете/4, pl. XIX.2.

58 Michajlov 1955, 65.

59 Ibid., 127, 149.

60 Ibid., 166-167.

61 Michajlov/Milčev 1959, 288.

62 Ibid., 283; Michajlov 1993, 24, see also the editors' remark on p. 32; Milčev 1960a, 38; idem 1985, 23, 34. The vivid discussion between P. Georgiev and A. Milčev - Georgiev 1986, 49; Milčev 1990, 81; Georgiev 1991, 68-69 - is concerned to a large extent with this problem. 
In 1971, in pits below the foundations of the Great Basilica, situated about $1 \mathrm{~km}$ to the north-east of the Inner City, Stančo Stančev Vaklinov found fragments of three ceramic groups - sand-tempered pots with incised decoration, grey pottery with polished decoration and cream - resp. rose-coloured flagons with one or two handles with extended lower ends and red slip. ${ }^{63} \mathrm{He}$ dated the material to the end of the eighth and ninth century, to the time before the basilica was built.

If not merely Margarita Vaklinova's interpretation, the earliest scientific argumentation on the provenance of this kind of vessel might belong to S. Vaklinov. ${ }^{64}$ The text says that all evidences are at hand to assume that this group is a straight continuation of a late Roman pottery type, the evolution of which cannot directly be traced in Medieval Bulgaria but whose production continued on the territory of Byzantium (here unpublished material from Nicopolis ad Nestum are concerned) and which is found in the Bulgarian political centres (Pliska and Preslav) from the eighth century onward. Does this mean that the vessels are to be regarded as contemporary Byzantine imports?

Although in her work about the early medieval vessels with red slip L. DončevaPetkova classifies this particular kind of fast-wheel pottery together with other vessels, she pays special attention to the difficult problem of its origin. ${ }^{65}$ According to her there are two possibilities:

- It could have been produced in workshops by the local population, who inhabited the Balkan Peninsula before the coming of the Slavs and the Proto-Bulgarians. Preserving late Antique traditions, these potters continued to use the fast wheel.

- It could have also been imported from one of the nearby Byzantine centres, e.g. Odessos, Nessebar or Serdica, which had then not yet been integrated into the Bulgarian State. ${ }^{66}$

In a later work she added a third one:

- The vessels could have been manufactured in Bulgaria by Byzantine captives. ${ }^{67}$

Trying to combine several indisputable facts, namely the qualitative concentration of the material in Pliska plus the affiliation of these vessels to the Medieval Bulgarian culture (as far as the incised sign IYI frequently occurs on their shoulders) on one side, and their technological uniqueness plus their relatively brief occurrence on the

63 Vaklinov 1972, 9-10; Vaklinov/Štereva 1993, 36-38.

64 Vaklinov/Vaklinova 1993, 19. Margarita Vaklinova here published the results from S. Vaklinov's excavations of the so-called great water reservoir in the citadel of Pliska, in which she used a manuscript of his from 1962 together with the original documentation. The almost intact vessel found there is published here in the Catalogue of finds from Pliska, Cat. No. 118, pl. X.118.

65 Dončeva-Petkova 1973, 17-18.

66 If I have understood Vaklinov/Vasklinova's sentence correctly, the idea is more or less the same.

67 Dončeva-Petkova 1992, 496. 

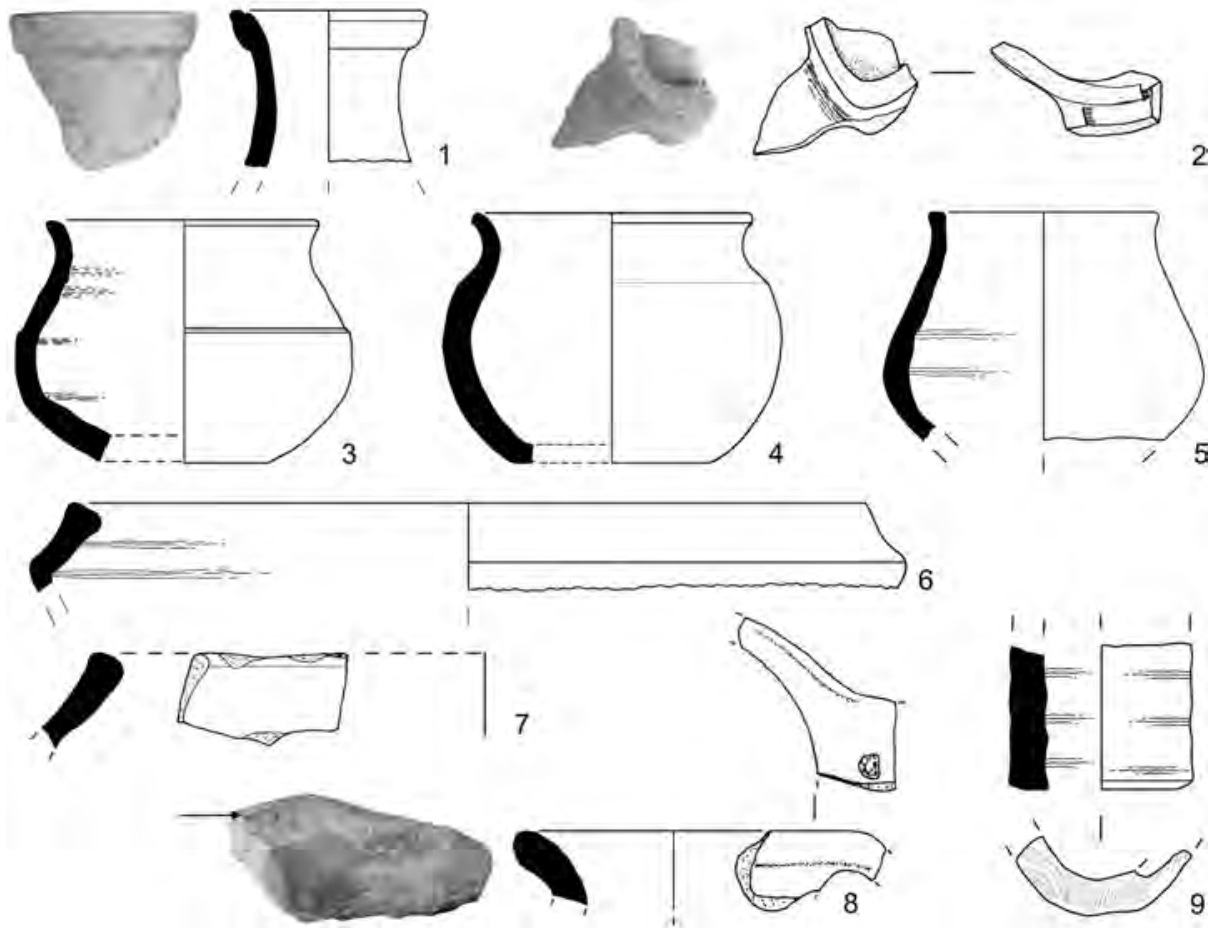

Fig. 2. Typology of the yellow pottery (continuation): spouted vessels (1-2), small cups (3-5), bowls (6-7), wide-opened vessel (8); ring base (9): 1. Asar dere 1961, sector A2, quad. 4, 1.10-1.30 m; 2. south gate 1964, $1.40 \mathrm{~m} ; 3 ., 5$. Asar dere 1960, sector A, quad. 7, 1.80-2 m; 4. Asar dere 1959, 0-0.40 m; 6. Asar dere 1959, sector I, quad. 4, $1.50 \mathrm{~m}$; 7. Asar dere 1998, trench 7c, 0-0.20 m; 8. Asar dere 1959, sector II, kiln No. 1 (with drop of glaze); 9. west stone wall 1974, sector North, quad. 34, 1.50-1.80 m. Scale=1:3

other, L. Dončeva-Petkova supposed that they were produced by order and especially for the capital.

S. Angelova was the first to contemplate the similarities between the 'secret passage' vessels and the 'ceramics with red slip' ${ }^{68}$ She came to the conclusion that one and the same potters could have made them, even using the same clay. This possible link fits quite well into her second scenario about the origin of the vessels from the 'secret passage', although it is also applicable for the first case - the still active local traditions could have had a strong impact on potters coming from Asia. Furthermore, the frequent occurrence of this pottery in Pliska makes her believe that one (if not the only) of its production centres was situated here.

68 Angelova 1984, 93-94, 110. 

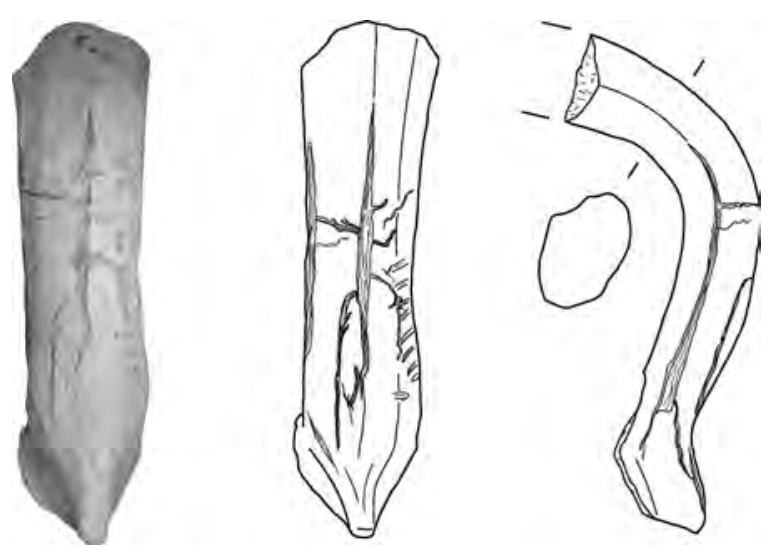

Fig. 3. Handle with black core and longitudinal fissures. Asar dere 1959, sector I, quad. 1, $0.8 \mathrm{~m}$ (excavations of A. Milčev). Scale=1:3

T. Balabanov goes even further: He is not only convinced of the local provenance of these ceramics from Pliska, but also locates their production along the bank of the Asar dere River ${ }^{69}$ more precisely to the double-chambered pottery kilns discovered there by A. Milčev in $1959 .{ }^{70}$ According to him, these facilities, used for the firing of glazed pottery during the ninth and tenth centuries, were used a century earlier for the production of the luxurious fast-wheel (yellow) pottery. As for the ateliers of the 'secret passage' vessels and their probable location at this place, Balabanov's hypothesis affords more scientific evidence, other than simply the suitable construction of the kilns. Among the surviving material from A. Milčev's excavations ${ }^{71}$ one fragment (Fig. 2.8), probably belonging to the group of socalled 'light-coloured ceramics' (because of the bad preservation and the small size of the fragment a determination of the technique is not reliable), according to the hardly readable signature was found in kiln No. 1 and even bears a drop of glaze. Another fragment suffered extremely high temperature - it has a completely black core and longitudinal fissures (Fig. 3). Such phenomena, however, can also occur under non-production conditions, e.g. secondary deposition, older materials in the production rooms or secondary firing. Even disregarding these possibilities, both examples are more than insufficient to prove a production of this pottery in the Asar dere area, as was otherwise readily presumed. ${ }^{72}$

The opinion of T. Balabanov that the vessels from the 'secret passage' were produced by potters from the central areas of the West Turk Khaganate under the strong influence of local (i.e. Bulgarian) tastes and fashion trends was already mentioned. Like S. Angelova, he also sees a direct link between them and the group discussed here, albeit explaining it slightly differently:

69 Balabanov 1983, 77.

70 Milčev 1960b.

71 It is stored in the archaeological department of the St. Kliment Ochridski University at Sofia, to which as a (former) student I was granted access.

72 Dončeva-Petkova, in print. 


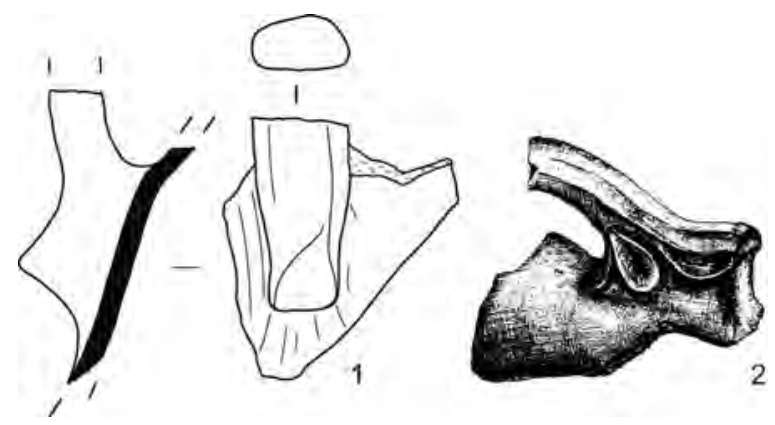

Fig. 4. Handle attachments with large periphery sides and sharpened protruding tips. 1. Asar dere 1952 (excavations of A. Milčev). Sca$1 \mathrm{e}=1: 3 ; 2$. 'secret passage'. Without scale

- Either native Bulgarian potters were influenced by their Asiatic colleagues and started making technically and morphologically similar vessels;

or vice versa:

- Potters of late antique/early Byzantine origin integrated into the Medieval community were making the 'light-coloured ceramics' with the Asians then being influenced in a certain way by their products. ${ }^{73}$

L. Dončeva-Petkova rather stresses the differences than the similarities between both groups, concluding that they were probably made by different potters. ${ }^{74}$

R. Rašev thinks that the flagons from the secret passage have no direct analogies among the Bulgarian ceramics where any feature of their technology, form and decoration is concerned. ${ }^{75}$ The only exclusion according to him is the extended lower end of the handles, but even this has a different form. It is true that most of the 'lightcoloured' handles do not bear exactly the same attachments with large peripheral sides and slightly sharpened and protruding tips like the secret passage vessels, ${ }^{76}$ but I can give examples for carefully modelled comparable ones (Fig. 4.1). Their sides are not as large, maybe because they did not need to provide any space for decoration. ${ }^{77}$ As far as this element is considered for having being borrowed from toreutics, R. Rašev supposed the following interaction: the 'secret passage' flagons imitate metal vessels while the 'light-coloured' flagons imitate the specimens from the 'secret passage', ${ }^{78}$ e.g. they are actually imitations of imitations. Theoretically therefore, the 'light-coloured'

73 Balabanov 1983, 72-73.

74 Dončeva-Petkova, in print: „Майсторите ... са вероятно други ...“.

75 Rašev 2004, 71: „Стомните нямат преки аналогии у нас по нито един от белезите на своята технология, форма и украса“.

76 Ibid., 68, fig. 4, 9.2,3, 10 .

77 There are also decorated ones: ibid., 71, fig. 12.1.

78 Ibid., 72: „Може да се допуска, че издатъците по дръжките на светлоглинените съдове с червена ангоба са имитация на първообраз, какъвто са можели да бъдат 'класическите' издатьци с украса на стомните от подземния ходник“. Similar ideas are shared by J. Dimitrov (Dimitrov 2004, 186), according to whom the light-coloured vessels made on a fast wheel with and without red slip are the closest derivatives of the 'secret passage' set. 

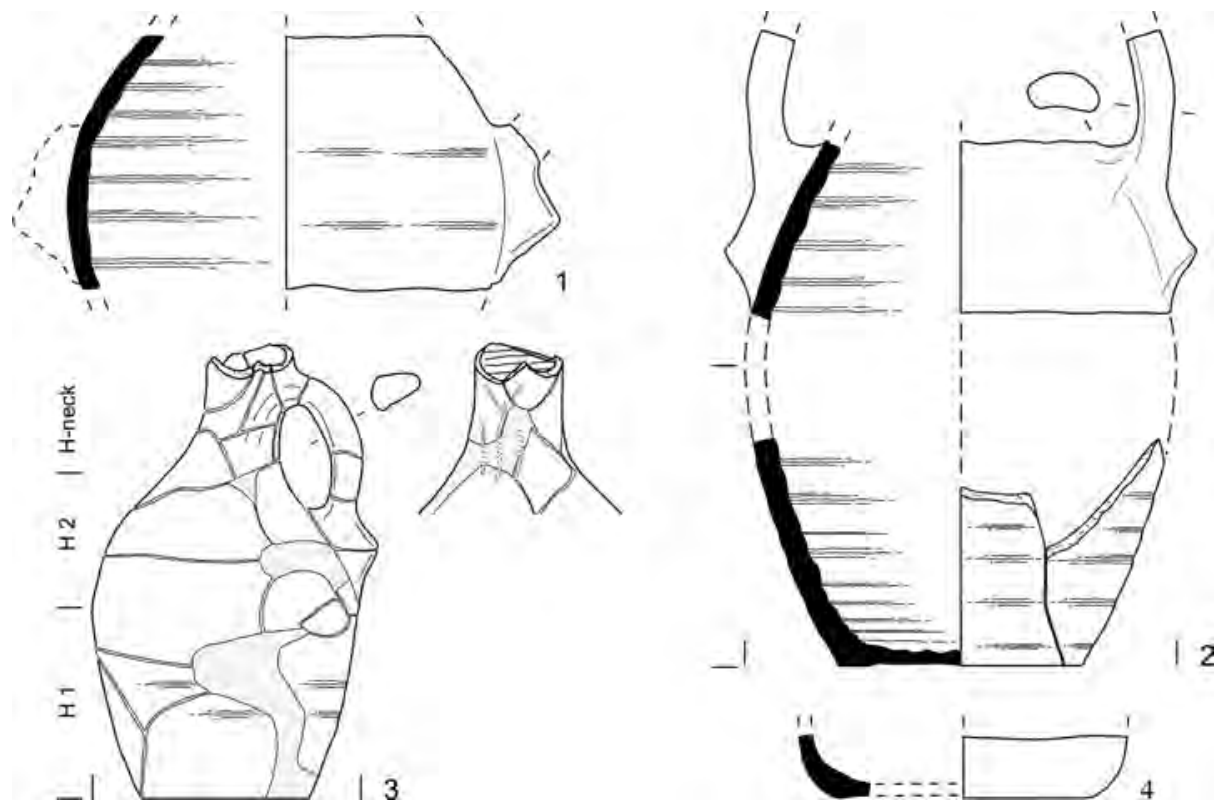

Fig. 5. Typology of the yellow pottery (continuation): flagons. 1. Type I (Asar dere 1959, sector I, 0.8 m); 2. Type II (pit below the fundaments of the Great Basilica, trench 21, 1971); 3. Type IV (secret passage below the temple in the Citadel); 4. Type III (Asar dere 1952). 1,4. Subgroup 1; 1,3. Subgroup 2. Scale=1:4

flagons could directly imitate metal vessels, especially if they were (presumably) made in the same ateliers.

To conclude:

- Since the 1970s the assumption that the so-called 'light-coloured ceramics made on a fast wheel' are of local Bulgarian (i.e. Pliskan) provenance prevailed, a theory which was confirmed by chemical analysis. It is therefore important to obtain yet more reliable evidence for the exact place of production.

- It seems that one of the crucial points in explaining the origin of the vessels from the secret passage is their relationship to the 'light-coloured ceramics'. The direction of influence has been evaluated in different ways and the formulated question is: "The same or different potters?" The decision depends on what is given more weight - its similarities or differences. 


\section{Why 'yellow pottery'?}

Is it not one and the same phenomenon standing behind the current expressions from Bulgarian archaeological literature of 'yellow pottery' (i.e. the 'secret passage' group) and 'light-coloured ceramics made on a fast wheel'/'ceramics with (red) slip'?

Both groups of vessels were thrown on a fast wheel and, as determined by chemical analysis, were made from one and the same Ca-rich material with buff firing colour (Fabric 1); only part of the 'light-coloured' ceramics was tempered with sand (Fabric 2). The most numerous form of vessel is the flagon with one or two handles (Fig. A and Fig. 5); spouted jars like these from the 'secret passage' (Fig. 1B) are known from Mound XXXIII and the Asar dere area (see below) (Fabric 1) but obviously there are also examples of Fabric 2 (Fig. 2.2). Unknown for the 'secret passage' group are the cups (Fig. 2.3-5), bowls (Fig. 2.6-7) and some other single forms (Fig. 2.8). Three types of flagons could be distinguished within both groups: Type I - with spherical body, Type II - with elongated body and Type III - with sunken body (Fig. 1A and Fig. 5.1,2,4); a fourth type with the maximal extension in the upper part of the body is more common for the 'light-coloured' ceramics (Fig. 5.3). Both groups are characterised by profiled rims (Fig. 1A) and handles with elongated lower ends (Fig. 1A, 3, 4 and 5.1-3); moreover, the flagons from the secret passage possess cut angular handles (Fig. 4.2), while those of the 'light-coloured' flagons are only strongly asymmetrical (Fig. 3, 4.1 and 5.23); one spouted jar has a ring base (Fig. 1B.2), a narrower and higher ring base belongs to Fabric 2 (Fig. 6.9); pedestal feet (Fig. 1A, 2) are attributes of two 'secret passage' flagons only. Careful smoothing and burnishing is a common way of surface treatment; only the vessels of Fabric 2 were left with a rough surface. Red slip is typical for part of the 'secret passage' and 'light-coloured' vessels; glaze-like covering (imitating gold?) only for the 'secret passage' group ${ }^{79}$. The engraved half-palmettes on the handles of the 'secret-passage' flagons are unique (Fig. 1A and Fig. 4.2); mouldings under the neck and single incised lines are frequent among the 'light-coloured' ceramics. ${ }^{80}$ Both groups present high-quality tableware, which was produced mainly for the population of Pliska; only single fragments of 'light-coloured' flagons have reached other places (Novi Pazar, Preslav, Nožarevo, Khan Krum, etc.). According to present-day dating the 'secret passage' group and the 'light-coloured' ceramics existed simultaneously and for a rather short period in the second half of the eighth and in the first half of the ninth century.

One part of the dissimilarities has already found its most probable explanation: the usage of the 'secret passage' assemblage - apparently for official occasions at the

79 Petrova/Brey, in print.

80 Unpublished examples. According to my observations the spouted vessels from Mound XXXIII has also one almost obliterated line below the handle. 


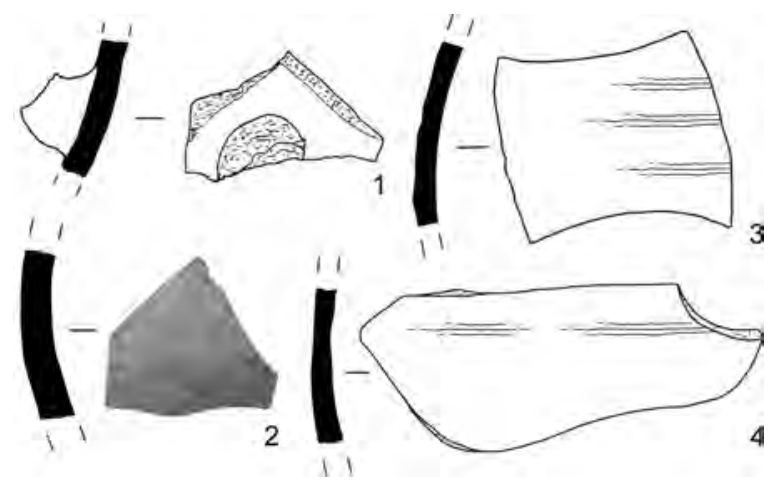

Fig. 6. Fragments from the secret passage group found 1997-2001 in the Asar dere area: 1. Ring handle (?) (trench 4c, 1.2-1.4 m); 2. Fragment with remains from the glaze-like covering layer (trench 4, 0-0.2 m); 3-4. Wall fragments with undulating and sharp edges, probably from one vessel (trench $8 \mathrm{~d}, 0.8-1 \mathrm{~m})$. Scale=1:3

court by only a handful of high-ranking noblemen, as well as the impetus for its creation - supposedly ordered by the Khan, are acceptable reasons for its superiority and the single act of its manufacture. ${ }^{81}$ Moreover, some of the elements, which make them look different, e.g. angular handles, pedestal feet, half-palmettes, were borrowed from toreutics or other fields of art. The usage of different fabrics resulted either from different methods of production, e.g. different workshops, or, more probably, are due to chronological reasons. But we strive towards a proper explanation of the similarities and whoever the potters and whatever the direction of influence might have been, it cannot have been merely by chance that such similar vessels occurred at one and the same time in one and the same place. It is a good motive for a common name I think.

Fortunately, I can point out another, if rather subjective reason. I already dealt with one of the new aspects given by the 'secret passage' material from the Bulgarian-German excavations in the Asar dere area. Morphological details facilitate the determination of two spout pieces, ${ }^{82}$ two rim fragments with thickened lip ${ }^{83}$ and the fragment of a (probable) ring handle (Fig. 6.1) as belonging to spouted jars. Some pieces still possess remains of the glaze-like covering (Fig. 6.2). Others produce the symptomatic clear metallic sound and are broken with undulating sides and sharp edges typical for glass pieces (Fig. 6.3-4 compared to Fig. 1, at left) ${ }^{84}$ The difficulties begin when the most significant formal or morphological features cannot be applied, e.g. with wall and base fragments. If the glaze-like covering is absent and the sherds, or parts of them, have their normal pale-yellow colour, i.e. they did not suffer strongly from secondary firing, it is almost impossible to say if they belong to such vessels as those

81 Rašev 1981; idem 2003, 158; idem 2004, 82-83; Angelova 1984, 94.

82 Dončeva-Petkova, in this volume, fig. 15.9-10.

83 Dončeva-Petkova, in the present volume, fig. 15.7-8.

84 Or to Rashev 2004, 68, pls IIA-IVA. 
in the secret passage. The wall thickness is also not a reliable parameter. ${ }^{85}$ What I find significant is that the overall thickness of the studied sherds is relatively equal (Fig. 6); the traces of the potter's fingers, left while turning the vessel, look more like flat and slender furrows than wide and wavy-like flutes. The rotating speed of the wheel seems to have been quite high, which enabled the potters to create an elegant body. ${ }^{86}$ Hence, for someone, who is trying to correctly classify a pile of sherds, it is not always an easy task to draw a clear boundary between the 'secret passage' group and the so-called 'light-coloured ceramics'. ${ }^{87}$

On such grounds the artificial boundary made between both groups should be removed by regarding them as one and the same classification group. The name here proposed for it - the terminus technicus 'yellow pottery' - is thought to be a suitable one: The association with the material from the Middle Danube is purposefully sought under the presumption that their origin is closely related. For keeping them apart geographical adjectives like 'Bulgarian' or 'from Bulgaria/Pliska' would have to be used. The designation secret passage group remains necessary, but now only as referring to an inseparable unit.

If we return to the problem of the origin of the yellow pottery from Pliska/ Bulgaria we will see that in the works discussed the archaeologists always tried to tackle the question of "who produced these ceramics?" and using different sources, or interpreting the same sources in a different way they presented various, and what is worth mentioning, always more than one possibility: for the 'secret passage' group - Byzantine potters, potters with local early Byzantine origin or Asian potters; for the 'light-coloured' ceramics - potters with local early Byzantine origin, Byzantine potters taken as captives, Asian-influenced Bulgarian potters or Asian potters under local influences. Of course an exhaustive list of possibilities is better than any false assumption. But is it not the question itself that has not actually been clearly stated? Formulating my question about the origin at the beginning I tried to avoid the not always fruitful ethnical personalisation implied inevitably in the 'who'-question. "Where did the tradition come from?" has several different (chronological, territorial or cultural) aspects, which deserve appropriate scrutiny. It is not the task here to discuss

85 Dončeva-Petkova, in print. It is true that on the discussed fragments it does not exceed 0.9 $\mathrm{cm}$ but the wall thickness of the vessels from the secret passage, except for flagons No. 2-3 and the spouted jars (Rašev 2004, pl. IB.2-3, pl. IVB) is equal or greater than one centimetre. According to my observations, thicknesses between 0.4 and $0.8 \mathrm{~cm}$ are quite frequent for the rest of the yellow pottery, which L. Dončeva-Petkova even calls 'thick-walled', differentiating it from the 'thin-walled' vessels from the 'secret passage'. Such a definition is only valid for parts of the fragments (mostly for Fabric 2) and should not be taken as leading criteria.

86 My observations coincide with the technical data given by Rašev 2004, 66.

87 Both L. Dončeva-Petkova and I have to admit that even after close scrutiny of the suspected pieces together, uncertainties of the determination of some of them could not be expelled. 
the problem of how (im)proper it may be to confer ethnical determinates on (groups of) archaeological objects, but in any case it is the very last thing to begin with. It should be preceded by a reasonable classification of the data - as will be done elsewhere. ${ }^{88}$ Here only the main steps shall be listed:

- $\quad$ Division of the archaeological material into technological subgroups (Fabric 1 - clay without temper and Fabric 2 - clay with sand temper).

- A typology as detailed as possible of the available vessel forms.

- Confirmation/correction of the present-day absolute and relative dating of the yellow pottery by stratographic analysis of finds. Discussion of the possible chronological discrepancy between Fabrics 1 and 2.

- The relation of the yellow pottery to the early and middle Byzantine pottery.

- The influence of toreutics and other forms of art on the yellow pottery.

- A systematic comparison of the yellow pottery on the Middle Danube,

- moreover its comparison with the so-called 'new style' in Central Asia.

\section{Conclusions}

Even after all these analytical and comparative studies we are sure not to be able to actually identify the potters. But it will become clear that among the Central Asiatic material on the one hand and the yellow pottery at the Middle and Lower Danube on the other there are evident similarities in the overall appearance (technology, colour, range of forms), but also profound differences in typology, morphology, and decoration. The plausible explanation in my opinion is not that of D. Bialeková. ${ }^{89}$ It is not any adherence to or deviation from the prototypes, but rather the prototypes themselves that were similar or different. The factor which actively contributes to the dissimilarities in the three regions, is the local milieu with its own traditions and/or sources of influence in material culture (having in mind the pottery production, toreutics and some other handicrafts).

Although the influence of toreutics is a feature typical for the tableware of almost every historical period and material culture, the simultaneous existence of the 'new style' in Central Asia and the yellow pottery in Southeast and Central Europe allows us to consider them to be part of a common short-living ceramic phenomenon or fashion trend, of supra-regional and supra-ethnical character and not as any completely independent manifestations of the material culture as presented in R. Rašev's point of view. As the dating suggests it could have originated in the East, indicating that between distant parts of the Old World contacts existed more on a cultural or/and an economical,

88 Petrova, forthcoming.

89 Bialeková 1968a, 28: „Allgemein ist aber damit zu rechnen, dass zwar die in ein anderes Milieu übertragene Keramik ihre charakteristischen Proportionen beibehält, doch zugleich in manchen Einzelheiten von der ursprünglichen Vorlage abweicht oder auch ganz untergeht“. 
than on an ethnical level. The mechanisms of these contacts could be revealed only by systematic analysis of other classes of archaeological material and historical sources. The exchange of technical achievements and fashion trends could have been of different nature and could have happened in various ways. As Cs. Bálint carefully supposed, the road to the Carpathian Basin could have passed through the Khazar Khaganate. ${ }^{90}$ The relationship of the Bulgarian early medieval material culture with the SaltovoMajaki culture is well known, but, provided that the impact of the Byzantine ceramic tradition is well detectable on the yellow pottery from Pliska, the way to the Lower Danube could have led through the Eastern Roman Empire. Moreover, willingly or not, Byzantine hands could also have passed on the metal vessels which the potters in Pliska tried to imitate. Leaving aside whether the mediator was the same or different, the highest grade of comparability between the yellow pottery at the Lower and Middle Danube suggests much more intensive exchange between the Avars and the Bulgarians in the second half of the eighth century.

\section{Bibliography}

Angelova 1984: Стефка Ангелова, “Местни традиции във формирането на битовата керамика в североизточна България през VII-X в. ”, in: Годишник на Софийския университет, Исторически факултет 77, 1984, pp. 71-118.

Angelova/Koleva/Angelova/Ivanova 1997: Стефка Ангелова/Румяна Колева/Елена Ангелова/ Ралица Иванова, “Знаци върху канцела на църква № 2 в Дръстьр”, in: Българите в Северното Причерноморие, Изследвания и материали 6, Велико Тьрново 1997, pp. 67-74.

Balabanov 1983: Тодор Балабанов, Занаятчийски производства в Плиска /VIII-XI в./. Дисертация за присъждане на научна степен “кандидат на историческите науки” (Unpublished PhD work), София 1983.

Bálint 1989: Csanád Bálint, Die Archäologie der Steppe: Steppenvölker zwischen Volga und Donau vom 6. bis zum 9. Jahrhundert, Wien-Köln 1989.

Bialeková 1967: Darina Bialeková, “Žlatá keramika z pohrebísk obdobia avarskej ríše v Karpatskej kotline”, in: Slovenská archeológia 15/1, 1967, pp. 5-76.

Bialeková 1968a: Darina Bialeková, "Zur Frage der Genesis der gelben Keramik aus der Zeit des zweiten awarischen Kaganates im Karpatenbecken”, in: Študijné Zvesti Archeologického Ústavu Slovenskej Akadémie Vied 16, Symposium über die Besiedlung des Karpatenbeckens im 7.-8. Jahrhundert, Nitra-Malé Vozokany 1966, 1968, pp. 21-33.

Bialeková 1968b: Darina Bialeková, "Zur Frage der grauen Keramik aus Gräberfeldern der Awarenzeit im Karpatenbecken”, in: Slovenská archeológia 16/1, 1968, pp. 205-227.

90 Bálint 1989, 175. The cup with doubled (or zoomorphic) handle from grave 186 in the cemetery Szekszárd-Bogyiszlói str (Rosner 1999, table 13.186-1) could be used as an argument in favour. 
Bialeková 1973: Darina Bialeková, "Beziehungen zwischen Mittelasien und dem Karpatenbecken im 6.-8. Jahrhundert", in: Berichte über den II. Internationalen Kongress für Slawische Archäologie II, Berlin 1973, pp. 321-330.

Bóna 1971: István Bóna, "Ein Vierteljahrhundert Völkerwanderungszeitforschung in Ungarn”, in: Acta Archaeologica Academiae Scientiarum Hungaricae 23, 1971, pp. 265-336.

Bóna 1985: István Bóna, "Die Awaren: ein asiatisches Reitervolk an der Mittleren Donau", in: Awaren in Europa. Schätze eines asiatischen Reitervolkes 6.-8. Jahrhunderts, Ausstellungskatalog, Frankfurt am Main 1985, pp. 5-20.

Daim 2002: Фалько Дайм, “История и археология авар”, in: Материаль по археологии, истории и этнографии Таврии 9, Симферополь 2002, pp. 273-384.

Dimitrov 2003: Янко Димитров, “Наблюдения върху битовата керамика от Обект 31 в Плиска”, in: Плиска-Преслав 9, Шумен 2003, pp. 181-221.

Dimitrov 2004: Янко Димитров, “Керамиката от разкопките на руската експедиция (19771980, 1983 г.) в Плиска”, in: Плиска-Преслав 10, Шумен, 2004, pp. 169-197.

Dončeva-Petkova 1977: Людмила Дончева-Петкова, Българската битова керамика през ранното средновековие (втората половина на VI - края на Х в.), София 1977.

Dončeva-Petkova 1973: Людмила Дончева-Петкова, "Ранносредновековни ангобирани съдове", in: Археология 15/3, 1973, pp. 14-21.

Dončeva-Petkova, 1979: Людмила Дончева-Петкова, “Западната крепостна стена в Плиска (проучвания на южния сектор през 1973 и 1974 г.)”, in: Плиска-Преслав 1, София 1979, pp. 81-96.

Dončeva-Petkova 1990, Ljudmila Dončeva-Petkova "Die protobulgarische Keramik in Bulgarien", in: Csanád Bálint (Ed.), Die Keramik der Saltavo-Majaki-Kultur und ihrer Varianten (=Varia Archaelogica Hungarica 3), Budapest 1990, pp. 77-100.

Dončeva-Petkova 1992: Людмила Дончева-Петкова, "Региональные варианты древнеболгарской керамики", in: Четвърти международен конгрес по славянска археология. Доклади и съобщения 1, София 1992, pp. 495-515.

Dončeva-Petkova, in print: Людмила Дончева-Петкова, "За една белоглинена керамика от Плиска", in: Сборник в чест на 60-годишнината на Рашо Рашев.

Fehér 1940: Геза Фехер, Ролята и културата на прабългарите: Значението на прабългарската и старомаджарската култура в изграждането на цивилизачията на Източна Европа, София 1940.

Fiedler 1992: Uwe Fiedler, Studien zu Gräberfeldern des 6. bis 9. Jahrhunderts an der unteren Donau (= Universitätsforschungen zur prähistorischen Archäologie 11), Bonn 1992.

Garam 1969a: Éva Garam, “A későavarkori sárga kerámia”, in: Archaeológia Értesitö 96, 1969, pp. 207-241.

Garam 1969b: Éva Garam, "Die spätawarenzeitliche gelbe Keramik", in: A Móra Ferenc Múzeum Évkönyve 2, 1969, pp. 151-162.

Georgiev 1986: Павел Георгиев, Review of "Плиска-Преслав 4 (1985): Укрепителните съоръжения на Плиска и Преслав”, in: Археология 28/2, 1986, pp. 48-51.

Georgiev 1991: Павел Георгиев, “Предизвикан отговор”, in: Исторически преглед 47/1, 1991, pp. 66-69.

Gold der Awaren 2002: Gold der Awaren: der Goldschatz von Nagyszentmiklós, Ausstellungskatalog, Budapest 2002.

Henning 2000a: Joachim Henning, "Vom Herrschaftszentrum zur städtischen Großsiedlung mit agrarischer Komponente: archäologische Nachweise der Landwirtschaft aus dem frühmittelalterlichen Pliska“, in: Плиска-Преслав 8, Шумен 2000, pp. 74-86. 
Henning 2000b: Joachim Henning, "Pliska - Machtzentrum zwischen Byzanz und Abendland: Neue Wege der Archäologie", in: Forschung Frankfurt 2, 2000, pp. 6-15.

Horváth 1935: Tibor Horváth, Die awarenzeitlichen Gräberfelder von Üllö und Kiskörös (=Archaeologia Hungarica 19), Budapest 1935.

Klanica 1986: Zdeněk Klanica, Počátky slovanského osídleni našich zemí, Praha 1986.

Kovačević 1977: Јован Ковачевић, Аварски Каганат, Београд 1977.

Kovrig 1963: Ilona Kovrig, Das awarenzeitliche Gräberfeld von Alattyán, Budapest 1963.

Maršak 1961: Борис Маршак, “Влияние торевтики на согдийскую керамику VII-VIII веков”, in: Труды Государственного Эрмитажа 5, Ленинград 1961, pp. 177-201.

Michajlov 1955: Стамен Михайлов, “Археологически материали от Плиска (1948-1951 г.)”, in: Известия на Археологическия институт 20, 1955, pp. 49-181.

Michajlov 1993: Стамен Михайлов, “Нови данни за Голямата базилика в Плиска”, in: Плиска-Преслав 6, Шумен 1993, 22-32.

Michajlov/Milčev 1959: Стамен Михайлов/Атанас Милчев, "Разкопки в Плиска през 1955 г.”, in: Известия на Археологическия институт 22, 1959, pp. 263-291.

Milčev 1960а: Атанас Милчев, “Разкопки в Плиска, западно от Вътрешния град през 1959 г.", in: Археология 2/3, 1960, pp. 30-43.

Milčev 1960b: Атанас Милчев, “Археологически разкопки и проучвания в местността Aсар-дере-Плиска през 1959 г.”, in: Годишник на Софийския университет, Философскоисторически факултет 53, 1960, pp. 33-66.

Milčev 1985: Атанас Милчев, “Разкопки и проучвания на Южната порта в Плиска (1963 -1970)", in: Плиска-Преслав 4, София 1985, pp. 16-43.

Milčev 1990: Атанас Милчев, “Критични бележки към рецензията на Павел Георгиев”, in: Исторически преглед 4, 1990, pp. 78-83.

Petrova/Brey 2005: Vassilena Petrova/Gerhard Brey, "Provenance studies of early mediaeval fast wheel pottery from Pliska, Bulgaria", in: M. Isabel Prudêncio/M. Isabel Dias/J. C. Waerenborgh (Eds), Understanding people through their pottery. Proceedings of the 7th European Meeting on Ancient Ceramics (EMAC'03). October 27-31, 2003, Lisbon. Trabalhos de arqueologia 42, 2005, S. 167-174.

Petrova, forthcoming: Vassilena Petrova, Archäologische und naturwissenschaftliche Untersuchungen zur gelben Keramik aus Pliska (Bulgarien), PhD work at the J. W. Goethe-University of Frankfurt am Main.

Pohl 2002: Walter Pohl, Die Awaren: ein Steppenvolk in Mitteleuropa 567-822 n. Chr., München 2002.

Rašev 1981: Рашо Рашев, “Свидетелство за средновековния бит”, in: Плиска-МадараПреслав 8, Шумен, 23.03.1981, p. 2.

Rašev 1983: Rasho Rashev, "Pliska - the first capital of Bulgaria", in: Andrew Poulter (Ed.), Ancient Bulgaria 2, Nottingham 1983, pp. 255-269.

Rašev 1995: Рашо Рашев, “Плисковският аул”, in: Плиска-Преслав 7, Шумен 1995, pp. 10-21.

Rašev 2003: Рашо Рашев, ”За началото на българската средновековна култура”, in: ПлискаПреслав 9, Шумен 2003, pp. 145-167.

Rašev 2004: Рашо Рашев, "Керамични съдове от подземния ходник на Крумовия дворец в Плиска“, in: Плиска-Преслав 10, Шумен 2004, pp. 61-100.

Rašev/Stanilov 1989, Рашо Рашев/Станислав Станилов, "Раннесредневековый могильник у с. Ножарево, Силистренский округ (предварительное сообщение)“, in: Проблеми на прабългарската история и култура 2, София 1989, pp. 214-200. 
Rosner 1999: Gyula Rosner, Das awarenzeitliche Gräberfeld in der Szekszárd-Bogyiszlói Straße (=Monumenta Avarorum Archaeologica 3), Budapest 1999.

Škorpil 1905: Карел Шкорпил, “Домашный быть и промысель”, in: Известия Русского Археологического Института в Константинополе 10, 1905, pp. 301-317.

Srednjaja Asia 1999: Средняя Азия в раннем средневековья (=Археология с древнейших времен до средневековья), Москва 1999.

Stančev 1948: Станчо Станчев, “Керамика от Голямата могила в Плиска”, in: Разкопки и проучвания 3, София 1948, pp. 227-233.

Stančev/Ivanov 1958: Станчо Станчев/Станчо Иванов, Некропольт до Нови Пазар, София 1958.

Stanilov 1997: Станислав Станилов, “Памятники аварского типа в староболгарской культуре”, in: Проблеми на прабългарската история и култура 3, Шумен 1997, pp. 186-232.

Stanilov/Dimitrov/Jankulov 1991: Станислав Станилов/Янко Димитров/Игор Янкулов, "Проучване на селището югоизточно от Вътрешния град на Плиска", in: Проблеми на прабългарската история и култура 2, София 1991, pp. 124-137.

Tomka 1989: Péter Tomka, "Die Frage der ethnischen oder kulturellen Verwandtschaft bzw. interethischen Wirkung im Spiegel der Begräbnissitten”, in: International Conference on Early Middle Ages, A Wosinsky Mór Múzeum Évkönyve, Szeksárd 1989, pp. 163-174.

Vaklinov 1972: Станчо Ваклинов, “Плиска през 1971 г. ”, in: Векове 1/3, 1972, pp. 3-10.

Vaklinov/Štereva 1993: Станчо Ваклинов/Ирина Щерева, “Проучвания на Голямата базилика в Плиска през 1971-1973 г.”, in: Плиска-Преслав 6, Шумен 1993, pp. 33-48.

Vaklinov/Vaklinova 1993: Станчо Ваклинов/Маргарита Ваклинова, “Голямото водохранилище на Плиска (Разкопки на Станчо Ваклинов през 1961 г.)”, in: Плиска-Преслав 6, Шумен 1993, pp. 5-21.

Vida 1999: Tivadar Vida, Die awarenzeitliche Keramik I (6.-7. Jh.) (=Varia Archaeologica Hungarica 8), Berlin-Budapest 1999.

Vitljanov/Dimitrov 1996: Стоян Витлянов/Янко Димитров, “За класификацията и хронологията на битовата керамика от манастира при Голямата базилика в Плиска", in: Епископ-Константинови четения 2, 1996, pp. 238-256. 



\title{
Geophysical prospecting in Pliska (Bulgaria): applied methods and results
}

\author{
NORBERT SCHLEIFER
}

The first German-Bulgarian excavation campaign in the year 1997 also marks the beginning of the incorporation of geophysical methods into archaeological prospecting in the outer part of the historical city of Pliska, the first Bulgarian capital.

A magnetic survey covering large areas within a reasonable period of time was conducted in order to deliver important further information to the archaeologists. As a consequence, geophysical methods were able to display one of their advantages, i.e. to lead to an improvement in selecting areas for excavation and thus to a more time and therefore cost-effective progress of a campaign. Moreover, they give the possibility for preliminary interpretation of extended structures as well as small-scaled features while the archaeological remains stay well-preserved in the ground.

Meanwhile, the third measuring campaign representing three years of continued investigations has been finished and further geophysical methods, like a 3D-geoelectrical survey, have been applied. This paper summarises the results that were achieved after three years of consecutive geophysical investigation and shows the advantages of using these methods for the archaeological investigations conducted at the first Bulgarian capitol, Pliska.

\section{Principles of magnetic survey}

Magnetic measurements were carried out with a FEREX ${ }^{\circledR}$ 4.032-magnetometer of the Foerster company. This instrument consists of three vertically-oriented probes assembled at a distance of $50 \mathrm{~cm}$ (Fig. 1). As each probe represents a single measuring unit, the instrument enables the measuring of three parallel transections while walking only one. It is thus possible to cover an area of 1-2 ha per day.

Before the survey, the archaeological site was divided into rectangular areas which were then covered by a measuring grid usually of $50 \mathrm{~cm} \times 25 \mathrm{~cm}$; refinable up to $25 \mathrm{~cm} \mathrm{x}$ $25 \mathrm{~cm}$. During the measurement the surveyor followed equidistant ropes tracking the area following a zig-zag course. 


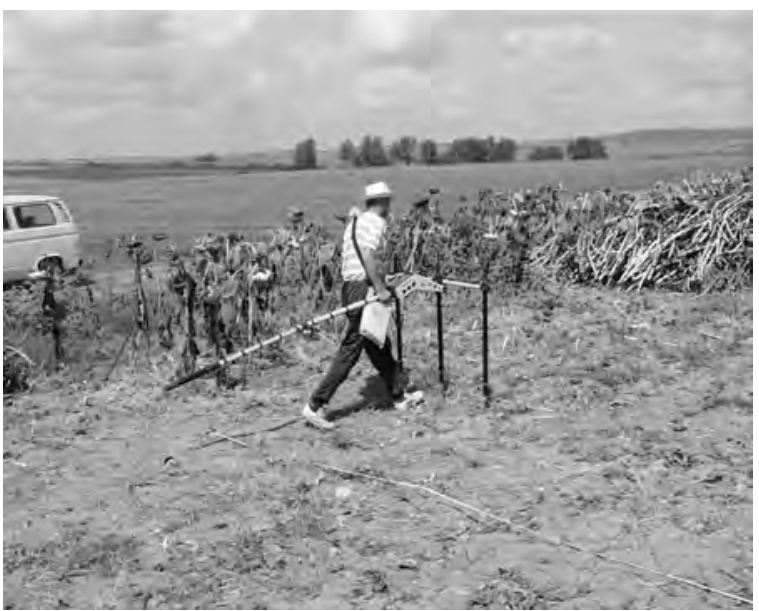

Fig. 1. The FEREX-magnetometer at work in Pliska

Each probe of the FEREX ${ }^{\circledR}$ 4.032, a fluxgate-magnetometer, measures the vertical gradient of the magnetic field of the earth. This is realised by two sensors within each probe measuring the strength of the earth's magnetic field $0.3 \mathrm{~m}$ and $1 \mathrm{~m}$ above the ground surface. The applied measurement is therefore called a gradiometer survey. The advantage of a gradiometer survey is that diurnal variations of the earth's magnetic field are eliminated and lateral variations of the magnetic properties of the soil can be better resolved. These anomalies usually increase or decrease the magnetic field up to $10 \mathrm{nT}$ (nanoTesla). As a comparison, the average magnetic field of the earth in our latitudes has a magnitude of $50.000 \mathrm{nT}$.

Archaeological structures like ditches, graves, pits or walls can be detected because they represent a disturbance of the natural distribution of magnetic minerals in the subsurface. In general, the magnetic susceptibility which describes the behaviour of materials in a magnetic field usually decreases with increasing depth; a phenomenon called "Le-Borgne"-effect after its discoverer. ${ }^{1}$ The enrichment of magnetic minerals in the top soil can have several reasons: ${ }^{2}$

a) influence of high temperatures (fire, lightning)

b) occurence of magnetic soil bacteria (biomagnetism)

c) higher clay content

d) postindustrial dust/volcanic ash

The accumulation of top soil in a ditch with a high magnetic susceptibility compared to the surrounding undisturbed soil leads to a positive magnetic anomaly. ${ }^{3}$ In contrast, a limestone wall with a lower susceptibility than the surrounding soil leads to

1 Le Borgnè 1955.

2 Mullins 1977; Maher/Taylor 1989; Thompson/Oldfield 1986; Fassbinder/Stanjek 1990.

3 Schleifer/Fassbinder/Irlinger/Stanjek 2003. 


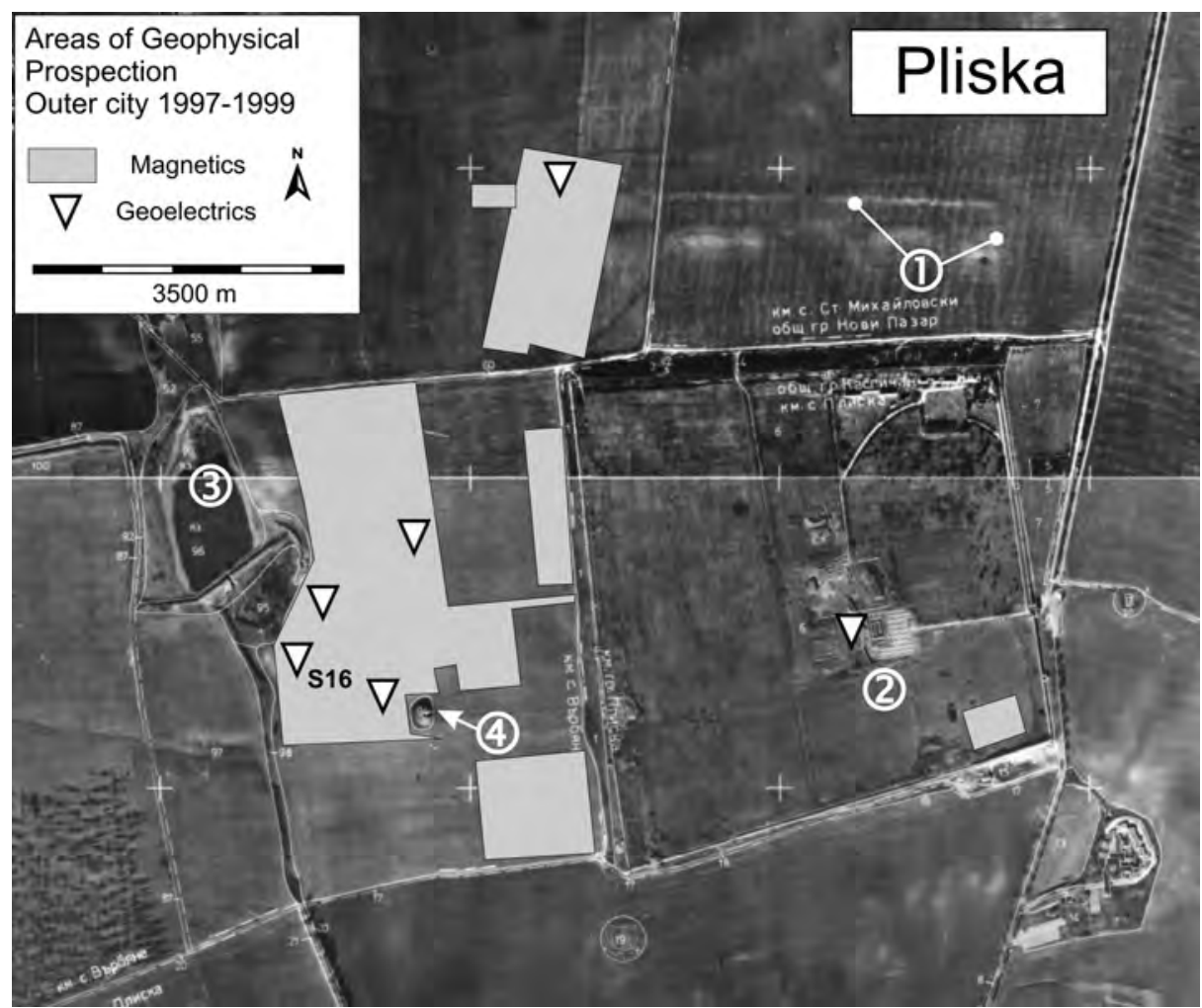

Fig. 2. Areas of geophysical prospecting in the outer city of Pliska from 1997-1999

a negative magnetic anomaly. Luckily, the susceptibility of almost all relevant archaeological remains leads to a measurable anomaly within the magnetic field. This fact and the ability of the method to cover large areas in a short time makes magnetic surveying the most widely used geophysical method in archaeology. ${ }^{4}$

\section{Magnetic survey results}

Between the years 1997 and 1998 the main area of investigation was located west of Mogila XXXIV, with direction towards the "Asar-dere" (Fig. 2). The results of this survey period are displayed in a so-called magnetogram (Fig. 3). Clearly visible is a half-moon shaped structure (Fig. 3.3) covering an area of $150 \mathrm{~m}$ x $150 \mathrm{~m}$. The structure extends from east to west and consists of alternating high magnetic (white) and low

4 Scollar/Tabbagh/Hesse/Herzog 1990. 


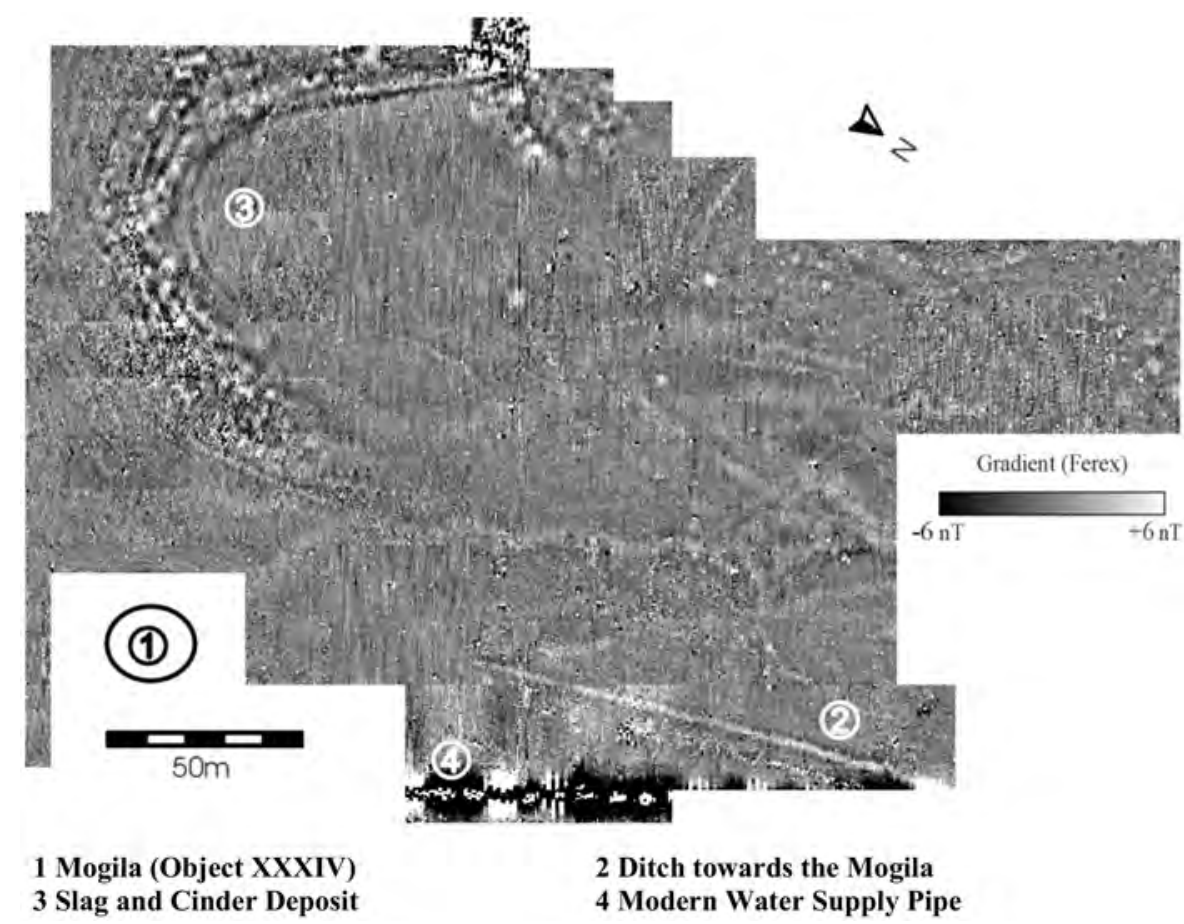

Fig. 3. Magnetogram of the area surveyed from 1997 to 1998. 1. Mogila (object XXXIV); 2. ditch towards the Mogila; 3. slag and cinder deposit

magnetic layers (black). The displayed feature is an early medieval slag heap and cinder deposit. These materials are characterised by a high magnetic susceptibility and, additionally, by remanent magnetisation. Remanent magnetisation is a magnetisation existing without a magnetic field, e.g. a permanent magnet. In most cases it is acquired while smelted material containing iron minerals is cooled down below a certain temperature, the so-called Curie temperature. The existence of a dominant remanent magnetisation results in the observed black and white pattern.

In the eastern part of Figure 3 one can track a positive linear anomaly over a distance of approximately $120 \mathrm{~m}$ (Fig. 3.2) before it reaches the edge of the magnetogram. This linear structure is a ditch which at first seems to correlate with Mogila XXXIV, with the ditch however vanishing before actually reaching the Mogila. In the northern part the ditch crosses a modern water supply pipe which can be easily recognised by its black and white pattern (Fig. 3.4).

Within the half-moon shaped feature several small positive magnetic anomalies with a size of about $5 \mathrm{~m}$ by $5 \mathrm{~m}$ can be spotted. These white anomalies represent settlement remains, whose fire places, kilns and bricks are responsible for the positive magnetic response. As mentioned before, the influence of heat leads to a chemical reaction of the 

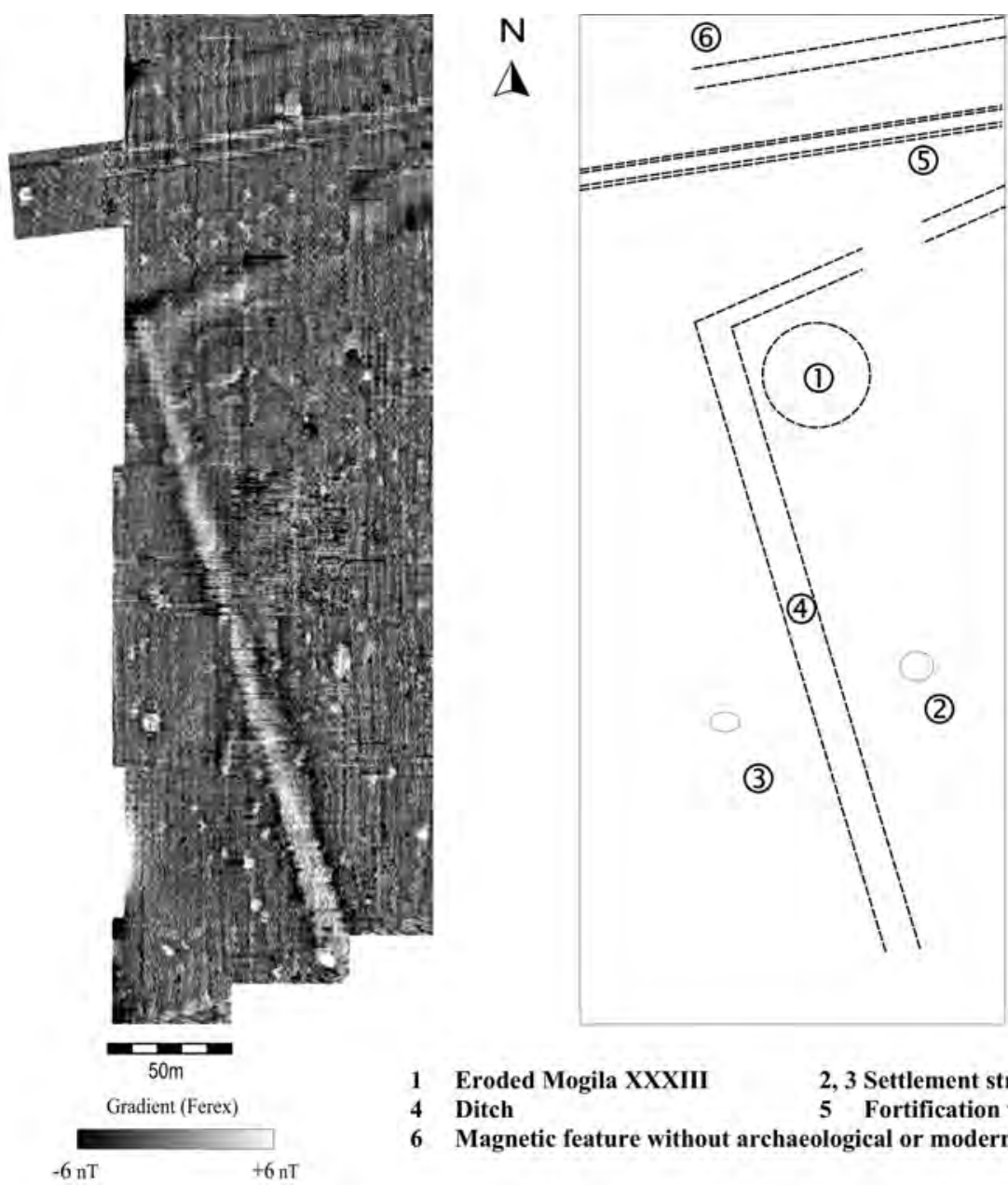

$$
\begin{array}{ll}
1 & \text { E } \\
6 & \text { D }
\end{array}
$$

Eroded Mogila XXXIII

Ditch

Magnetic feature without archaeological or modern evidence

Fig. 4. Magnetogram of the northwestern area (magnetic survey 1999). 1. eroded Mogila XXXIII; 2-3. settlement structures; 4. ditch; 5 . fortification wall; 6 . magnetic feature without archaeological or modern evidence

iron minerals in the soil or brick resulting in a higher magnetic susceptibility compared to the surrounding soil.

Due to harvesting, the main part of the magnetic survey of 1999 took place north of the Mogila XXXIV (Fig. 2); within this area another Mogila (Mogila XXXIII) could be found but unfortunately this one was almost completely eroded. Nevertheless, this Mogila is slightly visible within the magnetogram as a positive magnetic circular structure (Fig. 4.1). Although the measurements were not of the quality reached in 1998, we found linear structures related to this Mogila XXXIII and several settlement remains. The ditch (Fig. 4.4) creating a right angle at the location of the Mogila is 

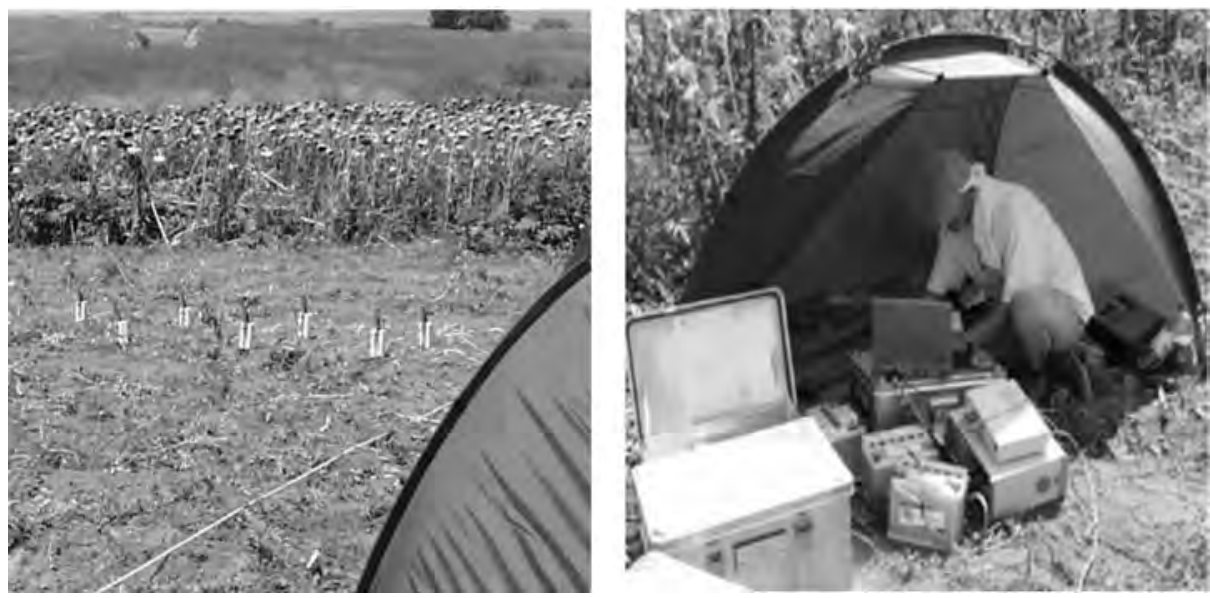

Fig. 5. Measurement set-up of a 3D-geoelectrical survey. At left: electrode array; at right: base unit with power supply

clearly visible in Figure 4, moreover, a gap can be seen within the northern part of the ditch which might be interpreted as a gate.

Additional east-west oriented almost parallel-running linear structures could be detected (Fig. 4.5, 6), while an excavation revealed that the more southern feature (5) was a fortification wall with a ditch. The excavation of feature (6) produced an astonishing result. Neither any archaeological nor modern evidence for the magnetic structure could be found, although it is clearly visible in the magnetogram. Further investigations were not possible. As this feature seems to be another appearance of the so-called "magnetic ghost"-phenomenon, ${ }^{5}$ the discrepancy between magnetic and archaeological interpretation could not be solved.

\section{D-geoelectrical survey}

The geoelectrical instrument SIP-256, developed at the Institute of Geophysics within the postgraduate programme "Archäologische Analytik" funded by the German Research Foundation (DFG) at the J. W. Goethe-University, Frankfurt/Main, allows the carrying out of 3D-surveys on small-scale archaeological objects (up to $10 \mathrm{~m}$ by $10 \mathrm{~m}$ in cross-section).

Compared to the magnetic survey, this method gives detailed information about the depth range of a structure and thus a 3D-image of the archaeological remains. Moreover, two additional physical parameters, electrical resistivity and phase shift are determined.

5 Schleifer 2004b. 


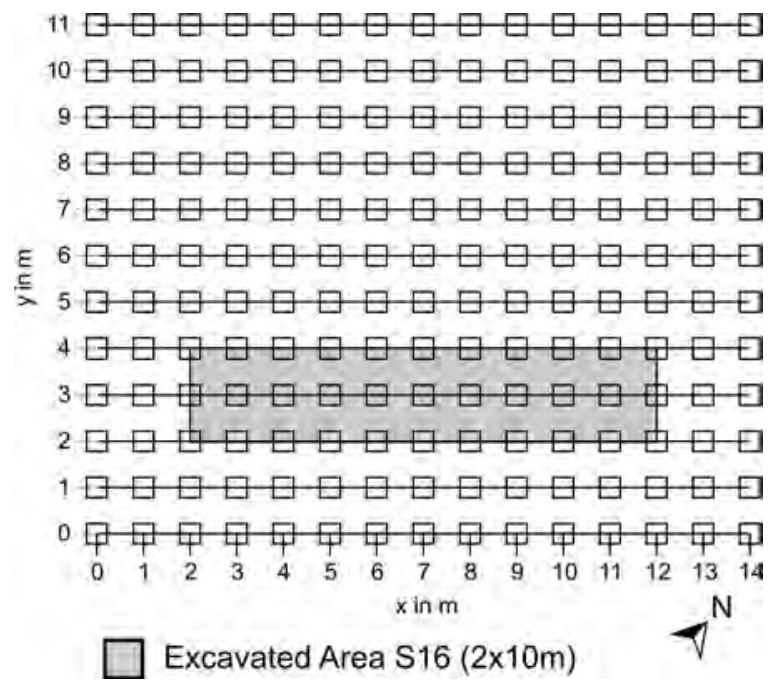

Fig. 6. Electrode set-up for the 3Dsurvey at location S16

Whereas the conventional electrical resistivity measurement has the longest tradition of all geophysical methods in archaeological prospection, ${ }^{6}$ the second parameter, called phase shift or phase angle, has been rarely used up to now. First attempts to apply the correlated method of induced polarisation (IP) were reported in the $60 \mathrm{~s}$ and $70 \mathrm{~s}^{7}$ Nowadays, the method is beginning to establish itself in archaeological prospecting. ${ }^{8}$

While carrying out an electrical survey, a current is injected into the ground by two electrodes and the voltage is measured with two additional electrodes. As the distance between the electrodes defines the investigated depth, an increase of the distance between the electrodes is equal to an increase of the depth of investigation. As a consequence, one has the possibility of varying the depth of investigation and thus to receive information about archaeological structures at various depths.

The electrical resistivity of the subsurface is calculated by comparing the amplitudes of the injected current and the measured voltage multiplied by a geometrical factor. It is influenced rather by the soil water content than by the material parameters.

As porous media like soil usually contain more water than dense materials, for example bricks, the electrical resistivity is mainly used for the detection of wall remains. The phase angle is a measure of the time shift between current and voltage and yields additional information about the clay content in the subsurface. Using both parameters, it is possible to distinguish between structures consisting of water saturated soil and clay or loam.

\footnotetext{
6 Scollar/Tabbagh/Hesse/Herzog 1990.

7 Aspinall/Lynam 1968; idem 1970.

8 Schleifer 2004a.
} 

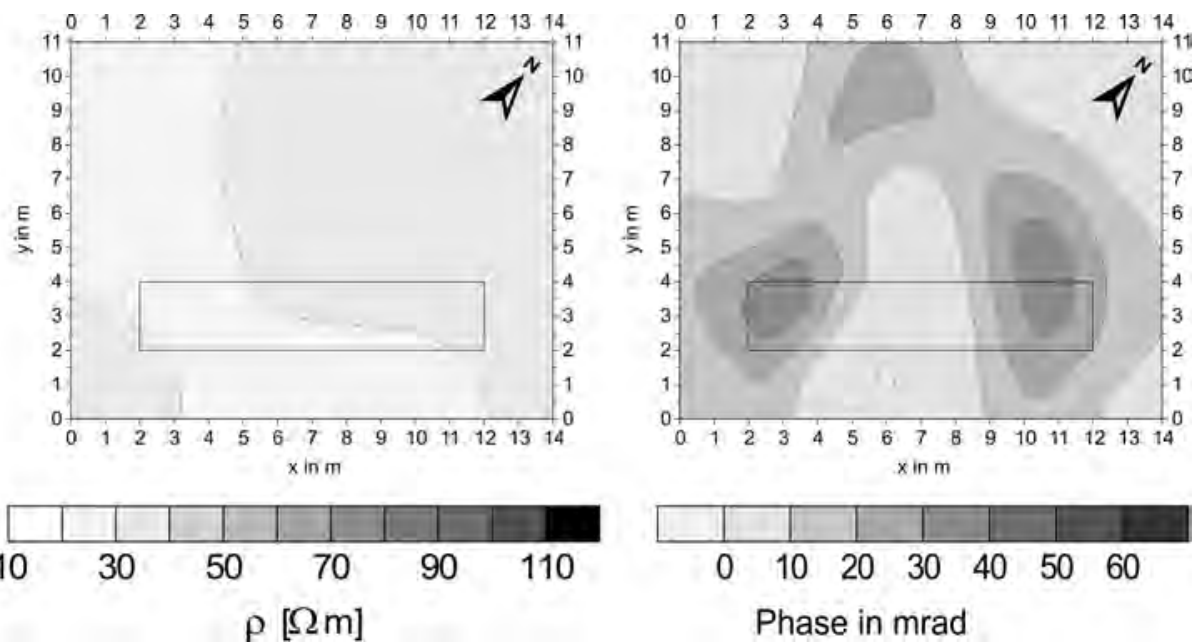

Fig. 7. Horizontal sections (depth range $2.3 \mathrm{~m}-2.9 \mathrm{~m}$ of the resulting subsurface model of the 3D-geoelectrical survey at S16. At left: resistivity; at right: phase angle. The rectangle represents the subsequently excavated area

In 1998, the development of the SIP-256 enabled the first field tests which were continued in 1999. Figure 5 shows the set-up of the instrument and the measurement electrodes in the field. A computer communicates with a base unit which controls the whole measurement cycle, with the electrical power necessary for a survey supplied by batteries. Altogether five locations were covered by electrical surveys (Fig. 2). Figure 6 shows a sketch of the electrode array at location S16, chosen after carrying out a magnetic survey.

The investigated area was measured by using twelve profiles with a length of $14 \mathrm{~m}$ each. The electrode spacing and distance between the profiles and therefore the resolution of the survey was $1 \mathrm{~m}$. The survey required two days of measurement, including the preliminary cutting of the maize.

The result of the geoelectrical survey is shown in Figure 7, displaying the horizontal section of the 3D-model at a depth-range of between $2.3 \mathrm{~m}$ and $2.9 \mathrm{~m}$ below the surface. Whereas there are no structures visible in the resistivity section, the section displaying the phase angle clearly shows three anomalies showing slightly higher phase angles of 20 to $40 \mathrm{mrad}$ (milliradian).

As a consequence of this result, the site for the subsequent excavation was chosen (see rectangles in Fig. 7). At the predicted depth the archaeologists excavated a settlement horizon (Fig. 8) beneath the slag deposit, correlating with the half-moon shaped magnetic anomaly in Figure 3. The electrical anomalies were caused by loam deposits. This loam was probably used as plaster for houses. 

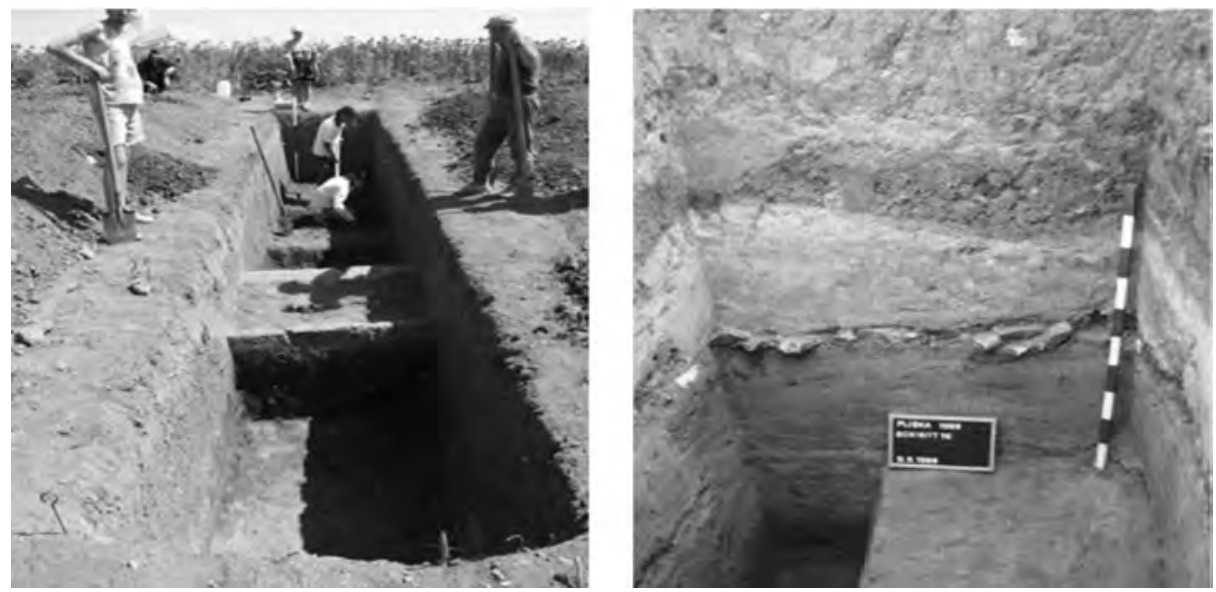

Fig. 8. Excavation at site S16. At left: near surface modern water pipe; at right: loam deposit with loose rocks representing a medieval settlement horizon

\section{Conclusions}

The geophysical methods used for the archaeological prospecting of the outer part of the historical city of Pliska proved their benefit in detecting large- and small-scale archaeological features. They lead to an improvement in selecting areas for excavation and thus to the avoidance of a more time- and cost-effective campaign. The results of the magnetic survey enabled the archaeologists to find large scale structures, like ditches and slag-deposits, whereas the electrical survey delivered a detailed image of small-scale settlement features at greater depths.

The measurement of the phase angle while carrying out an electrical survey showed the benefit of this additional parameter. Settlement remains which would otherwise have remained invisible could be detected. The appearance of a "magnetic ghost" was unexpected, but again indicates that it is always necessary to combine archaeological and geophysical methods to achieve a reliable interpretation. ${ }^{9}$

\section{Acknowledgements}

The author would like to thank the numerous German and Bulgarian students who finally realised this project with their enthusiasm and commitment. Moreover, I would like to thank my colleagues Dr. Jürgen Bigalke, Mark Kötter and Marco Hartlaub 
who carried out the field measurements during the years 1997 and 1998, together with Thorsten Sonnemann, Thomas Kind, Daniel Ziemann and Eyup Eyup.

Also thanks to the participants of the campaign of 1999, Kerstin Lebaillif, Nina Schücker and Jonas Svensson who carried out the main part of the magnetic survey during this year.

Special thanks to Andreas Vogel, a great archaeologist and organiser who played an important part in bringing two cultures together.

Also, I must thank the German Research Foundation (DFG) for funding the development of the SIP-256 and my postgraduate stipendia.

I am grateful to Prof. Henning who enabled me to participate in the 1999 campaign. The measurement results of this campaign became a main part of my $\mathrm{PhD}$ Thesis.

Finally, I would like to thank Prof. Andreas Junge who supported the collaboration between the two disciplines and was always a source of encouragement.

\section{Bibliography}

Aspinall/Lynam 1968: A. Aspinall/J. Lynam, "Induced Polarisation as a technique for archaeological surveying", in: Prospezioni Archaeologiche 3, 1968, pp. 91-93.

Aspinall/Lynam 1970: A. Aspinall/J. Lynam, "An induced polarisation instrument for the detection of near-surface features", in: Prospezioni Archaeologiche 5, 1970, pp. 67-75.

Fassbinder/Stanjek 1990: Jörg W. E. Fassbinder/Helge Stanjek, "Occurrence of magnetic bacteria in soil", in: Nature 343, 1990, pp. 161-163.

Le Borgnè 1955: E. Le Borgnè, "Susceptibilitèe magnètique anomale du sol superficiel”, in: Annale Geophysics 11, 1955, pp. 399-419.

Maher/Taylor 1989: B. A. Maher/R. M. Taylor, “Origin of soil magnetite”, in: Nature 340, 1989, p. 106.

Mullins 1977: C. E. Mullins, "Magnetic susceptibility of soils and its significance in soil science: a review", in: Journal of Soil Science 36, 1977, pp. 495-512.

Schleifer/Fassbinder/Irlinger/Stanjek 2003: Norbert Schleifer/Jörg W. E. Fassbinder/Walter E. Irlinger/Helge Stanjek, "Investigation of an Eneolithic Chamer-Group Ditchsystem near Riekofen (Bavaria) with Archaeological, Geophysical and Pedological Methods", in: György Füleky (Ed.), Papers of the $1^{\text {st }}$ International Conference on Soils and Archaeology, Szàzhalombatta, Hungary, Oxford 2001, pp. 59-63.

Schleifer 2004a: Norbert Schleifer, Anwendung der spektralen Induzierten Polarisation (SIP) in der archäologischen Prospektion (=Internationale Archäologie, Naturwissenschaft und Technologie 4), Rahden/Westfalen 2004.

Schleifer 2004b: Norbert Schleifer, "Ghost Features: A Proposal for Appropriate Management and a Forum for Discussion", in: Newsletter of the International Society of Archaeological Prospection 1, 2004, pp. 6-8.

Scollar/Tabbagh/Hesse/Herzog 1990: Irwin Scollar/Alain Tabbagh/Albert Hesse/Irmela Herzog, Archaeological Prospection and Remote Sensing, Cambridge 1990.

Thompson/Oldfield 1986: Roy Thompson/Frank Oldfield, Environmental Magnetism, London 1986. 


\title{
Soda-Kalk-Glas des 8. und 9. Jahrhunderts vom Asar-dere in Pliska (Bulgarien) im Vergleich mit frühmittelalterlichem Glas in Westeuropa
}

\author{
Karl Hans Wedepohl
}

Der Werkstoff Glas wurde in Mesopotamien und Ägypten in zwei vorchristlichen Jahrtausenden hauptsächlich zu Schmuck, aber auch schon zu Gefäßen verarbeitet. Kurz vor der Zeitwende entwickelte man die Technik des Glasblasens, so dass in der römischen Kaiserzeit Glas in großem Umfang zur Herstellung von Gefäßen benutzt werden konnte. In untergeordneten Mengen wurde damals auch schon Fensterglas gefertigt. Die Entwicklung der Glasindustrie im oströmischen Reich ist bisher wenig untersucht worden. Da Bulgarien im frühen Mittelalter unter west- und oströmischen Einflüssen war, sind hier die Informationen zur Glasentwicklung besonders aufschlussreich. Im ersten nachchristlichen Jahrtausend wurde Glas hauptsächlich aus Soda, Kalk und Quarzsand hergestellt. Die kaiserzeitlichen römischen Glashütten produzierten dieses Soda-Kalk-Glas in auffallend konstanter Zusammensetzung. Sie bezogen die Soda (Trona) von den Ufern der Salzseen im ägyptischen Wadi el Natrun und benutzten als Kalk Muschelschalen. Kurz vor der Jahrtausendwende ließ der Nachschub ägyptischer mineralischer Soda offenbar soweit nach, dass man als Alkalikarbonat die Asche von Strand- und Wüstenpflanzen verwenden musste. Neben Natriumkarbonat enthielt diese etwa gleiche Mengen Kalziumkarbonat. Dieser Soda-Rohstoff war im Nahen Osten seit vorchristlicher Zeit zur Herstellung von Waschmitteln und Glas benutzt worden. Man kann das jüngere Soda-Asche-Glas vom älteren Soda-Kalk-Glas an den höheren Gehalten von Magnesium und Kalium unterscheiden, die jeweils ein Gewichtsprozent deutlich überschreiten.

Die erste bulgarische Hauptstadt Pliska lag etwa $350 \mathrm{~km}$ nord-nordwestlich von Byzanz. Im Zentrum ihres etwa $22 \mathrm{~km}^{2}$ großen, fast rechteckigen, umwallten Gebietes befanden sich Paläste, Klöster und Basilikabauten, die von unterschiedlich ausgedehnten Siedlungsarealen umgeben waren. ${ }^{1}$

1 Rašev/Dimitrov 1999. 
Die früh- bis hochmittelalterliche Benutzung und eventuelle Herstellung von Glas in Pliska ist von Balabanov 1983 unter Angabe von chemischen Analysen beschrieben worden. ${ }^{2}$ Da sich die von ihm angeführten 26 Analysen hauptsächlich auf Fragmente (Gefäße, Armringe und Fensterscheiben) aus Soda-Asche-Glas beziehen, wurden für diese Untersuchung offenbar mehrheitlich Gläser benutzt, die nach $950 \mathrm{n}$.Chr. hergestellt wurden. Sie stammen überwiegend aus dem Palastzentrum, dem Krumpalast und dem Kleinen Palast. Zwei von Bezborodov und Marinov angefertigte Analysen von Fenster- und Gefäßglas aus dem Palastzentrum, die Balabanov zitiert, beziehen sich auf das Soda-Kalk-Glas, das hier wahrscheinlich die ältere Glasvarietät ist. Im Gebiet von Öfen an der westlichen Festungsmauer von Pliska fand Balabanov auch das wahrscheinlich ältere Soda-Kalk-Glas. Die beiden ebenfalls von Balabanov zitierten Analysen von Dončeva-Petkova an Glas aus der gleichen Fundstelle lassen keine Identifizierung des Glastyps zu.

Die chemische Zusammensetzung von Glas kann über die verwendeten Rohstoffe und ihre eventuelle Herkunft, über technische Kenntnisse am Ort der Verarbeitung und in günstigen Fällen über das Alter des Rohglases Auskunft geben. ${ }^{3}$

Die hier untersuchten Glasfragmente stammen aus dem Areal zwischen der Inneren Stadt und dem westlich gelegenen Trockental des Asar-dere in Pliska. Es sind 45 Fragmente aus den Schichten 3-10 der Grabung 1998 (deutsch-bulgarische Expedition), 14 Objekte aus der Altgrabung 1957 (A. Milčev) und 90 Objekte aus der Altgrabung 1952 (A. Milčev) ausgewertet worden. Die insgesamt etwa 150 Fragmente lassen sich in 40 Stücke Rohglas und Produktionsabfälle, 68 Teile Gefäßglas und 41 Stücke Flachglas einteilen. Mit den Glasfragmenten zusammen kommen auch poröse, z.T. verglaste Schlacken vor, die aber nicht aus der Glasherstellung, sondern wohl aus der Pyrometallurgie stammen. Die bei den Grabungen angeschnittenen Horizonte enthalten offenbar den Abtragungsschutt von Abfallgruben und Produktionsstätten. Somit kann man nur stark fragmentierte Gefäßteile erwarten, aus denen sich die Gefäßformen kaum noch rekonstruieren lassen. Das Vorkommen von Rohglas und von Produktionsrückständen mit Eindrücken durch benutzte Werkzeuge ermöglicht es, mit Sicherheit auf örtliche Verarbeitung von Rohglas zu Gefäßen und Fensterscheiben rückzuschließen, für die drei Typen von Glasöfen nötig waren: Arbeitsöfen, Kühlöfen und Strecköfen. Bisher ist die Identifizierung der Wandfragmente solcher Öfen schwierig. In römischer Zeit bestanden die Arbeitsöfen aus kegelstumpfförmigen, oben offenen Konstruktionen mit etwa einem Meter unterem Durchmesser. Sie waren aus lehmverschmierten Ziegeln oder Natursteinen aufgebaut und konnten jeweils nur einen Glashafen fassen. Die römischen Häfen waren dünnwandige, relativ flache Töpfe. ${ }^{4}$ In karolingischer Zeit wurden

2 Balabanov 1983.

3 Wedepohl 1998.

4 Gaitzsch 1999. 
die Häfen bereits durch dickwandige Gefäße mit steilen Wänden ersetzt. Die Öfen heizte man mit Holz. Milčev fand westlich der Inneren Stadt in einem Ofen mit indirekter Heizung 450 Keramikfragmente, die teilweise mit einer dünnen Glasschicht oder Glastropfen überzogen sind. ${ }^{5}$ Die Glasüberzüge finden sich auch auf Bruchflächen und können deshalb nicht von einer Glasur stammen, sondern sind bei einem Glasverarbeitungsprozess über die Keramik geflossen. Die meist schwarz oder auch rot gebrannten Keramikstücke mit Wandstärken von 0,7-1,0 cm lassen sich zu Röhren oder Zylindern mit etwa $10 \mathrm{~cm}$ Außendurchmesser ergänzen. Es sind wahrscheinlich Teile von Glasöfen oder Glashäfen.

Die Glasfragmente habe alle einen grünlichen Farbstich, je dicker die Wandstärke, umso mehr Farbe. Sie enthalten Gasblasen, die bei der Verarbeitung etwas ausgezogen wurden. Eine nur dünne irisierende Verwitterungsschicht lässt auf erhebliche Verwitterungsresistenz schließen. Aus Farbe und Verwitterungsresistenz, kann man vermuten, dass es sich in allen Fällen um Sodaglas handelt. Der verglichen mit vielen westlichen frühmittelalterlichen Siedlungsfunden hohe Anteil von Fensterglas zeigt, welchen Wert man in Pliska zur Zeit der Glasproduktion - die Ausgräber von 1998 stellen die Fundschichten in das 8./9. Jahrhundert - auf die Verglasung repräsentativer Bauwerke legte. Die meisten Scheibenfragmente sind 1,3-2,8 mm dick, also etwas dünner als die späteren großen gotischen Verglasungen. Im Gegensatz zu diesen sind alle von uns in Pliska untersuchten Glasfragmente farblos, abgesehen von dem durch etwa 1,5\% $\mathrm{Fe}_{2} \mathrm{O}_{3}$ bedingten Grünstich. Gleichzeitig verwendete man im Westen in Kirchenbauten schon zum Teil farbige Fenster, wie die des 9. Jahrhunderts im Kloster San Vicenzo al Volturno in Italien zeigen. Letztere wurden durch Zugabe von Mosaikgläsern zur Schmelze grün und blau gefärbt. ${ }^{6}$

Zur chemischen Analyse der Gläser von Pliska haben wir aus Listen, die im Institut für Archäologische Wissenschaften, Abt. für Ur- und Frühgeschichte der Universität Frankfurt a. Main archiviert sind, acht Proben ausgewählt, nämlich zwei Rohgläser aus der Altgrabung 1952 (Pli 7 = Probe 5 in der Frankfurter Liste und Pli $8=$ Probe 29 in der Frankfurter Liste), zwei Rohgläser aus der Altgrabung von 1957 (Pli 5 = Probe 4 in der Frankfurter Liste und Pli $6=$ Probe 6 in der Frankfurter Liste), ein Rohglas aus der Grabung 1998 (Pli 4 = Probe 33 in der Frankfurter Liste), zwei Glasscheiben aus der Grabung 1998 (Pli 3 = Probe 23 in der Frankfurter Liste und Pli $2=$ Probe 9 in der Frankfurter Liste) sowie ein Gefäßglas aus der Grabung von 1998 (Pli 1 = Probe 1 in der Frankfurter Liste). In den Listen finden sich außerdem nähere Angaben zu den Fundstellen, die von Interessenten abgerufen werden können. Die Analysen sind mit einem automatischen Röntgen-Fluoreszenzspektrometer PW 1480 von Philips ${ }^{\circledR}$ durchgeführt worden. Einzelheiten der verwendeten Linien, Röhrenanregung Analysatorkristalle

5 Milčev 1960.

6 Dell`Acqua 1997. 
und Detektoren hat Hartmann angegeben, der auch die in Tabelle 1 zusammengefassten Analysen ausführte. ${ }^{7}$ Zur Datenverarbeitung wurden ein Software-Satz X40 von Philips $^{\circledR}$ und zur Kalibrierung der Haupt- und Spurenelemente etwa 100 internationale Referenzgesteine und ähnliche Materialien benutzt. Als Messobjekte verwendeten wir Gläser, die unter Zugabe von Lithium-Tetraborat, Lithium-Metaborat und Lithium-Fluorid in Pt-Au-Tiegeln erschmolzen und dann in polierten Formen hergestellt worden waren.

Wie Tabelle 1 zeigt, sind die Analysenwerte der einzelnen Proben in Hauptkomponenten und Spurenelementen untereinander auffallend ähnlich. Das bestätigt unsere Annahme einer großen Einförmigkeit der 150 Proben aus Pliska nach Inspektion mit dem bloßen Auge und der Lupe. Ein Vergleich des Mittelwertes dieser Proben aus Tabelle 1 mit Mittelwerten von über 500 kaiserzeitlichen römischen Gläsern westeuropäischer Provenienz und ostfränkischen sowie karolingischen Gläsern aus Deutschland und Italien in Tabelle 2 offenbart eine überraschende Ähnlichkeit der Gläser aus Pliska mit dem erwähnten Vergleichsmaterial an Soda-Kalk-Glas aus neun Jahrhunderten in den meisten Hauptkomponenten. ${ }^{8}$ Diese Ähnlichkeit ist nur bei Verwendung sehr ähnlicher Rohstoffe und eines einzigen Rezeptes über die lange Zeit erklärbar. Die nachrömischen Glasproduzenten gaben etwas mehr Kalk in ihren Ansatz, wodurch sich der $\mathrm{SiO}_{2}$-Gehalt um einen unbedeutenden Anteil erniedrigte. Ihre Kalke enthielten wahrscheinlich auch etwas mehr MgO. Kleine, aber nicht unwichtige Abweichungen zeigen sich bei den Eisen- und Mangangehalten. Sie nehmen von den römischen Gläsern bis zu denen aus Pliska systematisch um mehr als den Faktor zwei zu. Dabei ist die Zunahme des Eisens durch die Verwendung eisenreicherer Sande bedingt. Diese Verwendung kann durch mangelnde Sorgfalt bei der Auswahl der Rohstoffe oder durch den Wunsch nach leicht grünlich gefärbten Gläsern bedingt sein. Letzteres ist weniger wahrscheinlich, weil die Produzenten des Rohglases ihrem Ansatz auch mehr Braunstein $\left(\mathrm{MnO}_{2}\right)$ zur Entfärbung des Eisens zugaben als die Römer zu ihren meisten Gläsern (1,13\% statt $0,47 \% \mathrm{MnO}$ ). Alle über $0,2 \% \mathrm{MnO}$ hinausgehenden Mangangehalte von Soda-KalkGläsern sind durch Zugabe von Braunstein bedingt. Eine Erhöhung der Eisengehalte korreliert mit der Erhöhung der Titangehalte, da beide Elemente hauptsächlich aus dem Schwermineral Magnetit im Quarzsand stammen. An den Fe/Ti-Verhältnissen kann man Rohgläser unterschiedlicher Provenienz unterscheiden. Die relativ hohen Strontiumgehalte in Gläsern aus Pliska (Tabelle 1) (bzw. Sr/Ca-Verhältnisse) sind durch Zugabe von Muschelschalen als Kalk zum Glasansatz zu erklären. ${ }^{9}$ Die beim Beginn

7 Hartmann 1994.

8 Daten und Zitate für römisches Glas aus Westeuropa, fränkisches, karolingisches und postkarolingisches Glas aus Deutschland s. Wedepohl 1998. Daten für karolingisches und postkarolingisches Glas aus Italien s. Freestone/Bimson 2001; Verita/Toninato 1990. Daten für postkarolingisches Glas aus Frankreich s. Barrera/Velde 1989.

9 Wedepohl/Baumann, 2000. 


\begin{tabular}{|c|c|c|c|c|c|c|c|c|c|c|}
\hline \multicolumn{9}{|c|}{ Gichts-\% } \\
\hline Probe & $\mathrm{SiO}_{2}$ & $\mathrm{TiO}_{2}$ & $\mathrm{Al}_{2} \mathrm{O}_{3}$ & $\mathrm{Fe}_{2} \mathrm{O}_{3}$ & $\mathrm{MnO}$ & $\mathrm{MgO}$ & $\mathrm{CaO}$ & $\mathrm{Na}_{2} \mathrm{O}$ & $\mathrm{K}_{2} \mathrm{O}$ & $\mathrm{P}_{2} \mathrm{O}_{5}$ \\
\hline Pli 1 & 71,8 & 0,13 & 2,1 & 1,18 & 0,83 & 0,78 & 6,64 & 15,6 & 0,67 & 0,12 \\
\hline Pli2 & 65,7 & 0,15 & 2,4 & 1,57 & 0,91 & 0,93 & 8,18 & 17,6 & 0,96 & 0,15 \\
\hline Pli3 & 64,8 & 0,16 & 2,5 & 1,62 & 1,53 & 1,0 & 7,67 & 17,7 & 0,79 & 0,15 \\
\hline Pli4 & 65,5 & 0,16 & 2,5 & 1,67 & 0,95 & 0,92 & 8,11 & 17,7 & 0.98 & 0,15 \\
\hline Pli 5 & 65,2 & 0,17 & 2,6 & 1,58 & 0,98 & 0,97 & 8,13 & 17,3 & 0,98 & 0,15 \\
\hline Pli 6 & 65,5 & 0,17 & 2,5 & 1,56 & 0,98 & 0,94 & 8,12 & 17,3 & 0,98 & 0,15 \\
\hline Pli 7 & 65,0 & 0,16 & 2,5 & 1,43 & 0,96 & 0,97 & 9,14 & 16,4 & 1,34 & 0,17 \\
\hline Pli 8 & 65,7 & 0,15 & 2,4 & 1,43 & 0,92 & 0,90 & 7,81 & 17,9 & 0,82 & 0,14 \\
\hline Mittel & 66,2 & 0,15 & 2,4 & 1,51 & 1,01 & 0,93 & 7,98 & 17,2 & 0,94 & 0,15 \\
\hline
\end{tabular}

\begin{tabular}{|c|c|c|c|c|c|c|c|c|c|c|c|c|c|c|}
\hline \multicolumn{10}{|c|}{$\mathrm{ppm}=10^{-4}$ Gewichts-\% } \\
\hline Probe & $\mathrm{Sc}$ & $\mathrm{V}$ & $\mathrm{Cr}$ & $\mathrm{Co}$ & $\mathrm{Ni}$ & $\mathrm{Zn}$ & $\mathrm{Ga}$ & $\mathrm{Rb}$ & $\mathrm{Sr}$ & $\mathrm{Y}$ & $\mathrm{Zr}$ & $\mathrm{Nb}$ & $\mathrm{Ba}$ & $\mathrm{Pb}$ \\
\hline Pli 1 & 6 & 26 & 19 & 13 & 20 & 22 & 2 & 10 & 497 & 7 & 67 & 2 & 247 & 142 \\
\hline Pli 2 & 6 & 28 & 19 & 11 & 23 & 27 & 7 & 13 & 583 & 9 & 79 & 3 & 285 & 186 \\
\hline Pli 3 & 10 & 38 & 20 & 16 & 31 & 30 & 5 & 9 & 676 & 8 & 86 & 2 & 330 & 168 \\
\hline Pli 4 & 1 & 30 & 23 & 17 & 22 & 27 & 2 & 14 & 587 & 7 & 81 & 3 & 304 & 141 \\
\hline Pli 5 & 10 & 32 & 24 & 14 & 21 & 27 & 7 & 14 & 586 & 10 & 85 & 2 & 288 & 213 \\
\hline Pli 6 & 10 & 32 & 22 & 12 & 21 & 25 & 6 & 14 & 585 & 7 & 86 & 4 & 302 & 210 \\
\hline Pli 7 & 8 & 28 & 21 & 15 & 20 & 30 & 3 & 19 & 599 & 8 & 86 & 2 & 316 & 166 \\
\hline Pli 8 & 8 & 30 & 17 & 10 & 18 & 28 & 6 & 10 & 581 & 8 & 81 & 2 & 284 & 187 \\
\hline Mittel & 7 & 31 & 21 & 14 & 22 & 27 & 5 & 13 & 587 & 8 & 81 & 3 & 295 & 177 \\
\hline
\end{tabular}

Tabelle 1. Chemische Analysen von fünf Rohgläsern (Pli 4-Pli 8), zwei Flachgläsern (Pli 2, Pli 3 ) und einem Gefäßglas (Pli 1) vom Asar-dere in Pliska (8./9. Jahrhundert) 


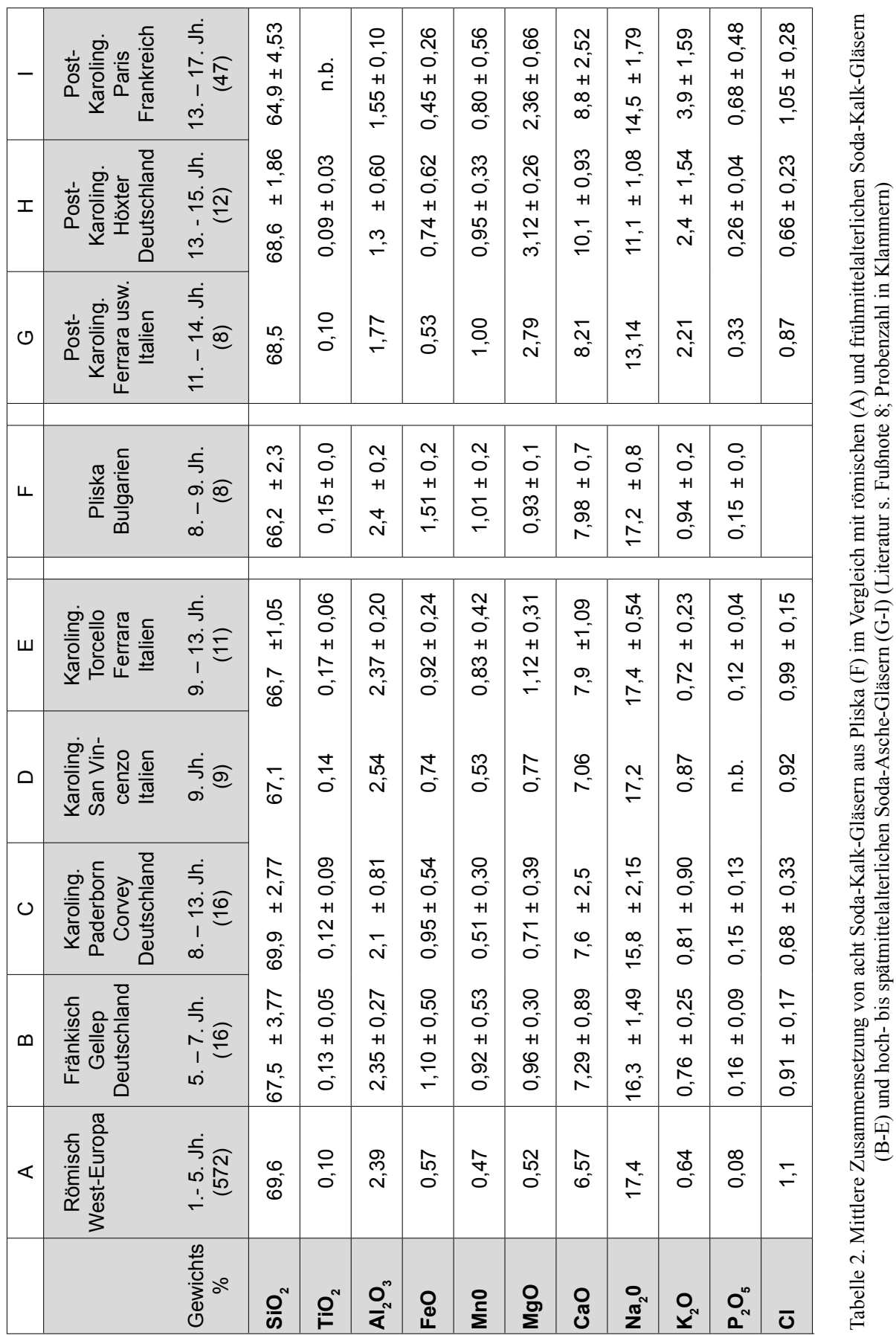


der Glasverarbeitung in Pliska noch nicht weit zurückliegende nachantike Urbanisierung des Gebietes und die große Erfahrung, die man bei der Verarbeitung von Rohglas zu Gefäßen und Fensterscheiben benötigt, lassen erwarten, dass die dort tätigen Glasmacher aus älteren Glaszentren einwanderten.

Für die Datierung der Gläser aus Pliska ist es wichtig, dass sich im 10. Jahrhundert im mediterranen Gebiet ein Wechsel im Rohstoff von dem Mineral Trona, auch Natron genannt, aus ägyptischen Salzseen zur Soda in der Asche von Strand- und Wüstenpflanzen des Nahen Ostens (später auch aus Spanien und Südfrankreich) vollzog. Dieser Wechsel ist an deutlich höheren $\mathrm{MgO}$ - und $\mathrm{K}_{2} \mathrm{O}$ - (aber auch $\mathrm{P}_{2} \mathrm{O}_{5}$-) Gehalten der Soda-Asche-Gläser klar zu erkennen. Die drei letzten Spalten von Tabelle 2 enthalten Mittelwerte von Soda-Asche-Gläsern des 11. bis 17. Jahrhunderts aus Italien, Frankreich und Deutschland mit 2,4 - 3,1\% $\mathrm{MgO}$ und 2,2 - 3,9\% $\mathrm{K}_{2} \mathrm{O}$ gegenüber $<1 \% \mathrm{MgO}$ und $<1 \% \mathrm{~K}_{2} \mathrm{O}$ in Soda-Kalk-Gläsern.

Gratuze und Barrandon beobachteten diesen Wechsel der Rohstoffe bei der Analyse islamischer Glasgewichte, die zwischen 850 und $950 \mathrm{zu}$ datieren sind. ${ }^{10}$ Die Ladung von 3 t Glas in einem Schiffswrack, das im 11. Jahrhundert bei Serce Limani an der anatolischen Küste sank, bestand ebenfalls vorwiegend aus Soda-Asche-Glas. ${ }^{11}$ Die Kompilation von Glasanalysen durch Bezborodov führt Perlen und Gefäße aus Soda-Asche-Glas an, die aus Usbekistan, Georgien, Syrien und vom Ladogasee in Nordrussland stammen und in den Zeitraum vom 7.-12. Jahrhundert datiert sind. ${ }^{12}$ Im Nahen Osten gab es offenbar Gebiete, in denen Aschensoda schon vor dem 10. Jahrhundert verwendet wurde. In Pliska ist der Wechsel des Glastyps offenbar erst im 10. Jahrhundert erfolgt, wie die unterschiedliche Zusammensetzung der Gläser vom Asar-dere (8./9 Jahrhundert) und aus den Palästen der späteren Zeit zeigt. Freestone und Gorin-Rosen berichteten über die umfangreiche Herstellung von Soda-Kalk-Rohglas in der byzantinischen Periode (6.-7. Jahrhundert) und von Soda-Asche-Rohglas in der islamischen Periode (11.-13. Jahrhundert) an der syrisch-palästinensische Küste und östlich vom Tiberias-See. ${ }^{13}$ Die offenbar für den Export bestimmten Rohglasmengen wurden hier in großen Tanköfen mit seitlicher Feuerung produziert. Eine derartige Rohglasschmelze von $9 \mathrm{t}$ Gewicht wurde in einer Höhle nahe der alten jüdischen Nekropole Bet She'arim wahrscheinlich im frühen 9. Jahrhundert hergestellt. Diese für das Gebiet wahrscheinlich erste Soda-Asche-Glasschmelze entglaste wohl wegen ihres derzeit ungewöhnlich hohen Kalziumgehaltes von $15 \% \mathrm{CaO}$, war nicht zu gebrauchen und verblieb am Ort. Für die Fehlcharge war wahrscheinlich die mangelnde Erfahrung mit dem neuen Rohstoff in der Übergangszeit von der hauptsächlichen Verwendung von mineralischer Soda zur Nutzung von Aschensoda verantwortlich. Alle von den genann-

\footnotetext{
10 Gratuze/Barrandon 1990.

11 Verita/Toninato 1990.

12 Bezborodov 1975.

13 Freestone/Gorin-Rosen 1999.
} 
ten Autoren aus dem syrisch-palästinensischen Gebiet aufgeführten Soda-Rohgläser haben mit 0,32-1,0\% FeO (Mittel 0,50\% FeO) zu wenig Eisen, um als Lieferanten für das Rohglas von Pliska in Frage zu kommen.

Im karolingischen Mitteleuropa machte sich der im 9. Jahrhundert einsetzende Mangel an mineralischer Soda (Trona) dadurch bemerkbar, dass man ein ganz neues Glasrezept auf der Grundlage lokaler Holzasche als Alkali- und Kalkträger einführte. Für sehr anspruchsvolle farblose Gläser wurde dort auch weiterhin Soda-Kalk-Glas benutzt, das zum Beispiel in einer Werkstatt neben dem Palast Karls des Großen in Paderborn um 780 zu Gefäßen verarbeitet wurde. ${ }^{14}$ Ein grünliches Gefäßfragment aus der Inneren Stadt von Pliska und ein blauer Armring aus dem Krum-Palast bestehen nach den Analysen 2 und 10 von Balabanov mit 20,65 und 14,23\% $\mathrm{K}_{2} \mathrm{O}$ aus einem $\mathrm{SiO}_{2}$-reichen, $\mathrm{CaO}$-armen Kaliglas. Seine Zusammensetzung weicht von den nordeuropäischen früh- bis hochmittelalterlichen Kaligläsern, die vorwiegend Holzaschegläser sind, erheblich ab.

Nach unseren chemischen Analysen und denen von Balabanov wurde in Pliska vor 900 n.Chr. Soda-Kalk-Glas wahrscheinlich aus importiertem Rohglas zu Gefäßen und Flachglas verarbeitet. Die verarbeitenden Glashütten befanden sich möglicherweise vor der westlichen Festungsmauer. Im Schutt am Asar-dere kam viel Rohglas und verarbeitetes Glas vor, das aus dieser Produktion stammen könnte. Die Gläser aus den Palästen bestehen vorwiegend aus Soda-Asche-Glas, das wahrscheinlich nach 950 angefertigt worden ist.

\section{Bibliographie}

Balabanov 1983: Тодор Балабанов, „За началото на стъклообработването в средновековна България“", in: Преслав 3, 1983, S. 228-240.

Barrera/Velde 1989: Jorge Barrera/Bruce Velde, „A study of French Medieval glass composition“, in: Archéologie Médievale 19, 1989, S. 81-130.

Bezborodov 1975: Michail Alekseevič Bezborodov, Chemie und Technologie der antiken und mittelalterlichen Gläser, Mainz 1975.

Dell'Acqua 1997: Francesca Dell'Acqua, ,Ninth-century window glass from the monastery of San Vicenzo al Volturno (Molise, Italy)“, in: Journal of Glass Studies 39, 1997, S. 33-41.

Freestone/Bimson 2001: Ian C. Freestone/Mavis Bimson, „The enamel (Appendix)”, in: John Mitchell/Inge L. Hansen (Hrsg.), San Vincenzo al Volturno 3. The Finds from the 1980-86 Excavations, Spoleto 2001, S. 105-116.

Freestone/Gorin-Rosen 1999: Ian C. Freestone/Yael Gorin-Rosen, „The great glass slab at Bet She'Arim, Israel: an early Islamic glassmaking experiment?“‘, in: Journal of Glass Studies 41, 1999, S. 105-116.

14 Wedepohl/Winkelmann/Hartmann 1997. 
Gaitzsch 1999: Wolfgang Gaitzsch, „Spätrömische Glashütten im Hambacher Forst. Die Werkstatt des ECVA-Produzenten", in: Artisanat et productions artisanales en milieu rural dans les provinces du nord-ouest de l'Empire romain, (=Monographies Instrumentum 9), Montagnac 1999, S. 125-149.

Gratuze/Barrandon 1990: Bernard Gratuze/Jean-Noël Barrandon, „Islamic glass weights and stamps: Analysis using nuclear techniques“, in: Archaeometry 32, 1990, S. 155-162.

Hartmann 1994: Gerald Hartmann, „Late-medieval glass manufacture in the Eichsfeld region (Thuringia, Germany)“, in: Chemie der Erde 54, 1994, S. 103-128.

Milčev 1960: Атанас Милчев, „Археологически разкопки в местността Асардере в Плиска“, in: Годишник на Софийския университет: Историко-филологически факултет 53/II, 1960, S. 33-66.

Rašev/Dimitrov 1999: Рашо Рашев/ Янко Димитров, Плиска 100 години археологически разкопки, Шумен 1999.

Verita/Toninato 1990: Marco Verita/Tullio Toninato, Riscontri analitici sulle origini della vetraria veneziana. (=Comitato Nazionale Italiano Dell'Association Internationale Pour L'Histoire Du Verre, Contributi Storico-Tecnici 1), Venezia 1990.

Wedepohl 1998: Karl Hans Wedepohl, „Mittelalterliches Glas in Mitteleuropa. Zusammensetzung, Herstellung, Rohstoffe“, in: Nachrichten der Akademie der Wissenschaften Göttingen, Mathematisch-physikalische Klasse 1998/1, S. 1-56.

Wedepoh1/Baumann 2000: Karl Hans Wedepohl/Albrecht Baumann, „The use of marine molluskan shells for Roman glass and the local raw glass production in the Eifel area", in: Naturwissenschaften 87/3, 2000, S. 129-132.

Wedepohl/Winkelmann/Hartmann 1997: Karl Hans Wedepohl/Wilhelm Winkelmann/Gerald Hartmann, „Glasfunde aus der karolingischen Pfalz in Paderborn und die frühe HolzascheGlasherstellung“, in: Ausgrabungen und Funde in Westfalen-Lippe 9A, 1997, S. 1-53. 



\title{
Periodisierung und Chronologie der Besiedlung und des Baugeschehens im Gebiet um die Große Basilika von Pliska
}

\author{
Pavel Georgiev
}

Die sogenannte Große Basilika und das sie umgebende erzbischöfliche Kloster gehören - neben der Residenz in der Inneren Stadt - zu den wichtigsten zentralen Bauten der Hauptstadt Pliska. Diese Anlage wurde als geistig-religiöser Mittelpunkt in der zweiten Hälfte des 9. Jahrhunderts errichtet, die Besiedlung des Areals selbst setzte jedoch nahezu ein Jahrhundert früher ein.

Die besondere Bedeutung der dort befindlichen baulichen Überreste ist lange bekannt. Bereits F. Kanitz, der erste Forscher in Aboba/Pliska, bemerkte, dass eine Straße vom „Kastell“, in welchem der von ihm als praetorium bezeichnete Palastkomplex lag, zu Gebäuderuinen aus schönem Baumaterial führe, was für ihren monumentalen Charakter spräche. ${ }^{1}$ Aus seinen Beschreibungen lässt sich schließen, dass der Zustand der Basilika und einiger Bauten des Erzbischofssitzes scheinbar besser waren als zu Beginn der ersten Grabungen an diesem Platz 20 Jahre später. K. Jireček beschreibt ihn als verwüstet, verweist aber darauf, dass die Bevölkerung die Stelle „Kliseri““ (Kirchplatz) nennt. ${ }^{2}$ F. Uspenskij und K. Škorpil bemerkten, dass entsprechend der schriftlichen Überlieferung die wichtigen Kultbauten auf die eine oder andere Weise mit dem ,Sarail-eri“ (Gebiet des Palastes) verbunden sind. ${ }^{3}$ Durch ihre Untersuchungen kamen sie zu dem Ergebnis, dass sich an dieser Stelle ,möglicherweise die älteste christliche Kirche in Bulgarien“ befunden habe, die ,zeitgleich mit der Bekehrung des Landes zum Christentum“ sei (F. Uspenskij). Außerdem sei sie mit Überresten ,eines der ersten bulgarischen Klöster, möglicherweise desselben, in dem Zar Boris die letzten Jahre seines Lebens verbrachte" verbunden (K. Škorpil).

Seit 1899 ziehen die Basilika und das Kloster die Aufmerksamkeit zahlreicher Forscher auf sich. ${ }^{4}$ Eine umfassende Untersuchung der Basilika und ihres unmittelbaren Umfeldes wurde jedoch erst in den Jahren 1971-1980 von einem Team unter der Leitung von St. Michajlov, St. Vaklinov, Ž. Văžarova und dem Autor durchgeführt. ${ }^{5}$ Vorrangige

\footnotetext{
1 Kanitz 1882, 262.

2 Ireček 1974, 935.

3 Uspenskij 1905a, 9; Škorpil 1905, 62, 104-105, 144-145.

$4 \mathrm{Zu}$ einer vollständige bibliographische Angaben siehe Georgiev/Vitljanov 2001.

5 Georgiev 1993a; ders. 1993b, 49-68.
} 


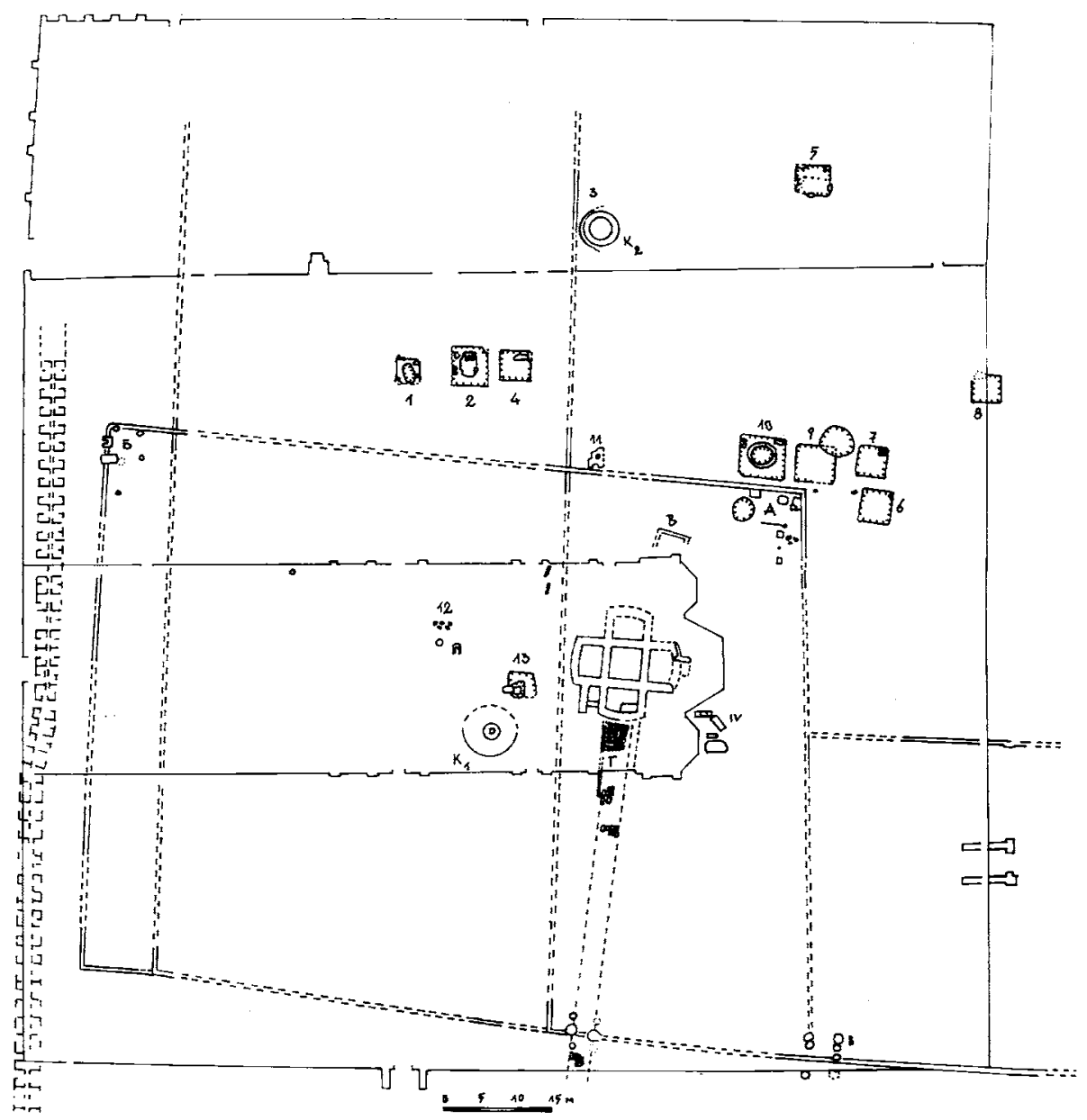

Abb. 1. Plan des Martyrions unter der Großen Basilika mit den dort freigelegten Wohnbauten

Aufgabe dieser archäologischen Untersuchungen war nicht nur die Freilegung der Überreste des Klosters und die Klärung der Baugeschichte der Großen Basilika, sondern auch die Erforschung der gesamten Siedlungsgeschichte in diesem Areal.

Nach Abschluss der Untersuchungen stellt der Bereich um die Große Basilika die größte vollständig erforschte Anlage auf dem Siedlungsareal von Pliska dar. Es können jetzt Aussagen zum Zeitraum ihres Bestehens und zum Baugeschehen getroffen und, dank der vergleichsweise klaren Formen der ergrabenen Befunde und Funde, eine Chronologie erstellt werden, in deren Rahmen die verschiedenen Bauphasen, Schichten und Funde bis auf wenige Jahrzehnte oder in einigen Fällen bis auf wenige Jahre genau eingeordnet werden können. Außerdem kann eine historische 


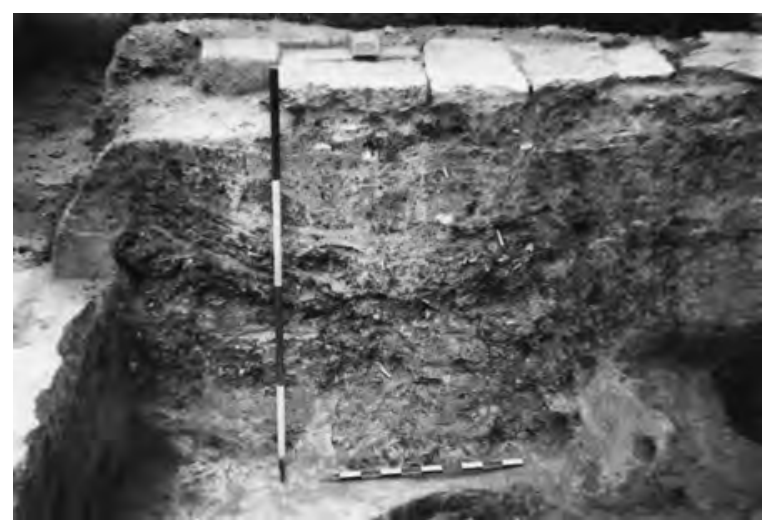

Abb. 2. Profil einer Hausgrube unter der Schicht des Palastes des Erzbischofs

Interpretation und eine Verknüpfung der archäologischen Befunde mit den überlieferten historischen Quellen unternommen werden. Somit bieten diese Untersuchungen und ihre Auswertungen die - innerhalb der bulgarischen Mittelalterarchäologie - seltene Möglichkeit, eine fundierte Baugeschichte eines geistig-religiösen Zentrums zu erstellen, die als Vergleichsgrundlage für kommende Forschungen an Baukomplexen ähnlichen Charakters dienen können.

Die Resultate der durchgeführten Grabungen einschließlich einer weiteren, ergänzenden Kampagne von 1988, sollen im Folgenden vorgestellt werden.

\section{Die frühmittelalterliche Siedlung}

Die frühesten Anzeichen von Besiedlung auf dem untersuchten Areal weisen auf eine große Siedlung hin. ${ }^{6}$ Die $30 \mathrm{~cm}$ starke Fundschicht dieser Siedlung liegt unmittelbar auf dem alten Humus und besteht aus roter, mit Siedlungsabfällen vermengert Erde. Insgesamt wurden 13 Gebäude untersucht, von denen zehn in den Boden eingetieft (Grubenhäuser) und drei ebenerdig errichtet waren (Abb. 1). Eine vergleichbare Schicht mit Hausbefunden konnte unter den Fundamenten der Gebäude des Objektes Nr. 31 etwa 400 m östlich der Großen Basilika erfasst werden. ${ }^{7}$ Eine hölzerne Umzäunung, die im Süden der Grabungsfläche erfasst werden konnte, zeigt, dass es sich um einen der größeren Wohnbezirke auf dem Gebiet der Äußeren Stadt gehandelt haben muss.

Die im Bereich der Basilika gemachten Funde erlauben eine Datierung der Siedlung an das Ende des 8. Jahrhunderts. Gesichert ist das Ende der Besiedlung, da die Bauten an dieser Stelle durch Schichten überlagert werden, die bereits christlicher Zeitstellung

6 Georgiev 1981, 190-197; ders. 1993a, 9-40; Vasilev 1995, 27-33.

7 Michailov, 1955, 138-168; Michailov/Milčev 1959, 268-288; Michailov 1963, 12-21, 37-39. 


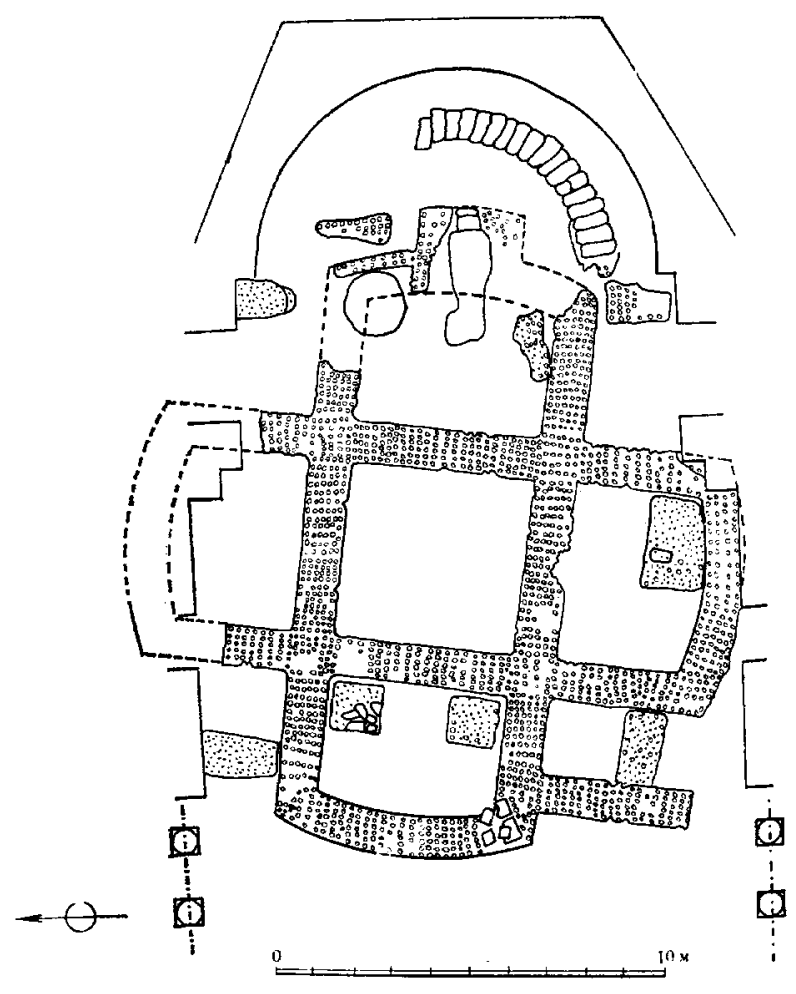

Abb. 3. Grundriss der Fundamente der kreuzförmigen Martyrions des Enravota

sind (Abb. 2). Die Übernahme der christlichen Religion um die Mitte des 9. Jahrhunderts ist ein unbestreitbarer terminus ante quem für das Bestehen dieser Siedlung.

In letzter Zeit wurde die Datierung des ersten Kultbaus, eines Gebäudes mit kreuzförmigem Grundriss, das am südwestlichen Ende der Siedlung entdeckt wurde (Abb. 1), erneut einer Diskussion unterzogen. Einige Forscher sehen darin eine frühbyzantinische Kirche, ${ }^{8}$ während andere ein heidnisches Heiligtum oder die Grabstätte eines Khans aus dem 8. oder 9. Jahrhundert in Erwägung ziehen. ${ }^{9}$ Trotz dieser unterschiedlichen Ansichten besteht jedoch kein Zweifel, dass die Siedlungsreste, bestehend aus Abfallgruben und sonstigen Gruben sowie Grubenhäusern oder ebenerdigen Bauten, unter dem Bauhorizont des kreuzförmigen Gebäudes liegen (Abb. 4). Oberhalb des Niveaus des vermutlichen Kultbaues fanden sich zudem noch weitere Gebäudereste vergleichbarer Art und Zeitstellung.

8 Milčev 1995, 52; Michailov 1995, 47-49.

9 Vaklinov 1977, 169-170; Bojadžiev 1986, 28-32. 


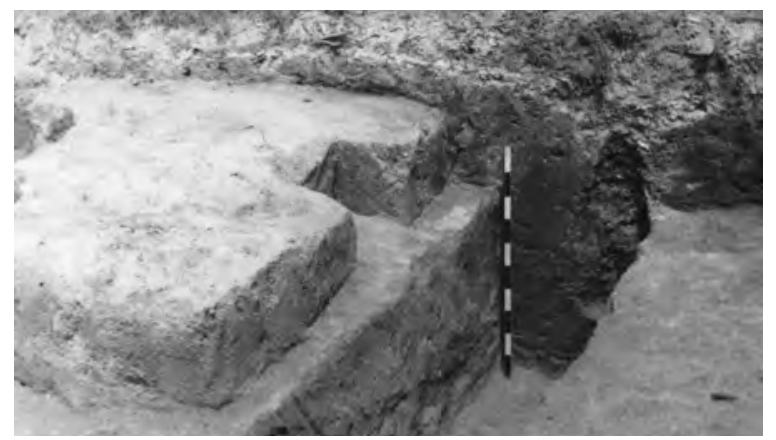

Abb. 4. Ansicht des Fußbodenestrichs eines ebenerdigen Hauses. Der Befund wird geschnitten von einer Sondage zur Erfassung der Palisade des Martyrions und einem Profil, das die Bauphasen der Basilika und des Erzbischofssitzes darüberliegend zeigt

Wenn man annimmt, der Kultbau sei tatsächlich spätantik, so folgt daraus, dass die Siedlung in das 4. bis 6. Jahrhundert oder sogar noch älter datiert werden müsste, was keinen Sinn ergibt. ${ }^{10}$ Geht man aber davon aus, dass es sich um einen Architekturkomplex heidnischen Charakters aus dem 8. Jahrhundert handelt, so muss auch die Siedlung unmittelbar in dieser Zeit bestanden haben. Unterstützt wird diese These durch die Grabungsbefunde, die zeigen, dass die Siedlungstätigkeit innerhalb der untersuchten Fläche kaum länger als ein halbes Jahrhundert angedauert haben wird. Auch die Keramik- und Metallfunde, wie zum Beispiel der Teil einer Gürtelgarnitur oder die Fingerringe mit symbolischen Verzierungen, erhärten diese Annahme. Im Übrigen stimmt diese Schlussfolgerung auch mit den zeitlichen Einordnungen anderer Siedlungsstrukturen in der Äußeren Stadt überein. ${ }^{11}$

Die Anlage der Siedlung erfolgte im Zeitraum vom Ende des 8. bis zur Mitte des 9. Jahrhunderts und ist also in etwa zeitgleich mit der Ansiedlung bei der Kirche Nr. 11. ${ }^{12}$ Beide Siedlungen entstanden in Folge der Ausdehnung der Besiedlung auf die wasserarme Terrasse östlich des Asar-dere. Diese Ausdehnung ist zeitgleich mit der Umgrenzung der Khansresidenz durch eine Erdbefestigung und mit deren Umwandlung in eine Umwehrung für die sich aus einer Siedlung des Lagertypus mit dem protobulgarischen Namen $\Pi \lambda \iota \sigma \kappa o \beta \alpha$ herausbildende Stadt. ${ }^{13}$ Wahrscheinlich geschah dies an der Wende vom 8. zum 9. Jahrhundert.

\section{Der christliche Gründungsbau: das Martyrion}

Auf Grundlage der Ausgrabungen kann der kreuzförmige Bau als Martyrion interpretiert werden (Abb. 3). Er war von einer hölzernen Palisade umgeben, deren Spuren

10 Georgiev 1998, 81-84.

11 Georgiev 2000b, 16-30.

12 Stanilov/Dimitrov/Jankulov 1991, 124-137.

13 Georgiev 2000a, 19-30; ders. 2000c. 

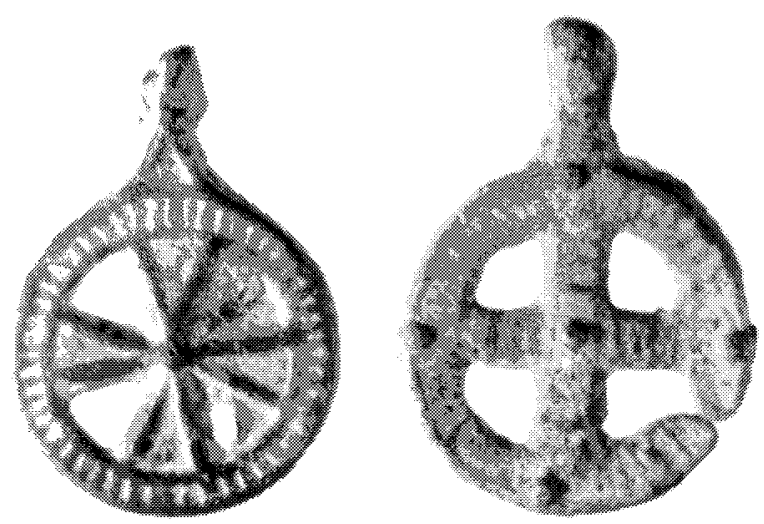

Abb. 5. Medaillon mit christlicher Symbolik aus der Fundschicht der Siedlung

nicht von denjenigen der Siedlungspalisade - deren südlichen Verlauf sie benutzt - unterschieden werden konnten (Abb. 1). Diese Feststellung ist hinreichend, um eine angenommene Verbindung zwischen der Siedlung und dem nahe der Paläste entstandenen Architekturensemble zu begründen. Nach dessen Errichtung bestand die Siedlung weiter, allerdings außerhalb seiner Umfassung. Durch diese Palisade ist vermutlich auch die Reihung einiger Häuser an der nordöstlichen Ecke des Areals zu erklären. Die mit dem Martyrion verbundenen Kulturschichten konnten vor allem in seiner unmittelbaren Umgebung und unter der südlich anschließenden Ziegel-Stein-Schicht nachgewiesen werden. Diese fand sich auch um den Brunnen der Siedlung, der zugleich in eine fons vitae mit kuppelförmiger Abdeckung und Öffnung umgewandelt wurde. Ihre Fundamente sind vergleichbar mit denjenigen des Raumes für den Sarkophag des Märtyrers.

Des weiteren können Funde, die in den nördlichen Ecken des Palisadenzauns gemacht wurden, in Zusammenhang mit dem Martyrion gebracht werden. Das Fundspektrum unterscheidet sich nicht wesentlich von dem der Siedlung. Es fanden sich Fingerringe oder Medaillons mit dem Motiv eines gleicharmigen Kreuzes in einem Kreis (Abb. 5). Dieses Symbol des Sieges des Christentums erkennen wir auch im Grundriss des kreuzförmigen Tempels wieder (Abb. 3).

Die Analyse von Grundriss und Bauornamentik des kreuzförmigen Gebäudes, des Ajasmo-Brunnens, der Gräber der kleinen Nekropole und der Funde, gibt Anlass zu einer Interpretation des gesamten Bauensembles als frühchristliches Martyrion, vergleichbar mit anderen spätantiken Bauten dieser Art. Die Schriftquellen bestätigen, dass um das Jahr 832 Khan Enravota - der Nachfolger des Omurtag - in der bulgarischen Hauptstadt wegen seines christlichen Glaubens hingerichtet wurde. Es kann vermutet werden, dass das Martyrion nach der offiziellen Annahme der christlichen Religion durch den Zaren Boris zu Ehren Enravotas errichtet worden ist, zumal dieser 
der selben Herrscherdynastie entstammte. Das Fehlen der genauen Lebensdaten des Enravota lässt einige Forscher an dieser Verwandtschaft zweifeln. ${ }^{14}$

Die Deutung der Gebäude unter den Fundamenten der Großen Basilika als Martyrion ist jedoch stichhaltig. Überzeugend sind die Hinweise auf seinen christlichen Charakter. Die Anhaltspunkte hierfür sind vornehmlich architektonischer Natur. Die Ausrichtung der Großen Basilika und der sie umgebenden Bauten des Erzbischofs folgt exakt derjenigen der Vorgängeranlage (Abb. 1). Der Altar der Basilika wurde genau über dem kreuzförmigen Gebäude errichtet. Dem Plan ihrer Erbauer zufolge, sollte das Martyrion als Krypta genutzt werden (Abb. 3). Der Sarkophag des Märtyrers wurde im Mittelschiff aufgestellt, unmittelbar vor den Altarschranken, und der AjasmoBrunnen wurde, ungeachtet der bautechnischen Problematik für die Basilika, in das südliche Seitenschiff integriert. Kurz gesagt liegt der architektonische und funktionale Zusammenhang der beiden Bauten auf der Hand. Dies kann nur dann richtig und zutreffend sein, wenn beide auch dem selben ideologischen Zweck gedient haben.

Die Abfolge und der Zusammenhang der beiden Gebäude innerhalb des Komplexes der Großen Basilika erlauben es, die Errichtung der ersten christlichen Bauten etwa in die Mitte des 9. Jahrhunderts zu setzen. Zieht man die historischen Ereignisse im Zusammenhang mit der Einführung des Christentums in der bulgarischen Hauptstadt mit in die Überlegung ein, so weisen diese in die Jahre 855-856. In dieser Zeit zeigen die historischen Quellen, dass der bulgarische Herrscher sich in der neuen Lehre unterweisen ließ und die Christianisierung der hauptstädtischen Gemeinschaft sich zu vertiefen begann. Das Martyrion mit kreuzförmigem Grundriss ist der erste christliche Kultbau in der Hauptstadt und zugleich Symbol für das Auftreten der neuen Religion. Bei der offiziellen Taufe des Fürsten Boris-Michail 864/865 wurde der Bau in eine Gemeindekirche umgewandelt und der Ajasmo-Brunnen als Massentaufstätte verwendet. Der Brand und die Zerstörung der christlichen Gebäude steht im Zusammenhang mit der heidnischen Verschwörung eines Teils der bulgarischen Boljaren im Jahre 865, von der die Annales Bertiniani berichten.

Die zerstörten christlichen Bauten im Bereich der Äußeren Stadt boten sich bei der Suche nach einem Platz für ein geistig-religiösen Zentrum in den Jahren nach der offiziellen Übernahme des Christentums an. Das kreuzförmige Martyrion und der Ajasmo-Brunnen sowie die Angaben über ein geheimes Christentum unter den Bewohnern der Siedlung ließen diese Stelle als „heiligen Ort“ erscheinen, der in der lokalen christlichen Tradition der Bulgaren tief verwurzelt war. Diese ideologische Anknüpfung war notwendig, um als ideologische Grundlage bei der Errichtung einer eigenständigen kirchlichen Organisation zu dienen, für die - wie wir aus den Schriftquellen wissen - Fürst Boris eingetreten ist. ${ }^{15}$

14 Canev 1998, 159-167.

15 Georgiev 1993a, 102-130. 


\section{Die Große Basilika und das Kloster des Erzbischofs}

Die Basilika und der sie umgebende Siedlungsbereich bedeckten während ihrer zweihundertjährigen Nutzung eine Fläche von insgesamt 23.000 qm. ${ }^{16}$ Die Bauphasen sind voneinander durch Mörtel- oder Abfallschichten, die als Folge von Zerstörungen interpretiert werden können, und durch Fußbodenniveaus getrennt. Ebenso wie die Grundrissänderungen der Basilika sind sie Teil der komplizierten Baugeschichte. Die Zusammenfassung aller Beobachtungen ergab zwei Grundrisspläne (Abb. 6a.b).

Der erste Grundriss (Abb. 6a) lässt einige Merkmale der westlichen Kirchenbautradition des frühen Mittelalters erkennen. Dieser Umstand erlaubt eine Datierung des Baubeginns in die Zeit der durch schriftliche Quellen überlieferten Anwesenheit lateinischer Kleriker in den Jahren zwischen 866 und 869.

Die Basilika hat eine Länge von ca. $102 \mathrm{~m}$ und eine Breite von $30 \mathrm{~m}$. Ihre Größe und einige technische Details lassen vermuten, dass sie das Ergebnis eines ambitionierten Bauprogramms ist, nämlich das Gebäude in seiner Pracht den größten Bauten des päpstlichen Roms anzunähern. Deshalb ist es sehr gut möglich, in ihr ein Werk der Bemühungen Fürst Boris' und des Gesandten des Papstes, Bischof Formosus von Porto, zu sehen. Wie die Schriftquellen bezeugen, sollte eine eigene, dem Papst unterstellten Diözese in Bulgarien geschaffen werden.

Die Veränderungen im Bauplan der Basilika (Abb. 6b) zeugen von klaren ideologischen Vorstellungen und wurden von der dauerhaften kirchlichen Anbindung Bulgariens an den Patriarchen von Konstantinopel beeinflusst. Nach der Errichtung eines dreiteiligen Altars und der Galerien über dem Narthex und den Seitenschiffen sowie von Mitatoria für den Fürsten und den Erzbischof, war die Basilika von Pliska mit allem ausgestattet, was das byzantinische Hof- und Kirchenzeremoniell erforderte. Das früheste mögliche Datum für diesen Umbau ist das Jahr 871, der Abschluss der Arbeiten erfolgte unmittelbar nach 875 .

Die Bauten, welche die Basilika umgeben, beziehen sich deutlich auf sie, was zeigt, dass sie zu einer Zeit errichtet wurden, als die Kirche nach dem neuen Plan umgebaut wurde. Die ältesten Bauten waren in Form eines peribolos angelegt, der die Basilika an drei Seiten mit eigenständigen Gebäuden umfasste und einen Friedhof für die Aristokratie und die Mönche mit einer Fläche von etwa 137 x 110 m einschloss. Die aus Steinblöcken und Ziegeln errichteten Gebäude des peribolos zeigen die Charakterzüge eines Bischofssitzes (episcopion) mit Wohnpalast (Abb. 7), wie zum Beispiel ein über einen Hypokaust geheiztes Bad, ein Kloster (monasterium clericorum) und eine Schule zur Ausbildung von Schreibern (didaskaleion mit scriptorium). Es gibt keinen Zweifel daran, dass es sich hierbei um die Bischofsresidenz des 870 begründeten Erzbistums Bulgarien handelt. Die bei den Grabungen entdeckten Inschriften des „Erzbischofs

16 Georgiev/Vitljanov 2001. 

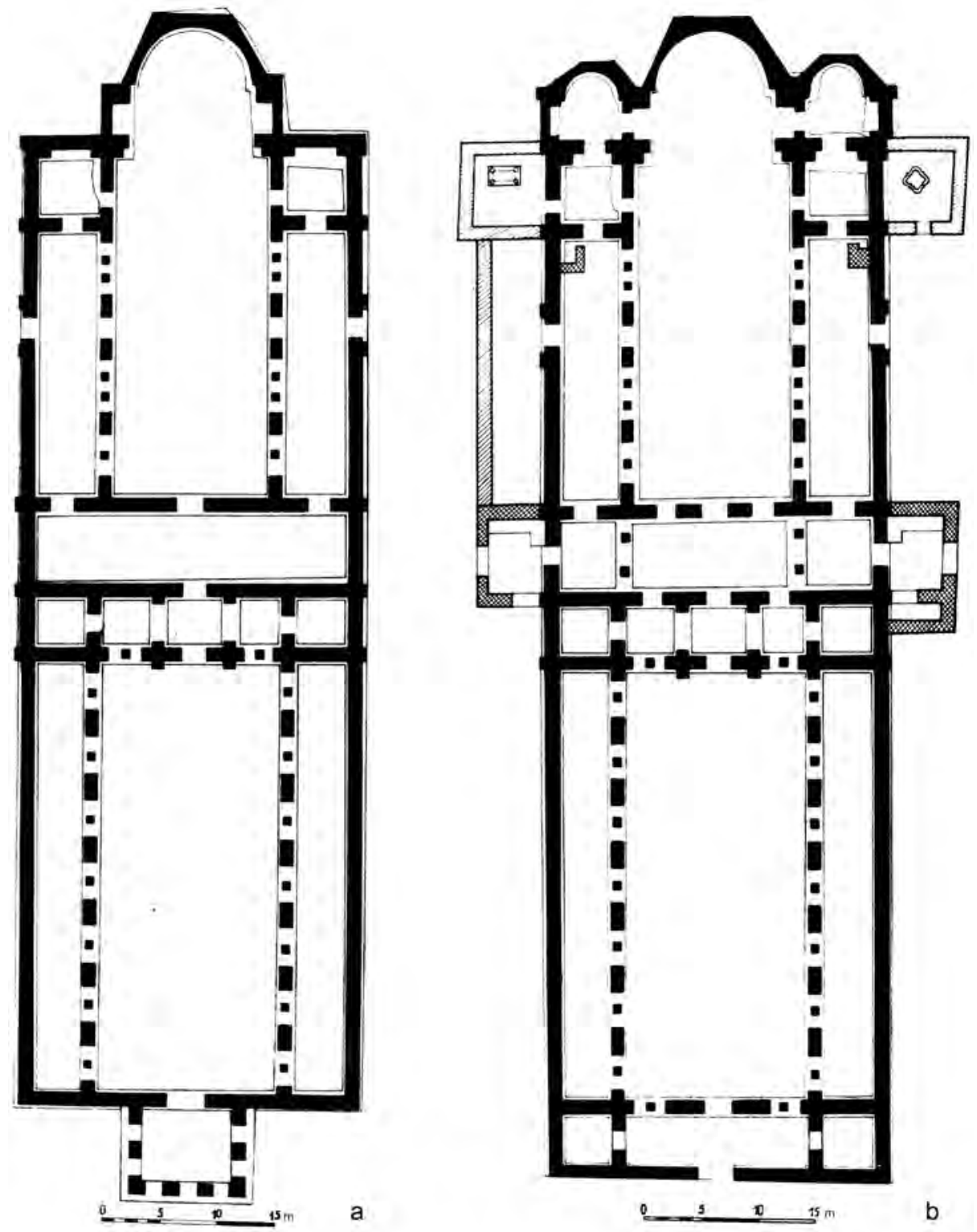

Abb. 6. Grundriss der Großen Basilika. a. erster Bau nach westlichem Vorbild (866-869), b. nach der Umwandlung in einen byzantinischen Bau (871-um 875) 


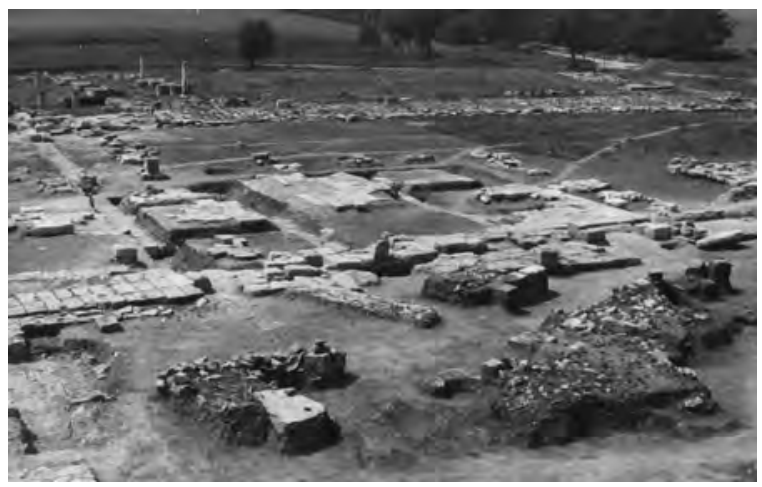

Abb. 7. Blick auf den erzbischöflichen Palast und die Basilika

Nikolaj“ (870-877) und des „Erzbischofs von Bulgarien Georg“ (878-886?) sind wichtige Zeugnisse der Konstituierungphase der bulgarischen Kirche.

Nördlich an die Residenz des Erzbischofs anschließend, wurde ein Kloster errichtet. Es besteht aus zwei Gebäudekomplexen, die unter anderem ein refectorium für etwa 70 Mönche, ein Wohngebäude sowie Wirtschafts- und Lagergebäude enthielten.

Die kulturellen Hinterlassenschaften der Klosterresidenz schlugen sich in einer grau-schwarzen Schicht nieder; diese wurde auch unmittelbar über den Bauresten des Martyrions und der Siedlung angetroffen. Sie ist mit Grobkeramik und anderen Kleinfunden durchsetzt, die allgemein in den Zeitraum vom Ende des 9. bis in die zweite Hälfte des 11. Jahrhunderts gestellt werden können.

Sehr komplex ist die Stratigraphie der nordwestlichen Ecke der Anlage. Der erste Befund ist eine große Kalkgrube $(\mu \alpha \lambda \alpha \kappa \tau \alpha \rho \varepsilon l \alpha)$, die während des Baus der Basilika benutzt wurde. Beim Umbau verfüllte man sie mit Abfallmaterialien. In diese Grube sind die Fundamente der Bauten, die den peribolos umgeben, eingetieft, namentlich die des Bades Nr. 1 aber auch die weiterer Wirtschaftsbauten des Klosters.

Die starke Nutzung der klösterlichen Bauten im Verlauf der zweiten Hälfte des 9. und besonders im 10. Jahrhundert führte zu einer flächendeckenden Anhebung des Bodenniveaus. In den ersten Jahrzehnten des 11. Jahrhunderts tiefte man in diese mittlerweile mächtige Kulturschicht Pfähle ein, die an die den peribolos bildenden Bauten anschlossen und eine zur Verteidigung des Klosters dienende Plattform trugen. Durch eine in diesem Bereich gefundene anonyme byzantinische Münze der Klasse A2 ist es möglich, diese Verteidigungsanlage mit den ersten Übergriffen der Petschenegen auf Nordostbulgarien in den 30er Jahren des 11. Jahrhunderts in Verbindung zu bringen. Wie die archäologischen Untersuchungen zeigen konnten, war die Verteidigungsplattform noch nicht vollendet, als die zinnengekrönte Umwehrung gewaltsam zerstört wurde. Ein erneuter Versuch das Kloster zu sichern endete mit einer weiteren Zerstörung. Nach diesem Vorfall konnte das Leben im Kloster anscheinend nicht mehr im gleichen Ausmaß wie zuvor vonstatten gehen und es wurde wahrscheinlich schon in den vierziger Jahren des 
11. Jahrhunderts endgültig verlassen. Es scheint, dass die Nutzung der Basilika noch bis in die Mitte des 11. Jahrhunderts andauerte, was sich jedoch bislang nicht durch archäologische Funde belegen lässt. ${ }^{17}$

Die Beobachtungen im Verlauf der Grabungen in den klösterlichen Gebäuden und Höfen erlauben eine feine Stratifizierung der Funde und Befunde. ${ }^{18}$ Es ist möglich, die grundlegenden Formen und Verzierungen der Grob- und Feinkeramik der Zeitabschnitte vom Ende des 9. bis zum Beginn des 10. Jahrhunderts, des 10. Jahrhunderts und schließlich auch der ersten Jahrzehnte des 11. Jahrhunderts voneinander zu unterscheiden.

Die vollständige Untersuchung der Große Basilika, der sich anschließenden Klosterbauten und des christlichen Gründungsbaus ist nicht allein für die Erforschung Pliskas von entscheidender Bedeutung, sondern auch für die der gesamten frühmittelalterliche Kultur Bulgariens. Die bisher gewonnenen Erkenntnisse zur Baugeschichte sowie die fundierte Interpretation der freigelegten Architekturreste können nun als Grundlage zur weiteren Erforschung der materiellen und geistigen Kultur des ersten bulgarischen Reiches und im Besonderen seiner christlichen Phase dienen.

(Übersetzung Raiko Krauß)

\section{Bibliographie}

Bojadžiev 1986: Стефан Бояджиев, „Мавзолей на първите български ханове?“, in: Музеи и паметници на културата 1986/2, S. 28-32.

Georgiev 1981: Павел Георгиев, „Ранносредновековно селище в района на Голямата базилика в Плиска“, in: Плиска-Преслав 2, 1981, S. 190-197.

Georgiev 1993а: Павел Георгиев, Мартириумът в Плиска и началото на християнството в България, София 1993.

Georgiev 1993b: Павел Георгиев, „Разкопки в Голямата базилика през 1978 и 1979 г.“, in: Плиска-Преслав 6, 1993, S. 49-68.

Georgiev 1998: Павел Георгиев, „Отговор на един опит за рецензия“ (=Rezension zu Milčev 1995)“, in: Археология, 1998/1-2, S. 81-84.

Georgiev 2000a: Павел Георгиев, „Землените укрепления на Абоба-Плиска“, in: ПлискаПреслав 8, 2000, S. 19-30.

Georgiev 2000b: Павел Георгиев, Селищна структура на Абоба-Плиска, in: Археология 41/3-4, 2000, S. 16-30.

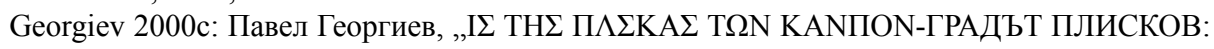
Произхода и значение на името“, in: Трудове на катедрите по история и богословие 3, Шумен 2000 (im Druck).

Georgiev/Vitljanov 2001: Павел Георгиев/Стоян Витлянов, Архиепископията-манастир в Плиска, София 2001.

17 Auf einem Graffito in der Apsis der Basilika las F. Uspenskij das Jahr 655, d.h. 1142. Vgl. Uspenskij 1905b, 237, Taf. 47,3. Nach einer Untersuchung der Abschrift können wir jedoch nicht bestätigen, dass es sich um ein Datum handelt.

18 Vitljanov/Dimitrov 1996, 238-255. 
Ireček 1974: Константин Иречек, Пътувания по България, София 1974.

Kanitz 1882: Felix Philipp Kanitz, Donaubulgarien und der Balkan: Historisch-geographischethnographische Reisestudien aus den Jahren 1860-1879 3, Leipzig 1882.

Michajlov 1955: Стамен Михайлов, „Археологически материали от Плиска (1948-1951 г.)“, in: Известия на Археологическия институт (София) 20, 1955, S. 49-181.

Michajlov 1963: Стамен Михайлов, „Разкопки в Плиска през 1959-1961 г.“, in: Известия на Археологическия институт (София) 26, 1963, S. 5-46.

Michajlov 1995: Стамен Михайлов, „Още веднъж за кръстовидната постройка под Голямата базилика в Плиска“, in: Археология, 1995/4, S. 47-49.

Michajlov/Milčev 1959: Стамен Михайлов/Атанас Милчев, „Разкопки в Плиска през 1955 г.“, in: Известия на Археологическия институт (София) 22, 1959, S. 268-288.

Milčev 1995: Атанас Милчев, Rezension zu Georgiev 1993a, in: Археология 1995/2, S. 52.

Škorpil 1905: Карел Шкорпил, “Постройки в Абобском укреплении”, in: Абоба-Плиска: Альбом (=Известия археологического института в Константинополе 10), Варна 1905, S. 62-145.

Stanilov/Dimitrov/Jankulov 1991: Станислав Станилов/Янко Димитров/Иван Янкулов, „Проучвания на селището, югоизточно от Вътрешния град на Плиска“, in: Проблеми на прабългарската история и култура 2, София 1991, S. 124-137.

Uspenskij 1905a: Фёдор Успенский, „Историко-археологическое значение Абобы и ее окрестностей: Раскопки: Наименования древнего поселения“, in: Абоба-Плиска: Альбом (=Известия археологического института в Константинополе 10), Варна 1905, S. 9-25.

Uspenskij 1905b: Фёдор Успенский, „Надписи староболгарския“, in: Абоба-Плиска: Альбом (=Известия археологического института в Константинополе 10), Варна 1905, 236239.

Vaklinov 1977: Станчо Ваклинов, Формиране на старобългарската култура, София 1977.

Vasilev 1995: Радослав Василев, „Нови данни за ранносредновековното селище в района на Голямата базилика в Плиска“, in: Плиска-Преслав 7, 1995, S. 27-33.

Vitljanov/Dimitrov 1996: Стоян Витлянов/Янко Димитров, „За класификацията и хронологията на битовата керамика от манастира при Голямата базилика в Плиска“, in: Епископ Константинови четения 2, Шумен 1996, S. 238-255.

Zanev 1998: Ц. Цанев, „Към въпроса за покрьстването на българите“, in: Преславска книжсовна школа 3, Шумен 1998, S. 159-167. 


\title{
Ergänzende Angaben zur frühmittelalterlichen Siedlung auf dem Gebiet der Großen Basilika
}

\author{
RADOSLAV VASILEV
}

Der Fundplatz der Siedlung unter den Ruinen der Großen Basilika mit dem sie umgebenden Klosterkomplex ist von besonders großer Bedeutung für die Geschichte der Hauptstadt Pliska im 9. Jahrhundert. In einem Teil dieser Siedlung, der vom eigentlichen Palastzentrum mehr als einen Kilometer weit entfernt liegt, sind nämlich die frühesten und damit bedeutungsvollsten Bauwerke nachgewiesen worden, die von der Christianisierung des mittelalterlichen Bulgarien künden. Dies ist der Grund dafür, dass in diesem Bereich von Pliska besonders intensiv geforscht wurde.

Die dort durchgeführten Ausgrabungen haben jedoch eine Reihe von Fragen aufgeworfen, die bislang noch nicht in jedem Fall völlig eindeutig beantwortet werden konnten: Warum entstand gerade an diesem Ort das frühe Martyrion mit kreuzförmigem Grundriss, ${ }^{1}$ und warum hat man gerade auf diese Stelle bald darauf den großen Basilikabau mit seinem ausgedehnten Atrium gesetzt? Schließlich wurde um diesen Kirchenbau herum eine riesige Klosteranlage erbaut. Was geschah mit den Menschen, die noch bis kurz vor diesem Zeitpunkt auf demselben Gelände in Grubenhäusern lebten und nun angesichts der sich auf tausende von Quadratmetern ausdehnenden Bautätigkeiten diesen Ort verlassen mussten? Wohin zogen alle diese Menschen, und kann der Platz, an dem sie neu angesiedelt wurden, lokalisiert werden?

Zunächst ist festzuhalten, dass in dem Teil der Siedlung, der sich auf dem Gelände des späteren Klosterkomplexes befand, mehrere Archäologen Ausgrabungen durchgeführt haben. ${ }^{2}$ Ihnen ging es dabei anfänglich nur darum, die Steinbauten, also die Kirche und das Kloster, sowie die dazugehörige Nekropole zu untersuchen. Erst in einem späteren Stadium der Arbeiten erkannte man auch die Überreste von in die Erde eingetieften Häusern (Abb. 2-4). Ihre Untersuchung war schwierig und erfolgte in sehr unterschiedlicher Intensität. Die Arbeiten zogen sich zudem über mehrere Jahrzehnte hin.

1 Eine Antwort auf diese Frage hat P. Georgiev (1993, 102-130) versucht zu geben.

2 Die ersten Grabungen erfolgten durch K. Škorpil und Kr. Mijatev. Die späteren Untersuchungen lagen in den Händen von St. Michailov, St. Vaklinov, T. Totev, Ž. Văžarova, P. Georgiev, St. Vitljanov, T. Balabanov und R. Vasilev. 


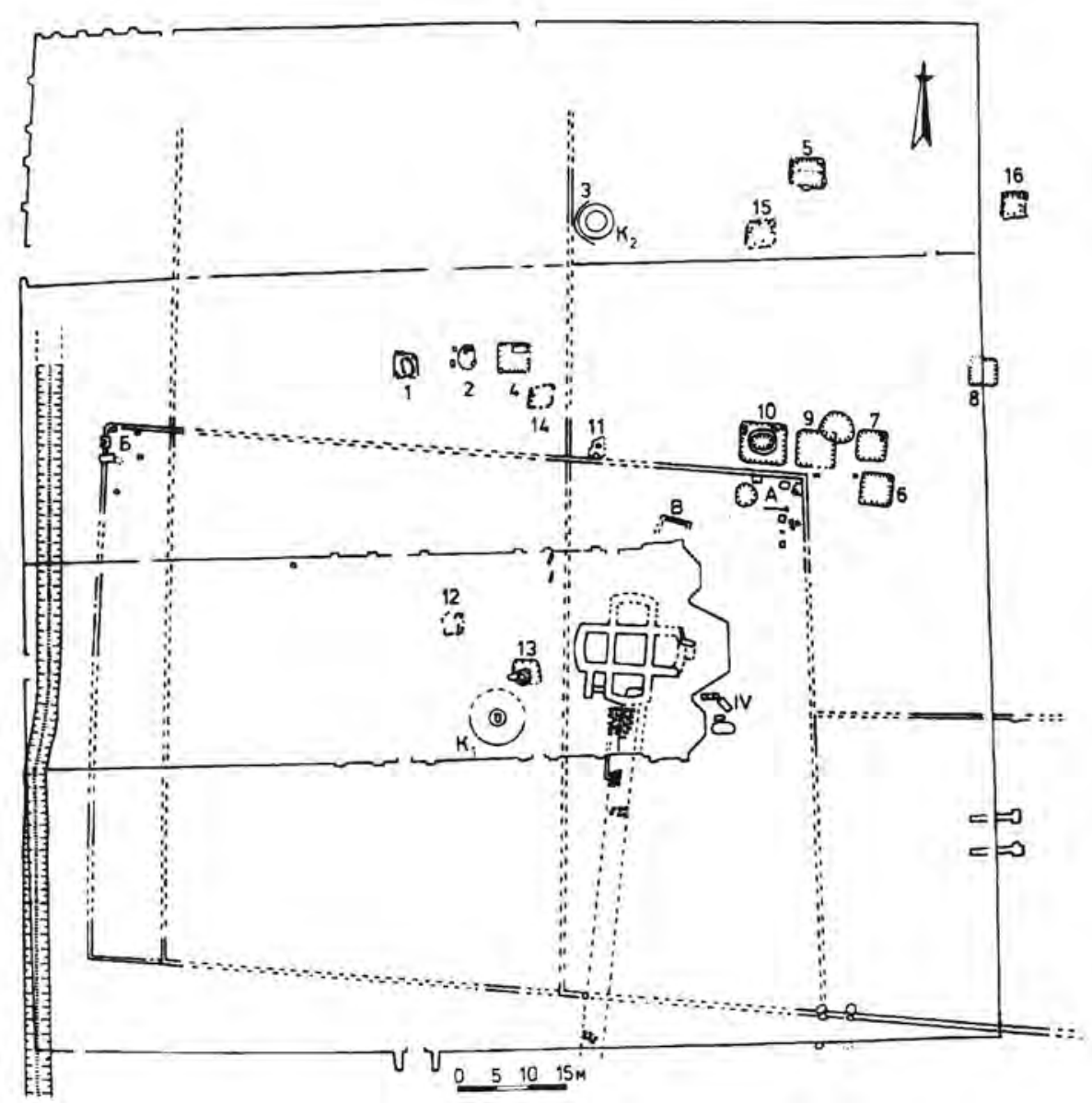

Abb. 1. Plan der Klosterkomplexes an der Großen Basilika mit den neuentdeckten Grubenhäusern Nr. 14, 15 und 16

Nachfolgend werden die Ergebnisse von Ausgrabungen in drei Teilsektoren der großen Gesamtfläche des Klosterkomplexes vorgestellt (Abb. 1). Bei diesen 1986 und 1992 durchgeführten Arbeiten wurden weitere Überreste der frühmittelalterlichen Siedlung freigelegt, die bislang aber noch nicht publiziert werden konnten. Die im Bereich der Siedlung untersuchten Flächen sind einige Hundert Quadratmeter groß und liegen alle nördlich der Kirche.

Der mit $15 \times 15$ m größte Grabungssektor befindet sich unmittelbar nördlich des Naos der Kirche. Zwischen diesem Grabungsbereich und der eigentlichen Kirche blieb nur jener mit Steinplatten belegte Streifen unerforscht, der sich um die Kirche und das 


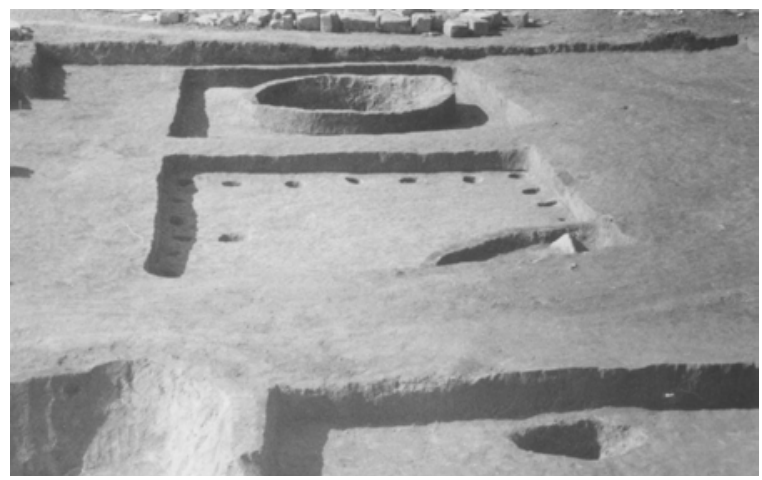

Abb. 2. Ansicht von Haus Nr. 9 im Vordergrund und von Haus Nr. 10 (von Osten)

Atrium herum erstreckt. Bei den von P. Georgiev organisierten Arbeiten traten in den 70er Jahren nördlich davon die Grubenhäuser Nr. 1, Nr. 2 und Nr. 4 zutage (Abb. 1), die sich ebenfalls auf dem Gelände des südlichen Klosterhofes befanden. Hier wurden auch die Steinbauhorizonte ermittelt und dabei zwei große Gebäude, der so genannte erzbischöfliche Palast und ein Verbindungsbau sowie die südliche Umfassungsmauer des nördlichen Klosterhofes freigelegt.

Die ersten Hinweise auf eine ältere Kulturschicht im Gebiet der Großen Basilika zeigten sich 1970 in Form von zwei Gruben im Bereich der Sondage Nr. 21. Eine dieser Gruben fand sich unter der Südwand der Kirche. In den Gruben wurden zahlreiche Keramikfragmente von drei Warenarten entdeckt: Keramik mit roter Engobe, ritzverzierte Keramik und graue Keramik mit Einglättstreifen.

Im weiteren Verlauf der 70er Jahre wurden dann bei genaueren Untersuchungen von Schichten unter der Kirche und um diese herum einige weitere große Gruben von über $2 \mathrm{~m}$ Durchmesser gefunden und ihr Inhalt vollständig untersucht. Die Gruben wurden zu einer Zeit angelegt, als man im Bereich des späteren Steinbaukomplexes noch in Grubenhäusern lebte. In der Füllung der Gruben fand sich eine große Anzahl von Keramikscherben der drei Warenarten sowie in beträchtlicher Zahl Fragmente von Tierknochen.

Im von mir untersuchten südöstlichen Teil des Sektors konnte ein $5 \mathrm{~cm}$ starker Mörtelstreifen erfasst werden, der einen Laufhorizont aus gelbem Lehm praktisch von oben versiegelte. Die sich stellenweise um einige Zentimeter einsenkende Mörtelschicht belegt eindeutig, dass die darunter liegende Eingrabung dem Bau des Klosters vorangegangen sein muss und wir sie unzweifelhaft mit der älteren Grubenhaussiedlung zu verbinden haben.

Das Fußbodenniveau aus gelbem Lehm lag $1 \mathrm{~m}$ unterhalb der heutigen Oberfläche und $15 \mathrm{~cm}$ unterhalb des Mörtelstreifens. Von der rundlichen Ausdehnung der Fußbodenfläche mit einem Durchmesser von ursprünglich etwa $4 \mathrm{~m}$ hat sich nur noch ein Bereich von $2 \mathrm{~m}$ Durchmesser erhalten. Hierbei handelt es sich um den nordwestlichen Teil der Fußbodenfläche. Der nordöstliche Teil wurde beim Anlegen der Fundamente 


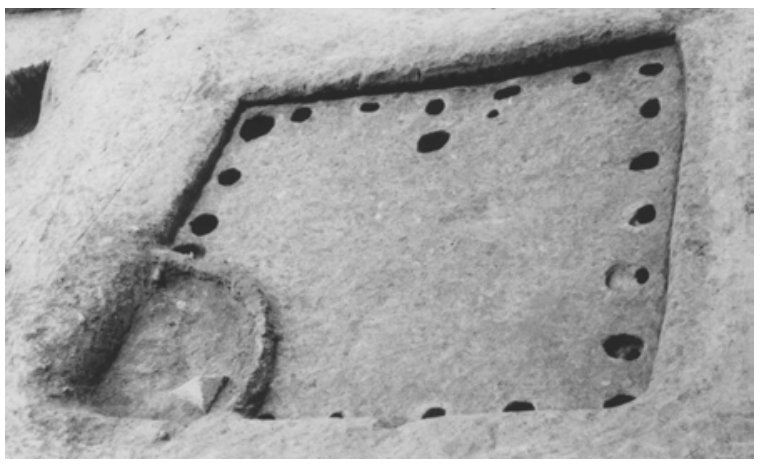

Abb. 3. Ansicht von Haus 9 (von

Norden)

für das Verbindungsgebäude zerstört. Die südliche Hälfte wiederum wurde beim Ausheben des Einhegungsgrabens um das Martyrion beseitigt. Dieser Graben zeichnete sich im Planum als heller Streifen ab. Im erhaltenen Teil des Fußbodenniveaus wurde eine flache Grube von $50 \mathrm{~cm}$ Durchmesser und $10 \mathrm{~cm}$ Tiefe gefunden, die mit Holzasche gefüllt war. Über dem eigentlichen Niveau aus gelbem Lehm war eine 3-4 cm dicke Holzkohleschicht zu beobachten. Diese Schicht erstreckte sich noch nördlich und südlich über den Fußboden hinaus. Aller Wahrscheinlichkeit nach sind das die Überreste einer verbrannten oberirdischen Konstruktion. Dieses Bodenniveau lag 35 $\mathrm{cm}$ höher als das Niveau, auf dem eine Anhäufung von verrußten und angebrannten Bruchsteinen als Bestandteile eines zerstörten Ofens gefunden wurde. Dieser Befund trat in der nordöstlichen Ecke des untersuchten Sektors zutage. Er lässt vermuten, dass der höher liegende Fußboden aus gelbem Lehm zu einem nur flach eingegrabenen oder sogar ebenerdigen Wohnhaus gehört hat. Wenn man die drei Flecken gebrannter Erde und die Feuerstelle von $50 \mathrm{~cm}$ Durchmesser sowie die Form des erhaltenen Fußbodenniveaus deuten will, könnte man annehmen, es habe sich um den Fußbodenestrich eines Hauses auf rundem Grundriss, also eine Jurte, gehandelt. Eine solche Deutung ist jedoch unsicher, da die überkommenen Reste doch recht spärlich sind und darüber hinaus keine Anhäufungen von Pfosten oder Pfählen festgestellt werden konnten. Die auf dem Fußboden gefundenen Keramikfragmente können relativ früh an das Ende des 8. bis zum Beginn des 9. Jahrhunderts datiert werden. Daher ist der Befund der frühmittelalterlichen Siedlung zuzuordnen.

Etwa $35 \mathrm{~cm}$ tiefer, als der Fußboden dieses ebenerdigen Hauses lag der Fußboden eines älteren Hauses. Den genauen Umriss dieses Baus konnte ich allerdings nicht ermitteln. Zu dem Gebäude gehörte ein aus kleinen und mittelgroßen Bruchsteinen lose, ohne Bindemittel gesetzter Ofen, der im Grabungsbefund nicht zu übersehen war. Seine Ausmaße betrugen in Nord-Süd-Richtung $90 \mathrm{~cm}$ und in Ost-West-Richtung $80 \mathrm{~cm}$. Die eigentliche Feuerkammer des Ofens war $80 \mathrm{~cm}$ lang und nord-südlich orientiert. Die Stärke seiner östlichen und westlichen Wand betrug $22-25 \mathrm{~cm}$, und sie war $35 \mathrm{~cm}$ 


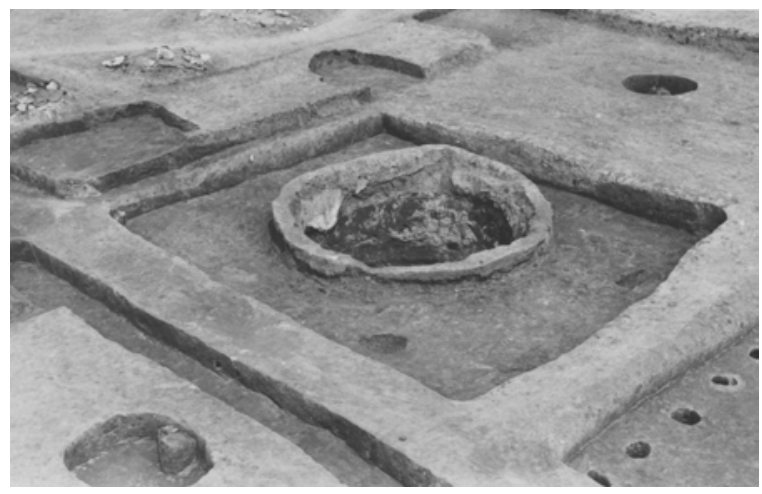

Abb. 4. Ansicht von Haus Nr. 10 (von

Südosten)

breit. Die Wände waren bis zu $20 \mathrm{~cm}$ hoch erhalten. Der Boden der Ofenkammer wurde nicht durch einen gestrichenen Lehmboden sondern durch den anstehenden Löß gebildet, der vom Feuer rot gebrannt war. Ich möchte annehmen, dass der Ofen an der nördlichen Wand eines kleineren Grubenhauses stand. Dieses war verhältnismäßig flach in den Boden eingetieft, und sein Boden lag bei etwa 1,30 m unter der heutigen und $80 \mathrm{~cm}$ unter der damaligen Oberfläche. Die Wandlängen des Hauses mögen im Norden und Süden etwa 2,20 m und im Osten und Westen etwa 2,50-2,70 m betragen haben. Der Ofen wurde direkt auf den Fußboden des Hauses gesetzt. In der Abfolge der allgemeinen Nummerierung der Grubenhäuser im Gebiet der Basilika ${ }^{3}$ trägt der Bau die Nr. 14 (Abb. 1). Datiert wird er wie die übrigen Häuser in die erste Hälfte des 9. Jahrhunderts.

Der im Jahre 1986 untersuchte zweite Sektor ist mit 5 x $5 \mathrm{~m}$ sehr viel kleiner als der soeben behandelte. Er besteht praktisch nur aus einem Quadranten und liegt unmittelbar nördlich der südlichen Umfassungsmauer des nördlichen Hofes und $25 \mathrm{~m}$ westlich der Räume an der östlichen Umfassungsmauer des Klosters. In einer Tiefe von 1,80 m unter der heutigen Oberfläche wurde die Schicht eines stark gestörten Estrichs aus hellgelbem Lehm ermittelt. An einigen Stellen befanden sich darauf 4-5 cm starke Brandflecken. Wegen des starken Zerstörungsgrades konnten die Wandumgrenzungen des zu diesem Fußbodenbefund gehörigen eingegrabenen Wohn- oder Wirtschaftsbaus nicht in allen Details sicher bestimmt werden. Dieser schlecht erhaltene Hausbefund ist nach oben von einer Mörtelschicht versiegelt, die in ihrem südlicheren Teil 10-15 cm stark ist und sich $2 \mathrm{~m}$ nördlich der Umfassungsmauer auf $5 \mathrm{~cm}$ verjüngt. Ähnlich wie jene im Sektor nördlich des Naos der Kirche weist auch diese Mörtelschicht im Bereich

3 P. Georgiev (1981, 190-197) untersuchte die Grubenhäuser mit den Nummern 1-3, 5 und 10-13. Grubenhaus Nr. 4 wurde durch J. Henning (1980, Abb. S. 26) freigelegt. Der Autor dieses Beitrages grub die Häuser mit den Nummern 6-10 aus: Vasilev 1995, 27-33. 
der darunter liegenden Hausgrube eine Absenkung um 15-20 cm auf. Dies zeigt, dass zum Zeitpunkt der Entstehung der Mörtelschicht die Hausgrube zwar bereits weitgehend verfüllt gewesen sein muss, aber noch als leichte Einsenkung sichtbar war. Unter der Mörtelschicht wurde eine 2-3 cm dicke Holzkohleschicht beobachtet, die wahrscheinlich analog zum gleichartigen Befund im Sektor nördlich des Naos von einem Brand stammt. In der Füllung der vermuteten Hausgrube wurde eine bearbeitete Marmorplatte gefunden. Dies zeigt wohl, dass das Grubenhaus erst nach der Zerstörung der Kirche oder einiger Gebäude des Komplexes, die mit einer Marmorverkleidung ausgestattet waren, aufgelassen wurde. Diese Annahme wird auch durch Dachziegelfragmente (Imbrices) unterstützen, die sich in der Grubenfüllung fanden.

Die im Hausgrubenbereich gefundenen Keramikfragmente sind nicht sehr zahlreich. Das Verhältnis von ritzverzierter Ware zu grauer Ware mit Einglättverzierung ist 4:1. Unter den Funden aus dem Hausgrubenbereich sind weiterhin eine kleine Knochenahle und zwei Keramikfragmente von Gefäßen mit roter Engobe hervorzuheben.

Der erwähnte Fußboden des Hauses bestand aus verdichtetem Humus, der mit kleinen Lößpartikeln durchmischt war. Das Material wurde von außen in die Hausgrube eingebracht und bildete eine 3-4 cm starke Zone. Soweit dies in den Grabungsgrenzen zu ermitteln war, scheint es sich um ein Grubenhaus mit rechteckigem Grundriss gehandelt zu haben. Die Grubenwände konnten aber nur im Westen und teilweise im Norden mit einer gewissen Wahrscheinlichkeit bestimmt werden. In der nordwestlichen Ecke zeichnete sich eine 50 × $30 \mathrm{~cm}$ große und $30 \mathrm{~cm}$ hohe Stufe aus Löß ab. Die östliche Begrenzung des Grubenhauses konnte nicht erfasst werden, da sie außerhalb der östlichen Grabungsgrenze zu suchen ist. Auf dem Fußboden wurde eine $10 \mathrm{~cm}$ starke Schicht angerußter Bruchsteine gefunden, die wahrscheinlich von einem zerstörten Ofen stammen. Darunter lag eine Schicht aus Holzkohle und verhärteter Asche. Wahrscheinlich stand der Ofen in dem Bereich, wo die Aschenschicht am stärksten war und eine größere Anzahl der verrußten Steine gefunden wurde. Die Größe des Fleckens beträgt etwa $80 \times 80 \mathrm{~cm}$.

Das beschriebene Grubenhaus wurde als Haus Nr. 15 bezeichnet (Abb. 1). Es liegt nur $50 \mathrm{~cm}$ nördlich der südlichen Umfassungsmauer des nördlichen Hofes und $25 \mathrm{~m}$ westlich der Räume um die östliche Umfassungsmauer. Das Haus ist $80 \mathrm{~cm}$ tief in den anstehenden Löß eingegraben, während die Eintiefung von der heutigen Oberfläche aus - wie oben erwähnt - 1,80 m beträgt. Die Grubenwände des rechteckigen Grundrisses sind auf die Haupthimmelsrichtungen orientiert, wobei die Form des Baues leicht zu einem Trapez zu tendieren scheint. Die Länge der westlichen und der östlichen Grubenwand ließ sich auf etwa 2,80 m Länge bestimmen bzw. schätzen. Die südliche Grubenwand konnte etwa auf einer Länge von 2,60 m und die nördliche auf einer Länge von 2,70 m erfasst werden, wobei die wirkliche Länge auf bis zu 3,0-3,20 m geschätzt werden kann. Der fast völlig zerstörte Steinofen muss sich in der Südostecke des Grubenhauses befunden haben. Die relativ starke Eintiefung der Hausgrube, 


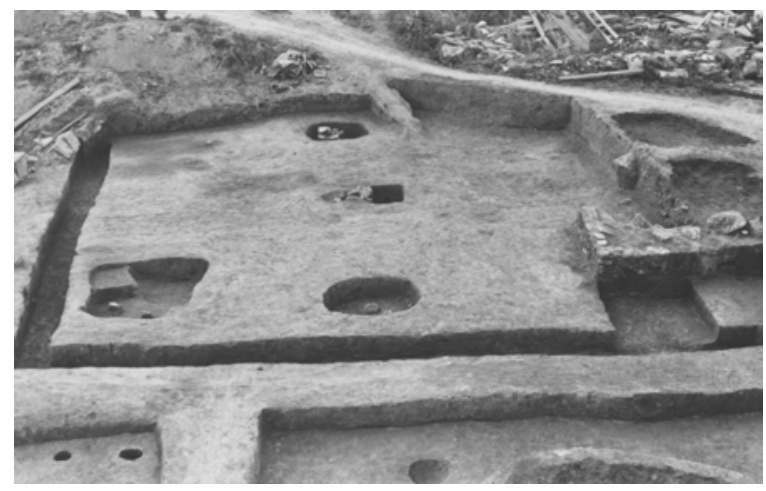

Abb. 5. Ansicht der Nordostecke der Einfriedung des Martyrions (von Norden)

ihre Überlagerung durch eine Mörtelschicht vom Bau der Mauer des Klosterkomplexes sowie die gefundenen Keramikfragmente datieren das Haus an das Ende des 9. Jahrhunderts. Für eine solche Zeitstellung dürfte vor allem auch der Umstand sprechen, dass in der Verfüllung des Hauses, fast auf dem Bodenniveau, Marmorplatten gefunden wurden. Diese lassen darauf schließen, dass das Haus offenbar erst nach der Zerstörung der Kirche verlassen wurde. Dies könnte frühesten am Ende der 60er Jahre des 9. Jahrhunderts erfolgt sein. Nicht auszuschließen ist jedoch auch eine spätantike Herkunft der Marmorplatten, denn unter den Funden des Grabungssektors ist auch das Bruchstück eines spätantiken Ziegels mit Stempelabdruck zu verzeichnen.

Das Haus wurde sicherlich von seinen Bewohnern nicht plötzlich aufgelassen, denn außer den zwei Knochenahlen fanden sich sonst keine weiteren Ausstattungsgegenstände. Spätestens nach der Errichtung der Mauer, vielleicht aber auch schon früher, nämlich nach dem Bau der Kirche, kann es nicht mehr bewohnt gewesen sein. Im Vergleich zu den nahe liegenden Häusern Nr. 3 und Nr. 5, die zehn Jahre früher untersucht worden sind, ist das Haus Nr. 15 tiefer in den anstehenden Boden eingegraben worden.

Der Orientierungs- und Lagebezug des Hauses Nr. 14 zu dem etwas südlich davon verlaufenden Einfriedungsgraben des Martyrions (Abb. 5) zeigt ebenso wie insbesondere die Lage der Häuser Nr. 1, 2, 4, 9 und 10, dass die Anlage dieser Grubenhäuser im Zusammenhang mit dem Grabensystem erfolgte. Dieses hat also bereits in einer frühen Phase existiert und war wenigstens schon rund ein Jahrzehnt lang vorhanden, als die Bewohner der Grubenhäuser diesen Teil der großen Siedlung verlassen mussten.

Die Ausgrabung unseres Grubenhauses Nr. 15, das genau nördlich der Häuser Nr. 9 und Nr. 10 liegt, deutet an, dass wahrscheinlich der gesamte Bereich der Siedlung, der schließlich dem Klosterkomplex weichen musste, ehemals sehr eng mit Häusern bebaut war. Die erheblichen Bodeneingriffe, die hier seit dem Mittelalter bis zum 19. Jahrhunderts allein durch den Bau von insgesamt neun Kalkbrennöfen mit 4$5 \mathrm{~m}$ Durchmesser erfolgten, haben aller Wahrscheinlichkeit nach weitere Grubenhäuser der frühen Siedlung zerstört. Man kann vermuten, dass sich nördlich der Mauern des 
Klosterhofes eine weitere Ansammlung von Häusern befunden hat, von denen lediglich die Häuser Nr. 5 und Nr. 15 archäologisch erfasst wurden (Abb. 1). Weitere Grubenhäuser können eventuell noch durch spätere Grabungen nachgewiesen werden, soweit nicht die erwähnten Bodeneingriffe aus verschiedenen Zeiten auch solche Bauten völlig zerstört haben.

Im Jahr 1986 wurde nördlich der Nordapsis der Großen Basilika eine weitere Sondagegrabung durchgeführt. Untersucht wurde das Areal unter dem Plattenbelag um die Apsiden der Kirche. Die ausgegrabene, $22 \mathrm{~m}^{2}$ große Fläche bildet in etwa ein Rechteck mit den Seitenlängen Ost-West $8 \mathrm{~m}$ und Nord-Süd 2,70 m. Unter den Steinplatten des Umgangs wurde eine Holzkohle-Asche-Schicht angetroffen, die wahrscheinlich vom Brand der früheren Kirche stammt. Die Schicht erstreckte sich von der Apsiswand beginnend bis zu $3 \mathrm{~m}$ nach Norden. Die Stärke dieser Brandschicht lag in diesem Bereich zwischen 10-12 cm und 18-20 cm. Das Vorkommen vereinzelter Holzkohlestücken konnte aber auch noch etwa 50-80 cm über diesen Bereich hinaus nach Norden beobachtet werden.

Im südlichen Teil der Sondagefläche wurde eine in Nord-Süd-Richtung verlaufende streifenförmige Verfärbung von $50 \mathrm{~cm}$ Breite (Ost-West gemessen) festgestellt. Nach dem Schneiden dieser Verfärbung erwies sie sich als ein bis $1,10 \mathrm{~m}$ unter die heutige Oberfläche hinabreichender Graben. Dieser gehört zur nördlichen Einhegung des Martyrions, deren Verlauf schon 1980 südlich der Häuser Nr. 9 und Nr. 10 erfasst werden konnte. Im Grabungssektor ließ sich der Graben auf $6 \mathrm{~m}$ Länge verfolgen. Er endet 1,20 m östlich der östlichen Annex-Bauten. Der Graben ist ebenfalls mit einer Mörtelschicht versiegelt, die vom Bau der Kirche stammt.

1992 war es erneut möglich, weitere Flächen auf dem ausgedehnten Gelände des Baukomplexes um die Große Basilika archäologisch zu untersuchen. Insbesondere betraf das ein Gebiet im Bereich der östlichen Umfassungsmauer, nördlich der Grabung von 1979. Fünf Nord-Süd aneinander gereihte Quadranten mit einer Seitenlänge von $5 \mathrm{~m}$ wurden ergraben, also insgesamt $125 \mathrm{~m}^{2}$. Wie bereits bei den Kampagnen 1979 und 1980 wurde in diesem Sektor eine komplizierte Situation angetroffen, da die Siedlungsschicht hier von zahlreichen Eingrabungen aus verschiedenen Zeiten durchschnitten wird. So kamen zwei christliche Bestattungen zum Vorschein, deren Grabgruben in die Kulturschicht eingetieft waren und sich an einer bereits zuvor bestehenden Mauer anordneten. Die Gräber enthielten keine Beigaben, und die Skelette waren zum Teil gestört.

Im von Süden nach Norden betrachtet vorletzten Quadranten wurde das Grubenhaus Nr. 16 ausgegraben (Abb. 1). Seine westliche Begrenzung befindet sich $4 \mathrm{~m}$ östlich vor der Außenfront der Ostmauer des Klosterkomplexes. Der Boden der Hausgrube liegt 1,30 m unter der heutigen Oberfläche. Die Seiten dieses eher kleineren Hauses sind nach den Himmelsrichtungen orientiert. Die Ecken des Hauses waren abgerundet. In der nordöstlichen Ecke der Hausgrube fanden sich in einer Höhe von $45 \mathrm{~cm}$ über 
dem Boden einige angerußte Bruchsteine aus hartem Sandstein. Außer einigen Holzkohlestücken gab es keine weiteren Reste einer Feuerstelle.

Die Hausgrube ist annähernd quadratisch. Die nördliche und die südliche Seite ist jeweils $3 \mathrm{~m}$ und die westliche und die östliche jeweils 2,80 m lang. Durch die Mitte des Hauses verlief ein Ost-West gerichteter, $50 \mathrm{~cm}$ breiter und in den Hausboden einschneidender Graben. Da dieser Graben von der heutigen Oberfläche aus 1,60 m tief hinabführt und damit noch $30 \mathrm{~cm}$ tiefer reicht als der Hausfußboden, dürfte er wohl zeitlich jünger als das Grubenhaus zu datieren sein. In der Auffüllung der Hausgrube wurden die drei üblichen keramischen Warenarten gefunden. In einer Tiefe von $60 \mathrm{~cm}$ unter der Oberfläche trat ein mit Schlacke ummantelter Roheisenblock (Ofensau) zutage, der in die Zeit nach der Auflassung des Grubenhauses zu datieren ist. Außerdem wurden zwei Knochenahlen, zwei Wetzsteine, ein Eisennadelfragment und ein Bronzegegenstand mit einem kurzen Dorn und einer rundlichen Knubbe gefunden.

Die Datierung des Grubenhauses ergibt sich aus der in der Verfüllung geborgenen Keramik. Die große Zahl von Fragmenten grauer Keramik und das Vorkommen von Scherben mit roter Engobe sprechen für eine frühe Datierung in die erste Hälfte des 9. Jahrhunderts. Dies entspricht der Datierung des weiter südlich liegenden, von der steinernen Umfassungsmauer des Klosterkomplexes geschnittenen Gubenhauses Nr. 8 (Abb. 1). Die im Bereich des Grubenhauses Nr. 16 freigelegten Gräber unterstützen ebenfalls seine frühe Datierung. Das Grab eines adulten Individuums schnitt $20 \mathrm{~cm}$ in den Fußboden des Hauses ein.

Die hier behandelten Untersuchungen zeigen, dass die drei neu entdeckten Grubenhäuser ebenso wie die bereits früher untersuchten Bauten dieser Art vom Gelände unter der Großen Basilika und dem Klosterkomplex von ihren Bewohnern verlassen wurden. Die in diesen Wohnbauten lebenden Menschen wurden offensichtlich an anderer Stelle und vermutlich nicht weit entfernt von ihren früheren Heimstätten neu angesiedelt. Hinweise auf einen solchen neuen Siedlungsort ergaben sich für mich bereits in den 80er Jahren im Zusammenhang mit der Ausgrabung von über 30 Grubenhäusern in einem Gelände etwa 600 m nordöstlich der Basilika. In der Nähe eines dieser Grubenhäuser (Nr. 20), etwa im Zentrum des besiedelten Areals, fand sich ein Bleisiegel des Fürsten Boris-Michail (852-889), - das bislang einzige aus Pliska. Ich habe die Hypothese geäußert, dass dieses Siegel vielleicht an einem Schriftdokument befestigt war, das für die aus dem südwestlichen Teil der Siedlung umgesiedelten Untertanen des Fürsten ausgestellt wurde. Mit diesem Dokument hat man ihnen möglicherweise irgendwelche besondere Rechte als Ausgleich für die erlittenen Verluste eingeräumt.

Bei früheren Untersuchungen wurden die Überreste der flacher eingetieften Häuser Nr. 11 und Nr. 12 freigelegt. Die Umrisse dieser Bauten konnten nicht sicher ermittelt werden, da sie nur seicht in den dunklen Humus eingegraben waren und sich die ebenfalls dunklen Hausreste kaum von diesem unterscheiden ließen. Der Fußbodenhorizont 
konnte hingegen mithilfe von im Brand rot gefärbten Flecken, die wahrscheinlich von offenen Feuerstellen stammten, erkannt werden. Der Ausgräber Georgiev schlug vor, darin flach eingegrabene, jurtenähnliche Häuser zu sehen. Er betonte jedoch, dass vorerst für eine solche Annahme keine wirklich sicheren Beweise beigebracht werden können. Es kann auch nicht ausgeschlossen werden, dass es sich hierbei um spätere Gebäude handelt, die bestanden haben, als die Kirche und das Kloster bereits nicht mehr in Benutzung waren. Abschließend möchte ich noch einmal hervorheben, dass lediglich die Bewohner des südwestlichen Teilbereiches der Siedlung umgesiedelt wurden. Der Ost- und Nordteil der Siedlung bestand bis in das 10. Jahrhundert fort.

(Übersetzung Raiko Krauß)

\section{Bibliographie}

Georgiev 1981: Павел Георгиев, „Ранносредновековно селище в района на Голямата Базилика“, in: Плиска-Преслав 2, 1981, S. 190-197.

Georgiev 1993: Павел Георгиев, Мартириумът в Плиска и началото на християнството в България, Sofia 1993.

Henning 1980: Joachim Henning, „Pliska: monomentales Zeugnis vom Beginn des bulgarischen Staates", in: Das Altertum 26, 1980, 18-26.

Vasilev 1995: Радослав Василев, „Нови данни за ранносредновековно селище в района на Голямата Базилика“, in: Плиска-Преслав 7, 1995, S. 27-33. 


\title{
Ein Herrenhof des 10.-11. Jahrhunderts in der Äußeren Stadt von Pliska
}

\author{
Stojan VitLJANOV
}

Im Verlauf der letzten Jahre wurden die traditionellen Untersuchungsmethoden zur archäologischen Erforschung Pliskas durch die Methode der Luftbildauswertung bereichert. Sie führte zur Entdeckung einiger bedeutsamer Denkmäler altbulgarischer Architektur, zu denen auch das in der nordwestlichen Ecke der Äußeren Stadt Pliskas gelegene Objekt Nr. 41 gehört (Abb. 1). ${ }^{1}$ Leider ist der Anteil dieser Methode an der Oberflächenprospektion in Bulgarien insgesamt noch sehr gering, da ihr Einsatz zumeist an fehlenden finanziellen Mitteln scheitert. ${ }^{2}$

Dieser Bericht hat den Charakter einer vorläufigen Mitteilung über die bisher gewonnenen Erkenntnisse der archäologischen Ausgrabungen des Objektes Nr. 41, da die Untersuchungen noch ganz am Anfang stehen. ${ }^{3}$ Der neu entdeckte Gebäudekomplex liegt auf einer leicht erhöhten Ebene zwischen zwei Trockentälern, die von der örtlichen Bevölkerung als Asar-dere und Denis-dere bezeichnet werden. ${ }^{4}$ Die Auswertung der Luftbilder zeigte ein großes, durch architektonische Strukturen umgrenztes Hofareal, in dem sich wiederum Bauten gruppierten, die ihrerseits Innenhöfe bildeten (Abb. 2). Das Prinzip des konzentrischen Aufbaus ist ganz allgemein an Stadtstrukturen sowie Befestigungs- und Kultbauten zu beobachten. So zeigen die hauptstädtischen Zentren Pliska und Veliki Preslav, aber auch der Hof (Aulé) von Khan Omurtag in der Nähe

1 Zu diesen Untersuchungen und ihren Resultaten vgl. Petrova 1992, 64-76; dies. 1984, 57-59. Hinsichtlich der Benennung des Objektes halten wir uns an die von K. Škorpil eingeführte und von St. Michajlov fortgesetzte Nummerierung, der zufolge unser Komplex die Nummer 41 erhält.

2 Zu den Anfängen der Luftbildprospektion in Bulgarien vgl. Petrova 1986, 81 und die dort zitierte Literatur.

3 An den einzelnen archäologischen Kampagnen nahmen teil: Pavlina Petrova vom Historischen Museum in Šumen, Kristina Velikova, damals Kustodin des Museums in Pliska, Dr. Nikolaj Iliev vom staatlichen Landwirtschaftsmuseum in Sofia sowie Archäologiestudenten aus Ljublin (Polen) unter Leitung von Dr. Stanislav Sziwek.

4 Vitljanov/Petrova 1984, 101. 


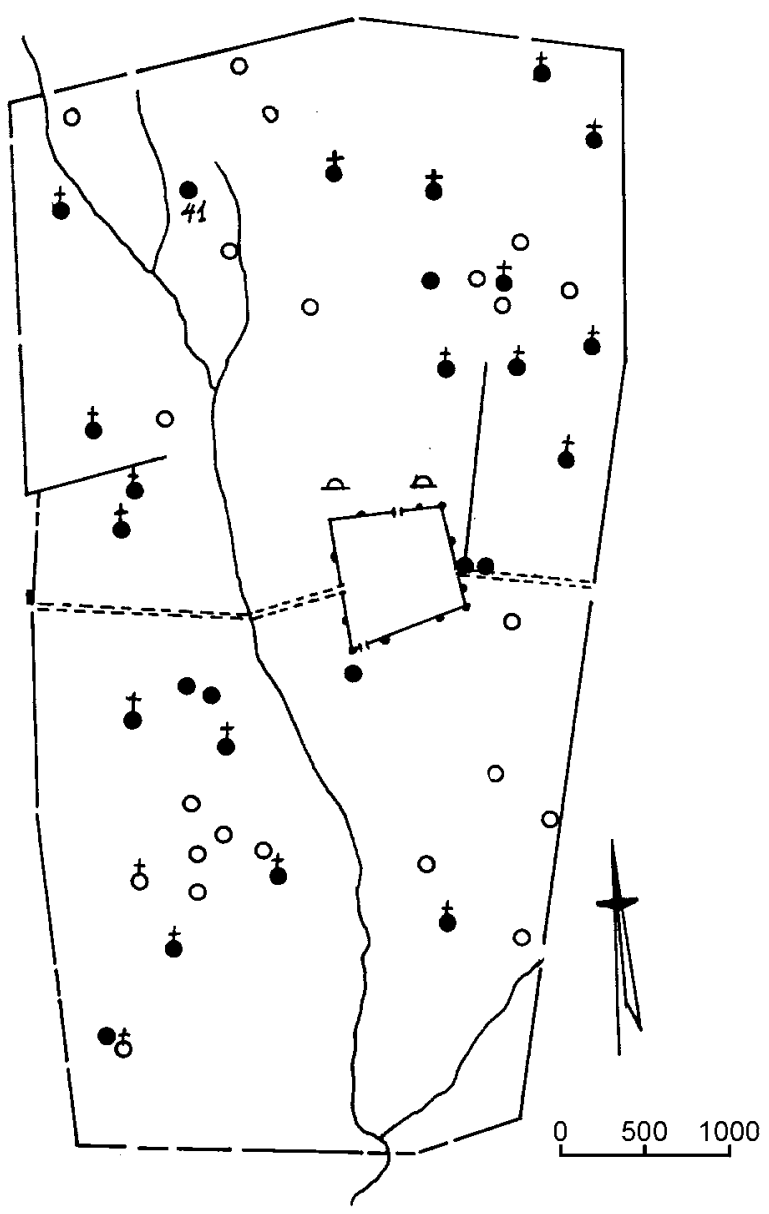

Abb. 1. Plan von Pliska innerhalb des Erdwalls mit dem Objekt 41 im Nordwesten

des Dorfes Zar Krum oder einige frühmittelalterliche Siedlungen und vorchristliche Kultbauten, einen solchen Aufbau. ${ }^{5}$

Durch archäologische Grabungen sollte nun die Nutzung und die zeitliche Stellung des Gebäudekomplexes Nr. 41 in Pliska geklärt werden. Zwecks einer ersten Sondierung wurde ein $5 \mathrm{~m}$ breiter Schnitt in Nord-Südrichtung durch das Objekt angelegt. Die Ergebnisse dieser ersten Untersuchung übertrafen die Erwartungen. Es fanden sich eine Vielzahl von Fragmenten altbulgarischer Keramik, zerstückelten Dachziegeln und Mauersteinen, die durch die Bodenbearbeitung verlagert worden waren. Auf

$5 \quad$ Mijatev 1965, 59-76. 
einigen der gefundenen Ziegel waren die aus Pliska und Veliki Preslav sowie anderen frühmittelalterlichen Siedlungen bekannten eingeritzten Markierungen zu sehen. Reste des Gebäudes wurden besonders häufig im nordwestlichen und im mittleren Teil des Schnittes angetroffen.

Während der ersten Grabung im Jahr 1983 konnten einige Zellenräume des westlichen und nördlichen Gebäudeflügels freigelegt werden (Abb. 3). Diese Räume waren Teil eines großen Komplexes, der ein ausgedehntes Hofareal umschloss. Von diesem Bau sind bisher acht Räume unterschiedlicher Größe untersucht worden. Das Mauerwerk, das aus örtlichem Mergelgestein besteht, wurde durch den Ackerbau auf dem Gelände stark zerstört. So waren von den Mauern nur ein bis zwei aufgehende Steinlagen mit einer Höhe von 30-40 cm erhalten. Die bis zu $1 \mathrm{~m}$ breiten Fundamente der Mauern waren höchstens $90 \mathrm{~cm}$ tief in den anstehenden Boden eingegraben. Sowohl die Tiefe als auch die beträchtliche Breite der Fundamente lassen auf ein zweigeschossiges Gebäude schließen. Wie die Räume im einzelnen genutzt wurden, lässt sich nicht sicher feststellen. Aller Wahrscheinlichkeit nach waren im Erdgeschoss Werkstätten, Ställe für Tiere sowie Lager- oder andere Wirtschaftsräume untergebracht.

Im östlichen Bereich des Südflügels waren die Fußbodenschicht und der Wandaufbau, der aus gut bearbeiteten Steinplatten bestand, erhalten. Wegen der starken Zerstörungen ist jedoch generell unklar, wo die Eingänge zu den Räumen lagen. Ausgehend vom Grundriss des Komplexes kann man grundsätzlich annehmen, dass sie in Richtung des Hofgeländes führten. Wahrscheinlich hat es aber ebenso Durchgänge zwischen den einzelnen Räumen gegeben.

Im Verlauf einer weiteren Grabungskampagne wurde im Bereich des Innenhofes ein Ost-West-orientiertes, 8,0 x 5,4 bzw. 5,6 m großes einräumiges Gebäude von unregelmäßig-viereckiger Form aufgedeckt. Zwei Meter nördlich von diesem Gebäude konnten wir die Fundamente eines weiteren, 10,0 x 4,9 m großen zweiräumigen Gebäudes erfassen, das Nord-Süd-orientiert war. In der Bauweise unterscheiden sich diese beiden Gebäude nicht von den bereits beschriebenen Räumen der Gebäudeflügel, die den Hof flankieren. Die Mauern, die man aus dem anstehenden Bruchstein mit Lehmverbindung errichtet hatte, sind fast vollständig durch den Ackerbau zerstört worden. Sie waren teilweise nur bis zu einer Höhe von ungefähr 20-30 cm erhalten, während sie an anderen Stellen bis auf den Grund ausgebrochen waren. Der Fußboden bestand aus festgestampftem, anstehendem Lehm, auf dem Brandspuren zu erkennen waren; Reste eines Estrichs wurden nicht entdeckt. Die Eingänge zu den Gebäuden konnten wir auf der nördlichen und westlichen Seite lokalisieren. Östlich des zweiräumigen Gebäudes stießen wir auf eine aus großen Steinplatten bestehende Pflasterung. Wie die Hoffläche insgesamt beschaffen war, lässt sich zum jetzigen Zeitpunkt allerdings noch nicht sagen.

Die beiden beschriebenen Gebäude gehören zu den bereits auf den Luftbildern erkannten Strukturen (Abb. 2). Der gesamte Komplex bestand demnach aus zwei Höfen, 


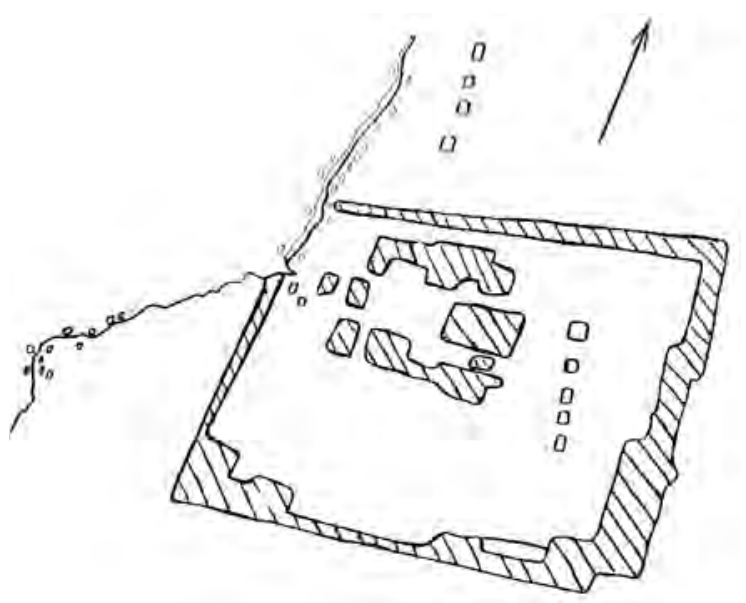

Abb. 2. Skizze der Fundstelle Nr. 41 nach dem Luftbild

die wahrscheinlich unterschiedliche Funktionen hatten. Die äußeren Begrenzungen der Höfe bildeten Flügelbauten mit zellenartigen, aufgereihten Räumen.

Im teilweise erforschten Hofbereich zwischen dem zweiräumigen Gebäude und dem westlichen Flügel des äußeren Gebäudes wurde ein weniger solide errichtetes Gebäude ausgegraben, das vielleicht als Wirtschafts- oder Lagerhaus diente. Von ihm sind nur die $20 \mathrm{~cm}$ hohen Reste der Fundamente im Boden erhalten.

An der östlichen Seite dieses Gebäudes, in der Flucht seiner Nordmauer, wurden Reste eines Portikus in Form eines Steinfundaments gefunden, in das eine Reihe von Holzpfosten eingesetzt war. In ihm wurden verschiedene wirtschaftliche Tätigkeiten ausgeführt. Davon zeugen zahlreiche Fragmente von Gebrauchskeramik, kleine eiserne Messer, Spinnwirtel, Knochennadeln und -ahlen. Von hier stammt auch ein interessantes und bis heute singuläres Tongefäß, das zur Herstellung von Butter diente. In der Form ähnelt es sehr den bis in die jüngste Vergangenheit in Bulgarien benutzten Butterfässern aus Holz, die in der ethnographischen Literatur beschrieben werden. ${ }^{6}$

Hinsichtlich des südlichen Flügels des umlaufenden Gebäudekomplexes verfügen wir nur über wenige Erkenntnisse. Die Untersuchung der Innenseite wie auch Sondierungen entlang der Außenmauer zeigten, dass auch hier mit zellenartigen, aufgereihten Räumen zu rechnen ist. Jedoch kann über den Grundriss und die Anzahl der Räume nichts Näheres gesagt werden. Auch vom aufgehenden Mauerwerk ist nichts erhalten geblieben. Es kann aber durchaus davon ausgegangen werden, dass dieser Gebäudeflügel dem westlichen und dem nördlichen ähnlich war.

Wie die übrigen noch nicht untersuchten Gebäudeteile dieses großen architektonischen Ensembles ausgesehen haben, kann man bis jetzt nur vermuten. Nach den 


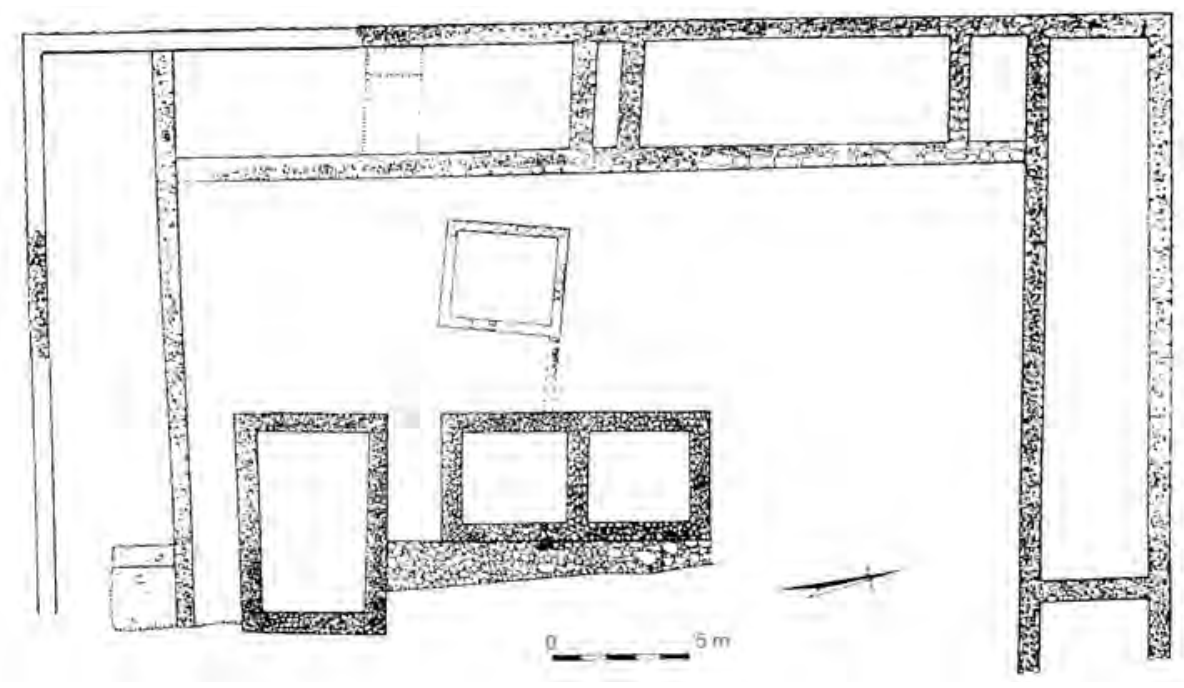

Abb. 3. Grundriss der ausgegrabenen Gebäude auf der Fundstelle Nr. 41

Luftbildbefunden und den Ergebnissen der geomagnetischen Prospektion, die ein Team bulgarischer und deutscher Forscher im Sommer 1998 durchführte, sind in dem sich östlich

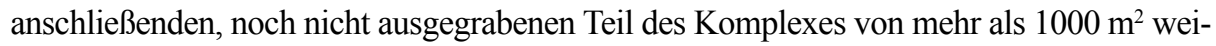
tere Gebäude errichtet worden (Abb. 4). Ihre oberflächlich sichtbaren Schuttreste ließen sich bei Geländebegehungen ausmachen. Über ihre Grundrisse und ihre Funktionen wird man aber erst nach ihrer vollständigen Freilegung etwas sagen können. Es lässt sich allerdings bereits die Vermutung äußern, dass sie einen zweiten Innenhof bildeten, in dem wahrscheinlich eine große Veranda lag, ein in der altbulgarischen Architektur häufig auftretendes Bauelement. Zu dieser Annahme hat uns auch der Umstand veranlasst, dass in der Mitte des Hofes eine steinerne Fundamentplatte mit einer Aussparung für einen Stützbalken gefunden wurde, die als Teil der Konstruktion der zum Hof hin offenen Wohnräume anzusehen ist.

Die Dächer der Gebäude waren mit großen flachen Ziegeln und gewölbten Firstziegeln (tegulae und imbrices) gedeckt. Diese Ziegel wiesen oft Zeichen und Linien auf, die mit Fingern und spitzen Gegenständen in den noch weichen, ungebrannten Ton geritzt worden waren. Dass es sich um einen hölzernen Dachstuhl gehandelt hat, beweisen die Vielzahl der gefundenen Nägel, Eisenklammern, dekorativen Beschläge sowie Brandreste.

Zwischen dem Ziegelschutt fanden sich an manchen Stellen auch Mörtelreste. Sehr wahrscheinlich waren die Innenwände einiger Gebäude sorgfältig mit weißem Mörtel verputzt, von dem an einem der erhalten gebliebenen Steinblöcke Spuren erkennbar waren.

Direkte archäologische Hinweise auf die Funktion der bisher freigelegten Gebäudeteile liefern die zahlreichen Kleinfunde. Sie sprechen eindeutig für einen wirtschaftlichen und handwerklichen Charakter der Anlage. Auf dem offenen Hofgelände vor den Räumen des 


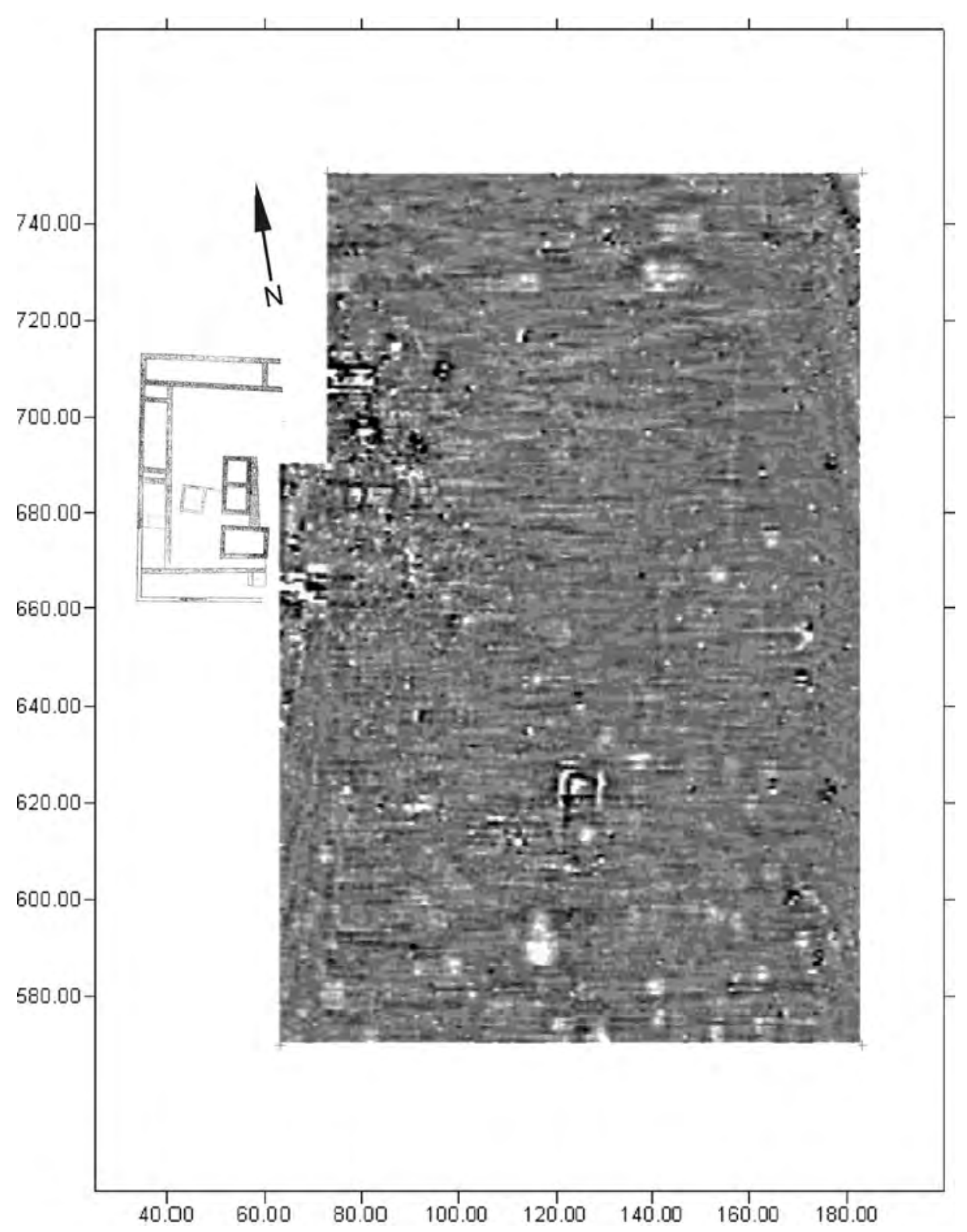

Abb. 4. Plan der prospektierten Fläche mit der Methode der Geomagnetik 
Nordflügels wurden in größeren Mengen Fragmente altbulgarischer Keramik gefunden, aus denen einige Gefäße, beispielsweise Töpfe mit eingeritzten Verzierungen, glasierte Krüge und Schüsseln rekonstruierbar waren. Anhand der Keramik kann eine grobe chronologische Einordnung in das 9. bis 11. Jahrhundert erfolgen. ${ }^{7}$

Neben Keramikscherben traten zahlreiche weitere Funde zutage. Dazu gehören eiserne Eimerhenkel, Teile der Bewaffnung (Pfeilspitzen und kleine, zu Schuppenpanzern gehörige Ringe) und des Pferdegeschirrs (Eisen- und Bronzeringe, Zügelteile, Beschläge und eine Eiskralle). Ein Hortfund bestand aus Agrargeräten, Geräten zur Viehhaltung und Waffen (Pflugmesser, Pflugschare, Hacken, Treibstachel, eine Sichel, ein Hufmesser, ein Teil einer Huffessel, eine Lanzenspitze). ${ }^{8}$ Neben Vorhängeschlössern und Eisenbeschlägen von Holzpfosten fanden sich Werkzeuge und Geräte zur Nahrungsmittelproduktion (Eisenbeschläge von Holzspaten, ein Treibstachel, eiserne Tierstriegel, Hacken- und Sichelfragmente, ein Bleigewicht für einen Angelhaken, Fragmente von Steintrögen und Drehmühlsteinen) sowie verschiedene kleinere Werkzeuge (ein Waagschälchen und der Arm einer Feinwaage, ein Eisenstylus, Schaber, kleine Eisenmesser, Meißel, Schnitzmesser, Bohrer, Äxte, Dachsbeile, Knochenahlen). Schmuck und Amulette (Kreuzenkolpien, Bleiamulette, Glasarmreifen, Gürtelschnallen und ein bronzener Fingerring) runden das Bild vom Leben an diesem Ort ab.

An verschiedenen Stellen des untersuchten Bereiches der Anlage sowie auch im nicht ausgegrabenen Gelände fanden sich Eisenschlacken, Roheisenstücke und Bruchstücke stark deformierter Eisengegenstände. Unweit des untersuchten Objektes hat man bei Sondierungen, die bereits 1948 von Nikola Mavrodinov durchgeführt worden sind, zahlreiche Eisenabfälle geborgen. Es handelte sich vor allem um limonitisierte Konkretionen von Pyrit bzw. Markasit, ${ }^{9}$ die sich im Zuge der Eisenverarbeitung in Form abgeschlagener Stücke und Roheisenbrocken mit einem Eisengehalt von $60 \%$ gebildet haben müssen. Nach Meinung Mavrodinovs befand sich im 9. und 10. Jahrhundert in der Äußeren Stadt Pliskas, in einiger Entfernung zu ihrem Zentrum und begrenzt von Asar-dere, Denis-dere und dem nördlichen Wall, ein großes Handwerkszentrum mit Schmiede- und Metallgusswerkstätten. ${ }^{10}$ Diese Überlegungen werden also durch unsere Funde unterstützt, die ebenfalls eine intensive eisenverarbeitende Tätigkeit bezeugen.

Obwohl die Erforschung des Baukomplexes noch ganz am Anfang steht, kann die Vermutung geäußert werden, dass seine Errichtung wahrscheinlich in die zweite Hälfte des 9. Jahrhunderts fällt. Hinsichtlich seiner architektonischen Struktur steht er mit wei-

7 Zur Keramik von Pliska vgl. Dončeva-Petkova 1977; Vitljanov/Dimitrov 1966, 238-256 und die dort zitierte Literatur.

8 Vgl. dazu den Beitrag des Autors im vorliegenden Band.

9 Mavrodinov 1948, 164.

10 Ebd., 165. 
teren Gebäuden in Pliska ${ }^{11}$ und Veliki Preslav ${ }^{12}$ in Verbindung. Im Besonderen ähnelt er einem Bauwerk, das im südwestlichen Teil der Äußeren Stadt Pliskas, in unmittelbarer Nähe zur heutigen Stadt liegt. Dieses ist in der Literatur als Objekt Nr. 40 bekannt und gehört in die Zeit des 9. und 10. Jahrhunderts. ${ }^{13}$ Der Bau entstand also in einer Zeit, in der an verschiedenen Stellen in der Äußeren Stadt Pliskas neue Siedlungen heranwuchsen sowie große Boljarenhöfe, Kirchen und Klosteranlagen errichtet wurden und die Äußere Stadt schrittweise die Gestalt einer durch eine steinerne Befestigungsanlage vom Herrschaftszentrum getrennten Vor- oder Unterstadt annahm.

Die Zerstörung des als Boljarenhof anzusprechenden Gebäudekomplexes erfolgte mutmaßlich in der Zeit der kriegerischen Ereignisse zwischen Bulgaren und Russen im Jahre 968 oder während der byzantinischen Angriffe in den Jahren 971 und 1001, die zu großen Zerstörungen und Bränden geführt haben. Davon zeugen die im untersuchten Bereich gefundenen Architekturfragmente aus Marmor, die zerstörten Steinblöcke und Steinpflasterungen sowie Ascheschichten und Reste von verbranntem Holz. Die endgültige Aufgabe des Hofes steht aber sicher im Zusammenhang mit dem Einfall der Petschenegen in den Jahren 1048/49, ${ }^{14}$ die daran anschließend für einige Jahrzehnte die Herrschaft über ganz Nordostbulgarien und über die Ebene von Pliska ausübten.

(Übersetzung: Joachim Henning)

\section{Bibliographie}

Čangova 1986: Йорданка Чангова, „За гражданските постройки в Преслав“, in: Преслав 1, София 1986, S. 139-157.

Dončeva-Petkova 1977: Людмила Дончева-Петкова, Битовата керамика през ранното средновековие (втората половина на VI - края на Х в.), София 1977.

Mavrodinov 1948: Никола Мавродинов, „Разкопки и проучвания в Плиска“, in: Разкопки и проучвания (София) 3, 1948.

Mijatev 1965: Кръстю Миятев, Архитектурата в средновековна България, София 1965.

Mladenov 1931: Стефан Младенов, „Печенеги, узи и кумани в българската история“, in: Българска историческа библиотека 4, 1931, S. 115-136.

Petrova 1984: Павлина Петрова, „Археологическо проучване на архитектурни комплекси от 1X-X в.“, in: Археология 25/1, 1984, S. 57-59.

Petrova 1986: Павлина Петрова, „Аеродистанционни изследвания на археологически паметници в България“, in: Годишник на музеите от Северна България. 12, 1986, S. 37-48.

Petrova 1992: Павлина Петрова, „Кьм въпроса за историко-археологическата топография на Външния град на Плиска по данни на аерометода“, in: Плиска-Преслав 5, Шумен 1992, S. 64-76.

11 Mijatev 1965, 68.

12 Čangova 1986, 139-157; Popkonstantinov 1980, 117-131; Totev 1998.

13 Petrova/Aladžov 1986, 37-48.

14 Vgl. hierzu Zlatarski 1972, 36-40, 88; Tăpkova-Zaimova 1980, 47-55; Mladenov 1931, 115-136. 
Petrova/Aladžov 1986: Павлина Петрова/Живко Аладжов, „Археологическо проучване на комплекс «А» (обект 40) във Външния град на Плиска“, in: Годишник на музеите от Северна България 12, 1986, S. 37-48.

Popkonstantinov 1980: Красимир Попконстантинов, „Граждански комплекси в Плиска и Преслав“, in: Средновековният български град, София 1980, S. 117-131.

Tăpkova-Zaimova 1980: Василка Тъпкова-Заимова, „Втората «варваризация» на Дунавските градове (X1-ХП в.)“, in: Средновековният български град, София 1980, S. 47-55.

Totev 1998: Тотю Тотев, Двориовият манастир в Преслав, Шумен 1998.

Vakarelski 1974: Христо Вакарелски, Етнография на България, София 1974.

Vitljanov/Dimitrov 1966: Стоян Витлянов/Янко Димитров, „За класификацията и хронологията на битовата керамика от манастира при Голямата базилика в Плиска“, in: Епископ-Константинови четения 2, Шумен 1966, S. 238-256.

Vitljanov/Petrova 1984: Стоян Витлянов/Павлина Петрова, „Разкопки на обект 41 във Външния град на Плиска“, in: Археологически открития и разкопки през 1983 г., Смолян 1984.

Zlatarski 1972: Димитър Златарски, История на българската държава през средните векове 2, София 1972. 



\title{
Ein Hortfund mit Eisengegenständen aus Pliska und das Problem der frühmittelalterlichen Agrartechnik in Bulgarien
}

\author{
StOJAN VitLJANOV
}

In den vergangenen Jahren hat die bulgarische Archäologie große Fortschritte in der Erforschung der materiellen und geistigen Kultur vergangener Epochen verzeichnen können. Eine Reihe von Fragen bezüglich der Landwirtschaft sind jedoch noch unzulänglich beantwortet. In den Museumsbeständen lagern immer noch zahlreiche Fundkomplexe mit Agrarwerkzeugen und Handwerksgeräten, die als unscheinbares Material von der bulgarischen Forschung zu wenig beachtet wurden. ${ }^{1}$ Die Veröffentlichung aller Neufunde oder einzelner Gegenstände, die es erlauben, verschiedene bisher unbekannte Seiten dieses Bereiches der materiellen Kultur zu beleuchten, ist daher von besonderer Bedeutung.

Im folgenden soll die Aufmerksamkeit auf einen vor einiger Zeit in Pliska, der ersten Hauptstadt des Bulgarenreiches im Frühmittelalter, gefundenen Hortfund gelenkt werden, der aus Agrargeräten, Hilfsmitteln zur Viehhaltung und Waffen besteht und in die Zeit zwischen das Ende des 9. und dem Anfang des 11. Jahrhunderts datiert. ${ }^{2}$

Er wurde im nordwestlichen Teil der Äußeren Stadt Pliskas gefunden, wo im Verlauf mehrerer archäologischer Untersuchungen ein großer adliger Eigenhof erforscht wurde (Abb. 1), dessen Produktions- und Wirtschaftscharakter durch dort gefundene Werkzeugformen, Agrargeräte und andere Alltagsgegenstände als gesichert gelten kann.

Der Hortfund wurde im Sommer 1990 von Raubgräbern auf dem Gelände des Hofes gefunden. Da an den eisernen Gegenständen entweder kein Interesse bestand oder man bei der Arbeit gestört wurde, wurden die Funde am Ort liegen gelassen und von Bauern der Filiale des Archäologischen Instituts und Museums der Bulgarischen

1 Ausnahmen bilden die Übersichtsdarstellungen zu den Agrargeräten: Henning 1987. Zu den eisernen Schmiedewerkzeugen: Vitljanov 1989/90, 145-170. Besonders in den letzten Jahren sind in großer Zahl neue Funde zutage getreten und es ergibt sich die Notwendigkeit der Erarbeitung eines „Corpus frühgeschichtlicher Eisenfunde aus Bulgarien“. Dieses wird im Zusammenwirken zwischen der Universität Frankfurt am Main und der Universität Šumen zur Zeit erarbeitet.

2 Das Objekt wird vom Autor untersucht. Vgl. auch den Beitrag des Autors zum Objekt Nr. 41 in diesem Band. 


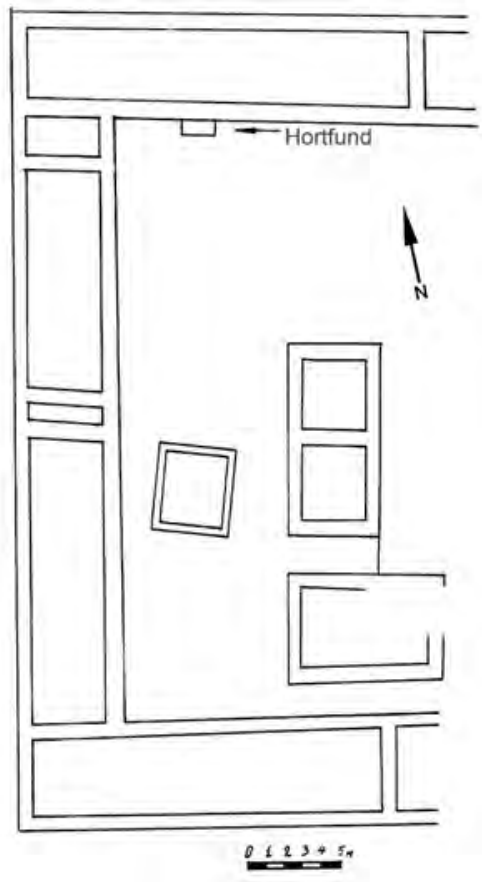

Abb. 1. Archäologisch erschlossene Baureste des Objektes 41 und Fundstelle des Hortfundes

Akademie der Wissenschaften in Šumen übergeben. Da der Suchtrichter noch klar erkennbar war, lässt sich der Fund einem der Gebäude des Komplexes zuordnen.

Der Fund besteht aus drei Pflugscharen, zwei Sechen, drei Hacken, einem Reutel, Huffesseln, einem Hufmesser und einer Lanzenspitze (Abb. 2). Die Pflugschare sind von unterschiedlicher Größe und zeigen zum Teil Spuren der Abnutzung. Der Grundform nach sind sie gleich und gehören zur Gruppe der symmetrischen Schare mit Tüllenschäftung. Das Arbeitsteil ist zungenförmig und jeweils deutlich breiter als die Schäftung. Dies lässt auf eine waagerechte Stellung im Arbeitsprozess schließen. Im Querschnitt ist das Arbeitsteil leicht gewölbt und vorne zugespitzt.

Die größte Schar ist $24 \mathrm{~cm}$ lang (Abb. 2,3; Kat. Nr. 1). Sie ist am besten erhalten und unterscheidet sich von den übrigen zwei Scharen durch ihre völlig längssymmetrische Form und ihre ausgezeichnete schmiedetechnische Fertigung. Das Stück zeigt keine Abnutzungsspuren. Sehr wahrscheinlich ist diese Schar erst kurz vor der Niederlegung hergestellt und noch nicht benutzt worden. Dafür sprechen auch die zwei Sechmesser im Hortfund, die den beiden abgenutzten Pflugscharen zugeordnet werden können; es ist also wahrscheinlich, dass die Stücke so deponiert wurden, wie sie zuvor

3 Zu ähnlichen Beobachtungen vgl. Vitljanov 1988, 26-30; Atanasov 1986, 24-34. 
bei der Arbeit mit dem Pflug zum Einsatz gekommen waren. ${ }^{3}$ Die beiden abgenutzten Schare haben geringere Ausmaße (18 bzw. 20 cm Länge, vgl. Abb. 2,1-2; Kat. Nr. 2-3) und zeigen deutliche einseitige Nutzungsspuren. Diese entstehen bei der Bodenbearbeitung und sind an zahlreichen frühmittelalterlichen Scharen zu beobachten. Die stärkste Abnutzung tritt in jenem Bereich der Schar auf, der den größten Widerstand im Boden zu überwinden hat, auf der Seite der Pflugfurche nämlich, die aus noch nicht aufgeschnittener Erde besteht. Mit Recht wird von einigen Autoren angenommen, dass diese Abnutzung mit einem einseitigen Streichbrett zusammenhängt, das die Erde nach rechts wendet. ${ }^{4}$ Demzufolge schneidet die linke Seite der Schar durch die feste, noch nicht aufgeschnittene Erde, während die andere Seite ohne großen Widerstand durch den bereits gelockerten Boden streichen kann. Der Umstand, dass die Schare in späterer Zeit bewusst asymmetrisch hergestellt wurden, zeigt, dass man die einseitige Abnutzung erkannt hatte und deshalb die im höheren Maße beanspruchte Seite verstärkte. Diese Besonderheit ist von einer Reihe von Forschern, die sich mit der Agrartechnik beschäftigt haben, bereits beschrieben worden. ${ }^{5}$

Ohne Zweifel sind die metallenen Arbeitsteile die wichtigsten funktionalen Bereiche der Pfluggeräte. Im Gegensatz zu den hölzernen Bestandteilen, die unterschiedlich geformt waren, haben sich die Eisenschneiden bis in unsere Zeit kaum verändert. Die Unterschiede zwischen den bislang bekannten Varianten sind sehr gering und lassen sich auf technische Verbesserungen und Veränderung der Arbeitsweisen zurückführen. Pflugschare werden zwar relativ selten in Horten gefunden, doch wenn dies der Fall ist, dann immer zusammen mit Sechen (Pflugmessern). Als Beispiel können die Hortfunde aus den mittelalterlichen Siedlungen Pliska, ${ }^{6}$ Preslav, ${ }^{7}$ Dălgopol, ${ }^{8}$ Središte ${ }^{9}$ angeführt werden.

Die Seche unterscheiden sich nur in ihren Maßen (Abb. 2,4-5; Kat. Nr. 4-5). Das Schneidenteil ist im Querschnitt keilförmig und der Schaft rechteckig. In senkrechter oder leicht angeschrägter Stellung zum Pflugbaum hatten Seche die Aufgabe, vor der Pflugschar senkrecht in den Boden einzuschneiden, wodurch das Aufreißen und Umwerfen der Scholle erleichtert wurde. Eine derartige Befestigung am Pflug ist auch durch bildliche Darstellungen belegt, so in einer frühmittelalterlichen Pflugzeichnung auf einem Steinblock der Kirche im Kleinen Palast von Pliska ${ }^{10}$ sowie an einem Pflug, dargestellt in einem angelsächsischen Kalendarium des 10./11. Jahrhunderts. ${ }^{11}$

\footnotetext{
4 Vgl. Henning 1982, $544 \mathrm{ff}$.

5 Vgl. ebd.; Balassa 1971, 312 Abb. 91; Sach 1962, 112 Taf. 6; Podwińska 1962, 191 Abb. 102, 194 Abb. 105; Leser 1931, 305 Abb. 155.

6 Antonova/Damjanov 1969, 40 Abb. 9; Balabanov 1985, 19-29.

7 Vitljanov 1988, 26-30.

8 Zlatarski 1960, 103-109.

9 Atanasov 1986, 24-34.

10 Ovčarov 1980, Abb. v.

11 Niederle 1921, 67 Abb. 11.
} 
Unsere Seche entsprechen der Form C nach Henning. ${ }^{12}$ Seche sind an der unteren Donau etwa seit dem 5. Jahrhundert bekannt, diese Form jedoch, für die ein verhältnismäßig kurzer und gebogener Körper charakteristisch ist, fand erst im 8. bis 10 . Jahrhundert eine weite Verbreitung. Häufig sind sie mit asymmetrischen Tüllenscharen vergesellschaftet. Die enge Beziehung zwischen bestimmten Formen der Sechmesser und der Schare, die mehrfach in der Literatur festgestellt wurde, ${ }^{13}$ kann durch die Nutzung verschiedener Pflugformen erklärt werden, an denen diese befestigt waren. Damit ergibt sich die Frage, zu welcher hölzernen Grundkonstruktion die Seche und Schare unseres Fundes gehörten. Bei der Bestimmung der entsprechenden Pflugform ist die Gestaltung des Pflugbaumes und der Winkel, in dem das Sech zum Pflugbaum steht und die Erde schneidet, von Bedeutung. Nur die tief liegenden, zur Erdoberfläche annähernd parallel stehenden Pflugbäume boten die Möglichkeit zur Befestigung der kurzen, gebogenen Seche des Typs C, zu denen auch unsere Funde gehören. Die oben genannten Parallelen und ethnographische Vergleiche zeigen eindeutig, dass es sich dabei um Formen der Vierseitpflüge handelt. Es ist aber hier zu erwähnen, dass ethnographischen Parallelen zufolge auch andere Kombinationen von Schar und Sech möglich sind.

Genaue Entsprechungen für die Schar-Sech-Kombination unseres Fundes sind in Pliska ${ }^{14}$, Preslav, ${ }^{15}$ Dălgopol ${ }^{16}$ Božurovo, ${ }^{17}$ Središte ${ }^{18}$ und anderen frühmittelalterlichen Siedlungen entdeckt worden. Gleicher Zeitstellung sind auch weitere Funde von Sechmessern, die in einer Reihe von Siedlungen im unteren Donaugebiet gefunden wurden. ${ }^{19}$

Der Reutel (Abb. 2,12; Kat. Nr. 9), dessen Form in Bulgarien weit verbreitet ist, ${ }^{20}$ besitzt einen verhältnismäßig kurzen Schaft mit einer konischen, weit geöffneten Tülle und eine breite dreieckige Schneide. Am oberen Ende der Tülle befindet sich ein Nietloch, so dass mittels eines Nagels der Holzschaft in der Tülle befestigt werden konnte. Reutel haben keinen direkten Bezug zur Bodenbearbeitung, sie wurden normalerweise dazu benutzt, die sich an der Pflugschar oder an den Holzteilen des Pfluges ansammelnde Erde und Strohreste abzukratzen. Nach ethnographischen Angaben wurden sie bisweilen auch zum Distelstechen oder bei Rodungsarbeiten benutzt.

12 Vgl. Henning 1982, 563 Abb. 5.

13 Ebd. 535 (mit Literatur).

14 Antonova/Damjanov 1969, 40; Balabanov 1985, 19-29.

15 Vitljanov 1988, 26-30.

16 Zlatarski 1960, 105-109.

17 Bobčeva 1972, 10 Abb. 5.

18 Atanasov 1986, 24-34.

19 Henning 1987, 53 Abb. 21.

20 Čangova 1962, 27ff. Abb.7, Taf.4; Balabanov 1985, 19-29; Totev 1966, 34 Abb. 1g. 

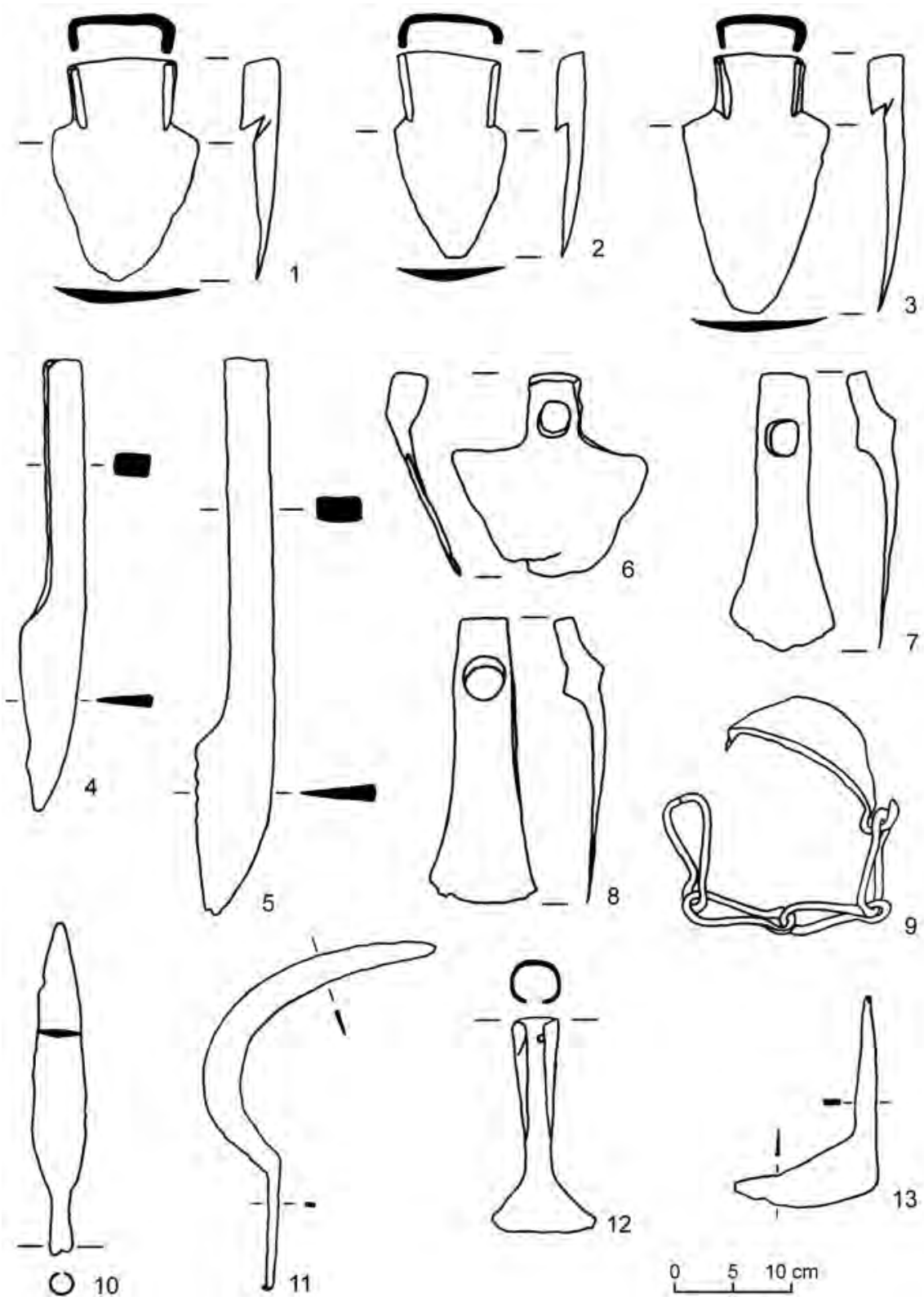

Abb. 2. Hortfund aus dem Objekt 41
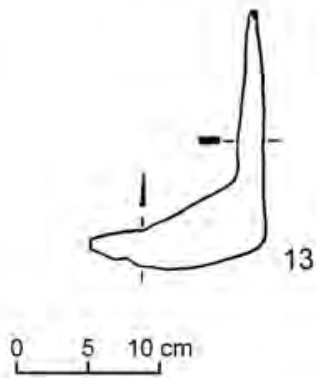
Die drei Hacken aus dem Hortfund gehören ihrer Form nach zwei unterschiedlichen Gruppen an. Zur ersten Gruppe ist das Stück (Abb. 2,6; Kat. Nr. 6) mit trapezförmigem Hackenblatt und horizontal ausladenden Schultern, einer runden Öffnung im Schaft sowie einem rechteckigen Nacken zu zählen. Die Schneide ist stark abgenutzt und das Blatt ist in der Mitte eingerissen. Für diese klassische Hackenform sind Massivität und Größe ebenso typisch, wie der Winkel zwischen Blatt und Hackenstiel. Beides zusammen bestimmt die Effektivität und die Qualität des Gerätes. Die Schwere des Hackenblattes erhöht aus funktionaler Sicht die Einschlagkraft und ihre erhebliche Größe sowie der Arbeitswinkel zwischen Blatt und Stiel erlaubten es, viel Erde zu bewegen. Hacken dieser Art sind besonders für den Hackfruchtanbau geeignet.

Die anderen zwei Hacken (Abb. 2,7-8; Kat. Nr. 7-8) besitzen längliche, schmale Körper mit verbreiterten Schneiden. Jeweils im massiven oberen Teil befindet sich ein Schaftloch, das von viereckigen Schaftlappen begleitet wird. Hacken dieser Form werden in erster Linie zur Bearbeitung von Bodenflächen, die mit Wurzeln durchsetzt sind, verwendet. Ähnliche Hackenformen sind vereinzelt schon aus der Römerzeit bekannt, erlangten jedoch erst im 5. und 6. Jahrhundert größere Verbreitung und wurden besonders im 8. bis 10. Jahrhundert zur dominierenden Form. ${ }^{21}$

Die einzige Sichel des Fundes (Abb. 2,11; Kat. Nr. 10) besitzt verhältnismäßig geringe Ausmaße, ein breites Blatt mit einer weiten Krümmung und eine Griffangel, die in der Schwerpunktmitte des Gerätes liegt. Es handelt sich also um den Typ der ausbalancierten Bogensichel. Das Schneidenteil ist stark korrodiert, so dass sich nicht entscheiden lässt, ob die Schneide glatt oder gezähnt war. Wahrscheinlich hatte sie jedoch eine gezähnte Schneide, so wie es ansonsten von dieser im Frühmittelalter weit verbreiteten Form bekannt ist. ${ }^{22}$

Unter den Funden sind die Huffessel und das Hufmesser von besonderem Interesse, da es sich bei ihnen um selten nachgewiesene Geräte handelt. Die Huffessel (Abb. 2,9; Kat. Nr. 11) besteht aus einem bogenförmig gekrümmten Blech, das beidseitig in Haken mündet, die durch eine aus vier Gliedern bestehende Kette so miteinander verbunden sind, dass sie den Huf umschließen. Nach ethnographischen Parallelen wurden diese Fesseln an die Vorderhufe eines Pferdes gelegt. Während die bisher bekannten und bei Nomadenvölkern weit verbreiteten Huffesseln aus organischem Material, vor allem aus Knochenteilen, Lederriemen oder Bast bestehen und zur Sicherung der Tiere während der Wanderungen dienen, werden eisernen Fesseln vor allem dazu genutzt, die Arbeitspferde auf der Weide festzuhalten. Für eine solche Deutung der eisernen Huffesseln spricht auch der Umstand, dass sie oft innerhalb von Gebäuden wirtschaftlichen Charakters sowie im Kontext mit wirtschaftlichen Materialien gefunden werden ${ }^{23}$ wie

21 Henning 1987, 79 Taf. 35, 82 Abb. 38.

22 Ebd. 89-91, Taf. 43.

23 Vgl. Kirpičnikov 1973, 74. 
auch in unserem Fall. Ihre Vergesellschaftung mit Pfluggeräten legt nahe, dass neben dem Rind auch bereits das Pferd als Zugtier eingesetzt wurde. In Bulgarien wie auch in Russland beginnt dieser Prozess früher als in Westeuropa und kann an das Ende des 10. und den Beginn des 11. Jahrhunderts datiert werden, also in den Zeitraum, in den auch der Fund von Pliska gehört. Wahrscheinlich kommt in dieser Zeit auch das Kummetgeschirr auf, wie es für die Anspannung des Pferdes beim Pflügen notwendig ist. Diese Form der Pferdenutzung in der Wirtschaft bezeugt eine hochmittelalterliche Miniatur der Radživilovsker Chronik. ${ }^{24}$

Das Hufmesser ist verhältnismäßig klein (Abb. 2,13; Kat. Nr. 12) und zeigt sichtbare Spuren längeren Gebrauchs. Sein Vorkommen im Hortfund legt nahe, dass man für Pferde als Zugtiere besondere Sorgfalt aufwandte, indem die Hufe ausgeschnitten bzw. mit Hufeisen beschlagen wurden. Davon zeugen ebenfalls die im Baukomplex selbst gefundenen Hufeisen.

Der einzige Gegenstand des Fundes, der eine andere Funktion als die übrigen Gegenständen hat, ist eine blattförmige Lanzenspitze (Abb. 2,10; Kat. Nr. 13). Diese Form ist im Bulgarien des 8. bis 11. Jahrhundert weit verbreitet. Der Umstand, dass die Lanzenspitze zusammen mit den übrigen Geräten gefunden wurde, könnte dafür sprechen, dass ihr Besitzer auch bei den Feldarbeiten eine Bewaffnung mit sich führte. Daraus folgt, dass der Inhaber des außerhalb der Steinbefestigung von Pliska gelegenen Hofes nicht nur Bauer, sondern auch Krieger war. Die Vergesellschaftung von Waffen und Agrargeräten ist keine Ausnahme. Vor einiger Zeit wurde bei der Ausgrabung einer der Gebäude des Palastklosters von Preslav ein Hortfund mit Pflugscharen und zwei blattförmigen Lanzenspitzen gefunden, die der Lanzenspitze aus Pliska entsprechen. ${ }^{25}$ Ähnliche Beispiele sind auch von anderen südost- und osteuropäischen Fundorten bekannt. ${ }^{26}$

Zur Befundsituation lässt sich sagen, dass der Hort direkt in eine zu diesem Zweck ausgehobene Grube gelegt worden war, die unmittelbar südlich vor dem Raum Nr. 1 des nördlichen Teils des bisher ergrabenen Gebäudes lag. In der Nähe des Hortfundes wurde vor Jahren ein eiserner Spatenbeschlag entdeckt, der möglicherweise beim Vergraben der Geräte verlorengegangen war oder vom Besitzer vergessen wurde. Zweifellos gehörte der Fund einem örtlichen Bauern, der die Gegenstände in einer Krisensituation, die Pliska und die Umgebung betraf, verbergen wollte. Höchstwahrscheinlich erfolgte dies bei einem der Petschenegen-Einfälle in Nordostbulgarien zu Beginn des 11. Jahrhunderts.

Schlussfolgernd kann man feststellen, dass der hier beschriebene Hort zu den gröBeren Funden dieser Art der letzen Jahre in Bulgarien gehört. Mit seinen vielfältigen Bestandteilen beleuchtet er wichtige Fragen hinsichtlich der Geschichte der frühmittelalterlichen Agrartechnik in Bulgarien.

24 Černezov 1977, 23-28.

25 Unpublizierte Materialien aus der Grabung von T. Totev (Šumen) in Preslav.

26 Henning 1989, 87-104. 


\section{Katalog}

Der Hortfund befindet sich zur Zeit in der Filiale des Archäologischen Instituts und Museum der Bulgarischen Akademie der Wissenschaften und ist dort zeitweilig inventarisiert. Nach Abschluss der Grabungen im Objekt 41 und deren Publikation werden die Funde in das Museum Pliska überführt.

1. Pflugschar (Abb. 2,3). Mit symmetrischem Blatt. Aus einem Stück aufgekohltem Eisen hergestellt. Länglich zungenförmiger Körper, der oben in eine breite, geöffnete Tülle übergeht. Das Blatt ist leicht gewölbt. Gut erhalten. Ohne sichtbare Abnutzungsspuren. Maße: Gesamtlänge $24 \mathrm{~cm}$; Länge der Tülle $6 \mathrm{~cm}$; Tüllenbreite $8,5 \mathrm{~cm}$; größte Breite des Blattes 13,5 cm; Inv.-Nr. 133/91.

2. Pflugschar (Abb. 2,1). Gleiche Grundform wie Nr. 1 nur kürzer. Einseitig asymmetrisch abgenutzt. Tülle und Blatt außerdem bereits bei der Herstellung leicht asymmetrisch zusammengesetzt. Auf der Innenseite des Blattes ungleichmäßige Abnutzungsspuren. Maße: Gesamtlänge $20 \mathrm{~cm}$; Länge der Tülle $6 \mathrm{~cm}$; Tüllenbreite $9,5 \mathrm{~cm}$; größte Breite des Blattes 13,0 cm; Inv.-Nr. 134/91.

3. Pflugschar (Abb. 2,2). Gleiche Grundform wie Nr. 2. Tülle gegenüber Blatt leicht asymmetrisch. Spitze abgebrochen. Maße: Gesamtlänge 18,0 cm; Länge der Tülle 5,6 cm; Tüllenbreite 8,5 cm; größte Breite des Blattes 9,5 cm; Inv.-Nr. 135/91.

4. Sech (Abb. 2,5). Langgezogener Schaft in Form eines massiven Messers. Rücken leicht gebogen. Maße: Gesamtlänge 49,0 cm; Länge der Schneide 16,0 cm; größte Breite des Blattes 7,5 cm; Schaft mit rechteckigem Querschnitt: 3,6 x 1,8 cm. Inv.-Nr. 136/91.

5. Sech (Abb. 2,4). Gleiche Grundform wie Nr. 4. Maße: Gesamtlänge 38,4 cm; Länge der Schneide 5,5 cm; größte Breite des Blattes 7,0 cm; Schaft mit rechteckigem Querschnitt: 2,8 x 2,0 cm. Inv.-Nr. 137/91.

6. Hacke (Abb. 2,6). Breites gerundetes Blatt mit waagerechter Schulter und rundem Schaftloch. Quadratischer Nacken. Maße: größte Breite 18,0 cm; Höhe des Blattes 12,5 cm; Gesamthöhe 18,5 cm; Durchmesser des Schaftloches 3 cm. Inv.-Nr. 138/91.

7. Hacke (Abb. 2,7) mit langgezogenem Blatt. Im Oberteil Schaftloch mit beidseitigen Schaftlochlappen. Maße: Länge 24,5 cm; größte Breite der Schneide 9,5 cm; Durchmesser des Schaftloches 3,5 cm. Inv.-Nr. 139/91.

8. Hacke (Abb. 2,8). Gleiche Grundform wie Nr. 7. Maße: Länge 24,0 cm; größte Breite der Schneide 9,5 cm; Durchmesser des Schaftloches 3,5 cm. Inv.-Nr. 140/91.

9. Reutel (Abb. 2,12). Langgezogener Schaft mit konischer Tülle und breiter dreieckiger Schneide. Im oberen Schaftteil Nietloch zur Befestigung eines hölzernen Schaftes. Maße: Gesamtlänge 13,0 cm; Durchmesser der Tülle 2,5 cm; Schneidenbreite 6,5 cm. Inv.Nr. 141/91. 
10. Sichel (Abb. 2, 9). Bogenförmige Schneide in ausbalancierter Position zur Griffangel. Maße: Gesamtlänge 34,0 cm; Tiefe der Bogenkrümmung $11 \mathrm{~cm}$; Länge des Heftes 10,5 cm; größte Schneidenbreite 3,5 cm. Inv.-Nr. 142/91.

11. Huffessel (Abb. 2,9). Länglich-elliptisches Eisenblech mit beidseitigen Hakenenden. An einem dieser Enden Kette aus 4 achtförmigen Gliedern. Maße: Gesamtlänge 35 cm. Inv.-Nr. $143 / 91$.

12. Hufmesser (Abb. 2,13). Bogenförmiger flacher Körper mit Griffangel. Maße: Länge des Schneidenteils 9,0 cm; größte Breite 3,5 cm; Länge der Griffangel 9,0 cm. Inv.-Nr. 144/91.

13. Lanzenspitze (Abb. 2,10). Weidenblattförmig mit im Querschnitt runder Tülle. Tülle leicht beschädigt. Maße: Gesamtlänge 22,0 cm; Breite 3,5 cm. Inv.-Nr. 145/91.

(Übersetzung: Raiko Krauß)

\section{Bibliographie}

Antonova/Damjanov 1969: Вера Антонова/Стефан Дамянов, „Материали от сондажни проучвания в Плиска“, in: Археология 11/2, 1969, S. 25-42.

Atanasov 1986: Георги Атанасов, „За прехода от рало към плуг“, in: Българска етнография 2, 1986, S. 24-34.

Balabanov 1985: Тодор Балабанов, „Земеделски оръдия от Плиска (IX-XI в.)“, in: Българска етнография 1985/2, S. 19-29.

Balassa 1971: Istvan Balassa, „The Appearance of the Onesided Plough in the Carpathian Basin“, in: Acta Ethnographia Academiae Scientiarum Hungaricae 20, 1971, S. 411-437.

Bobčeva 1972: Любка Бобчева, „Оръдия на труда от средновековието в музея в Толбухин“, in: Музеи и паметници на културата 12, 1972, S. 8-12.

Čangova 1962: Йорданка Чангова, „Средновековни оръдия на труда в България“, in: Известия на Археологическия институт 25, 1962, S. 19-55.

Černezov 1977: Алексей Владимирович Чернецов, „Следы пахоты на миниатуре Радживолловской летописи“, in: Краткие сообщения института истории материальной културы 150, 1977, S. 23-28.

Henning 1982: Joachim Henning, ,Die Entwicklung der Landwirtschaftstechnik und gesellschaftliche Veränderungen im Übergang von der Antike zum Mittelalter im unteren Donaugebiet", in: Joachim Herrmann/Irmgard Sellnow (Hrsg.), Produktivkräfte und Gesellschaftsformationen in vorkapitalistischer Zeit, Berlin 1982, S. 525-547.

Henning 1987: Joachim Henning, Südosteuropa zwischen Antike und Mittelalter: Archäologische Beiträge zur Landwirtschaft des 1. Jahrtausends u. Z., Berlin 1987.

Henning 1989: Йоахим Хеннинг, „Восточное по происхождению оружие и снаряжение всадников в кладах сельскохозяйственных железных изделии в Юго-Восточной Европе (VIII-X вв.)“, in: Проблеми на прабългарската история и култура 1, Варна 1989, S. 87-104.

Kirpičnikov 1973: Анатолий Николаевич Кирпичников, Снаряжение всадника и верхового коня на Руси IX-XII вв. (=Свод археологических источников Э1-36), Ленинград 1973.

Leser 1931: Paul Leser, Entstehung und Verbreitung des Pfluges, Münster 1931. 
Niederle 1921: Lubomír Niederle, Život starých slovanů (=Základy kulturnich starožitnosti slovanských 3.1), Praha 1921.

Ovčarov 1980: Димитър Овчаров, „Изображения на рала върху рисунки-графити от Плиска (VIII-X в.)“, in: Векове 9/1, 1980, S. 41-47.

Sach 1962: František Šach, „Rádlo a pluh na územi Československa“, in: Vědecké práce zemédelského musea (1961), Praha 1962.

Podwińska 1962: Zofia Podwińska, Technika uprawi roli w Polsce średniowiecznej, WrocławWarszawa-Kraków 1962.

Totev 1966: Тотю Тотев, „Колективна находка от средновековни оръдия на труда от с. Златар“, in: Археология 8/4, 1966, S. 33-35.

Vitljanov 1988: Стоян Витлянов, „Колективна находка от земеделски оръдия на труда от околностите на Преслав“", in: Българска етнография 1, 1988, S. 26-30.

Vitljanov 1989/90: Stojan Vitljanov, „Das Schmiedehandwerk in Bulgarien vom VII.-XIV. Jahrhundert“, in: Slavia Antiqua 32, 1989-90, 145-170.

Zlatarski 1960: Димитър Златарски, „Колективна находка от славянски сечива от с. Дългопол“, in: Известия на Варненското археологическо дружество 11, 1960, S. 103-109. 


\title{
Ein früher Haustypus in der Siedlung südöstlich der Inneren Stadt von Pliska
}

\author{
Stanislav Stanilov \& Janko Dimitrov
}

Die Untersuchung von Wohnbauten der Durchschnittsbevölkerung Pliskas ist ein relativ neues Forschungsthema. Obwohl in Pliska bereits seit 100 Jahren ausgegraben wird, sind erst seit dem Beginn der 1950er Jahre neben der Steinarchitektur auch einige Grubenhäuser bekannt geworden. ${ }^{1}$ Seit dieser Zeit wurden auf dem riesigen Gebiet der Siedlungsagglomeration einige Hundert dieser für das bulgarische Frühmittelalter typischen Bauten registriert und teilweise untersucht. Ihre Erforschung bietet gute Möglichkeiten, sowohl das Stadtbild von Pliska zu rekonstruieren als auch die Lebensweise der Mehrzahl der hier lebenden Bevölkerung zu erforschen. In der bulgarischen Fachliteratur gibt es Versuche einer chronologisch-typologischen Ordnung der Wohnhäuser in Pliska. ${ }^{2}$ Diese Untersuchungen sind jedoch über 20 Jahre alt, während in der Zeit danach Feldforschungen neue Aussagen zu Topographie und Bauweise der Grubenhäuser aus der hauptstädtischen Phase Pliskas und der darauf folgenden Zeitspanne geliefert haben. Die Siedlung südöstlich der Inneren Stadt ist eine der wenigen systematisch und vergleichsweise gut erforschten Objekte dieser Art auf dem großen Gebiet der Äußeren Stadt zwischen der steinernen Festungsmauer und dem Erdwall. ${ }^{3}$

Die Siedlung befindet sich im südöstlichen Viertel des äußeren Territoriums etwa $1,8 \mathrm{~km}$ vom Osttor entfernt (Abb. 1). Sie ist auf einer niedrigen Erhebung angelegt worden, die im Westen durch einen deutlichen Geländeeinschnitt begrenzt wird und nach Osten allmählich in ein kleines Tal abfällt, in dem auch heute noch eine Quelle entspringt. Der Boden ist über viele Jahre mit schweren landwirtschaftlichen Maschinen bearbeitet worden. Wenn man von der Fundstreuung der Keramik und angebrannter Bruchsteine ausgeht, betrug die im Mittelalter bewohnte Fläche ca. 100 ha. Diese ungewöhnlich große Ausdehnung wird aber unter anderem mit der Verteilung des Materials durch die landwirtschaftliche Bodenbearbeitung zu erklären sein.

1 Michajov 1955, 139-170; Michajlov/Milčev 1959, 263-291.

2 Balabanov 1988, 11-15; Balabanov 1992, 146-169.

3 Vorläufige Berichte über die Untersuchungsergebnisse in der Veröffentlichungsreihe „Archeologičeski otkritija i proučvanija“ (Archäologische Funde und Forschungen) zwischen 1983 und 1994; Stanilov/Dimitrov/Jankulov 1991, 124-137. 


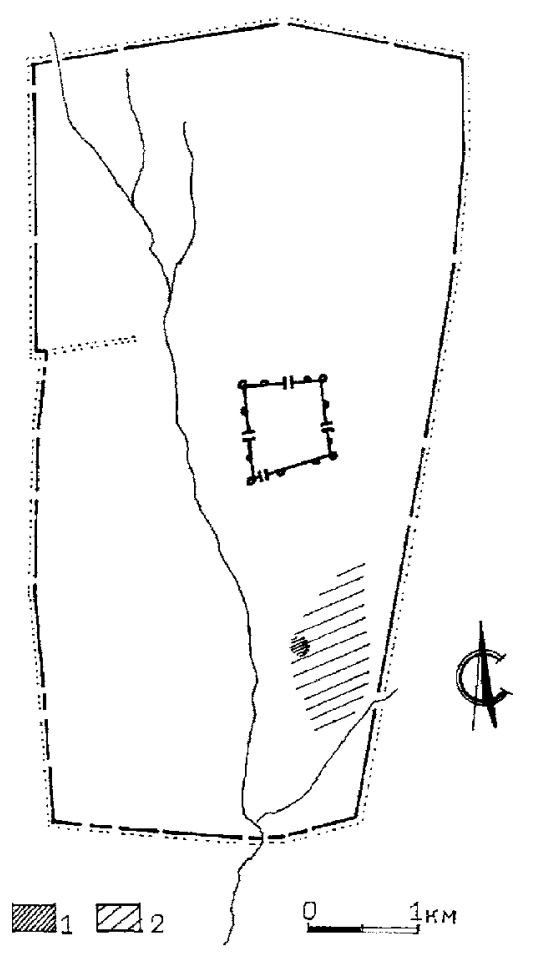

Abb. 1. Lage der Siedlung in Bezug auf die Befestigungsanlage von Pliska.

Legende: 1. durch Grabungen untersuchtes Gebiet;

2. ungefähre Ausdehnung der Siedlung

Die durch reguläre Grabungen von 1982 bis 1993 erforschte Fläche befindet sich im nordwestlichen Teil des durch die archäologische Fundstreuung gekennzeichneten Terrains. Auf einer Fläche von $8000 \mathrm{~m}^{2}$ wurden Reste von ebenerdigen und Grubenhäusern sowie von hölzernen Umzäunungen, die große, rechteckige Areale umschließen, gefunden (Abb. 2).

Die Spuren dieser Umzäunungen zeichnen sich als schmale Gräben ab, welche anfänglich irrtümlich als Kanäle angesehen wurden. Das Profil der Gräben (Abb. 3) zeigt ein vergleichsweise einheitliches Bild - senkrechte Wände und annähernd gleiche Breite an der Mündung und am Grund. Sehr selten sind die Wände nachlässig eingeschnitten und der Grund gerundet. Es gibt Sektoren, in denen die Gräben ein wannenförmiges Profil mit einer Differenz von 0,60 m zwischen Mündungs- und Bodenbreite haben. Wenn man die Wind- und Wassererosion mit in Betracht zieht, hatten die Gräben wahrscheinlich eine Tiefe von 0,70 bis 1,20 m. Im Profil der gut gestampften Grabenverfüllung erkennt man einen $20-25 \mathrm{~cm}$ breiten Streifen bröckeliger roter Erde, die sich durch ihre Struktur klar abgrenzen lässt (Abb. 3c-f). Diese Streifen verlaufen stets an der Innenseite der Gräben. Wir nehmen an, dass dies die Spuren von senkrecht nebeneinander angeordneten Balken einer Einfriedung sind. 


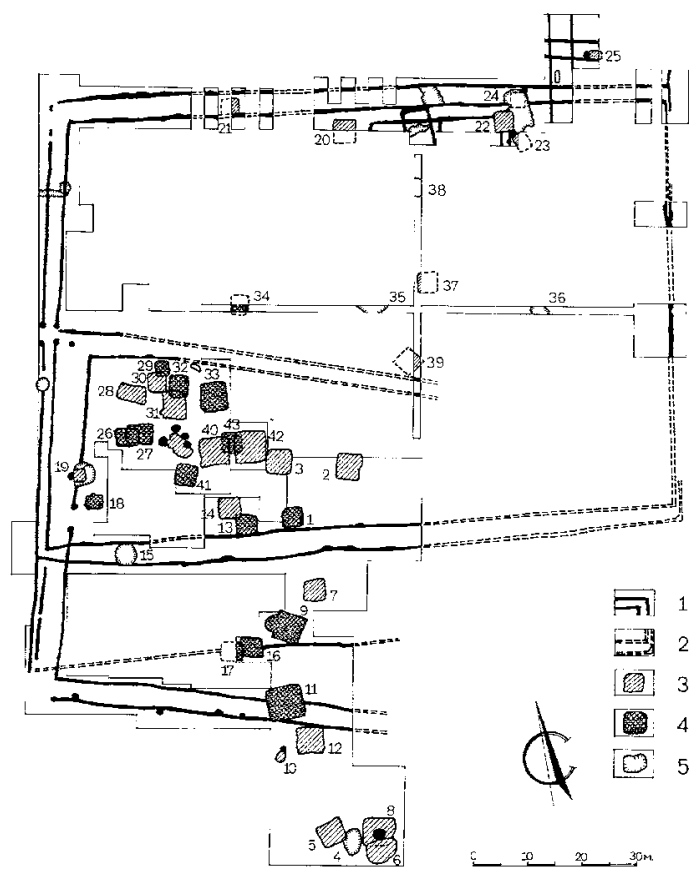

Abb. 2. Plan der Siedlung.

Legende: 1. Gräben für hölzerne Umzäunungen; 2. rekonstruierte Trasse der Gräben; 3. Häuser mit steinernen und in die Hauswand eingeschnittenen Öfen; 4. Häuser mit in den Boden eingetieften steinernen Öfen; 5. Gruben

Die Forschungen zeigten die Umrisse eines Hofes mit einer Erweiterung an der südlichen Seite und den Teil eines zweiten Hofes, der den ersten stellenweise überschneidet sowie vereinzelte Einfriedungen anderer Höfe (Abb. 2). Bei der Untersuchung der Verfüllung an den Stellen, wo sich die Gräben überschneiden, konnte die relativchronologische Abfolge der Umzäunungen nicht geklärt werden. Die umgrenzten Felder haben eine rechteckige Form und sind Ost-West orientiert mit einer leichten Abweichung nach Süden. Der erste der sogenannten Höfe - als Hof I bezeichnet - war bereits Gegenstand eines kurzen Vorberichtes. ${ }^{4}$ Seine Umgrenzung ist im Westen und Norden vollständig und im Süden und Osten in Teilen untersucht. Sie hat die Abmessungen von 116-122 $\mathrm{m}$ und 82-87 $\mathrm{m}$ und umgibt ein Areal von $8200 \mathrm{~m}^{2}$. Die geomagnetischen Untersuchungen des deutschen Forschungsteams zeigten, dass sich die Überreste dieser Hofstellen nach Norden und Süden fortsetzen, wohingegen sie im Osten nicht festgestellt werden konnten (Abb. 11). Die mit dieser Methode prospektierte Fläche ist zwar bislang noch klein, doch es gibt noch viele Areale, an denen sie Erfolg versprechend eingesetzt werden kann - beispielsweise im Osten des Terrains, wo Scherben und gebrannte Bruchsteine an die Oberfläche gepflügt wurden. In der

4 (wie Anm. 3). 
A
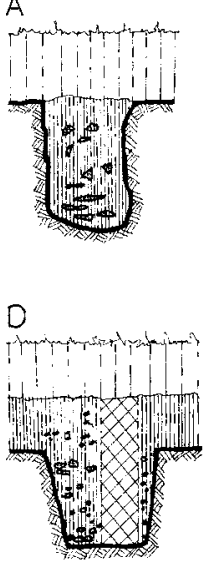

B

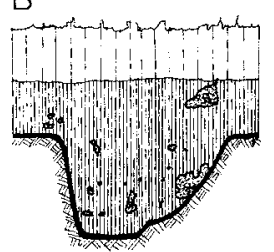

E

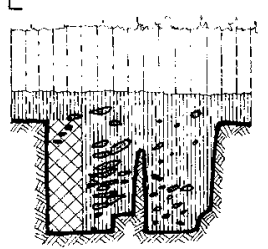

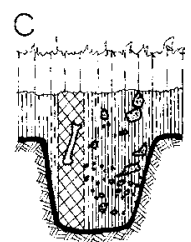

F

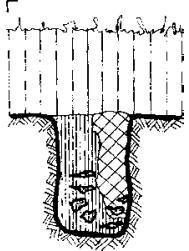

Abb. 3. Profile der Zaungräben mit Verfüllung.

Legende: 1. Humus; 2. bröckelige schwarze Erde; 3. braune Erde; 4. braune Erde durchmischt mit Lössstücken; 5. Löss

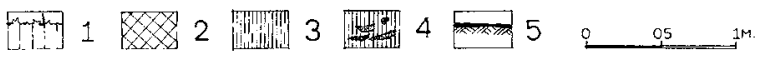

Mitte der westlichen Begrenzung der Höfe I und II sind Eingänge von $3 \mathrm{~m}$ Breite ausgespart worden, die auf einen Weg hin ausgerichtet sind, der eine Verbindung zum Zentrum von Pliska herstellt.

Leider konnten wir nicht die gesamte Fläche eines Hofes freilegen um seiner Organisationsstruktur näher zu kommen. Die Sondagen zeigten aber, dass die Häuser in der westlichen Hälfte enger standen als in der östlichen. Überreste ebenerdiger Häuser sind selten und bestehen aus von stark durch Feuereinwirkung in Mitleidenschaft gezogenener Fußböden sowie aus einzelnen Ansammlungen von Pfostenlöchern. Nahe der Mitte der inneren Linie der Nordumfassung von Hof I umschließt der Graben ein rechtwinkliges Areal, auf dem man eine hölzerne Konstruktion vermuten kann. Insgesamt wurden auf der freigelegten Fläche die Reste von vier ebenerdigen und 36 Grubenhäusern festgestellt sowie sechs eingetiefte Objekte, die nicht als Wohnhäuser genutzt wurden, sondern wahrscheinlich eine wirtschaftliche Funktion hatten.

Gegenstand unserer Betrachtung sind 15 Grubenhäuser (Abb. 2d); die übrigen werden von uns nur zum Vergleich herangezogen. In sieben dieser Häuser (Nr. 1, 9, 11, 13, 16, 17 und 20) konnten Heizvorrichtungen festgestellt werden. Anfänglich waren alle Häuser mit einer $0,65 \mathrm{~m}$ tiefen, rechteckigen Feuergrube mit Abmessungen von 1,60-2,20 m x 1,25-1,65 m ausgestattet (Abb. 4, 5). Der eigentliche Ofen aus Bruchsteinen nahm die Hälfte dieser Grube ein, die andere Hälfte bestand aus der Befeuerungsgrube mit einem stark angebrannten Boden, die wahrscheinlich zum Ausschaufeln der Glut diente. Drei der Öfen wurden später abgerissen, um danach an gleicher Stelle, aber auf einem um 10-20 cm höheren Lehmverputz neu errichtet zu werden (Abb. 6a-b). Alle sieben sind jedoch letztmalig nach dem Zuschütten der Grube zu ebe- 

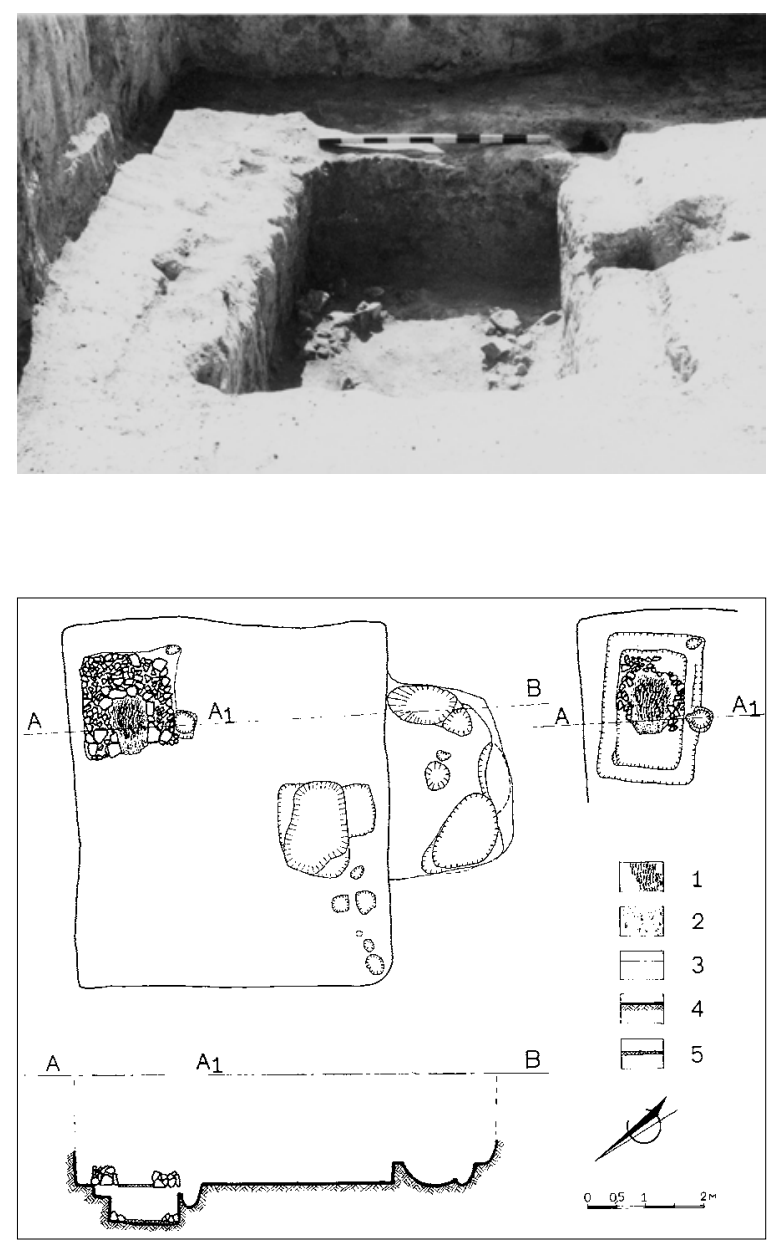

Abb. 4. Überreste eines steinernen Ofens, eingetieft in den Boden von Haus Nr. 9 (Blick von Westen)
Abb. 5. Haus Nr. 9. Grundriss und Schnitte.

Legende: 1. gebrannter Lehmestrich (in der Aufsicht); 2. Asche und Holzkohle; 3. Niveau der heutigen Oberfläche; 4. Löss; 5. gebrannter Lehmestrich (im Querschnitt)

ner Erde errichtet worden (Abb. 5, 6a-b). Hier muss an die davon abweichende Situation in einem der Häuser (Nr. 11) hingewiesen werden, wo die Ofengrube einen Brandfleck über dem Boden schneidet (Abb. 7). Bei diesem Brandfleck handelt es sich um einen älteren Typ der Heizvorrichtung, von dem wir nur vermuten können, dass es sich um eine Feuerstelle gehandelt hat. In Haus Nr. 11 wurden, genau wie in den Häusern Nr. 18, 29 und 32, eingetiefte Öfen mit einer vollständig abgetragenen Kammer gefunden (Abb. 7-8), wobei die Bruchsteine auch in der Verfüllung fehlten. Offenbar wurden diese Häuser verlassen und die Steine zum Bau anderer Öfen verwendet. Besonders wichtig ist die stratigraphische Lage der Verfüllung der Grubenhäuser mit eingegrabenen Öfen (Nr. 13, 29, 32 und 43) zu den sie schneidenden Häusern mit ebenerdig errichteten Öfen (Abb. 6). Diese zeigt, dass die Häuser mit den eingegrabenen Öfen 


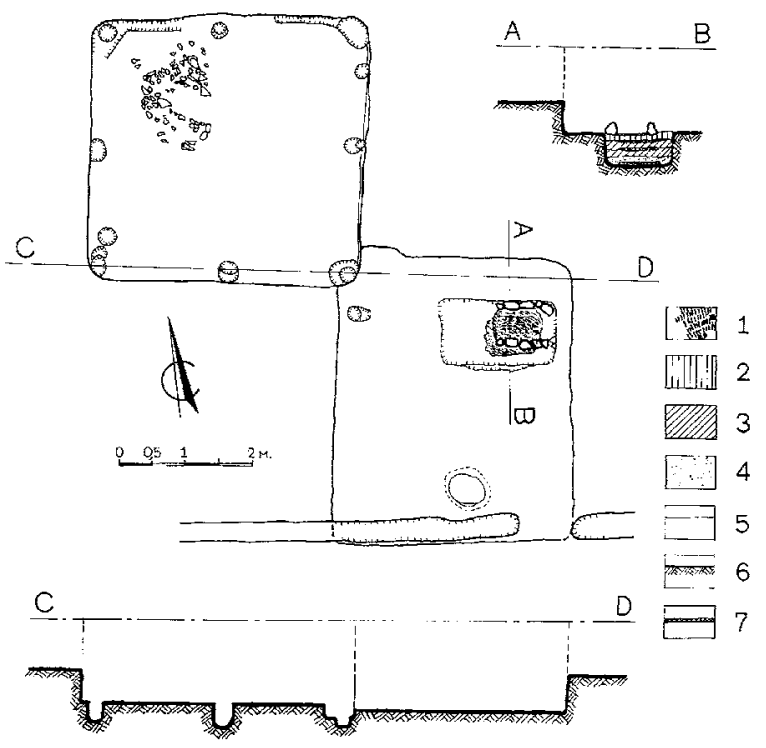

Abb. 6. Häuser Nr. 13 und 14. Lageplan und Schnitte.

Legende: 1. gebrannter Lehmestrich (in der Aufsicht); 2. Lössverfüllung; 3. mit Löss vermischte schwarze Erde; 4. Asche und Holzkohle;

5. Niveau der heutigen Oberfläche; 6. Löss; 7. Gebrannter Lehmestrich (im Querschnitt)

relativchronologisch älter sind. Zum Vergleich können drei Häuser mit eingegrabenen Öfen aus dem Baukomplex Objekt 31 in der Äußeren Stadt von Pliska herangezogen werden, wovon zwei unter steinernen Bauten liegen. ${ }^{5}$ Die gleichen Öfen besitzen auch zwei Grubenhäuser nahe des Asar-dere, die aufgrund der Keramik ins 8.-9. Jahrhundert datiert werden. ${ }^{6}$ Besonders kennzeichnend ist der Vergleich mit einer im südwestlichen Viertel der Äußeren Stadt gelegenen Siedlungsstelle, auf der die Häuser mit den eingegrabenen Öfen die zentrale Fläche der Ansiedlung einnehmen, während sich die Häuser mit ebenerdigen Öfen an der Peripherie befinden. ${ }^{7}$

Die verhältnismäßig frühe Datierung der Häuser mit eingegrabenen Öfen wird durch die vorläufige Beobachtung des keramischen Materials aus der Verfüllung bestätigt. Die Keramik ist stets fragmentiert; ganze Gefäße wurden nicht gefunden. Es handelt sich um zwei Arten - Tafel- und Haushaltskeramik. Zur Tafelkeramik zählen die Gefäße aus fein gemagertem Ton mit Glättverzierung. Auf der Töpferscheibe gearbeitet sind folgende Formen: Kannen, amphorenartige Kannen, Schüsseln, Töpfe - große sogenannte Delvi und kleine, mit und ohne runde Ohrenhenkel. Die Gefäße sind dickwandig, bei geringer Temperatur reduzierend gebrannt und vereinzelt von unterschiedlicher Färbung. Darüber hinaus zählen zur Tafelkeramik die Kannen und amphorenartigen Kannen aus hellem Ton, die auf der hand- aber häufiger fußgedreh-

5 Michajlov/Milčer 1959, 271-273, Abb. 12-14; Michajlov 1963, 12-16, Abb. 1-IV, VI, 9.

6 Milčev 1960, 30-37, Abb. 2-9.

7 Unpubliziert. Die Information über diese Siedlung erhielten wir vom Ausgräber Todor Balabanov, dem wir an dieser Stelle herzlich danken. 


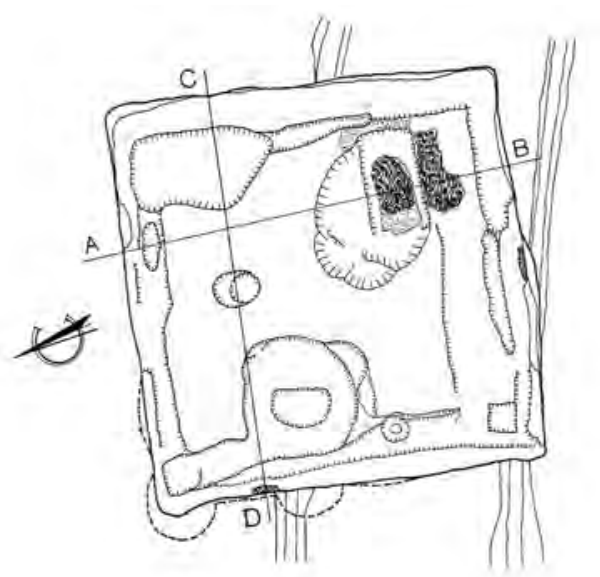

Abb. 7. Haus Nr. 11 und die Umzäunung im Süden des Hofes II. Lageplan und Schnitte.

Legende: 1. gebrannter Lehmestrich; 2. Asche und Holzkohle; 3. Holzreste; 4. Niveau der heutigen Oberfläche;

5. Löss
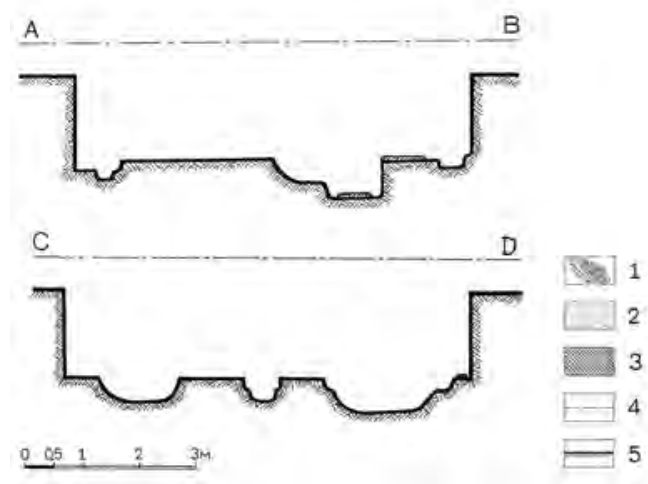

ten Töpferscheibe gefertigt wurden. Die Mündungen sind schmal, trichterförmig, gerade oder profiliert und die Henkel haben im unteren Abschnitt eine charakteristische Ausstülpung. Die Wandungen dieser Gefäße sind glatt oder leicht gefurcht und in der Mehrzahl der Fälle ist die Oberfläche mit roter Engobe gefärbt. Vollständig fehlt die Tafelkeramik mit gelbgrüner Glasur, die man aus den gut datierten Kulturschichten des 9. und vor allem 10. Jahrhunderts kennt.

Als Haushaltskeramik wird die aus mit relativ grobem Quarzsand gemagertem Ton gefertigte Keramik bezeichnet. Sie hat dicke Wandungen und ist unregelmäßig gebrannt. Sie ist in einer einzigen Form vertreten - henkellose Töpfe mit kurzen Hälsen und unprofilierten Rändern. Die Verzierung besteht aus eingeritzten geraden und Wellenlinien in wenigen Varianten, die ausschließlich in horizontaler Richtung aufgetragen wurden. Vollständig fehlen Scherben von Haushaltskeramik mit Grübchen- und Strichbündelverzierungen, die mit einem Knochen in senkrechter Richtung eingeritzt wurden. Neben der Tafel- und Haushaltskeramik wurden in geringen Mengen auch Amphoren gefunden, die als Transportkeramik bezeichnet werden können. Gleichartige 

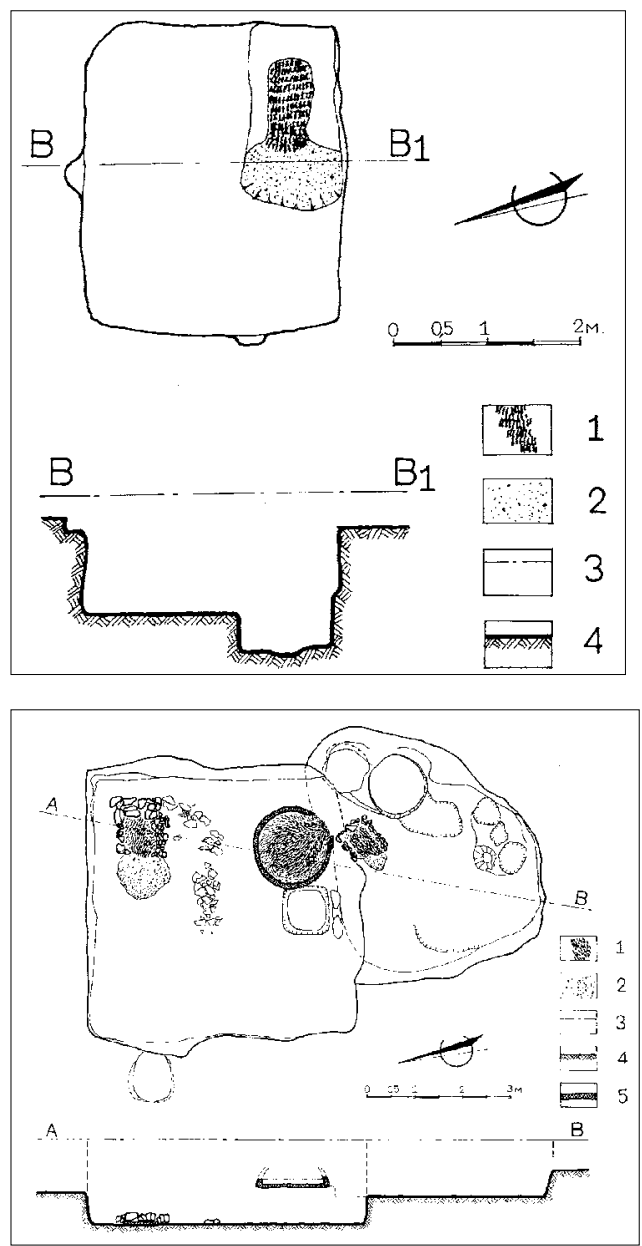

Abb. 8. Haus Nr. 18. Grundriss und Schnitte.

Legende: 1. gebrannter Lehmestrich; 2. Asche und Holzkohle; 3 . Niveau der heutigen Oberfläche; 4. Löss

Abb. 9. Häuser Nr. 6 und Nr. 8. Lageplan und Schnitte.

Legende: 1. gebrannter Lehmestrich (in der Aufsicht); 2. Asche und Holzkohle; 3. Niveau der heutigen Oberfläche; 4. Löss; 5. gebrannter Lehmestrich (im Querschnitt)

Keramiktypen stammen auch aus den heidnischen Nekropolen ${ }^{8}$ (ohne Amphoren), aus Hügel XXXIII in Pliska, ${ }^{9}$ aus den Mauergruben des „Krumpalastes ${ }^{\text {“10 }}$, aus der Siedlung im Gebiet der Großen Basilika ${ }^{11}$ und den erwähnten zwei Häusern nahe des Asar-dere. ${ }^{12}$

Der Keramikkomplex aus der Verfüllung der Grubenhäuser mit eingegrabenem Ofen kann mit dem aus der Verfüllung der Gräben verglichen werden. Obwohl die

8 Fiedler 1992, 121-170.

9 Georgiev 1955, 29-35; Stančev 1949, 235-246.

10 Die Keramik aus dem Palast des Krum konnten wir mit freundlicher Unterstützung durch Rašo Rašev durchsehen, dem wir für diese Möglichkeit herzlich danken.

11 Geogiev 1993, 19-27, Abb. 12-24; Vasilev 1995.

12 Milčev 1960, 36-38, Abb. 10-14. 


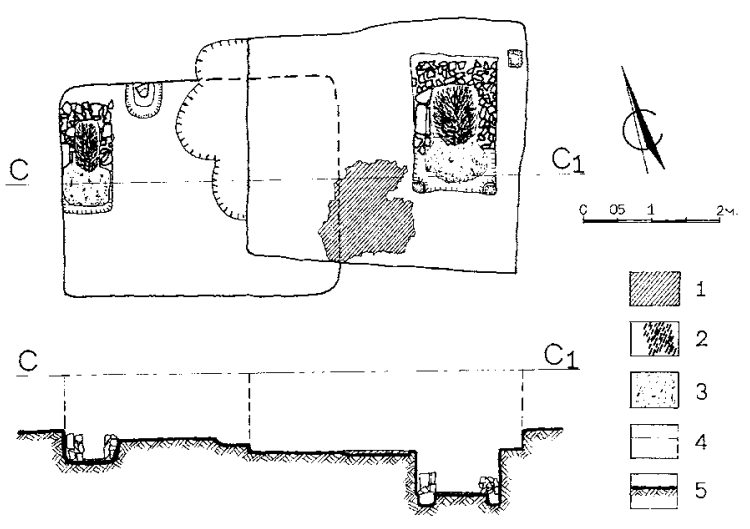

Abb. 10. Häuser Nr. 26 und 27. Lageplan und Schnitte.

Legende: 1. Lehmestrich; 2. gebrannter Lehmestrich; 3. Asche und Holzkohle; 4. Niveau der heutigen Oberfläche; 5. Löss

aus den Gräben stammende Keramik nicht sehr zahlreich ist - insgesamt nur etwa 700 Scherben - umfasst sie alle oben genannten Typen. ${ }^{13}$ Nachweislich sind also Keramikscherben aus der Zeit des Bestehens der Grubenhäuser mit eingegrabenem Ofen in die Zaungräben gelangt. Im oberen Teil der Verfüllung des inneren Grabens der nördlichen Umgrenzung von Hof I fand sich eine Münze des Kaisers Nikephoros I Genikos und seines Sohnes Staurakios (802-811), durch die die Verfüllung in das erste Viertel des 9. Jahrhunderts datiert werden kann. ${ }^{14}$ Dies ist eine der beiden einzigen Münzen dieses Kaisers, die in Pliska gefunden wurden.

In der Siedlung südöstlich der Äußeren Stadt von Pliska wurden Häuser mit einem dritten Ofentyp untersucht, der nicht aus Steinen aufgebaut sondern in die Wandung der Hausgrube eingeschnitten ist. Die Öfen haben eine ovale Form und einen mit Lehm bestrichenen Boden, der häufig über einer Schicht aus kleinen Steinen oder Keramikscherben liegt. In der Siedlung gibt es insgesamt nur vier dieser Häuser - drei davon liegen an der Peripherie von Hof I und eines südlich der Grenzen von Hof II. Zwei davon schneiden die Gräben und ein drittes ist in die Verfüllung eines Grubenhauses mit ebenerdigem Ofen aus Bruchsteinen eingegraben (Abb. 9). Diese gesicherte Stratigraphie reicht unserer Meinung nach aus, um die Häuser mit den eingeschnittenen Öfen als die jüngsten zu datieren.

Die relativchronologische Abfolge von eingegrabenen steinernen Öfen über steinerne Öfen zu ebener Erde hin zu Öfen, die in die Wandung des Grubenhauses eingeschnitten sind, widerspricht der von Svetlana Pletnjova vorgeschlagenen Abfolge der Heizvorrichtungen im südöstlichen Viertel der ummauerten Festung. ${ }^{15}$ Nach den Erkenntnissen des

13 Ähnliche Charakteristika mit der Keramik vom Hof I in: Stanilov/Dimitrov/Jankulov 1991, 127-133, Abb. 4-5.

14 Bestimmung durch I. Jordanov.

15 Pletnjova 1992, 54, Abb. 26. 


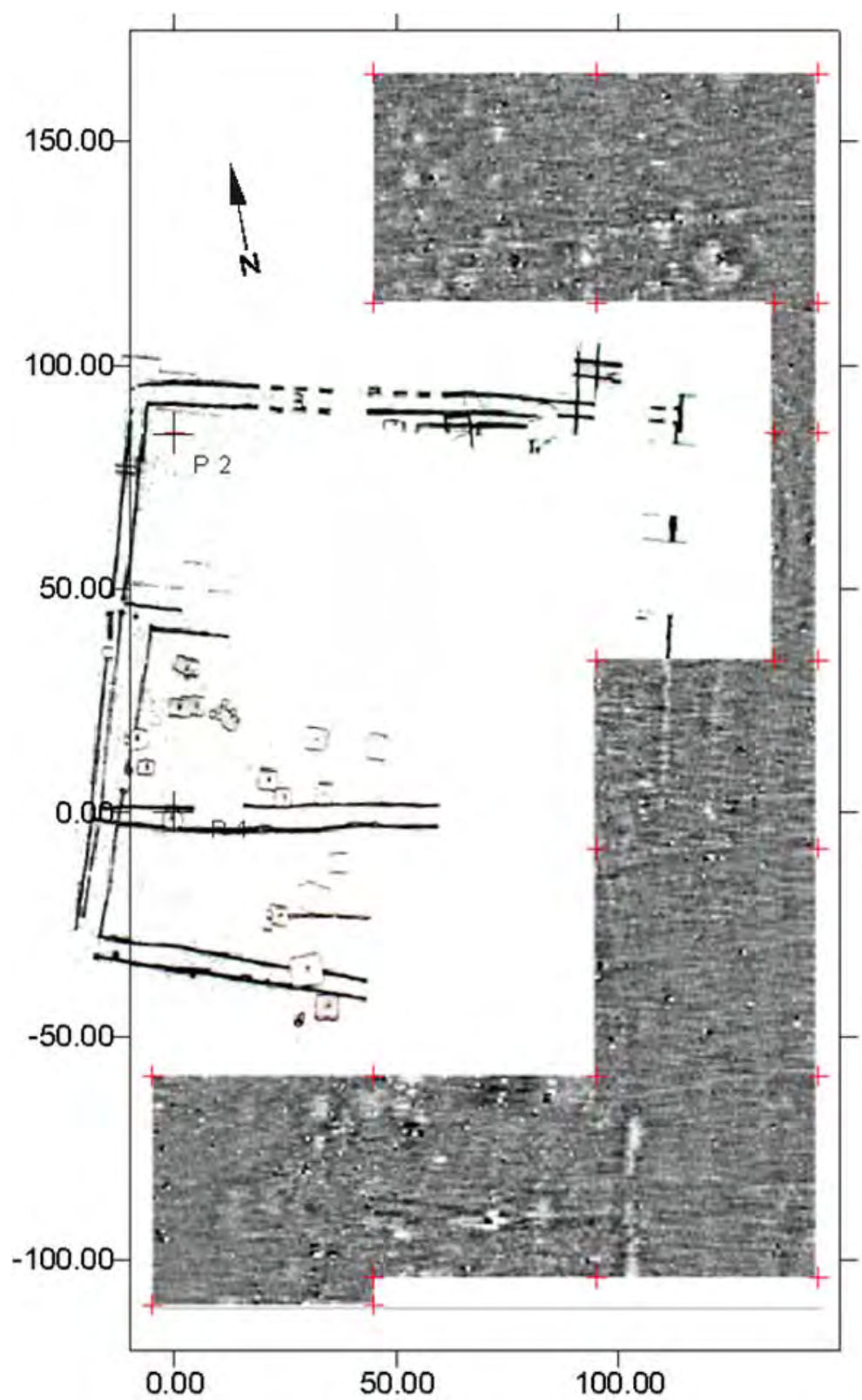

Abb. 11. Geomagnetische Flächenmessung von 1998 im Umfeld des Grabungsobjektes (deutsch-bulgarisches Feldforschungsprojekt) 
russischen Teams sind die in die Wandung eingeschnittenen Öfen die frühesten, darauf folgen die eingegrabenen und die in Stein gesetzten. Die jüngsten wären demnach die ebenerdigen und die in Stein gesetzten Öfen. Diese relative Abfolge könnte im Ergebnis einer Neubearbeitung der Keramik korrigiert werden. ${ }^{16}$

Die oben dargestellte relative Abfolge kann nicht immer mit der gemessenen Tiefe der Hausgruben in Einklang gebracht werden. Allgemein sind die Hausgruben im südöstlichen Teil des Terrains mit 1,40 bis 2,00 m tiefer als die im nordwestlichen mit 1,00 bis $1,30 \mathrm{~m}$. Im Grunde gleichen sich die Tiefen der Hausgruben mit den eingegrabenen und den ebenerdigen Öfen weitgehend. Einzig die Hausgruben der Häuser mit den eingeschnittenen Öfen sind mit Tiefen von 1,05 bis 1,20 m wesentlich flacher.

Ein gleiches Ergebnis zeigt auch die Korrelation mit der Lage der Öfen in den Häusern. Der Großteil der in Stein gesetzten Öfen - unabhängig davon, ob es sich um eingetiefte oder ebenerdige handelt - befindet sich an der Ostwand oder in der nordöstlichen bzw. südwestlichen Ecke. Vom dritten Ofentyp sind zwei in die Nordwand, einer in die Westwand und ein vierter in die Nordostecke eines Hauses eingeschnitten. Die Tradition der Lage der Heizeinrichtung kann mit den klimatischen Gegebenheiten erklärt werden, da in Nordostbulgarien die kalten Winde vornehmlich aus Nordosten wehen.

Die beobachteten Hauskonstruktionen zeigen gleichfalls eine große Vielfalt. Ein Großteil der 15 Häuser mit in den Boden eingetieften Öfen zeigt Spuren einer Holzverkleidung an Wand und Boden oder nur an den Wänden (Abb. 7). Bei vielen Bauten finden sich an den Wänden oder in den Ecken hölzerne Auflager für die Dachkonstruktion. Diese folgen aber weder einer vorgegebenen Norm, noch ist ihre Anordnung einheitlich. Der überwiegende Teil der Häuser mit ebenerdigen Öfen zeigt keine Spuren von Holzverkleidung, obwohl auch hier die Auflager vorhanden sind. Von den Häusern mit eingeschnittenem Ofen hat nur eines diese Auflager - drei dicht nebeneinander an der dem Ofen gegenüberliegenden Hauswand.

Wenn wir also von den durch Feldforschungen gewonnenen Daten ausgehen, so scheint für die relative Chronologie der Häuser der Siedlung südöstlich der Inneren Stadt der eingegrabene und aus Bruchsteinen gesetzte Ofentyp entscheidend zu sein. Unserer Meinung nach sind die 15 Häuser dieses frühen Typs zu zahlreich, als dass sie alle gleichzeitig mit der hölzernen Befestigung und ihrem begrenzten Innenraum bestanden haben können. Wahrscheinlich sind einige älter als die Holzkonstruktionen, andere gleichzeitig und wieder andere später. Die Untersuchung von Haus 26 verdeutlicht diese Überlegungen (Abb. 10). Diese Hausgrube überschneidet zum Teil die Verfüllung von Haus 27, welches einen eingegrabenen Ofen aufweist. Haus 26 besitzt ebenfalls einen solchen Ofen, unterscheidet sich aber durch sein Keramikinventar von dem oben genannten. Während die Tafelkeramik nur ein etwas weniger vielfältiges Formenspektrum aufweist, zeigen sich unter der Haushaltskeramik Töpfe mit stärker auskragenden, teilweise profilierten Rändern. Auch die Ritzverzierungen sind vielfältiger und bestehen 
aus senkrechten Linienbündeln und einzelnen Grübchen. Hier wurden auch vereinzelt Scherben mit gelbgrüner Glasur gefunden, die auf frühmittelalterlichen Fundplätzen in Bulgarien zweifellos am Ende des 9. bzw. am Beginn des 10. Jahrhunderts auftreten. ${ }^{17}$

Eine erkennbare stratigraphische Beziehung zwischen Hausgrube und Zaungraben war nur bei Haus 11 zu beobachten (Abb. 7). Das Haus fällt durch seine Größe von $45,6 \mathrm{~m}^{2}$ und seine 2,5 $\mathrm{m}$ eingetiefte Hausgrube auf und zeigt Spuren von massiven Verkleidungen an Boden und Wänden. Der Ofen war in die Südostecke eingetieft, wobei davon nur noch die teilweise zerstörte Grube gefunden wurde. Das Haus war nicht parallel zur Umgrenzung des Hofes II ausgerichtet, und die Beobachtungen des Profils zeigten, dass es später als diese errichtet wurde, da die Hausgrube die Struktur des südlichen Verlaufs störte. Trotzdem stellen die gleichartigen Keramikfunde das Haus und die Umzäunung in einen gewissen zeitlichen Zusammenhang innerhalb des 8.-9. Jahrhunderts. Dabei ist zu bedenken, dass wir nicht wissen, wie lange diese Umzäunung benutzt und wie oft sie erneuert wurde.

Die oben gemachten Beobachtungen führen zu der Überlegung, dass die Umzäunung und die Häuser nicht zeitgleich sein müssen, wobei die Umzäunung älter als die Häuser sein könnte. Der Vergleich mit anderen untersuchten Siedlungen der Äußeren Stadt reicht jedoch nicht aus, um diese These zu unterstützen. So zeigt z.B. die von Radoslav Vasilev vorgestellte Siedlung keine hölzerne Umzäunung der Höfe und weist zudem eine andere Struktur auf; die Häuser stehen hier weit auseinander und überlagern sich nur in Ausnahmefällen. ${ }^{18}$ In der Siedlung südöstlich der Inneren Stadt sind die Hausgruben dagegen eng gedrängt und überlagern sich häufig. Dieser Umstand kann nur durch den gedrängten Raum innerhalb der Umzäunung erklärt werden.

Zum Schluss möchten wir darauf hinweisen, dass die genannten Beobachtungen und Argumente nur vorläufigen Charakter besitzen. Die endgültigen Ergebnisse der Untersuchungen können erst nach der vollständigen Bearbeitung der Dokumentation und der Funde vorgestellt werden.

(Übersetzung: Raiko Krauß)

\section{Bibliographie}

Balabanov 1988: Тодор Балабанов, „Массовое жилище в Плиске (VIII-XI вв)“, in: Tpyды V-ого международного конгресса ахреологов-славистов 2, Киев 1988, S. 11-15.

Balabanov 1992: Тодор Балабанов, „Жилища покрай северната и източната крепостна стена на Плиска“, in: Плиска-Преслав 5, 1992, S. 146-169.

Dimitrov 1994: Янко Димитров, „Стратиграфията на Плиска и проучванията на руската експедиция (1977-1980 г.)“, in: Археология 36, 1994, No. 3-4, S. 48-50.

17 Dončeva-Petkova 1977, 130-131.

18 Vasilev 1993, 35-39, Abb. 1. 
Dončeva-Petkova 1977: Людмила Дончева-Петкова, Българска битова керамика през ранното средновековие (втората половина на VI-края на X в.), София 1977, S. 130-131.

Fiedler 1992: Uwe Fielder, Studien zu Gräberfeldern des 6. bis 9. Jahrhunderts an der unteren Donau (=Universitätsforschungen zur prähistorischen Archäologie 11), Bonn 1992.

Geogiev 1993: Павел Георгиев, Мартириумът в Плиска и началото на християнството в България, София 1993.

Georgieva 1955: Соня Георгиева, „Разкопки на могили XXXIII и XXXII в Плиска“, in: Известия на Археологическия институт 20, 1955, S. 29-35.

Michajlov 1955: Стамен Михайлов, „Археологически материали от Плиска (1948-1951 г.)“, in: Известия на Археологическия институт 20, 1955, S. 139-170.

Michajlov 1963: Стамен Михайлов, „Разкопки в Плиска през 1959-1961 г.“, in: Известия на Археологическия институт 26, 1963, S. 12-16.

Michajlov/Milčev 1959: Стамен Михайлов/Атанас Милчев, „Разкопки в Плиска през 1955 г.“, in: Известия на Археологическия институт 22, 1959, S. 263-291.

Milčev 1960: Атанас Милчев, „Разкопки в Плиска западно от Вътрешния град, 1959 г.“, in: Археология 2/3, 1960, S. 30-37.

Pletnjova 1992: Светлана Плетнева, „Стратиграфические исследования Плиски (Работы советского отряда 1977-1980 гг.)“, in: Плиска-Преслав 5, Шумен 1992, S. 35-63.

Stančev 1949: Станчо Станчев, „Керамиката от Голямата могила в Плиска“, in: Разкопки и проучвания (София) 3, 1949, S. 235-246.

Stanilov/Dimitrov/Jankulov 1991: Станислав Станилов/Янко Димитров/И. Янкулов, "Проучване на селището, югоизточно от Вътрешния град на Плиска", in: Проблеми на прабългарската история и култура 2, Шумен 1991, S. 124-137.

Vasilev 1993: Радослав Василев, “За планировката на някои ранносредновековни селища във Външния град на Плиска”, in: Приноси към българската археология (София) 2, 1993, S. 35-39.

Vasilev 1995: Радослав Василев, “Нови данни за ранносредновековното селище в района на Голямата базилика в Плиска", in: Плиска-Преслав 7, 1995, S. 23-33. 



\title{
A virtual view of Pliska: \\ Integrating remote sensing, geophysical and archaeological survey data into a geographical information system
}

\author{
Irene Marzolff \& JoAchim Henning
}

\begin{abstract}
1. Introduction
The integration of spatial data about the surface and near surface into a geographical information system (GIS) on a local, regional or supra-regional scale has been of growing importance for archaeological and cultural research in the last decades. Non-destructive methods of prospecting and combined spatially oriented archaeological interpretation of excavation and survey data offer a progressive approach towards efficient documentation of buried archaeological structures threatened by destruction through landscape transformation and erosion. With rapidly developing technologies of highresolution remote sensing, digital photogrammetry, near-surface geophysical sensing and $3 \mathrm{D}$ visualization techniques, both the documentation and analytical capabilities of GIS present an ever-increasing potential for supplementing traditional archaeological excavation and survey techniques. ${ }^{1}$

In the case of the study presented here, archaeologists and geographers joined forces within Frankfurt University's interdisciplinary Graduate School of Archaeological Analytics with the aim of introducing GIS techniques to the investigations being carried out by a German-Bulgarian archaeological team since 1997 at Pliska, the early medieval Bulgarian center of power and Europe's largest post-Roman settlement agglomeration. With the remarkable extent of $21.8 \mathrm{~km}^{2}$ the settlement must have been a true metropolis. The city was abandoned by the thirteenth/fourteenth century at the latest, and with the exception of the present-day town of Pliska, previously a village with the Turkish name Aboba, in the southern part of the site, it is nowadays largely under agricultural cultivation. This presents, of course, a challenge to archaeology and its cooperating disciplines. Excavations already started more than a hundred years ago, but since 1899 archaeological work there had succeeded in uncovering less than $1 \%$ of the site. This situation changed dramatically after the completion of the German-Bulgarian
\end{abstract}

1 See e.g. Allen 1990, Bewley 2003, Doneus 2001, Doneus/Scharrer 1999, Ford/Griffith/Watson 2005, Forte 2000, Neubauer 2001. 
field campaigns that ran from 1997 to 2001. More than 53.3 hectares were explored by geophysical measurement, and after the analysis and mapping of the data suitable sites for 31 excavation trenches were chosen and accurately located within the new plan. The basic archaeological results are presented in this volume. Unfortunately there is only a very limited amount of printed basic information on Pliska's archaeology and history that is easily accessible to the non-Bulgarian reader. ${ }^{2}$

\section{The Pliska site GIS}

By merging various spatial data - maps, aerial photography, relief data, geomagnetic survey images, locations of excavation sections and other points of interest - in a geographical information system, a basis was to be established for the visualization and further spatial interpretation of excavation features and geophysical survey measurements. In addition, the combination and synopsis of spatial information from multiple sources was expected to be of great use in archaeological prospecting in the Pliska area.

ESRI GIS software (ArcView 3.2, ArcGIS 9.0) and Leica Geosystems image processing software (ERDAS Imagine 8.x) were used for all image and data processing. A first step in establishing the Pliska site GIS was the integration of point and image data obtained by archaeological and geophysical survey in a common cartographic coordinate system. These primary data were subsequently combined with secondary information derived from the primary layers: relief data and archaeological features. The visualization tools of the GIS could then be used for the construction of 2D maps and $3 \mathrm{D}$ views, showing all features in their spatial associations. Examples of these maps are given in plates 21-25.

While some base data for the Pliska site GIS could be acquired from other sources, most data were collected in the field or derived as secondary data from GIS analysis and visual interpretation. The following list gives an overview of the main layers incorporated into the Pliska GIS.

2 See e.g. Dončeva-Petkova 2001, Henning 1980, ibid. 2000, Rašev 1983. 


\begin{tabular}{|c|c|c|}
\hline & Data type & Data model \\
\hline \multirow{7}{*}{ 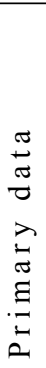 } & Topographical Map 1:25000, edition 1943 & raster (scanned) \\
\hline & Topographical Map 1:5000, edition 1986 & raster (scanned) \\
\hline & Orthophotomap 1:5000, 1987 & raster (scanned, $0.4 \mathrm{~m}$ resolution) \\
\hline & Aerial photography, approx. 1:9000, 1992 & raster (scanned, $0.4 \mathrm{~m}$ resolution) \\
\hline & Aerial photography, approx. 1:7000, 1942 & raster (scanned, $0.4 \mathrm{~m}$ resolution) \\
\hline & Geomagnetic survey images $1997-2001$ & $\begin{array}{l}\text { ASCII, converted to raster }(0.5 \mathrm{~m} \\
\text { resolution })\end{array}$ \\
\hline & $\begin{array}{l}\text { Point survey data (height points, location of } \\
\text { excavation sections, geomagnetic survey areas) }\end{array}$ & ASCII, converted to vector \\
\hline \multirow{7}{*}{ 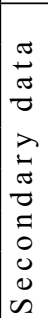 } & Surface elevation & raster (10 $\mathrm{m}$ and $1 \mathrm{~m}$ resolution) \\
\hline & Potential flowpaths & raster (1 m resolution) \\
\hline & Boundaries of Outer and Inner Town & vector polygons \\
\hline & Geomagnetic survey area & vector polygons \\
\hline & Excavation sections & vector polygons \\
\hline & Grubenhaus sites & vector points \\
\hline & Wall-and-ditch systems & vector polylines \\
\hline
\end{tabular}

\subsection{Base data}

As a topographical base for the Pliska GIS, orthophoto maps as well as medium and large-scale topographic maps covering both the Outer Town with surroundings and the area of the Inner Town were acquired in 1999. Unlike the original aerial photographs, orthophotos have been corrected for the relief distortions resulting from the camera's central perspective: like maps, they have parallel perspective and correct scales and geometry for direct measuring and mapping.

A major problem was the lack of coordinates on these maps and orthophotos: while both scale and a $500 \mathrm{~m}$ grid are indicated in the map frame, the grid itself is not marked with coordinates as this information was regarded a state secret in Bulgaria in the past. ${ }^{3}$ From the sparse information available, and with the aid of the truncated map coordinates marked on a 1939 1:40000 scale Bulgarian Military Map, coordinates for a Bulgarian Gauß-Krüger Transverse Mercator Projection were reconstructed. When GPS readings of the surroundings of Pliska were available in 2001, this reconstruction proved to be accurate to within approx. $500 \mathrm{~m}$. The error results in an offset to the true GPS coordinates only, and does not affect the internal geometry and scale of the GIS.

3 Mugnier 2002. 


\subsection{Additional remote sensing data, geophysical and geodetic survey data}

All further data were subsequently georeferenced to the topographic base data and the 1987 orthophoto map, and integrated into the GIS. For the scanned aerial photographs from 1992 and 1942 this was accomplished by image-to-image rectification with a second order polynomial transformation. A multi-temporal composite was produced from the black-and-white photographs of 1942, 1987 and 1992 for a simultaneous view of structural landscape changes during these 50 years.

Geomagnetic survey images and point survey data were originally taken in a local coordinate system used by the archaeological survey; this local system was converted to the GIS coordinate system by affine transformation using reference points identifiable on the aerial photographs. The original ASCII data were converted into raster and vector format respectively.

\subsection{Derivation of relief data}

Digital elevation models (DEM) were derived from the base data by spatial interpolation techniques. For a general topographic overview of the surroundings of Pliska, an elevation model with $10 \mathrm{~m}$ resolution was interpolated from contour lines, which were digitized from the 1:25,000 map. For the areas covered by geomagnetic survey west of the Inner Town, a higher resolution $(1 \mathrm{~m})$ elevation model was derived from height points measured with a total station. Depending on the topographical situation, these points had been taken by the archaeologists in a roughly regular grid at intervals of 5$20 \mathrm{~m}$ during the field campaigns in 1999-2001.

From the latter, large-scale DEM topographic analysis was carried out generating data sets of slope gradient and potential flowpaths of superficial runoff. The University of Leuven's USLE2D software was employed for modeling the flowpaths using a multiple flow algorithm. ${ }^{4}$

\subsection{Archaeological features}

Additional vector layers were digitized interactively over the base data layers for selected elements (town boundaries, excavation sections, outlines of the geomagnetic survey area). Layers of potential grubenhaus sites and bank-and-ditch systems were drawn from visual interpretation of the geomagnetic data, relief data and aerial pho-

4 Desmet/Govers 1996. 
tography (see below). Each feature is described in an attribute table, which forms an integral part of the GIS database.

\section{A virtual vision of the site of Pliska: synopsis of the information layers}

The GIS allows for a visual combination of individual layers of spatially referenced data stacked in interchangeable order with any user-defined cartographic symbology. Control of layer visibility (off, on, semi-transparent) facilitates the collective examination of information about the surface which in reality cannot be viewed all at once in the field, and 3D tools allow the observer to adopt any position towards the area of interest, which may be magnified or reduced at will.

An overview of the topographic situation of Pliska is given in a 3D view from the south-east in plate 21 (top, figure A) and demonstrates the situation of Pliska's Inner Town, 49 hectares in size, on a flat ridge on a south-facing slope with a gradient of just $1-2^{\circ}$. Over the full extent of the Outer Town, which stretches some $6.5 \mathrm{~km}$ from north to south and covers an area of $22 \mathrm{~km}^{2}$, this slope is dissected by the Asar-dere valley, the sides of which in several places fall steeply from the adjacent ridges. Modern is located in the southern Asar-dere valley just within the Outer Town's limits, and close to the junction with a smaller valley running east of the Inner Town. This is more or less the area shown in plate 22, where the geophysical survey areas (53.4 ha) of the 1997-2001 campaigns are marked on the orthophoto map.

In this black-and-white orthophoto map, and even more so in the multitemporal color composite, the farmed fields differ greatly in reflection and texture, and yet there are many conspicuous structures not related to agricultural working but rather to accelerated erosion, accumulation or deliberate leveling of the ground. Thus, several archaeological features, some of them hitherto undetected, could be identified from the aerial photos (see also Pl. 23): a bank-and-ditch system adjoining the Inner Town to the north, the Mound XXXIII in its north-western corner, now leveled, a crescent-shaped structure depicting the remains of a slag heap at the edge of an artisans' quarter between the Asar-dere valley and Mound XXXIV, and parts of a rampart-and-ditch system running north-north-east from Mound XXXIV. All of these objects also appear on the geomagnetic survey images overlaying the 1992 aerial photograph in plate 23 .

From the combined imagery, point and linear geomagnetic anomalies were interpreted in order to identify potential grubenhaus sites and rampart-and-ditch systems. In order to differentiate better between anomalies caused by natural processes - e.g. soil erosion or colluvial infill - and anthropogenic anomalies, layers of contour lines and potential flowpaths ( $\mathrm{Pl}$. 24, right) were consulted, the latter indicating possible invisible courses of erosion rills or depressions which might be reflected in the geomagnetic images. Several linear structures visible as geomagnetic anomalies could thus be excluded 
from the bank-and-ditch layer shown in Plate 23, while others must be considered to be clearly anthropogenic on the grounds of incompatibility with both relief morphometrics and potential flowpaths.

In the subsequent excavation campaigns excavation trenches were placed in order to confirm some of the sites and structures identified by this procedure. All of the features thought to be grubenhäuser or ditches, as well as some of the ramparts could be confirmed (compare Pl. 24, left, and Pl. 23).

Geomagnetic anomalies within the survey area interpreted as grubenhäuser show a mean distribution of 10 features per hectare, with a slightly higher density east of or within the area of the main excavation trench (11.3 sites/ha) than outside towards the Asar-dere valley ( 8.7 features/ha), where in the lower occupation layers the eighth/ ninth centuries artisan quarter was detected. No significant tendency towards flatter sites can be observed for the location of the grubenhäuser: $87.5 \%$ of the grubenhaustype geomagnetic anomalies can be found within the $84.5 \%$ of the area analyzed west of the Inner Town with slope gradients of less than $3^{\circ}$. Only gradients of more than $7^{\circ}$ - a mere $1.6 \%$ of the area - appear free of potential grubenhaus sites.

Geomagnetic anomalies caused by rampart-and-ditch structures prevail over those attributed to grubenhaus features in the survey area named as Poluostrov (literally "peninsula", but more precisely a spur), north-west of the Inner Town where a small tributary joins the Asar-dere valley (Pl. 25). Three excavation trenches were positioned in order to explore the geomagnetic line structures mapped, and these in fact turned out to be fortification ditches of some kind, probably designed to defend the spur-like elevation between the two watercourses of the Asar-dere. The majority of the interesting structures visible on plate 25 , however, will have to be the subject of future field exploration.

\section{Conclusions}

The primary function of the Pliska GIS was the establishment of a space-oriented inventory of various information layers about the area of the medieval city. In a first step, the combination of multi-temporal aerial photographs enabled the recognition and assessment of temporary and permanent agricultural and soil marks visible at the surface. The integration of geophysical survey images and relief data - derived by surface analysis from topographic maps - could further enhance the interpretation of spatial relationships and facilitate the discrimination between relief-induced and anthropogenic structures. Thus new insights were gained for further excavation planning, and subsequent results could be fed back into the GIS, confirming previous assumptions from the interpretation of the geophysical data. In this context, the mapping and 3D tools of the GIS proved of valuable assistance for the visualization of all features in their spatial associations. 


\section{Bibliography}

Allen 1990: Kathleen M. S. Allen (Ed.), Interpreting space: GIS and archaeology, London, 1990.

Bewley 2003: Robert H. Bewley, “Aerial survey for archaeology”, in: Photogrammetric Record 18/04, 2003, pp. 273-292.

Desmet/Govers 1996: P. J. J. Desmet/G. Govers, "A GIS-procedure for automatically calculating the ULSE LS-factor on topographically complex landscape units", in: Journal of Soil and Water Conservation 51/5, 1996, pp. 427-433.

Dončeva-Petkova 2001: Ljudmila Dončeva-Petkova, "Pliska - Heidnische und christliche Hauptstadt", in: Antike Welt 4, 2001, pp. 359-401.

Doneus 2001: Michael Doneus, "Precision Mapping and Interpretation of Oblique Aerial Photographs", in: Archaeological Prospection 8, 2001, pp. 13-27.

Doneus/Scharrer 1999: Michael Doneus/Gabriele Scharrer, "The City Map of Ancient Carnuntum - Combining Archaeological Prospection, Photogrammetry and GIS", in: Proceedings of the XVII CIPA Symposium, Recife/Olinda 1999. CD-Rom publication (8/2005: http://cipa. icomos.org/fileadmin/papers/olinda/99c501.pdf).

Ford/Griffith/Watson 2005: Margaret Ford/Richard Griffiths/Linda Watson, "The Sandford Inventory of Earth Buildings constructed using a GIS", in: Building and Environment 40, 2005, pp. 964-972.

Forte 2000: Maurizio Forte, "Archaeology and virtual micro-topography: the creation of DEMs for reconstructing fossil landscapes by Remote Sensing and GIS Applications", in: Gary R. Lock (Ed.), Beyond the Map: Archaeology and Spatial Technologies, Amsterdam 2000, pp. 199-213.

Henning 1980: Joachim Henning, "Pliska - monumentales Zeugnis vom Beginn der Geschichte des bulgarischen Staates", in: Das Altertum 26/1, 1980, pp. 18-26.

Henning 2000: Joachim Henning, "Pliska - Machtzentrum zwischen Byzanz und Abendland: Neue Wege der Archäologie", in: Forschung Frankfurt 2, 2000, pp. 6-15.

Mugnier 2002: Clifford J. Mugnier, "Grids \& Datums: Republic of Bulgaria", in: Photogrammetric Engineering \& Remote Sensing 1, 2002, pp. 19-21.

Neugebauer 2001: Wolfgang Neugebauer, "Images of the invisible: prospection methods for the documentation of threatened archaeological sites", in: Naturwissenschaften 88, 2001, pp. 13-24.

Rašev 1983: Rašo Rašev, "Pliska - The First Capital of Bulgaria", in: Andrew G. Poulter (Ed.), Ancient Bulgaria. Papers presented to the international symposium on the ancient history and archaeology of Bulgaria, University of Nottingham 1981, vol. 2, Nottingham 1983, pp. 255-290. 



\title{
Kabiyuk: another Pliska?
}

\author{
JoAChim Henning \& Eyub F. Eyub
}

\section{Introduction}

In the 1898 edition of the annual Известия Русского археологического института в Константинополе Karel Škorpil, a scholar and teacher of Czech origin who helped in establishing the late nineteenth-century Bulgarian education system, published for the first time his hypothesis of an early medieval "first capital" of Bulgaria. This was Pliska/Pliskova, the center that according to Škorpil would have existed roughly 200 years before the Bulgarian ruler's see of Preslav was first mentioned in the written sources. ${ }^{1}$ This assumption has taken very deep root in the Bulgarian national identity. As to the site of Pliska, Śkorpil claimed that this was the large fortification near to the village of Aboba in northeastern Bulgaria where he initiated excavations financed and carried out by the Russian Archaeological Institute in Constantinople in 1899. The resulting monograph, which remains to this day the most solid scholarly presentation ever produced on this site, had appeared already in 1905 and all skepticism that had been expressed over his theory has since faded. For the first time in Bulgaria archaeology was used to decide a debate among historians. The nineteenth-century belief that an accepted European nation needs a permanent and dignified capital was certainly helpful in spreading the imagination of the Pliska capital in a time when the Bulgarian people had just reclaimed their national sovereignty from the Ottoman Empire. Škorpil's arguments, however, were strictly scholarly. They are not only intriguing but are to some extent convincing, and cannot be discounted out of hand.

However, the written source base that might be used for deducing such a permanent capital, founded by the Bulgars under their early leader Asparuh after settling south of the Danube River or somewhat later, is extremely scanty. In fact "Pliskova" appears as a place name in the Byzantine written sources even later than Preslav, namely in connection with John I Tzimiskes successful campaign of 971/972 against Bulgaria. Byzantine documents and the so-called Protobulgarian stone inscriptions (mostly written in Greek) mention a number of courtyards/palaces (aulai) or houses/building compounds

1 For a detailed description of Škorpil's argumentation, see: Dončeva-Petkova 1999 and idem 2000 . 
(oikoi) probably all fortified. These are mostly un-named, and thus difficult to localize, with the exception of Durostorum and the aule at the Tiča River. These sites were owned and probably alternately used by the ruler. ${ }^{2}$ Khan Omurtag's column inscrip-

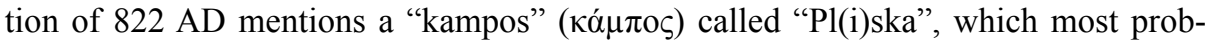
ably should be translated as "Pliska field" or "Pliska region", since contemporaneous Byzantine sources prefer to use the word "kampos" in connection with a topographical expression (river, place, locality) in order to name a particular landscape or region. It was never used in Byzantine documents for describing a fortified encampment of the Bulgars or a military camp of their own army invading the Balkans. However, since Uspenskij and Zlatarski translated "kampos" in just this sense, the impression of a huge camp-like town or capital became widespread. ${ }^{3}$ In the northeastern Bulgarian basin landscape of what is today called Pliska plain the fortification of Aboba, however huge it may be, is not the only important early medieval fortified site and in principle Škorpil's arguments can be applied equally to others in that area. There are for example the earthen rampart lines east of Aboba in Novi Pazar, which probably represent a defense for the protection of the Pliska plain to the east, and the large rectangular rampart fortification of Kabiyuk $8 \mathrm{~km}$ west of Pliska (Fig. 1). However, archaeological research following Škorpil's evaluation, in the last 100 years at least and until the German-Bulgarian field work begun, was always strongly focused on, if not limited to, the Aboba fortification. ${ }^{4}$

In the course of time these German-Bulgarian archaeological field campaigns in the Outer Town of Aboba-Pliska, realized from 1997 to 2001, ${ }^{5}$ were accompanied more and more by methodological discussions about the dating and the subsequent interpretation of the monuments of this settlement agglomeration. More than once traditional belief clashed with doubts resulting from methodological concerns, archaeological observations and scientific results. ${ }^{6}$ When these problems culminated in the prohibition on investigating the "hot areas" of stratigraphy and of relative and absolute dating of the Aboba fortification the campaigns so far organized jointly with the Bulgarian Academy of Sciences (BAN) came to an end. German-Bulgarian fieldwork now in alliance with the Sofia and Shumen universities, and joined by further institutions, however, continued in fortified sites of the period in question such as Silistra (2002: geoelectric prospecting of the stone fortification of Durostorum/Drastar), Čatalar (2002 and 2003) ${ }^{7}$ and Kabiyuk (2003) continued as long as it was tolerated by the BAN, which still has a monopoly on granting or refusing excavation permission all over Bulgaria.

2 For an overview, see: Ziemann (forthcoming).

3 Uspenskij/Škorpil 1905, 545-546; Zlatarski [1918] 1970, 580.

4 Rašev/Dimitrov 1999.

5 See the articles of Henning and of Dončeva-Petkova in this volume.

6 The areas of discussions are named in: Henning 2000.

7 See the article of Henning/Balabanov/Milo/Ziemann in this volume. 


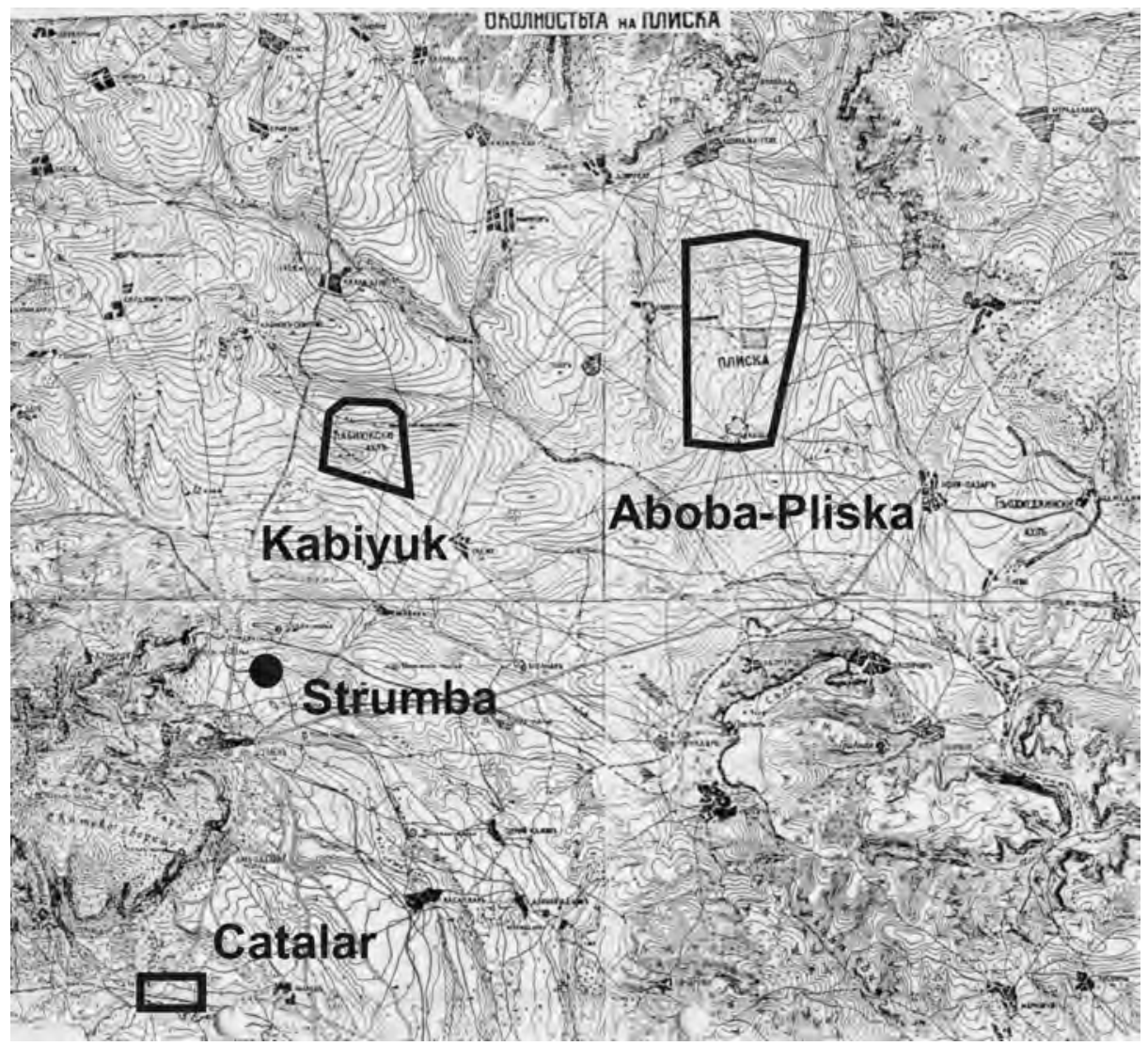

Fig. 1. Important early medieval sites in the Pliska basin

The first ever scientific field research campaign in the Kabiyuk fortification was realized in 2003 by the German-Bulgarian team (without BAN participation) and financed by the University of Frankfurt. It delivered spectacular results and thus became one of the crowning events of the University's seven years of research work in northeastern Bulgaria. The fortified site of Kabiyuk was formerly described in Rašo Rašev's extended compilation of early Bulgar earthen rampart fortifications (published by the BAN branch in Shumen) as a widely empty refuge or enclosure for housing cattle herds or horses of the Bulgars in times of unrest. The Aboba fortification, meanwhile, was praised as the true "aul" and the sole permanent old Bulgarian rulers' see. ${ }^{8}$ However, the 2003 results, which are now published here, clearly contradicted this traditional assumption and questioned the theory of a permanent capital in the pagan period of 
Bulgaria's history. In spite of these unexpected and promising new results (or perhaps because of them?) the Bulgarian Academy of Sciences (BAN) refused the formal request to continue the archaeological research work in the Kabiyuk fortification. This request was jointly addressed to the BAN by the universities of Shumen and Frankfurt and explicitly stressed the enormous significance of that new discovery. In the meantime the site was used by an army of treasure hunters who dug trenches, extended holes and even tunnels, thus destroying many of the valuable discovery situations and, in large part, the extended stone monuments. After more than three years of paralysis and inactivity on the part of the BAN in protecting that important site, the local government finally put an end to this and placed the site under police protection. Excavations of the BAN have now started in Kabiyuk and are directed by Rašo Rašev (BAN). ${ }^{9}$

\section{The fortification and the geomagnetic survey of 2003}

The archaeological site of Kabiyuk is situated in the fields of the village of Konjovets $10 \mathrm{~km}$ north of the town of Shumen (Pl. 32); it represents one of the three large early medieval fortifications of the Pliska plain and extends $8 \mathrm{~km}$ west of Aboba-Pliska. The area encircled by a rectangular rampart-and-ditch fortification has a surface of $3.7 \mathrm{~km}^{2}(370 \mathrm{ha}$ ). The lengths of the four sides of the fortification are approximately $2,000 \mathrm{~m}, 1,200 \mathrm{~m}, 1,980 \mathrm{~m}$ and 2,360 m. ${ }^{10}$ The inner construction of the earthen rampart is unknown since no regular archaeological rampart trench was ever positioned. In the southwestern part of the fortification a natural rock hill ( $338 \mathrm{~m}$ above sea level) provides an excellent outlook for watching and controlling the whole Pliska plain. Kabiyuk (from the Turkish for "low hill") is the particular name given to this impressive rock elevation that dominates the surrounding flat landscape and is visible from several kilometers away. In the eastern part of the fortification two smaller barrows, probably artificially constructed and thus possibly burial mounds, are to be found. The fortification encloses the source of the small river Tchiflik-dere in its northern extension. A group of "standing stones", so-called Devtašlari, interpreted as "Protobulgarian" burial or memorial monuments, ${ }^{11}$ inside the eastern part of the fortification represents the starting point for a chain of several kilometers of multiple such groups connecting the Kabiyuk fortification with that of Aboba (Pl. 32, symbol No. 3). This chain of groups of "standing stones" ends at the western outer rampart line of the Aboba fortification and it has been considered that this line perhaps marks the route of a sort of procession road between the two sites. This visible connection line between Aboba and Kabiyuk as well as the general similarity of the rectangular rampart lines gave cause for Karel

9 Krumov 2007; Rašev 2007.

10 For these data see: Rašev 1982, 101.

11 One of these stone groups has been excavated by Rašev 1992. 
Škorpil, who described this fortification in the "Aboba-Pliska" monograph, ${ }^{12}$ to assume a contemporaneity of the two fortifications.

The inner area of the fortification was never explored archaeologically, although some observations about structures visible on the surface are reported. According to Škorpil, in his day, building structures were visible south of the rock hill and Roman coins, brick fragments and the remains of a water conduit have been discovered between these stone-built houses.

An area $300 \mathrm{~m}$ east of the rock hill used for agriculture was chosen for the geomagnetic survey (Pl. 34). The area explored has an extension of c. 6 ha. The measurements were carried out with a magnetometer of the type "Förster Ferex 4.032" with three channels. The width of the measuring grid was $0.25 \mathrm{~m}$ by $0.50 \mathrm{~m}$. The measurement procedure was completed in a west-east direction in a zigzag mode and for the measurement square units a size of 50 by $51 \mathrm{~m}$ or smaller was chosen. The measured values were visualized by 256 grayscale values with an amplitude range of $-5 \mathrm{nT}$ (white) to $+5 \mathrm{nT}$ (black).

As a result of these measurements six buildings became visible (Pl. 33). All of these buildings were evidently elements of a planned regular settlement structure since all of them had the same orientation and respected a grid pattern. This grid pattern was strictly oriented in accordance with the cardinal points. The buildings seem to represent structures predominantly of the courtyard type with cell-like rooms composed around inner yards. Two peristyle houses with "classical" nearly quadratic outlines are clearly visible. While the one at the lower edge of the map is visible only in parts the other one was matched completely. This house has a size of c. 30 by $35 \mathrm{~m}$. Two entrances are visible in the south and in the west. Dark dots in the centers of many of the rooms can probably be interpreted as pillars supporting an upper floor. These building structures have to be related in general to the Mediterranean traditions of architecture. The best parallels can be found among excavated settlement structures of pre-Roman, Roman, late Antique and Byzantine periods (Fig. 2).

The aerial orthophotographs of the inner area of the Kabiyuk fortification demonstrate a very close correlation between those building structures detected by geophysics and similar regular pattern structures visible from the air in the territory around the three elevations. These two structural patterns clearly have the same orientation and most probably belong to the same widespread occupation pattern.

Agricultural plowing activities that were carried out roughly in these areas and illegal digging by treasure hunters in 2007 have brought to light a series of stone structures, single stone blocks. Judging from some graffiti on these stone blocks, representing e.g. the IYI symbol well known from many early medieval monuments of the Pliska plain, at least a certain number of stone buildings seems to belong to the early medieval occupation period.

12 Škorpil 1905, 38-40. 

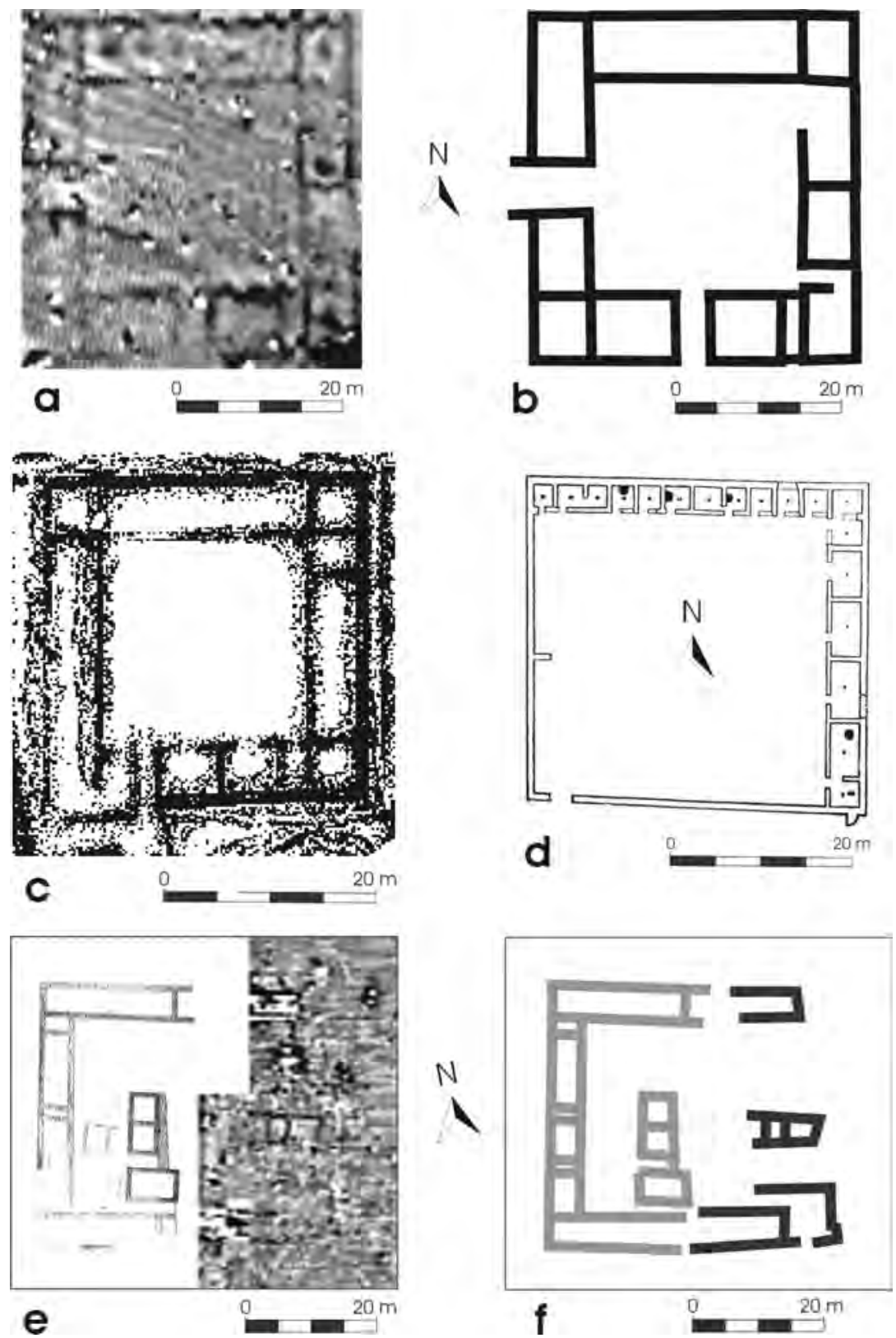

Fig. 2. The peristyle building of Kabiyuk: a - geomagnetic mapping, b - schematic ground-plan of the same building. Comparable layouts: c - Davina Kula near Skopje, early Byzantine fortress with sixth/seventh centuries occupation, d - Pliska, south of the Inner Town, so-called caravansery, e - Courtyard complex No. 40 from the Outer Town of Pliska with geomagnetic survey results (German-Bulgarian team), f - schematic ground-plan of the same building. 


\section{Conclusions}

The geophysical prospecting campaign realized in 2003 in the Kabaiyuk fortification in the Pliska plain, which also included the analysis of aerial photos, has detected a planned, regular stone building pattern of Mediterranean character, which covers large parts of the inner area of that fortification. It is still too early for speculation about the chronology of that pattern. Recent discoveries by treasure-hunters, however, seem to attest that there are stone buildings of early medieval age perhaps superimposing older ones, which probably date back to Late Antiquity or earlier. In 2007, south of the Kabaiyk fortification near to the village of Konjovets, excavations in a group of four burial mounds have delivered the first aristocratic equestrian burial with exceptional grave goods from the early settlement period of the Bulgars in the late seventh to early eighth centuries. Whereas the provenance and the meaning of Antique constructing materials in the Aboba-Pliska fortification is still under discussion, without having found a really plausible explanation, the Kabiyuk site may yet deliver the answer. Whereas the mysterious absence of "pagan" burials in the Aboba-Pliska fortification is a very noticeable circumstance that calls for explanation the Kabaiyuk fortification seemingly does not have such problems. For the time being we cannot exclude that Kabiyuk was one of the important aulai of the Bulgarian rulers, a fortified aristocratic see that perhaps did not emerge merely by fortune in a place with evident Mediterranean settlement traditions. Without excavations it will remain an unresolved question as to whether this was just another Pliska, another contemporaneous aule or the long-sought after early example of an early ruler's see of the Bulgars, a predecessor of the Aboba complex. The GermanBulgarian team was denied the opportunity of harvesting the fruits of its discovery and joint research work that was started in the fortification of Kabiyuk.

\section{Bibliography}

Dončeva-Petkova 1999: Людмила Дончева-Петкова, "Карел Шкорпил и историята на проучванията на Плиска"/ "Karel Škorpil und die Geschichte der Pliska-Forschungen”, in: Joachim Henning (Ed.), Zwischen Byzanz und Abendland: Pliska, der östliche Balkanraum und Europa im Spiegel der Frühmittelalterarchäologie, Internationales Kolloquium auf der Ebernburg, Bad Münster am Stein, 15. bis 18. November 1999 (Kurzfassungen der Referate, dt./bulg), Frankfurt am Main 1999, pp. 7-12.

Dončeva-Petkova 2000: Людмила Дончева-Петкова, “100 години археологически разкопки в Плиска”, in: Плиска-Преслав 8, Шумен 2000, pp. 9-18.

Henning 2000: Joachim Henning, "Pliska - Machtzentrum zwischen Byzanz und Abendland: Neue Wege der Archäologie", in: Forschung Frankfurt 2, 2000, pp. 6-15. 
Krumov 2007: Красимир Крумов, “За иманярското откритие в могилата Кабиюк”, in: Страница за прабългарите, 6 Май 2007, (http://www.protobulgarians.com/ Saavrementi\%20temi/Kabijuk/htm).

Mikulčić 2002: Ivan Mikulčić, Spätantike und frühbyzantinische Befestigungen in Nordmakedonien. Städte - Vici - Refugien - Kastelle, München 2002.

Milčev 1992: Атанас Милчев, "Разкопки около Южната порта и югозападната кръгла кула във Вътрешния град на Плиска”, in: Плиска-Преслав 5, Шумен 1992, pp. 185-211.

Rašev 1982: Рашо Рашев, Старобългарски укрепления на Долния Дунав, VII - XI в., Варна 1982.

Rašev 1992: Рашо Рашев, “Девташларите - мегалитни паметници на българската езическа култура”, in: Плиска-Преслав 5, Шумен 1992, pp. 5-34.

Rašev 1995: Рашо Рашев, “Плисковският аул”, in: Плиска-Преслав 7, Шумен 1995, pp. 10-22.

Rašev 2007: Рашо Рашев, “Търсят хански гробове в Кабиюк Стандарт”, понеделник 4 Юни 2007 No. 5172-XIV, (http://www.standartnews.com/bg/article.php?d=2007-06-04\&article=191016).

Rašev/Dimitrov 1999: Рашо Рашев/Янко Димитров, Плиска. Сто години археологически разкопки, Шумен 1999.

Škorpil 1905: Карел Шкорпил, “Укрепления Абобской равнины”, in: Абоба-Плиска: Материаль для болгарских древностей (1), Альбом (2) (Известия Русского археологического института в Константинополе 10), София 1905, pp. 30-61

Uspenskij/Škorpil 1905: Фёдор Иванович Успенский/Карел Шкорпил, "Вновь открытая надпись Омуртага. Столицы (аулы, становища) древних Болгар”, in: Aboba-Pliska 1905, pp. 544-554.

Ziemann (forthcoming): Daniel Ziemann, Vom Wandervolk zur Großmacht: Die Entstehung Bulgariens im Frühmittelalter, Köln (forthcoming).

Zlatarski [1918] 1970: Васил Златарски, История на Българската държава през средните векове, vol. 1: История на Първото българско иарство, part 1: Eпоха на хунобългарското надмощие (679-852) [1918], София 1970. 


\title{
Khan Omurtag's stone palace of AD 822: a "modernized" eighth century timber fort
}

\author{
Joachim Henning, Todor Balabanov, Peter Milo \& Daniel Ziemann
}

\section{Introduction}

According to the famous Greek column inscription found in 1905 near the village of Čatalar (district of Shumen), ${ }^{1}$ khan Omurtag, the ruler of early medieval Bulgaria from 815 to $831 \mathrm{AD}$, came from or was in the "Pliska kampos" in the year $822 \mathrm{AD}$ and built a palace (aulē) at the Tiča River (Fig. 1). This is the first reference to Pliska in the written sources. From the same inscription we can deduce that Omurtag's palace was a fortified structure, that Greeks and Slavs were seen in opposition to the Bulgarians, and that the ruler built a bridge over the Tiča River. The fortified palace was also decorated with four columns and two bronze lions. ${ }^{2}$ Much ink has been spilled in disputes over whether "Pliska kampos" referred to the Pliska basin as a topographical characterization or to a fortified military camp named Pliska. Many similar expressions can be found in the contemporaneous Byzantine literature where the description is of topographical units meaning "field". ${ }^{3}$ Thus Pliska field, Pliska basin or Pliska plain would be just some of the possible translations. In any case, the ruling center in the Pliska plain must have had some kind of defense whatever its level of preservation, quality or stage of reconstruction once Nikephoros I Genikos had burnt a timber palisade-like fortification to the ground in his attack ten years previously $(811 \mathrm{AD})$. Therefore the translation problem hardly concerns the fortification character of the ruler's see in the Pliska plain. The same is true for Omurtag's fortified palace as mentioned on the column. This is inde-

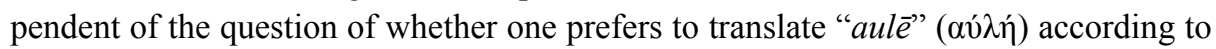
its Greek meaning as "palace" or if this Greek word was used in order to name an "aul", a steppe-nomadic and predominantly fortified tribal or ruling center.

1 This village has been renamed several times: Čatalar (until 1899) - Čatali - Krumovo - Tsar Krum - Khan Krum (1977).

2 Beševliev 1963, 260, No. 56. For the primary publication and older discussions on translation details, see: Uspenskij/Škorpil 1905, vol. 1: 545-546, vol. 2 (Plates): CXV-1-II; Zlatarski [1918] 1970, 409, 577-580.

3 Rašev 1995, 12-13. 


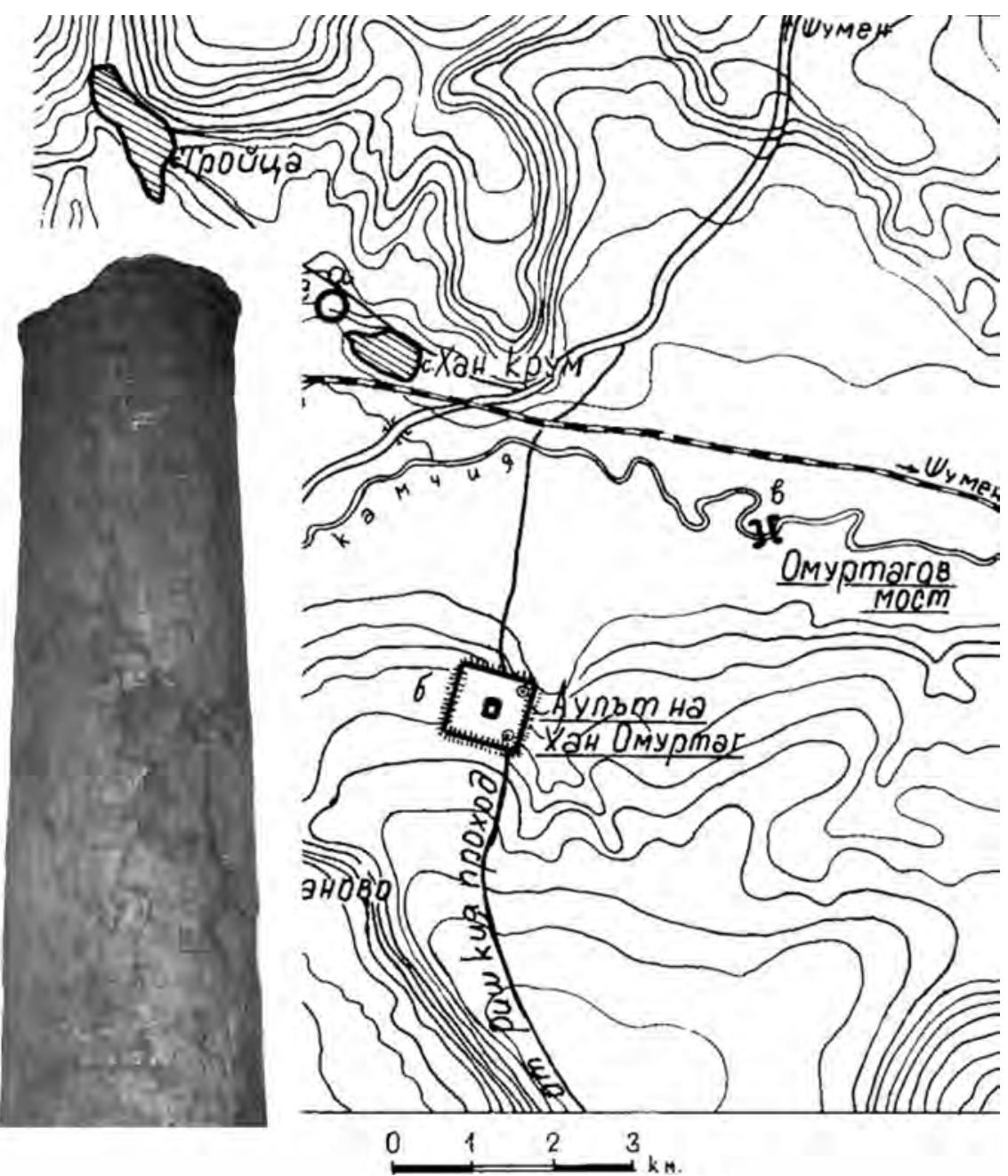

Fig. 1. The Čatalar column and the topographical position of Omurtag's aule at the north-south traffic route from the Pliska plain to the Balkan pass of Riš

The archaeologist is more interested in discovering which particular fortification was most likely referred to in the written record. The fortification complex of AbobaPliska offers several possible solutions. However, as a result of the German-Bulgarian research campaigns in Aboba-Pliska, it seems unlikely that the big outer rampart fortification encircling the Outer Town was built much earlier than the late ninth or first half of the tenth century. ${ }^{4}$ Consequently, one of the fortification lines enclosing the

4 See the article of Henning in this volume. 
Inner Town has to be taken into account. The joint expedition was not permitted to realize regular excavations at the stone fortification encircling the Inner Town of AbobaPliska, which would have helped to verify the assumed dating of that "Roman-like" defense installation. Thus an alternative for bridging that gap had to be sought, which was found in the aule of khan Omurtag.

It is to the credit of Vera Antonova and Svetlana Dremsizova-Nelčinova that they discovered the true Omurtag palace mentioned in the column inscription of AD 822. They succeeded in localizing that building and fortification complex to a position surprisingly close to the finding place of the column still in the meadows of the village of Čatalar, and realized a series of successful excavation campaigns. A large rectangular rampart fortification formerly classified, and not without reason, as a late antique or early Byzantine settlement, ${ }^{5}$ turned out to have been rebuilt later and then became an important early medieval fortified ruling center. Prior to this discovery the palace center and later Bulgarian capital of Preslav, most probably the successor of Pliska, was thought to have originally been the palace of Omurtag mentioned in the Čatalar inscription. Interpretation now moved in quite another direction and after the whole inner palace area of the Čatalar fortification had been uncovered no further doubt was possible: the aule of Omurtag had been found. A range of corresponding publications may be consulted for details concerning the excavation results. ${ }^{6}$

Our thanks must go to Todor Balabanov, then director of the Archaeological Museum of Veliki Preslav, for inviting the German-Bulgarian excavation team - working until then in Aboba-Pliska's Outer Town - to take part in two joint prospecting and excavation campaigns in the Čatalar fortification. According to the exploration results of V. Antonova and Sv. Dremsizova-Nelčinova the Omutag fortification resembles in many details the Aboba-Pliska fortification, although the Catalar complex has of course much smaller dimensions. Thus the following research results of Catalar are equally important for interpreting Aboba-Pliska.

\section{The 2002 and 2003 exploration campaigns in the aule of khan Omurtag}

In two summer campaigns, each lasting two weeks in 2002 and 2003, geomagnetic prospecting activities accompanied by nine archaeological trial trenches were realized in the territory of the Čatalar fortification. This fieldwork was organized under the joint auspices of the Frankfurt University and the Archaeological Museum of Veliki Preslav,

5 The excavations later uncovered two early Christian basilicas (Antonova 1968). T. Balabanov has excavated parts of the late antique stone fortification on the bottom of one of the earthen mounds at the eastern front of the fortification (Balabanov 2004). 


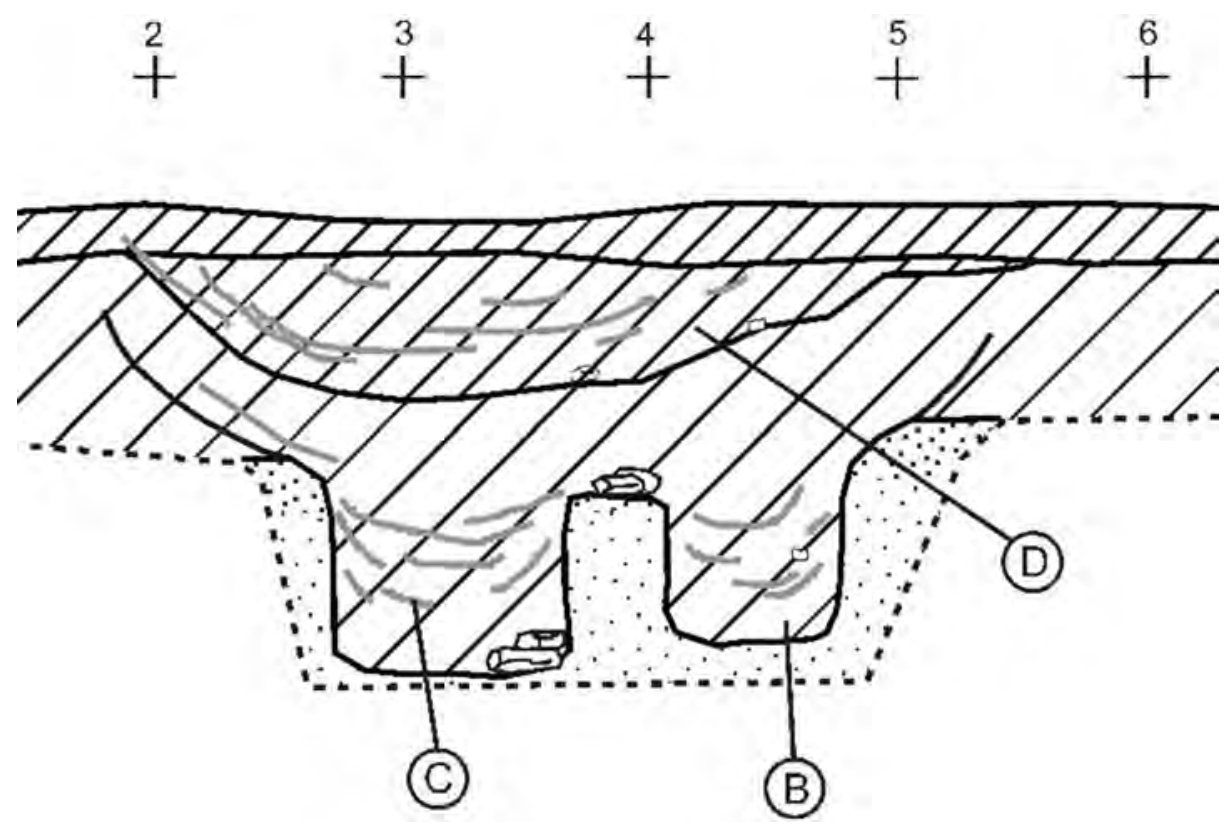

Fig. 2. Aulē of Omurtag. Section 1: double palisade ditch

as part of an archaeological summer school program in Bulgaria supported by the Volkswagen foundation (2002-2004). A number of Bulgarian universities and research institutions were involved. ${ }^{7}$

For training and practical exercise in methods of geomagnetic surveying $\mathrm{PhD}$ students and undergraduates from participating universities succeeded in exploring nearly the whole territory between the inner stone-built enclosure of the palace and the outer earthen rampart of the fortified complex. ${ }^{8}$ The measurements were carried out with a Foerster Fluxgate gradiometer on a total surface area of approximately 11 ha $\left(108,200 \mathrm{~m}^{2}\right)$.

7 Furthermore we are grateful to the following institutions and individuals for supporting the summer school program: University of Sofia (Senior lecturer Dr. Stefka Angelova, Prof. Dr. Veselin Kulev), University of Shumen (the university's president Prof. Dr. Dobrin Dobrev; the Dean of the Faculty of Philosophy, Prof. Dr. Stojan Vitljanov), University of Veliko Tărnovo (Prof. Dr. Krazimir Popkonstantinov), Archaeological Museum of Varna (Director Dr. Alexander Minčev), Museum of History in Balčik (Director Darin Kanavrov) and $\mathrm{Mu}-$ seum of History in Silistra (Director Dr. Ivan Bačvarov).

8 The two geomagnetic measurement teams were lead by Peter Milo (2002) and Daniel Ziemann (2003). Geodetic surveying was in the hands of Klaus and Peter Henning. Prospecting was supported by Eyub F. Eyub und Jordanka Ziemann. 


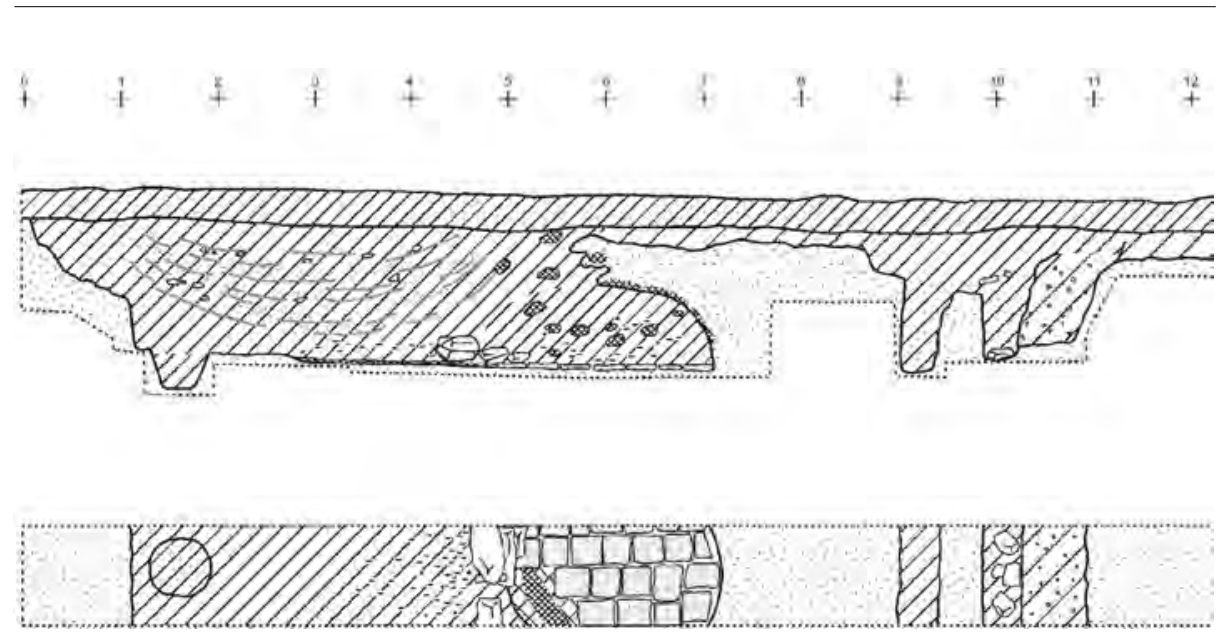

Fig. 3. Aulē of Omurtag. Section 4: double palisade ditch and grubenhaus with baking furnace

One of several important results was the detection of a rectangular double palisade line (Pl. 36, No. 2), which became visible as a light-grey geomagnetic anomaly line. This line runs approximately parallel to the inner stonewall enclosure of the palace complex and the outer earthen rampart positioned in the middle and just between them. The nature of this line was explored with five trial trenches (Nos 1,2,4-6) sectioning that line. The result was in principle the same in all five trenches. A double ditch line of two meters depth came to light (Figs 2-3). Without doubt, the feature represents a solid palisade construction seemingly encircling the palace. The size of this rectangular palisade installation is 250 by $350 \mathrm{~m}$. The palisade ditches were filled in their lower parts exclusively with late antique materials such as amphora fragments, small pieces of bricks and the usual so-called kitchen ceramic. The latter material was exclusively well burnt and of red, yellow or blue-grey color. In the upper part of the palisade ditch fillings of trench No. 1 two small fragments of early medieval ceramic with the typical corrugated surface and of modest hardness were found. All palisade ditches delivered large amounts of animal bones. To determine the chronology of this palisade line three samples of animal bones from trench No. 1 were taken for AMS 14C dating. Two samples were taken from the lower ditch fillings (Fig. 2-B: sample No. 1 and C: sample No. 2) and a third from the upper filling (Fig. 2-D: sample No. 3). The calibrated dating results of the two samples from nearly the bottom of the palisade ditches, measured in the laboratory of Erlangen, are rather similar. Sample No. 1 dates with higher probability between cal. $688 \mathrm{AD}$ and $781 \mathrm{AD}$ whereas sample No. 2 dates with higher probability between cal. $687 \mathrm{AD}$ and $780 \mathrm{AD}$. Sample No. 3 from the upper ditch filling dates with higher probability between cal. $801 \mathrm{AD}$ and $895 \mathrm{AD}$. As regards these dating results it is clear that the palisade fortification was most probably constructed several decades before $822 \mathrm{AD}$ and thus precedes the building of Omurtag's aule, which is certainly represented by the rectangular stone-built compound in the center of the complex. 
Further results of interest relate to the grubenhaus settlement that was already detected in the northern parts of the complex through the excavation campaigns of V. Antonova and Sv. Dremsizova-Nelčinova. These excavators had uncovered seven grubenhäuser (P1. 36, symbol No. 7). The mapping of the geomagnetic measurement results showed a large number of dot-like anomalies especially in the western half of the fortified area. One of these dots was chosen for investigation by a trial trench ( $\mathrm{Pl}$. 36, trench No. 3), and this trench attested a grubenhaus as the cause of that particular dot anomaly. Another example of a well-preserved grubenhaus, which had to be assumed from the discovery of a similar dot anomaly, came to light in trench No. 4 (Fig. 3). This trench had been laid out in order to find the double palisade line and this was reached successfully. Additionally, the grubenhaus was sectioned by this trench. This sunken floor hut possessed a relatively well-preserved baking furnace with a pavement constructed of late antique brick stones. Thus there is reason to assume that the many dot anomalies indicate more or less completely the extension of the grubenhaus occupation at least in the western half of the fortification.

Apart from these irregularly scattered structures, found in the inner area of the fortification and most probably representing the usual grubenhaus dwelling type, relatively regularly composed lines of mostly rectangular anomalies of roughly the same size were observed (Pl. 36, symbol No. 4). These anomalies formed two separate lines absolutely parallel to the fortification lines, one near to the western rampart line and the other near to the western palisade line. Unfortunately, there was no time to verify one of these structures by a trial trench. Therefore it is a matter of speculation to assume a probable contemporaneity of the strictly ordered fortification and stone-built palace structures and these regular anomalies. A large rectangular ditch-like anomaly in the western part of the fortification was analyzed through three sections (Nos 7-9). Only the nature of the ditch was thus attested whereas no datable materials came to light.

\section{Conclusions}

The geophysical and archaeological investigations of the Čatalar fortification complex have proven the existence of a solid double palisade fortification that was probably built some decades before the stone palace compound was created by khan Omurtag in $822 \mathrm{AD}$. Thus it seems that the Čatalar inscription does not reveal the whole truth. Evidently, Omurtag did not found the complex at this site but ordered a reconstruction, rebuilding or "modernization" in stone of the formerly timber-built fort. Comparable processes have also been assumed for Aboba-Pliska. Double palisade lines forming rectangular enclosures have been uncovered in the Outer Town in the "selishte" locality, dated by a coin find to the early ninth century. ${ }^{9}$ Obvious palisade lines have also

9 Stanilov/Dimitrov/Jankulov 1991. 
appeared in several other parts of Aboba-Pliska without forming clear structures, however. While the palisade rectangles of the Outer Town of Aboba-Pliska were sometimes identified as timber-built courtyards and thus forerunners of the tenth/eleventh century stone-built courtyard complexes, the finding situation of Catalar suggest that a military background is more likely. A possible explanation would be to interpret these rectangular palisade installations as timber-built military forts predominantly of the period preceding the Byzantine invasion of $811 \mathrm{AD}$. After their destruction they were in part rebuilt or replaced by stone forts.

The rampart fortification built out of timber and earth and faced with dry-stonewalls, as discovered by the Russian archaeological expedition in the Inner Town of AbobaPliska (P1. 29-b, symbol 3), was brought in connection with the same events. ${ }^{10}$ A trial trench sectioning a secret passage that connects the so-called Krum palace (Pl. 29-b, No. 1) with that fortification laid out in 1999 by the German-Bulgarian team delivered large quantities of burnt and thus well preserved wooden construction elements (Pl. 29-d). Wooden remains of the same passage excavated by Rašo Rašev in its northern parts together with a large set of vessels of the yellow pottery type (P1. 29-c), which is in fact datable to the time around $800 \mathrm{AD}$, were analyzed for dendrochronology. The chemical timber conservation treatment, however, caused several problems for the application of the $14 \mathrm{C}$ wiggle matching method. Thus the fist attempts at dating were not satisfactory and further efforts are needed. Without further progress in this field of scientific dating, the above-mentioned assumptions remain possible but, as yet, hypothetical.

Dating of the grubenhaus settlement inside the rampart fortification of Čatalar is another problem that still cannot be resolved with certainty. Unfortunately, no stratigraphical relation between these dwellings and the palisade enclosure were to be observed. AMS 14C dating of animal bones from two of these grubenhäuser meanwhile delivered ambiguous results. The sample of the grubenhaus from trench 4 dates to a range between cal. $657 \mathrm{AD}$ and $781 \mathrm{AD}$ (2 sigma, 93.4\%) and consequently seems to be contemporaneous with the palisade line. However, the sample from the grubenhaus in trench No. 3 dates between cal. $426 \mathrm{AD}$ and $604 \mathrm{AD}$ (2 sigma, 93.4\%) and would thus need to be formally attributed to the early Byzantine occupation stage, which seems unlikely. Arguing from the structural point of view the appearance of a small church building among the grubenhäuser would suggest a dating of at least parts of the settlement to the time after Christianization. The same conclusion can probably be derived from the random distribution of these dwellings, which shows little relation to the strict composition of the palace compound and the palisade. Last but not least, the general picture of the large rectangular rampart defense containing the many grubenhäuser supports the impression of a refuge in times of incursions and unrest. And this fits best to the later ninth and tenth centuries.

10 Pletnjova 1992. 


\section{Bibliography}

Aboba-Pliska 1905 / Абоба-Плиска 1905: Абоба-Плиска: Материаль для болгарских древностей, 2 vol. (1: text, 2: Альбом / plates) (Известия Русского археологического института в Константинополе 10), София 1905.

Antonova 1968: Вера Антонова, “Две раннохристиянски съркви във външното укрепление на аула на чомуртаг при гара Цар Крум (Шуменско)”, in: Археология 10, 1968, pp. 5267.

Antonova/Dremsizova-Nelčinova 1981: Вера Антонова/Цветана Дремсизова-Нелчинова, Аулът на Хан Омуртаг при Чаталар, София 1981.

Balabanov 2004: Тодор Балабанов, “Нови проучвания в аула на хан Омуртаг: предварително съобщение”, in: Известия на историческия музей-Шумен 12, 2004, 124-137.

Beševliev 1963: Veselin Beševliev, Die protobulgarischen Inschriften, Berlin 1963.

Pletneva 1992: Светлана Александровна Плетнева, “Стратиграфические исследования Плиски (работы Советского отряда 1977-1980 гг.)”, in: Плиска-Преслав 5, Шумен 1992, pp. 35-63.

Rašev 1995a: Рашо Рашев, “Плисковският аул”, in: Плиска-Преслав 7, Шумен 1995, S. 1021.

Stanilov/Dimitrov/Jankulov 1991: Станислав Станилов/Янко Димитров/Игор Янкулов, “Проучване на селището, югоизточно от Вътрешния град на Плиска”, in: Проблеми на прабългарската история и култура 2, Шумен 1991, pp. 124-137.

Uspenskij/Škorpil 1905: Фёдор Иванович Успенский/Карел Шкорпил, “Вновь открытая надпись Омуртага. Столицы (аулы, становища) древних Болгар”, in: Aboba-Pliska 1905, pp. 544-554.

Zlatarski [1918] 1970: Васил Златарски, История на Българската държава през средните векове, vol. 1: История на Първото българско царство, part 1: Епоха на хунобългарското надмощие (679-852) [1918], София 1970. 


\title{
The early medieval boyar courtyard of Strumba near Shumen
}

\author{
Joachim Henning \& Peter Milo
}

\section{Introduction}

Courtyard houses or building complexes with a central roofless yard have been known in the eastern Mediterranean cultures nearly as long as stone architecture has existed. However, in the Bulgarian territories, this building type experienced a visible decline after the fall of the early Byzantine fortified borderline at the Danube River around AD 600 and the subsequent massive spread of a modest rural cottage architecture that preferred organic construction materials. These cottages were usually dug partly into the ground and thus had a sunken floor (so-called grubenhäuser). Their predominant use as dwellings is clearly attested by the regular presence of heating installations, in most cases of stone ovens. This type of cottage became the absolutely dominant style of dwelling architecture in early medieval Bulgaria's countryside and is also known in particularly great numbers from the old Bulgarian ruling centers in the Pliska plain, especially from the so-called Outer Town of the Aboba-Pliska fortification. Beside these grubenhäuser, which clearly dominate the Outer Town's settlement structures, stonebuilt courtyard complexes, however, appear anew in the later development stages of this important fortified site. Aerial photographs ${ }^{1}$ have shown recently that these architectural units hitherto known from just a few excavated examples in Aboba-Pliska's Outer Town ${ }^{2}$ existed there in much greater numbers than were formerly assumed. Not a single case of such a building complex is known, however, that can be dated to the pre-Christian period of Aboba-Pliska. On the contrary, their number seems to spring up in the tenth century at the earliest, and no doubt many of them existed in the first half of the eleventh century, that is, in the time of Byzantine rule in Aboba-Pliska.

Grubenhaus dwellings still existed everywhere in this late period and many of these eleventh century cottages have been excavated in particular in the Inner Town area. ${ }^{3}$ It

1 Petrova 1992.

2 Especially well-explored archaeological exemples are the building complexes No. 31 (Michajlov 1963), No. 40 (Petrova/Aladžov 1986) and No. 41 (Vitljanov 1999 and his article in this volume).

3 Michajlova 1992, 183; Balabanov 1992, 167. 
is, however, an open question as to what the relationship was between those courtyard building complexes and the rural grubenhaus dwellings. A solution to that question would certainly help to answer the following no less important question: What was the function of these stone-built complexes?

There is a serious debate over the question of whether these buildings were monasteries or "feudal manors" (феодални имения). ${ }^{4}$ This question is nearly impossible to answer purely by evaluating the architectural ground plan since courtyard style and the presence of a church building are elements that have equally to be expected in monasteries and in laic noble courts. But there is an important difference in the economic organization of the two institutions, which has been stressed by Stojan Vitljanov. ${ }^{5}$ Monks in eastern monasteries, unlike their western Benedictine counterparts in the eighth/ninth centuries and later, were obliged to do heavy agricultural fieldwork in order to assure the food supply of the monastic community. For the operation of laic manors, however, workers of different social positions were necessary and certain relations to dependent peasants have to be assumed. Thus a certain symbiosis between noble court and the rural population, living predominantly in grubenhaus dwellings, would not be surprising.

On the other hand, what seems so far to be the restricted appearance of courtyard complexes to the area of the administrative center of Aboba-Pliska would support the view that these building complexes were purely dwellings of aristocratic character without manorial or agricultural significance.

Thus the discovery of a courtyard building structure in the locality of Strumba, north of the town of Shumen and thus far away from Aboba-Pliska, offered an interesting opportunity for exploring in more detail a probable example of that institution and to contribute to the above-mentioned questions. In the framework of the German-Bulgarian archaeological field campaigns a geophysical prospecting activity was realized in this locality in $2003 .^{6}$

Pavlina Petrova discovered the site more than two decades ago through analysis of aerial photographs and subsequent field walking. By these means the approximate extension of the site was established and the aerial photos seemed to indicate the presence of a stone-built complex. A limited archaeological excavation directed by Pavlina Petrova followed and was focused on the central part of the building complex. ${ }^{7}$ This excavation succeeded in uncovering remains of stone architecture such as walls and foundations of columns belonging to a large building with an inner open yard. The

4 Aladžov 1997.

5 Vitljanov 1995, 94

6 We are most grateful to Georgi Atanasov from the Museum of History in Shumen and to Stojan Vitljanov, St Konstantin Preslavski University in Shumen for supporting this measurment campaign.

7 Petrova 1993. 
excavated structures were interpreted as a rural manor (имение). Ceramics and small finds came to light, which made a general dating of the complex between the ninth and eleventh centuries possible.

\section{Magnetic prospecting}

Since only a small part of the building complex was excavated, whereas the aerial photographs showed a rather extended building complex, a geophysical survey seemed to be promising. The summer of 2003 offered excellent conditions for that. Geomagnetic measurement areas were positioned all around the former archaeological excavation space on a surface area of 200 by $250 \mathrm{~m}^{2}$ (Pl. 35-a). As a result of the geomagnetic survey new stone building structures became visible in continuation of the excavated structures and in other parts representing totally new elements of that building complex (Pl. 35-b). The excavated parts of the site and the newly detected structures made the reconstruction of an extended courtyard stone building complex possible ( $\mathrm{Pl}$. 35-c). The survey team succeeded in detecting the layout of the whole architectural complex and it became clear that former excavations had uncovered just a small part of it.

The measurements were made with a magnetometer of the type "Förster Ferex 4.032 " with three channels. The width of the measuring grid was $0.25 \mathrm{~m}$ by $0.50 \mathrm{~m}$. The procedure of measurement was done in a zigzag mode and for the measurement square units a size of 50 by $51 \mathrm{~m}$ or smaller was chosen. Idrisi software was used for processing the results, while Corel Draw was used for plotting the grayscale maps. The measured values were visualized by 256 grayscale values with an amplitude range of $-5 \mathrm{nT}$ (white) to $+5 \mathrm{nT}$ (black). Thus, dark and light colors represented high and low magnetization of the underground, respectively. All amplitudes outside this range are allotted maximal or minimal values and were accordingly printed in white or black.

As mentioned above, the geophysical detected walls corresponded very closely with those architectural elements uncovered by the earlier excavations. Archaeologically excavated walls continued in the geophysical mapping and the architectural complex now became much more easily understandable. The traces of walls seem to belong mostly to one single extended building compound. Walls became visible by negative magnetic anomalies, which usually reflect stonewall foundations. When combining wall structures detected by the magnetic survey with those discovered archaeologically a reconstruction of the whole building structure was the result. The outer walls of the inner courtyard building seem to form a large rectangular enclosure measuring c. $40 \mathrm{~m}$ in width and c. $50 \mathrm{~m}$ in length. The width of the walls can be estimated at $1.5 \mathrm{~m}$. An entrance existed at the west side of the building. Inside of the building rooms or cells are visible, which are composed around an inner courtyard.

At the eastern side of the inner courtyard compound a church building can be deduced. Its layout seems to correspond with the basilica type. A good parallel to this 
geophysical result is the basilica detected with the same method on the acropolis of Pisidian Antioch in Turkey. ${ }^{8}$ In that case the magnetic survey provided a very clear outline of a basilica with dimensions of about $25 \mathrm{~m}$ by $50 \mathrm{~m}$. The central apse was $10 \mathrm{~m}$ wide. Unfortunately the structure discovered in the Strumba locality is not so clear. But a protuberance at the eastern end of our structure can hardly be interpreted other than as an apse. Also the division of the building's body into three sections (probably naves) and the general east-west orientation speak in favor of a basilica building. This church then would have been $23 \mathrm{~m}$ long and $15 \mathrm{~m}$ wide.

An outer enclosure wall surrounded the whole compound. This enclosure is approximately $144 \mathrm{~m}$ by $83 \mathrm{~m}$ large. At the northern part of that wall smaller rooms or little buildings have been attached. In the southwestern part of the compound the downhill acting erosion seems to have destroyed some parts of the structures. An interruption of the wall line and a strong anomaly in the middle of the western side of the enclosure may reflect an entrance to the complex.

Generally, the magnetometer map is characterized by a very low noise indicating low susceptibilities of the subsoil. Dipole anomalies with randomly oriented minima dispersed over the area signalize iron objects. Some of these dipoles will certainly reflect modern ferrous litter while others may reflect ferrous features associated with the complex. Two belt-like zones with a great number of such dipolar magnetic anomalies probably indicate two roads running alongside the northern and the southern outer wall of the complex.

Besides this a further 60 anomalies seem to be archaeologically relevant. All of them have to be interpreted as pits or similar pit-like structures filled probably with deposits of enhanced magnetization. They are sometimes rounded in shape and cover areas between 0.5 and $35 \mathrm{~m}^{2}$ in principle. Most of them, however, have an extension of 5 to $10 \mathrm{~m}^{2}$. Some of the larger pits have a rectangular shape and most probably they can be interpreted as sunken floor huts (grubenhäuser). Such archaeologically relevant anomalies are distributed north and south of the stone complex with a higher density in the north, however.

From the occupation layer inside the courtyard, characterized by early medieval pottery, an animal bone sample was chosen for AMS 14C dating. The calibrated dating range with the highest probability ( 2 sigma, $93.1 \%$ ) is that between cal. $773 \mathrm{AD}$ and $981 \mathrm{AD}$ and this corresponds roughly with general expectations concerning these complexes. Another example of a more or less precise dating comes from the courtyard No. 40 from Aboba-Pliska's Outer Town where a hoard of 15 Byzantine gold coins (solidi) was found, which was collected between 912 and $931 \mathrm{AD}$ and buried thereafter. ${ }^{9}$

8 Taşlialan et al. 2003, 278, fig. 2.

9 Aladžov 1985. 


\section{Conclusions}

The geomagnetic measurements in the Strumba locality near Shumen, which covered a surface area of 50,000 $\mathrm{m}^{2}$ have successfully completed and enriched the results of an archaeological trial excavation and field and aerial photo analysis. The complete ground plan of a rectangular courtyard type building complex, well known until now only from Aboba-Pliska's Outer Town, was detected. As an element of this building complex a church of the basilica type came to light. Church buildings of that type appear in monasteries as well as in private manor houses of the Bulgarian nobility (boyars). Thus, the appearance of that church per se does not allow for a definitive answer as to the function of this compound. However, since monasteries usually favor exceptional topographical positions and are characterized by their inner organizational structure of self-sufficiency, in this particular case the non-spectacular position in a flat and purely agricultural landscape and the great number of accompanying (most probably) rural dwelling structures of the grubenhaus type would definitively speak more for a rural laic installation, thus a boyar courtyard.

It is no less important to recognize, that this rectangular architectural building type was evidently not restricted to the important power center of Aboba-Pliska. According to the pottery finds and the AMS 14C-dating the compound seems to have existed somewhere between the ninth and the tenth century. This is roughly the same period as the so-called "curtis" existed in the great Moravian stronghold of Breclav-Pohansko (Pl. 35-d). The great number of examples for that type of building complex that is known from early medieval Bulgaria calls into question the assumption of their western European provenance. ${ }^{10}$ Since such rectangular building compounds are unknown from the rural sphere of contemporaneous Western Europe, for the time being one should avoid using the term curtis for them.

\section{Bibliography}

Aladžov 1985: Живко Аладжов, “Съкровище от византийски златни монети от Плиска”, in: Нумизматика 20/1, 1985, pp. 31-40.

Aladžov 1997: Живко Аладжов, “За облика и характера на комплексите от Външния град на Плиска”, in: Известия на Историческия музей Шумен 9, 1997, pp. 101-105.

Balabanov 1992: Тодор Балабанов, “Жилища покрай северната и източната крепостна стена в Плиска", in: Плиска-Преслав 5, Шумен 1992, pp.146-169.

Macháček 2007: Jiří Macháček, Pohansko bei Břeclav: Ein frühmittelalterliches Zentrum als sozialwirtschaftliches System (Studien zur Archäologie Europas 5), Bonn 2007.

10 Machaček 2007, 350. 
Michajlov 1963: Стамен Михайлов, “Разкопки в Плиска през 1959-1961 г.”, in: Известия на Археологическия институт 26, 1963, pp. 5-46.

Michajlova 1992: Тонка Михайлова, “Сгради и съоръжения на запад от Тронната палата в Плиска - X-XI в.”, in: Плиска-Преслав 5, Шумен 1992, pp. 170-184

Petrova 1992а: Павлина Петрова, “Към въпроса за историко-археологическата топография на Външния град на Плиска по данни на аерометода”, in: Плиска-Преслав 5, Шумен 1992, pp. 64-76.

Petrova 1993: Павлина Петрова, “Постройка от ранносредновековно имение край Шумен”, in: Известия на историческия музей Шумен 8, 1993, pp. 234-242.

Petrova/Aladžov 1986: Павлина Петрова/Живко Аладжов, “Археологическо проучване на комплекс 'A' (обект 40) във Външния град на Плиска”, in: Годишник на музеите от Северна България 12, 1986, pp. 37-48.

Taşlialan/Bagnall/Smekalova/Smekalov 2003: Mehmed Taşlialan/Roger S. Bagnall/Tatyana Smekalova/Sergey Smekalov, "Magnetic survey on the acropolis of Pisidian Antioch", in: Archaeological Prospection. $5^{\text {th }}$ International Conference on Archaeological Prospection. September 10-14, 2003, Cracow, Poland (Archaeologia Polona 41), Warszawa 2003, pp. 278-280.

Vitljanov 1995: Стоян Витлянов, “Стопанският облик на столичните манастири през IXХ в.”, in: Плиска-Преслав 7, Шумен 1995, pp. 92-100.

Vitljanov 1999: Стоян Витлянов, “Феодално имение от X-XI век във Външния град на Плиска - Ein Herrenhof des 10.-11. Jahrhunderts in der Äußeren Stadt von Pliska”, in: Joachim Henning (ed.), Zwischen Byzanz und Abendland: Pliska, der östliche Balkanraum und Europa im Spiegel der Frühmittelalterarchäologie, Internationales Kolloquium auf der Ebernburg, Bad Münster am Stein, 15. bis 18. November 1999 (Kurzfassungen der Referate, dt./bulg.), Frankfurt am Main 1999, pp. 63-65. 


\section{Chapter VI}

Pliska AND the Balkans 



\title{
Der Beginn von Pliska und der bulgarischen Landnahmezeit
}

\author{
RAŠO RAŠEV
}

Der Begriff „Landnahmezeit“ wird in vorliegenden Ausführungen zwar in einem allgemeinen Sinn, wie in der ungarischen historischen Fachliteratur üblich, benutzt, beschränkt sich jedoch im Unterschied dazu auf einen viel kürzeren Zeitraum. Er beschreibt nur die kurze Periode der Niederlassung von Asparuch im Bereich des Unterlaufes der Donau zwischen etwa 665 und 700 n. Chr. Die Bestimmung der ältesten materiellen Hinterlassenschaften des ersten Bulgarenreiches, die in diese Zeit fallen, stellt für die bulgarische Archäologie noch ein ungelöstes Problem dar.

Die Vorstellungen über den Beginn von Pliska und der bulgarischen frühmittelalterlichen Kultur werden bis heute noch stark von den Nachrichten aus den Schriftquellen geprägt. So wird angenommen, dass Pliska bereits im Jahr 680 entstand, als Asparuch bis in den Raum um Varna vorstieß. Zuvor bewohnten die Protobulgaren das sogenannte Onglos-Gebiet, das sich den zeitgenössischen Quellen zufolge zu beiden Ufern des untersten Donaulaufes erstreckte und von Norden und Süden von Erdwällen begrenzt wurde (Abb. 1). ${ }^{1}$ In diesem Raum liegen die slawischen Gräberfelder von Nalbant und Satu Nou (județ Tulcea), die eine Anzahl handgearbeiteter Gefäße geliefert haben und die man daher ins 7. Jahrhundert datiert. Hinterlassenschaften der Protobulgaren aus der Zeit, als sich hier Asparuch aufhielt, sind dagegen nicht bekannt. Der Belegungsbeginn der birituellen Nekropole von Istria ist kurz nach 700 anzusetzen, ${ }^{2}$ so dass sie nicht auf den kurzzeitigen Aufenthalt Asparuchs in dieser Gegend in Zusammenhang stehen werden kann. Einige Einzelfunde und Horte byzantinischer Münzen aus der zweiten Hälfte des 7. Jahrhunderts, die hier und in Silistra sowie am Schwarzmeerufer zutage traten, sind Hinweise auf die unruhigen Zeiten, die mit der Ankunft der Protobulgaren anbrachen. ${ }^{3}$

In Pliska sind Hinterlassenschaften aus der Zeit Asparuchs zu erwarten. Das völlige Fehlen von Münzen aus der Zeit des 7. bis 8. Jahrhunderts lenkt dabei den Blick vorrangig auf das archäologische Material. Im Verlauf der letzten 25 Jahre sind Ge-

1 Rašev 1982, 68-79; ders. 1997a, 49-54; Fiedler 1992, 21-24, Abb. 2.

2 Fiedler 1992, 308-311.

3 Jurukova 1966, 223-227; Comşa 1980, 41-47; Bonev 1985, 62-76; Popović 1986, 103-104; Angelova/Penčev 1989, 38-43. 


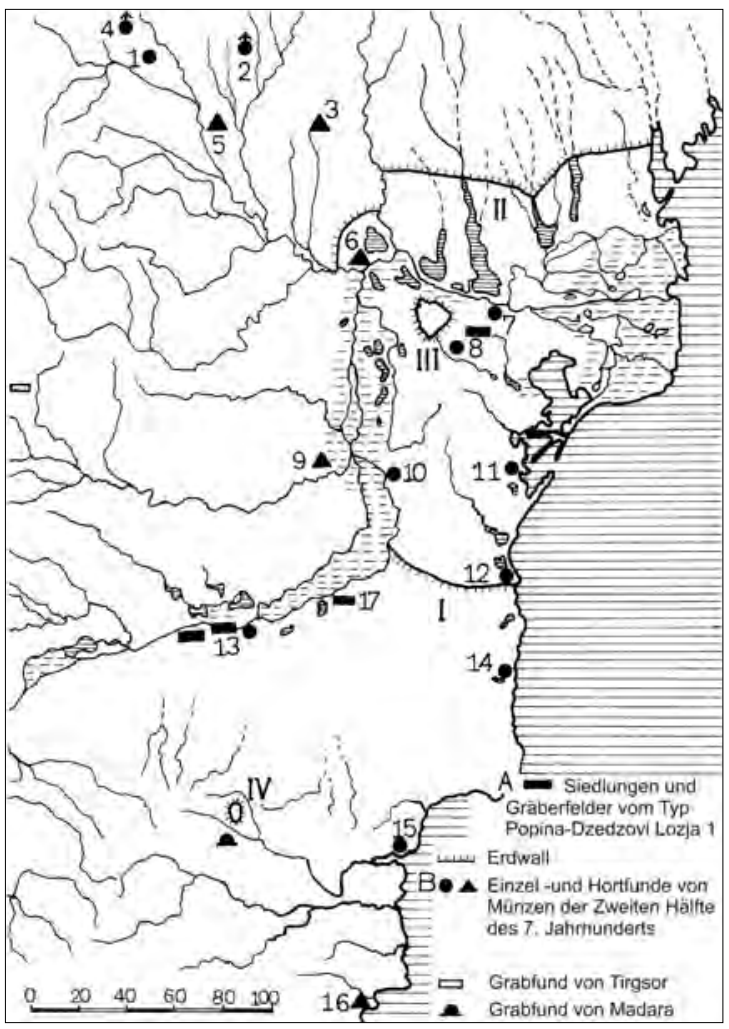

Abb. 1. Archäologische Fundstellen aus dem letzten Viertel des 7. Jahrhunderts aus dem Raum der nordöstlichen Balkanhalbinsel

Legende:I.KleinerErdwall,II. Südlicher Wall in Besarabien, III Erdwall-Lager bei Niculițel, IV. Pliska

A: 8. Nalbant, 13. Popina-Džedžovi lozja I und Garvan, 17. Satu Nou

B: 1. Skultu, 2. Obîrşeni Vaslui, 3. Voinești, 4. Berezeni-Iaşi, 5. Udeşti, 6. Galac, 7. Tulcea-Museum, 8. Valea Teilor, 9. Liua Petri, 10. Topolu, 11. Istria, 12. Constanța, 14. Mangalia, 15. Varna, 16. Nesebăr (Messembria)

bäude und Anlagen aufgedeckt worden, die man mit der frühesten Existenzphase der Stadt zu verbinden hat. Dazu gehört der große Erdbefestigungswall. Die angelegten Wallschnitte haben zwar eine gute Vorstellung von seiner Konstruktion, jedoch nur recht ungenaue Angaben zu seiner Zeitstellung vermittelt. Diese beruhen auf einigen im Wallschnitt 1 gefundenen Keramikfragmenten mit eingeritzter Verzierung, die aber kaum genauer datiert werden können (Abb. 2,1-3). Die Deutung der Erdwallbefestigung als ,eine der frühesten Befestigungsbauten, die unmittelbar nach dem Jahr 681 erbaut wurden“, ${ }^{4}$ basiert nicht auf der Datierungsqualität dieser Scherben, sondern auf der traditionellen Verbindung des Beginns von Pliska mit dem Zeitpunkt der Entstehung des bulgarischen Staates.

Aus den niedergebrannten Bauresten des sogenannten Krum-Palastes, der von Kr. Mijatev aufgedeckt und von 1976 bis 1979 vollständig ausgegraben wurde, stammen vier verschiedene keramische Warenarten, darunter auch grob mit Sand gemagerte und mit Einritzlinien verzierte Fragmente von Töpfen (Abb. 3). Auch diese Scherben

4 Rašev 1984, 13 Abb. 6. 

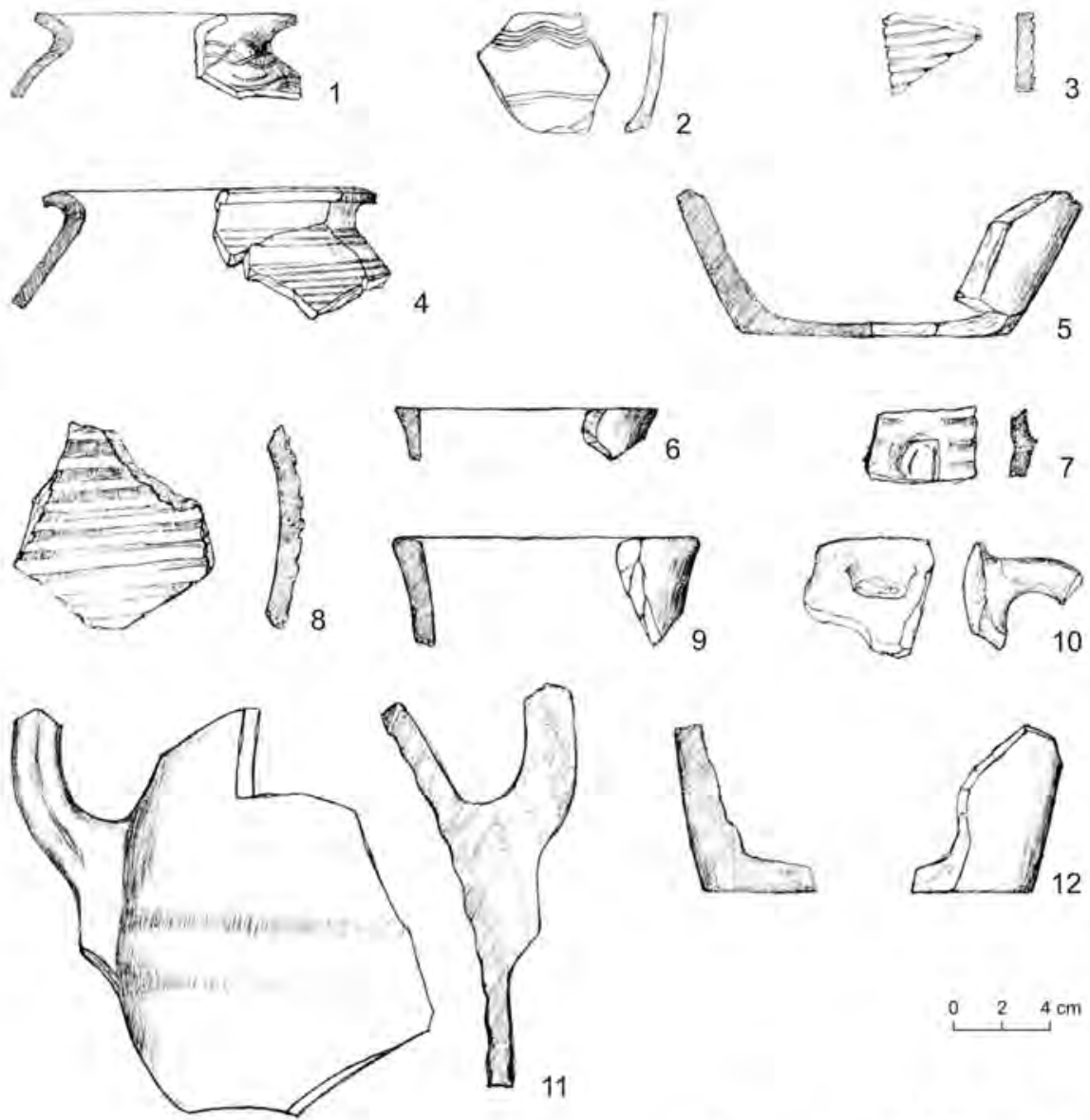

11
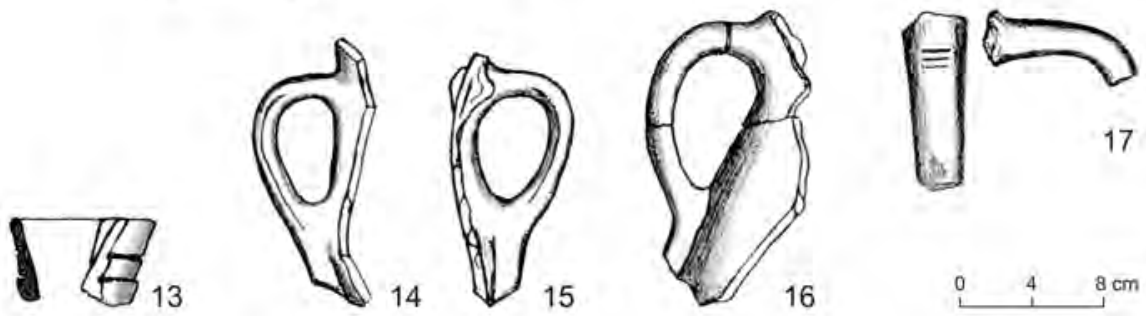

Abb. 2. Keramikfragmente aus Pliska und Zlatna Niva. 1.-3. Pliska, Wallschnitt 1 durch die Erdwallanlage, 4-10. Zlatna Niva, Kultanlage, 11-12. Pliska, Palastzentrum, Grube im Quadranten 153, 13.-17. Pliska, Zitadelle, Grube im Quadranten 212-242 

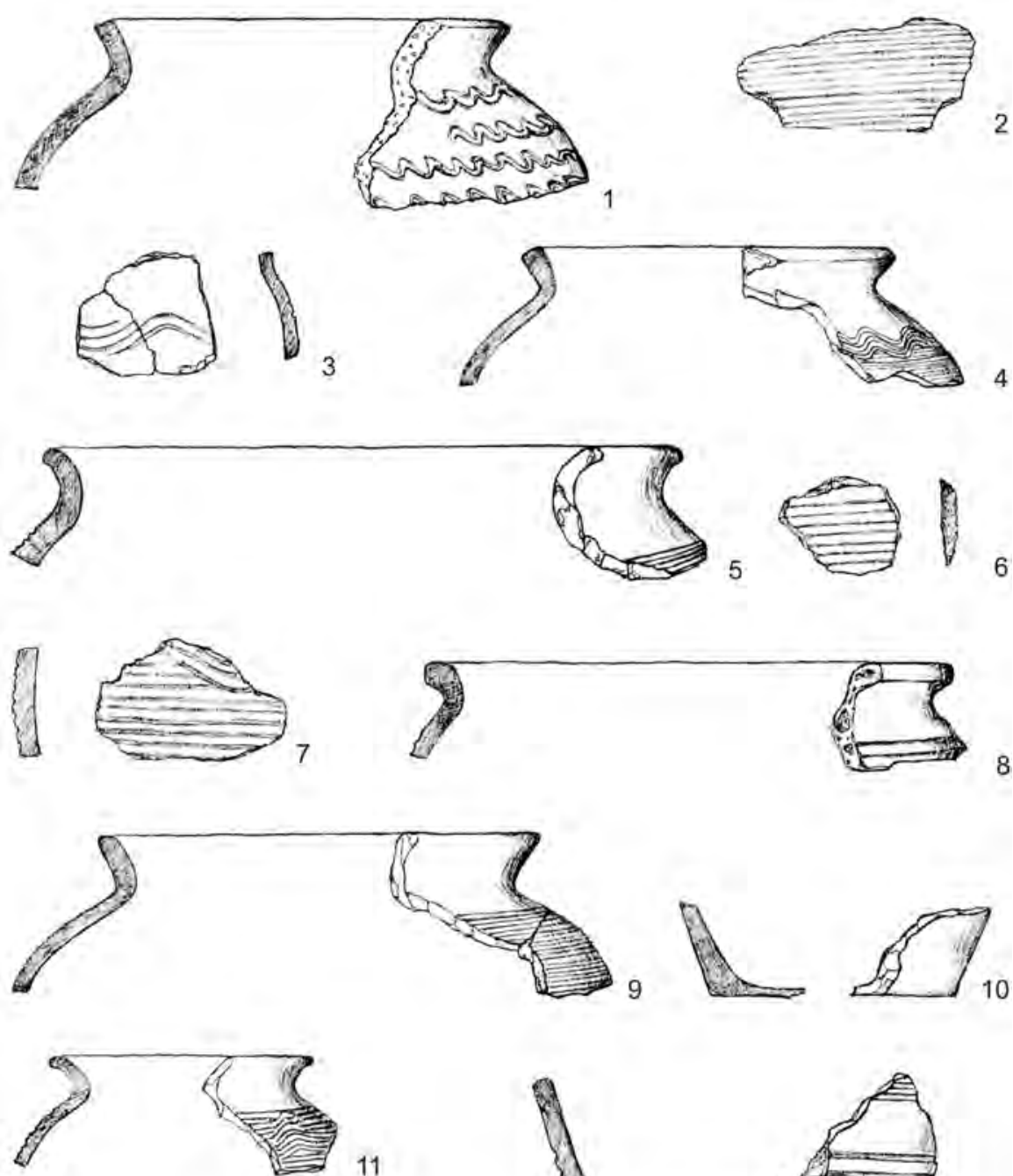

11
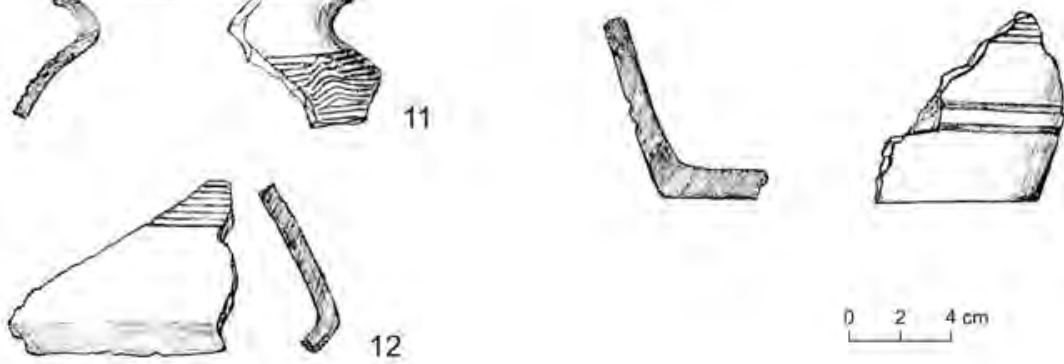

Abb. 3. Keramikfragmente aus den niedergebrannten Bauresten des sogenannten Krum-Palastes 
erlauben keine genauere Datierung. Andere Keramikfragmente stammen hier von Kannen mit roter Engobe, wie sie auch aus anderen frühen Objekten in Pliska bekannt geworden sind. Im ausgebrannten, zum Krum-Palast gehörigen Geheimgang wurden zahlreiche Gefäße aus einem sehr fein geschlämmten Ton gefunden: 36 Kannen, „Teekessel" und eine Amphore. Einige dieser Kannen mit Standfuß stellen Nachbildungen von Metallgefäßen des sassanidischen Typs dar. Die „Teekessel“ haben Analogien unter der sogenannten gelben spätawarischen Keramik des 7. Jahrhunderts. Diese Bezüge erlauben keine Datierung vor das 8. Jahrhundert. Und wenn das Gebäude - wie schon sein Ausgräber angenommen hat - wirklich der Palast des Krum war und im Jahr 811 niedergebrannt wurde, dann wäre das Keramikservice an den Anfang des 9. Jahrhunderts zu setzen. Eine identische Datierung würde sich für ein weiteres, ebenfalls im Geheimgang gefundenes Keramikservice mit Kannen und einer Amphore aus grauem Ton ergeben, das zur Variante der protobulgarischen Keramik gehört.

Unter einigen Steingebäuden und Pflasterungen im Zentrum Pliskas wurden in den letzten 20 Jahren Reste des frühesten Besiedlungshorizontes der Hauptstadt entdeckt. Er war durch Holzbauten geprägt. Als zu diesen gehörig wurden in letzter Zeit ovale Gruben bestimmt, in denen senkrechte Holzpfosten gestanden haben. Einen vollständigen Grundriss kennen wir bisher nur von einem runden Holzgebäude. ${ }^{5}$ Die in seinen Pfostengruben gefundenen Keramikfragmente gehören zu den gleichen Warengruppen wie jene aus dem sogenannten Krum-Palast und bieten in gleicher Weise kaum Möglichkeiten für eine genauere Datierung. Eine bronzene Gürtelzunge kann nur annähernd ins 8. bis 9. Jahrhundert datiert werden. ${ }^{6}$ Aus Pfostengruben anderer Bauten, deren Grundrisse nicht vollständig ermittelt werden konnten, kamen ausschließlich Scherben von schnell gedrehten Kannen aus feinem gelbem Ton mit einem Henkel zu Vorschein. Die Oberfläche dieser Keramik war mit roter Engobe überzogen. Kennzeichen dieser Gefäße sind ihr trichterförmiges Oberteil und die massiven Ausprägungen der oberen Henkelenden (Abb. 2,11-17). Aus einem nur seicht eingetieften Wohnbau vom Jurtentyp, der westlich vom Thronpalast zutage trat und der frühen Gruppe von Wohnbauten zuzurechnen ist, stammt nur ein einziges, uncharakteristisches Keramikfragment.

Auch aus ihrem Umfeld können keine genaueren Angaben zur Anfangsdatierung der Hauptstadt gewonnen werden. Im Bereich einiger der als Devtašlari bezeichneten Megalithe fand man Bronzeglöckchen, die nach Vergleichsstücken in das 8. und 9. Jahrhundert datiert werden können. ${ }^{7}$ Aus der runden Kultanlage, die bei Zlatna Niva ausgegraben wurde, stammen Keramikscherben aus feinem, grauem Ton mit Sandmagerung und eingeritzter Verzierung, die man nicht genauer datieren kann (Abb. 2,4-10). ${ }^{8}$

\footnotetext{
5 Rašev/Dočeva 1989, 291-313; Rašev 1995, Abb. 4 bis Abb. 8.

6 Stanilov 1991, 67-71.

7 Rašev 1992, Abb. 31,1-3.

8 Rašev 1991, 209-220.
} 
Zu nennen ist hier schließlich noch der 1997 entdeckte, 12 m tiefe Schacht mit Skelettresten zweier Pferde und zweier Hunde. ${ }^{9}$ Die hier gefundenen Scherben erlauben jedoch keine chronologische Absicherung des Befundes.

Aus der Sicht dieser Daten muss man sich den Beginn von Pliska und seine Entwicklung als Residenz des Khans und als Ansiedlung der vorchristlichen Periode in folgender relativer Abfolge vorstellen. ${ }^{10}$ Im Anfangsstadium, das man aufgrund der oben genannten Keramik allgemein in die ersten Jahrzehnte des 8. Jahrhunderts setzen kann, entstand im Raum östlich des Asar-dere-Baches, der damals vielleicht PliskaBach hieß, die befestigte Residenz des Khans. Sie bestand aus Holzbauten und leichten, ebenerdigen Wohnhütten. Wie verschiedene noch laufende Untersuchungen zeigen, war die Residenz vielleicht von einem eigenen Erdwall mit Graben umgeben, zu dem die beobachteten Reste zwischen den Hügeln Nr. XXXII und XXXIII gehörten. Im Umfeld dieser Erdwallanlage entstanden vier oder fünf offene Siedlungen im Bereich der späteren Areale der Großen Basilika und des Objektes Nr. 31, der Kirche Nr. 11, des Asar-dere und des Objektes Nr. 13. Südlich der letztgenannten Stelle ist mit den Resten einer weiteren Siedlung jener frühen Zeit zu rechnen. Unter Berücksichtigung der an diesen Stellen gefundenen Keramik scheinen die Siedlungen nicht gleichzeitig entstanden zu sein. Die wahrscheinlich älteste Siedlung ist jene nahe am Asar-dere. Die von dort stammende Keramik zeichnet sich durch Dickwandigkeit, grobkörnige Sandmagerung und tief eingeritzte Verzierungslinien aus. ${ }^{11}$ Das Erscheinen dieser Siedlungen führte zur Errichtung des äußeren Erdbefestigungswalls mit Graben. Durch diesen Wall wurde die Wasserversorgung dieser Siedlungen sichergestellt, denn die Anlage umschloss den Nordabschnitt des Asar-dere-Baches auf einer Länge von 7 km sowie seinen im Bereich der Kirche Nr. 11 entspringenden Nebenarm. Diese Entwicklungsetappe Pliskas endete aus der Sicht der Keramikfunde gegen Mitte des 8. Jahrhunderts. Es ist hervorzuheben, dass aus Pliska die Variante jener handgemachten Keramik fehlt, die man vor allem aus slawischen Bestattungsplätzen entlang des Donauufers kennt. Sofern diese nicht zusammen mit scheibengedrehter Keramik auftritt, kann sie spätestens an das Ende des 7. Jahrhunderts datiert werden. Demzufolge wird man den Beginn einer sesshaften Siedlungstätigkeit in Pliska frühestens um 700 ansetzen dürfen.

Auf diese Weise erlangt die Frage nach der Keramikdatierung vorrangige Bedeutung. Leider gibt es bislang noch keine allgemein anerkannten Kriterien für eine relative Chronologie, sondern allein die Annahme, dass handgearbeitete Gefäße des slawischen Typs (Keramikgruppe wie aus den Siedlungen und Gräberfeldern der Art Popina-Džedžovi lozja I) älter seien, als die auf der Töpferscheibe gearbeiteten Formen.

9 Rašev/Stanilov 1998, 67-71.

10 Rašev 1990, 69-71; ders. 1995, Abb. 1.

11 Beobachtungen an Keramikfunden, die 1981 bei Oberflächenprospektionen zutage traten. 
Diese Prämisse einer chronologischen Frühdatierung von handgemachter Keramik war der Grund dafür, dass die im Grab 48 des Gräberfeldes von Babovo zusammen mit zwei handgemachten Töpfen gefundenen Gefäße der Warengruppe aus grauem Ton mit Einglättverzierung sowie der Gruppe mit Einritzmustern in die Zeit gegen Mitte des 7. Jahrhunderts datiert wurden. ${ }^{12}$ Dieses wichtige Grab ist leider schlecht publiziert worden ${ }^{13}$ und alle Schlussfolgerungen, die aus diesem Befund abgeleitet werden, sollten diesen Umstand beachten. Handelt es sich vielleicht in Wirklichkeit um zwei zeitlich ganz verschiedene Gräber, die dicht beieinander angelegt worden sind? Eine so große Anzahl von Gefäßbeigaben in einer Grabgrube ist für slawische Gräberfelder an der unteren Donau ungewöhnlich. Aus dem älteren Nutzungshorizont der beiden Siedlungen bei Garvan und Popina sind keine Hausgruben bekannt, deren Funde eine gleichzeitige Verwendung von handgemachter und von scheibengedrehter Keramik belegen würden. Wie wenig es weiterhilft, wenn das gemeinsame Vorkommen beider Keramikgruppen in geschlossenen Komplexen einer relativen Materialchronologie als Maßstab zugrunde gelegt wird, zeigt ein Beispiel aus Pliska. Aus einer Hausgrube, die ansonsten nur Keramikformen des 9. und 10. Jahrhunderts geliefert hat, kam auch ein handgemachter Tonteller ans Licht. Dieser Umstand führte jedoch keinesfalls zu einer Datierung des Grubenhauses in das 7. Jahrhundert, obwohl dies die Zeit des frühesten Erscheinens solcher handgemachten Tonteller slawischer Art ist. Vielmehr muss das Auftreten dieses Gefäßes als ein besonderer Fall des Fortlebens älterer hauswerklicher Herstellungstraditionen aufgefasst werden. ${ }^{14}$ Ähnlich könnte sich vielleicht auch der Fall des Grabes Nr. 48 von Babovo erklären. Der Datierungswert von handgearbeiteten Gefäßen und ihres gemeinsamen Auftretens mit Töpferscheibenkeramik sollte in jedem Einzelfall gesondert bewertet werden, wobei der Umstand zu beachten ist, dass Komplexe mit solchen Funden aus den in einiger Entfernung von der Donau landeinwärts liegenden slawischen Gräberfeldern wie Tărgovište, Razdelna und Dălgopol gänzlich fehlen. Einige solcher Bedenken wurden von Autoren geäußert, die als erste auf die zwischen beiden Keramikgruppen bestehenden Verbindungen hingewiesen haben. ${ }^{15}$ Wir möchten dem noch hinzufügen, dass die Klassifizierung von Gefäßen aus grauem Ton aus Brandgräberfeldern als Pastyrsker Typ des 7. Jahrhunderts nicht ganz zutreffen kann. Es handelt sich hier vielmehr um spätere Derivate dieses Typs, die im besten Fall als ,pastyroid“ bezeichnet werden könnten. Es ist unsicher, ob sich die Erscheinung des gemeinsamen Vorkommens der beiden technologischen Gruppen, wie sie aus der Penkovka-Kultur bekannt ist, überhaupt bis an die untere Donau ausgebreitet hat. Diese Unklarheit ergibt sich allein schon daraus, dass die handgemachte Keramik vom Penkovka-Typ hier vor dem Ende des 6. Jahrhunderts nicht bekannt ist.

12 Koleva/Daskalov 1993, 159-164.

13 Văžarova 1976, 57 Abb. 33.

14 Dimitrov 1994, 28-33 Abb. 1, Abb. 2.

15 Angelova/Dončeva-Petkova 1992, 18-19. 
Die Frage nach dem Beginn von Pliska ist auch Bestandteil der übergreifenden Frage nach dem Beginn frühmittelalterlichen materiellen Kultur in Bulgarien. Zwei ausländische Forschergruppen, die in Bulgarien gearbeitet haben - eine deutsche im Kastell Iatrus und eine polnische in Stărmen - haben Komplexe vorgelegt, die in die Zeit zwischen dem Ende des 7. und dem Anfang des 8. Jahrhunderts datierbar sein sollen. In Krivina (Kastell Iatrus) handelt es sich um die Hausgruben Nr. 58/12 und $30 / 39,{ }^{16}$ in Stărmen um die Objekte Nr. 63 und $79 .{ }^{17}$ Die stratigraphische Lage der Grubenhäuser in Krivina und die in diesen Bauten gefundene Keramik lässt jedoch nur die Deutung zu, dass es sich hier um Objekte handelt, die keinesfalls vor das 9. Jahrhundert zu setzen sind. ${ }^{18}$ Diese Feststellung trifft auch auf die Befunde von Stărmen zu. An dieser Stelle ist ein Blick auf die Daten aus den birituellen Gräberfeldern hilfreich. Auch aus diesen Objekten fehlen Hinweise auf ein gleichzeitiges Vorkommen von handgearbeiteter und gedrehter Keramik. Die beiden ältesten von ihnen, Novi Pazar und Istria, setzen jeweils um 700 bzw. um 720 ein. ${ }^{19} \mathrm{Im}$ ursprünglich für die frühmittelalterliche bulgarische Keramik aufgestellten Chronologieschema sind die Gefäße aus diesen Gräberfeldern in das 8. Jahrhundert gesetzt worden. ${ }^{20}$ Im neuen System tauchen sie zwar weiterhin in der gleichen typologischen Zuordnung auf, doch ihre Zeitstellung wurde, ohne dass dazu konkrete neue Argumente entwickelt wurden, auf das 7. Jahrhundert vorverlegt. ${ }^{21}$ Ein möglicher Grund dafür könnte der Einfluss von Cs. Bálint, Herausgebers des Sammelbandes über die Saltovo-Keramik und ihre Varianten, sein, der dazu tendiert, für diese Keramik und den Beginn der Saltovo-Majaki-Kultur, die bisher traditionell ins 8. Jahrhundert gesetzten wurden, eine frühere Datierung anzunehmen. ${ }^{22}$ Die Gefäße aus den oben genannten zwei Gräberfeldern weisen in der Tat einige frühe Merkmale in Form, Farbe und Oberflächenbehandlung auf, die sie von Gefäßen aus anderen birituellen Gräberfeldern unterscheiden. Dagegen fehlen bei anderen Gefäßen, die ebenfalls ins 7. Jahrhundert gesetzt wurden, jegliche Anhaltspunkte für eine nähere Datierung, da es in den entsprechenden Gräbern entweder gar keine begleitenden Gegenstände oder aber nur solche gibt, die sich nicht näher datieren lassen. So wurden zum Beispiel die Tongefäße aus den Gräbern Nr. 10, Nr. 16 und Nr. 34 von Novi Pazar zusammen mit Knochenröhrchen für Nadeln gefunden, die keine genauere Datierung erlauben (Abb. 5A,10.34). ${ }^{23}$ In anderen Gräbern fanden sich zwar Beigaben, deren Zeitstellung sich über Vergleiche relativ gut datieren lassen, doch be-

16 Wendel 1986, 95-96, Abb. 44.

17 Kurnatowska 1990, 96-73, Taf. 43, Taf. 54.

18 Diaconu 1988, 198.

19 Fiedler 1992, 246, 251-252, 266.

20 Dončeva-Petkova 1977, Abb. 33.

21 Dies. 1990, Abb. 1, Abb. 2.

22 Bálint 1996, 61-62.

23 Stančev/Ivanov 1958, Taf. V,10, Taf. VI,16, Taf. XII,34. 


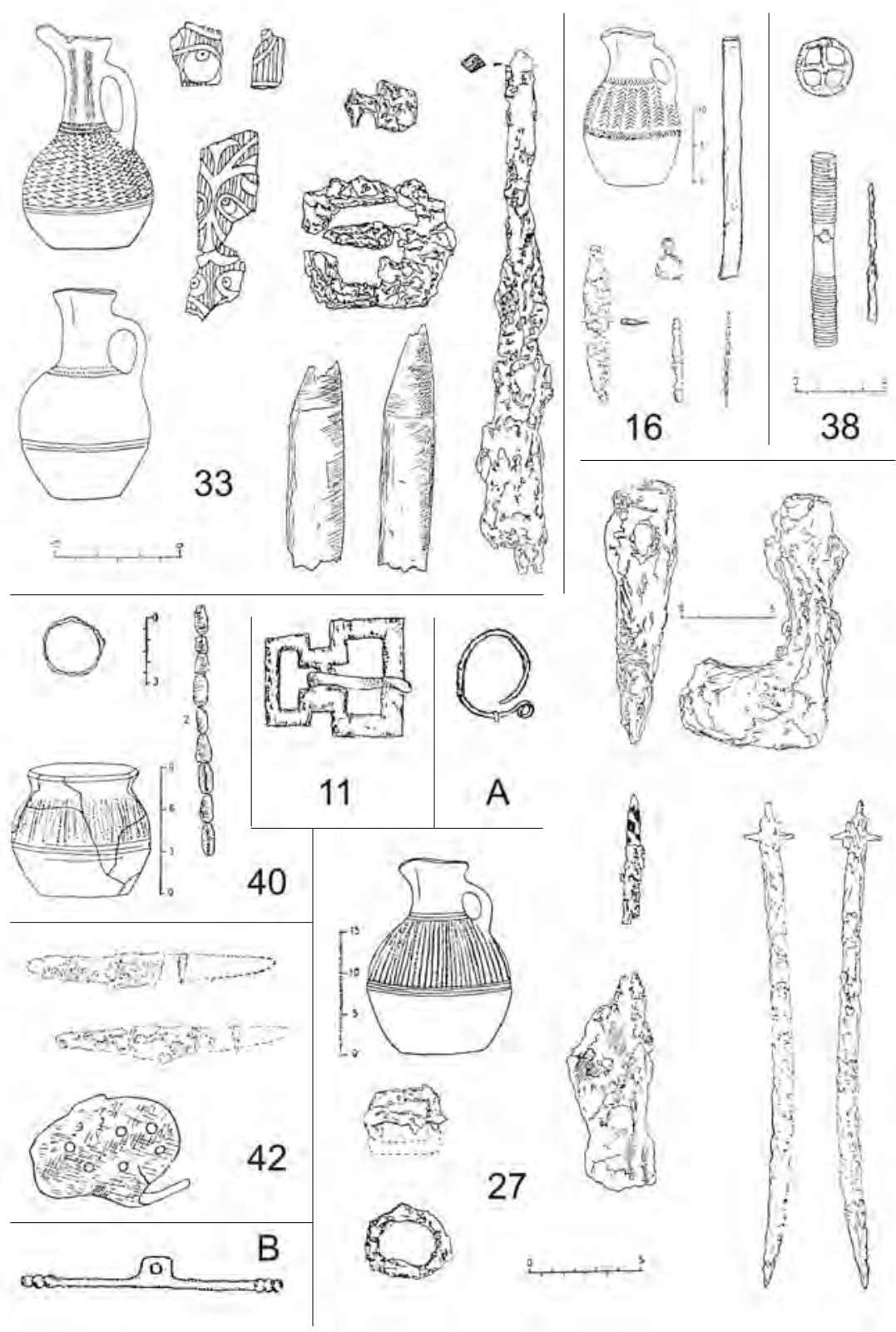

Abb. 4. Gräber mit datierenden Beifunden aus der Gräberfeld bei Novi Pazar 

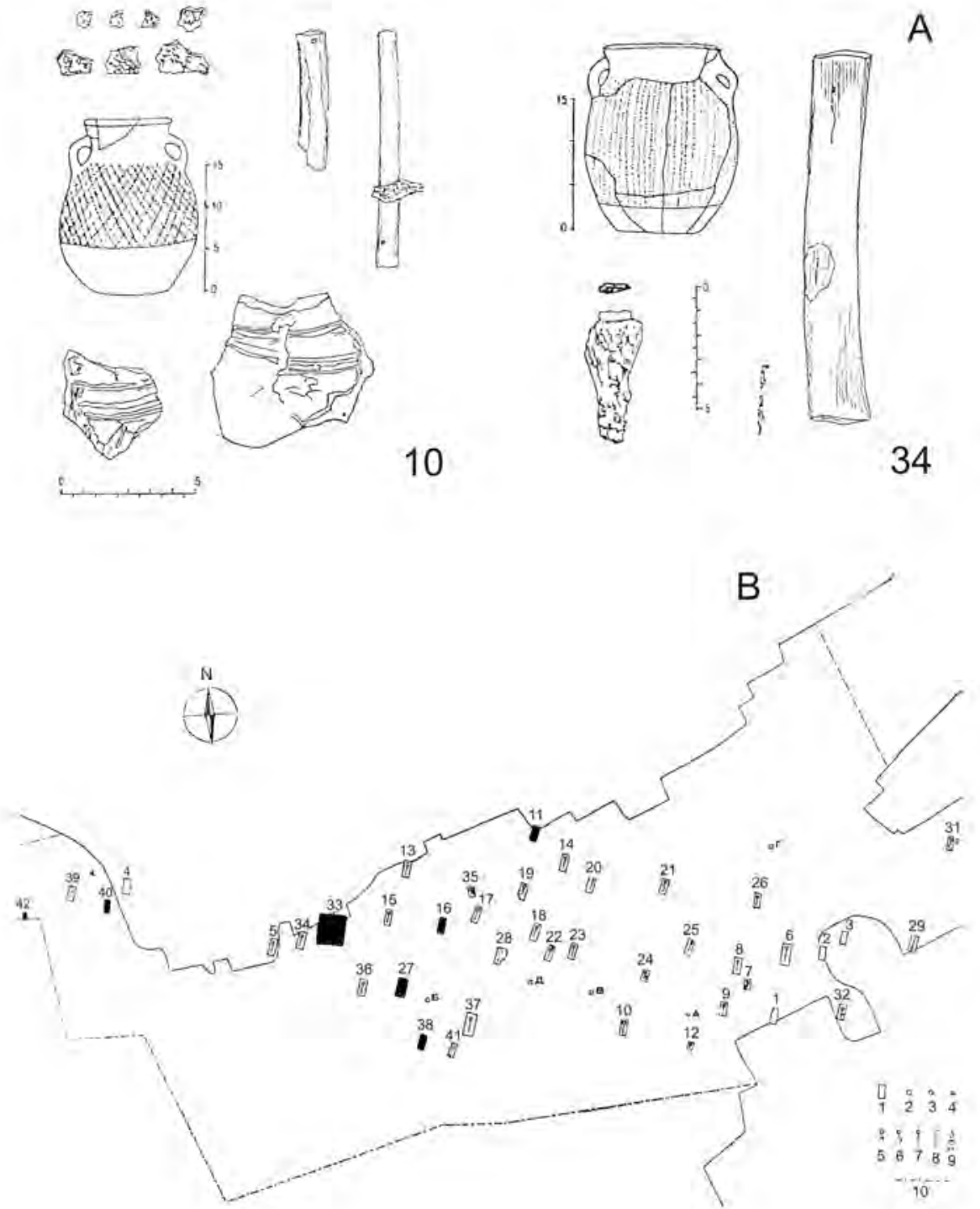

Abb. 5. A: Gräber Nr. 10 und 34 aus dem Gräberfeld von Novi Pazar, B: Lage der Gräber mit datierenden Beifunden im Gräberfeld von Novi Pazar. 
treffen diese Datierungen jeweils erst die Zeit nach 700 n. Chr. Die entsprechenden Befunde stammen ausschließlich aus der Westhälfte des Gräberfeldes von Novi Pazar (Abb. 5B). Die beiden Kannen aus Grab Nr. 33 (Abb. 4,33) wurden zusammen mit Knochenplättchen aufgefunden, die mit einem Pflanzenornament aus runden Blättern mit zentralem Punkt verziert sind. ${ }^{24}$ Hierbei handelt es sich um die sogenannten Rundblätter des spätawarischen gegossenen Gürtelschmucks, dessen Beginn um 710/720 datiert wird. In die mittel- oder spätawarische Zeit lässt sich das kleine Bronzerondell mit eingesetztem Kreuz aus Grab Nr. 38 setzen (Abb. 4,38). ${ }^{25}$ Spätawarische Parallelen hat der Kettenschmuck mit Melonenperlen aus Grab Nr. 40 (Abb. 4,40). ${ }^{26}$ Die bronzene Gürtelschnalle aus Grab 11 (Abb. 4,11), ${ }^{27}$ für die es byzantinische Vorformen aus dem 6.und 7. Jahrhundert gibt, könnte an den Übergang vom 7. zum 8. Jahrhundert oder später zu datieren sein. Der Säbel aus Grab 27 (Abb. 4,27) mit seiner recht ausgeprägten, geschwungenen Schneide findet Parallelen unter mittel- und spätawarischen Fundstücken. ${ }^{28}$ Der Fingering aus Grab 42 (Abb. 4,42) gehört zu den Ringen mit offener Spange und ausladender elliptischer Schaufläche, die vor dem 8. Jahrhundert noch nicht vorkommen. Der Ohrring, den man auf dem Gräberfeldgelände vor Beginn der Ausgrabungen gefunden hat (Abb. 4A), besitzt gute Parallelen aus dem 8. bis 9. Jahrhundert aus dem unteren Donauraum. Die bronzene Zügelstange, die zwischen den Gräbern gefunden wurde (Abb. 4B), und der Bronzeknebel aus Grab 16 (Abb. 4,16) kann man sehr gut auf Funde der Saltovo-Kultur des 8. bis 9. Jahrhunderts beziehen. Diese Analogien zeigen, dass man den Belegungsbeginn des Gräberfeldes von Novi Pazar nicht vor 700 und damit nicht in die Zeit der Ansiedlung unter Asparuch im heutigen Nordostbulgarien um 660/670 n. Chr. setzen kann. Auch die Brandgräberfelder haben keine solchen Materialien geliefert. Die bronzene Gürtelschnalle aus Grab Nr. 15 des Gräberfeldes von Razdelna, bei der es sich um einen byzantinischen Typ aus der Mitte oder der zweiten Hälfte des 7. Jahrhunderts handelt, ${ }^{29}$ dürfte wohl ein Altstück mit Amulettcharakter ohne Datierungsrelevanz sein. Wohl auch ihr zerbrochener Rahmen sowie das völlige Fehlen sonstiger Funde aus dem Gräberfeld, die in diese frühe Zeit datierbar wären, lassen darauf schließen. Damit kann der Belegungsbeginn in Razdelna frühestens auf 700 n. Chr. gesetzt werden. Die aufgezeigten Parallelen einiger Gegenstände aus den Gräberfeldern besitzen recht breite Datierungsgrenzen, wobei diese in der Regel nur allgemein das ,7.-8. Jahrhundert ${ }^{\star 30}$ einschließen und für

24 Stančev/Ivanov 1958, Taf. XI,3.4.

25 Ebd., Taf. XIII,38-1; Kovrig 1963, Taf. VIII,85-10, 11; Garam 1995, Taf. 64,72-78, Taf. 135,962-1, Taf. 143,1049-4, Taf. 158,1190-5.

26 Stančev/Ivanov 1958, Taf. XIII,40-2; vgl. Daim 1987, Abb. 28.

27 Stančev/Ivanov 1958, Taf. VI,11-1; vgl. Grabfunde 1989, Taf. 2 bis Taf. 15.

28 Stančev/Ivanov 1958, Taf. IX,6; vgl. Garam 1991, Abb. 2,7, Abb. 12,13.

29 Fiedler 1990, 197-198, Taf. 59,11.

30 Angelova/Dončeva-Petkova 1992, 18. 
den sicheren Nachweis eines Belegungsbeginns dieser Gräberfelder im letzten Viertel des 7. Jahrhunderts kaum zu gebrauchen sind.

So ergibt sich, dass es gegenwärtig nicht möglich ist, sicher in das letzte Viertel des 7. Jahrhunderts datierbare Altertümer der bulgarischen materiellen Kultur zu benennen. Diese Situation könnte einerseits damit zusammenhängen, dass Spezialstudien zu diesem Problem im Unterschied zum Beispiel zu den gut ausgearbeiteten methodischen und chronologischen Kriterien für die Bestimmung der Landnahmezeit von Awaren ${ }^{31}$ und Ungarn ${ }^{32}$ in Bulgarien noch völlig fehlen. Doch andererseits könnte sie sich auch daraus erklären, dass Funde dieser Art gar nicht in den Boden gelangt sind. So oder so steht die Untersuchung dieses Problems noch ganz am Anfang.

(Übersetzung: Joachim Henning)

\section{Bibliographie}

Angelova/Dončeva-Petkova 1992: Стефка Ангелова/Людмила Дончева-Петкова, „Разпространение на т. нар. «Пастирска керамика» в България“, in: Археология 34/1, 1992, S. 18-19.

Angelova/Penčev 1989: Стефка Ангелова/Владишир Пенчев, „Сребърно съкровище от Силистра“", in: Археология 28/2, 1989, S. 38-42.

Bálint 1984: Чанад Балинт, „Археология эпохи обретения бенграми родины (часть I)“, in: Западная Сибир в эпоху средневековья, Томск 1984, S. 112-128.

Bálint 1993: Csanad Bálint, „Probleme der archäologischen Forschung zur awarischen Landnahme“, in: Ausgewählte Probleme europäischer Landnahmen des früh-und Hochmittelalters 1, Sigmaringen 1993, S. 195-273.

Bálint 1996: Чанад Балинт, „О принадлежности находки в Малой Перещепине Куврату (история вопроса)“, in: Материаль I тыс. н.э. по археологии и истории Украины и Венгрии, Киев 1996, S. 56-62.

Bonev 1985: Чавдар Бонев, „Начало Дунайской Болгарии в свете некоторых археологических данных и монетных находок“, in: Études balcaniques 1985/2, S. 62-76.

Comşa 1980: Мариа Комша, „Преселването на Аспаруховите българи от Северното Причерноморие на Балканския полуостров“", in: Известия на Българското историческо дружество 33, 1980, S. 41-47.

Daim 1987: Falko Daim, Das awarische Gräberfeld von Leobersdorf, NÖ 1, Wien 1987.

Diaconu 1988: Petre Diaconu, „Sur les problèm archéologiques de la cité Jatrus“, in: Dacia 32/12, 1988, S. 198.

Dončeva-Petkova 1977: Людмила Дончева-Петкова, Българската битова керамика през ранното средновековие (втората половина на VI - края на X в.), София 1977.

Dončeva-Petkova 1990: Ljudmila Dončeva-Petkova, ,Die protobulgarische Keramik in Bulgarien“, in: Csanad Bálint (Hrsg.), Die Keramik der Saltovo-Majaki-Kultur und ihrer Varianten (=Varia Archaeologica Hungarica 3), Budapest 1990, S. 77-100.

31 Bálint 1993, 195-273.

32 Ders. 1984, 112-128; Mesterházy 1994, 23-65. 
Dimitrov 1994: Янко Димитров, „За сляванските археологическите паметници в Плиска“, in: Епископ-Константинови четения 1, 1994, S. 28-33.

Fiedler 1992: Uwe Fiedler, Studien zu Gräberfeldern des 6. bis 9. Jahrhunderts an der unteren Donau (=Universitätsforschungen zur prähistorischen Archäologie 11), Bonn 1992.

Garam 1991: Éva Garam, „A Tiszakécske-Óbögi avarkori sírok“, in: Communicationes archaeologicae Hungariae 1991.

Garam 1995: Éva Garam, Das awarenzeitliche Gräberfeld von Tiszafüred, Budapest 1995.

Grabfunde 1989: Byzantinische Grabfunde aus Sizilien, München 1989.

Jurukova 1966: Jordanka Jurukova, „Particulatités dans la circulation des monnais byzantines du VI-VII s. sur le littoral occidental de la Mer noire“, in: Byzantinobulgarica 2, 1966, S. 223-227.

Koleva/Daskalov 1993: Румяна Колева/Методи Даскалов, „Керамиката от ранносредновековния некропол край с. Бабово, Русенско“, in: Приноси към българската археология 2, 1993, S. 159-164.

Kovrig 1963: Ilona Kovrig, Das awarenzeitliche Gräberfeld von Alattyan, Budapest 1963.

Kurnatowska 1980: Zofia Kurnatowska, „Osadnictwo wczesnosriedniowieczne“, in: Styrmen nad Jantra (Bulgaria), Wrocław-Warszawa-Kraków-Gdańsk 1980.

Mesterházy 1994: Károly Mesterházy, „Die Landnahme der Ungarn aus archäologischer Sicht“, in: Ausgewählte Probleme europäischer Landnahmen des Früh- und Hochmittelalters 2, Sigmaringen 1994, S. 23-65.

Popović 1986: Вл. Поповић, „Кубрат, Кубер и Аспарух“, in: Старинар 37, 1986, S. 103-106.

Rašev 1982: Rašo Rašev, „L'Onglos: témoinages ecrites et faits archéologiques“, in: Bulgarian Historical Review 1982/1, S. 68-79.

Rašev 1985: Рашо Рашев, ,Земленото укрепление на Плиска“, in: Плиска-Преслав 4, София 1985, S. 7-15.

Rašev 1990: Рашо Рашев, „Към топографията на Плиска и Преслав“, in: Векове 19/4, 1990, S. 69-73.

Rašev 1992: Рашо Рашев, ,Девташларите: мегалитни паметници на българската история и култура“, in: Плиска-Преслав 5, Шумен 1992, S. 5-34.

Rašev 1995: Рашо Рашев, „Плисковският аул“, in: Плиска-Преслав 7, Шумен 1995, S. 10-21.

Rašev 1997: Rašo Rašev, „La plus ancienne période de l'état bulgare“, in: Von der Scythia zur Dobrudža (=Miscelanea bulgarica 11), Wien 1997, S. 49-54.

Rašev/Stanilov 1998: Rascho Raschev/Stanislav Stanilov, „Kenotaph für einen Herrscher bei der ersten bulgarischen Hauptstadt Pliska“, in: Das Altertum 44, 1998, 67-72.

Rašev/Dočeva 1989: Рашо Рашев/Валентина Дочева, „Юртообразна постройка в Плиска“, in: Проблеми на прабългарската история и култура 1, София 1989, S. 291-313.

Stančev/Ivanov 1958: Станчо Станчев/Стефан Иванов, Некрополът до Нови пазар, София 1958.

Stanilov 1991: Станислав Станилов, „Паметници на металлопластика от VIII-IX век в България“, in: Проблеми на прбългарската история и култура 2, Шумен 1991, S. 181-197.

Văžarova 1976: Живка Въжарова, Славяни и прабългари, София 1976.

Wendel 1986: Michael Wendel, „Die Mittelalterlichen Siedlungen“, in: Iatrus-Krivina 3, Berlin 1986. 



\title{
Zur Siedlungsstruktur der Nordostprovinz des Ersten Bulgarenreiches
}

\author{
VLADIMIR I. KOZLOV
}

Günstige und überdurchschnittlich abwechslungsreiche geographische Gegebenheiten mussten sich unvermeidlich auf die Ausprägung bestimmter Sitten und Gebräuche einer frühmittelalterlichen Zivilisation auswirken. Für Donaubulgarien sind so seine besondere Offenheit, Bodenständigkeit sowie Bereitschaft zu erklären, sich auf eine sehr wirkungsvolle Weise die Naturbedingungen zu Nutze zu machen. In diesem Zusammenhang ist es besonders interessant, das Problem der Herausbildung und Entwicklung des Besiedlungssystems der Träger jener Zivilisation im immer noch schlecht erforschten Raum seiner nordöstlichen Peripherie, dem Steppengebiet zwischen Donau und Dnestr, mit den Methoden der Landschaftsarchäologie zu verfolgen.

Den methodologischen Zugang zu diesen Fragen gewinnt man, indem archäologische Siedlungsobjekte auf ihr Aussehen, die historische Entwicklung ihrer Strukturen und ihre soziale Gliederung hin untersucht sowie ihre allgemeine Einbettung in Zeit und Raum und in die natürliche Umwelt analysiert werden. ${ }^{1}$ Als Ausgangspunkt kann hier der Umstand dienen, dass sich Landschaften durch eine komplizierte Verbindung zwischen anthropogenen und natürlichen Elementen auszeichnen und diese uns auch Formen und Mittel ihrer kulturellen und sozialökonomischen Nutzung verraten können.

Landschaftsarchäologie ist letztendlich eine Archäologie der sozialen Reproduktion, wie das C. Barrett, R. Bradly und M. Green besonders deutlich gezeigt haben. ${ }^{2}$ Die topographischen Gegebenheiten bilden zusammen mit dem Klima, den Böden sowie der Pflanzen- und Tierwelt jenen von der Natur fortdauernd gebotenen Rahmen, in den sich die Entwicklung eines jeden gesellschaftlichen Organismus einfügen muss. Es wäre jedoch nicht ausreichend, wenn man die geographische Sphäre nur als einfache funktionale Determinante für soziales und wirtschaftliches Handeln auffassen wollte. Die Umwelt sicherte nicht schlechthin den Lebensunterhalt. Sie ließ sich vielmehr nur in Abhängigkeit von kulturellen Faktoren nutzen. Das heißt, die Ausschöpfung ihrer Ressourcen hing vom kulturellen Entwicklungsstand, von einem durch Wissen und Erfahrung der Menschen bestimmten Alltagsverhalten ab. Um die Übertreibungen eines

1 Soja 1971; Johnson 1972; Renfew 1984; Fletcher 1986.

2 Barrett/Bradley/Green 1991. 


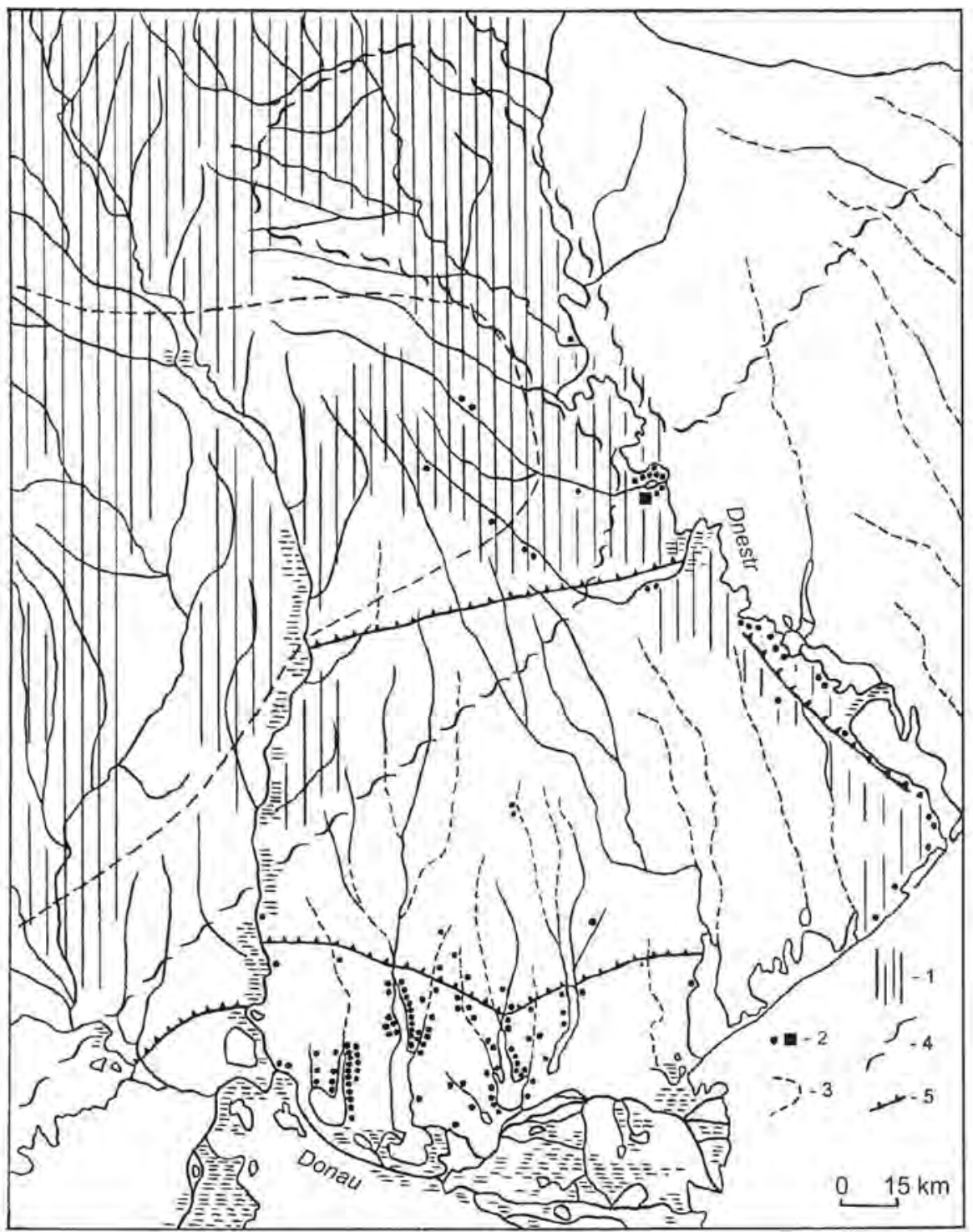

Legende: 1. Verbreitung des Kulturtyps Luka-Rajkoveckaja (Hlincea I), 2. Siedlungen des Ersten Bulgarenreiches, 3. Ostgrenze des Gebietes der Rèdukènen'-Hlincea II-Kultur, 4. Grenze zwischen Steppen und Lösssteppen, 5. Erdwälle

Abb. 1. Frühmittelalterliche Fundstellen der Steppen- und Lösssteppenzone im Gebiet zwischen Dnestr und Donau. 
Umweltdeterminismus zu vermeiden, muss man einerseits versuchen herauszufinden, in welchen Fällen der Naturfaktor der entscheidende war, in welchen er gegenüber dem sozialen überwog, und andererseits in welchen Fällen eine weitestgehende gesellschaftliche Bestimmtheit der Naturnutzung früher Gesellschaften vorliegt.

Wir wollen einen Blick auf die Breite von Daten werfen, die uns den hier interessierenden Zusammenhang von sozialökonomischen und natürlichen Faktoren beleuchten können.

Die untersuchte Region stellt zwar eine geographische Einheit dar, ist aber gleichzeitig in verschiedenartige Teillandschaften gegliedert: die Steppenebene, begrenzt von der Waldsteppe, die großen Flüsse und maritimen Uferzonen und dies alles durchsetzt von Seen, Schwemminseln und Sümpfen.

Die sichtbaren Spuren menschlicher Umgestaltungen belehren uns darüber, dass die Bevölkerung zweifellos zwischen solchen Gebieten zu unterscheiden wusste, die mit Gewinn zu nutzen waren und solchen, die dies kaum erlaubten. Bereiche mit entscheidenden Eingriffen in die Umwelt sind diejenigen mit menschlichen Ansiedlungen, und vor allem die Siedlungen selbst, in denen sich das soziale Leben konzentrierte, wodurch Vorgänge der Materialablagerungen in einem Maße beschleunigt wurden, wie das in keinem anderen geographischen Landschaftstyp der Fall war. ${ }^{3}$

Besiedelte Bereiche waren natürlich auf das Engste mit den Agrarlandschaften verbunden, die sich in Flächen mit Gemüse- und Obstanbau und Äcker unterteilten. Außerdem kam es zu jenen enormen Eingriffen in das besiedelte Landschaftsbild, die unter Aufwendung eines großen Teils des gesellschaftlichen Leistungsvermögens zum Entstehen mächtiger Erdwallanlagen als Befestigungen zur (Grenz-)Verteidigung führte.

Sein umfangreiches Potential an vorhandenen Ressourcen für die Sicherung des Lebensunterhalts machte das Land aufnahmefähig für eine große Bevölkerungszahl. Zwischen dem ausgehenden 7. und dem frühen 11. Jahrhundert bestand hier ein funktionierendes weitreichendes Netz aus ortsfesten Siedlungen, dessen Ausbreitung und Struktur durch 137 archäologische Fundstellen mit Siedlungsresten erschließbar wird. ${ }^{4}$ Diese Siedlungspunkte verteilen sich auf zwei geographisch deutlich ausgeprägte Landflächenmassive. Das Dnestr-Massiv, das im Wesentlichen die rechte Uferseite des Dnestr umfasst, zählt 35 Siedlungspunkte oder 20\% des Fundstellenbestandes. Die Fundstellen gliedern sich räumlich in drei Gruppen: eine um Kalfa, eine um Tudorovo und eine weitere im Küstengebiet (um Aspron). Das Donau-Massiv im Gebiet der Seen im unteren Donaubereich hat 102 Siedlungen oder $80 \%$ des Fundstellenbestandes geliefert. Auch hier sind drei Gruppen erkennbar: die Kagul-Gruppe, die Jalpug-Gruppe und schließlich die Katlabuch-Gruppe. Diese in den beiden Massiven erkennbaren

3 Burovskij 1996.

4 Datenstand von 1995. 


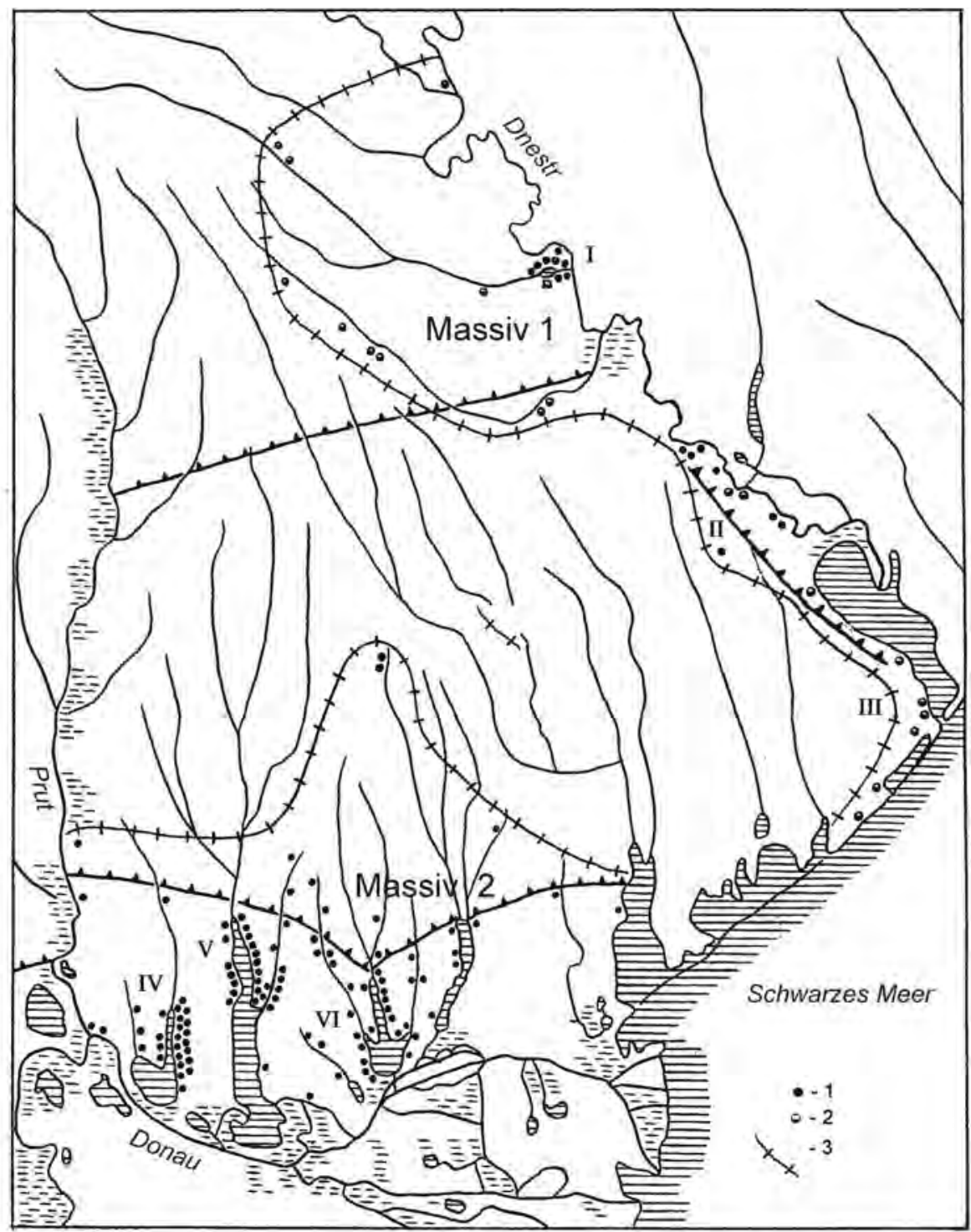

Legende: Massiv 1: Dnestr-Massiv, Massiv 2: Donau-Massiv, 1. einschichtige Siedlung, 2. zweischichtige Siedlung, 3. Grenzen der Massive, I. Siedlungsgruppe von Kalfa, II. Siedlungsgruppe von Tudorovo, III. Küstengruppe (um Aspron), IV. Kagul-Gruppe, V. Jalpug-Gruppe, VI. Katlabuch-Gruppe

Abb. 2. Lage der Fundstellen des Ersten Bulgarenreiches im Steppengebiet zwischen Donau und Dnestr. 
Gruppen von Siedlungen lassen sich weiter in folgende Strukturen oder Bevölkerungseinheiten unterteilen: in Einzelsiedlungen, in Siedlungshaufen oder -nester (2 bis 6 Siedlungspunkte) und in Agglomerationen von Siedlungen (7 bis 19 Siedlungspunkte). Weiterhin können nach ihrer Lage um Seen und an den Flüssen zwei Siedlungstypen unterschieden werden. Die Mehrzahl der Siedlungen liegt im Bereich der Hochufer von trinkwasserhaltigen Seen und Flussfjorden (Limane) sowie häufig auf den zweiten Terrassen oder den erhöhten Ufern der Flüsse jeweils mit einem Wasserzugang über sanfte Hangbereiche (Abb. 1 und 2).

Ausgehend von der Flächengröße der Siedlungsstellen lassen sich fünf Kategorien unterscheiden: Kleinstsiedlungen mit einer Fläche von bis zu 0,5 ha; Kleinsiedlungen zwischen 0,5 und 1,5 ha; mittelgroße Siedlungen zwischen 1,5 und 4,5 ha; Großsiedlungen zwischen 4,5 und 9 ha und Siedlungen maximaler Größe zwischen 9 und 30 ha. Die Fläche der einzigen Burgwall-Befestigung, gelegen in Kalfa, beträgt 40 ha (Abb. 3-6).

Mit Ausnahme also dieses Burgwall-Vorpostens von Kalfa am Dnestr, verfügt keine andere Siedlungsstelle über eigene Befestigungsanlagen. Von der Bevölkerung aber wurde in dieser Zeit eine Art kollektiven Schutzes organisiert. So hat man den Siedlungsraum des Donau-Massivs durch den „unteren Trajanswall“ auf einer Länge von $126 \mathrm{~km}$ abgeschirmt. Er wurde bereits unter Khan Asparuch zur Sicherung gegen die nördlich angrenzenden chasarischen Gebiete in dem als „Ongl“ bezeichneten Raum errichtet. ${ }^{5}$ Was den ,oberen Trajanswall“ mit 138 km Länge betrifft, so muss man seinen Bau aufgrund archäologischer Belege an die Wende zum 10. Jahrhundert setzen und mit staatlichen Aktivitäten Bulgariens zur Sicherung seiner Nordgrenze nach der Abwehr des Ungarneinfalls am Ende des 9. Jahrhunderts in Verbindung bringen. Möglicherweise gehörte auch der sogenannte Simev-Wall, der entlang des Dnestr-Limans und des Dnestr bis zum Dorf Raskaec' verlief, zum System des flächenhaften Schutzes der nördlichen Grenzgebiete Bulgariens. ${ }^{6}$

Hier ist also festzuhalten, dass die Grenz- und Verteidigungswälle sowie die Erdwallanlagen dieses Raumes als ein Resultat der breit angelegten Befestigungspraxis des Ersten Bulgarenreiches im gesamten Verlauf seiner Geschichte zu gelten haben. Sie zeigen uns den tatsächlichen Verlauf der Grenze, der sich oft geändert hat, und sie sind Symbole für die Sicherung der neu gewonnenen Territorien.?

Eine bemerkenswerte Besonderheit der Siedlungen des Dnestrgebietes ist das zeitlich vorangehende oder zeitlich synchrone Auftreten einer Schicht mit Materialien der Kultur Luka-Rajkoveckaja (Hlincea I), die völlig untypisch für die Siedlungen in der Nähe der Donau sind. Eine solche zweischichtige Situation ist für 19 von 35 Sied-

5 Kozlov 1995, 80-84.

6 Čebotarenko/Subbotin 1991, 125, 127; Maljukevič 1999, 43.

7 Kozlov 1965, 81; ders. 1997, 99-101; Fiedler 1989, 156; Rašev 1981, 99-103; ders. 1995a, 75. 


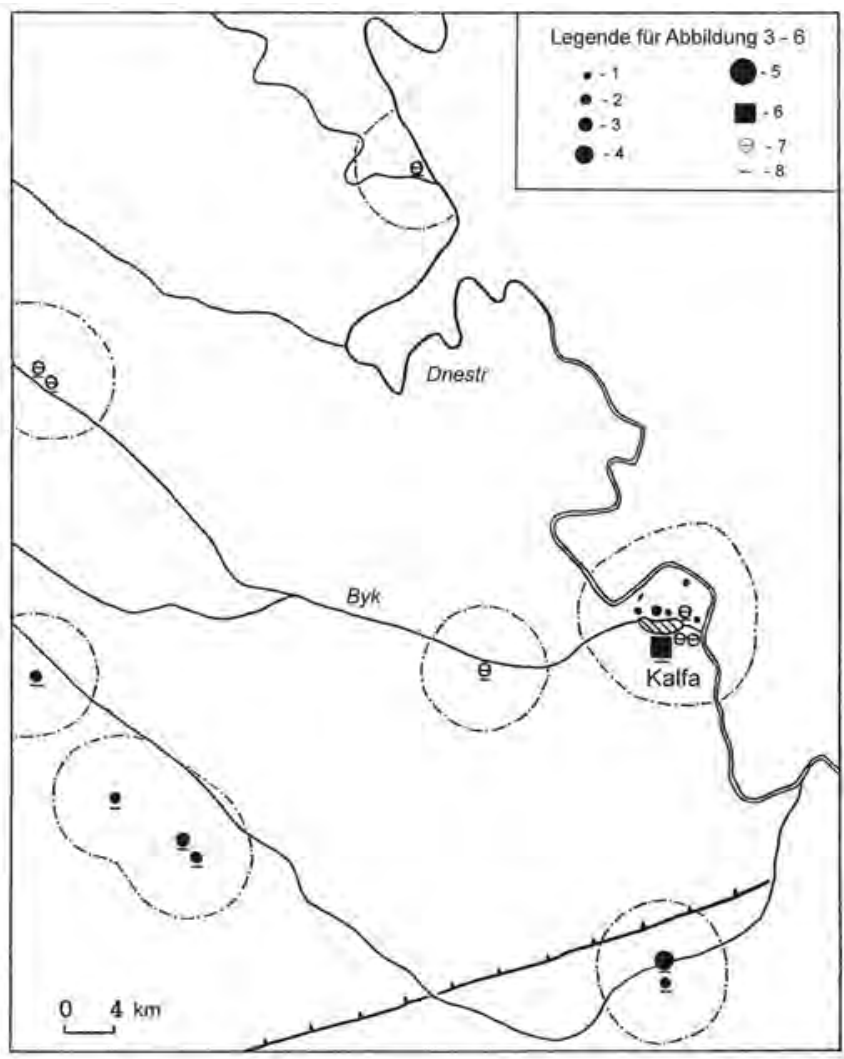

Legende: 1. Siedlungstyp 1, 2. Siedlungstyp 2, 3. Siedlungstyp 3, 4. Siedlungstyp 4, 5. Siedlungstyp 5, 6. Burgwall, 7. Fundstellenausdehnung unbekannt, 8. zweischichtige Fundstellen (Die Legende gilt für die Abbildungen 3. bis 6.)

Abb. 3. Verbreitung und Arten von Siedlungen in der Kalfa-Gruppe.

lungsfundstellen sowie für den Burgwall von Kalfa zu belegen. ${ }^{8}$ Auffällig ist, dass sich die geographische Verteilung von Fundstellen dieser Kultur mit einer Nachricht der Chronik „Povest' vremennych let“ zu decken scheint. Diese berichtet von einer Abwanderung des Stammes der Tiwerzen den Dnestr entlang bis zum Meer und nach Süden bis an die Donau (hier ohne Erwähnung des Meeres): „über dem Dnestr siedelnd, zogen sie zum Meer“ („,седяху бо по Днестру оли до моря”) und „übersiedelten an die Donau““(„приседяху к Дунаеви”). ${ }^{9}$

Das Fehlen ostslawischer Siedlungen nördlich des Donaudeltas und in unmittelbarer Küstennähe lässt vermuten, dass dieses später zu Bulgarien gehörende Gebiet im

8 Čebotarenko 1973; Fedorov/Čebotarenko 1974, 40-52; Smilenko/Kozlov 1986.

9 PSRL 1, 1962, 13. 


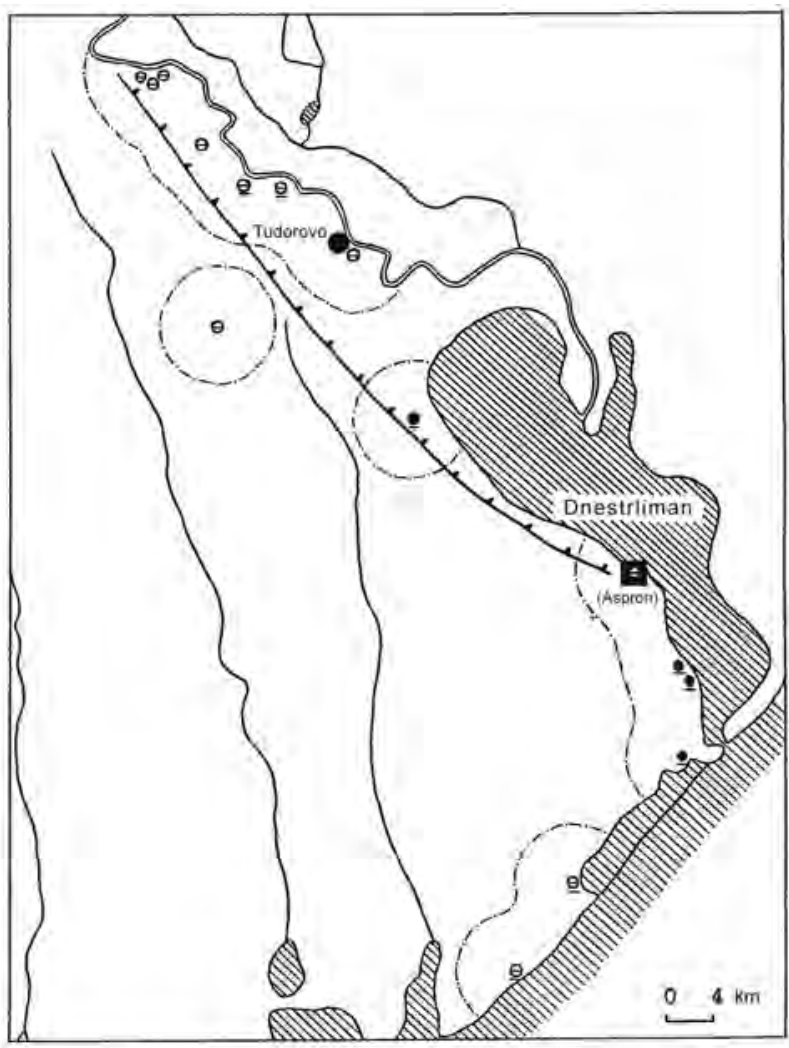

Abb. 4. Verbreitung und Arten von Siedlungen in der Siedlungsgruppe von Tudorovo und in der Küstengruppe (um Aspron). Legende s. Abb. 3

8. Jahrhundert offenbar von Bulgaren kontrolliert wurde, die eine reiternomadisch-viehzüchterische Lebensweise praktizierten. Fundstellen dieser Art sind bislang erst in sehr geringer Zahl erforscht. Zu nennen sind Ėtulija VI, Safjany und Bogatoe I (Abb. 5-7).

Als erstes trat ein Wandel der Lebensweise in den Gebieten in Donaunähe ein. Später, zeitgleich mit dem sprunghaften Anstieg der Zahl von Siedlungen und dem Anwachsen der in ihnen lebenden Bevölkerung in der ersten Hälfte des 9. Jahrhunderts, kam es zusammen mit den ökonomischen und außenpolitischen Erfolgen des Staates zu einer Kolonisation der Dnestr-Gebiete, die bis zu dieser Zeit in Teilen von Ostslawen besiedelt waren (Abb. 7 und 8).

Es ist von Bedeutung, dass vor dem Erscheinen der Ungarn und Petschenegen im unmittelbaren Vorfeld der bulgarischen Gebiete und zur Zeit der größten Blüte des Landes unter der Herrschaft des Zaren Simeon die Grenze am unteren Dnestr und an seinem Nebenfluss Byk verlief. ${ }^{10}$ Weiter muss man konstatieren, dass auf dem linken

10 Kozlov 1999, 20-22. 


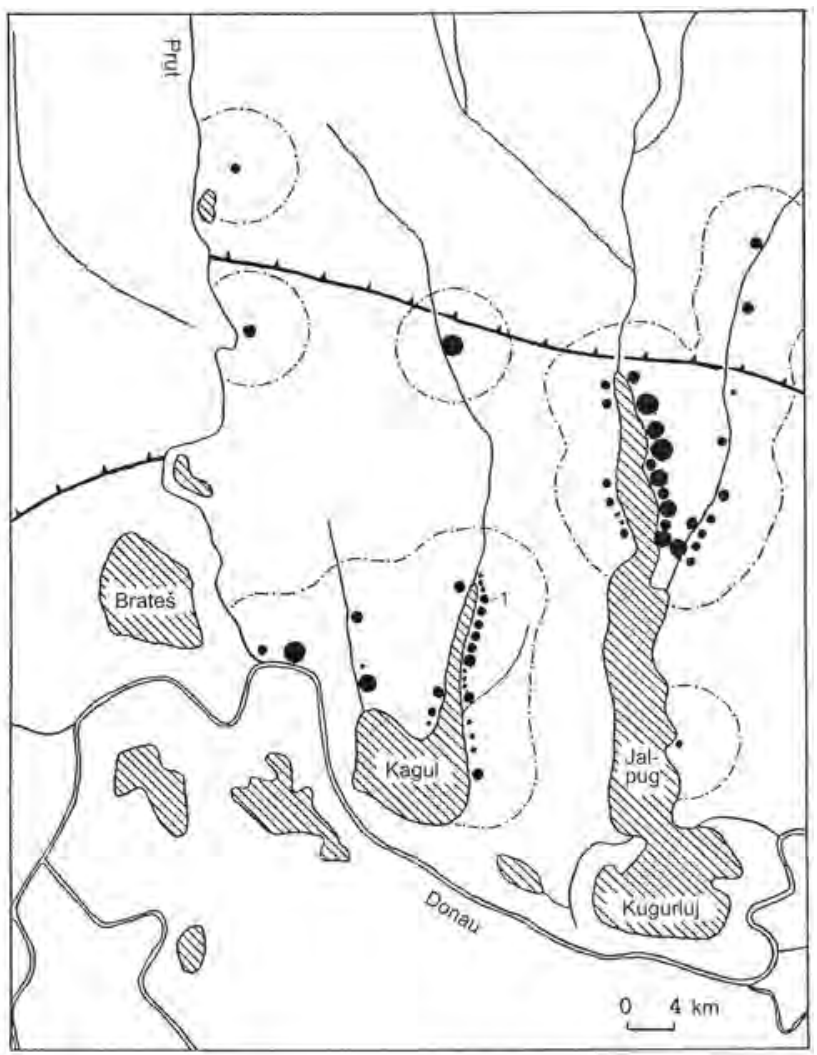

Abb. 5. Verbreitung und Arten von Siedlungen in der Kagul-Gruppe und in der JalpugGruppe. 1. Ėtulija VI. Legende s. Abb. 3

Dnestr-Ufer und in nordöstlicher Richtung Fundstellen der hier behandelten Kulturerscheinung nicht festgestellt werden konnten. Offensichtlich bildete damals genau der Lauf des Dnestr eine natürliche Grenze, hinter der Donaubulgarien begann. Dem entsprechen auch die Nachrichten des Kaisers Konstantinos Porphyrogennetos über „verlassene Befestigungen“, die „diesseitig des Flusses Dnestr, auf dem nach Bulgarien gerichteten Landstreifen an den Flussübergängen lagen“. ${ }^{11}$ Weiter nach Westen - wenn man den Forschungsergebnissen von M. Comşa und R. Rašev folgt - könnte die Grenze entlang des Flusses Žižija verlaufen sein mit dem nördlichsten Siedlungsendpunkt von Bela im Umfeld der Stadt Černovcy. ${ }^{12}$

Es wird erkennbar, dass die Gründe für die Wahl der Siedlungsplätze, ihre Anordnung im Territorium, ihr Grundriss, die Dauer ihres Bestehens, die Dynamik ihres Wachstums sowie ihre gesamte Anzahl von einer ganzen Reihe von Faktoren bestimmt wurden, die sowohl im Bereich natürlicher und geographischer als auch sozialer und

11 Const. Porph., De adm. imperio, c. 37.

12 Rašev 1995b, 89-95; Comşa 1963, 413-438. 


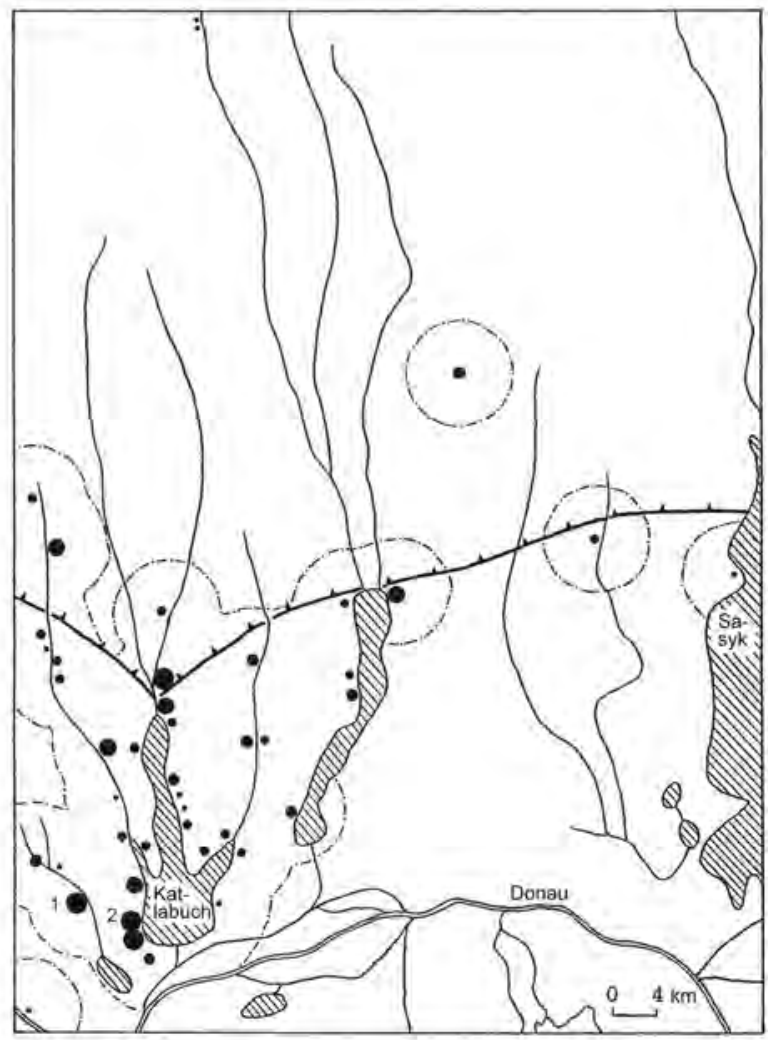

Abb. 6. Verbreitung und Arten von Siedlungen in der Katlabuch-Gruppe. 1. Saf'jany, 2. Bogatoe I. Legende s. Abb. 3

politischer Gegebenheiten lagen. Die Gesamtheit von Umweltelementen und von Produkten menschlichen Wirkens lässt nicht nur die Art der Verbindung der Bevölkerung mit dem Mikromilieu und ihren Anpassungsgrad an dasselbe erkennen, sondern erschließt auch die Basis sozial-ökonomischer Organisation der sich dahinter verbergenden menschlichen Gemeinschaft.

Wichtige Rückschlüsse erlaubt die Bewertung der Ökonomiezonen, die mit dem jeweiligen Siedlungssystem verbunden waren. ${ }^{13}$ Als Bewertungseinheit wird ein angemessenes wirtschaftlich genutztes Territorium um die Siedlung oder Siedlungsgruppe mit einem Radius von 4-5 km angesetzt. ${ }^{14}$ Die zu erwartende wirtschaftliche Produktivität des Siedlungsumfeldes lässt sich aufgrund der Eigenschaften des Mikromilieus formulieren, in dem man die potentiellen Anteile für Ackerbau- und Weideflächen, das Gewässersystem, die Rohstoffquellen für verschiedene Handwerkstätigkeiten usw. in Rechnung stellt. Eine solche Analyse des Siedlungsumfeldes zeigt, dass sich der

13 Masson 1976, 125-147; Afanas'ev 1987, 21-38.

14 Afanas'ev 1987, 24; Jarmen/Vita-Finzi/Higgs 1972, 61-66. 


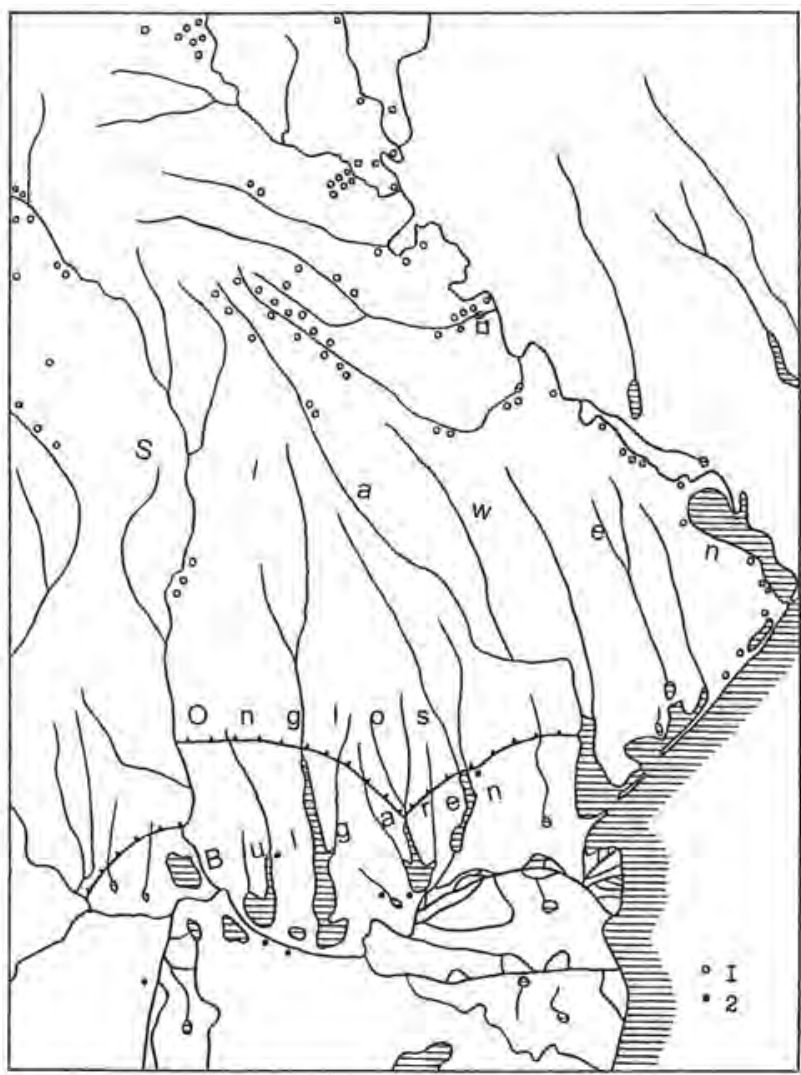

Legende: 1. ostslawische Siedlungen, 2. Siedlungen der Donaubulgaren

Abb. 7. Ethnische und politische Situation am Ende des 8. Jahrhunderts.

Landschaftscharakter beträchtlich auf die wirtschaftliche Spezialisierung und die Lebensweise der Bevölkerung auswirken und ein Überwiegen dieser oder jener Tätigkeiten wie Ackerbau, Viehwirtschaft, Jagd, Fischfang, Handwerk usw. hervorrufen konnte.

Man muss betonen, dass in den ersten Phasen der Kolonisierung unserer Gebiete unter den Bedingungen einer extensiven Bodennutzung im Regenfeldbau der Einfluss natürlicher Faktoren auf die Entwicklung der Ansiedlungen noch sehr stark und unmittelbar war. Dies förderte zunächst die Tendenz einer gleichmäßigen Verteilung der Besiedlung, was mit dem Bestreben zusammenhängen dürfte, eine möglichst effektive Ausnutzung der Naturressourcen zu erreichen. ${ }^{15}$ Andererseits bildeten sich schon in jener Zeit kleine Ketten von Ansiedlungen auf den ackerbaulich ungünstigen Sandböden des Dnestr-Gebietes sowie isoliert liegende Siedlungspunkte mit Vorpostenfunktion aus. Offenbar hatten solche Siedlungspunkte besonders in Zeiten der Kriegsgefahr Sonderfunktionen, wodurch ihre Bedeutung wuchs.

15 Blouet 1972, 3-15; Afanas'ev 1987, 29. 


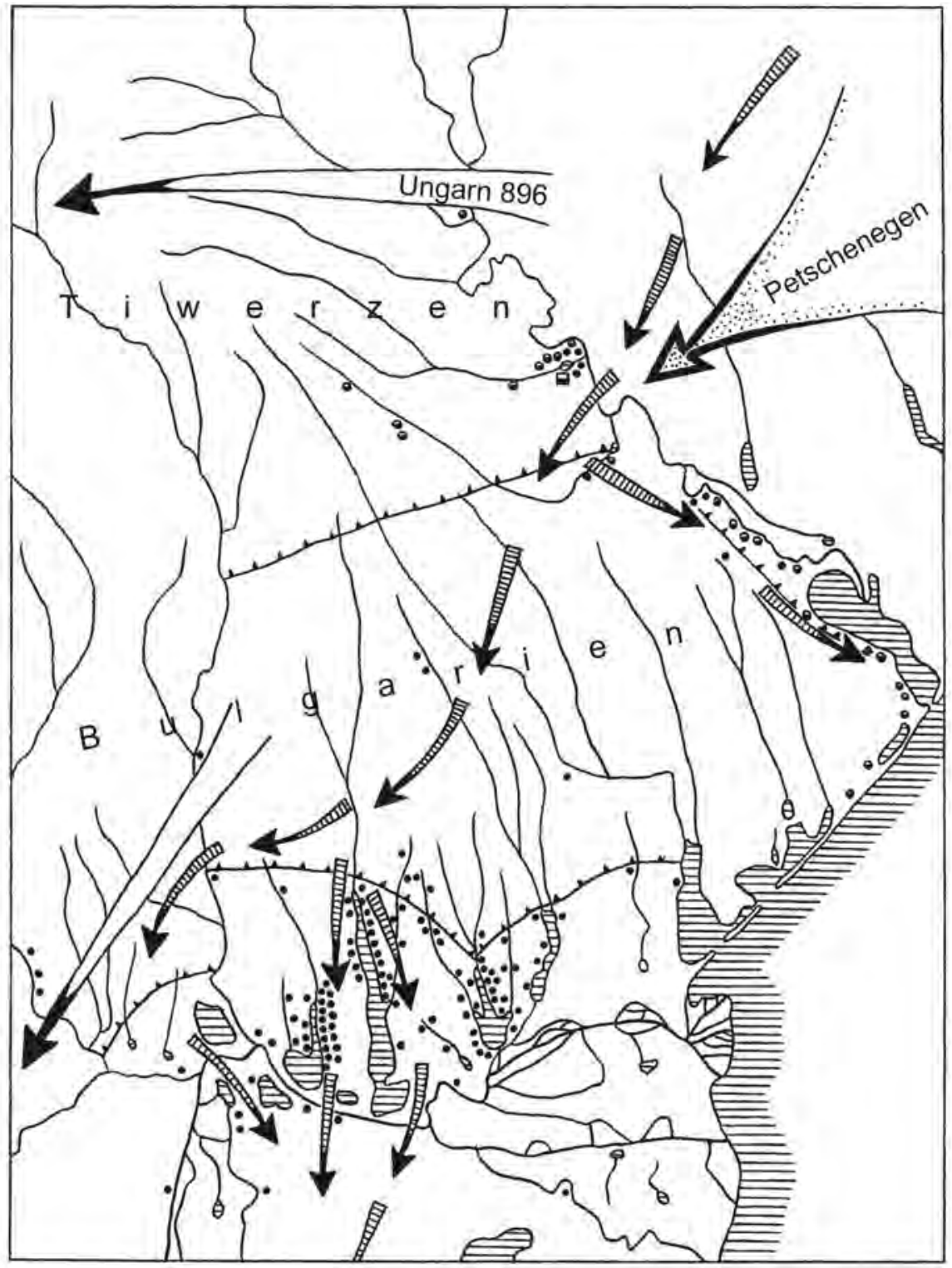

Abb. 8. Veränderung der ethnischen und politischen Situation an der Wende vom 9. zum 10. Jahrhundert: der Ungarneinfall nach Bulgarien in den Jahren 894 und 895 


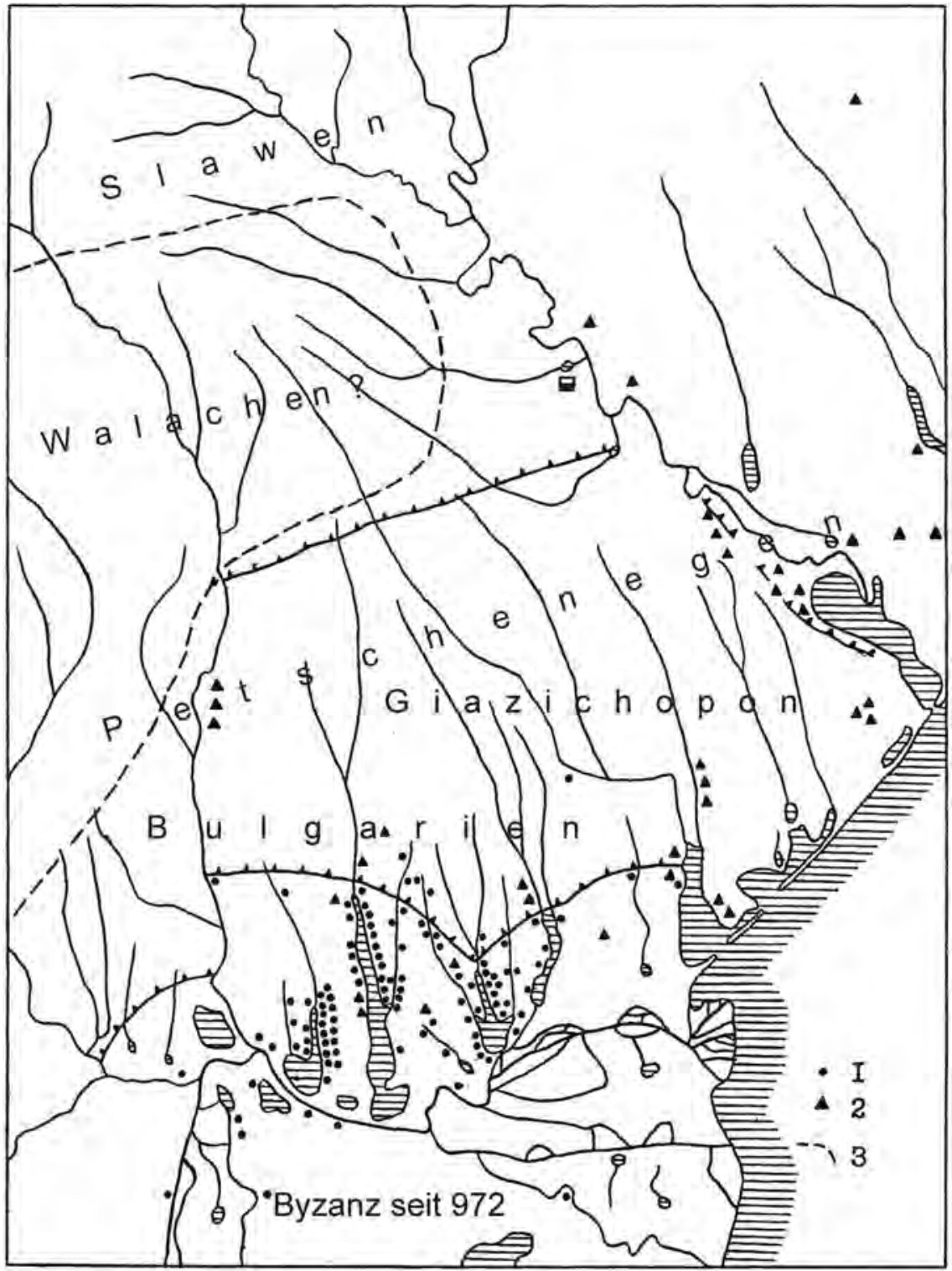

Legende: 1. Siedlung der Donaubulgaren, 2. Reiternomadische Bestattung des 10./11. Jahrhunderts (nach A. O. Dobroljubskij), 3. Grenze der Kultur Rèdukènen'-Hlincea II

Abb. 9. Ethnische und politische Situation im 10. und im frühen 11. Jahrhundert. 
Als Beispiel für den weiteren Gang der Siedlungsentwicklung wollen wir das Hauptmassiv im Donauraum betrachten. Wenn man von der naheliegenden Annahme ausgeht, dass die wirtschaftliche Nutzung der Gebiete aller drei Siedlungsgruppen etwa gleichzeitig begann, so muss man im weiteren Verlauf mit ungleichmäßigen Entwicklungen rechnen. Für die Kagul-Gruppe sind das Überwiegen kleinerer Siedlungen und ein niedriges Niveau der Ressourcennutzung kennzeichnend. Dagegen sind für die Jalpug-Gruppe das Vorherrschen großer und mittelgroßer Siedlungen und ein hohes Niveau der Ressourcennutzung typisch. Schließlich gehören zu der Katlabuch-Gruppe meist kleine Siedlungen und eine hoch entwickeltes Niveau der Ressourcennutzung ist zu beobachten. Hier bietet es sich an, die konstatierte Ungleichmäßigkeit als Ergebnis der ablaufenden sozialökonomischen Entwicklung der Gesellschaft in Raum und Zeit $\mathrm{zu}$ verstehen. Somit muss man davon ausgehen, dass dem erfassten Siedlungsschema ein dynamisches System zugrunde lag.

Die archäologischen Auswertungen zeigen, dass besonders gegen Ende des 9. Jahrhunderts in den Formen des Siedlungssystems „Deformationen“ auftraten. Die Ursachen dafür liegen offensichtlich in der beschriebenen ungleichmäßigen Entwicklung der einzelnen Regionen, aber auch in der Umwandlung einzelner Siedlungen in Zentren mit Administrativfunktionen bzw. in Orte mit großer Bevölkerungsdichte und wahrscheinlich auch in religiöse Zentren. Doch auch die Auswirkungen von Krieg und Politik sind in Rechnung zu stellen. So zerstörte offenbar der Ungarneinfall gegen Ende des 9. Jahrhunderts im großen Umfang die ökonomische Stabilität der Region dadurch, dass die kulturelle und politische Vorherrschaft Bulgariens geschwächt wurde. Einerseits verschwinden mit Ausnahme des Burgwall-Vorpostens von Kalfa alle Siedlungen auf dem Dnestr-Massiv, während sich demgegenüber im Bereich des Donau-Massivs die Siedlungsdichte erhöht und Agglomerationen von Siedlungen und Großsiedlungen hervortreten. Es bilden sich vier solcher Siedlungsanhäufungen aus, zwei innerhalb der Katlabuch-Gruppe und jeweils eine im Kagul- und im Jalpug-Raum. Dies lässt auf einen sehr plötzlich einsetzenden Anstieg der Bevölkerung schließen, der offenbar durch einen starken Zustrom von Umsiedlern aus dem DnestrGebiet verursacht wurde (Abb. 5, Abb. 6, Abb. 8, Abb. 9).

Im 10. Jahrhundert werden die mit Byzanz verbündeten ${ }^{16}$ und reiternomadisch im Thema Chopon (Giazichopon) lebenden Petschenegen zu einem wichtigen Faktor in der Geschichte der nordöstlichen Außenbereiche Bulgariens. ${ }^{17}$ Das Ende aller Siedlungen in der Region ist mit der byzantinischen Eroberung in Verbindung zu bringen, vor allem aber mit dem Einfall des nomadisierenden Reitervolkes der turksprachigen Ugusen am Anfang des 11. Jahrhunderts.

16 Kozlov 1997, 112-114.

17 Const. Porph., De adm. imperio, c. 37. 


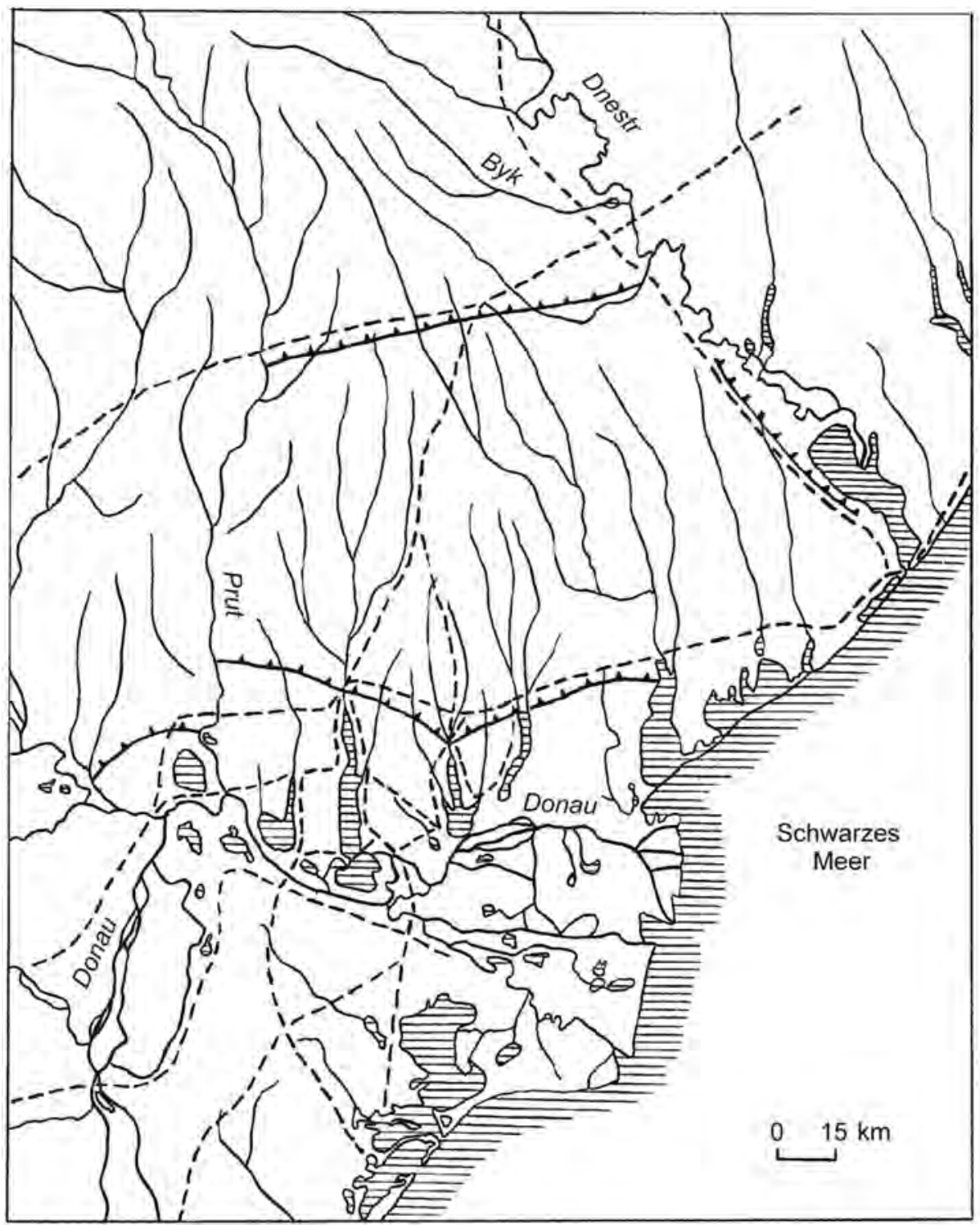

Abb. 10. Wichtigste Verkehrswege und Verbindungsrouten in den Steppenbereichen zwischen Dnestr und Donau und in der Norddobrudža im 9. und 10. Jahrhundert (Rekonstruktionsversuch) 
Im Grundriss der Siedlungen kann man einige Elemente beobachten, die sich aus dem örtlichen Oberflächenrelief, der Siedlungsart und wahrscheinlich auch aus der Sozialstruktur erklären. So werden bei der Nutzung des bewohnten Gebietes folgende Regeln erkennbar: 1. Die Ausbreitung der Siedlungsobjekte sowie der Siedlungen selbst folgt den Formen der Uferlinien und Schluchten, die das Siedlungsgebiet begrenzten; 2. Eine ungeregelte Haufenanordnung der Wohnbauten dominiert; 3. Produktionsanlagen liegen an der Peripherie der Siedlungen. Da eines der typischen Merkmale eine fließende Verteilung von Gebäuden über das ganze Siedlungsgelände ist, lässt sich ausschließen, dass es einen durch Straßenzüge oder Reihenstruktur geprägten planmäßigen Siedlungsaufbau gegeben hat. Dies wird in unserer Region durch eine Reihe von Ausgrabungsergebnissen bezeugt (Ėtulija VI, Saf'jany, Bogatoe I), die auch durch rumänische Archäologen auf Fundstellen der Steppenebene Bèrègan bestätig werden konnten (Dridu, Bucov-Rotar, Bucov-Tioca). ${ }^{18}$

Die inneren Grundzüge aller in unserer Region sichtbaren Siedlungssysteme werden einerseits durch die allgemeine Tendenz geprägt, das ausgedehnte umliegende Territorium zu kontrollieren, andererseits dadurch, dass es zur Zentralisierung und zu engen Beziehungen mit dem kontinuierlich bestehenden Siedlungskern im Bereich des Donau-Massivs kommt. Dazu trug wahrscheinlich auch eine besondere Kontrolle der Hauptverbindungswege und Kommunikationslinien bei, die sich auf Flussübergänge, den Transportverkehr usw. konzentrierte.

Eine Bewertung der Fundstellen nach ihrer räumlichen Verteilung, dem Ausmaß von Siedlungsanhäufungen und nach ihrer Grundrissgestalt ermöglicht es, als unterste soziale Grundeinheit des Siedlungswesens die Territorialgemeinde herauszustellen, die sich aus Kleinfamilienwirtschaften zusammensetzte. Wie schon von verschiedener Seite betont wurde, ${ }^{19}$ korrespondiert diese Struktur mit der zunehmenden Ausprägung staatlicher Gesellschaftsstrukturen. Die Siedlungsverteilung in der Landschaft ist durch konzentrische Ordnungsprinzipien, Hierarchien, Rücksichtnahme und Segmentalität gekennzeichnet. Deutlich erkennbar ist auch die Kooperation der Siedlungen untereinander. Alle Arten struktureller und funktionaler Unterteilungen sind voneinander abhängig und gesetzmäßig verteilt nach ihren Beziehungen im Gesamtsystem wie auch nach ihrer Beziehung zu einem einheitlichen Ganzen. Es ist offensichtlich, dass sich hier der Urtyp einer Organisation des besiedelten Raumes widerspiegelt wie auch der sozialökonomische und politische Aufbau der ganzen Region, die wahrscheinlich eines der Komitate des Ersten Bulgarenreiches war.

18 Čebotarenko/Šterbakova 1974, 146, Abb. 6, 154; Kozlov 1991, 16-17; Zaharia 1967, 166, Taf. 1; Comşa 1978, 14, Abb. 4-5.

19 Sedov 1960, 156; Timoščuk 1990, 95-108. 


\section{On the settlement structure of the north-eastern province of the First Bulgarian Kingdom (summary)}

This paper examines the organization and development of the social and political space of the northeastern province of the First Bulgarian State in the steppe region between the Danube and Dniester rivers from the landscape archaeology perspective.

The region in question represents a geographical entity, but it is characterized by an azonality of landscapes. Archaeological data demonstrate that the system of the 137 settlements of the region, dated between late eighth and early eleventh centuries, has a distinct structure organized in a determinate manner.

The system is subdivided in two major associations: the Dniester one and the Danube one, each consisting of three groups. Within the groups, three varieties of demophores can be distinguished: individual settlements, settlement clusters, and agglomerations.

The monuments are divided into five types according to their sizes. The distribution of settlements in space is characterized by a hierarchical, discrete and segmented structure.

Historically, the first sedentary settlements appear in the Danube area in late eighth century. By the middle of the ninth century, they spread over to the Dniester area, where Southern Slavic population peacefully coexists with the Eastern Slavs. The invasion of the Magyars in late ninth century undermined the cultural and political hegemony of Bulgaria in the region. The demise of all the settlements in the region is connected with the Byzantine aggression, but mainly with the invasion of nomadic Torkies in early eleventh century.

The analysis of archaeological sources allows drawing of the following conclusions: The system of settlements has a corporate character: all the types of structural subdivisions are interdependent and organized in a coherent way. It is obvious that this situation reflects the archetype of administrative organization of the entire region, which was probably one of the Bulgarian comitates.

(Übersetzung: Joachim Henning)

\section{Bibliographie}

Afanas'ev 1987: Геннадий Евгеньевич Афанасьев, „Население лесостепной зоны бассейна Среднего Дона в VIII-X вв.“, in: Археологические открытия на новостройках 2, Москва 1987, S. 21-38.

Barrett/Bradley/Green 1991: John C. Barrett/Richard Bradley/Martin Green, Landscape, Monuments and Society: The prehistory of Cranborne Chase, Cambridge-New York-Port Chester-Melbourne-Sidney 1991. 
Blouet 1972: Bryan W. Blouet, „Factors Influencing the Evolution of Settlement Patterns“, in: Peter J. Ucko/Ruth Tringham/G. W. Dimbleby (Hrsg.), Man, settlement and urbanism: proceedings of a meeting of the Research Seminar in Archaeology and Related Subjects held at the Institute of Archaeology, London University, London 1972, S. 3-15.

Burovskij 1996: Андрей Михайлович Буровский, Возникновение и проблематика антропоэкологии (Социально-философские аспекты), Автореферат докторской диссертации, Красноярск 1996.

Čebotarenko 1973: Георгий Феоктистович Чеботаренко, Калфа - городище VIII-X вв. на Днестре, Кишинев 1973.

Čebotarenko/Ščerbakova 1974: Георгий Феоктистович Чеботаренко/Т.А.Щербакова, „Раскопки поселения у с. Этулия“, in: Археологические исследования Молдавии (1973 г.), Кишинев 1974, S. 140-155.

Čebotarenko/Subbotin 1991: Георгий Феоктистович Чеботаренко/Леонид Васильевич Субботин, Исследования Траяновых валов в Днестровско-Дунайском междуречье (=Древности Юго-Запада СССР), Кишинев 1991.

Comşa 1963: Maria Comşa, „La civilisation balcano-Danubienne (IX-X ${ }^{\mathrm{e}}$ sincles) sur le territoire de la R.P. Roumanie (Origine, evolution et appartenance ethnique)“, in: Dacia 7, 1963, S. 413-438.

Comşa 1978: Maria Comşa, Cultura materială veche Româneasca: Asezarile din secolele VIII-X de la Bucov-Ploieşti, Bucureşti 1978.

Const. Porph., De adm. imperio: Constantine Porphyrogenitus, De administrando imperio, Greek text ed. by Gy. Moravcsik. Engl. transl. by R. J. H. Jenkins (=Dumbarton Oaks texts 1/Corpus fontium historiae Byzantinae 1), Washington DC 1993. Deutsche Übersetzung: Die De administrando imperio genannte Lehrschrift des Kaisers Konstantinos Porphyrogennetos für seinen Sohn Romanos / übersetzt, eingeleitet und erklärt von Klaus Belke (=Die Byzantiner und ihre Nachbarn/Byzantinische Geschichtsschreiber 19), Wien 1995.

Fedorov/Čebotarenko 1974: Георгий Борисовитч Федоров/Георгий Феоктистович Чеботаренко, Памятники древних славян VI-XIII вв. (=Археологическая карта Молдавии 6), Кишинев 1974.

Fiedler 1989: Uwe Fiedler, „Die Grablegen der Protobulgaren an der unteren Donau“, in: Проблеми на прабългарската история и култура, София 1989, S. 153-158.

Fletcher 1986: Roland Fletcher, „Settlement archeology: world-wide comparisons“, in: World Archeology 18, 1986, No.1, S.59-83.

Jarmen/Vita-Finzi/Higgs 1972: M. Jarmen/Claudio Vita-Finzi/Eric Higgs, „Catchment Analyses in Archeology“, in: Peter J. Ucko/Ruth Tringham/Geoffrey W. Dimbleby (Hrsg.), Man, settlement and urbanism: proceedings of a meeting of the Research Seminar in Archaeology and Related Subjects held at the Institute of Archaeology, London University, London 1972, S. 61-66.

Johnson 1972: Gregory A. Johnson, „A test of the utility of Central Place Theory in archeology“, in: Peter J. Ucko/Ruth Tringham/G. W. Dimbleby (Hrsg.), Man, settlement and urbanism: proceedings of a meeting of the Research Seminar in Archaeology and Related Subjects held at the Institute of Archaeology, London University, London 1972, S. 769-785.

Kozlov 1991: Владимир И. Козлов, Население степного междуречья Дуная и Днестра кониа VIII - начала XI веков н.э. (Балкано-дунайская культура), Автореферат кандидатской диссертации, Ленинград 1991.

Kozlov 1995: Владимир И.Козлов, „Фортификация в социально-политическом пространстве Первого Болгарского царства“, in: Археологические изысквания: „Фортификация древности и средневековья “ вып. 20, С.-Петербург 1995, S. 80-84. 
Kozlov 1997: Владимир И. Козлов, „Славяно-болгарская колонизация степного междуречья Дуная и Днестра в раннем средневековье“, in: Tpydы VI Международного Конгресса славянской археологии 3 «Этногенез и этнокультурные контакты славян», Москва 1997, S. 99-101.

Kozlov 1999: Владимир И. Козлов, „К вопросу о северо-восточных границах Первого Болгарского царства“, in: Материаль ХХVIII Межвузовской научно-методической конференции преподавателей и аспирантов, вып. 11. - Четвертые Державинские чтения "История и современные проблемы болгаристики и славистики” 1, СанктПетербург 1999, S. 20-22.

Maljukevič 1999: Алексанер Е. Малюкевич, Охранные исследования Моложской экспедиции в 1998 г. (=Охрана и исследования памятников археологии в Одессокй области 1), Одесса 1999.

Masson 1976: Вадим Михайлович Массон, Экономика и социальный строй древних обществ, Ленинград 1976, S. 125-147.

PSRL 1: Полное собрание русских летописей 1: Лаврентьевская летопись и Суздальская летопись по академическому списку, Москва 1962.

Rašev 1981: Рашо Рашев, „Землената укрепителна система на Пьрвото Българско царство“, in: Плиска-Преслав 2, София 1981, S. 99-103;

Rašev 1995a: Рашо Рашев, Фортификачия Первого Болгарского царства (681-1018 г2.). (=Археологические изысквания: Фортификация в древности и средневековье, вып. 20), Санкт-Петербург 1995.

Rašev 1995b: Рашо Рашев, „Североизточната археологическа граница на Първото Българско царство“, in: Българите в Северното Причерноморие 4, Велико Търново 1995, S. 89-95;

Renfew 1984: Colin Renfrew, Approaches to Social Archeology, Cambridge MA 1984.

Sedov 1960: Валентин Васильевич Седов, Сельские поселения иентральных районов Смоленской земли (VIII-XV вв.) (=Материалы и исследования по археологии 92), Москва 1960.

Smilenko/Kozlov 1986: Алла Трофимовна Смиленко/Владимир И. Козлов, „Славянское поселение конца I тысячелетия н.э. у с. Шабо на Днестровском лимане“, in: Археологические исследования средневековых памятников в Днестровско-Прутском междуречье, Кишинев 1986, S. 51-149.

Timoščuk 1990: Борис Анисимович Тимощук, Восточно-славянская община VI-IX вв. н.э., Москва 1990.

Soja 1971: Edward M. Soja, The Political Organization of Space (=Association of American Geographers: Commission on College Geography Research, Paper No. 8), Washington DC 1971.

Zaharia 1967: Eugenia Zaharia, Sapăturile de la Dridu: Contribuție la archeologia şi istoria perioadei de formare a populului român, Bucureşti 1967. 


\title{
Archäologische Zeugnisse frühslawischer Besiedlung in Bulgarien
}

\author{
StefKa Angelova \& Rumuana Koleva
}

Die Ansiedlung der Slawen auf der Balkanhalbinsel, namentlich auf dem Gebiet des heutigen Bulgarien, ist ein in der nationalen und der internationalen Geschichtsforschung rege diskutierter Vorgang. Untersucht werden die Chronologie der Slaweneinfälle, deren Ausdehnung und Umfang sowie die Ursachen, die zur endgültigen Ansiedlung der Slawen südlich der Donau führten. ${ }^{1}$

Weite Verbreitung hat dabei die These Ž. Văžarovas von einer frühslawischen Landnahme am Ende des 6. und im 7. Jahrhundert gefunden, die hauptsächlich auf den von ihr zur sogenannten Kultur I zusammengefassten archäologischen Materialien aus Nordostbulgarien beruht. ${ }^{2}$ Ein Vergleich mit frühslawischen Kulturen in der Ukraine, der Republik Moldau und Rumänien lässt jedoch erkennen, dass Hinterlassenschaften dieser Art von der Forschung in jenen Gebieten erst in die erste Hälfte oder sogar an das Ende des 7. Jahrhunderts datiert werden. ${ }^{3}$ Die These Văžarovas steht zudem im Widerspruch zu den Schriftquellen sowie zu den jüngst gewonnenen Befunden. ${ }^{4}$

Gegenstand dieser Abhandlung soll nicht die Chronologie oder die Charakteristik der Kultur I, sondern vielmehr der Versuch sein, die in der Literatur seit längerem bekannten Fundstellen mit frühslawischer Keramik und anderen Funden des 6. und beginnenden 7. Jahrhunderts zu analysieren. ${ }^{5}$ Für viele dieser Funde und Befunde fehlen bislang genauere Angaben zu ihren zeitlichen Einordnungen, ihren Fundumständen und ihrer Deutung. Die hier vorliegenden materiellen Hinterlassenschaften stammen von 43 Fundstellen in Bulgarien und der Norddobrudscha (Abb. 1). Wie der Karte zu entnehmen ist, wurde slawische Keramik zusammen mit Bügelfibeln, wie sie aus gesicherten slawischen Komplexen außerhalb Bulgariens bekannt sind, an neun Fundstellen

1 Dujčev 1972, 11-69; Lemerle 1954, 349-361; Tăpkova-Zaimova 1971; Angelov 1971; Petrov 1981.

2 Văžarova 1976a; dies. 1976b; dies. 1986.

3 Pletneva/Rusanova 1966, 276-279; Kišvasi-Komša 1957, 309-327; Milčev/Angelova 1971, 22-29.

4 Văžarova 1981, 16-59.

5 Comşa 1970, 322-330; Diaconu 1979, 165-166. 


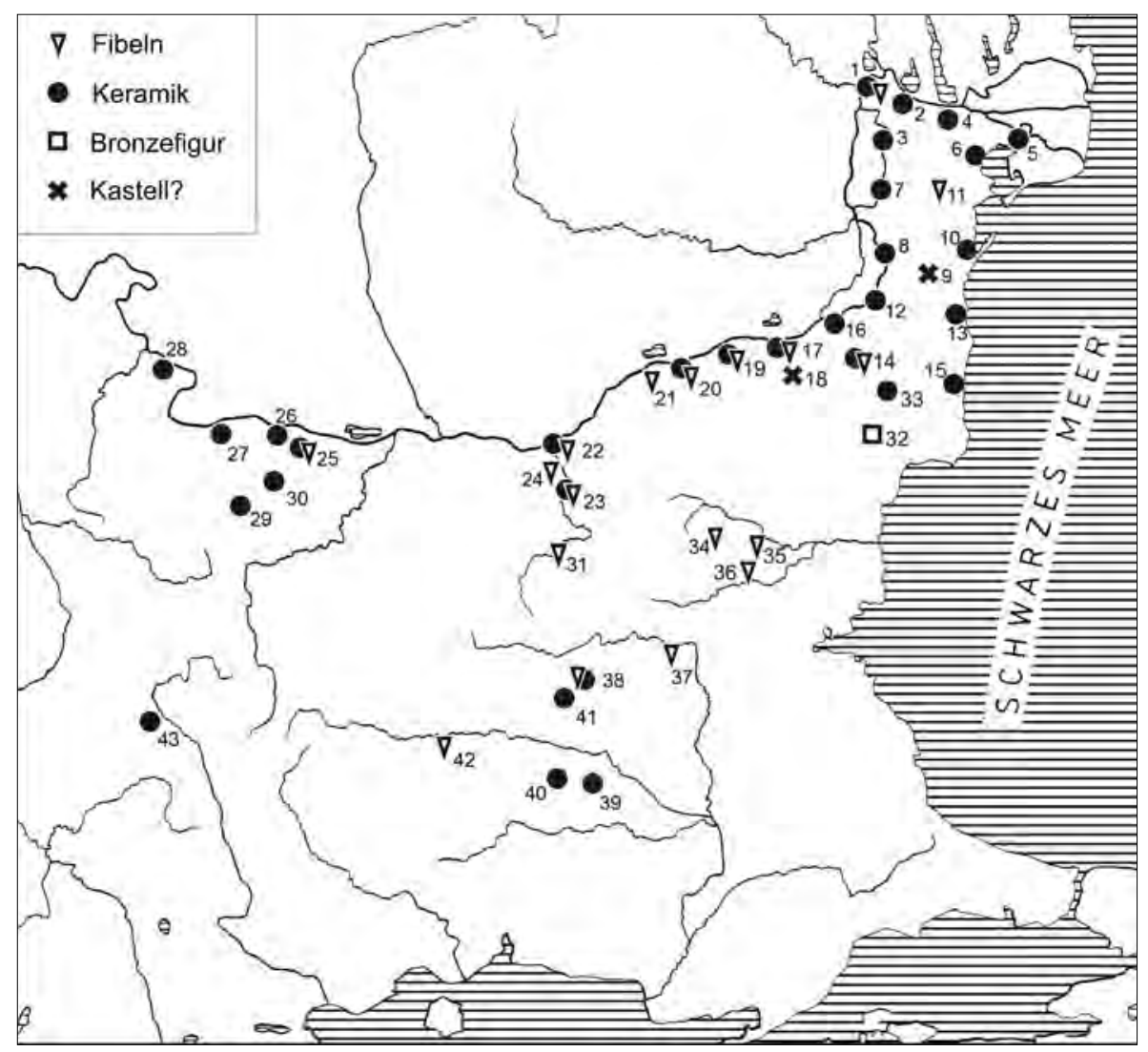

Abb. 1. Karte der Fundorte (Nummern verweisen auf den Katalog)

nachgewiesen. An 21 Fundorten fand sich lediglich slawische Keramik, während einzeln gefundene Bügelfibeln von zehn Fundorten bekannt sind. Unbekannt ist die Herkunft eines menschlichen Figürchens vom Typ Martynovka, das in der Sammlung des Museums von Dobrič (Kat.-Nr. 32) aufbewahrt wird. Dass für die zwei Befestigungen Ulmetum und Adina die Präsenz von Slawen bereits für die Anfangsjahre der Regierung Justinians I. (527-565) belegt werden kann, ist seit längerem bekannt. ${ }^{6}$

In den Befestigungen am Donaulimes wurde Keramik der Penkovka-Art gefunden, die den Typen I bis III nach O. M. Prichodnjuk entspricht. ${ }^{7}$ Zum ersten Typ gehören Gefäße von doppelkonischer Form mit scharfem oder abgerundetem Übergang in der Gefäßmitte. Die Gefäßmündung ist unsauber gearbeitet und weist einen gerundeten oder

6 Dujčev 1972, 44-46; Beševliev 1968, 21.

7 Prichodnjuk 1991, 75-108. 
leicht nach innen gezogenen Rand auf. Dem zweiten Typ werden Töpfe mit breitem, rundlichem Gefäßkörper, dessen größte Breite in der Mitte liegt, zugeordnet. Sie besitzen einen kurzen Randbereich, und die Randlippe ist mehr oder weniger nach innen geneigt. Der dritte Typ umfasst Töpfe mit einem schlanken, rundlichen Körper, dessen größte Breite in der Mitte liegt. Die Mündung ist kurz und leicht nach innen geneigt. Keramik dieser Art wurde in Dinogetia (Kat.-Nr. 1), Troesmis (Kat.-Nr. 3), Aegyssus (Kat.-Nr. 4), Independența (Kat.-Nr. 5), Beroe (Kat.-Nr. 7), Capidava (Kat.-Nr. 8), Histria (Kat.-Nr. 10), Callatis (Kat.-Nr. 15), Durostorum (Kat.-Nr. 17), Nova Černa (Kat.-Nr. 20), Iatrus (Kat.-Nr. 22), Augusta (Kat.-Nr. 25), Jakimovo (Kat.-Nr. 29), Goleš (Kat.-Nr. 33) und in den Festungen Südbulgariens Ljubenovo (Kat.-Nr. 39), Konstantia (Kat.-Nr. 40) und Pautalia (Kat.-Nr. 43) gefunden. Penkovka-Keramik der genannten Typen stammt aus den Siedlungen von Kosloduj (Kat.-Nr. 26) und Vălčedrăm (Kat.-Nr. 30).

Keramik vom Typ IV nach Prichodnjuk, die von ihm als Prag-Korčak-Typ bezeichnet wurde, ist in Dinogetia, Nova Černa, Stărmen (Kat.-Nr. 23) und Ljubenovo gefunden worden. Die bisher genaueste innere Chronologie der Penkovka-Kultur, deren Keramiktypologie wir hier zugrundelegen, zeigt, dass die Typen I bis IV in den frühen Phasen am Ende des 5. und im 6. Jahrhundert auftreten. ${ }^{8}$ Die übrige frühslawische Keramik, die in Niculițel (Kat.-Nr. 2), Tomis (Kat.-Nr. 13), Durostorum (Kat.-Nr. 17), Stărmen (Kat.-Nr. 23.1), Almus (Kat.-Nr. 27), Dorticum (Kat.-Nr. 28), Jakimovo (Kat.-Nr. 29), Vălčedrăm (Kat.-Nr. 30), Augusta Traiana (Kat.-Nr. 38), Ljubenovo (Kat.-Nr. 39), Karasura (Kat.-Nr. 41) und Pautalia (Kat.-Nr. 43) zutage trat, kann aufgrund der im Katalog benannten Parallelen aus gesicherten slawischen Fundkomplexen ebenfalls in das 6. und beginnende 7. Jahrhundert datiert werden. Insgesamt dominiert in den genannten Siedlungen die Keramik vom Penkovka-Typ oder die Kombination von Keramik der Typen Penkovka und Prag, eine Erscheinung die auch aus der Ukraine, Moldawien, Jugoslawien, der Slowakei und anderen Gebieten bekannt ist. ${ }^{9}$

Wie bereits erwähnt, wurden an neun Fundstellen Bügelfibeln im Zusammenhang mit frühslawischer Keramik gefunden, so dass jene mit dem slawischen Vordringen in Verbindung gebracht werden müssen. Parallelen aus slawischen Fundkomplexen nördlich der Donau besitzen die Bügelfibeln aus Dinogetia, Durostorum ${ }^{10}$, Nova Černa, Iatrus, Augusta Traiana und Stărmen (Kat.-Nr. 23.3). Die Fibel aus einem Körpergrab mit Nische von Trophaeum Traiani ähnelt dem Fibelpaar aus Grab 280 des Gräberfeldes von Dančeny in Moldawien. Obwohl für Slawen die paarige Trageweise von Fibeln nicht typisch ist, kann im vorliegenden Fall die Beigabe von Keramik der Penkovka-Art den Ausschlag für die ethnische Deutung des Grabfundes von Dančeny geben. ${ }^{11}$ An dieser Stelle muss erwähnt werden, dass auch das Fibelpaar

8 Prichodnjuk 1991, 80-81, 84-85, Taf. II.

9 Sedov 1978, 122-125.

10 Zum slawischen Charakter der Fibel mit umgeschlagenem Fuß vgl. Angelova 2003.

11 Rafalovič 1986, 25-27, Taf. 14,1-5. 
aus dem Körpergrab Nr. 42 von Beroe ${ }^{12}$ seine nächsten Parallelen zu slawischen Komplexen findet. ${ }^{13}$ Birituelle Bestattungstraditionen finden sich im 6. und 7. Jahrhundert bei den Trägern der Penkovka-Kultur. ${ }^{14}$ Dies kann auf verschiedene Weise, etwa durch unterschiedliche ethnische Zusammensetzung der Bevölkerung oder durch Fremdeinflüsse, erklärt werden. Auf jeden Fall werden die Träger der Penkovka-Kultur, die Anten, in den Schriftquellen dieser Zeit als Slawen bezeichnet. Die Fibel von Nigriniana-Candidiana (Kat.-Nr. 19) steht jener nahe, die im Gräberfeld von Lači gefunden wurde und die J. Werner mit der slawischen Eroberung des Nordwestbalkans in Verbindung brachte. Der Einzelfund von Stărmen (Kat.-Nr. 23.2) hat seine nächsten Parallelen in gepidischen Funden. Die frühslawische Siedlung von Stărmen, deren Keramik von den Ausgräbern zwischen 540 und 599 datiert wird, könnte vielleicht mit dem Fibelfund in einem zeitlichen Zusammenhang stehen. Ähnlich verhält es sich mit den Fibeln von Augusta. ${ }^{15}$ Allerdings wurden hier die Fibeln wie auch die Keramik in der letzten frühbyzantinischen Schicht gefunden.

Zehn weitere Funde von einer, zwei oder drei Fibeln kommen hinzu. Die Stücke von Tărnovo und Ibida ähneln denen aus der slawischen Siedlung Vutcani-Vaslui (historische Provinz Moldawien/Rumänien $)^{16}$ und aus dem Grab Nr. 280 von Dančeny. Die Bügelfibel mit fünf Knöpfen aus Riš (Kat.-Nr. 35.1) besitzt ihre Parallelen im slawischen Gräberfeld von Sărata Monteoru und der slawischen Siedlung von Poian (Südost-Siebenbürgen). Eine weitere Fibel aus Riš (Kat.-Nr. 35.3) mit drei Knöpfen an der Kopfplatte ähnelt ebenfalls jener aus Sărata Monteoru. ${ }^{17}$ Der Typ ist von V. Bierbrauer als Typ Bratei beschrieben und in die Zeit zwischen der ersten Hälfte und der Mitte des 5. Jahrhunderts datiert worden. ${ }^{18}$ Die Fibeln aus Ljuljakovo (Kat.-Nr. 36.1) und Kabyle (Kat.-Nr. 37.1) wurden von J. Werner als slawisch angesprochen. ${ }^{19}$ Eine solche Deutung wird durch eine Fibel dieser Art aus der Basilika von Demetria bekräftigt, aus der auch slawische Keramik stammt. ${ }^{20}$ Die Fibel aus Plovdiv (Kat. Nr. 42.1) ${ }^{21}$ besitzt Analogien in den Funden von Sărata Monteoru sowie aus der slawischen Siedlung Chanska II (Republik Moldau).

12 Petre 1987, 77-78, Abb. 233b.

13 Nestor/Zaharia 1959, 511, Abb. 1,2.

14 Rafalovič/Lapušnjan 1973, 141; Teodor 1978, 19.

15 Nach freundlicher Mitteilung von S. Mašov, dem am dieser Stelle herzlich gedankt werden soll, wurde in Augusta auch eine typisch slawische Fibel gefunden.

16 Teodor 1978, 41, Abb. 15,1.

17 Die Fibeln aus Riš wurden uns durch G. Atanasov (Historisches Kreismuseum Šumen) zugänglich gemacht, dem hier herzlich gedankt werden soll.

18 Bierbrauer 1989, 141-149.

19 Werner 1950, 161-166.

20 Aupert, 1976, 646, Abb. 144.

21 Die Fibel wurde uns von P. Moreva zugänglich gemacht, der wir hiermit herzlich danken möchten. 
Die Gestaltung der Kopfplatte der Bügelfibel von Dervent ähnelt dem in der slawischen Siedlung von Bucureşti-,,Str. Soldat Ghivan“ gefundenen Stück. ${ }^{22}$ Fast identisch mit dem Einzelfund von Novgrad (Kat.-Nr. 24.1) ist die Fibel aus Stărmen. Die kleine Fibel aus Appiaria ist nach Form, Größe und Verzierung völlig mit der aus Novi Banovci (Vojvodina) identisch und könnte sogar in derselben Form gegossen worden sein. ${ }^{23}$ Einige kleine Bügelfibeln aus gepidischen Komplexen haben ihre Analogie in Sărata Monteoru, ${ }^{24}$ so dass die Vermutung nahe liegt, dass diese Fibeln ursprünglich von den Gepiden zu den Slawen gelangt sind. Das gleiche könnte auch für die Fibeln aus Stărmen und Novgrad zutreffen. Die zweite Fibel aus Kabyle (Kat.-Nr. 37.2), für die uns keine genauen Parallelen bekannt sind, kann wahrscheinlich ebenfalls mit Slawen verbunden werden, so wie es von Werner für das Fibelfragment, dessen Fuß mit einem menschlichen Gesicht verziert ist, angenommen wurde. Leider verfügen wir über keine Abbildung der Fibel von Tušovica und sind daher nicht in der Lage, ihren genauen Typ zu bestimmen. ${ }^{25}$

Der früheste Nachweis slawischer Präsenz findet sich in einer Brandschicht in Troesmis. Dort wurden entsprechende Keramik und Münzen, deren späteste nach 539/540 datiert, gefunden. Zur gleichen Zeit gingen wahrscheinlich auch Ulmetum und Adina verloren, die Justinian später wiedereroberte, weil ,sich die Barbaren/Slawen unablässig dort versteckten, Reisende ständig aus dem Hinterhalt überfielen und die Umgebung unpassierbar machten“" ${ }^{26}$ Zwischen 537/538 und 575/576 drangen die Slawen vermutlich auch in Beroe, Durostorum, Nigriniana und Pautalia ein. Aus der Zeit Justinians I. (527-565) sind je ein Münzhort aus Capidava ${ }^{27}$ und Tomi ${ }^{28}$ bekannt und aus der Zeit Justins II. (565-578) stammen zwei Münzhorte aus Durostorum ${ }^{29}$ und einer aus Beroe in der Norddobrudscha ${ }^{30}$. Der terminus ante quem für die Niederlassung von Slawen in Augusta und in Ljubenovo ergibt sich aus den spätesten Münzen aus den Brandschichten, Prägungen aus der Zeit Tiberios I. Konstantinos (578-582). In derselben Zeit sind die Münzhorte von Axiopolis $^{31}$ und Augusta ${ }^{32}$ verborgen worden. Die slawische Präsenz in Dinogetia und Capidava ist durch Schlußmünzen aus den Brandschichten in die Zeit vor

22 Constantiniu 1966, 665-678, Abb. 2,1.

23 D. Dimitrov, dem wir an dieser Stelle herzlich danken möchten, hat uns den Einzelfund zugänglich gemacht.

24 Csallany 1961, Taf. 213,1-3.5.

25 Eine sehr allgemeine Nachricht über das Stück erhielten wir von G. Atanasov (Historisches Kreismuseum Šumen).

26 Prokopios, De aedificiis, 169.

27 Jordanov 1987, 207.

28 Dimian 1957, 191.

29 Gerasimov 1965, 249. Der zweite Hortfund ist unpubliziert.

30 Mitrea 1981, 388.

31 Ders. 1980, 376.

32 Mašov 1980, 16. 
591/592 zu datieren. Etwas später, im Jahr 599, liegt die obere chronologische Grenze für die Keramik aus Stărmen. In die Regierungszeit des Maurikios Tiberios (582-602) datieren je ein Münzhort von Ibida, ${ }^{33}$ Tropaeum Traiani $^{34}$, Ulmetum $^{35}$ sowie zwei aus Kabyle. ${ }^{36}$ Aus Tărnovo stammt ein Münzhort mit Schlussmünzen aus der Zeit Phokas (602-610). ${ }^{37}$ Vor 613/614, in die Zeit des Heraklios, datieren die slawischen Funde aus Independența, Istria, Axiopolis, Tropaeum Traiani und Ibida. Die bisher spätesten, nämlich aus der Zeit vor 629-632, sind jene aus Tomi, Callatis und Tărnovo. Die hier angeführten frühslawischen Funde aus Befestigungen und offenen Siedlungen, für die keine ausreichenden stratigraphischen Einbindungen vorliegen, dürften wohl ebenfalls in die Zeit vor den spätesten frühbyzantinischen Münzfunden aus den betreffenden Objekten zu datieren sein. Jedoch verlangt diese Frage weitere Untersuchungen mit dem Ziel der Gewinnung neuer chronologisch relevanter Funde und Befunde.

Die archäologischen und schriftlichen Quellen zeigen, dass einige der Befestigungen am skythischen Limes und an der Schwarzmeerküste - obschon in stark veränderter Form - auch nach der slawischen Ansiedlung weiterexistierten. Dazu gehören Troesmis, Ulmetum, Istria, Ibida, Tomi und Durostorum. Eine gleiche Situation ist für die Zentren südlich des Haemus vorauszusetzen, so für Philippopolis, Karasura, Augusta Traiana. Aus den Siedlungen Dinogetia, Capidava, Augusta, Pautalia und Ljubenovo fehlen Hinweise auf eine anhaltende Nutzung nach ihrer Zerstörung am Ende des 6. Jahrhunderts. Hier fanden sich Hinterlassenschaften, die erst wieder in das frühe Mittelalter gehören.

Die Zusammenhänge, in der die Mehrzahl der hier behandelten archäologischen Materialien gefunden wurden, unterstützen die These von I. Dujčev, V. Beševliev und M. Comşa, wonach die frühe slawische Ansiedlung südlich der Donau im Rahmen eines Föderatenstatus erfolgte. Das Überwiegen von Keramik des Penkovka-Typs sowie das Vorkommen von Bügelfibeln, wie sie nur im Penkovka-Kulturkreis zu finden sind, erlaubt die Schlussfolgerung, dass die Mehrzahl der slawischen foederati zur Gruppe der Anten gehörte. Die Datierung dieser Hinterlassenschaften in die 30er Jahren des 6. Jahrhunderts, wie sie jetzt für Troesmis, Ulmetum und Adina möglich ist, zwingt zu einer Korrektur des von Comşa ursprünglich entworfenen Bildes vom Auftreten erster Funde des Penkovka-Typs an der unteren Donau im dritten Viertel des 6. Jahrhunderts. ${ }^{38}$ Zwischen den vorgestellten slawischen Funden und der Gruppe Popina-Garvan (Kultur I) besteht weder eine kulturelle noch eine chronologische Verbindung. Die Wurzeln für die Kultur Hlinčea I und ihrer Entsprechung an der unteren Donau, der Gruppe Popina-Garvan, sind im Kulturkreis Prag-Korčak zu suchen.

33 Poenaru/Mitrea 1979, 265.

34 Mitrea 1980, 376.

35 Jordanov 1987, 207.

36 Mitteilung von J. Jurukova, der wir an dieser Stelle danken möchten.

37 Aleksiev 1986, 137-138.

38 Comşa 1973, 215-217. 
Unbekannt bleibt das spätere Schicksal jener Slawen, die bereits im 6. Jahrhundert den Föderalenstatus erlangten. Möglicherweise verblieb ein Teil von ihnen noch bis in die Zeit der massenhaften slawischen Ansiedlung an den von ihnen ursprünglich aufgesuchten Orten oder vermischte sich in den 20er und 30er Jahren des 7. Jahrhunderts mit den Neuankömmlingen, wie es von Beševliev vermutet wurde. Genau so gut wäre es möglich, dass ein anderer Teil von ihnen die byzantinischen Festungen verließ und mit der restlichen örtlichen Bevölkerung nach Süden zog. Nur eine genaue Erforschung der slawischen Kultur des 8. bis 9. Jahrhunderts auf dem gesamten Gebiet Bulgariens wird uns einer befriedigenden Antwort auf diese Frage näher bringen.

\section{Katalog}

1. Dinogetia (Garvăn, Dobrudscha, RO)

Spätantike und frühbyzantinische Festung. Die oberste Schicht enthält späteste Münzen der Jahre 591/592 und ist abgebrannt.

1.1. Innerhalb der Festung wurden die Überreste von slawischen Häusern mit Keramik der Typen I, II und IV nach Prichodnjuk gefunden. Die Häuser sind ebenfalls abgebrannt. Abb. 5,2-11.

1.2. Im selben Niveau, aus welchem die Keramik stammt, wurde die Kopfplatte einer Bügelfibel mit halbrunder Kopfplatte (ähnlich Typ I D nach Werner) gefunden. Abb. 5,1.

Lit.: TIR L-35, 1969, 38; Ştefan/Barnea/Comşa/Mitrea 1961, 587, 593.; Barnea 1966, 237-239, Abb. 13; Comşa 1970, Abb. 1; Ştefan u. Mitarb. 1959, 633, Abb. 7 (Fibel); Scorpan 1972, 371 (Münzen).

2. Niculițel (Dobrudscha, RO)

Erdbefestigung.

2.1. In der Wallschüttung wurden einige Fragmente frühslawischer Keramik, in Machart und Verzierung ähnlich der Gruppe Popina-Garvan gefunden.

Lit.: Škorpil 1905a, 517-518 Taf. 63,6; Diaconu 1972, 317, Abb. 7.

3. Troesmis (Iglița -Turcoaia, Dobrudscha, RO)

Spätantike und frühbyzantinische Festung. Die spätesten Münzen der byzantinischen Zeit wurden unter Maurikios Tiberios 591/592 geprägt.

3.1. Keramik des Typs II nach Prichodnjuk wurde im Haus in C 15 gefunden. Außerhalb des Hauses wurde eine Münze von Justinian I. (539/549) gefunden, die einen terminus ante quem für die Zerstörung des Hauses darstellt.

Lit.: TIR L-35, 1969, 73-74; Baumann 1980, 165, Taf. 22,2 (Keramik); Oberländer-Târnoveanu 1980, 288 (Münzen, stratigraphische Angaben).

4. Aegyssus (Tulcea, Dobrudscha, RO)

Spätantike und frühbyzantinische Festung.

4.1. In den frühbyzantinischen Häusern auf dem Gebiet der Festung wurde Keramik der Typen I und III nach Prichodnjuk gefunden.

Lit.: TIR L-35, 1969, 21-22; Vasiliu 1980, 437-449, Taf. VIII,1-5.I. 
5. Independența (=Murighiol, Dobrudscha, RO)

Spätantike und frühbyzantinische Festung.

5.1. Keramik der Typen I und II nach Prichodnjuk wurde in den Schichten 12 und 13 gefunden. Das Ende der Schicht 12 wird über Münzen des Heraklios (613/614) datiert. Abb. 4,5-8.

Lit.: TIR L-35, 1969, 52; Opaiț 1991a, 157, 198, Taf. 34.

6. Halmiris (Cetatea Zaparojenilor, Tulcea, Dobrudscha, RO)

Frühbyzantinische Festung.

6.1. Unpublizierte frühslawische Keramik, die nach M. Comşa die Anwesenheit von frühen Slawen auf dem Gebiet der Festung anzeigt.

Lit.: TIR, 1969, 39; Comşa 1973, Abb. 14, N 15.

7. Beroe (Piatra Frecăței, Dobrudscha, RO)

Spätantike und frühbyzantinische Festung.

7.1. Frühslawische Keramik der Typen I-III nach Prichodnjuk wurde in den Gebäuden, von denen eines eine Kaserne ist, gefunden. Die Schicht mit den Gebäuden wird zwischen 537/538 und 575/576 datiert. Sie zeigt Brandspuren und wird nicht von späteren Eingrabungen gestört. Abb. 6.

Lit.: TIR L-35, 1969, 26; Vâlceanu/Barnea 1975, 209-218, Abb. 3,4; Diaconu 1979, 165-166, Abb. 1, 2.

8. Capidava (Topalu/Capidava, Dobrudscha, RO)

Spätantike und frühbyzantinische Festung. Zerstört am Ende des 6. - Beginn des 7. Jahrhunderts. Die spätesten Münzen wurden unter Maurikios Tiberios (582-602) geprägt.

8.1. Keramik vom Typ II nach Prichodnjuk wurde bei den Ausgrabungen der Festung im Jahre 1949 gefunden.

Lit.: TIR L-35, 1969, 29; Scorpan 1968, 364, Abb. 22,a.b.

9. Ulmetum (Panteleimonul de Sus, Dobrudscha, RO)

Spätantike und frühbyzantinische Festung. Nach Angaben des Prokopius befreite und erneuerte Justinian die Stadt von den Slawen, die sich dort lange Zeit aufhielten.

Lit.: TIR L-35, 1969, 76; Beševliev 1968, 21.

10. Histria (Istria, Dobrudscha, RO)

Spätantike und frühbyzantinische Festung. Abgebrannt am Ende des 6. Jahrhunderts. Die spätesten Münzen in der Brandschicht sind 592/593 geprägt worden. Die darauf folgenden zwei Siedlungsschichten zeigen Spuren vom Verfall der Siedlung. Sie werden um 614 datiert.

10.1. Keramik des Typs II nach Prichodnjuk wurde in den letzten zwei Siedlungsschichten gefunden. Sie kann zwischen 592/593 und 614 datiert werden.

Lit.: TIR L-35, 1969, 45; Pippidi/Bordenache/Eftimie 1962, Abb. 4.2; Suceveanu/Scorpan 1971, 170-172.

11. Ibida (Slava Rusă, Dobrudscha, RO)

Spätantike und frühbyzantinische Festung. In Schicht 5 kann eine Unterbrechung des Münzumlaufes im Jahre 585/586 festgestellt werden, die wahrscheinlich im Zusammenhang mit den slawisch-awarischen Einfällen steht. Die spätesten Münzen sind von 613-615.

11.1. Von der Festung stammen zwei Fragmente von Bügelfibeln mit halbrunder Kopfplatte, die zum Typ II A nach Werner gehören. ${ }^{39}$

Lit.: TIR L-35, 1969, 67; Opaiț 1991b, 55.

39 Werner 1950, Taf. 36. 1.2. 
12. Axiopolis (Cernavodă, Dobrudscha, RO)

Spätantike und frühbyzantinische Festung.

12.1. Unpublizierte Keramik, die nach M. Comşa die Anwesenheit von frühen Slawen in der Festung bezeugt.

Lit.: TIR L-35, 1969, 24; Comşa 1973, Abb. 14,N 10.

13. Tomis (Constanța, Dobrudscha, RO)

Spätantike und frühbyzantinische Festung. Die spätesten in der Festung gefundenen Münzen sind von 629/631 und 630/631. In einer Siedlungsschicht des 6. Jahrhunderts unter der frühbyzantinischen Basilika fand sich ein handgefertigter Topf. Nach seiner Form und der Art der Verzierung steht er der Keramik aus der Nähe von București nahe..$^{40}$ Die Verzierung mit plastischen Leisten und Grübchen findet sich auch auf der Keramik vom Typ Penkovka. ${ }^{41}$ I. Rusanova bezeichnet ähnliche Gefäße als Unikate, die man zu einem geringen Anteil (1-5\%) in der Keramikgruppe vom Prager Typ findet. ${ }^{42}$

Lit.: TIR L-35, 1969, 72-73; Scorpan 1971, 139, Abb. 5; ders. 1972, 372.

14. Tropaeum Traiani (Adamclisi, Dobrudscha, RO)

Spätantike und frühbyzantinische Festung. Die Festung wurde nach 586/597 aufgegeben und verfiel allmählich. Eine dörfliche Siedlung ist bis 598/599 nachweisbar.

14.1. Nach M. Comşa wurde in den frühbyzantinischen Schichten frühslawische Keramik gefunden (unpubliziert).

14.2. In einem Grab trat eine Bügelfibel mit halbrunder Kopfplatte des Typs II C nach Werner zutage. ${ }^{43}$ Zwei weitere Exemplare wurden in einem Grab zusammen mit Keramik vom Typ Penkovka in Danceni gefunden. ${ }^{44}$

Lit.: TIR L-35, 1969, 74-75; Scorpan 1972, 370; Comşa 1973, Abb. 14, N 13; Papuc 1987, 207-216.

15. Callatis (Mangalia, Dobrudscha, RO)

Spätantike und frühbyzantinische Festung. Die spätesten Münzen stammen aus den Jahren $628 / 629$ und 630/631.

15.1. Keramik des Typs II nach Prichodnjuk wurde in der Festung unter der Brandschicht gefunden, die das Ende der Besiedlung belegt.

Lit.: Vulpe/Barnea 1968, 475-476; Diaconu 1959, Abb. 1,2-3.

16. Dervent, Păcuiul lui Soare (Dobrudscha, RO)

Frühbyzantinische Festung.

16.1. Kopfplatte einer Bügelfibel mit halbrunder Kopfplatte des Typs II A oder II B nach Werner.

Lit.: Ivanov 1984, 40; Diaconu 1962, 447-449.

17. Durosturum (Silistra, BG)

Spätantike und frühbyzantinische Festung.

17.1. Frühslawische Keramik wurde in der Brandschicht über den Ruinen des römischen Bades im östlichen Teil Silistras gefunden. ${ }^{45}$

40 Zirra/Cazimir 1963, 56-71, Abb. 15,1.8.

41 Prichodjuk 1991, Abb. 7,4, Abb. 8,7, Abb. 9,7.12.

42 Rusanova 1973, 11-12.

43 Werner 1950, 160-162, Taf. 39.

44 Rafalovič 1986, 25-27, Taf. 14,1-5.

45 Funde aus unpublizierten Grabungen von P. Donevski. 
17.2. Frühslawische Keramik aus dem frühbyzantinischen Kastell. Unter den Fragmenten finden sich Scherben ähnlich dem Typ II nach Prichodnjuk. Parallelen zu anderen Fragmenten sind im Fundmaterial slawischer Siedlungen des 6.-7. Jahrhunderts belegt. Abb. 4,1.

17.3. Fragment einer Bügelfibel mit halbrunder Kopfplatte. Erhalten ist ein Teil des Bügels und des Fußes, der mit zwei Paaren stilisierter Vogelköpfe verziert ist. Bronze. Maße: Länge 3,5 cm, Breite 1,4 cm. Die Fibel hat Parallelen in sicheren slawischen Zusammenhängen in Chansk II. ${ }^{46}$ Sie wurde in einer Brandschicht beim nordwestlichen fünfeckigen Turm des frühbyzantinischen Kastells gefunden. Die Schicht enthielt außerdem Fragmente eines Topfes vom Pastyrsker Typ und eine Münze des Justin II. und Sophia (565-576). Abb. 4,3.4.

17.4. Bogenförmige Fibel mit sternförmiger Fußplatte. Feldinv.-Nr. 2/1992. Abb. 4,2

Lit.: Angelova 1973, 89-90.

18. Adina (nicht lokalisiertes Kastell, östlich von Silistra?)

Nach Angaben des Prokopius wurde das Kastell von Justinian I. nach seiner Zerstörung durch die Slawen wieder aufgebaut.

Lit.: Beševliev 1968, 21.

19. Nigriniana-Candidiana (Malăk Preslavec, BG)

Spätantike und frühbyzantinische Festung.

19.1. Bronzene Bügelfibel. Die Kopf- und Fußplatte ist jeweils halbrund mit fünf Knöpfen und mit einem eingeritzten radialen Ornament verziert. Typ I L nach Werner. Analogie in einer Fibel aus der Nekropole bei Lači ${ }^{47}$ (bei Kruja, nördliches Dalmatien), die Werner im Zusammenhang mit der slawischen Eroberung des nordwestliche Balkans sieht. ${ }^{48}$ Museum Silistra, Inv.-Nr. 1777 II. Abb. 2,1.

Lit.: Velkov 1959, 24-29; Georgieva 1952, 282.

\section{Nova Černa $(B G)$}

Spätantike und frühbyzantinische Festung.

20.1. In einer Abfallgrube wurden Scherben frühslawischer Keramik des frühen Prager Typs zusammen mit einer Bügelfibel (20.4.) mit halbrunder Kopfplatte gefunden.

20.2. In einem abgebrannten Grubenhaus unter dem westlichen Befestigungswall wurde frühbyzantinische Keramik zusammen mit einem ganzen und weiteren fragmentierten handgemachten Töpfen gefunden. Das vollständig erhaltene Gefäß hat eine gerundete Wandung und seine maximale Ausdehnung in der Mitte des Gefäßkörpers. Es erinnert an Typ II nach Prichodnjuk. Abb. 8.

20.3. Außerhalb der Befestigung, unmittelbar neben dem westlichen Wall, wurden 1970 ovale Wirtschaftsgruben und drei Backöfen ausgegraben. Die dabei gefundene Keramik ist frühbyzantinisch, germanisch sowie vom Penkovka-Typ I-II nach Prichodnjuk. Abb. 9.

20.4. Eine fast vollständig zerstörte Bügelfibel mit halbrunder Kopfplatte, wahrscheinlich Typ II A, wurde in einer Abfallgrube zusammen mit frühslawischer Keramik gefunden. Ihre Größe verweist auf eventuelle Parallelen aus Tărnovo und Tropaeum Traiani.

Lit.: Milčev/Angelova 1971, 23-24; Angelova 1980, 3.

46 Rafalovič 1986, 97 Abb. 29,2.

47 Werner 1950, 155, Taf. 31,55.

48 Ebd., 171-172. 
21. Appiaria (Rjachovo, BG)

Spätantike und frühbyzantinische Festung.

21.1. Bügelfibel mit halbrunder Kopfplatte. Bronze. Kopfplatte mit fünf Knöpfen und einem eingeritztem Ornament in zwei Zonen. Ein mit Querkanneluren versehener Fuß, der in einem stilisierten Tierkopf endet. Hoher Nadelhalter. Maße: Länge 4,4 cm, Breite 2,7 cm. Analogie zu Fibeln aus Novi Banovci, Bosnien und Herzegovina. ${ }^{49}$ Privatsammlung. Abb. 2,7.

Lit.: Škorpil 1905b, 450-451, CXV 4,I.III.

22. Iatrus (Krivina, BG)

Frühbyzantinisches Kastell. Nach M. Wendel wird der Ort nach der Zerstörung des Kastells am Anfang des 7. Jahrhunderts nicht aufgegeben. Ein Verfall der Siedlung kann festgestellt werden (Phase E). In einer frühbyzantinischen Schicht wurden Funde dokumentiert, welche die Anwesenheit von Slawen belegen. Es treten Grubenhäuser auf, Scherben handgemachter Keramik und eine Bügelfibel mit halbrunder Kopfplatte.

22.1. In der Schicht neben dem erhaltenen Teil des Hauses 55/4s wurden frühbyzantinische Keramik sowie einige handgemachte Scherben gefunden. Darunter befindet sich der untere Teil eines Topfes, der den slawischen Töpfen aus Nova Černa und Hărlec ähnelt (Typ II nach Prichodnjuk). Ein weiterer Topf dieser Art ist im Bereich der Schulter verziert. Abb. 3,7.8.

22.2. Eine bronzene Bügelfibel mit halbrunder Kopfplatte (Typ I K nach Werner) wurde in Objekt 66/23 N gefunden. ${ }^{50}$ Sie hat eine Parallele in einer Fibel aus der slawischen Nekropole von Sărata Monteoru. ${ }^{51}$ Abb. 3,9.

Lit.: Wendel 1986, 207, Taf. 40,a.b, Taf. 23,1.2, 179 N 665.

\section{Stărmen (BG)}

23.1. Bei den Grabungen in der frühmittelalterlichen Siedlung wurde handgefertigte slawische Keramik gefunden. Die publizierten Fragmente können nicht bestimmt werden. Einzig das restaurierte Gefäß aus Objekt 79 kann zum Typ IV nach Prichodnjuk gestellt werden. In einem Vorbericht des polnischen Teams wurde die frühslawische Keramik um 549-599 datiert. An gleicher Stelle bestand eine frühbyzantinische Siedlung, wie die dort gefundenen Münzen und Keramikfragmente belegen. Abb. 3,2.

23.2. Aus der Gegend um Stărmen stammt eine Bügelfibel mit halbrunder Kopfplatte mit einer Tiermaske am Fuß. Abb. 3,3.

23.3. Über eine zweite Bügelfibel mit halbrunder Kopfplatte des Typs I K nach Werner berichtet A. Haralambieva.

Lit.: Kurnatovska 1980, 69 Taf. 54,73, Abb. 5; Vălev 1982, 89, Abb. 20,1-10; Michajlov 1982, 118; Hensel/ Dymaszewska/Dymaszewski/Hilczerowna 1970, 235-236, Abb. 3; Ivanov/Dimova/Antonov 1972, 31; Haralambieva 1993, 30 Abb. 6,8.

\section{Novgrad (BG)}

24.1. Bronzene Bügelfibel mit halbrunder Kopfplatte, ähnlich der aus Stărmen. Nach S. Stefanov stammt die Fibel aus der frühmittelalterlichen Siedlung. An derselben Stelle wurden jedoch Gebäudereste gefunden, die über Münzen Justins II. (565-576) datiert werden.

Lit.: Stefanov 1974, 44.

49 Menghin 1987, 225 Abb. V,11k-m.

50 Werner 1950, 155, Taf. 31,50.

51 Nestor 1957, 289-295, Taf. 1,7.I. 
25. Augusta (Hărlec, BG)

Spätantike und frühbyzantinische Festung. Die Zerstörung der Siedlung durch einen slawischawarischen Überfall im Jahre 582 wird durch einen Münzhort in der letzten, abgebrannten Schicht bestätigt. Die Schlussmünze im Hortfund wurde unter Tiberios I. Konstantinos (578-582) geprägt.

25.1. Ein Topf des Typs II nach Prichodnjuk wurde neben der Festungsmauer gefunden. Abb. 3,4.

25.2. Zwei Bügelfibeln mit halbrunder Kopfplatte mit drei Knöpfen und rhombischer Fußplatte wurde auf dem Gelände der Festung gefunden. Sie sind mit Ritzungen verziert. Abb. 3,5.6.

Lit.: TIR K-34, 1976, 19; Mašov 1976, 38 Abb. 3; ders. 1980, 18 Abb. 14, Abb. 19.

26. Kosloduj (BG)

26.1. Aus dem zerstörten Brandgräberfeld im heutigen Stadtzentrum stammt eine Urne des Typs I nach Prichodnjuk.

Lit.: Angelova/Koleva 1992, 173, Taf. I,13.

27. Almus (Lom, BG)

Spätantike und frühbyzantinische Festung.

27.1. In der Westecke der Festung, unmittelbar neben der westlichen Festungsmauer, wurden drei Gefäße gefunden. ${ }^{52}$ Eines ist handgemacht, die anderen beiden sind auf der Töpferscheibe gefertigt. Der handgemachte Topf ist fast identisch mit einem in Vărba do Galamoč (Bosnien und Herzegovina) gefundenen. ${ }^{53}$

Lit.: TIR K-34, 1976, 14.

28. Dorticum (Vrăv, BG)

Spätantike und frühbyzantinische Festung.

28.1. Vom Gebiet der Festung stammt frühslawische Keramik. Die von Kr. Mijatev puplizierten ganzen Gefäße gehören zum Typ II nach Prichodnjuk.

Lit.: Mijatev 1948, 48, Abb. 57,3.4; Štereva 1991, 68, Abb. 4, Abb. 5.

29. Jakimovo (BG)

Frühbyzantinische Befestigung in der Flur Gradišteto.

29.1. In der Flur Gradišteto und in der Flur Nad Urvata wurde frühslawische Keramik gefunden, die an den Beginn des 7. Jahrhunderts datiert werden kann.

Lit.: Milčev (Manuskript); Angelova/Koleva 1992, 173-179, Taf. III.

30. Vălčedrăm (BG)

30.1. Frühslawische Keramik, die an das Ende des 6. und den Beginn des 7. Jahrhunderts datiert werden kann.

Lit.: Milčev (Manuskript); Angelova/Koleva 1992.

52 Mitteilung von B. Stoičkov, für die wir ihm an dieser Stelle danken.

53 Miletić 1980/1981, 213-224, Taf. I.2. 


\section{Tărnovo (BG)}

Frühbyzantinische Festung. Die spätesten Münzen in der frühbyzantinischen Schicht sind von Heraklios (610-641) und seinem Sohn Konstantin.

31.1. Bronzene Bügelfibel mit halbrunder Kopfplatte des Typs II C nach Werner. ${ }^{54}$ Sie wurde im Gebäude N, Sektor IX am Westhang des Carevec-Hügels in einer frühbyzantinischen Schicht gefunden.

Lit.: Angelov 1973, 271; Dremsizova-Nelčinova 1983, 18 Abb. 7a.

32. Region Dobrič, ohne genauen Fundort (BG)

32.1. Dem Historischen Museum Dobrič wurde eine bronzene Figur des Typs „Martinovka“ ohne genaue Fundortangaben übergeben. Abb. 2,2.

Lit.: Jotov 1991, 70-71.

\section{Goleš (BG)}

Frühbyzantinische Festung. Die spätesten Münzen auf dem Territorium sind von Justin II. (565-578).

33.1. Keramik des Typs II nach Prichodnjuk wurde bei Ausgrabungen auf dem Gelände der Festung gefunden. $.^{55} \mathrm{Abb} .3,1$.

Lit.: Părvan 1924, 219.

\section{Tušovica (BG)}

Frühbyzantinische Festung in der Flur Kaleto.

34.1. Aus der Flur Kaleto stammt eine kleine Bügelfibel mit halbrunder Kopfplatte des Typs I K nach Werner. ${ }^{56}$ Maße: Länge 3,4 cm. ${ }^{57}$ Historisches Kreismuseum Šumen, Inv.-Nr. 109.

Lit.: Dremsizova-Nelčinova/Antonova 1975, 61 Nr. 313.

\section{Riš (BG)}

Aus der Gegend um Riš wurden dem Historischen Kreismuseum Šumen drei Bügelfibeln mit halbrunder Kopfplatte übergeben. Aufgrund der fehlenden Fundortangaben können diese Funde nicht mit einer der nahegelegenen frühbyzantinischen Festungen in Verbindung gebracht werden. Ein Zusammenhang darf jedoch nicht ausgeschlossen werden.

35.1. Bügelfibel mit halbrunder Kopfplatte und fünf Knöpfen, von denen einer abgebrochen ist. Lyraförmige Fußplatte, die mit zwei stilisierten Vogelköpfen verziert ist. Kopf- und Fußplatte sind mit geritzten Ornamenten verziert. Maße: Länge 4,4 cm, Breite 2,5 cm. Gehört zum Typ I C nach Werner. ${ }^{58}$ Sie ähnelt einer in Sărata Monteoru gefundenen Fibel..$^{59} \mathrm{Zu}$ sammen mit frühslawischer Keramik wurde eine solche Fibel auch in Poian (südöstliches Siebenbürgen) gefunden. ${ }^{60}$ Mus. Inv. Nr. 9093. Abb. 2,6.

54 Werner 1950, 160-162, Taf. 39.

55 Information von G. Atanasov, Historisches Museum Silistra, für die wir ihm an dieser Stelle danken.

56 Werner 1950, 155.

57 Die Fibel wurde uns von G. Atanasov zur Verfügung gestellt.

58 Werner 1950, Nr. 20.

59 Nestor/Zaharia 1959, Abb. 3.

60 Szekely 1970, 125-136, Abb. 7,1.1a. 
35.2. Bügelfibel mit halbrunder Kopfplatte, fünf Knöpfen und rhombischer Fußplatte mit stilisierten Vogelköpfen. Sie endet in einem Tierkopf. Kopf- und Fußplatte sind mit geritzten Ornamenten verziert. Bronze, gegossen. Nach den Abmessungen slawischer Typ (klein), kann aber bisher nicht näher bestimmt werden.

35.3. Gegossene Bronzefibel mit dreieckiger Kopfplatte und drei Knöpfen. Verlängerte rhombische Fußplatte. Der Bügel und das Ende der Fußplatte sind mit geritzten Linien verziert. Maße: Länge 5,8 cm, Breite 2,4 cm. Eine ähnliche Fibel ohne Verzierung wurde in Sărata Monteoru gefundenen. ${ }^{61}$ Mus. Inv. Nr. 9070. Abb. 2,5.

Lit.: Dremsizova-Nelčinova/Antonova 1975, 57, Nr. 281, Nr. 282.

36. Ljuljakovo (BG)

36.1. Bügelfibel mit halbrunder Kopfplatte des Typs I B nach Werner. ${ }^{62}$ Abb. 2,3.

Lit.: Ovčarov/Vaklinova 1978, Abb. 98.

37. Kabyle (BG)

Spätantike und frühbyzantinische Festung.

37.1. Bügelfibelfragment mit halbrunder Fußplatte des Typs I B nach Werner. Abb. 2,9.

37.2. Bügelfibel mit halbrunder Kopfplatte mit fünf Knöpfen, von denen der mittlere leicht länglich ist. Bronze. Verziert mit einem geritzten S-Ornament. Länglicher rhombischer Fuß mit zwei halbrunden Ausstülpungen und stark stilisierten Tierköpfen am Ende. Maße: Länge 8,1 cm, Breite 3,5 cm.

Lit.: Werner 1950, 152, Nr. 10; Krajčev 1986, 4.

38. Augusta Traiana (Stara Zagora, $\mathrm{BG}$ )

Spätantike und frühbyzantinische Stadt. Die letzte frühbyzantinische Schicht wird in das 6. bis frühe 7. Jahrhundert datiert. Die letzten Münzen darin sind von Maurikios Tiberios (582-602).

38.1. In einem Grubenhaus, das in ein spätantikes Gebäude mit Mosaiken eingetieft ist, wurde handgemachte slawische Keramik gefunden. Darunter befand sich auch ein kleines Gefäß mit zylindrischem Körper. Die Form und die Art der Fertigung erinnern an Gefäße aus dem Gebiet des awarischen Khaganats. ${ }^{63}$

38.2. Aus dem Stadtgebiet stammt ein Gefäß, das eine seltene Form im heutigen Bulgarien darstellt. Seine nächste Parallele hat das Gefäß in Argos, in einer Brandschicht mit Münzen der Jahre $585 / 586 .{ }^{64}$

38.3. Bügelfibel mit halbrunder Kopfplatte des Typs I K nach Werner. Sie ist einer Fibel aus Sărata Monteoru ähnlich. ${ }^{65}$ Abb. 2,8 .

Lit.: Nikolov 1965, 18; Dončeva-Petkova 1977, 143; Werner 1950, Nr. 49.

\section{Ljubenovo (BG)}

Frühbyzantinische Festung. Die spätesten Münzen der frühbyzantinischen Schicht sind von Tiberios I. Konstantinos (578-582).

39.1. Frühslawische Keramik, ähnlich Typ II und IV nach Prichodnjuk. Einige Scherben erinnern an frühe Formen des Prager Typs. Abb. 7.

Lit.: Aladžov/Balabanjan 1972, 105-139.

61 Nestor/Zaharia 1959, Abb. 1,2.

62 Werner 1950, 151, Taf. 27,6.

63 Eisner 1952, Taf. 40,4, Taf. 61,1, Taf. 99,4; Točik 1968, Taf. 17,29.

64 Aupert 1980, Abb. 32.

65 Nestor 1957, Abb. 1,7. 
40. Konstantia (Marica, BG)

Frühbyzantinische Festung.

40.1. Keramik des Typs II nach Prichodnjuk wurde auf dem Gebiet der frühbyzantinischen Befestigung gefunden. Die stratigraphischen Zuordnung ist unsicher, der archaische Typus zeigt jedoch, dass ein Zusammenhang mit den frühbyzantinischen Schichten nicht ausgeschlossen werden kann.

Lit.: Aladžov 1981, 254-265.

41. Karasura (Rupkite, BG)

Frühbyzantinische Festung.

41.1. In einem Raum an der nördlichen Festungsmauer wurde eine Münze aus der zweiten Hälfte des 6. Jahrhunderts zusammen mit spätantiker Keramik gefunden. Dabei lag auch ein handgemachter Topf vom Prager Typ. ${ }^{66}$

Lit.: Nikolov/Jankov/Wendel/Böttger 1984, 154.

42. Philippopolis (Plovdiv, BG)

Spätantike und frühbyzantinische Stadt.

42.1. Bügelfibel mit halbrunder Kopfplatte und fünf Knöpfen, von denen einer abgebrochen ist. Bronze. Rhombische Fußplatte mit einem Paar Vogelköpfen und einem Paar gewöhnlicher Ausstülpungen. Auf der Fußplatte ist ein menschliches Gesicht dargestellt. Kopf- und Fußplatte sind mit geritzten, geometrischen Ornamenten verziert. Maße: Länge 6,9 cm, Breite $3,5 \mathrm{~cm}$. Die Fibel gehört zum Typ I D nach Werner. Eine ähnliche wurde in der Nekropole von Sărata Monteoru gefunden. ${ }^{67}$ Museum Plovdiv. Abb. 2.4.

43. Pautalia (Kjustendil, BG) ${ }^{68}$

Frühbyzantinische Festung in der Flur Hisarlăka. Die spätesten Münzen der Befestigung sind von Justin II. (565-578).

43.1. Aus der Festung stammen Fragmente frühslawischer Keramik des Typs II und IV nach Prichodnjuk.

Lit.: Gočeva 1970, 233-235.

(Übersetzung: Joachim Henning/Raiko Krauß)

66 Wir danken V. Neševa für die zusätzliche Information.

67 Nestor/Zaharia 1959, Abb. 11,2.

68 Wir danken R. Ivanov für die Bereitstellung der Funde und für die zusätzlichen Informationen. 

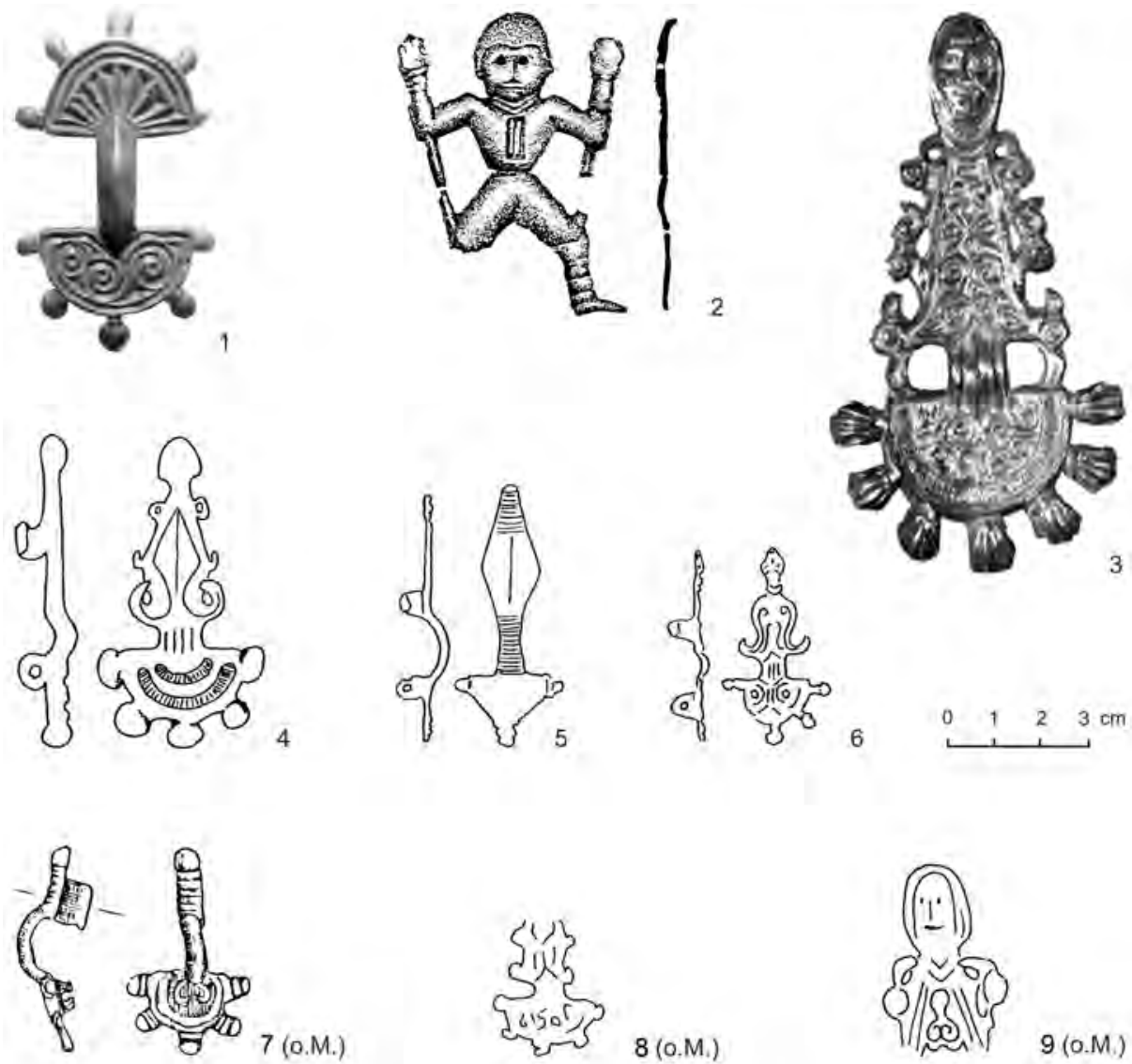

Abb. 2. 1. Nigriniana-Candidiana, 2. Region Dobrič, 3. Ljuljakovo, 4. Philippopolis, 5.6. Riš, 7. Appiaria, 8. Augusta Traiana, 9. Cabyle 

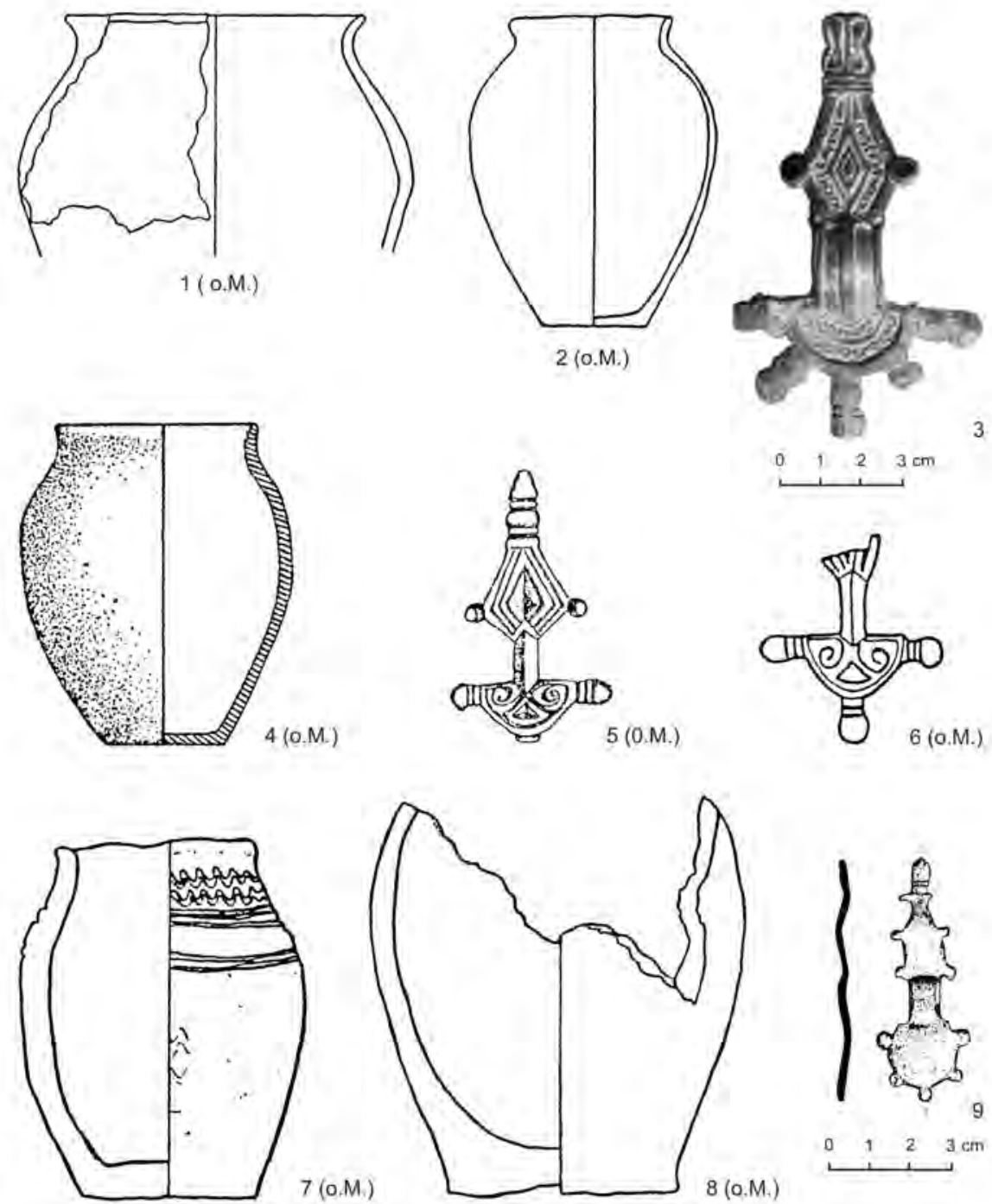

Abb. 3. 1.2. Goleš, 3. Stărmen, 4.-6. Augusta, 7.-9. Iatrus 

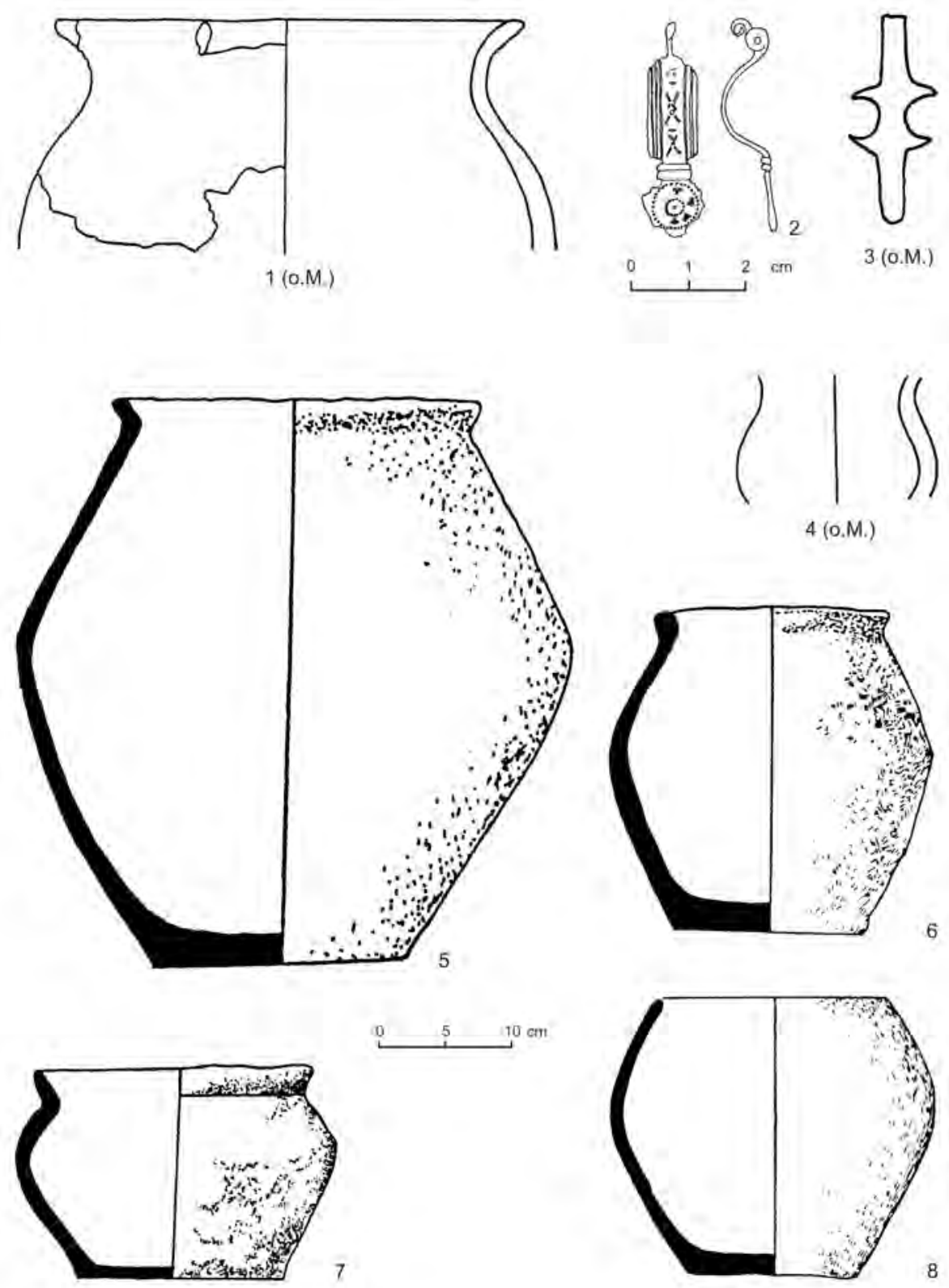

Abb. 4. 1.-4. Durostorum, 5.-8. Independența 

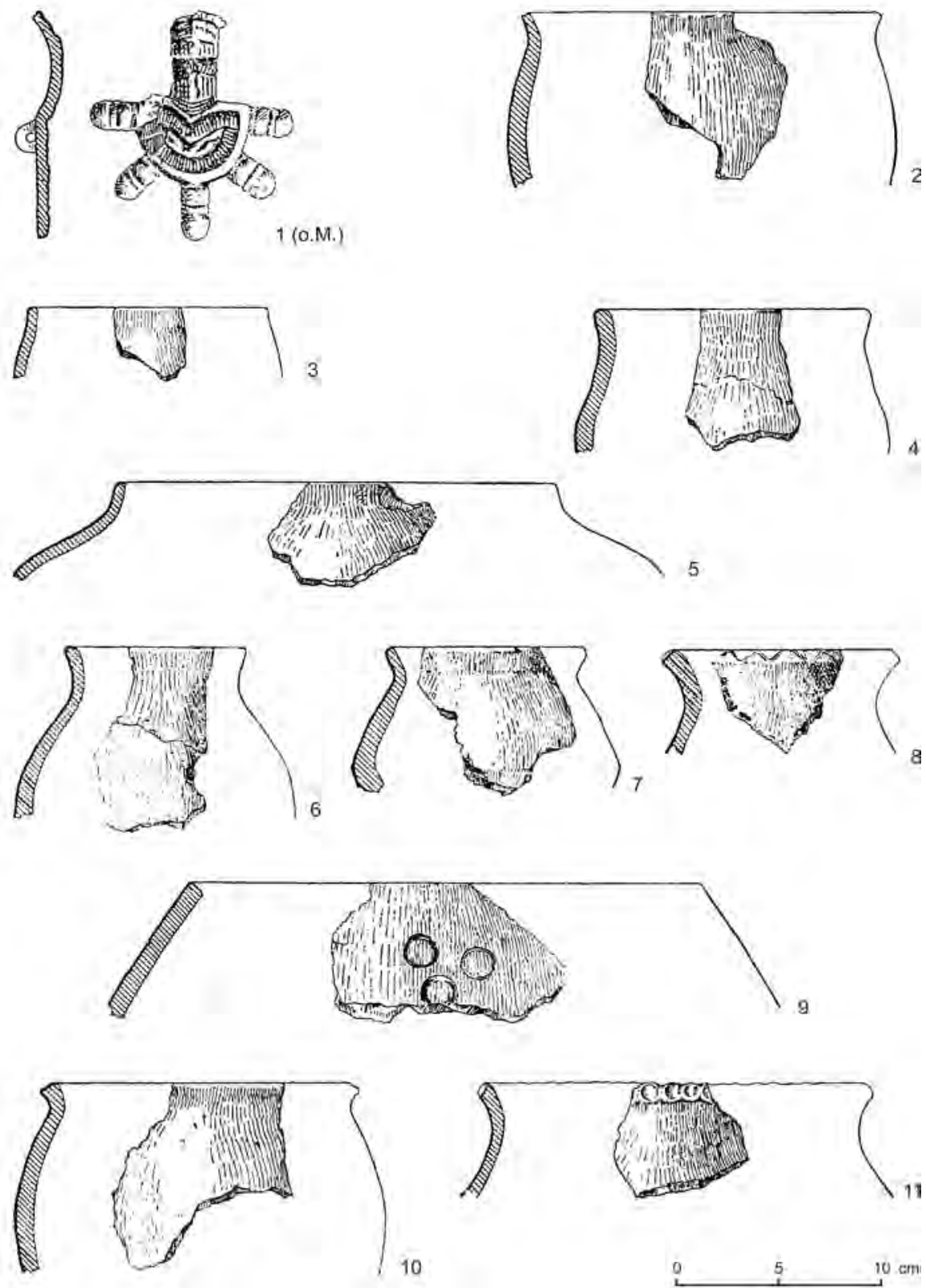

Abb. 5. 1.-11. Dinogetia 

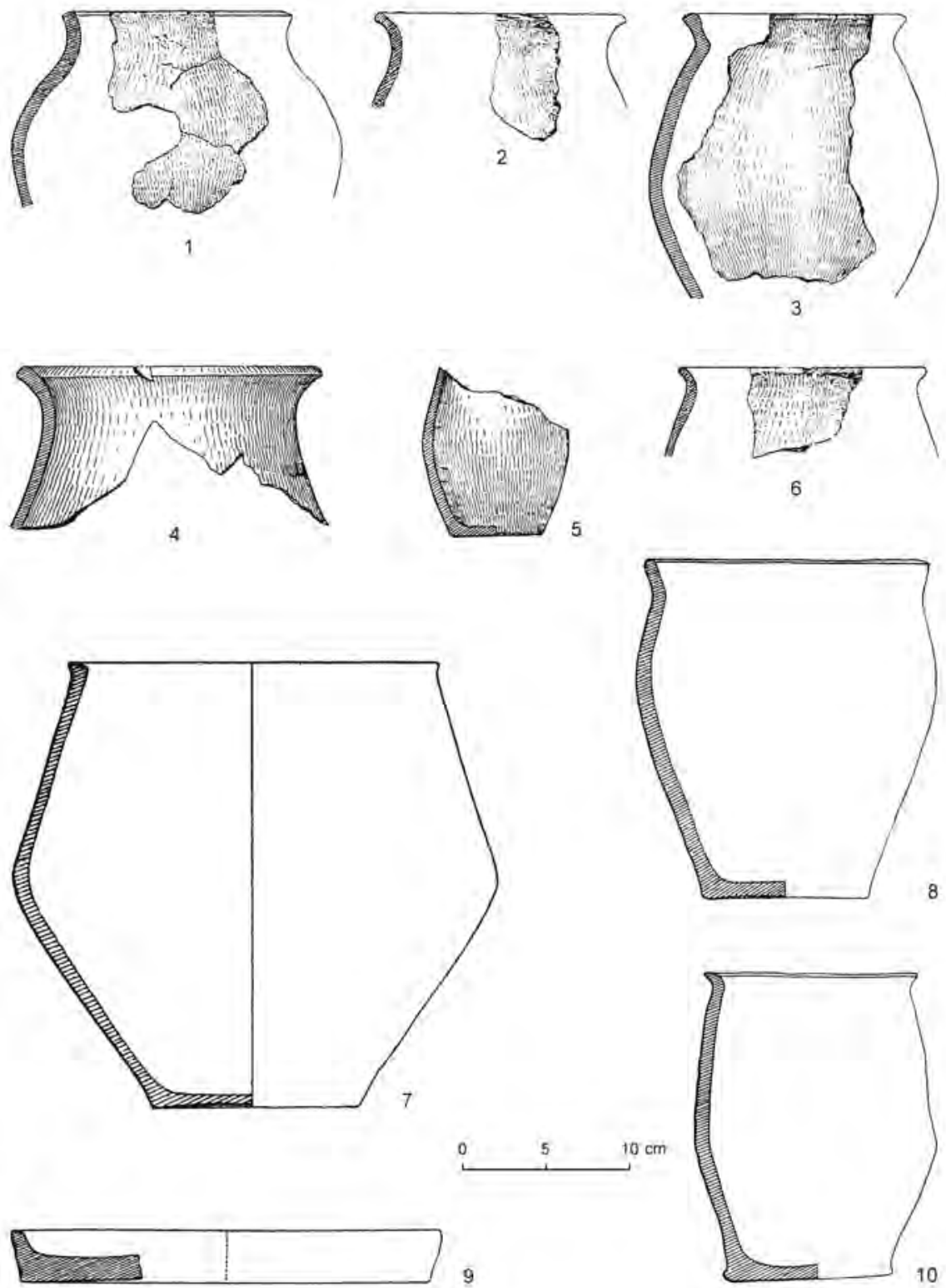

Abb. 6. 1.-10. Beroe 

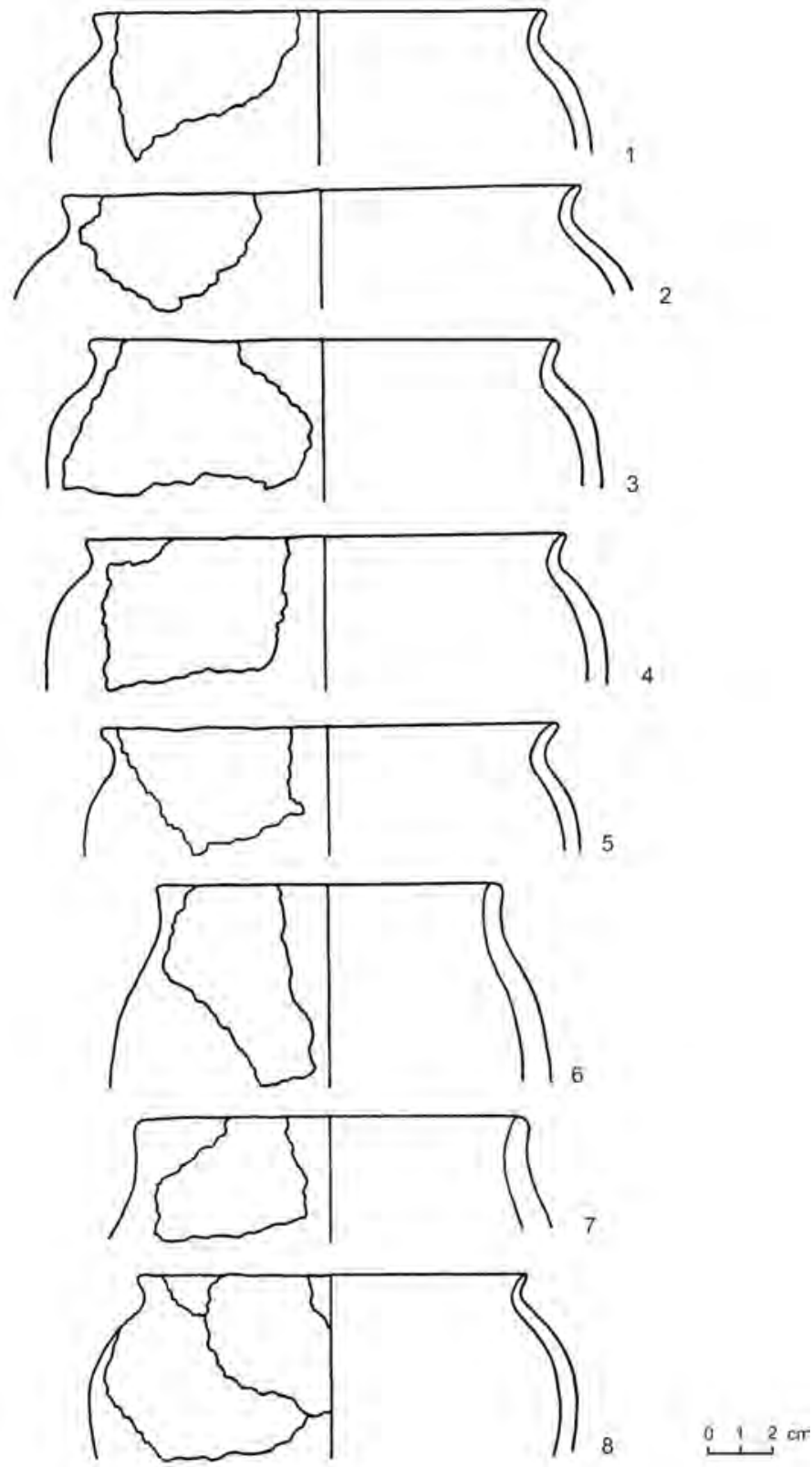

Abb. 7. 1.-8. Ljubenovo 

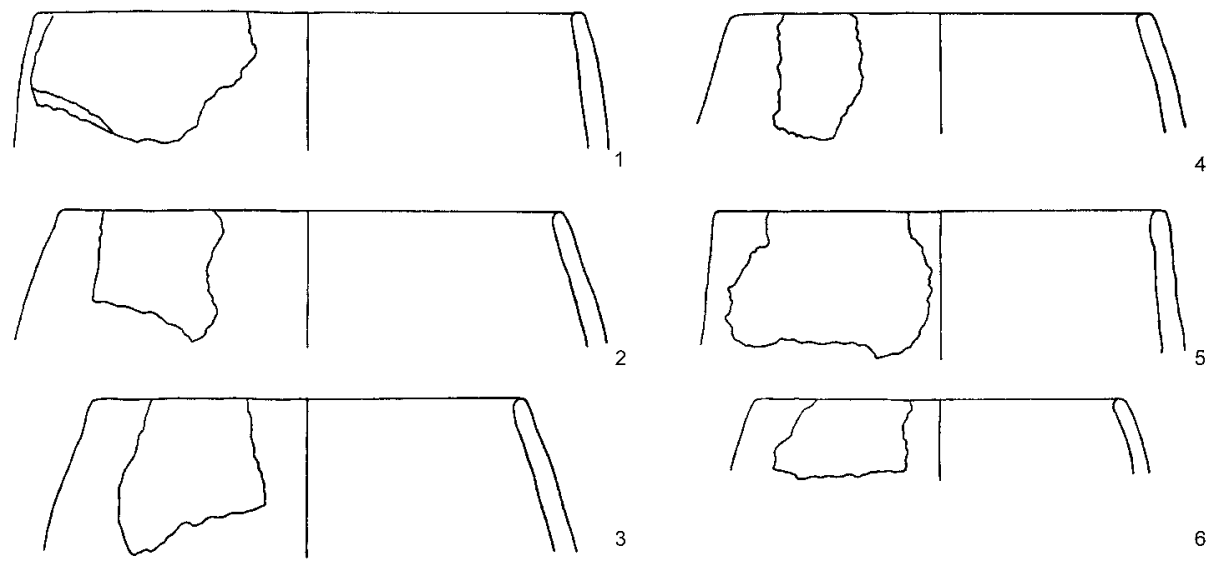

3

Abb. 8. 1.-6. Nova Černa - Grubenhaus unter dem Wall
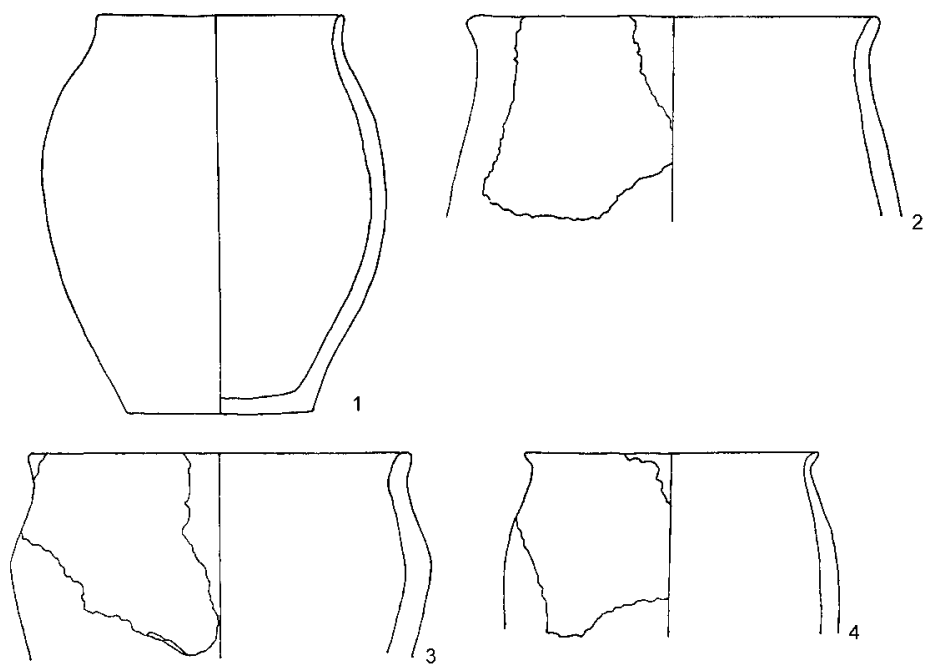

언. $2 \mathrm{~cm}$

Abb. 9. 1.-4. Nova Černa - Wirtschaftsgrube außerhalb der Befestigung 


\section{Bibliographie}

Aladžov 1981: Димчо Аладжов, „Археологически проучвания на Констанция (1967-1977)“, in: Известия на Начионалния исторически музей 3, 1981, S. 254-265.

Aladžov/Balabanjan 1972: Димчо Аладжов/Дикран Балабанян, „Разкопки в с. Любеново през 1968 г.“, in: Родопски сборник 3, 1972, S. 105-139.

Aleksiev 1986: Йордан Алексиев, „Разкопки на южния склон на хълма Царевец“, in: Археологически открития и разкопки през 1985 г., Велико Търново 1986, S. 137-138.

Angelov 1971: Димитър Ангелов, Образувание на българската народност, София 1971.

Angelov 1973: Никола Ангелов, „Културни пластове преди изграждането на двореца“, in: Царевград Търнов 1, София 1973, S. 268-275.

Angelova 1973: Стефка Ангелова, „Крепостната стена на Дуростурум-Дръстър-Силистра“, in: Археология 15/3, 1973, S. 89-90.

Angelova 1980: Стефка Ангелова, „По въпроса за раннославянската култура на юг и на север от Дунав през VI-VII в.“, in: Археология 22/4, 1980, S. 1-12.

Angelova 2003: Стефка Ангелова, „Етническият състав на населението в ранновизантийския Доростол през VI-VII в.“, in: Сборник в памет на д-р Петър Горбанов 2 (=Годишник на Софийския Университет, Исторически факултет, кн. Археология; Studia Archaeologica, Supplementum 1), София 2003, S. 245-251.

Angelova/Koleva 1992: Стефка Ангелова/Румяна Колева, „За някои особености на раннославянската керамика в Северозападна България“, in: Приноси към българската археология 1, София 1992, S. 173-179.

Aupert 1976: Pierre Aupert, „Chronique des fouilles et découverts archéologiques en Grèce en 1975“, in: Bulletin de correspondance hellénique 100/2, Athénes 1976, S. 646.

Aupert 1980: Pierre Aupert, „Céramique Slave à Argos (585 ap. J. C.)“, in: Études argiennes (=Bulletin de correspondance hellénique, Supplément 6), Paris 1980, S. 373-394.

Barnea 1966: Ion Barnea, „L'incendie de la cité de Dinogetia au VI e siècle“, in: Dacia N.S. 10, 1966, S. 237-259.

Baumann 1980: Victor Heinrich Baumann, „Observații topo-stratigrafice asupra locuirii de la Troesmis (Casetele 1-40)“, in: Peuce 8, 1980, S. 159-196.

Beševliev 1968: Веселин Бешевлиев, „За славянските племена в Северна България от VI до IX в.“, in: Преслав 1, София 1968, S. 17-28.

Bierbrauer 1989: Volker Bierbrauer, „Bronzene Bügelfibeln des 5. Jahrhunderts aus Südosteuropa“, in: Jahresschrift für mitteldeutsche Vorgeschichte 72, 1989, S. 141-149.

Comşa 1970: Maria Comşa, „Contributions a la question de la pénétration des Slaves au Sud $\mathrm{du}$ Danube durant $\mathrm{VI}^{\mathrm{e}}-\mathrm{VII}{ }^{\mathrm{e}}$ siècle", in: I ${ }^{e}$ Congrès International d'Archéologie Slave 3, Wrocław-Warszawa-Kraków 1970, S. 322-330.

Comşa 1973: Maria Comşa, „Die Slawen im karpatisch-donauländischen Raum im 6.-7. Jh.“, in: Zeitschrift für Archäologie 7, 1973, S. 197-228.

Constantiniu 1966: Margareta Constantiniu, „Elemente romano-bizantine în cultura materială a populației autohtone din partea centrală a Munteniei in sec. VI-VII“, in: Studii și cercetări de istorie veche 17/4, 1966, S. 665-678.

Csallany 1961: Deszö Csallany, Archäologische Denkmäler der Gepiden im Mitteldonaubecken (454-586 u. Z.), Budapest 1961.

Diaconu 1959: Petre Diaconu, „Un noi tip ceramic din epoca romanobizantină“, in: Studii şi cercetări de istorie veche 10/2, 1959, S. 487-490.

Diaconu 1962: Petre Diaconu, „Fibula digitată desoperită la Dervent“, in: Studii şi cercetări de istorie veche $13 / 2,1962$, S. 447-449. 
Diaconu 1972: Petre Diaconu, „Despre daterea »circumvalației« şi a biserici »treflate« de la Niculițel“, in: Studii şi cercetări de istorie veche 23/2, 1972, S. 307-319.

Diaconu 1979: Petre Diaconu, „Autour de la pénétration des Slaves au sud de Danube“, in: Rapports du III Congrès International d'Archeologie Slave 1, Bratislava 1979, S. 165-166.

Dimian 1957: Irmia Dimian, „Câteva descoperiri monetare bizantin pe teritoriul R.P.R.“, in: Studii și cercetării de numismatică 1, 1957, S. 189-216

Dončeva-Petkova 1977: Людмила Дончева-Петкова, Българска битова керамика през ранното средновековие (втора та половина на VI - края на X в.), София 1977.

Dremsizova-Nelčinova 1983: Цветана Дремсизова-Нелчинова, „Разкопки на сектор IX на Царевец - Велико Търново: Ранновизантийска епоха“, in: Проучвания и консервация на паметниците на културата в България 1, 1983, S. 15-22.

Dremsizova-Nelčinova/Antonova 1975: Цветана Дремсизова-Нелчинова/Вера Антонова, Каталог на археологическите паметници в Шуменски окръг, София 1975.

Dujčev 1972: Иван Дуйчев, “Балканският югоизток през VI в.” in: Българско средновековие, София 1972, S. 11-69.

Eisner 1952: Jan Eisner, Devinska Nová Ves: Slovanské pohrěbiště, Bratislava 1952.

Georgieva 1952: Соня Георгиева, „Разкопки на Обект S в «Горното градище» при с. Кадъкьой“, in: Известия на Археологическия институт 18, 1952, S. 259-283.

Gerasimov 1965: Тодор Герасимов, „Монетни съкровища намерени в България през 1964“, in: Известия на Археологическия институт 28, 1965, S. 248-250.

Gočeva 1970: Златозара Гочева, „Крепост в м. Хисарлька в гр. Кюстендил“, in: Известия на Българското историческо дружество 27, 1970, S. 233-235.

Haralambieva 1993: Anna Haralambieva, „Bügelfibeln aus dem 7. Jahrhunderts südlich der unteren Donau“, in: Actes du XII Congrés International des Sciences Préhistoriques et Protohistorique 4, Bratislava 1993, S. 25-32.

Hensel/Dymaszwewska/Dymaszewski/Hilczerowna 1970: Витолд Генсель/Уршула Дымачевска/ Александер Дымачевский/София Гильчерубна, „Резултаты полских археологических исследований в городище Стырмен, округ Русе в Болгарии 1962-1968“, in: Советская археология 1970/3, S. 235-236.

Ivanov 1984: С. А. Иванов, „Оборна балканских провинции Византии и проникновение „варваров“ на Балканы в первой половине VI века“, in: Византийский Временник 45 , 1984, S. 35-53.

Ivanov/Dimova/Antonov 1972: Димитър Иванов/Виолета Димова/Й. Антонов, Окръжен исторически музей Русе: Пътеводител, София 1972.

Jordanov 1987: Ivan Jordanov, „Dobrudža (491-1092): selon les donnés de la numismatique et de la sphragistique“, in: Dobrudža: Etudes ethno-culturelles, Sofia 1987, S. 204-210.

Jotov 1991: Валери Йотов, „Бронзовата фигура от Южна Добруджа“, in: Векове 1991/1-2, S. 70-71.

Kišvasi-Komša 1957: Мариа Кишваси-Комша, "Некоторые исторические выводы в связи с несколькими археологическими памятниками на територии PHP”, in: Dacia N.S. 1, 1957, S. 309-327.

Krajčev 1986: И. Крайчев, „Една интересна находка в Ямболския музей“, in: Народен другар (Ямбол) 3.07.1986, S. 4.

Kurnatowska 1980: Zofia Kurnatowska, „Osadnictwo wczesnosredniowieczne“, in: Styrmen nad Jantra (Butgaria): Badania archeologiczne w latach 1961-1964 i 1967-1968, WrocławWarszawa-Kraków-Gdańsk 1980, S. 69-246.

Lemerle 1954: Paul Lemerle, „Invasions et migrations dans les Balkans depuis la fin de l'époque romaine jusqu'au VIIIe siecle“, in: Revue Historique 211, Paris 1954, S. 349-361. 
Mašov 1976: Спас Машов, „Ранносредновековни фибули от Августа при с. Хърлец, Врачански окр.“, in: Археология 18/1, 1976, S. 35-38.

Mašov 1980: Спас Машов, Августа, Враца 1980.

Menghin 1987: Wilfried Menghin (Hrsg.), Germanen, Hunnen und Awaren: Schätze der Völkerwanderungszeit (=Ausstellungskatalog des Germanischen Nationalmuseums Nürnberg), Nürnberg 1987.

Michajlov 1982: Стамен Михайлов, „Общ поглед върху укрепеното селище при Стърмен и мястото, което то заема в развитието на ранносредновековния български град“, in: Ранносредновековно селище при с. Стърмен (=Разкопки и проучвания 7), София 1982, S. 118-143.

Mijatev 1948: Кристю Миятев, Славянската керамика в България и нейното значение за славянската археология на Балкана, София 1948.

Milčev (Manuskript): Атанас Милчев, „Археологическо проучване в долината на р. Цибрица (Якимово и Вълчедръм, Михайловградска област)““(=unpubliziertes Manuskript im Archiv der Universität Sofia, Historische Fakultät, Archäologie).

Milčev/Angelova 1971: Атанас Милчев/Стефка Ангелова, „Археологически разкопки и проучвания в местността Калето при с. Нова Черна, Силистренски окр. през 1967-1969 г.“, in: Годишник на Софийския Университет, философско-исторически факултет 63/3, История 1971, S. 1-113.

Miletić 1980/1981: Nada Miletić, „Ranosrednjovekovne keramičke posude iz Vrbe kod Glamoča“, in: Glasnik Zemalijskog Muzeja Bosne i Hercegovine u Sarajevo: Arheologija N.S. 35/36, 1980/1981, S. 213-224.

Mitrea 1980: Bucur Mitrea, „Découvertes monetaires en Roumanie“, in: Dacia N.S. 34, 1980, S. 375-377.

Mitrea 1981: Bucur Mitrea, „Découvertes monetaires en Roumanie - 1980“, in: Dacia N.S. 35, 1981, S. 384-389.

Nestor 1957: Ion Nestor, „La nécropole slave d'époque ancienne de Sărata Monteoru“, in: Dacia N.S. 1, 1957, S. 289-295.

Nestor/Zaharia 1959: Ion Nestor/Eugenia Zaharia, „Săpăturile de la Sărata Monteoru“, in: Materiale şi cercetării arheologice 6, 1959, S. 509-514.

Nikolov 1965: Димитър Николов, „Августа Траяна - Верея (II-VI в.)“, in: Археология 7/3, 1965, S. 11-21.

Nikolov/Jankov/Wendel/Böttger 1984: Димитър Николов/Димитър Янков/Михаел Вендел/ Буркхард Бьотгер, „Разкопки на средновековния пласт на обект «Антична пътна станция Карасура»“, in: Археологически открития и разкопки през 1983 г., Смолян 1984, S. 154.

Oberländer-Târnoveanu 1980: Ernst Oberländer-Târnoveanu, „Monede antice şi bizantine descoperite la Troesmis“, in: Peuce 8, 1980, S. 248-280.

Opaiţ 1991a: Andrei Opaiț, „Ceramica din aşezarea şi cetatea de la Independența (Murighiol) secolele V î.e.n. -VII e.n.“ in: Peuce 10/1, 1991, S. 133-182, Peuce 10/2, 1991, S. 165-216.

Opaiț 1991b: Andrei Opaiț, „O săpătura de salvare in oraşul antic Ibida“, in: Studii şi cercetări de istorie veche 42/1-2, 1991, S. 21-56.

Ovčarov/Vaklinova 1978: Димитър Овчаров/Маргарита Ваклинова, Ранновизантийски паметници от България IV-VII в., София 1978.

Papuc 1987: Gheorghe Papuc, „O fibulă de la Tropaeum Traiani şi cîteva considerații asupra fibulelor de acest tip“, in: Pontica 20, 1987, S. 207-216.

Pârvan 1924: Vasile Pârvan, „Sur un relief inedit du VII s. representant la Sainte Vierge“, in: Bulletin de la section historique de l'Academie Romaine 11, Bucureşti 1924, S. 218-223. 
Petre 1987: Aurelian Petre, La romanité en Scytie Mineure (IIe-VIIe siècle de notre ère), Bucureşti 1987.

Petrov 1981: Петър Петров, Образувание на българската държава, София 1981.

Pippidi/Bordenache/Eftimie 1962: Dionisie M. Pippidi/Gabriela Bordenache/Victoria Eftimie, „Şantierul arheologic Histria: Sectorul T“, in: Materiale şi cercetării arheologice 8, 1962, S. 383-389.

Pletnjova/Rusanova 1966: Светлана Плетнёва/Ирина П. Русанова, Rezension zu Văžarova 1965, in: Советская археология 10/3, 1966, S. 276-279.

Poenaru-Bordea/Mitrea 1979: Gheorghe Poenaru-Bordea/Bucur Mitrea, „Découvertes monetaires en Roumanie“, in: Dacia N.S. 33, 1979, S. 264-268.

Prichodnjuk 1991: Олег Михайлович Приходнюк, „Новые данные о пеньковской культуре“, in: Раннеславянский мир: Материаль и исследования, Москва 1991, S. 75-108.

Prokopios, De aedificiis: Prokopios von Caesarea, De aedificiis $=$ Прокопий Кесарийски, „За строежите“, превод и бележки Иван Дуйчев, in: Извори за българската история 2: Гръики извори за българската история 1, София 1958, S. 154-178.

Rafalovič 1968: Исаак Александрович Рафалович, „Поселение VI-VII вв. у с. Ханска“, in: Краткие сообщения института археологии 113, 1968, S. 75-103.

Rafalovič 1986: Исаак Александрович Рафалович, Данчены: Могильник черняховской культуры II-IV вв. н.э., Кишинев 1986.

Rafalovič/Lapušnjan 1973: Исаак Александрович Рафалович/В. Л. Лапушнян, "Работы Реутской археологической экспедиции", in: Археологические исследования в Молдовии в 1972, Кишинев 1973, S. 110-143.

Rusanova 1973: Ирина П. Русанова, Славянские древности VI-IX вв. между Днепром и Западным Бугом (=Археология СССР 25), Москва 1973.

Scorpan 1968: Constantin Scorpan, „Contribuții arheologice la probleme etnice ale Dobrogei antice“, in: Pontica 1, 1968, S. 361-364.

Scorpan 1971: Constantin Scorpan, „Noi descoperiri getice în Dobrogea romană secole II-VI e.n.“, in: Pontica 4, 1971, S. 137-141.

Scorpan 1972: Constantin Scorpan, „Date archeologice referitoare la sec. VI şi VII pe teritoriul Dobrogei (Resultate inedite la Tropaeum şi Sacidava)“, in: Pontica 5, 1972, S. 349-372.

Sedov 1978: Валентин Васильевич Седов, Происхождение и ранняя история славян, Москва 1978.

Škorpil 1905a: Карел Шкорпил, „Окопы и земляны укрепления Болгарии“, in: Известия Русского археологического института в Константинополе 10, 1905, S. 515-520.

Škorpil 1905b: Карел Шкорпил, „Некоторыя из дорог восточной Болгарии“, in: Известия Русского археологического института в Константинополе 10, 1905, S. 440-459.

Ştefan/Barnea/Comşa/Mitrea 1961: Gheoghe Ştefan/Ioan Barnea/Maria Comşa/Bucur Mitrea, „Şantierul arheologic Garvăn (Dinogeția)“, in: Materiale şi cercetării arheologice 7, Bucureşti 1961, S. 583-598.

Ştefan u. Mitarb. 1959: Gheorghe Ştefan u. Mitarb., Săpăturile de la Garvăn“, in: Materiale şi cercetării arheologice 5, Bucureşti 1959, S. 565-586.

Stefanov 1974: Стефан Стефанов, „Новград: Старинни селища“, in: Известия на Археологическия институт 34, 1974, S. 250-311.

Štereva 1991: Ирина Щерева, „Приноси към проучването на ранното средновековие в Северозападна България“", in: Историко-археологически изследвания: В памет на проф. д-р Станчо Ваклинов, Велико Търново 1991, S. 67-72.

Suceveanu/Scorpan 1971: Alexandru Suceveanu/Constantin Scorpan, „Stratigrafia Histriei romane tîrzii în lumine săpăturilor din 1969 şi 1970 in sectorul central“, in: Pontica 4, 1971, S. 155-172. 
Székely 1970: Z. Székely, „Die frühesten slawischen Siedlungen in Siebenbürgen“, in: Slavia Antiqua 17, 1970, S. 125-136.

Tăpkova-Zaimova 1971: Василка Тъпкова-Заимова, “Нашествия и етнически промени на Балканите", in: Археологически открития и разкопки през 1985 г., Вилико Търново 1986, S. 137-138.

Teodor 1978: Dan Gh. Teodor, Teritoriul est-carpatic în veacurile V-XI e.n., Iaşi 1978.

TIR L-35, 1969: Tabula Imperii Romani: L-35, Romula-Durostorum-Tomis, Bucureşti 1969.

TIR K-34, 1976: Tabula Imperii Romani: K-34 Naissus-Dyrrhachion-Scupi-Serdica-Thessalonike, hg. von Jaroslav Sasel, Ljubljana 1976.

Točik 1968: Anton Točik, Slawisch-awarisches Gräberfeld in Štúrovo (=Archaeologia Slovaca. Catalogi 2), Bratislava 1968.

Vâlceanu/Barnea 1975: P. Vâlceanu/Alexandru Barnea, „Ceramica lucrata cu mîna din asezarea romano-byzantina de la Piatra Frecâței“, in: Studii şi cercetări de istorie veche 26/2, 1975, S. 209-218.

Vălev 1982: Въло Вълев, „Археологически проучвания в югозападната част на ранносредновековното укрепено селище при Стьрмен (сектор II)“, in: Ранносредновековно селище при с. Стърмен (=Разкопки и проучвания 7), София 1982, S. 70-113.

Vasiliu 1980: Ioan Vasiliu, „Doua locuințe feudale timpurii de la Aegyssus“, in: Peuce 8, 1980, S. 437-449.

Văžarova 1976а: Живка Въжарова, Славянски и славяно-български селища в българските земи от края на VI-XI в., София 1976.

Văžarova 1976b: Живка Въжарова, Славяни и прабългари на територията на България по данни на некрополите от VI-XI в., София 1976.

Văžarova 1981: Живка Въжарова, „Славяни и номади на територията на днешните български земи“, in: Плиска-Преслав 3, София 1981, S. 16-59

Văžarova 1986: Живка Въжарова, Средновековното селище с. Гарван, Силистренски окръг VI-XI в., София 1986.

Velkov 1959: Велизар Велков, „Принос към античната география на Мизия. (NigrinianisCandidiana)“, in: Археология 1/1-2, 1959, S. 24-29;

Vulpe/Barnea 1968: Radu Vulpe/Ion Barnea, Din istoria Dobrogei 2, Bucureşti 1968.

Wendel 1986: Michael Wendel, „Die mittelalterlichen Siedlungen“, in: Iatrus-Krivina: Spätantike Befestigung und frühmittelalterliche Siedlung an der unteren Donau 3: Die mittelalterlichen Siedlungen, Berlin 1986, S. 27-210.

Werner 1950: Joachim Werner, ,Slawische Bügelfibeln des 7. Jahrhunderts“, in: Gustav Behrens/ Joachim Werner (Hrsg.), Festschrift zum 75. Geburtstag von Paul Reinecke am 25. September 1947, Mainz 1950, S. 150-172.

Zirra/Cazimir 1963: Vlad Zirra/Gheorghe Cazimir, „Unele rezultate ale săpăturilor arheologice de pe Cîmpul Boja din cartierul Militari“, in: Cercetari arheologice în Bucureşti 1, 1963, S. 56-71. 



\title{
Die Ausgrabungen in Iatrus und Karasura: $\mathrm{Zu}$ einigen Aspekten der Frühmittelalterforschung in Bulgarien
}

\author{
Michael Wendel
}

Die zwischen 1972 und 1978 in den frühmittelalterlichen Schichten über dem Limeskastell Iatrus bei Krivina, Bez. Ruse ${ }^{1}$ und die seit 1981 in der spätantiken Straßenstation und frühbyzantinischen Festung Karasura (Carassura) bei Rupkite, Gemeinde Čirpan, ${ }^{2}$ durchgeführten systematischen archäologischen Untersuchungen erbrachten beachtliche Ergebnisse zur Chronologie und Struktur dieser Siedlungsplätze. Die Ausgrabungsergebnisse machten sowohl Iatrus am Donaulimes wie auch Karasura in Nordthrakien zu wichtigen Zeugen für die Siedlungsgeschichte des frühen Mittelalters im Ostteil der Balkanhalbinsel.

Nach den Grabungsergebnissen hatte Iatrus im 6. Jahrhundert mehr dörflichen als städtischen Charakter. Es gibt für diese Zeit keine Hinweise auf die ethnische und soziale Zusammensetzung seiner Bewohner. Man kann aber annehmen, dass es sich um Föderaten gehandelt hat. Die nahezu vollständige Zerstörung des Kastells in der Mitte oder in der zweiten Hälfte des 5. Jahrhunderts (Ende Periode C), die Bauweise der in der Folgezeit errichteten Gebäude und auch die materielle Kultur deuten auf einen solchen Bevölkerungswechsel hin. Die Ausgräber nehmen eine weitere Brandkatastrophe am Ende des ersten Drittels des 6. Jahrhunderts an, bei der das gesamte Kastell völlig zerstört worden ist. ${ }^{3}$ In der Regierungszeit Iustinians I. (527 bis 565) wird Iatrus wieder

1 Die deutsch-bulgarischen Ausgrabungen begannen 1958 in Zusammenarbeit zwischen den Wissenschaftsakademien Bulgariens und der DDR und wurden vor allem in den siebziger Jahren intensiviert, vgl. Ivanov 1966; Iatrus-Krivina 1979, 9-14; Wendel 1986, 31-33. Die Ausgrabungen wurden 1981 eingestellt und während der achtziger Jahre in nur geringem Umfang durch das Museum Ruse weitergeführt. Vgl. Stančev 1989; 1990; 1995. Im Jahre 1992 wurden die Untersuchungen durch das Deutsche Archäologische Institut und die Bulgarische Akademie der Wissenschaften wieder aufgenommen und seitdem jährlich durchgeführt. Zu den Grabungsergebnissen bis 1989 vgl. Iatrus-Krivina 1995.

2 Die deutsch-bulgarischen Ausgrabungen in Rupkite begannen 1981 und wurden unter der Federführung beider Wissenschaftsakademien ohne Unterbrechung bis 1990 geführt. Vgl. Herrmann/Nikolov 1983; Böttger/Wendel 1983; Herrmann/Nikolov/Wendel 1986; Herrmann/Wendel/Neševa 1986; vgl. die Aufsätze in: Zeitschrift für Archäologie 26, 1992, 153-299; Wendel 1996; ders. 2002.

3 v. Bülow 1995, 60. 


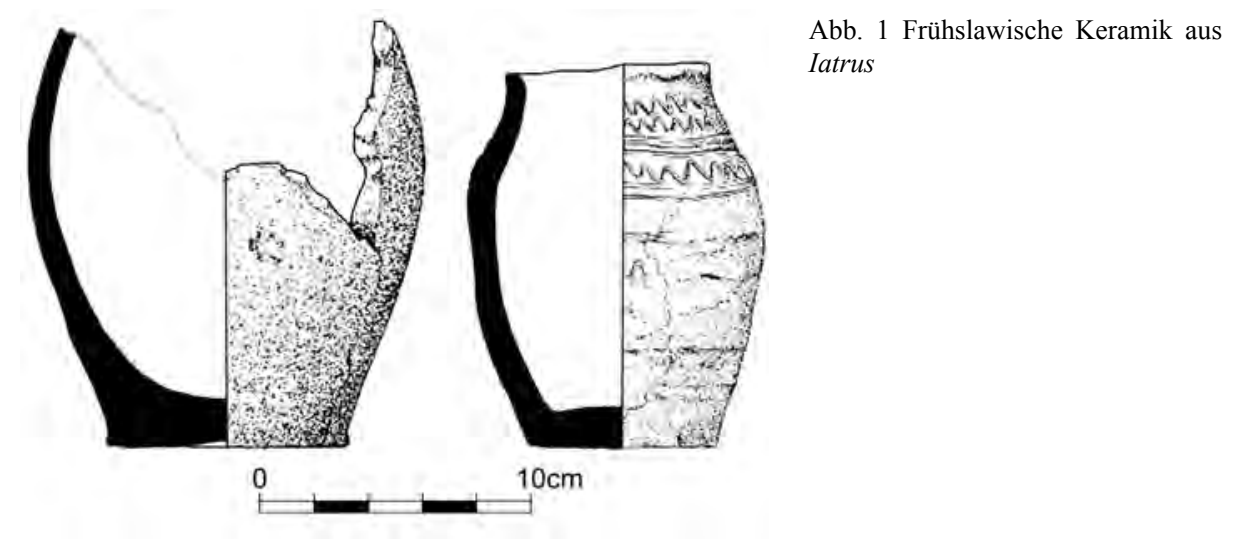

aufgebaut. ${ }^{4}$ Dass der Ort danach schon in den achtziger Jahren des 6. Jahrhunderts durch Awaren und Slawen zumindest stark gelitten hat, ist anhand des Münzspiegels, der mit Prägungen Iustins II. (565 bis 578) endet, anzunehmen. ${ }^{5}$ Iatrus wird danach aber noch zweimal im Zusammenhang mit den Feldzügen des Maurikios 596 und 600 erwähnt. ${ }^{6}$ Daraus ist zu schließen, dass die Festung um die Jahrhundertwende noch existierte und bewohnt war. Das bedeutet aber auch, dass Iatrus von den Awareneinfällen in den achtziger Jahren des 6. Jahrhunderts nicht zu stark betroffen gewesen sein kann. Darauf deutet auch die geringere Anzahl von spätantiken und frühbyzantinischen Festungen im Mittelabschnitt des unteren Donaulimes hin. An einigen Stellen gelang es in Iatrus Gebäudereste nachzuweisen, die über den Schuttschichten der justinianischen Periode (D 2) bzw. der nachjustinianischen Zeit bis zum endgültigen Fall des Kastells (D 3) angelegt worden waren und in die Zeit nach 600 datiert werden müssen. ${ }^{7}$ Ihre Bauweise unterschied sich nicht von der der vergangenen Periode. Die auf Stein- oder Lehmfundamenten und -sockeln errichteten Wände bestanden aus an der Luft getrockneten Lehmziegeln oder mit Lehm verschmiertem Rutengeflecht. Die aus diesen Gebäuden geborgenen Fundmaterialien sind frühbyzantinischer Provenienz. An der Keramik wurden im Vergleich mit den Funden aus dem 6. Jahrhundert Veränderungen in den Formen sowie der Vielfalt und Zusammensetzung der Typen festgestellt. ${ }^{8}$ Auch die zum Inventar gehörenden Dreilagenkämme, Tonlampen mit Warzendekor, Schmuckscheiben und Fibeln mit umgeschlagenem Fuß konnten ins 7. Jahrhundert datiert werden. ${ }^{9}$ Vereinzelt kam in diesen Fundkomplexen auch frühslawische handgearbeitete Keramik vor (Abb. 1). ${ }^{10}$

\footnotetext{
4 Prokopius, de aedif. IV, 7 (S. 131).

5 v. Bülow 1995, 66.

6 Theophylaktos Simokattes hist. VII, 2, 16 (S. 249) u. VII, 13, 9-11 (S. 268-269).

7 Wendel 1986, 51-56, 78, 103 bzw. 184-185, 191-194.

8 Ebd., 115-118.

9 Ebd., 164, 165, 176-183.

10 Ebd., 136-137.
} 
In diesen Zusammenhang gehören auch die an einem Abbruch beim heutigen Friedhof, in unmittelbarer Nähe des Gradište gefundenen Reste von Leichenbrand, die auf ein frühslawisches Brandgräberfeld hindeuten. ${ }^{11}$

Auch in der spätantiken Festung Karasura ist ein Zerstörungshorizont an vielen Bauwerken und Gebäuden zu verfolgen, der nach allen bisher vorliegenden Erkenntnissen in die erste Hälfte des 6. Jahrhunderts datiert werden kann. ${ }^{12}$ So sind am Mauerwerk von zahlreichen Bauwerken längliche, von Nord nach Süd verlaufende breite Risse festzustellen, die durch Erdbeben verursacht worden sind. Die Schäden müssen im Zuge der justinianischen Baumaßnahmen kurzfristig beseitigt worden sein. ${ }^{13}$ In völlig einheitlicher Bauweise wurden die Nord- und Ostflanke der Festung erneuert und verstärkt. Ganz offensichtlich erwarteten die Verteidiger der Festung Angriffe vornehmlich aus Richtung Beroia und vom Schwarzen Meer her. ${ }^{14}$

Karasura war in der Spätantike eine wichtige Kreuzwegfestung und ein bedeutendes frühchristliches Zentrum in der Grenzzone zwischen den großen thrakischen Städten Philippopolis und Beroia. Sehr wahrscheinlich wurde der Ort während der Plünderungen Thrakiens durch Slawen und vor allem Awaren in den achtziger Jahren des 6. Jahrhunderts zerstört. ${ }^{15}$ Die Festungsmauern wurden zumindest teilweise geschleift und viele Gebäude, darunter auch beide Basiliken, zerstört. ${ }^{16}$ Das Leben in den Ruinen ging jedoch, wenn auch bescheiden, weiter. Einige Gebäude, darunter das Haus S 5/ W 34, das nur etwa $10 \mathrm{~m}$ oberhalb des Nordwestturmes entdeckt worden ist, ${ }^{17}$ nutzten die geschleifte und abgeräumte Festungsmauer teilweise als Fußboden, wurden aber bald darauf wieder gewaltsam zerstört, wie die eilig in ihnen zurückgelassenen Gebrauchsgüter belegen. Zahlreiche keramische Gefäße, Schildbuckel, Fibeln mit umgeschlagenem Fuß und Tonlampen mit Warzendekor datieren dieses Ereignis nicht viel später als in die erste Hälfte des 7. Jahrhunderts. Vielleicht waren die Kriegszüge und Plünderungen der Provinz Thrakien am Beginn der Regierungszeit des Kaisers Herakleios (610 bis 641) durch Slawen und Awaren der Grund für die erneute Zerstörung.

11 Wendel 1986, 29.

12 Die Čirpaner Anhöhen sind sehr erdbebengefährdet. Das letzte große Beben, bei dem die Stadt und die umliegenden Dörfer, darunter auch Rupkite, nahezu vollständig zerstört worden sind, datiert in das Jahr 1928. Starke Erdbeben sind für die Mitte des 6. Jahrhunderts häufig bezeugt; vgl. Theophanes Confessor 225-229.

13 Prokopius. de aedif. IV, 11 (S. 146); vgl. Beševliev 1970, 130.

14 Die Einfallrichtungen von Slawen und Awaren, die Lage der Balkanpässe und der Verlauf der Hauptstraßen bedingten diese Angriffsrichtung, die ja dann bei den großen Awareneinfällen in den achtziger Jahren auch so eingehalten wurde.

15 Theophylacti Simocattae hist. I, 4 (S. 47), 7 (S. 53); Soustal 1991, 72; Böttger 1992, 242 245; 248-249.; Wendel 1992, 280.

16 Böttger 1992, 242-245.

17 Vgl. dazu die unterschiedlichen Meinungen von Herrmann 1992, 175 u. Wendel 1992, 280. Die Publikation des Befundes ist in Vorbereitung. 


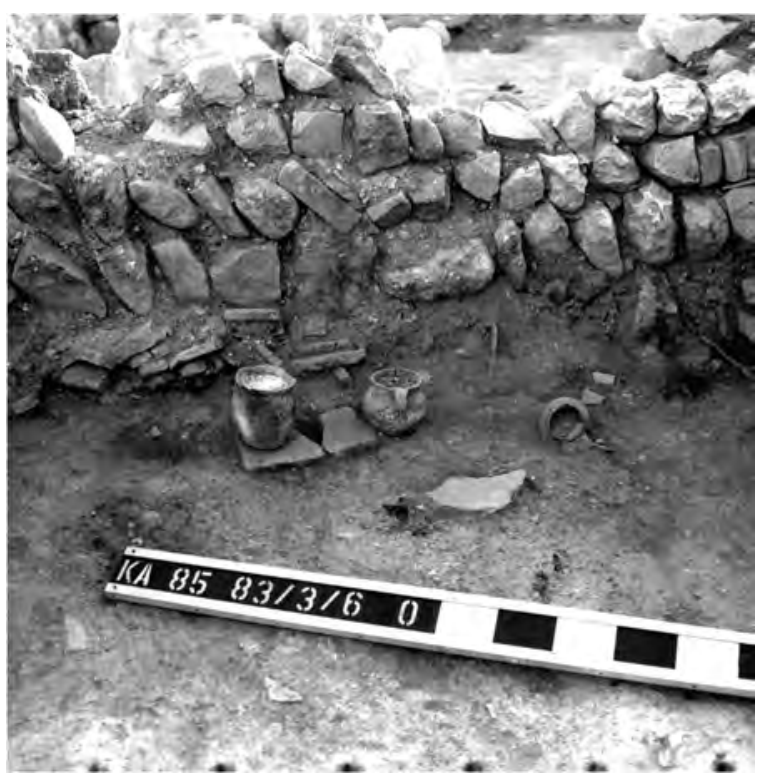

Abb. 2 Fundsituation eines Hauses in Fischgrätentechnik mit primitiver Keramik aus Karasura

Erst danach trat in Karasura ein grundlegender Bevölkerungswechsel ein, der sich sowohl im Hausbau als auch im Fundmaterial dokumentiert. In den Ruinen richtete sich eine neue Bevölkerung ein, die sich durch die Verwendung einer für Karasura völlig neuen Bautechnologie, nämlich das Ausbessern bzw. den Neuaufbau von Mauern in Fischgrätentechnik sowie durch den Gebrauch von primitiver, handgearbeiteter Keramik auszeichnete (Abb. 2, Abb. 3). ${ }^{18}$ Die Bauweise in Fischgrätentechnik und die fremden Keramikformen weisen auf eine Bevölkerungsgruppe hin, die schon längeren Kontakt zur provinzialen Kultur hatte und die in der Lage war, diese - wenn auch primitiv - zu adaptieren. Schon in der zweiten Hälfte des 6. Jahrhunderts wurden Slawen, Armenier und Kutriguren als Ausgleich für Bevölkerungsverluste in der Umgebung der Städte Philippopolis und Beroia angesiedelt. Möglich ist, dass die Neusiedler in Karasura zu einer dieser Gruppen gehört haben, möglich ist aber auch, dass sie slawischen Ursprungs waren und zu denjenigen Slawen gehörten, die sich schon seit der Mitte des 7. Jahrhunderts südlich des Balkangebirges niedergelassen hatten. ${ }^{19}$ Das völlige Fehlen von Münzen und anderen datierenden Funde in den Gebäuden dieser Fremdbevölkerung erschwert die Bestimmung des Zeitraumes ihrer Anwesenheit in Karasura.

Im Inventar des ältesten Hausgrubenhorizontes der frühmittelalterlichen Siedlung von Krivina vom Ende des 7. und Anfang des 8. Jahrhunderts dominiert dünnwandige Keramik miteingeritzterVerzierung. ${ }^{20}$ Gleichzeitigwurden frühbyzantinischeGebrauchsgegenstände

18 Vgl. Wendel 1992, 280-290.

19 Soustal 1991, 75 sowie Anm. 125 u. 126.

20 Wendel 1986, 137 u. Taf. 23,3-7,24, Taf. 40,d-h. 


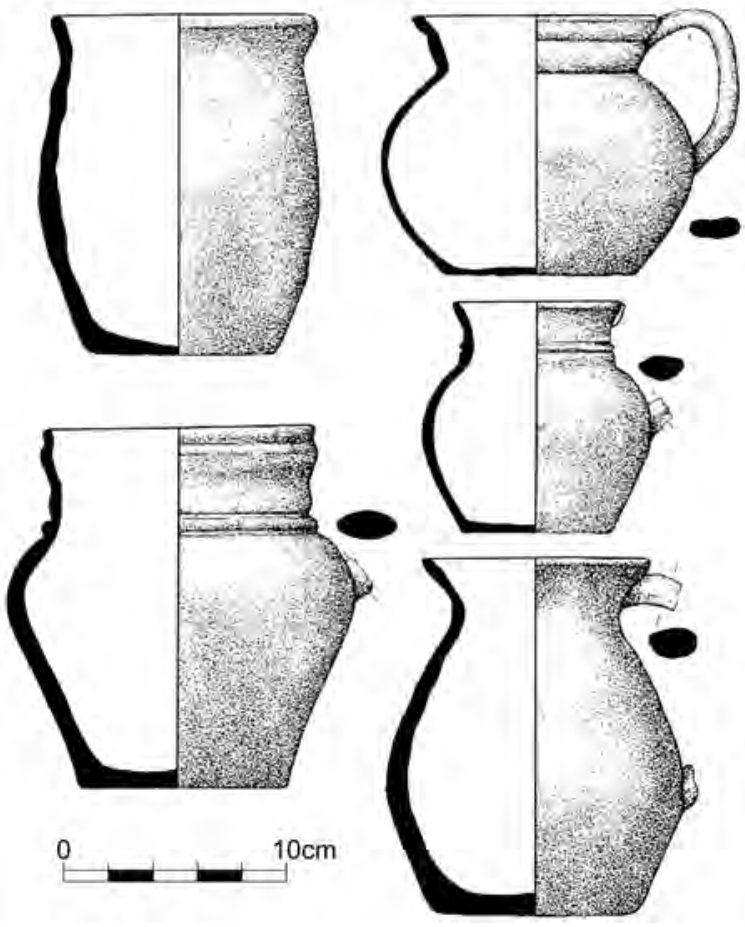

Abb. 3 Primitive Keramik aus den „Fischgrätenhäusern” in Karasura

geborgen, die erst im Verlauf des 9. Jahrhunderts gänzlich aus dem frühmittelalterlichen Fundgut verschwinden. ${ }^{21}$ Auch die frühen Gruben-Langhäuser, die in Krivina erstmals für die Balkanhalbinsel nachgewiesen werden konnten, verschwinden im 9. Jahrhundert gleichzeitig mit den frühbyzantinischen Funden aus dem Siedlungsbild. Das slawo-bulgarische Element dominiert nunmehr eindeutig die materielle Kultur der Bewohner (Abb. 4). Man kann aber davon ausgehen, dass wenigstens ein Teil der Einwohner von Iatrus den Fall des Donaulimes überlebt und während des 7. Jahrhunderts eine gegenüber dem Ende des 6. Jahrhunderts nur wenig veränderte materielle Kultur besaß.

Bis zu ihrer Zerstörung am Ende des 9. Jahrhunderts entwickelte sich die frühmittelalterliche Siedlung bei Krivina friedlich und weitestgehend ohne Störungen. In der zweiten Hälfte des 9. Jahrhunderts vollzogen sich in Bulgarien beträchtliche politische und administrative Veränderungen. Als herausragendes innenpolitisches Ereignis kann die Christianisierung und Überwindung der damit verbunden Widerstände, die in Boljarenaufständen und Zarenentthronung gipfelten, gesehen werden. ${ }^{22}$ In deren Folge wird auch die Hauptstadt von Pliska nach Preslav, an eine weitaus geschütztere Stelle verlegt. Es ist belegt, dass sich am Ende des 9. Jahrhunderts auch das Siedlungsbild in

21 Wendel 1986, 194-197.

22 Zlatarski 1927, 202-277; Istorija 1981, 213-238. 


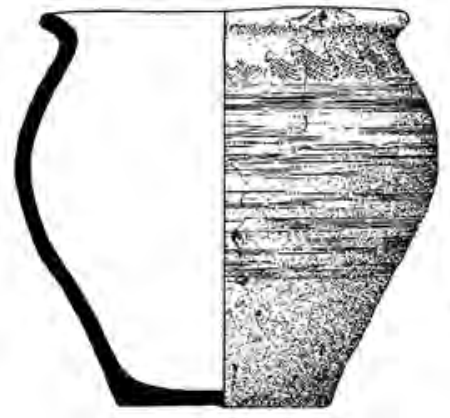

Abb. 4 Slawo-bulgarische Keramik mit eingeritzter Verzierung aus Iatrus

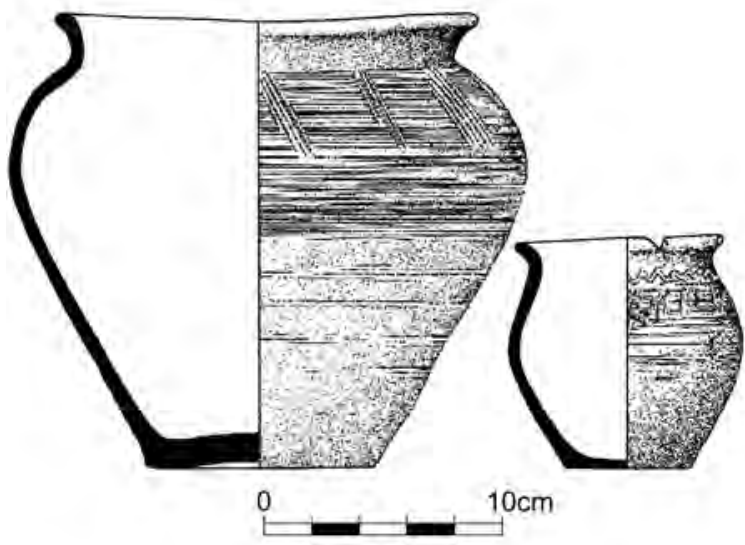

Nordbulgarien veränderte. ${ }^{23}$ Die Ortschaften verdichten und erweitern sich, viele von ihnen wie Stărmen, Jakimovo, Nova Černa, Capidava u.a. werden befestigt. Nicht überall aber wurde ein derart massiver Zerstörungshorizont wie in Krivina festgestellt, der von mir mit den Magyareneinfällen um 895/96 in Zusammenhang gebracht worden ist. ${ }^{24}$ Die Siedlung wurde danach unverzüglich wieder aufgebaut, aber völlig anders organisiert. Siedlungsstruktur und materielle Kultur weisen beträchtliche Veränderungen auf. Es gibt keine Langhäuser mehr und den nach einem System angeordneten quadratischen Grubenhäusern stehen Repräsentationsbauten gegenüber. Schätze nahezu unikaler und prägefrischer byzantinischer Goldmünzen, Waffenfunde und Handelsartikel belegen eine Umwandlung der Siedlung in einen Ort mit militärischer Funktion. Die Veränderungen in der materiellen Kultur wurden von mir mit dem Zustrom von Siedlern aus dem Norden der Donau erklärt, eine These, die auf heftige Kritik gestoßen ist und deren Erhärtung sicherlich noch weiterer vergleichender Fundanalysen im unteren Donaugebiet bedarf. ${ }^{25}$ Ein wichtiges Indiz für diese These waren große Fragmente von Kesseln mit Innenösen,

23 Istorija 1981, 350-352.

24 Wendel 1986, 197-198.

25 Angelova 1986, 212-213. 

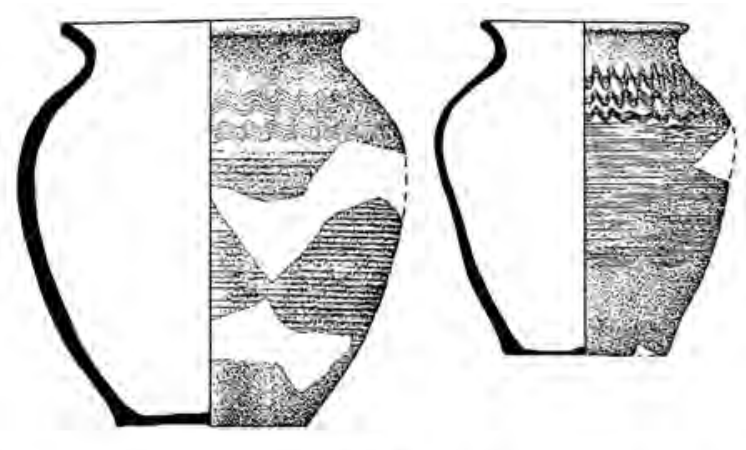

Abb. 5. Slawo-bulgarische Keramik mit eingeritzter Verzierung aus $\mathrm{Ka}$ rasura

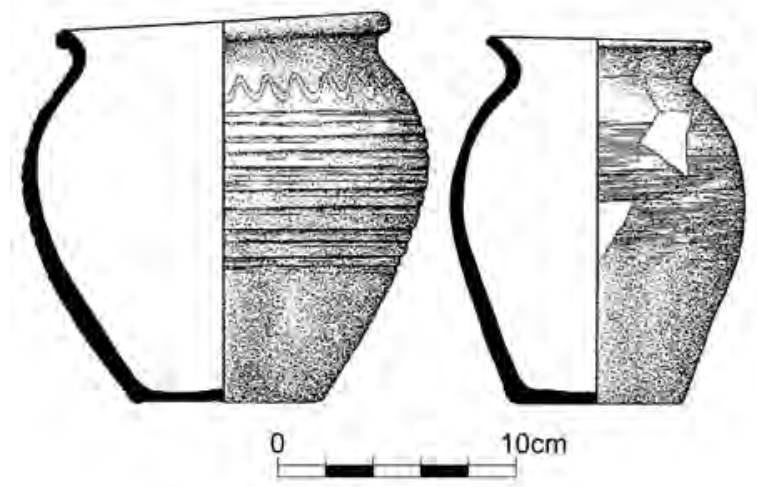

sogenannte Petschenegenkessel, im Fundbestand von Hausgruben seit dem zweiten Drittel des 10. Jahrhunderts. Sie waren dort mit der Keramik mit eingeritzter Verzierung vergesellschaftet, die sich im Habitus beträchtlich von der des 9. Jahrhunderts unterscheidet. Dieser Datierungsansatz ist bislang der früheste für die nordbulgarischen Gebiete. ${ }^{26}$

Die endgültigeZerstörung derSiedlungkann durch einen einzigartigen Goldmünzschatz sehr genau datiert und mit den Feldzügen Svjatoslavs um 968/69 in Verbindung gebracht werden. ${ }^{27}$ Danach wurde der Ort nicht wieder aufgebaut.

Nach der Zerstörung der „Fischgrätenhäuser“ wurde die Besiedlung des Kaletohügels bei Rupkite erneut unterbrochen. Es muss ein abermaliger Bevölkerungswechsel eingetreten sein, der sich wiederum in einer völlig veränderten materiellen Kultur äußert. Die neuen Siedler errichteten ihre Bauten nun außerhalb der Ruinen der Festung Karasura in der freien Ebene nördlich des Kaletohügels. Von dieser Freilandsiedlung konnten mehrere halbeingetiefte Grubenhäuser und birnenförmige Gruben ausgegraben werden, die durch slawo-bulgarische Keramik in das 8. bis 10. Jahrhunderts datiert werden (Abb. 5). ${ }^{28}$

26 Wendel 1981.

27 Wendel 1986, 72-74; Schönert-Geiß 1986, 230-239.

28 Wendel 1992, 290-293. 
Der höchste Teil des Kaletohügels mit der zerstörten Basilika 1, in die am Ende des 9. Jahrhunderts eine kleine Kirche eingebaut worden war, diente diesen Siedlern als Friedhof. ${ }^{29}$ Der orientierungsgleiche Einbau der mittelalterlichen Kirche in Apsis und Mittelschiff der frühbyzantinischen Basilika 1 spricht dafür, dass auch deren Ruine noch sichtbar war und als christlicher Bau akzeptiert worden ist. Da alle der mehr als 300 bisher untersuchten Gräber ausnahmslos christlich West-Ost orientiert waren, müssen auch die neuen Siedler Christen gewesen sein. Ihre Hausbauweise und auch das Fundinventar aus den Gräbern können als slawisch bzw. slawo-bulgarisch angesprochen werden.

Die slawo-bulgarische Siedlung ging durch Brand zugrunde. Schätze byzantinischer Anonymi (976 bis 1030/35 n. Chr.) bestimmen den Zeitpunkt ziemlich genau. Für die Zerstörung kommt nur die große Balkanoffensive der Byzantiner unter Johannes Tzimiskes (969 bis 976) und seines Nachfolgers Basileios II. (976 bis 1025) am Ende des 10. bzw. am Anfang des 11. Jahrhunderts in Frage.

Die Verbreitung von Fundstellen mit der typischen frühslawischen Kultur - handgearbeitete primitive Keramik, Grubenhäuser und Brandbestattung - zeigt ein verblüffendes Bild, das weder mit den schriftlichen noch den toponomastischen Quellen übereinstimmt. ${ }^{30}$ Überliefern diese Quellen die massenhafte Ansiedlung von Slawen in den Gebieten südlich der Donau, so bietet die archäologische Karte ein außerordentlich ärmliches Bild. Dieser Umstand kann nicht mit ungenügender Forschungstätigkeit erklärt werden, denn bei der Masse der bekannten und untersuchten frühmittelalterlichen slawo-bulgarischen Fundstellen wurde frühslawisches Material keineswegs übersehen. Dadurch gerät die archäologische Forschung in einen eklatanten Widerspruch zur Historiographie und Toponomastik. Das gilt aber nur dann, wenn die aus Osteuropa gut bekannte frühslawische Kultur die einzige war, die den landnehmenden Slawen zugeschrieben werden kann.

Unterzieht man die Fundstellen mit frühslawischem Material einer genaueren Prüfung, so lassen sich zwei Kategorien feststellen: frühslawische Freilandsiedlungen und Brandgräberfelder sowie frühslawische Funde in oder bei frühbyzantinischen Orten mit frühmittelalterlicher slawo-bulgarischer Siedlungsschicht.

Zur ersten Kategorie gehören in Nordwestbulgarien solche Siedlungen wie JakimovoGradišteto, ${ }^{31}$ Vălčedrăm-Pečena mogila, ${ }^{32}$ Bežanovo-Stublata ${ }^{33}$ und Sevlievo-Dolni livadi. ${ }^{34}$ An allen diesen Orten wurde auch Keramik mit eingeritzter Verzierung geborgen. In

29 Wendel 1992, 292.

30 Zur Zusammenstellung der wichtigsten schriftlichen Quellen u. Literatur vgl. Waldmüller 1976, 605-614; Ditten 1978, 77-98; Istorija 1981, 84-87; u. die toponomastischen Zeugnisse bei Angelov 1980, 64-77; sowie Schramm 1981, 140-165.

31 Čičikova 1960, 77; Dimitrova 1962, 74; Milčev 1963.

32 Dimitrova 1962, 74; Milčev 1964, 24; Văžarova 1965, 119.

33 Văžarova 1961.

34 Džambazov 1963, 97. 
Nordostbulgarien sind es Siedlungen und Brandgräberfelder wie Stărmen, ${ }^{35}$ Nova Černa, ${ }^{36}$ Staro selo-Jurta, ${ }^{37}$ Garvan-Stareca, ${ }^{38}$ Garvan-Momčila, ${ }^{39}$ Popina-Džedžovi lozja, ${ }^{40}$ PopinaDrenčeto, ${ }^{41}$ Srebărna-Opaška ${ }^{42}$ Goljam izvor-Nad pjasăka, ${ }^{43}$ Vinica, ${ }^{44}$ Babovo ${ }^{45}$ Juper ${ }^{46}$ u.a. An all diesen Orten wurde ebenfalls, wie in den übrigen Brandgräberfeldern auch, auf der langsamen Drehscheibe gefertigte slawische Keramik mit eingeritzter Verzierung gefunden. Eine Ausnahme ist nur Garvan-Momčila, wo lediglich eine Herdstelle und ein halbzerstörter Ofen mit frühslawischer Keramik untersucht worden sind. Aus Südbulgarien sind mir bisher weder frühslawische Freilandsiedlungen noch Brandgräberfelder bekannt geworden.

Zur zweiten Kategorie von Fundstellen mit frühslawischem Material zählen in Nordbulgarien solche wie Ratiaria-Arčar ${ }^{47}$ Iatrus-Krivina ${ }^{48}$ und Novgrad ${ }^{49}$ mit frühslawischen Bügelfibeln und handgemachter Keramik, Montana-Montana (ehemals Mihajlovgrad), ${ }^{50}$ Abrittus-Razgrad, ${ }^{51}$ Khan Krum, ${ }^{52}$ Durostorum-Silistra ${ }^{53}$ oder DineiaVojvoda ${ }^{54}$ Aus Südbulgarien sind frühslawische Funde beispielsweise aus Serdika-Sofia, ${ }^{55}$ Pernik, ${ }^{56}$ Goranovci, ${ }^{57}$ Pautalia-Kjustendil, ${ }^{58}$ Ablanica, ${ }^{59}$ Karasura-Rupkite, ${ }^{60}$ Beroia-Stara Zagora, ${ }^{61}$ Ljubenovo ${ }^{62}$ und Kabyle-Kabile ${ }^{63}$ veröffentlicht worden.

35 Kurnatowska 1980, 69-81.

36 Milčev/Angelova 1971, 22-29.

37 Angelov 1952.

38 Văžarova 1976, 11-38; 1986, 8-21.

39 Văžarova 1965, 118.

40 Ebd., 108-110, 156-157.

41 Ebd., 116-118.

42 Ebd., 118.

43 Văžarova 1980; dies. 1982.

44 Antonova 1967.

45 Văžarova 1976, 38-61.

46 Ebd., 61-76.

47 Mihajlov 1961, 41 Abb. 3,3, 42-43.

48 Wendel 1986, 136-137, Taf. 22,11, Taf. 23,1-2, Taf. 40a-e, Taf. 65,664.

49 Stefanov 1974, 297, Abb. 44g.

50 Aleksandrov 1981, 66; Montana 1987, 72.

51 Georgieva 1961, 28-30.

52 Antonova 1968, 58-65.

53 Angelova 1980, 4.

54 Ebd., 4.

55 Stančeva 1959, 61-62.

56 Čangova 1963, 69-72.

57 Gladičeva 1976, 75; Ivanov 1980, 124.

58 Mihajlov 1980, 219; Mihajlov/Sestrimska 1979, 186; dies. 1981, 136.

59 Văžarova 1976, 278-281.

60 Wendel 1992, 288-290.

61 Nikolov 1980, 85.

62 Aladžov/Balabanjan 1968, 131.

63 Mihajlov 1961, 43. 
In solchen Orten wie Montana, Krivina, Pernik, Dolno Cerovo, Kjustendil, Stara Zagora oder Rupkite haben die Slawen sowohl halbeingetiefte Grubenhäuser mit Öfen oder Herden als auch frühbyzantinische Gebäude zum Wohnen genutzt. In Montana, Pernik, Kjustendil, Dolno Cerovo und Rupkite (rechnet man die „Fischgrätenhäuser“ den Slawen zu) wurden nach der Zerstörung Gebäude im Inneren nach dem alten, frühbyzantinischen Bauprinzip neu- bzw. wieder aufgebaut, verkleinert oder geteilt. An all diesen Fundorten konnte gleichzeitig Keramik mit eingeritzter Verzierung gefunden werden, die bisher als typologische Weiterentwicklung der primitiven handgemachten galt und allgemein ins 9. bis 11. Jahrhunderts datiert wird. ${ }^{64}$

Auffallend ist, dass es trotz des guten Forschungsstandes in Ostbulgarien östlich der Linie Silistra - Khan Krum - Kabile nach meiner Kenntnis keine Fundstelle mit frühslawischem Material gibt, was bedeutet, dass der gesamte Küstenstreifen des Schwarzen Meeres auf einer Breite von rund $80 \mathrm{~km}$ (!) fundleer ist. Die frühesten Brand- und Körpergräberfelder, beispielsweise aus der Umgebung von Varna, wie Devnja, Razdelna oder Varna selbst, werden in das 8. Jahrhundert datiert und auf Grund der dort geborgenen Keramik vom Typ Saltovo-Majack mit Slawen und Bulgaren aus den Anfängen des bulgarischen Reiches in Verbindung gebracht. ${ }^{65}$ Diese Fundlücke an der Schwarzmeerküste kann nicht mit der Ansiedlung der Asparuhbulgaren erklärt werden, da ja aus ihrem ursprünglichen Siedlungszentrum, wie beispielsweise aus Khan Krum oder Vinica, frühslawisches Material bekannt ist. Gerade aber dieses Gebiet soll, ebenso wie die fruchtbare thrakische Ebene, wo sich auch nur vereinzelt frühslawische Fundstellen finden, schnell durchgehend slawisiert worden sein. ${ }^{66}$

Bei der Auflistung und Kartierung sogenannter heidnischer Nekropolen, also slawischer Brand- und protobulgarischer, Nord-Süd ausgerichteter Körpergräber, ist die Situation noch krasser. ${ }^{67}$ Die meisten dieser Nekropolen bleiben auf Nordostbulgarien beschränkt, wobei die Körpergräberfelder das Zentrum des Bulgarenreiches gut anzeigen. West- und Südbulgarien bleiben dagegen bis auf das Körpergräberfeld von Tuhovisšte völlig fundfrei.

Als Fazit bleibt: unter der Prämisse, dass den fast hundert Jahre einfallenden und landnehmenden Slawen lediglich die sogenannte frühslawische Kultur zu eigen war, haben diese Einfälle nach den archäologischen Quellen überhaupt nicht stattgefunden. Dabei ist verständlich, dass bei durchweg auf Plünderung angelegten Raubzügen, wie es für die Awaren gelten kann, außer Streufunden nahezu nichts von deren materieller Kultur zurückbleibt. Doch die Slawen siedelten sich, nach den schriftlichen und toponomastischen Quellen, zwischen der Mitte des 6. und dem 7. Jahrhundert massenhaft in

64 Mijatev 1948; Čangova 1959; Văžarova 1965, 92-158; Dončeva-Petkova 1977, 33-110 (mit ausführlicher Literatur 7-14).

65 z.B. Vaklinov 1973; ders. 1977, 13-43; Važarova 1970; dies. 1971; dies. 1979.

66 Schramm 1981, 153-155.

67 Vgl. dazu Fiedler 1992. 
Südosteuropa bis weit nach Griechenland hinein an und müssen demnach auch materiell-kulturelle Zeugnisse ihres Lebens und ihrer Tätigkeit hinterlassen haben.

Die Datierung frühmittelalterlicher Siedlungsplätze bzw. -schichten aus dem 7. bis 11. Jahrhundert erfolgt im Arbeitsgebiet mangels Münzfunden in den meisten Fällen durch Fundvergleich, vor allem der Keramik. Kann die frühslawische handgearbeitete Keramik anhand der Typen und der zeitlichen Bestimmung im Vergleich mit Funden aus Osteuropa relativ sicher ins 6. und 7. Jahrhundert datiert werden, ${ }^{68}$ so ist die zeitliche Bestimmung der Keramik mit eingeritzter Verzierung problematischer. Der Grund für diese Schwierigkeiten ist wohl in der Forschung selbst zu suchen.

Die frühslawische handgearbeitete oder primitive Keramik wurde von Einwanderern hergestellt und benutzt, die in ganz- oder halbeingetieften Hausgruben lebten und ihre Toten nach heidnischem Brauch verbrannten. Auch die Keramik mit eingeritzter Verzierung kommt in Siedlungen mit halbeingetieften Grubenhäusern und selbst in den meisten Brandgräberfeldern vor. Die Christianisierung der Bulgaren 864 gilt als terminus ante quem für die heidnischen Bestattungssitten und das damit verbundene Fundmaterial auf dem Territorium des Bulgarenreiches. Wie schon erwähnt, sind aus Südbulgarien keine Brandgräberfelder bekannt. Hier stellt sich eine andere Situation als nördlich des Balkangebirges dar. Die Verbreitung der christlichen Friedhöfe zeigt vor allem für die Bergregionen der Rhodopen ganz eindeutig ein Überwiegen von spätantik-frühbyzantinischen Friedhöfen, die bis ins Mittelalter hinein belegt waren. Damit wird für diese Region, im Gegensatz zu Nordbulgarien, eine ununterbrochene christliche Tradition bestätigt, die in Karasura, aber auch in allen größeren Orten Thrakiens lückenlos nachweisbar ist.

In diesem Zusammenhang interessiert der Befund aus dem Friedhof AblanicaMirulja. ${ }^{69}$ Dort wurden in Steinkisten christlich bestattete Individuen ausgegraben, denen sowohl frühbyzantinische als auch frühslawische Schmuckstücke mit ins Grab gegeben worden waren. Aus den Gräbern wurde gleichzeitig frühslawische handgemachte und auf der langsamen Drehscheibe gefertigte Keramik mit eingeritzter Verzierung geborgen. Die Sitte der Bestattung in Steinkisten bzw. Kammern aus Steinen, Steinplatten oder Ziegeln ist eine spätantik-frühbyzantinische Tradition, die auf den meisten frühmittelalterlichen Friedhöfen Südbulgariens, so auch in Karasura, zu beobachten ist. Der Befund zeigt deutlich, dass den wahrscheinlich slawischen, christlich Bestatteten von Ablanica sowohl frühbyzantinische als auch frühslawische Elemente der materiellen Kultur sowie Keramik mit eingeritzter Verzierung bekannt und zu eigen waren. Ganz offensichtlich hatten die hier Bestatteten schon länger als die Slawen im Norden Kontakt zur frühbyzantinischen Kultur. Sie waren nicht nur kulturell assimiliert, sondern auch christianisiert.

68 z.B. Kucharenko 1961; Rafalovič 1972; Rusanova 1963; dies. 1973; Sedov 1970; ders. 1979 u.a.

69 Văžarova/Čačeva 1968; Važarova 1976, 270-293; neuerdings dazu auch Angelova/Koleva 2001. 
Ähnliche Verhältnisse können auch in der Hausbauweise nachgewiesen werden. Das in slawischen Siedlungen vorherrschende Grubenhaus mit Ofen und/oder Herd ist geradezu ein „Markenzeichen“ der slawischen Kultur und immer mit Keramik mit eingeritzter Verzierung vergesellschaftet. Gleichzeitig wurden aber auch frühbyzantinische Gebäude zum Wohnen genutzt, neu eingerichtet bzw. in derselben Art wieder aufgebaut. Die Festungen Pernik oder Dolno Cerovo wurden nach dem alten frühbyzantinischen Festungsprinzip auch im Inneren mit kettenförmig aneinandergereihten Gebäuden und Räumen wieder errichtet. Aus solchen Räumen hat man sowohl frühbyzantinische, frühslawische als auch Keramik mit eingeritzter Verzierung geborgen. Ähnliche Befunde gibt es aus Kjustendil, Montana, Rupkite oder Krivina, wo einerseits sowohl von Hand als auch auf der langsamen Drehscheibe gefertigte Keramik aus frühbyzantinischen Gebäuden und andererseits frühbyzantinische Keramik aus Hausgruben geborgen worden ist.

In frühbyzantinischer Zeit befanden sich die großen Produktionszentren, wie Fabriken und Manufakturen, aber auch die Werkstätten von Handwerkern in Vierteln außerhalb, am Rande oder in den größeren Ortschaften, vor allem von Städten, wo der entsprechende Markt und die Handelsrouten vorhanden waren. ${ }^{70}$ Von dort wurden sowohl die Umgebung und das unmittelbare Einzugsgebiet versorgt, als auch Waren für die Fernmärkte im ganzen Reich produziert. Die Rohstoffe wurden angeliefert. Die Handelswege funktionierten. Diese Produktionsweise setzte einen Markt und WareGeld-Beziehungen voraus. Mit dem Limesfall wurde diese Kette regional unterbrochen. Geld war, wie der fehlende Münzumlauf im Ostteil der Balkanhalbinsel belegt, kaum noch vorhanden. Die Produktionsstätten außerhalb der Stadtmauern waren zerstört und die Rohstoffanlieferung durch die Blockierung von Straßen und Wegen bzw. wegen der allgemeinen Unsicherheit nicht mehr möglich. Wahrscheinlich war auch ein Teil der Rohstoffquellen nicht mehr zugänglich. Minen und Steinbrüche waren aufgelassen bzw. zerstört und die Menschen geflüchtet. Auch die Handwerkerviertel in den Städten waren dezimiert, ein großer Teil der Fachkräfte physisch vernichtet oder geflohen.

Die Ansiedlung der Slawen im freien Land, in den Städten und deren Umgebung brachte eine grundlegende Veränderung in der Produktionsweise mit sich. Es wurde jetzt dort produziert, wo Rohstoffe vorhanden und Handwerker ansässig waren. Es gab zumindest im östlichen Teil der Balkanhalbinsel keine Manufakturen und keine Fabriken, also auch keine Massenproduktion mehr. Die Handelswege waren, je weiter sie sich vom Zentrum der byzantinischen Macht entfernten, unterbrochen. Trotzdem muss zumindest noch bis zur Mitte bzw. dem Ende des 7. Jahrhunderts eine, wenn auch begrenzte Versorgung zumindest der Städte mit Produkten und Waren angenommen werden. In den entfernteren Gebieten wurden die Produzenten weitestgehend selbstgenügsam und produzierten nur für einen begrenzten, regionalen Markt. Kurzum,

70 Velkov 1977, 137-172; Demandt 1989, 337-352. 
die Produktion fiel in einem großen Teil der Balkanhalbinsel von der Stufe einer zum Teil staatlich beeinflussten Marktwirtschaft auf das Niveau der Selbstgenügsamkeit bzw. die Versorgung des unmittelbaren und örtlichen Marktes zurück. Das heißt auch, dass der ländlich-dörfliche Bereich selbst Waren zum eigenen Bedarf produzieren musste. Da auch die landnehmenden Slawen keine uniforme Masse waren, sondern aus zu unterschiedlichen Zeiten eingewanderten und sesshaft gewordenen Gruppen bestanden, die unterschiedlichen Kontakt zur frühbyzantinischen Kultur fanden, wurde dort entsprechend der vorliegenden Erfahrungen sowie nach Geschmack und Tradition produziert. Der obzwar begrenzte Markt und sicher auch die technologische Erfahrung, die von der verbliebenen Provinzialbevölkerung vermittelt wurde, bedingten nicht nur eine schnellere technologische Entwicklung, sondern auch eine Angleichung der produzierten Waren auf einem relativ einheitlichen Niveau. So beruhen z.B. Zweikammerbrennöfen für Keramik mit eingeritzter Verzierung auf spätantiken Konstruktions- und Funktionsprinzipien. Solche Öfen wurden unter anderen in den ländlich-frühslawischen Siedlungen von Popina-Džedžovi lozja, ${ }^{71}$ Garvan-Stareca, ${ }^{72}$ Jakimovo ${ }^{73}$ und Vălčedrăm, ${ }^{74}$ in frühmittelalterlichen Freilandsiedlungen wie Vinica, ${ }^{75}$ Hotnica, ${ }^{76}$ Topola, ${ }^{77}$ aber auch in der Hauptstadt Pliska-Asadere ${ }^{78}$ ausgegraben. Die Haltbarkeit der frühbyzantinischen Keramikerzeugnisse war begrenzt. Trotzdem werden diese Keramikformen noch längere Zeit in Benutzung gewesen sein. Nachschub aus den noch produzierenden Keramikmanufakturen und -zentren in den von diesen Ereignissen nicht betroffenen Gebieten, wie z.B. dem südlichen Teil der Balkanhalbinsel und Kleinasien, kam nur noch in begrenztem Umfang und wenn, dann in die großen, von den Versorgungslinien noch nicht oder nur sporadisch abgeschnittenen Städte auf die Balkanhalbinsel. Die von slawischen Handwerkern produzierten Produkte wurden daher, mangels Alternativen, bald zu den vorherrschenden Waren. Die in den Städten zurückgebliebene Provinzialbevölkerung, die mit den Neusiedlern schnell Kontakt bekam, war bald auf deren Gebrauchserzeugnisse angewiesen. Andererseits begannen die noch ansässigen, provinzialen Handwerker auch für den Geschmack der slawischen Neusiedler zu produzieren. Diese Kausalität bewirkte bald einen Innovationsschub, nicht nur in der Keramikproduktion.

Am Fallbeispiel ist dieser Prozess an der Keramikproduktion in Karasura, und zwar an der Verwendung bestimmter Tone mit und ohne Glimmer, darzustellen. Weder die

71 Unpubliziert, erwähnt bei Dončeva-Petkova 1977, 29 Anm. 52.

72 Văžarova 1986, 115, 121.

73 Unpubliziert, erwähnt bei Dončeva-Petkova 1977, 29 Anm. 54.

74 Unpubliziert, erwähnt ebd., 29 Anm. 55.

75 Totev 1973a; ders. 1973b.

76 Sultov 1969.

77 Bobčeva 1977.

78 Dončeva-Petkova 1977, 30 Anm. 61. 
spätantik-frühbyzantinische noch die hochmittelalterliche Drehscheibenware enthält Beimengungen von Glimmer, die ein Kennzeichen der örtlichen Tonvorkommen sind. Das heißt, diese Keramik kam von Produzenten - vielleicht aus Beroia oder Philippopolis - die einen größeren Markt, darunter auch Karasura bedienten. Die von Hand oder auf der langsamen Drehscheibe gefertigte prähistorische oder frühmittelalterliche Keramik wurde dagegen aus diesen örtlichen Rohstoffen mit Glimmerbeimengungen hergestellt, d.h. sie wurde am Ort gefertigt.

Man muss also davon ausgehen, dass auf der einen Seite frühbyzantinische Kulturgüter auch noch im 7. Jahrhundert, sicher regional unterschiedlich, in bestimmtem Umfang weiterproduziert und verhandelt und somit auch in Gebrauch waren. Andererseits begann sich die uns bekannte frühmittelalterliche Kultur und damit auch deren Markenzeichen, die sogenannte Keramik mit eingeritzter Verzierung, zu verbreiten. Das beweisen nicht nur die rumänischen Fundkomplexe, sondern auch die Urnen und die Kultkeramik aus den frühen slawischen Nekropolen des 7. und 8. Jahrhunderts. Erst unter dieser Prämisse kann auch die slawische Ansiedlung im 6. und 7. Jahrhundert südlich der Donau archäologisch belegt werden. Spätestens mit der Binnenkolonisation des Bulgarenreiches im ausgehenden 8. und vor allem im 9. Jahrhundert setzte sich diese Keramikgattung dann als das massenhafte Kulturgut auf der gesamten Balkanhalbinsel, südlich und nördlich der Donau, bis nach Griechenland hin durch. Man muss also, folgt man diesen Gedanken, schlussfolgern, dass die materielle Kultur des 7. bis 9 . Jahrhunderts auf der Balkanhalbinsel regional unterschiedlich durch drei wesentliche Elemente repräsentiert wird: das frühbyzantinische, das frühslawische und das sich entwickelnde frühmittelalterliche.

\section{Bibliographie}

Aladžov/Balabanjan 1972: Димчо Аладжов/Д. Балабанян, „Разкопки в село Любеново през 1968 г.“, in: Родопски сборник 3, 1972, S. 105-139.

Aleksandrov 1981: Георги Александров, „Разкопки на крепостта Монтана (Михайловград)“, in: Археологически открития и разкопки, Преслав 1981, S. 65-66.

Angelov 1980: Dimităr Angelov, Die Entstehung des bulgarischen Volkes, Berlin 1980.

Angelov 1952: Н. Ангелов, "Новооткрити селища по брега на Дунава между Русе и Тутракан”, in: Известия на Археологическия институт 18, 1952, S. 370-378.

Angelova 1980: Стефка Ангелова, „По вопроса за раннославянската култура на юг и на север от Дунава през VI-VII в.“, in: Археология 22/4, 1980, S. 1-12.

Angelova 1986: Stefka Angelova, „Bemerkungen zu den Ergebnissen der Untersuchung der frühmittelalterlichen Siedlung über den Ruinen des spätantiken Kastells Iatrus“, in: IatrusKrivina, Berlin 1986, S. 211-213.

Angelova/Koleva 2001: Stefka Angelova/Rumjana Koleva, „Zur Chronologie frühmittelalterlicher Nekropolen in Südbulgarien“, in: Michael Wendel (Hrsg.), Karasura: Untersuchungen zur 
Geschichte und Kultur des Alten Thrakien 1. 15 Jahre Ausgrabungen in Karasura. Symposium Čirpan/Bulgarien 1996, Weissbach 2001, S. 263-270.

Antonova 1967: Вера Антонова, „Средновековното селище в чашата на язовир Виница, Шуменско“, in: Известия на исторически музей Шумен 4, 1967, S. 3-33.

Antonova 1968: Вера Антонова, „Две раннохристиански църкви във външното укрепление на аула на Хан Омуртаг при гара Цар Крум (Шуменско)“, in: Археология 10/4, 1968, S. 52-67.

Beševliev 1970: Veselin Beševliev, Zur Deutung der Kastellnamen in Prokops Werk „De aedificiis “, Amsterdam 1970.

Bobčeva 1977: Любка Бобчева, „Грънчарски пещи за старобългарската керамика при с. Топола, Толбухинско“, in: Известия на Народния музей Варна 13 (28), 1977, S. 172-177.

Böttger 1992: Burkhard Böttger, „Zu den Ergebnissen der Untersuchung an den spätantiken Schichten im Nordwestsektor des Kaletohügels von Karasura“, in: Zeitschrift für Archäologie 26, 1992, S. 233-248.

Böttger/Wendel 1983: Burkhard Böttger/Michael Wendel, „Karasura und die Sondierungsarbeiten im Jahre 1981“, in: Klio 65, 1983, S. 9-25.

v. Bülow 1995: Gerda von Bülow, ,Die Siedlungsperiode D 1 in Iatrus. Die Siedlungsperiode D 2 in Iatrus“, in: Iatrus-Krivina, Berlin 1995, S. 55-66.

Čangova 1959: Йорданка Чангова, „Средновековна битова керамика от България (VIII-XI в.)“, in: Археология 1/1-2, 1959, S. 135-141.

Čangova 1963: Йорданка Чангова, „Проучвания в крепостта Перник“, in: Археология 5/3, 1963, 32-41.

Čičikova 1960: Мария Чичикова, „Отчетна конфернция за постиженията на българската археология през 1959 г.“, in: Археология 2/2, 1960, S. 76-78.

Demandt 1989: Alexander Demandt, Die Spätantike. Römische Geschichte von Diocletian bis Justinian 284-565 n. Chr., München 1989.

Dimitrova 1962: А. Димитрова, „Седма отчетна конфернция на Археологическия институт при БАН за 1961 г.“, in: Археология 4/3, 1962, S. 74-76.

Ditten 1978: Hans Ditten, „Zur Bedeutung der Einwanderung der Slawen“, in: Friedhelm Winkelmann (et. al.), Byzanz im 7. Jahrhundert. Untersuchungen zur Herausbildung des Feudalismus (=Berliner Byzantinistische Arbeiten 48), Berlin 1978, S. 73-160.

Dončeva-Petkova 1977: Людмила Дончева-Петкова, Българска битова керамика през ранното средновекожие, София 1977.

Džambazov 1963: Н. Джамбов, „Осма отчетна конференция на Археологическия институт при БАН за 1962 г.“, in: Археология 5/3, 1963, S. 96-99.

Fiedler 1992: Uwe Fiedler, Studien zu Gräberfeldern des 6. bis 9. Jahrhunderts an der unteren Donau (= Universitätsforschungen zur prähistorischen Archäologie 11), Bonn 1992.

Georgieva 1961: Соня Георгиева, „Средновековното селище над развалините на античния град Абритус“, in: Известия на Археологическия институт 24, 1961, S. 9-36.

Gladičeva 1976: Иванка Гладичева, „Национална археологическа конференция“, in: Археология 18/1, 1976, S. 63-76.

Herrmann 1992: Joachim Herrmann, „Karasura 1981-1991. Zu den bisherigen Ergebnissen von Ausgrabungen und Forschungsarbeiten in Südthrakien zwischen Stara Zagora und Plovdiv“, in: Zeitschrift für Archäologie 26, 1992, S. 153-180.

Herrmann/Nikolov 1983: Joachim Herrmann/Dimitar Nikolov, „Beginn und erste Ergebnisse archäologischer Ausgrabungen in der antiken Straßenstation Karasura, VR Bulgarien. Einführung“", in: Klio 65, 1983, S. 5-7. 
Herrmann/Nikolov/Wendel 1986: Joachim Herrmann/Dimitar Nikolov/Michael Wendel, „Karasura - antike Straßenstation und mittelalterliche Siedlungen bei Rupkite, Bez. Stara Zagora (VR Bulgarien)“, in: Das Altertum 2, 1986, S. 85-91.

Hermann/Wendel/Neševa 1986: Йоахим Херманн/Михаел Вендел/Виолета Нешева, „Археологически проучванийяа в Карасура“, in: Археология 30/4, 1986, S. 1-11.

Iatrus-Krivina 1979: Iatrus-Krivina, Spätantike Befestigung und frühmittelalterliche Siedlung an der unteren Donau 1: Ergebnisse der Ausgrabungen 1966-1973 (=Schriften zur Geschichte und Kultur der Antike 17), Berlin 1979.

Iatrus-Krivina 1986: Iatrus-Krivina, Spätantike Befestigung und frühmittelalterliche Siedlung an der unteren Donau 3: Die mittelalterlichen Siedlungen (Schriften zur Geschichte und Kultur der Antike 17), Berlin 1986.

Iatrus-Krivina 1995: Iatrus-Krivina, Spätantike Befestigung und frühmittelalterliche Siedlung an der unteren Donau 5: Studien zur Geschichte des Kastells Iatrus (Forschungsstand 1989) (=Schriften zur Geschichte und Kultur der Antike 17), Berlin 1995.

Istorija 1981: История на България 2, София 1981.

Ivanov 1980: С. Иванов, „Разкопки на м. «Манастира» с. Горановци, Кюстендилски окръг“, in: Археологически открития и разкопки, София 1980.

Ivanov 1966: Teofil Ivanov, „Die Ausgrabungen der Jahre 1958, 1960 und 1962 in Iatrus“, in: Klio 47, 1966, S. 11-21.

Kucharenko 1961: Июри Владимирович Кухаренко, Средновековые памятники Полесья, Москва 1961.

Kurnatowska 1980: Zofia Kurnatowska, „Osadnictwo wczesnośredniowieczne“, in: Styrmen na Jantra (Butgaria). Badania archeologiczne w latach 1961-1964 I 1967-1968, WrocławWarszawa-Kraków-Gdańsk 1980, S. 69-284.

Mihajlov 1961: Стамен Михайлов, „Ранносредновековни фибули в България“, in: Известия на Археологическия институт 24, 1961, S. 37-60.

Mihajlov 1980: Стамен Михайлов (et.al.), „Разкопки на обект «Художествена галерия» Кюстендил на сектор I и сектор II“", in: Археологически открития и разкопки, София 1980, S. 217-221.

Mihajlov/Sestrimska 1979: Стамен Михайлов/Мария Сестримска, „Археологически разкопки на обект «Килийно училище», Кюстендил“, in: Археологически открития и разкопки, София 1979, S. 185-187.

Mihajlov/Sestrimska 1981: Стамен Михайлов/Мария Сестримска, „Разкопки на обект «Художествена галерия» гр. Кюстендил“, in: Археологически открития и разкопки, София 1981, S. 135-137.

Mijatev 1948: Кристю Миятев, Славянска керамика в България и нейното значение за славянската археология на Балкана, София 1948.

Milčev 1963: Атанас Милчев, „Ранносредновековни български накити и кръстове енколпиони от Северозападна България““, in: Археология 5/3, 1963, S. 22-37.

Milčev 1964: Атанас Милчев, „Проучвания на раннославянската култура в България и на Плиска през последните двадесет години“, in: Археология 6/1, 1964, S. 23-35.

Milčev/Angelova 1971: Атанас Милчев/Стефка Ангелова, „Археологически разкопки и проучвания в местността «Калето» при с. Нова Черна“, in: Годишник на Софийския университет: Историко-филологически факултет 63/3, 1971, S. 31-48.

Montana 1987: Монтана 1, София 1987.

Nikolov 1980: Димитър Николов (et.al.), „Разкопки на обект Партиен дом в Стара Загора“, in: Археологические открития и разкопки, София 1980, S. 84-86. 
Prokopius, de aedif.: Procopi Caesariensis opera omnia, rec. Jacob Haury, vol. 4: Periktismaton, libri VI sive de aedificiis, ed. ster. corr. Gerhard Wirth, Leipzig 1964.

Rafalovič 1972: Изак Александрович Рафалович, Славяне VI-IX веков в Молдавии, Кишинев 1972.

Rusanova 1963: Ирина Петровна Русанова, „Поселенийе у с. Корчака на p. Теререве“, in: Материалы и исследования по археологии СССР 108, 1963, S. 39-50.

Rusanova 1973: Ирина Петровна Русанова, Славянские древности между Днепром и Западным Бугом, Москва 1973.

Schönert-Geiß 1986: Edith Schönert-Geiß, „Der Goldfund von Krivina“, in: Iatrus-Krivina 1986, S. 230-239.

Schramm 1981: Gottfried Schramm, Eroberer und Eingesessene. Geographische Lehnnamen als Zeugen der Geschichte Südosteuropas im ersten Jahrtausend n. Chr., Stuttgart 1981.

Sedov 1970: Валентин Васиевич Седов, Славяне Верхнего Поднепровья, Москва 1970.

Sedov 1979: Валентин Васиевич Седов, Произхождение и ранняя история славян, Москва 1979.

Soustal 1991: Peter Soustal, Tabula Imperii Byzantini 6. Thrakien, Wien 1991.

Stančev 1989: Димитър Станчев, „Разкопки в кастела Ятрус“, in: Археологические открития и разкопки, Кърджъли 1989, S. 101-102.

Stančev 1990: Димитър Станчев, „Разкопки в Ятрус“, in: Археологически открития и разкопки, Кюстендил 1990, S. 99-100.

Stančev 1995: Dimitar Stančev, „Grabungen im Kastell Iatrus von 1984 bis 1988“, in: IatrusKrivina 1995, S. 123-130.

Stančeva 1959: Магдалина Станчева, „Ранносредновековна керамика от София“, in: Археология 1/3-4, 1959, S. 61-68.

Stefanov 1974: С. Стефанов, „Новград. Старини селища“, in: Известия на Археологическия институт 34, 1974, S. 250-311.

Sultov 1969: Богдан Султов, „Новооткрит керамичен център при с. Хотница от римската и старобългарска епоха“, in: Археология 11/4, 1969, S. 12-24.

Theophanes Confessor: Theophanis Chronographia, rec. Carl de Boor, vol. 1, textum graecum continens, Leipzig 1883.

Theophylaktos Simokattes, hist.: Theophylacti Simocattae Historiae, ed. Carl de Boor, ed. corr. cur. Peter Wirth, Stuttgart 1972.

Totev 1973a: Тотю Тотев, „Керамични пещи в чашата на язовир Виница край Преслав“, in: Археология 15/4, 1973, S. 58-68.

Totev 1973b: Тотю Тотев, „Старобългарски производствен сентар на язовир Виница край Преслав“, in: Известия на историческия музей Шумен 6, 1973, S. 159-187.

Vaklinov 1973: Stančo Vaklinov, „Die slawische Kultur in Bulgarien und die byzantinische Hinterlassenschaft", in: Berichte über den II. Internationalen Kongress für slawische Archäologie 2, Berlin 1973, S. 195-236.

Vaklinov 1977: Станчо Ваклинов, Формиране на старобългарска култура VI-XI век, София 1977.

Văžarova 1961: Живка Важарова, „Славянското селище в местността Стублата край с. Бежаново, Ловешко“, in: Известия на Археологическия институт 24, 1961, S. 317-326.

Văžarova 1965: Живка Важарова, Славянски и славянобългарски селища в българските земи от края на VI-XI век, София 1965.

Văžarova 1970: Živka Văžarova, „Slawen und Protobulgaren (nach archäologischen Angaben)“, in: Berichte über den II. Internationalen Kongress für Slawische Archäologie 1, Berlin 1970, S. 9-53. 
Văžarova 1971: Živka Văžarova, „Slawen und Protobulgaren auf Grund archäologischer Quellen“, in: Zeitschrift für Archäologie 5, 1971, S. 266-288.

Văžarova 1976: Живка Важарова, Славяни и прабългари (по данни на некрополите от VI-XI в. на територията на България), София 1976.

Văžarova 1979: Živka Văžarova, ,Zur Frage der Ethnogenese und der materiellen Kultur des bulgarischen Volkes (zwei Nekropolen aus Nordostbulgarien)“", in: Известия на Археологическия институт 35, 1979, S. 5-31.

Văžarova 1980: Живка Важарова, „Разкопки на средновековно селище край с. Горни Извор, Разградски окръг”, in: Археологически открития и разкопки, София 1980, o. S.

Văžarova 1986: Живка Важарова, Средновековното селище с. Гарван, Силистренски окръг VI-XI в., София 1986.

Văžarova /Čačeva 1968: Живка Важарова/Вера Чачева, „Средновековен некропол при с Абланица, Благоевградски окръг“, in: Археология 10/2, 1968, S. 27-35.

Velkov 1977: Velizar Velkov, Cities in Thrace and Dacia in Late Atiquitiy (Studies and Materials), Amsterdam 1977.

Waldmüller 1976: Lothar Waldmüller, Die ersten Begegnungen der Slawen mit dem Christentum und den christlichen Völkern vom VI. bis VIII. Jahrhundert, Amsterdam 1976.

Wendel 1981: Michael Wendel, „Zu einigen Funden von Kesseln mit Innenösen in der frühmittelalterlichen slawisch-bulgarischen Siedlung bei Krivina, Bez. Ruse, VR Bulgarien“, in: Плиска-Преслав 3, София 1981, S. 90-92.

Wendel 1986: Michael Wendel, „Die mittelalterlichen Siedlungen“, in: Iatrus-Krivina 1986, S. 24-210.

Wendel 1992: Michael Wendel, „Die Gemarkung des Dorfes Rupkite bei Čirpan (Bulgarien) im Mittelalter", in: Zeitschrift für Archäologie 26, 1992, S. 279-299.

Wendel 1996: Michael Wendel, „Die Wiederaufnahme der Ausgrabungen in Karasura beim Dorf Rupkite, Gemeindeverband Čirpan in Zentralbulgarien“, in: Terra \& Praehistoria. Festschrift Klaus-Dieter Jäger (= Beiträge zur Ur- und Frühgeschichte Mitteleuropas 9), Wilkau-Hasslau 1996.

Wendel 2001: Michael Wendel, „Der Fundplatz Karasura“, in: Karasura. Untersuchungen zur Geschichte und Kultur des Alten Thrakien 1. 15 Jahre Ausgrabungen in Karasura. Symposium Čirpan/Bulgarien 1996, Weissbach 2001, S. 5-31.

Zlatarski 1927: Васил Златарски, История на българската държава през средните векове, София 1994 (reprint). 


\title{
Ergebnisse und Erfahrungen aus den polnischen Untersuchungen in Stărmen und Odărci
}

\author{
Zofia Kurnatowska \& Henryk Mamzer
}

Die Untersuchungen polnischer Expeditionen in Stărmen und dann in Odărci begannen auf Initiative von Prof. W. Hensel im Jahre 1961. Sie waren Teil eines breit angelegten Forschungsprogramms. Ziel dieser Untersuchungen war es, die Herausbildung der Kultur der Südslawen zu erforschen. Dies war gleichzeitig als Beitrag zu vergleichenden Studien zur Kultur des frühmittelalterlichen Europas gedacht, die man damals im Institut für Geschichte der materiellen Kultur der Polnischen Akademie der Wissenschaften betrieben hat. Als Ergebnis dieser Arbeiten wurden im Laufe der Jahre mehrere Darstellungen zu einzelnen europäischen Kulturprovinzen publiziert. Eines der Forschungsprobleme, denen besondere Aufmerksamkeit geschenkt wurde, war das der Entstehung von Siedlungen mit Stadtcharakter in den verschiedenen slawischen Siedlungsgebieten, darunter auch in Südosteuropa. ${ }^{1}$ Die in den oben genannten Objekten gemeinsam mit den bulgarischen Archäologen durchgeführten Ausgrabungen (Abb. 1) ${ }^{2}$ waren darauf gerichtet, diese allgemeinen historischen Fragestellungen auf konkrete Beispiele zu beziehen, sie also im konkreten Einzelfall zu studieren. Der Charakter beider ausgewählter Fundstellen war verschieden und ermöglichte es, unterschiedliche Forschungsfragen zu verfolgen.

Die Ausgrabungen in Stărmen wurden in den Jahren 1961 bis 1964 und 1967 bis 1968 durchgeführt. Die Ergebnisse der polnischen Forschungen wurden in einer 1980 erschienenen Monographie niedergelegt. ${ }^{3}$ Auch der von bulgarischen Kollegen untersuchte Teil der Fundstelle wurde bearbeitet und in Form einer Monographie veröffentlicht. ${ }^{4}$ Die in Jahren 1967, 1969 bis 1974 und 1976 bis 1977 in Odărci organisierten Ausgrabungen wurden von polnischer Seite bisher leider nur in Form eines umfangreichen Berichtes, der im Jahre 1981 veröffentlicht wurde, bekannt gemacht. ${ }^{5}$ Infolge des vorzeitigen Todes von Urszula und Aleksander Dymaczewski wurden die

1 vgl. Hensel 1972.

2 vgl. Szymański 1973; Leciejewicz 1976, 1979; Szymański/Dąbrowska 1979.

3 Styrmen nad Jantrą 1980.

4 vgl. Michajlov/Džingov/Vàlov/Dimova 1982.

5 Dymaczewska/Dymaczewski 1981. 


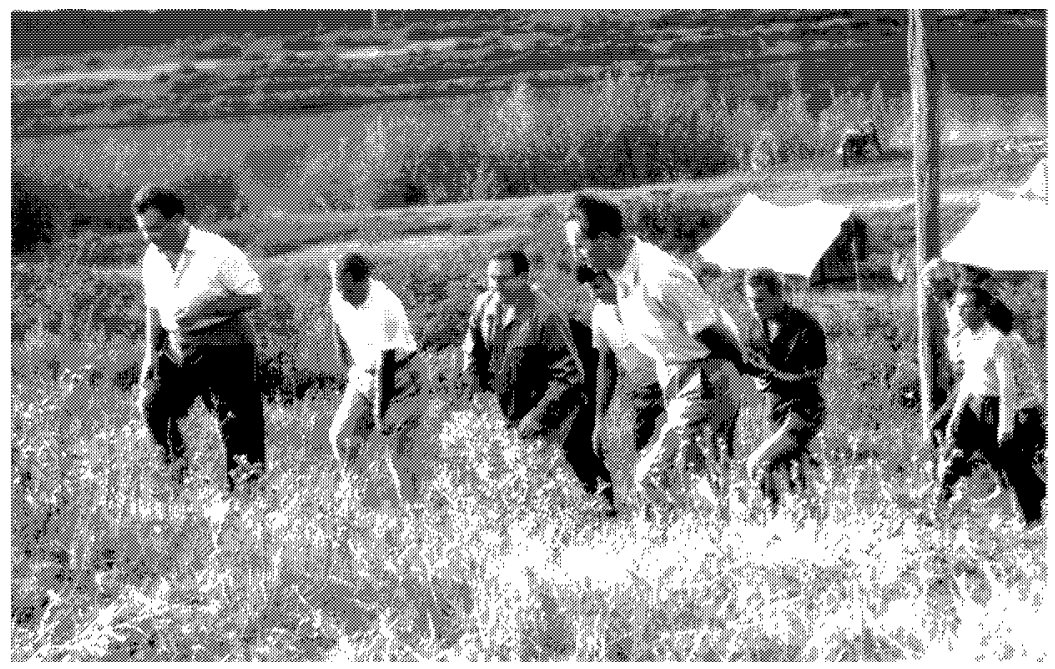

Abb. 1. Stărmen. Polnisch-bulgarische Expedition auf dem Wall des Burgwalles. S. Michajlov (2.v.1.), W. Hensel (3.v.1.), G. Džingov (7.v.1.) und V. Vălov (8.v.1.)

Arbeiten an einer Monographie über diesen Fundplatz unterbrochen. Dagegen wurden die frühmittelalterlichen Materialien aus dem bulgarischen Sektor von Odărci in einer Monographie veröffentlicht. ${ }^{6}$ Neben der monographischen Veröffentlichung von Ergebnissen der Untersuchungen in Stărmen erschienen auch Analysen zu speziellen Fundkategorien. ${ }^{7}$ Auch zu Odărci sind verschiedene ausführliche Fundanalysen veröffentlicht worden. ${ }^{8}$

Der Kulturkontext der südslawischen Länder war von einer besonderen Komplexität, derer man sich bei den Forschungen bewusst bleiben musste. Diese Komplexität liegt in den antiken Wurzeln, den speziellen Traditionen der slawischen Stämme, die den Balkan besiedelten, und im Einfluss der Kultur der Nomaden, besonders im nordöstlichen Teil Bulgariens, begründet. Die Forschungsarbeiten wurden, vielleicht teilweise unbewusst, auf die Suche nach einer slawischen Kulturidentität gerichtet, die das Bestehen universaler und keinen Änderungen unterworfener Kultureigenschaften voraussetzte. Dies ergibt sich z.B. bereits aus der Wahl des Grabungsplatzes Stărmen selbst, wo solche von den Slawen bevorzugten Umweltbeziehungen wie die Lage der Siedlungen in Niederungsgebieten zu erwarten waren.

6 Dončeva-Petkova/Ninov/Parušev 1999.

7 vgl. Danielczyk 1970; dies. 1972; dies. 1974; Dekówna 1975; Dymaczewska 1972; Dzięczkowski 1966; Gładykowska-Rzeczycka 1971; Klichowska 1966; Kociszewski 1979; Krzyżanowska 1971; Kurnatowska 1973; Mamzer 1973; ders. 1978.

8 Krzyżanowska 1983; Kurnatowska/Szamałek 1990; Szamałek 1977; ders. 1983. 


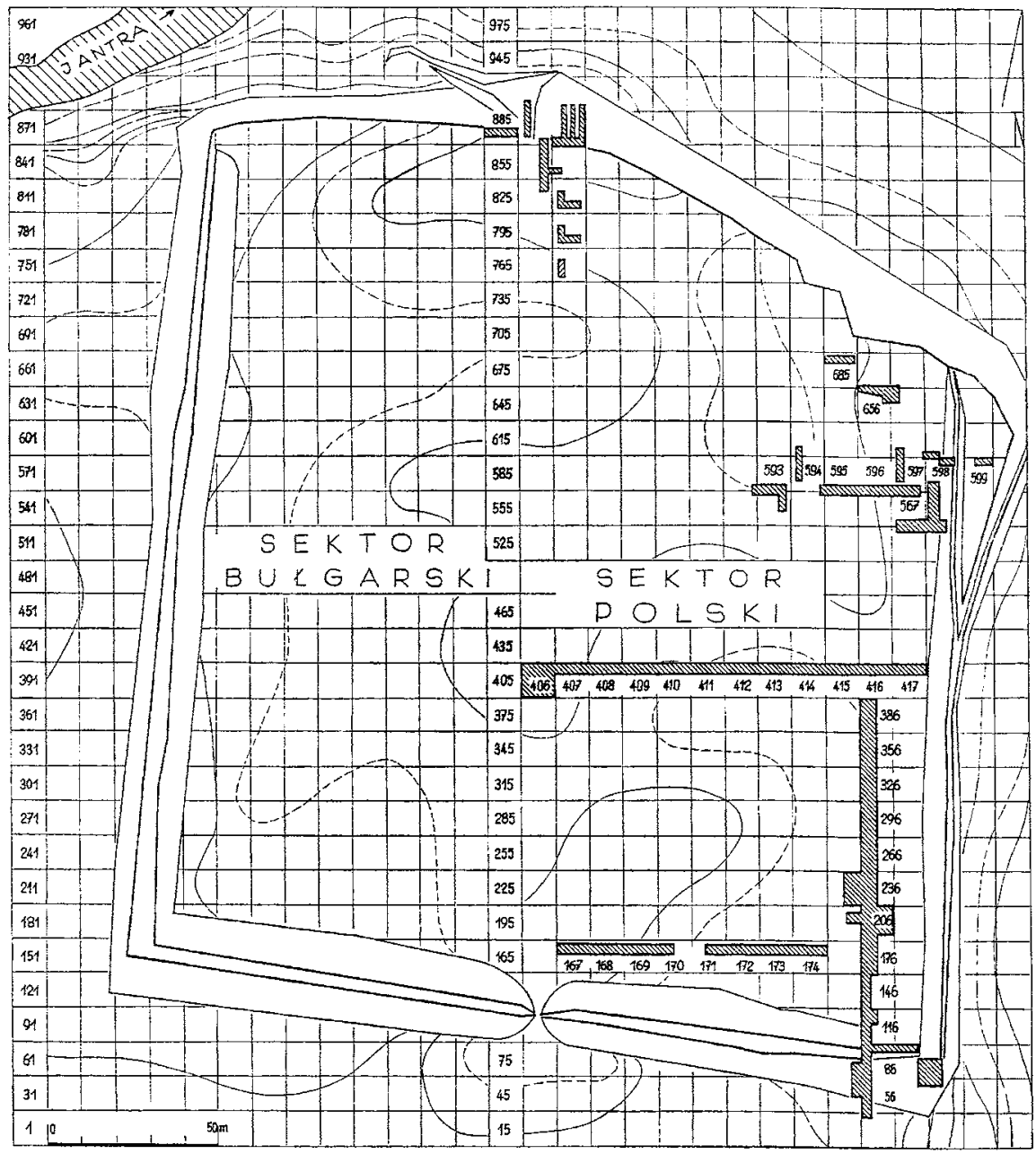

Abb. 2. Stărmen. Plan des Burgwalles mit gekennzeichneter Grabungsfläche im polnischen Sektor

Im Ergebnis der Ausgrabungen in Stărmen(Abb. 2 und 3) gelang es, die Veränderungen aufzuzeigen, denen die slawische Gesellschaft hinsichtlich dieser Beziehungen unterlag. Es konnten zunächst die Überreste einer unbefestigten Siedlung erschlossen werden, die am Ende des 7. Jahrhunderts entstanden ist und als solche längere Zeit fortbestand.

Es waren deutliche Elemente slawischer Kultur zu erkennen, wie sie auch aus den nördlich der Karpaten liegenden Gebieten bekannt sind: Bebauungen in Form von Grubenhäusern mit einem Steinofen in der Ecke (Abb. 4), freistehende kuppelförmige Brotbacköfen und eine typische Keramik mit Analogien aus der ganzen Donauzone. 


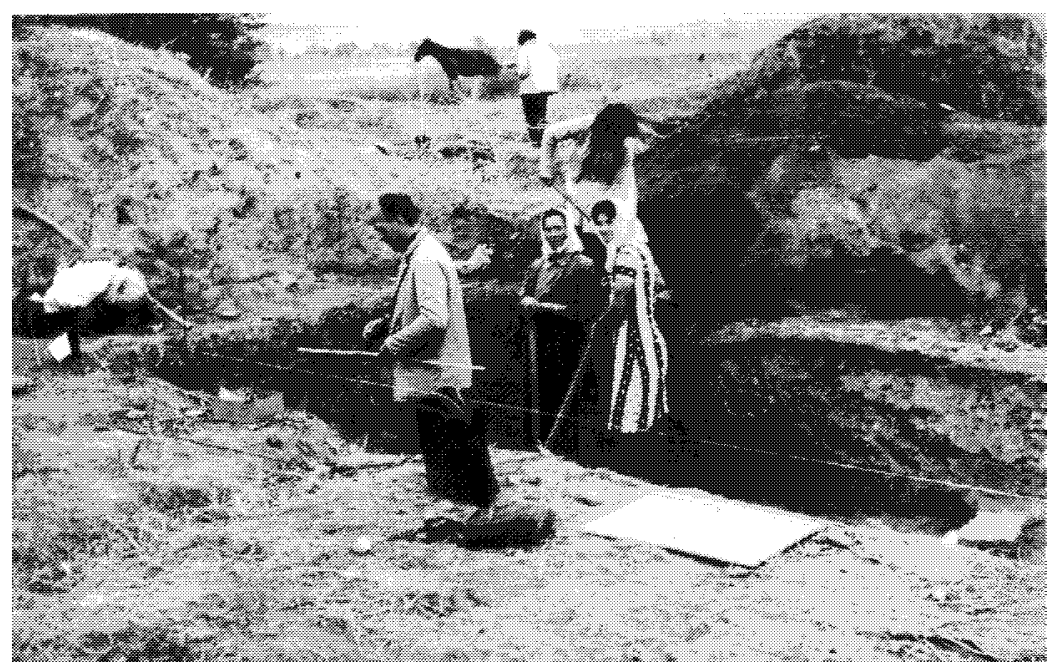

Abb. 3. Stărmen. Arbeit auf der Grabungsfläche

Am Ende des 9. Jahrhunderts entstand auf dieser Siedlungsstelle eine Burganlage mit einzelnen frühstädtischen Elementen. Das Befestigungssystem (Abb. 5) war für diese Region nicht typisch, da es offenbar Beziehungen zu den Wällen mit Steinblenden besaß, die vor allem aus den böhmisch-mährischen Gebieten bekannt sind. Innerhalb der Burg wurden u.a. Spuren handwerklicher Produktion festgestellt, darunter vor allem des Schmiedehandwerks. Es gelang, zwei Nutzungshorizonte der Burg voneinander abzugrenzen. Mit dem älteren ließ sich die Anwesenheit slawischer Reiterkrieger innerhalb der Burg verbinden, also von Vertretern der damaligen Elite. Es wurden nämlich typisch karolingische Sporen freigelegt, die, wie bekannt, von den Nomaden nicht benutzt wurden und die stets ein Kennzeichen der slawischen Eliten sind. Im Inventar des jüngeren Horizonts waren dagegen Elemente vorhanden, die aus dem protobulgarischen Milieu übernommen wurden, u.a. Säbelteile, Riemenschmuck und ein Börsenbeschlag. Einen solchen Einfluss zeigen auch die im zoologischen Material festgestellten Wandlungen im Haustierspektrum. Die Endstufe der Kultur der Bewohner der Burg Stărmen entspricht also schon völlig der Kultur des 1. bulgarischen Staates (Abb. 6), wie sie aus dessen Hauptzentren bekannt ist. Eine eingehende Analyse der Bebauung und des Inventars der Burg erlaubte es, die Anlage als ein Wirtschafts- und Verwaltungszentrum eines kleinen Gebietes anzusprechen, das von seiner Größe her zwischen einer Burg-Stadt und einem großen Dorf einzuordnen wäre.

Die Untersuchungen in Stărmen, einer Burg mit lokalem Charakter, die in Nordbulgarien an der Jantra, einem Nebenfluss der Donau, entstanden war, haben jedoch keine nennenswerten Aufschlüsse dazu geliefert, wie antike Kulturelemente 


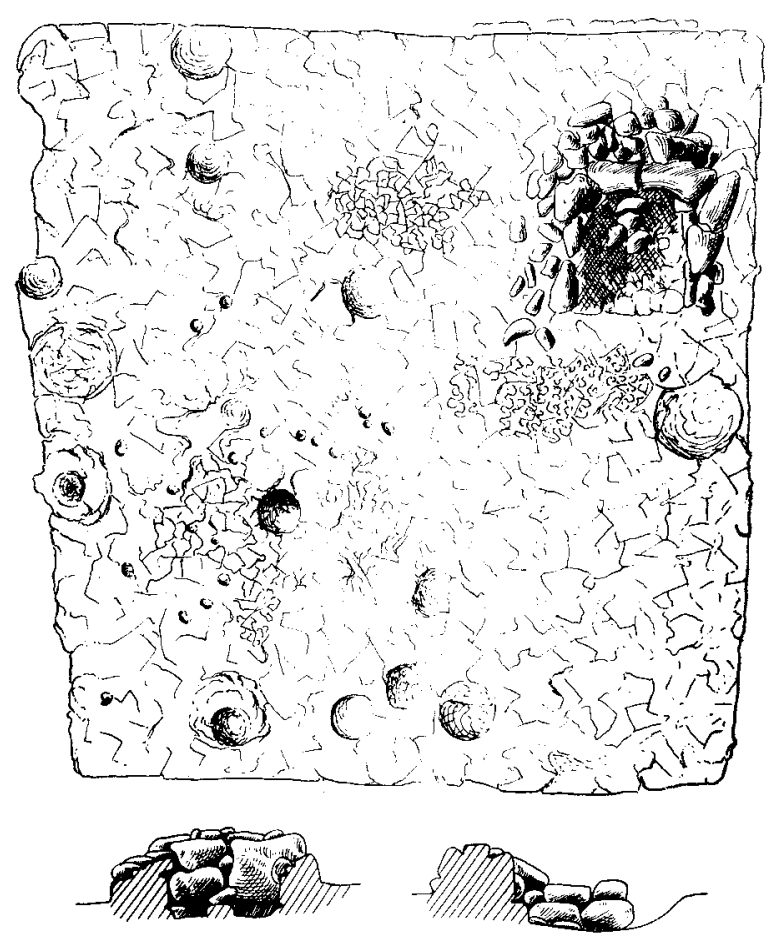

Abb. 4. Stărmen. Grubenhaus mit einem Ofen in der Ecke

Aufnahme bei den aus dem außerrömischen Gebiet eingewanderten Gruppen fanden. ${ }^{9}$ Das einzige entdeckte Sakralgebäude war nur in geringen Resten erhalten und bot keine Möglichkeit zu einer eingehenden Analyse. ${ }^{10}$ So hoffte man, durch die Untersuchung des nahe am Schwarzen Meer gelegenen Fundortes Odărci bessere Ausgangspunkte für die Beantwortung offen gebliebener Fragen zu gewinnen. Untersucht wurde eine Siedlung aus der Zeit des ersten bulgarischen Staates, die direkt auf den Ruinen einer byzantinischen Festung aus dem 4. bis 7. Jahrhundert angelegt worden war. Es konnten also unterschiedliche Kulturelemente direkt miteinander verglichen werden. Am Fundort waren die frühbyzantinischen Baureste gut erhalten (Abb. 7 und 8). Eine Analyse der Bautechnik frühmittelalterlicher Häuser, die sich teilweise an ältere byzantinische Gebäude anlehnten, zeigte, dass die byzantinische Bautechnik den Bewohnern in der Zeit des ersten bulgarischen Staates unbekannt war. Und dies obwohl im Gegensatz zu Stărmen beim Bau der oberirdischen Hausteile Steinbauten vorherrschten (Abb 9). Also erwies sich die Wirkung des antiken Erbes für diese Zeit als sehr beschränkt.

9 vgl. Dymaczewski 1973.

10 vgl. Danielczyk 1972. 


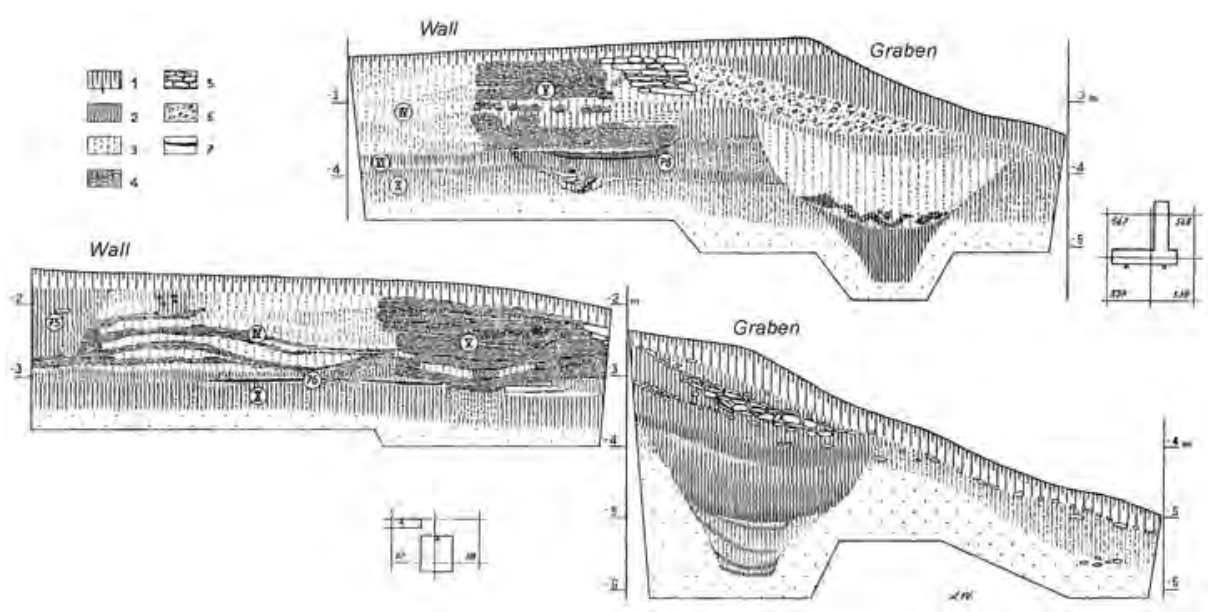

Abb. 5. Stărmen. Schnitte durch den Wall und den Festungsgraben des östlichen Burgwalls

Die von polnischen Archäologen durchgeführten Ausgrabungen in Stărmen und Odărci waren schließlich der Ausgangspunkt für verschiedene weiterführende Studien. Sie bildeten u.a. eine der Grundlagen für das 1977 veröffentlichte 3. Heft der Serie „Kulturen des frühmittelalterlichen Europas“. ${ }^{11}$ Selbstverständlich war es für die Darstellung eines Gesamtbildes der Kultur der Südslawen nötig, auch Ergebnisse von Untersuchungen und Studien aus anderen südslawischen Ländern einzubeziehen. Eine ganze Reihe analytischer Untersuchungsergebnisse besonders aus Stărmen schuf die Möglichkeit, interessante Vergleiche mit solchen Gebieten anzustellen, die im Frühmittelalter von anderen slawischen Gruppen besiedelt waren. Diese Erkenntnisse flossen auch in unterschiedliche Vergleichsstudien ein. ${ }^{12}$ Als besonders wertvoll erwiesen sie sich z.B. im Zusammenhang mit Aussagen zur Besiedlungsstruktur in der Zeit der Staatsbildung und hinsichtlich der Rolle nicht-agrarischer Zentren - Burgen - in diesem Prozess. ${ }^{13}$ Diese vergleichenden Untersuchungen ermöglichten es, sowohl die aus verschiedenen Gründen erwachsenen Unterschiede, als auch auffällige Gemeinsamkeiten zwischen einzelnen Regionen aufzuzeigen. Das für südslawische Länder vergleichsweise reiche Kulturinventar ließ es bisweilen zu, verschiedene Elemente und Eigenschaften der untersuchten Prozesse plastischer darzustellen. Dies betraf solche charakteristischen Züge früher Staatsformationen, wie z.B. die Konzentration der wesentlichen militärischen, ökonomischen und gesellschaftlichen Kräfte des sich bildenden Staates in seiner geographischen Mitte. In den Siedlungsstrukturen spiegelte sich dieser Vorgang im Bau einiger mächtiger Zentralburgen wieder. Neben militärischen oder ökonomi-

11 Kurnatowska 1997

12 z.B. Dymaczewski 1970; ders. 1973; Kurnatowska 1970; dies. 1974; dies. 1980.

13 Kurnatowska 1984, 1995. 


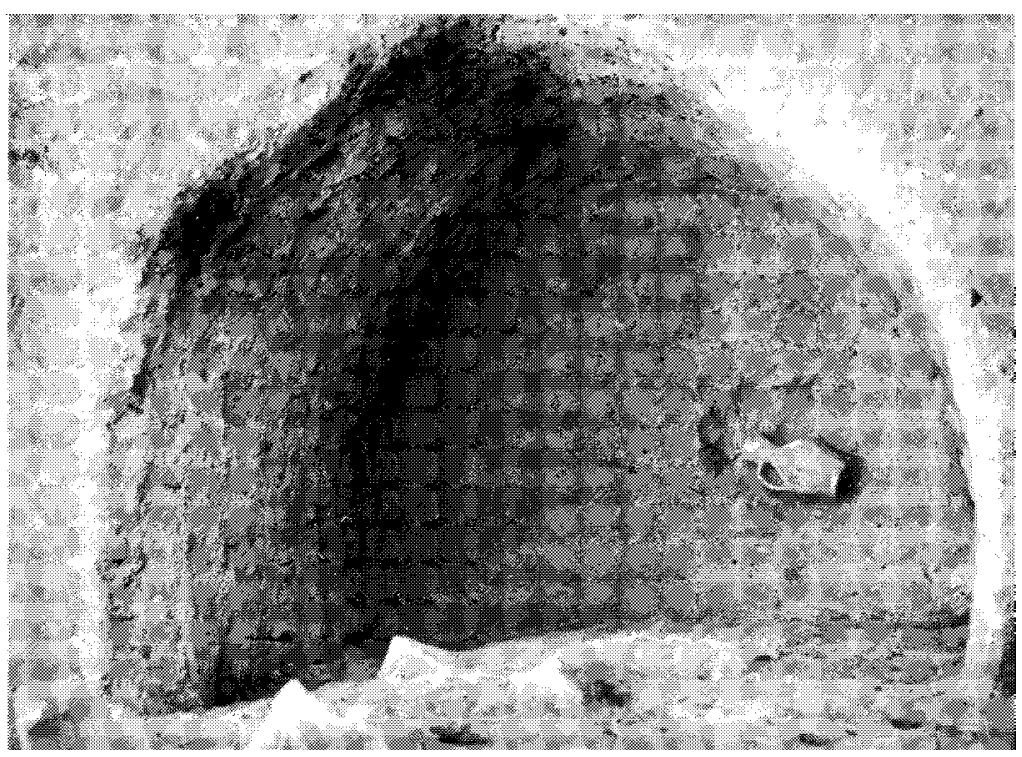

Abb. 6. Stărmen. Vorratsgrube mit einem glasierten Gefäß auf der Grubensohle

schen Aufgaben dienten sie auch in besonderem Maße der Repräsentation, wie sie für das frühmittelalterliche Bulgarien besonders deutlich auch durch die Nachrichten der Schriftquellen beleuchtet wird.

Der bereits erwähnte Umstand, dass sich die frühmittelalterlichen Gemeinschaften, die die von uns untersuchten Orte bewohnten, bei ihren wirtschaftlichen Tätigkeiten nicht gerade von größter technischer Rationalität und Nützlichkeit haben leiten lassen, wurde durch die Untersuchungen zur Eisenmetallurgie des frühmittelalterlichen Bulgariens, u.a. bei den metallurgischen Analysen des reichen Fundmaterials aus Stărmen und Odărci (Abb. 10) deutlich bestätigt. ${ }^{14}$ Dies wurde zum Ausgangspunkt für breiter angelegte allgemeine Kulturüberlegungen.

Bei Betrachtungen der Kultursituation im Donau-Balkangebiet am Beginn des Frühmittelalters glaubt man zu erkennen, dass viele Elemente nicht zu einem Milieu zu passen scheinen, das sich früher im Bereich der antiken Kultur befand. Die slawische Kultur des anbrechenden Frühmittelalters soll sich aber auch von der in solchen barbarischen Regionen am Ausgang des Altertums unterschieden haben, in denen allenfalls mit einer partiellen Anwesenheit von Slawen zu rechnen ist, wie z.B. im Kreis der Černjachov-Kultur. ${ }^{15}$ Übereinstimmungen zwischen der materiellen Kultur der Slawen jenseits der Karpaten und im Donau-Balkangebiet sollen darauf hinweisen, dass sich

14 Mamzer 1973, 1979, 1985b, 1988.

15 vgl. Godłowski 1999. 


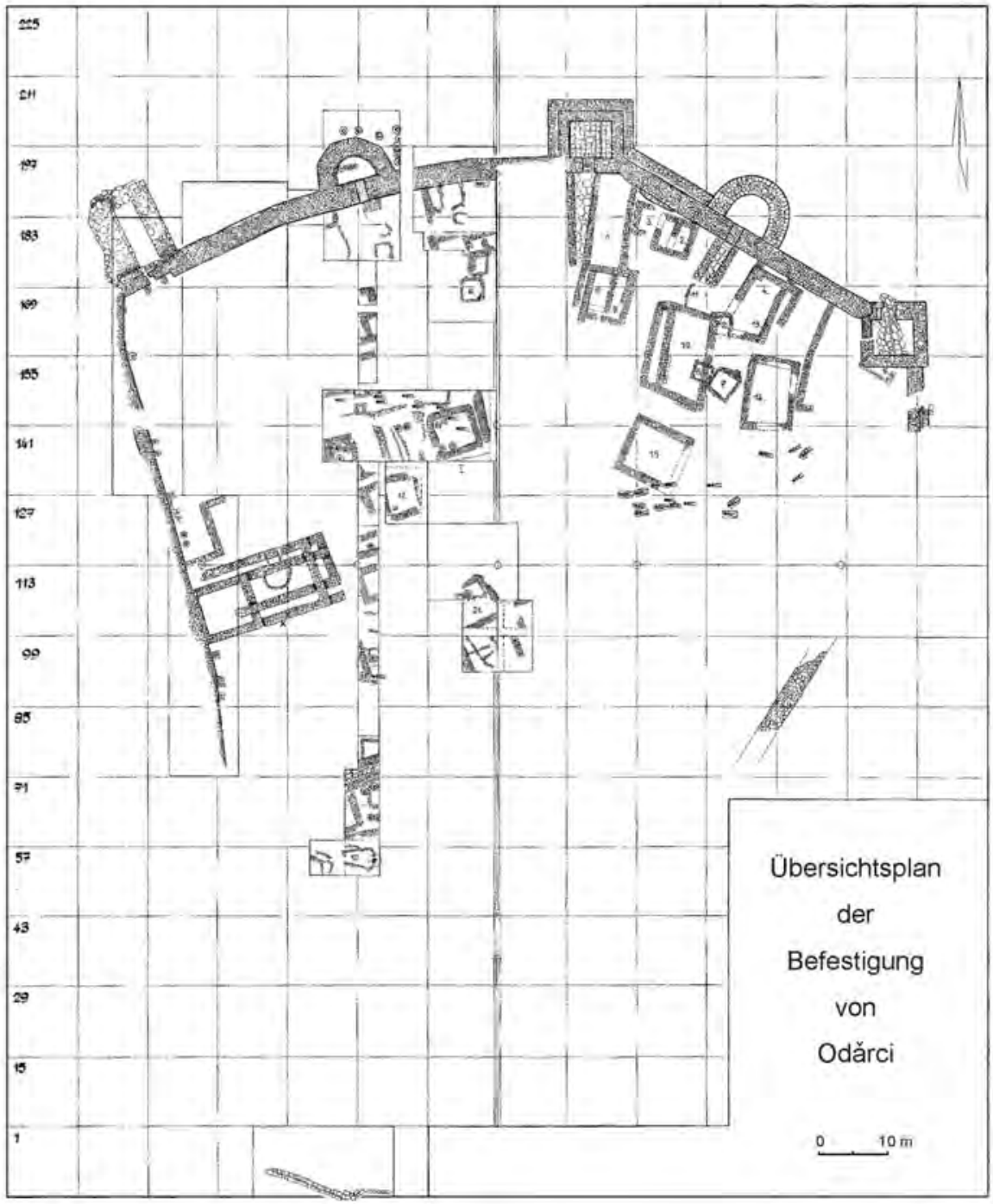

Abb. 7. Odărci. Lageplan der Fundstelle mit Mauerresten der byzantinischen Festung und der slawischen Siedlung

diese Einschätzung der Sonderstellung slawischer Kultur auf deren Gesamtheit am Anfang des Frühmittelalters bezieht lässt, d.h., dass sich die Kultur der Slawen in ihren ursprünglichen Siedlungsgebieten erst allmählich ausgeformt haben soll.

Hierbei handelt es sich um eine bewertende Beurteilung, die davon ausgeht, dass die slawische Kultur am Anfang des Frühmittelalters in den ehemaligen Gebieten antiker Zivilisation höher entwickelt gewesen seien soll, als die der Slawen während 


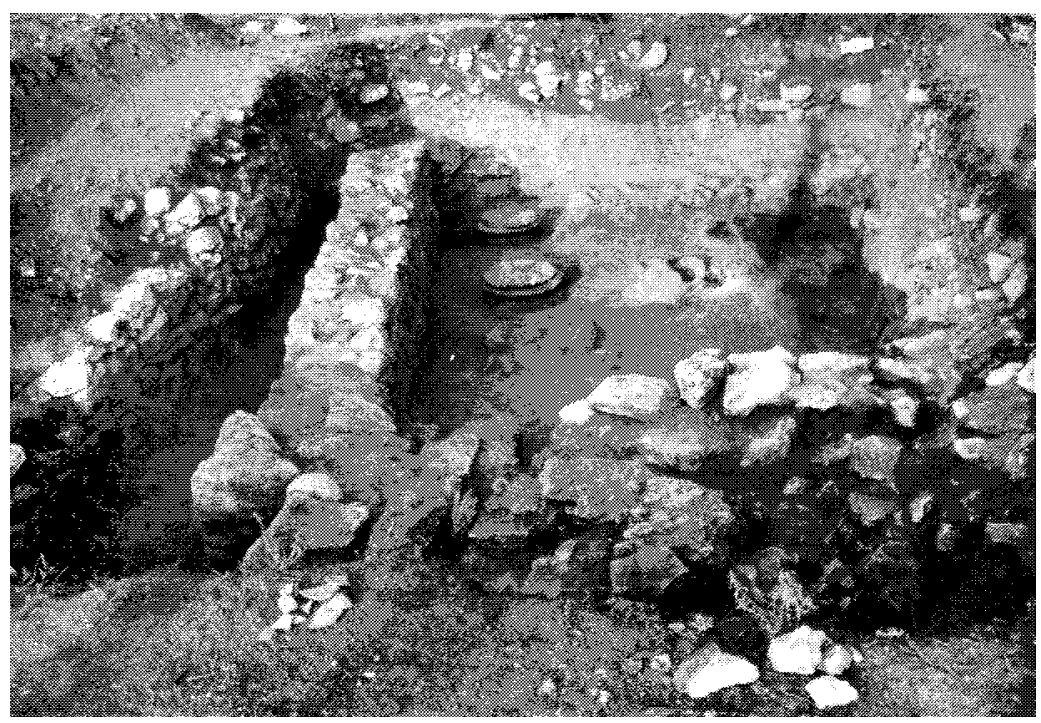

Abb. 8. Odărci. Überreste byzantinischer Häuser

eines früheren Zeitraumes. Eine Einschätzung dieser Art ist Resultat und Ausdruck eines klassischen anthropologischen Evolutionismus, demzufolge jede folgende Entwicklungsstufe höher als die frühere sei. Die Idee des Zivilisationsfortschritts, genauer des wissenschaftlich-technischen Fortschritts, liefert hier die Bewertungsgrundlage der Untersuchungen. Die Forschungsmethode ist also folgende: Auf Grund von erhaltenen materiellen Überresten wird der Entwicklungsstand einzelner voneinander abhängiger Herstellungstechnologien beurteilt, und dies entscheidet über das Niveau der gesamten wirtschaftlichen Entwicklung. Letztere wird als ein Maßstab für die gesellschaftliche Entwicklung betrachtet. In der Praxis wird dieser Gedankengang vielfach auf folgendes reduziert: Beliebige Änderungen, fortschrittliche oder regressive, zumeist sogar nur auf einem Feld der materiellen Kultur, werden als Widerspiegelung dementsprechender gesellschaftlicher Veränderungen gedeutet.

In den Kategorien dieser Fortschrittsidee wird die Meinung formuliert, wonach es in der Kultur der Slawen am Anfang des Frühmittelalters zu einer Wende infolge des wirtschaftlichen Fortschritts, ausgelöst durch die allgemeine Verbreitung des Pflugackerbaus, gekommen sei.

Die Ergebnisse, die wir durch Untersuchungen sowohl auf dem Gebiet des europäischen Barbaricums als auch im Donau-Balkan-Gebiet an der Wende vom Altertum zum Frühmittelalter gewonnen haben, stehen im Widerspruch zu der genannten Hypothese. Die Eisenmetallurgie des beginnenden Frühmittelalters ist im gesamten slawischen Gebiet in technologischer Hinsicht durch ein niedriges Produktionsniveau charakterisiert. Das Schmelzen erfolgte in primitiven, nur wenig 


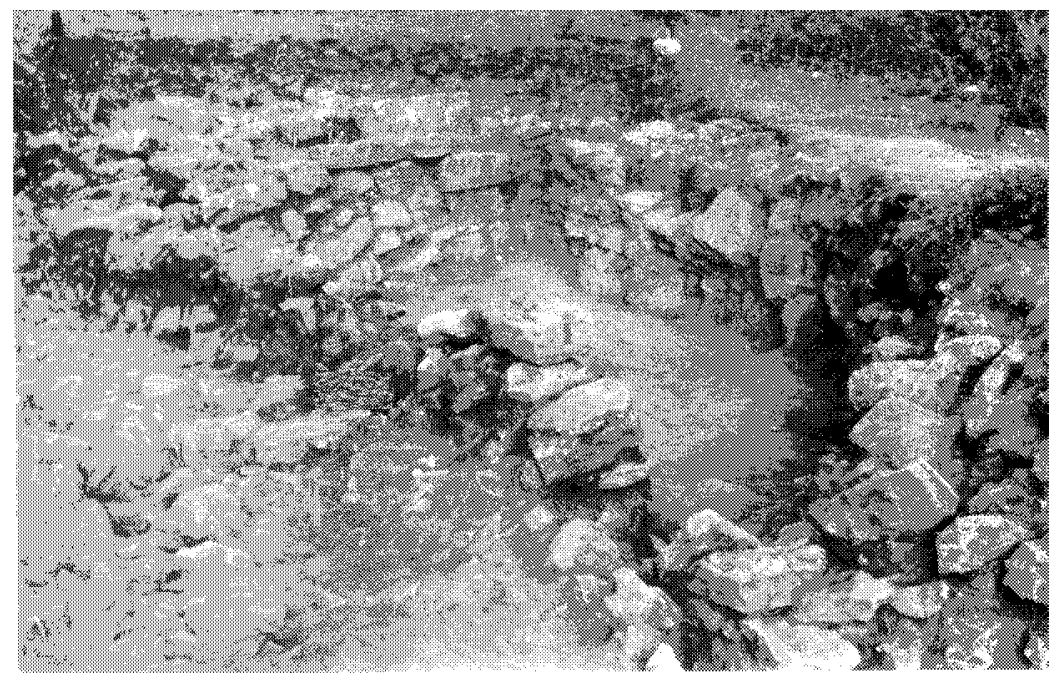

Abb. 9. Odărci. Frühmittelalterliches Haus

vertieften Gruben - sogenannten Schmelzfeuerstellen. Bei den in verhältnismäßig geringen Mengen hergestellten Erzeugnissen handelte es sich um kleine Gegenstände des täglichen Gebrauchs, wie Messer oder Beschläge für eine breite Verwendung. Die Ergebnisse unserer Untersuchungen stellen einerseits die Entwicklungsabhängigkeit von Metallurgie und Landwirtschaft in Frage und bezweifeln anderseits die Behauptung, dass der technologische Faktor der Hauptfaktor der wirtschaftlichen Gesellschaftsentwicklung gewesen sei.

Die Steigerung der Produktion und vor allem die Ausweitung des Produktsortiments durch die Herstellung neuer Formen landwirtschaftlicher und anderer Werkzeuge, die wir im Übergang vom anbrechendem Frühmittelalter (6. bis 7. Jahrhundert) und der späteren Phase des Frühmittelalters (9. bis 10./11. Jahrhundert) feststellen können, suggerieren eine solche Abhängigkeit. Denn es ist anzunehmen, dass der Aufschwung solcher Produktionszweige, wie vor allem der Landwirtschaft, eine Erhöhung des Bedarfs an Eisen bewirkt haben sollte. Der Produktionsanstieg, wie er beispielsweise auch am Material aus Stărmen und Odărci zu ersehen ist, hatte einen sprunghaften Charakter. Bei der Eisenmetallurgie handelte es sich vor allem um eine quantitative Erhöhung, da sich die Qualität der produzierten eisernen Gegenstände überwiegend nicht verändert hat. Man kann sagen, dass sich die technische Qualität des Eisens mit der Entwicklung seiner Produktion verschlechterte. Dies war die Folge einer Erhöhung der Kapazität durch die Verwendung von sogenannten Grubenöfen im Vergleich zu den bisher genutzten Schmelzfeuerstellen. Die Tatsache, dass es bei den Öfen dieses Typs keine Möglichkeit gab, die flüssige Schlacke nach außen abzuführen, führte zur einer erneuten Oxydation der bereits produzierten Eisenmoleküle. 


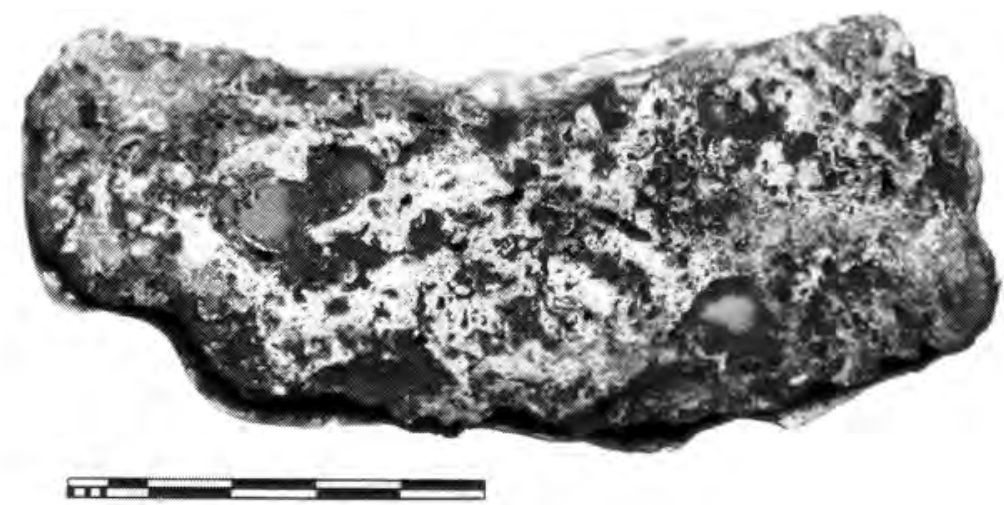

Abb. 10. Odărci. Eisenluppe

Damit verbunden war die Eisenmenge im Verhältnis zum verbrauchten Rohstoff geringer als bei den früher verwendeten kleinen Schmelzfeuerstellen. Die Notwendigkeit zum Abschluss des Reduktionsvorganges sowie die wegen der gesteigerten Kapazität der Grubenöfen bestehende Notwendigkeit zur Erhöhung der Temperatur führten außerdem zum Entkohlen des bereits reduzierten Eisens. Allein schon dadurch wurde das Metall in niedrigerer Qualität als zuvor erzeugt. Die Vergrößerung der Eisenproduktion war also nicht mit einer technischen Weiterentwicklung dieses Produktionszweiges verbunden.

Diese bei den Studien über die Eisenproduktion im frühmittelalterlichen Bulgarien gewonnenen Erkenntnisse flossen in die Interpretation der Untersuchungsergebnisse zur Eisenmetallurgie in Mitteleuropa an der Wende des Altertums ein. ${ }^{16}$ Die damals in dieser Zone allgemein verwendeten Schachtöfen wurden gewöhnlich als ein Zeichen des hohen Niveaus der Eisenmetallurgie sowohl zu einem früheren Zeitraum, als auch vor allem in der darauffolgenden Zeit des Frühmittelalters betrachtet. Aus technologischer Sicht erfüllte jedoch die Verwendung des Schachtofens, dessen Ziel eine Rationalisierung des Reduktionsverfahrens war, diese Erwartungen nicht. Es war mit diesem Ofen nämlich unmöglich, die flüssige Schlacke nach außen abzuführen. Es handelt sich hier um eine ähnliche Situation wie bei den Grubenöfen des Donau-Balkangebietes. Obwohl absolut mehr Eisen erzeugt wurde, war die prozentuale Ausbeute im Verhältnis zum verbrauchten Rohstoff kleiner und die technische Qualität des Eisens schlechter, als die von Eisen, das in Schmelzfeuerstellen gewonnen wurde.

Die Einführung von Schachtöfen, die jeweils nur einmal verwendet werden konnten, erfolgte also nicht, weil die damaligen Hersteller einen technischen Fortschritts bewirken wollten. Die Einführung erfolgte nicht aus technologischen Gründen oder um die Leistung zu erhöhen oder die technische Qualität des produzierten Eisens zu verbessern.

16 Mamzer 1985a. 
Mit anderen Worten waren der technische Fortschritt und die damit verbundenen rationalen, technologischen und auf eine Steigerung des Nutzens gerichteten Kenntnisse nicht die Faktoren, die über die Weiterentwicklung der Eisenmetallurgie entschieden. Da der technologische Faktor also nicht hauptsächlich für die Weiterentwicklung der Eisenmetallurgie verantwortlich war, hatte die Produktionssteigerung, die wir zwischen dem Anfang des Frühmittelalters und späteren Phasen dieser Periode beobachten, einen extensiven Charakter. Sie beruhte auf einer Erhöhung des Arbeitsaufwandes, entsprechend den Bedürfnissen bei einem gleichzeitigen Festhalten an einer im Prinzip unveränderten Technik. Somit müssen wir annehmen, dass die Änderungen in der Produktionsgröße mit der Änderung der Produktionsorganisation verbunden waren. Diese wiederum stand mit der gesamten Organisationsstruktur der damaligen Gesellschaft in direktem Zusammenhang.

Um das Problem näher darzustellen, werfen wir einen Blick auf Nachrichten, die wir den Miracula Sancti Demetrii (L. II, IV, 101, 190) entnehmen können. Diese Quelle beschreibt die Einfälle der Slawen und Awaren in Thessaloniki im 7. Jahrhundert. Wir erfahren, dass es damals unter den Slawen, die Thessaloniki belagerten, eine bestimmte Gruppe von Kriegern gab, die u.a. mit Beilen bewaffnet waren und sich von der kaum bewaffneten Masse der übrigen Krieger abhoben. Wir erfahren auch aus dieser Quelle, dass es spezialisierte Schmiede gab, die Pfeilspitzen in großen Mengen produzierten. Wenn wir diese Informationen mit den archäologischen Angaben über die Eisenprodukte verbinden, die zu Beginn des Frühmittelalters ausschließlich aus kleinen Gegenständen zum tagtäglichen Gebrauch bestanden, drängt sich der Schluss auf, dass die Eisenproduktion damals vor allem auf militärische Bedürfnisse ausgerichtet war. Es handelte sich dabei zugleich um eine spezialisierte Produktion, einerseits für den Bedarf einer ausgewählten Kriegergruppe, und anderseits zur Sicherung der Ausrüstung der übrigen Masse von Kriegern, die nur mit Bögen bewaffnet war und die eiserne Pfeilspitzen benötigte. Andere wirtschaftliche Bedürfnisse wurden nur im geringen Umfang befriedigt. Dies führt letztlich zum Schluss, dass der gesellschaftliche Status der Schmiede zu jener Zeit in einem wesentlich höheren Grade vom militärischen Bedarf der Gesellschaft als vom wirtschaftlichen abhängig war. Wenn man bedenkt, dass die gesamte damalige Wirtschaft im hohen Grade Prestigecharakter hatte, d.h. auf das Herstellen prestigeträchtiger Erzeugnisse und somit die Festigung der Stellung der gesellschaftlichen Eliten gerichtet war, kann man davon ausgehen, dass der Status der Schmiede höher als der jener Bevölkerungsteile war, die sich mit reiner wirtschaftlicher, insbesondere landwirtschaftlicher Tätigkeit befasste. Erst der Vorgang zunehmender gesellschaftlicher Differenzierung, dessen Wirksamkeit wir für die späteren Phasen des Frühmittelalters annehmen können und der zur Herausbildung von zwei gegensätzlichen Gruppen der damaligen Gesellschaft führte, bewirkte eine Änderung der gesellschaftlichen Lage der Schmiede. Es erfolgte schließlich eine Gleichstellung der Schmiede mit der in der landwirtschaftlichen Produktion arbeitenden Bevölkerung. 
Dieser Wandel in der gesellschaftlichen Stellung der Schmiede wurde scheinbar zu einer der Hauptursachen, die zur Steigerung der Eisenproduktion und vor allem zur Erweiterung des Warensortiments landwirtschaftlicher und sonstiger Werkzeuge führte. Es ist auch eine allmähliche Verbesserung der Schmiedetechniken und des Eisens selbst zu beobachten. Neue, verbesserte Öfen in Schachtkonstruktion aus Steinen oder aus Steinen und Ziegeln kamen in Gebrauch.

Auf diese Weise wurden die Wandlungen in der Organisationsstruktur der Gesellschaft, die wiederum mit Veränderungen in der Produktionsorganisation eng verbunden waren, zu Faktoren, die über die gesamte wirtschaftliche Entwicklung entschieden. Der technische Fortschritt war also ein Ergebnis gesellschaftlicher Veränderungen und kein Faktor, der die Weiterentwicklung der Produktion bewirkte.

Ein aufschlussreiches Beispiel für den dominierenden Einfluss gesellschaftlicher Veränderungen auf wirtschaftliche Vorgänge verbindet sich mit der nächsten Etappe des Frühmittelalters, in der der wirtschaftliche Aufschwung gehemmt wurde, der ursprünglich durch die beginnende gesellschaftliche Schichtung in Richtung Feudalismus ausgelöst worden war. Die diesen Aufschwung hemmenden Faktoren waren die Zentralisierung der Gesellschaft und die Unterordnung der Interessen der gesellschaftlichen Gruppen unter diejenigen einer herrschenden Oberschicht, die die bisher von den gesellschaftlichen Mittelschichten ausgeübte, ausbeutende Rolle vollständig übernommen hatte. Die Organisationsstruktur der slawisch-bulgarischen Gesellschaft näherte sich damals im gewissen Sinne dem byzantinischen System an. Schließlich erfolgte sogar eine Adaption der byzantinischen Rechtsnormen, wie des Nomos Georgikos oder die rechtliche Sanktionierung von Verhaltensnormen, wie sie u.a. in den Verfügungen des Khans Krum zu finden sind. Hinzu kamen Festlegungen, die die Abhängigkeitsverhältnisse zwischen den Dorfgemeinschaften, dem Staat und den Feudalgruppen regelten. Diese Normen dienten der Sicherung der Interessen der herrschenden Gruppe. Diesem Zweck dienten auch die Übernahme und Verbreitung byzantinischer Kulturmuster. Sie waren Ausdruck des Strebens nach einem Herrscherprestige, ähnlich dem byzantinischen.

Der Prozess der Zentralisierung der Gesellschaft war eine der Ursachen für die Existenz sogenannter Staatsdörfer, deren Produktionserträge direkt der herrschenden Gruppe zuflossen. Dadurch wurde eine Spezialisierung insbesondere bei der Entwicklung verschiedener Zweige der Luxusproduktion bewirkt, die vor allem in den Hauptzentren des Staates, wie Pliska oder Preslav, konzentriert war. Glas-, Baukeramik-, Schmuckproduktion, Goldschmiedekunst und andere Branchen, die Güter von prestigebildender Bedeutung herstellten blühten auf. Die gesellschaftliche Stellung der mit diesen Bereichen verbundenen Produzenten näherte sich wieder dem Status jener Handwerker an, die einstmals für den Bedarf der Stammeseliten produzierten.

Der Zentralisierungsprozess der slawisch-bulgarischen Gesellschaft bewirkte eine Blockierung bestimmter wirtschaftlicher Mechanismen, die zunächst im Zuge gesellschaftlicher Desintegration einer sich in Richtung des Feudalismus entwickelnden 
Gesellschaft in Gang gekommen waren. Wir haben es hier mit einer Situation zu tun, die an die von A. Dabinović beschriebene wirtschaftliche Lage von Raška erinnert. ${ }^{17}$ Er beschreibt, wie „der wirtschaftliche Rückschritt von Raška“ dadurch bewirkt wurde, ,dass eben auf diesem Gebiet noch im Mittelalter die Gesetzessammlung Nomos Georgikos Anwendung fand." In Bulgarien war seine Einführung am Anfang des 9. Jahrhundert mit dem Zentralisierungsprozess von Gesellschaft und Wirtschaft des ersten bulgarischen Staates verbunden.

Daraus folgt, dass der technische Fortschritt mit dem wirtschaftlichen Fortschritt nicht gleichbedeutend ist. Es war also das Niveau solcher wirtschaftlicher Aktivitäten, wie sie in unserer Analyse beschrieben wurden, welches das gesamte Geflecht gesellschaftlicher Erscheinungen bestimmte, in die diese Tätigkeiten eingebettet waren. Dagegen kommt dem zuvor erreichten technischen Entwicklungsstand der Wirtschaft, entgegen der Hypothese aus der Sicht der Fortschrittsidee, keine solche Funktion zu. Daher fällt es schwer an eine stufenweise technologische Evolution und eine abhängig davon verlaufende wirtschaftliche Entwicklung zu glauben. Eine bewusste Orientierung auf technologische Effektivität, auf die Steigerung der Produktionsleistung und im Zusammenhang damit auf die wirtschaftliche und im Erfolgsfalle auf die gesellschaftliche Entwicklung, entsprach nicht dem Wesen und dem Funktionsmechanismus der damaligen Gesellschaften. Die Fortschrittsidee ist unser eigenes Denkprodukt, das in der westlichen neuzeitlichen Kultur ausgebildet wurde und dessen Wurzeln in der Epoche der Aufklärung liegen. Diese in die Vergangenheit rückprojizierte Fortschrittssichtweise entspringt also unseren heutigen Erwartungen. Dies gilt auch für die zu dieser Perspektive gehörende Kontinuitätsidee. Auch sie hat mit der von uns untersuchten Wirklichkeit wenig zu tun.

Wir haben in diesem Beitrag zwei Arten von Untersuchungen beschrieben, eine mit vergleichender Orientierung und eine zu allgemeinen Kulturerscheinungen. Unsere Forschungsarbeiten in Bulgarien - Ausgrabungen sowie eine eingehende Bewertung der aufgefundenen Hinterlassenschaften - haben uns dazu angeregt. Das in der Regel reiche Kulturinventar, das auf diesen Fundstellen erschlossen wurde, ermöglichte es, verschiedene Analysestränge zu verfolgen. Der Blick auf bestimmte kulturelle Erscheinungen und Prozesse im Gebiet der nordwestslawischen Länder, aus der Perspektive unserer Studien zum Balkanraum, führte dazu, dass wir vergleichbare Erscheinungen, die dort zunächst weniger deutlich erkennbar waren, besser verstehen konnten. Auch die sehr viel größere Zahl von Informationen der Schriftquellen zur Geschichte Südosteuropas haben die Möglichkeiten für eine Interpretation verbessert. Aus allen diesen Gründen können wir die Untersuchungen auf dem Gebiet Bulgariens als besonders fruchtbar einschätzen.

17 Dabinović 1941. 


\section{Bibliographie}

Dabinović 1941: Antun Dabinović, „Državnopravni odnos Hrvata prema istočnom carstvu“, in: Rad Hrvatske Akademije znanosti i umjetnosti 122, 1941, S. 49-148.

Danielczyk 1970: Bożena Danielczyk, ,Wyroby z miedzi i jej stopów z wcześnosredniowiecznego grodziska w Styrmen (Bułgaria)“, in: Slavia Antiqua 16, 1970, S. 253-271.

Danielczyk 1972: Bożena Danielczyk, „Wczesnośredniowieczny obiekt sakralny ze Styrmen, okręg Ruse (Bułgaria)“, in: Slavia Antiqua 19, 1972, S. 183-197.

Danielczyk 1974: Bożena Danielczyk, „Badania nad surowcem bizantyjskich monet „,brązowych“ znalezionych w Styrmen, okręg Ruse (Bułgaria)”, in: Wiadomości Numizmatyczne 18, 1974, S. 24-29.

Dekówna 1975: Maria Dekówna, ,Wyroby szklane z grodziska w Styrmen (Bułgaria)”, in: Slavia Antiqua 22, 1975, S. 177-277.

Dončeva-Petkova/Ninov/Parušev 1999: Ljudmilla Dončeva-Petkova/Lavar Ninov/Veselin Parušev, Odàrci. Selište ot Pàrvoto bàlgarsko carstvo 1, Sofia 1999.

Dymaczewska 1972: Urszula Dymaczewska, „Ceramika z osady średniowiecznej w Styrmen (Bułgaria)“, in: Slavia Antiqua 19, 1972, S. 199-226.

Dymaczewska/Dymaczewski 1981: Urszula Dymaczewska/Aleksander Dymaczewski, „Resultats des fouilles archeologiques effectuées à Odărci, departement de Tolboukhine (Bulgarie) au cours des années 1967, 1969-1974 et 1976-1977 (partie occidentale)“, in: Slavia Antiqua 27, 1981, S. 145-171.

Dymaczewski 1970: Aleksander Dymaczewski, „Quelques problèmes du developpement de la Bulgarie du nord est à la periode du Haut Moyen Age sur la base des fouilles effectuées à Styrmen de 1961-1964“, in: I Międzynarodowy Kongres Archeologii Stowiańskiej, Warszawa 14.-18.9.1970 V, Wrocław 1970, S. 62-70.

Dymaczewski 1971: Aleksander Dymaczewski, „Probleme der Anpassung der Slawen an das Kulturmilieu der römischen Provinzen im Lichte archäologischer Materialien“, in: Berichte über den II. Internationalen Kongreß für Slawischen Archäologie III, Berlin 1971, S. 161-166.

Dzięczkowski 1966: Andrzej Dzięczkowski, „Mięczaki (Mollusca) w próbkach z wykopalisk w Styrmen nad Jantrą (Bułgaria)“, in: Slavia Antiqua 13, 1966, S. 320-323.

Gładykowska-Rzeczycka 1971: Judyta Gładykowska-Rzeczycka, „Szkielety ludzkie z grodziska w miejscowości Styrmen w Bułgarii“, in: Slavia Antiqua 18, 1971, S. 249-282.

Godłowski 1999: Kazimierz Godłowski, „Spór o Słowian“, in: Henryk Samsonowicz (Hrsg.), Narodziny średniowiecznej Europy, Warszawa 1999, S. 52-85.

Hensel 1972: Witold Hensel, „Wieś i miasteczko w średniowiecznej Bułgarii - Styrmen pod Białą w okręu Ruse“, in: Witold Hensel, Archeologia i prahistoria. Studia i szkice, Wrocław 1972, S. 276-313.

Klichowska 1966: Melania Klichowska, „Wykopaliska w Styrmen w świetle badań botanicznych“, in: Slavia Antiqua 13, 1966, S. 315-320.

Kociszewski 1979: Longin Kociszewski, „Badania fizykochemiczne próbek ceramiki zabytkowej ze Styrmen“, in: Slavia Antiqua 26, 1979, S. 131-141.

Krzyżanowska 1971: Aleksandra Krzyżanowska, „Monety antyczne i wczesnośredniowieczne z grodziska w Styrmen (Bułgaria)“, in: Slavia Antiqua 18, 1971, S. 223-248.

Krzyżanowska 1983: Aleksandra Krzyżanowska, „Monety rzymskie i bizantyjskie znalezione w czasie wykopallisk na grodzisku w Odercy (Bułgaria)“, in: Slavia Antiqua 29, 1983, S. 179-203.

Kurnatowska (Hilczerówna) 1970: Zofia Kurnatowska (Hilczerówna), „Le problème de la civilisation Dridu (Remarques polemiques)“, in: Slavia Antiqua 17, 1970, S. 161-170. 
Kurnatowska (Hilczerówna) 1972: Zofia Kurnatowska (Hilczerówna), „Elementy uzbrojenia i oporządzenia jeździeckiego z wczesnośredniowiecznego grodziska w Styrmen w Bułgarii“, in: Slavia Antiqua 20, 1972, S. 87-124.

Kurnatowska (Hilczerówna) 1973: Zofia Kurnatowska (Hilczerówna), „Structure sociale des Sclavenes à la lumière d'une analyse de l'habitat", in: Balcanoslavica 1, 1973, S. 87-96.

Kurnatowska (Hilczerówna) 1977: Zofia Kurnatowska (Hilczerówna), Stowiańszczyzna poludniowa, Wrocław 1977.

Kurnatowska (Hilczerówna) 1980: Zofia Kurnatowska (Hilczerówna), „Quelques notes sur le processus de differenciation du paysage d'habitat des populations slaves dans les Balkans et sur le Danube pendant les IX ${ }^{\mathrm{e}}$ et $\mathrm{X}^{\mathrm{e}}$ siècles“", in: Raports du III ${ }^{e}$ Congrès International d Archeologie Slave II, Bratislava 1980, S. 243-254.

Kurnatowska (Hilczerówna) 1984: Zofia Kurnatowska (Hilczerówna), „Der Bildungsprozess des polnischen Staates und seine Spiegelung in der Besiedlungsstruktur“, in: Interaktionen der mitteleuropäischen Slawen und anderer Ethnika 6.- 8. Jahrhundert. Symposium Nove Vozokany 3.- 7. Oktober 1983, Nitra 1984, S. 165-172.

Kurnatowska (Hilczerówna) 1995: Zofia Kurnatowska (Hilczerówna), „Archäologie über die Anfänge der slawischen Staaten“, in: Sbornik Praci Filosofické Fakulty Brnenské Univerzity, Ř. E 40, 1995, S. 165-172.

Kurnatowska/Szamałek 1990: Zofia Kurnatowska/Krzysztof Szamałek, „Keramik vom SaltovoTyp und Tonkessel im Keramikmaterial von Styrmen und Odàrcy, Bulgarien“, in: Csanád Bálint (Hrsg.), Die Keramik Saltovo-Majaki Kultur und ihrer Varianten. Varia Archaeologica Hungarica III, 1990, S. 245-254.

Leciejewicz 1976: Lech Leciejewicz, Słowiańszczyzna zachodnia, Wrocław 1976.

Leciejewicz 1978: Lech Leciejewicz, Normanowie, Wrocław 1978.

Mamzer 1973: Henryk Mamzer, „Technologia części uzbrojenia znalezionych na grodzisku w Styrmen, okręg Ruse“, in: Slavia Antiqua 20, 1973, S. 125-129.

Mamzer 1979: Henryk Mamzer, „Technologia produkcji przedmiotów żelaznych ze Styrmen nad Jantrą w Bułgarii“, in: Slavia Antiqua 25, 1979, S. 225-243.

Mamzer 1985a: Henryk Mamzer, „Problem rozwoju metalurgii żelaza w Europie Środkowej u schyłku starożytności“, in: Przeglad Archeologiczny 32, 1985, S. 69-103.

Mamzer 1985b: Henryk Mamzer, „Społeczno-gospodarcze aspekty rozwoju metalurgii żelaza na terenie Bułgarii Naddunajskiej w okresie wczesnego średniowiecza“, in: Balcanica Posnaniensia 2, 1985, S. 181-198.

Mamzer 1988: Henryk Mamzer, Studia nad metalurgia żelaza na terenie pótnocno-wschodniej Butgarii we wczesnym średniowieczu, Wrocław1988.

Mamzer 1992: Henryk Mamzer, „Z problemów socjogenezy pierwszego państwa bułgarskiego (681-1018)“. in: Michał Tymowski/Marek Ziółkowski (Hrsg.), Geneza i funkcjonowanie wczesnych form państwowości na tle porównawczym, Warszawa 1992, S. 97-116.

Michajlov/Džingov/Vàlov/Dimova 1982: Stamen Michajlov/Georgi Džingov/Vàlo Vàlov/ Violeta Dimova, Ranno-srednovekovnoto selište pri selo Stàrmen, Sofie 1982.

Styrmen nad Jantrą. 1980: Witold Hensel (Hrsg.), Styrmen nad Jantra (Butgaria). Badania archeologiczne w latach 1961-1964 i 1967-1968, Wrocław-Warszawa-Kraków-Gdańsk 1980.

Szamałek 1977: Krzysztof Szamałek, „Późnorzymskie lampy gliniane z Odercy, okr. Tołbuchin (Bułgaria)“, in: Archeologia 28, 1977, S. 125-133.

Szamałek 1983: Krzysztof Szamałek, „Wczesnośredniowieczna ceramika z Odercy“, Slavia Antiqua 29, 1983, S. 143-174.

Szymański 1973: Wojciech Szymański, Stowiańszczyzna Wschodnia, Wrocław 1973.

Szymański/Dąbrowska 1979: Wojciech Szymański/Elzbieta Dąbrowska, Awarzy, Wegrzy Wrocław 1979. 


\title{
Westliche Einflüsse auf der östlichen Balkanhalbinsel im Spiegel der früh- und hochmittelalterlichen Reitausrüstung
}

\author{
THOMAS KIND
}

Eine Rekonstruktion des westlichen Einflusses in Südosteuropa muss im Wesentlichen von der archäologischen Forschung geleistet werden, da die Schriftquellen nur sehr geringe Rückschlüsse erlauben. Neben den bekannten diplomatischen Kontakten im Zusammenhang der Kriege mit Großmähren sei hier auf den Missionsversuch unter Papst Nikolaus I. verwiesen. ${ }^{1}$ Die Fundgruppe der Reitersporen, deren Auftreten nach dem bisher zu ermittelnden Fundbild im Frühmittelalter weitgehend auf Westund die westlichen Teile Mitteleuropas beschränkt ist, bietet sich hier für eine weitere Untersuchung an. „Ausreißer“ aus diesem Verbreitungsbild erlauben mit großer Wahrscheinlichkeit die Annahme von Kontakten.

Sporen waren noch in der Römischen Kaiserzeit und der frühen Völkerwanderungszeit im ganzen Reichsgebiet sowie im germanischen Siedlungsraum verbreitet. ${ }^{2}$ Noch in der älteren Merowingerzeit lässt sich eine weite Verbreitung der Reitersporen - und der Sitte, diese ins Grab mitzugeben - feststellen, ${ }^{3}$ jedoch fällt hier bereits die Fundlücke in den jetzt zunehmend slawisch besiedelten Regionen ins Auge. ${ }^{4}$ Es gelang bisher noch nicht, zu klären, ob diese Erscheinung Ergebnis der Fundüberlieferung oder Ausdruck einer ethnischen Bindung ist. Allein in den Randgebieten des Frankenreiches, wo Reitsitte, günstige Überlieferungsverhältnisse und eine relativ gute Forschungssituation zusammenkommen, ist es möglich, eine kontinuierliche Entwicklung der Sporenformen zu rekonstruieren. Mangels entsprechender Funde im westslawischen Siedlungsgebiet vor dem 8. Jahrhundert, das vergleichbar gut erforscht worden ist, soll und muss hier davon ausgegangen werden, dass sich in der Nichtüber-

1 Als eines der wenigen Beispiele siehe die päpstlichen Antworten auf die Anfrage des bulgarischen Khan: Gjuzelev 1995; Heiser1979.

2 Vgl. hierzu als immer noch grundlegend Jahn 1921. In der Völkerwanderungszeit: Svoboda, 1965, 197; B. Schmidt 1961/1970/1975.

3 Rettner 1997.

4 Sofern diese künftig westslawischen Gebiete überhaupt schon wieder besiedelt sind. Zum Problem des Hiatus zwischen germanischer und slawischer Besiedlung im heutigen Nordostdeutschland: Brather 1996a, 15-16. 
lieferung von Sporen eine andere - slawische - Reittradition abzeichnet, gemäß der der Gebrauch von Sporen unbekannt war und auch längere Zeit blieb, während bei den Germanen zumindest ein gelegentlicher Gebrauch von Sporen vorkam. ${ }^{5}$ Eine ausschließliche Erklärung der Lücke im Verbreitungsbild durch ethnische Besonderheiten ist jedoch unstatthaft, da Reitersporen auch bei den Nordgermanen des 5. bis 9. Jahrhunderts völlig außer Gebrauch kamen. Obwohl Reitergräber mit reicher Ausstattung vielerorts belegt sind kann hier kein Fund angeführt werden. ${ }^{6}$

Schon länger bekannt ist das vollständige Fehlen von Reitersporen in Fundkomplexen, die den Nomaden der eurasischen Steppen (Hunnen, Alanen, Magyaren, Chazaren, Pečenegen, Mongolen) zuzuschreiben sind.?

Schwieriger ist eine Beurteilung der Reitsitte in den Gebieten des Römischen Reiches hinsichtlich der einheimischen, romanisierten bzw. gräkisierten Bevölkerung. Schon während der Römischen Kaiserzeit ist hier ein Gebrauch von Sporen nur vereinzelt belegt. Die meisten Funde stammen aus den römisch beeinflussten Siedlungsgebieten der Germanen. An diesem Gegensatz zwischen Reichsgebiet und Peripherie ändert sich im Frühmittelalter im Grundsatz nichts. Wie aber das Beispiel der Verbreitung des Tassilokelchstils - des bekanntesten Verzierungsstils des 8. und wahrscheinlich noch des frühen 9. Jahrhunderts - zeigt, ist die Fundlücke im romanischen Westen, neben einer weitgehenden Aufgabe der Beigabensitte im Grabbrauch, wahrscheinlich mit dem Stand der Forschung zu erklären. ${ }^{8}$

5 Die von J. Żak (1959 u. 1988) vertretene und nachfolgend vielfach übernommene Datierung der Hakensporen ab dem 6. Jahrhundert kann nicht aufrechterhalten werden (vgl. Gabriel 1988 , 114). Es ist auch zu erwägen, ob die berühmte Stelle bei Theophylaktos Simokates (1985, 164 Anm. 812) über die Slawen vom fernen Rand des Ozeans, die angeblich kein Eisen kennen, dahingehend zu verstehen ist, dass sie sicherlich keine schwere, in Eisen gepackte Reiterei kennen, wie sie bei den Franken und den Byzantinern (Kataphrakten) vorhanden war, aber natürlich Eisen als solches. Die Nachricht bei Theophylaktos stammt jedoch eindeutig aus dem militärischen Bereich. Für das byzantinische Gebiet ist an einer entwickelten Kavallerie nicht zu zweifeln. Sporen sind jedoch nirgends erwähnt oder belegt. Brather $(1996,16)$ vermutet in dieser Angabe eine reine Schutzbehauptung, für die ein älterer Topos verwendet wurde. Auch das ist natürlich denkbar.

6 Arwidsson 1942; ders. 1954; ders. 1977; Jørgensen 1999.

7 Bálint 1989, 122; Viollet-le-Duc 1874, 402; Demmin 1893, 617. Zu den Awaren: Keller/ Bierbrauer 1965, 382; Eisner 1933, 254; Klanica 1986, 95. Zu den Ungarn: Hampel 1905, 260-261. Die einzige bekannte Ausnahme von Reitersporen im reiternomadischen Milieu stammt aus Prazdničnij im Kubangebiet: Kirpičnikov 1973, 64 Anm. 35.

8 Man beachte die völlige Fundleere in der Verbreitung des Tassilokelchstiles bei der Kartierung anlässlich seiner ersten Definition durch Günther Haseloff (1951) und in seinem Überblick über den erweiterten Kenntnisstand 25 Jahre danach (Haseloff 1976/77) im Vergleich mit den Neukartierungen durch Kleemann (1992a), Schulze-Dörrlamm (1998) und Wamers (1999). 
Aussagen zur Zusammensetzung der byzantinischen Reitausrüstung lassen sich, gleichfalls bedingt durch den Forschungsstand, nur sehr eingeschränkt treffen. Mir ist jedoch bislang kein entsprechender Fund bekannt geworden. Auch in den historischkunstgeschichtlich orientierten Arbeiten zur byzantinischen Bewaffnung finden Sporen keine Erwähnung. ${ }^{9}$ Ähnliches gilt für die Reitausrüstung bei den Sassaniden und Arabern.

Es kann zusammenfassend festgestellt werden, dass beim derzeitigen Forschungsstand die These einer westeuropäischen Herkunft der Reitersporen für das Frühmittelalter als Grundlage einer weiterführenden Untersuchung verwendet werden kann. Das Vorkommen von Sporen in Fundkomplexen ist nicht als Beleg für eine Reiterei als solche zu sehen, sondern für eine spezielle Reittradition. Sporen sind nicht unbedingt notwendig zum Reiten. Die Steuerung des Pferdes erfolgt in jedem Fall mit Hilfe des Schenkeldrucks. Der Einsatz des Zügels, Gewichtsverlagerungen des Reiters und Stöße mit den Fersen - mit oder ohne Bewehrung durch Sporen - können die Führung des Pferdes nur unterstützen. Eine Verwendung von Reitersporen ist auch im militärischen Bereich nicht zwingend, in dem eine Hilfestellung mit dem Zügel wegen der Führung von Schutz- und Angriffswaffen mit beiden Händen nur sehr eingeschränkt möglich ist, wie die schon angesprochene schwere Reiterei der Parther, Arsakiden, Sassaniden und der sogenannten Kataphrakten zeigt. ${ }^{10}$

Im Folgenden sollen daher die Sporenfunde der östlichen Balkanhalbinsel, aus dem heutigen Rumänien und Bulgarien, vorgestellt und eingeordnet werden. Diese Regionen liegen östlich der zumindest zeitweise mit Westeuropa eng verbundenen Gebiete. Der Schwerpunkt meines Interesses liegt dabei auf den frühmittelalterlichen Stücken, auch wenn die hochmittelalterlichen Funde noch angeführt werden. Die übrigen Bestandteile der Reitausrüstung sollen nur kurz gestreift werden. Der Diskussion vorgreifend soll hier schon erwähnt werden, dass bei den übrigen Metallbeschlägen der Reitausrüstung keine sicheren Fremdbezüge festzustellen sind. So sind Steigbügel aus Metall schon lange als asiatische Erfindung bekannt, die erst durch Vermittlung der Awaren in Europa bekanntgemacht worden sind. Es fällt auf, dass, im Gegensatz

9 Bivar 1972, mit einem Glossar der Teile der Reitausrüstung auf Seite 291. Für das späte 10. Jahrhundert werden Sporen in der byzantinischen Armee zwar wiederholt bei Leon Diakonos genannt (Loretto 1961, 32, 92, 101, 123, 126, 137), jedoch ist nicht geklärt, wie der Quellenwert des Leon in dieser Hinsicht einzuschätzen ist und ob es sich dabei nicht bereits um aus dem Westen übernommene Ausrüstungsteile handeln könnte. Träger der Sporen sind die schwer gepanzerte Reiterei, ein Patrikios, die kaiserliche Garde und der Kaiser selbst. Für die Wertung der Quelle ist außerdem die vom Übersetzer und Herausgeber betonte gelehrte, antikisierende Abhängigkeit des Leon von älteren, besonders spätantiken Quellen zu beachten.

10 Vgl. z.B. Brentjes/Brentjes 1991, 116-120, 122, Abb. S. 117, Abb. S. 120, Abb. S. 123; von der Osten o. J., 87-89, 101, 116, Taf. 60, Taf. 67. 

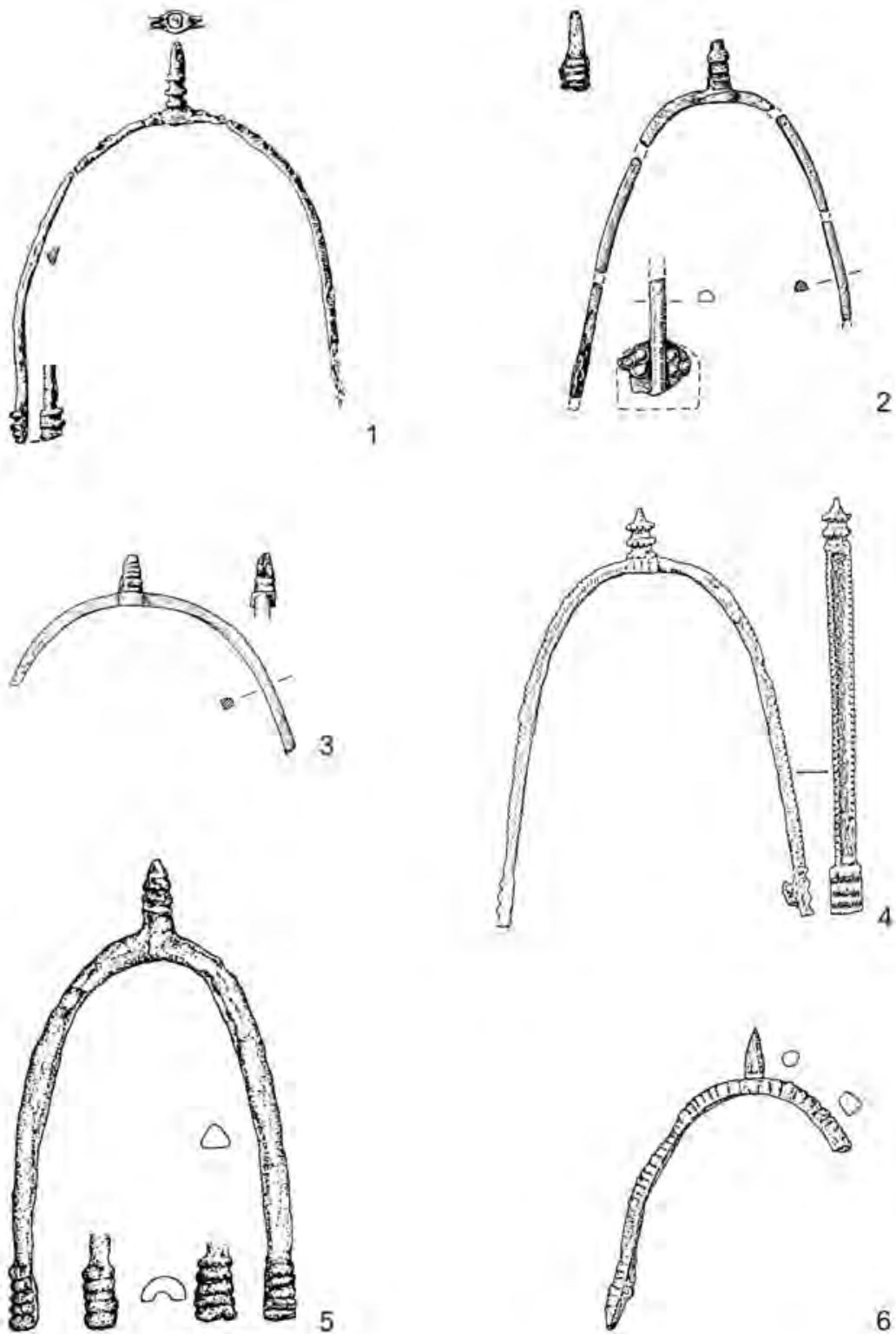

1. Stărmen Fund 404 (Liste 1 Nr. 41); 2 Weismain-West Grab 3 (Liste 1 Nr. 42); 3. Weismain-West Grab 20 (Liste 1 Nr. 42); 4. Slovenj Gradec (Liste 1 Nr. 40); 5. Mužla-Čenkov (Liste 1 Nr. 39); 6. Baardorf (Liste 6 Nr. 1)

Abb. 1. Sporen des 8.-9.Jahrhunderts (Nachweise siehe Liste 1), Eisen. M 1:2. 
zu den Sporen, die seit karolingischer Zeit entwickelten Steigbügelformen West- und Mitteleuropas nicht bis nach Südosteuropa verbreitet wurden. ${ }^{11}$ Die östlichen Einflüsse auf diesen Teil der Ausrüstung sind innerhalb der Funde von Waffenteilen aus Stărmen bereits durch Z. Kurnatowska erarbeitet worden. ${ }^{12}$

Die Reitersporen sind im slawischen und bulgarischen Siedlungsgebiet als Fremdlinge anzusprechen; hingegen kann für eine bestimmte Form im Bereich der baltischen und der ,autochthonen rumänischen Bevölkerung“ auch eine ältere Tradition in die Überlegung einbezogen werden. In jedem Fall muss man für die jeweiligen Sporen die Vergleichsstücke und typologischen Kennzeichen exakt diskutieren. Ein Ausgreifen über das oben genannte Arbeitsgebiet hinaus ist hierbei unerlässlich ${ }^{13}$. Generell fällt die Uneinheitlichkeit des Materials trotz der geringen Anzahl der Stücke auf.

Ich möchte die Besprechung der Sporenfunde mit einem Exemplar aus Stărmen beginnen. ${ }^{14}$ Dieser Sporn zeichnet sich durch auffallend dünne Sporenschenkel aus, an deren Enden kleine gerippte Plättchen angebracht sind (Abb. 1,1). Hinweise auf die Art der Riemenbefestigung sind nicht erhalten und lassen sich auch nicht rekonstruieren, da nach den in Frage kommenden frühmittelalterlichen Parallelen sowohl Schlaufen durch nach innen umgebogene Bügelenden, als auch Besätze mit einer bis drei Nieten denkbar wären. Der Scheitel des Sporenbügels ist leicht tellerartig verdickt. Hier ist ein schmaler gerippter Stachel eingenietet. Mit diesem Merkmal und wegen der Rippenzier und dem hohen schlanken Bügel lässt er sich sowohl mit den Schlaufensporen, wegen der kleinen Plättchen an den Bügelenden aber auch mit den Nietsporen in Verbindung bringen. Somit steht er generell noch in der Formentradition merowingerzeitlicher Reitersporen. $^{15}$

11 Zu den karolingischen Formen des Westens vgl.: Stein 1967, 85; 416; Liste 19; Taf. 116; Rempel 1964. Verbreitungskarten: Schulze-Dörrlamm 1988, 425-427, Karte Abb. 49-51. Siehe auch Vignatiová 1981, 85, 89 Abb. 5,11. Ein Steigbügel mit abgedrehter Öse stammt aus Mikulčice (Měchurová 1983, 75,78 Nr.13 Taf. IV,2) und markiert den südöstlichsten Fundpunkt dieser westlichen Form.Die aus Rumänien und Bulgarien stammenden Steigbügel entsprechen im gesamten frühen und hohen Mittelalter dem Spektrum Osteuropas und Asiens: Borisov 1989, 131, 134, Kat.Nr. 19, Abb. 156; Čangova 1992, 181-182, 217, Abb. 168; Rašev 1983, Abb. 5; Chalikov 1983, Abb. 1; Horedt 1986, 71, 81, 85, Abb. 37,4 u. 39; Spinei 1985, 113-118, Abb. 33, 36, 38; ders., 1997, 160, 166, Abb. 19,1.5.

12 Kurnatowska 1973, 104-105, 120, 123.

13 Dieser Aufsatz entsteht im Zusammenhang mit der Erarbeitung der Dissertation des Verfassers. Typologische Begründungen können hier nur anhand von Beispielen gegeben werden. Für Details sei auf die in Vorbereitung befindliche Arbeit verwiesen.

14 Kurnatowska 1973, 104, 120, 123, Abb. 5,1; dies. 1980, 87, 169-170, 206, Taf. XXVII,404.

$15 \mathrm{Zu}$ dieser Sporengruppe zusammenfassend: Kind 1997, 24-45. Zu den spätmerowingischen Sporen siehe Stein 1967, 27-30, 85-86. 
Fassbar wird diese Gruppe in den spätmerowingerzeitlichen Gräbern des alamannischen und baiuwarischen Siedlungsraumes, wo ab dem 7. Jahrhundert bis zum Ende der Beigabensitte hochbügelige Schlaufensporen- und niederbügelige Nietsporenformen in die Gräber gelangten. Es besteht vor allem wegen der verhältnismäßig geringen typologischen Weiterentwicklung bis in den Horizont des Tassilokelchstils hinein kaum ein Zweifel, dass diese Formen bis in das 8. Jahrhundert hinein reichen. Zugleich ist es unwahrscheinlich, dass die Beigabensitte so abrupt geendet haben soll, wie dies im allgemeinen Forschungstrend zur Frühdatierung postuliert wird.

Eine direkte Parallele ist mir nicht bekannt. Trotz ihres relativ hoch gewölbten Bügels erscheint es mir angebracht, mit den verwandten Nietsporen fortzufahren. Zuvor seien jedoch für die Untergliederung des Stachels mit einigen auffallend kräftigen, plastischen Rippen noch weitere Parallelen genannt: Weismain-West Grab 3 (Abb. 1,2), ${ }^{16}$ Slovenj Gradec (Abb. 1,4, Karte 1) ${ }^{17}$ Auch der Nietteller am Stachelscheitel des Sporns aus Stărmen ist als gängiges Merkmal anzusehen. Gerade durch dieses, aber auch durch den schlanken Bügel lässt sich außerdem eine Verbindung mit dem Sporn aus Bootz feststellen. $^{18}$

Die Vorherrschaft des eingenieteten Stachels im germanisch-romanisch geprägten Westen hat I. Gabriel für das 8. bis 9. Jahrhundert bereits herausgestellt - im Unterschied zu den Hakensporen im slawischen Siedlungsgebiet. ${ }^{19}$ Diese technische Differenzierung reicht bereits in die späte Merowingerzeit zurück. Hier sind die Bügel jedoch meistens wesentlich massiver. Kombiniert sind diese Stücke mit Material der Stufen 5 und 6

16 Schwarz 1984, 93, 108-111, 113, 115-116, 126, 192-193, Abb. 59,3-4a. Zur Datierung des Fundes: U. Koch 1993/94.

17 P. Korošec 1979, 1,242, 2,66, Taf. 85,1-2. Eine gewisse Ähnlichkeit ist außerdem durch die kräftige Rippung mit einem Sporn aus Objekt 549 von Mužla-Čenkov (Abb. 1,5) gegeben. Vgl. Hanuliak/Kuzma/Šalkovský 1993, 35, 88, 179, Taf. 150,21. Dieser Sporn, dessen Befestigungsform nicht geklärt werden kann, ist jedoch deutlich massiver. Sicherlich zu Recht wird er als ältester bekannter Sporn von diesem Fundplatz angesehen (Hanuliak/ Kuzma/Šalkovský 1993, 88).

18 Gde. Garlin, Lkr. Prignitz: Corpus 1977, 12/5, Abb. 12/5,2. Der Befundzusammenhang zu diesem Siedlungsfund ist leider unbekannt. Die Siedlung existierte nach der Keramik mindestens im 8.-10. Jahrhundert. K. Wachowski (1986/87) schlug aus typologischen Gründen eine Datierung in die erste Hälfte des 8. Jahrhunderts vor (Wachowski 1986/87, 73). Eine Ähnlichkeit besteht ebenfalls mit den Sporenpaar aus dem Grab von Vitzke, Gde. Kuhfelde in der Altmark (Wachowski 1986/87, 73; vgl. Corpus 1977, 18/18, Abb. 18/18,12). Gemeinsam ist den genannten eine grundsätzliche Ähnlichkeit verglichen mit dem spätmerowingischem Material, in das es sich jedoch nicht wirklich einordnen lässt. Somit dürfte die vorgeschlagene Datierung gerechtfertigt sein, auch wenn eine Beschränkung auf die erste Hälfte des 8. Jahrhunderts von der durch Wachowski vertretenen frühen Datierung des Auftretens der Nietplattensporen herrührt.

19 Gabriel 1988, 110-116, Abb. 2. 


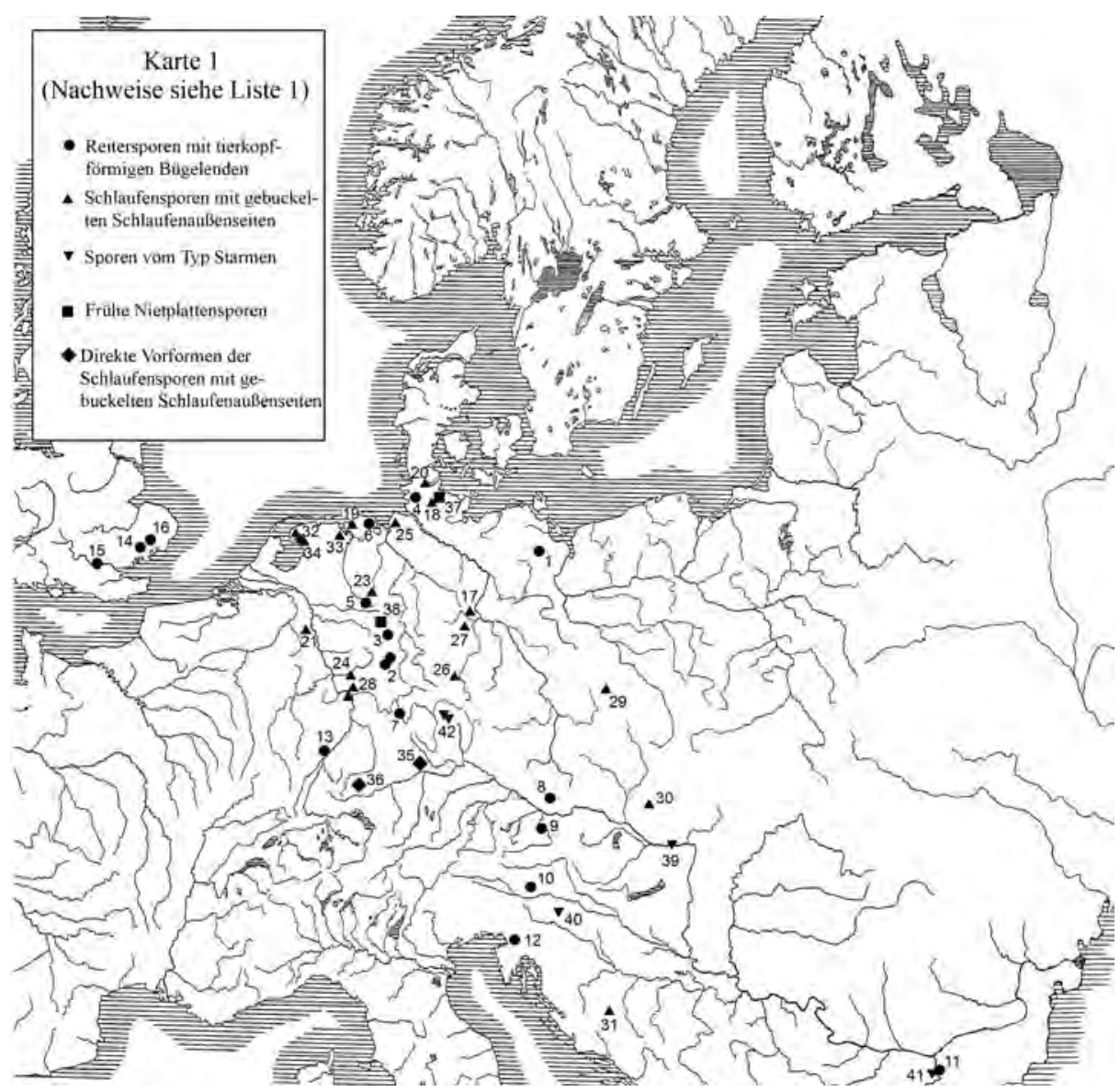

Karte 1

des Gräberfeldes von Schretzheim nach U. Koch, ${ }^{20}$ aber auch noch mit Elementen der Stufen A/B nach F. Stein. In jüngerer Zeit sind wiederholt Vorschläge zur Gliederung des 8. Jahrhunderts vorgestellt worden, ohne dass ein allgemein anerkannter Konsens erreicht werden konnte. ${ }^{21}$ Dabei ist eine Typologisierung des Fundbestandes des frühen 8. Jahrhunderts noch vergleichsweise einfach. Der Mangel an materialreichen und gut datierbaren Komplexen verhinderte jedoch bisher die Erstellung einer unstrittigen Gliederung.

20 U. Koch 1977.

21 Weis 1999, 83-89, 93-95, Tab. 7; Siegmund 1998, 198-203, 207-221, Abb. 82; Burzler 1993, 198-199, 201-210, 213, 215-220, 222-225, 229-232. 
Die Schlankheit verbindet den Sporn aus Stărmen mit dem Sporentyp 1 nach R. Pöllath, der von ihm zweifellos chronologisch richtig vor - unrichtigerweise aber auch neben - die Sporen mit voll entwickelten Nietplatten gestellt wird. ${ }^{22}$ K. Schwarz hatte versucht, diese Form anhand der mitgefundenen Spathen ausschließlich der ersten Hälfte des 8. Jahrhunderts zuzuweisen. ${ }^{23}$ Die Datierung der Grabfunde 3 und 20 von Weismain-West (Abb. 1,2.3) ist bereits wiederholt angegriffen und korrigiert worden. ${ }^{24}$ Demzufolge ist ein Datierungsansatz um die Mitte (Grab 3) bzw. in die zweite Hälfte des 8. Jahrhunderts (Grab 20) vorzuziehen. Die geringe Anzahl geschlossener Funde verbietet den Versuch einer statistischen Untermauerung vorgeschlagener Stufengliederungen. Die hier besprochenen und die folgenden Formen lassen sich jedenfalls im spätmerowingischen Spektrum nur noch sehr bedingt unterbringen.

Zusammenfassend kann festgestellt werden, dass das Exemplar aus Stărmen dem Umfeld der genannten Stücke zugewiesen werden kann. Nach den angeführten Argumenten erscheint eine Datierung um die Mitte oder in die zweite Hälfte des 8. Jahrhunderts wahrscheinlich. Die kleine Gruppe ähnlicher Sporen kann als solche chronologisch nicht weiter unterteilt werden. Der Stărmener Fund kann nach den Begleitfunden erst im 9. Jahrhundert in den Boden gelangt sein, zweifellos erstaunlich spät.

Gleichermaßen aufgrund seines noch recht schlanken Bügels, der aus einem Stab mit hochdreieckigem Querschnitt besteht, lässt sich ein weiterer Sporn aus Stărmen (Abb. 5,1) chronologisch mit dem ersten verbinden. Seine Bügelenden fehlen. Wegen der noch in die spätmerowingische Zeit zurückreichenden Parallelen wären am ehesten Schlaufen zu erwarten. ${ }^{25}$

Ein weiteres Exemplar aus Stărmen lässt sich hier anschließen ${ }^{26}$ Es handelt sich um ein Fragment, dass bereits von Z. Hilczerowná mit ziemlicher Sicherheit als Bügelende eines Sporns angesprochen wurde. Sein tierkopfartig profiliertes Ende mit einem schmalen Durchzug wäre somit als Teil eines Schlaufensporns anzusehen (Abb. 2,5). Für die

22 Pöllath 1998, 150-151. Der Autor gestattete freundlicherweise die Einsicht in die Arbeit.

23 Schwarz 1984, 105, 107-108. Grab 3 gehört der ersten Belegungsgeneration (um 710 - um 720/30), Grab 20 der zweiten Generation an (Ende erste Hälfte des 8. Jahrhunderts). So urteilte auch - mit geringfügigen Korrekturen - Kleemann (1992b, 43-4), der Grab 3 wegen der Spatha vom Typ Arkebek in seine Stufe III (740-770), Grab 20 wegen der Spatha des Sondertyps 2 in dieselbe Stufe oder Stufe IV datiert.

24 U. Koch 1993/94, 193; Pöllath 1999, 160, 163, Abb. 9.

25 Kurnatowska 1973, 105-106, 120, 123, Abb. 5,3; Dies. 1980, 107, 157, 235, Taf. LVI,1293. Aufgrund der Fundsituation im Obj. 84 (Phase II1) kann das Stück erst im späten 9. Jahrhundert in den Boden gekommen sein. Grundsätzlich wäre auch eine Nietplattenkonstruktion denkbar, jedoch ist der hochgewölbt-dreieckige Querschnitt des Bügels ungewöhnlich.

26 Kurnatowska 1973, 105, 123, Abb. 5,2; Dies. 1980, 87, 152, Abb. 53,425. 

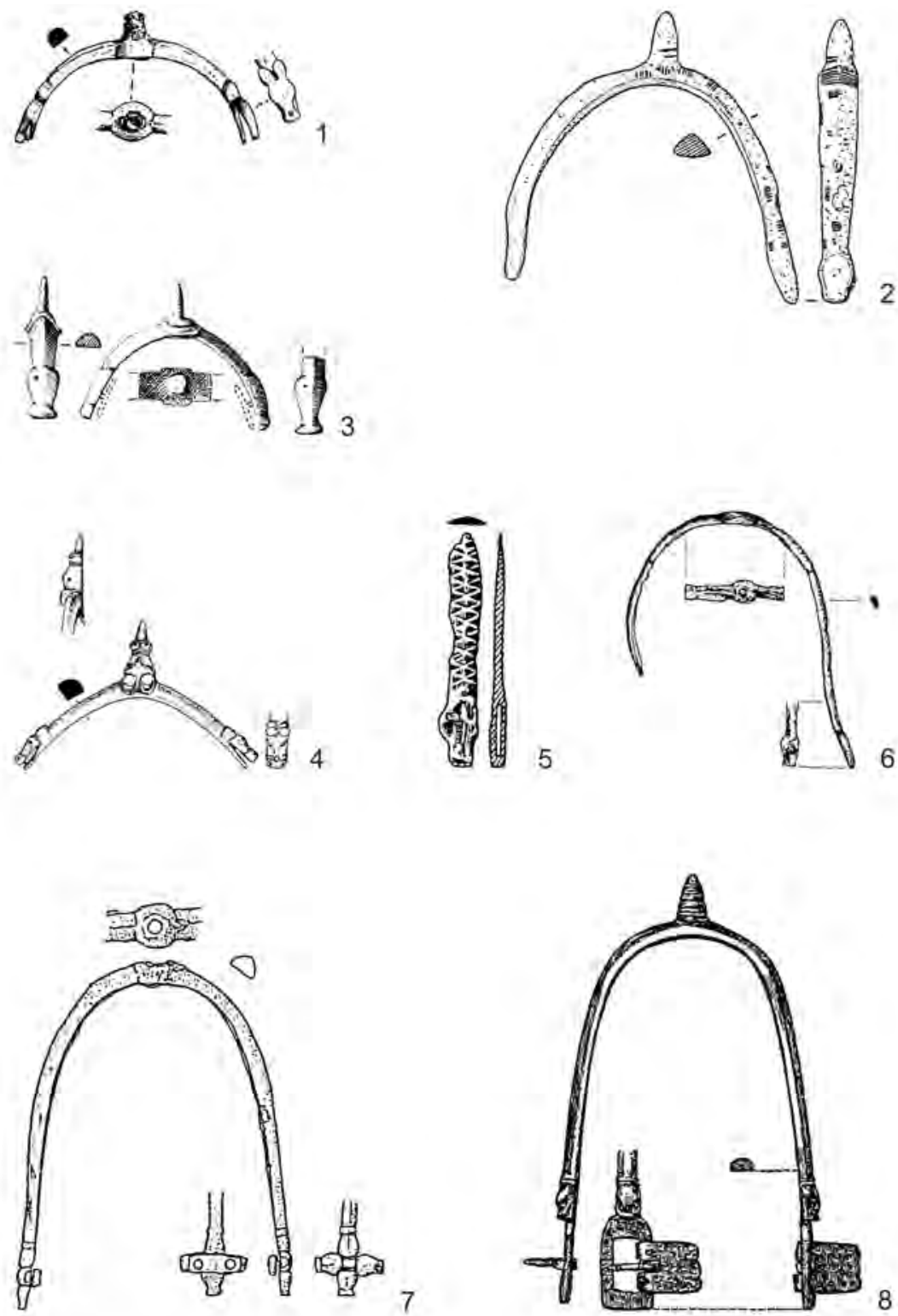

1. Icklingham (Liste 1 Nr. 14); 2. Immenstedt (Liste 1 Nr. 4); 3. Alt Käbelich (Liste 1 Nr. 1); 4. Pakenham (Liste 1 Nr. 16); 5. Stărmen Fund 425 (Liste 1 Nr. 11); 6. Büraberg (Liste 1 Nr. 2); 7. Hemmaberg (Liste 1 Nr. 10); 8. Kingston (Liste 1 Nr. 15)

Abb. 2. Sporen des Tassilokelchstilhorizontes (Nachweise siehe Liste 1), Eisen; 1,4,8 Bronze. M 1:2. 
Verzierung mit Tauschierung in Kreuzschraffur lassen sich keine Parallelen namhaft machen. Streifentauschierung ist sowohl aus spätmerowingerzeitlichen als auch frühkarolingerzeitlichen Zusammenhängen bekannt. ${ }^{27}$ Nun existieren zwar eine Reihe von Sporen mit gleichartigen oder ähnlichen Bügelenden, jedoch gehören diese allesamt zu den niederbügeligen Nietsporen, wobei die Sporen aus Alt-Käbelich (Abb. 2,3) ${ }^{28}$ und Suffolk (Abb. 2,1.4) ${ }^{29}$ wesentlich deutlichere Tierköpfe aufweisen. Dennoch möchte ich eine Zuordnung dieses Stücks zum Tassilokelchstil vorschlagen, was eine Herstellung in der zweiten Hälfte des 8 . Jahrhunderts voraussetzen würde. ${ }^{30}$ Die Verwendung dieses stilistischen Merkmals zwingt allerdings zu der Annahme zahlreicher parallel verlaufender Entwicklungen im 8. Jahrhundert und einem entsprechenden Nebeneinander formal recht verschiedener Sporen (vgl. Abb. 2,1-8, Abb. 3,1). Bemerkenswert ist, dass - ähnlich wie bei dem Sporn aus dem Horizont II von Stărmen (d.h. Ende 9. bis Ende 10. Jahrhundert) - das Brandgrubengrab 10 von Alt Käbelich erst relativ spät angelegt worden sein kann, da hier neben der chronologisch besser zum Sporn passenden Feldberger und Menkendorfer Ware auch Woldegker Keramik vorkommt, was nicht vor dem späten oder sogar erst ausgehenden 9. Jahrhundert denkbar ist. Es muss allerdings in beiden Fällen mit einer sekundären Befundlage gerechnet werden.

27 Beipiele für spätmerowingische Sporen mit Streifentauschierung: Runder Berg: U. Koch 1982, 82, Abb. 1,11; Unterjesingen: Stein 1967, 28, 30, 51-52, 108, 292-298, Nr. 183 Abb. 44,1-2. Für frühkarolingische Exemplare: Stein 1967, 84-86, 88, 348-349, Taf. 58,7.

28 V. Schmidt 1984, 338-340, 343-344, Abb. 5 b.

29 Icklingham: de Shortt 1964, 60 Abb. 1; Pakenham: Hinton, 1974, 55, Abb. o.Nr. Beide Stücke sind ohne Fundzusammenhang. Aufgrund der vielperiodigen Belegung des Platzes Icklingham und der relativen Ferne zu den anderen Sporen dieser Gruppe wäre auch die von de Shortt vorgeschlagene Datierung in die spätkeltisch-römische Phase denkbar. Es gab jedoch unzweifelhaft auch eine frühmittelalterliche Besiedlungsphase und die angeführten technischen Details - wie die Verwendung von Email oder die geschlitzten Nietenden - sind entgegen der Meinung von Shortt keine eindeutigen Hinweise (vgl. Wilson 1965, 111-112). Im Gegenteil ist das Wiederaufkommen der Emaillierung eines der wesentlichen Merkmale des Tassilokelchstils, wie es das namengebende Gefäß zeigt. Die Emaileinlagen für die Augen des Tierkopfes sind auch vom Sporenpaar von Welbsleben bekannt (Haseloff 1951, 36, Taf. 13; zum Email: Haseloff 1951, 63).

30 Anzumerken ist jedoch, dass sich stilisierte Tierköpfe bereits im spätmerowingerzeitlichen Material finden. Verwiesen sei hier auf die Spathaknäufe der Typen Weillohe-Untermassing, Niedertraubling-Schretzheim 566, Andernach-Hintschingen 14 (nach: Menghin 1983, $136-$ 137, Abb. 77 [zur Zeitgruppe E bzw. F, 2. und 3.Drittel 7. Jh.]), sowie bei Sporen - hier allerdings noch stärker stilisiert - aus Aschheim (Dannheimer 1988, 29, 31-33, Taf. 15,1213), Fridingen Grab 108 (von Schnurbein 1987, 38, Taf. 27,12) und wahrscheinlich auch aus Oberdischingen (Schiek 1967, 146-147, Taf. 135,D1). Stilisierte Tierköpfe an den Bügelenden sind auch von einer wikingerzeitlichen Sporengruppe von Gotland bekannt (vgl. Nylén 1997, 224-231 Nr. 2, 4-17, Abb. 8,2.4.6.13.16-17). Die Stilisierung der Tierköpfe und die Art der Flechtbandverzierung sind aber von völlig anderer Art und daher typologisch nicht mit der hier behandelten Form zu verbinden. 
Wiederholt ist bei dem oben gesagten deutlich geworden, dass die Untergliederung des 8. und 9. Jahrhunderts immer noch erhebliche Schwierigkeiten bereitet. Aus den Datierungsansätzen lässt sich ersehen, dass hier von einer konservativen Gliederungsvorstellung ausgegangen wird, was bedeutet, dass man ein Nacheinander der Horizonte Tassilokelchstil, Biskupija-Crkvina und Trewhiddle propagiert. Aufgrund des Mangels einer hinreichend großen Anzahl geschlossener und materialreicher Fundkomplexe kann dieses Aufeinanderfolgen vorerst ebensowenig kombinationsstatistisch bewiesen werden wie alternative Vorstellungen, ${ }^{31}$ Eine ausführliche Diskussion ist hier schon aus Platzgründen nicht möglich. Ein weiteres Problem stellt die absolute Datierung dieser Stufen dar. Über das einzelne historische Datum hinaus, das sich aus der Inschrift auf dem Tassilokelch ergibt (768/69-788 n. Chr.), lassen sich nur über Fundmünzen aus Gräbern Hinweise auf eine absolute

31 So hat R. Pöllath die Stile des Tassilokelches und von Biskupija-Crkvina als reine Kunststile aufgefasst - was prinzipiell richtig ist - und vertritt daraus schlussfolgernd die Auffassung, dass sie nur Beiwerk zur formenkundlichen Entwicklung darstellen (Pöllath 1999, Abb. 211). Entsprechend wird der Sporn von Welbsleben (mit Tassilokelchstilornament) in die Stufe V gesetzt und damit mit Biskupija-Crkvina Sarkophag-Grab parallelisiert. Grab 1 von Biskupija-Crkvina erscheint dagegen schon in Stufe IV, parallel zu den Grabinventaren A und B von Bendorf und Dunum 326. Letzteres ist auch deshalb beachtenswert wegen seiner Zusammensetzung aus Tassilokelchstil-Sporen, Riemendurchzug, Riemenschnalle und Gürtelschnalle zusammen mit einer vogelförmigen Riemenzunge. Ähnlich ist die Zusammensetzung der Inventare Biskupija-Crkvina Grab1 und Bendorf Grab B (Mischform). Kann daraus der Schluss gezogen werden, diese Vergesellschaftung sei von Neuheit beabsichtigt gewesen? Normalerweise sind diese Riemenzubehörensembles mit Knopfriemenzungen ausgestattet (vgl. Barleben, Gojače-Boršt und Sundremda). Es lässt sich wegen der geringen Zahl nicht erkennen, welche Komplexe schon bei der Herstellung zusammengehörten und welche erst im Laufe der Benutzung durch andere Teile ergänzt wurden. Ähnliches gilt für den Versuch einer Verbindung dieser Erscheinung mit der Chronologie der Awarenzeit, wie ihn R. Pöllath am Inventar des Grabes 108 von Mikulčice mit einer Knopfriemenzunge und dem Fragment einer Riemenzunge mit Kreislappenranke versuchte. Dieses Grab wäre nach Pöllath in die Phase SPA II zu datieren - richtiger wäre m.E. SPA II und III (vgl. Daim 1987, 145, 147; Stadler 1993, 240). Am Beispiel dieses Grabes geht Z. Klanica $(1995,396)$ von einer „Vermischung mit einem Altstück“ aus. Dies kann nicht ausgeschlossen werden, auch wenn sich diese Kombination in Olomouc wiederholt, obzwar nicht in einem Fundkomplex (vgl. Profantová 1992, 689, Nr. 35, Taf. 33,7-8). Im Grab 22 von Modrá ist eine Riemenzunge mit Spiralhakenzier - ähnlich wie im Sarkophaggrab von Biskupija-Crkvina (vgl. Cibulka 1958, 328-329, Abb. 67, Taf. XVIII,1, XIX) - mit einer gegossenen Riemenzunge awarischer Prägung mit gewulstetem Rand vergesellschaftet (vergleichbar SPA III). Auch hier ist eine gleichzeitige Herstellung in Form einer Garnitur fraglich. 
Datierung gewinnen. Entgegen der bisher oft vorgebrachten Ansicht muss eher von einer Gewichtsgeldwirtschaft ausgegangen werden, in der - zumindest außerhalb der politischen und administrativen Zentren - ein Umtausch in die jeweils aktuellen Gepräge und damit verbunden eine kurze Umlaufzeit der Münzen, nicht vorausgesetzt werden darf. ${ }^{32}$ Somit liefern diese Münzen nur einen terminus post quem für die Niederlegung der Grabkomplexe. ${ }^{33}$

Für die m.E. als vorläufig anzusehenden Horizonte ergibt sich für die Materialgruppe der Sporen folgendes Bild:

Tassilokelchstilhorizont: Schlaufen- und Nietsporen (mit Ansätzen zur Entwicklung vom Bügel abgesetzter Nietplatten), Verzierungen mit Buckeln, Wülsten, Rillen und Rippen, die häufig rhythmisch angeordnet sind, oft sind die Unterteile der Stacheln verziert. Riemengarnituren: D-förmige gebuckelte Schnallen mit Laschenbeschlag, Knopfriemenzungen, Riemendurchzüge mit schmalen, oft ebenfalls gebuckelten Platten. Datierung: Zweite Hälfte 8. Jahrhundert bis Anfang 9. Jahrhundert.

Horizont von Biskupija-Crkvina: Entwicklung der Nietplattensporen und Schnallensporen, Trend zur Massivität, mit flächenhafter Verzierung oder nur auf den Nietplatten, Scheiteln und Stachelunterteilen aufgebrachter plastischer Zier (Spiralranken u.a. ornamentale Motive). Riemengarnituren: Eckige Schnallen mit Laschenbeschlag, gebuckelt, häufiger aber rhythmisch profiliert, Riemendurchzüge mit profilierten, aber auch ovalen Platten, vogelförmige Riemenzungen, daneben auch große Riemenzungen mit rundem oder spitzem Abschluss, oder auch mit kleinem Knopf. Datierung: Ende 8. Jahrhundert bis erste Hälfte 9. Jahrhundert.

Karolingischer Haupthorizont: Nietplatten- und Schnallensporen diverser Formen, Verzierung mit vegetabilen Ornamenten. Riemengarnituren: rechteckige Schnallen mit Laschenbeschlag, Riemendurchzüge mit großen, meist ovalen Platten, u-förmige Riemenzungen. Datierung: Mitte bis zweite Hälfte des 9. Jahrhunderts. ${ }^{34}$

32 Giesler 1974, 521-543; Kleemann 1992b, 35-37, Abb. 13. Für die jüngere Merowingerzeit wird die Verwendung ausschließlich zeitgenössischer Münzen ebenfalls als bewiesen angesehen. Grundlage dafür sind 14 münzdatierte Gräber, von denen lediglich drei ältere Münzen enthalten (vgl. Burnell 1999, 90-92). Eine Auflistung münzdatierter Komplexe der Merowingerzeit gibt auch Siegmund (1998, 523-528, Liste 12, speziell die jüngere Merowingerzeit 527-528). Parallel hierzu werden historische Daten mit Fundmaterialien aus Paderborn zur Gewinnung einer Datierungsgrundlage verbunden (vgl. Pöllath 1999, 163).

33 So bereits Werner (1978/79) zu den zeitgleichen Münzen aus den typologisch recht unterschiedlichen Gräbern von Biskupija-Crkvina. Allerdings stützt er sich - wegen der geringen Materialbasis durchaus zu Recht - bei der Einordnung auf historische Überlegungen über den Zeitpunkt des Einsetzens des karolingischen Einflusses im Adriaraum.

34 Vgl. Schulze-Dörrlamm 1993, 565. 
Trewhiddle-Horizont: Nietplattensporen, Bügelenden mit dachförmigem Querschnitt. Riemengarnituren: Riemenzubehör ebenfalls mit dachförmigem Querschnitt, spitzovale Riemenzungen. Datierung: Mitte bis Ende des 9. Jahrhunderts. ${ }^{35}$

Relativstratigraphisch ist zu den genannten Stücken des Tassilokelchstiles eine Gruppe von Schlaufensporen als zeitgleich anzusehen (Liste 1b, Abb. 3,2-6), von denen lediglich ein Exemplar auf der Balkanhalbinsel vorkommt ist, nämlich das Exemplar von Gornji Vrbljani (Bosnien-Herzegowina). Weitere Vergleichsstücke streuen entlang des Grenzsaumes des Karolingerreiches (vgl. Karte 1). Daneben sind noch unverzierte Schlaufensporen bekannt, die jedoch nicht den Weg bis nach Südosteuropa gefunden haben. Wichtig ist bei diesen, dass sie - neben den verzierten Schlaufensporen mit gebuckelter Schlaufenaußenseite - als einer der Ausgangspunkte zur Entwicklung der Hakensporen mit nach innen umgebogenen Hakenenden anzusehen sind. Deren Vertreter fehlen im hier behandelten Gebiet nahezu völlig.

Lediglich ein unpubliziertes Fragment aus Car Asen könnte zu diesen Sporen zählen. ${ }^{36}$ Seine Verzierung in Form einer kugeligen Verdickung an der Stachelbasis, die von einer Rippe begleitet wird, findet ihre überzeugendsten Parallelen in dieser Gruppe. ${ }^{37}$ Typologisch lässt sich dieser Hakensporn zweifellos aus dem Motivschatz des Tassilokelchstilhorizonts herleiten. Jedoch fehlen der größte Teil des Bügels und die Bügelenden. Eine karolingische Zeitstellung ist aber aufgrund der Stachelgestaltung mit einer Wulst an der Basis und einer Rippe darüber sicher.

Über dieses Stück hinaus stammen die südöstlichsten Vertreter der Hakensporen aus dem heutigen Ungarn (Sötjör), ${ }^{38}$ dem Westrand Rumäniens (Oradea Mare, Abb. 6,1), ${ }^{39}$ Niederösterreich (Steinbrunn) $)^{40}$ und dem slowakischen Pobedim (Abb. 5,5) ${ }^{41}$. Die

35 Vgl. hierzu U. Koch 1993/94, 193; von Freeden 1983, 459. Der namengebende Hortfund von Trewhiddle ist nach den enthaltenen Münzen um 872-75 oder später in den Boden gelangt.

36 Museum Ruse, Inv. Nr. III 559. A. Stančev gestattete freundlicherweise die Ansicht dieses und des in Anm. 83 genannten Stückes.

37 Daneben kommt in dieser Gruppe die Gestaltung des Stachelunterteiles durch mehrere Rippen und/oder ein sanduhrförmig eingezogenes Element vor. Vgl. z.B. Żak/MaćkowiakKotkowska 1988, 310, Nr. 44 Taf. I,4, 315-316, Nr. 59 Taf. XII,1, 318-319, Nr. 67 Taf. II,3, 329, Nr. 98 Taf. VIII,8, 346 Nr. 144 Taf. VI,9; Schuldt 1982, 137-138 Abb. 37b.

38 Szöke 1994, 182, 208 Taf. 10,4.

39 Żak/Maćkowiak-Kotkowska 1988, 339, Nr. 126 Taf. V,3.

40 Ebd., 296-297, Nr. 1 Taf. XIV,2.

41 Vendtová 1969 154, 157, 228, Abb. 30,1-2.4; Bialeková 1977, 110, 118, 120-123, Abb. 4. 

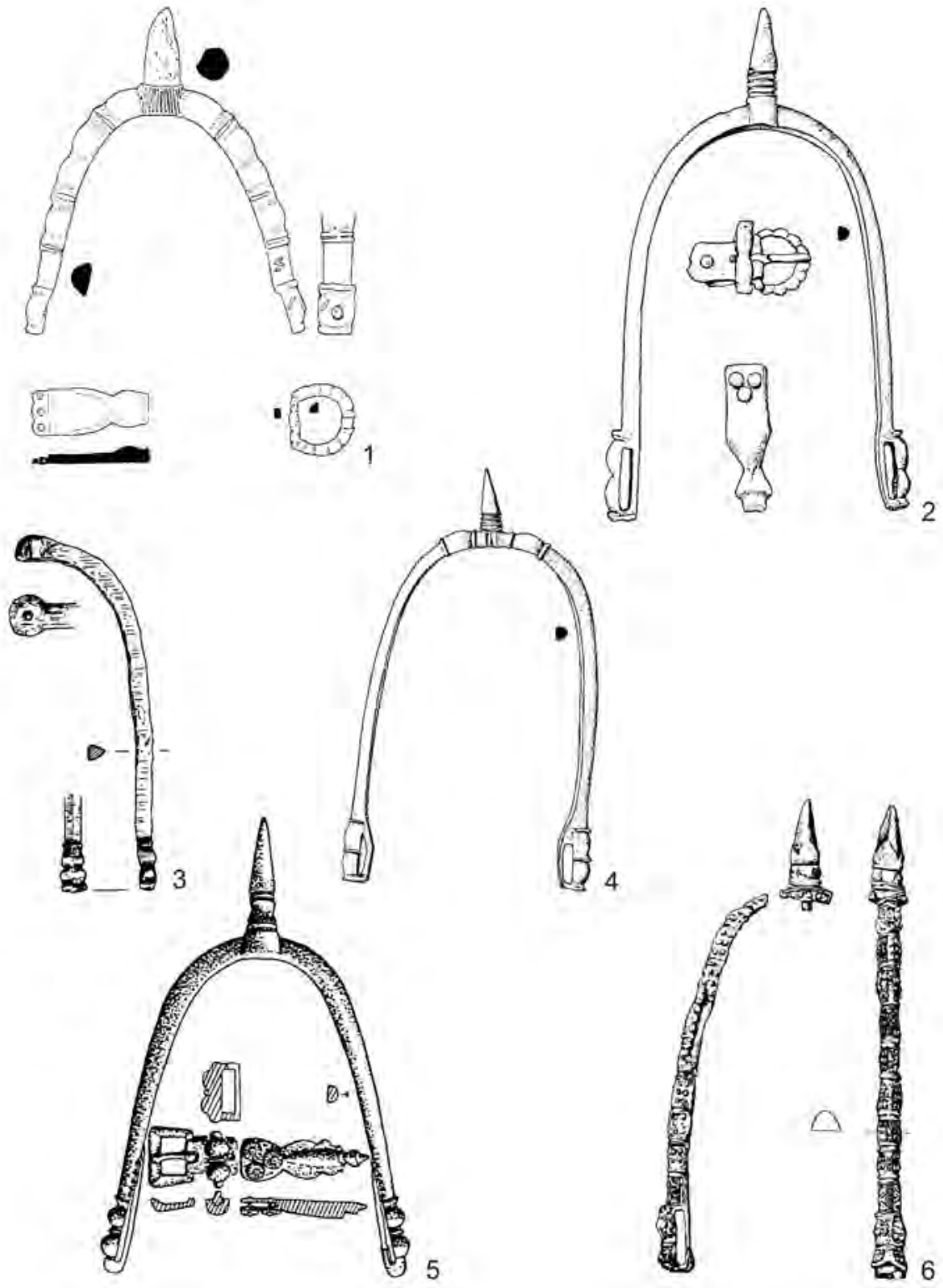

1. Gojače-Bořšt (Liste 1 Nr. 12); 2. Sundremda Grab 27 (Liste 1 Nr. 26); 3. Runkel-Enerich (Liste 1 Nr. 24); 4. Gornji Vrbljani (Liste 1 Nr. 31); 5. Dunum Grab 326 (Liste 1 Nr. 19); 6. Haithabu (Liste 1 Nr. 20)

Abb. 3. Sporen des Tassilokelchstilhorizontes (Nachweise siehe Liste 1), Eisen; 1,2,6 Bronze. M 1:2. 
Formen gleichen schon durch ihre Verzierung (Rippen, Wülste) denen des späteren großmährischen Bereichs, wobei der Sporn aus Oradea Mare zu jener Prachtgruppe gehört, die sonst nur aus den unteren Grabungsschichten der großmährischen Zentralorte bekannt und dort mit spätawarischen Bronzefunden vergesellschaftet ist. ${ }^{42}$ Allein durch die Ausführung dieser Prunkstücke ist unzweifelhaft der Einfluss einer hochentwickelten Bronzetechnologie erkennbar.

Dem genannten Exemplar ist aufgrund der Stachelverzierung einer der Sporen von Odărci (Abb. 6,8) an die Seite zu stellen. ${ }^{43}$ Aufgrund der längeren Schenkel kann dieses Stück nicht zu einem Hakensporn ergänzt werden. Es ist eher von einem Nietsporn oder frühen Nietplattensporn auszugehen. Diese Beobachtung kann als eines der Argumente gegen eine mögliche sukzessive Zunahme der Bügelhöhe im Laufe der Entwicklung der Hakensporen herangezogen werden, wie sie von J. Żak vertreten wurde. ${ }^{44}$ In die gleiche Richtung verweist das Nebeneinander von hoch- und niederbügeligen Nietsporen im Umkreis des Tassilokelchstilhorizontes, das schon in der Gleichzeitigkeit von niederbügeligen Niet- und hochbügeligen Schlaufensporen im spätmerowingischen Material vorweggenommen worden ist. Die Form des Bügelendes des Sporns aus Odărci ist auf der schlechten Abbildung leider nicht erkennbar.

Ebenfalls nur grob einzuordnen sind zwei Sporen aus Pernik, deren Umriss in der ansonsten für wissenschaftliche Fragestellungen ungenügenden Abbildung für einen zeitlichen Zusammenhang mit den Nietsporen, d.h. allgemein in das späte 8. Jahrhundert, oder auch zu den Nietplattensporen des 9. Jahrhunderts sprechen könnte. ${ }^{45}$ Eine endgültige Entscheidung würde eine Seitenansicht voraussetzen. Die Stachelformen sind innerhalb des gesamten genannten Zeitraumes vertreten.

Ähnliches gilt - allerdings hier mehr wegen der schlechten Erhaltung - für einen Sporn aus Pliska. ${ }^{46}$ Sollte es sich bei der in der Beschreibung genannten Öffnung im Bügelende um eine Schlaufe handeln, so wäre eine Einschränkung auf das 8. Jahrhundert wahrscheinlich. Der ebenda erwähnte „flache“ Stachel hat keine Parallelen.

42 Mikulčice (Abb. 6,2-4): Poulík 1957, 268-271, Abb. 50,5; Kavánová 1976, 12, 104 , Taf. I,10.12, Taf. II,4; Klanica 1986, 95-106, Abb. 28-34; Żak/Maćkowiak-Kotkowska 1988, 301, 304, 305-306, Nr. 14, 16, 25, 30-31, Taf. V,4-5, XIII,1.4.8. Uherské Hradiště: Profantová 1994, Abb. 6,3-4; Galuška 1994, 233-234, Abb. 1,4. Strakonice: Profantová 1994, 68, 82, Abb. 5,1. Sadská (Abb. 6,5): Żak/Maćkowiak-Kotkowska 1988, 308-309, Nr. 39 Taf. X,1. Ujście (Abb. 6,8): ebd., 335, Nr. 117 Taf. IX,7. Steinbrunn: ebd., 296-297, Nr. 1 Taf. XIV,2. Fröslunda: ebd., 339, Nr. 127 Taf. VII,2. Drawsko (Abb. 6,3): ebd. 1988, 321, Nr. 74 Taf. V,1.

43 Dončeva-Petkova 1987, 75, Abb. 7a.

44 Gruppen A-F (1959) bzw. A-G der Neuvorlage Żak/Maćkowiak-Kotkowska 1988, 26-34, 40-97, 408-415, Tab. 4,9-12.

45 Čangova 1992, 184, 217 Abb. 171,1-2.

46 Vitljanov 1996, 107 Nr. 1 Taf. XXIII,17. 
Eine Ausnahme von der genannten Regel der Verbreitung von Hakensporen scheint das Paar aus dem Grab 80 von Kjulevča, in der Nähe der Felsen von Madara und der ersten Hauptstadt des Bulgarischen Reiches Pliska, zu sein. ${ }^{47}$ Jedoch sind an einem dieser Sporen die Haken an den Bügelenden nach außen umgebogen. Bei dem zweiten Exemplar ist die Konstruktion weniger eindeutig erkennbar, aber nach der Beschreibung als ähnlich anzunehmen (Abb. 4,1). ${ }^{48}$ An und für sich ist die Biegerichtung der Bügelenden ein unwesentliches Detail, handelt es sich doch in beiden Fällen um technisch einfachere Ausbildungen von Schlaufen, wie sie von den meisten der merowingerzeitlichen Sporen bekannt sind. Allerdings ist diese Herleitung nicht die einzige Möglichkeit. In der späten Kaiserzeit erscheinen bereits vereinzelt Reitersporen mit nach außen umgebogenen Bügelenden, offensichtlich als einfachere Ausführungen der älteren Knopfsporen. Diese Sporen haben einen deutlichen Verbreitungsschwerpunkt in Osteuropa. Nach dem Abbrechen der ostgermanischen und baltischen Gräberfelder sind sie noch aus Siedlungen auf dem Gebiet des heutigen Weißrusslands, Moldawiens und Rumäniens bekannt, die nur allgemein um die Mitte und in die zweite Hälfte des 1. Jahrtausends n.Chr. datiert werden können. ${ }^{49}$ Der Sporn aus Dodeşti (Abb. 4,9) zeigt mit dem spitzrhombisch erweiterten Scheitel noch sehr deutlich diese Herkunft. ${ }^{50}$ Anzuschließen ist hier noch das Exemplar aus Medişorul Mare (Abb. 4,10) ${ }^{51}$ Daneben sind diese ebenso grob gearbeiteten und stets unverzierten Hakensporen im Westen aus Gräbern des 7. Jahrhunderts sowie von frühmittelalterlichen Befestigungen und Siedlungen bekannt (Abb. 4,2.3.7), ${ }^{52}$ ohne dass Wechselbeziehungen mit dem östlichen Mitteleuropa und Osteuropa erkennbar wären, oder auch nur für die östlichen Stücke in jedem Fall eine frühmittelalterliche Zeitstellung gesichert wäre. Auffälligerweise treten solche Sporen überwiegend in Gräbern der ausgehenden Merowingerzeit im alamannischen Gebiet auf (vgl. Liste 2). Hier kommen sowohl nach innen als auch

47 Văžarova 1976, 128, 133, Abb. 82,2-3; dies. 1979, 1920, Abb. 8d, 16d-e.

48 Dies. 1976, Abb. 82,3; dies. 1979, Abb. 16d. Die Konstruktion der Bügelenden ist in der Zeichnung Abb. 16d nicht erkennbar. Das Foto Abb. 82,3 lässt in den Bügel integrierte Schlaufen als möglich erscheinen.

49 z.B. Mitrofanov 1978, 108-109; Teodor 1980, 65.

50 Teodor 1978, 65, 149, 190, Abb. 31,3; vgl. Jahn 1921, 85-88, Abb. 85. Dasselbe gilt beispielsweise für den Sporn aus Hailfingen: Żak 1958, 95-96, Nr. 27, Abb. 3e.

51 Székely 1988, 171, 196, Abb. 20,1; Madgearu 1994, 155-156, Abb. 3,1; A. Madgearu bezweifelt die Datierung des Fundkomplexes in das 7.-8. Jahrhundert durch Z. Székely wegen der aus demselben Grubenhaus mit Ofenresten in einer Ecke geborgenen Keramik, mit dem Verweis auf die Sporen mit nach außen umgebogenen Bügelende der Römischen Kaiserzeit. Angesichts der hier und im folgenden angeführten Belege, die dieses Konstruktionsprinzips in das Frühmittelalter stellen, greift diese pauschale Kritik sicherlich zu kurz. Eine Verschleppung des Fundes aus einem älteren Befund - entsprechende Reste sind auf dem Platz vorhanden - ist natürlich nicht auszuschließen, aber eben auch nicht zwingend anzunehmen.

52 Siehe Liste Nr. 2. 

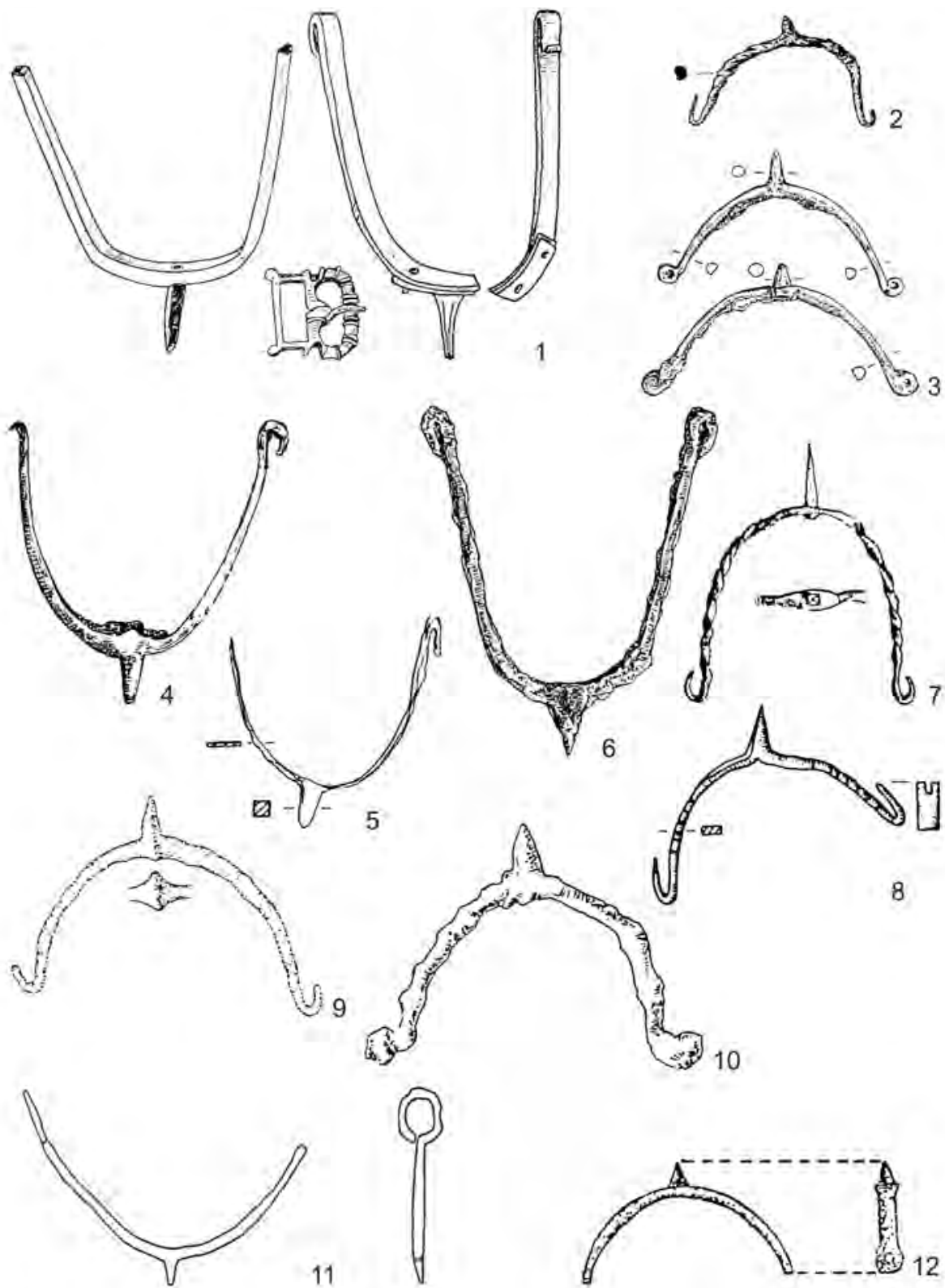

1. Kjulevča Grab 80 (Liste 2 Nr. 26); 2. Büraberg (Liste 2 Nr. 1); 3. Moos-Burgstall Grab 4 (Liste 2 Nr. 6); 4. Hailfingen Grab 4 (Liste 2 Nr. 3); 5. Gorodok (Liste 2 Nr. 42); 6. Tyniec Mały (Liste 2 Nr. 20); 7. Wittenheim (Liste 2 Nr. 28); 8. Zawada (Liste 2 Nr. 19); 9. Dodeşti (Liste 2 Nr. 24); 10. Medişorul Mare (Liste 2 Nr. 25); 11. Komarevo (s. Anm. 66); 12. Şura Mică (s. Anm. 62)

Abb. 4. Sporen mit nach außen umgebogenen Enden (Nachweise siehe Liste 2), Eisen. M 1:2; 1. o.M. 


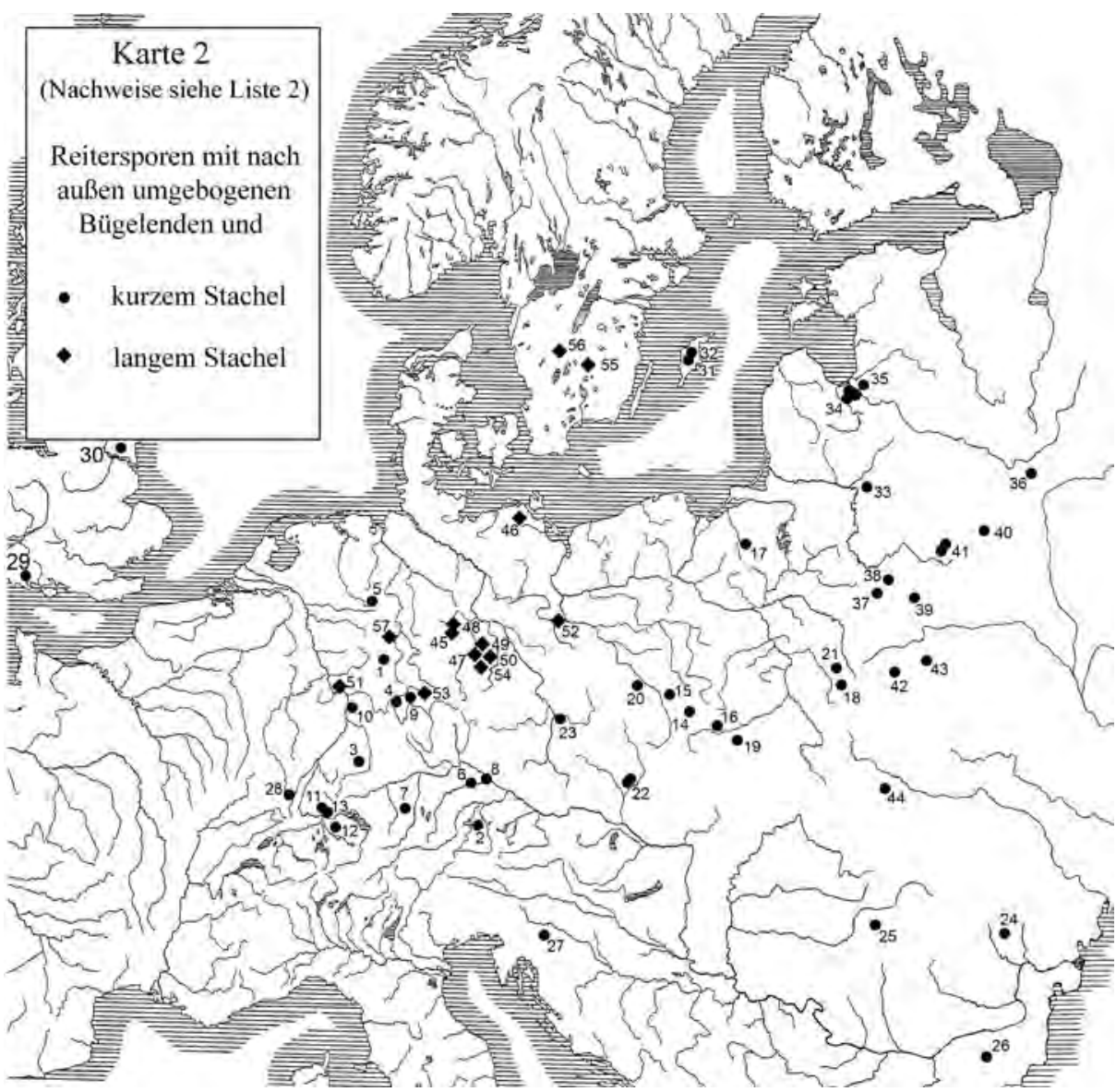

Karte 2

nach außen umgebogene Bügelenden vor. Belege aus dem frühen und mittleren 7. Jahrhundert fehlen. Vereinzelte Funde liegen auch noch aus der Siedlung Wittenheim im Elsass (Abb. 4,7) und von den Burganlagen Büraberg (Abb. 4,2) und Gaulskopf vor, ${ }^{53}$ wobei zwei Stücke tordiert sind. Sie können entsprechend des Belegungszeitraums der Siedlungsstellen nur allgemein in den Zeitraum vom Ende des 7. bis zum 10. Jahrhundert datiert werden. Die Sporen von Kjulevča unterscheiden sich insbesondere von den frühen Stücken durch die große Bügelhöhe. Diese verbindet sie mit den Sporen mit langem Stachel des 10. Jahrhunderts, bei denen vereinzelt ähnliche Bügelenden auf-

53 Nachweise Liste Nr. 2. Vom Gaulskopf stammt dagegen nur ein sehr niederbügeliger Hakensporn mit nach innen umgebogenen Enden: Best 1997, 170, 172, Abb. 9,3. Ein ähnliches Stück kam in der frühmittelalterlichen Siedlung Lengerich-Höhne zutage: Ruhmann 1999, 239. 
treten, wodurch diese Riemenbefestigungsart noch bis in das 10. Jahrhundert belegbar ist. Einer der beiden Sporen zeigt im Scheitelbereich eine angenietete Platte. ${ }^{54}$ Dieses Merkmal ist bisher viel zu selten, um typologische Bedeutung zu erlangen. Als Grund für diesen Zusatz ist bisher sowohl eine mögliche Verstärkung der Ferse ${ }^{55}$ als auch eine Größenanpassung an den Fuß des letzten Trägers zur Diskussion gestellt worden. ${ }^{56}$

Eine gute Ergänzung zu dem bisher Gesagten bieten zwei weitere Sporen mit nach außen umgeschlagenen Bügelenden. Der eine Sporn besitzt einen zweigeteilten Stachel mit geripptem Unterteil und relativ langer schlanker Spitze. Diese Form ist gut den karolingischen Sporen anzuschließen. Sein Fundort ist leider nicht näher bekannt, das Stück befindet sich heute als vermeintlich maurischer Fund im Nationalmuseum Madrid $^{57}$. Das zweite Stück hat dagegen einen sehr kurzen Stachel und das nach außen umgebogene Bügelende ist s-förmig erneut nach außen umgeschlagen. Es stammt aus dem Grab 451 von Middle Harling (Norfolk). Seine chronologische Einordnung muss sich im wesentlichen auf die mitgefundene Schnalle mit gebuckeltem rechteckigen Rahmen und Laschenbeschlag stützen, die eine Verknüpfung mit dem kontinentalen Zeithorizont des Tassilokelchstiles (zweite Hälfte des 8. Jahrhundert) wahrscheinlich macht. ${ }^{58}$ Nach den genannten Belegen kann die weite chronologische und chorologische Verbreitung dieser Konstruktion zur Verbindung des Sporns mit dem Fußriemen nur unterstrichen werden (vgl. Karte 2). Es fällt dagegen das geringe Vorkommen dieser Konstruktionsart in Mitteleuropa auf, besonders wenn man die Überlieferungssituation in die Betrachtung einbezieht. Hier muss ein grundlegender Unterschied, verglichen mit den Verbreitungen anderer Formen, festgestellt werden. Im Gegensatz zu der sonst - trotz weiträumiger Fundstreuung - erkennbaren Bindung an Zeitphasen oder historische Räume kann dieser typologischen Gruppe nur Indifferenz in jeder Hinsicht attestiert werden. Hierfür ist weder der Mangel an gut datierbaren Komplexen im Allgemeinen noch die Datierungsprobleme für das 1. Jahrtausend Osteuropas im Besonderen, vor dem Auftauchen von Münzen und anderen Importen, allein verantwortlich zu machen. Die Konstruktionsweise eines nach außen umgebogenen Bügelendes ist zweifelsfrei bereits in der späten römischen Kaiserzeit ausgeprägt worden. ${ }^{59} \mathrm{Am}$

54 Vgl. Văžarova 1976, Abb. 82,3; dies. 1979, Abb. 16d.

55 Dies. 1976, 19.

56 Werner 1977, 148. Ähnliches ist auch für den angeblich römischen Oberflächenfund aus Zugmantel anzunehmen (Jacobi 1930, 51, Abb. 25,2).

57 Mus. Arqueológico Nacional, Saal XXX.

58 Margeson 1995, 78, Abb. 76,9. Hier wird eine Datierung in das späte 9. oder frühe 10. Jahrhundert vorgeschlagen, da diese Schnallenform in Wikingergräbern unüblich sei. Es ist jedoch zu beachten, dass im Norden mit einem Weiterlaufen des Tassilokelchstils bis in das frühe 9. Jahrhunderts zu rechnen ist (Wamers 1999) und die feinchronologische Gliederung der darauffolgenden Zeit erhebliche Schwierigkeiten bereitet.

59 Jahn 1921, 69-70; Ursachi 1987, 111, 120, Abb. 6,4-5; Glodariu/Moga 1989, 104-105, Abb. 92,1-2; Torbov 1998, 58-59, Abb. 2,27. 
Ende der Entwicklungsreihe stehen Sporen mit langem Stachel, die nach dem Auftreten dieses typologischen Merkmals in das 10. Jahrhundert gesetzt werden müssen. Der Komplex von Kjulevča ist aufgrund der mitgefundenen lyraförmigen Schnalle im 9. Jahrhundert in den Boden gelangt. ${ }^{60}$

Unklar ist die Einordnung von zwei weiteren Sporen aus Odărci (Abb. 6,7) ${ }^{61}$ Es könnte sich sowohl um Hakensporen in der Art derjenigen aus Kjulevča oder auch um stark korrodierte Sporen einer anderen Art handeln.

Vermutlich ebenfalls im weitesten Sinne in römischer Tradition steht ein irrig als Ösensporn bezeichnetes Exemplar aus dem Grubenhaus 14/15 in Şura Mică $\left(\right.$ Abb. 4,12) ${ }^{62}$. Die mitgefundene Keramik legt hier wie auch bei Medişorul Mare eine frühmittelalterliche Zeitstellung nahe. Nach den vorliegenden Abbildungen kann nicht entschieden werden, ob hier Ösen oder Nietlöcher vorliegen. Als Öse wäre die Form völlig singulär. Sporen mit blechartigen Bügeln und Nietenden sind aus der Römischen Kaiserzeit wiederholt bekannt. ${ }^{63}$ Es ist sogar zu erwägen, ob in diese Nietlöcher nicht Knopfenden eingenietet waren. Als Beispiel für ein überraschend spätes Vorkommen auch dieser kaiserzeitlichen Konstruktionsart kann Zurkovka (Raj. Smolensk) angeführt werden. Auch wenn es sich bei den Langkurganen um Kollektivgräber handelt, muss der Komplex doch noch im 9. Jahrhundert zugänglich gewesen $\operatorname{sein}^{64}$. Dass prinzipiell mit bandförmigen Nietsporen noch im 8. und 9. Jahrhundert zu rechnen ist, belegt einer der Sporen vom Gaulskopf (Kr. Höxter) ${ }^{65}$ In denselben Zusammenhang gehört ein Sporn aus Komarevo in Nordbulgarien (Abb. 4,11), ${ }^{66}$ der nach der mitgefundenen hellenistischen Hebelstangentrense zwar zweifelsfrei in die letzten Jahrhunderte vor Christi Geburt zu datieren ist. Seine Konstruktion in Form einer gebogenen großen Schlaufe mit einer Öffnung in der Bügelebene findet aber eine bemerkenswerte Fortset-

60 U. Fiedler $(1992,218)$ datiert Ende 9. Jahrhundert, L. Révész $(1987,282)$ setzt die Stücke im Karpatenbecken beginnend mit der Landnahme durch die Ungarn an, in Bulgarien und anderen Regionen (ebd., 273) lediglich allgemein in das 9.-11. Jahrhundert. Abzuleiten sind sie vermutlich von Funden Osteuropas bzw. Westasiens aus dem 8.-10. Jahrhundert (ebd., 277, 279).

61 Dončeva-Petkova 1987, 75, Abb. 7b-c.

62 Nägler/Rill 1981, 46-47, Abb. 12,1-3; Madgearu 1994, 155, Abb. 2,3. Die von M. Rill (Nägler/Rill 1981) und R. R. Heitel (Rill/Heitel 1994/95, 416, Anm. 85) vertretene Ansicht, mit diesem Sporn sei das Eindringen der Slawen in diesem Raum spätestens ab dem Anfang des 9. Jahrhundert zu belegen, ist nicht nachvollziehbar.

63 Jahn 1921, 71-88, Abb. 74-76, 78-79, 85, 88. Zur Vorsicht gemahnt hier ein Sporn aus Turnava, Bulgarien, der tatsächlich als Ösensporn verstanden werden könnte. Der Lesefund stammt aus dem Bereich einer Siedlung und eines Gräberfeldes des 2. und 1. Jahrhunderts v. Chr. (vgl. Torbov 1998, 59, Abb. 25).

64 E. A. Schmidt 1958, 165, 168, Abb. 4,9; Sedov 1974, 33. Die Datierung beruht auf mitgefundenen Gürtelteilen.

65 Best 1999.

66 Torbov 1998, 58 Abb. 12. Zum Fundkomplex s. Nikolov 1965, 185, Abb. 25. 
zung im Frühmittelalter im Gebiet des Baltikum und zwar ausschließlich dort. ${ }^{67}$ Auch hier ist ein bislang unerkannter Traditionsstrang aus mediterran-provinzialrömischem Kontext zu vermuten.

Ähnlich ungewiss ist die Einordnung eines Nietsporns mit bandförmigem Bügel aus Madara, der in der Aufsicht einen propellerartigen Umriss besitzt. ${ }^{6}$ Genaue Vergleichsstücke sind mir nicht bekannt, ihre entfernte Ähnlichkeit mit völkerwanderungszeitlichen Sporen aus Tumiany im ehemaligen Ostpreußen lässt an eine spätantike Zeitstellung denken. ${ }^{69}$

Den Hauptzweig der Sporenentwicklung bilden dann wieder die Nietplattensporen, die aus dem Arbeitsgebiet allerdings kaum bekannt geworden sind. In Tătăria in Rumänien ist ein Paar solcher Sporen mit großen Nietplatten mit zwei Nietreihen gefunden worden..$^{70}$ Die Sporenschenkel und die Stachel sind massiv, an den Stachelbasen sitzt jeweils eine Rippe (Abb. 5,3). Diese Merkmale weisen sie als zu einer Gruppe zugehörig aus, die mehrfach in Großmähren belegt ist, darüber hinaus aber entlang der fränkischen Randzone bis zum Ärmelkanal nachzuweisen ist (Liste 3, Karte 3). Sie kommt im Zusammenhang mehrerer der oben skizzierten Horizonte vor und kann nur allgemein in das 9. Jahrhundert gesetzt werden. Nach den Vorstellungen von U. Giesler ${ }^{71}$,

67 Aukškiemiai: Gaerte 1929, 340, Abb. 277a; Grinerti: Latvijas PSR archeologija (Riga 1974) 372 Abb. 55,16; Tervete: ebd. 372, Abb. 55,19. Eine Datierung ist nur vage in das Frühmittelalter möglich. Weitere Beispiele aus dem baltischen Siedlungsraum könnten noch angeführt werden. Technologisch verwandt ist eine Gruppe merowingerzeitlicher Sporen aus Süddeutschland, die U. Koch vorgelegt hat (U. Koch 1986). Vgl. dazu Bern-Bümpliz Grab 171 und Kienberg: Moosbrugger-Leu 1971, 114-117, Taf. 21,9-10; Lausanne-Bel Air Grab 48: Moosbrugger 1965, Abb. 1CT 433. Bemerkenswert ist für dieses Konstruktionsprinzip eine scheinbare chronologische Teilung in eine Gruppe vom Ende des 6. bis zum ersten Drittel des 7. Jahrhunderts und in eine zweite in die zweite Hälfte des 7. Jahrhunderts. Sogar in Regionen mit sehr guter Überlieferung und vorbildlichem Forschungsstand können also solche scheinbaren Effekte auftreten. Zu Ergänzen ist neben Oberderdingen, Ldkr. Karlsruhe Grab 71 (freundl. Hinweis K. Bangardt; unpubl. Magisterarbeit Bonn 1993) ein Siedlungsfund aus Villiers-le-Sec (Fassbinder 1999, Abb. IV.136). Erfreulicherweise gibt es auch mit Frohnhausen einen Beleg für eine Kontinuität dieses Konstruktionsprinzips in der Einflusszone des Karolingerreiches aus der zweiten Hälfte des 8. Jahrhunderts (Westphal 1999, Abb. Nr. V. 68).

68 Vitljanov 1996, 62, 108, Nr. 4 Taf. XXIII,11.

69 Heydeck 1893-1895, Taf. V,15, Taf. IX,19; Jahn 1921, 36-38, Abb. 42-43. Allerdings ist aufgrund der Grundform auch eine Zuweisung in die Latènezeit möglich (Jahn 1921, 22, Abb. 16-17).

70 Horedt 1954, 496-498, Abb. 3; ders. 1958, 113, Abb. 33; Madgearu 1994, 154, 158, Abb. 2,1 .

71 Vgl. Giesler 1974, Abb. 5-6. Entscheidend ist hierfür die von Giesler vertretene Datierung des Horizontes von Biskupija-Crkvina ab 770. 


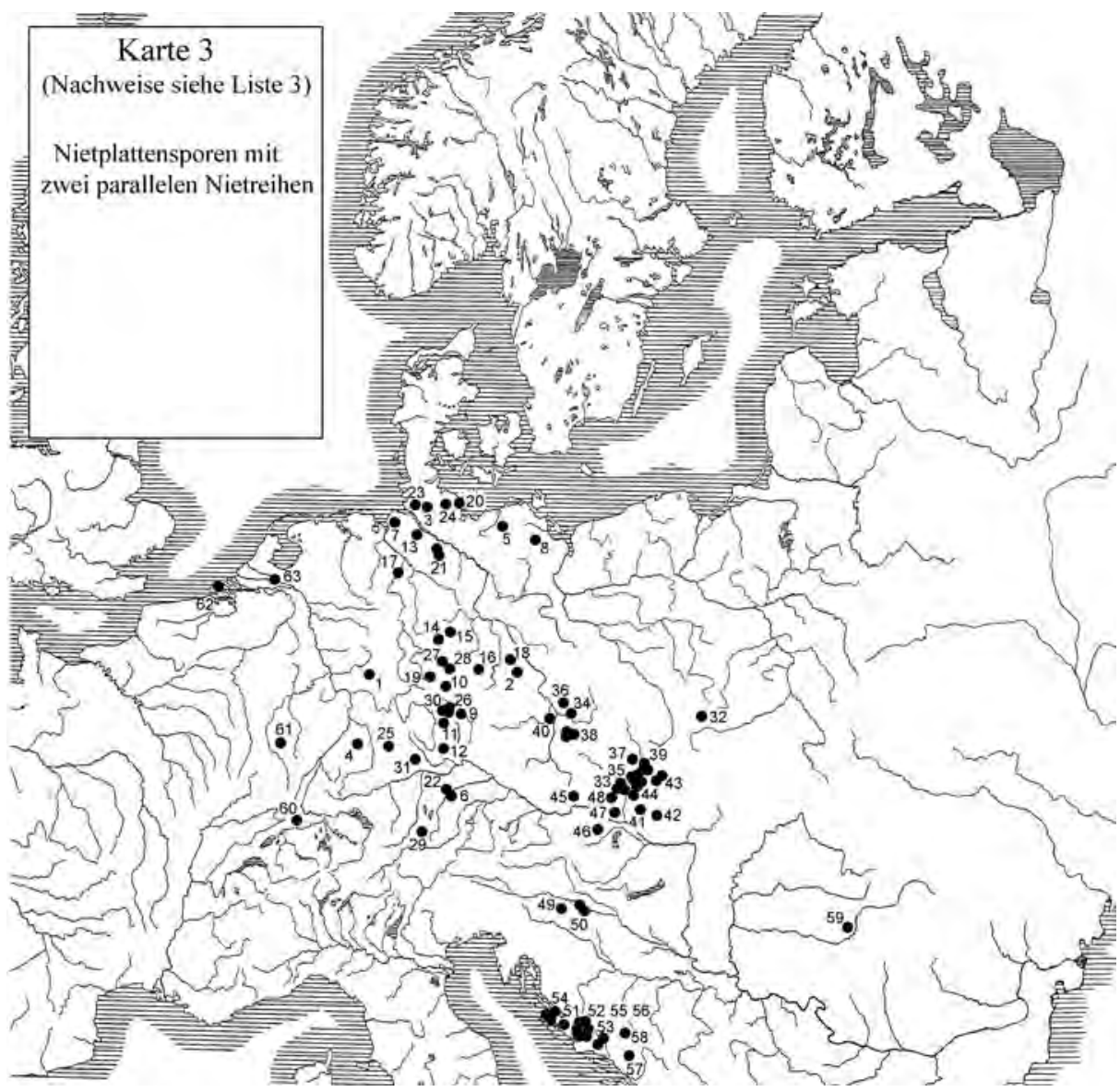

Karte 3

J. Kleemann ${ }^{72}$ und R. Pöllath ${ }^{73}$ ist ein Auftreten dieser Form ab dem späten 8. Jahrhundert möglich, jedoch wegen der massiven Ausprägung der Stücke erst im frühen 9. Jahrhundert wahrscheinlich. Den Vorstellungen M. Schulze-Dörrlamms über die Herausbildung der Stachelformen zufolge sind sie hingegen erst in das mittlere und dritte Drittel des 9. Jahrhunderts zu stellen. ${ }^{74}$ Die Entwicklung der Nietplattensporen ist unzweifelhaft von derjenigen der Nietsporen abhängig, erstere übernehmen jedoch durchgehend die langen Bügel der Schlaufen- und Schnallensporen. Ansätze zu Niet-

72 Vgl. Anm. 23 (Stufe IV).

73 Vgl. U. Koch 1993/94, 160-161, Abb. 9 (Stufe C/III 730/50-760/90). Aufgrund seiner massiven Grundform wäre das Paar nach Pöllaths Typologie der Stufe IV oder sogar V zuzuordnen, wodurch es sich der hier vertretenen Datierung annähern würde.

74 Schulze-Dörrlamm 1993, 564-565. 

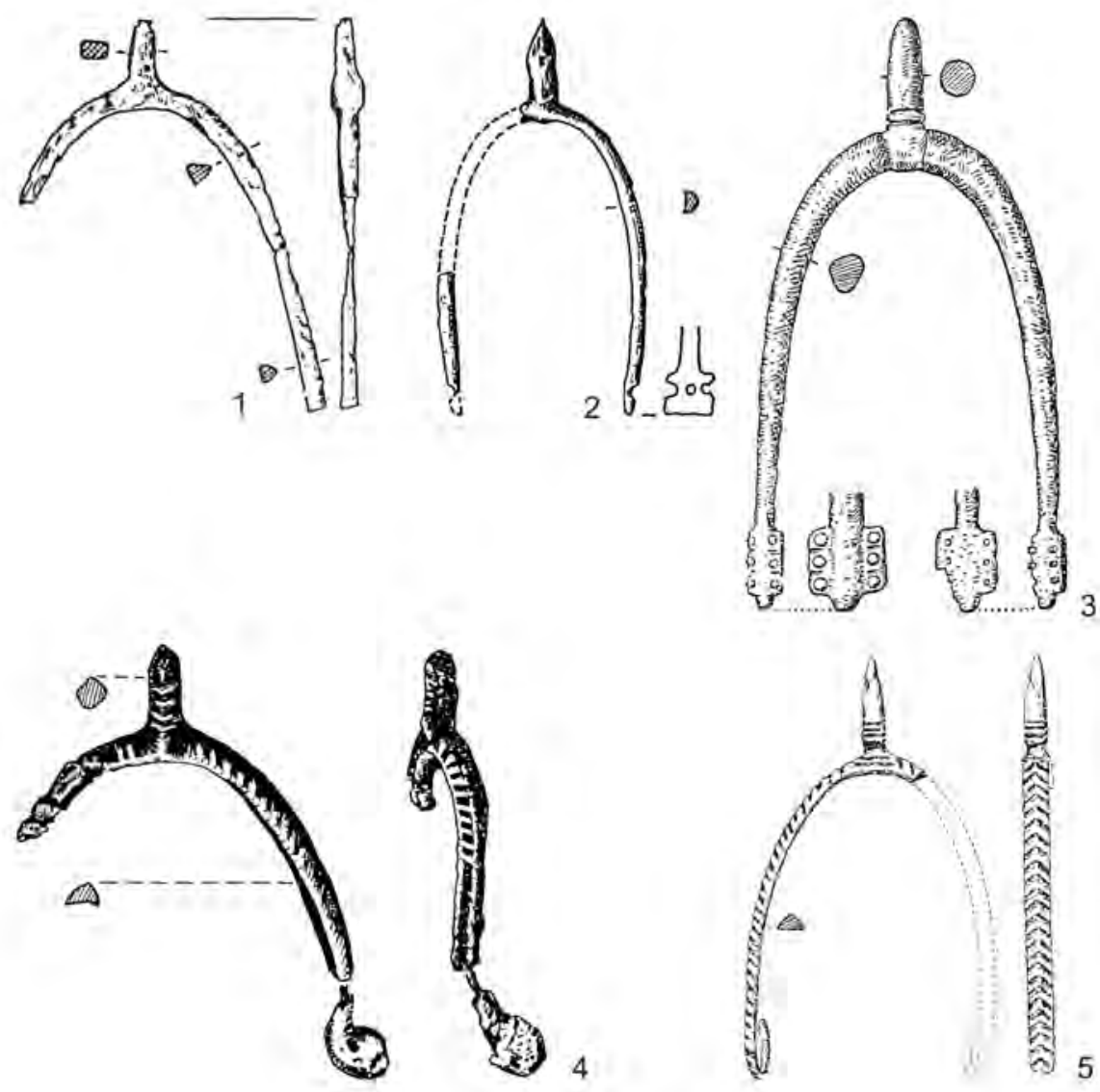

1. Stărmen Fund 1293 (s. Anm. 25); 2. Stărmen Fund 880 (s. Anm. 76); 3. Tătăria (Liste 3 Nr. 59); 4. Breaza (s. Anm. 78); 5. Pobedim (s. Anm. 41)

Abb. 5. Sporen des 8. und 9.Jahrhunderts, Eisen, M 1:2; 3,4 o.M.

platten finden sich an einer Reihe von Sporen, die aufgrund ihrer Form und Verzierung mit dem Horizont des Tassilokelches zu parallelisieren sind. ${ }^{75}$ Die frühesten echten Nietplatten treten jedoch offenbar erst im Horizont von Biskupija-Crkvina auf, der in das frühe 9. Jahrhundert zu setzen ist.

Einer anderen Nietplattensporengruppe gehört ein weiterer Sporn aus Stărmen an (Abb. 5,2). ${ }^{76}$ Hier zeigt die schlecht erhaltene Nietplatte eine quer zur Bügelebene stehende Reihe von drei Nietlöchern. Soweit erkennbar waren diese vermutlich in einer Rille versenkt, wie es für eine große Gruppe von Sporen mit zungenförmigen,

75 Als Beispiel sei hier auf die in der Liste 1 genannten Exemplare verwiesen.

76 Kurnatowska 1973, 105-106, 120, 123, Abb. 5,7; dies. 1980, 152, 207, Abb. 53,880. 

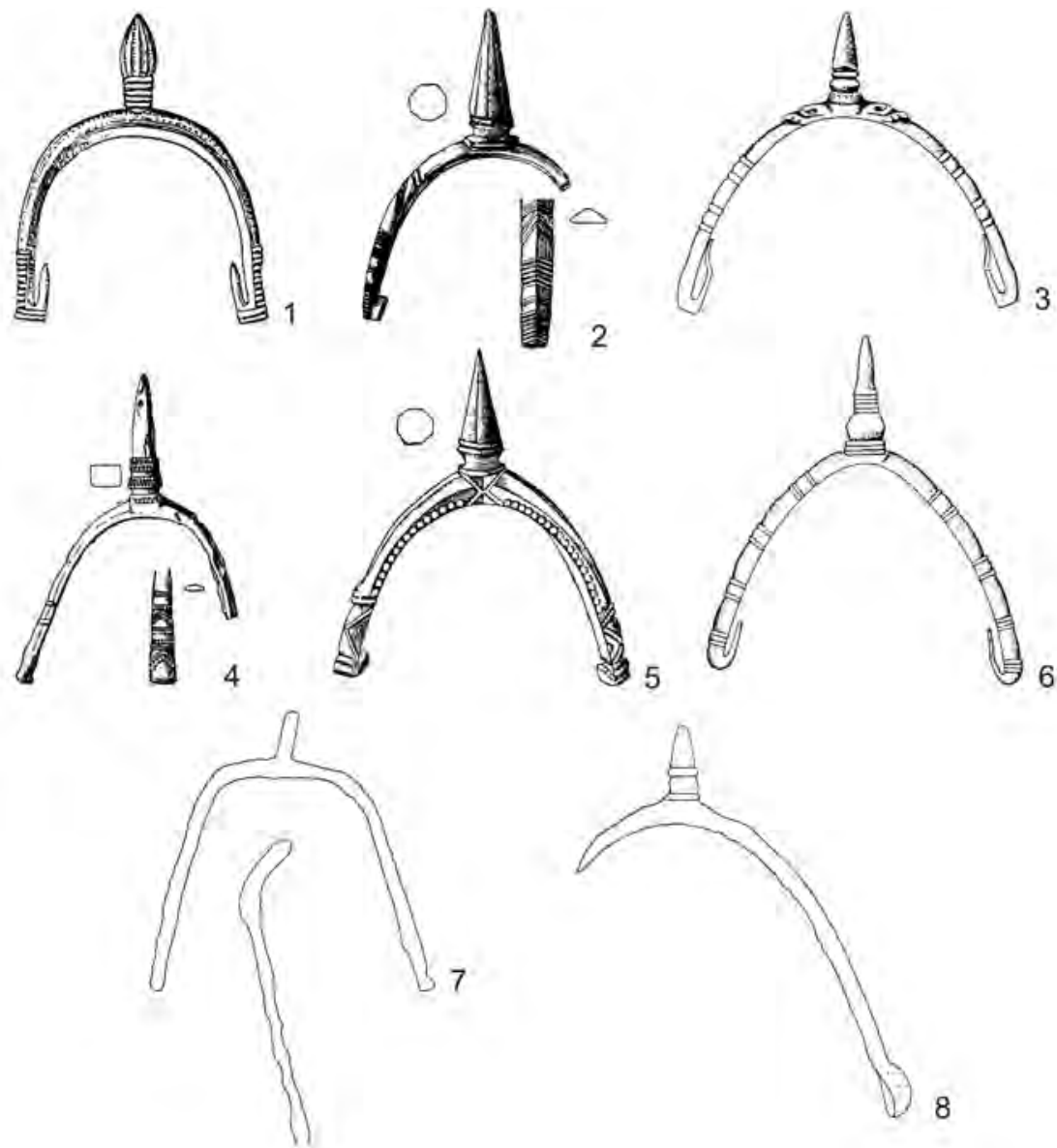

1. Oradea Mare (s. Anm. 39); 2. Mikulčice (s. Anm. 42); 3. Drawsko (s. Anm. 42); 4. Mikulčice (s. Anm. 42); 5. Sadska (s. Anm. 42); 6. Ujście (s. Anm. 42); 7. Odărci (Umzeichnung durch Verf. nach Vorlage s. Anm. 61); 8. Odărci (Umzeichnung durch Verf. nach Vorlage s. Anm. 43)

Abb. 6. Sporen des 8. und 9. Jahrhunderts, 1-5 Bronze, 6-8 Eisen. M 1:2, 3,4 o.M.

quadratischen oder profilierten Nietplatten zu beobachten ist. ${ }^{77}$ Um exakte Parallelen heranziehen zu können, wären erkennbare Verzierungselemente nötig. Chronologisch kann diese Gruppe nur allgemein in das 9. Jahrhundert gestellt werden. Der Stachel dieses Sporns scheint in den Bügel eingenietet zu sein, ein Merkmal, das oben bereits besprochen wurde und wohl zu Recht mit direktem westlichen Einfluss verknüpft wird, wohingegen sonst das Ausschmieden aus einem Stück im westslawischen Siedlungsgebiet im Fundmaterial vorherrschend ist.

77 Diese Gruppe soll hier nicht näher behandelt werden. Als Überblick vgl. Bialeková 1977. 
Vermutlich ebenfalls zu einem Nietplattensporn gehört der Sporn von Breaza (Abb. 5,4) ${ }^{78}$ bei dem leider keines der Bügelenden erhalten ist. Die Verzierung mit Streifentauschierung ist ein zwar altertümliches, aber durchaus übliches Merkmal.

Zahlenmäßig häufiger belegt sind diejenigen Sporen, die erst in das 10. Jahrhundert zu setzen sind. Formal noch eng verwandt mit den Nietplattensporen ist ein Fund aus dem Museum Šumen..$^{79}$ Die Verzierung des Sporenkörpers mit Scheintorsion, der relativ kurze Stachel und die Gesamtproportion stehen noch in der Tradition des 9. Jahrhunderts. Dieses Bild wird jedoch durch die Gestaltung der Bügelenden gestört. Die eckige Platte mit zwei parallelen Durchzügen ist von zahlreichen Sporen mit langem Stachel bekannt und daher nicht vor das 10. Jahrhundert zu datieren. Diese Befestigungsform hat ihren geographischen Schwerpunkt eindeutig in Osteuropa und reicht nur in sehr seltenen Ausnahmen über die Weichsel oder gar über die Elbe hinaus nach Westen (vgl. Karte 5). Demzufolge dürfte dieses Exemplar kaum aus dem Westen in das Bulgarenreich gelangt, sondern eher auf Kontakte mit der Kiewer Rus zurückzuführen sein. Hier schließen sich die Sporen mit langem Stachel aus Preslav, ${ }^{80}$ Čelopeč (Abb. 7,1), ${ }^{81}$ Alčedar ${ }^{82}$ und $\mathrm{Car}^{\mathrm{Asen}}{ }^{83}$ an. Ihre Formen entsprechen im allgemeinen dem gängigen Trend der Zeit. Es fehlen jedoch in dieser - allerdings recht kleinen - Gruppe diejenigen mit altertümlich wirkenden Bügelenden wie zum Beispiel Nietplatten. Ebenso sind die aus Mitteleuropa vielfach bekannten schlanken langen Stachel eher selten (mit Ausnahme eines Exemplars von Preslav), die keulenartig geschwollenen Stachel der drei anderen Exemplare sind dagegen wiederum als ein in erster Linie osteuropäisches Merkmal anzusehen, was auch für die Bügelenden mit zwei Riemendurchzügen gilt. Im Vergleich zu den mitteleuropäischen Formen erscheinen besonders die beiden Stücke aus dem Museum Šumen fremdartig, ein direkter Import ist daher auszuschließen.

Die charakteristischen Merkmale hochmittelalterlicher Sporen sind die zunehmende Schwingung der Bügelebene, die Entwicklung und Vergrößerung der Stachelspitze sowie Umformungen der Bügelenden, wie zum Beispiel durch eine Reduktion der Nietplatten oder eine Vereinfachung der Riemendurchzüge. Diese Entwicklungsschritte laufen in loser Koppelung nebeneinander ab. So ist es zu erklären, dass gerade in

78 Nägler 1969, 100-101, 118, Abb. 6,2-3; Madgearu 1994, 154, Abb. 2,2. Das nach außen umgebogene Bügelende ist nach A. Madgearu auf eine Beschädigung zurückzuführen und stellt nicht die ursprüngliche Konstruktion dar. Auffallend ähnlich ist die Abbildung bei V. Ursachi (1987, Abb. 6,12). Möglicherweise liegt hier eine Verwechslung vor. Die Bügelhöhe des Stückes wäre sowohl für die Spätlatène- als auch für die Kaiserzeit recht ungewöhnlich.

79 Inv. Nr. 4916. Bedauerlicherweise konnte P. Petrova, Museum Šumen, meiner Bitte um eine Publikationsgenehmigung dieser Stücke nicht entsprechen.

80 Museum Preslav, unpubliziert.

81 Mutafčiev 1914, Abb. 243,8.

82 Feodorov 1954, 19, Abb. 18,1.

83 Museum Ruse, Inv. Nr. III 682 


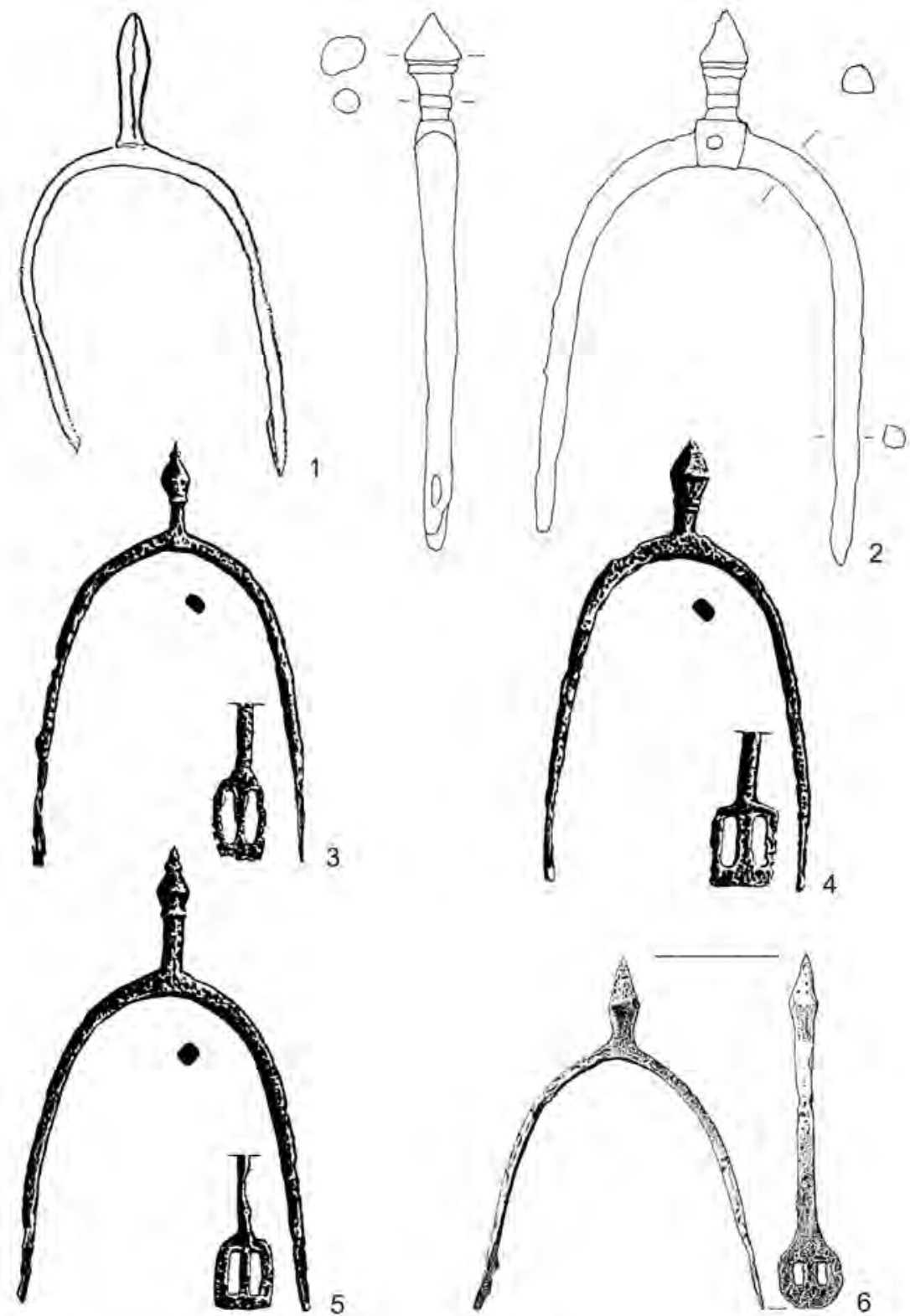

1. Čelopeč (Umzeichnung durch Verf. nach Vorlage s. Anm. 80); 2. Pliska (Zeichnung des Verf., vgl. Anm. 84); 3.-5. Ras (s. Anm. 86); 6. Braničevo-Svetinja (s. Anm. 87)

Abb. 7. Sporen des 10.-11.Jahrhunderts, Eisen. M 1:2, 1 o.M. 
Randgebieten nur einzelne Schritte Anwendung bei der Neuentwicklung von Sporen finden. Das gilt zum einen für einen weiteren Sporn aus Preslav (s. u.), sowie für einen Sporn aus Pliska (Abb. 7,2) ${ }^{84}$ Letzterer wurde in einer undatierten Kulturschicht vor der Mauer der Inneren Stadt gefunden. Hier ist der Bügel zwar noch gerade, der Stachel aber bereits wieder etwas verkürzt und mit einer stark verdickten Spitze versehen. Es besteht kein Grund, ihn zu der sehr kleinen Sondergruppe karolingerzeitlicher Sporen mit entfernt ähnlicher Spitze zu stellen, da entsprechende Verzierungen fehlen. Dagegen ist die Gestaltung der Bügelenden im Frühmittelalter nicht vorstellbar. Gemäß der Stachelspitze ist dieser Sporn etwa in das 11. Jahrhundert zu datieren. Parallelen hierzu sind in Westeuropa nicht bekannt, ${ }^{85}$ recht ähnliche Stücke liegen jedoch aus Zvirići und Mogorjelo (Bosnien-Hercegowina) und Ras (Serbien) (Abb. 7,3-5) vor. ${ }^{86}$

Von der Grundform her gesehen, nämlich einem geraden Bügel bei gleichzeitig verdickter Stachelspitze, gehört auch ein Sporn aus Braničevo-Svetinja in Serbien (Abb. 7,6) hierher. ${ }^{87}$ Auffallend ist das Fehlen von Sporen mit langem Stachel der westeuropäischen Form und die Herausbildung von Sonderformen, wie sie im östlichen Adriaraum vorkommen. ${ }^{88}$ Eine wie auch immer geartete ethnische oder politische $\mathrm{Zu}$ weisung ist unbegründet. Das Vorhandensein von Sporen als solches ist sicherlich als ein in letzter Konsequenz westlicher Einfluss zu werten; die Formen können jedoch nicht mehr direkt mit dem mitteleuropäischem Spektrum verbunden werden. Es muss also von einer gewissen Eigenständigkeit der Entwicklung ausgegangen werden. Diese kann jedoch zurzeit nicht räumlich eingegrenzt werden. Angesichts des häufigen Einsatzes von Söldnertruppen kann auch über eine erschlossene politische Zugehörigkeit eines Fundplatzes keine Aussage zur Herkunft der Sporen gemacht werden, wie zum

84 Dončeva-Petkova 1992, 141, Abb. 40.

85 Für West- und Mitteleuropa sind in dieser Zeit Sporen mit langen ungegliederten Stacheln typisch, die z.T. schon nicht mehr mit dem Bügel in einer Ebene liegen sondern zur Bügelebene einen stumpfen Winkel bilden. Eine in die Zukunft weisende Herausbildung von abgesetzten, verdickten Stachelspitzen ist ab dem frühen 11. Jahrhundert festzustellen. Zur Anfangsdatierung dieser Entwicklung ist der Fundort Colletière am See Paladru von herausragender Bedeutung, da er nur vom ausgehenden 10. bis zur Mitte des 11. Jahrhundert besiedelt war (vgl. Colardelle/Verdel 1991; dies. 1993, 214, Abb.148). Weiter östlich sind solche Formen nur spärlich und - soweit datierbar - später anzusetzen. Allgemein gebräuchlich wurden Stachel mit verdickten pyramiden-, doppelpyramiden- oder kugelförmigen Stachelspitzen erst an Sporen mit geschwungener Bügelebene, wie sie ab der zweiten Hälfte des 11. Jahrhundert entwickelt worden sind. Zusammenfassend dazu: Kind 1997, 119-124, 139-142, 150-155.

86 Miletić 1963, 157-158, Abb. 2,3; Zekan 1994, 67-68, Taf. VIII,3; Popović 1999, 258, Abb. 221,1-3.

87 Popović/Ivanišević 1988, 162, Abb. 3,1.

88 Typ Varivode nach Kind 1997, 125, Taf. XLVII,2389; Jelovina 1986, 57-59, 63, 67-69, Taf. VIII,102-103, Taf. IX,116, Taf. XIII,165-166, Taf. XVIII,204-205, Taf. XX,214-216; Zekan 1987, 46, 57 Abb. o.Nr.; ders. 1994, Taf. VII,1.4-5. 


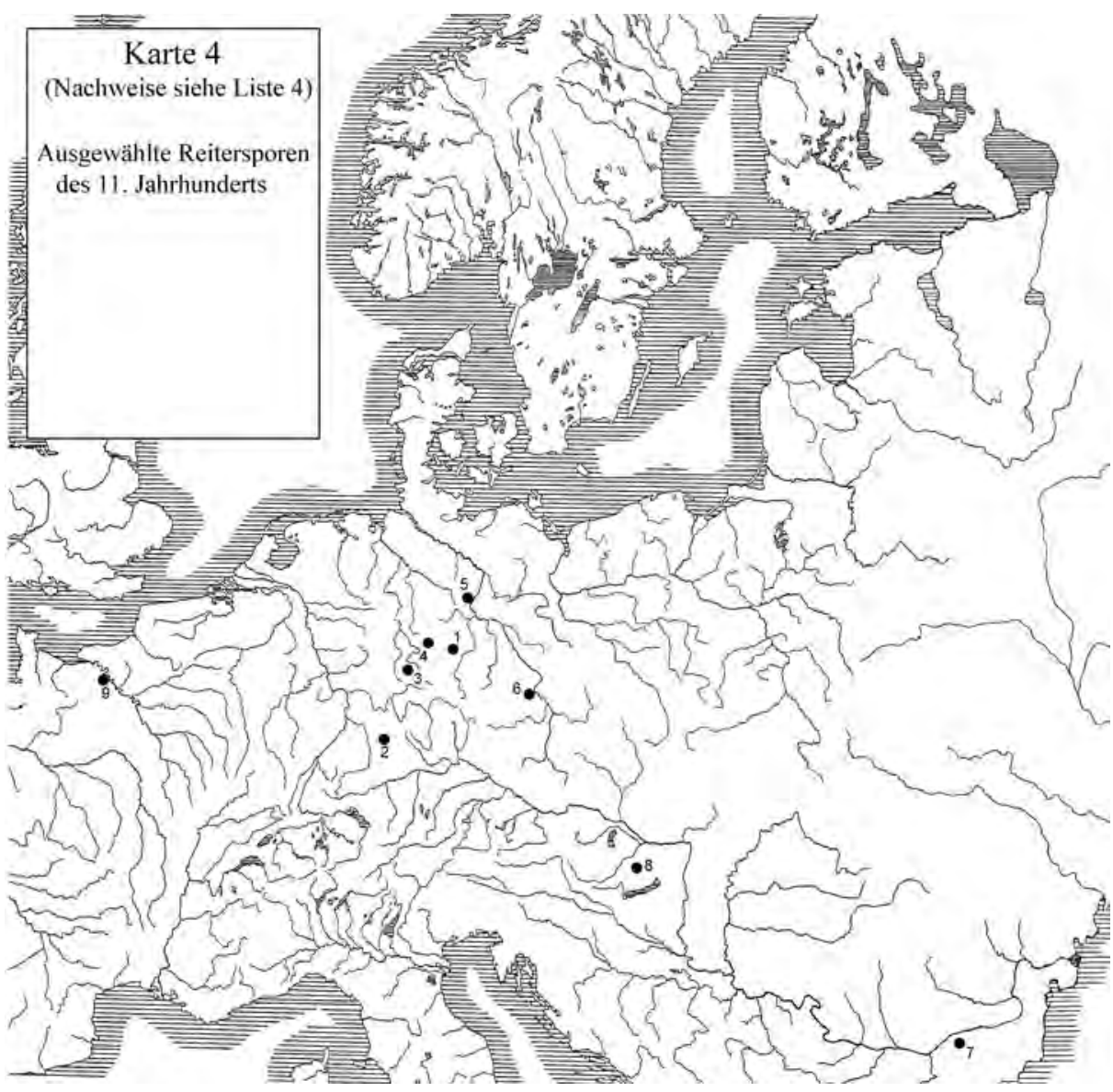

Karte 4

Beispiel im Falle von Ras (Horizont IIIa) oder auch Păcuiul lui Soare aus ihrer Zugehörigkeit zum byzantinischen Herrschaftsraum. ${ }^{89}$

Im Arbeitsgebiet einmalig ist ein Sporn aus Păcuiul lui Soare mit leicht geschwungener Bügelebene und ehemals vermutlich schwach ausgebogenem oder in sich geschwungenem langen Stachel mit einer kleinen Pyramidenspitze (Abb. 8,1) ${ }^{90}$ Er gehört zu einer relativ seltenen Gruppe von Sporen, die zwischen Frankreich und Siebenbürgen sehr lückenhaft verbreitet ist (Abb. 8,2-4, Karte 4), jedoch schwingt bei diesem Exemplar die Bügelebene nicht s-förmig aus. Insofern steht es der zuvor be-

89 R.-J. Lilie $(1999,75,79,102)$ betont sowohl die regelhafte Verwendung von Söldnern seit dem 11. Jahrhundert, die schon bald den Kern des byzantinischen Heeres bilden sollten, als auch die Integration vieler Ausländer in die einheimische Oberschicht im 12. Jahrhundert.

90 Baraschi 1977, 145, Taf. XXII,3. 


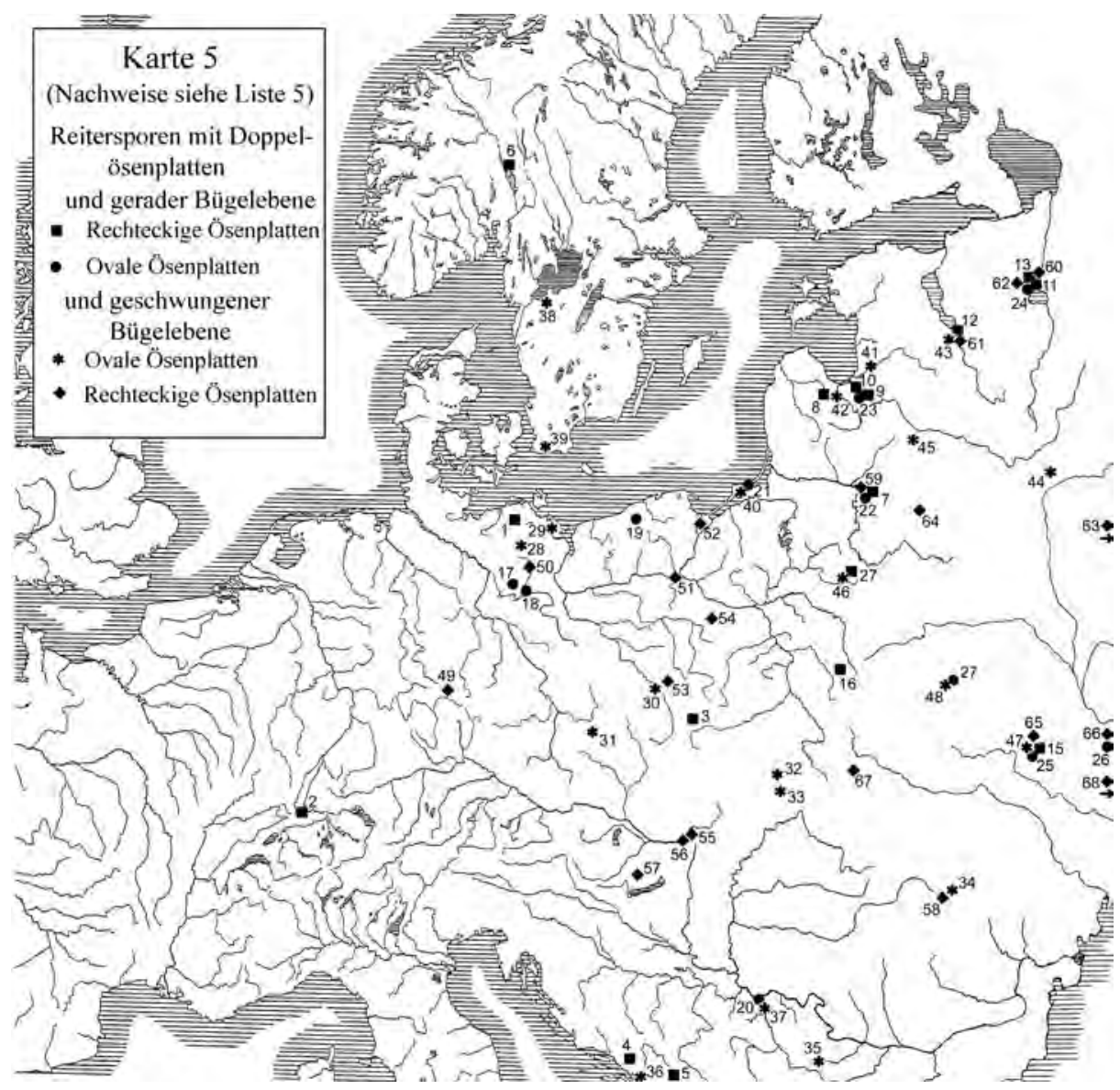

Karte 5

handelten Gruppe noch näher als die westeuropäischen Stücke. Diese Sporengruppe gehört in das 11. Jahrhundert, wobei keines der Exemplare sicher in die erste Hälfte dieses Jahrhunderts gesetzt werden kann. ${ }^{91}$ Generell kann jedoch festgestellt werden, dass Sporen mit verdickten und vom Stachelhals abgesetzten Spitzen eine westliche Entwicklung sind, die sich erst mit zeitlicher Verzögerung bis ins östliche Mitteleuropa verbreitete. Das genannte Exemplar belegt dies augenfällig. Die Ausformung dieser Stachelform geht parallel mit der Entstehung der nicht mehr in einer Ebene liegenden, sondern geschwungenen Bügelebene, ist jedoch nicht an diese gebunden. Auch verläuft

91 Siehe die in Liste 4 genannten Belege. Vgl. zur Datierung die Zusammenfassung bei Kind 1997, 138-139. 

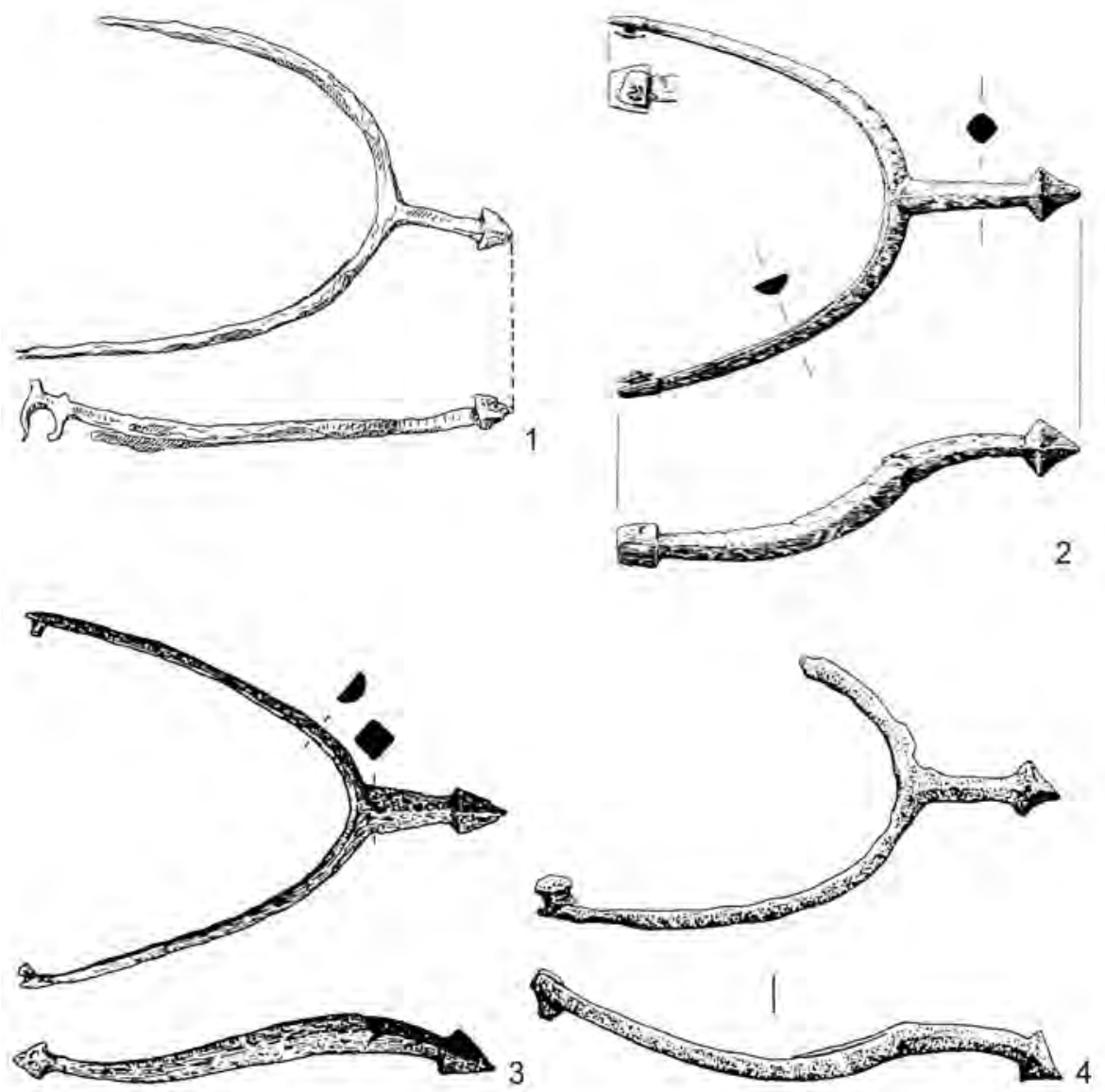

1. Păcuiul lui Soare (Liste 4 Nr. 7); 2. Grasburg (Liste 4 Nr. 3); 3. Hasenburg (Liste 4 Nr. 4); 4. Montfort-sur-Risle (Liste 4 Nr. 9)

Abb. 8. Sporen des 11. Jahrhunderts (Nachweise siehe Liste 4). M 1:3.

die Entwicklung der Spitze nicht linear in Form einer Größenzunahme. Die früheste gesicherte Datierung einer solchen Form liegt aus Colletière am Paladru-See vor. In dieser Flachmotte, die auf naturwissenschaftlichem und numismatischem Weg sicher in die Zeit zwischen 990 und 1045/50 datiert werden kann, wurden mehrere Reitersporen geborgen, die zwar noch die geraden Bügelschenkel zeigen, aber bereits eine deutlich abgesetzte und verdickte Spitze besitzen. Es handelt sich durchweg um auffallend große Spitzen, meist Pyramiden.$^{92}$ Diese Form ist eindeutig als westeuropäisch anzusprechen, da sie östlich der Elbe und der Westalpen nur ganz vereinzelt vorkommt. Die Funde aus

92 Colardelle/Verdel 1993, 214, Abb. 148,1-10. 
Windischgarsten ${ }^{93}$ und aus Csabrendek ${ }^{94}$ sind als „Ausreißer“ in Richtung Südosten zu werten. Ähnlich datiert ein Sporn mit kleiner Pyramidenspitze aus der mittleren Belegungsphase von Dăbica in Siebenbürgen (Abb. 9,3). ${ }^{95}$

Es mag auffallen, dass im Gegensatz zu meiner oben umrissenen These einige Sporen aus dem byzantinischen Herrschaftsbereich genannt worden sind. Hierzu zählt der Sporn des 11. Jahrhunderts aus Pliska und die gleichzeitigen Funde aus der Festung Ras. Gerade in der letzteren Anlage fanden sich drei von insgesamt fünf Sporen in der Schicht IIIa, die über Münzen in die erste Hälfte des 12. Jahrhunderts zu stellen ist. ${ }^{96}$ Man muss jedoch die diffuse politische Lage auf der Balkanhalbinsel beachten. Das Beispiel Serbien ist hier gut geeignet. Offiziell gehört das Fürstentum (Županat) zum byzantinischen Reich, jedoch ist der Zeitraum 1090 - 1204 durch Aufstände und deren Niederschlagung gekennzeichnet. Die Anwesenheit von Söldnern ist wiederholt bezeugt. ${ }^{97}$ Somit kann weder über die ethnische noch über die politische Zugehörigkeit der Sporenträger etwas ausgesagt werden. Ohne Neufunde ist zu dieser Frage nichts Entscheidendes zu formulieren.

Sporen mit stark geschwungener Bügelebene und ebenfalls stark verdickter Stachelspitze sind - ebenso wie die frühen Rädchensporen - im Gegensatz zu der zuvor besprochenen Gruppe häufig und flächendeckend im Arbeitsgebiet vorhanden ${ }^{98}$. Zu nennen sind hier Păcuiul lui Soare, ${ }^{99}$ Bîtca Doamnei, ${ }^{100}$ Dăbîca, ${ }^{101}$ Lechinta de Mures, ${ }^{102}$ Vințu de Jos, ${ }^{103}$ Lencăuți-Cernăuți, ${ }^{104}$ Putnei, ${ }^{105}$ Seuthopolis, ${ }^{106}$ Pernik, ${ }^{107}$ Djadovo, ${ }^{108}$

93 Karnitsch 1931, 48, Taf. 4A 2696.

94 Régészeti 3/10, Abb. 15,5.

95 Zur typologischen Ansprache und zur Datierung ist eine Ansicht der Bügelebene Voraussetzung, um festzustellen ob und wenn ja wie stark die Bügelschenkel geschwungen sind. Anhand der Abbildung bei Pascu/Rusu/Jambor/Edroiu (1968, Abb. 4,9) kann dieses nicht beurteilt werden.

96 Popović/Ivanišević 1988, 258.

97 Ćirković 1995.

98 Rädchensporen finden sich in Păcuiul lui Soare (Pascu/Rusu/Jambor/Edroiu 1968, 145-146, Taf. XXII,4-6), Seuthopolis, Pernik, Sîncrăieni (Vulpe 1955, 563, Abb. 4,79) und Măgura Codlei (Costea 1968, 87, Abb. 7,3-7).

99 Baraschi 1977, 145, 189, Taf. XXII,1.

100 Scorpan 1965, Abb. 5,11.13-15, 6,8; Spinei 1986, 66, 236, Abb. 11,7-8.

$101 \mathrm{Pascu} /$ Rusu/Jambor/Edroiu 1968, Abb. 4,6.9, Abb. 5,4.5.

102 Popescu 1925, Taf. XX,8-9.

103 Simina 1995, 476, Abb. 7,11.

104 Spinei 1997, 154, Abb. 11,1-2.

105 Ebd., 166, Abb. 19,4.

106 Čangova 1972, 46, 145, Abb. 33,2-3.

107 Dies. 1992, 184-185, Abb. 172.

108 Borisov 1989, 131, 134, Abb. 157a-c. 

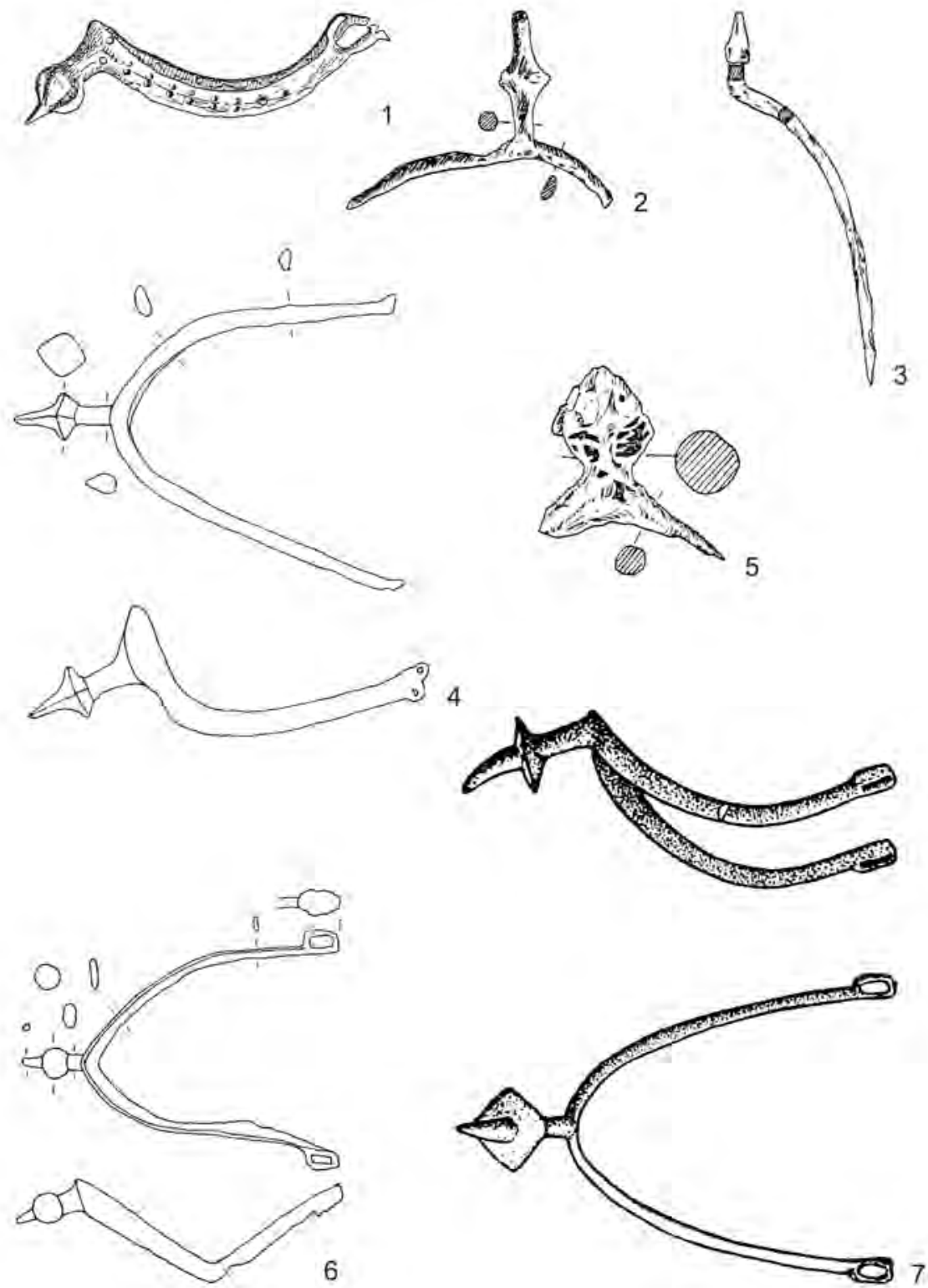

1. Păcuiul lui Soare (s. Anm. 99); 2. Dăbîca (s. Anm. 101 Abb. 4,6); 3. Dăbîca (s. ebd. Abb. 4,9); 4. Museum Šumen (Zeichnung des Verf.); 5. Dăbîca (s. Anm. 101 Abb. 5,4); 6. Museum Šumen Nr. 9476 (Zeichnung des Verf.); 7. Bîtca Doamnei (s. Anm. 100 Abb. 6,8)

Abb. 9. Sporen des 12.-13.Jahrhunderts, Eisen. 4,6,7 M 1:2, sonst o.M. 
Preslav $^{109}$ und Balčik ${ }^{110}$. Hierzu gehört ebenfalls ein Sporn aus dem Museum Šumen (Abb. 9,6). ${ }^{11}$ Es fällt bei diesen wiederum das Vorherrschen von Ösenplatten an den Bügelenden auf, jedoch sind auch quer zur Bügelebene gestellte Ösen und asymmetrische Konstruktionen festzustellen, ohne dass sich hieraus Schlussfolgerungen zur räumlichen Herkunft ableiten lassen. Die Formen der stark verdickten Stachelspitzen entsprechen dem aus dem übrigen Europa bekannten Bild.

Ein Unikat ist aus Madara bekannt geworden. ${ }^{112}$ Nach der stark geschwungenen Bügelebene gehört es ebenfalls in den Rahmen der ersten Hälfte des 12. Jahrhundert. Die Zusammenstellung ist wegen des generell doch als gering zu wertenden Publikationsstandes sicherlich nicht vollständig, zumal die meist wenig detaillierte Wiedergabe in Form von Fotos keine Analyse aller Details erlaubt. Das Formenspektrum entspricht dem aus West- und Mitteleuropa bekannten, so dass eine direkte Verbindung mit Südosteuropa in dieser Zeit postuliert werden kann. Beachtenswert ist, dass typologisch frühe Sporen dieser Gruppe, deren Einsetzen im frühen 12. Jahrhundert zu suchen ist, fehlen. Ebenso kommen die in Mitteleuropa in großer Zahl und Variationsbreite fassbaren Bügelenden mit Nietkonstruktionen nur selten vor. ${ }^{113}$ Dagegen sind nahezu alle Sporen dieser Gruppe aus Südosteuropa so spät anzusetzen, dass sie erst in das 13. Jahrhundert datieren, also mit den Rädchensporen zumindest partiell zeitgleich sind.

Erwähnenswert ist noch eine Sonderform, die in Bîtca Doamnei (Abb. 10,2) belegt ist. ${ }^{114}$ Dieses Exemplar weist zwar eine in dieser Ausprägung einzigartige Verzierung durch aufgesetzte Metallkügelchen auf, kann aber sonst gut an eine osteuropäische Form angeschlossen werden. Diese wurde bisher als Typ Vjaz'ma definiert und zusammengestellt (vgl. Karte 6). ${ }^{115}$ Typologisch ist diese - der kurbelartig wirkenden Seitenansicht der Bügelebene zufolge - ausgesprochen spät zu datieren, ${ }^{116}$ so dass mit großer Sicherheit von einer regionalen Sonderform gesprochen werden kann, die ganz am Ende der Stachelsporenentwicklung steht. An den Bügelenden sitzen die schon ge-

109 Vitljanov 1996, 62, 107, Nr. 2 Taf. XXIII,12.

110 Unpubliziert, freundlicher Hinweis V. Iotov, Dobrič.

111 Inv. Nr. 9476

112 Vitljanov 1996, 62, 108, Nr. 3 Taf. XXIII,1; Popov 1936, Abb. 108A.

113 z.B. aus Lencăuți-Cernăuți: Spinei 1994/95, Abb. 4,1.

114 Scorpan 1965, 449 Abb. 5,11.

115 Kind 1997, 148-149.

116 Diese Beobachtung machte bereits Z. Hilczerówna (1956) anhand von Sporen aus Tum und Fordon. 


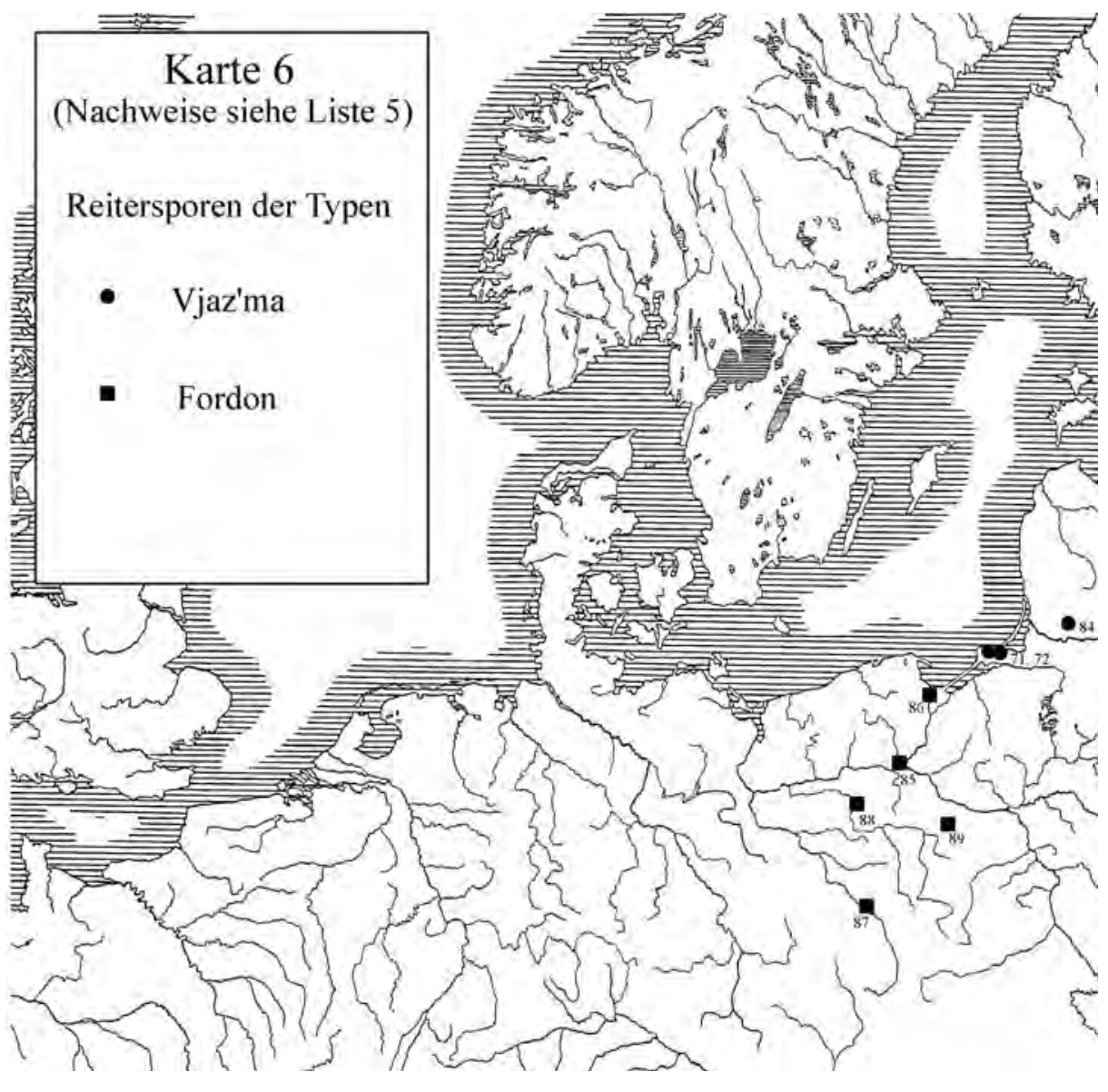

Karte 6

nannten Ösenplatten bzw. einfache, zur Bügelebene quer gestellte Ösen. Auffällig ist insgesamt eine vergleichsweise geläufige Verzierung dieser Sporengruppe unter Verwendung von Bunt- oder Weißmetall. ${ }^{117}$

Zum gleichen Typ zählt ein Sporn aus Preslav, obwohl die Bügelebene des Stückes eher muldenartig ausbuchtet. ${ }^{118}$ Auch hier ist der Stachel lang und ungegliedert, aber gegenüber der Bügelebene deutlich ausgebogen. Anzuschließen ist ein nahe ver-

117 Eine ähnliche Verzierung findet sich auch in Koknese (Latvijas PSR archeologija, Riga 1974, 372 Abb. 60,20) und Martinsalas (Latvijas PSR archeologija 1974, 371-372, Abb. 51,13). Gleichzeitig gibt es mehrere Belege für die seit Jahrhunderten ungebräuchlich gewordene Streifentauschierung in Asote (Šnore 1962, 582, Abb. 3), Vjaz'ma (Jurkina 1981, 110, Abb. 2,12) und Grodno (Voronin 1954, 54, Abb. 22,14).

118 Museum Preslav, unpubliziert. 

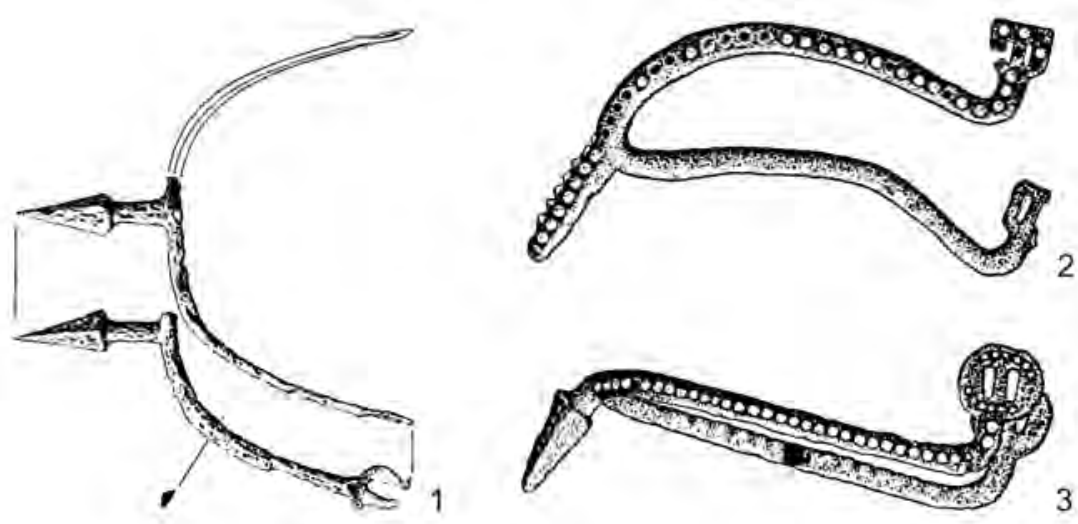

1. Braničevo-Rudine (s. Anm. 87 Abb. 13,1); 2. Bîtca Doamnei (Liste 5 Nr. 58); 3. Bîtca Doamnei (Liste 5 Nr. 90)

Abb. 10. Sporen des 12.-13.Jahrhunderts, Eisen. o.M.

wandter Sporn, der ebenfalls aus Bîtca Doamnei (Abb. 10,3) stammt und mit Reihen aufgesetzter Metallkügelchen verziert ist. ${ }^{119}$ Seine Form ist sehr ähnlich, jedoch endet der Stachel hier in einer abgesetzten kegelförmigen Spitze. Diese ist im Vergleich mit den west- und mitteleuropäischen Formen jedoch sehr schlank und nur geringfügig gegenüber dem Stachelhals verbreitert (vgl. Karte 6, Typ Fordon), was diese Stücke typologisch mit der Sonderform Typ Fordon verknüpft. ${ }^{120}$ Diese Datierung wird durch die mitgefundenen Münzen Belas III. von Ungarn (1172 - 1196) gestützt. ${ }^{121}$

Zusammenfassend kann also gesagt werden, dass eine kontinuierliche Sporennutzung im hier betrachteten Arbeitsgebiet nicht festzustellen ist. Insgesamt lassen sich drei Phasen im Gebrauch von Sporen im Arbeitsgebiet erkennen: eine frühe Gruppe von Sporen, die zu dem Bestand des 8. Jahrhunderts gehört, aber offensichtlich überwiegend oder sogar vollständig erst im 9. Jahrhundert in den Boden gelangt ist; eine zweite recht kleine Gruppe im 10. und mutmaßlich frühen 11. Jahrhundert und zuletzt eine dritte im späten 12. und 13. Jahrhundert. Im Unterschied dazu sind von den Rädchen-

119 Scorpan 1965, 449, Abb. 5,13.15. Eine ähnliche Verzierung mit aufgesetzten Weißmetallhalbkügelchen besitzt einer der Sporen mit langem Stachel aus dem Museum Šumen. Für diese Gruppe ist eine solche Verzierung jedoch einzigartig.

120 Typ Fordon: Kind 1997, 156-157. Nahe verwandt mit diesem und dem zuvor genannten Typ ist eine überwiegend im Baltikum belegte Form, deren langer Stachel eine lange zylindrische Manschette aufweist (vgl. Zschille/Forrer 1891, 11-12, Taf. VII,3; Kulakov 1990, 77, Taf. LX: Grab 49).

121 Scorpan 1965. 
sporen des 14. bis 15. Jahrhunderts eine größerer Zahl aus den Festungen und Städten sowohl Rumäniens als auch Bulgariens bekannt geworden. Nach der eingangs aufgestellten These wären diese mit Kontakten nach Mittel- oder Westeuropa zu verbinden.

Wie ist dieses Bild jedoch im Angesicht der Überlieferungsbedingungen zu werten? Generell kann festgestellt werden, dass Sporen im Arbeitsgebiet selten sind, misst man sie am gesamten Fundmaterial. Die im Vergleich zum Frühmittelalter recht große Zahl hochmittelalterlicher Belege ist sicherlich mit einer vergleichsweise intensiveren Erforschung der prominenten Plätze zu erklären, die wegen der vorhandenen Steinstrukturen und ihrer exponierten Lage leicht auffindbar sind. Nun wird die extreme Seltenheit der Sporen in frühmittelalterlicher Zeit durch eine ungünstige Überlieferungslage relativiert. Reitausrüstung ist in den Grabfunden ebenso wie in den Horten selten. ${ }^{122}$ Lediglich Steigbügel sind in Hortfunden vergleichsweise oft belegt. ${ }^{123}$ Das oben umrissene Bild ist somit nur mit einiger Vorsicht als Basis einer Interpretation zu verwenden. Das Auftreten der Sporen im späten 12. bis 14. Jahrhundert kann danach zwanglos mit dem vom ungarischen König geförderten Auftreten mitteleuropäischer Händler und Bergleute erklärt werden. Hierzu kamen noch die Aktivitäten des Deutschen Ritterordens in Siebenbürgen, der italienischen Seehandelsstädte im östlichen Mittelmeerraum und im Schwarzen Meer sowie der Einfluss der Kreuzritter, der in der Errichtung des Lateinischen Kaiserreiches in Byzanz 1204 gipfelte. Kriegszüge des Lateinischen Kaiserreiches sind aus den Schriftquellen bekannt und reichten bis nach Bulgarien hinein. ${ }^{124}$ Die weitgehende Fundlücke der Sporen im 11. bis 12. Jahrhundert - mit der Ausnahme Păcuiul lui Soare - wäre im Gegensatz dazu mit einem Fehlen solcher Aktivitäten und Einflüsse zu verbinden, das geringe Vorkommen ab dem 10. Jahrhundert mit dem Vordringen der Ungarn und Pečenegen, wodurch die reiternomadische Reitweise und Ausrüstung für einige Zeit vorherrschend wurde. ${ }^{125}$ Beachtlich ist der gelungene Nachweis von osteuropäischen Bezügen im Fundmaterial Bulgariens des 10. und 11. Jahrhunderts. Als eine mögliche Erklärung kommt hier sowohl Entwicklungen im Zusammenhang mit dem Einfall Svjatoslavs 969 als auch Verbindungen

122 Fiedler 1992, 218-220.

123 Henning 1989, 88, 90, 94, Abb. 3; Curta 1997, 227, Abb. 3. Reitersporen sind lediglich in den Hortfunden des großmährischen Bereichs vereinzelt nachzuweisen. Der Sporn des Hortes von Žabokreký nad Nitrou (Henning 1987, 119, Kat.Nr. 89; ders. 1989) ist zu streichen. Die beiden Horte dieses Fundortes sind 1961 bzw. 1962 entdeckt worden. Der Sporn in der von Henning zitierten Publikation von 1948 kann mit diesen daher nichts zu tun haben. Höchstwahrscheinlich stammt er aus dem Grabfund von 1871 aus Žabokreký. Die Geschlossenheit des Fundes von Čelopeč ist leider unsicher. Er wurde kurz nach 1900 von Bergleuten beim Bau einer Hütte, vermutlich in einer Kulturschicht gefunden (s. Anm. 81). Die Datierung des Fundkomplexes spricht nicht gegen einen geschlossenen Fund.

124 Bak 1997, 1228; Dujčev 1983, 921.

125 Rill/Heitel 1994/95, 416, Anm. 85; Dončeva-Petkova 1998. 
mit der „Warägergarde“ in byzantinischen Diensten in Betracht. ${ }^{126}$ Wie ist jedoch der frühmittelalterliche Fundbestand zu erklären? Auffällig ist für das 9. Jahrhundert, für das politische Kontakte Bulgariens mit dem fränkischen Westen aus den Schriftquellen bekannt sind, das Fehlen der zeitgenössischen Reitersporen, wie sie aus den großmährischen Gräberfeldern vorliegen. Das kann selbstverständlich ein Zufall sein. Die einzigen Ausnahmen bilden hier nur das Paar aus Tărtăria und vermutlich auch das Fragment von Breaza. Deren Anwesenheit kann außer durch einen direkten westlichen Einfluss auch mit den ebenfalls belegbaren Beziehungen des Karpatenbeckens mit Großmähren erklärt werden. ${ }^{127}$ Eine Ableitung dieser Stücke aus der materiellen Kultur der Bulgaren ist - wie aus den hier zusammengestellten Parallelen hinreichend deutlich geworden sein dürfte - völlig unangebracht. ${ }^{128}$ Parallel zu diesem Sporentyp ist mit dem Vorhandensein eigenständiger Traditionen zu rechnen, die noch in der Kaiserzeit wurzeln, wie es bereits zu den Sporen von Kjulevča und Şura Mică ausgeführt wurde. Eine ethnische Interpretation ist nicht möglich, was besonders im Hinblick auf eine historische Interpretation des Massengrabes 80 von Kjulevča sehr zu bedauern ist.

Weiter überrascht das Auftreten von Sporen im Arbeitsgebiet, deren Herstellung noch in das 8. Jahrhundert gesetzt werden muss. Die dünne Streuung karolingischer Funde erinnert an das ebenfalls nur gelegentliche Auftreten von Funden gleicher Zeitstellung im gesamten westslawischen Siedlungsraum. ${ }^{129}$ Doch sind diese Sporen im hier behandelten Arbeitsgebiet nicht heimisch geworden, so dass sie letztlich nicht zu einer eigenständigen Tradition führten, wie - im Gegensatz dazu - für das westslawische Gebiet anhand der Entwicklung der Hakensporen zu beobachten ist. Erklärlich ist dieser Umstand schon allein durch eine größere räumliche Distanz und das Fehlen einer

126 Ehrhardt 1983.

127 Als Beleg mag hier das Ersuchen einer Gesandtschaft König Arnulfs an Bulgarien dienen, den großmährischen Salzhandel zu unterbinden. Diese Stelle ist wegen der dortigen Salzquellen auf Siebenbürgen bezogen worden (Horedt 1986, 103). Dagegen argumentiert M. Eggers (1995, 66-67).

128 So wendet sich bereits R. R. Heitel (Rill/Heitel 1994/95, 427, Anm. 124) zu Recht deutlich gegen die Tendenz einer „Bulgarisierung“ Transsilvaniens, wie sie einige ungarische Forscher annehmen. Zur Frage einer bulgarischen Oberhoheit über Siebenbürgen: Göckenjan 1996, 1841; Angelov/Ovčarov 1986, 59. Heitel irrt allerdings, wenn er wie bereits Şt. Pascu (Pascu/Rusu/Jambor/Edroiu 1968, 177, 200) zwei Fundstücke aus Dăbîca als karolingisch anspricht. Hierbei handelt es sich zum einen um einen Pyramidenstachelsporn des späten 11.-12. Jahrhunderts (Pascu/Rusu/Jambor/Edroiu 1968, Abb. 5,4), zum anderen um ein Fragment, das zu einem Sporn mit langem Stachel des 10.-11. Jahrhunderts, aber genauso gut zu einem spätmittelalterlichen Rädchensporn mit langem Rädchenhalter (Pascu/Rusu/ Jambor/Edroiu 1968, Abb. 5,5) gehören könnte.

129 Brather 1996b, Abb. 4, 17; Wachowski 1983; ders. 1987; ders. 1992. Zum Tassilokelchstilornament siehe die neuere Kartierungen bei E. Wamers (1994, Abb. 21), J. Kleemann 1992a, Abb. 1), M. Schulze-Dörrlamm (1998) und speziell für das mittlere Donaugebiet bei H. Zoll-Adamikowa (1998, Abb. 3) 
direkten Kontaktzone. Daraus ergibt sich die Frage, ob an den betroffenen Fundstellen Stărmen, Odărci, Car Asen und Pernik die Anwesenheit einer Fremdgruppe auch durch andere Funde belegt werden kann. Dies ist zu verneinen. Sowohl für die Trachtelemente als auch die übrigen Teile von Bewaffnung und Reitausrüstung kann ansonsten ein für Südosteuropa zu erwartendes einheitliches Spektrum festgestellt werden. Die Gürtelbeschläge gehören beispielsweise in das Umfeld der ungarischen Kultur. ${ }^{130} \mathrm{Zu}$ beachten sind hierbei jedoch die generellen Schwierigkeiten mit der Chronologie. Die gut belegten Phasen sind jedenfalls deutlich später, da ein Großteil der Schmuckformen und Gürtelbeschläge nicht vor das 10. Jahrhundert gesetzt werden kann. Deutlich wird dies am Beispiel von Odărci durch einen Friedhof am Fuß der Siedlung mit vielen ähnlichen, z.T. identischen Formgruppen aus dem 10. und 11. Jahrhundert, der mutmaßlich zu Recht von L. Dončeva-Petkova mit den Petschenegen verbunden wird. ${ }^{131}$ Es ist dabei allerdings zu beachten, dass hier exakte Datierungen vorliegen, die gerade durch die Interpretation von Münzen gewonnen werden, die ja erst ab der Wiedereroberung durch Byzanz und der damit verbundenen Wiedereinführung einer monetären Geldwirtschaft regelhaft im archäologischen Niederschlag der materiellen Kultur erscheinen können. ${ }^{132}$ Einer der wenigen - sicher früher anzusetzenden - Funde aus der Phase I von Stărmen ist ein Ohrring des 6. bis 7. Jahrhunderts. ${ }^{133}$ Nur ein einziger Fund aus Stărmen kann neben den Reitersporen sicher aus West- bzw. dem westlichen Mit-

$130 \mathrm{Zu}$ den Bewaffnungselementen: Kurnatowska 1973. Zu den Gürtelteilen und den sich ergebenen Datierungsspannen: Danielczyk 1969, 260-264, 268, Abb. 2; dies. 1972, Abb. 4; Milčev 1966, 332-339 (Ohrringe), 348-351 (Gürtelapplikationen); Kurnatowska 1980, 151, Abb. 53; Dymaczewska/Dymaczewski 1980; Dymaczewski 1973; ders. 1979; DončevaPetkova 1981; dies. 1987; Michajlov/Dončeva-Petkova/Toptanov 1975; dies. 1980.

Für den Zeitraum des 8.-9. Jahrhundert kommen in Stărmen lediglich zwei Kreuzanhänger mit Parallelen im späten 9. Jahrhundert, ein weiterer Ohrring und vier Styli in Frage, ohne dass zweifelsfrei für sie eine Datierung ins 10. Jahrhundert ausgeschlossen werden kann (Danielczyk 1972, 194-195, Abb. 6; Kurnatowska 1980, 107, 111, Abb. 26,1360.328.863).

131 Dončeva-Petkova 1998.

132 So erscheinen Münzen ab Johannes Tzimiskes (969-976) regelhaft und oft in größerer Anzahl nach einer Phase, in der Münzen sich nicht nachweisen ließen. Als Beispiele seien hier neben Stărmen (s.u.) genannt: Ivanov 1996; Hensel/Rauhutowa 1977; dies. 1980. Als seltene Ausnahmen sind hier eine Münze aus Stărmen von Konstantin VII und Zoe (913959) sowie Münzen von Leon VI (886-912) aus Odărci anzusehen (Kurnatowska 1980, 254; Dončeva-Petkova 1998, 21; dies. 1987, 81).

133 Kurnatowska 1980, 72, Abb. 3, Taf. LIV,1172; Dymaczewski 1973, 19, Abb. 3. 
teleuropa hergeleitet werden. Es handelt sich um ein Glättglas. ${ }^{134}$ Derartige Funde sind seit der Römischen Kaiserzeit bekannt und im Frühmittelalter überwiegend im westlichen Skandinavien, auf den britischen Inseln, in Nordfrankreich, dem nordwestlichen Mitteleuropa sowie dem westlichen Ostseebereich belegt. Sie datieren überwiegend in die jüngere Wikingerzeit. ${ }^{135}$ Ihre Verbreitung im östlichen Baltikum wird mit der Anwesenheit von Skandinaviern oder deutschen Händlern verbunden. ${ }^{136}$ Eine Herkunft aus Nordwesteuropa wird auch durch die chemische Analyse gestützt, der zufolge es sich um ein Holzascheglas handelt, eine Glasart, deren Entstehung im Westeuropa der Karolingerzeit vermutet wird. ${ }^{137}$

Auch hinsichtlich des Charakters der Fundorte besteht keine Einheitlichkeit. Es handelt sich bei Odărci und Stărmen Phase I um offene Siedlungen, wohingegen Car Asen als Befestigung anzusehen ist. ${ }^{138}$ Zweifelsfrei kann gesagt werden, dass es sich bei den drei genannten Fundorten nicht um überregionale Zentren handelt, bzw. exakter, dass ein Fundniederschlag, wie er für solche zu erwarten wäre, im Fundbild nicht

134 Dekówna 1975, 240-246, 277, Abb. 3. Das Stück stammt aus der II. Phase von Stărmen. Aufgrund anhaftender Mörtelreste wurde eine sekundäre Nutzung als Bauschmuck für eine Kirche vermutet. Welche weiteren Funde gemeint sind, wenn A. Dymaczewski (1973, 30) von „verschiedene(n) Gegenstände(n) fränkischer Herkunft“ spricht, zu denen auch ein Sporn gehören soll, bleibt unklar. Möglicherweise gehört ein zweites Glasfragment ebenfalls zu den westlichen „Fremdlingen“. M. Dekówna (1975, 187, 220-221, 265, Tab. 1, Abb. 1,11) schlägt für ein kleines transluzides oliv-grünliches Fragment die Zuweisung zu einem Rüsselbecher vor. Falls diese Ansprache zutreffen sollte, ist das Fragment eher der jüngeren Gruppe mit glatten, eng anliegenden Rüsseln zuzuordnen. Diese datieren in das 7. Jahrhundert, fehlen aber im Gegensatz zu den älteren Formen völlig in Süddeutschland und an der mittleren Donau (vgl. Böhme 1988, Abb. 28-30 mit Verbreitungskarten; U. Koch 1998, 158; Siegmund 1998, 167. U. Näsman (1984, 68-69) verweist auf das Erscheinen von Altstücken noch in Komplexen des 8. Jahrhunderts. Zu weiterführender Literatur siehe die Arbeiten von U. Koch (1998) und F. Siegmund (1998). Dass diese Einschätzung zu kurz greift, beweist das Grab von Borre, das neben den reichverzierten Beschlägen und Reitzubehör auch Fragmente eines Rüsselbechers enthielt. Dieses Grab muss nach dem gleichnamigen Stil in die zweite Hälfte des 9. bis in den Beginn des 10. Jahrhunderts datiert werden. (Müller-Wille 1986, 154-157, Abb. 1,11; Schulze-Dörrlamm 1988, 435, Abb. 59).

135 Steppuhn 1998, 74-75, Taf. 17-18, Fundliste 3, Karte Abb. 30; ders. 1999, 114.

136 Sie erscheinen dort erstmals in Komplexen des 10.-12. Jahrhunderts: Caune 1994.

137 Alle bisher beprobten Glättgläser gehören zu dieser Gruppe, vgl.: Dekówna 1975, 245246; Steppuhn 1998, 99-102; ders. 1999, 135. Zu den Glasanalysen von Holzaschegläsern: Stephan/Wedepohl/Hartmann 1992, 114-119. Zur Entwicklung der Holzaschegläser: Wedepohl/Winkelmann/Hartmann 1997, 49. Das in Anm. 134 genannte mögliche Rüsselbecherfragment kann über die chemische Zuordnung nicht geographisch eingegrenzt werden. Sodagläser sind sowohl im Mittelmeerraum, wo der Rohstoff Soda ausschließlich vorkommt, als auch in Westeuropa gefertigt worden. Zur Analyse des Stücks siehe Dekówna 1975, zum Sodaglas die genannten Arbeiten und Wedepohl/Pirling/Hartmann 1997.

138 Kurnatowska 1980; S. Michajlov/L Dončeva-Petkova/D. Toptanov (1975) sprechen auf Seite 137 von „etablissement fortifié“. Zu Car Asen: Dimova 1993; Dimitrov 1993. 
erkennbar wird. Lediglich Stărmen kann eine lokal begrenzte zentralörtliche Funktion attestiert werden. Pernik ist wegen seiner Lage südlich des Balkangebirges von den zuvor genannten ohnehin abzusetzen, da hier höchstwahrscheinlich ein intensiverer byzantinischer Einfluss vorliegt. ${ }^{139}$ Beachtenswert ist die Tatsache, dass Stărmen, Odărci und Pernik sich auf Plätzen einer frühbyzantinischen Vorbesiedlung befinden. ${ }^{140} \mathrm{Ob}$ hier ein bewusster Bezug besteht, kann bei der geringen Zahl der Fundpunkte nicht beurteilt werden. Auffallend ist jedenfalls, dass auch im südlichen und östlichen Alpenraum eine ganze Reihe spätantiker Höhensiedlungen namhaft gemacht werden kann, die im Frühmittelalter weiter, bzw. erneut genutzt oder zumindest begangen worden sind. Als erstes Beispiel sei Invillino genannt, berühmt besonders wegen seiner spätantiken Befunde. Die nachfolgende Besiedlung des 7. bis 9. Jahrhunderts wurde auch bei den sorgfältigen und aufwendigen Untersuchungen nur als Nachklang gewertet. Gesichert ist immerhin die kontinuierliche Belegung des Gräberfeldes auf dem Colle Santino mit einer Kirche für das 7. bis 9. Jahrhundert und der Gräber auf dem Colle de Zuca für das 4./5. bis zum 8./9. Jahrhundert. Die zeitgleiche Siedlung zu den letzteren fehlt ab der zweiten Hälfte des 7. Jahrhunderts, d.h. beginnend mit der Aufgabe des castrum auf dem Colle Santino. In Invillino wird - wie auch bei den anderen bekannten Höhensiedlungen - die Befestigung am Ende der Spätantike aufgegeben, was hier aber erst im 7. Jahrhundert der Fall war und nicht wie weiter östlich bereits im 6. Jahrhundert. ${ }^{141}$ Ein sehr ähnliches Bild bietet der Burgberg von Säben in Südtirol. ${ }^{142}$ Die Anlage auf dem Hemmaberg in Kärnten ist anhand der Kirchen und Mosaiken in das fünfte und die erste Hälfte des 6. Jahrhunderts datiert. Das Ende der Anlage wird nur wegen der Keramik, unter der sich ein Fragment des Prager Typs befindet, in das späte 6. Jahrhundert gesetzt. Zu den beiden Sporen des 8. Jahrhunderts von diesem Platz fehlen also zeitgleiche Befunde. ${ }^{143}$ Ganz adäquat ist der Fundbestand vom Kåpile bei Jadersdorf und vom Ullrichsberg in Kärnten. ${ }^{144}$ Zeitlich ähnlich ist der Sporn von Castelfeder, Gde. Montagna im Etschtal

139 Zu Pernik vgl. Anm. 11. An der Ungewissheit des Habitus der byzantinischen Alltagskultur, wie sie S. Vaklinov $(1973,207)$ feststellt, hat sich leider nichts Wesentliches geändert.

140 Im Fall von Pernik ist eine Kontinuität wahrscheinlich. In Stărmen wird diese ansonsten kaum nachgewiesene Phase durch Münzen von Justinian I. (527-565) und Konstantin II. (624-668) reflektiert (Hensel 1980, 295 (Resümee). Nach A. Dymaczewski $(1973,18)$ ist in Odărci eine kleine Befestigung ergraben worden, die u.a. eine Schnalle vom Typ Sucidava und eine Münze des Phokas (602-610) erbracht hat (Dončeva-Petkova 1987, 70, 74; Dymaczewska/ Dymaczewski 1980, 155-156, Abb. 5; Michajlov/Dončeva-Petkova/Toptanov 1975, 133). Geht man nach der Wiederbenutzung einer frühbyzantinischen Befestigung, so muss auch Iatrus-Krivina diesen Plätzen hinzugesellt werden (vgl. Herrmann 1973; Wendel 1986, 183 188, 205-206).

141 Bierbrauer 1987; ders. 1988.

142 Bierbrauer/Nothdurfter 1988; Gleirscher 1986; Kromer 1980.

143 Szameit 1994b, 88, Taf. 4,3-4. Zur Anlage auf dem Hemmaberg: Glaser 1991, 80, 107-108; ders. 1997.

144 Felgenhauer-Schmiedt 1993, 42, Taf. 44,1.2.6; A. Neumann 1955, 182, Taf. 17 R1. 


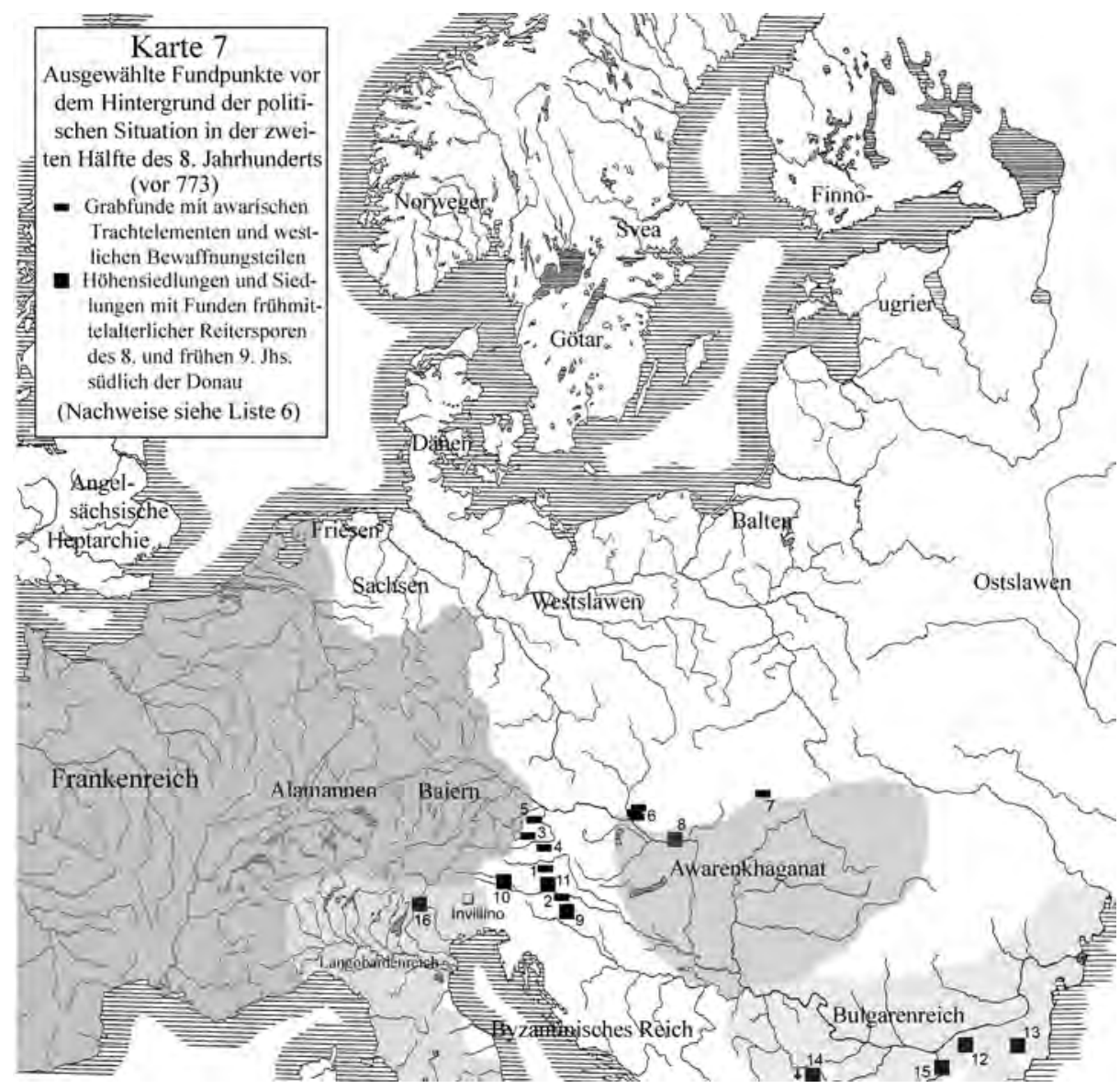

Karte 7

anzusprechen. ${ }^{145}$ Gleiches gilt für den Lesefund aus der Humusschicht der später erbauten Vorburg der bereits genannten Befestigung Ras. ${ }^{146}$

S. Ciglenečki hat die Enddatierungen der spätantiken Höhensiedlungen im östlichen Alpenraum zusammengestellt. ${ }^{147}$ Eine Kontinuität der Befestigungen oder auch nur der Besiedlung ist nicht festzustellen, aber eine „Begehung“ doch mancherorts an vereinzelten Funden ablesbar. Die Durchsicht der Fundmaterialien steht zwar zum großen Teil noch aus, es fehlen jedoch deutlich erkennbare Befunde für diese Zeit. Doch bezeugen zumindest die Nekropolen die durchgehende Besiedlung der Region. Wenn

145 Dal Ri/Rizzi 1995, 103, Abb. 18,2.

146 Popović/Ivanišević 1988, 273, 367, Abb. 238,13.

147 Ciglenečki 1987, 146-148. 
eine Besiedlung nach dem 6. Jahrhundert zu fassen ist, so handelt es sich überwiegend um Anlagen in Rand- oder Nachbargebieten Italiens: Friaul, Slowenien, und besonders Istrien. Der südliche Alpenraum fällt hier besonders auf - möglicherweise bedingt durch den Forschungsstand. ${ }^{148}$

Aus dem Genannten kann leider nicht auf den genauen Weg des westlichen Einflusses geschlossen werden, der durch die vorgestellten Reitersporen an der unteren Donau erkennbar wird. Kompliziert wird diese Situation zusätzlich dadurch, dass in der Zeit, in die diese Sporen typologisch zu setzen sind, der direkte Weg entlang der Donau durch das Awarenkhaganat versperrt wird (siehe Karte 7). Auch die Träger dieses Einflusses entziehen sich einer Analyse. Im südalpinen Raum ist auf den genannten Plätzen anhand der Grabformen, der Grabsitte, Trachtsitte und einzelner Schmuckformen die Anwesenheit einer romanischen Bevölkerung auch über das Ende der Spätantike hinaus wahrscheinlich gemacht worden. ${ }^{149}$ Weiter östlich wurde dagegen eine Gruppe von Gräbern herausgearbeitet, die durch das Zusammentreffen von awarischen Trachtelementen und westlicher Bewaffnung und/oder Reitausrüstung charakterisiert ist (vgl. Karte 7). Diese Gruppe aus der Mitte des 8. Jahrhunderts ist wiederholt mit der Entwicklung einer einheimischen Oberschicht unter Beeinflussung aus beiden genannten Richtungen verbunden worden. ${ }^{150}$ Durch die Nietsporen von Grabelsdorf und Baardorf ist auch eine typologische Parallelität zu den behandelten Reitersporen gegeben, wenn

148 Bierbrauer 1987, ders. 1988; Dal Ri/Rizzi 1995, Abb. 18; Castelfeder (Sporn 8./9. Jahrhundert, Scheibenfibel 10./11. Jahrhundert); Popović 1999, 273, 367, Abb. 238,13. Zur Problematik frühmittelalterlicher Höhensiedlungen äußert sich neuerdings Martin P. Schindler (2001, 72-77). Danach lassen sich in Churrätien eine Reihe von Höhensiedlungen des 7.-8.Jahrhunderts benennen, die mit einfachen Steinmauern befestigt und mutmaßlich mit der einheimischen romanischen Oberschicht zu verbinden sind. Letzteres kann für Sagogn sogar mit einer Schriftquelle belegt werden. Die genaue Funktion der Anlage wird daraus jedoch nicht deutlich. Auch in Churrätien fällt der topographische Bezug zu überregionalen Verkehrswegen auf. Ansonsten erinnern die Befunde an gewöhnliche offene Siedlungen. Im Fundmaterial fallen sie durch Goldmünzen, Bestandteile der Reitausrüstung und anspruchsvoll verzierte Trachtgegenstände auf. Wie bei den diskutierten Siedlungen sind daraus eine erhebliche Konzentration von Reichtum und geographisch weiträumige Beziehungen zu erschließen. Zu dem umrissenen Fundtyp ist auch der Runde Berg bei Urach zu zählen, auf dem nach einer spätantiken Besiedlung ebenfalls eine befestigte Siedlung des 7.-8. Jahrhunderts mit ähnlich auffallendem Fundmaterial bestand (Übersicht in: U. Koch, 1991, 114-116; zum Fundmaterial: U. Koch 1984, 193-194). Ähnlich zu datierendes Fundmaterial ist auch von anderen süddeutschen Höhensiedlungen bekannt (z.B. von der Gelben Bürg bei Dittenheim: Dannheimer 1962, 96, 174 Taf. 21,14).

149 Bierbrauer 1987, ders. 1988, Bd. I,141-173, 302-303, 332-340, Abb. 62, Bd. II,168-169.

150 Szameit 1993, 226-230, ders. 1994a, ders. 1994b; Gleirscher 1996, 23-29, Abb. 10. Auch im nordwestslawischen Bereich wird das Erscheinen von qualitätvollen Schwertern und Reitersporen mit der Rezeption westlicher Adelskultur durch eine einheimische gesellschaftliche Elite verbunden (Brather 1996b, 57, 59). 
auch nicht im Detail. ${ }^{151} \mathrm{Ob}$ die Funde an der mittleren Donau mit der Gruppe frühmittelalterlicher Höhensiedlungen oder der Rezeption westlicher Reittechnik durch eine slawische, bulgarische oder eine andere Oberschicht zu verknüpfen sind, kann abschließend nicht entschieden werden. Es ist vor Ort eine reine romanische, slawische, bulgarische oder auch eine polyethnische Bevölkerung denkbar. ${ }^{152}$ Als Quelle für den erkannten westlichen Einfluss kommt sowohl das fränkische, bairische als auch das langobardische Siedlungsgebiet in Frage. Inwieweit Reitersporen durch die romanische Bevölkerung West- und Südeuropas oder durch die Bevölkerung des byzantinischen Reiches genutzt wurden, entzieht sich wegen des ungenügenden Forschungsstandes einer Beurteilung. Hinweise auf Aktivitäten irgendeiner dieser Gruppen im besprochenen Raum im 8. Jahrhundert fehlen in den Schriftquellen. ${ }^{153}$ Das kann an der allgemein spärlichen Überlieferungslage oder auch an späteren Überarbeitungen liegen. Gerade eigenständige baiuwarische oder langobardische Aktivitäten, die keinen Bezug zur fränkischen Reichspolitik besaßen, könnten durchaus aus den Quellen verschwunden sein. Als Beispiel für eine noch erkennbare Umformung der Überlieferung sei hier auf die Neubearbeitung der Vita des Heiligen Magnus von Füssen verwiesen. ${ }^{154}$ In dieser wurden die antifränkischen Tendenzen des probaierischen Bischofs Wikterp von Augsburg - mit Sitz in Epfach - und die wohl von ihm initiierte Gründung der Zelle von Füssen durch Magnus aus dem Kloster St. Gallen, das von dem ebenfalls antifränkisch eingestellten Abt Otmar geleitet wurde, nachträglich geglättet und korrigiert. Die Motivation hierzu lag wohl im Wunsch begründet, die eigene historische Legitimation mit der zur Abfassungszeit aktuellen politischen Lage - in der sich die fränkisch-karolingische

151 Szameit 1993, 220-221, 223, Abb. 7,13, Taf. 1,22, Taf. 2,C6.

152 Falls das Glättglas aus der zweiten Phase von Stărmen mit derselben Einflusswelle an die unteren Donau gelangt sein sollte, gewänne die Anwesenheit einer germanischen Personengruppe an Wahrscheinlichkeit, da dieses Objekt in den überwiegend weiblichen Tätigkeitsbereich zu stellen ist (vgl. Steppuhn 1999, 116, 126). Zweifelsfrei ist es nicht als Prestigeobjekt anzusehen, für das man eine Weitergabe über große Entfernungen hinweg wahrscheinlich machen könnte. Die Siedlungsbefunde bestehen ausschließlich aus Gruben und Grubenhäusern (Dymaczewski 1973, 19-22). Hinweise auf einen signifikanten Wechsel der Bauweise, wie er in den Ringwällen der Niederlausitz beobachtet und mit einem politischen und ethnischen Wechsel verbunden wurde (Henning 1991, 130-132), sind nicht zu erkennen.

153 Es muss hier nochmals darauf hingewiesen werden, dass eine Datierung der besprochenen Stücke in das 8. Jahrhundert allein auf typologischem Weg erzielt wurde. Eine Niederlegung der Sporen, soweit durch den Befund bekannt, ist deutlich später anzusetzen. Wegen der geringen Zahl der überlieferten Stücke, kann nicht geklärt werden, inwieweit wir von regional rückschrittlichen und von Räumen, die von der Hauptentwicklung abgekoppelt waren, auszugehen haben, in denen typologisch ältere Entwicklungen über eine längere Zeit erhalten blieben. Ein intensiver Gebrauch ein und desselben Reitersporns über mehrere Generationen hinweg scheint aufgrund der fälligen Materialbeanspruchung nur schwer vorstellbar.

154 Walz 1989. 
Seite durchgesetzt hatte - in Einklang zu bringen. Somit wurden die Frankenkönige noch nachträglich zu Förderern oder Gründern diverser kirchlicher Einrichtungen erklärt, womit sich die Hoffnung verband, diese neugeschaffene Tradition möge sich durchsetzen und auszahlen. ${ }^{155}$ Da sich auf der Balkanhalbinsel ähnliche Traditionen, die auf westliche Einflüsse hinweisen könnten, nicht erhalten haben, ist ein völliges Verschwinden älterer Vorstöße aus den Schriftquellen durchaus denkbar.

\section{Listen}

\section{Liste 1}

Sporen des Tassilokelchstil-Horizontes

a) mit tierkopfartig gestalteten Bügelenden

1 Alt Käbelich, D: V. Schmidt 1984, 338-340, 343-344, Abb. 5b.

2 Büraberg, Gde. Ungedanken, D: Wand 1974, 152, Taf. 36,4.

3 Frohnhausen, D: Westphal 1999, Abb. V.68.

4 Immenstedt, D: Lindenschmit 1880, Taf. IV,23.

5 Liesborn, Gde. Wadersloh, D: Isenberg/Peine/Wemhoff 1994, 32-35, Abb. o. Nr. S. 31.

6 Schortens, D: Rötting 1999, 242, 244, 246, Abb. 13a.

7 Zellingen, D: unpubl., freundl. Hinweis S. Gerlach.

8 Auhof bei Perg, A: Tovornik 1986, 418-419, Taf. VI,59,2; Röntgenbild: freundl. Hinweis E. Szameit.

9 Heinbuch, A: unpubl., freundl. Hinweis E. Szameit.

10 Hemmaberg, Gde. Globasnitz, A: Szameit 1994b, 88, Taf. 4,4.

11 Stărmen, BG: Kurnatowska 1980, 87, 152, Abb. 53,425.

12 Gojače-Bořšt, SLO: Giesler 1974, 525, 537, 541 Nr. 22 Abb. 4,22; Svoljšak/Knific 1976, 54-55, 89, Taf. 2,1.

13 Strasbourg, F: Forrer 1915, 657, Abb. 214 J.

14 Icklingham, GB: de Shortt 1964, 60, Abb. 1.

15 Kingston upon Thames, GB: Boon 1959, 195, Abb. 1.

16 Pakenham, GB: Hinton 1974, 55, Abb. o. Nr.

b) mit gebuckelten Ösen und/oder Tassilokelchstilornament

17 Barleben, D: Schulz 1940, Abb. 2.

18 Bendorf, D: Gabriel 1981, 246-248, 252-253, Abb. 2.

19 Dunum, D: Schmid 1970, 43, 57, 60, Abb. 7.

20 Haithabu, D: Vierck 1986, 387-388, Abb. 183.

21 Jülich, D: Haseloff 1951, 36-37, Abb. 22, Taf. 14.

22 Mainz, D: Haseloff 1951, 36-37, Abb. 20, Taf. 12.

23 Osnabrück, D: Schlüter/Zehm 1991, Abb. 31,4.

24 Runkel-Ennerich, D: Goßler/Posluschny 1998, Abb. 3.

25 Sievern, Gde. Langen, D: Schmid 1969, 27-30, Abb. 2,1.

26 Sundremda, D: Vinski 1977-78, 194, Taf. VI,2.

155 Walz 1989, 16, 20, 65, 99-100. 
27 Welbsleben, D: Haseloff 1951, 36-37, Abb. 21, Taf. 13,1-2.

28 Wiesbaden, D: Zschille/Forrer 1899, 12, Taf. XXII,5.

29 Kamieńsk, PL: Wachowski 1987, 524, Abb. 3,3.

30 Smolenice, SK: unpubliziert.

31 Gornji Vrbljani, BiH: Vinski 1977-78, 190-191, 194, 197-198, Taf. VI,1.

32 Britsum, NL: Boeles 1951, 467, 550, Abb. 85.

33 Rhee/Zeijen, Gde. Vries, NL: van Giffen 1940, 199-200, Abb. 22,29e.

34 Termunten, NL: Pleyte 1877, 113-115, Taf. XLIII,2.3. Es handelt sich um 2 Exemplare.

Typologische Vorläuferform

35 Kirchheim/Ries, D: Neuffer-Müller 1983, 36-38, 132, Taf. 12 D 1-2.

36 Runder Berg, Gde. Bad Urach, D: U. Koch 1984, 85, Taf. 9,1.

c) andere frühe Nietplattensporen dieses Horizontes

37 Bendorf, D: Gabriel 1981, 248-249, 252-253, 256, Abb. 4.

38 Fürstenberg, Gde. Wünnenberg, D: Melzer 1991, 19-20, 64, 116, Abb. $28,7$.

Typ Stărmen

39 Mužla-Čenkov, SK: Hanuliak/Kuzma/Šalkovský 1993, 32, 88, 179, 181, Taf. 149,14.

40 Slovenj Gradec, SLO: P. Korošec 1979, 1,242, 2,66, Taf. 85,1-2.

41 Stărmen, BG: Kurnatowska 1980, 87, 169-170, 206, Taf. XXVII,404.

42 Weismain-West, D: Schwarz 1984, 93, 108-113, 115-116, 123, 126, Abb. 59,3.4, 66,4. Es liegen 3 Exemplare aus den Gräbern 3 und 20 vor.

\section{Liste 2}

a) Sporen mit nach außen umgebogenen Bügelenden und kurzem Stachel

1 Büraberg, Gde. Ungedanken, D: Wand 1974, 152, Taf. 36,2.

2 Freilassing-Salzburghofen, D: Dannheimer 1974, 645.

3 Hailfingen, D: Veeck 1931, 278, Taf. Q 1.

4 Karlburg, D: Ettel 1991, Abb. 119,6.

5 Lengerich-Hohne, D: Stiegemann/Wemhoff 1999, 239, IV.78 Hakensporn.

6 Mamming, D: unpubliziert, freundlicher Hinweis U. von Freeden.

7 Mindelheim, D: Werner 1955, 8, 27, Taf. 27 A 7.

8 Moos-Burgstall, D: von Freeden 1987, 503, 522-523, 547, 555, 560-561, 608, Taf. 46,11.12.

9 Münnerstadt-Burghausen, D: Gimperlein 1992, 158, Abb. 99,20.

10 Schaafheim, D: Möller 1987, 126, Taf. 98,4.

11 Wielenbach, D: Dannheimer 1974, 631, 644-645, Abb. 3,18.

12 Elgg-Ettenbühl, CH: Moosbrugger-Leu 1971, 114-115, Taf. 21,8.

13 Schleitheim, CH: Wanner 1867, 15, Taf. VIII,11; Guyan 1965, 12, Taf. VIII,58d. Es handelt sich um 2 Exemplare

14 Będzin, PL: Rogaczewska 1997, 135, 137, Abb. 3p.

15 Kościeliska, PL: Lodowski 1980, 36, Abb. 4.

16 Mogiła, Gde. Kraków-Nowa Huta, PL: Poleski 1992, Abb. 1,7-9. Es liegen von diesem Fundort 3 Exemplare vor.

17 Niedanowo, PL: Piaskowski 1982, 203, 222, Abb. 1 i.

18 Strzyżów, PL: Gurba 1965, 48-49, Abb. 1. 
19 Tarnów-Zawada, PL: Poleski 1992, Abb. 1,6.

20 Tyniec Mały, PL: Petersen 1939, 66, 188, Abb. 94,2.

21 Wołajowice, PL: Uzarowiczowa 1964, 412, 416, Abb. 10a.

22 Mikulčice, CZ: Klanica 1986, 95-106, Abb.28,7-9. Es liegen von diesem Fundplatz 3 Exemplare vor.

23 Toušeň, CZ: Profantová 1994, 82, Abb. 5,3.

24 Dodeşti, RO: Teodor 1980, 65, Abb. 31,3.

25 Medişorul Mare, RO: Székely 1988, 171, 196, Abb. 20,1.

26 Kjulevča, BG: Văžarova 1976, 128, 133, Abb.82,2.3.

27 Mrsunjski Lug, HR: Vinski/Vinski-Gasparini 1950, 22-23, Abb. o. Nr.

28 Wittenheim, F: Schweitzer 1982, 184, Taf. 110,8.

29 Hod Hill, Gde. Stourpaine, GB: de Shortt 1959, 71, Abb. 25,5.

30 Middle Harling, GB: Margeson 1995, 78, Abb. 76,9.

31 Ganthem, S: Statens Histor. Mus. och k. Myntkabinettet. Samlingarnas tillväxt under år 1894. Kgl. Vitterhets Hist. Akad. Månadsbl. 1894 (1897), 39-78 bes. 42 Abb. 16.

32 Norrbys, S: Olsson 1935, 57, Taf. 31,160 A-D.

33 Vilnius, LT: Żak 1958, 95, Nr. 21 Abb. 2g.

34 Kente, LV: Latvijas PSR archeologija (Riga 1974), 371, Abb. 37,6.

35 Koknese, LV: Latvijas PSR archeologija (Riga 1974), 371, Abb. 60,22.

36 Cerkovišče, RUS: Kirpičnikov 1973, 56, 103, Nr. 11, Abb. 34,2.

37 Bogata, BY: Żak 1958, 95, Nr. 17, Abb. 2c

38 Gorodišče, BY: Mitrofanov 1978, 108-109, Abb. 58,27-29.

39 Labenščina, BY: Mitrofanov 1978, 108-109, Abb. 25,1.

40 Ščakovo, BY: Pobol'1967, 226, 239, Abb. 23,9.

41 Selišče, BY: Mitrofanov 1978, 108-109, Abb. 52,19, 54,6. Es liegen von diesem Fundplatz 2 Exemplare vor.

42 Gorodok, UKR: Musianowicz 1979, 179-180, 205, Taf. IV,6.

43 Peresopnica, UKR: Kirpičnikov 1973, 57, 103, Nr. 14, Abb. 34,4.

44 Revno, UKR: Michailina/Timošuk 1983, 210, Abb. 4,14.

b) Sporen mit nach außen umgebogenen Bügelenden und langem Stachel

45 Benzingerode, D: Corpus 33/5, Abb. 33/5,1

46 Gnoien, D: Schoknecht 1984, 17-28, Abb. 6c.

47 Kr. Grimma, D: Corpus 153/82, Abb. 153/82,1

48 Heimburg, D: Corpus 33/21, Abb. 33/21,1

49 Köllmichen, Gde. Prösitz, D: Coblenz 1989, Abb. 3,1.

50 Rötha, D: Brachmann 1978, 85-86, Abb. 40q.

51 Saalburg, Gde. Bad Homburg, D: unpubliziert, freundlicher Hinweis N. Goßler.

52 Sielow, D: Corpus 96/21, Abb. 96/21,1.

53 Sulzfelder Forst, D: Böhaker 1993, 179, Abb. 99,2.

54 Wiprechtsburg, Gde. Groitzsch, D: Vogt 1987, 57, Abb. 23,2.

55 Enehagen, S: Fornvännen 1908, 201-203, Abb. 19.

56 Liljenäs, S: Olsson 1935, 63, Taf. 46,195; A-F: Palmgren 1878-80, 15-16, Abb. 9. Der Fund erscheint bei Żak (1958, 94, 99, Nr. 15 Abb. 2a) unter dem Fundort Broby. 
Liste 3

Nietplattensporen mit 4 oder mehr Nieten in zwei Reihen parallel der Bügelebene (mit aufgenommen wurden Sporen derselben Form, auch wenn die Zahl der Nieten auf der in jedem Fall großen Nietplatte nicht mehr sicher zu bestimmen ist)

1 Arnsburg, D: Austermann 1994/95, 122-123, Abb. 19,1.

2 Baderitz, D: Coblenz 1989, 7, Abb. 6,1.

3 Bendorf, D: Gabriel 1981, 251-252, 257, Abb. 6.

4 Bietigheim, D: R. Koch 1982, 68, Abb. 5.

5 Dahmen, D: unpubliziert, freundlicher Hinweis U. Schoknecht

6 Epolding/Mühlthal, D: Dannheimer 1968, 25, 145, Taf. 16,10.

7 Federsen Wierde, D: unpubliziert, freundlicher Hinweis J. Schuster.

8 Friedland, D: Stange 1996, 417, 420, Abb. 4e.

9 Friesen, D: Hoffmann 1993-94, 36-37, Abb. 31,4.

10 Henfstädt, D: Rempel 1940, Abb. 3.

11 Hohenfels-Matzhausen, D: Stroh 1954, 8, Taf. 9 J3.

12 Kallmünz-Krachenhausen, D: Stroh 1954, 9, Taf. 13 K7.8.

13 Ketzendorf, Gde. Buxtehude, D: Thieme 1978-80, 80, Abb. 4,3-6. 11.

14 Klein Schneen, Gde. Friedland, D: Raddatz 1967, 24, Abb. 8.

15 König Heinrichs Vogelherd, Gde. Pöhlde, D: Claus 1992, 72-73, 77, 103, Taf. 21,4-6.

16 Kretzschau-Groitzschen, D: Brachmann 1978, 68-71 Abb. 31 a.

17 Liebenau, D: Genrich 1972, 31-32, Taf. 4,3.

18 Mehrstetten, D: G. Neumann 1932, 133.

19 Meiningen, D: Rempel 1940, Abb. 4.

20 Oldenburg, D: Gabriel 1984, 119-122, 145, Nr. 1.2, Abb. 36,1.2.

21 Oldendorf/Luhe, D: Laux 1978/80, 93, 97, 108-109, Abb. 1,1.2, 3,1.2. Es liegen 2 Paare vor.

22 Pullach, D: R. Koch 1982, 70-71, Abb. 7.

23 Rensing, D: Kersten 1939, 157, 193, Abb. 189a.

24 Scharstorf, Gde. Schellhorn, D: Meier 1990, 104-105, 132, Nr. 1, Taf. 23,1.

25 Schnaitheim, Gde. Heidenheim, D: Gross 1991, 29.

26 Schweinthal, Gde. Egloffstein, D: Böhnlein 1991, 165, Abb. 98,2.

27 Süßenborn, D: Timpel 1967, Taf. 47.

28 Taubach, D: Rempel 1966, 38, 133, Nr. 157, Taf. 58 A1.

29 Tutzing-Traubing, D: Dinklage 1941, 496, Taf. V,4.

30 Weismain-West, D: Schwarz 1984, 97, 108-109, 112-116, 126, Abb. 68,11.12, Abb. 69,12.13, Abb. 70,8.11. Es liegen 3 Paare vor.

31 Weißenburg, D: Junkelmann 1992, 98-99, Abb. 2.

32 Szczaworyż, PL: Poleski 1992, 322, Abb. 5,3.

33 Břeclav-Pohansko, CZ: Kalousek 1971, 75-76, 111-114, 126, Abb. 106,2-3, Abb. 174,11-12, Abb. 205,12-13; Vignatiová 1980, 164-166, 194, 196-197, Abb. 2,1-2. Es liegen insgesamt 4 Paare vor.

34 Kolin, CZ: Kavánová 1976, 82-83, 101, Taf. IX,2.

35 Mikulčice, CZ: Kavánová 1976, 70-71, 77, 98, 104, Taf. III,5, VIII,3; Klanica 1985, 509, 524, 535-536, Abb. 17,8-9. Es liegen 2 Paare sowie mehrere weitere unpublizierte Sporen aus Gräbern vor.

36 Nymburk-Zálabi, CZ: Profantová 1994, 75-76, 84, Abb. 7,6.

37 Prostějov, CZ: Dostál 1966, 154, Nr. 96, Taf. LXXI,2-3.

38 Stará Kouřim, CZ: Šolle 1966, 260, 269, 300-303, 311, 324-325, Abb. 11a hr., Abb. 55,6, Abb. 11b hr., Abb. 1230,9-10, Taf. XXVII,1. Es liegen 2 Paare vor. 
39 Staré Město, CZ: Hrubý 1955, 184, 186-187, 352, 411-412, 452-453, 457, 473, 506-507, 524525, Abb. 32,1-5, Taf. 62,8, Taf. 63, Taf. 65,15-16, Taf. 81,1-2. Insgesamt liegen 7 Paare vor.

40 Vlkov, CZ: Schneider 1898, (201)-(214), Abb. 15.

41 Ducové, SK: Ruttkay 1978, 68, Abb. 30.

42 Nitra, SK: unpubliziert, freundlicher Hinweis G. Fusek.

43 Pobedim, SK: Vendtová 1969, 164, 227, Abb. 38,20, Abb. 44,7. Es handelt sich um 2 Exemplare.

44 Skalica, SK: Budinský-Krička 1959, 95-96, 114, 133, Taf.XXIII,4.10.

45 Gars-Thunau, A: unpubliziert, Ausstellung im Institut für Ur- und Frühgeschichte Wien.

46 Pottschach, A: Caspart/Geyer 1931, 168, 194, Taf. II,4.5.

47 Ziegelofen Pach, A: Frisinger 1977, 22-24, Nr. 50, Taf. 22,4325.

48 Zisterdorf, A: Pittioni 1943, 28-29, 39, Taf. XV,3-4.13-14.

49 Brezje bei Zreče, SLO: Pahič 1969, 233-234, 255, 295-296, Taf. 9,4.

50 Ptuj, SLO: J. Korošec 1950, 134-135, 158, 161, 342, 354, Abb. 26, Taf. 30; 36. Insgesamt liegen 2 Paare vor.

51 Biljane Donje, HR: Jelovina 1986, 62, Taf. XII,155-156.

52 Biskupija-Crkvina, HR: Jelovina 1986, 43, 48, 50-52, 54-56, 58, Taf. I,9-10, Taf. III,2930.43-44, Taf. IV,50-51, Taf. VI,65-66.72-73, Taf. VII,82-83, Taf. IX,109.112.114-115. Insgesamt handelt es sich um 8 Paare und 2 einzelne Exemplare.

53 Koljane Gornje, HR: Jelovina 1986, 65-67 Taf. XV,186-187, Taf. XVI,190-191, Taf. XVII,196-197. Insgesamt sind es 3 Paare.

54 Nin, HR: Belošević 1980, 99-100, 160-162, Taf. XXVI,3-4, Taf. XXVII,1-2, Taf. XXIX,18.22. Es sind von diesem Fundplatz 3 Paare bekannt.

55 Ostrovica, HR: Jelovina 1986, 68, Taf. XIX,209.

56 Podgrade, HR: Jelovina 1986, 68, Taf. XIX,211.

57 Mostar, BiH: Vinski 1983, 489, 500-501, Abb. 17,3.

58 Sultanovica, BiH: Čremošnik 1951, Taf. I,1.2.

59 Tărtăria, RO: Horedt 1954, 496-497, Abb. 3.

60 Crémine, CH: Quiquerez 1844, 99, Taf. II,12.

61 Eix, F: Liénard 1885, 53, Taf. XXXVIII,5.

62 Domburg (Walcheren), NL: Capelle 1976, 40, Nr. 503, Taf. 38,503.

63 Wijk by Duurstede, NL: van Es/Verwers 1980, 170-172, Abb. 123,1-2.

Liste 4

Reitersporen mit gerader oder leicht geschwungener Bügelebene und langem Stachel mit kleiner abgesetzter Spitze

1 Bösleben-Wüllersleben, D: Timpel 1982, 77, Taf. XXVIII,7.

2 Criesbach, D: Kost 1951/52, 91-92, Abb. 15,5.

3 Grasburg, Gde. Hohenroda-Mansbach, D: Sippel 1977, 65-66, Abb. o. Nr. S. 66.

4 Hasenburg, Gde. Haynrode, D: Timpel 1990, 1718, Nr. 02/24, Taf. VIII,6.

5 Wolmirstedt, D: Rempel 1953, 230-231, Nr. 15, Abb. 19,15.

6 Babina, Gde. Bilina, CZ: Schranil 1928, 308, Taf. LXX,12.

7 Păcuiul lui Soare, RO: Baraschi 1977, 145, Taf. XXII,3.

8 Nyirád, H: Régészeti 3, 43/12, Abb. 50,22.

9 Montfort-sur Risle, F: Halbout/Pilet/Vaudour 1987, 232, Nr. 957, Abb. 957. 
Liste 5

a) Sporen mit gerader Bügelebene und rechteckiger Doppelösenplatte

(Nicht dargestellt werden Sporen mit Schnallenenden und Doppelösenplatten, deren Proportionen denen von diesen Schnallenenden sehr ähnelt. Diese Form ist im Nordseeraum mit deutlichem [Überlieferungs-] Schwerpunkt in England verbreitet. Es kann bei einzelnen Stücken mit sehr großen Ösen aus Mittel- und Südeuropa nicht ausgeschlossen werden, dass sie zu dieser Gruppe gehören. Jedoch ist in keinem Fall die Schnallenkonstruktion erhalten, so dass diese Möglichkeit nicht erhärtet werden kann.)

1 Neu-Nieköhr - Walkendorf, D: Schuldt 1967, 32, Nr.I,1898, Taf.15j.

2 Basel, CH: Berger 1963, 62, Taf. 28,7.

3 Strzegowa, PL: Muzolf 1997, 158, 163, Abb. 4,1.

4 Mogorjelo, BiH: Zekan 1994, 63, Taf. V,3.

5 Ras, YU: Popović 1999, 258, 354, Abb. 221,1-3.

6 Torshov, N: Rygh 1885, 31, 75, Abb. 585.

7 Ukmergè, LT: Urbanavičius/Urbanavičiené 1988, 25, Abb. 32,10.

8 Atvases, LV: Latvijas PSR archeologija (Riga 1974), 372, Taf. 55,21.

9 Koknese, LV: Latvijas PSR archeologija (Riga 1974), 372, Taf. 60,20.

10 Martinsalas ciems, LV: Latvijas PSR archeologija (Riga 1974), 371-372, Abb. 51,13.

11 Novgorod, RUS: Arcichovskij 1958, Nr.2, 229, Abb. 1,5.6; Medvedev 1959, 186, 191, Abb. 23,15.

12 Pskov, RUS: Grozdilov 1962, 61, Abb. 50,5.

13 Rjurikovo Gorodišče, RUS: Nosov 1990, 120-121, Abb. 43,1.

14 Volkovysk, BY: Zverugo 1967, 335, Abb. 10,9.

15 Gorodišče, UKR: Kirpičnikov 1973, 63, 65, Taf. XVIII,1.6.

16 Podgorcy, UKR: Kučera 1962, 34, Abb. 13,4-5.

b) und runder oder ovaler Doppelösenplatte

17 Sechszehneichen, Gde. Bantikow, D: Plate/Plate 1983, 202, 208, Abb. 26,149,2.

18 Spandau, Land Berlin, D: unpubliziert, freundliche Hinweis A. von Müller.

19 Wietrzno, PL: von Kleist 1955, 19, 36, Taf. 30,4.

20 Braničevo-Svetinja, YU: Popović/Ivanišević 1988, 162, Abb. 33,1.

21 Irzekapinis, Gde. Klincovka, RUS: Kulakov 1990, 74, 76, Taf. XXXIX; LIV.

22 Ukmergè, LT: Urbanavičius/Urbanavičiené 1988, 25, Abb. 29,9.

23 Lejasdopeles, LV: Latvijas PSR archeologija (Riga 1974), 372, Abb. 64,7.

24 Novgorod, RUS: Medvedev 1959, 191 Abb. 23,14.

25 Gorodišče, UKR: Kirpičnikov 1973, 65, Taf. XVIII,5.

26 Knjascha Gora, UKR: Kirpičnikov 1973, 65, Taf. XVIII,4.

27 Kolodjažin, UKR: Jura 1962, 108, Abb. 36,5.

c) geschwungener Bügel und runde Doppelösenplatte

28 Klatzow, D: unpubliziert, freundlicher Hinweis U. Schoknecht.

29 Neppermin, D: Corpus 44/99, Abb. 32,2.

30 Opole-Ostrówek, PL: Wachowski 1984, 52, 86, 97, 110, Abb. 34c.

31 Chrudim, CZ: Frolík 1983, 524-525, Abb. 4,2.

32 Nižná Šebastová, SK: Budinský-Krička 1970, 176-177, Taf. II,1.

33 Svinica, SK: Čaplovič 1983, 387, Taf. IV,1.

34 Bîtca Doamnei, RO: Scorpan 1965, 449, Abb. 5,13.15. 
35 Pernik, BG: Čangova 1992, 184-185, Abb. 172,2-3.

36 Trebinje, BiH: Anđelič 1962, 173-175, Abb. 1.

37 Braničevo-Rudine, YU: Popović/Ivanišević 1988, Abb. 13,1.

38 Husaby, S: Olsson 1935, 68, Taf. 54,221 A-C.

39 Lingsmölla, S: Fornvännen 1909, 299, Abb. 85.

40 Irzekapinis, Gde. Klincovka, RUS: Kulakov 1990, 75 Taf. L.

41 Asote, LV: Šnore 1962, 582, Abb. 5,4.

42 Tervete, LV: Latvijas PSR archeologija 1974, 372, Abb. 79,1.

43 Pskov, RUS: Grozdilov 1962, 61, Abb. 50,6.

44 Cerkovišče, Gde. Selifonovo, RUS: Sedov 1960, 56, Abb. 25,8.

45 Braslav, BY: Alekseev 1966, 174-175, Abb. 43,17.

46 Volkovysk, BY: Zverugo 1967, 337, Abb. 10,5.

47 Gorodišče, UKR: Kirpičnikov 1973, 66, Taf. XX,1.

48 Kolodjažin, UKR: Jura 1962, 108, Abb. 36,6.

d) geschwungener Bügel und rechteckige Doppelösenplatte

49 Großer Gleichberg, Gde. Römhild, D: G. Neumann 1963, 30, Abb. 20,6.

50 Zirzow, D: unpubliziert, freundlicher Hinweis U. Schoknecht.

51 Fordon, PL: Rauhut/Rauhutowa/Potemski 1959-60, 158-159, 163, Taf. XXVII,2.7.

52 Gdańsk, PL: Jażdżewski/Chmielewski 1952, 65-66, Taf. 52a.

53 Opole-Ostrówek, PL: Wachowski 1984, 52, 86, 97, 110, Abb. 29d, 32e, 33a-b; Sarnowska 1956, 218, Taf. XLIV,4; Hilcezerówna 1956, 90, 91, 96-97, Taf. VI,10/102, VII,17/130.

54 Tum, PL: Nadolski 1962, 114, 117, Abb. 16.

55 Chl'aba/Dunaj, SK: Hanuliak 1989, 210, Taf. XIII,35.

56 Esztergom, H: Régészeti 5,8/***, Abb. 60,1.

57 Sümeg, H: Régészeti 3,54/-, Abb. 73,4.

58 Bîtca Doamnei, RO: Scorpan 1965, 449, Abb. 5,11.

59 Ukmergè, LT: Urbanavičius/Urbanavičiené 1988, Abb. 29,3.

60 Novgorod, RUS: Arcichovskij 1958, 229, Abb. 1,3; Medvedev 1959, 186, 191, Abb. 21,7.

61 Pskov, RUS: Grozdilov 1962, 61, Abb. 48,6.

62 Rjurikovo Gorodišče, RUS: Nosov 1990, 120-121, Abb. 43,2.

63 Slobodka, RUS: Nikol'skaja 1963, 26-27, 30, Abb. 3,16.

64 Novogrudok, BY: Gurevič 1976, 29, Abb. 60.

65 Gorodišče, UKR: Kirpičnikov 1973, 65-66, Taf. XIX,1.3.

66 Knjascha Gora, UKR: Kirpičnikov 1973, 65, Taf. XX,2.

67 Krilos, UKR: Ratič 1957, 54, Taf. IX,18.21.

68 Martynovka, UKR: Kirpičnikov 1973, 58, Taf. XIX,6.

\section{Liste Typ Vjaz'ma}

69 Bîtca Doamnei, RO: Scorpan 1965, 449, Abb. 5,11.

70 Preslav, BG: unpubliziert, Museum Preslav.

71 Wüstung, ehem. Grebieten, RUS: Gaerte 1929, 340, Abb. $277 f$ f.

72 Irzekapinis, Gde. Klincovka, RUS: Kulakov 1990, 75, Nr. 61-32 Taf. L.

73 Ukmerge, LV: Urbanavičius/Urbanavičiene 1988, 25, Abb. 31,4.

74 Asote, LT: Šnore 1962, 582, Abb. 3.

75 Koknese, LT: Latvijas PSR archeologija (Riga 1974), 372, Abb. 60,20. 
76 Lejasdopeles, LT: Latvijas PSR archeologija (Riga 1974), 372, Abb. 64,7.

77 Martinsalas ciems, LT: Latvijas PSR archeologija (Riga 1974), 371, Abb. 51,13.

78 Vjaz'ma, RUS: Jurkina 1981, 110, Abb. 2,12.

79 Grodno, BY: Voronin 1954, 38, 54, Abb. 22,14, 38,1. Es liegen 2 Exemplare vor.

80 Novogrudok, BY: Gurevič 1976, 29, Abb. 61.

81 Gorodišče, UKR: Kirpičnikov 1973, 65, 107, Nr. 223, Taf. XVIII,6.

82 Knjascha Gora, UKR: Kirpičnikov 1973, 65, 106, Nr. 183, Taf. XVIII,4.

83 Kolodjažin, UKR: Jura 1962, 108, Abb. 36,5.

84 Darbutai, LT: Zabiela 1995, 131, 296, Abb. 117,2.

\section{Liste Typ Fordon}

85 Fordon, PL: Rauhut/Rauhutowa/Potemski 1959-60, 158-159, 163, Taf. XXVII,2.7. Es sind 2 Exemplare bekannt.

86 Gdańsk, PL: Jażdżewski/Chmielewski 1952, 65-66, Taf. 52a.

87 Opole-Ostrówek, PL: Wachowski 1984, 50-51, 86, 97-98, 110, Nr. 41, 58, 59, Abb. 32e, Abb. 33a-b. Insgesamt liegen 3 Exemplare vor.

88 Poznań, PL: Błaszczyk 1972, 179, Abb. 106B.

89 Tum, PL: Nadolski 1962, 114, 117, Abb. 16.

90 Bîtca Doamnei, RO: Scorpan 1965, 449, Abb. 5,13.15.

91 Novgorod, RUS: Medvedev 1959, 186, 191, Nr. 10, Abb. 21,7; Arcichovskij 1958, 229 , Abb. 1,3. Es handelt sich um 2 Exemplare.

92 Slobodka, RUS: Nikol'skaja 1963, Abb. 3,16.

93 Braslav, BY: Alekseev 1966, 174-175, Abb. 43,17.

94 Grodno, BY: Voronin 1954, 38, Abb. 13,2.

95 Gorodišče, UKR: Kirpičnikov 1973, 65-66, Nr. 274-276, Taf. XIX,1-3. Es handelt sich um insgesamt 3 Exemplare.

96 Kolodjažin, UKR: Jura 1962, 108, Abb. 36,6.

97 Martynovka, UKR: Kirpičnikov 1973, 58, 106, Nr. 178-179, Taf. XIX,6.6a.

98 Rajki, UKR: Kirpičnikov 1973, 65-66, 106, Nr. 204, Taf. XIX,4.

\section{Liste 6}

a) Grabfunde mit awarischen Trachtelementen und merowingisch-karolingischer Bewaffnung oder Reitausrüstung

1 Baardorf, Gde. Hörzendorf, A: Szameit, 1993, 221-224, Taf. 2 C 6.

2 Grabelsdorf, Gde. St. Kanzian, A: Szameit 1993, 214, 216, 220-221, 226, Taf. I,22.

3 Hohenberg, Gde. Aigen, A: Fischbach 1895, 252, Taf. II.

4 Krungl, Gde. Bad Mitterndorf, A: Szameit 1993, 224; Gleirscher 1996, 23.

5 Micheldorf, Gde. Kremsdorf, A: Szameit 1993, 225; Gleirscher 1996, 23.

6 Devínská Nova Ves, CZ: Eisner 1952, 24-26, 38-39, 403, Taf. 13,5, Taf. 15,3, Taf. 17,10. Es sind insgeamt 5 Exemplare aus drei Gräbern von diesem Fundplatz bekannt.

7 Šebastovce, SK: Budinský-Krička/Točík 1991, 50-51, Taf. XXXIII,36. 
b) Reitersporen des 8. bis frühen 9. Jahrhunderts von Höhensiedlungen und aus Siedlungen südlich der Donau

8 Mužla-Čenkov, SK: Hanuliak/Kuzma/Šalkovský 1993, 35, 88, 179, Taf. 150,21.

9 Hemmaberg, Gde. Globasnitz, A: Szameit 1994b, 88, Taf. 4,3-4.

10 Kappele, Gde. Jadersdorf, A: Felgenhauer-Schmiedt 1993, 42, Taf. 44,1.2. Vom Fundplatz stammen 2 Exemplare.

11 Ullrichsberg, A: A. Neumann 1955, 182, Taf. 17 R1.

12 Car Asen, BG: unpubliziert, freundlicher Hinweis A. Stančev.

13 Odărci, BG: Dončeva-Petkova 1987, 75, Abb. 7a.

14 Pernik, BG: Čangova 1992, 184, 217, Abb. 171,1-2.

15 Stărmen, BG: Kurnatowska 1973, 104, 120, 123, Abb. 5,1-3.

16 Castelfeder, Gde. Montagna, I: Dal Ri/Rizzi 1995, 103, Abb. 18,2.

\section{Bibliographie}

Alekseev 1966: Леонид Васильевич Алексеев, Полоикая земля (очерки истории Белорусии в IX-XIII вв.), Москва 1966.

Anđelič 1962: Pave Anđelič, „Mamuza trebinjskog župana Grda“, in: Glasnik Zemaljskog muzeja u Sarajevu Arheologija N.S. 17, 1962, S. 173-175.

Angelov/Ovčarov 1986: Dimităr Angelov/Dimităr Ovčarov, „Slawen, Protobulgaren und das Volk der Bulgaren", in: Joachim Herrmann (Hrsg.), Welt der Slawen: Geschichte, Gesellschaft, Kultur, Leipzig-Jena-Berlin 1986, S. 57-80.

Arcichovskij 1958: Артемий Владимирович Арциховский, „Разкопки 1956 и 1957 гг. в Новгороде“, in: Советская археология 2, 1958, S. 227-242.

Arwidsson 1942: Greta Arwidsson, Valsgärde 6 (=Die Grabfunde von Valsgärde I), UppsalaStockholm 1942.

Arwidsson 1954: Greta Arwidsson, Valsgärde 8 (=Die Grabfunde von Valsgärde II), UppsalaStockholm 1954.

Arwidsson 1977: Greta Arwidsson, Valsgärde 7 (=Die Grabfunde von Valsgärde III), UppsalaStockholm 1977.

Austermann 1994/95: Matthias Austermann, „Grabungen in einer latènezeitlichen und mittelalterlichen Siedlung bei Arnsburg, Kr. Gießen“, in: Berichte der Kommission für Archäologische Landesforschung in Hessen 3, 1994/95 (1995), S. 113-143.

Bak 1997: János M. Bak, ,s.v. Ungarn“, in: Lexikon des Mittelalters VIII, München-Zürich 1997, S. 1224-1234.

Bálint 1989: Csanád Bálint, Die Archäologie der Steppe, Wien-Köln 1989.

Baraschi 1977: Silvia Baraschi, „Arme şi piese de echipament (Secolele X-XV)“, in: Petre Diaconu/Silvia Baraschi, Păcuiul lui Soare. (=Aşezarea medievală [Secolele XIII-XV], volume II), Bucureşti 1977, S. 145-156.

Belošević 1980: Janko Belošević, Materijalna kultura hrvata od VII do IX stoljeća, Zagreb 1980.

Berger 1963: Ludwig Berger, Die Ausgrabungen am Petersberg in Basel: Ein Beitrag zur Frühgeschichte Basels, Basel 1963.

Best 1997: Werner Best, „Die Ausgrabungen in der frühmittelalterlichen Wallburg Gaulskopf bei Warburg-Ossendorf, Kr. Höxter“, in: Germania 75, 1997, S. 159-192. 
Best 1999: Werner Best, „IV.112 Nietsporn“, in: Christoph Stiegemann/Matthias Wemhoff (Hrsg.), 799 - Kunst und Kultur der Karolingerzeit. Karl der Große und Papst Leo III. in Paderborn (=Katalogbände der Ausstellung Paderborn 1999), Mainz 1999, S. 249-250.

Bialeková 1977: Darina Bialeková, ,Sporen von slawischen Fundplätzen in Pobedim (Typologie und Datierung)“', in: Slovenská Archeologiá 25, 1977, S. 103-158.

Bierbrauer 1987: Volker Bierbrauer, Invillino - Ibligo in Friaul I: Die römische Siedlung und das spätantike-frühmittelalterliche castrum, München 1987.

Bierbrauer 1988: Volker Bierbrauer, Invillino - Ibligo in Friaul II: Die spätantiken und frühmittelalterlichen Kirchen, München 1988.

Bierbrauer/Nothdurfter 1988: Volker Bierbrauer/Hans Nothdurfter, „Die Ausgrabungen im spätantik-frühmittelalterlichen Bischofssitz Sabiona-Säben“, in: Schlern 62, 1988, S. 243-300.

Bivar 1972: Adrian David H. Bivar, „Cavalry equipment and tactics on Euphrates“, in: Dumbarton Oaks Papers 26, 1972, S. 273-291.

Błaszczyk 1972: Włodzimierz Błaszczyk, ,Wyniki badań archeologicznych w strefie osady św: Gotarda na Starym Mieście w Poznaniu“, in: Fontes archaeologici Posnanienses 23, 1972 (1973), S. 120-191.

Böhaker 1993: Peter Böhaker, „Sulzfelder Forst“, in: Bayerische Vorgeschichtsblätter/Beihefte 6, 1993, 179-183.

Böhme 1988: Horst Wolfgang Böhme, „Rüsselbecher im fränkischen Reich“, in: Jahrbuch des Römisch-Germanischen Zentralmuseums Mainz 35, 1988 (1991), S. 752-755.

Böhnlein 1991: A. Böhnlein, „Egolffstein-Schweinthal“, in: Bayerische Vorgeschichtsblätter/ Beihefte 4, 1991, S. 165.

Boeles 1951: Pieter Catharinus Johannes Albertus Boeles, Friesland tot de elfde eeuw zijn vooren vroege geschiedenis, s' Gravenhage 1951.

Boon 1959: G. C. Boon, „A bronze spur from the Thames at Kingston“, in: The Antiquaries Journal 39, 1959, S. 195-1999.

Borisov 1989: Boris D. Borisov, „Medieval Settlement and Necropolis $\left(11^{\text {th }}-12^{\text {th }}\right.$ century “, in: Aleksander Fol/Jan G. P. Best/R. Katinčarov et al. [Hrsg.], Djadovo: Bulgarian, Dutch, Japanese Expedition. 1. Medieval Settlement and Necropolos (11 $11^{\text {th }}$ th Century), Tokyo 1989.

Brachmann 1978: Hansjürgen Brachmann, Slawische Stämme an Elbe und Saale: Zu ihrer Geschichte und Kultur im 6. bis 10. Jahrhundert auf Grund archäologischer Quellen (=Schriften zur Ur- und Frühgeschichte 32), Berlin 1978.

Brather 1996a: Sebastian Brather, Feldberger Keramik und frühe Slawen: Studien zur nordwestslawischen Keramik der Karolingerzeit (=Universitätsforschungen zur Prähistorischen Archäologie 34), Bonn 1996.

Brather 1996b: Sebastian Brather, „Merowinger- und karolingerzeitliches „Fremdgut“ bei den Nordwestslawen: Gebrauchsgut und Elitenkultur im südwestlichen Ostseeraum“, in: Prähistorische Zeitschrift 71, 1996, S. 46-84.

Brentjes/Brentjes 1991: Burchard Brentjes/Helga Brentjes, Die Heerscharen des Orients, Berlin 1991.

Budinský-Krička 1959: Vojtech Budinský-Krička, Slovanské mohyly v Skalici [Slawische Hügelgräber in Skalica] (=Archaeologica Slovaca Fontes II), Bratislava 1959.

Budinský-Krička 1970: Vojtech Budinský-Krička, „Príspevok k poznaniu včasnostredovekej dediny na východnom Slovensku“, in: Slovenská Archeologiá 18, 1970, S. 176-177.

Budinský-Krička/Točík 1991: Vojtech Budinský-Krička/Anton Točík, Šebastovce: Gräberfeld aus der Zeit des awarischen Reiches, Nitra 1991. 
Burnell 1999: Simon Burnell, „Die reformierte Kirche von Sissach BL: Mittelalterliche Kirchenbauten und merowingerzeitliche ,Stiftergräber“", in: Archäologie und Museum 38, Liestal 1999, S. 90-92.

Burzler 1993: Anke Burzler, „Die frühmittelalterlichen Gräber aus der Kirche Burg“, in: Markus Höneisen (Hrsg.), Frühgeschichte der Region Stein am Rhein. Archäologische Forschungen am Ausfluß des Untersees (=Antiqua 26/Schaffhauser Archäologie 1), Basel 1993, S. $198-210$.

C̆angova 1972: Йорданка Чангова, Средновековното селище над тракийския град Севтополис XI-XIV век, София 1972.

Čangova 1992: Йорданка Чангова, Перник, m. III: Крепостта Перник VIII-XIV в., София 1992.

Capelle 1976: Torsten Capelle, Die frühgeschichtlichen Metallfunde von Domburg auf Walcheren (=ROB Nederlandse Oudheden 5), Amersfoort 1976.

Čaplovič 1983: Dušan Čaplovič, „Stredoveké zaniknuté Dedinské osídlenie na východnem Slovensku“, in: Slovenská Archeologiá 31, 1983, S. 357-413.

Caspart/Geyer 1931: J. Caspart/E. Geyer, „Ein frühgeschichtliches Gräberfeld bei Pottschach“, in: Mitteilungen der Anthropologischen Gesellschaft Wien 61, 1931, S. 162-194.

Caune 1994: Andris Caune, „10.-17. gs. gludināstiklu atradumi Latvijā“, in: Arheologija un etnogrāifija 17, 1994, S. 47-52.

Chalikov 1983: Альфред Хазанович Халиков, „Семеновский клад железных изделии“, in: Преслав 3, 1983, 254-262.

Cibulka 1958: Josef Cibulka, Velkomoravský kostel v Modré u Velehradu: A Začátky Křeštanství na Moravě, Praha 1958.

Ciglenečki 1987: Slavko Ciglenečki, Höhenbefestigungen aus der Zeit vom 3. bis 6. Jahrhundert im Ostalpenraum, Ljubljana 1987.

Ćirković 1995: Sima Ćirković, „s.v.Serbien“, in: Lexikon des Mittelalters VII, München-Zürich 1995, S. 1777-1781.

Claus 1992: Martin Claus, Die Ausgrabungen an der Wallburg König Heinrichs Vogelherd bei Pöhlde (Stadt Herzberg am Harz, Ldkr. Osterode am Harz) (=Materialhefte zur Ur- und Frühgeschichte Niedersachsen 23), Stuttgart 1992.

Coblenz 1989: Werner Coblenz, „Reitersporen von Burgen des 9. bis 11. Jahrhunderts in Sachsen“, in: Slovenská Archeologiá 37, 1989, S. 5-20.

Colardelle/Verdel 1991: Michel Colardelle/Éric Verdel, „L’Habitat fortifie médiéval de Colletiere a Charavines (Isère)“, in: Horst Wolfgang Böhme (Hrsg.), Burgen der Salierzeit. Teil 2: In den südlichen Landschaften des Reiches, Sigmaringen 1991, S. 285-302.

Colardelle/Verdel 1993: Michel Colardelle/ÉricVerdel, Les habitats du lac de Paladru (Isère) dans leur environnement: La formation d'un terroir an XIe siècle (=Documents d'Archéologie française 40), Paris 1993.

Corpus: Joachim Herrmann/Peter Donat (Hrsg.), Corpus archäologischer Quellen zur Frühgeschichte auf dem Gebiet der DDR, Berlin 1977-1985.

Costea 1968: Florea Costea, „Obiecte metalice descoperite în cetatea de pe Măgura Codlei“, in: Cumidava 2, 1968, S. 79-89.

Čremošnik 1951: Irma Čremošnik, „Nalaz staroslavenskih mamuza iz Sultanovicá“, in: Glasnik Zemaljskog muzeja u Sarajevu, Arheologija N.S. 6, 1951, S. 311-321.

Curta 1997: Florin Curta, „Blacksmiths, warriors and tournaments of value: Dating and interpreting early medieval hoards of iron implements in Eastern Europe“, in: Ephemeris Napocensis 7, 1997, S. 211-268. 
Daim 1987: Falko Daim, Das awarische Gräberfeld von Leobersdorf NÖ (=Studien zur Archäologie der Awaren 3), Wien 1987.

Dal Ri/Rizzi 1995: Lorenzo Dal Ri/Gianni Rizzi, „Il territorio altoatesino alla fine del VI e nel VII secolo d.C.“, in: Gian Pietro Brogiolo (Hrsg.), Città, castelli, campagne nei territori di Frontiera (secoli VI-VII). 5o seminario sul tardoantico e l'altomedioevo in Italia centrosettentrionale. Monte Barro-Galbiate (Lecco) 9-10 giugno 1994 (=Documenti di Archeologia 6), Mantova 1995, S. 87-120.

Danielczyk 1969: Bozena Danielczyk, „Wyroby z miedzi i jej stopów z wczesnośredniowiecznego grodziska w Styrmen (Bułgaria)“, in: Slavia Antiqua 16, 1969, S. 253-271.

Danielczyk 1972: Bozena Danielczyk, „Wczesnośredniowieczny obiekt sakralny ze Styrmen, okrăg Ruse (Bułgaria)“, in: Slavia Antiqua 19, 1972, S. 183-197.

Dannheimer 1962: Herrmann Dannheimer, Die germanischen Funde der späten Kaiserzeit und des frühen Mittelalters in Mittelfranken (=Germanische Denkmäler der Völkerwanderungszeit Serie A, Band 7), Berlin 1962.

Dannheimer 1968: Herrmann Dannheimer, Epolding-Mühlthal. Siedlung, Friedhöfe und Kirche des frühen Mittelalters (=Veröffentlichungen der Kommisson zur Archäologischen Erforschung des Spätrömischen Raetien/Münchener Beiträge zur Vor- und Frühgeschichte 13), München 1968.

Dannheimer 1974: Herrmann Dannheimer, ,Aus der Siedlungsarchäologie des frühen Mittelalters in Bayern“, in: Georg Kossack/Günter Ulbert (Hrsg.), Studien zur vor- und frühgeschichtlichen Archäologie. Festschrift für Joachim Werner zum 65. Geburtstag (=Münchener Beiträge zur Vor- und Frühgeschichte, Ergänzungsband 1/II), München 1974, S. 629-657.

Dannheimer 1988: Herrmann Dannheimer, Aschheim im frühen Mittelalter: Teil I. Archäologische Funde und Befunde (=Veröffentlichungen der Kommisson zur Archäologischen Erforschung des Spätrömischen Raetien/Münchener Beiträge zur Vor- und Frühgeschichte 32/I), München 1988.

Dekówna 1975: Maria Dekówna, „Wyroby szklane z grodziska w Styrmen (Bułgaria)“, in: Slavia Antiqua 22, 1975, S. 177-277.

Demmin 1893: August Demmin, Die Kriegswaffen in ihrer historischen Entwicklung von den ältesten Zeiten bis auf die Gegenwart, Leipzig 1893.

Dimitrov 1993: Димитър И. Димитров, ,Керамика от ранносредновековна крепост до село Цар Асен, Силистренско“, in: Добруджа 10, 1993, S. 76-122

Dimova 1993: Виолета Димова, „Ранносредновековната крепост до село Цар Асен, Силистренско (Крепостни съоръжения, жилищна архитектура)“, in: Добруджа 10, 1993, S. 54-75.

Dinklage 1941: Karl Dinklage, „Zur deutschen Frühgeschichte Thüringens“, in: Mannus 33, 1941, S. 480-507.

Dončeva-Petkova 1981: Людмила Дончева-Петкова, „Средновековно селище при с. Одърци Толбухинкси окрьг“, in: Известия на Народния музей Варна 17 (32), 1981, S. 19-28.

Dončeva-Petkova 1987: Ludmilla Dončeva-Petkova, „Sur la chronologie du site bulgare medieval pres du village Odărci, Dép. de Tolbuhin“, in: Dobrudža. Etudes ethno-culturelles, Sofia 1987, S. 69-82.

Dončeva-Petkova 1992: Людмила Дончева-Петкова, „Сгради при южния сектор на западната крепостна стена на Плиска“, in: Плиска-Преслав 5, Шумен 1992, S. 124-145.

Dončeva-Petkova 1998: Ludmilla Dončeva-Petkova, „Adornments from a 11th century Pechenegs' necropolis by Odartsi village, Dobrich District (North-Eastern Bulgaria)“, in: Archeologia Bulgarica 3, 1998, S. 126-138. 
Dostál 1966: Bořivoj Dostál, Slovanská pohřebiště ze středni doby hradištni na Moravě, Praha 1966.

Dujčev 1983: Ivan Dujčev, „Bulgarien“, in: Lexikon des Mittelalters II, München-Zürich 1983, S. 914-928.

Dymaczewska/Dymaczewski 1980: Urszula Dymaczewska/Aleksander Dymaczewski, „Résultats des Fouilles archéologiques effectuées à Odărci, Département de Tolboukhine (Bulgarie), au cours des années 1967, 1969-1974 et 1976-1977“, in: Slavia Antiqua 27, 1980, S. 145-171.

Dymaczewski 1973: Aleksander Dymaczewski, „Die frühmittelalterliche Siedlung von Stărmen in Nordostbulgarien“, in: Balcanoslavica 2, 1973, S. 17-31.

Dymaczewski 1979: Aleksander Dymaczewski, „Die Ergebnisse polnisch-bulgarischer Ausgrabungen in Odărci, Bezirk Tolbuchin“, in: Rapports du IIIe Congrès International d'Archéologie slave Bratislava 7-14 septembre 1975 1, Bratislava 1979, S. 221-224.

Eggers 1995: Martin Eggers, Das „,großmährische Reich“. Realität oder Fiktion? Eine Neuinterpretation der Quellen zur Geschichte des mittleren Donauraumes im 9. Jahrhundert (=Monographien zur Geschichte des Mittelalters 40), Stuttgart 1995.

Ehrhardt 1983: Harald Ehrhardt, „Byzanz und Skandinavien“, in: Lexikon des Mittelalters II, München-Zürich 1983, S. 1313-1314.

Eisner 1933: Jan Eisner, Slovensko v pravěku (=Práce učené společnosti šafaříkovy v Bratislavé, svazek 13), Bratislava 1933.

Eisner 1952: Jan Eisner, Devínska Nová Ves: Slovanské pohřebiště, Bratislava 1952.

van Es/Verwers 1980: Willem A. van Es/W. J. H. Verwers, Excavations at Dorestad: 1. The Harbour: Hoogstraat I (=ROB Nederlandse Oudheden 9), Amersfoort 1980.

Ettel 1991: Peter Ettel, „Villa Karloburg - frühmittelalterlicher Zentralort in Mainfranken“, in: Das Archäologische Jahr in Bayern 1991 (1992), S. 149-153.

Fassbinder 1999: Stefan Fassbinder, „Kat.Nr. IV. 136“, in: Christoph Stiegemann/Matthias Wemhoff (Hrsg.), 799 - Kunst und Kultur der Karolingerzeit. Karl der Große und Papst Leo III. in Paderborn (=Katalogbände der Ausstellung Paderborn 1999, Mainz 1999), S. 260.

Felgenhauer-Schmiedt 1993: Sabine Felgenhauer-Schmiedt, Das Kappele (,,die Kåpile“) ob Jadersdorf: Eine spätantik-frühmittelalterliche Höhensiedlung in Oberkärnten (=Aus Forschung und Kunst 27), Klagenfurt 1993.

Feodorov 1954: Георгий Борисович Федоров, „Итоги трехлетних работ в Молдавии в области славяно-русской археологии“, in: Краткие сообщения 56, 1954, S. 8-23.

Fielder 1992: Uwe Fiedler, Studien zu Gräberfeldern des 6. bis 9. Jahrhunderts an der unteren Donau (=Universitätsschriften zur Prähistorischen Archäologie 11), Bonn 1992.

Fischbach 1895: Otto Fischbach, „A Hohenbergi Leletröl“, in: Archeologiai Értesitö 15, 1895, S. 249-253.

Forrer 1915: Robert Forrer, „Neue Materialien zum südwestlichen und südlichen Stadtmauerring des römischen Straßburg“, in: Anzeiger für Elsässische Altertumskunde 7, 1915, S. 595-686.

von Freeden 1983: Uta von Freeden, „Das frühmittelalterliche Gräberfeld von Grafendobach in Oberfranken“, in: Berichte der Römisch-Germanischen Kommission 64, 1983 (1984), S. 417-507.

von Freeden 1987: Uta von Freeden, „Das frühmittelalterliche Gräberfeld von Moos-Burgstall, Ldkr. Deggendorf, in Niederbayern“, in: Berichte der Römisch-Germanischen Kommission 68, 1987, S. 493-637.

Frisinger 1977: Herwig Frisinger, Studien zur Archäologie der Slawen in Niederösterreich (=Mitteilungen der prähistorischen Kommission der Österreichischen Akademie der Wissenschaften 17/18), Wien 1977. 
Frolík 1983: Jan Frolík, „K počátkům Chrudimi“, in: Archeologické Rozhledy 35, 1983, S. 524-525.

Gabriel 1981: Ingo Gabriel, „Karolingische Reitersporen und andere Funde aus dem Gräberfeld von Bendorf, Kr. Rendsburg-Eckernförde", in: Offa 38, 1981 (=Festschrift K. W. Struwe), S. 245-258.

Gabriel 1984: Ingo Gabriel, Starigard/Oldenburg. Hauptburg der Slawen in Wagrien. 1. Stratigraphie und Chronologie (=Offa-Bücher 52), Neumünster 1984.

Gabriel 1988: Ingo Gabriel, „Hof- und Sakralkultur sowie Gebrauchs- und Handelsgut im Spiegel der Kleinfunde von Starigard/Oldenburg“, in: Berichte der Römisch-Germanischen Kommission 69, 1988, S. 103-291.

Gaerte 1929: Wilhelm Gaerte, Urgeschichte Ostpreußens: Ostpreußische Landeskunde in Einzeldarstellungen, Königsberg in Preußen 1929.

Galuška 1994: Ludek Galuška, „The Development of Slavonic Pottery in the Staré Město Region from the End of the 8th up to the Middle of the $10^{\text {th }}$ centuries“, in: Cenek Staňa (Hrsg.), Slawische Keramik in Mitteleuropa vom 8. bis zum 11. Jahrhundert. (=Internationale Tagungen in Mikulčice, Forschungsprobleme des frühen Mittelalters I), Brno 1994, S. 233-242.

Genrich 1972: Albert Genrich, Der gemischtbelegte Friedhof bei Liebenau, Kr. Nienburg 1, Hildesheim 1972.

Giesler 1974: Ulrike Giesler, „Datierungen und Herleitung der vogelförmigen Riemenzungen“, in: Georg Kossack/Günther Ulbert (Hrsg.), Studien zur Vor- und frühgeschichtlichen Archäologie. Festschrift für Joachim Werner (=Münchner Beiträge zur Vor- und Frühgeschichte, Ergänzungsband 1/II), München 1974, S. 521-543.

van Giffen 1940: Albert Egges van Giffen, „Oudheidkundige aanteekeningen over Drentsche Vondsten (VII)“, in: Nieuwe Drentsche Volksalmanak 58, 1940, S. 180-216.

Gimperlein 1992: W. Gimperlein, „Münnerstadt-Burghausen“, in: Bayerische Vorgeschichtsblätter/Beihefte 5, 1992, S. 158-159.

Gjuzelev 1995: Vasil Gjuzelev, „s.v.Responsa“, in: Lexikon des Mittelalters VII, MünchenZürich 1995, S. 759.

Glaser 1991: Franz Glaser, Das frühchristliche Pilgerheiligtum auf dem Hemmaberg (=Aus Forschung und Kunst 26), Klagenfurt 1991.

Glaser 1997: Franz Glaser, Frühes Christentum im Alpenraum: Eine archäologische Entdeckungsreise, Darmstadt 1997.

Gleirscher 1986: Paul Gleirscher, „Säben - von der Spätantike ins frühe Mittelalter: Stand der archäologischen Forschung“", in: Schlern 60, 1986, S. 552-562.

Gleirscher 1996: Paul Gleirscher, „Neues zum Gracarca-Friedhof über Grabelsdorf: GracarcaBericht 2“, in: Carinthia I 186, 1996, S. 11-45.

Glodariu/Moga 1989: Ioan Glodariu/Vasile Moga, Cetatea dacică de la Căpîlna, București 1989.

Göckenjan 1996: Hansgerd Göckenjan, „s.v. Siebenbürgen“, in: Lexikon des Mittelalters VII, München-Zürich 1996, S. 1840-1842.

Goßler/Posluschny 1998: Norbert Goßler/Axel Posluschny, „Zu einem frühkarolingischen Sporn aus der Siedlung von Runkel-Ennerich, Kr. Limburg-Weilburg“, in: Germania 76, 1998, S. 885-895.

Gross 1991: Uwe Gross, Mittelalterliche Keramik zwischen Neckarmündung und Schwäbischer Alb (=Forschungen und Berichte der Archäologie des Mittelalters in Baden-Württemberg 12), Stuttgart 1991.

Grozdilov 1962: Г. П. Гроздилов, „Раскопки древнего Пскова“, in: Археологически сборник вып. 4 (Славянские древности), Ленинград 1962, S. 61-75. 
Gurba 1965: Jan Gurba, „Z problematyki osadnictwa wczesnośredniowiecznego na Wyżynie Lubelskiej“, in: Annales Universitatis Maria Curie-Skłodowska. Sectio F. Nauki filozoficzne i humanistyczne 20, 1965 (1968), S. 45-57.

Gurevič 1976: Фрида Давидовна Гуревич, „Два етапа в истории древнерусских городов Понеманья“, in: Краткие сообщения 146, 1976, S. 25-31.

Guyan 1965: Walter Ulrich Guyan, Das alamannische Gräberfeld von Schleitheim-Hebsack (=Materialhefte zur Ur- und Frühgeschichte der Schweiz 5), Basel 1965.

Halbout/Pilet/Vaudour 1987: Patrick Halbout/Christian Pilet/Chaterine Vaudour, „L'equipment du cavalier et du cheval“", in: Corpus des objects domestiques et des armes en fer de Normandie du $I^{e r}$ au XV siècle: Centre archéologique de Normandie (=Cahier Annales Normandie 20), Caen 1987, S. 231-235.

Hampel 1905: Josef Hampel, Alterthümer des frühen Mittelalters in Ungarn, Braunschweig 1905. Hanuliak 1989: Milan Hanuliak, „Praveké, včasnodejnné a stredoveké osídlenie v Chl'abe“, in: Slovenská Archeológia 37, 1989, S. 209-212.

Hanuliak/Kuzma/Šalkovský 1993: Milan Hanuliak/Ivan Kuzma/Peter Šalkovský, Mužla-Čenkov I. Osidlenie z 9.-12. storočia (=Materialia Archaeologica Slovaca 10), Nitra 1993.

Haseloff 1951: Günther Haseloff, Der Tassilokelch (=Münchener Beiträge zur Vor- und Frühgeschichte 1), München 1951.

Haseloff 1976/77: Günther Haseloff, „Der Silberbecher aus der Regnitz bei Pettstadt, Ldkr. Bamberg“, in: Jahresberichte der Bayerischen Bodendenkmalpflege 17/18, 1976/77 (1978), S. 132-177.

Heiser 1979: Lothar Heiser, Die Responsa des Papstes Nikolaus I. (858-867), Münster 1979.

Henning 1987: Joachim Henning, Südosteuropa zwischen Antike und Mittelalter: Archäologische Beiträge zur Landwirtschaft des 1. Jahrtausends unserer Zeitrechnung (=Schriften zur Ur- und Frühgeschichte 42), Berlin 1987.

Henning 1989: Йоахим Хеннинг, „Восточное по происхождению оружие и снаряжение всадников в кладах сельскохозяйственных железних изделии в юго-восточной Европы (VIII-X вв.)“, in: Проблеми на прабългарската история и култура (=Втора международна среща по прабългарска археология, Шумен 1986), София 1989, S. 87-104.

Henning 1991: Joachim Henning, „Germanen - Slawen - Deutsche: Neue Untersuchungen zum frühgeschichtlichen Siedlungswesen östlich der Elbe“, in: Prähistorische Zeitschrift 66, 1991, S. 119-133.

Hensel 1980: Withold Hensel (Hrsg.), Styrmen nad Jantra (Butgaria): Badania archeologiczne w latach 1961-1964 i 1967-1968, Wrocław 1980.

Hensel/Rauhutowa 1977: Withold Hensel/Jadwiga Rauhutowa, „Badania archeologiczne na stanowisku Gradište w Debrešte: Sprawozdanie tymczasowe z prac w 1975 r.“, in: Slavia Antiqua 24, 1977, S. 141-153.

Hensel/Rauhutowa 1980: Withold Hensel/Jadwiga Rauhutowa, „Wstępne wyniki badań na stanowisku Gradište w Debrešte (Macedonia) w świetle prac wykopaliskowych przeprowadzonych w 1978 r.“, in: Slavia Antiqua 27, 1980, S. 79-117.

Herrmann 1973: Joachim Herrmann, „Der bisherige Beitrag der Ausgrabungen auf der Stelle des römisch-byzantinischen Kastells Jatrus bei Kriwina, Bez. Russe in der VR Bulgarien zum Problem des Übergangs von der Antike zum Mittelalter“, in: Balcanoslavica 2, 1973, S. 33-49.

Heydeck 1893-1895: Heydeck, „Das Gräberfeld von Daumen und ein Rückblick auf den Anfang einer deutsch-nationalen Kunst", in: Prussia 19, 1893-1895, S. 41-80.

Hilczerówna 1956: Zofia Hilczerówna, „Ostrogi polskie z X-XIII wieku: Poznańskie Towarzystwo Przyjaciół Nauk“, in: Wydzait Historii i Nauk Społecznych. Prace Komisji Archeologicznej II Zeszyt 2, Poznań 1956. 
Hinton 1974: David A. Hinton, A Catalogue of the Anglo-saxon ornamental Metalwork 700-1100 in the Department of Antiquities Ashmolean Museum, Oxford 1974.

Hoffmann 1993/94: Ullrich Hoffmann, „Friesen“, in: Björn-Uwe Abels/Jochen Haberstroh (Hrsg.), Ausgrabungen und Funde in Oberfranken 9, 1993-94 (Sonderdruck aus: Geschichte am Obermain: Jahrbuch Colloqium Historicum Wirsbergense 20,1995/96) S. 1-81.

Horedt 1954: Kurt Horedt, „Voievodatul de la Balgrad - Alba Julia“, in: Studii şi cercetări de istorie veche 5, 1954, S. 487-512.

Horedt 1958: Kurt Horedt, Untersuchungen zur Frühgeschichte Siebenbürgens, Bucureşti 1958.

Horedt 1986: Kurt Horedt, Siebenbürgen im Frühmittelalter (=Antiqitas 3/28), Bonn 1986.

Hrubý 1955: Vilem Hrubý, Staré Město: Velkomoravske pohřebiště „,Na valach“ (=Monumenta archaeologica III), Praha 1955.

Isenberg/Peine/Wemhoff 1994: Gabriele Isenberg/Hans-Werner Peine/Matthias Wemhoff, „Westfälische Klöster und Stifte“, in: Archäologie in Deutschland 1/1994, S. 22-37.

Ivanov 1996: Пламен Иванов, „Крепостта Големият град при Старо село, община Мездра (Теренно проучване през 1994г.)“, in: Известия на музеите в Северозападна България 24, 1996, S. 73-88.

Jacobi 1930: Heinrich Jacobi, „II. Die Ausgrabungen der Jahre 1925-28. 2. Kastell Zugmantel“, in: Saalburg-Jahrbuch 7, 1930, S. 35-78.

Jahn 1921: Martin Jahn, Der Reitersporn: Seine Entstehung und früheste Entwicklung (=Mannus-Bibliothek 21), Leipzig 1921.

Jażdżewski/Chmielewski 1952: Konrad Jażdżewski/Waldemar Chmielewski, „Gdańsk wczesnośredniowieczny w świetle badań wykopaliskowych z lat 1948/9“, in: Studia Wczesnośredniowieczna 1, 1952, S. 34-81.

Jelovina 1986: Dušan Jelovina, Mačevi i ostruge karolinškog obilježja u muzeju Hrvatskih arheoloških spomenika / Schwerter und Sporen karolingischer Formgebung im Museum kroatischer archäologischer Denkmäler, Split 1986.

Jørgensen 1999: Anne N. Jørgensen, Waffen und Gräber: Typologische und chronologische Studien zu skandinavischen Waffengräbern 520/30 bis 900 n. Chr. (=Nordiske Fortidsminder Serie B17), København 1999.

Junkelmann 1992: Markus Junkelmann, Die Reiter Roms. Teil III: Zubehör, Reitweise, Bewaffnung (=Kulturgeschichte der Antiken Welt 53), Mainz 1992.

Jura 1962: Роман Александрович Юра, „Древній Колодяжин“, in: Археологические памьятки УРСР 12, 1962, S. 57-130.

Jurkina 1981: Татьяна Васильевна Юркина (Сергина), „О разкопах в Вязьме на Смоленщине“, in: Краткие сообщения 164, 1981, S. 106-111.

Kalousek 1971: František Kalousek, Břeclav-Pohansko, velkomoravské pohřebiště a kostela: I. Archeologické prameny z pohřebiště, Brno 1971.

Karnitsch 1931: Paul Karnitsch, „Oberösterreichische Waffenfunde aus der Karolingerzeit“, in: Heimatgaue - Zeitschrift für Oberösterreichische Geschichte, Landes- und Volkskunde 12, 1931, S. 47-52.

Kavánová 1976: Blanka Kavánová, Slovarské ostruhy na území, Praha 1976.

Keller/Bierbrauer 1965: Erwin Keller/Volker Bierbrauer, „Beiträge zum awarenzeitlichen Gräberfeld von Devínska Nová Ves“, in: Slovenská Archeologiá 13, 1965, S. 380-385.

Kersten 1939: Karl Kersten, Vorgeschichte des Kreises Steinburg (=Vor- und frühgeschichtliche Untersuchungen des Museums vorgeschichtlicher Altertümer Kiel, N.F. 5/Offa-Bücher 5: Die vor- und frühgeschichtlichen Denkmäler und Funde in Schleswig Holstein 1), Neumünster 1939. 
Kind 1997: Thomas Kind, Studien zu früh- und hochmittelalterlichen Reitersporen im germanisch-slawischen Siedlungsraum Mitteleuropas (=Ungedruckte Magisterarbeit), Berlin 1997.

Kirpičnikov 1973: Анатолий Н. Кирпичников, Снаряжение всадника и веховово коня на Руси IX-XIII вв. (=Археология СССР, Свод археологических источников Е1-36), Ленинград 1973.

Klanica 1985: Zedeněk Klanica, „Mikulčice - Klášteřisko“, in: Pamatky archeologické 76, 1985, S. 474-539.

Klanica 1986: Zedeněk Klanica, Počátky slovanského osídlení našich zemí, Praha 1986.

Klanica 1995: Zedeněk Klanica, „Zur Periodisierung vorgroßmährischer Funde aus Mikulčice“, in: Falko Daim/Lumĭr Poláček (Hrsg.), Studien zum Burgwall von Mikulčice 1 (=Spisy AÚ AV ČR Brno 2), Brno 1995, S. 379-469.

Kleemann 1992a: Jörg Kleemann, „Ein Beschlag mit anglo-karolingischer Tierstil-Verzierung aus Jülich-Bourheim (Kr. Düren)“, in: Kölner Jahrbuch für Vor- und Frühgeschichte 25, 1992, S. 137-141.

Kleemann 1992b: Jörg Kleemann, Grabfunde des 8. und 9. Jahrhunderts im nördlichen Randgebiet des Karolingerreiches, Köln 1992.

von Kleist 1955: Diether von Kleist, Die urgeschichtlichen Funde des Kreises Schlawe (=3. Beiheft zum Atlas der Urgeschichte), Hamburg 1955.

R. Koch 1982: Robert Koch, „Stachelsporen des frühen und hohen Mittelalters“, in: Zeitschrift für Archäologie des Mittelalters 10, 1982, S. 63-83.

U. Koch 1977: Ursula Koch, Das Reihengräberfeld von Schretzheim (=Germanische Denkmäler der Völkerwanderungszeit, Serie A 13), Berlin 1977.

U. Koch 1982: Ursula Koch, „Die frühmittelalterlichen Funde vom Runden Berg bei Urach“, in: Archäologisches Korrespondenzblatt 12, 1982, S. 81-92.

U. Koch 1984: Ursula Koch, Die Metallfunde der frühgeschichtlichen Perioden aus den Plangrabungen 1967-1981 (=Der Runde Berg bei Urach 5. Heidelberger Akademie der Wissenschaften, Kommission für Alamannische Altertumskunde 10), Heidelberg 1984.

U. Koch 1986: Ursula Koch, „Ein spätmerowingischer Sporn mit Ringöse in Straubing“, in: Jahresberichte des Historischen Vereins Straubing 88, 1986, S. 165-168.

U. Koch 1991: Ursula Koch, „Die frühgeschichtlichen Perioden auf dem Runden Berg“, in: Helmut Bernhard u.a. (Hrsg.), Der Runde Berg bei Urach (=Führer zu archäologischen Denkmälern in Baden-Württemberg 14), Stuttgart 1991, S. 83-127.

U. Koch 1993/94: Ursula Koch, „Drei Langsaxe aus Ostbayern“, in: Berichte der Bayerischen Bodendenkmalpflege 34/35, 1993/94 (1995), S. 181-201.

U. Koch 1998: Ursula Koch, , s.v. Glas“, in: Reallexikon zur germanischen Altertumskunde 12, Berlin-New York 1998, S. 153-166.

J. Korošec 1950: Josip Korošec, Staroslovansko grobišče na Ptujskem gradu (=Slovenska Akademija Znanosti in Umetnosti, Razred za zgodovino in Družbene vede 1), Ljubljana 1950.

P. Korošec 1979: Paola Korošec, Zgodnjesrednjeveška arheološka slika karantanskih Slovanov, Ljubljana 1979.

Kost 1951/52: Emil Kost, „Ausgrabungsergebnisse auf dem Tuffhügel „Burgstall“ am Weinberghang zwischen Niedernhall und Criesbach (Kochertal, Kr. Künzelsau)“, in: Württembergisch Franken N.F. 26/27, 1951/52, S. 79-97.

Kromer 1980: Karl Kromer, „Das frühgeschichtliche Gräberfeld von Säben bei Klausen in Südtirol“, in: Archaeologica Austriaca 64, 1980, 1-49.

Кučera 1962: Мауш П. Кучера, „Древний Плиснеськ“, in: Археологические памьятки УССР 12, 1962, S. 34-56. 
Kulakov 1990: Владимир И. Кулаков, „Древности пруццов“, in: Археология СССР G1-9, 1962, Москва 1990.

Kurnatowska 1973: Zofia Kurnatowska, „Elementy uzbrojenia i oporządzenia jeździeckiego z wczesnośredniowiecznego grodziska w Styrmen w Bułgarii“", in: Slavia Antiqua 20, 1973, S. 87-124.

Kurnatowska 1980: Zofia Kurnatowska, „Osadnictwo wczesnośredniowieczne“, in: Withold Hensel (Hrsg.), Styrmen nad Jantra (Butgaria): Badania archeologiczne w latach 19611964 i 1967-1968, Wrocław u.a. 1980, S. 69-246.

Laux 1978-80: Friedrich Laux, „Der Reihengräberfriedhof in Oldenburg, Samtgemeinde Amelinghausen, Kr. Lüneburg/Niedersachsen“, in: Hammaburg N.F. 5, 1978-80, (1983), S. 91-147.

Liénard 1885: Félix Liénard, Archéologie de la Meuse (=Description des voies anciennes et des monuments aux époques celtique et galloromaine 3), Verdun 1885.

Lilie 1999: Ralf-Johannes Lilie, Byzantinische Geschichte des oströmischen Reiches 326-1453, München 1999.

Lindenschmit 1880: Ludwig Lindenschmit, Handbuch der deutschen Alterthumskunde 1: Die Alterthümer der merowingischen Zeit, Braunschweig 1880.

Lodowski 1980: Jerzy Lodowski, Dolny Ślask na poczatku średniowiecza (VI-X w): Podstawy osadnicze i gospodarcze, Wrocław u.a. 1980.

Loretto 1961: Franz Loretto (Übers.), Nikephoros Phokas - Der bleiche Tod der Sarazenen - und Johannes Tzimiskes: Die Zeit von 959 bis 976 in der Darstellung des Leon Diaconos (=Byzantinische Geschichtsschreiber 10), Graz-Wien-Köln 1961.

Madgearu 1994: Alexandru Madgearu, „Pinteni datați în secolele VIII-IX, descoperiți în jumătatea de sud a Transilvaniei“", in: Mousaios 4/1, 1994, S. 153-163.

Margeson 1995: Sue Margeson, „VIII. Objects from Burial 451“, in: Andrew Rogerson, A late Neolithic, Saxon and Medieval site at Middle Harling, Norfolk (=East Anglian Archaeology 74), Norfolk 1995, S. 46-53.

Měchurová 1983: Zedeňka Měchurová, „Třmeny a jiné současti sedla z časně středověkého období“, in: Časopis moravského muzea 68, 1983, 61-89.

Medvedev 1959: Александр Филиппович Медведев, Оружие Новгорода Великово (=Материалы и исследования по археологии СССР 65/Труды Новгородской експедиции 2), Москва 1959.

Meier 1990: Dirk Meier, Scharstorf: Eine slawische Burg in Ostholstein und ihr Umland. Archäologische Funde (=Offa-Bücher 70), Neumünster 1990.

Melzer 1991: Walter Melzer, Das frühmittelalterliche Gräberfeld von Wünnenberg-Fürstenberg, Kr. Paderborn (=Bodenaltertümer Westfalens 25), Münster 1991.

Menghin 1983: Wilfried Menghin, Das Schwert im Frühen Mittelalter: Chronologisch-typologische Untersuchungen zu Langschwertern aus germanischen Gräbern des 5. bis 7. Jahrhunderts $n$. Chr. (=Wissenschaftliche Beibände Anzeiger des Germanischen Nationalmuseums 1), Stuttgart 1983.

Michajlina/Timoščuk 1983: Л. П. Михайлина/ Борис Анисимович Тимощук, „Славянские памятники Бассейна Верхнего Прута VIII-X вв.“, in: Славяне на Днестре и Дунае. Сборник научных трудов, 1983, S. 205-219.

Michajlov/Dončeva-Petkova/Toptanov 1975: Стамен Михайлов/Людмила Дончева-Петкова/ Димитър Топтанов, „Разкопки на градището при с. Одърци, Толбухински окръг (19711973)“, in: Археология 17, 1975, S. 62-71. 
Michajlov/Dončeva-Petkova/Toptanov 1980: Stamen Michailov/Ludmilla Dončeva-Petkova/Dimităr Toptanov, „Fouilles archeologiques pres du village Odărci, Département de Tolboukhine (Bulgarie) au cours des années 1971-1977““, in: Slavia Antiqua 27, 1980, S. 119-144.

Milčev 1966: Atanas Milčev, „Die frühmittelalterlichen bulgarischen Schmucksachen und KreuzEnkolpien aus Nordwestbulgarien“, in: Slavia Antiqua 13, 1966, S. 325-357.

Miletić 1963: Nikola Miletić, „Nakit i oružje IX-XII veka u nekropolama Bosne i Hercegovine“, in: Glasnik Zemaljskog muzeja u Sarajevu N.S. 18, 1963, S. 155-178.

Mitrofanov 1978: Алексей Григорьевич Митрофанов, Железный век средней Белоруссии (VII-VI в.н.е. до VIII в.н.е.), Минск 1978.

Möller 1987: Jutta Möller, Katalog der Grabfunde aus Völkerwanderungs- und Merowingerzeit im südmainischen Hessen (Starkenburg) (=Germanische Denkmäler der Völkerwanderungszeit, Serie B11), Stuttgart 1987.

Moosbrugger 1965: Rudolf Moosbrugger, „Der verzierte Sax aus Grab 48 von Lausanne-Bel Air“, in: Jahrbuch der schweizerischen Gesellschaft für Ur- und Frühgeschichte 52, 1965, S. 112-117.

Moosbrugger-Leu 1971: Rudolf Moosbrugger-Leu, Die Schweiz zur Merowingerzeit: Die archäologische Hinterlassenschaft der Romanen, Burgunder und Alamannen. Handbuch der Schweiz zur Römer- und Merowingerzeit, Bern 1971.

Müller-Wille 1986: Michael Müller-Wille, „Bild und Bildträger: Beispiele im Borre- und Jellingestil“, in: Helmuth Roth (Hrsg.), Zum Problem der Deutung frühmittelalterlicher Bildinhalte. Akten des 1. Internationalen Kolloquiums in Marburg an der Lahn, 15. bis 19. Februar 1983 (=Veröffentlichungen des Vorgeschichtlichen Seminars der Philipps-Universität Marburg an der Lahn, Sonderband 4), Sigmaringen 1986, S. 153-174.

Musianowicz 1979: Krystina Musianowicz, „Zespół osadniczy z Gorodka obwód Roweński (USRR) w świetle wczesnośredniowiecznego osadnictwa Wołynia“, in: Wiadomości archeologiczne 44, 1979, S. 168-205.

Mutafčiev 1914: Петър Мутафчиев, „Сондажи при с. Челопеч“, in: Известия на Българското археологическо дружество 4, 1914, S. 264-266.

Muzolf 1997: Błażej Muzolf, „Badania na skale Grodzisko Pańskie w Strzegowej, województwo Katowice“, in: Badania archeologiczne na Górnym Ślasku i ziemiach pogranicznych w 1994 roku, 1997, S. 158-165.

Nadolski 1962: Andrzej Nadolski, „Early mediaeval Łęczyca“, in: Archeologia Polana 5, 1962, S. 101-122.

Nägler 1969: Thomas Nägler, „Cercetările din cetatea de la Breaza (Făgăraş)“, in: Studii şi Comunicări (Sibiu) 14, 1969, S. 100-118.

Nägler/Rill 1981: Thomas Nägler/M. Rill, „Şantierul arheologic Şura Mică (jud. Sibiu). Raport preliminar (1976-1978)“", in: Studii şi Comunicări (Sibiu) 21, 1981, S. 39-48.

Näsman 1984: Ulf Näsman, „Vendel Period Glass from Eketorp-II, Öland, Sweden: On Glass and Trade from the late 6 th to the late $8^{\text {th }}$ centuries A.D.“", in: Acta Archaeologica (København) 55, 1984 (1986), S. 55-116.

Neuffer-Müller 1983: Christiane Neuffer-Müller, Der alamannische Adelsbestattungsplatz und die Reihengräberfriedhöfe von Kirchheim am Ries (Ostalbkreis) (=Forschungen und Berichte zur Vor- und Frühgeschichte in Baden-Württemberg 15), Stuttgart 1983.

A. Neumann 1955: Alfred Richard Neumann, „Keramik und andere Kleinfunde vom Ulrichsberg“, in: Carinthia I. 145, 1955, S. 143-182.

G. Neumann 1932: Gotthard Neumann, „Ein bemerkenswerter Reitersporn vom Festenberg bei Baderitz“, in: Mitteilungen des Landesvereins Sächsischer Heimatschutz 21, 1932, S. 131-139. 
G. Neumann 1963: Gotthard Neumann, „Vor- und Frühgeschichte“, in: Das Gleichberggebiet: Ergebnisse der heimatkundlichen Bestandsaufnahme im Gebiet von Haina und Römhild/ Thüringen (=Werte der Deutschen Heimat 6), Berlin 1963, S. 14-57, 185-226.

Nikolov 1965: Димитър Николов, „Тракийски паметници във Врачанско“, in: Известия на Археологически институт 28, 1965, S. 163-202.

Nikol'skaja 1963: Т. Н. Никольская, „Работа верхнеокской археологической експедиции“, in: Краткие сообщения 96, 1963, S. 25-31.

Nosov 1990: Евгений Николаевич Носов, Новгородское (Рюриково) городщще, Ленинград 1990.

Nylén 1997: Erik Nylén, „Den gotländskt charnersporren - en fulländad konstruktion och en studie kring sannolika förändringar inom nordisk ridkonst under förhistorisk tid“, in: Gotländskt Arkiv 69, 1997, S. 213-232.

Olsson 1935: Harald Olsson, Bidrag till den svenska sporrens historia samt några arkeologiska virtnesbörd om hästen såsom villebråd, drag - och riddjur (=Ungedrucktes Manuskript im Antikvarisk Topografiskt Arkiv), Stockholm 1935.

von der Osten o.J.: Hans Henning von der Osten, Die Welt der Perser: Große Kulturen der Frühzeit, Stuttgart o.J.

Pahič 1969: Stanko Pahič, „Antični in staroslovanski grobovi v Brezju nad Zrečami“, in: $R a$ zprave, Slovenska Akademija Znanosti in Umetnosti, Razred za zgodovinske in družbene vede, classis I: Historia et Sociologia (=Dissertationes VI), Ljubljana 1969, 215-308.

Palmgren 1878-80: L. F. Palmgren, ,Fornlemningar i Torskinge och Ås socknar (Småland) på Svenska Fornminnesföreningens bekostnad undersökta år 1876“, in: Svenska Fornminnesförening Tidskrift 4, 1878-80 (1879-81), S. 15-18.

Pascu/Rusu/Jambor/Edroiu 1968: Stefan Pascu/Mircea Rusu/Petre Jambor/Nicolé Edroiu, „Cetatea Dăbîca“, in: Acta Musei Napocensis 5, 1968, S. 153-202.

Petersen 1939: Ernst Petersen, Der ostelbische Raum als germanisches Kraftfeld im Lichte der Bodenfunde des 6.- 8. Jahrhunderts, Leipzig 1939.

Piaskowski 1982: Jerzy Piaskowski, „Metaloznawcze badania przedmiotów żelaznych z Niedanowa i Pasymia-Ostrowa, woj. Olsztyn, oraz Bogaczewa-Kuli, woj. Suwałki“, in: Sprawozdania Archeologiczne 34, 1982, S. 202-222.

Pittioni 1943: Richard Pittioni, Der frühmittelalterliche Gräberfund von Köttlach, Ldkr. Gloggnitz, Niederdonau (=Sonderschriften der Zweigstelle Wien des Archäologischen Instituts des Deutschen Reiches 14), Brünn-München-Wien 1943.

Plate/Plate 1983: Christa Plate/Friedrich Plate, „Die slawische Siedlung von Tornow-Sechzehneichen, Kr. Kyritz“, in: Veröffentlichungen des Museums für Ur- und Frühgeschichte Potsdam 17, 1983, S. 202-208.

Pleyte 1877: Willem Pleyte, Nederlandsche Oudheden van de vroegste Tijden tot op Karel den Grotte (Friesland), Leiden 1877.

Pobol‘ 1967: Леонид Двыдович Поболь, „Поселения железково века около д. Шатково Бобрюсково района“, in: Белорусские древности. Доклады к конференции по археологии Белоруссии, январь - февраль 1966, Минск 1967, S. 182-242.

Pöllath 1998: Ralph Pöllath, Die Karolingerzeit in Nordostbayern: Studien zur Besiedlungsgeschichte anhand der Gräberfelder und Einzelfunde aus Metall (=Ungedruckte Dissertation), München 1998.

Pöllath 1999: Ralph Pöllath, „Karolingerzeitliche Grabfunde in Nordostbayern“, in: Archäologische Arbeitsgemeinschaft Ostbayern/West- und Südböhmen. 8. Treffen 17. bis 20. Juni 1998 in Běšiny bei Klatovy, Rahden/Westphalen 1999, S. 146-172. 
Poleski 1992: Jacek Poleski, „Datierungsgrundlagen der älteren Phasen des Frühmittelalters (bis zum Ende des 10.Jahrhunderts) in Kleinpolen“, in: Kazimierz Godłowski/Renata Maria Madyda-Legutko (Hrsg.), Probleme der relativen und absoluten Chronologie ab der Latènezeit bis zum Frühmittelalter (=Materialien des III. Internationalen Symposiums: Grundprobleme der frühgeschichtlichen Entwicklung im nördlichen Mitteldonaugebiet), Kraków 1992, S. 318-338.

Popescu 1925: Dorin Popescu, „Fouilles de Lechinta de Mures“, in: Dacia 2, 1925, S. 304-344.

Popov 1936: Рафаил Попов, „Материалы от разкопките презь 1934/35 г.“, in: Maдара: Рзкопки и проучвания 2 (=Издания на Народния археологически музей 33), София 1936, S. 32-97.

Popović 1999: Marco Popović, The Fortress of Ras/Tvrđava Ras (=Archaeological Institute monographs 34/Arheološki Institut Posebna izdanja 34), Belgrad 1999.

Popović/Ivanišević 1988: Marko Popović/Vujadin Ivanišević, „Grad Braničevo u sredn’em veku“, in: Starinar 39, 1988, S. 125-179.

Poulík 1957: Josef Poulík, „Výsledky výzkumu na velkomoravském Hradišti „Valy“ u Mikulčic I. Zpráva za r. 1954-56“, in: Pamatky archeologické 48, 1957, S. 241-388.

Profantová 1992: Nadà Profantová, „Awarische Funde aus den Gebieten nördliche der awarischen Siedlungsgrenze“, in: Falko Daim (Hrsg.), Awarenforschungen 2. (=Archaeologia Austriaca. Monographien 2 = Studien zur Archäologie der Awaren 4), Wien 1992, S. 605801.

Profantová 1994: Nadà Profantová, „K nálezům ostruh z konce 7.-9. stol. v Čechách“, in: Mediaevalia Archaeologica Bohemica 1993 (=Pamatky archeologické Supplement 2), Praha 1994, S. 60-85.

Quiquerez 1844: Auguste Quiquerez, „Notice historique sur quelques Monumens de l'ancien Évêché de Bâle, réuni au Canton de Berne“, in: Mitteilungen der Anthropologischen Gesellschaft Zürich 2, 1844, S. 85-100.

Raddatz 1967: Klaus Raddatz, „Kleinere ur- und frühgeschichtliche Funde aus der Göttinger Gegend“, in: Göttinger Jahrbuch 15, 1967, S. 13-30.

Rašev 1983: Рашо Рашев, „Късни номади в Плисковското поле“, in: Преслав 3, 1983, S. $242-252$.

Ratič 1957: Олексій Онисимович Ратич, Древньоруськи археологични памятки територии західніх областей УРСР, Киев 1957.

Rauhut/Rauhutowa/Potemski 1959/60: Lechosław Rauhut/Jadwiga Rauhutowa/Czesław Potemski, „Sprawozdanie z badań wykopaliskowych w Fordonie pow. Bydgoszcz na grodzisku „Wyszogród“ w roku 1958“, in: Wiadomości archeologiczne 26, 1959-60, S. 142-163.

Régészeti: Magyarország régészeti topográfiája [Archaeological sites of Hungary] 1-8, Budapest 1966-1989

Rempel 1940: Heinrich Rempel, „Ein frühdeutsches Reitergrab aus der Gemarkung Henfstädt, Ldkr, Hildburghausen“, in: Mannus 32, 1940, S. 314-320.

Rempel 1953: Heinrich Rempel, „Zu den Reitersporen der Hildagsburg“, in: Hans Dunker, Die Hildagsburg: Der Burgwall von Elbeu, Kreis Wolmirstedt (=Abhandlungen und Berichte zur Naturkunde und Vorgeschichte VIII/5), Magdeburg 1953, 230-232.

Rempel 1964: Heinrich Rempel, „Frühe Steigbügel aus Mitteldeutschland“, in: Varia Archaeologica. Festschrift für Wilhelm Unverzagt zum 70. Geburtstag (=Deutsche Akademie der Wissenschaften Berlin, Schriften der Sektion für Vor- und Frühgeschichte 16), Berlin 1964, S. 310-315.

Rempel 1966: Heinrich Rempel, Reihengräberfriedhöfe des 8.-11. Jahrhunderts aus SachsenAnhalt, Sachsen und Thüringen (=Deutsche Akademie der Wissenschaften Berlin, Schriften der Sektion für Vor- und Frühgeschichte 20), Berlin 1966. 
Rettner 1997: Arno Rettner, „Sporen der älteren Merowingerzeit“, in: Germania 75, 1997, S. 133-157.

Révész 1987: Laszlo Révész, „Lyraförmige Schnallen in dem Karpatenbecken“, in: Acta Archaeologica Academiae Scientiarum Hungaricae 39, 1987, S. 257-285.

Rill/Heitel 1994/95: M. Rill/Radu Robert Heitel, „Die Archäologie der ersten und zweiten Phase des Eindringens der Ungarn in das innere karpatische Transilvanien“, in: Dacia N.S. 38/39, 1994/95 (1996), S. 389-439.

Rötting 1999: Hartmut Rötting, „Zu Bestattung und Repräsentation im friesischen und fränkischen Stil im Spiegel herausgehobener Grabanlagen von Schortens, Landkreis Friesland“, in: Über allen Fronten: Nordwestdeutschland zwischen Augustus und Karl dem Großen (=Archäologische Mitteilungen aus Nordwestdeutschland, Beiheft 26), Oldenburg 1999, S. 231-248.

Rogaczewska 1997: Aleksandra Rogaczewska, „Wyniki badań wykopaliskowych na Górze Zamkowej w Będzinie, województwo Katowice“, in: Badania archeologiczne na Górnym Ślasku i ziemiach pogranicznych w 1994 roku, 1997, S. 132-137.

Ruhmann 1999: Christiane Ruhmann, „Kat.-Nr. IV. 78“, in: Christoph Stiegemann/Matthias Wemhoff(Hrsg.), 799 - Kunst und Kultur der Karolingerzeit. Karl der Große und Papst Leo III. in Paderborn. Katalogbände der Ausstellung Paderborn 1999, Mainz 1999, S. 239.

Ruttkay 1978: Alexander Ruttkay, „Ducové, okres Trnava (B-3)“, in: Významné slovenska náleziska na Slovensku, Bratislava 1978, S. 63-72.

Rygh 1885: Oluf Rygh, Norske Oldsager: Ordnede og Forklarede, Christiana 1885.

Sarnowska 1956: Wanda Sarnowska, „Uzbrojenie średniowieczne w świetle wykopalisk w latach 1948-51 w Opolu na Śląsku“, in: Materiały Wczesnośredniowieczne 4, 1956, S. 218-230.

Schiek 1967: Siegwalt Schiek, „Oberdischingen“, in: Fundberichte aus Schwaben N.F. 18/2, 1967, S. 146-147.

Schindler 2001: Martin P. Schindler, „Das Fundmaterial der frühmittelalterlichen Siedlung“, in: Margerita Primas u.a.(Hrsg.), Wartau - Ur- und frühgeschichtliche Siedlungen und Brandopferplatz im Alpenrheintal (Kanton St. Gallen, Schweiz): I. Frühmittelalter und römische Epoche (=Universitätsforschungen zur Prähistorischen Archäologie 75), Bonn 2001, S. 57-81.

Schlüter/Zehm 1991: Wolfgang Schlüter/Bodo Zehm, „201. Osnabrück-Innenstadt, Fst.-Nr. 10“, in: Archäologische Mitteilungen aus Nordwestdeutschland 15, 1992 (=Fundchronik für den Regierungsbezirk Weser-Ems 1991), S. 316-318.

Schmid 1969: Peter Schmid, „Das Gräberfeld von Sievern - Bemerkungen zu Neufunden aus dem frühen Mittelalter“, in: Jahrbuch der Männer vom Morgenstern 50, 1969, S. 21-34.

Schmid 1970: Peter Schmid, „Das frühmittelalterliche Gräberfeld von Dunum, Kr. Wittmund (Ostfriesland): Grabung 1967-68“, in: Neue Ausgrabungen und Forschungen in Niedersachsen 5 , 1970, S. 40-62.

B. Schmidt 1961/1970/1975: Berthold Schmidt, Die späte Völkerwanderungszeit in Mitteldeutschland (=Veröffentlichungen des Landesmuseums für Vorgeschichte Halle 18/25/29), Berlin 1961, 1970 (Katalog Teil 1: Südteil), 1975 (Katalog Teil 2: Nord- und Ostteil).

E. A. Schmidt 1958: Евгений Альфредович Шмидт, „Длинные курганы у дер. Цурковки в Смоленском районе“, in: Советская археология 3, 1958, S. 162-169.

V. Schmidt 1984: Volker Schmidt, „Untersuchungen auf dem slawischen birituellen Gräberfeld von Alt Käbelich, Kr. Strasburg“, in: Jahrbuch zur Bodendenkmalpflege in Mecklenburg 1984, S. 337-346.

Schneider 1898: Ludwig Schneider, „Suevisch-slavische Ansiedlungen in Böhmen“, in: Zeitschrift für Ethnograghie, Anthropologie und Urgeschichte 30, 1898, S. 201-214. 
von Schnurbein 1987: Alexandra von Schnurbein, Der alamannische Friedhof bei Fridingen an der Donau (Kreis Tuttlingen) (=Forschungen und Berichte zur Vor- und Frühgeschichte Baden-Württemberg 21), Stuttgart 1987.

Schoknecht 1984: Ulrich Schoknecht, „Bronzezeitliche und slawische Siedlungsgruben aus Gnoien, Kr. Teterow“, in: Mitteilungen des Bezirksfachausschuss für Ur- und Frühgeschichte Neubrandenburg 31, 1984, S. 17-28.

Schranil 1928: Josef Schranil, Die Vorgeschichte Böhmens und Mährens, Berlin-Leipzig 1928.

Schuldt 1967: Ewaldt Schuldt, Die slawischen Burgen von Neu Nieköhr/Walkendorf, Kr. Teterow (=Beiträge zur Ur- und Frühgeschichte der Bezirke Rostock, Schwerin und Neubrandenburg 1), Schwerin 1967.

Schuldt 1982: Ewaldt Schuldt, „Die frühslawische Befestigung von der Sternberger Burg, Kr. Sternberg“, in: Jahrbücher zur Bodendenkmalpflege in Mecklenburg 1982, S. 97-147.

Schulz 1940: Walter Schulz, „Zeugnisse Karolingischer Metallkunst in Mitteldeutschland“, in: Mannus 32, 1940, S. 266-275.

Schulze-Dörrlamm 1988: Mechthild Schulze-Dörrlamm, „Untersuchungen zur Herkunft der Ungarn und zum Beginn ihrer Landnahme im Karpatenbecken“, in: Jahrbuch des RömischGermanischen Zentralmuseums Mainz 35, 1988 (1991), S. 373-478.

Schulze-Dörlamm 1993: Mechthild Schulze-Dörrlamm, „Bestattungen in den Kirchen Großmährens und Böhmens während des 9. und 10. Jahrhunderts“, in: Jahrbuch des Römisch-Germanischen Zentralmuseums Mainz 40, 1993 (1995), S. 557-620.

Schulze-Dörlamm 1998: Mechthild Schulze-Dörrlamm, „Das karolingische Kreuz von Baume-les-Messieurs, Dép. Jura“, in: Archäologisches Korrespondenzblatt 28, 1998 (1998), S. 131-150.

Schwarz 1984: Klaus Schwarz, Frühmittelalterlicher Landesausbau im östlichen Franken zwischen Steigerwald, Frankenwald und Oberpfälzer Wald (=Monographien des RömischGermanischen Zentralmuseums Mainz 5), Mainz 1984.

Schweitzer 1982: Joël Schweitzer, L'Habitat rural en Alsace au Haut Moyen-Age, Strasbourg 1982.

Scorpan 1965: Constantin Scorpan, „L'Ensemble archéologique féodal de Bîtca Doamnei“, in: Dacia N.S. 9, 1965, S. 441-454.

Sedov 1960: Валентин В. Седов, „Древнерусские сельские поселенийа Смоленской земли“, in: Краткие сообщения 79, 1960, S. 56-58.

Sedov 1974: Валентин В. Седов, Длинные курганы Кривичей (=Свод археологических источников Е1-8), Москва 1974.

de Shortt 1959: H. de Shortt, „A Provincial Roman spur from Longstock Hants and other spurs from Roman Britain“, in: The Antiquaries Journal 39, 1959, S. 61-76.

de Shortt 1964: H. de Shortt, „Another Spur of the First Century A.D. from Suffolk“, in: The Antiquaries Journal 44, 1964, S. 59-62.

Siegmund 1998: Frank Siegmund, Merowingerzeit am Niederrhein: Die frühmittelalterlichen Funde aus dem Regierungsbezirk Düsseldorf und dem Kreis Heinsberg (=Rheinische Ausgrabungen 34), Köln-Bonn 1998.

Simina 1995: Nicola Marcel Simina, „Contribuții la Cunoaşterea feudalismului timpuriu pe teritoriul comunei Vințu de Jos (Jud. Alba)“, in: Acta Musei Napocensis 32/1, 1995, S. $473-$ 490.

Sippel 1977: Klaus Sippel, „Die Grasburg bei Hohenroda-Mansbach, Kr. Hersfeld-Rotenburg“, in: Fuldaer Geschichtsblätter 53/3, 1977, S. 45-85.

Šnore 1962: Эльвира Давидовна Шноре, „Шпоры городища Асоте и их место в классификации шпор“, in: Šwiatowit 24, 1962, S. 577-585. 
Šolle 1966: Miloš Šolle, Stará Kouřim a projevy velkomoravské hmotné Kultury v čechách (=Monumenta archaeologica 15), Praha 1966.

Spinei 1985: Victor Spinei, Realități etnice şi politice în Moldova meridională în secolele X-XIII. Români şi turanici, Iaşi 1985.

Spinei 1986: Victor Spinei, Moldavia in the $11^{\text {th }}-14^{\text {th }}$ centuries (=Bibliotheca historica Romaniae, Monographs XX), [ohne Ortsangabe] 1986.

Spinei 1994/95: Victor Spinei, „La Bucovine à l'époque des grandes migrations et au haut moyen âge“, in: Dacia N.S. 38/39, 1994/95, S. 365-388.

Spinei 1997: Victor Spinei, „Bucovina în mileniul întunecat“, in: Victor Spinei (Hrsg.), Spatiul nord-est carpatic în mileniul întunecat, Iaşi 1997, S. 133-188.

Stadler 1993: Peter Stadler, „Die zeitliche Einordnung des awarischen Fundmaterials von Baardorf, Grabelsdorf, St. Peter bei Grafenstein und vom Kanzianiberg in Kärnten anhand der Seriation des gesamten awarischen Fundmaterials aus Männergräbern“, in: Archaeologia Austriaca 77, 1993, S. 235-242.

Stange 1996: Hartmut Stange, „Altslawische Funde aus einer Burganlage von Friedland, Lkr. Mecklenburg-Strelitz“, in: Jahrbuch für Bodendenkmalpflege in Mecklenburg 44, 1996 (1997), S. 415-424.

Stein 1967: Frauke Stein, Adelsgräber des 8. Jahrhunderts in Deutschland (=Germanische Denkmäler der Völkerwanderungszeit Serie A9), Berlin 1967.

Stephan/Wedepohl/Hartmann 1992: Hans-Georg Stephan/Karl Heinz Wedepohl/Gerald Hartmann, „Die Gläser der hochmittelalterlichen Waldglashütte Steimcke: Berichte über die Grabungsergebnisse Teil 2 - Chemische und formenkundliche Analysen der Gläser“, in: Zeitschrift für Archäologie des Mittelalters 20, 1992, S. 89-123.

Steppuhn 1998: Peter Steppuhn, Die Glasfunde von Haithabu (=Berichte über die Ausgrabungen in Haithabu 32), Neumünster 1998.

Steppuhn 1999: Peter Steppuhn, „Der mittelalterliche Gniedelstein: Glättglas oder Glasbarren? Zu Primärfunktion und Kontinuität eines Glasobjektes vom Frühmittelalter bis zur Neuzeit“", in: Nachrichten aus Niedersachsens Urgeschichte 68, 1999, S. 113-139.

Stiegemann/Wemhoff 1999: Christoph Stiegemann/Matthias Wemhoff (Hrsg.), 799 - Kunst und Kultur der Karolingerzeit. Karl der Große und Papst Leo III. in Paderborn (=Katalogbände der Ausstellung Paderborn 1999), Mainz 1999.

Stroh 1954: Armin Stroh, Die Reihengräber der karolingisch-ottonischen Zeit in der Oberpfalz (=Materialhefte zur Bayerischen Vorgeschichte 4), Kallmünz/Opf. 1954.

Svoboda 1965: Bedřich Svoboda, Čechy v době stěhování národů (=Monumenta archaeologica 13), Praha 1965.

Svoljšak/Knific 1976: Drago T. Svoljšak/Timotej Knific, ,Vipavska Dolina: Zgodnjesrednjeveška najdišča“, in: Situla 17, 1976, S. 9-163.

Szameit 1993: Erik Szameit, „Das frühmittelalterliche Grab von Grabelsdorf bei St.Kanzian am Klopeinersee, Kärnten“, in: Archaeologica Austriaca 77, 1993, S. 213-234.

Szameit 1994a: Erik Szameit, „Merowingisch-karantanisch-awarische Beziehungen im Spiegel archäologischer Bodenfunde des 8. Jahrhunderts - Ein Beitrag zur Frage nach den Wurzeln frühmittelalterlicher Erscheinungen im Ostalpenraum“, in: Neues Alt-Villach 31, 1994, S. 7-23.

Szameit 1994b: Erik Szameit, „Zu Funden des 8. Jahrhunderts aus Kärnten“, in: Acta Histriae II, 1994, S. 79-102.

Székely 1988: Zoltán Székely, „Aşezări din secolele VII-VIII în Bazinul superior al Tìrnavei Mari, in: Studii şi cercetari de istorie veche 39/2, 1988, S. 169-198.

Szöke 1994: Béla Miklós Szöke, „A Népvándorlás kor és a korai középkor története Nagykanizsán és környékén“, in: Nagykanizsa. Városi monográfia, Nagykanizsan 1994, S. 143-214. 
Teodor 1978: Dan G. Teodor, Teritoriul est-carpatic în veacurtile V-VI e.n.: Contributi Archeologice si istorice la problema formárci poprulni român, Iaşi 1978.

Teodor 1980: Dan G. Teodor, The East Carpathian Area of Romania V-XI centuries A.D. (=British Archaeological Reports International Series 81), Oxford 1980.

Theophylaktos Simokates: Theophylaktos Simokates, Geschichte. Übersetzt und erläutert von Peter Schreiner (=Bibliographie der griechischen Literatur 20), Stuttgart 1985.

Thieme 1978-80: Bettina Thieme, „Ausgewählte Metallbeigaben aus dem Gräberfeld von Ketzendorf, Kr. Stade“, in: Hammaburg N.F. 5, 1978-80 (1983), S. 65-89.

Timpel 1967: Wolfgang Timpel, „Zwei neue frühmittelalterliche Sporengräber aus Thüringen“, in: Ausgrabungen und Funde 12, 1967, S. 273-277.

Timpel 1982: Wolfgang Timpel, Gommerstedt - ein hochmittelalterlicher Herrensitz in Thüringen (=Weimarer Monographien zur Ur- und Frühgeschichte 5), Weimar 1982.

Timpel 1990: Wolfgang Timpel, Mittelalterliche Keramik im westlichen Thüringen 8.-12. Jahrhundert: II. Katalog und Tafeln (=Weimarer Monographien zur Ur- und Frühgeschichte 24), Weimar 1990.

Torbov 1998: Nartsis Torbov, „Spurs from the $2^{\text {nd }}$ century BC- $1^{\text {st }}$ century AD found in northwestern Bulgaria“, in: Archeologia Bulgarica 2, 1998, S. 54-63.

Tovornik 1986: Vlasta Tovornik, „Die frühmittelalterlichen Gräberfelder von Gusen und Audorf bei Perg in Oberösterreich 2: Auhof bei Perg“, in: Achaeologica Austriaca 70, 1986, S. 413-483.

Urbanavičius/Urbanavičiené 1988: Vytautas Urbanavičius/Saulė Urbanavičiené, „Archeologiniai Tyrimai“, in: Lietuvos Archeologija 6, 1988, S. 25-31.

Ursachi 1987: Vasile Ursachi, „Cetatea dacică de la Brad“, in: Thraco-Dacica 8, 1987, S. 100-126.

Uzarowiczowa 1964: Anna Uzarowiczowa, „Wyniki badań sondażowych na osadzie wczesnośredniowiecznej w Wołajowicach, pow. Hrubieszów“, in: Wiadomości archeologiczne 30, 1964, S. 398-416.

Vaklinov 1973: Stančo Vaklinov, „Die slawische Kultur in Bulgarien und die byzantinische Hinterlassenschaft", in: Berichte über den II. Internationalen Kongreß für Slawische Archäologie Berlin 24.-28. August 1970 II, Berlin 1973, S. 195-236.

Văžarova 1976: Živka Văžarova, Slavjani i Prabălgari - po danni na nekropolite ot VI-XI v. na teritorijata na Bălgarija, Sofija 1976.

Văžarova 1979: Živka Văžarova, „Zur Frage der Etnogenese und der materiellen Kultur des bulgarischen Volkes: zwei Nekropolen aus Nordostbulgarien“, in: Culture et art en Bulgarie medievale (VIIIe-XIVe s.) (=Известия на археологически институт 35), Sofia 1979, S. 5-30.

Veek 1931: Walther Veeck, Die Alamannen in Württemberg (=Germanische Denkmäler der Völkerwanderungszeit Serie A1), Berlin-Leipzig 1931.

Vendtová 1969: Viera Vendtová, „Slovanské osídlenie Pobedima a okolia“, in: Slovenská Archeologiá 17, 1969, S. 119-232.

Vierk 1986: Hajo Vierck, „Mittel- und westeuropäische Einwirkungen auf die Sachkultur von Haithabu/Schleswig“, in: Herbert Jankuhn/Kurt Schietzel/Herbert Reichstein (Hrsg.), Archäologische und naturwissenschaftlichen Untersuchungen an ländlichen und frühstädtischen Siedlungen im deutschen Küstengebiet vom 5. Jahrhundert v.Chr. bis zum 11. Jahrhundert nach Chr. 2: Handelsplätze des frühen und hohen Mittelalters, Weinheim 1986, 366-422.

Vignatiová 1980: Jana Vignatiová, „Současti jezdecké výstroje z nálezů na Pohansku u Břeclavě“, in: Sborník praci filozofické fakulty brněnské univerzity, Řada archeologicko-klassická E 25, Brno 1980, S. 161-198.

Vignatiová 1981: Яна Вигниатова, „Снаряжение всадника и верхого коня из Бржецлав// Поганско“, in: Славяни и номади VI-XII в., Международен симпозиум по славянска археология, Рилски манастир НРБ 1977 г. (=Плиска-Преслав 3), София 1981, S. 85-89. 
Vinski 1977/78: Zdenko Vinski, „Novi Ranokarolinski Nalazi u Jugoslaviji“, in: Vjesnik Arheoloskog muzeja u Zagrebu 3/10-11, 1977/78, S. 143-208.

Vinski 1983: Zedenko Vinski, „Zu karolingischen Schwertfunden aus Jugoslawien“, in: Jahrbuch des Römisch-Germanischen Zentralmuseums Mainz 30, 1983, S. 465-501

Vinski/Vinski-Gasparini 1950: Zedenko Vinski/Ksenija Vinski-Gasparini, Gradište u Mrsunjskom Lugu: Izložba prvog iskapanja slavenske utvrde iz ranog srednjeg vijeka u Hrvatskoj. Arheološkog Muzeja w Zagrebu, Zagreb 1950.

Viollet-le-Duc 1874: Eugène Emmanuel Viollet-le-Duc, Dictionnaire raisonné du mobilier français de l'époque Carlolingienne à la renaissance, Paris 1874.

Vitljanov 1996: Стоян Витлянов, Старобългарското въоръжение по археологически данни от Плиска, Мадара и Велики Преслав, София 1996.

Vogt 1987: Hans-Jürgen Vogt, Die Wiprechtsburg Groitzsch: Eine mittelalterliche Befestigung in Westsachsen (=Veröffentlichungen des Landesmuseums für Vorgeschichte Dresden 18), Berlin 1987.

Voronin 1954: Николай Николаевич Воронин, Древнее Гродно 1 (=Материалы и исследования по археологии СССР 41), Москва 1954.

Vulpe 1955: Radu Vulpe, „Săpăturile de salvare de la Sîncrăieni (1954) (r. Ciuc, Regiunea Autonomă Maghiară) )“, in: Studii şi cercetări de istorie veche 6, 1955, S. 559-569.

Wachowski 1983: Krzysztof Wachowski, „Das Problem der Chronologie der karolingischen Einflüsse auf das Gebiet von Jugoslawien“, in: Zeitschrift für Archäologie des Mittelalters 11, 1983, S. 163-176.

Wachowski 1984: Krzysztof Wachowski, „Militaria z grodu na Ostrówku w Opolu“, in: Studia nad kultura wczesnopolskiego Opola. Polska Akademia Nauk - Oddziat we Wroctawu. Prace Komisj Archeologicznej 2, Warszawa-Wrocław 1984, S. 11-112.

Wachowski 1986/87: Krzysztof Wachowski, „Merowingische und karolingische Sporen auf dem Kontinent", in: Zeitschrift für Archäologie des Mittelalters 14/15, 1986/87, S. $49-79$.

Wachowski 1987: Krzysztof Wachowski, „Der karolingische Fundhorizont in Südpolen“, in: Archäologisches Korrespondenzblatt 17, 1987, S. 523-528.

Wachowski 1992: Krzysztof Wachowski, Kultura karolińska a Stowiańszczyczna zachodnia (=Studia archeologiczne 23), Wrocław 1992.

Walz 1989: Dorothea Walz, Auf den Spuren der Meister: Die Vita des Heiligen Magnus von Füssen, Sigmaringen 1989.

Wamers 1994: Egon Wamers, „Die frühmittelalterlichen Lesefunde aus der Löhrstraße (Baustelle Hilton II) in Mainz“, in: Mainzer Archäologische Schriften 1, Mainz 1994

Wamers 1999: Egon Wamers, „Zwischen Salzburg und Oseberg: Zum Ursprung und Ikonographie des nordischen Greiftierstils", in: Uta von Freeden/Ursula Koch/Alfried Wieczorek (Hrsg.), Völker an Nord- und Ostsee und die Franken. Akten des 48. Sachsensymposiums in Mannheim vom 7. bis 11. September 1997, Bonn 1999, S. 195-228.

Wand 1974: Nobert Wand, Die Büraburg bei Fritzlar (=Kasseler Beiträge zur Vor- und Frühgeschichte 4), Marburg 1974.

Wanner 1867: Martin Wanner, Das alamannische Todtenfeld bei Schleitheim und die dortige römische Niederlassung, Schaffhausen 1867.

Wedepohl/Pirling/Hartmann 1997: Karl Heinz Wedepohl/Renate Pirling/Gerald Hartmann, „Römische und fränkische Gläser aus dem Gräberfeld von Krefeld-Gellep“, in: Bonner Jahrbücher 197, 1997, S. 177-189.

Wedepohl/Winkelmann/Hartmann 1997: Karl Heinz Wedepohl/Wilhelm Winkelmann/Gerald Hartmann, „Glasfunde aus der karolingischen Pfalz in Paderborn und die frühe HolzascheGlasherstellung“, in: Ausgrabungen und Funde in Westfalen-Lippe 9/A, 1997, S. 41-53. 
Weis 1999: Matthias Weis, Ein Gräberfeld der späten Merowingerzeit bei Stetten an der Donau (=Materialhefte zur Archäologie in Baden-Württemberg 40), Stuttgart 1999.

Wendel 1986: Michael Wendel, Iatrus-Krivina: Spätantike Befestigung und frühmittelalterliche Siedlung an der unteren Donau (=Schriften zur Geschichte und Kultur der Antike 17), Berlin 1986.

Werner 1955: Joachim Werner, Das alamannische Gräberfeld von Mindelheim (=Materialhefte zur Bayerischen Vorgeschichte 6/Veröffentlichungen der Schwäbischen Forschungsgemeinschaft der Kommission der Bayerischen Landesgeschichte 1: Studien zur Geschichte von Bayern und Schwaben 3), Kallmünz/Opf. 1955.

Werner 1977: Joachim Werner, Die Ausgrabungen in St.Ulrich und Afra in Augsburg 1961-68 (=Veröffentlichungen der Kommission zur Archäologischen Erforschung des Spätrömischen Raetien/Münchner Beiträge zur Vor- und Frühgeschichte 23), München 1977.

Werner 1978/79: Joachim Werner, „Zur Zeitstellung der altkroatischen Grabfunde von Biskupija-Crkvina (Marienkirche)“, in: Schild von Steier 15/16, 1978/79 (=Festschrift Walter Modrijan), S. 227-237.

Westphal 1999: Herbert Westphal, „Kat.Nr. V.68.“, in: Christoph Stiegemann/Matthias Wemhoff (Hrsg.), 799 - Kunst und Kultur der Karolingerzeit. Karl der Große und Papst Leo III. in Paderborn (=Katalogbände der Ausstellung Paderborn 1999), Mainz 1999, S. 302.

Wilson 1965: David M. Wilson, „On the dating of two spurs“, in: The Antiquaries Journal 45, 1965, S. 111-112.

Zabiela 1995: Gintautas Zabiela, Lietuvos Medinès pilys, Vilnius 1995.

Żak 1958: Jan Żak, „Ostrogi z zaczepami haczykowato odgiętymi na zewnątrz“, in: Przeglad Archeologiczny 11, 1958, S. 88-105.

Żak 1959: Jan Żak, Najstarsze ostrogi zachodniosłowiańskie Wczesnośredniowiecznie ostrogi o zaczepach haczykowato zagiętych do wnętrza, Warszawa 1959.

Żak/Maćkowiak-Kotkowska 1988: Jan Żak/Lidia Maćkowiak-Kotkowska, Studia nad uzbrojeniem środkowoeuropejskim VI-X wieku: Zachodniobaltyjskie $i$ stowiańskie ostrogi o zaczepach haczykowato zagiętych do wnętrza (=Uniwersytet im Adama Mickiewiecza w Poznaniu Seria Archeologia 31), Poznań 1988.

Zekan 1987: Mate Zekan, „Srednjovjekovne nekropole“, in: Bribir u srednjem vijeku, 1987, S. 46-57.

Zekan 1994: Mate Zekan, „Karolinški i poslijekkarolinški nalazi iz Bosne i Hercegovine“, in: Livanjski kraj u povijesti, Split-Livno 1994, S. 63-68.

Zoll-Adamikowa 1998: Helena Zoll-Adamikowa, „Eine Knopfriemenzunge kleinen Formats vom Wawel in Kraków: Das östlichste Vorkommen frühkarolingischer Tierornamentik“, in: Anke Wesse (Hrsg.), Studien zur Archäologie des Ostseeraumes von der Eisenzeit zum Mittelalter (=Festschrift für Michael Müller-Wille), Neumünster 1998, S. 515-520.

Zschille/Forrer 1891: Richard Zschille/Robert Forrer, Der Sporn in seiner Formen-Entwicklung: Ein Versuch zur Charakterisierung und Datierung der Sporen unserer Kulturvölker 1, Berlin 1891.

Zschille/Forrer 1899: Richard Zschille/Robert Forrer, Der Sporn in seiner Formen-Entwicklung: Ein Versuch zur Charakterisierung und Datierung der Sporen unserer Kulturvölker 2, Berlin 1899.

Zverugo 1967: Ярослав Генрихович Зверуго, „Оружие древнего Волковыска“, in: Белорусские древности: Доклады к конференции по археологии Белоруссии, январьфевраль 1967, Минск 1967, S. 335-339. 


\title{
The rebellion of the nobles against the baptism of Khan Boris (865-866)
}

\author{
DANIEL ZIEMANN
}

One of the most important events for the history of the First Bulgarian Empire was the baptism of Khan Boris I., which is dated to ca. 864 or $865 .{ }^{1}$ Most of the overviews of Bulgarian history start with a new chapter when they turn to the reign of Boris, who changed his name to Michael because of his godfather, the emperor Michael. ${ }^{2}$ Christianization is therefore seen as a turning point in Bulgarian history, as the end of the old pagan era of the Proto-Bulgarians and the beginning of the new Christian Bulgaria. ${ }^{3}$

This perspective also has consequences for the interpretation of Pliska and its monuments. It is the common knowledge in Bulgarian historiography that in 893 the capital of the Bulgarian Empire was moved from Pliska to Preslav. ${ }^{4}$ As an explanation it is argued that the new capital Preslav seems to reflect the new look of a modern Christian kingdom with its churches, monasteries and monuments to the old Bulgarian language, while Pliska on the other hand with its palaces and pagan sanctuaries seems to represent the old face of a Protobulgarian capital. Furthermore it has been argued that Pliska had been one of the centers of opposition against Christianization. ${ }^{5}$ Therefore Pliska was linked to the two attempts to reestablish the old pagan religion: the first time

1864 is preferred by most of the historians: Vaillant/Lascaris 1933; Petrov 1964; Gjuzelev 1969, 74-83; Cankova-Petkova 1973, 30-37; Gjuzelev 1976; Ist. Bălg. 2, 214-215; Božilov/ Gjuzelev 1999, 171-174; for 865 e.g.: Bury 1912, 385 n. 4, Zlatarski 1927, 27-31; for a summary of the different opinions: Podskalsky 2000, 52-53.

2 Zlatarski 1927, 29; Bury 1912, 385; Gjuzelev 1969, 81; Ist. Bălg. 2, 214-215; Božilov/Gjuzelev 1999, 172.

3 Zlatarski 1927, 351 ff. started with his second volume; Beševliev 1980, 298 finished the historical part of his book; the Ist. Bălg. 2, starts 213 with a new chapter as well as Božilov/ Gjuzelev 1999, 169.

4 Zlatarski 1927, 254-255; Ist. Bălg. 2, 238; Božilov/ Gjuzelev 1999, 225.

5 Zlatarski 1927, 255; Gjuzelev 1969, 474-475; Ist. Bălg. 2, 283; Božilov/ Gjuzelev 1999, 225. 
immediately after the conversion in 864-865, and a second time after the resignation of Boris in 889 , when Boris' son Vladimir Rasate returned to paganism. Regino of Prüm, almost the sole source for these events, informs us of this. ${ }^{6}$

This paper shall take a closer look at the rebellion that followed the baptism of Khan Boris. Who stood behind the rebellion? Was it really the pagan Proto-Bulgarian class of Boyars who tried to stop the growing influence of the Slavs? Can Pliska really be seen as a center of paganism? What do these events reveal about the structure of the Bulgarian kingdom?

The conversion to Christianity is mentioned by several different sources. ${ }^{7}$ In Byzantine chronicles Christianization is presented as a result of military successes of the Byzantines and a great famine in Bulgaria, by which the Bulgarians were moved to adopt the new faith. ${ }^{8}$ Some chronicles like Theophanes Continuatus focus more on the personal aspect of conversion. Theophanes Continuatus describes two legendary stories about the motives for the baptism of Khan Boris. In the first one he is converted by his sister, who had been led captive in Constantinople, where she had embraced the Christian faith. She was released by the empress Theodora in exchange for a captive monk, Theodore Kupharas. After her return to Bulgaria she labored incessantly to convert her brother who remained a pagan until Bulgaria was visited by a terrible famine. Boris appealed to the God of his sister, and the famine stopped immediately. In the second tale Boris commanded a monk named Methodius to paint a picture that was supposed to strike terror in the hearts of those who gazed upon it. Methodious could not imagine anything more terrible than the Last Judgement and because of the terror of this picture, Boris received instruction in Christian doctrine and was secretly baptized at night. ${ }^{9}$

About the following events Theophanes Continuatus and the other Byzantine chronicles are less informative. He reports that after receiving the message of the baptism the whole Bulgarian people revolted against Boris/Michael, but he together with

6 Regino of Prüm, Chronicon, a. 868, 96.

7 For an overview of the sources, see e.g.: Zlatarski 1927, 27-30; Petrov 1964, 575-578; Gjuzelev 1969, 78, n. 61, 127.

8 Genesios (Lesmueller-Werner/Thurn), 69; Theoph. Cont. (Bekker), 163; the versions of the Symeon Logothetes, e. g. Georg. Mon. Cont., 732-733 who says that Boris/Michael himself came to Constantinople to be baptized; Skylitzes (Thurn), 91.

9 Theoph. Cont. (Bekker), 162-164; Skylitzes (Thurn), 90-91. 
only a few supporters and under the sign of the cross crushed the rebellion and made the rest of the people Christians. ${ }^{10}$

Western sources present a more detailed description of the rebellion. The Annals of St Bertin, probably composed by the archbishop Hincmar of Reims, say that after Boris/Michael had received baptism his nobles (proceres sui) stirred up the people to slay him, and all the Bulgarians of the ten districts of the kingdom (intra decem comitatus) gathered round his palace. Invoking the name of Christ, Boris/Michael together with 48 companions (cum quadraginta tantum octo hominibus) issued from his palace against the menacing multitude, and as the gates opened, seven clergy, each with a lighted taper in his hand, suddenly appeared and walked in front of the royal procession. Then the rebellious crowd was afflicted with a strange illusion. They imagined that the palace was on fire and was about to fall on their heads, and that the horses of the king and his followers were walking erect on their hind feet and kicking them with their fore hooves. Subdued by mortal terror, they could neither flee nor prepare to strike; they fell prostrate on the ground. The king put to death 52 nobles (ex proceribus) who stirred up the people against him (qui populum maxime adversus eum incitaverunt), while he spared the rest and allowed them to return back home (reliquuum autem populum inlaesum abire permisit). He sent an embassy to Louis the German, the king of the Eastern Frankish Kingdom, begging him to send a bishop and priests and received them graciously. Louis, who obviously did not have the material resources for such a great task, asked his brother Charles II the Bald, the king of the Western Frankish Kingdom to send him vessels, vestments, and books for the use of the Bulgarian Church. Charles received what he wanted and sent it to his brother Louis. Boris also sent an embassy with his own son ${ }^{11}$ and many of his nobles (ex proceribus regni sui) to Pope Nicholas I with questions about the sacrament of Christian faith and asking him for priests and bishops.

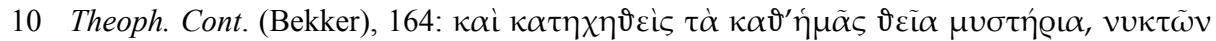

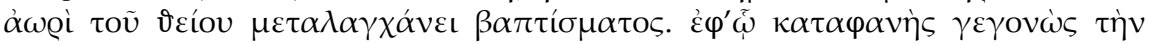

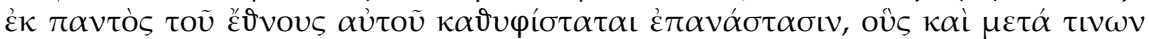

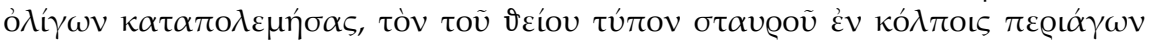

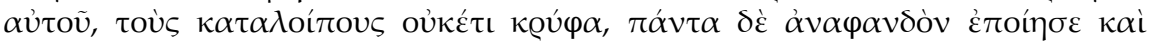

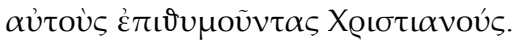

11 The participation of Boris' son is doubted by most of the historiography; Zlatarski 1927, 85, n. 2; Gjuzelev 1969, 197, n. 47, 317; Božilov/Gjuzelev 1999, 177. 
The embassy presented to the pope, along with other gifts, the arms which the king had worn when he triumphed over his unbelieving adversaries. ${ }^{12}$ The embassy took place in August 866. ${ }^{13}$

The report of the Annals of St Bertin obviously depends on another important source for the events, the famous Responsa Nicolai papae ad consulta Bulgarorum by Pope Nicholas I. As the Annals of St Bertin already mentioned, Boris had dispatched ambassadors to Rome, who submitted to him 106 questions on the political, social and religious obligations that the Christian faith imposed upon the Bulgarians. We only have Pope Nicholas' responses, but they obviously kept the structure and the order of the questions. Furthermore each response begins with a small summary of each question. ${ }^{14}$ One of the answers is directly related to the events of the rebellion: "Now I refer to your report on how you received the Christian religion and how you made your whole people be baptized and how after baptism they stood up with great ferocity against you, declaring that you had brought a bad law, and how they intended to kill you and to establish another king, and how you, inspired by the power of God, armed yourself against them and defeated all of them, the big and the small ones, and how you executed all the nobles (omnes primates eorum atque maiores) together with their

12 Annales Bertiniani, 85-86: Rex Bulgarorum, qui praecedente anno, Deo inspirante et signis atque afflictionibus in populo regni sui monente, christianus fieri meditatus fuerat, sacrum baptisma suscepit. Quod proceres sui moleste ferentes, concitaverunt populum adversus eum, ut illum interficerent. Quotquot igitur fuerunt intra decem comitatus, adunaverunt se circa palatium eius. Ille vero, invocato Christi nomine, cum quadraginta tantum octo hominibus, qui erga christianam devotionem ferventes sibi remanserant, profectus est contra omnem illam multitudinem; et mox ut portas civitatis exiit, apparuerunt ei et his qui cum eo erant septem clerici, et unusquisque eorum tenebat cereum ardentem in manu sua, sicque praecedebant regem et illos qui cum eo erant. Eis vero qui contra eum insurrexerant visum erat, quod magna villa ardens super eos caderet, et equi eorum qui cum rege erant, sicut contrariis videbatur, erecti incedebant et cum anterioribus pedibus eos percutiebant; tantusque timor eos apprehendit, ut nec ad fugiendum nec ad defendendum se praepararent, sed prostrati solo se movere nequibant. Rex autem ex proceribus, qui populum maxime adversus eum incitaverunt, interfecit numero quinquaginta duos, reliquum autem populum inlaesum abire permisit; et mittens ad Hludowicum regem Germaniae, qui ei foedere pacis coniunctus erat, episcopum et presbiteros postulavit, et ab eo missos cum debita veneratione suscepit. Hludowicus autem ad Karolum, fratrem suum, mittens, in ministerium clericorum apud fratrem suum vasa sacrata sacrasque vestes ac libros petiit. Unde Karolus ab episcopis regni sui non parvam summam accipiens, ei ad dirigendum regi. Bulgarorum rex filium suum et plures ex proceribus regni sui Romam direxit et arma, quibus indutus fuerat, quando in Christi nomine de suis adversariis triumphavit, cum aliis donis sancto Petro transmisit et plures quaestiones de sacramentis fidei consulendo Nicolao papae direxit et episcopos atque presbiteros mitti ab eo sibi poposcit; quod et obtinuit.

13 Lib. Pont. (Duchesne), 164.

14 Dujčev 1949, 127-129. 
children (cum omni prole sua), while you saved the minor or lower class (mediocres vero seu minores nihil mali pertulerint). You wanted to know about those who lost their lives, whether this was a sin." Nicolas answered, that "this certainly cannot be done without any sin and without your guilt, that the children, who did not participate in the plans of their parents and who did not rise in arms against you, were killed despite their innocence together with the malefactors." 15

The resemblance to the report of the Annals of St Bertin makes it very likely that Hincmar of Reims received the information about the events in Bulgaria and about the Bulgarian embassy directly from Rome. The question whether the execution of the nobles was to be regarded as a sin is rather astonishing, if we take into acount that the Bulgarian king considered himself a ruler by the grace of God. Such a question seems even to challenge the position of Boris/Michael as Bulgarian king.

There had been different kinds of explanations for the rebellion. Zlatarski interpreted it as the resistance of a traditional Hunno-Bulgarian noble class confronted with a centralising policy of Boris/Michael, which was focused on Byzantium and promoted the Slavs instead of the Proto-Bulgarians. ${ }^{16}$ Vasil Gjuzelev put less emphasis on the confrontation between Proto-Bulgarian and Slav groups, but instead described the rebellion as a blind, not fully conscious and instinctive reaction of traditional and maybe Western orientated nobles with an anti-Byzantine tendency. ${ }^{17}$ The historians largely agree about the anti-Byzantine thrust of the rebellion. ${ }^{18}$

It is quite clear that the events are presented from the perspective of the victorious Christian party, that of Khan Boris/Michael and his companions. As far as the report by Hincmar is concerned, there are certain aspects that attracted the attention of historiography. An interesting detail is the reference to the ten districts of Bulgaria, which could be used to reconstruct the administrative structures of the Bulgarian kingdom. ${ }^{19}$

15 Responsa, 577, cap. 17: Igitur referentes, qualiter divina clementia Christianam religionem perceperitis qualiterque populum vestrum baptizari omnem feceritis, qualiter autem illi, postquam baptizati fuerunt, insurrexerint unanimiter cum magna ferocitate contra vos, dicentes non bonam vos eis legem tradidisse, volentes etiam vos occidere et regem alium constituere, et qualiter vos divina cooperante potentia adversus eos praeparati a maximo usque ad modicum superaveritis et manibus vestris detentos habueritis qualiterque omnes primates eorum atque maiores cum omni prole sua gladio fuerint interempti, mediocres vero seu minores nihil mali pertulerint: de his nosse desideratis, qui vita privati sunt, utrum ex illis peccatum habeatis. Quod utique sine peccato evasum non est nec sine culpa vestra fieri potuit, ut proles, quae in consilio parentum non fuit nec adverus vos arma sustulisse probatur, innocens cum nocentibus trucidaretur.

16 Zlatarski 1927, 51-57.

17 Gjuzelev 1969, 114-117.

18 Ist. Bălg. 2, 218-219; Božilov/ Gjuzelev 1999, 176.

19 Venedikov 1979, 16-30. 
Another interesting aspect is the number of 52 executed nobles on one side against the 48 supporters of the Khan on the other side. But it is difficult to decide, whether these figures really reveal the ratio of the two parties or whether they are just of a symbolic character. The emphasis on the social aspect of the rebellion is one obvious detail that can be observed. To put it more precisely, the report stresses that the punishment by Boris/Michael was mainly carried out against the members of the noble class. The nobles, the primates and maiores of the Responsa, or the proceres of the Annals of St Bertin, were put to death while the mediocres seu minores of the Responsa or the reliquum populum of the Annals of St Bertin were saved.

We have little evidence as to a social division of Bulgarian society. An inscription probably by Khan Malamir tells us that he held banquets and drinking bouts for Bulgarians while he presented large gifts to the "Boilads" and "Bagaines". ${ }^{20}$ Sometimes we find a combination of the different sectors of society, employing the terms "inside" and "outside". In the Miracle of Saint George with a Bulgarian, George answers the question about his rank by saying that he does not hold any duty and does not live where the king lives but outside. ${ }^{21}$ In the De Ceremoniis by Constantine VII Porphyrogennetos we find a distinction between three groups, six major Boljars, the "inner boyars" and the "outer boyars." 22 An epitaph of the time of Khan Omurtag (814-831) tells us about a nobleman who "died inside"23. From these examples can be concluded that there was a kind of noble class in Bulgaria that was perhaps divided into an inner circle around the Khan himself and his family and an outer circle including, for example, the holders of minor offices..$^{24}$

20 Beševliev 1963, No. 57, 277-278 (text and German translation), 278-280 (commentary);

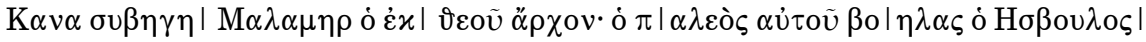

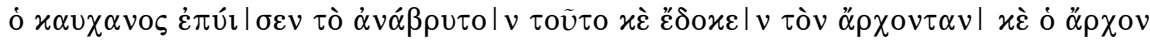

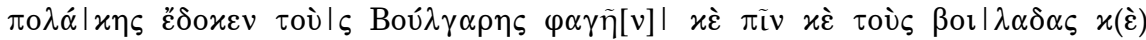

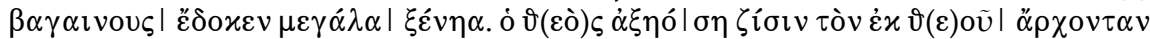

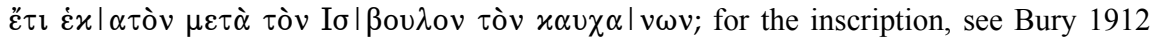
370; Zlatarski 1918, 335; Beševliev 1963, 291; Ist. Bălg 2, 159; Gjuzelev 1999, 157.

21 Loparev 1894, 20; Zlatarski 1921, 303-309; Dujčev 1954, 233-234.

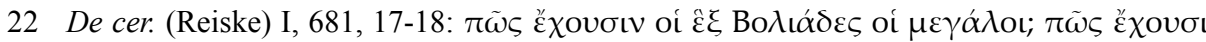

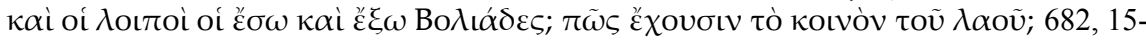
17; Zlatarski 1921, 298-312; Dujčev 1954, 231-244.

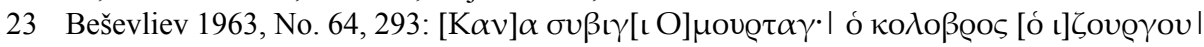

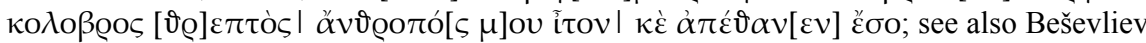
1992, No. 66, 236-237.

24 For a more detailled discussion of this problem: Zlatarski 1921, 298-312; Dujčev 1954, 231-244. 
What can we say about the ethnic make-up of the noble class? Is there really a traditional Proto-Bulgarian class, which tries to defend its privileges and faith against the rising group of Christian Slavs? Actually we do not have any clear evidence for a confrontation between Slavs and Proto-Bulgarians as it was depicted in the historiography. In the middle of the ninth century, Bulgaria had already changed to a multiethnic kingdom. There is evidence for Greek and Slav commanders and artisans in high positions. ${ }^{25}$ When Khan Omurtag talks about moving his army against the Slavs, he talks about those Slavs who lived outside the Bulgarian kingdom and who were integrated step-by-step into the Bulgarian Kingdom in the course of the ninth century. ${ }^{26}$

If there is no clear evidence for a conflict between Slavs and Protobulgarians within the noble class, what can we say about the role that these circles play in relation to Christianization and the revolt against it? For investigating the personal background and the reasons for the rebellion, it is useful to look at its political implications. From the report of the Annals of St Bertin and from the Responsa as well it becomes clear that the Khan did not act on his own, though there is the obvious attempt of mystifying his victory as a sign of God. The number of 48 companions that can be combined with the 58 executed noblemen could also be interpreted as members of the noble class, perhaps the so-called "inner boyars." Many nobles (plures ex proceribus) took also part in the embassy to the pope. In the Responsa we obtain even more information about the relationship between the nobles and Christianization. One of the answers deals directly with the relationship between the Bulgarian king and his nobles. The pope had been asked about his opinion that the Khan was accustomed to having supper at a table separated from the nobles, who had to sit on the floor and had to eat from the ground. The pope did not want to interfere in the customs of the court but advised that the nobles should be regarded with respect and that the kings of the Old Testament used to dine

25 In 813 a Bulgarian embassy led by a certain Dargameros, a Slav, was sent to the emperor Michael in order to start consultations about a peace treaty. Theophanes, Chron. (de Boor),

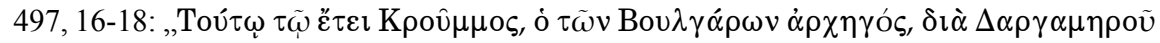

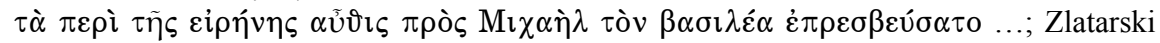
1918, 262, n. 7, 290, 384; Dujčev 1962, 193, Theophanes, Chron. (Mango), 686, n. 2; proof of commanders of most likely non-Bulgarian origin within the Bulgarian army is presented by an inscription with the Greek names: Leon, Bardanes, Johannes, Kordylis and Gregoras (Beševliev 1963, No. 47, 220-229, text 220, 8-221, 30).

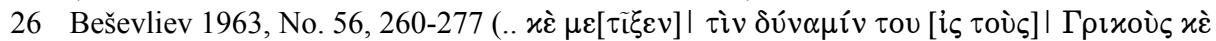
$\Sigma x \lambda \alpha ́ \beta$ ous ...) 
together with their friends and even with their servants. ${ }^{27}$ This can be interpreted as a clear signal for the nobles that in his opinion the Christian faith did not necessitate an exalted position of the ruler as that of the Byzantine emperor, but a moderate relationship between the king and his nobles as in the Frankish Kingdoms. ${ }^{28}$ Nicholas himself sometimes had a tense relationship with the Western emperor Louis II of Italy and he had exercised his power by refusing the divorce of king Lothar II and sealing the fall of his kingdom..$^{29}$ There is no doubt that the Responsa has an anti-Byzantine tendency in criticizing some of the mandates of the Greek clergy in Bulgaria. ${ }^{30}$ In fact Byzantium's Christianization of Bulgaria was not a voluntary act, at least at this point in time and with this method. Though there is early evidence that Khan Boris planned to convert to the Christian faith, it is evident that military failure affected the timing of his final decision. ${ }^{31}$ From that point on Greek clergy poured into Bulgaria, and Patriarch Photios composed a long letter in which he explained the foundations of the Christian faith and the duties of a ruler to the neophyte. ${ }^{32}$ The omnipresence of the Greek clergy, who tried to influence many aspects of the political, social and cultural life of the Bulgarian Empire, is clearly revealed by the Responsa. Cruelty, uncertainty and despotism seem to have stirred up Bulgaria. Obviously the Greeks were blamed for the situation while the Bulgarians hopefully turned to the pope for answers. The desire for a written law is indicated more than one time in the Responsa. It seems that the Responsa are not directed only to the Khan himself but to both the embassy (that is the nobles) and the Khan.

27 Responsa, 583, cap. 42: Asseritis, quod rex vester cum ad manducandum in sedili, sicut mos est, ad mensam sederit, nemo ad convescendum, etiam neque uxor eius, cum eo discumbat, vobis procul in sellis residentibus et in terra manducantibus; et idcirco, quid vobis hinc praecipiamus, nosse desideratis. Unde nos, quia non contra fidem, quod agitur, est, licet bonos mores satis impugnet, non tam praecipientes quam suadentes hortamur, ut ad Christianae religionis cultores principes attendatis et humilitatis eorum considerantes fastigium deponatis ex vobis omne ad nihil utile supercilium; legerunt enim illi in evangelio dicentem Dominum: "Discite a me, quia mitis sum et humilis corde, et invenietis requiem animabus vestris. " Nam antiqui reges, quorum multi sanctorum consortium meruerunt ac ideo veraciter reges dicti sunt, quoniam sancti repperti sunt, cum amicis, quin immo cum servis suis convivati fuisse memorantur; quin potius ipse rex regum et dominus dominantium redemptor noster non solum cum servis et amicis suis, apostolis scilicet, recubuisse, verum etiam cum publicanis et peccatoribus et recubisse et manducasse discribitur.

28 For the image of the Byzantine emperor, see e. g. the papers in: Hunger 1975; for the Frankish Empire, e. g. Hannig 1982; Krah 1987.

29 For Nicolas I., see e. g.: Perels 1920, 53-180; Betz 1965.

30 Dvornik 1948, 114; Heiser 1979, 132-133.

31 Genesios (Lesmueller-Werner/Thurn), 69; Georg. Mon. Cont., 732-733; Skylitzes (Thurn), 91; Sullivan 1966, 69-72.

32 Photios, Epist. (Laourdas / Westerink), 1-39; a commentary is given by White/ Berrigan 1982; Podskalsky 2000, 53-54. 
The question about the sinful deeds of the Khan in acting against the rebellions shows that there was a group that skeptically observed the crude policy of the Khan and its Greek advisors, but instead of returning to the old religion tried to implement a different kind of Christianity and looked for alternatives in the West. It is not by chance that the embassies to King Louis and the pope were directly linked to the rebellion. Furthermore, by asking the pope to send a patriarch, the Bulgarians revealed the wish for an independent church with its own organisation. We cannot be sure whether it was Boris himself who regretted his cruel policy or whether a group of nobles urged him to contact the Western church in order to reduce or eliminate the Byzantine influence in Bulgaria. But it is very likely that the rebellion was a major impetus for a political change, which resulted in the aforementioned embassies to Louis the German and the pope. We can go even further and say that the embassies were a direct consequence of the rebellion. Though after four years of Latin missionary work, the Byzantine church prevailed at last, the Bulgarians achieved their main goal by establishing a more independent organization of their church. After all it seems to be more reasonable to examine the political outcome of the rebellion than to presuppose a conflict between ethnic groups, for which there is no basis in the sources.

These results have consequences for our view of Pliska. Looking at Pliska we have to realize that Pliska is far from being a center of paganism. Though considered to be the capital of the Bulgarian kingdom, neither any grave of a Bulgarian Khan nor a pagan cemetery has been discovered so far. ${ }^{33}$ Instead the latest archeological research calls for reexamination and reinterpretation of the monuments. ${ }^{34}$ But on the other hand we have direct evidence from the Christian era, when Pliska probably became the seat of the Bulgarian Patriarch. ${ }^{35}$ There may even be proof of the Latin mission in Pliska. ${ }^{36}$

In sum, the rebellion of the Bulgarian nobles against Boris/Michael, which has always been interpreted in the framework of a permanent conflict between a traditional Proto-Bulgarian ruling class and Christian Slavs, has to be linked very closely to the embassies to Rome and to Louis the German. The reexamination of the events revealed the existence of an opposition group among the nobles against the policy of Boris/Michael and the Greek clergy. The embassies are probably a direct consequence of the rebellion, and were sent with the expectation that the pope would bring a "better" law, bolster the authority of the nobles against the Bulgarian ruler, and help to establish the organization of an independent church. It is very likely that the later conflicts of the reign of Vladimir Racate, who reigned from 889 to 893, are not just a return to paganism, but have a similar political and personal background to the revolt of 865-866. But this issue requires further study.

33 Rašev/Dimitrov, Pliska, 35 with further literature 71-101.

34 See the other papers of this volume.

35 Georgiev/Vitljanov 2001, 192-201.

36 Georgiev 1993, 110-130. 


\section{Bibliography}

Annales Bertiniani: Georg Waitz (Ed.), Annales Bertiniani (=Monumenta Germaniae Historica SS rerum Germanicarum in usum scholarum 5), Hannover 1883.

Beševliev 1963: Veselin Beševliev, Die protobulgarischen Inschriften, Berlin 1963.

Beševliev 1980: Veselin Beševliev, Die protobulgarische Periode in der bulgarischen Geschichte, Amsterdam 1981.

Beševliev 1992: Веселин Бешевлев, Първобългарски надписи, София ${ }^{2} 1992$.

Betz 1965: Karl-Ulrich Betz, Hinkmar von Reims, Nikolaus I., Pseudo-Isidor: fränkisches Landeskirchentum und römischer Machtanspruch im 9. Jahrhundert, Bonn 1965.

Božilov/Gjuzelev 1999: Васил Гюзелев/Ижан Божилов, История на средновековия България VII-XIV век, София 1999.

Bury 1912: John B. Bury, A History of the Eastern Roman Empire from the Fall of Irene to the Accension of Basile I (802-867), London 1912, reprint 1965.

Cankova-Petkova 1973: Genoveva Cankova-Petkova, "Contribution au sujét de la conversion des bulgares au Christianisme", in: Byzantinobulgarica 4, 1973, pp. 21-39.

De cer. (Reiske): Johann Jakob Reiske (Ed.), Constantini Porphyrogeniti imperatoris De cerimoniis aulae byzantinae libri duo Graece et Latine 1/2, Bonn 1829-1830 (CSHB) (cap. II, 44-45, ed. Haldon, in: Travaux et Mémoires du Centre de recherche d'histoire et civilisation de Byzance, Collège de France 13 [2000], pp. 201-352 [text: pp. 203-235]).

Dujčev 1949: Ivan Dujčev, "Die Responsa Nicolai I. Papae ad Consulta Bulgarorum als Quelle für die bulgarische Geschichte", in: Leo Santifaller (Ed.), Festschrift zur Feier des zweihundertjährigen Bestandes des Haus-, Hof- und Staatsarchivs 1 (=Mitteilungen des österreichischen Staatsarchivs, Ergänzungsband II), Wien 1949, pp. 349-362, reprint in: Ivan Dujčev, Medioevo Bizantino-Slavo I (=Storia e Letteratura. Raccolta Studi e Testi 102), Rome 1965, pp. 125-148.

Dujčev 1954: Ivan Dujčev, "Les boliars dits intérieurs et extérieurs de la Bulgare Médiévale", in: Acta Orientalia Academiae Scientiae Hungariae 3/3, 1954, pp. 167-178, reprint in: Ivan Dujčev, Medioevo Bizantino-Slavo I (=Storia e Letteratura. Raccolta Studi e Testi 102), Rome 1965, pp. 231-244.

Dujčev 1962: Ivan Dujčev, "San Teodoro Studita ed i Bulgari”, in: Bullettino dell'Istituto Storico Italiano per il Medio Evo e Archivio Muratoriano 73, 1962, pp. 71-83, reprint in: Ivan Dujčev, Medioevo Bizantino-Slavo I (=Storia e Letteratura. Raccolta Studi e Testi 102), pp. 193-205.

Dvornik 1948: Francis Dvornik, The Photian schism: history and legend, Cambridge 1948, reprint 1970.

Genesios (Lesmueller-Werner/Thurn): Anni Lesmueller-Werner/Ioannes Thurn (Eds), Iosephi Genesii Regum Libri quattuor (=CFHB Ser. Berolin. 14), Berlin 1978.

Georg. Mon. Cont.: Immanuel Bekker (Ed.), Theophanes Continuatus, Ioannes Cameniata, Symeon Magister, Georgios Monachus, Bonn 1838, pp. 761-924.

Georgiev 1993: Павел Георгиев, Мартириумът в Плиска и началото на християнството в България, София 1993.

Georgiev/Vitljanov 2001: Павел Георгиев/Стоян Витлянов, Архиепископията-манастир в Плиска, София 2001.

Gjuzelev 1969: Ижан Божилов, Княз Борис I., София 1969. 
Gjuzelev 1976: Vasil Gjuzelev, The adoption of Christianity in Bulgaria, Sofia 1976, reprint in Vasil Gjuzelev, Medieval Bulgaria, Byzantine Empire, Black Sea-Venice-Genoa,Villach 1988, pp. 115-127.

Hannig 1982: Jürgen Hannig, Consensus fidelium: frühfeudale Interpretationen des Verhältnisses von Königtum und Adel am Beispiel des Frankenreiches (=Monographien zur Geschichte des Mittelalters 27) Stuttgart 1982.

Heiser 1979: Lothar Heiser, Die Responsa Nicolai I. papae ad consulta Bulgarorum des Papstes Nikolaus I. (858-867): Ein Zeugnis päpstlicher Hirtensorge und ein Dokument unterschiedlicher Entwicklungen in den Kirchen von Rom und Konstantinopel (=Trierer Theologische Studien 36), Trier 1979.

Hunger 1975: Herbert Hunger (Ed.), Das Byzantinische Herrscherbild, Darmstadt 1975.

Ist. Bălg. 2: Димитър Ангелов/Петър Петров/Борислав Примов (Eds), История на България 2: Първа Българска Държава, София 1981.

Ivanov 1943: Йордан Иванов, Старобългарски разкази, София 1943.

Krah 1987: Adelheid Krah, Absetzungsverfahren als Spiegelbild von Königsmacht: Untersuchungen zum Kräfteverhältnis zwischen Königtum und Adel im Karolingerreich und seinen Nachfolgestaaten (=Untersuchungen zur deutschen Staats- und Rechtsgeschichte N.F. 26), Aalen 1987.

Lib. Pont. (Duchesne): Louis Duchesne (Ed.), Liber Pontificalis I-III, Paris I-II 1886/92, III 1957, reprint 1981.

Loparev 1894: Хрисанф М. Лопарев, Чудо святаго Георгия о Волгарине: Памятник византйской преводной литературы, Ст. Петерсбур 1894.

Perels 1920: Ernst Perels, Nikolaus I. und Anastasius Bibliothecarius, Berlin 1920.

Petrov 1964: Петър Петров, “За годаната на налагане на християнството в България”, in: Известия на института за история 14-15, 1964, pp. 569-590.

Petrov 1965: Петър Петров, “Покръстването на Българите”, in: Исторически преглед 21/3, 1965, pp. 33-60.

Photios, Epist. (Laourdas/Westerink): Basilius Laourdas/Leendert Gerrit Westerink (Eds), Photii Patriarchae Constantinopolitani epistulae et Amphilochia I, Leipzig 1983.

Podskalsky 2000: Gerhard Podskalsky, Theologische Literatur des Mittelalters in Bulgarien und Serbien (865-1459), München 2000.

Rašev/Dimitrov 1999: Рашо Рашев/Янко Димитров, Плиска, Шумен 1999.

Regino of Prüm, Chron.: Friedrich Kurze (Ed.), Reginonis Abbatis Prumiensis Chronicon (=Monumenta Germaniae Historica SS rerum Germanicarum in usum scholarum 50) Hannover 1890, reprint 1989.

Responsa Nicolai I papae: Ernst Perels (Ed.), Responsa Nicolai I papae ad consulta Bulgarorum (=Monumenta Germaniae Historica Epp. VI [Karolini Aevi IV] ), Berlin 1925, pp. 568-600.

Sullivan 1966: Richard E. Sullivan: "Khan Boris and the Conversion of Bulgaria: A Case Study of the Impact of Christianity on a Barbarian Society", in: Studies in Medieval and Renaissance History 3, 1966, pp. 53-139.

Theophanes, Chron. (de Boor): Carl de Boor (Ed.), Theophanis Chronographia 1. Textum Graecum continens, Leipzig 1883.

Theophanes, Chron. (Mango): Cyril Mango/Roger Scott/Geoffrey Greatrex (Eds), The Chronicle of Theophanes Confessor: Byzantine and Near Eastern History AD 284-813, Oxford 1997.

Theoph. Cont. (Bekker): Immanuel Bekker (Ed.), Theophanes Continuatus, Ioannes Cameniata, Symeon magister, Georgios monachus, Bonn 1838, pp. 3-431.

Vaillant/Lascaris 1933: André Vaillant/Michael Lascaris, "La date de la conversion des Bulgares”, in: Revue des Études Slaves 13, 1933, pp. 5-15. 
Venedikov 1979: Иван Венедиков, Военното и административното устройсво на България през IX иХ век, София 1979.

White/Berrigan 1982: Despina Stratoudaki White/Joseph R. Berrigan, The Patriarch and the Prince: the letter of Patriarch Photios of Constantinople to Khan Boris of Bulgaria, Brookline Mass. 1982.

Zlatarski 1918: Васил Златарски, История на българската държава през средните векове 1/1, София 1918, reprint 2002.

Zlatarski 1921: Васил Златарски, “Кой са били вътрешни и външни боляри”, in: Юбилеен сборник в чест на Стефан Савов Бобчев, София 1921, pp. 45-57, reprint in: Избрани произжедения 1, София 1972, pp. 298-312.

Zlatarski 1927: Васил Златарски, История на българската държава през средните векове 1/2, София 1927, reprint 2002. 


\title{
Die Ausgrabungen in der Kirche Nr. 2 des Erzbischofsitzes von Drăstăr (1993-1999)
}

\author{
Stefka Angelova
}

Drăstăr, Nachfolger der berühmten römischen Stadt Durostorum, Sitz der XI. claudischen Legion, in der Spätantike bekannt unter dem Namen Dorostolon, ist eines der wenigen Zentren des ersten Bulgarischen Reiches, dessen Stadtgeschichte sich in literarischen, epigraphischen, siegelkundlichen und numismatischen Quellen - mindestens bis ins 12. Jahrhundert - widerspiegelt. ${ }^{1}$ Ein besonderer Akzent lag stets auf der Kirchengeschichte der spätantiken wie der mittelalterlichen Stadt. ${ }^{2}$ Rettungs- und seit Mitte der siebziger Jahre des 20. Jahrhunderts auch reguläre Grabungen zeigen, dass sich der Kern der mittelalterlichen Stadt in den Umrissen der im 6. Jahrhundert am Donauufer errichteten Festung entwickelt hat und während des 9. Jahrhunderts einige Umbauten erfuhr. ${ }^{3}$

Gegenstand der vorliegenden Arbeit sind die zusammenfassende Darstellung der wichtigsten Ergebnisse der archäologischen Untersuchungen der monumentalen Kirche und der sie umgebenden Gebäude sowie einige Angaben über die große Nekropole innerhalb und außerhalb der Kirche (Abb. 1). ${ }^{4}$

Die Kirche wurde zwischen 1993 und 1999 nahezu vollständig freigelegt. Es handelt sich um einen basilikalen Bau, der in seiner Gesamtgestaltung viele Elemente der Kirchenbautradition des 6. Jahrhunderts auf dem Balkan zeigt (Abb. 2). Diese Tradition wurde bei der Mehrzahl der repräsentativen Sakralbauten in den Hauptstädten Pliska und Preslav aus der Zeit der Christianisierung festgestellt. Der Platz für die Errichtung der Basilika und des Gebäudekomplexes, der sie als ein eigenständiges Architekturensemble heraushebt, wurde ausgesprochen passend gewählt. Die Basilika nimmt das zentrale Gebiet des nördlichen Teils der befestigten Stadt ein und war offensichtlich einer der wichtigsten städtebaulichen Akzente im neuen Bauplan, der

1 Ivanov 1925, 282; Mutafčiev 1947, 275; Velkov 1988, 25-31; Beševliev 1979, 198-200.

2 Allgemeine Angaben siehe bei Soustal 1997, 115-125.

3 Angelova 1988, 32-52.

4 Die Ausgrabungen wurden mit Unterstützung des historischen Museums Silistra und der Universität „Kliment Ohridski“, Sofia, durchgeführt. Die digitale Bearbeitung der Pläne und Fotos erfolgte durch Dejan Jankulov (Sofia) und Angela Ehrlich (Frankfurt am Main). 


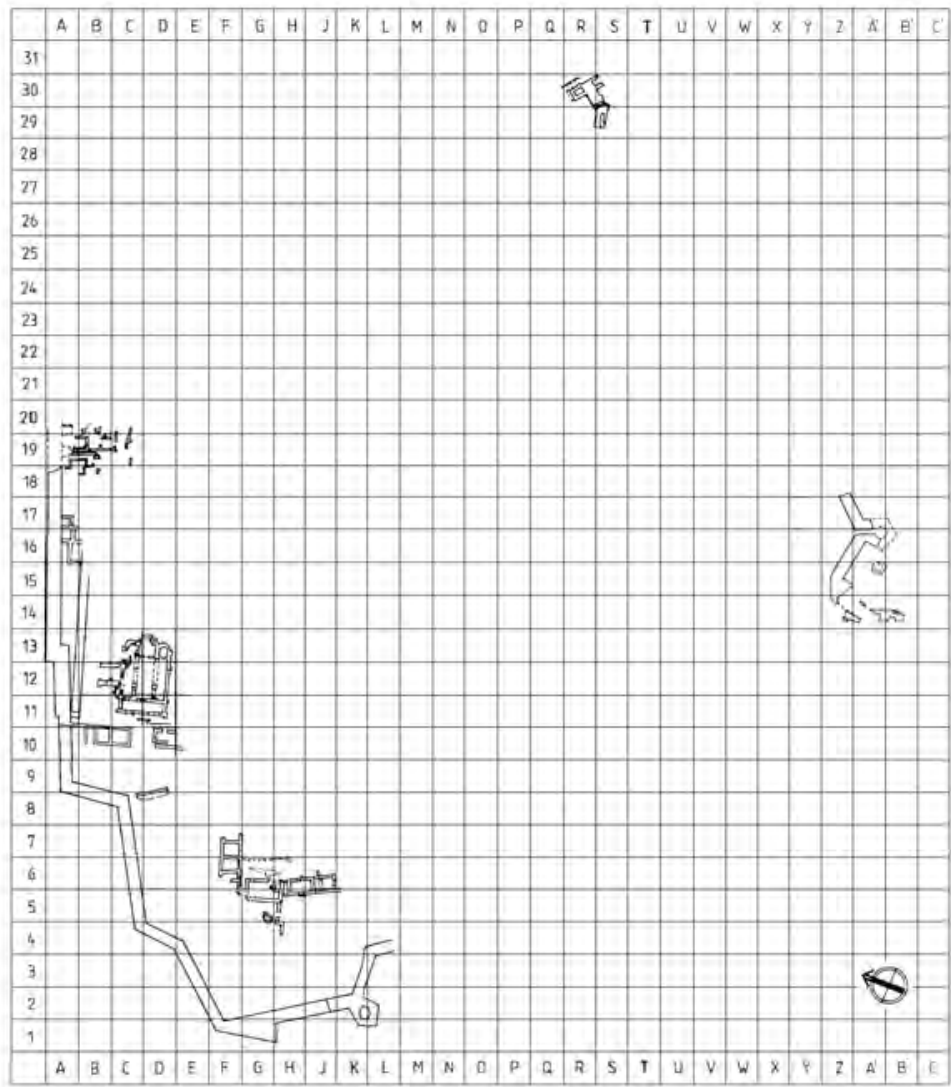

Abb. 1. Rekonstruierter Grundriss der frühbyzantinischen Festung mit Ausbesserungen des 9. Jahrhunderts und Bauten den 9. und 10. Jahrhunderts (1 Quadrat $=10 \times 10 \mathrm{~m})$

am Ende des 9. Jahrhunderts in Drăstăr realisiert wurde. Bei einer Sondage zur Untersuchung der Fundamente der Basilika am zentralen Eingang der Vorhalle zum Naos sowie in einer Sondage östlich des Presbyteriums und im Presbyterium selbst wurde eine Kulturschicht aus der vorchristlichen Periode der Stadt beobachtet, die slawische und protobulgarische Keramik enthielt und in die Zeit vom Ende des 7. bis zum 9. Jahrhundert datiert werden konnte. Hinzu kamen auch frühbyzantinische Funde des 6. Jahrhunderts.

Die 25,40 m x 14,70 m große Basilika wurde am Ende des 9. Jahrhunderts errichtet. Die einräumige, ungegliederte Vorhalle hatte Eingänge von Westen und von Süden. Die drei Schiffe (Mittelschiff $5 \mathrm{~m}$, südliches Schiff $3 \mathrm{~m}$ und nördliches 2,80 m breit) waren mit massiven bis zu $42 \mathrm{~cm}$ hohen Stylobaten voneinander getrennt und mit drei Eingängen versehen. Über den Stylobaten erhoben sich anfänglich je acht massive rechteckige 


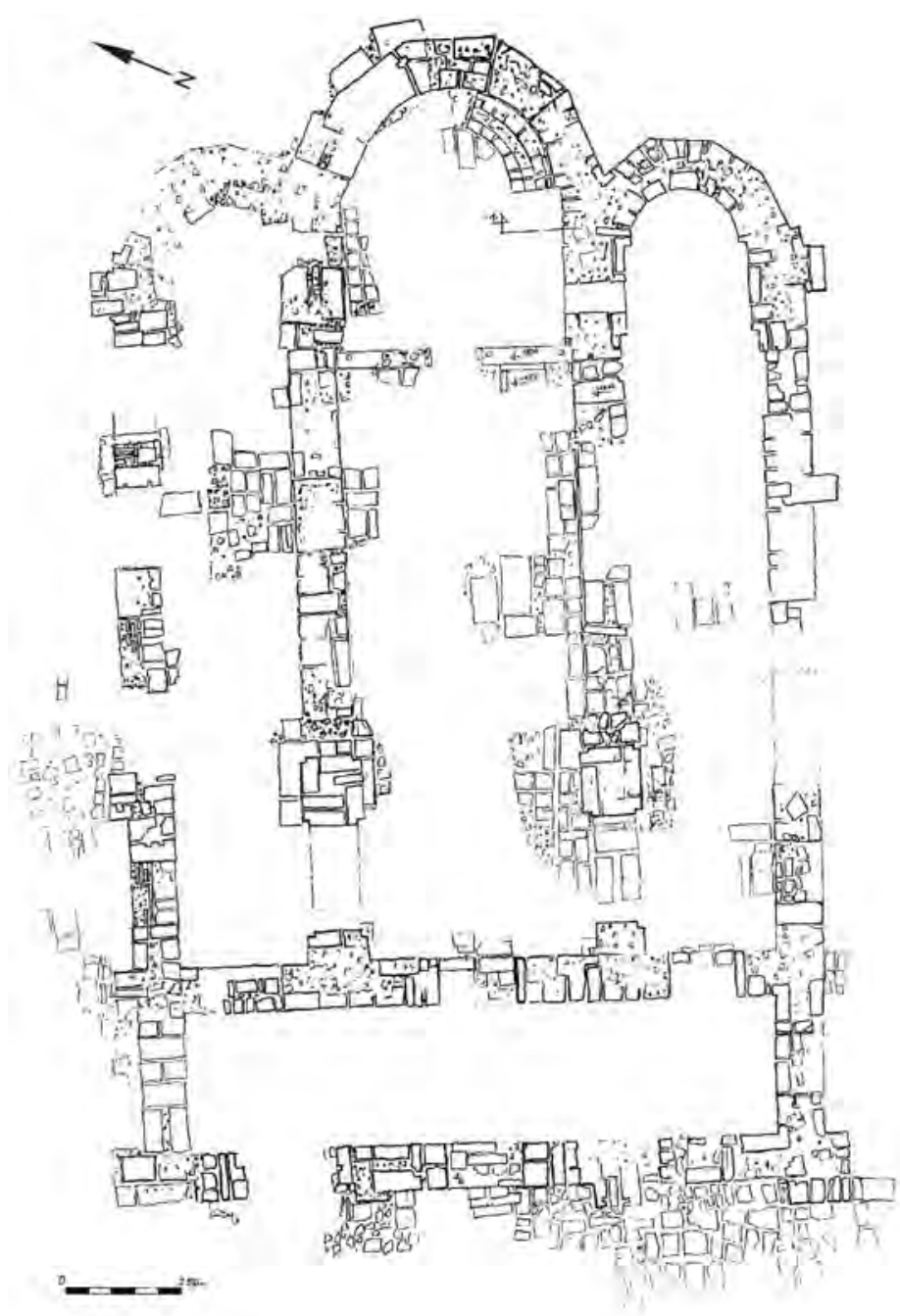

Abb. 2. Grundriss der Kirche des 10.-13. Jahrhunderts

Pfeiler (zwei an der östlichen Wand zur Vorhalle und zwei im Altarraum, Abb. 3), die das Gewölbe trugen. Die drei Schiffe endeten im Osten in einem dreigeteilten Altarraum mit Apsiden, die innen gerundet und von aussen fünfseitig waren. Die nördliche und südliche Apside (Protesis und Diakonikon, Abb. 4) öffneten sich zu den Schiffen hin. Der zentrale Altarraum (Presbyterium) war hingegen vom Mittelschiff durch eine marmorne Kanzel getrennt, über der sich niedrige Altarschranken erhoben, wie sie für die damalige Zeit typisch waren. Südlich vor diesen befand sich ein gemauertes Reliquiarium (Abb. 5). 


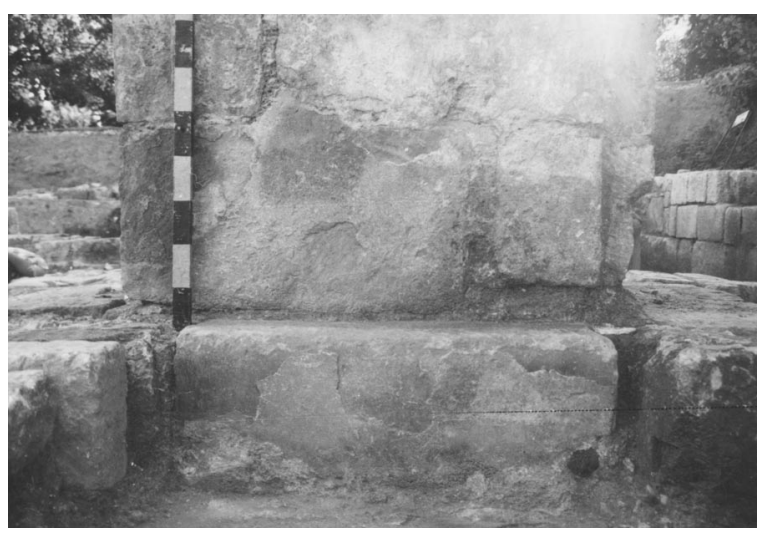

Abb. 3. Pfeiler

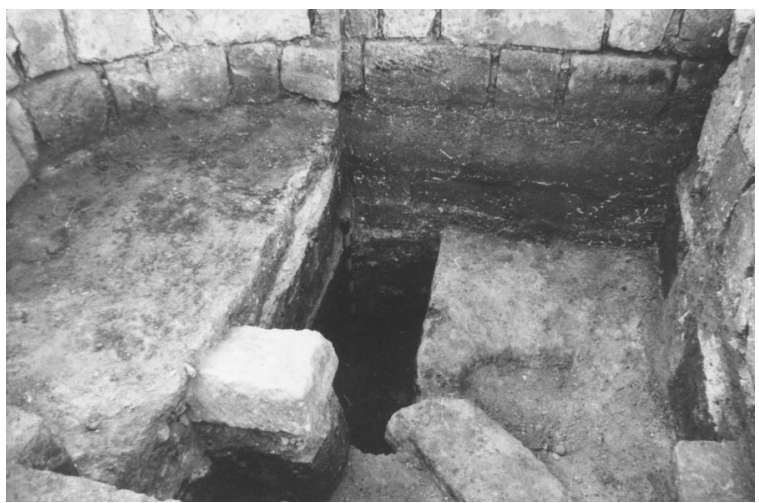

Abb. 4. Diakonikon. Fundamentsondage

Nur wenige Elemente des ersten Kirchenbaues haben sich erhalten. Dies sind in erster Linie die 1,80 m tiefen Fundamente aus Bruchsteinen und kleinen Quadern, die in horizontaler und vertikaler Richtung durch zerbrochene frühbyzantinische Baukeramik ausgeglichen wurden. Als Bindemittel diente ein leicht rötlicher Mörtel. Der eigentliche Bau stand auf einer Ausgleichschicht aus Quadern (Abb. 6). Über dieser Lage sind vom ersten Bau nur noch zwei Reihen des aufgehenden Mauerwerkes vorhanden. Erhalten sind die Stylobate und marmornen Platten des Fußbodenbelages der Vorhalle, der darunter liegende Mörtelestrich sowie eine Mörtelwanne. Die rechteckigen Wandpfeiler, welche wahrscheinlich ein dekoratives Bogensystem an der nördlichen, westlichen und südlichen Fassade stützten, wurden ebenfalls in dieser Zeit errichtet. Beibehalten wurde auch die Anzahl und die Form der Apsiden. Vor der westlichen Fassade erstreckt sich ein Fußboden aus Steinplatten. An einigen Stellen sind in der Kirche Spuren von hellrosafarbenem Feinputz erhalten. Der Bau der von uns so genannten ersten Bauperiode war - auch wenn er nur in zwei Reihen des aufgehenden Mauerwerks erhalten ist - aus sorgfältig bearbeiteten Quadern in Läufer-Binder-Anordnung mit rotem Mörtel aufgemauert. Die Fugen sind mit einer Mörtelmasse von satter roter Farbe verstrichen, die auch einen dekorativen Effekt hatte. 


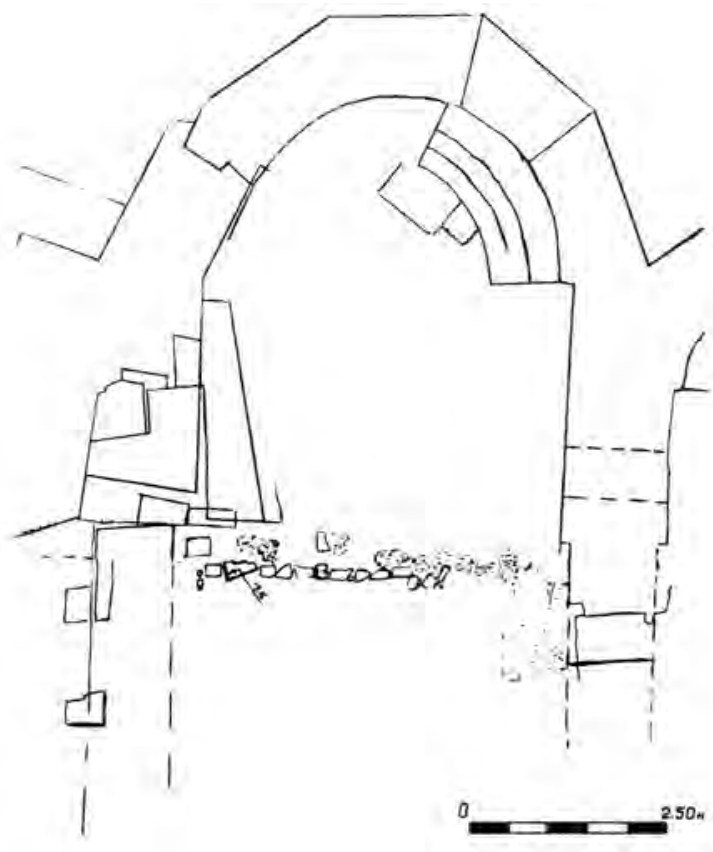

Abb. 5. Presbyterium während der ersten Bauphase. Fundament der Kanzel und des Reliquiariums

Die ungegliederte Vorhalle, die schmalen, durch massive und hohe Stylobate vom Hauptschiff getrennten Seitenschiffe, der dreigeteilte Altarraum mit den von außen fünfseitigen Apsiden, das dekorative Arkadensystem an der Fassade des Baues sowie die Bautechnik sind Elemente der frühbyzantinischen Kirchenbauweise. Wie bereits erwähnt, erschien diese Tradition in den monumentalen Kirchen des ersten Bulgarischen Reiches in den letzten Jahrzehnten des 9. bis 10. Jahrhunderts.

Bereits in der ersten Hälfte oder der Mitte des 10. Jahrhunderts wurde die Basilika in Drăstăr zu einer Kuppelbasilika umgebaut und im Presbyterium ein dreistufiges Synthronon errichtet (Abb. 2). Die drei steinernen Sitze des Synthronon stehen auf einer Ausgleichschicht aus drei Reihen Ziegeln. Dem Altarraum war zusätzlich ein Raum vor der Protesis und wahrscheinlich auch einer vor dem Diakonikon angegliedert. Das Fußbodenniveau wurde um durchschnittlich $60 \mathrm{~cm}$ angehoben. Die vier zentralen Pfeilerpaare und diejenigen an der westlichen Wand des Naos wurden durch Erweiterungen in kreuzförmige umgewandelt. Diese Erweiterungen wurden mittels zusätzlicher Bruchsteinmauern unterfangen. Der neue Fußbodenbelag aus Quadern, Kalkstein- und Marmorplatten erfuhr häufig Erneuerungen, da die Kirche in dieser Gestalt fast bis in die Mitte des 13. Jahrhunderts in Benutzung war. Darüber erkennt man klar die Brandspuren aus dem Jahre 1242, die von einem Tatarenüberfall herrühren, der die Gebäude in der gesamten ummauerten Stadt vernichtete. ${ }^{5}$

5 Penčev 1987, 26-29. 


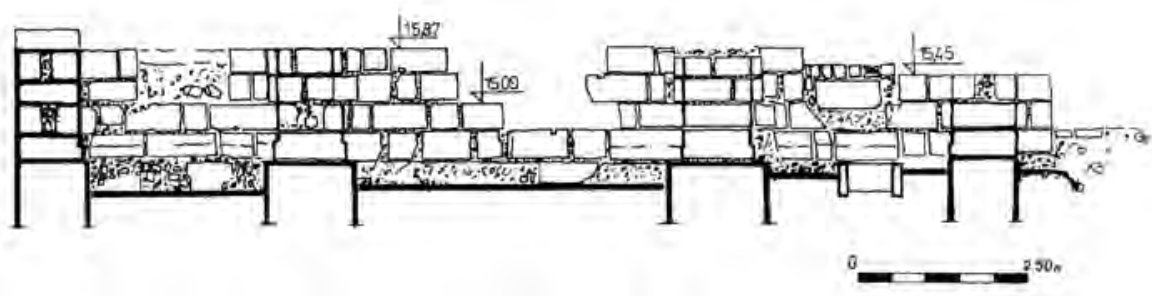

Abb. 6. Ostwand der Vorhalle. Blick von Osten

Der Belag ist außerdem durch eingebrachte Bestattungen, vornehmlich des 14. Jahrhunderts, stark beschädigt.

Beim Umbau der Kirche (als zweite Bauphase bezeichnet), wurden folgende Veränderungen vorgenommen: In die nördliche und südliche Mauer wurden von innen je drei einstufige Nischen aus Ziegelsteinen eingelassen, die wahrscheinlich von Bögen abgeschlossen wurden (Abb. 7). Entlang der Wände erscheinen mehrfarbige Fresken, die trotz ihres fragmentierten Zustandes erlauben, die Gestalten von heiligen und weltlichen Personen sowie geometrische und florale Motive zu identifizieren (Abb. 8). Die Farben sind vielfältig und satt - Ockertöne, Weiß, Zinnoberrot, Dunkelrot, Braun, Blau in verschiedenen Nuancen, Grün, Gelb u.a. kommen vor. Malereien fanden sich auch auf Säulen der Altarschranken, Gesimsen und ähnlichen Baugliedern. An einigen Stellen wurden die Malereien direkt auf den älteren, hellrosafarbenen Putz aufgetragen. Die Menge der gefundenen Fragmente zeigt, dass nicht die gesamte Kirche bemalt war. Wir haben Grund zu der Annahme, dass auch während dieser Bauphase die marmorne Kanzel in Benutzung war. Auch das gemauerte Reliquiarium vor der Kanzel wurde wiederhergestellt, wobei sein Standort leicht nach Norden verschoben wurde.

Von der Bauornamentik der Kirche sind die meisten der aus Kalkstein, marmorisiertem Kalkstein und seltener aus Marmor gearbeiteten Gesimse erhalten. Diese stammen vornehmlich von den Zierleisten unterhalb des Daches und können dem Typ Preslav zugeordnet werden. Spezifisch sind hier der stark ausgestülpte runde Torus und ein oder zwei Reihen Zahnschnitt. Zahlreich sind die rechteckigen und quadratischen Platten des als opus sectile ausgeführten Fußbodens, der wahrscheinlich einen Großteil des Bodens bedeckte. Kleine Tesserae aus farbigem Marmor und Glas weisen dazu auf andere Mosaiktypen hin. Die Fenstergläser von $18 \mathrm{~cm}$ Durchmesser sind aus grünlichem, halbdurchsichtigem Glas. Der Oberteil einer Säule aus feinem weißen Kalkstein mit pilzförmigem Abschluss lässt an das Vorhandensein eines Ambo denken, der möglicherweise aufgrund der zahlreichen späteren Zerstörungen des Interieurs nicht gefunden wurde. Zahlreich wurden auch Gesimse und Kapitelle freigelegt, auf denen Reste von Bemalung sichtbar sind (Abb. 9).

Während dieser Periode wurde ein steinernes Verbindungsgebäude westlich der Kirche errichtet. Der Raum zwischen beiden Gebäuden war mit Steinen gepflastert. Von 


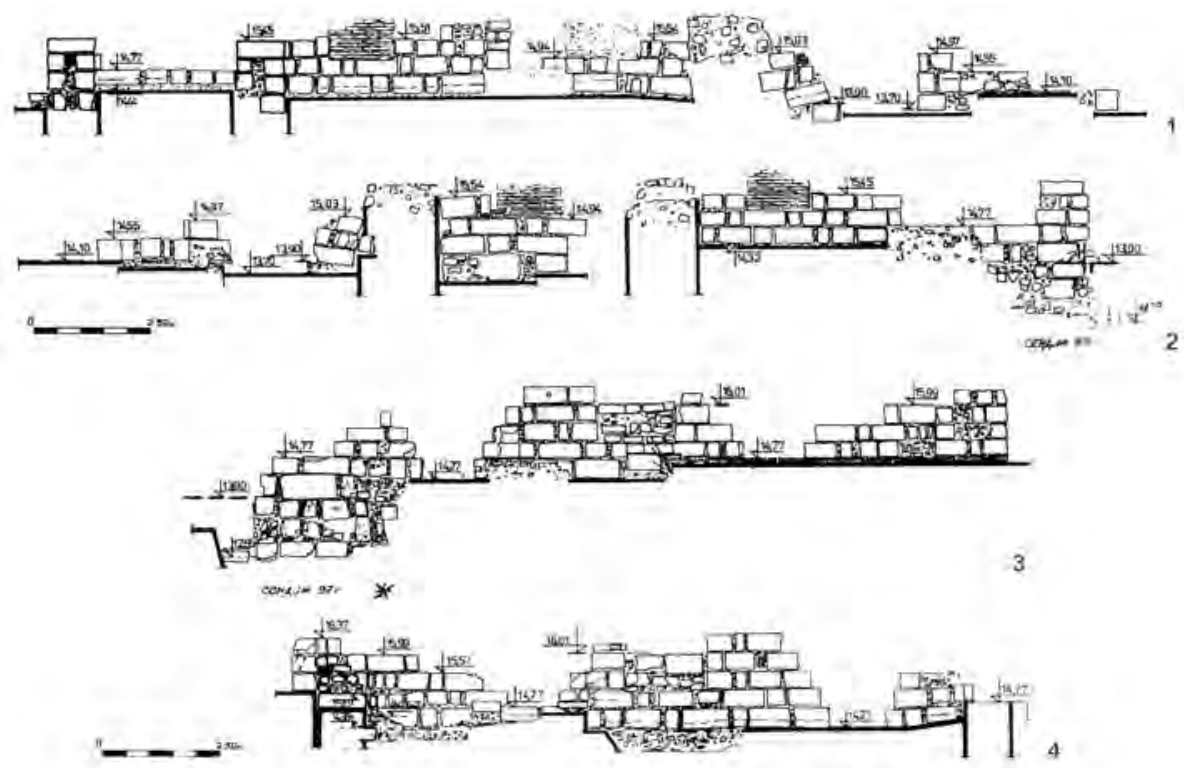

Abb. 7. 1. Nordwand, Blick von Norden; 2. Nordwand, Blick von Süden; 3. Vorhalle: Westwand, Fassade; 4. Vorhalle: Westwand, Blick von Osten

diesem Bau wurden bislang sechs Räume freigelegt, von denen der nördlichste mit der nördlichen Festungsmauer verbunden ist, die ebenfalls im 9. Jahrhundert wiederhergestellt wurde. So formiert sich ein Gebäudekomplex um die Kirche herum, der sie aller Wahrscheinlichkeit nach auch von Süden und Osten umgrenzte. Ein sicheres Zeugnis der Existenz von Bauten in Süden sind die hier freigelegten Fußbodenpflasterungen. Südlich der Kirche wurden in den letzten Jahren außerdem massive Basen und Säulentrommeln aus feinem, gelblichem Kalkstein gefunden. Diese gehörten zu einer Kolonnade oder einer gedeckten Galerie. Das Baptisterium wurde bislang nicht entdeckt. Der nördliche Hof des Komplexes wird von der Festungsmauer begrenzt. Zwischen dieser und der nördlichen Wand der Kirche erstreckte sich ebenfalls ein Fußbodenbelag.

An dieser Stelle soll angemerkt werden, dass die Kirche bislang das einzige Gebäude in Drăstăr ist, das während der Petschenegeneinfälle der Jahre 1036 und 1048 nicht von Bränden in Mitleidenschaft gezogen wurde. Unabhängig davon diente sie während dieser Zeit wohl kaum als Kirche, da Keramik- und Münzfunde aus der zweiten Hälfte des 11. Jahrhunderts bezeugen, dass ein Teil der Vorhalle, die zentrale Apsis und der östliche Teil des Nordschiffes zu Wohnzwecken genutzt wurden. Damals war das Reliquiarium teilweise zerstört und möglicherweise geplündert worden. Die Mehrzahl der Gräber und Häuser des 11. Jahrhunderts wurden außerhalb der Kirche freigelegt. Wir möchten weiterhin erwähnen, dass sich Petschenegengräber auch innerhalb der Kistengräber des 9. und 10. Jahrhunderts in der Nordhälfte der Vorhalle und 


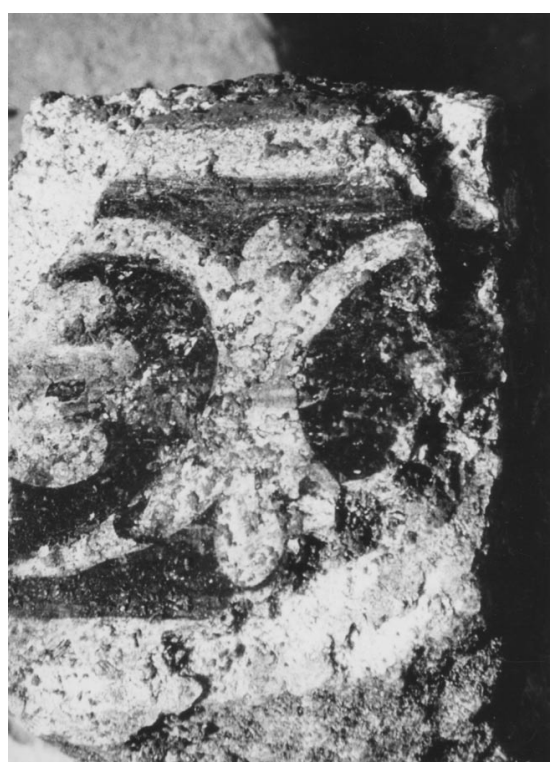

Abb. 8. Palmettenfries von der Ausmalung der Kirche im 10. Jahrhundert

in der westlichen Hälfte des Nordschiffes fanden. In der Mehrzahl der Fälle stören die Gräber des 11. Jahrhunderts nicht die älteren Bestattungen.

Niedergebrannt und stark zerstört sind die Gebäude im Westen sowie der Bodenbelag des nördlichen und südlichen Hofes. Hier wurden ebenerdige Bauten und Grubenhäuser, Abfallgruben und zahlreiche Gräber gefunden, die aufgrund von stratigraphischen Beobachtungen und wegen ihres Charakters in das 11. Jahrhundert datiert werden können. Solche Häuser zeigen sich auch innerhalb der Grenzen des Verbindungsbaues westlich der Kirche. Es ist zu erwarten, dass auch in den noch nicht freigelegten Flächen des südlichen und östlichen Hofes die Situation in der zweiten Hälfte des 11. Jahrhunderts nicht grundsätzlich verschieden ist. Alle diese Angaben bewegen uns zu der Annahme, dass die Kirche während dieser Zeit nicht in Benutzung war. Noch geringer sind die Angaben über das Schicksal des Komplexes während des 12. Jahrhunderts, als sich die byzantinische Herrschaft an der unteren Donau stabilisierte. Münzen des 12. Jahrhunderts sind ausgesprochen selten. Sporadisch findet sich gut datierbare Importkeramik aus dieser Zeit. Ebenso verhält es sich mit kunstgewerblichen Gegenständen aus Metall, Knochen, Steatit u.a. Von den Ausgrabungen des Komplexes sind bisher keine Siegel des 12. Jahrhunderts bekannt. Drăstăr wird in den Kirchenurkunden aus der Zeit des Kaisers Alexios I. Komnenos (1081-1118) als Metropolis erwähnt. Aus einer Urkunde des Jahres 1143 von Nil Doksopatros geht hervor, dass der Metropolis in Drăstăr fünf Bistümer untergeordnet waren. An die Metropolis in Drăstăr sind außerdem Briefe des byzantinischen Poeten Johannes Zezes adressiert, die zwischen 1143 und 1154 geschrieben wurden. Es wäre jedoch riskant, die Metropolis von 

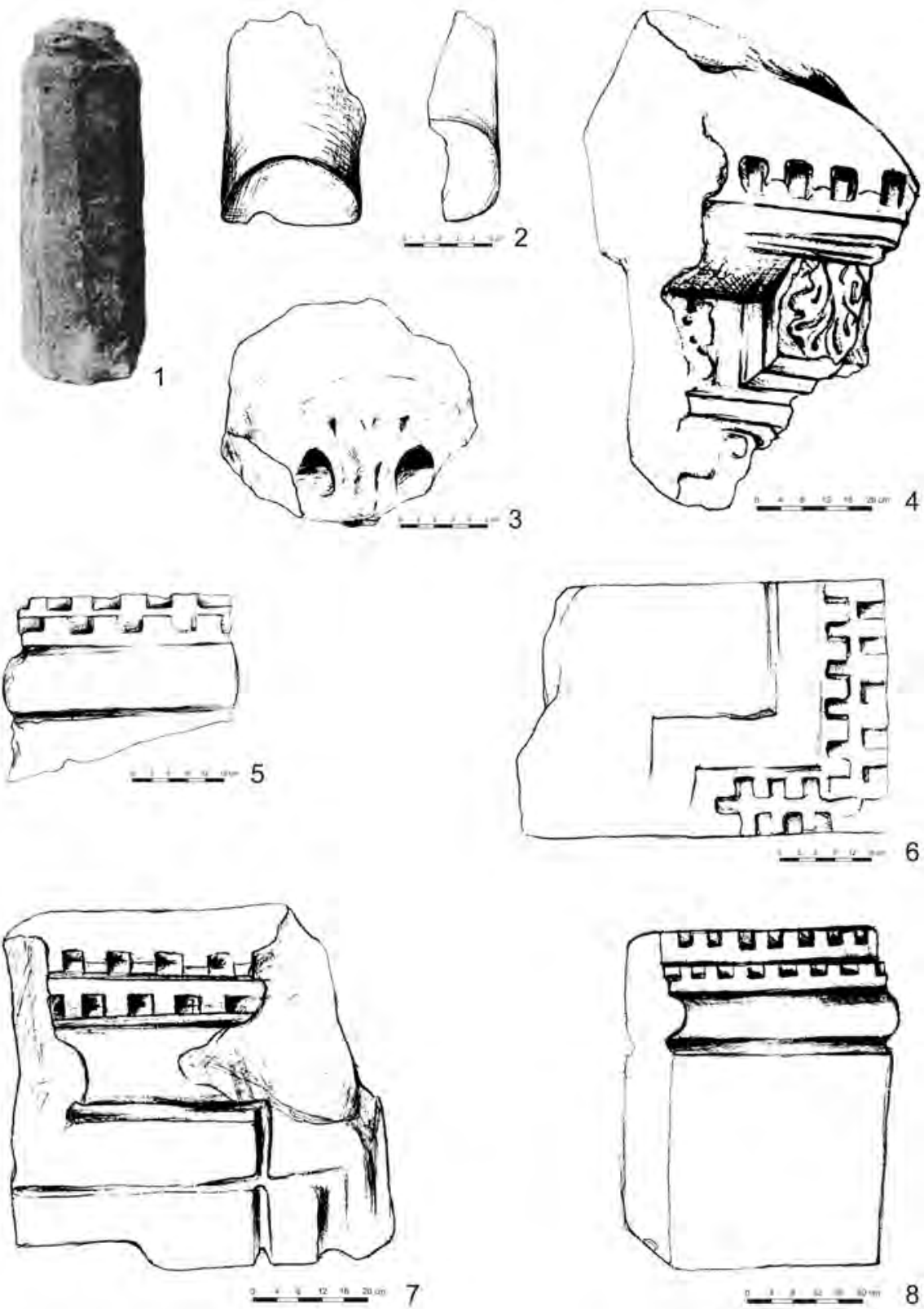

Abb. 9. Architekturfragmente des Kirchenschmucks. 1.-2. Kleine Säulen der Altarschranken; 3.-8. Kapitelle und Gesimse 
Drăstăr des 11. und 12. Jahrhunderts mit der von uns untersuchten Kirche zu verbinden. Für eine solche Lokalisierung sind weitere archäologische Untersuchungen erforderlich. Die Erforschung dieses monumentalen Komplexes aus der Zeit des ersten Bulgarischen Reiches trägt nicht dazu bei, eines der grundlegenden Probleme der archäologischen Forschung - die Topographie von Drăstăr während des 12. Jahrhunderts - zu lösen.

Mehrdeutig sind die Angaben über das Schicksal der Kirche während des 13. Jahrhunderts. Einerseits wird die Ansicht, der Bau hätte bis zum Überfall der Tataren im Jahre 1242 bestanden, durch die Spuren eines Brandes direkt über dem Bodenbelag des 10. Jahrhunderts, über den Stylobaten und dem zugemauerten Eingang von der Vorhalle zum Nordschiff bestärkt. Geborgen wurde eine große Zahl von Münzen bulgarischer Prägung, Gepräge aus Thessaloniki und Konstantinopel sowie lateinische Imitationen. Alle wiesen Spuren starker Brandeinwirkung auf. Man fand jedoch über der durchschnittlich $50 \mathrm{~cm}$ mächtigen Zerstörungsschicht - beispielsweise im westlichen Teil des Mittelschiffes und im zentralen und südlichen Teil der Vorhalle - Spuren von Feuerstellen, Fußbodenschichten mit Ziegelsteinlagen und Abfallgruben, die als sichere Anzeichen einer - wenngleich kurzen - profanen Nutzung der Kirche zu Wohnzwecken zu gelten haben.

Spuren eines zweiten Bodenniveaus fehlen völlig. Keramik und Münzen des 13. Jahrhunderts finden sich auf dem Höhenniveau $15,05 \mathrm{~m}$, was zeigt, dass diese Häuser in die Trümmer der allmählich zerfallenden Kirche eingetieft wurden. In der Vorhalle befanden sich auch Gräber, die sicher in das 13. Jahrhundert datiert werden können, obwohl die Gräber dieser Zeitstellung in ihrer Mehrzahl außerhalb der Kirche lagen.

Bauliche Überreste von Häusern mit Quadern, welche aller Wahrscheinlichkeit nach aus der Zerstörung der obersten Teile der Kirche oder aus anderen monumentalen Bauten stammen, wurden südlich der Kirche gefunden. Als Bindemittel diente hier Lehm. Die Mehrzahl dieser Gebäude war, ältere Gräber überdeckend, an die südliche Fassade der Kirche gebaut. Die Gebäude wiederum wurden von späteren Bauten gestört oder es befanden sich jüngere Gräber über ihnen. Fußbodenpflasterungen, Überreste von Feuerstellen oder Öfen sowie der Inhalt der Kulturschicht, wie zahlreiche Keramik, Haushaltsgegenstände und andere mit dem Alltagsleben im Zusammenhang stehende Funde bezeugen die Funktion dieser Gebäude. Besonderes Interesse verdient ein zweiteiliges Gebäude über den Ruinen des Verbindungsbaues, das die Basilika von Westen begrenzt. Wie wir bereits erwähnt haben, wurde dieses Verbindungsgebäude bei einem Brand zerstört. Die baulichen Überreste wie auch die zahlreichen ebenerdigen Wohnbauten und die Grubenhäuser mit Münzfunden und anderen Funden des 11., 12. und 13. Jahrhunderts, haben das Bodenniveau um ca. $1 \mathrm{~m}$ angehoben. Wie sich bei weiteren Untersuchungen herausstellte, wurden vor der Errichtung des zweiteiligen Baues einige Grubenhäuser und Abfallgruben in das Verbindungsgebäude und außerhalb der Räume eingetieft, die aufgrund der Münz- und anderer Funde an das Ende des 12. und den Beginn des 13. Jahrhunderts datiert werden müssen. 


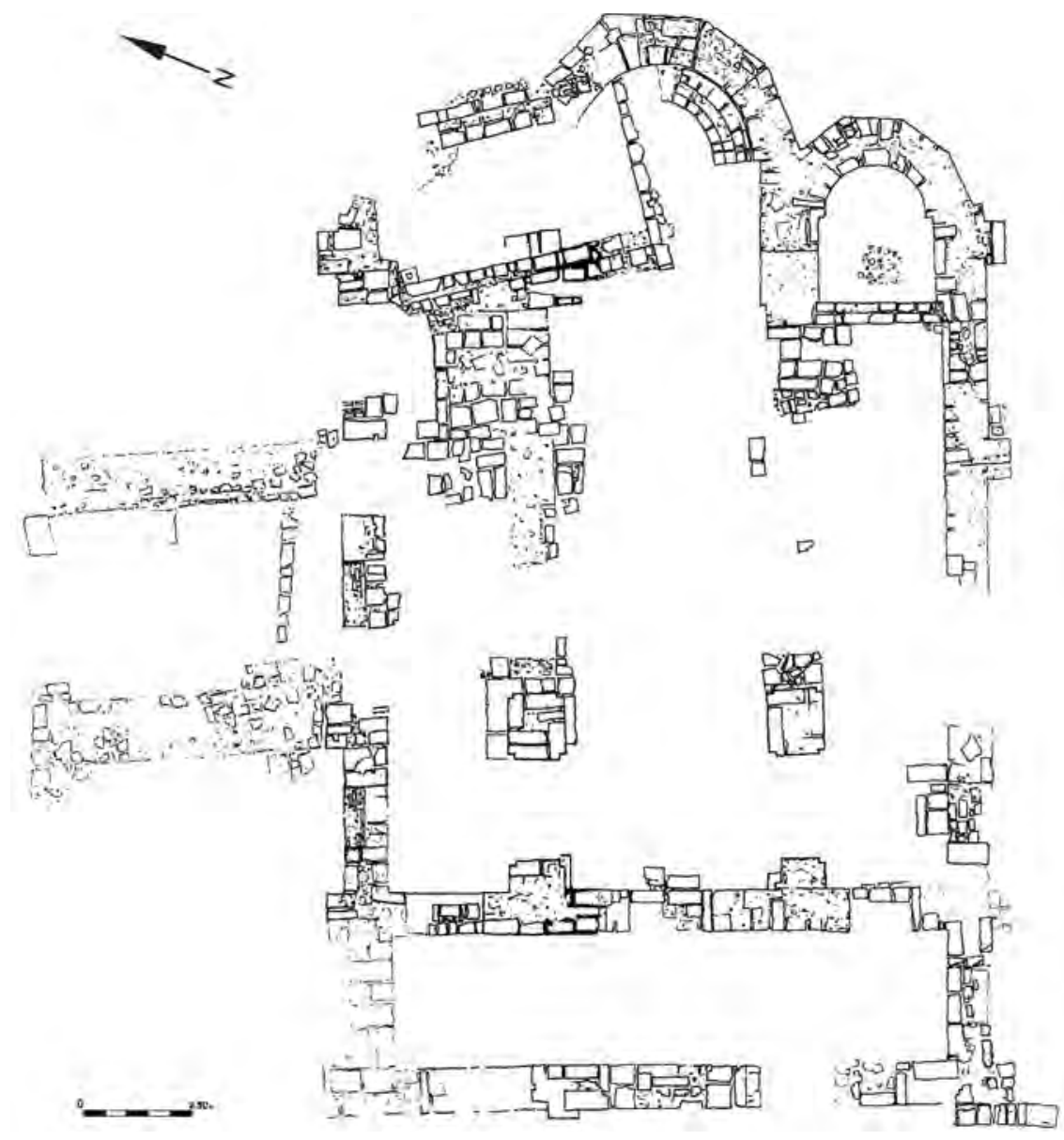

Abb. 10. Grundriss der Kirche in den letzten Jahrzehnten des 14. Jahrhunderts

Das zweiteilige Gebäude mit den inneren Abmessungen von $4 \mathrm{~m}$ ist nach Osten verschoben. Seine Mauerflucht beeinträchtigte nicht die Mauern des Verbindungsgebäudes aus dem 10. Jahrhundert. Die $75 \mathrm{~cm}$ breiten Mauern gründen auf $55 \mathrm{~cm}$ tiefen Pfeilern in einer Schicht aus planiertem Bauschutt. Das Gebäude wurde bei einem schweren Brand im 13. Jahrhundert, wahrscheinlich ebenfalls 1242, zerstört, wobei der gesamte Hausrat und viele Münzen erhalten blieben. Das Gebäude wurde während des 14. Jahrhunderts neu erbaut. Dabei entstanden durch eine Längs- und zwei Quermauern sechs Wohnräume. In einem dieser Räume wurde eine Matrize für Wachssiegel mit der Darstellung eines doppelköpfigen Adlers gefunden. Das neu errichtete Gebäude wurde ebenfalls durch einen Brand vernichtet, der durch Münzen des Ivan Strazimir, Ivanko Terter, Murad I. (1362-1389) und Bajasid I. (1389-1402) datiert werden kann. 
Die Geschichte der Kirche während des 13. Jahrhunderts ist repräsentativ für die gesamte Stadt. Wenn wir die Angaben zur Geschichte des Komplexes während des 13. Jahrhunderts verallgemeinern, so könnte man annehmen, dass die Kirche, zumindest bis zum Brand 1242 in eine Gemeindekirche umgewandelt worden war, die in einem dicht bebauten Wohnviertel stand. Die Bevölkerung fuhr fort, um die Kirche herum zu bestatten. Gräber mit Merkmalen des 13. Jahrhunderts fanden sich nur in der Vorhalle. Auf den baulichen Zustand der Kirche selbst wurde keine besondere Sorgfalt gelegt. Die Wandmalereien verfielen nach und nach, so dass sich Fragmente davon in den Füllungen der Gräber und in Abfallgruben fanden, die durch Münzen des 13. Jahrhunderts datiert werden können.

Die Namen einiger Metropoliten aus Drăstăr wie Kyril, Averkios, Theodul, Joseph und Kalinik wurden laut P. Mutavčiev unzweifelhaft erst später in den Synodikos des Boril aufgenommen und standen darüber hinaus an letzter Stelle unter den Hierarchen der nordbulgarischen Territorien. Mutavčiev unterstreicht diese These damit, dass mit der Gründung des zweiten Bulgarischen Reiches der Metropolit von Drăstăr die Zugehörigkeit und den Rechtsstand, erster unter seinen Brüdern in den nordbulgarischen Ländern zu sein, an das Erzbistum Tărnovo abgetreten habe. ${ }^{6}$

Bei den Grabungen und zufälligen Freilegungen auf dem Territorium von Drăstăr wurden bislang keine Spuren von Kirchenbautätigkeiten im 13. und 14. Jahrhundert gefunden. Wir können daher wohl mit Recht annehmen, dass die bestehenden Kirchen renoviert und weiter genutzt worden sind. Kann aber diese Kirche auch die Funktionen einer Metropoliten- und Gemeindekirche erfüllt haben?

Unserer Meinung nach ist das sehr gut möglich. In diesem Falle war das im Jahre 1242 verbrannte Gebäude westlich der Kirche möglicherweise das Wohnhaus des Metropoliten von Drăstăr aus der ersten Hälfte des 13. Jahrhunderts. Die Funde aus der Brandschicht haben sehr repräsentativen Charakter. So überwiegt die graphitierte Keramik gegenüber der einfachen Haushaltskeramik. Auch gehören die Gräber innerhalb der Vorhalle und die meisten außerhalb der Kirche begüterten Personen.

Nach dem Brand von 1242, der bei allen bisher untersuchten Gebäuden nachgewiesen werden konnte, folgt eine Unterbrechung der Siedlungsaktivität, welche sich klar durch das Fehlen von Münzen und anderen Materialien aus der zweiten Hälfte des 13. und dem Beginn des 14. Jahrhunderts abzeichnet.

Vergleichbar ist auch die Situation in der Basilika und den sie umgebenden Gebäuden. Durch Schutt erhöhte sich das Niveau innerhalb des Gebäudes um 70 bis $80 \mathrm{~cm}$. Auf einem Niveau von 15,80 m wurden die Überreste eines dritten Fußbodenbelages gefunden, d.h. 1,40 m über dem ersten Laufhorizont. Teile davon, wie Steinplatten, Architekturfragmente und Ziegel, fanden sich im Bereich vor dem Altarraum und in einem Teil des Mittelschiffs der Kirche (Abb. 10). In den Fußboden wurde auch ein 

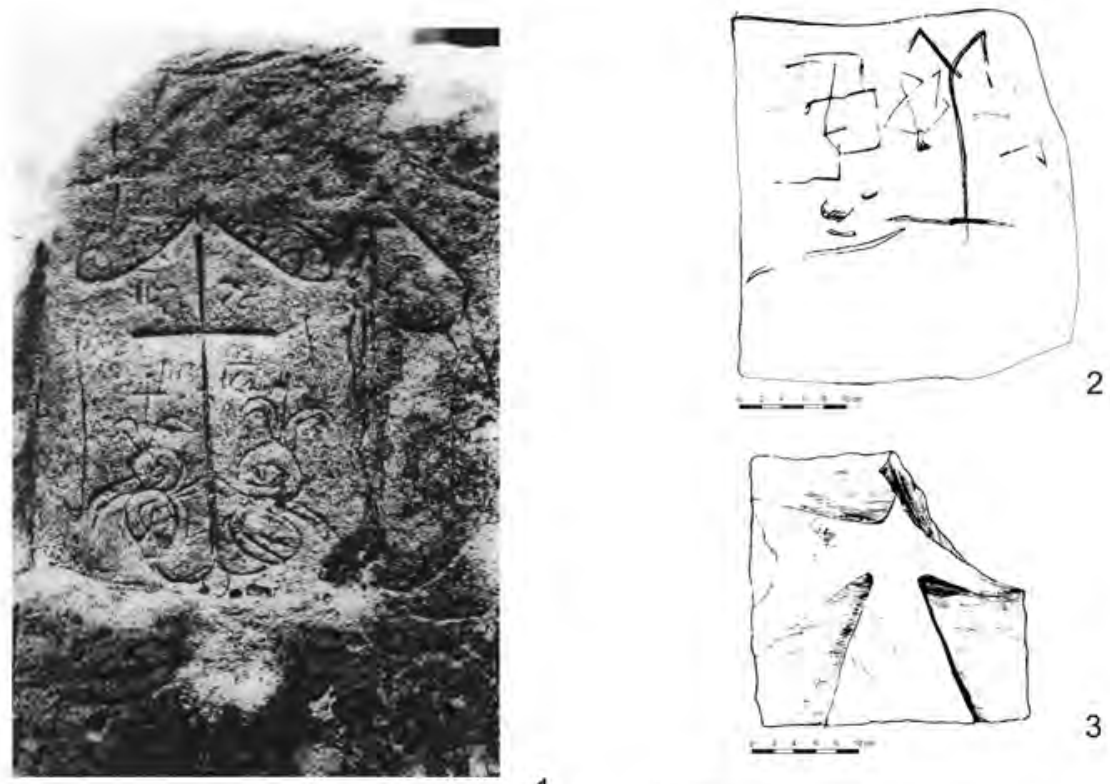

1
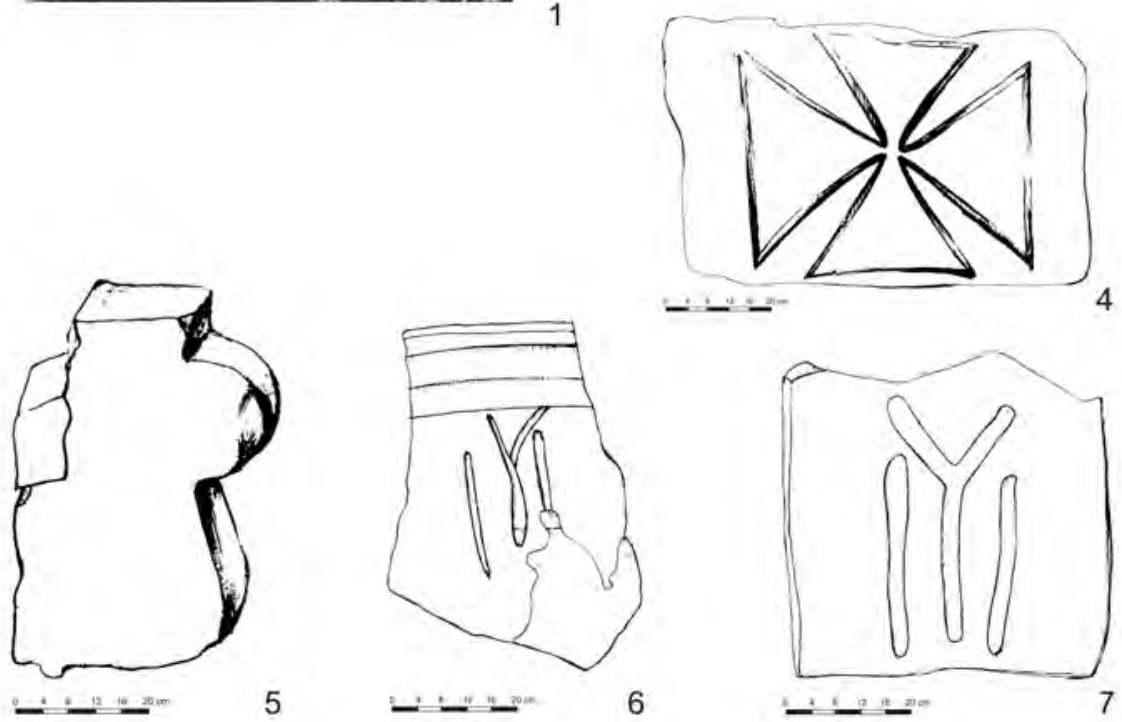

Abb. 11. 1. Zeichnung der Kirche an der Innenwand der Vorhalle (Graffito); 2. Stein mit Graffito; 3. Stein mit Kreuzrosette, in der Kirche verbaut; 4. Grabkreuz, im 14. Jahrhundert in den Bodenbelag eingelassen; 5. Frühbyzantinischer Ziegel, für die Ausschmückung der Kirche verwendet; 6. 7. Ziegel (imbrex und tegula) aus dem 9.-10. Jahrhundert 

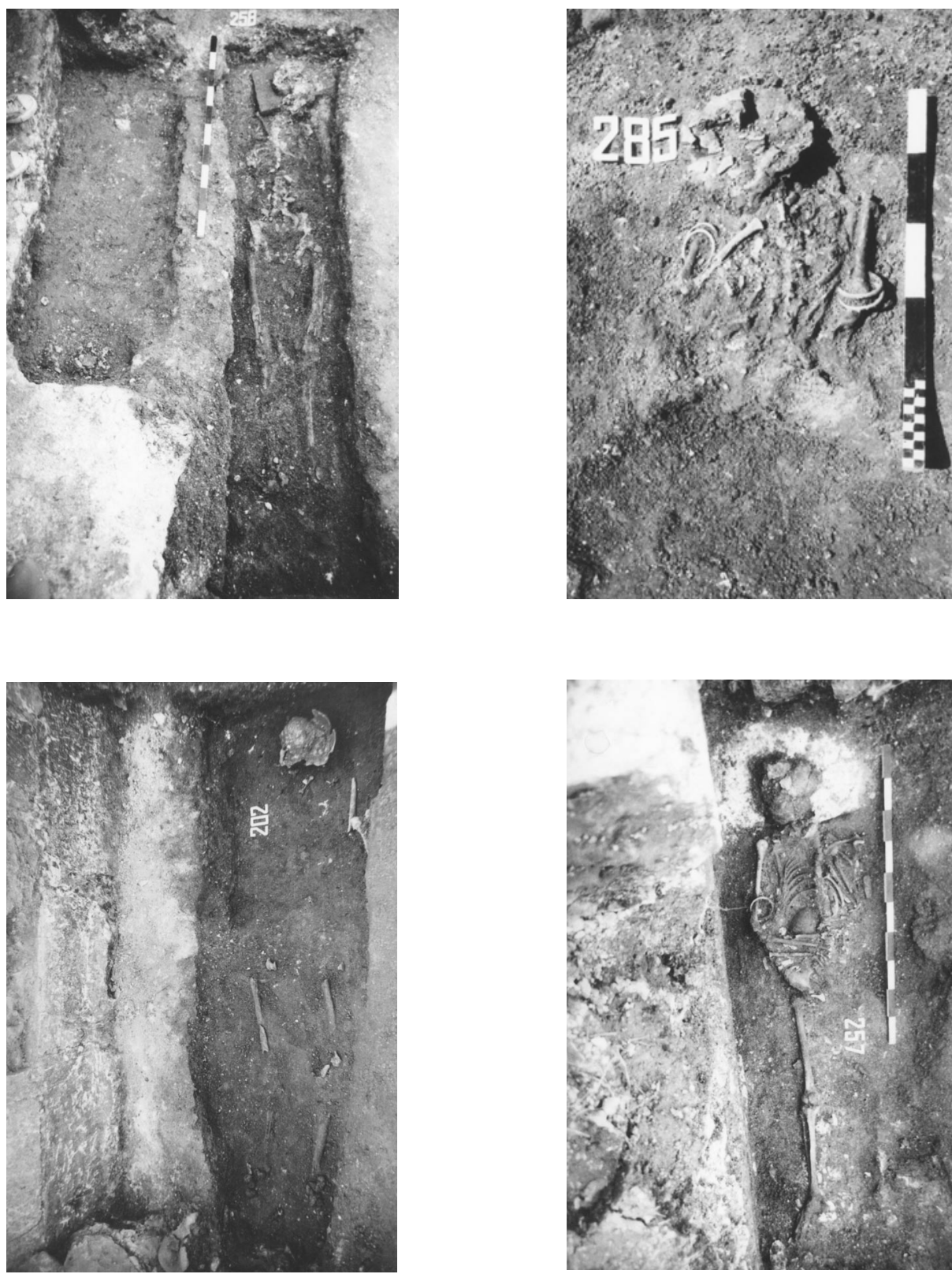

Abb. 12. Gräber aus der Zeit vom 11. bis Mitte des 12. Jahrhunderts (Gräber Nr. 199/200, 285, 202, 257) 
großes steinernes Kreuz eingearbeitet (Abb. 11,4). Im südlichen Abschnitt fanden sich verbrannte Gegenstände und Münzen des Dobrotiza, die in Drăstăr in den 70er Jahren des 14. Jahrhunderts geprägt wurden sowie Münzen von Ivanko Terter, Ivan Alexander und der Zarin Theodora. Wahrscheinlich wurde in den letzten Jahrzehnten des 14. Jahrhunderts in einem Teil des Presbyteriums und über den Ruinen der Nordapsis ein zweigeschossiges Gebäude errichtet (Abb. 10). Davon sind lediglich das Kellergeschoss und einige Elemente, die mit der Konstruktion der ersten Etage verbunden waren, erhalten. Obwohl der Bau mit Lehm als Bindemittel errichtet wurde, sind die Wandverkleidungen sorgfältig aus Quadern gearbeitet, die wahrscheinlich aus den zerstörten Bereichen der Kirche genommen wurden. Das Kellergeschoss mit den Abmessungen von $6,5 \mathrm{~m}$ x 4,5 m war bewohnbar, was eine Feuerstelle im südlichen Teil anzeigt. Darum herum wurden Keramik des 14. Jahrhunderts, ein massiver eiserner Leuchter und eine Streitaxt gefunden. Während dieser Zeit wurde das Diakonikon von Westen durch eine zweilagige Quadermauer mit Lehmmörtel abgeschlossen und der Eingang zum Presbyterium vermauert. Eine Feuerstelle und die Überreste eines Bodenniveaus innerhalb des Diakonikons können durch eine Münze des Andronikos II. Palaeologos (1282-1328) datiert werden. Über dieser Schicht wurden zahlreiche Ziegel gefunden, die zeigen, dass dieser Teil der Kirche noch während des 14. Jahrhunderts ein Dach trug. Dieser Umstand und die Lage der reichsten Bestattungen westlich der Trennmauer des Diakonikons im südlichen Seitenschiff und in Teilen im Mittelschiff führen zu der Annahme, dass der südliche Teil der Kirche während der zweiten Hälfte des 14. Jahrhunderts als Bestattungskapelle diente. Das Niveau des westlichen Eingangs zur Vorhalle und der Eingänge zum südlichen Seitenschiff und zum Mittelschiff waren angehoben um einen Ausgleich mit dem damaligen Außenniveau zu erzielen. Von innen wurden dagegen Schwellen errichtet. Gleichzeitig wurden mit Quadern, fragmentierter Baukeramik und Mörtelbrocken, die mit Schlamm als Bindemittel vermischt waren, der südliche Eingang zur Vorhalle und die Nischen in der Südwand der Kirche verschlossen. Das Nordschiff war offensichtlich schon zerstört und wurde nicht genutzt.

Man nimmt an, dass die Metropole von Drăstăr bis zum Ende des zweiten Bulgarischen Reiches Bestand hatte. Der Metropolit von Drăstăr nahm an der Zusammenkunft des Zaren Ivan Alexander gegen die Häretiker und die Juden in Tărnovo im Jahre 1360 teil. Dies ist das letzte Zeugnis der kirchlichen Autorität. Es ist schwer zu sagen, ob die Umbauten in der alten Basilika mit der Einrichtung des Metropolitensitzes zusammenhängen und wann diese von statten gingen. Auf jeden Fall scheint dies vor dem Jahr 1360 gewesen zu sein. Die Umwandlung der Kirche in eine Grabkapelle erfolgte wahrscheinlich in den letzten Jahrzehnten vor der Einnahme der Stadt durch die osmanischen Türken. Am Ende des 14. und am Beginn des 15. Jahrhunderts wird die Nutzung aller noch vorhandenen Teile der Basilika als Kirche eingestellt. Dies wird durch die vorgefundenen Siedlungsniveaus mit Münzen des Ivan Šišman (1371-1395) und Bajasid I. (1389-1402) in der südwestlichen Ecke des Südschiffes, der Vorhalle 

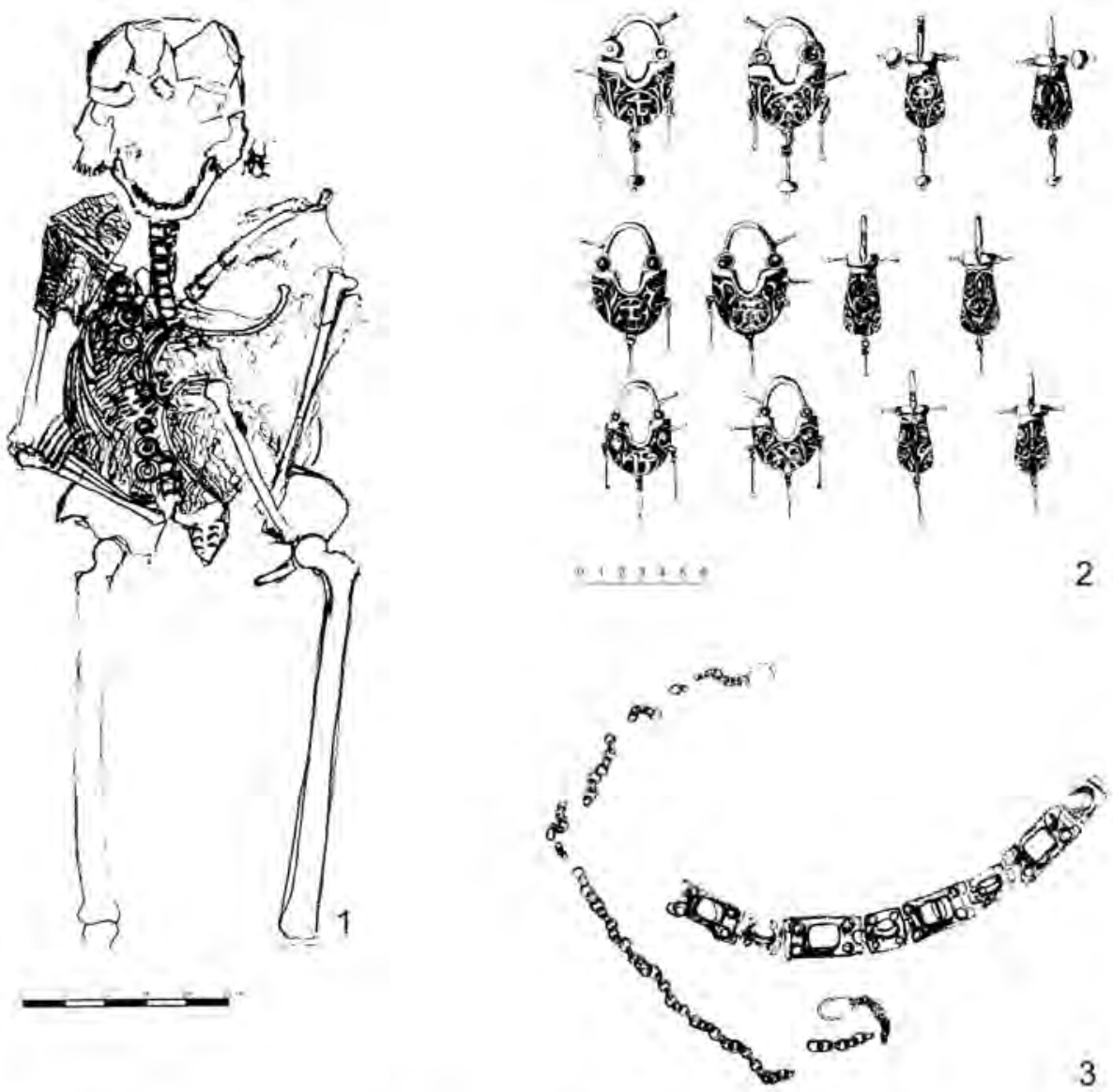

\section{T $=3$ MRTh}

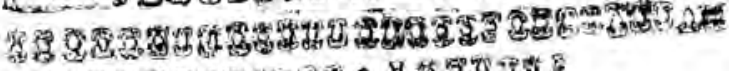

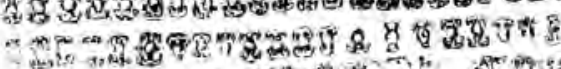

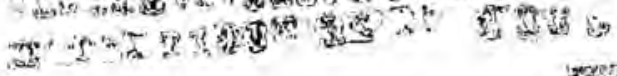

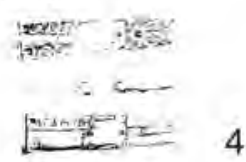

Abb. 13. Gräber des 14. Jahrhunderts. 1. Grab Nr. 162-a, wahrscheinlich Gemahlin des Ivanko Terter; 2. Ohrringe aus Golddraht mit der Darstellung des zweiköpfigen Adlers und dem Monogramm TERTER in Ligaturschrift (zwei aus Grab Nr. 162-a und einer aus einem gestörten Kindergrab im östlichen Teil des Mittelschiffes); 3. Zwei Halsketten aus Gold mit gefassten farbigen Steinen und Silber (Grab Nr. 91);

4. Gürtelgarnitur aus vergoldetem Silber (Grab Nr. 93-a) 
und dem Gebiet westlich davon dokumentiert. Zahlreiche Häuser des 15. Jahrhunderts wurden auch außerhalb der Kirche untersucht. In der Wand eines der Gebäude südlich der Basilika wurde ein Säulenfragment aus sizilianischer Breccia gefunden, auf welcher der Name des Khans Omurtag zu lesen ist. Die Bearbeitung dieses Fundes steht noch aus. Bereits jetzt kann jedoch gesagt werden, dass die Inschrift zur Gruppe der Bauinschriften gehört. Dieses Denkmal unterstützt die von Prof. V. Beševliev geäußerte Hypothese zur Lokalisierung des ,,berühmten Hauses an der Donau“ in Drăstăr. ${ }^{7}$

Wenn wir das bisher Gesagte zusammenfassen, können wir die These aufstellen, dass die von uns untersuchte Basilika bereits am Ende des 9. Jahrhunderts den Status eines Erzbischofssitzes innehatte. Ihre Erneuerung in der Mitte des 10. Jahrhunderts stand im Zusammenhang mit der Umwandlung in einen Patriarchensitz. Dies wurde bereits durch Historiker bestätigt.

Im Zusammenhang hiermit gilt dem Grab Nr. 98 besondere Aufmerksamkeit, welches unmittelbar vor der Kanzel des Presbyteriums lag. ${ }^{8}$ Der darin bestattete Mann im Alter von 55-60 Jahren war in Mönchstracht gekleidet. Unter seinem Kopf lag ein Ziegel mit einem eingeritztem Kreuz. Auf seiner Brust wurde ein Kreuz aus Bergkristall mit silberner Einfassung gefunden. Unzweifelhaft handelt es sich hier um einen Vertreter des höchsten geistlichen Standes in Bulgarien und sehr wahrscheinlich sogar um einen der Patriarchen des ersten Bulgarischen Reiches.

In den Kistengräbern der Kirche (im mittleren und südlichen Teil der Vorhalle) sowie in den Kistengräbern östlich der Apsiden wurden die Vertreter der weltlichen Aristokratie des 9. bis 10. Jahrhunderts beigesetzt.

Sicher konnten die Gräber des 11. bis 13. Jahrhunderts festgestellt werden (Abb. 12). Die Gräber der Vertreter der Dynastie der Herrscher der Dobrudža lagen vornehmlich im südlichen und im Mittelschiff der Kirche. Diese können in die Zeit der Herrschaft des Ivanko Terter Dobrotiza (1376-1388) datiert werden. ${ }^{9}$

Es scheint, dass die in Grab Nr. 162 (Abb. 13) bestattete Person entweder die Gemahlin oder eine sehr nahe Verwandte des Sohnes des Dobrudža-Fürsten Dobrotiza (1360-1385) - Ivanko Terter (1385-1395) war, von dem bekannt ist, dass er von 13761388 in Drăstăr residierte. Nach der Stadtchronik von Nesebăr erschlug eben jener Ivanko - dort unter seinem Familiennamen Terter erwähnt - in Drăstăr (Tristria) den Michail Paleologos 1376/1377. ${ }^{10}$ Er prägte in Drăstăr auch Münzen zum Angedenken, dass ihm die Stadt als Eroberung des Dobrotiza überlassen wurde. Dobrotiza selbst gelangte nach 1369 in Drăstăr zur Herrschaft, als er die Städte Drăstăr, Varna, Emona und Kosjak zu Verbündeten im Krieg gegen das Ungarische Königreich machte. Sein

\footnotetext{
7 Beševliev 1979.

8 Dieses Grab wird in einer gesonderten Publikation behandelt werden.

9 Gjuzelev 1995, 63ff.

10 Ebd.
} 
Verhältnis zum Königtum in Tărnovo ist nicht ganz geklärt. Die These, dass der Sohn des Dobrotiza über längere Zeit die Unabhängigkeit anstrebte, kann nicht grundsätzlich von der Hand gewiesen werden.

Der doppelköpfige Adler erscheint als Abzeichen der herrschaftlichen Würde und findet in Byzanz und den Balkanländern während des 13. bis 14. Jahrhunderts breite Verwendung.

Die Entdeckung dieses Grabes ist von großer Bedeutung für die ereignisreichen letzten Jahrzehnten des 14. Jahrhunderts. Wann die Herrschaft des Ivanko Terter in Drăstăr ein Ende fand, ist nicht bekannt. Auf jeden Fall ist die Stadt in der Zeit von 1388 bis 1396 erneut unter die Herrschaft der in Tărnovo residierenden Könige gelangt. In einem Gebäude westlich der Basilika wurde eine Matrize für Wachssiegel mit einem doppelköpfigen Adler gefunden. Dieses verbrannte beim Einfall der Türken, wie die Münzen des Sultan Bajasid I. zeigen, die zusammen mit Münzen des Ivan Šišman und Ivanko Terter in den Brandschichten gefunden wurden.

Ausgehend von der Geschichte des basilikalen Komplexes im 14. Jahrhundert, den die archäologischen Ausgrabungen freigelegt haben, haben wir Anlass zu der Vermutung, dass die von uns untersuchten Bauten sowie die Kapelle und die Nekropole Teil des Grundbesitzes des Ivanko Terter waren.

(Übersetzung: Raiko Krauß)

\section{Bibliographie}

Angelova 1988: Стефка Ангелова, „Археологнческото проучване на средновековния Дръстьр (Резултати и перспективи)“, in: Дуросторум-Дръстър-Силистра, Силистра 1988, S. 32-52.

Beševliev 1979: Веселин Бешевлиев, Първобългарски надписи, Софиа 1979, S. 198-200.

Gjuzelev 1995: Васил Гюзелев, Очерци върху историята на българския Североизток и Черноморието (краят на XII - началото на XV в.), Софиа 1995.

Ivanov 1925: Йордан Иванов, Богомилски книги и легенди, Софиа 1925.

Mutafčiev 1947: Петър Мутафчиев, „Съдбините на средновековниня Дръстър“, in: Добруджа 10, 1947, S. 275- 285.

Penčev 1987: Васил Пенчев, „Към историята на Дръстьр през XIII в. (по нумизматични данни)", in: Нумизматика 21/2, 1987, S. 26-29.

Soustal 1997: Peter Soustal, „Dorostolon-Silistra. Die Donaustadt im Lichte neuerer Forschung“, in: Miscellanea Bulgarica: Von der Scythia zur Dobrudza 11, Wien 1997, S. 115-125.

Velkov 1988: Велизар Велков, „Античният Дуросторум“, in: Дуросторум-ДръстърСилистра, Силистра 1988, S. 25-31. 


\title{
Zur ethnischen Zugehörigkeit einiger Nekropolen des 11. Jahrhunderts in Bulgarien
}

\author{
LJudmila DonČEva-PetKova
}

Es ist bekannt, dass Gräberfelder aller Epochen eine wichtige Quelle für Untersuchungen zur religiösen, sozialen und ethnischen Zugehörigkeit der Bestatteten sind. Aus diesem Grund ist auch die Erforschung mittelalterlicher Nekropolen, besonders derjenigen des ersten bulgarischen Reiches während der heidnischen und christlichen Periode, von wesentlicher Bedeutung.

In der zweiten Hälfte des 20. Jahrhunderts wendete sich eine Reihe von Forschern stärker den Untersuchungen von mittelalterlichen Gräberfeldern vom Ende des 7. bis 11. Jahrhunderts zu, so dass aus dieser Zeit inzwischen rund einhundert Fundorte bekannt sind. Besonders wichtig ist die Erforschung der heidnischen Nekropolen, unter denen sich sowohl Gräberfelder mit ausschließlich Brandbestattungen als auch birituelle Gräberfelder mit Brand- und Körperbestattungen finden. Die Fragen, die sich aus der Erforschung dieser Gräberfelder ergeben, sind zahlreich und kompliziert. Am schwierigsten ist es, die ethnische Zugehörigkeit der auf den birituellen Nekropolen Bestatteten zu bestimmen. Wurden auf einem solchen Gräberfeld nur Protobulgaren oder auch Slawen bestattet?

Ein interessantes Bild entsteht mit dem Wandel der Bestattungssitte in den Jahrzehnten nach der Christianisierung der Bulgaren. Auf den ersten Blick scheint klar: die Brandgräber verschwinden und bei den Körpergräbern ist eine Übernahme des christlichen Brauches festzustellen, erkennbar besonders an der sich verändernden Lage der Hände. Im Unterschied zur heidnischen Periode, als in die Gräber Beigaben - insbesondere viele Tongefäße - gelangten, sollten Grabbeigaben nach der Christianisierung im Jahre 864 nicht mehr auftreten. Dennoch findet man noch einige Zeit später in Bestattungen vom Ende des 10. und besonders des 11. Jahrhunderts persönliche Gegenstände und Beigaben, darunter vor allem Anhänger. Bisher wurde aufgrund fehlender Daten den Nekropolen des 11. Jahrhunderts nicht genügend Aufmerksamkeit geschenkt; sie wurden einfach als bulgarische Gräberfelder aufgefasst.

Es ist bekannt, dass im 11. Jahrhundert große Umbrüche in der Geschichte der Bulgaren stattfanden. Nach 1018 stand ganz Bulgarien unter byzantinischer Herrschaft. Bald darauf folgte die Zeit der Einfälle von Nomaden (Petschenegen, Usen, Kumanen) und Normannen. Sie beginnen im Jahre 1027 und erfolgen dann 1032, 1034, 1035 
und 1036. Am dramatischsten war schließlich das Jahr 1048, das mit dem Einfall des Kegan und der Ankunft von Hunderttausenden Männern, Frauen und Kindern (nach Skylizes 800.000 Personen) unter Tirich verbunden wird. Die Schriftquellen sprechen von der Ansiedlung von Petschenegen um Sofia, Niš und Ovče pole, von der Taufe des Tirich, vom Aufstand der Petschenegen gegen die Herrscher in Konstantinopel, von ihrem Eindringen in Nordbulgarien und ihrer Ansiedlung im Gebiet von Sto Mogili, von der Niederlage der byzantinischen Truppen bei Devnja, Hadrianopel und Preslav, sowie vom 30jährigen Friedensvertrag des byzantinischen Kaisers Konstantin IX. Monomachos mit dem Ziel der endgültigen Ansiedlung der Petschenegen im Thema Paristrion. ${ }^{1}$

Es ist natürlich zu erwarten, dass die Petschenegen, nachdem sie die Donau überquerten, Zeugnisse ihrer Anwesenheit im heutigen Nordbulgarien hinterlassen haben. Archäologisch wurden diese zuerst in einigen frühmittelalterlichen Siedlungen nachgewiesen, so in Zar Asen, Odărci, Kaliakra, Krivina, Pliska, Preslav und Silistra. ${ }^{2}$ Die Spuren von Bränden, Zerstörungen oder verlassenen Häusern sowie die Schlussmünzen - anonyme byzantinische Folles der Klasse B, die von den Numismatikern in die Jahre 1028-1034 oder 1030-1035/1042 eingeordnet werden - zeigen, dass einige dieser Siedlungen (Zar Asen, Odărci, Skala) aller Wahrscheinlichkeit nach in den 30er Jahren des 11. Jahrhunderts zerstört wurden. Wie Ausgrabungen bei Odărci und Zar Asen zeigen konnten, wurden die Siedlungen von der bulgarische Bevölkerung verlassen. Die Petschenegen wiederum nutzen nicht die Häuser ihrer Vorgänger, sondern wohnten wahrscheinlich in Jurten, deren Spuren sich in den Schwarzerdeböden der Dobrudža nicht nachweisen lassen.

Bei den Ausgrabungen in Odărci wurden Feuerstellen sowie zahlreiche Fragmente von so genannten Tonkesseln und von Gefäßen mit Ösenhenkeln an der Innenseite (Typ II) ausschließlich in den obersten Schichten des Hügels Kaleto und an seinem Fuß nachgewiesen, niemals in Befunden der bulgarischen frühmittelalterlichen Siedlung. Keramik dieser Art trat auch in den oben erwähnten Siedlungen Nordostbulgariens, zuletzt auch in Tutrakan, ${ }^{3}$ in Nordwestbulgarien in Gigen ${ }^{4}$ sowie in Südbulgarien auf dem Hisarlăka bei Sliven ${ }^{5}$ zutage. Pfeilspitzen, Feuerstähle, Anhänger und Teile des Pferdegeschirrs wie Trensen, Trensenknebel aus Horn oder Eisen und Steigbügel sind vergleichbar mit Funden, die im Gebiet des heutigen Südrusslands, der Ukraine und Moldawiens gemacht wurden und den Petschenegen zugeordnet werden konnten. ${ }^{6}$

1 Zlatarski 1934, 91; Angelov 1968, 106-108; Istorija 1982, 64, 65; Tăpkova-Zaimova 1976, 75-80.

2 Dončeva-Petkova 1971, 34-37 Anm. 17, Anm. 22, Anm. 24; dies. 1981, 24, Taf. VI,5; Dimitrova 1975, 37-57, Taf. II,IV-VI; Džingov 1981, 35 Taf. 8; Wendel 1986, 144, Taf. 37,414, Taf. 44,a-c; Angelova 1987, 98, Taf. II,12.

3 Mitteilung von Raliza Vasileva.

4 Dončeva-Petkova 1971, 34, Abb. 7.

5 Grabungen und Mitteilung von Irina Štereva.

6 Pletnjova 1958, 155-159, Abb. 3,4. 


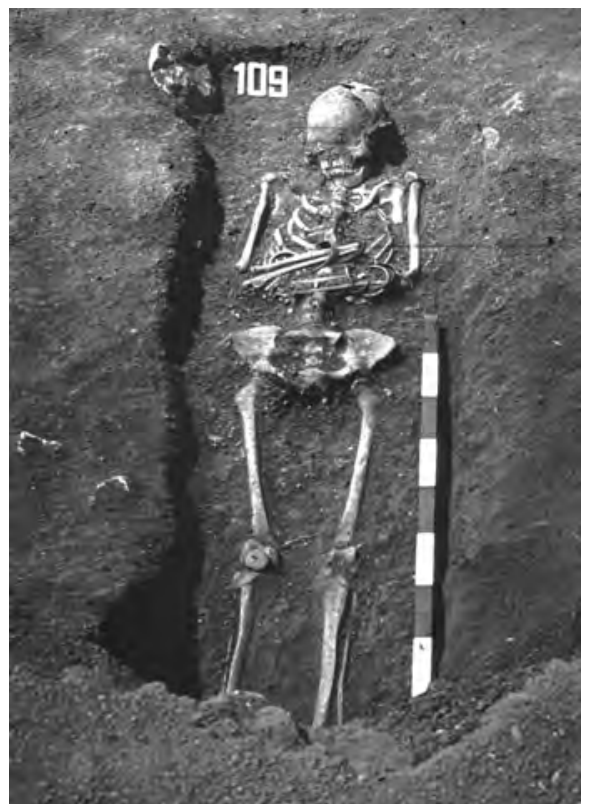

Abb. 1. Einfache Grabgrube (Grab 109)

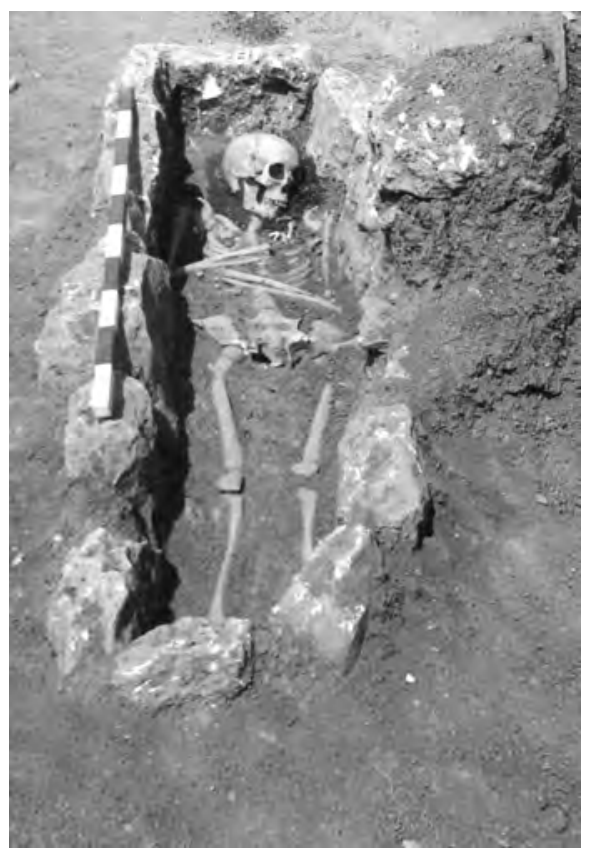

Abb. 3. Grabgrube mit Steinen umgeben (Grab 281)

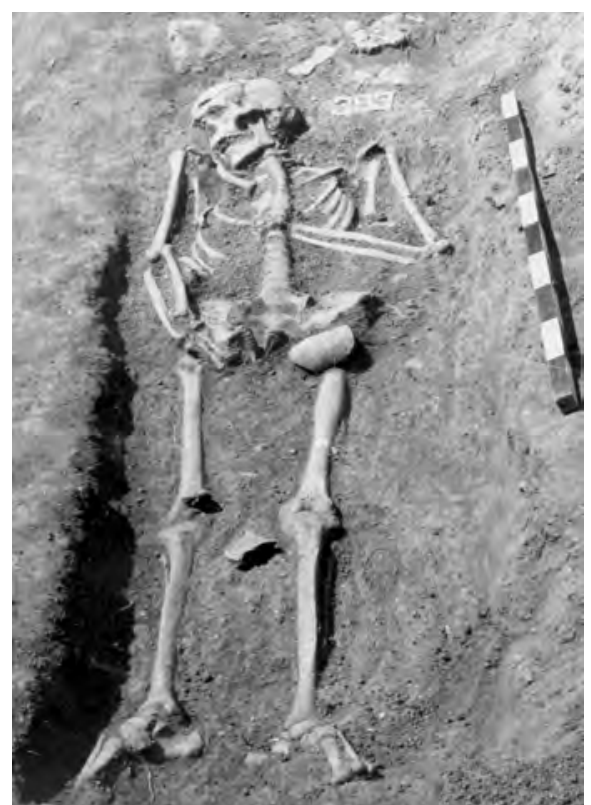

Abb. 2. Grabgrube am Kopf des Bestatteten mit Steinen markiert (Grab 393)

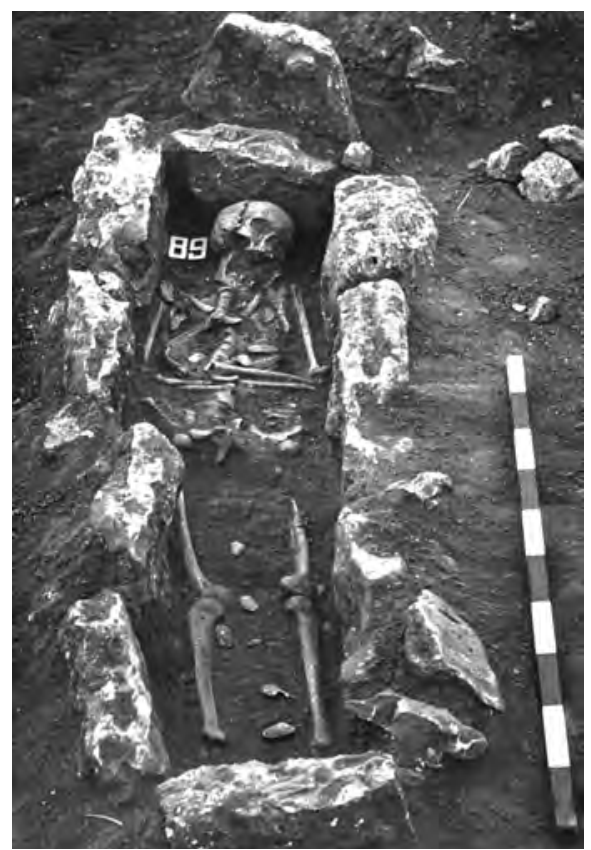

Abb. 4. Steinkammer (Grab 89) 
Anders ist das Bild in großen Zentren wie Pliska. Die in den Häusern gefundenen anonymen Folles der Klassen $\mathrm{B}$ und $\mathrm{C}$ sowie petschenegische, bulgarische und auch byzantinische Keramik deuten darauf hin, dass die bulgarische Bevölkerung dort unter der Herrschaft der Petschenegen weiter siedelte. ${ }^{7}$ Ähnlich war die Situation in Drăstăr. ${ }^{8}$

Wo die Petschenegen die zuvor ansässigen Bewohner am Leben ließen, legten diese später ihre eigenen Nekropolen an. Besonders wichtig sind in diesem Zusammenhang die Ergebnisse der Forschungen in Odărci. Im Verlauf der Untersuchungen in der frühmittelalterlichen Siedlung auf dem Hügel Kaleto wurden Gräber gefunden, die manchmal nur 20 bis $30 \mathrm{~cm}$ unterhalb der heutige Erdoberfläche eingegraben waren, aber oberhalb der Häuser lagen, wo sie zum Teil sogar eine der Hausseiten überschnitten. ${ }^{9}$ Am Beginn der Untersuchungen stellten wir uns die Frage, wer hier bestattet wurde, da die Grablegen nicht zeitgleich mit den Häusern waren. ${ }^{10}$ Damals nahmen wir an, dass die Petschenegen die bulgarische Siedlung zerstörten und sich bald darauf wieder aus dieser Gegend zurückzogen. Im Jahre 1983 wurde jedoch südöstlich am Fuß des Hügels die lange gesuchte mittelalterliche Nekropole gefunden. Die Untersuchungen wurden 1991 nach der Freilegung von 535 Gräbern beendet. Zu Beginn waren wir überzeugt, dass es sich um eine Nekropole aus der christlichen Periode der Siedlung handelt. Mit fortschreitender Erforschung kamen jedoch Zweifel auf, ausgelöst durch Besonderheiten der Grabanlagen, des Bestattungsrituals und der Beigaben.

Das bereits bei den Untersuchungen in der Siedlung auf dem Hügel gewonnene Bild wiederholte sich: Die Gräber störten auch hier ältere Häuser (Nr. 116, 118, 121, 128,130 ), waren in zeitlich vorangehende Siedlungsbauten eingetieft und überlagerten deren Mauern. ${ }^{11}$ In Haus Nr. 121 wurden beispielsweise neun Gräber gefunden.

Die Vermutung, dies sei eine petschenegische Nekropole, erhärtete sich immer mehr. Um diese These zu bestätigen oder zu verwerfen, wurden die Besonderheiten des Grabrituals, des Grabbaues und der Funde analysiert und mit anderen, den Petschenegen zugewiesenen Gräbern Bulgariens, Russlands, der Ukraine und Rumäniens verglichen.

Die in der Nekropole von Odărci praktizierten Bestattungsformen sind sehr verschiedenartig. Es überwiegen einfache Grabgruben (Abb. 1). Aber auch solche sind zahlreich, die von einer, zwei oder vier Seiten mit unbearbeiteten Steinen umrahmt und mit Steinen bedeckt sind (Abb. 2). Es wurden auch Gräber gefunden, die mit Steinplatten eingefasst sind (Abb. 3). Darunter sind solche, die zusätzlich mit Steinen abgedeckt

7 Dončeva-Petkova 1993, 250-260.

8 Angelova 1987, 133-135.

9 Im östlichen Sektor, wo das bulgarische Team arbeitete, wurden 60 Gräber freigelegt. Im westlichen Sektor entdeckten die polnischen Kollegen ebenfalls Gräber. Vgl. Dymaczewska/ Dymaczewski 1980, 171.

10 Dončeva-Petkova 1981, 26; Michailov/Dončeva-Petkova/Toptanov 1980, 144.

11 Auf dem Gebiet der Nekropole wurden 17 Häuser entdeckt. 


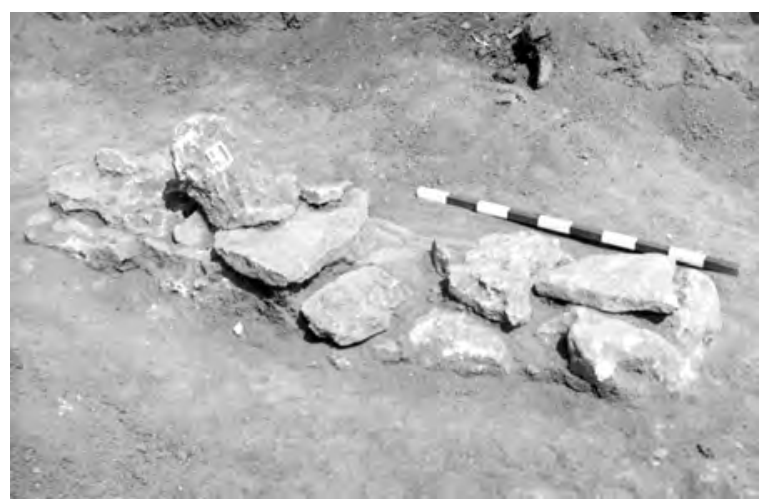

Abb. 5. Steinkammer vor der Öffnung (Grab 90)

sind und als Steinkammern bezeichnet werden können (Abb. 4, Abb. 5). Diese Diversität von Grabformen ist für nahezu alle bisher gefundenen Nekropolen des 10. bis 11. Jahrhunderts in Nordostbulgarien charakteristisch. ${ }^{12}$

Im Fall von Odărci sind die mit Steinen abgedeckten Gräber von besonderem Interesse. Einige der Gräber wurden mit drei bis zehn Platten, andere mit kleinen, unbearbeiteten Steinen bedeckt. Besonders interessant sind fünf Gräber mit rundem (Nr. 19, 352, 409) oder ellipsenförmigem Grubenumriss (Nr. 218, 221), über denen kleine, $20-40 \mathrm{~cm}$ hohe Grabhügel aus unbearbeiteten Steinen aufgehäuft worden sind. Wahrscheinlich befanden sich auch über weiteren Gräbern Steinschüttungen, die jedoch im Laufe der Zeit zerstreut wurden; zahlreiche einzeln liegende Steine konnten im nordwestlichen Teil der Nekropole beobachtet werden.

Eine Besonderheit der petschenegischen Gräber Russlands sind 0,5-1 m hohe Erdhügel über den Gräbern. ${ }^{13}$ Bei Sarkel-Belaja Veža wurden jedoch auch Gräber ohne Hügelschüttung entdeckt. ${ }^{14}$ Man kann annehmen, dass die Gräber südlich der Donau eine Reminiszenz darstellen und in der Gegend um Odărci Steine für die Schüttung verwendet wurden, weil dieses Material in der Umgebung von der frühbyzantinischen Festung sowie aus der bulgarischen Siedlung zur Verfügung stand.

Die Gräber sind in charakteristischer Weise West-Ost orientiert. Eine genaue Ausrichtung liegt bei 140 Gräbern vor. An der Mehrzahl der Gräber wurden jedoch saisonale Abweichungen in nördlicher (bei 256 Gräbern) und südlicher Richtung (bei 136 Gräbern) beobachtet, die zwischen $3^{\circ}$ und $20^{\circ}$ variieren, in seltenen Fällen aber auch $45^{\circ}$ bis $50^{\circ}$ erreichen können. Nur drei unter Steinhügeln liegende Gräber (Nr. 218, 221, 409) sind Nord-Süd orientiert (mit einer leichten Abweichung nach Osten).

12 Malamed 1989, 117 Anm. 9; Neševa 1979, 47 Abb. 2; Zachariev 1979, 129-131, Abb. 41-43; Dončeva-Petkova 1984, 181. Antonova/Vitljanov 1985, 64-66.

13 Pletnjova 1958, 153; dies. 1990, 9.

14 Dies. 1990, 33. 
West-Ost orientiert sind auch die Gräber innerhalb der steinernen Festung von Pliska, vor dem östlichen Tor, beim ehemaligen Motel und um den Hügel XXXIV.$^{15}$ In einigen Fällen wurden Abweichungen nach Norden, Süden und Südwesten festgestellt. ${ }^{16}$ Nach S. A. Pletnjova ist die West-Ost-Orientierung mit saisonbedingten Abweichungen auch für petschenegische Gräber typisch. So sind beispielsweise in der Nomadennekropole von Sarkel-Belaja Veža die nach Süden abweichenden Gräber wahrscheinlich im Winter angelegt worden. ${ }^{17}$

In der Nekropole von Odărci konnten unterschiedliche Formen der Skelettlagerung festgestellt werden. In den meisten Fällen wurde in gestreckter Rückenlage bestattet. Auffallend war jedoch eine große Vielfalt in der Position und Haltung der Hände (Abb. 1-3). Es überwog die Lage der Hände auf dem Bauch, wobei sich die Handflächen berührten oder die Hände, nach der unterschiedlichen Position der Armknochen zu urteilen, parallel oder selten überkreuz lagen und leicht zum Becken oder zur Brust gerichtet waren. In seltenen Fällen ruhten eine Hand auf der Brust und die andere auf dem Bauch oder im Beckenbereich. In anderen Fällen lagen beide Hände, seltener eine Hand, parallel zum Körper oder auf der Hüfte. Die Arme waren bisweilen angewinkelt und die Hände gegen die Schultern gerichtet, oder sie lagen auf der Brust. Diese vielfältigen Formen der Handhaltungen konnten in allen Nekropolen des 10. bis 11. Jahrhunderts in Nordostbulgarien beobachtet werden. ${ }^{18}$ Nach S. A. Pletnjova wurden die Petschenegen des nordpontischen Raumes jedoch mit entlang des Körpers gestreckten Armen bestattet. ${ }^{19}$

In 20 Gräbern der Nekropole von Odărci wurden so genannte Pseudohocker angetroffen. Diese Bestattungen sind durch die Anwinkelung eines oder beider Beine und der Drehung des Oberkörpers nach Norden oder Süden gekennzeichnet. Auch hier lagen die Hände in unterschiedlichen Positionen. Auffallend ist, dass überwiegend weibliche Tote als Pseudohocker bestattet wurden (Abb. 6). Grablegungen dieser Form fanden sich auch entlang der Festungsmauer von Pliska ${ }^{20}$ und in der Nomadennekropole von SarkelBelaja Veža ${ }^{21}$.

15 Zachariev 1979, 129; Dončeva-Petkova 1984, 181; Antonova/Vitljanov 1985, 65; Dimitrov 1993, 47. An dieser Stelle möchte ich mich herzlich bei J. Dimitrov für seine Mitteilung über die Nekropole im Gebiet des Motels bedanken. Die Gräber nördlich von Hügel XXXIV und in seiner Umgebung wurden von J. Dimitrov, L. Dončeva-Petkova, R. Vasilev und P. Georgiev entdeckt.

16 Zachariev 1979,137, Nr. 10, Nr. 20; Antonova/Vitljanov 1985, 65.

17 Pletnjova 1958, 153; dies. 1990, 11.

18 Văžarova 1976, 270, 324, 329, 333-345, 350; Malamed 1989, 118; Dončeva-Petkova 1984, 181; Zachariev 1979, 129, Abb. 41-43; Antonova/Vitljanov 1985, 65; Neševa 1979, 47; Aladžov 1991, 91-93.

19 Pletnjova 1958, 155; dies. 1990, 15-17, Abb. 3-8.

20 Zachariev 1979, 130, Abb. 41,3.4.9.; Abb. 17,42.26; Dončeva-Petkova 1984, 181; Antonova/ Vitljanov 1985, 66.

21 Pletnjova 1990, 12, Abb. 2,38/1. 


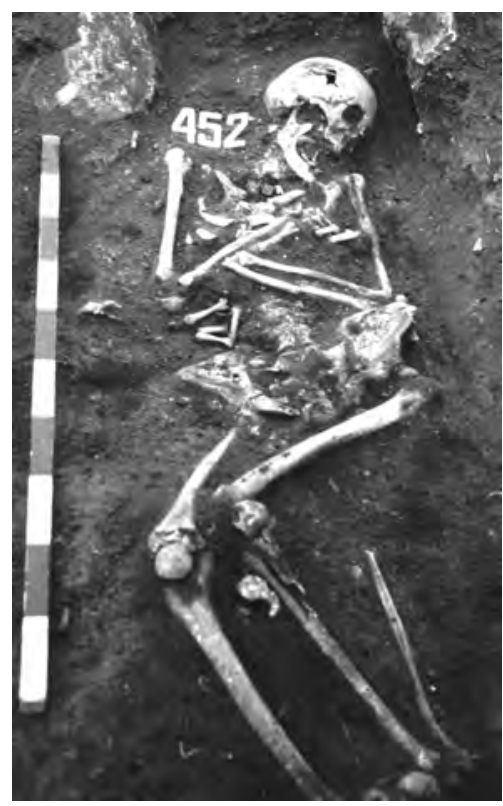

Abb. 6. Pseudohocker (Grab 452)

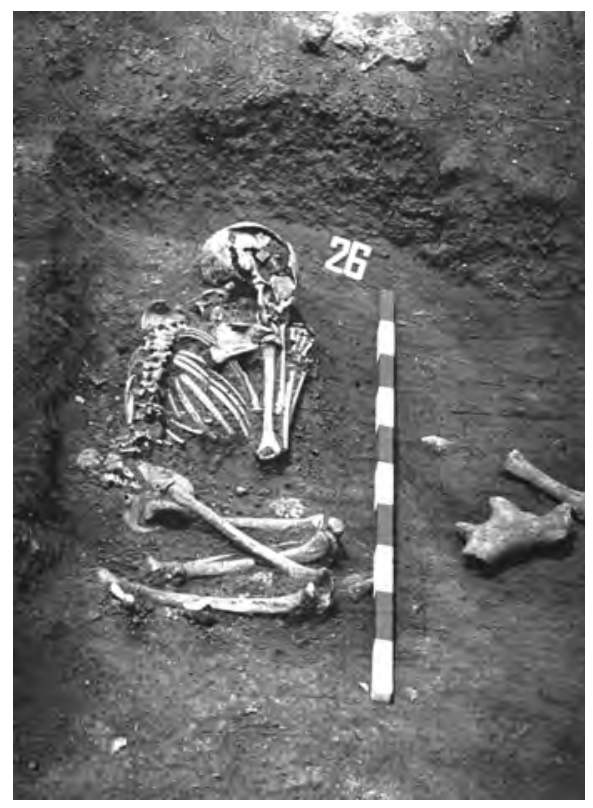

Abb. 7. Hocker (Grab 26)

In der Nekropole von Odărci fanden sich drei Hockergräber. Zwei Bestattungen (Nr. 221 und 409) waren nach Norden orientiert und mit Steinschüttungen überdeckt, während die dritte (Nr. 26) nach Westen ausgerichtet und mit einer rechteckigen Steinplatte abgedeckt war (Abb. 7).

In vielen Fällen konnten heidnische Elemente im Bestattungsritus nachgewiesen werden. Grab Nr. 218 war Nord-Süd orientiert und es fehlte der Schädel. Dies kann kaum durch eine Störung erklärt werden, da das Grab mit einem Steinhügel versehen war. Bei Grab Nr. 487 fand sich der noch gut erhaltene Schädel etwa $30 \mathrm{~cm}$ außerhalb der Kammer. In Grab Nr. 37 lag der Schädel vom übrigen Skelett abgetrennt mit dem Gesicht zum Boden gewendet. Die Füße der Bestatteten aus den Gräbern Nr. 38 und 342 waren abgetrennt und lagen jeweils neben dem Skelett. In einigen Fällen fehlen die Füße ganz (Nr. 37, 167, 297, 374, 394, 473, 490) oder waren gefesselt (Nr. 407, 448, 481, 503). In einigen Gräbern lagen Steine auf verschiedenen Bereichen des Skelettes, so dass vermutet werden kann, dass der Kopf (Nr. 19, 500), die Brust oder das Herz (Nr. 354), der Bauch (Nr. 45, 93) oder die Füße (Nr. 42, 230, 231, 354, 400) beschwert wurden. Das Skelett Nr. 352 wurde rituell zerstört und unter einem Steinhügel verborgen. Bei anderen Skeletten fehlten der Schädel oder einzelne Gliedmaßen, wobei nicht gesagt werden kann, ob sie intentional abgetrennt wurden.

In vielen Gräbern fanden sich - vor allem im Bereich der Brust - Kohlestückchen sowie seltener Kalk- und Feuersteine. Die von der nördlichen Wand des Grabes Nr. 238 


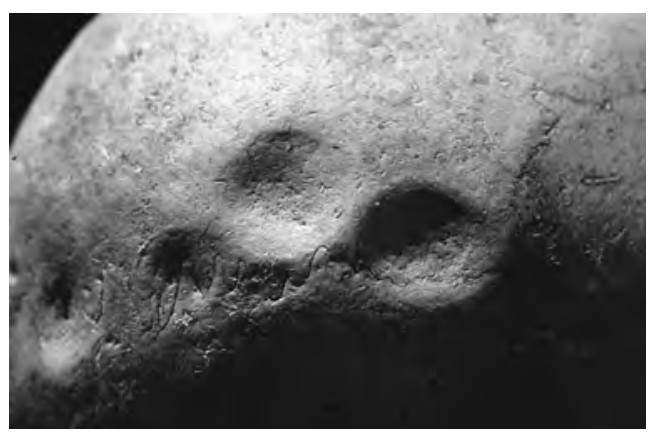

Abb. 8. Schädel mit Trepanationen

herabgefallenen Steine waren geschwärzt, und darüber lagen ebenfalls Kohlereste. Grab Nr. 12 wurde angezündet, so dass die Erde verziegelte und die Wirbelsäule und die Rippen des Bestatteten verkohlten. Schwarz verbrannt sind die Hüft- und Beinknochen von Skelett Nr. 15. Diese Maßnahmen wurden vielleicht zur Vorbeugung gegen Wiedergänger vorgenommen.

In die Gräber Nr. 26, 30, 71, 94, 138, 182, 213, 218, 248, 262, 274, 299, 374, 448, 463, 489, 494, 498, 500, 516, 525 und 532 gelangten Tierknochen von Rind, Schaf, Schwein und Pferd. Die Beigabe von Pferdefleisch ist eine Besonderheit bei den in Russland gefundenen Petschenegengräbern. ${ }^{22}$

Wichtige Erkenntnisse wurden durch anthropologische Untersuchungen gewonnen. ${ }^{23}$ Insgesamt waren die Verstorbenen verhältnismäßig jung, etwa die Hälfte der Bestattungen sind Kinder. Nur fünf Männer waren zwischen 45 und 50 Jahre alt, ein Mann ist etwa 60 Jahre alt geworden. Bei den Frauen waren neun zwischen 45 und 50 und zwei weitere 50 bis 55 Jahre alt. ${ }^{24}$ Die anthropologischen Untersuchungen zeigten zudem, dass sich die Bestatteten im Typus - europid mit leicht mongolischem Einschlag - nicht von denen der übrigen mittelalterlichen Nekropolen in der Dobrudža unterscheiden. Dieser Typus ist aber auch charakteristisch für die turksprachigen Petschenegen. ${ }^{25}$

Ein weiteres Merkmal der Bestatteten in der Nekropole bei Odărci sind echte und versuchte Trepanationen. Diese wurden bei 20 Männern und 23 Frauen in den Altersgruppen zwischen 20 und 70 Jahren durchgeführt; gehäuft treten sie jedoch im Alter zwischen 30 und 40 Jahren auf. Oft sind ein bis zwei, manchmal sogar fünf, acht oder elf Vertiefungen an den Schädeln erkennbar. In einem Falle wurde bei einem siebenjährigen Kind eine echte Trepanation, d.h. eine völlige Heraustrennung des Knochens,

22 Pletnjova 1958, 155; dies. 1990, 15-17, Abb. 3-10.

23 Die Untersuchungen wurden von J. Jordanov und Br. Dimitrova vom Institut für Morphologie der Bulgarischen Akademie der Wissenschaften durchgeführt.

24 Bemerkenswert ist hier, dass die Knie einer älteren Frau angewinkelt waren, während eine andere mit zusammengebundenen Füßen bestattet wurde.

25 Pletnjova 1990, 92-97. 


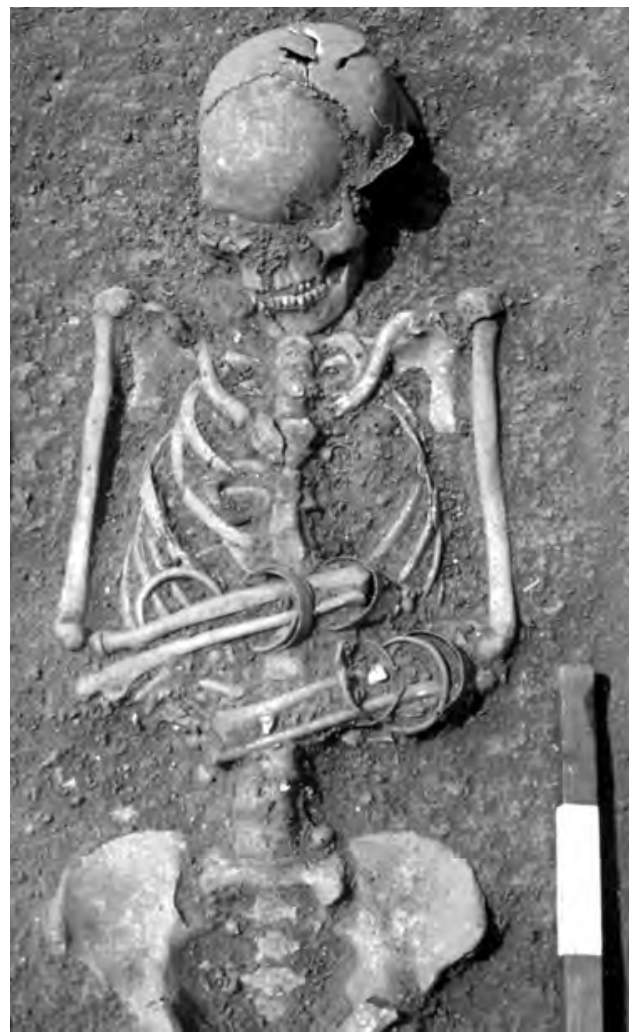

Abb. 9. Bestattung mit Schmuckausstattung (Grab 109)

durchgeführt. Die Trepanationen erfolgten häufig an den Schädelnähten (Abb. 8). Es ist schwierig, die Gründe für die Trepanationen zu benennen. Möglicherweise waren sie rituell bedingt, dienten aber wahrscheinlich vorwiegend der Krankheitsbekämpfung.

Skelette mit Schädeltrepanationen fanden sich meist in einfachen Gruben oder in mit Steinen markierten Gräbern, seltener kamen sie in Steinplatten- und Steinkammergräbern vor. Auch konzentrierten sie sich nicht etwa nur in einem Teil des Gräberfeldes, sondern fanden sich in der ganzen Nekropole. Trepanierte Schädel wurden auch neben dem Palast in Pliska und bei der Kirche des Čergubilja Mostič in Preslav gefunden. ${ }^{26}$ P. Boev schreibt sie den Protobulgaren zu, wenngleich in den publizierten birituellen Nekropolen keine Trepanationen angeführt werden. Für protobulgarische Bestattungen ist die künstliche Schädeldeformation typisch, ${ }^{27}$ jedoch nicht für die Nekropolen des 11. Jahrhunderts.

In Odărci wurden in 157 Gräbern Beigaben wie Anhänger, Münzen, Eisenmesser, Gürtelhaken, Pfeilspitzen, ein Astragal, eine Hacke und Feuersteine gefunden. Anhänger

26 Boev 1964, 299-301.

27 Boev/Kondova/Čolakov 1987, 35-37. 


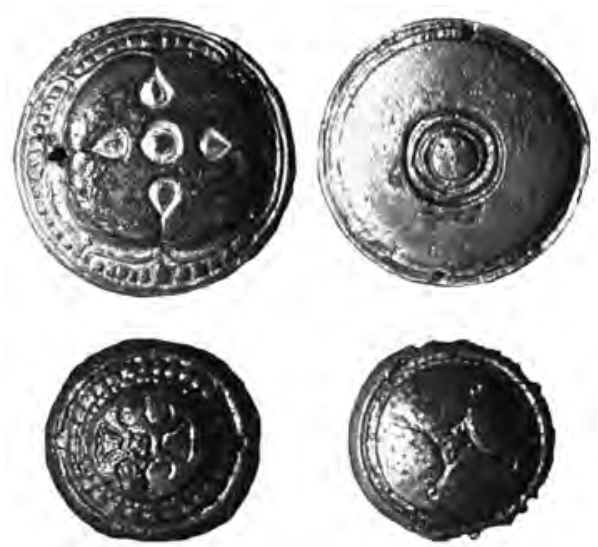

Abb. 10. Applikationen aus einer Kupferlegierung mit Silber- und Goldüberzug (Gräber Nr. 1, 4, 81 und 109)

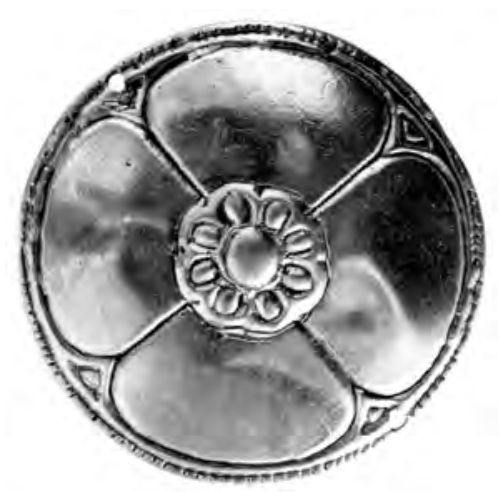

Abb. 11. Applikation aus vergoldeter Silberlegierung (Grab 278)

kamen oft in einfachen Grabgruben oder in mit kleinen Steinen markierten Gräbern zutage, während sie nur selten in Gräbern mit Steinplatten oder in Steinkammergräbern lagen. Sie fehlen fast vollständig in Hockergräbern, mit Ausnahme der Gräber Nr. 182 und 221. Von den 137 Gräbern mit Anhängern sind 78 Kinderbestattungen (bis 14 Jahre), 15 Bestattungen sind Mädchen bis 18 Jahre und 21 sind Frauen bis 40 Jahre. Anhänger kamen aber auch in 17 Gräbern mit männlichen Individuen zutage, deren Alter zwischen 18 bis 40 Jahren lag. Nur in drei Gräbern waren die Bestatteten über 40 Jahre alt.

Das Diadem sowie Perlen, Armreife, Fingerringe und Gürtelschnallen können über den Vergleich mit Funden anderer Nekropolen lediglich in den weiten Rahmen vom 10. bis 12. Jahrhundert datiert werden (Abb. 9).

Die Nekropole von Odărci beeindruckt durch die Fülle an runden, seltener ellipsenförmigen oder polygonalen Applikationen (Abb. 10 und 11). Sie wurden zumeist unter dem Kinn auf der Brust gefunden. Manchmal lagen sie an den Schultern, im Bereich des Nackens, beiderseits des Schädels oder in der Gegend der Hüfte (Abb. 12 und 13). Viele sind mit Sicherheit sekundär verwendet worden, da sie außer den zwei gegenüberliegenden Nietlöchern zusätzliche Durchbohrungen zur Befestigung an Bekleidung, Bändern, Mützen oder Zöpfen aufweisen. Bei einigen Applikationen waren dünne Baumwollfäden in den Löchern erhalten.

Solcher Art Applikationen entdeckte man auch in der Nekropole ${ }^{28}$ und bei den Festungsmauern ${ }^{29}$ von Pliska, bei der Kirche des Čergubilja Mostič in Preslav ${ }^{30}$ und

28 Dončeva-Petkova 1984, 188, Abb. 4,p, Abb. 8,ž-i; Antonova/Vitljanov 1985, 44-51, 69, Taf. 8,9.

29 Dimitrov 1993, 49 Abb. 10.

30 Grabung von K. Popkonstantinov. 


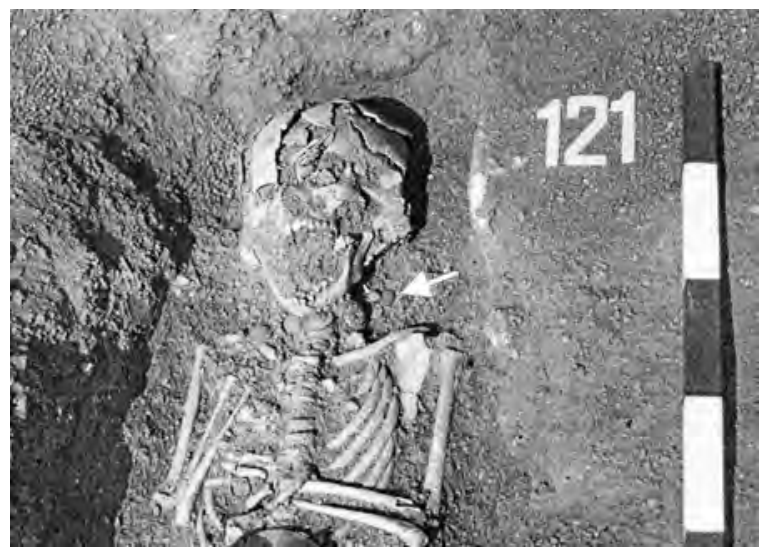

Abb. 12. Kindergrab. Man erkennt die Applikationen unter dem Kinn (Grab 121)

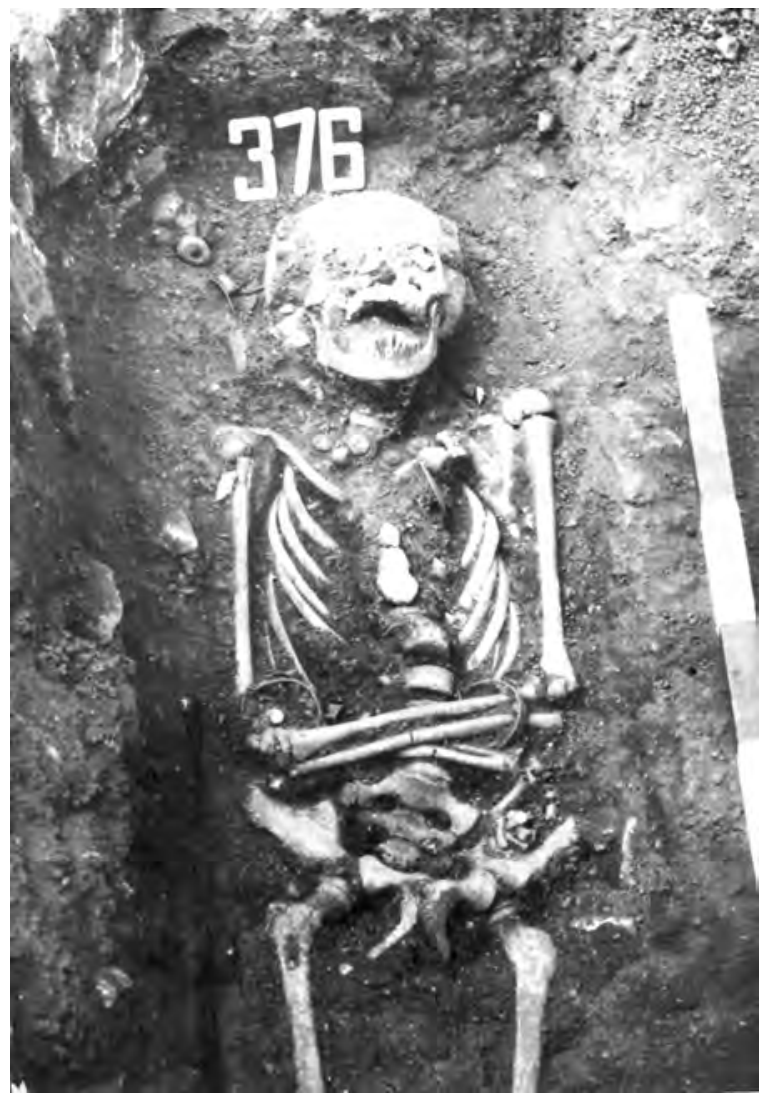

Abb. 13. Kindergrab mit Applikationen und anderen Schmucksachen (Grab 376) 
auf dem Gelände der Basilika auf dem Sakalovo-Hügel ${ }^{31}$, die nach Ansicht von T. Totev in den Jahren der byzantinischen Herrschaft zerstört wurde.

In zwei Gräbern der Nekropole bei Odărci wurden herzförmige Applikationen mit gewölbter Innenfläche gefunden (Abb. 14). Diese lagen auf der Brust der Bestatteten und waren wohl ebenfalls auf der Bekleidung aufgenäht; bei einem Exemplar sind die Fäden noch erhalten. Wie ukrainische Parallelen zeigen, dienten sie jedoch primär der Verzierung von Pferdegeschirr und waren im Bereich der Stirn, zwischen den Augen und am Maul angebracht. Sie werden in die zweite Hälfte des 10. und an den Beginn des 11. Jahrhunderts datiert. ${ }^{32}$ Die Verwendung der herzförmigen Applikationen für das Pferdegeschirr legt nahe, dass auch einige der runden Anhänger diese Funktion hatten und ähnlich wie antike Phaleren genutzt wurden.

In der Nekropole von Odărci wurden weitere Anhänger unterschiedlicher Formen gefunden. Einige bestehen aus einer Kupferlegierung (Abb. 15), andere sind aus Silber (Abb. 16). Sie waren jedoch stets vergoldet. Auch bronzene Glöckchen mit kreuzförmigen Ritzungen, ein lyraförmiger Gürtelhaken und kleine runde Applikationen, die solchen aus Rostov am Don, Kasan, Kišinëv und Odessa gleichen, ${ }^{33}$ gehören zu den Beigaben.

Aus sechs Gräbern, die in der Gegend der Nekropole oder auf dem Hügel Kaleto gefunden wurden, stammen Münzen. Davon ist eine hellenistisch (2.-1. Jahrhundert v. Chr.), eine römisch (4. Jahrhundert) und vier weitere sind frühbyzantinisch (6. Jahrhundert). Die Gräber gehören zu früheren Schichten und können nicht mit der Nekropole in Bezug gesetzt werden. Wichtig für deren Datierung sind die in vier Gräbern gefundenen Miliarenses: aus Grab Nr. 109 kamen eine Münze aus der Zeit des Kaisers Leon VI. (886-908) und zwei von Basileios II. (989) zutage, in Grab Nr. 118 fand sich eine weitere von Basileios II. Grab Nr. 33 enthielt ebenfalls eine Münze Basileios' II. und eine von Konstantin VIII. (989-1025). Grab Nr. 495 schließlich erbrachte eine Münze von Konstantin IX. Monomachos (1042-1055).

Ähnlich wie die Applikationen sind auch die Silbermünzen mit zwei gegenüberliegenden Löchern an den Rändern versehen und wurden in der Gegend der Halswirbeln gefunden. Nur die Münze aus Grab Nr. 33 lag an der Hüfte.

Es ist durchaus wahrscheinlich, dass die Nekropole nur in einem verhältnismäßig kurzen Zeitraum genutzt wurde. Die Schmuckstücke wie Ohrringe, Perlen, Applikationen, Anhänger, Armreife und Fingerringe sind stilistisch sehr einheitlich. Auch konnten lediglich in zwei oder drei Fällen Überlagerungen von Gräbern festgestellt werden. Eine für die kurze Belegungszeit vorauszusetzende hohe Sterblichkeitsrate lässt an Epidemien denken.

31 Totev 1976, 46-48 Abb. 15.

32 Orlov 1984, 36-38.

33 Pletnjova 1958, 1 Abb. 3, 158 Abb. 4; dies. 1990, 73 Abb. 26,14. 


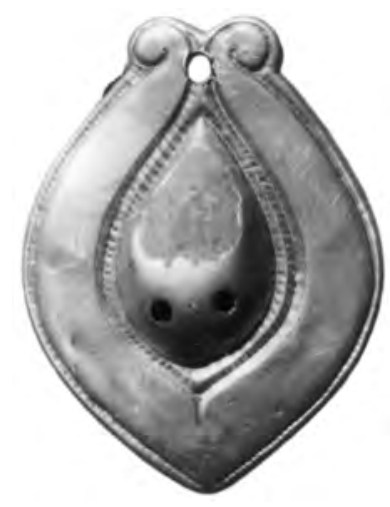

Abb. 14. Große herzförmige Applikation aus vergoldeter Silberlegierung (Grab 123)
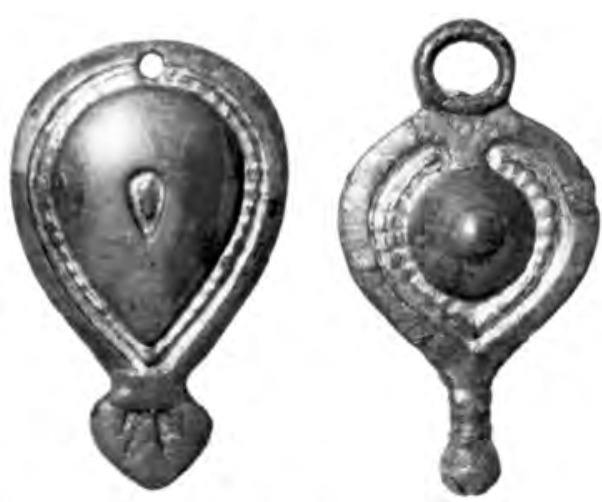

Abb. 15. Anhänger aus vergoldeter Kupferlegierung

Wichtig für den Beginn der Belegung des Gräberfeldes sind die späten Münzen des Konstantin IX. Monomachos, des Kaisers, der mit den Petschenegen Frieden schloss und sie im Thema Paristrion ansiedelte. Diese Münzen zeigen, dass die Nekropole nicht vor die Mitte des 11. Jahrhunderts datiert werden kann.

Nach Abschluss der Grabung und der Bearbeitung des Materials können wir sagen, dass die Nekropole wahrscheinlich eine petschenegische ist. Dafür sprechen vor allem die stratigraphischen Befunde, wie die Lage der Gräber über den Häusern und das Fehlen einer Siedlung des 11. Jahrhunderts auf dem Hügel Kaleto oder in der näheren Umgebung. Eine Ausnahme bilden die Feuerstellen und einige für Petschenegen charakteristische Funde und Befunde wie die Tonkessel, die Orientierung der Gräber und die Lage der Skelette. Auch aufgrund der vergleichsweise geringen Anzahl von erwachsenen Individuen liegt die Vermutung nahe, dass die Nekropole von der kurz zuvor eingewanderten Bevölkerung angelegt wurde.

Ob die Petschenegen die Gegend des heutigen Dorfes Odărci im Jahre 1032 oder 1036 erreichten, ist strittig. Schwierigkeiten bereitet dabei vor allem die unterschiedliche Einordnung der anonymen byzantinischen Folles der Klasse B. ${ }^{34}$ Für die folgenschweren Ereignisse der Zeit legen die Verletzungen an den Schädeln einiger der bestatteten Männer zwischen 25 und 30 Jahren Zeugnis ab. ${ }^{35}$ Es versteht sich, dass diese Bestatteten sowohl zu den Verteidigern der Siedlung als auch zu angreifenden Petschenegen gehören können. Wenig wahrscheinlich ist, dass die in den 30er Jahren des 11. Jahrhunderts einfallenden Petschenegen die Nekropole am Fuße des Hügels angelegt haben. An der

34 Diese Frage wurde detailliert dargestellt von Parušev 1999.

35 Kondova/Čolakov 1993, 53. 

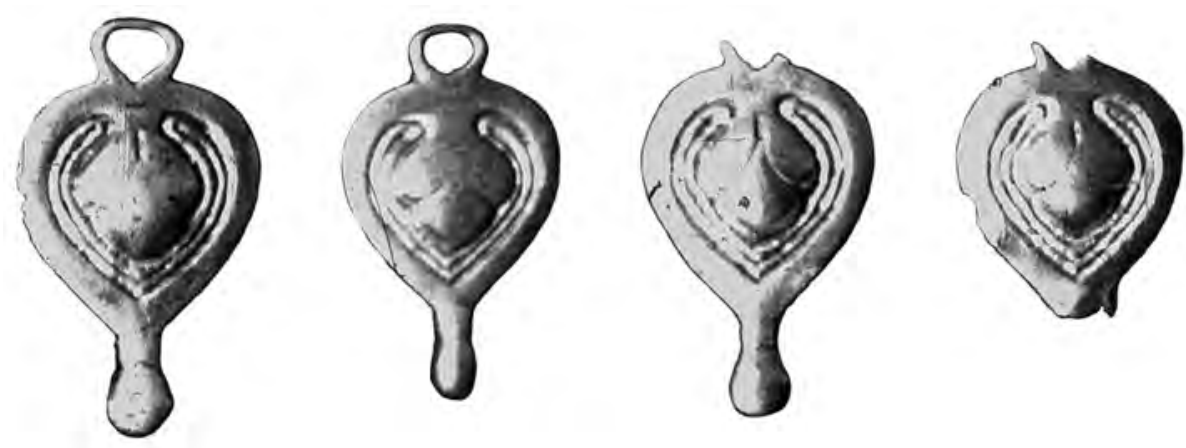

Abb. 16. Anhänger aus vergoldeter Silberlegierung

Mehrzahl der Skelette fehlen Spuren von Verletzungen und es scheint, als wenn die Pfeilspitzen in der Mehrzahl der Fälle als Beigaben in die Gräber gelangt sind. Es ist nicht ausgeschlossen, dass die Nekropole von einer Gruppe Petschenegen stammt, die sich nach dem 1035 geschlossenen Friedensvertrag mit dem byzantinischen Kaiser in der Gegend niedergelassen hat. Dafür sprechen besonders die Miliarenses - vor allem die zeitlich jüngsten des Konstantin IX. Monomachos.

Fraglich ist, ob es sich bei den Bestatteten um Heiden oder Christen handelt. Einige Funde, wie zum Beispiel Kreuzanhänger, Medaillons mit Darstellungen Heiliger und die allmähliche Abwendung von traditionellen petschenegischen Grabriten, könnten darauf hindeuten, dass die Nekropole von Odărci von einer christianisierten Bevölkerung angelegt wurde. Eine Reihe von Elementen verweist auf die Einhaltung alter und die Annahme neuer Grabriten und somit auf das Vorhandensein eines religiösen Synkretismus, der wiederum typisch für das 11. Jahrhundert ist. Auch die Petschenegen orientierten ihre Gräber traditionell in Richtung Westen. Einige Nord-Süd orientierte Gräber der Nekropole sind möglicherweise Zeugnisse älterer Glaubensvorstellungen in der Tradition der Turkstämme.

Der Synkretismus tritt auch neben alten heidnischen Traditionen auf. Diese äußern sich in der Aufschüttung von Grabhügeln, in den neben dem Körper ausgestreckten Armen, in den Bestattungen in Hockerstellung, den rituellen Zerstörungen einiger Skelette, in der Beschwerung des Toten mit Steinen, in der Beigabe von Tierknochen, Holzkohle und Kalk in der Grabgrube. Christliche Bräuche zeigen sich in dem Bemühen, die Hände auf Brust, Bauch oder Hüfte zu legen und in der Markierung von Gräbern mit Steinen, während der Synkretismus durch die Verflechtung von petschenegischen Applikationen, Anhängern und Glöckchen mit christlichen Perlen, Armreifen, Fingerringen, Anhängern, Kreuzen und Medaillons deutlich wird.

Viele dieser Besonderheiten konnten auch in den Gräbern entlang der Festungsmauer und vor dem Osttor von Pliska festgestellt werden. Hier überwogen die einfachen Grab- 
gruben. Dennoch traf man auch auf mit Steinen markierte oder bedeckte Gräber. Unter den Grablegungen fanden sich auch Skelette in Hockerlage, und die Anhänger sowie die runden Applikationen sind vergleichbar mit jenen aus der Nekropole von Odărci. Die Gräber in Pliska wurden fast übereinstimmend in die Mitte des 11. Jahrhunderts datiert. ${ }^{36}$ Wie es scheint, gehören in diese Zeit auch die Bestattungen um das ehemalige Motel sowie in der Umgebung des Hügels XXXIV. Bedauerlicherweise wurden die Skelette noch nicht von Anthropologen untersucht, so dass bezüglich eventuell vorhandener Trepanationen keine Aussagen gemacht werden können. Mit Sicherheit aus dem 11. Jahrhundert - und nicht aus dem 7. bis 8. Jahrhundert wie P. Boev annimmt ${ }^{37}$ - ist der 1956 beim Palast des Omurtag in Pliska gefundene trepanierte Schädel.

Der Schädel mit Trepanationen aus einem Grab bei der Kirche des Čergubilja Mostič in Preslav und das Vorkommen von runden Applikationen in Gräbern dieser Region zeigen, dass es dort in der Flur Selište Funde gibt, die mit denen von Odărci vergleichbar sind. Wegen der Zerstörung der Schicht bei der Basilika in der Flur Skalova Mogila kann nicht mit Sicherheit gesagt werden, ob die dort gefundenen runden Applikationen aus Gräbern stammen.

Darüber hinaus gibt es auch in der Nekropole neben der Kirche des Heiligen Georg beim Dorf Goren Kosjak in der Gegend Ovče pole Gräber mit runden Applikationen. ${ }^{38}$ Runde Applikationen und Anhänger, die denen von Odărci ähneln, wurden auch in der Nekropole beim Dorf Matičana bei Priština (Kosovo) gefunden. ${ }^{39}$

Man kann nicht behaupten, dass diese runden Applikationen ein ethnisches Kennzeichen der Petschenegen darstellen. Dennoch ist es sehr wahrscheinlich, dass es sich um Petschenegen handelt. Diese Gegenstände markieren, genau wie die großen ellipsenförmigen und die feingeschmiedeten Anhänger, den Weg dieser Völkerschaften durch das nördliche Schwarzmeergebiet, die Ukraine, Moldavien, die Dobrudža, Nordbulgarien und Makedonien. ${ }^{40}$ Runde Applikationen finden sich auch in ungarischen Nekropolen, aber diese sehen etwas anders aus und sind gewöhnlich mit Nieten an der Rückseite versehen. Außer herzförmigen Anhängern sind nur wenige andere Typen mit denen aus Odărci vergleichbar. ${ }^{41}$ Die formale Ähnlichkeit von Funden ist

36 Zachariev 1979, 136; Dončeva-Petkova 1984, 189; Antonova/Vitljanov 1985, 70; Balabanov 1985, 121, 130; Dimitrov 1993, 31.

37 Boev 1964, 289.

38 Beldedovski 1990, 50, Taf. 6.

39 Jovanović/Vuksanović 1981, Nr. 97.

40 Orlov 1984, 29 Abb. 4,26-31.50-57.63-64; Spinei 1985, 186 Abb. 14,9-11, 209 Abb. 37,1013; Barnea 1967, 280-282, Abb. 168,10-15, Abb. 172,19-27, Abb. 173,1-3.9; Vasiliu 1984, Anm. 29-33, Anm. 39, 529 Taf. 5.

41 Hampel 1904, 141 Abb. 161, 147 Abb. 188-189; Točik 1968, 119 Taf. 53,22-26, 124 Taf. 58,10-12; Fodor 1996, 139,4, 143,1, 165,3, 210, 242,1, 254,24, 259,3, 306,1; Révész 1996, 361, Abb. 138. 
dadurch erklärbar, dass beide Völker ursprünglich in der Gegend der Schwarzmeersteppen Nachbarn waren und sich die Magyaren nach Mitteleuropa zurückzogen, während die Petschenegen ihr ehemaliges Gebiet zwischen Dnepr und Donau besiedelten. ${ }^{42}$ Erst sehr viel später erscheint ein Teil der Petschenegen innerhalb der Magyaren in ihrem europäischen Ansiedlungsgebiet. ${ }^{43}$

Wir hoffen, dass durch weitere Untersuchungen von Nekropolen dieser Zeitstellung die Frage nach den petschenegischen Gräbern weiter erhellt wird. Bis jetzt bilden die Untersuchungen der Nekropole von Odărci erst den Anfang zur Erforschung der geistigen und materiellen Kultur der Petschenegen in Bulgarien.

(Übersetzung Raiko Krauß)

\section{Bibliographie}

Aladžov 1991: Живко Аладжов, Некропол в рамките на Преславската архиепископия (патриашия) в Големия иарски двореи във Велики Преслав 1, София 1991.

Angelov 1968: Димитър Ангелов, История на Византия, София 1968.

Angelova 1987: Stefka Angelova, „Sur la caractéristique du Haut Moyen âge provenant de Drăstăr (Silistra), in: Dobrudža. Etudes ethno-culturelles, Sofia 1987, S. 95-99.

Antonova/Vitljanov 1985: Вера Антонова/Стоян Витлянов, "Плиска: Западната крепостна стена - сектор Север“, in: Плиска-Преслав 4, София 1985, S. 44-78.

Artamonov 1962: Михайл Йлларионович Артамонов, История хазар, Москва 1962.

Balabanov 1985: Тодор Балабанов, „Разкопки на северната и източната крепостна стена в Плиска (1977-1978)“, in: Плиска-Преслав 4, София 1985, S. 120-132.

Barnea 1967: Ion Barnea, „Podoabe de metal“, in: Gheorge Ştefan/Ion Barnea/Maria Comşa u.a. (Hrsg.), Dinogetia 1: Aşezarea feudală timpurie de la Bisericuța-Garvăn, București 1967, S. $172-285$.

Beldedovski 1990: Звонко Белдедовски, Брегалничкиот басен во римскиот и раниот средновековен период (=Зборник Щип 6), Щип 1990.

Boev 1964: Петер Боев, Символични трепанации от България, in: Известия на Института по Морфология 9/10, 1964, S. 299-310.

Boev/Kondova/Čolakov 1987: Петер Боев/Нели Кондова/Славчо Чолаков, „Изкуствената деформация на главата като етноопределящ белег“, in: Българска етнография 12/1, 1987, S. 35-45

Dimitrov 1975: Димитър Илиев Димитров, „Номадска керамика в Североизточна България“, in: Известия на Народния музей Варна 11 (26), 1975, S. 37-58.

Dimitrov 1993: Янко Димитров, „Църква и некропол във Външния град на Плиска (края на X-XI в.)“, in: Плиска-Преслав 7, Шумен 1993, S. 42-70.

Dončeva-Petkova 1971: Людмила Дончева-Петкова, „Средновековни глинени съдове с вътрешни уши“, in: Археология 13/4, 1971, S. 32-38.

Dončeva-Petkova 1981: Людмила Дончева-Петкова, „Средновековно селище при с. Одърци, Толбухински окръг“, in: Известия на Народния музей Варна 17 (32), 1981, S. 19-28.

42 Artamonov 1962, 341, 344-345, Karte von Chasarien im 8.-10. Jahrhundert.

43 Györffy 1990, 123-191; Pálóczi-Horváth 1989, 27-38. 
Dončeva-Petkova 1984: Людмила Дончева-Петкова, „Некропол при южния сектор на западната крепостна стена на Плиска“, in: Сборник в памет на проф. Ст. Ваклинов, София 1984, S. 181-191.

Dončeva-Petkova 1993: Людмила Дончева-Петкова, „Глинени съдове от ХІ в. от Плиска“, in: Преслав 4, София 1993, S. 250-260.

Dymaczewska/Dymaczewski 1980: Urszula Dymaczewska/Aleksander Dymaczewski, „Résultats des fouilles archéologiques effectuéles à Odărci, département de Tolboukhin (Bulgarie), au cours des années 1967, 1969-1974 et 1976-1977“, in: Slavia Antiqua 27, 1980, S. 145-171.

Džingov 1981: Георги Джингов, „Калиакра през старобългарската епоха (VII-IX в.)“, in: Известия на Народния музей Варна 17 (32), 1981, S. 219-41.

Fodor 1996: István Fodor (Hrsg.), A honfoglaló Magyarság: Kiállitási katalógus (=Ausstellungskatalog des Magyar Nemzeti Múzeum 1996), Budapest 1996.

Györffy 1990: György Györffy, A magyarság keleti elemei, Budapest 1990.

Hampel 1904: József Hampel, „Ornamentika a honfoglalási kor emlékein“, in: Archeologiai Értesitö 24, 1904, S. 105-141.

Istorija 1982: История на България 3, София 1982.

Jovanović/Vuksanović 1981: Vojislav Jovanović/Ljiljana Vuksanović, Matičane: Necropole sudslave de 10e et 11e siècle (=Inventaria Archaeologica Jugoslavija 25), o.O. 1981.

Kondova/Čolakov 1993: Нели Кондова/Славчо Чолаков „Антропологични данни за физическия тип, продължителността на живота и заболеваемостта на една средновековна популация от Добруджа“, in: Българска етнография 6/4, 1993, S. 53-62.

Malamed 1989: Катя Маламед, „Некропол в сектор «Нивата»“, in: Дуранкулак 1, София 1989, S. 159-179.

Michailov/Dončeva-Petkova/Toptanov 1980: Stamen Michailov/Ljudmila Dončeva-Petkova/Dimităr Toptanov, „Fouilles archéoloqiques près du village Odărci, département de Tolboukhin (Bulgarie), au cours des années 1971-1977“،, in: Slavia Antiqua 27, 1980, S. 119-144.

Neševa 1979: Виолета Нешева, „Средновековен некропол във Вътрешния град на Преслав“, in: Археология 21/2, 1979, S. 47-60.

Orlov 1984: Р.С. Орлов, „Північно причерноморскький центр художно і металобработки у X - XI ст.“, in: Археологія 47, 1984, S. 24-44.

Pálóczi-Horváth 1989: András Pálóczi-Horváth, Pechenegs-Cumans: Asian Steppe peoples in medieval Hungary, Budapest 1989.

Parušev 1999: Веселин Парушев, „Моливдовули и монети“, in: Людмила Дончева-Петкова, Одърии: Селище от Първото българско изарство 1, София 1999, S. 131-140.

Pletnjova 1958: Светлана Александровна Плетнёва, „Печенеги, торки и половцы в южнорусских степях“, in: Труды Волго-Донской Археологической Экспедиции (=Материалы и исследования по археологии СССР 62), Москва 1958, S. 151-226.

Pletnjova 1990: Светлана Александровна Плетнёва, Печенеги и гузы на нижнем Дону: по материалам кочевнического могильника у Саркела Белой Вежи, Москва 1990.

Révész 1996: László Révész, A karosi honfoglalás kori temetök, Miskolc 1996.

Spinei 1985: Victor Spinei, Realități etnice şi politice in Moldiva meridională in secolele XXIII. Romani şi turanici, Iaşi 1985.

Tăpkova-Zaimova 1976: Василка Тьпкова-Заимова, Долни Дунав - гранична зона на византийския запад, София 1976.

Točík 1968: Anton Točík, Altmagyarische Gräberfelder in der Südwestslowakei (=Archaeologica Slovaca 3), Bratislava 1968. 
Totev 1976: Тотю Тотев, „Базиликата при Сакалова могила в Преслав“, in: Преслав 2, София 1976, S. 38-57.

Vasiliu 1984: Ioan Vasiliu, „Cimitirul feudal-timpuriu de la Isaccea“, in: Peuce 9, 1984, S. 529-532.

Văžarova 1976: Живка Въжарова, Славяни и прабългари по данни на некрополите от VI - ХІ в. на територията на България, София 1976.

Wendel 1986: Michael Wendel, „Die mittelalterlichen Siedlungen“, in: Iatrus-Krivina 3, Berlin 1986, S. 27-207.

Zachariev 1979: Иван Захариев, „Южната крепостна стена на Плиска и некропольт, открит до нея“, in: Плиска-Преслав 1, София 1979, S. 108-138.

Zlatarski 1934: Васил Златарски, История на българската държава през средните векове, София 1934. 


\title{
Catalogue of archaeological finds from Pliska*
}

\author{
JOACHIM HENNING
}

\section{Introduction}

Archaeological excavations at Pliska started in 1899 that is more than 100 years ago. On the occasion of this anniversary in 1999 members of the German-Bulgarian Pliska expedition have organized two scientific events. The one was an international conference at the Ebernburg castle near Bad Muenster am Stein in the beautiful middle Rhenish region, which was realized by the Johann Wolfgang Goethe University of Frankfurt am Main (most of the papers have been included in this publication). And the other was an exhibition of archaeological materials found in Pliska, which were brought together and presented in Sofia by Ljudmila Dončeva-Petkova of the Archaeological Institute of the Bulgarian Academy of Sciences. In close cooperation the two institutions created a catalogue of the most important archaeological finds from Pliska ${ }^{1}$ that have been discovered since Karel Škorpil started excavations there in the late nineteenth century. ${ }^{2}$

This catalogue was published in Bulgarian language in a limited edition and given to the participants of the Ebernburg conference and then shortly after to the visitors of the opening event of the exhibition in Sofia. Only a few exemplars may have reached archaeological libraries or a limited number of specialists.

* The author of these lines translated the catalogue from Bulgarian into German. He is most grateful to all collaborators of the Department of Early Medieval Archaeology at the University of Frankfurt for their valuable assistance in producing the final layout of this catalogue. Vasilena Petrova (Frankfurt) invested much time proving the descriptions of the finds (text improvements, unifications and completions). Where necessary she inserted the latest literature. To the photographer Angela Ehrlich (Frankfurt) we owe the professional illustrations of the materials. Günter Prinzing (Mainz) was more than helpful in proving the written data of the inscriptions. We thank Ljudmila Dončeva-Petkova (Sofia) for checking again the catalogue for mistakes. Last but not least we address our gratefulness to the following excavators, which made their findings available for this catalogue: Stojan Vitljanov, Pavel Georgiev, Rašo Rašev, Ljudmila Dončeva-Petkova, Janko Dimitrov, Ivan Jordanov, Živko Aladžov, Stanislav Stanilov, Radoslav Vasilev, Tonka Michajlova.

1 Henning/Dončeva-Petkova 1999.

2 Aboba-Pliska 1905. 
Because of the strong scientific demand the Frankfurt University decided to prepare a revised new edition of the catalogue including improved colored illustrations. Since the descriptions of the items contain all basic measurement data one did without putting scales on the tables. The catalogue numbers correspond with the item numbers on the tables. The transliteration of Cyrillic characters into Latin characters follows the international ISO 9 standard. No version of English, German or French style phonetic transcription has been applied. The following abbreviations have been used:

\section{Abbreviations}

AIM d. BAW

Hist. Mus. Šumen

Mus. Pliska

Nat. Arch. Mus. Sofia

Nat. Hist. Mus. Sofia

Anf.

Av.

Br.

Dm.

Gew.

$\mathrm{H}$.

Inv.-Nr.

L.

Max.

Qu.

Rev.

St.

$\mathrm{T}$.
Archaeological Institute and Museum of the Bulgarian Academy of Sciences, Sofia

Museum of History, Šumen

Museum in the National Historical and Archaeological

Reservation of Pliska

National Museum of Archaeology, Sofia

National Museum of History, Sofia

Anfang (beginning)

Avers (averse)

Breite (width)

Durchmesser (diameter)

Gewicht (weight)

Höhe (height)

Inventarnummer (inventory number)

Länge (length)

maximal (maximum)

Quadrat (square)

Revers (reverse)

Stärke (thickness)

Tiefe (depth) 


\title{
Katalog archäologischer Funde aus Pliska*
}

\author{
JOACHIM HENNING
}

\section{Einführung}

Archäologische Ausgrabungen in Pliska begannen 1899, also vor mehr als 100 Jahren. Anlässlich dieses Jubiläums haben 1999 Mitglieder der Deutsch-Bulgarischen PliskaExpedition zwei wissenschaftliche Veranstaltungen organisiert. Eine davon war eine internationale Tagung auf der Ebernburg bei Bad Münster am Stein im schönen MittelRhein-Gebiet, die von der Johann Wolfgang Goethe-Universität Frankfurt am Main ermöglicht wurde (Die Mehrzahl der Beiträge wurde in die vorliegende Publikation aufgenommen). Und die andere war eine Ausstellung archäologischer Materialien, die in Pliska gefunden und von Ljudmila Dončeva-Petkova vom Archäologischen Institut der Bulgarischen Akademie der Wissenschaften in Sofia zusammen getragen und präsentiert wurden. In enger Zusammenarbeit haben die beiden Institutionen einen Katalog der bedeutendsten archäologischen Fundstücke geschaffen, ${ }^{1}$ die in Pliska gefunden worden sind, seit Karel Škorpil am Ende des 19. Jahrhunderts dort mit Ausgrabungen begann. ${ }^{2}$

Dieser Katalog in bulgarischer Sprache wurde in einer begrenzten Auflage hergestellt und an die Teilnehmer der Ebernburg-Konferenz sowie kurz darauf an die Besucher der Ausstellungseröffnung in Sofia übergeben. Nur wenige Exemplare dürften archäologische Bibliotheken oder eine begrenzte Zahl von Spezialisten erreicht haben.

* Der Autor dieser Zeilen hat die Übersetzung des Kataloges aus dem Bulgarischen ins Deutsche vorgenommen. Er ist allen Mitarbeitern der Abteilung Frühmittelalterarchäologie an der Frankfurter Universität für ihre wertvolle Hilfe bei der Erstellung der Endform dieses Kataloges zu Dank verpflichtet. Vasilena Petrova (Frankfurt) hat viel Zeit für die Überprüfung der Beschreibung von Fundgegenständen (Textverbesserungen, Vereinheitlichungen und Ergänzungen) aufgewendet. Wo erforderlich, hat sie neuere Literatur eingefügt. Wir verdanken die professionellen Abbildungen des Materials der Fotografin Angela Ehrlich (Frankfurt). Günter Prinzing war überaus hilfreich bei der Überprüfung der Angaben zu den Inschriften. Wir danken Ljudmila Dončeva-Petkova (Sofia) dafür, dass sie den bulgarischen Katalogtext nochmals auf Fehler durchgesehen hat. Schließlich gilt unser Dank den folgenden Ausgräbern, die ihre Funde für den Katalog zur Verfügung gestellt haben: Stojan Vitljanov, Pavel Georgiev, Rašo Rašev, Ljudmila Dončeva-Petkova, Janko Dimitrov, Ivan Jordanov, Živko Aladžov, Stanislav Stanilov, Radoslav Vasilev, Tonka Michajlova.

1 Henning/Dončeva-Petkova 1999.

2 Aboba-Pliska 1905. 
Wegen der starken Nachfrage hat sich die Frankfurter Universität entschlossen, eine überarbeitete Neuauflage des Kataloges mit verbesserten Farbabbildungen zu erstellen. Da die Beschreibungen der Gegenstände alle wesentlichen Maßangaben enthalten, wurde darauf verzichtet, Maßstäbe auf die Tafeln zu setzen. Die Katalognummern entsprechen den Fundstück-Nummerierungen auf den Tafeln. Folgende Abkürzungen wurden verwendet:

\section{Abkürzungen}

AIM d. BAW

Hist. Mus. Šumen

Mus. Pliska

Nat. Arch. Mus. Sofia

Nat. Hist. Mus. Sofia

Anf.

Av.

Br.

Dm.

Gew.

$\mathrm{H}$.

Inv.-Nr.

L.

Max.

Qu.

Rev.

St.

$\mathrm{T}$.
Archäologisches Institut und Museum der Bulgarischen Akademie der Wissenschaften, Sofia Historisches Museum, Šumen

Museum im Nationalen Historisch-archäologischen Reservat Pliska

Nationales Archäologisches Museum, Sofia

Nationales Historisches Museum, Sofia

Anfang

Avers

Breite

Durchmesser

Gewicht

Höhe

Inventarnummer

Länge

maximal

Quadrat

Revers

Stärke

Tiefe 


\begin{abstract}
$\mathrm{Katalog}^{3}$
Bearbeitet von Ljudmila Dončeva-Petkova, Angela Ehrlich, Joachim Henning, Vasilena Petrova
\end{abstract}

1. Medaillon des Khans Omurtag (814-831). Im Wohngebäude der Festung „Carevec“, Veliko Tărnovo. 40er Jahre des 13. - 20er Jahre des 14. Jhs. Ein fast identisches Stück wurde von K. Škorpil in einem Grab bei dem Dorf Belogradec, Bezirk Varna, unweit von Pliska gefunden (Škorpil 1905, 387, Abb. 151).

Gold. Die Öse zum Aufhängen fehlt.

Av.: Frontal-Brustbild des Herrschers. Er ist bartlos, bekleidet mit Divitision und Chlamys, die an der rechten Schulter mit einer Fibel zusammengehalten wird. Auf dem Kopf trägt er eine Krone (stemma) mit Kreuz, von der zu beiden Seiten die Pendilien herabhängen. In der Rechten hält er ein Kreuzzepter, in der Linken hält er die Akakia (?) vor die Brust. In der oberen Hälfte befindet sich die umlaufende Inschrift in lateinischen und griechischen Buchstaben:

CAN-ESY-bHГIWMORTAГ

K $\alpha \nu \varepsilon \sigma \nu \beta \eta \gamma \imath \Omega \mu o \rho \tau \alpha \gamma$

Übersetzung: „(Medaillon) des Khans sjubigi Omortag“.

Die Darstellung und die Inschrift sind mit einem Perlenband umgeben.

Rev.: Oberfläche ganz glatt, stark poliert durch langes Tragen.

Dm.: 2,2 cm; St.: 0,5 cm; Gew.: 2,7423 g; Goldgehalt: 21,27 K.

Filiale des AIM d. BAW, Veliko Tărnovo.

Jordanov 1976, 21-23, Abb. 11; Beševliev 1979, Nr. 86, 234, Abb. 184-185; Beševliev 1981, 288; Slavčev/Jordanov 1979, 25-31, Abb. 2a,b; Jordanov 2001a, 25, Nr. 2.

2. Siegel des Fürsten Boris-Michail (864-889). Frühmittelalterliche Siedlung im Bereich der Großen Basilika, ca. 0,5 km nordöstlich davon.

Blei. Unvollständiger Abdruck, nach oben gerutscht. Auf beiden Seiten fehlen Teile der Inschriften. Av.: Umlaufende Inschrift zwischen zwei Perlenbändern:

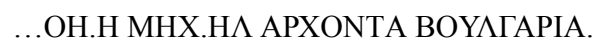

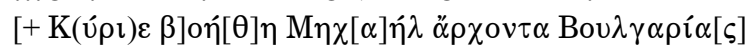

Übersetzung: „Herr, hilf Michael, dem Archon (Herrscher) Bulgariens“.

Im Zentrum Brustbild von Jesus Christus (mit Kreuznimbus), der mit der rechten Hand segnet und in der Linken das Evangelium hält.

Rev.: Umlaufende Inschrift zwischen zwei Perlenbändern:

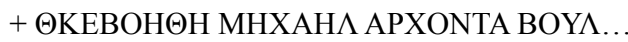

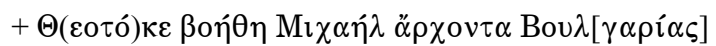

Übersetzung: „Gottesmutter, hilf Michael, dem Archon (Herrscher) Bulgariens“. Im Zentrum das Brustbild der betenden Gottesmutter (Hände vor der Brust) mit Nimbus, Mandyas und Maphorion.

Dm.: 2,6x2,7 cm; St.: 0,05 cm.

Mus. Pliska, Inv.-Nr. 3920.

Vasilev 1991, 3-7, Abb. 1a,b; Jordanov 2000, 138, Nr. A,1; Jordanov 2001a, 32-33, Nr. B,23; Jordanov 2001b, 219, 226, Kat.-Nr. 1.

3 Die Katalognummern entsprechen der Nummerierung der Funde auf den Tafeln. 
3. Ring. Äußere Stadt. Regierungszeit des Khans Omurtag (814-831).

Gold. Runder Ring, rechteckige Platte, flankiert an beiden Seiten von jeweils drei Granulatperlen. Auf der Platte griechische Inschrift in drei Reihen:

TOYTA T $\mid \triangle$ AKTY $\mid$ I T $\Delta$ O APX

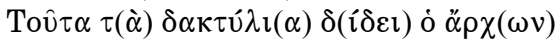

Übersetzung: „Diese Ringe gibt der Archon“.

Dm. Ring: 1,9 cm (außen), 1,4 cm (innen); Ausmaße Platte: 1,1x0,8x0,12 cm; Goldgehalt: $22 \mathrm{~K}$.

Hist. Mus. Šumen, Inv.-Nr. 16030

Beševliev 1979, Nr. 88, Abb. 188; Beševliev 1981, 288.

4. Follis Nikephoros I. und Stavrakios (802-811). Siedlung im Südosten der Äußeren Stadt im Bereich der Kirche Nr. 11, Qu. 9, T. 0,40 m.

Kupfer.

Av: Brustbilder der beiden sich gegenüberstehenden Herrscher.

Rev: M.

Dm.: 2,2x2,3 cm.

Mus. Pliska, Inv.-Nr. 2303.

Jordanov 2000, 144, Kat.-Nr. 36.

5. Kanne. Unterirdischer Gang am Krum-Palast, südliche Abzweigung. Anf. 9. Jh.

Ton. Ohne Magerung, gelbe Brennfarbe. Sphärischer Körper, enger Hals, profilierter Mündungsrand, hohler Standfuß, im Querschnitt fünfeckiger Henkel, dessen unteres verlängertes Ende mit je zwei zweiblättrigen eingravierten Halbpalmetten auf beiden Seiten verziert ist. Glatte Wandung mit Resten eines glasurartigen Überzugs.

H.: 26,6 cm; Dm. Mündung: 5 cm; Dm. Körper: 16 cm; Dm. Boden: 10 cm.

Mus. Pliska, Inv.-Nr. 3843.

Rašev 2004, 84, Kat.-Nr. 2, Abb. 7,1, Taf. IA,2, Taf. IB,2; Petrova/Brey 2005.

6. Steinblock. Stadtbau, östlich der Ziegelumfassungsmauer (Zitadelle). 9. Jh.

Kalkstein. Auf einer Längsseite gravierte menschliche Figur, Reiter, zwei Tiere und Inschrift.

L.: $49 \mathrm{~cm}$; Br.: $21 \mathrm{~cm}$.

Nat. Arch. Mus. Sofia, Inv.-Nr. 3693.

Stančev 1955, 211-214, Abb. 28a,b; Georgiev 1991, 191-208, Abb. 1-4.

7. Löwenstatue. Osttor. Anf. 9. Jh.

Kalkstein. Erhalten sind Teile des Kopfes (Augen, Mähne) und des Körpers. Der Stein ist oben abgeflacht; er ist Basis für eine Säule. Auf der Schulter des Löwen ist ein eingeritztes Zeichen: Y. In drei Teile zerbrochen.

L.: $1,20 \mathrm{~m}$; H.: $46 \mathrm{~cm}$.

Mus. Pliska, Inv.-Nr. 43.

Mollov 1943, 69-70, Abb. 138.

8. Pfeilspitze. Innere Stadt. 8.-9. Jh.

Eisen. Tüllenspitze mit Widerhaken. Schafttülle konisch und lang gestreckt.

L.: $10 \mathrm{~cm}$; Max. Br.: 4,5 cm; Dm. Tülle: $1 \mathrm{~cm}$.

Mus. Pliska, Inv.-Nr. 119. 
9. Pfeilspitze. Innere Stadt. 8.-9. Jh.

Eisen. Schaftdornpfeilspitze mit lang gezogenem rhombischem Blatt mit Mittelgrat. Zwischen Schaftdorn und Blatt eine wulstige Rippe.

L.: 10,7 cm; Max. Br.: 2,7 cm.

Mus. Pliska, Inv.-Nr. 20.

10. Pfeilspitze. Innere Stadt. 8.-9. Jh.

Eisen. Tüllenpfeilspitze mit blattförmiger Spitze, deren untere Seiten gerundet sind.

L.: $10 \mathrm{~cm}$; Max. Br. $2 \mathrm{~cm}$; Dm. Tülle: $1 \mathrm{~cm}$.

Mus. Pliska, Inv.-Nr. 117.

11. Pfeilspitze. Südliche Festungsmauer. 9.-11. Jh.

Eisen. Schaftdornpfeilspitze mit rhombischem Blatt. Zwischen Schaftdorn und Blatt eine Querrippe.

L.: 9,5 cm; Max. Br.: 2 cm.

Mus. Pliska Inv.-Nr. 118.

12. Pfeilspitze. Südliche Festungsmauer. 9.-11. Jh.

Eisen. Schaftdornpfeilspitze mit kurzem breitem rhombischem Blatt. Schaftdorn lang gezogen und tordiert.

L.: $7 \mathrm{~cm}$; Max. Dm.: $1,1 \mathrm{~cm}$

Mus. Pliska Inv.-Nr. 2664.

13.-14. Pfeilspitzen. Objekt 41. 11. Jh.

Eisen. Schaftdornpfeilspitzen mit lang gezogenen pyramidenförmigen Spitzen und scharf abgesetzten Schaftdornen.

Nr. 13 - L.: 4,8 cm; L. Spitze: 3,8 cm; Max. Br.: 0,5 cm. Nr. 14 - L.: 4,8 cm; L. Spitze: 4 cm; Max. Br.: 0,75 cm.

Mus. Pliska, Inv.-Nr. 3735, 3740.

15. Pfeilspitze. Objekt 41. Anf. 11. Jh.

Eisen. Tüllenpfeilspitze mit lang gestreckter konischer Tülle und schwach abgesetzter kegelförmiger Spitze.

L.: $6,3 \mathrm{~cm}$; L. Spitze: $2,4 \mathrm{~cm}$; Dm. Tülle: $1 \mathrm{~cm}$.

Mus. Pliska, Inv.-Nr. 3739.

Ausgrabungen S. Vitljanov.

16. Pfeilspitze. Objekt 41. 10 - Anf. 11. Jh.

Eisen. Schaftdornpfeilspitze mit rhombischem Blatt, dessen größte Breite im oberen Drittel liegt, und lang gezogenem Schaftdorn. Zwischen Blatt und Schaftdorn ein kräftige Querrippe.

L.: $8,4 \mathrm{~cm}$; L. Spitze: $4,4 \mathrm{~cm}$.

Mus. Pliska, Inv.-Nr. 2666.

Ausgrabungen S. Vitljanov. 
17. Lanzenspitze. 8.-9. Jh.

Eisen. Lanzenspitze mit dreikantigem lang gezogenem Blatt mit Mittelgrat und konischer Tülle. L.: $37 \mathrm{~cm}$; Max. Br.: $5 \mathrm{~cm}$.

Mus. Pliska, Inv.-Nr. 2464.

Jotov 2004, Kat.-Nr. 515.

18. Lanzenspitze. Objekt 41. Anf. 11. Jh.

Eisen. Lanzenspitze mit flachem lang gezogenem lorbeerblattförmigem Blatt und konischer Tülle, die korrodiert ist.

L: 21,5 cm; L. Tülle: $4 \mathrm{~cm}$; Max. Br.: $3 \mathrm{~cm}$.

Mus. Pliska, Inv.-Nr. 3799.

Ausgrabungen S. Vitljanov.

19. Lanzenspitze. Innere Stadt. 10. - Anf. 11. Jh.

Eisen. Lanzenspitze mit langer vierkantiger Spitze und konischer Schafttülle. Unterhalb des Blattansatzes eine breite umlaufende Rippe.

L.: $24 \mathrm{~cm}$; L. Schneide: $17 \mathrm{~cm}$; Dm. Tülle: $1,5 \mathrm{~cm}$.

Mus. Pliska, Inv.-Nr. 122.

20. Steigbügel. Gebäude Nr. 32. 9.-10. Jh.

Eisen. U-förmiger Umriss, stabförmiger Bügel und breite gerade Trittplatte, die mit profilierter Kante und vier symmetrisch angeordneten Löchern versehen ist. Riemenplatte fünfeckig mit rechteckiger Riemenöffnung in der oberen Hälfte und zwei runden Öffnungen darunter.

H.: $19,5 \mathrm{~cm}$; Br.: $11,8 \mathrm{~cm}$; Br. Tritt: $6,9 \mathrm{~cm}$.

Mus. Pliska, Inv.-Nr. 2397.

Rašev 1984, 7-8, Abb. 7,b; Jotov 2004, 152, 154, Kat.-Nr. 790, Abb. 91, Taf. LXXV.

21. Steigbügel (eines Steigbügelpaares/zusammen mit Nr. 24 gefunden). Gräberfeld bei der südlichen Festungsmauer, Grab Nr. 20. 11. Jh.

Eisen mit Silbertauschierung. Ovaler Umriss, im Oberteil mit rundem Querschnitt, im Unterteil als schmale bandförmige Trittplatte ausgeformt. Zwischen Ober- und Unterteil zwei modellierte Tierköpfe (wahrscheinlich Pferdeköpfe). Im zugespitzten Oberteil rechteckige Riemenöffnung, auf der beidseitig punktförmigen Silbertauschierungen angebracht sind.

H.: 12,2 cm; Dm.: 10,7 cm; Br. Tritt: 4,7 cm.

Mus. Pliska, Inv.-Nr. 2604.

Zachariev 1979, 137, Abb. 47; Rašev 1983, 249-250, Abb. 3, Abb. 4a, Abb. 5a; Jotov 2004, 154, Kat.-Nr. 798-799, Abb. 94, Taf. LXXVI.

22. Reitersporn. Komplex südlich des Westtores. 11. Jh.

Eisen, versilbert. U-förmiger Bügel mit ovalem Querschnitt, in den zugespitzten Enden je eine ovale Öffnung. Im Scheitelpunkt des Bügels eine würfelförmige (sekundär?) durchlochte Verdickung, darauf aufsitzend der Stachel mit kurzem geschwollenem Hals und verdickter kegelförmiger Spitze.

L.: $18,8 \mathrm{~cm}$; Br.: $10 \mathrm{~cm}$; L. Dorn: $3,8 \mathrm{~cm}$.

Mus. Pliska, Inv.-Nr. 2003.

Dončeva-Petkova 1992, 141, Abb. 40; Jotov 2004, 164, Kat.-Nr. 824, Abb. 100, Taf. LXXVIII. 
23. Trense. Westliche Festungsmauer, Nordsektor. 10. - Anf. 11. Jh.

Eisen. Zweiteilige Gebissstange aus zwei stabförmigen Gliedern, die durch einen Ring verbunden sind. In den Ösen große Zügelringe.

L.: $15 \mathrm{~cm}$; Dm. Ringe: $5 \mathrm{~cm}$.

Mus. Pliska, Inv.-Nr. 3152.

Antonova/Vitljanov 1985, 75, Taf. IX,29; Jotov 2004, 136, Kat.-Nr. 732, Taf. LXVIII.

24. Trense (zusammen mit Nr. 21 gefunden). Gräberfeld an der südlichen Festungsmauer, Grab Nr. 20 . 11. Jh.

Eisen. Trense mit zweiteiliger Gebissstange, in den Ösen je ein Zügelring mit je einer einfachen Querstange (davon eine zerbrochen).

L.: $17 \mathrm{~cm}$; Dm. Ringe: $4,5 \mathrm{~cm}$.

Mus. Pliska, Inv.-Nr. 2603.

Zachariev 1979, 137, Abb. 47; Jotov 2004, 135, Kat.-Nr. 728, Abb. 94, Taf. LXVII.

25. Trensenstange. 9.-10. Jh.

Knochen. Mondsichelförmig mit rechteckiger Riemenschlaufe an der Außenseite sowie gegenüberliegende ovaler Öffnung. Die Oberfläche ist mit Kreisaugenornamenten, die Ränder mit Kerbschnittbändern verziert.

L.: $10 \mathrm{~cm}$; Max. Br:: 3,3 cm.

Mus. Pliska, Inv.-Nr. 113.

Jotov 2004, 136, Kat.-Nr. 752, Taf. LXVII.

26. Kandarrenkette. Objekt 41. Anf. 11. Jh.

Eisen. Geschmiedet. Bogenförmig geschwungene Klammer mit an einem Ende erhaltenem Ring zur Befestigung der Kette, von der vier Glieder in Achterform erhalten sind.

L.: 34 cm; L. Klammer: 11,5 cm; L. Kette: 24 cm; Br.: 6,5 cm.

Mus. Pliska, Inv.-Nr. 3799.

Ausgrabungen S. Vitljanov.

27. Hornzapfen. Nordöstlich der Ziegelumfassungsmauer (Zitadelle). 10. Jh.

Horn. Vierkantig. Auf der glatten Oberfläche auf jeder Seite Verzierung aus Kreisaugen. Am oberen abgeschnittenen Ende eine kleine Durchlochung zum Aufhängen.

L.: $17 \mathrm{~cm}$.

Nat. Hist. Mus. Sofia, Inv.-Nr. 4621.

Stančev 1955, 207, Abb. 26,14.

28. Steinblock. Südliche Festungsmauer. 9. Jh.

Weißer Kalkstein. Quaderförmiger Block mit auf einer Breitseite tief eingeritztem sternförmig angeordnetem Y-Zeichen.

L.: $39 \mathrm{~cm}$; Br.: $34 \mathrm{~cm}$; St.: $29 \mathrm{~cm}$.

Nat. Hist. Mus. Sofia, Inv.-Nr. 5581.

Ausgrabungen I. Zachariev.

29. Ziegel. Westliche Festungsmauer, Südsektor. 9. Jh.

Ton. Ziegelrote Brennfarbe. Plattenförmig, auf einer flachen Seite vor dem Brand eingeritzte Zeichnung eines Hirsches. 
Erhaltene L.: $21 \mathrm{~cm}$; Br.: $25 \mathrm{~cm}$; St.: $5 \mathrm{~cm}$.

Mus. Pliska, Inv.-Nr. 3245.

Ausgrabungen L. Dončeva-Petkova.

30. Ziegel. Westliche Festungsmauer, Südsektor. 9. Jh.

Ton. Gelbe Brennfarbe. Plattenförmig, auf einer flachen Seite vor dem Brand eingeritzte Zeichnung eines Pferdchens.

L.: $29 \mathrm{~cm}$; Br.: 23,5 cm; St.: 4,7 cm.

Mus. Pliska, Inv.-Nr. 3244.

Ausgrabungen L. Dončeva-Petkova.

31. Ziegel, sekundär wieder verwendet im 11. Jh. Gräberfeld vor dem Osttor. 9. Jh.

Ton. Gelbe Brennfarbe. Plattenförmig mit vor dem Brand eingeritztem kreuzförmigem Zeichen. L.: $34 \mathrm{~cm}$; Br.: $32 \mathrm{~cm}$; St.: $5 \mathrm{~cm}$.

Mus. Pliska, Inv.-Nr. 3246.

Ausgrabungen J. Dimitrov.

32. Dachziegel. Östliche Festungsmauer. 9. Jh.

Ton. Gelbe Brennfarbe. Tegula. Auf der Innenseite vor dem Brand eingeritztes Zeichen IYI.

L.: $56 \mathrm{~cm}$; Br.: $36 \mathrm{~cm}$; St.: $3 \mathrm{~cm}$.

Mus. Pliska, Inv.-Nr. 3248.

Ausgrabungen R. Vasilev.

33. Dachziegel. Große Basilika. Zweite Hälfte 9. Jh.

Ton. Gelbe Brennfarbe. Imbrex. Auf der Oberseite vor dem Brand eingeritztes Zeichen IYI. L.: $44,5 \mathrm{~cm}$; Br.: 14,5-10,5 cm; St.: $1,5 \mathrm{~cm}$.

Mus. Pliska, Inv.-Nr. 3247.

Georgiev/Vitljanov 2001, Abb. 73.

34. Wasserleitungsrohr. Östlich der Palastbasilika. 9. Jh.

Ton. Braune Brennfarbe. Sich verengende zylindrische Form mit enger Tülle. In die Oberfläche vor dem Brand eingeritzte horizontale Linien sowie ein Ritzzeichen.

L.: $38 \mathrm{~cm}$; Dm.: $12,3 \mathrm{~cm}$.

Mus. Pliska, Inv.-Nr. 3945.

35. Wasserleitungsrohr. Kleiner Palast, Bad. 9. Jh.

Blei. Zylindrisch, schmal, aus einer Platte zusammengebogen und gelötet.

L.: $72 \mathrm{~cm}$; Dm.: 6/12 cm.

Mus. Pliska, Inv.-Nr. 89.

36. Steinplatte. Pflaster im Südostteil der Ziegelumfassungsmauer (Zitadelle). 9. Jh.

Kalkstein. Auf einer Seite gemeißeltes Zeichen IYI.

L.: $51 \mathrm{~cm}$; Br.: 28-30 cm; St.: 10-19 cm; Br. Ritzlinien: 2,8-3,5 cm; T. Ritzlinien: 1-1,2 cm.

Mus. Pliska Inv.-Nr. 3249.

Dončeva-Petkova 1980, 11, Abb. 2. 
37. Ziegel. Durchgang des Westtores. 9. Jh.

Ton. Rote Brennfarbe. Vor dem Brand auf einer Seite eingeritzt: ein symbolisch-anthropomorphes Bild der Sonne oder eine apotropäische Maske der Medusa Gorgona (in ihrer mittelalterlichen Ausführung).

L.: $23 \mathrm{~cm}$; Br.: 18,5 cm; St.: 4-5,5 cm.

AIM d. BAW, Sofia, Inv.-Nr. 5262.

Michajlov 1974, 231-232, Abb. 28; Ovčarov 1978, 30-31; Rašev 2003, 167.

38. Rosette. Großer Wasserspeicher. 9. Jh.

Bronze, gegossen. Gravur. Um ein erhabenes rundes Mittelteil sind sieben trapezförmige Strahlen gruppiert. Auf einer Seite des Mittelteils das eingravierte Zeichen IYI. Auf der anderen Seite eine Aufhängeröse. Auf jedem Strahlenblatt jeweils zwei Zeichen.

Dm.: $3,9 \mathrm{~cm}$.

Nat. Arch. Mus. Sofia, Inv.-Nr. 5257.

Vaklinov 1978, 245-254; Petrova 1992; Georgiev 1995; Teofilov 2000; Rašev 2003, 165.

39. Stark fragmentierter Krug. Siedlung im Bereich der Großen Basilika, Grubenhaus Nr. 1. Ende 8. Jh. - Mitte 9. Jh.

Ton. Ohne Magerung, gelb-braune Brennfarbe. In die Gefäßwand wurde vor dem Brand das Zeichen IYI eingeritzt, flankiert von zwei Adler-Darstellungen (eine frontal, die andere im Profil). Hergestellt auf der Fußtöpferscheibe.

Erhaltene H.: $19 \mathrm{~cm}$; Max. Dm.: 15,5 cm.

Mus. Pliska, Inv.-Nr. 3873.

Georgiev 1978, 30-39, Abb. 1a,b.

40. Anhänger. Komplex im Südsektor der westlichen Festungsmauer. 11. Jh.

Kupfer. Lötung, Gravur. Hohl, tropfenförmig mit Aufhängeröse. Stilisierte Darstellung eines Löwenkopfes, umrahmt von Pflanzenmotiven, orientiert auf die Blickrichtung des Trägers.

H.: 3,4 cm; Max. Dm.: $1,7 \mathrm{~cm}$.

Mus. Pliska, Inv.-Nr. 3220.

Dončeva-Petkova 1992, 141, Abb. 41v.

41. Topf. Hügel XXXIII. Anf. 9. Jh.

Ton. Sandgemagert, hellgraue Brennfarbe. Annähernd zylindrischer Gefäßkörper, leicht ausladende Mündung mit gerundetem Rand, flacher Boden mit umlaufendem Profilrand (Quellboden). Gefäßwand verziert mit in Abstand eingeritzten parallelen Linienbändern. Hergestellt auf der Handtöpferscheibe. Ergänzt.

H.: 16,6 cm; Dm. Mündung: $11 \mathrm{~cm}$; Dm. Körper: $13 \mathrm{~cm}$; Dm. Boden: $8 \mathrm{~cm}$.

Nat. Arch. Mus. Sofia, Inv.-Nr. 3658.

Stančev 1949, 229, Abb. 12; Dončeva-Petkova 1977, 161, Kat.-Nr. 114, Taf. VI,114.

42. Topf. Hügel XXXIII. Anf. 9. Jh.

Ton. Sandgemagert, ziegelrote Brennfarbe. Ovaler Gefäßkörper, abgesetzter Hals, ausladende Mündung mit schräg abgestrichener Lippe. Schulter mit Wellenband und Gefäßkörper mit waagerechter dichter Liniengurtung verziert. Hergestellt auf der Handtöpferscheibe.

H.: 17,5 cm; Dm. Mündung: $12 \mathrm{~cm}$; Dm. Körper: $16 \mathrm{~cm}$; Dm. Boden: $10 \mathrm{~cm}$. 
Nat. Arch. Mus. Sofia, Inv.-Nr. 3650.

Stančev 1949, 229, Abb. 1,8, Georgieva 1955, 21, Abb. 16,8; Dončeva-Petkova, 1977, 162, Kat.Nr. 129.

43. Topf. Hügel XXXIII. Anf. 9. Jh.

Ton. Ohne Magerung, ziegelrote Brennfarbe. Sphärischer Gefäßkörper, abgesetzter Hals, ausladende Mündung mit gerundetem Rand, flacher Boden. Die Oberfläche ist komplett poliert und mit horizontalen eingeritzten Rillen bedeckt. Hergestellt auf der Handtöpferscheibe. Ergänzt.

H.: 14,3 cm; Dm. Mündung: 9,5 cm; Dm. Körper: 16,6 cm; Dm. Boden: 9,5 cm.

Nat. Arch. Mus. Sofia, Inv.-Nr. 3644.

Stančev 1949, 229, Abb. 1,16, Georgieva 1955, 23, Abb. 18,1; Dončeva-Petkova 1977, 156, Kat.-Nr. 156, Taf. X,156.

44. Topf. Hügel XXXIII. Anf. 9. Jh.

Ton. Ohne Magerung, rot-braune Brennfarbe. Sphärischer Gefäßkörper, kurzer, abgesetzter Hals mit auswärtsgeneigtem, verdicktem Rand, flacher Boden. In der unteren Hälfte des Körpers horizontale eingeritzte Rillen, in der oberen Hälfte netzförmige Einglättstreifen. Hergestellt auf der Handtöpferscheibe. Ergänzt.

H.: 21 cm; Dm. Mündung: 16,5 cm; Dm. Körper: 23 cm; Dm. Boden: 13,3 cm.

Nat. Arch. Mus. Sofia, Inv.-Nr. 3651.

Stančev 1949, 231, Abb. 2,4; Dončeva-Petkova 1977, 165, Kat.-Nr. 152, Taf. X,152.

45. Topf. Hügel XXXIII. Anf. 9. Jh.

Ton. Ohne Magerung, gelb-braune Brennfarbe. Sphärischer Gefäßkörper, gerader Hals, gerundeter Boden, zwei Henkel zwischen Hals und Schulter. Die polierte Oberfläche ist mit horizontalen Kanneluren bedeckt. Hergestellt auf der Handtöpferscheibe. Ergänzt.

H.: 24 cm; Dm. Mündung: 14,5 cm; Dm. Körper: 22,7 cm; Dm. Boden: 14 cm.

Mus. Pliska: Inv.-Nr. 52.

Stančev 1949, 231, Abb. 2,8, Georgieva 1955, 25, Abb. 20,4; Dončeva-Petkova 1977, 167, Kat.Nr. 164.

46. Kanne. Hügel XXXIII. Anf. 9. Jh.

Ton. Ohne Magerung, rot-braune Brennfarbe. Rundlicher Körper, schmaler und langer Hals, kleeblattförmige Mündung, flacher Boden. Der Gefäßkörper ist mit flach eingeritzten Horizontallinien bedeckt, die Wandung darüber und der Hals sind poliert. Hergestellt auf der Handtöpferscheibe.

H.: 28 cm; Dm. Mündung: 7x7,5 cm; Dm. Körper: 20 cm; Dm. Boden: 13,3 cm.

Nat. Arch. Mus. Sofia, Inv.-Nr. 3642.

Stančev 1949, 231, Abb. 2,11; Georgieva 1955, 25, Abb. 2,20; Dončeva-Petkova 1977, 175, Kat.-Nr. 231.

47. Kanne. Hügel XXXIII. Anf. 9. Jh.

Ton. Ohne Magerung, hellbraune Brennfarbe. Sphäroidischer Gefäßkörper, schmaler Hals, kleeblattförmige Mündung, rundlicher Boden, im Querschnitt runder Henkel, am Hals und an der Schulter befestigt. Die polierte Oberfläche ist mit Kanneluren bedeckt. In oberen Teil des Henkels und auf dem Hals knospenförmige Aufsätze. Hergestellt auf der Handtöpferscheibe. Ergänzt. 
H.: $31 \mathrm{~cm}$; Dm. Mündung: 7x9 cm; Dm. Körper: $31 \mathrm{~cm}$; Dm. Boden: $12 \mathrm{~cm}$.

Nat. Arch. Mus. Sofia, Inv.-Nr. 3663.

Stančev 1949, 230, Abb. 2,9; Georgieva 1955, 25, Abb. 20,3; Dončeva-Petkova 1977, 177, Kat.Nr. 239, Taf. XVII,139.

48. Ausgusskanne. Hügel XXXIII. Anf. 9. Jh.

Ton. Ohne Magerung, gelb-graue Farbe. Sphärischer Gefäßkörper, schmaler, zylindrischer Hals, ringförmige Mündung, flacher Boden. An der breitesten Stelle des Gefäßkörpers runder Henkel, diesem gegenüber zylindrische Tülle. Glatte Oberfläche. Hergestellt auf der Fußtöpferscheibe.

H.: 21,5 cm; Dm. Mündung: $6 \mathrm{~cm}$; Dm. Körper: $18 \mathrm{~cm}$; Dm. Boden: 8,5 cm.

Nat. Arch. Mus. Sofia, Inv.-Nr. 3628.

Stančev 1949, 231, Abb. 2,4; Georgieva 1955, 25, Abb. 21,1; Dončeva-Petkova 1977, 178, Kat.Nr. 247, Taf. XVIII,247.

49. Vorratsgefäß. Hügel XXXIII. Anf. 9. Jh.

Ton. Ohne Magerung, rot-braune Brennfarbe. Ovaler Gefäßkörper, abgesetzter Hals, ausladende Mündung mit gerundeter Lippe. Über der breitesten Stelle des Gefäßkörpers sind vier breite parallele Linien eingeritzt. Unter und über diesen schräge Einglättstreifen. Hergestellt auf der Handtöpferscheibe. Ergänzt.

H.: 32,5 cm; Dm. Mündung: 20,6 cm; Dm. Körper: 30 cm; Dm. Boden: 16,5 cm.

Nat. Hist. Mus. Sofia, Inv.-Nr. 3668.

Stančev 1949, 231; Abb. 2,3; Georgieva 1955, 23, Abb. 18,3; Dončeva-Petkova 1977, 195, Kat.Nr. 373.

50. Amphora. Hügel XXXIV. Anf. 9. Jh.

Ton. Ohne Magerung, ocker-gelbe Brennfarbe. Sphäroidischer Gefäßkörper mit breiten Schultern, schmaler Hals, rundlicher Boden, massive flache Henkel. Dicht eingeritzte horizontale Furchen und polierte Oberfläche. Hergestellt auf der Handtöpferscheibe. Abgebrochene Mündung. Ergänzt.

Erhaltene H.: 40 cm; Dm. Hals: 5 cm; Max. Dm.: 34 cm.

Mus. Pliska: Inv.-Nr. 3919.

Ausgrabungen L. Dončeva -Petkova, P. Georgiev, S. Stanilov und R. Vasilev.

51. Kapitell. Große Basilika. 4. Jh., weitere Nutzung in der zweiten Hälfte 9. Jh.

Marmor. Säulenkapitell, korinthisch. Untere Reihe mit fünf Bündeln von Akanthus-Blättern. Ausschnitte zwischen den Bündeln berühren sich. Vier Blätter stützen diagonale Voluten. Es fehlen Kaulis und Helices, der Kalathos ist nicht sichtbar. Der Abakus ist zweiteilig. Die AbakusBlüte sieht wie eine eingerollte Ranke aus.

H.: $37 \mathrm{~cm}$; H. der unteren Akanthus-Reihe: $20 \mathrm{~cm}$; Br. Voluten: 5,2 cm; Dm. Säulenansatz: $36 \mathrm{~cm}$.

Nat. Arch. Mus. Sofia, Inv.-Nr. 5582.

52. Kempferkapitell. Große Basilika. Zweite Hälfte 9. Jh.

Marmorisierter Kalkstein. Auf einer Schmalseite Relief eines lateinischen Kreuzes. An der Basis Loch zur Befestigung auf der Säule. Fragmentiert.

H.: $60 \mathrm{~cm}$; Ausmaße an der Basis: 28x16 cm; Ausmaße am Abakus: 42x32 cm; H. Abakus: $9 \mathrm{~cm}$. Nat. Arch. Mus. Sofia, Inv.-Nr. 1048. 
53. Quaderstein mit eingeritzten Kreuzen. Basilika Nr. 12. Ende 9.-11. Jh.

Kalkstein. Unregelmäßig bearbeiteter Quaderstein mit eingeritzten Kreuzen auf den beiden glatten, nebeneinander liegenden Flächen.

Ausmaße: $23 \times 17 \times 11,5 \mathrm{~cm}$.

Mus. Pliska, Inv.-Nr. 1826.

Michajlov 1949, 176, Abb. 6.

54. Siegel des Erzbischofs Georgios von Bulgarien. Im Bereich der Großen Basilika, nordöstlich der Klostermauer. (?-893).

Blei. Unvollständiger, nach oben gerutschter Abdruck der Darstellungen. Teile der Inschriften auf beiden Seiten fehlen.

Av.: Umlaufendes Inschrift:

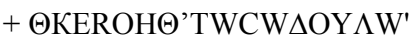

In der Mitte Büste der siegreichen Gottesmutter mit Nimbus, Mandyas und Maphorion. Vor sich auf Brusthöhe hält sie den nimbierten jungen Christus. Auf beiden Seiten findet sich anstelle der Titel jeweils ein Kreuz graviert.

Rev.: Inschrift in fünf Reihen:

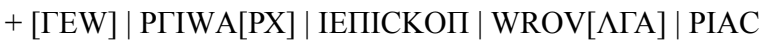

Die zusammengesetzten Inschriften auf beiden Seiten lauten:

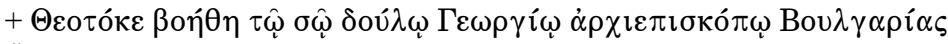

Übersetzung: „Gottesmutter, hilf deinem Knecht Georgios, dem Erzbischof Bulgariens“.

Dm.: $2 \times 2 \mathrm{~cm}$; St.: 0,3-0,4 cm; Gew.: 9,5 g.

Mus. Pliska, Inv.-Nr. 3921.

Vasilev 1992, 26-29, Abb. 1.a.b, Abb. 2; Jordanov 1992, 284, Nr. 10a; Jordanov 2001a, 79, Nr. 136; Jordanov 2001b, 219-220, 226, Nr. 4; Jordanov 2003, 53, Nr. 19,4.A.d.

55. Dreifaches Enkolpion-Reliquiar. Westliche Festungsmauer. Gefunden in Kulturschicht aus der zweiten Hälfte des 9./10. Jh.

Gold, Holz. Schnitzwerk, Lötungen, Pseudogranulationen, Kerbschnitte, Niello. Die drei Kreuze sind ineinander geschachtelt. Auf den beiden äußeren Seiten des ersten goldenen Kreuzes sind in chronologischer Folge sieben Szenen aus den großen Christlichen Feiertagen dargestellt. Auf seiner Vorderseite: oben - Verkündigung, links - Christi Geburt, rechts - Präsentation im Tempel, unten - Taufe, in der Mitte - Verklärung; auf seiner Rückseite: auf dem unteren Kreuzarm - Anastasis, auf dem waagerechtem Kreuzarm - die Himmelfahrt (Maria Orans im Zentrum, eingerahmt jeweils von einem Baum, auf ihrer beiden Seiten je sechs Apostel), auf dem oberen Kreuzarm - Christus in der von vier Engeln gehaltenen Mandorla. Auf der Schauseite des zweiten (inneren) Kreuzes - die Kreuzigung auf Golgatha mit den beiden Figuren von der Gottesmutter und dem Apostel Johannes; rückseitig - die siegreiche Gottesmutter mit den Heiligen Kirchenvätern Johannes Chrysostomos, Gregor von Nazianz, Basielios der Große und Nikolaos. Das dritte (innerste) Kreuz ist aus Holz und stellt die eigentliche Reliquie (vom wahren Kreuz?) dar. Am seinem horizontalen Kreuzarm sind Knochenbruchstücke appliziert.

H. mit Öse: 7,2 cm. Erstes Kreuz - H.: 4,2; Br:: 3,2 cm. Zweites Kreuz - H.: 4 cm; Br:: 3 cm. Drittes Kreuz - H.: 3,7; Br.: 2,7 cm. Gesamtgew.: 42 g, Goldgehalt: 22 K.

Nat. Arch. Mus. Sofia, Inv.-Nr. 4882.

Dončeva-Petkova 1976, 59-66, Abb. 1-5; Dončeva-Petkova 1979b, 74-91, Abb. 1-15; Kartsonis 1986, 94-125; Winkelmann/Gomolka-Fuchs 1987, 93-94, Nr. 57-58; Evans/Wixom 1998, 331332, Nr. 225. 
56. Enkolpion-Reliquiar. Gräberfeld im Südhof der Großen Basilika. Grab Nr. 5. Ende 9. - erste Hälfte 10. Jh.

Bronze, gegossen. Auf der Vorderseite schematische Reliefdarstellung der Kreuzigung Jesu Christi, rückseitig betende Gottesmutter.

L. senkrechter Kreuzarm: 5,5 cm; L. waagerechter Kreuzarm: 2,3 cm.

Mus. Pliska.

Vitljanov 1979, 63-64, Abb. 2; Georgiev/Vitljanov 2001, 135, 166-167, 175, Abb. 70,11.12, Abb. 71, Kat.-Nr. 68.

57. Enkolpion. Nordöstlich des Osttores. 10.-11. Jh.

Kupfer. Schnitzwerk, Inkrustation. Flaches Kreuz mit sich verbreiternden Armen. In der Mitte runde Fassung mit grüner Glasinkrustation. Am Ende eines Kreuzarmes Öse zum Aufhängen.

L.: 4,7 cm, Br.: $3,7 \mathrm{~cm}$.

Mus. Pliska, Inv.-Nr. 1295.

58. Enkolpion. Gräberfeld an der westlichen Festungsmauer, Grab Nr. 10. 50er bis 60er Jahre des 11. Jh.

Bronze, gegossen. Schmale, an den Enden sich verbreiternde Arme. Ein Kreuzarm ist länger als die übrigen und hat eine Öse, die beschädigt ist.

H. mit Öse: 4,6 cm; L. senkrechter Kreuzarm: 3,8 cm; L. waagerechter Kreuzarm: 2,5 cm.

Mus. Pliska, Inv.-Nr. 3222.

Dončeva-Petkova 1984, 190, Abb. 6g.

59. Enkolpion-Reliquiar. Gräberfeld östlich des Osttores, Grab Nr. 18. 11. Jh.

Kupfer. Schnitzwerk, Lötungen, Inkrustationen. Kassettenförmig. Stark sich verbreiternde Kreuzarme, in runde Medaillons übergehend. Hergestellt aus zwei gleichartigen kreuzförmigen Blechen, die mit einem schmalen Seitenblech zusammengehalten werden. Auf der Schauseite im Zentrum und auf den Kreuzarmen runde Eintiefungen für Inkrustation (zwei mit grünem Glas erhalten). Auf der Rückseite sind diese Stellen mit konzentrischen Kreisen besetzt. Auf die übrigen Bereiche der Oberfläche sind Fäden aufgelötet, die an verschiedenen Stellen große und kleine Kreise bilden. Eine Öse am Ende des oberen Kreuzarmes.

Gesamte H.: 7,5 cm; H. senkrechter Kreuzarm: 6,8 cm; L. waagerechte Kreuzarm: 5,6 cm; St.: $1,1 \mathrm{~cm}$.

Mus. Pliska, Inv.-Nr. 3424.

Dimitrov 1995, 54, Abb. 6,1.

60. Enkolpion. Gräberfeld östlich des Osttores, Grab Nr. 45. Erste Hälfte des 11. Jh.

Bronze, gegossen. Reliefverzierung, Gravuren. Flach mit runder Öse und stark sich verbreiternden Kreuzarmen, an die sich runde Medaillons anschließen. Auf der Schauseite im Zentrum und auf den Kreuzarmen jeweils zwei Kreisaugenmotive, rückseitig jeweils eines.

H.: 4,5 cm; Br.: 3,3 cm; St.: 0,15 cm.

Mus. Pliska, Inv.-Nr. 3473.

Dimitrov 1995, 54, Abb. 6,2.

61. Medaillon. Siedlung im Bereich der Großen Basilika. 8. - erste Hälfte 9. Jh.

Blei, gegossen. Rund mit Öse und Strahlenkreuz im Kreis.

H. mit der Öse: $2,8 \mathrm{~cm}$; Dm.: $2 \mathrm{~cm}$. 
Mus. Pliska, Inv.-Nr. 3908.

Georgiev 1993, 34, Abb. 31a.

62. Pokal. Kirche Nr. 36. Ende 9.-10. Jh.

Ton. Rote Brennfarbe. In Form eines tiefen Kelches mit hohem trichterförmigen Fuß. Gefäßoberfläche mit eingeritzten wellenförmigen und geraden Linien verziert und mit gelbbrauner Glasur bedeckt.

H.: $17 \mathrm{~cm}$; Dm. Mündung: 13,5 cm; Dm. Boden: $10 \mathrm{~cm}$.

Nat. Arch. Mus. Sofia, Inv.-Nr. 4582.

Michajlov 1955, 52, Abb. 3.

63. Weihrauchgefäß. Komplex im Südsektor der westlichen Festungsmauer, Raum Nr. 1. 11. Jh. Bronze, gegossen. Sphärischer Körper, profilierte Mündung mit vier Ösen für eine Kettenaufhängung und hohler konischförmiger Fuß.

H.: $7 \mathrm{~cm}$; Dm. Mündung: 8,5 cm; Dm. Boden: 3,5 cm.

Mus. Pliska, Inv.-Nr. 1974.

Dončeva-Petkova 1979a, 84, Abb. 14.

64.-66. Stili. Große Basilika, Südsektor an der westlichen Festungsmauer, Objekt 41. Ende 9.-10. Jh.

Eisen. Tordiertes Heft. Oberes Ende flach und trapezförmig verbreitert, unteres verjüngt und zugespitzt.

Nr. 64 - L.: 10 cm; Max. Br.: 0,7 cm; Dm.: 3 cm. Nr. 65 - L.: 13,3 cm; Max. Br.: 0,8 cm; Dm.: 0,5 cm. Nr. 66 - L.: 7,2 cm; Max. Br.: 0,5 cm; Dm.: 0,3 cm.

Mus. Pliska, Inv.-Nr. 2467, 3223, 3761.

Ausgrabungen P. Georgiev, L. Dončeva-Petkova und S. Vitljanov.

67. Oberteil einer Buchschließe. Große Basilika, Qu. 163, T. 0,60 m. Ende 9.-10. Jh.

Bronze, gegossen. Ähnelt einem Schwert mit Kugelknauf und schmaler keilförmiger Klinge.

L.: $3,6 \mathrm{~cm}$; Dm.: $0,8 \mathrm{~cm}$.

Mus. Pliska, Inv.-Nr. 3913.

Georgiev/Vitljanov 2001, 140, 173, Abb. 70,24, Kat.-Nr. 27.

68. Unterteil einer Buchschließe. Narthex der Großen Basilika, T. 0,20 m. Ende 9.-10. Jh.

Bronze, gegossen. Ähnelt in der Form einer dreiteiligen Schnalle mit zwei runden und einer rechteckigen Unterteilung.

L.: 2,1 cm; Dm. Mittelteil: $1,5 \mathrm{~cm}$.

Mus. Pliska, Inv.-Nr. 3915.

Georgiev/Vitljanov 2001, 140, 173, Abb. 70,23, Kat.-Nr. 28.

69. Bleisiegel von David, kaiserlicher Spatharios und Kommerkiarios von Debeltos (870-893).

Zweiter nördlicher Hof der Großen Basilika.

Blei. Schlechter Zustand.

Av.: Zwischen zwei Perlenkreisen steht der umlaufende Segensspruch:

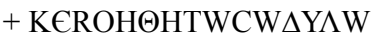

Im Zentrum Doppelkreuz auf einem Postament aus vier Treppen.

Rev.: Inschrift in fünf Reihen: 
$+\triangle \mathrm{A} \Delta \mathrm{R}^{\prime}|\mathrm{C} \Pi \mathrm{A} \Theta \mathrm{AP}$.$| .KOVMC \left|\mathrm{P} \ldots \mathrm{P}{ }^{\prime} \Delta \mathrm{E}\right| \ldots \Lambda \mathrm{TY}$

Die zusammengestellte Inschrift auf beiden Seiten lautet:

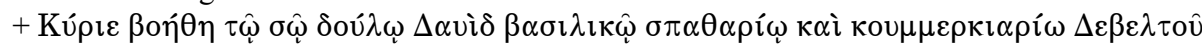

Übersetzung: „Gottesmutter, hilf deinem Knecht David, (dem) kaiserlichen Spatharios und

Kommerkiarios von Debeltos“.

Dm.: 2,1x2,2 cm; St.: 0,25 cm.

Mus. Pliska, Inv.-Nr. 3923.

Jordanov 1992, 285-286, Nr. 12; Jordanov 2001b, 223, 229, Nr. 9.

70. Hornspitze. Sondage westlich vom Hügel XXXIV. 8. - Anf. 9. Jh.

In die geglättete Oberfläche sind Zeichen, Buchstaben und Zeichnungen eingeritzt.

L.: 11,5 cm; Max. Br.: 1,5 cm.

Nat. Arch. Mus. Sofia, Inv.-Nr. 4010.

Michajlov 1955, 66-71, Abb. 19, Abb. 20.

71. Henkel eines Tongefäßes. Nördlich der Ziegelumfassungsmauer (Zitadelle). 11. Jh.

Ton. Ziegelrote Brennfarbe. Nach dem Brand mit gespitztem Gerät ist ein IYI Zeichen sowie eine altslawische Inschrift in drei Reihen eingeritzt:

ПОКА | ЗОВЬК | РНЧАГА

ПОКАЗОВЬ КРНЧАГ.

Übersetzung: „Amphora von Pokaz“.

L.: $11 \mathrm{~cm}$; Max. Br.: $5 \mathrm{~cm}$.

Nat. Arch. Mus. Sofia, Inv.-Nr. 4623.

Michajlov 1955, 80-83, Abb. 28, Abb. 29.

72-74. Pflugschare. Objekt 41. 10. - Anf. 11. Jh.

Eisen. Dreieckiges Arbeitsteil und breite offene Tülle.

Nr. 72 - L.: 24 cm; Max. Br.: 13 cm; Br. Tülle: 7 cm. Nr. 73 - L.: 20 cm; Max. Br.: 13,5 cm; Br. Tülle: 8,5 cm. Nr. 74 - L.: $17 \mathrm{~cm}$; Max. Br. $10 \mathrm{~cm}$; Br. Tülle: $8,5 \mathrm{~cm}$.

Mus. Pliska, Inv.-Nr. 3799 A, B, V.

Ausgrabungen S. Vitljanov.

75. Pflugschar. Komplex im Südsektor der westlichen Festungsmauer, Grubenhaus Nr. 2. Erste Hälfte 11. Jh.

Eisen. Schmales und kurzes dreieckiges Arbeitsteil, lange offene Tülle.

Gesamt L.: $33 \mathrm{~cm}$; L. Arbeitsteil: $15 \mathrm{~cm}$.

Mus. Pliska, Inv.-Nr. 2011.

Dončeva-Petkova 1992, 135, Abb. 33a.

76. Sechmesser. Südwestlicher Rundturm. Anf. 11. Jh.

Eisen. Dreieckiges Arbeitsteil und langer, vierkantiger Schaft.

Gesamt L.: 48 cm; L. Schneide: 16,5 cm; Max. Br.: 6,7 cm.

Mus. Pliska, Inv.-Nr. 3196.

Milčev 1992, 197, Abb. 28.

77.-78. Sechmesser. Objekt 41. 10. - Anf. 11. Jh.

Eisen. Im Querschnitt dreieckiges Arbeitsteil, langer massiver Schaft mit rechteckigem Querschnitt. 
Nr. 77 - L.: 38 cm; L. Schneide: 17 cm; Max. Br.: 5,5 cm. Nr. 78 - L.: 46; L. Schneide: 19 cm; Max. Br.: $5 \mathrm{~cm}$.

Mus. Pliska, Inv.-Nr. 3799 G, D.

Ausgrabungen S. Vitljanov.

79. Reutel. Objekt 41. Anf. 11. Jh.

Eisen. Dreieckiges Arbeitsteil und Tülle mit Schaftloch.

L.: 6,5 cm; Max. Br.: 6,5 cm; Dm. Tülle: $2,5 \mathrm{~cm}$.

Mus. Pliska. Inv.-Nr. 3799 I.

Ausgrabungen S. Vitljanov.

80. Sichel. Objekt 41. Anf. 11. Jh.

Eisen. Bogenförmige Schneide und schmale vierkantige Griffangel mit zugespitztem und umgebogenem Ende.

L. gestreckt: $49 \mathrm{~cm}$; Max. Br.: 3,5 cm.

Mus. Pliska, Inv.Nr. 3799 K.

Ausgrabungen S. Vitljanov.

81. Sichel. Objekt 41. 10. - Anf. 11. Jh.

Eisen. Bogenförmige und innenseitig gezähnte Schneide mit schmaler vierkantiger Griffangel, deren Ende zugespitzt ist.

L. gestreckt: $39 \mathrm{~cm}$; L. Griff: $14 \mathrm{~cm}$; Max. Br.: $3 \mathrm{~cm}$.

Mus. Pliska, Inv.-Nr. 3711.

Ausgrabungen S. Vitljanov.

82. Zweizack. Südwestlicher Rundturm. Anf. 11. Jh.

Eisen. Zweizinkig mit konischem Tüllenschaft. Bei einer der Zacken ist einen Widerhaken erhalten geblieben.

L.: 42,3 cm; L. Tülle: 16,3 cm, Dm.: 3-3,7 cm.

Mus. Pliska, Inv.-Nr. 3197.

Milčev 1992, 197, Abb. 28a

83. Hacke. Objekt 41. Anf. 11. Jh.

Eisen. Trapezförmiges Blatt, Schaft mit Schaftloch.

L.: $18 \mathrm{~cm}$; H. Blatt: $13 \mathrm{~cm}$; Max. Br.: 17,5 cm.

Mus. Pliska, Inv.-Nr. 3799 E.

Ausgrabugen S. Vitljanov.

84.-85. Hacken. Objekt 41. Anf. 11. Jh.

Eisen. Schmales trapezförmiges Blatt. Das Schaftloch ist auf beiden Seiten mit dreieckigen Lappen versehen.

Nr. 84 - L.: 24 cm; Max. Br.: 9,5 cm; Dm. Schaftloch: 4 cm. Nr. 85 - L.: 25 cm; Max. Br.: 9,2 cm; Dm. Schaftloch: 3-4 cm.

Mus. Pliska, Inv.-Nr. 3799 Ž, Z.

Ausgrabungen S. Vitljanov. 
86. Dechsel. Komplex im Südsektor der westlichen Festungsmauer, Gebäude I B. Ende 9. - 10. Jh. Eisen. Lange trapezförmige Schneide mit Schaftloch, das mit dreieckigen Lappen versehen ist. Das andere Ende ist als Hammernacken geformt.

L.: $20 \mathrm{~cm}$; Max. Br.: $7 \mathrm{~cm}$; Dm. Schaftloch: $3 \mathrm{~cm}$.

Mus. Pliska, Inv.-Nr. 3215.

Dončeva-Petkova 1992, 126, Abb. 7.

87.-88. Spatenbeschläge. 10. - Anf. 11. Jh.

Eisen. U-förmig. Auf der Innenseite eine Rinne zum Befestigen des Holzteiles.

Nr. 87 - H.: 16 cm; Max. Br.: 15,5 cm. Nr. 88 - H.: 16 cm; Max. Br.: 16 cm.

Mus. Pliska, Inv.-Nr. 2465, 3731.

89. Hippe. Komplex im Südsektor der westlichen Festungsmauer, Gebäude V. Erste Hälfte 11. Jh. Eisen. Breite bogenförmige Schneide mit einem flachen trapezförmigen Rückenaufsatz (securis). Schmale vierkantige Griffangel mit zugespitztem umgebogenem Ende.

L.: 3,7 cm; Max. Br.: 6,7 cm.

Mus. Pliska, Inv.-Nr. 2021.

Dončeva-Petkova 1992, 136, Abb. 34b.

90. Striegel. Objekt 41. 10. Jh.

Eisen. Rechteckiges Arbeitsteil mit kleinen Zähnen am unteren Rand. Entgegengesetzte zugespitzte Griffangel.

L.: $21 \mathrm{~cm}$; Br. 6,5 cm; L. Angel: 5,5 cm.

Mus. Pliska, Inv.-Nr. 3753.

Ausgrabungen S. Vitljanov.

91. Arbeitsgerät eines Hufschmiedes. Komplex im Südsektor der westlichen Festungsmauer, beim Raum Nr. 5. 10. - Anf. 11. Jh.

Eisen. Besteht aus einer vierkantigen Angel, einer Spitze zum Auskratzen und einer gebogenen Platte, die in ein breites, geknicktes Messer übergeht.

Gesamt L.: 30,5 cm; L. Spitze: 3,9 cm; L. Messer: 6,5 cm.

Mus. Pliska, Inv.-Nr. 2010.

Dončeva-Petkova 1992, 133, Abb. 25.

92. Hufmesser. Objekt 41. Anf. 11. Jh.

Eisen. Besteht aus einer gebogenen dreieckigen Klinge und einem schmalen Griff, dessen Ende hakenförmig umgebogen ist.

H.: $12 \mathrm{~cm}$; H. Arbeitsteil: $3,5 \mathrm{~cm}$; Br.: $9 \mathrm{~cm}$.

Mus. Pliska, Inv.-Nr. 3799 M.

Ausgrabungen S. Vitljanov.

93. Ochsenhufeisen. Objekt 41. 10.-11. Jh.

Eisen. Sichelförmig mit gerundeten Enden und sechs runden Öffnungen zur Befestigung.

L.: $12 \mathrm{~cm}$; Max. Br.: 4,5 cm; Dm. Loch: 0,5 cm.

Mus. Pliska, Inv.-Nr. 3769.

Ausgrabungen S. Vitljanov. 
94.-95. Viehglocken. Komplex im Südsektor der westlichen Festungsmauer. 10. - Anf. 11. Jh. Eisen. Elliptische Form und mit großen halbrunden Befestigungsösen zum Aufhängen (bei der kleineren abgebrochen).

Nr. 94 - H.: 5,5 cm; Max. Dm.: 6 cm. Nr. 95 - H.: 10,5 cm; Max. Dm.: 3,4 cm.

Mus. Pliska, Inv.-Nr. 2002, 2004.

Dončeva-Petkova 1992, 137, Abb. 35a,b.

96. Roheisen. Südliche Festungsmauer. 10. Jh.

Eisen. Quaderförmig.

Ausmaße: 31x8-8,6x4,7 cm; Gew.: 7,6 kg.

Mus. Pliska, Inv.-Nr. 2995 B.

Ausgrabungen I. Zachariev.

97. Hammer. Innere Stadt. 9.-11. Jh.

Eisen. Quaderförmig, mit Schwammbildung an den Bahnen und mit rundem Schaftloch.

Ausmaße: 18,5x9,5x8,5 cm; Dm. Loch: $4 \mathrm{~cm}$.

Mus. Pliska, Inv.-Nr. 92.

98. Tiegelfragment. Hügel XXXIV. Anf. 9. Jh.

Ton. Sandgemagert, ziegelrote Brennfarbe. Die Form ähnelt einer antiken Lampe, ist aber mit einem Ausguss versehen. Verglaste Oberfläche. Zerbrochen.

L.: $6,7 \mathrm{~cm}$; erhaltene H.: $3 \mathrm{~cm}$.

Mus. Pliska, Inv.-Nr. 3944.

Ausgrabungen L. Dončeva-Petkova, P. Georgiev, S. Stanilov und R. Vasilev.

99. Gussform für Schmuck. Gebäude nordöstlich der Ziegelumfassungsmauer (Zitadelle). Raum V. 11. Jh.

Talkschiefer. Plattenförmig. Auf einer Seite sind fünf Formen zum Guss von Schnallen, Riemenzungen, Kreuzen und Medaillons eingeritzt.

L.: $9,5 \mathrm{~cm}$; Br.: $9 \mathrm{~cm}$; St.: $3 \mathrm{~cm}$.

Nat. Arch. Mus. Sofia, Inv.-Nr. 3745.

Stančev 1955, 192, Abb. 12.

100.-104. Aryballoi. Westlich vom Thronpalast, Grube bei Gebäude Nr. 1. Ende 10. - erste Hälfte 11. Jh.

Ton. Braune Farbe. Geschwärzte Oberfläche.

Nr. 100 - H.: 16,6 cm; Max. Dm.: 11,1 cm; Dm. Boden: 1,2 cm; Dm. Öffnung: $1 \mathrm{~cm}$. Nr. 101

- H.: 11,5 cm; Max. Dm.: 9 cm; Dm. Boden: 2 cm; Dm. Öffnung: 1 cm. Nr. $102-$ H.: 11,2 cm; Max. Dm.: 8,8 cm; Dm. Boden: 2,5 cm; Dm. Öffnung: 1 cm. Nr. 103 - H.: 11,4 cm; Max. Dm.: 8,3 cm; Dm. Boden: 2 cm; Dm. Öffnung: 1 cm. Nr. 104 - H.: 11,5 cm; Max. Dm.: 9,4 cm; Dm. Boden: $1 \mathrm{~cm}$; Dm. Öffnung: $1 \mathrm{~cm}$.

Mus. Pliska, Inv.-Nr. 3855, 2456, 3853, 3854, 3852.

Michajlova 1987, Taf. I-II; Michajlova 1992, 177.

105. Bartaxt. Innere Stadt. 9.-11. Jh.

Eisen. Bartförmige Schneide, spitzer Nacken und rundes Schaftloch in der Mitte. 
L.: $10 \mathrm{~cm}$; L. Schneide: $4 \mathrm{~cm}$; Dm. Schaftloch: 2,2 cm.

Mus. Pliska, Inv.-Nr. 93.

106. Axt. 9.-10. Jh.

Eisen. Die Schneide ist T-förmig, das gegenüberliegende schmale Ende knauffömig. Das Schaftloch ist auf beiden Seiten mit dreieckigen Lappen versehen.

L.: $15 \mathrm{~cm}$; L. Schneide: 10,5 cm; Max. Br.: $4 \mathrm{~cm}$.

Mus. Pliska, Inv.-Nr. 3216.

107. Axt. 9.-11. Jh.

Eisen. Breite T-förmigen Schneide, Hammernacken und rundes Schaftloch mit beidseitigen dreieckigen Lappen.

L.: $17 \mathrm{~cm}$; L. Schneide: $10 \mathrm{~cm}$; Max. Br.: $3 \mathrm{~cm}$.

Mus. Pliska, Inv.-Nr. 95.

108. Bartaxt. 9.-11. Jh.

Eisen. Bartförmige Schneide, Hammernacken und rundes Schaftloch mit beidseitigen dreieckigen Lappen.

L.: $14,5 \mathrm{~cm}$; L. Schneide: $8,5 \mathrm{~cm}$; Max. Br.: $4,5 \mathrm{~cm}$.

Mus. Pliska, Inv.-Nr. 3217.

109.-110. Zwei Meißel. Objekt 41. 10. Jh.

Eisen. Der Kopf ist rund, die obere Hälfte des schmalen und langen Schafts ist oval im Querschnitt, die untere viereckig. Die Arbeitsfläche ist flach, leicht gebogen und mit zugespitztem Rand.

Nr. 109 - L.: 19,8 cm. Nr. 110 - L.: 19,5 cm.

Mus. Pliska, Inv.-Nr. 3730.

Ausgrabungen S. Vitljanov.

111. Meißel. Objekt 41. 10. Jh.

Eisen. Im Querschnitt rechteckiger Schaft. Schmale Arbeitsfläche mit Schneide. Verdicktes Schaftende und Schlagfläche mit Schwammbildung.

L.: 18,3 cm; Br. 1-1,6 cm; Dm. Kopf: $3 \mathrm{~cm}$.

Mus. Pliska, Inv.-Nr. 3773.

Ausgrabungen S. Vitljanov.

112. Bohrer. Objekt 41. 10. Jh.

Eisen. Dreieckige Spitze mit spiralförmiger Windung. Langer Schaft, oben mit vierkantigem, unten mit ovalem Querschnitt, spitzwinkliges umgebogenes Ende.

L.: $30 \mathrm{~cm}$; L.: Arbeitsteil: $3 \mathrm{~cm}$; Br.: $1,5 \mathrm{~cm}$.

Mus. Pliska, Inv.-Nr. 3751.

Ausgrabungen S. Vitljanov.

113. Schlüssel in Statuettenform. Südlich des Westteils des Kleinen Palastes. 10.-11. Jh.

Bronze. Guss, Gravuren. Verzierungen: Männliche Figur, Laute spielend.

H.: $15,7 \mathrm{~cm}$. 
Nat. Arch. Mus. Sofia, Inv.-Nr. 5263.

Michajlov 1955, 77-80, Abb. 26, Abb. 27; Georgiev 2000; Rašev 2003, 164-165.

114. Steckfederschloss. Westliche Festungsmauer, Südsektor. 11. Jh.

Eisen mit Kupferüberzug. Zylindrischer Körper und Verschlussbügel.

L.: 15,5 cm; L. Schlosszylinder: $9 \mathrm{~cm}$; Dm.: $3 \mathrm{~cm}$.

Mus. Pliska, Inv.-Nr. 2014.

Dončeva-Petkova 1992, 136-137, Abb. 34j.

115. Schloss. Objekt 41. 10. Jh.

Eisen. Kastenförmiger Körper, hakenförmig umgebogener Schließstift und Verschlussbügel.

L.: 7,5 cm; Ausmaße Verschlussteil: 3,5x2,5x12 cm.

Mus. Pliska, Inv.-Nr. 3720 M.

Ausgrabungen S. Vitljanov.

116. Kanne. 8. - Anf. 9. Jh.

Ton. Ohne Magerung, ziegelrote Brennfarbe. Bauchiger Körper, gestreckter Hals, kleeblattförmiger Ausguss, flacher Boden. Graue polierte Oberfläche.

H.: 16,5 cm; Dm. Mündung: 8,5x9,5 cm; Dm. Gefäßkörper: $12 \mathrm{~cm}$; Dm. Boden: 8,5 cm.

Mus. Pliska, Inv.-Nr. 2450.

117. Kanne. Unterirdischer Gang zum Krum Palast, nördliche Abzweigung. 8. - Anf. 9. Jh.

Ton. Ohne Magerung, graue Brennfarbe. Bauchiger Körper, kleeblattförmige Mündung, ovaler Henkel. Unterhalb des Halses und im breitesten Bereich des Gefäßkörpers sind breite waagerechte Rillen eingeritzt. Auf dem Hals befindet sich ein vor dem Brand eingeritztes Zeichen IYI. Der Boden ist gebrochen.

H.: 24,6 cm; Dm. Mündung: 6,5x7,1 cm; Dm. Gefäßkörper: 17,5 cm.

Mus. Pliska, Inv.-Nr. 1579.

Ausgrabungen R. Rašev.

118. Doppelhenkelkrug. Großer Wasserspeicher. Ende 8. - Anf. 9. Jh.

Ton. Ohne Magerung, gelbe Brennfarbe. Ovaler Gefäßkörper. Schmaler Hals, flacher Boden. Zwei vom Hals bis zu den Schultern reichende Henkel, die jeweils in profilierte Aufsätze münden. Die Oberfläche ist mir roter Engobe überzogen. Auf der Schulter ein vor dem Brand eingeritztes Zeichen X. Hergestellt auf der Fußtöpferscheibe. Die Mündung ist abgebrochen.

Erhaltene H.: 30 cm; Dm. Gefäßkörper: 17,7 cm; Dm. Boden: $11 \mathrm{~cm}$.

Nat. Arch. Mus. Sofia, Inv.-Nr. 5264.

Ausgrabungen S. Stančev

119. Krug. Unterirdischer Gang unter dem heidnischen Heiligtum im Palastzentrum. Anf. 9. Jh.

Ton. Sandgemagert, gelbe Brennfarbe. Schmaler ovaler Gefäßkörper. Der Henkel endet in profilierten Aufsatz. Die Oberfläche ist mir dunkel-roter Engobe überzogen. Auf der Schulter befindet sich ein vor dem Brand eingeritztes Zeichen: IYI. Hergestellt auf der Fußtöpferscheibe. Die Mündung ist abgebrochen.

H.: 21 cm; Dm. Gefäßkörper: 13,5 cm; Dm. Boden: 7 cm. 
Mus. Pliska, Inv.-Nr. 3849.

Ausgrabungen R. Rašev.

120. Doppelhenkelkrug. Kleiner Palast. 9. Jh.

Ton. Ohne Magerung, graue Brennfarbe. Nahezu zylindrischer Körper, gewölbte Schulter, schmaler Hals, trichterförmige Mündung, flacher Boden, zwei ovale Henkel. Die Oberfläche ist mit einer Zone aus Einglättstreifen überzogen, die von zwei Rillen begrenzt sind. Auf der Schulter und auf einem Henkel ist je ein Zeichen eingeritzt, auf dem Boden befindet sich ein Reliefzeichen.

H.: 30 cm; Dm. Mündung: 6 cm; Dm. Gefäßkörper 14 cm; Dm. Boden: $10 \mathrm{~cm}$.

Nat. Arch. Mus. Sofia Inv.-Nr. 3221.

Stančev/Ivanov 1958, 68-69, Abb. 10,1-4; Dončeva-Petkova 1977, 181, Kat.-Nr. 268, Taf. XX,268.

121. Doppelhenkelkrug. 9. Jh.

Ton. Ohne Magerung, grau-schwarze Brennfarbe. Ovaler Gefäßkörper, schmaler Hals, trichterförmige Mündung, flacher, unebener Boden. Der massive bogenförmige Henkel ist von außen einfach gekehlt. Unter dem Hals und auf der Schulter sind je drei waagerechte Rillen angebracht. Die Oberfläche ist stellenweise poliert. Ein Teil der Mündung ist abgebrochen.

H.: 23 cm; Dm. Mündung: 4,6 cm; Dm. Gefäßkörper: 13 cm; Dm. Boden: $8 \mathrm{~cm}$.

Nat. Hist. Mus. Sofia, Inv.-Nr. 3222.

Stančev/Ivanov 1958, 67-68, Abb. 10,1; Dončeva-Petkova 1977, 179, Kat.-Nr. 257.

122. Backform. Siedlung im Südosten der Äußeren Stadt, Wohnung Nr. 26. 9. Jh.

Ton. Sandgemagert, ziegelrote Brennfarbe. Flacher, unebener Boden, niedrige, leicht nach außen geneigte Seitenwände. Handgemacht. Rekonstruiert.

H.: 3,8 cm; Dm. Rand: 23 cm; Dm. Boden: $22 \mathrm{~cm}$; St.: $1 \mathrm{~cm}$.

Mus. Pliska, Inv.-Nr. 2377.

Dimitrov 1994, 29, Abb. 2.

123. Topf. Siedlung im Bereich der Großen Basilika, Grubenhaus Nr. 7. Ende 8. - erste Hälfte 9. Jh.

Ton. Sandgemagert, braune Brennfarbe. Ovaler Gefäßkörper, eingezogener kurzer Hals, unregelmäßiger ausbiegender Mündungsrand mit gerundeter Lippe. Die Verzierung reicht vom Hals bis zum Boden und besteht aus mit einem Kamm eingeritzten Wellenbändern und waagerechten Linien. Hergestellt auf der Handtöpferscheibe. Rekonstruiert.

H.:12,7 cm; Dm. Mündung: 8,5 cm; Dm. Gefäßkörper: $12 \mathrm{~cm}$; Dm. Boden: 6,8 cm.

Nat. Arch. Mus. Sofia, Inv.-Nr. 2566.

Vasilev 1995, 31, Abb. 8.

124. Topf. Objekt 41. 10. Jh.

Ton. Feinsandmagert, ziegelrote Brennfarbe. Konischer Gefäßkörper, sich aufwärts verbreiternd und lang gezogen, hochstehende Schulter, eingezogener kurzer Hals, ausbiegender Mündungsrand, flacher Boden. Die Verzierung besteht aus waagerechten dichten Linien.

H.: 32,7 cm; Dm. Mündung: 21,5 cm; Dm. Gefäßkörper: 24,5 cm; Dm. Boden: 11,8 cm. Mus. Pliska, Inv.-Nr. 3704.

Ausgrabungen S. Vitljanov. 
125. Topf. Objekt 41. 10. Jh.

Ton. Sandgemagert, graue Brennfarbe. Konischer Gefäßkörper, sich aufwärts verbreitend und lang gezogen, hochstehende Schulter. Die glatte Oberfläche ist mit gelb-grüner Glasur überzogen.

H.: 18,5 cm; Dm. Mündung: 12,5 cm; Dm. Gefäßkörper: 14,5 cm; Dm. Boden: 8 cm.

Mus. Pliska, Inv.-Nr. 3709.

Ausgrabungen S. Vitljanov.

126. Topf. Große Basilika, Gebäude Nr. 1, Raum Nr. 7, Qu. 129, T. 1 m. 10. Jh.

Ton. Ziegelrote Brennfarbe. Annähernd doppelkonischer Gefäßkörper, schwach ausbiegende Mündung, flacher Boden mit eingeritztem und reliefiertem Zeichen. Die glatte Oberfläche ist mit brauner Glasur überzogen.

H.: 16,5 cm; Dm. Mündung: 10 cm; Dm. Gefäßkörper: 12,5 cm; Dm. Boden: 7,5 cm.

Mus. Pliska, Inv.-Nr. 3881.

Georgiev/Vitljanov 2001, 114-115, 176, Abb. 55,1, Kat.-Nr. 89.

127. Topf. Komplex im Südsektor der westlichen Festungsmauer, Wohnhaus Nr. 2. Anf. 11. Jh. Ton. Sandgemagert, ziegelrote Brennfarbe. Konischer Gefäßkörper, sich aufwärts verbreiternd, weit ausladende Mündung und flacher Boden. Auf den Schultern eine eingeritzte Wellenlinie, auf der Wandung weit auseinanderliegende waagerechte Rillen. Hergestellt auf der Handtöpferscheibe.

H.: 11,2 cm; Dm. Mündung: $11 \mathrm{~cm}$; Dm. Gefäßkörper: $12 \mathrm{~cm}$; Dm. Boden: 7,2 cm.

Mus. Pliska, Inv.-Nr. 1978.

Dončeva-Petkova 1992, 132, Abb. 22d.

128. Topf. Gebäude nordöstlich der Ziegelumfassungsmauer (Zitadelle), Raum B. 11. Jh.

Ton. Sandgemagert, graue Brennfarbe. Kugelförmiger Gefäßkörper, eingezogener langer Hals, ausbiegende Mündung mit schräg abgeschnittenem Rand, flacher Boden mit umlaufendem Profilrand (Quellboden) und Reliefzeichen: X. Unter dem Hals befinden sich eine Reihe von eingetieften Grübchen, darunter folgen waagerechte, gerade Linien auf dem ganzen Gefäßkörper. H.: 17,5 cm; Dm. Mündung: $13 \mathrm{~cm}$; Dm. Gefäßkörper: 16,5 cm; Dm. Boden: 11,5 cm. Nat. Arch. Mus. Sofia, Inv.-Nr. 3676.

Stančev 1955, 192, Abb. 11a.4.

129. Topf mit einem Henkel. Gebäude östlich der Ziegelumfassungsmauer (Zitadelle), Raum B. 11. Jh.

Ton. Sandgemagert, graue Brennfarbe. Ovaler Gefäßkörper, hoher Hals mit Reliefkragen, flacher Boden. Auf der Schulter ist eine Reihe von kleinen Grübchen angebracht. Der Henkel wurde ergänzt.

H.: 17; Dm. Mündung: 8,5cm; Dm. Gefäßkörper: 15,5 cm; Dm. Boden: 8,5 cm.

Nat. Arch. Mus. Sofia, Inv.-Nr. 5265.

Stančev 1955, 192, Abb. 11,1.

130. Schüssel. Objekt 41. 10. Jh.

Ton. Sandgemagert, ziegelrote Brennfarbe. Sich nach oben verbreiternde konische Form, Standplatte.

H.: 19,5 cm; Dm. Mündung: 21,8 cm; Dm. Boden: 9,5 cm. 
Mus. Pliska. Inv.-Nr. 3710.

Ausgrabungen S. Vitljanov.

131. Schüssel. Große Basilika. Ende 9. - erste Hälfte 10. Jh.

Ton. Ohne Magerung, weiße Brennfarbe. Sich aufwärts verbreiternder konischer Gefäßkörper mit Deckelpfalz, zwei Henkel, die vom Gefäßrand bis zum Boden reichen. Glatte Wandung, bedeckt mit einer gelb-grün gefleckten Glasur. Boden nicht erhalten.

H.: $8,5 \mathrm{~cm}$; Dm. Mündung: $21 \mathrm{~cm}$.

Mus. Pliska, Inv.-Nr. 3877.

Ausgrabungen P. Georgiev und S. Vitljanov.

132. Schüssel. Objekt 41. 10. - Anf. 11. Jh.

Ton. Ziegelrote Brennfarbe. Halbsphärischer Gefäßkörper, hohler konischer Standfuß. Die Oberfläche ist mit flachen eingeritzten Linien verziert und mit gelb-grüner Glasur überzogen. Hergestellt auf der Handtöpferscheibe.

H.: 9,5 cm; Dm. Mündung: 20,8 cm; Dm. Boden: 9,4 cm.

Mus. Pliska, Inv.-Nr. 3701.

Ausgrabungen S. Vitljanov.

133. Tasse. Westlich des Großen Wasserspeichers. 10. Jh.

Ton. Ziegelrote Brennfarbe. Kugelförmiger Gefäßkörper, leicht ausbiegender Gefäßrand, flacher Boden, Henkel vom Hals bis zur Mitte des Körpers. Die Oberfläche ist mit waagerechten Rillen verziert und mit gelb-grüner Glasur überzogen. Hergestellt auf der Handtöpferscheibe.

H.: 7 cm; Dm. Mündung: 5,8 cm; Dm. Gefäßkörper: 7 cm; Dm. Boden: 4,3 cm.

Mus. Pliska, Inv.-Nr. 1312.

134. Krug. Handelsräume nördlich des Südtores, Raum Nr. 19. 10. Jh.

Ton. Ziegelrote Brennfarbe. Langgezogener Gefäßkörper, gewölbte Schulter, trichterförmige Mündung, flacher Boden. Der schmale Henkel sitzt zwischen Hals und Schulter. Die Oberfläche ist mit gelb-grüner Glasur überzogen. Hergestellt auf der schnellrotierenden Handtöpferscheibe. H.: 22,8 cm; Dm. Mündung: $6 \mathrm{~cm}$; Dm. Gefäßkörper: 10,8 cm; Dm. Boden: 6,5 cm.

Mus. Pliska, Inv.-Nr. 2443.

Milčev 1979, 171, Abb. 104.

135. Krug. Objekt 41. 10. Jh.

Ton. Gelb-braune Brennfarbe. Schmaler, langgezogener Gefäßkörper, gewölbte Schulter, schmaler Hals, trichterförmige Mündung, flacher Boden und Henkel zwischen Hals und Schulter. Unterhalb der Schulter sind waagerechte gerade Linien eingeritzt. Auf der Schulter ein vor dem Brand eingeritztes Zeichen: IYI. Hergestellt auf der schnellrotierenden Handtöpferscheibe.

H.: 49 cm; Dm. Mündung: 8,5 cm; Dm. Gefäßkörper: $19 \mathrm{~cm}$; Dm. Boden: $11 \mathrm{~cm}$.

Mus. Pliska, Inv.-Nr. 3706.

Ausgrabungen S. Vitljanov.

136. Kleiner Krug. Sondage zwischen Krum-Palast und Osttor. 11. Jh.

Ton. Ohne Magerung, ziegelrote Brennfarbe. Sphärischer Gefäßkörper auf einem niedrigen Standring. Der langgezogene Hals ist mit zwei plastischen Ringen versehen und endet in einer 
Kleeblattmündung. Die Oberfläche ist mit eingeritzten waagerechten Linien verziert und mit gelb-grüner Glasur überzogen. Hergestellt auf der Fußtöpferscheibe.

H.: 18,5 cm; Dm. Mündung: 4,5x5,2 cm; Dm. Gefäßkörper: 8,6 cm; Dm. Boden: 3,7 cm.

Mus. Pliska, Inv.-Nr. 3211.

Ausgrabungen T. Balabanov.

137. Krug. Gebäude nordöstlich der Ziegelumfassungsmauer (Zitadelle), Raum B. 11. Jh.

Ton. Sandgemagert, rosa Brennfarbe. Zylindrischer Gefäßkörper, schräg einziehende Schulter, hoher Hals mit plastischem Ring, kleeblattförmige Mündung, flacher Boden. Der flache Henkel ist dreifach gekehlt und mit zwei knospenförmigen Aufsätzen im oberen Bereich versehen. Hergestellt auf der Fußtöpferscheibe.

H.: 33 cm; Dm. Mündung: 6x7 cm; Dm. Gefäßkörper: 11,5 cm; Dm. Boden: 11,2 cm.

Nat. Arch. Mus. Sofia, Inv.-Nr. 3679.

Stančev 1955, 192, Abb. 11,2.

138. Krug. Nordhof des Klosters an der Großen Basilika. 11. Jh.

Ton. Ohne Magerung, ziegelrote Brennfarbe. Sich aufwärts verengender, konischer Gefäßkörper, enger Hals, trichterförmige Mündung, flacher Boden. Die Wandung ist mit senkrechten Furchen verziert, die Oberfläche ist flächendeckend mit brauner Glasur überzogen. Hergestellt auf der Fußtöpferscheibe. Mündungsrand abgebrochen.

Erhaltene H.: $27 \mathrm{~cm}$; Dm. Oberteil des Gefäßkörpers: $10 \mathrm{~cm}$; Dm. Boden: $18 \mathrm{~cm}$.

Mus. Pliska, Inv.-Nr. 45.

Mijatev 1943, 77, Abb. 143.

139. Vorratsgefäß. Handelsräume nördlich des Südtors, Raum Nr. 19. Ende 10. - Anf. 11. Jh.

Ton. Ohne Magerung, graue Brennfarbe. Sphärisch-konischer Gefäßkörper, kurzer Hals, enge Mündung, flacher Boden. Die Wandung ist mit eingeritzten waagerechten Rillen und netzförmig angeordneten Einglättstreifen verziert. Hergestellt auf der schnelldrehenden Handtöpferscheibe. H.: 35 cm; Dm. Mündung: 18 cm; Dm. Gefäßkörper: 35 cm; Dm. Boden: 16 cm.

Mus. Pliska, Inv.-Nr. 3250.

Milčev 1979, 169, Abb. 101.

140. Vorratsgefäß. Komplex im Südsektor der westlichen Festungsmauer, Wohnhaus Nr. 8. 40er Jahre des 11. Jh.

Ton. Ziegelrote Brennfarbe. Massiver, ovaler Gefäßkörper, sich nach oben verjüngend und in eine profilierte Mündung übergehend. Die Oberfläche ist geglättet und mit waagerechten eingeritzten Linien in großem Abstand verziert. Im Mittelbereich des Gefäßkörpers röhrenförmiger horizontaler Henkel mit Reliefbändern auf beiden Seiten. Der Boden fehlt. Rekonstruiert.

H.: $50 \mathrm{~cm}$; Dm. Mündung: 14,5 cm; Dm. Gefäßkörper: $34 \mathrm{~cm}$.

Mus. Pliska, Inv.-Nr. 3949.

Dončeva-Petkova 1993b, 259, Abb. 18a,b.

141. Amphora. Palastzentrum. Ende 10. Jh.

Ton. Ohne Magerung, ziegelrote Brennfarbe. Breiter Gefäßkörper, sich nach unten verjüngende Wandung, gewölbte Schulter, runder Boden, enger Hals. Zwischen Hals und Schulter zwei massive Henkel. Die Oberfläche ist mit tiefen Furchen verziert und mit gelber Engobe überzogen.

H.: $38 \mathrm{~cm}$; Dm. Mündung: 8x9 cm; Dm. Gefäßkörper: 28,5 cm. 
Mus. Pliska, Inv.-Nr. 3851.

Ausgrabungen R. Rašev.

142. Amphora. Komplex im Südsektor der westlichen Festungsmauer, Wohnhaus Nr. 8. 40er Jahre des 11. Jh.

Ton. Hellorange Brennfarbe. Ovaler Gefäßkörper, enger Hals, Kragenrand, rundlicher Boden. Massive Henkel mit elliptischem Querschnitt, von unterhalb der Mündung aufschwingend und bis auf die Schulter ziehend. Die Wandung ist glatt, nur auf der Schulter und im Bereich des Bodens gefurcht. Ein Henkel gebrochen.

H.: 49 cm; Dm. Mündung: 12,5 cm; Dm. Gefäßkörper: 29 cm; Br. Henkel: $6 \mathrm{~cm}$.

Mus. Pliska, Inv.-Nr. 3906.

Dončeva-Petkova 1993b, 257, Abb. 17.

143. Feldflasche. 11. Jh.

Ton. Rot-braune Brennfarbe. Runder Gefäßkörper, auf einer Seite konvex und mit konzentrischen Kreisen verziert, auf der anderen abgeflacht (Boden). Enger Hals mit plastischem Ring, in einen Kragenrand übergehend. Zwei Henkel mit elliptischem Querschnitt vom Hals bis zur Schulter.

H.: 22 cm; Dm. Mündung: 4,3 cm; Dm. Gefäßkörper: $11 \times 16$ cm.

Mus. Pliska, Inv.-Nr. 2451.

144. Kessel. Komplex im Südsektor der westlichen Festungsmauer, Grube Nr. 14. 30er - 40er Jahre des 11. Jh.

Ton. Gelbe Brennfarbe. Fast zylindrischer Gefäßkörper, schwach sich nach unten verbreiternd, konvexer Boden, rechtwinklig ausbiegender Rand. Auf zwei sich gegenüber liegenden innenseitigen Verbreiterungen des Randes sind Durchlochungen zum Aufhängen des Kessels über der Feuerstelle angebracht. Glatte Wandung. Auf dem Boden x-förmig sich kreuzende Linien und eine eingeritzte Darstellung, die einem Pferd ähnelt. Schmauchspuren. Rekonstruiert.

H.: $21 \mathrm{~cm}$; Dm. Rand: $30 \mathrm{~cm}$; Max. Dm.: $31 \mathrm{~cm}$.

Mus. Pliska, Inv.-Nr. 3920.

Dončeva-Petkova 1993a, 82-83, Abb. 7.

145. Leuchter. Komplex im Südsektor der westlichen Festungsmauer, Wohnhaus Nr. 8. 40er Jahre des 11. Jh.

Ton. Sandgemagert, ziegelrote Brennfarbe. Schlecht gebrannt. Halbkugeliger Gefäßkörper und niedriger, innen hohler Fuß. Auf dem Boden Durchlochung. Handgeformt.

H.: $6 \mathrm{~cm}$; Dm. Mündung: 8,7 cm; Dm. Boden: $7 \mathrm{~cm}$.

Mus. Pliska, Inv.-Nr. 3960.

Dončeva-Petkova 1993b, 259, Abb. 19.

146. Lampe. Westlich des Thronpalastes. 11. Jh.

Ton. Hellrote Brennfarbe. Halbkugeliger niedriger Gefäßkörper, flacher Boden und flacher, an der Wand angesetzter Griff. Handgeformt.

H.: $3 \mathrm{~cm}$; Dm. Mündung: 9,5 cm; Dm. Boden: $8 \mathrm{~cm}$; L. Griff: 4,5 cm; Br. Griff: 2,8 cm.

Mus. Pliska, Inv.-Nr. 3219.

Ausgrabungen T. Michajlova. 
147. Messer. Südliche Festungsmauer. 9.-11. Jh.

Eisen, Knochen. Klinge einseitig geschliffen, Knochengriff mit Kreisaugenmotiven verziert.

L.: $16 \mathrm{~cm}$; L. Schneide: $9 \mathrm{~cm}$.

Mus. Pliska, Inv.-Nr. 2615.

148. Messer. Große Basilika, Südsektor. 10. Jh.

Eisen, Bronze. Klinge einseitig angeschliffen, im Übergang zum Griff angefalztes Bronzeblechband. Tropfenförmiges Griffende aus Bronze. Griff mit drei Bronzenieten.

L.: $21,5 \mathrm{~cm}$; L. Schneide: $11,5 \mathrm{~cm}$; Br. $1,3 \mathrm{~cm}$.

Mus. Pliska, Inv.-Nr. 3871.

Ausgrabungen P. Georgiev und S. Vitljanov.

149. Schere. Westlich des Thronpalastes. 10. - Anf. 11. Jh.

Eisen. Die beiden Schneidenteile sind durch einen Niet und zwei kleinen Platten verbunden. Am Griff befinden sich drei hintereinander liegende quadratische Verbreiterungen. Die dünnen Griffringe sind offen und enden mit konischen Verdickungen.

L.: $21 \mathrm{~cm}$; Dm. Griffringe: $2,8 \times 3,8 \mathrm{~cm}$.

Mus. Pliska, Inv.-Nr. 2476.

Ausgrabungen T. Michajlova.

150. Fingerhut. Innenstadt. 10. Jh.

Bronze. Konische Form. Oberfläche mit kleinen punktförmigen Grübchen bedeckt.

H.: $1,9 \mathrm{~cm}$; Dm.: 1,8/2 cm.

Mus. Pliska, Inv.-Nr. 951.

151. Spielstein. Palastzentrum. 9.-10. Jh.

Knochen. Scheibenförmig, auf der glatten Oberseite Kreisaugenmuster.

Dm.: $5,8 \mathrm{~cm}$; St.: $0,5 \mathrm{~cm}$.

Nat. Arch. Mus. Sofia, Inv.-Nr. 2412.

Stančev 1960, Kat.-Nr. 64, Abb. 3B,3.

152. Feuerstahl. Siedlung im Südosten der Äußeren Stadt. 9.-10. Jh.

Eisen. Lyraförmige Gestalt.

L.: $6 \mathrm{~cm}$; Br.: $2 \mathrm{~cm}$.

Mus. Pliska, Inv.-Nr. 2263.

Ausgrabungen S. Stanilov und J. Dimitrov.

153. Feuerstahl. Objekt 41. 10. Jh.

Eisen. Ursprünglich lyraförmige Gestalt. Enden abgebrochen.

L.: $8 \mathrm{~cm}$; St.: $0,8 \mathrm{~cm}$.

Mus. Pliska, Inv.-Nr. 3742.

Ausgrabungen S. Vitljanov.

154. Schnellwaage. Kloster an der Großen Basilika, Qu. 298, T. 0,80-1 m. Ende 10. - Anf. 11. Jh. Eisen. Ungleicharmig. Am kurzen Arm Haken zum Aufhängen von Gegenständen, am langen Arm ein Laufgewicht. 
L. Waagenbalken: $26 \mathrm{~cm}$; St.: 0,7 cm.

Mus. Pliska, Inv.-Nr. 3872.

Vitljanov 1981, 18-22, Abb. 1-3; Georgiev/Vitljanov 2001, 139, 176, Abb. 79, Kat.-Nr. 88.

155. Gewichte. Südsektor der westlichen Festungsmauer. Ende 9.-10. Jh.

Blei, gegossen. Gravuren. Fünf quaderförmig und eines rund mit kreisförmigen Maßzeichen.

Maße: $5,1 \times 5 \times 2,5 \mathrm{~cm} ; 705,330$ g. $5 \times 4,8 \times 2 \mathrm{~cm} ; 624,960$ g. 4,2x4,2x2 cm; 358,850 g. 4,2x4,2x1,9 cm; 338,920 g. $4 \times 3,5 \times 1,7$ cm; 269,500 g. Dm.: 5,2x5 cm, St.: 0,01 cm; 338,30 g.

Mus. Pliska, Inv.-Nr. 2013.

Dončeva-Petkova 1981, 22-28, Abb. 1a,b, 6a,b; Kvinto 1990, 24-26.

156. Follis Basileios' I. mit Konstantin und Leon (870-879). Große Basilika, zweiter Nordhof (im Bereich des Brunnens).

Kupfer.

Av.: Brustbild des Kaisers zusammen mit seinen Söhnen.

Rev.: Inschrift in fünf Reihen.

Dm.: 2,5x2,6 cm; Gew.: 7,6 g.

Mus. Pliska, Inv.-Nr. 3927.

Jordanov 2000, 144, Kat.-Nr. 39; Jordanov 2001b, 224, 227, Kat.-Nr. 2.

157. Follis Leons VI. (886-912). Westliche Festungsmauer, Nordsektor, Qu. 30, T. 1,80 m, auf dem Bodenniveau eines Grubenhauses.

Kupfer.

Av.: Brustbild des Kaisers.

Rev.: Inschrift in vier Reihen.

Dm: 2,6-2,7 cm; Gew.: 5,9 g.

Mus. Pliska, Inv.-Nr. 3928.

Vitljanov 1979, 63-64, Abb. 3; Jordanov 2000, 144, Kat.-Nr. 44.

158. Follis Leons VI. mit Alexander (886-912). Aus dem Gebiet des Gräberfeldes im Südhof der Großen Basilika. Qu. 112, T. 0,20 m (im Graben einer Wasserleitung).

Kupfer.

Av.: Beide Herrscher auf dem Thron mit Zepter.

Rev.: Inschrift in vier Reihen:

+ LEON | SALE $\xi A N \mid$ dROSbASIL | ROMEON

Dm.: 2,7 cm; Gew.: 8,3 g.

Mus. Pliska, Inv.-Nr. 3931.

Jordanov 2000, 144, Kat.-Nr. 40; Jordanov 2001b, 224-225, 227, Kat.-Nr. 3.

159. Follis Konstantins VII. und der Zoe (913-919). Erzbischofspalast nördlich der Großen Basilika, südwestlicher Raum, Qu. 76, T. 0,80 m (Fußbodenniveau).

Kupfer.

Av.: Brustbild von Konstantin und Zoe, die das Patriarchenkreuz tragen.

Rev.: Inschrift in fünf Reihen.

Dm.: $2,6 \times 2,8 \mathrm{~cm}$. 
Mus. Pliska, Inv.-Nr. 3932

Jordanov 2000, 144, Kat.-Nr. 48; Jordanov 2001b, 225, 227, Kat.-Nr. 4.

160. 15 byzantinische Solidi. Objekt 40. Von 912 bis 931 .

Gold. Zwei Solidi von Konstantin VII. und Romanos I. (920-921) und 13 Solidi von Romanos I. mit Christophoros (921-931).

Hist. Mus. Šumen, Inv.-Nr. 12134-12148.

Aladžov 1985, 31-40; Aladžov 2000.

161. Anonymer Follis Klasse A-1 (970-976).

Kupfer.

Av.: Brustbild Christus mit dem Evangelium in der linken Hand.

Rev.: Inschrift in vier Reihen.

Dm.: 2,2x2,3 cm.

Mus. Pliska, Inv.-Nr. 3933

162. Anonymer Follis Klasse A-2 (976-1030).

Kupfer.

Av.: Brustbild von Jesus Christus mit dem Evangelium in der linken Hand.

Rev.: Inschrift in vier Reihen:

IhSUS | XRISTUS | BASILEU | BASILE

Dm.: $2,6 \mathrm{~cm}$.

Mus. Pliska, Inv.-Nr. 3936

163. Anonymer Follis Klasse B (1030/1935-1042).

Kupfer.

Av.: Brustbild von Jesus Christus mit dem Evangelium in der linken Hand.

Rev.: Inschrift zwischen den Armen eines Kreuzes.

Dm.: $2,7 \mathrm{~cm}$.

Mus. Pliska, Inv.-Nr. 3937.

164. Anonymer Follis Klasse C (1042-1050).

Kupfer.

Av.: Jesus Christus in ganzer Gestalt mit dem Evangelium in der Hand.

Rev.: Inschrift IC XI | NI KA zwischen den Armen eines Kreuzes.

Dm.: $2,7 \times 2,9 \mathrm{~cm}$.

Mus. Pliska, Inv.-Nr. 3939.

165. Follis Konstantins X. (1059-1067). Krum Palast, Qu. 153b, auf dem Fußboden eines Wohnbaus.

Kupfer.

Av. : Brustbild von Jesus Christus.

Rev.: Brustbild des Kaisers. In seiner Rechten trägt er ein Zepter mit Kreuz an der Spitze.

Dm.: $2,7 \times 3 \mathrm{~cm}$.

Mus. Pliska, Inv.-Nr. 3941.

Jordanov 2000, 165, Kat.-Nr. 560. 
166. Follis Konstantins X. und der Eudokia (1059-1067). Am Steinweg zur Großen Basilika, ca. $50 \mathrm{~m}$ vom Osttor entfernt. Oberflächefund.

Kupfer.

Av.: Brustbild von Jesus Christus.

Rev.: Kaiser und Kaiserin sich gegenüberstehend und zwischen sich ein langes Zepter haltend.

Dm.: $2,75 \times 3 \mathrm{~cm}$.

Mus. Pliska, Inv.-Nr. 3942.

Jordanov 2000, 165, Kat.-Nr. 561.

167. Nomisma Akexios' I. Komnenos (1092-1118).

Billon.

Av.: Darstellung Jesu Christi, auf dem Thron sitzend mit dem Evangelium in der Linken.

Rev.: Brustbild des Herrschers mit Reichsapfel in der Linken und Zepter in der Rechten.

Dm.: 2,6x2,7 cm; Gew.: 3,8 g.

Mus. Pliska, Inv.-Nr. 3943.

Jordanov 2000, 165, Kat.-Nr. 568.

168. Gürtel. Östlich der Großen Basilika, Sarkophag Nr. 4. Ende des 9. - Anfang des 10. Jhs.

Leder, Textil, stark beschädigt. Schnalle, zwei Aufhänger, eine Riemenzunge und eine Schlaufe. Dazu gehört höchstwahrscheinlich ein Messer mit Messerscheide.

Schnalle: Gold, gehämmert. Perlendraht. Ovaler Schnallenring mit glatter Oberfläche und rundem Querschnitt. Schnallenring und -dorn durch Scharnier mit fünfeckiger Platte verbunden. Der längste Rand der Platte mit einem Perlendraht verziert, Oberfläche mit schachbrettartig angeordneten plastischen Blättchen bedeckt. Auf der Rückseite drei kleine Ösen zur Befestigung am Gürtel.

Schnallenring - Ausmaße: 3,8x1,8 cm. Platte - H.: $3 \mathrm{~cm}$; Br.: $2,5 \mathrm{~cm}$; St.: 0,3 cm. Goldgehalt: $22 \mathrm{~K}$.

Hist. Mus. Šumen, Inv.Nr. 1893.

Zwei Aufhänger: Silber. Vergoldung, Perlendraht. Glatte, abgerundete Platte, mit einem ovalen Ring durch ein Scharnier verbunden. Über dem Scharnier ist ein Perlendraht appliziert. Auf der Rückseite der Platte quer ageordnete Leisten zur Befestigung am Gürtel (nur in Fragmenten erhalten).

Ausmaße Platte: 3x2 cm; Dm. Ring: 1,7x1 cm.

Hist. Mus. Šumen. Inv.-Nr. 1894.

Riemenzunge: Gold, gehämmert. Perlendraht. Fünfeckige Kassette mit Bordüre in der Form eines plastischen floralen Frieses (sog. Cyma von Lesbos), der aus gespitzten Blättern über Doppelbögen besteht. Die Platte hat einen erhabenen Rand und ist mit schachbrettartig angeordneten plastischen Blättern bedeckt. Zwischen Platte und Bordüre eine Trennleiste, die auf beiden Seiten mit einen Perlendraht flankiert ist.

Maße: 4,9x3 cm; Goldgehalt: $22 \mathrm{~K}$.

Hist. Mus. Šumen, Inv.-Nr. 1892.

Schlaufe: Silber. Ellipsenförmiger Draht mit rundem Querschnitt.

L.: 4,1 cm; Br.: 1,8 cm; St. 0,4 cm.

Messer: Eisen. Holzscheide mit zwei silbernen Beschlägen. Die Beschläge bestehen aus elliptisch geformten Blechen und sind mit Schlaufen zur Befestigung am Gürtel versehen. Ortband aus Silberblech.

Messer - L.: 32,5 cm; Br.: 1,3/2,4 cm. Oberer Beschlag - Dm.: 2,6 cm; Br.: 0,6 cm. Zweiter 
Beschlag - Dm.: 2 cm; Br.: 0,6 cm. Ortband - Dm.: 1,5 cm; Br.: 0,5 cm.

Hist. Mus. Šumen, Inv.-Nr. 1896.

Michajlov 1979, 51-58, Abb. 32-36; Inkova 2000, 53-60, Abb. 2-12, Abb. 13,1, Abb. 18, Abb. 20.

169. Gürtel. Östlich der Großen Basilika, Sarkophag Nr. 4. Erste Hälfte 10. Jh.

Leinen. Silberne lyraförmige Schnalle, Kupferschlaufe von dreieckiger Form und silberne Riemenzunge. Diese ist kassettenartig und hat gedrückte zylindrische Form. Auf ihrer elliptischen Schauseite ist ein Kreuz eingeritzt.

Rekonstruierter Gürtel - L.: 72 cm. Schnalle - L.: 4,5 cm; Br.: 3,4 m; St.: 0,45 cm. Dreieckige Schlaufe - H.: 3,5 cm; Max. Br.: 4 cm; St.: 0,4 cm; Riemenzunge - L.: 0,8 cm; Br.: 0,32 cm.

Hist. Mus. Šumen, Inv.-Nr. 1897.

Michajlov 1979, 58, Abb. 37; Michajlov/Savov/Malecki/Ivanov 1979, 64-68, Abb. 7-9; Inkova 2000, 60, Abb. 13,2-4.

170. Schnallenplatte. Siedlung im Gebiet der Großen Basilika. 8. - erste Hälfte 9. Jh.

Bronze mit Versilberung. Gerundetes unteres Ende, Scharnier am oberen Ende, auf der Rückseite Stifte zur Befestigung am Gürtel. Glatte Schauseite.

H.: $3 \mathrm{~cm}$; Max. Br.: $2 \mathrm{~cm}$.

Mus. Pliska, Inv.-Nr. 3912.

Georgiev 1993, 30, Abb. 27a.

171. Schnalle. Innere Stadt. 10. Jh.

Bronze, gegossen. Rechteckige Schnallenplatte mit rechteckigem Durchbruch an einem Ende und Scharnier an dem anderen. Auf der Platte eingerahmte Darstellung eines nach Links schreitenden Löwen mit kurzem Körper in Seitenansicht und großem Kopf in Frontalansicht.

L.: $4,6 \mathrm{~cm}$; Br.: $3 \mathrm{~cm}$.

Nat. Arch. Mus. Sofia, Inv.-Nr. 2828.

Aladžov 1981, Abb. 2.

172. Schnalle. 10.-11. Jh.

Bronze, gegossen. Lyraförmig.

Ausmaße: $3,1 \times 2,9-3 \mathrm{~cm}$.

Mus. Pliska, Inv.-Nr. 3225.

173. Schnalle. Große Basilika, Südsektor. 10.-11. Jh.

Eisen, gegossen. Fünfeckiger Rahmen mit langem Dorn. Kleiner Haken an der hinteren Schmalseite.

L.: 4,9 cm; Max. Br.: 2,5 cm.

Mus. Pliska, Inv.-Nr. 3870.

Ausgrabungen P. Georgiev und S. Vitljanov.

174. Schnalle. 10.-11. Jh.

Bronze, gegossen. Rechteckige Form, mit knospenförmigen Verdickungen an den Verbindungsstellen zwischen Rahmen und Steg, der den (fehlenden) Schnallendorn aufnahm.

L.: $2,8 \mathrm{~cm}$; Br.: $1,8 \mathrm{~cm}$.

Mus. Pliska, Inv.-Nr. 3227. 
175. Riemenzunge. Siedlung im Gebiet der Großen Basilika. 8. - erste Hälfte 9. Jh.

Blei, gegossen. Abgerundetes Ende, rechteckiger Durchbruch am oberen Ende und mit reliefierten Fischgräten- und Erlenzweigmustern auf beiden Seiten.

H.: 3,9 cm; Max. Br.: 1,8 cm; St.: 0,2 cm.

Mus. Pliska, Inv.-Nr. 3914.

Georgiev 1993, 30-31, Abb. 27e.

176. Riemenzunge. 8.-9. Jh.

Bronze, gegossen. Gerundetes unteres Ende, rechteckiger (beschädigter) Durchbruch am oberen Ende. Auf der Schauseite ein durchbrochenes Ornament aus Rhomben und mittig geschnürten Voluten .

L.: $4 \mathrm{~cm}$; Br.: $1,7 \mathrm{~cm}$.

Mus. Pliska, Inv.-Nr. 2483.

Stanilov 1991, 186, Abb. IV,3.

177. Riemenzunge. Gräberfeld im südostlichten Bereich der Inneren Stadt, Grab Nr. 2. 10. - Anf. 11. Jh.

Bronze, gegossen. Länglich-schmale Platte mit gerundetem Ende. Auf der Schauseite mit stilisierten Palmetten verziert, auf der Rückseite vier kleine Nieten.

Mus. Pliska, Inv.-Nr. 3209.

Pletneva 1992, Abb. 32,1.

178.-184. Gürtelapplikationen. Innere Stadt. 10. Jh.

Bronze, gegossen. Herz- oder blattförmig mit stilisierten Pflanzenornamenten sowie Knospen im Randbereich einiger Stücke.

Ausmaßen: 1,5x2 cm; $1,5 \times 2 \mathrm{~cm} ; 1,6 \times 2 \mathrm{~cm} ; 2 \times 2,5 \mathrm{~cm} ; 2 \times 2,5 \mathrm{~cm} ; 2,8 \times 1,8 \mathrm{~cm} ; 2,8 \times 1,8 \mathrm{~cm}$.

Mus. Pliska, Inv.-Nr. 3232, 3233, 3234, 3231, 3230, 3237, 3238.

185. Gürtelapplikation. Objekt 41. 10. Jh.

Bronze, gegossen. Annähernd vierblättriger Umriss, mit erhabenem Mittelpunkt, Reliefbordüre und Knospen. Rückseite mit zwei Nieten.

H.: $1,7 \mathrm{~cm}$; Max. Br.: $1,5 \mathrm{~cm}$.

Mus. Pliska, Inv.-Nr. 3767.

186. Gürtelapplikation. Palastzentrum. 10. Jh.

Bronze, gegossen. Dreiblättrig mit Palmetten und kleinen Knospen.

L.: $2,2 \mathrm{~cm}$; $\mathrm{Br} .: 1,5 \mathrm{~cm}$.

Mus. Pliska, Inv.-Nr. 3214.

187. Ohrring. Gräberfeld östlich der Apsis der Großen Basilika. Grab Nr. 27. 10. Jh.

Gold. Treibtechnik, Lötungen, Filigranarbeiten, Granulationen. Ring bestehend aus einem Drahtverschluss und einer massiven Ringhälfte mit aufgelöteten Filigranfäden. In der Mitte nach oben und nach unten weisende, jeweils ein auf Granulationskränze gesetztes Hohlkügelchen mit Knospenenden, die auf einem kleinen Kranz aus Filigrandraht ruhen. Die Ansatzpunkte des oberen und unteren Teils sind mit Granulationskränzen und Filigranfäden umgewickelt.

H.: 4,5 cm; Br.: 2,4 cm; Gewicht: 5,55 g. 
Mus. Pliska, Inv.-Nr. 3905.

Văžarova 1980, 52, Abb. 1.

188. Ohrring. Gräberfeld östlich der Apsis der Großen Basilika, Grab Nr. 27. 10. Jh.

Gold, Perle. Treibtechnik, Lötungen, Filigrantechnik, Granulationen. Ring bestehend aus einem Drahtverschluss und einer massiven Ringhälfte mit aufgelöteten Drähten, die Granulen nachahmen. In der Mitte ein nach unten und nach oben weisendes geripptes Querstäbchen mit je einer Perle (die obere fehlt). Zwischen Ring und Verschluss auf beiden Seiten jeweils ein doppelkonisches, in Filigranfäden gefasstes Hohlkügelchen.

H.: 3,5 cm; Br.: 1,9 cm; 3,20 g.

Mus. Pliska, Inv.-Nr. 3904.

Văžarova 1980, 52, Abb. 2.

189. Ohrring. Gräberfeld im Südostteil der Inneren Stadt, Grab Nr. 16. 10. Jh.

Silber. Ring mit massivem Gehänge in Traubenform mit Körnung und Kugeln. Beiderseits davon Granulationskränze.

H.: 4,2 cm; Dm.: $2,7 \mathrm{~cm}$.

Mus. Pliska, Inv.-Nr. 3210.

Pletneva 1992, Abb. 32,7.

190. Ohrring. Gräberfeld östlich des Osttores. Grab Nr. 2. 11. Jh.

Kupfer. Ellipseförmiger Drahtring mit einem doppelkonischen, durchbrochenen Anhänger.

H.: $4 \mathrm{~cm}$; H. Anhänger: $1,8 \mathrm{~cm}$; Dm.: $1,1 \mathrm{~cm}$.

Mus. Pliska, Inv.-Nr. 3411.

Dimitrov 1995, 55, Abb. 7,2.

191. Zwei Ohrringe. Gräberfeld im Südsektor der westlichen Festungsmauer, Grab Nr. 21. 11. Jh.

Silber. Treibtechnik, Lötung, Filigrantechnik, Granulationen. Drahtverschluss und reich verzierter, halbmondförmiger und durchgebrochener Ring, der sich aus vier Zipfeln, kleinen Ringen und traubenartigen Elementen zusammensetzt.

H.: 3 und 3,1 cm; Br.: 2 und 2,2 cm.

Mus. Pliska, Inv.-Nr. 2486.

Dončeva-Petkova 1984, 182-183, Abb. 4g.

192. Perlenhalskette. Gräberfeld östlich des Osttores, Grab 28. 11. Jh.

Glas. 807 Glasperlen von unterschiedlicher Form (kugelig, zylindrisch, oval, dreiblättrig, konkav einziehend) und Farbe (gelb, grün, blau, vergoldet, versilbert).

Ausmaße: zwischen $0,3 \times 0,4$ und $0,5 \times 1,1 \mathrm{~cm}$.

Mus. Pliska, Inv.-Nr. 3443.

Dimitrov 1995, 55, Abb. 7,16-44.

193. Zwei Anhänger. Gräberfeld östlich der Großen Basilika, Grab Nr. 27. 10. Jh.

Gold. Schnitzwerk, Lötung, Filigrantechnik. Hohle, tropfenförmige Kügelchen mit Ösen. Filigranfäden am Ösenansatz, etwas unterhalb davon sowie am Ansatz der knospenförmigen Enden. 
H.: 2,9 und $3 \mathrm{~cm}$; Max. Dm.: 1,6 und 1,4 cm; Gew.: 3,08 und 3,65 g.

Mus. Pliska, Inv.-Nr. 3901, 3902.

Văžarova 1980, 52, Abb. 4.

194. Anhänger. Objekt 41. 10. Jh.

Bronze, gegossen. Tropfenförmig mit flachem Rücken und einer Öse zum Aufhängen. Auf der Schauseite tief eingravierter Rhombus mit bogenförmig geschwungenen Seiten.

Gesamte H.: $4 \mathrm{~cm}$; H. ohne Öse: $2,7 \mathrm{~cm}$; Br:: 2,2 cm.

Mus. Pliska, Inv.-Nr. 3726.

Ausgrabungen S. Vitljanov.

195. Zwei Anhänger. Gräberfeld östlich der Großen Basilika, Grab Nr. 27. 10. Jh.

Gold. Schnitzwerk, Lötung, Filigrantechnik. Linsenförmiger Hohlkörper und Ösen mit Scharnierbefestigung. Seitlich umlaufender filigraner Kranz.

H. mit Ösen: 2,15 und 2,2 cm; Dm.: 1,5 cm; Gew.: 2,10 g.

Hist. Mus. Šumen, Inv.-Nr. 2899, 3900.

Văžarova 1980, 52, Abb. 3.

196. Zwei Anhänger. Gräberfeld östlich der Großen Basilika, Grab Nr. 24. 10. Jh.

Gold. Schnitzwerk, Lötung, Filigrantechnik. Hohlkörper von kugelig-abgeflachter Form. Am Ösenansatz Filigrankranz.

Dm.: 1,2 cm; St.: 0,9 cm; Dm. Ösen: 0,5 cm; Gew.: 1,88 und 1,98 g.

Hist. Mus. Šumen, Inv.-Nr. 20614, 20615.

Văžarova 1979, 79, Abb. 15.

197. Fingerring. Siedlung an der Großen Basilika. 8. - Anf. 9. Jh.

Kupfer. Gravuren. Offener Blechfingerring mit ovaler Verbreiterung, die mit stilisierten Pflanzenornamenten verziert ist.

Ausmaße Schaufläche: $1,8 \times 2 \mathrm{~cm}$.

Mus. Pliska, Inv.-Nr. 3910.

Georgiev 1993, 31, Abb. 29a.

198.-199. Zwei Fingerringe. Siedlung am Objekt 31. 8. - Anf. 9. Jh.

Kupfer. Gravuren. Offene Blechfingerringe und ovale Verbreiterungen, die mit stilisierten Pflanzenornamenten verziert sind.

Nr. 198 - Ausmaße Schaufläche: 1,4x1,6 cm. Nr. 199 - Ausmaße Schaufläche: 1,2x2 cm.

Mus. Pliska, Inv.-Nr. 3909, 3911.

Michajlov/Milčev 1959, 287, Abb. 25,6 (Nr. 198); Georgiev 1993, 31, Abb. 29v (Nr. 199).

200. Fingerring. Gräberfeld östlich der Großen Basilika, Grab Nr. 27. 10. Jh.

Gold. Inkrustationen, Emaille. Massiver Ring mit runder Schaufläche, diese eingefasst von feinem Granulatkranz und verziert mit einer achtblättrigen grünen, gelben und weißen Rosette auf dunkelblauem Hintergrund.

Dm. Ring: 2,5 cm; Dm. Schauplatte: 1,2 cm; Gew.: 7,58 g.

Mus. Pliska, Inv.-Nr. 3903.

Văžarova 1980, 53, Abb. 6a,b. 
201. Fingerring. Gräberfeld östlich des Osttores. 11. Jh.

Silber. Ring zweifach tordiert.

Dm.: $2,5 \mathrm{~cm}$.

Mus. Pliska, Inv.-Nr. 3417.

Dimitrov 1995, 55, Abb. 7,3.

202.-205. Armringe. Gräberfeld östlich des Osttores, Gräber Nr. 5, 17, 45 und 115. 11. Jh.

Glas. Weiß-durchsichtig und schwarz. Ringe mit ovalem und quadratischem Querschnitt.

Nr. 202 - Dm.: 4,8 cm; St.: 0,5. Nr. 203 - Dm.: 4,5 cm; St.: 0,4 cm. Nr. 204 - Dm.: 6,5 cm; St.: 0,7 cm. Nr. $205-$ Dm.: $6,5 \mathrm{~cm}$; St.: 0,5 cm.

Ausgrabungen J. Dimitrov.

206. Armring. Gräberfeld östlich des Osttores, Grab Nr. 28. 11. Jh.

Glas. Dunkelblau, halbdurchsichtig. Ring mit ovalem Querschnitt. Oberfläche mit Spiralornamenten aus aufgelegter gelber Glaspaste verziert.

Dm.: $5,3 \mathrm{~cm}$; Br.: 0,3 cm.

Mus. Pliska, Inv.-Nr. 3432.

Dimitrov 1995, 59, Abb. 9,22.

207.-209. Armringe. Gräberfeld am Objekt 20, Grab Nr. 5. 11. Jh.

Glas. Blau, halbdurchsichtig. Ringe mit ovalem Querschnitt (einmal mit aufgetragener Rille). Verzierung der Oberfläche durch bogen-, spiral- und zick-zack-förmige Linien aus aufgelegter gelber Glaspaste.

Nr. 207 - Dm.: 7,8 cm; St.: 0,6 cm. Nr. 208 - Dm.: 6,9 cm; St.: 1,3 cm. Nr. 209 - Dm.: 7,2 cm; Br.: $1,2 \mathrm{~m}$.

Mus. Pliska, Inv.-Nr. 3395, 3398, 3399.

Dimitrov 1998, 72, Abb. 3a,b,v.

210. Armring. Gräberfeld im Südsektor der westlichen Festungsmauer, Grab Nr. 7. 50er - 60er Jahre des 11. Jh.

Bronze. Dünnes Blech mit Scharnierverschluss. Die Oberfläche ist mit eingepunzten Punkten und bogenförmigen Figuren verziert.

Dm.: 6x6,3 cm; Br.: 1,3 cm; St.: 0,1 cm.

Dončeva-Petkova 1979a, 91, Abb. 22z; Dončeva-Petkova 1984, 186, Abb. 8g.

211. Armring. Gräberfeld östlich des Osttores, Grab Nr. 27. 11. Jh.

Kupfer. Offene Spange in Form eines dünnen Blechs mit Scharnierverschluss. In die Oberfläche eingepunzte Punkte und Kreise.

Dm.: $6 \mathrm{~cm}$; Br.: $1,5 \mathrm{~cm}$.

Mus. Pliska, Inv.-Nr. 3428.

Dimitrov 1995, 57, Abb. 8,7.

212. Armring. Gräberfeld östlich des Osttores. 11. Jh.

Bronze, gegossen. Offen, mit ovalem Querschnitt und Schlangenkopfenden.

Dm.: $6,8 \mathrm{~cm}$; St.: $0,4 \mathrm{~cm}$.

Mus. Pliska, Inv.-Nr. 3462.

Dimitrov 1995, 57, Abb. 8,3. 
213. Armring. Gräberfeld östlich des Osttores. 11. Jh.

Bronze, gegossen. Offen, mit ovalem Querschnitt und verbreiterten Enden in Form eines Scharnierverschlusses.

Dm.: $6 \mathrm{~cm}$; St.: 0,3 cm.

Mus. Pliska, Inv.-Nr. 3464.

Ausgrabungen J. Dimitrov.

214. Armring. Gräberfeld östlich des Osttores, Grab Nr. 28. 11. Jh.

Kupferlegierung. Offen, mit rechteckigem Querschnitt. Die Enden sind stilisierte Schlangenköpfe. Oberfläche mit gepunzter Kreisverzierung.

Dm.: $5,2 \mathrm{~cm}$.

Mus. Pliska, Inv.-Nr. 3426.

Dimitrov 1995, 57, Abb. 8,6.

215. Armring. Gräberfeld östlich des Osttores, Grab Nr. 55. 11. Jh.

Kupferlegierung. Offen, mit rechteckigem Querschnitt und stilisierten Tierköpfen an den Enden. Verzierung aus geraden und sich kreuzenden Linien und eingepunzten kleinen Kreisen.

Dm.: ca. 6,2 cm; St.: 0,5 cm.

Mus. Pliska, Inv.-Nr. 3467.

Dimitrov 1995, 57, Abb. 8,8.

216. Armring. Gräberfeld östlich des Osttores, Grab Nr. 42. 11. Jh.

Kupferlegierung. Offen, ein Ende kräftig verbreitert, das andere abgebrochen. Oberfläche mit eingepunzten Kreisen verziert.

Dm.: 3,4x3,9 cm; Br.: 0,5/1,1 cm.

Mus. Pliska, Inv.-Nr. 3468.

Dimitrov 1995, 57, Abb. 8,13.

217. Armring. Gräberfeld östlich des Osttores, Grab Nr. 78. 11. Jh.

Kupferlegierung, gegossen. Offener Ring aus rechteckigen und quadratischen Teilen verziert mit kreuzförmigen Aussparungen, Kreisaugen und Linien.

Dm.: 3,4x3,7 cm; Br.: 1,5 cm.

Mus. Pliska, Inv.-Nr. 3479.

Dimitrov 1995, 59, Abb. 9,17.

218. Zwei Armringe. Gräberfeld östlich des Hügels XXXIV, Grab Nr. 1. 11. Jh.

Silber. Offen, mit zweifach tordiertem Körper. Die Enden bilden aus dünnen Blechstücken und Drähten geformte Tiermäuler und haben Haken und Öse.

Dm.: $6 \mathrm{~cm}$.

Mus. Pliska, Inv.-Nr. 3461.

Dimitrov 1998, 69, Abb. 2d.

219. Sechs Knöpfe. Gräberfeld östlich der Großen Basilika, Grab Nr. 27. 10 Jh.

Gold. Schnitzwerk, Lötungen, Filigrantechnik. Kugelförmige Hohlkörper mit dünnen Befestigungsösen. Filigranfäden am Ösenansatz und an den knospenförmigen Unterseiten.

Dm.: von 1,8 bis 2,3 cm; Gew.: 2,10 g, 2,90 g, 3,17 g, 3,57 g. 
Mus. Pliska, Inv.-Nr. 3894-3998, 3906.

Văžarova 1980, 52, Abb. 5.

220. Knopf. Gelände der Großen Basilika, Qu. 119, T. 0,20-0,40 m. 10. Jh.

Gold. Filigrantechnik. Kugelförmig mit Filigranfaden am Ösenansatz.

H. mit Öse: 1,6 cm; Dm.: 1,1 cm; Gew.: 1,28 g; Goldgehalt: $20 \mathrm{~K}$.

Mus. Pliska, Inv.-Nr. 3893.

Georgiev/Vitljanov 2001, 135, 175-176, Abb. 70,26, Kat.-Nr. 80.

221. Knopf. Gelände der Großen Basilika, Qu. 206. 10. Jh.

Gold. Treibtechnik, Filigrantechnik. Rund-ovaler Körper mit Öse. Durch Eintiefungen werden neun gerundeten Blättchen dargestellt.

H.: 2,1 cm; Dm.: 1,4x2 cm; Gew.: 2,722 g; Goldgehalt: $20 \mathrm{~K}$.

Mus. Pliska, Inv.-Nr. 3892.

Georgiev/Vitljanov 2001, 135, 138, 175, Abb. 70,25, Kat.-Nr. 79.

222. Applikation. Gräberfeld im Südsektor der westlichen Festungsmauer, Grab Nr. 21. 11. Jh. Kupferlegierung mit Vergoldung, gegossen. Runde Form. Erhöhter Mittelteil mit eingraviertem Kreis sowie einem volutenförmigen Ornament, umrahmt von einem Reliefkranz. Am Rand zwei kleine Durchlochungen zur Befestigung.

Dm.: $2,5 \mathrm{~cm}$.

Mus. Pliska, Inv.-Nr. 1990.

Dončeva-Petkova 1984, 188, Kat.-Nr. 2e, Abb. 4p.

223-224. Applikationen. Gräberfeld östlich des Osttores, Grab Nr. 28. 11. Jh.

Kupferlegierung, gegossen. Runde Form. Konvexer Mittelteil, einmal mit zentraler Vertiefung, einmal mit knospenartiger Erhöhung in der Mitte. Rand mit Kranz aus Pseudogranulation und zwei kleinen Durchlochungen zur Befestigung.

Nr. 223 - Dm.: 3,6 cm. Nr. 224 - Dm.: 3,9 cm.

Mus. Pliska, Inv.-Nr. 3440, 3441.

Dimitrov 1995, 61, Kat.-Nr. 28, Abb. 10,4.6.

225. Applikation. Gräberfeld östlich des Osttores, Grab Nr. 2 (?). 11. Jh.

Silber mit Vergoldung, gegossen. Runde Form. Ähnelt einem stilisierten Vogel. Auf der Rückseite zwei kleine Nieten. Am Rand kleine Durchlochungen zur Befestigung.

Ausmaße: $3,5 \times 3,4 \times 0,6 \mathrm{~cm}$.

Mus. Pliska, Inv.-Nr. 3409.

Dimitrov 1995, 51, Kat.-Nr. 2, Abb. 10,3.

226. Applikation. Gräberfeld östlich des Osttores. 11. Jh.

Silber mit Vergoldung, gegossen, Niello. Herzförmig mit drei Knospen im Randbereich. Stark aufgewölbte Bereiche auf der Schauseite bilden eine dreiblättrige Palmette, die von einem Kranz in Pseudogranulationstechnik umgrenzt ist. Die Pflanzenmotive auf den Blättchen sind in Niello ausgeführt.

H.: $3,2 \mathrm{~cm}$; Br.: $3,1 \mathrm{~cm}$; St.: $1,1 \mathrm{~cm}$.

Mus. Pliska, Inv.-Nr. 3410.

Dimitrov 1995, 50-51, Abb. 10,1. 
227. Applikation - Zaumzeugverzierung. Gräberfeld östlich des Osttores, Grab Nr. 2. 11. Jh. Silber mit Vergoldung. Weidenblattförmige Form. Konvexer Mittelteil umrahmt mit einem Kranz aus Pseudogranulation sowie verziert durch Eintiefungen und kompliziertes Flechtband. Auf der Rückseite drei kleine Nieten. Zwei kleine Durchlochungen zur Befestigung.

H.: 7,1 cm; Max. Br.: 3,8 cm.

Mus. Pliska, Inv.-Nr. 3408.

Dimitrov 1995, 49, Abb. 10,2.

228. Säule mit Inschrift. Fundort: Vărbjane, Bezirk Šumen. Sekundär verwendet. Regierungszeit des Khans Omurtag (814-831).

Weißer Marmor. Zylinderförmig, oben konisches Loch. Bei der Beschriftung nach unten gedreht.

Inschrift in fünf Reihen in griechischer Sprache, nicht sehr sorgfältig gravierte Buchstaben:

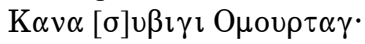

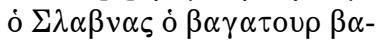

$$
\begin{aligned}
& \gamma \alpha \imath v[o \varsigma] \theta \rho \varepsilon \pi \tau \text { ò } \alpha_{\alpha} v \theta \rho o-
\end{aligned}
$$

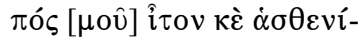

$$
\begin{aligned}
& \sigma \alpha \varsigma \dot{\alpha} \pi \dot{\varepsilon} \theta \alpha \nu \varepsilon v .
\end{aligned}
$$

Übersetzung: „Khan Sjubigi Omurtag (sagt): Slavnas Bagatur Bagainos wurde von mir aufgezogen und er wurde krank und starb“.

H.: 63 cm; Dm. oben: 33 cm; Dm. unten: 30 cm; H. Buchstaben: 5,2-6,2 cm.

Nat. Arch. Mus. Sofia, Inv.-Nr. 643.

Beševliev 1963, 292, Nr. 63; Beševliev 1979, 219-220, Kat.-Nr. 64, Abb. 155.

229. Säulenbruchtück mit Inschrift. Fundort: Mogila, Bezirk Šumen. Regierungszeit des Khans Omurtag (814-831).

Kalkstein. Vier erhaltene Reihen der Inschrift:

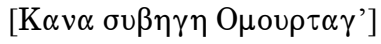

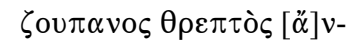

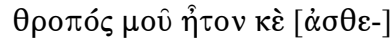

$v \eta \tilde{\sigma} \alpha \varsigma \dot{\alpha} \pi \dot{\varepsilon} \theta \alpha \nu \varepsilon v \hat{\eta} \tau[\mathrm{ov} \delta \dot{\varepsilon}]$

$\gamma \varepsilon v \varepsilon \hat{\alpha} \varsigma$ E $\rho \eta \eta \rho \eta \varsigma$.

Übersetzung: „Khan Sjubigi Omurtag (sagt): ....... Der Župan wurde von mir aufgezogen, und da er krank wurde, starb er. Er war aus dem Geschlecht Ermiar“.

H.: $29 \mathrm{~cm}$; Dm.: $36 \mathrm{~cm}$; H. Buchstaben: $6 \mathrm{~cm}$.

Nat. Arch. Mus. Sofia, Inv.-Nr. 664.

Beševliev 1963, 290, Nr. 62; Beševliev 1979, 219, Kat.-Nr. 63, Abb. 154.

230. Zwei Ohrringe. Gräberfeld östlich des Osttores, Grab Nr. 93. 11. Jh.

Kupfer. Treibtechnik, Lötung, Filigrantechnik, Granulationen. Massive, reich verzierte halbmondförmige Anhänger mit fein geflochtenen Filigranfäden, die Kreisen und Rosseten bilden. An beiden Ansätzen des Verschlussdrahts Hohlkügelchen.

H.: $6 \mathrm{~cm}$; Br.: $3,2 \mathrm{~cm}$.

Mus. Pliska, Inv.-Nr. 3491.

Dimitrov 1995, Kat.-Nr. 93, Abb. 7,1. 
231. Perlenhalskette. Gräberfeld östlich des Osttores, Grab Nr. 93. 11. Jh.

Glas. 323 Perlen von unterschiedlicher Form (gezwickelt, flach, oval, zylindrisch, eckig, mehrseitig) und Farbe (blau, gelb, mit weißer und gelber Paste belegt).

Ausmaßen: 2,5x0,6 bis $0,9 \mathrm{x} 1 \mathrm{~cm}$.

Mus. Pliska, Inv.-Nr. 3487.

Dimitrov 1995, Abb. 7,18.25-29.31.38.39.41.

232. Fingerring. Gräberfeld östlich des Osttores, Grab Nr. 93. 11. Jh.

Bronze, gegossen. Ring mit viereckiger Verbreiterung, verziert mit eingetieften Punkten.

Dm.: $1,7 \mathrm{~cm}$.

Mus. Pliska, Inv.-Nr. 3406.

Dimitrov 1995, 55, Kat.-Nr. 93, Abb. 7,15.

233-236. Vier Armringe. Gräberfeld östlich des Osttores, Gräber Nr. 45 und 93. 11. Jh.

Kupferlegierung, gegossen. Offen, mit rechteckigem oder ovalem Querschnitt. Die Enden bilden stilisierte Tierköpfe. Oberfläche eines Ringes mit Kerblinien verziert, sonst unverziert.

Dm.: 5,5, 5,7, 6,2 und $6,4 \mathrm{~cm}$; St.: von 0,3 bis $0,5 \mathrm{~cm}$.

Mus. Pliska, Inv.-Nr. 3470, 3471, 3492 A, B.

Dimitrov 1995, 59, Abb. 9,14-16.

237. Armring. Gräberfeld östlich des Osttores, Grab Nr. 93. 11. Jh.

Kupferlegierung, gegossen. Offen, mit rechteckigem Querschnitt, verziert mit Linien und Punkten. Die spitz zulaufenden Enden bilden stilisierte Schlangenköpfe.

Dm.: 6x6,3 cm; St.: 0,2 cm.

Mus. Pliska, Inv.-Nr. 3492 V.

Dimitrov 1995, 57, Abb. 8,5. 


\section{Bibliographie}

Aboba Pliska 1905: Материаль для болгарских древностей: Абоба-Плиска с альбомом (=Известия Русского археологического института в Константинополе 10), София 1905.

Aladžov 1981: Живко Аладжов, „Бронзови токи с животински изображения от ранното средновековие“, in: Археология 23/4, 1981, S. 22-27.

Aladžov 1985: Живко Аладжов, „Съкровище от византийски златни монети от Плиска“, in: Нумизматика 20/1, 1985, S. 31-40.

Aladžov 2000: Zivko Aladjov, „On the importance of the gold coins' hoards from Pliska“, in: Macedonian Numismatic Journal 4, 2000, S. 107-120.

Antonova/Vitljanov 1985: Вера Антонова/Стоян Витлянов, „Плиска. Западна крепостна стена - сектор север (Археологически разкопки 1973-1975 г.)“, in: Плиска-Преслав 4, София 1985, S. 44-78.

Beševliev 1963: Veselin Beševliev, Die protobulgarischen Inschriften, (=Berliner Byzantinische Arbeiten 23), Berlin 1963.

Beševliev 1979: Веселин Бешевлиев, Първобългарски надписи, София 1979.

Beševliev 1981: Veselin Beševliev, Die protobulgarische Periode der bulgarischen Geschichte, Amsterdam 1981.

Dimitrov 1994: Янко Димитров, „За славянските археологически паметници в Плиска“, in: Епископ-Константинови четения 1, 1994, S. 17-34.

Dimitrov 1995: Янко Димитров, „Църква и некропол във Външния град на Плиска (края на X-XI в.)“, in: Плиска-Преслав 7, Шумен 1995, S. 42-70.

Dimitrov 1998: Янко Димитров, „Два некропола във Външния град на Плиска“, in: Tрудове на катедрите по история и богословие към Шуменския университет 2, 1998, S. 69-80.

Dončeva-Petkova 1976: Ljudmila Dontcheva, „Une croix pectorale-reliquaire en or récemment trouvée a Plisка“, in: Cahiers archéologique 25, 1976, S. 59-66.

Dončeva-Petkova 1977: Людмила Дончева-Петкова, Българската битова керамика през ранното средновековие (втората половина на VI - края на X в.), София 1977.

Dončeva-Petkova 1979a: Людмила Дончева-Петкова, „Западната крепостна стена в Плиска (Проучвания на южния сектор през 1973 и 1974 г.)“, in: Плиска-Преслав 1, София 1979, S. 81-97.

Dončeva-Petkova 1979b: Ljudmila Donceva-Petkova. „Croix d'or-reliquaire de Pliska. Culture et art en Bulgarie médiévale (VIIIe - XIVe s.)“, in: Известия на Археологическия институт 35, 1979, S. 74-91.

Dončeva-Petkova 1980: Людмила Дончева-Петкова, Знаци върху археологически паметници от средновековна България VII-X в., София 1980.

Dončeva-Petkova 1981: Людмила Дончева-Петкова, „Оловни тежести от Плиска“, in: Нумизматика 15/3, 1981, S. 22-28.

Dončeva-Petkova 1984: Людмила Дончева-Петкова, „Некропол при южния сектор на западната крепостна стена на Плиска“, in: Сборник в памет на проф. Станчо Ваклинов, София 1984, S. 181-191.

Dončeva-Petkova 1992: Людмила Дончева-Петкова, „Сгради при южния сектор на западната крепостна стена на Плиска“, in: Плиска-Преслав 5, Шумен 1992, S. 124-145.

Dončeva-Petkova 1993a: Людмила Дончева-Петкова, „Нови проучвания край западната крепостна стена на Плиска“, in: Плиска-Преслав 6, Шумен 1993, S. 79-84. 
Dončeva-Petkova 1993b: Людмила Дончева-Петкова, „Глинени съдове от ХІ в. от Плиска“, in: Преслав 4, София 1993, S. 250-262.

Evans/Wixom 1998: Helen Evans/William D. Wixom (Hrsg.), The Glory of Byzantium. Art and Culture of the Middle Byzantine Era A.D. 843-1261, New York 1998.

Georgiev 1978: Павел Георгиев, „Глинен съд с изображения на орли и знак от Плиска“, in: Археология 20/3, 1978, S. 30-39.

Georgiev 1991: Павел Георгиев, „Прабългарска култова церемония върху рисунка-графит с надписи от Плиска (по времето на хан Маламир [831-836])“, in: Проблеми на прабългарската история и култура 2, Шумен 1991, S. 198-208.

Georgiev 1993: Павел Георгиев, Мартириумът в Плиска и началото на християнството в България, София 1993.

Georgiev 1995: Pavel Georgiev, „The Bronze Rozette from Pliskas (on decoding the runic

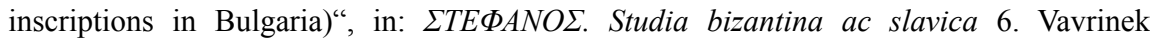
(=Byzanyinoslavica 56), 1995, S. 547-555.

Georgiev 2000: Павел Георгиев, „Статуетката-ключ от Плиска“, in: Старини 1, 2000, S. 79-86.

Georgiev/Vitljanov 2001: Павел Георгиев/Стоян Витлянов, Архиепископията-манастир в Плиска, София 2001.

Georgieva 1955: Соня Георгиева, „Разкопки на могили XXXIII и XXXII в Плиска“, in: Известия на Археологическия институт 20, 1955, S. 11-41.

Henning/Dončeva-Petkova 1999: Йоахим Хеннинг/Людмила Дончева-Петкова (Hrsg.), Първопрестолна Плиска: 100 години археологически проучвания, Frankfurt am Main 1999.

Inkova 2000: Мариела Инкова, „Коланът от саркофаг № 4 при Голямата базилика в Плиска“, in: Плиска-Преслав 8, Шумен 2000, S. 52-73.

Jordanov 1976: Иван Йорданов, „Едностранни златни монети-медальони с името на хан Омуртаг", in: Нумизматика 11/4, 1976, S. 18-34.

Jordanov 1992: Иван Йорданов, „Византийски оловни печати от Плиска“, in: ПлискаПреслав 5, Шумен 1992, S. 281-301.

Jordanov 2000: Иван Йорданов, „Монетите и печатите от Плиска (1899-1999)“, in: ПлискаПреслав 8, Шумен 2000, S. 135-167.

Jordanov 2001а: Иван Йорданов, Корпус на печатите на средновековна България, София 2001.

Jordanov 2001b: Иван Йорданов, „Печати и монети от Голямата базилика“, in: Georgiev/ Vitljanov 2001, S. 219-227.

Jordanov 2003: Ivan Jordanov, Corpus of Byzantine seals from Bulgaria. Vol. 1: Byzantine seals with geographical names. Sofia 2003.

Jotov 2004: Валери Йотов, Въоръжението и снаряжението от българското средновековие (VII - XI в.), Варна 2004.

Kartsonis 1986: Anna D. Kartsonis, Anastasis: The making of an Image, Princeton 1986.

Kvinto 1990: Лидия Квинто, „Отново за оловните тежести от Плиска“, in: Нумизматика 24/4, 1990, S. 24-26.

Michajlov/Savov/Malecki/Ivanova 1979: Александър Михайлов/Александър Савов/Михаил Малецки/Надежда Иванова, „Консервация на нож и колан от саркофаг № 4 в Плиска“, in: Плиска-Преслав 1, София 1979, S. 64-68.

Michajlov 1949: Стамен Михайлов, „Разкопки в Плиска през 1945-1947 година“, in: Разкопки и проучвания 3, София 1949, S. 171-225. 
Michajlov 1955: Стамен Михайлов, „Археологически материали от Плиска (1948-1951 г.)“, in: Известия на Археологическия институт 20, 1955, S. 49-181.

Michajlov 1974: Стамен Михайлов, „Разкопки на Западната порта в Плиска“, in: Известия на Археологическия институт 34, 1974, S. 204-250.

Michajlov 1979: Стамен Михайлов, „Каменните саркофази до Голямата базилика в Плиска“, in: Плиска-Преслав 1, София 1979, S. 44-59.

Michajlov/Milčev 1959: Стамен Михайлов/Атанас Милчев, „Разкопки в Плиска през 1955 г.“, in: Известия на Археологическия институт 22, 1959, S. 263-291.

Michajlova 1987: Тонка Михайлова, „Сфероконуси от Плиска“, in: Археология 29/1, 1987, S. $15-23$.

Michajlova 1992: Тонка Михайлова, „Сгради и съоръжения на запад от Тронната палата в Плиска - X-XI в.“, in: Плиска-Преслав 5, Шумен 1992, S. 170-184.

Mijatev 1943: Кръстю Миятев, „Крумовият дворец и други новооткрити постройки в Плиска“, in: Известия на Археологическия институт 14, 1943, S. 73-135.

Milčev 1979: Атанас Милчев, „Материали, открити в занаятчийските и търговските помещения северно от южната порта на Вътрешния град на Плиска“, in: ПлискаПреслав 1, София 1979, S. 139-176.

Milčev 1992: Атанас Милчев, „Разкопки около Южната порта и югозападната кръгла кула във Вътрешния град на Плиска“, in: Плиска-Преслав 5, Шумен 1992, S. 185-211.

Mollov 1943: Иван Моллов, „Почиствания и проучвания в Плиска през 1930 и 1931 г.“, in: Известия на Археологическия институт 14, 1943, S. 69-72.

Ovčarov 1978: Димитьр Овчаров, „Култът към сльнцето в езическите религиозни представи на българите“, in: Векове 7/1, 1978, S. 30-36.

Petrova 1992: Павлина Петрова, „Кьм въпроса за седмолъчната розета от Плиска, in: Приноси към българската археология 1, София 1992, S. 103-106.

Petrova/Brey 2005: Vassilena Petrova/Gerhard Brey, "Provenance studies of early mediaeval fast wheel pottery from Pliska, Bulgaria", in: M. Isabel Prudêncio/M. Isabel Dias/J. C. Waerenborgh (Hrsg.), Understanding people through their pottery. Proceedings of the $7^{\text {th }}$ European Meeting on Ancient Ceramics (EMAC'03). October 27-31, 2003, Lisbon. Trabalhos de arqueologia 42, 2005, S. 167-174.

Pletneva 1992: Светлана Александровна Плетнева, „Стратиграфические исследования Плиски (работы Советского отряда 1977-1980 гг.)“, in: Плиска-Преслав 5, Шумен 1992, S. 35-63.

Rašev 1983: Рашо Рашев, „Късни номади в Плисковското поле“, in: Преслав 3, София 1983, S. 242-252.

Rašev 1984: Рашо Рашев, „Нови данни за сграда 32 в Плиска“, in: Музеи и паметнищи на културата 24/2, 1984, S. 5-8.

Rašev 2003: Рашо Рашев, „Съмнителни и недостоверни паметници на прабългарската култура“, in: Studia protobulgarica et mediaevalia europensia. В чест на професор Веселин Бешевлиев, София 2003, S. 158-174.

Rašev 2004: Рашо Рашев, „Керамични съдове от подземния ходник на Крумовия дворец в Плиска“, in: Плиска-Преслав 10, Шумен 2004, S. 61-100.

Škorpil 1905: Карел Шкорпил, „Памятники в окрестностях Абобской равнины: Стана, Провадийския горы, водораздельныя возвышенноси и Шуменския горы“, in: AbobaPliska 1905, S. 385-442.

Slavčev/Jordanov 1979: Петър Славчев/Иван Йорданов, ,Златни медальони на хан Омуртаг (814-831)“, in: Археология 21/2, 1979, S. 25-32. 
Stančev 1949: Станчо Станчев, „Керамика от Голямата могила в Плиска. Предварително съобщение“, in: Разкопки и проучвания 3, София 1949, S. 227-233.

Stančev 1955: Станчо Станчев, „Разкопки и новооткрити материали в Плиска през 1948 г.“, in: Известия на Археологическия институт 20, 1955, S. 183-227.

Stančev 1960: Станчо Станчев, „Материали от Дворцовия център в Плиска“, in: Известия на Археологическия институт 23, 1960, S. 23-65.

Stančev/Ivanov 1958: Станчо Станчев/Стефан Иванов, Некрополът до Нови пазар, София 1958.

Stanilov 1991: Станислав Станилов, „Паметници на металопластиката от VIII-IX в. в България““, in: Проблеми на прабългарската история и култура 2, Шумен 1991, S. 181-197.

Teofilov 2000: Теофил Теофилов, „Древни научни познания, закодирани в седмолистната розета от Плиска“, in: Плиска-Преслав 8, Шумен 2000, S. 125-127.

Vaklinov 1978: Stančo Vaklinov, „Ein Denkmal runischen Schrifttums Pliskas“, in: Studia in Honorem Veselin Besevliev, Sofia 1978, S. 245-254.

Vasilev 1979: Радослав Василев, „Източната крепостна стена на Плиска (Разкопки през 1972-1974 г.)“, in: Плиска-Преслав 1, София 1979, S. 98-107.

Vasilev 1991: Радослав Василев, „Оловен печат на княз Борис-Михаил от Плиска“, in: Нумизматика 25/1-2, 1991, S. 3-5.

Vasilev 1992: Радослав Василев, „Новооткрит оловен печат на архиепископ Георги в Плиска“, in: Нумизматика и сфрагистика 1-2, 1992, S. 3-6.

Vasilev 1995: Радослав Василев, „Нови данни за ранносредновековното селище в района на Голямата базилика“, in: Плиска-Преслав 7, Шумен 1995, S. 27-33.

Văžarova 1979: Живка Въжарова, „Некропольт до Голямата базилика в Плиска“, in: ПлискаПреслав 1, София 1979, 69-80.

Văžarova 1980: Живка Въжарова, „Златни накити от гроб 27 в Плиска“, in: Археология 22/1, 1980, S. 52-56.

Vitljanov 1979: Стоян Витлянов, „Манастирски некропол при Голямата базилика в Плиска“, in: Векове 8/6, 1979, S. 62-65.

Vitljanov 1981: Стоян Витлянов, „Желязна теглилка (кантар) от Плиска“, in: Нумизматика 15/3, 1981, S. 18-22.

Zachariev 1979: Иван Захариев, „Южната крепостна стена на Плиска и некропольт, открит до нея (Разкопки през 1971-1974 г.)“, in: Плиска-Преслав 1, София 1979, S. 108-138.

Winkelmann/Gomolka-Fuchs 1987: Friedhelm Winkelmann/Gudrun Gomolka-Fuchs, Frühbyzantinische Kultur, Leipzig 1987. 


\section{Picture credits}

Angelova

1-13: Autor

Angelova/Bucharov

1-12: authors

Angelova/Koleva

siehe Liste im Artikel

BAKIRTZIS

1-4. author

Dimitrov

1: nach K. Škorpil 1905; 2: nach St. Michajlov 1955; 3: nach P. Petrova 1992; 4-9 Autor

Dimitrov

1-9: author

Dončeva-Petkova

1-16. Autor

DončEva-PetKova

1, 21.2: J. Henning; 2: author; 3-5, 7-8, 10, 12, 14-15, 17-18, 20: drawings by L. Petrova; 6.1-3, 11-12, 19, 21.3, 22: photographs by K. Georgiev; 6.6-8: photographs by R. Staneva; $6.4-5,13.3-$ 4: after Văzharova 1976, fig. 50.2 on p. 96, fig. 2 on p. 140, fig. 2 on p. 117, fig. 2a on p. 100; 13.1-2: after Stančev/Ivanov 1958, fig. 9.3 on p. 67, table XV.1; 16: after Bălgarite 2004, table 13.1-7; 21.1: photograph by A. Ehrlich.

FIEDLER

1-5: Autor

GEORGIEV

1-7: Autor

HENNING

1, 2, 3, 4a, 4b, 4d, 6a: digital enhancements and photos: author, aerial photo (3): courtesy of geodetical service Pleven; 4c: photo: A. Ehrlich; 5: courtesy of S. Angelova, digital enhancement: author; 6b: courtesy of S. Vitljanov; 7: analysis: A. Vogel \& V. Petrova, computer graphics: author; 8: digital photos: A. Ehrlich, digital enhancement: author; 9: courtesy of L. Dončeva-Petkova, computer graphics: author; 10A: Michajlov 1949; 10B: Dimitrov 2003, 182 fig. 1 
HENNING/EyUB

1: map after Škorpil 1905; 2a-b: C University of Frankfurt; 2c: after Mikulčić 2002; 2d: after Milčev 1992; 2e-f: after Vitljanov (in this volume).

Henning/Balabanov/Milo/Ziemann

1: map after Antonova/Dremsizova-Nelčinova 1981; photo: A. Ehrlich; 2: design: A. Ehrlich; 3: design A. Ehrlich

Joint Pliska excavations

Pls 1-19: photos: (C) University of Frankfurt and Archaeological Institute Sofia. Photographer: A. Ehrlich; digital enhancement: A. Ehrlich and K.-H. Engemann; Pl. 20: photos: author; Pls 2123: measurement and excavation data: (C) University of Frankfurt, draft: J. Henning; data analysis and digital enhancement: I. Marzolff; Pl. 24: measurement and excavation data: (C) University of Frankfurt, a: draft: J. Henning; a-b: data analysis and digital enhancement: I. Marzolff; Pl. 25: measurement and excavation data: (C) University of Frankfurt, draft: J. Henning, data analysis and digital enhancement: I. Marzolff; Pl. 26: excavation data: (C) University of Frankfurt, computer design: J. Henning, digital enhancement: A. Ehrlich; Pl. 27: Excavation data: (C) University of Frankfurt, a: computer design: J. Henning, digital enhancement: A. Ehrlich, b-c: photos: J. Henning; Pl. 28: excavation data: (C) University of Frankfurt, computer design: J. Henning, digital enhancement: A. Ehrlich; Pl. 29: excavation data: (C) University of Frankfurt, a, d: photos: J. Henning, b: computer design: J. Henning, digital enhancement: A. Ehrlich, c: photo: A. Ehrlich, (C) University of Frankfurt and Archaeological Institute Sofia (part of the Pliska catalogue); Pl. 30: Excavation data of grubenhaus No. 4: (C) J. Henning; a: computer design: J. Henning, digital graphics: A. Ehrlich, ground plan data after P. Georgiev and R. Vasilev; b-c: photos: (C) J. Henning; Pl. 31: a: measurement data: (C) University of Frankfurt, computer design: J. Henning, digital enhancement: A. Ehrlich; b: photo: J. Henning (mockup in the museum of Shumen); Pl. 32-34: measurement data: (C) University of Frankfurt, computer design: E. F. Eyub, digital enhancement A. Ehrlich; P1. 35: a-c: measurement data: (C) University of Frankfurt, computer design: P. Milo, digital enhancement: A. Ehrlich; d: B. Dostál; Pl. 36: geomagnetic measurement data and excavation data from 2002-2003: (C) University of Frankfurt, computer design: J. Henning, digital graphics: A. Ehrlich.

\section{HIRSCHFELD}

1-8, 10-15: author, 9: after Ponting 2003, 86;

Pl. 20: author

IVISON

1: after Lightfoot/Ivison 2002, 2, fig. A; 2: ibid., 2, fig. B; 3: ibid., 4, fig. C; 4: ibid., 22, fig. G; 5: photograph by author; 6: plan by Benny Arubas and with additions by Eric A. Ivison (2004); 7: plan by Gary Tompsett and Caitlin Evans, with additions by Christopher S. Lightfoot, 2004; 8: after Lightfoot/Ivison 2002, 24, fig. J; 9-16, 22: photographs by Christopher S. Lightfoot; 17: photograph by author; 18-19, 23-24: photographs by Toğrul Çakar; 20-21: photographs by Irfan Yazici

\section{KIRILOV}

1: after Knoblauch/Witschel 1993; 2: after Provost 2001; 3: after Karagiorgou 2001; 4: after Dontas 2000; 5: after Dintchev 1997b; 6: after Knoblauch/Witschel 1993; 7: after Frantz 1988; 8: after Bavant/Ivaniševič 2003; 9: after Berger 1998; 10: after Dintchev 1997b 


\section{KIND (SPOREN)}

siehe Listen im Anhang des Artikels

\section{Kozlov}

1-10. Autor

KURNATOVSKa/MAMZER

1, 3, 7-9: Archiv des Instituts für Archäologie und Ethnologie der Polnischen Akademie der Wissenschaften; 8-9: Fotos von J. Heller; 2, 4-6: nach Styrmen nad Jantra in: W. Hensel (Ed.) 1980; 10: nach Mamzer 1988, Abb. 11

MiLINKOVIĆ

1-2: nach I. Mikulčić; 3, 9: nach Đ. Basler; 4-5: nach M. Živić; 6: nach B. Bavant/V. Ivanišević; 7, 10, 12, 14-16: Autor; 8: nach V. Ivanišević; 11: nach Đ. Stričević; 13: nach V. Skarić; 16: nach M. Kazanski/V. Ivanišević (verändert); 17: nach T. Janakievski/I. Mikulčić; 18: nach I. Mikulčić; 19: nach G. von Bülow; 20: nach B. Bavant/V. Ivanišević

Petrova

1A-B (right), 2-3, 4.1, 5-6: autor; 1A.1-4 (left): after Rašev 2004, fig. 7.2, 1, 3-4; 1B.1-4 (left): after Rašev 2004, fig. 17; 4.2: after Rašev 2004, fig. 10.1

PRINZING

1-2: after Beševliev 1963; 3: after Georgiev 1978

RAŠEV

1-3: author; 4.5: after Stančev/Ivanov 1958

\section{SCHLEIFER}

1: photograph courtesy of J. Henning; 2: unpublished aerial photograph, source J. Henning; 3-4, 6-8: author; 5: photograph courtesy of J. Henning

StANILOV/Dimitrov

1-11: Autor

VASILEV

1-5: Autor

VitLJANOv1

1-4: Autor

VitLJANOv2

1-4: Autor

WENDEL

1-5: Autor 


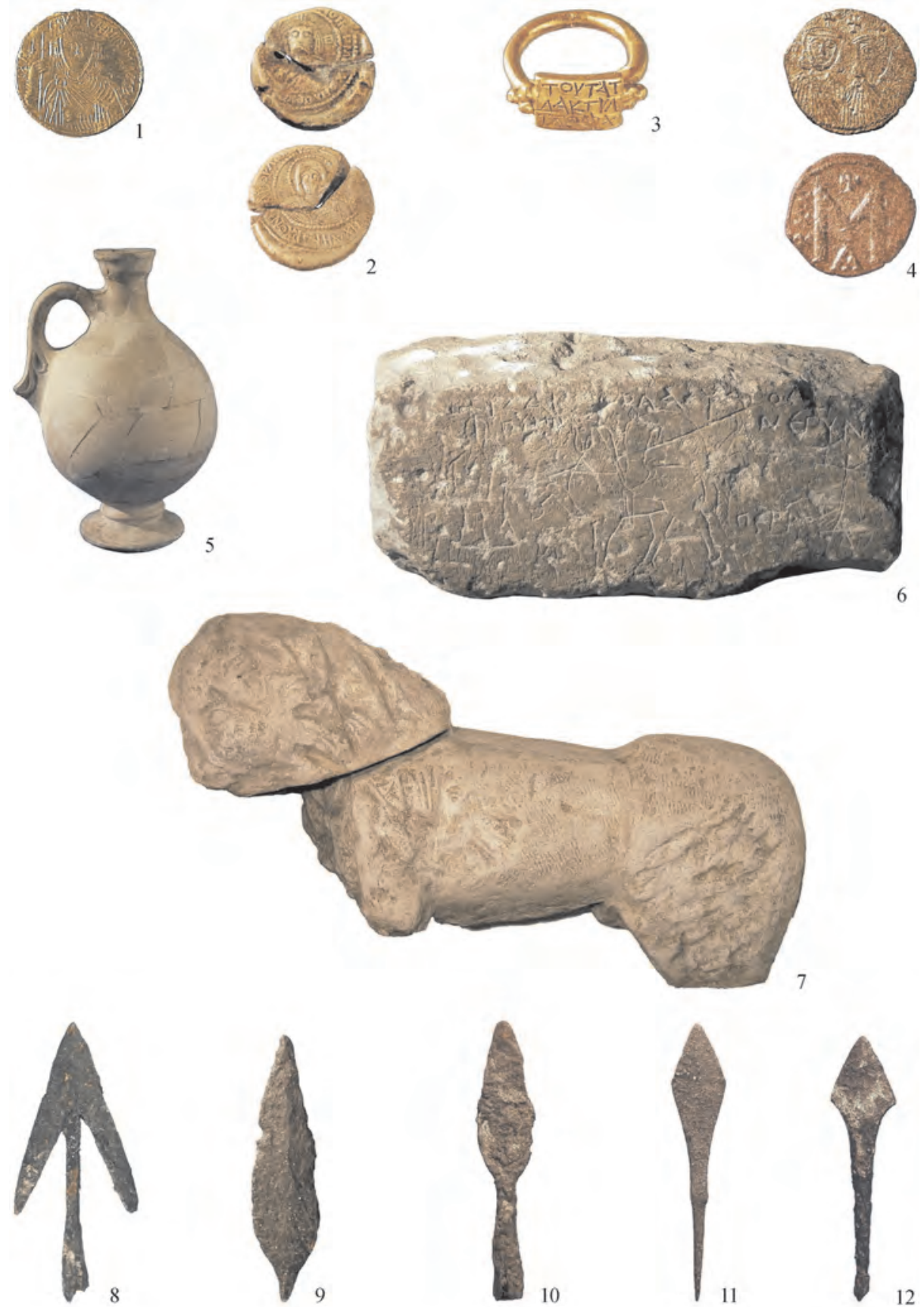

Archäologische Funde aus Pliska / Archaeological finds from Pliska 

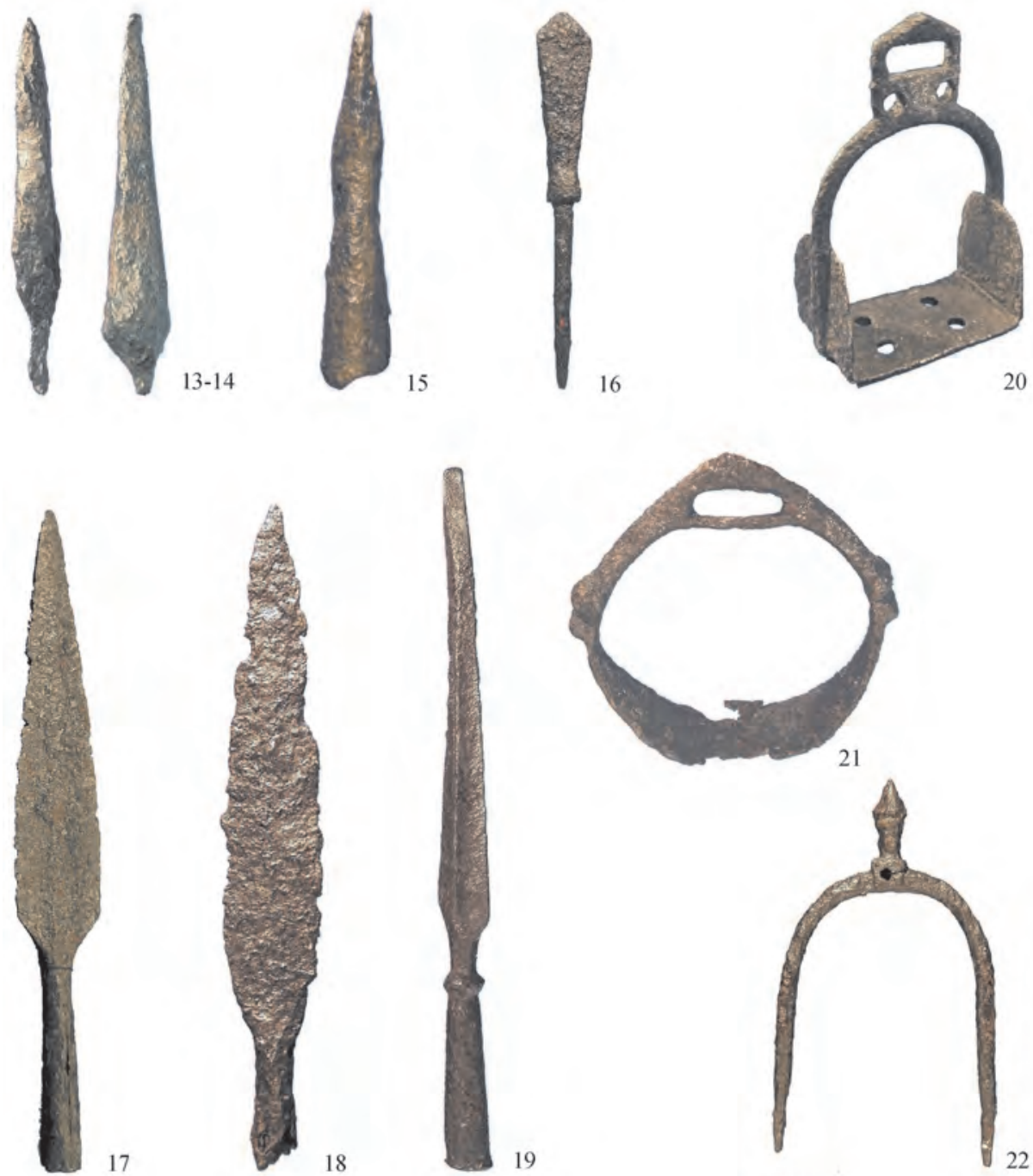

17

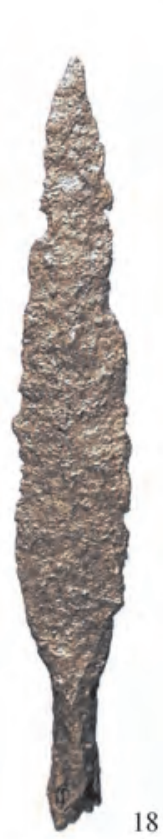

19
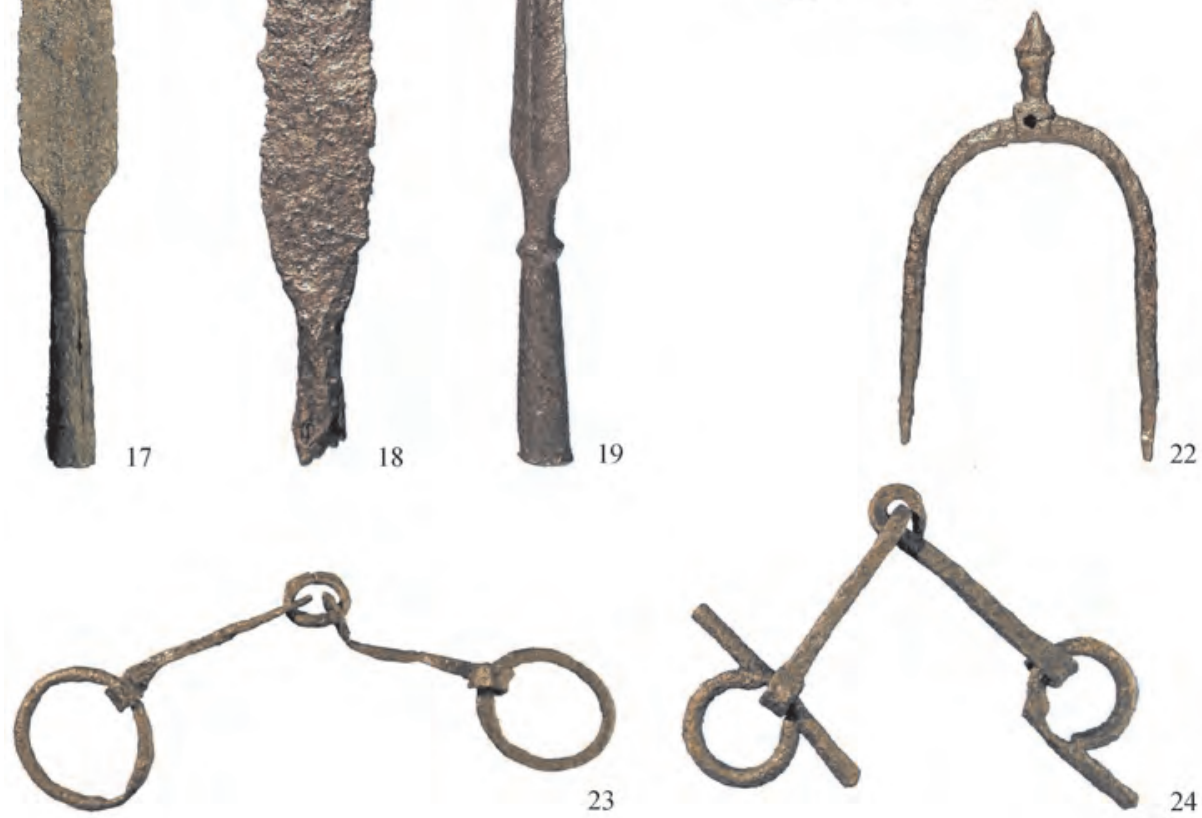

24

Archäologische Funde aus Pliska / Archaeological finds from Pliska 


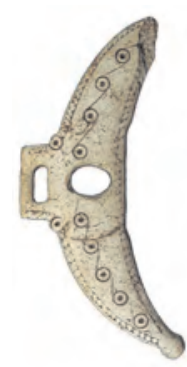

25

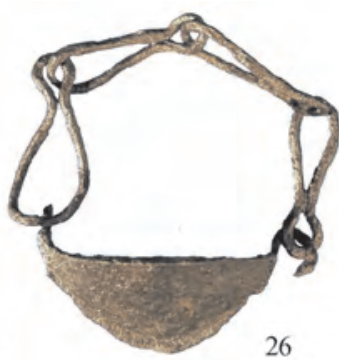

26

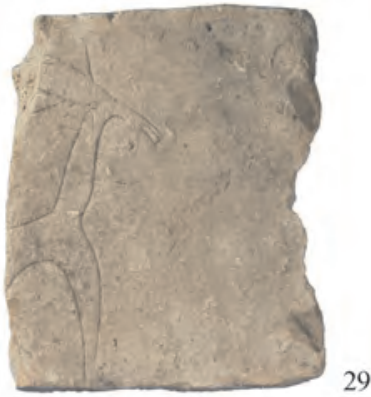

29
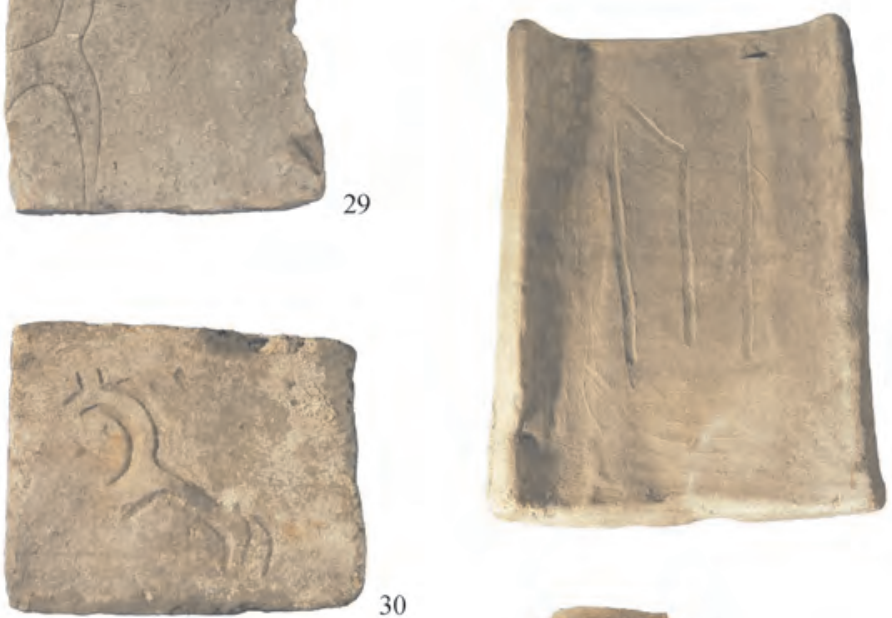

32
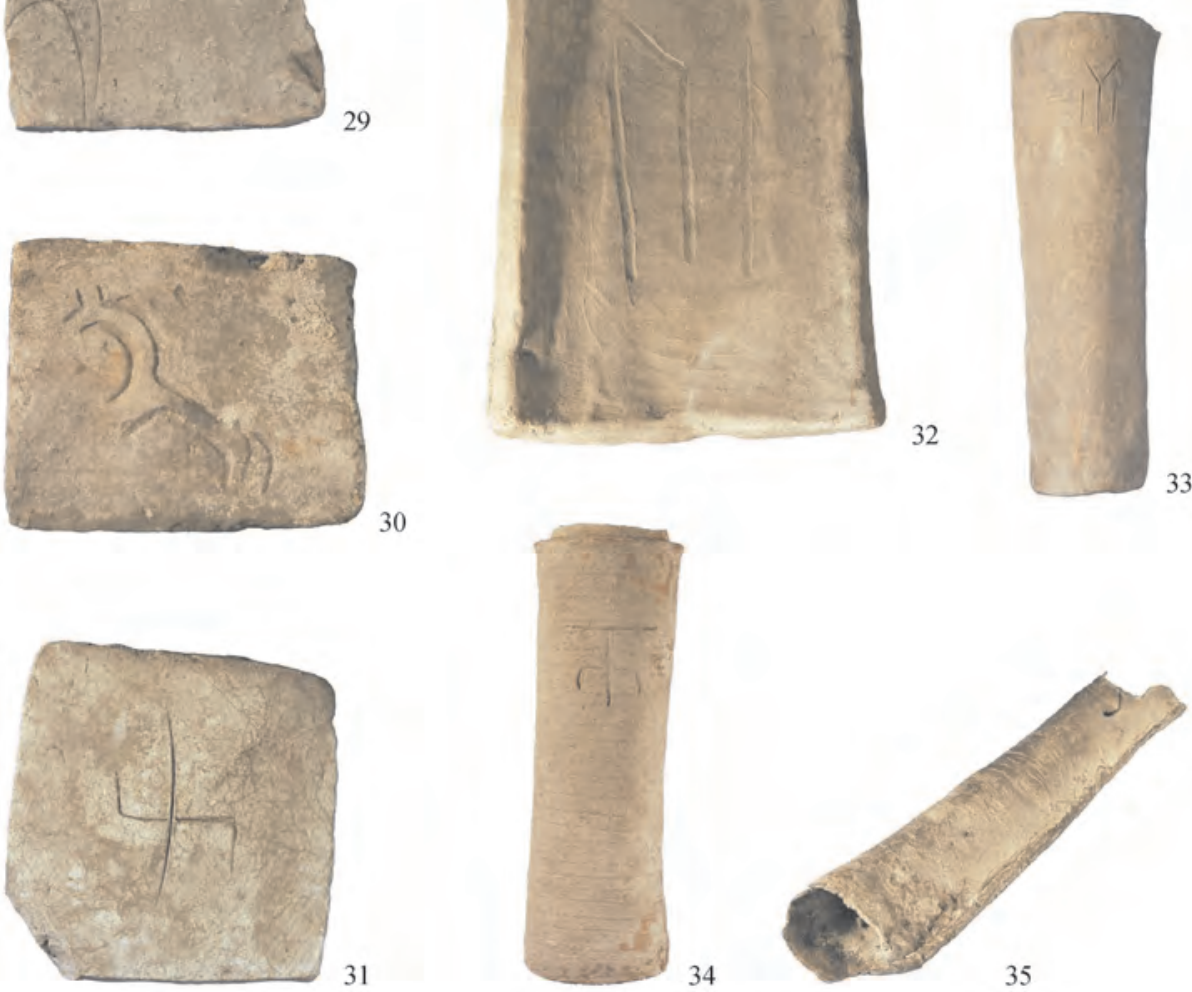

Archäologische Funde aus Pliska / Archaeological finds from Pliska 

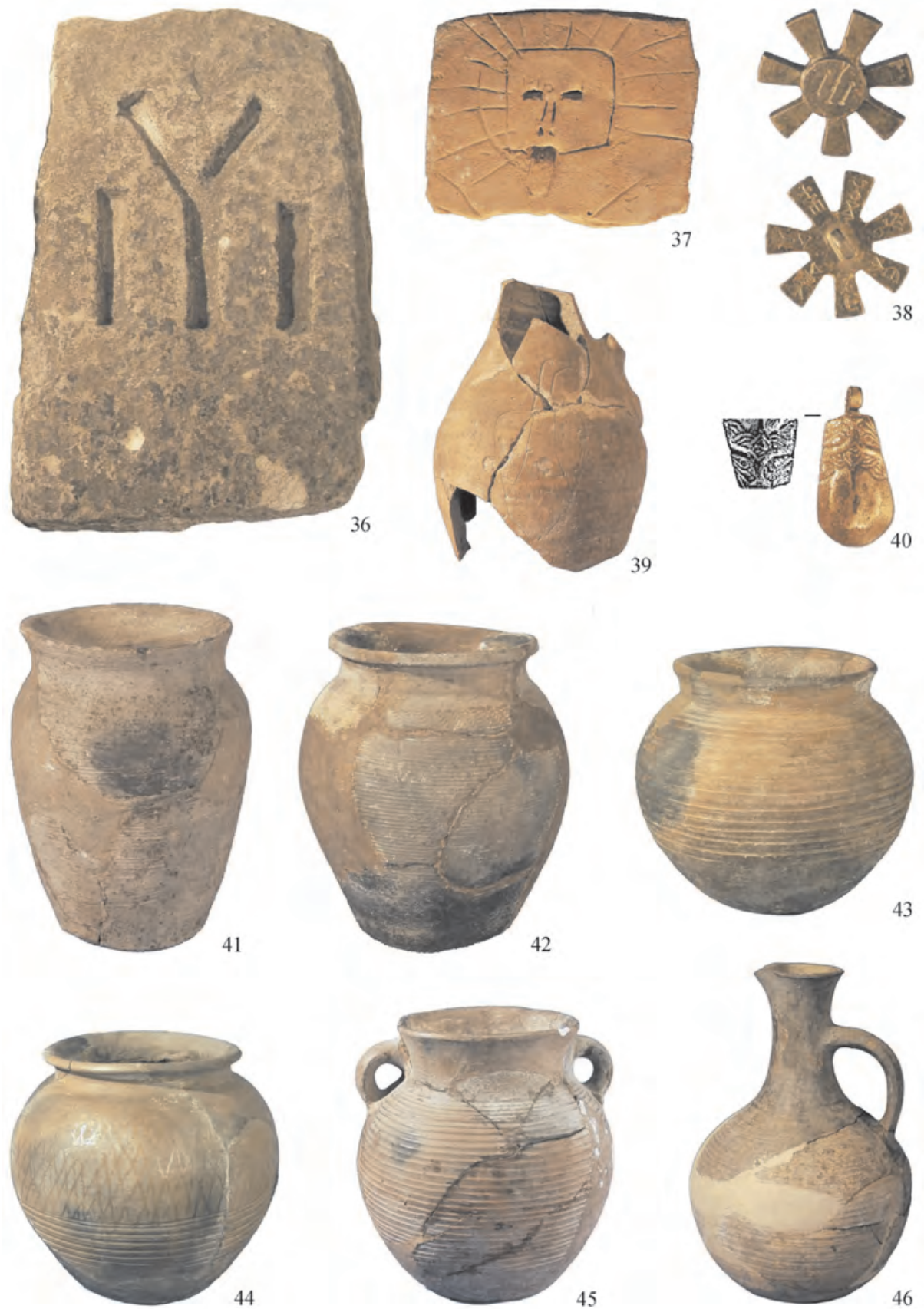

Archäologische Funde aus Pliska / Archaeological finds from Pliska 

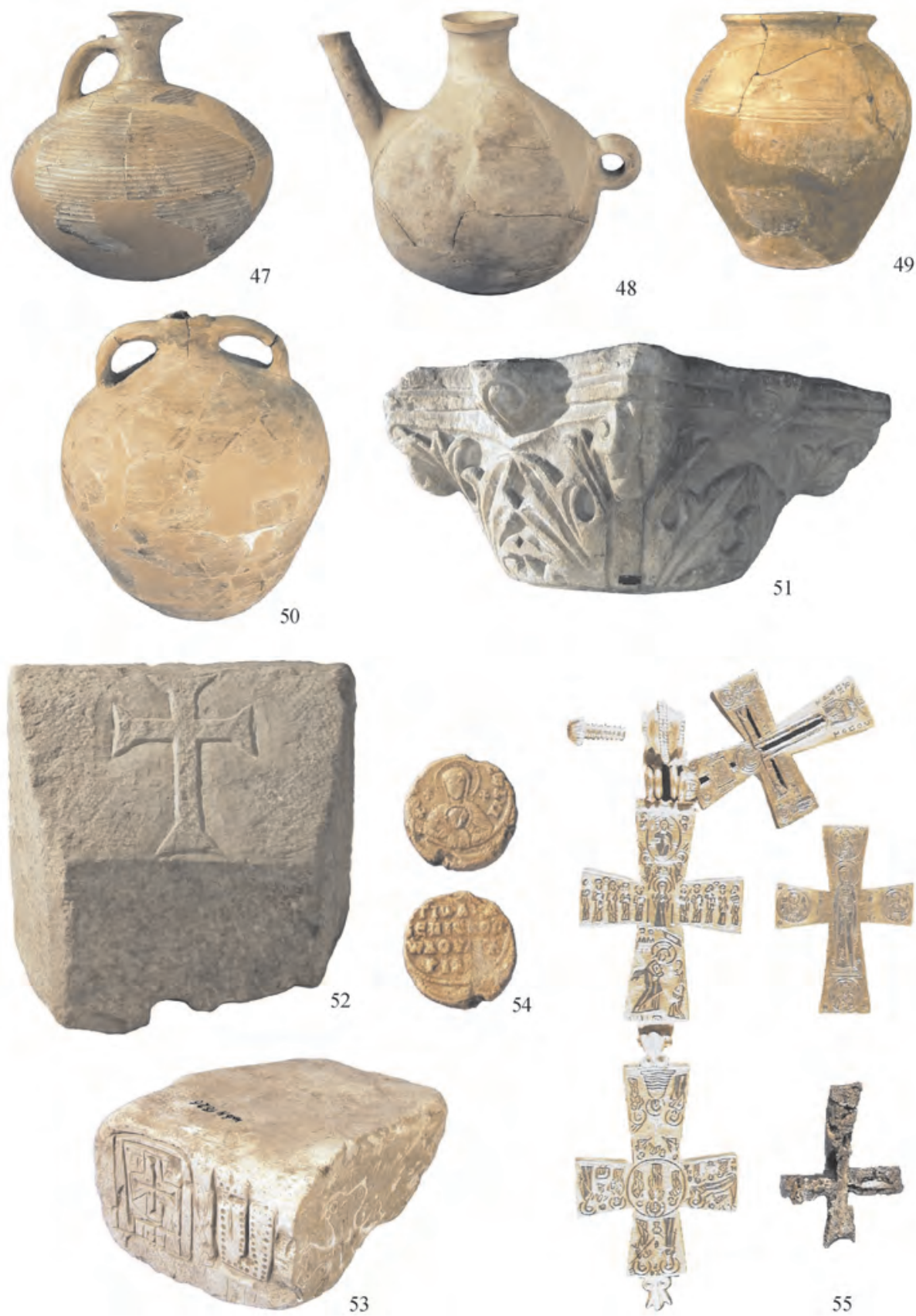

Archäologische Funde aus Pliska / Archaeological finds from Pliska 

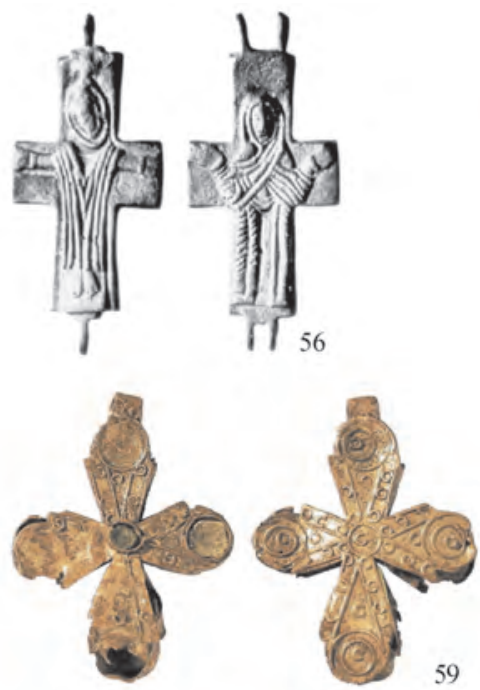

59
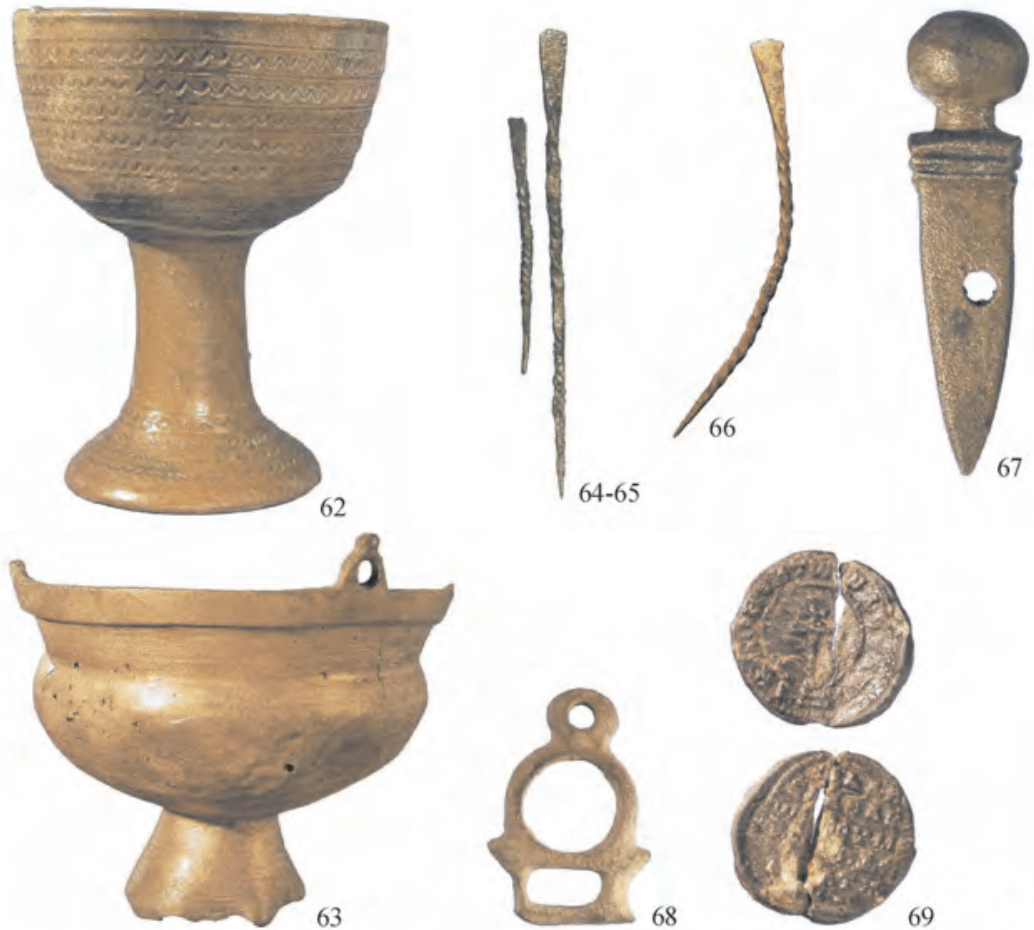

69

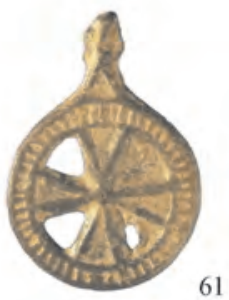

67

Archäologische Funde aus Pliska / Archaeological finds from Pliska 

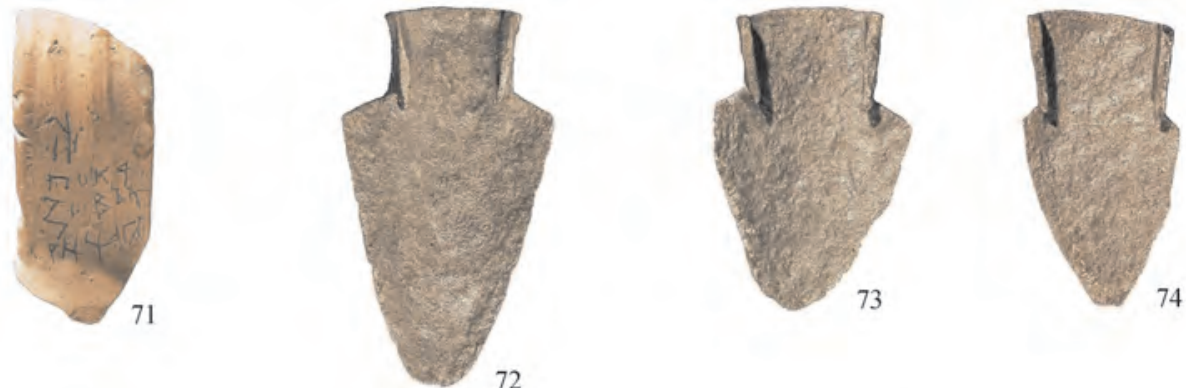

72
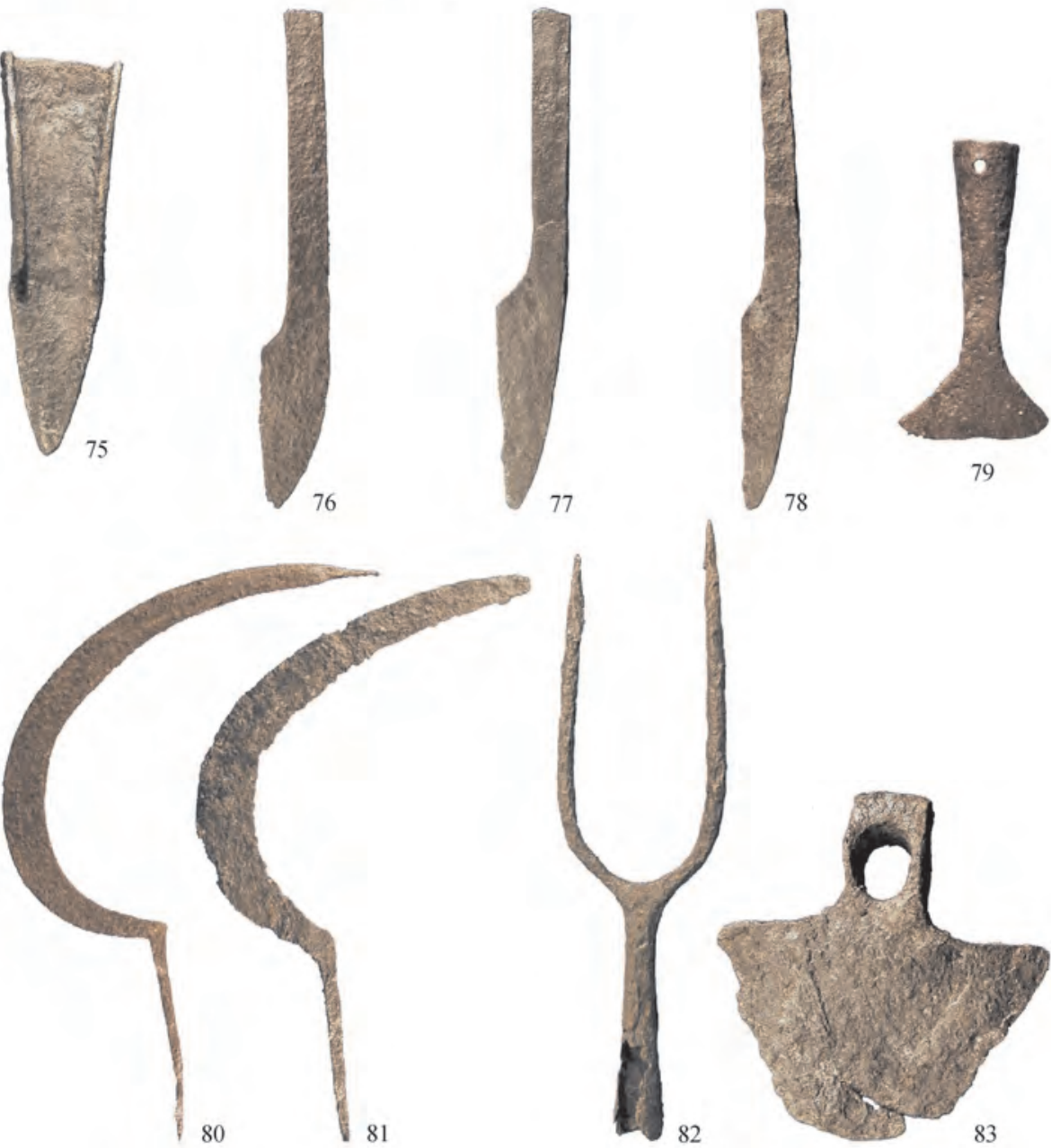

Archäologische Funde aus Pliska / Archaeological finds from Pliska 

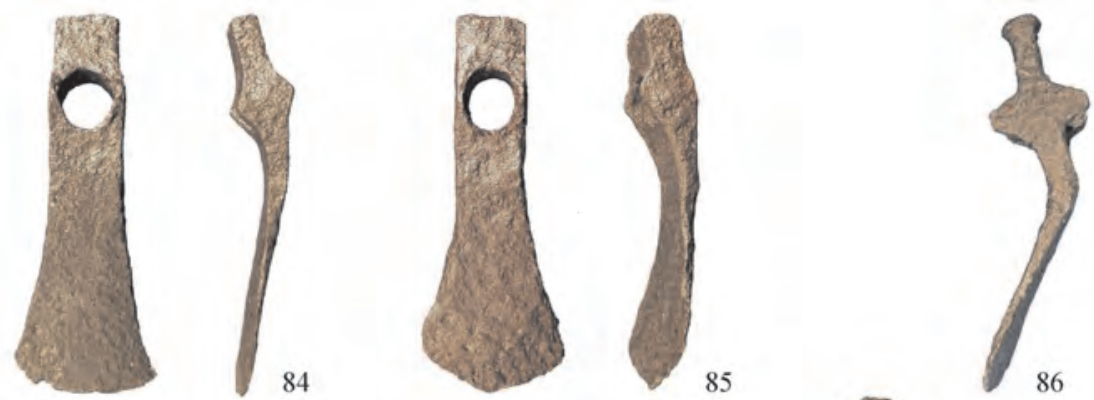

85

86
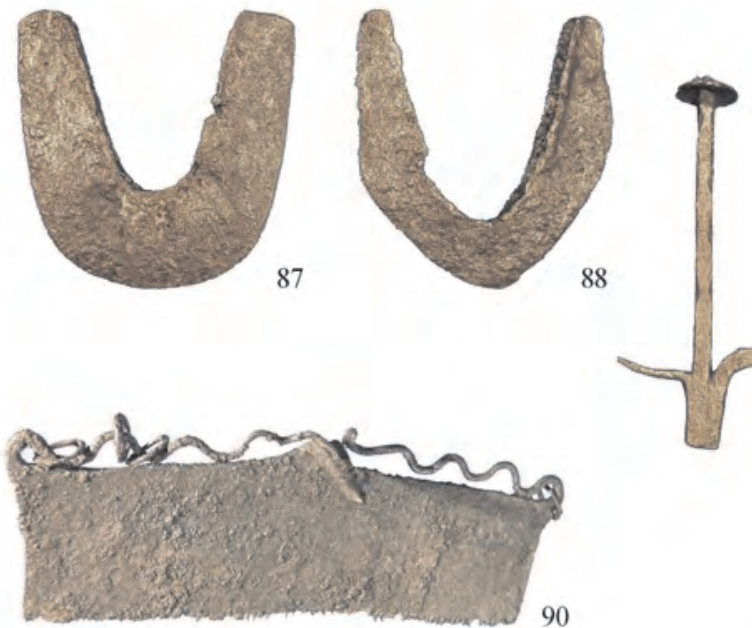

90
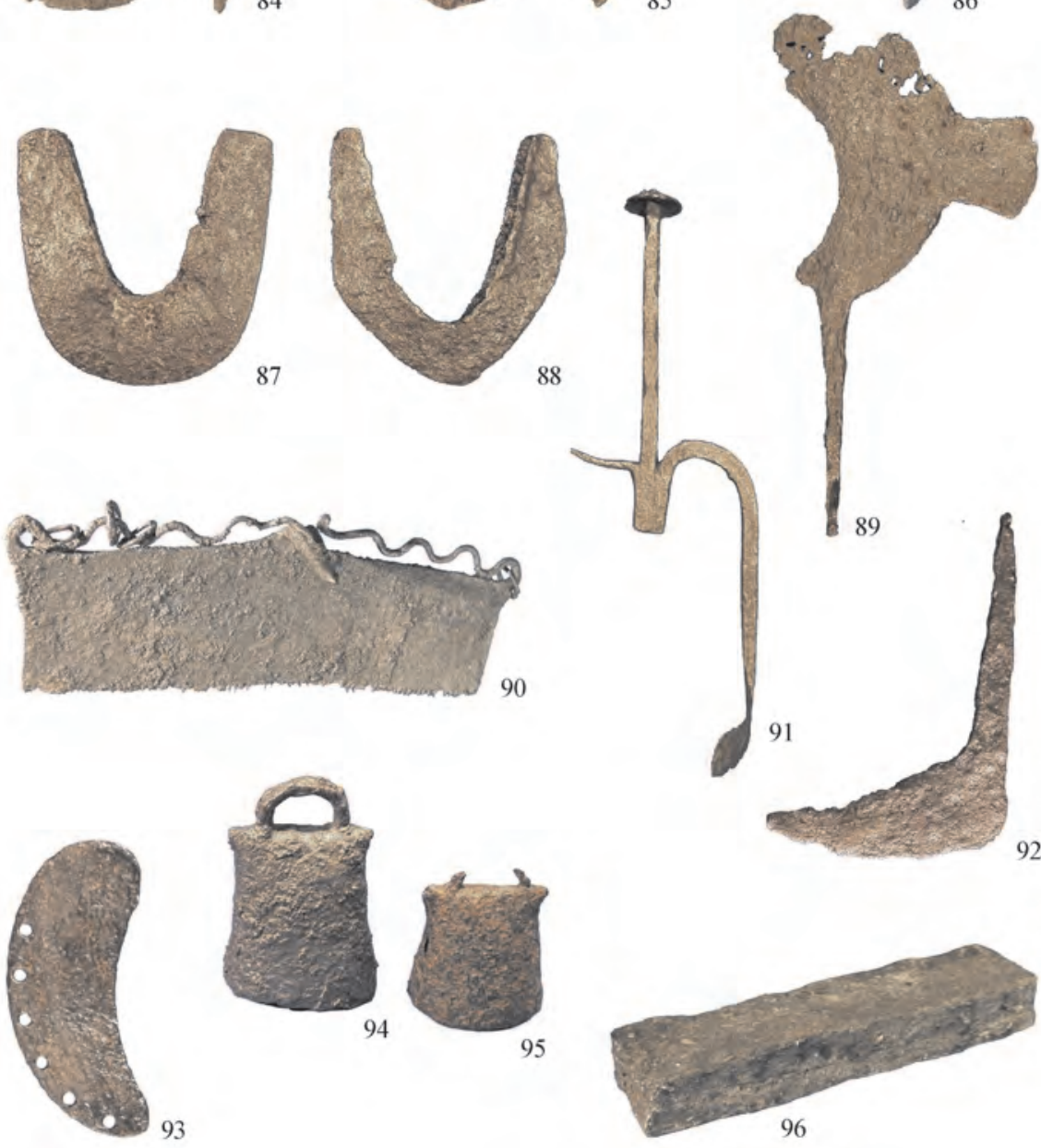

Archäologische Funde aus Pliska / Archaeological finds from Pliska 

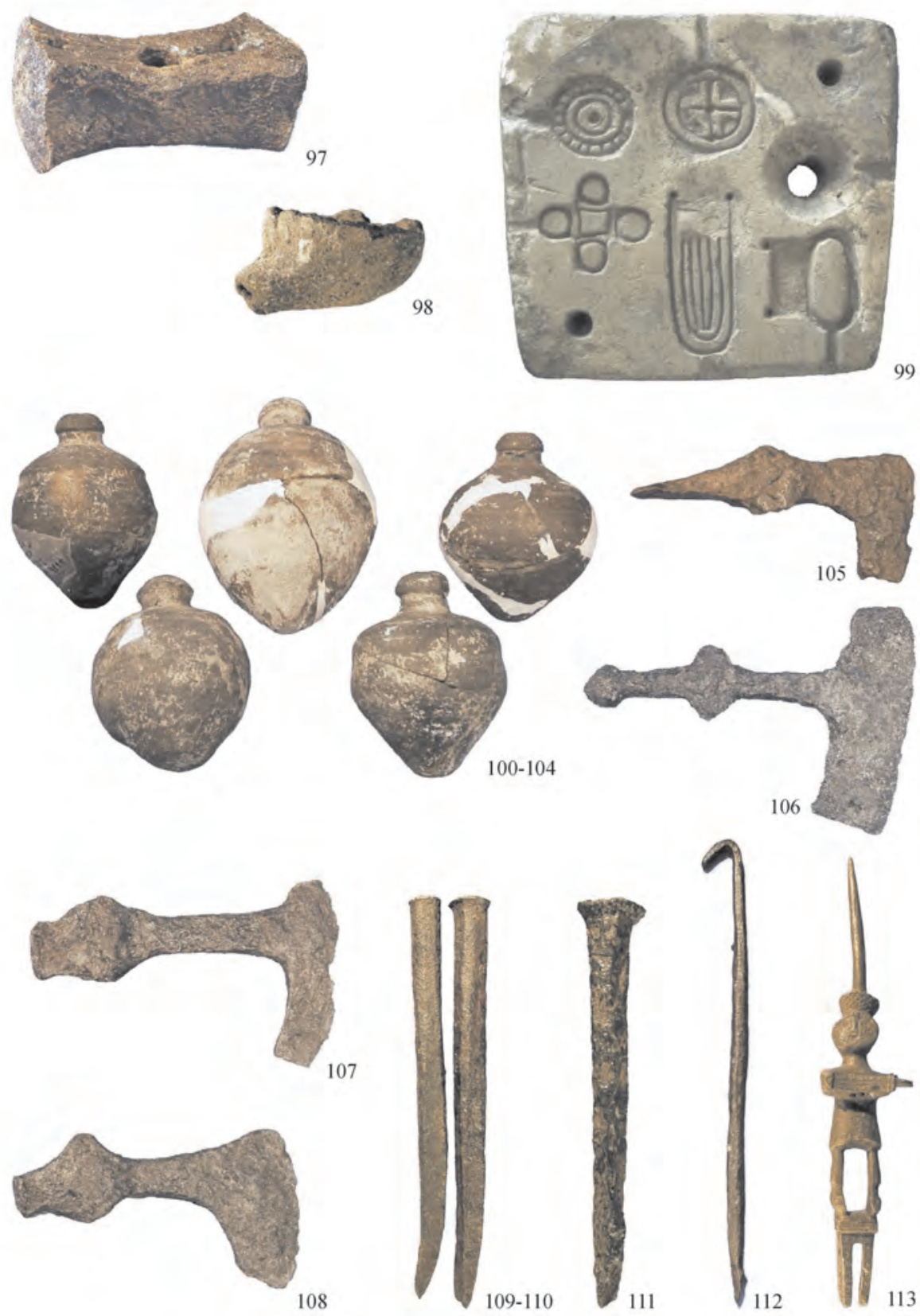

Archäologische Funde aus Pliska / Archaeological finds from Pliska 

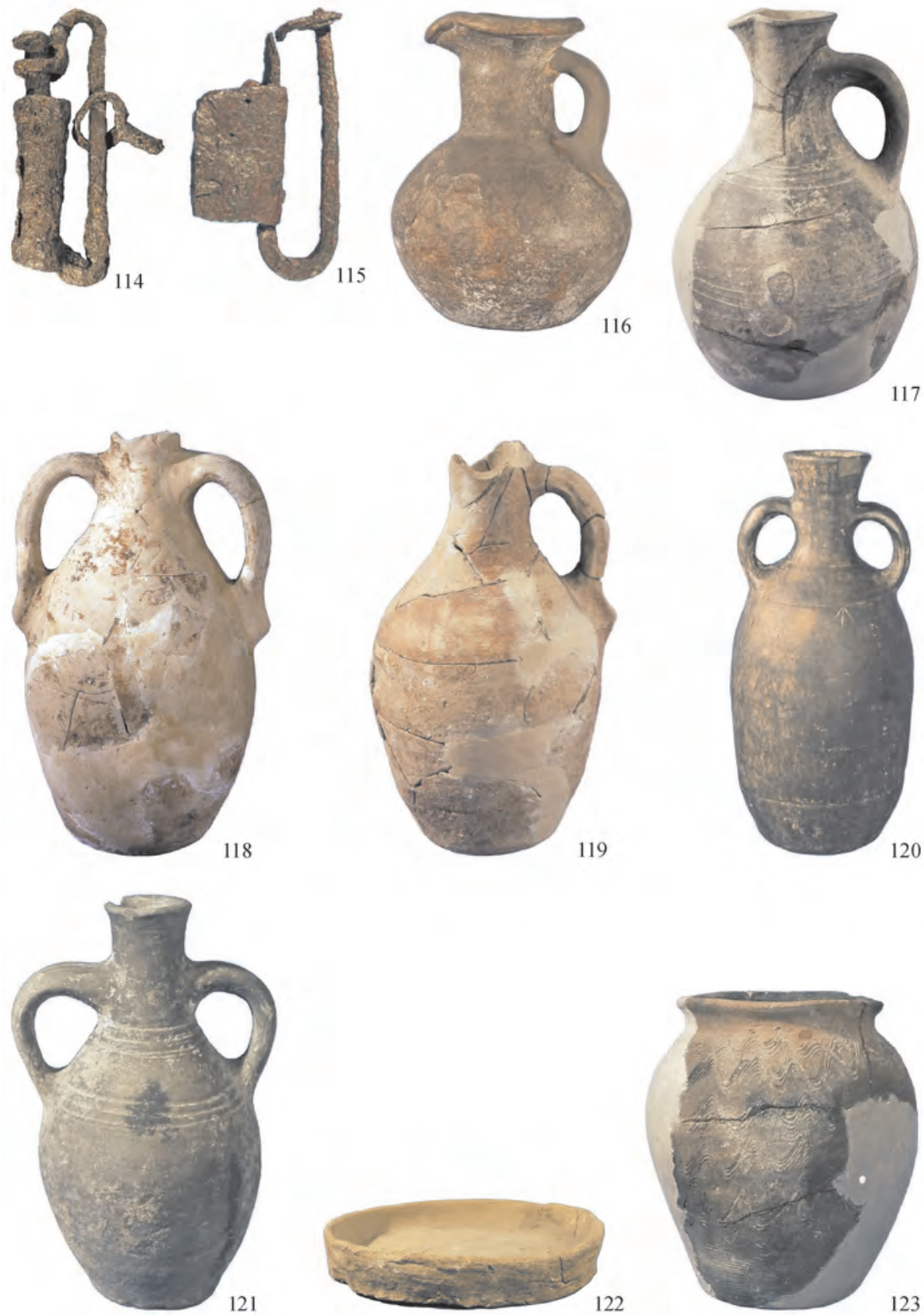

Archäologische Funde aus Pliska / Archaeological finds from Pliska 

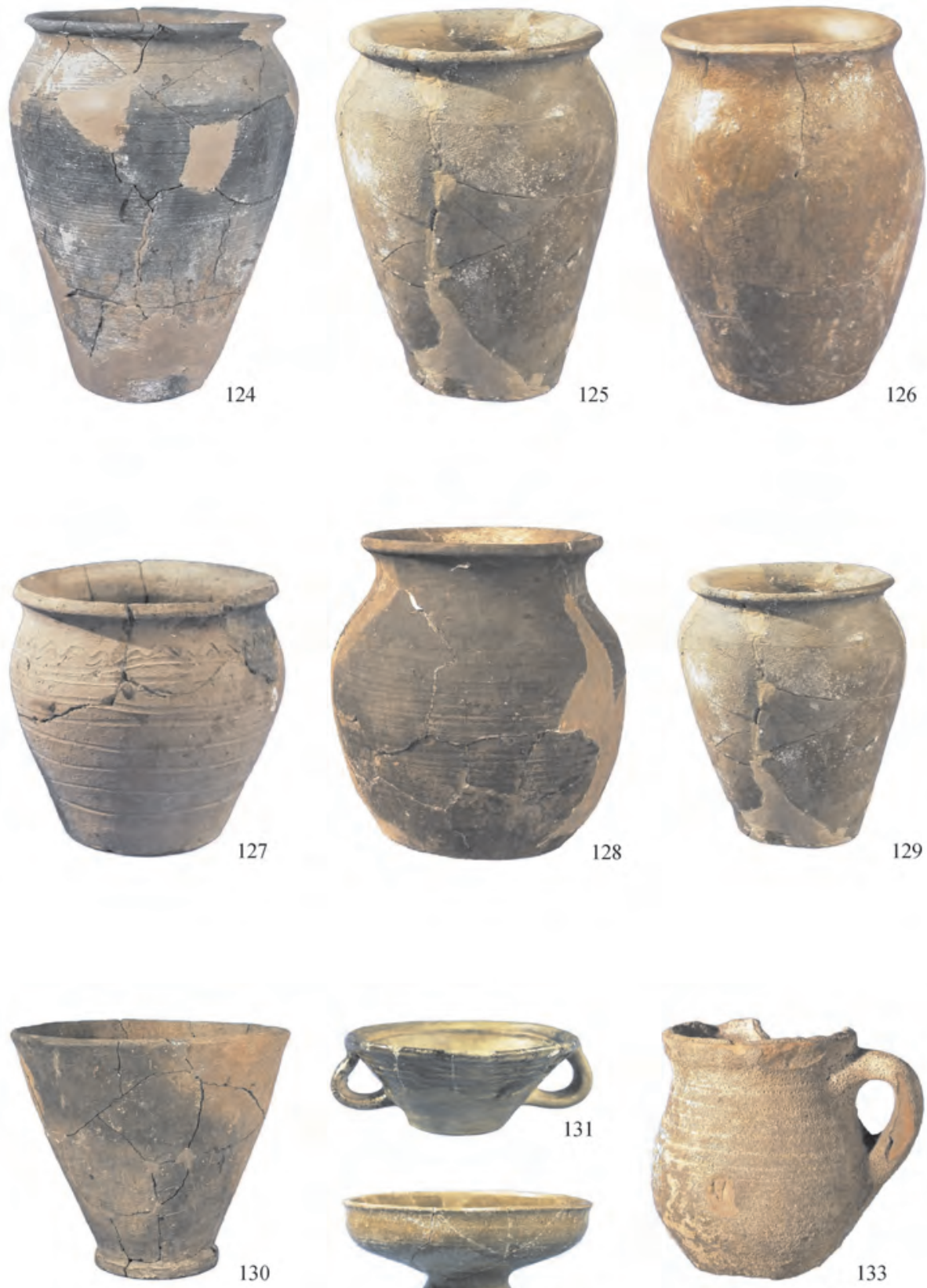

132

Archäologische Funde aus Pliska / Archaeological finds from Pliska 

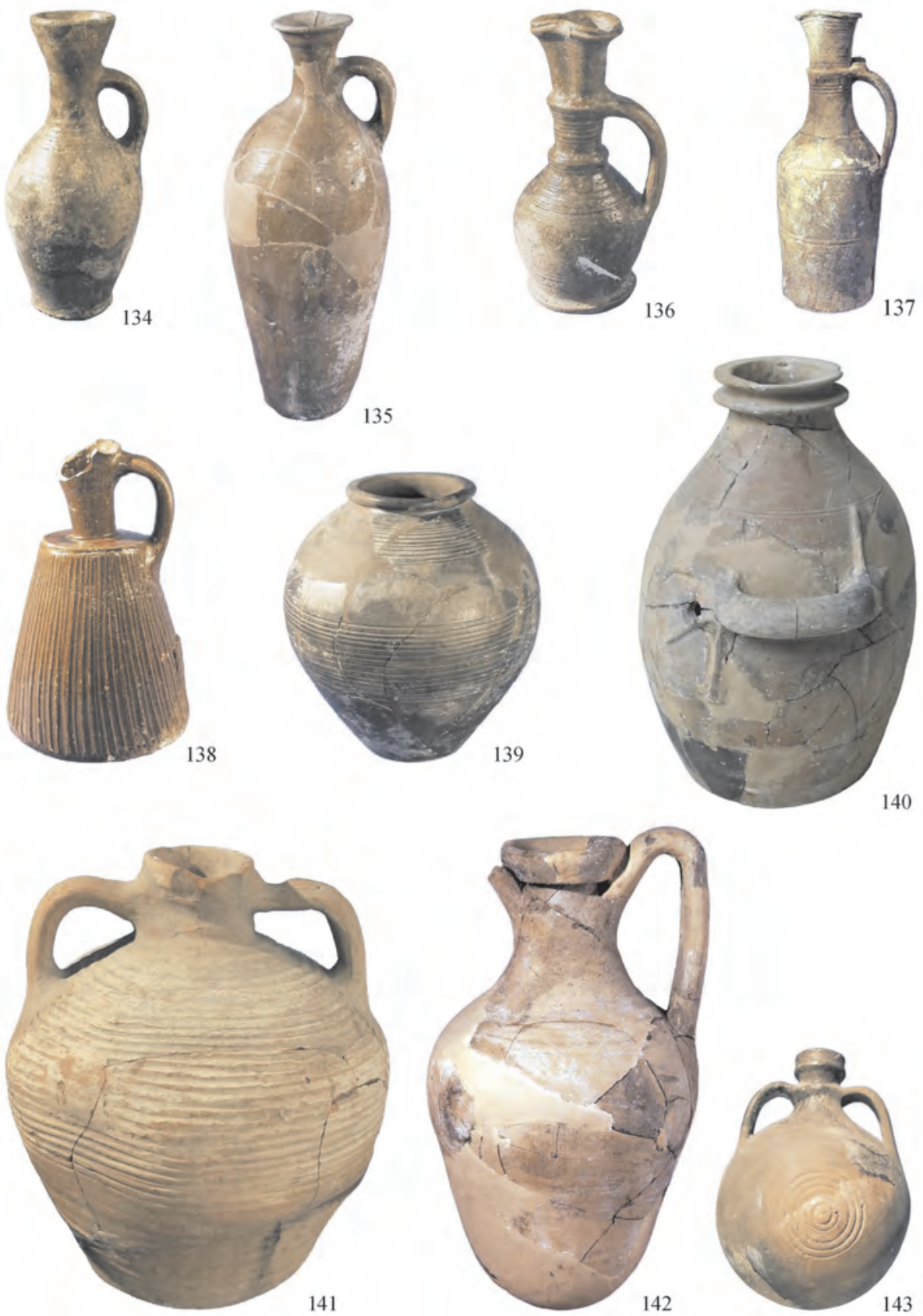

Archäologische Funde aus Pliska / Archaeological finds from Pliska 

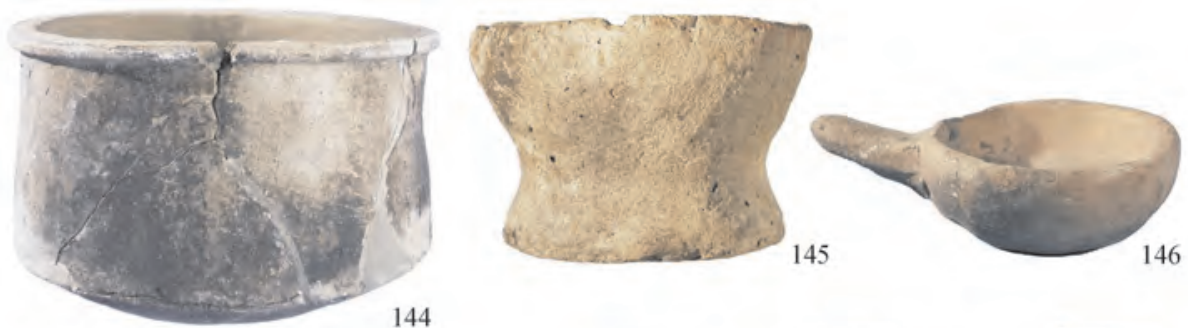

144
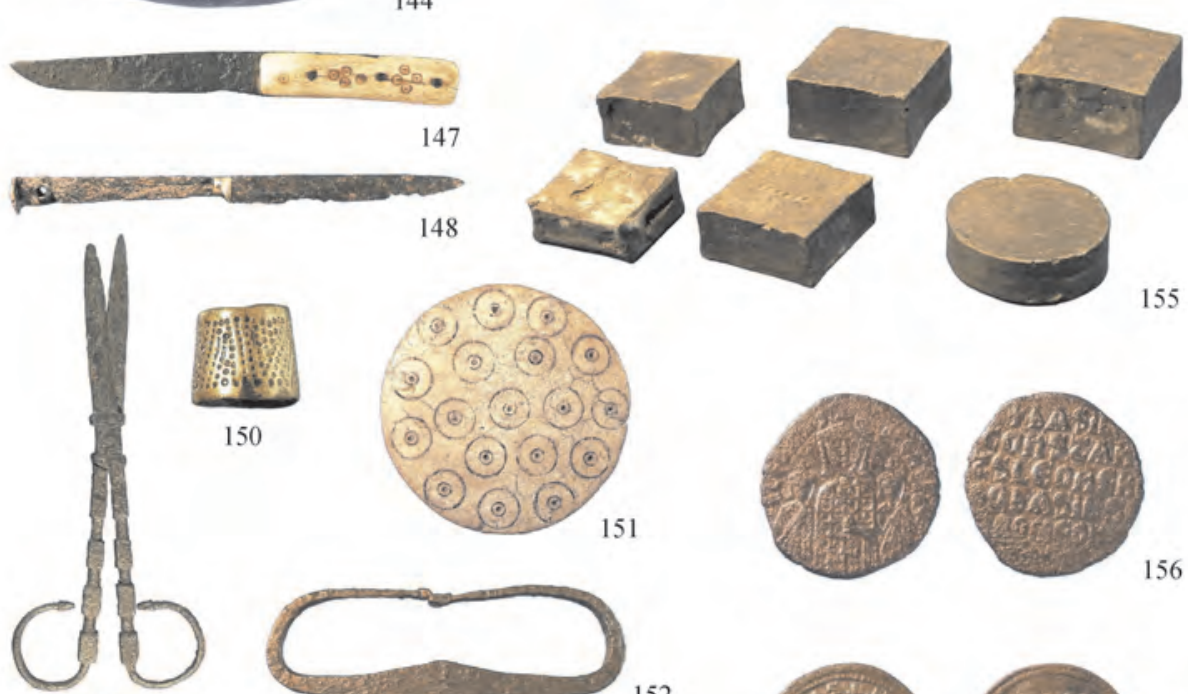

149
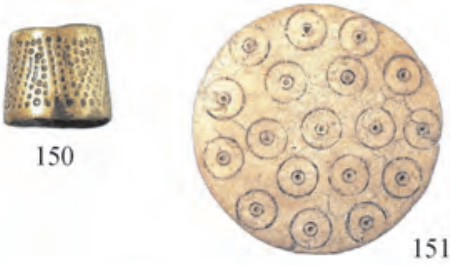

151
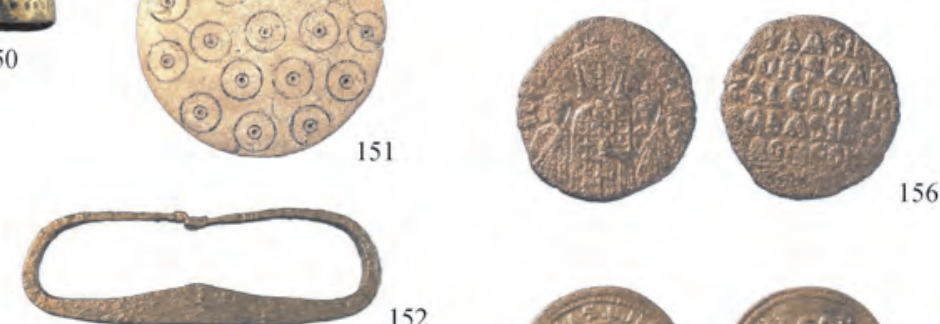

152
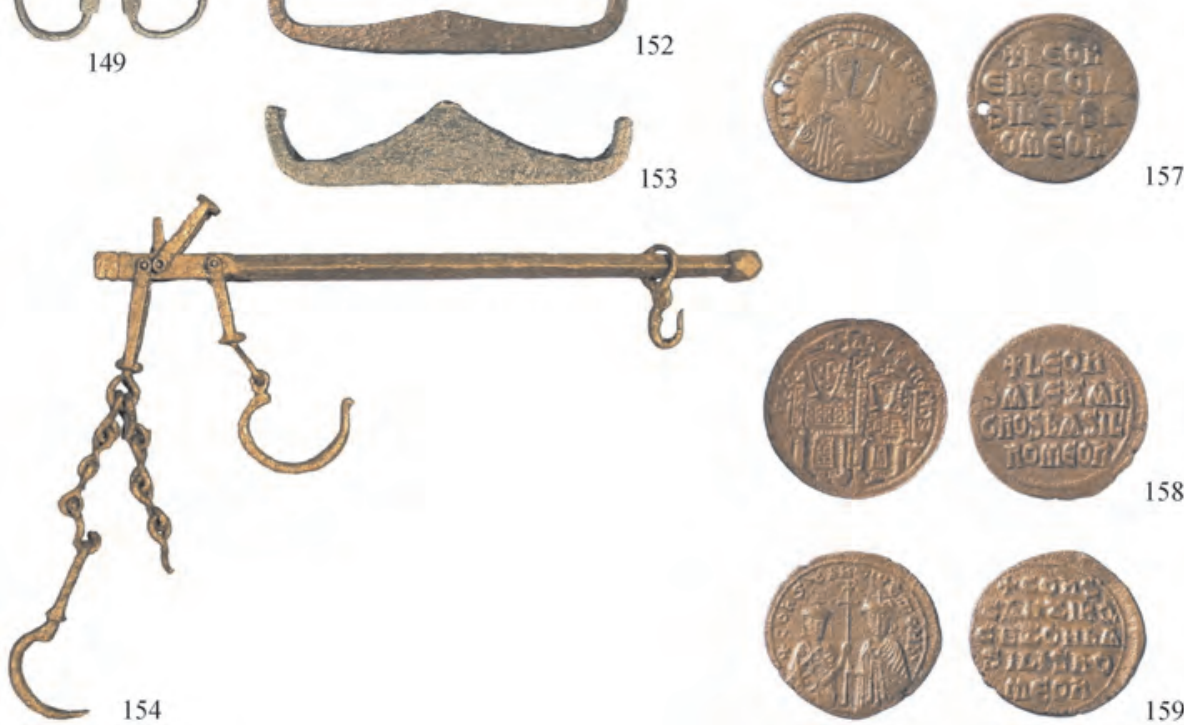

Archäologische Funde aus Pliska / Archaeological finds from Pliska 

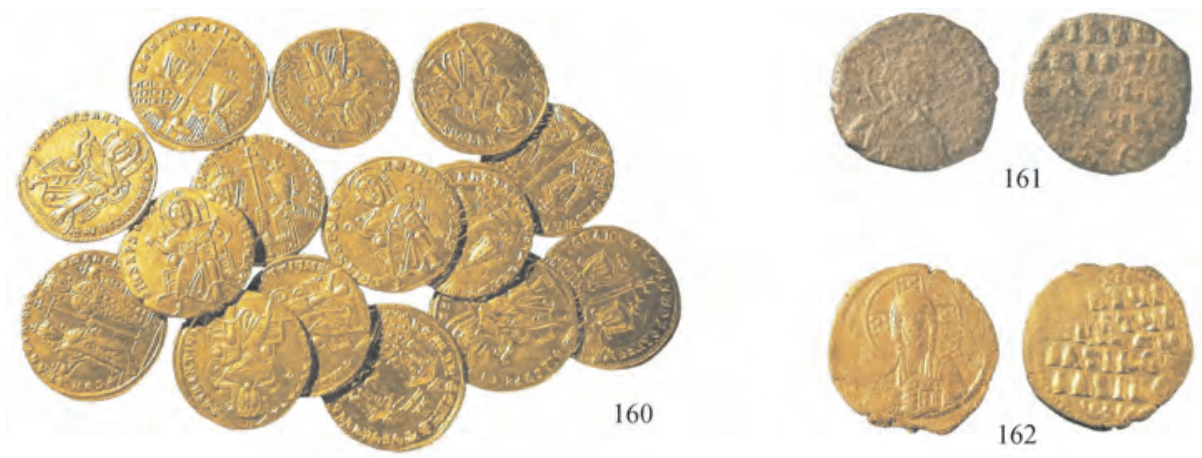

161
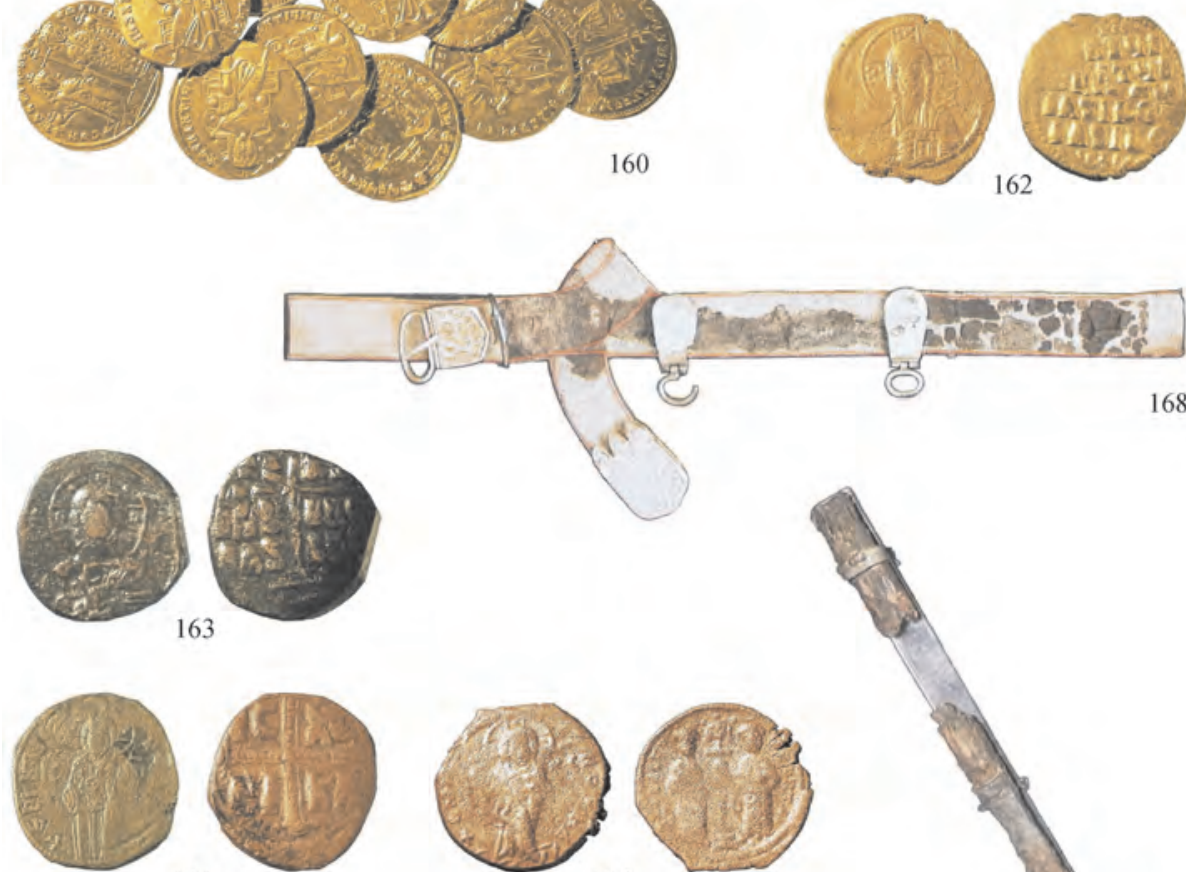

164
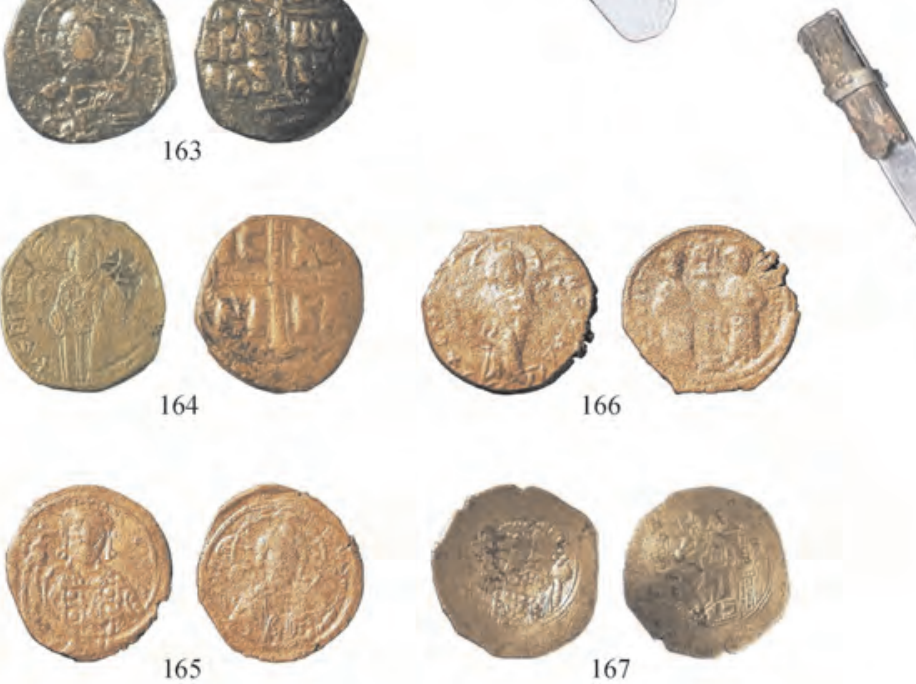

167
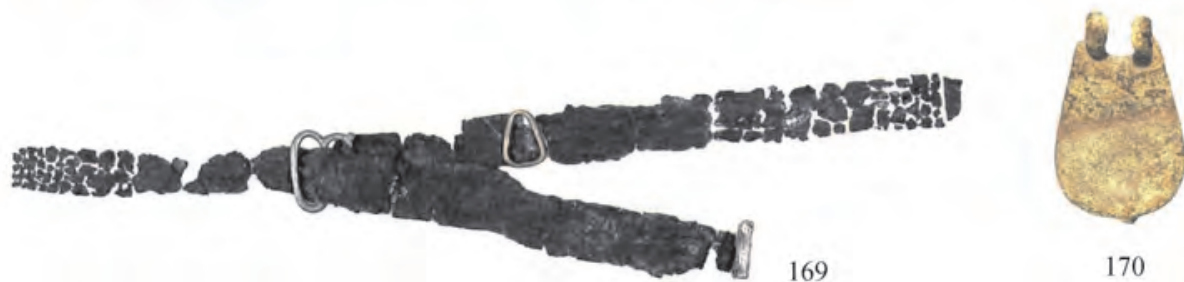

Archäologische Funde aus Pliska / Archaeological finds from Pliska 

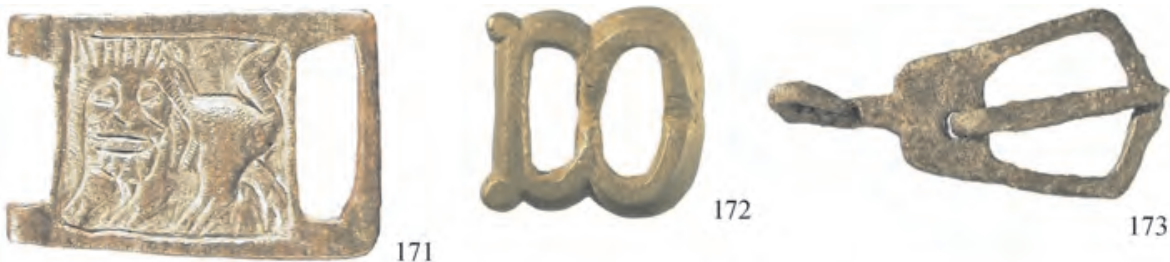

171
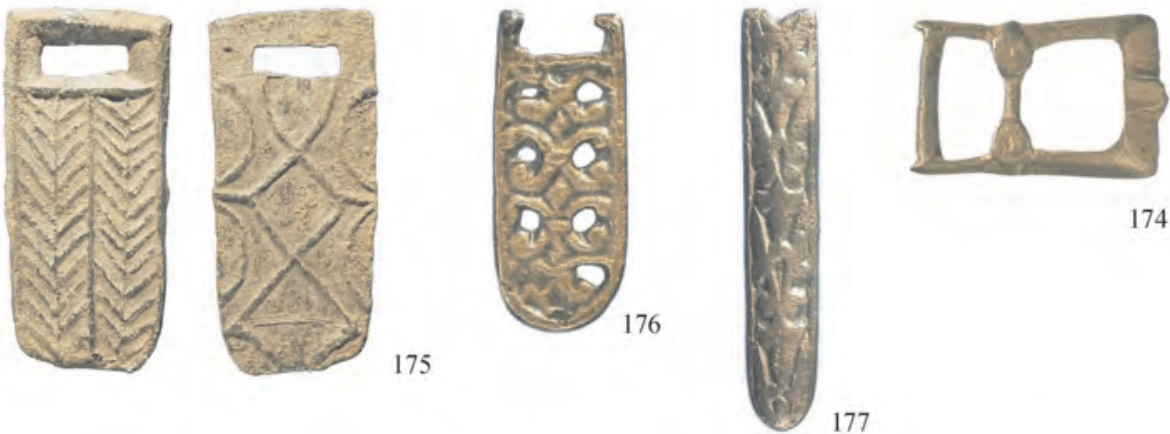

175
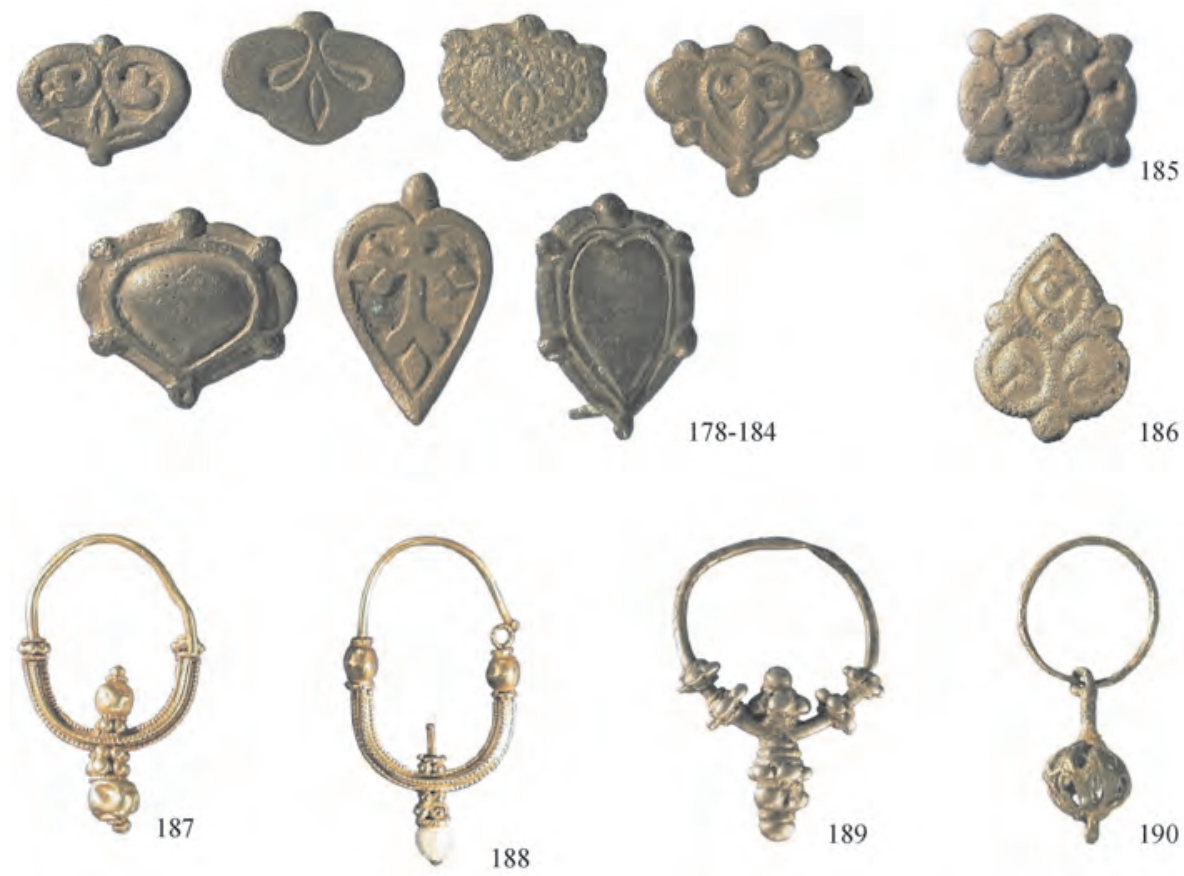

Archäologische Funde aus Pliska / Archaeological finds from Pliska 

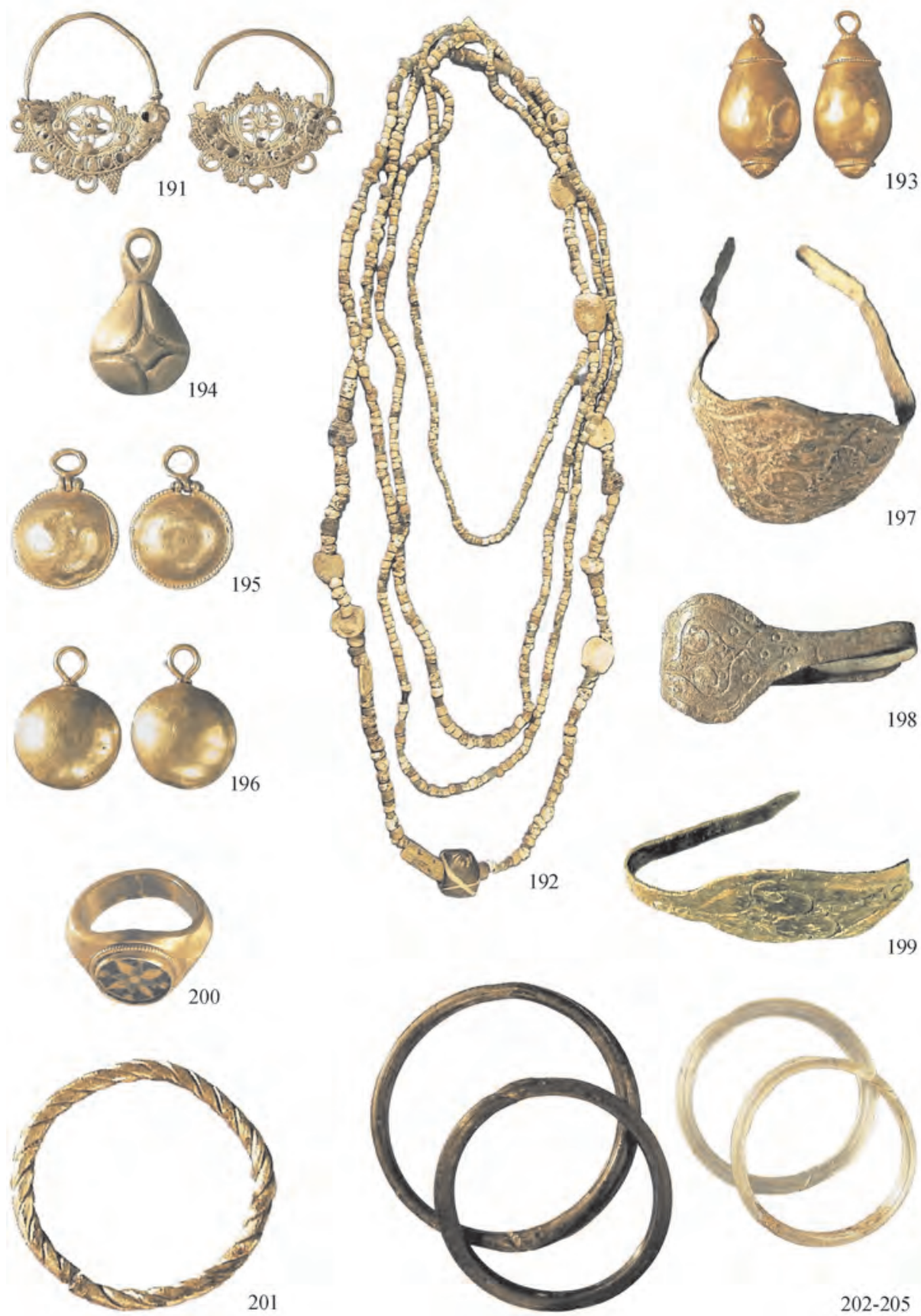

Archäologische Funde aus Pliska / Archaeological finds from Pliska 

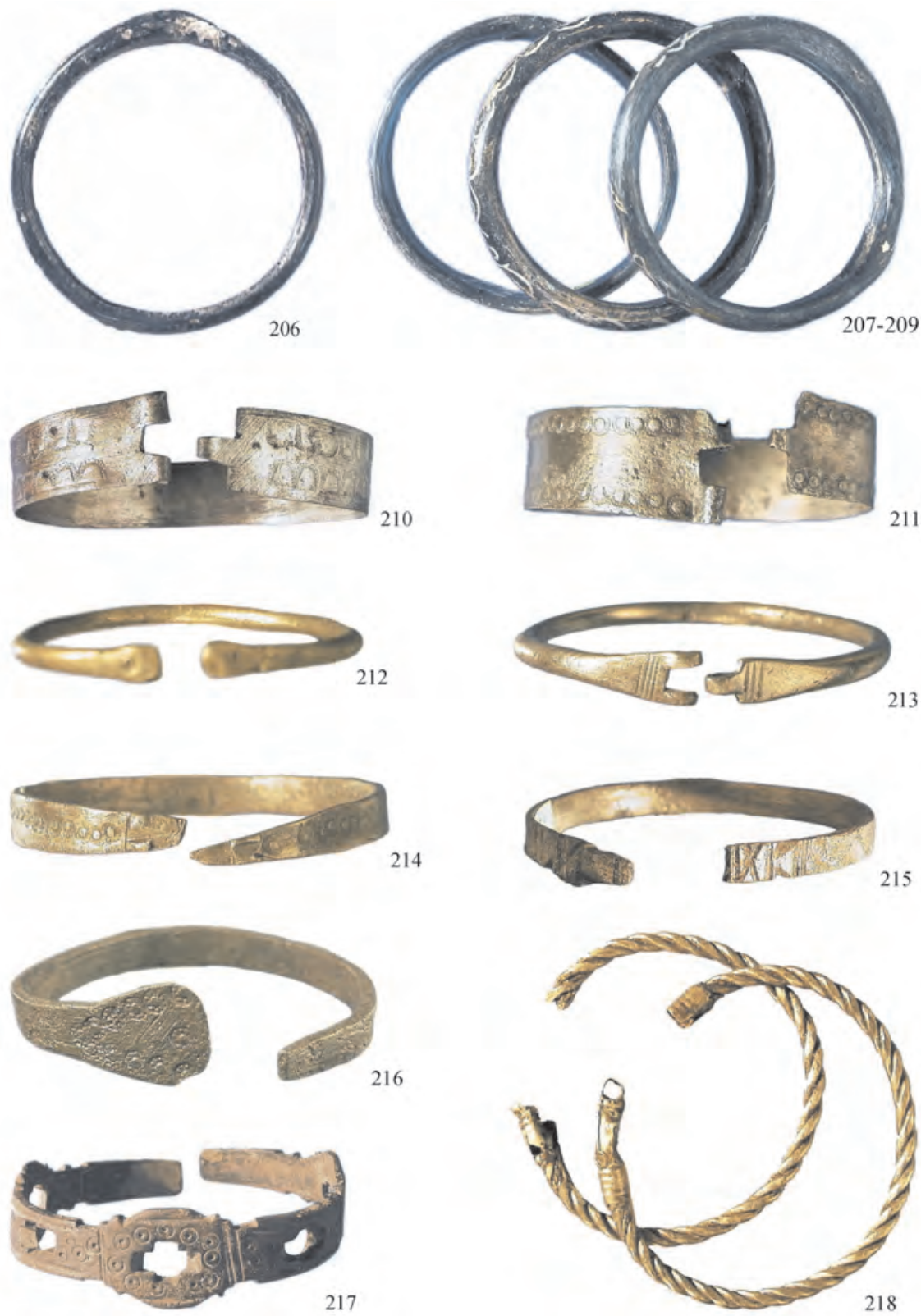

16

Archäologische Funde aus Pliska / Archaeological finds from Pliska 

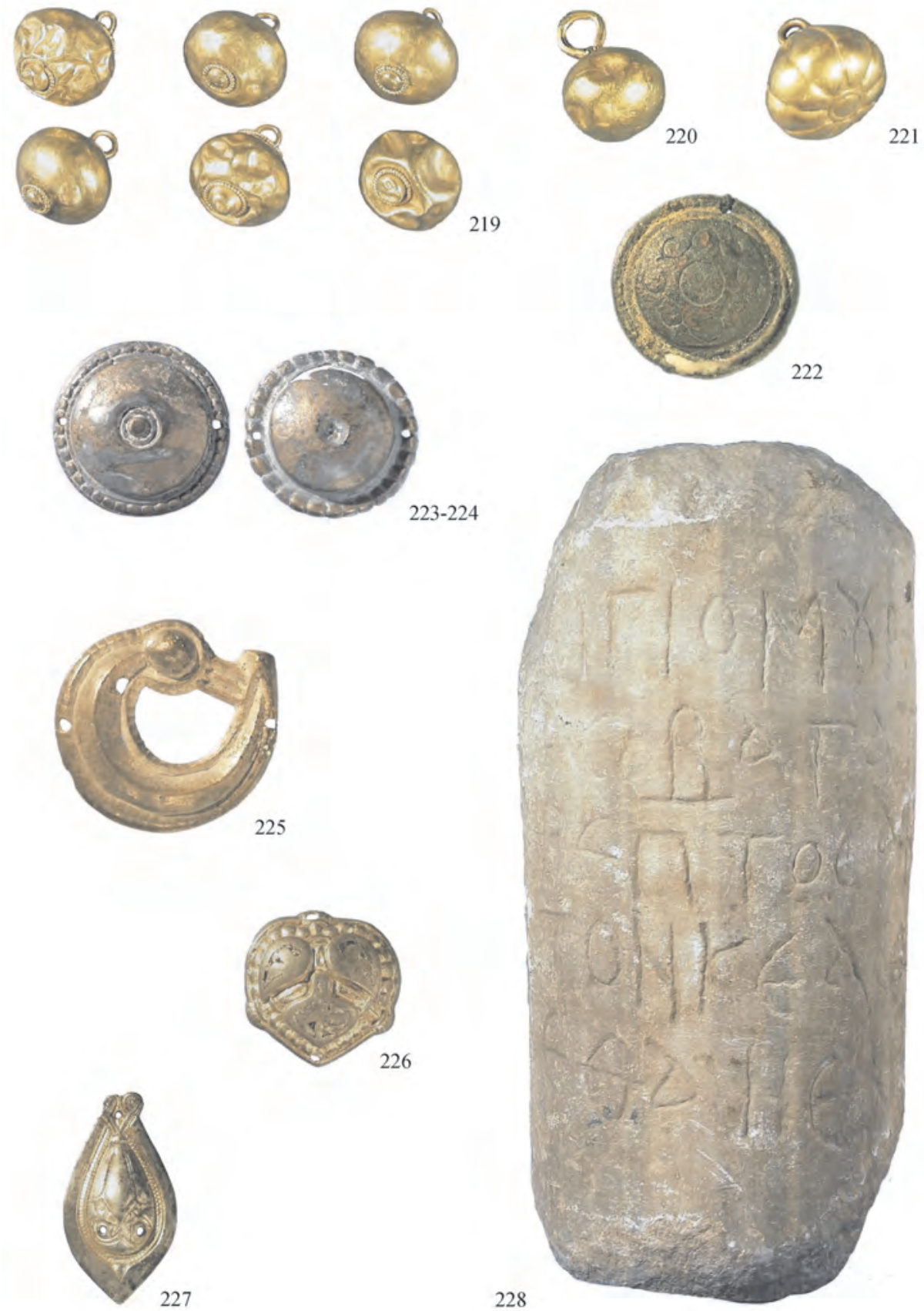

Archäologische Funde aus Pliska / Archaeological finds from Pliska 

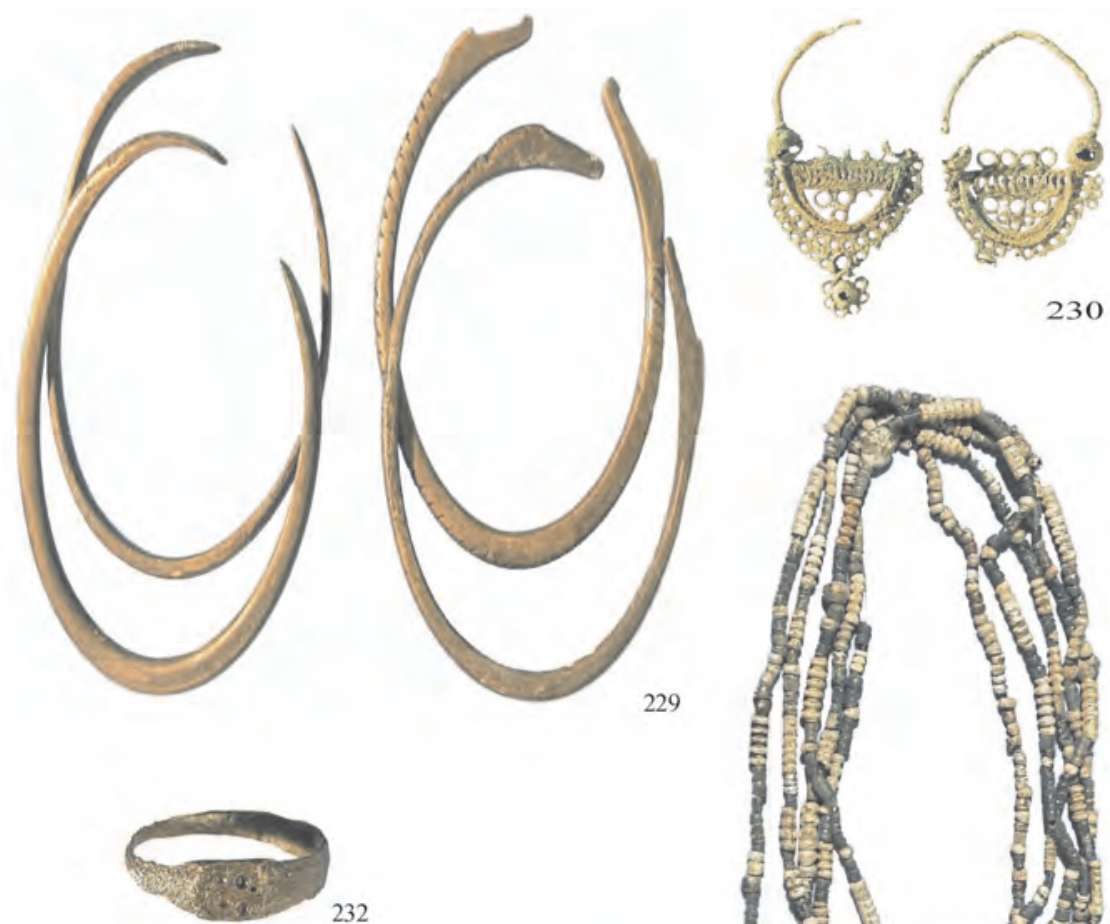

232
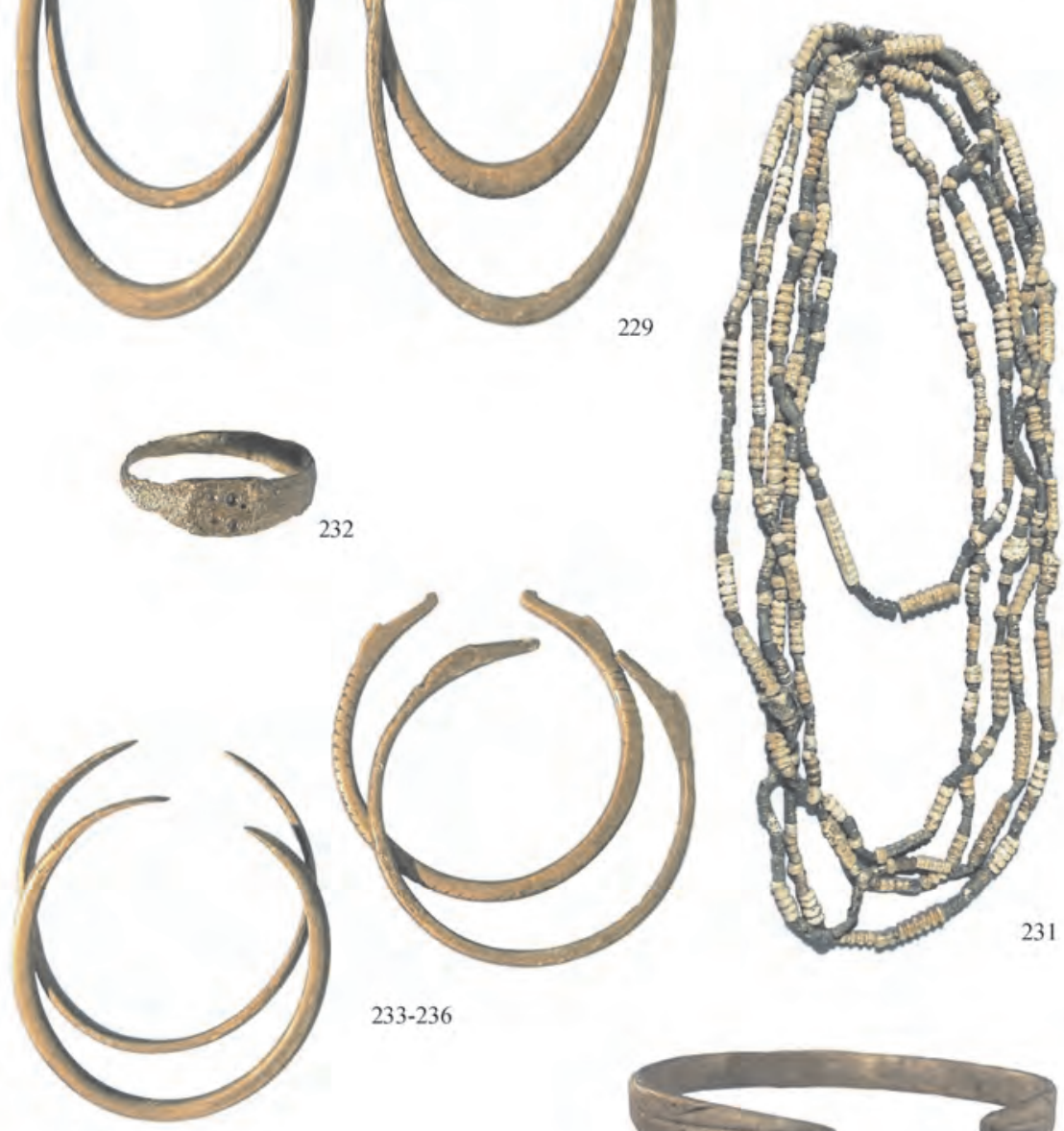

233-236

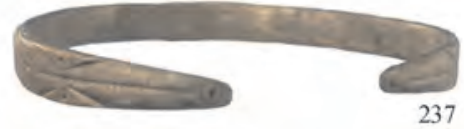



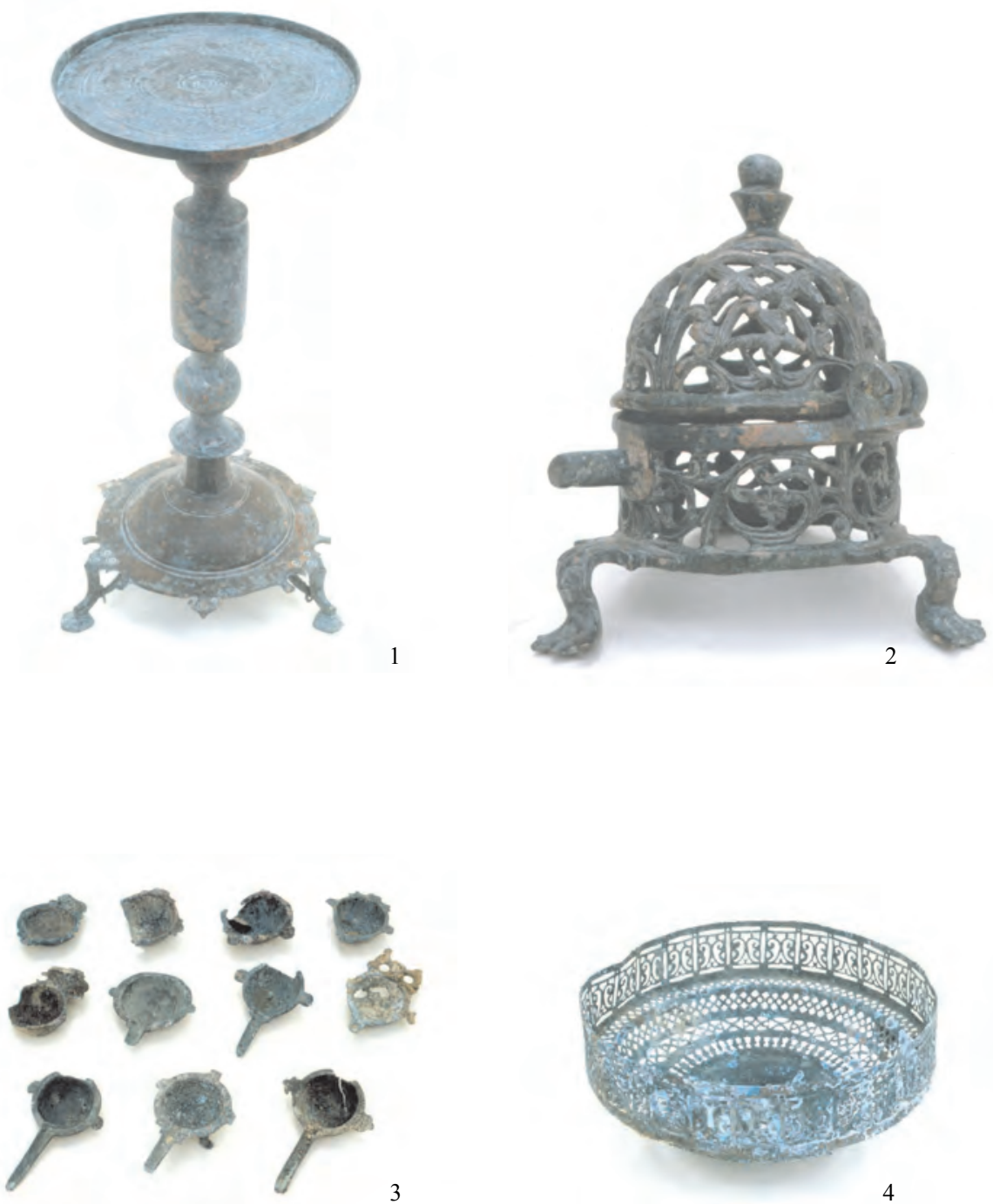

1: bronze lamp stand from the large hoard; 2: incense burner; 3:bronze bowl for filling oil lamps; 4: grille of mosque lamp 


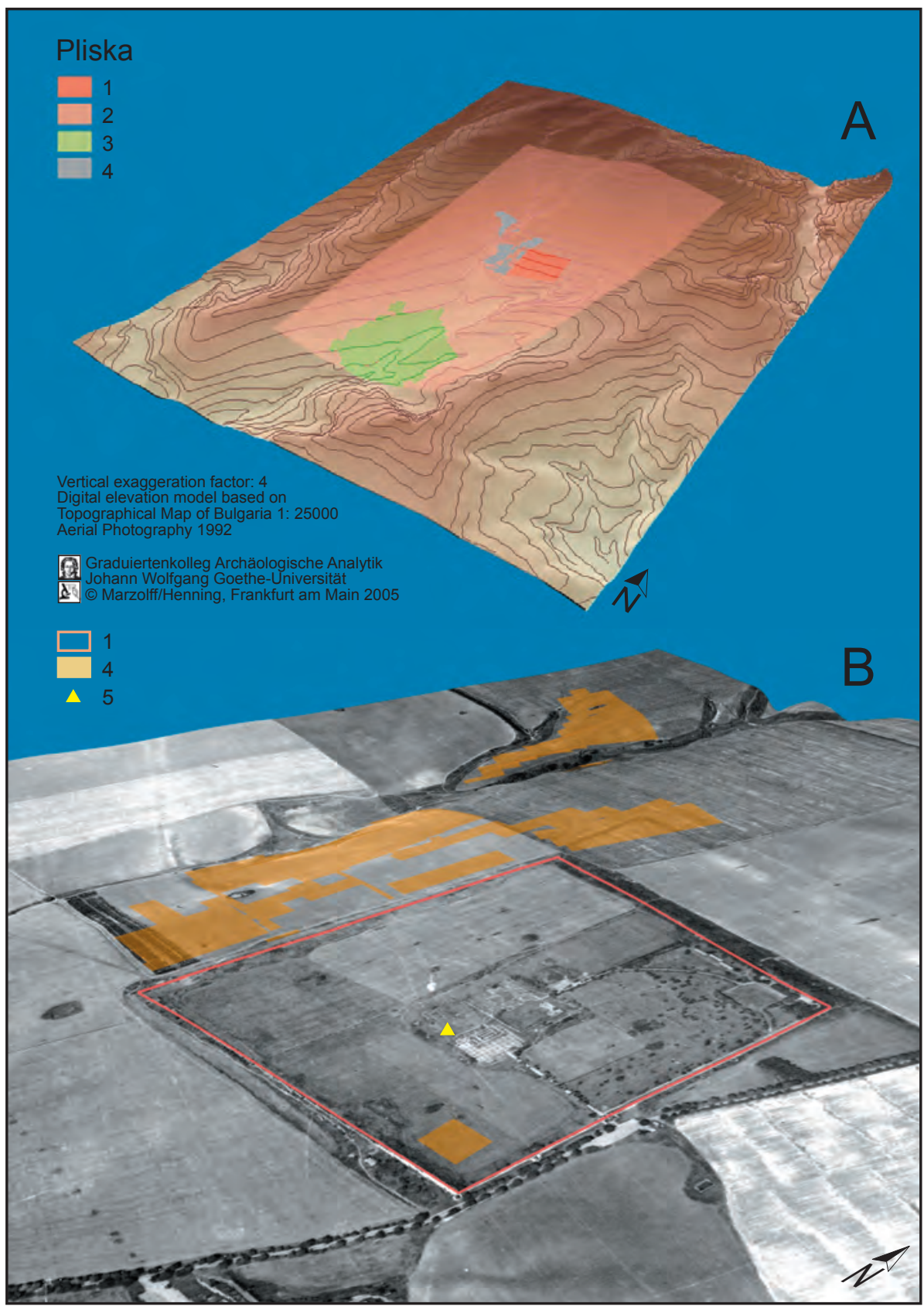

Topographic situation in 3D views with contour lines (A - total view) and with aerial photo overlay (B - core area); key: 1 - Inner Town, 2 - Outer Town, 3 - present-day town named Pliska, 4 - geomagnetic survey area, 5 - geoelectrics (section 21) 


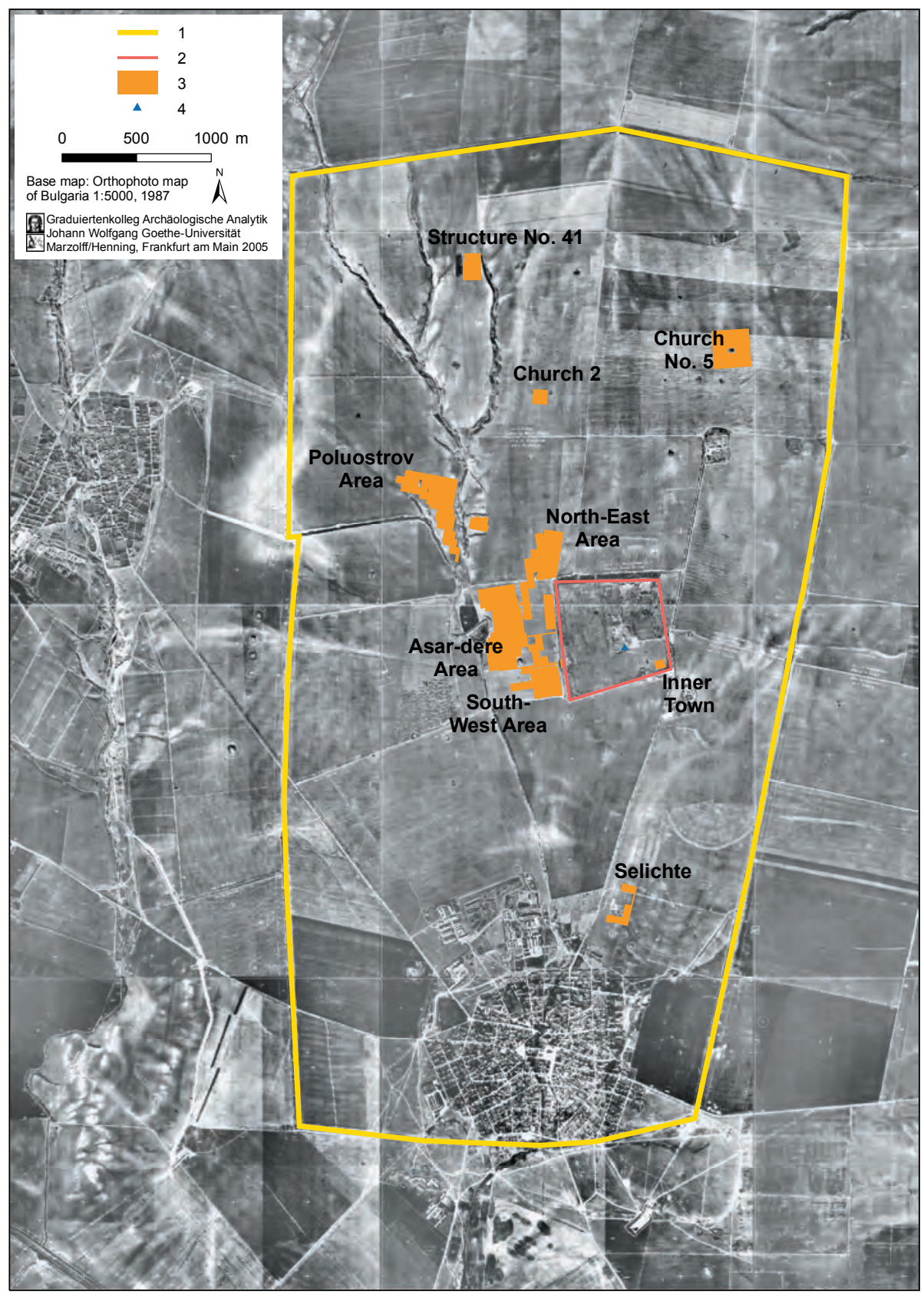

Orthophoto map of Pliska with survey areas of the German-Bulgarian expedition (1997-2001); key: 1 - earthen rampart-ditch fortification (Outer Town), 2 - stone fortification wall (Inner Town), 3 - geomagnetics, 4 - geoelectrics (secret passage of the "Krum Palace") 


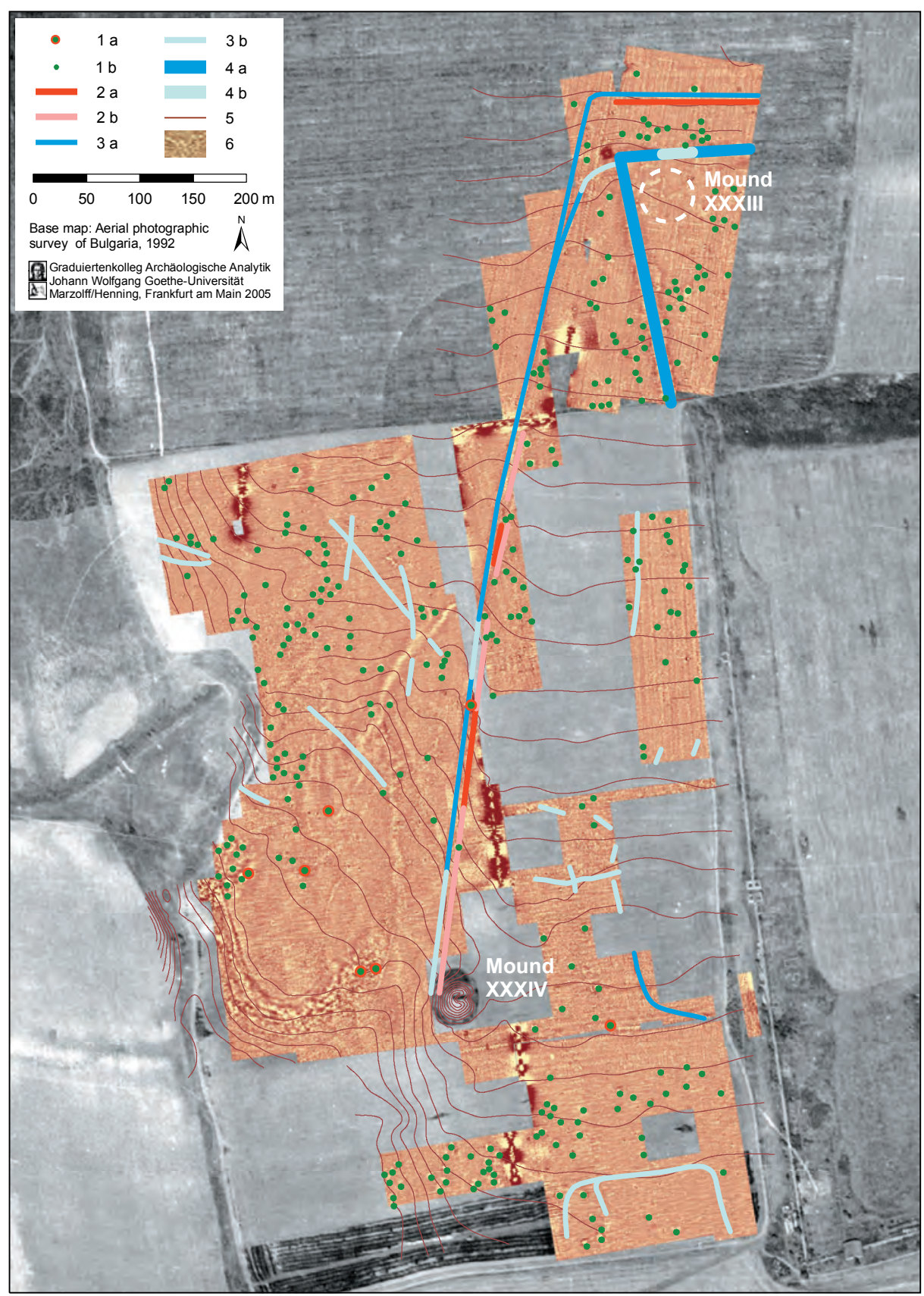

Pliska. Investigation area (1997-2001) west of Pliska's Inner Town; key: 1 - grubenhaus, 2 - rampart/fortification wall, 3 - ditch, 4 - broad ditch, a - confirmed, b - expected, 5 - contour lines $(0.5 \mathrm{~m}), 6$ - geomagnetics 


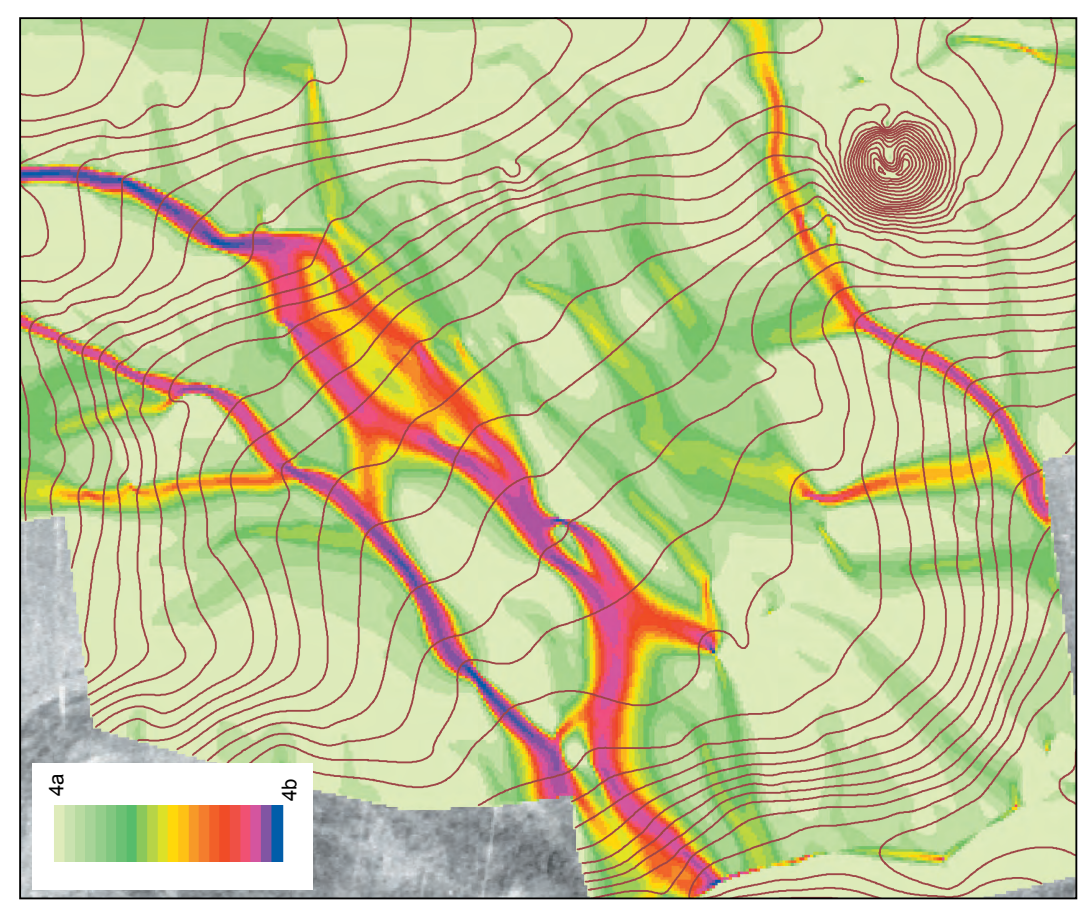

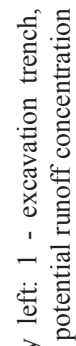

츤

离

घ

胥

象

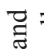

\&

过

ㄴ.

홍

焉

矛

肴 范

픙

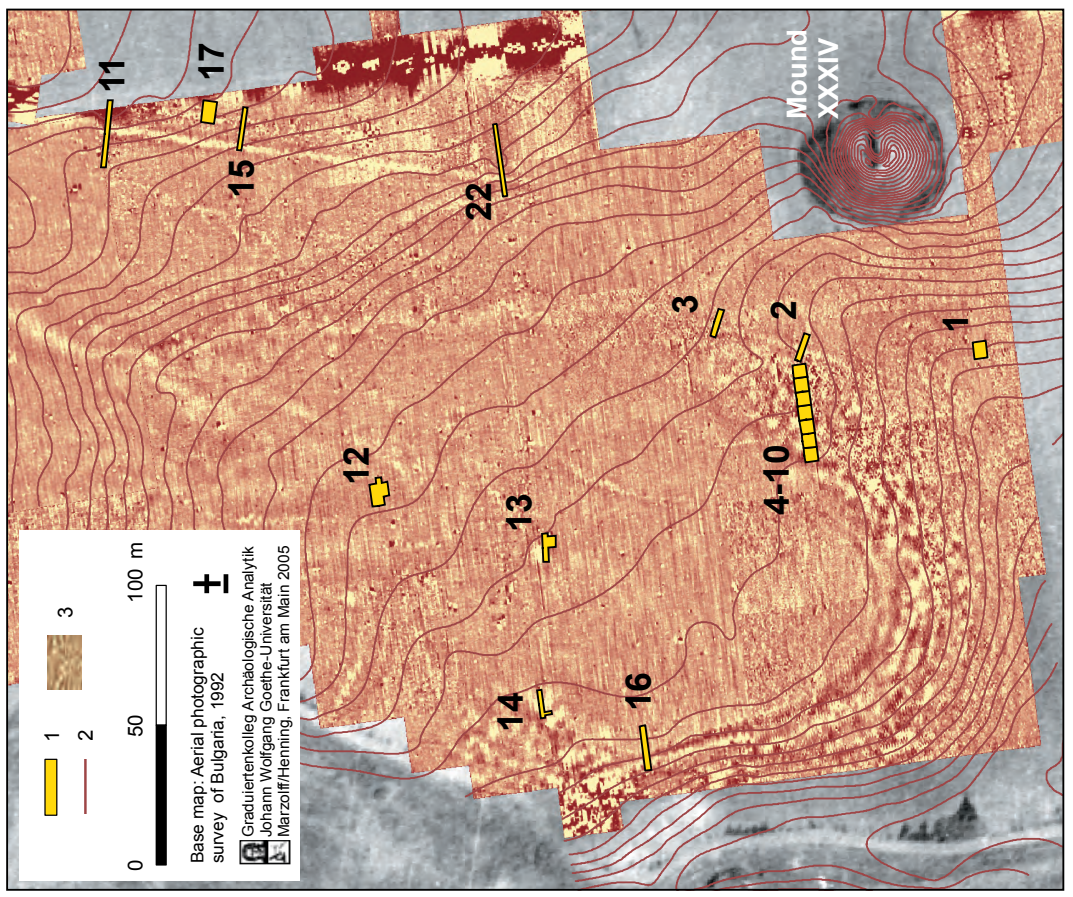

응 है

讯 :

흘 크

ฉิ

沓

苟

. ․ㅡㄹ

矛

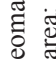

on $>$

ह

$\circ$

可

政

n

牙

a

फ

屯े

3

Ð

흔

竞 


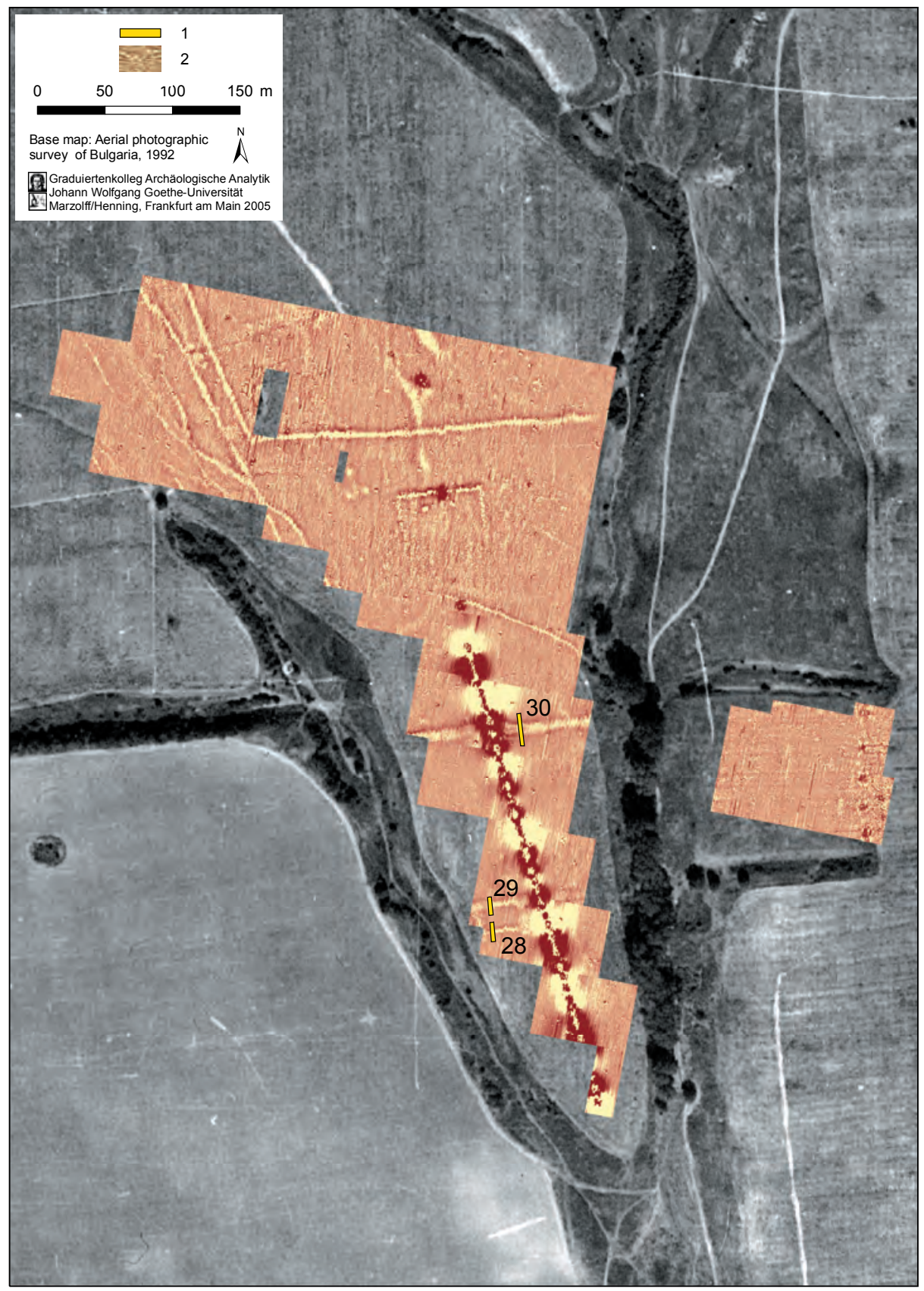

Pliska. Investigation of the Poluostrov area in the Outer Town territory (2001); key: 1 - archaeological excavation trench, 2 - geomagnetics 


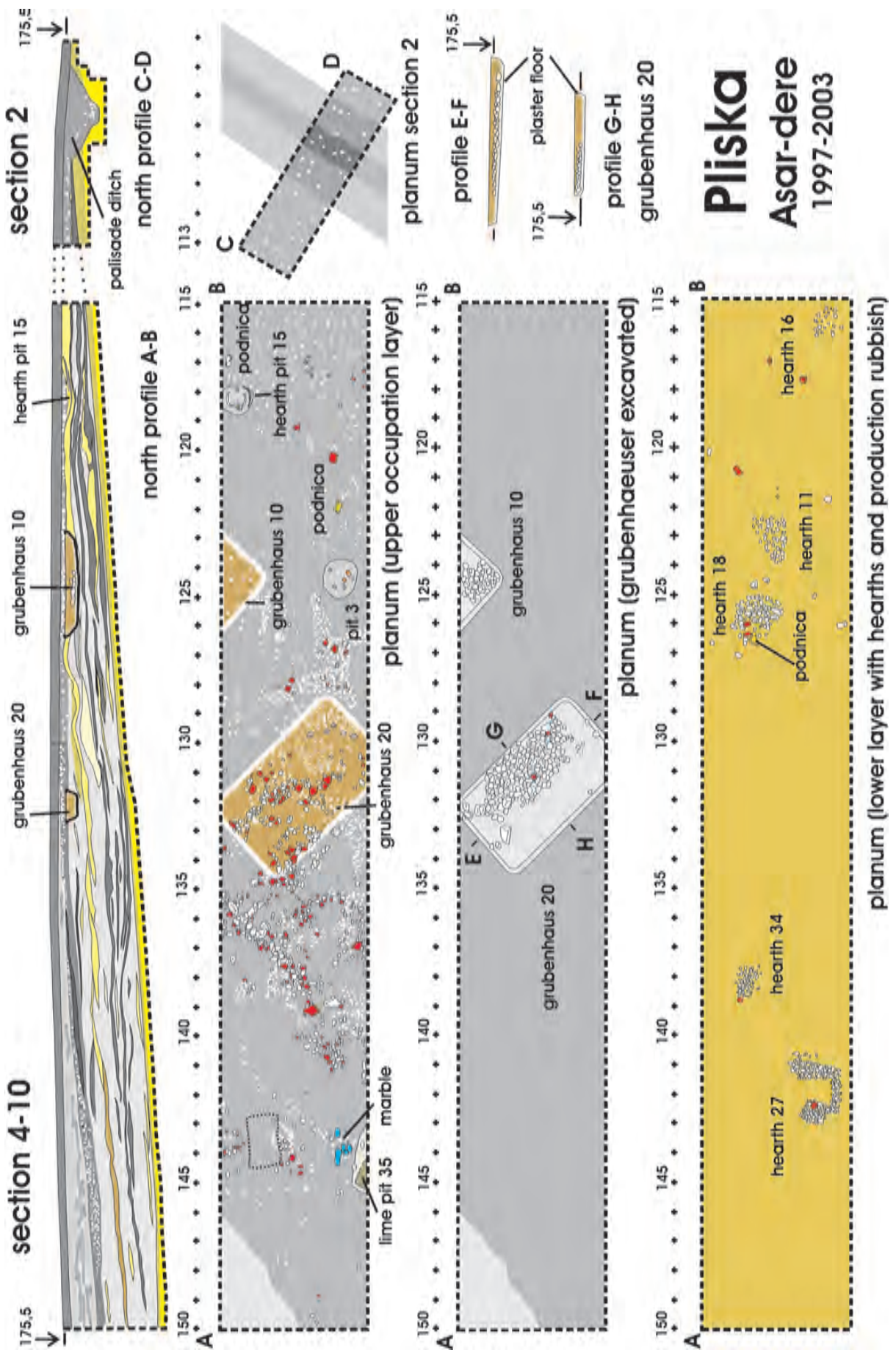




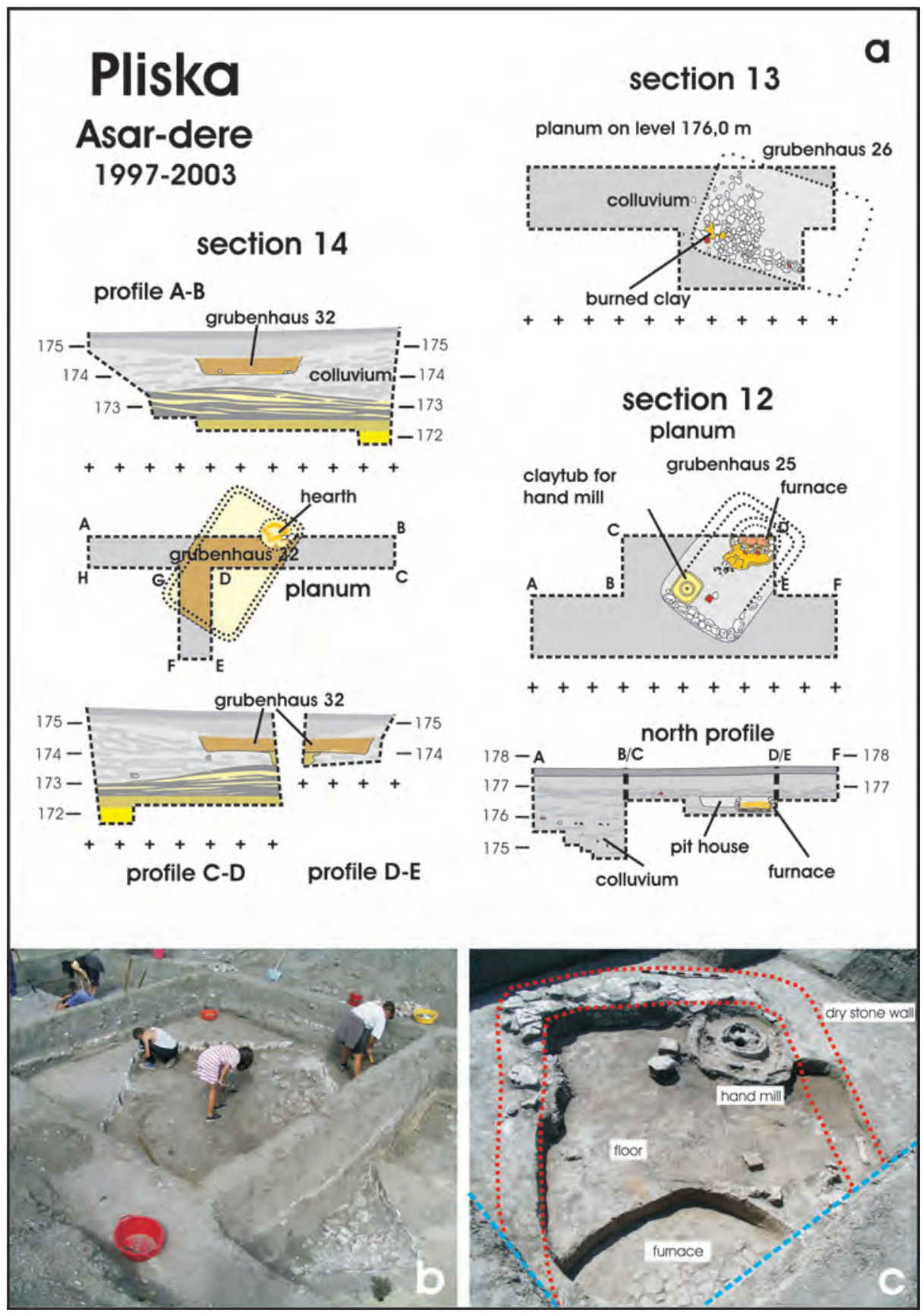

Grubenhaus situations in the Asar-dere area: a - grubenhäuser No. 25, 26, 32; b - grubenhaus No. 20; c - grubenhaus No. 25 


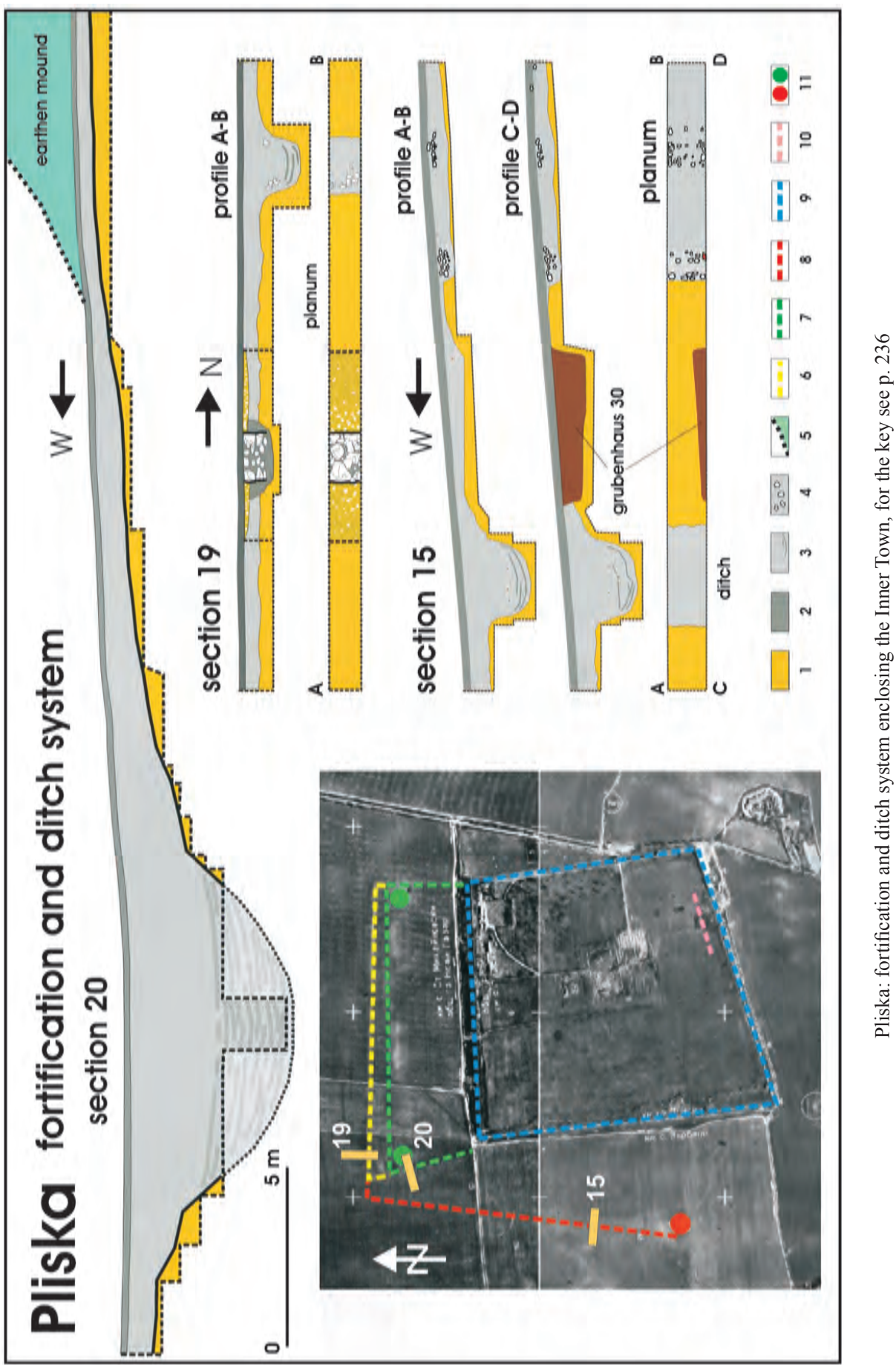




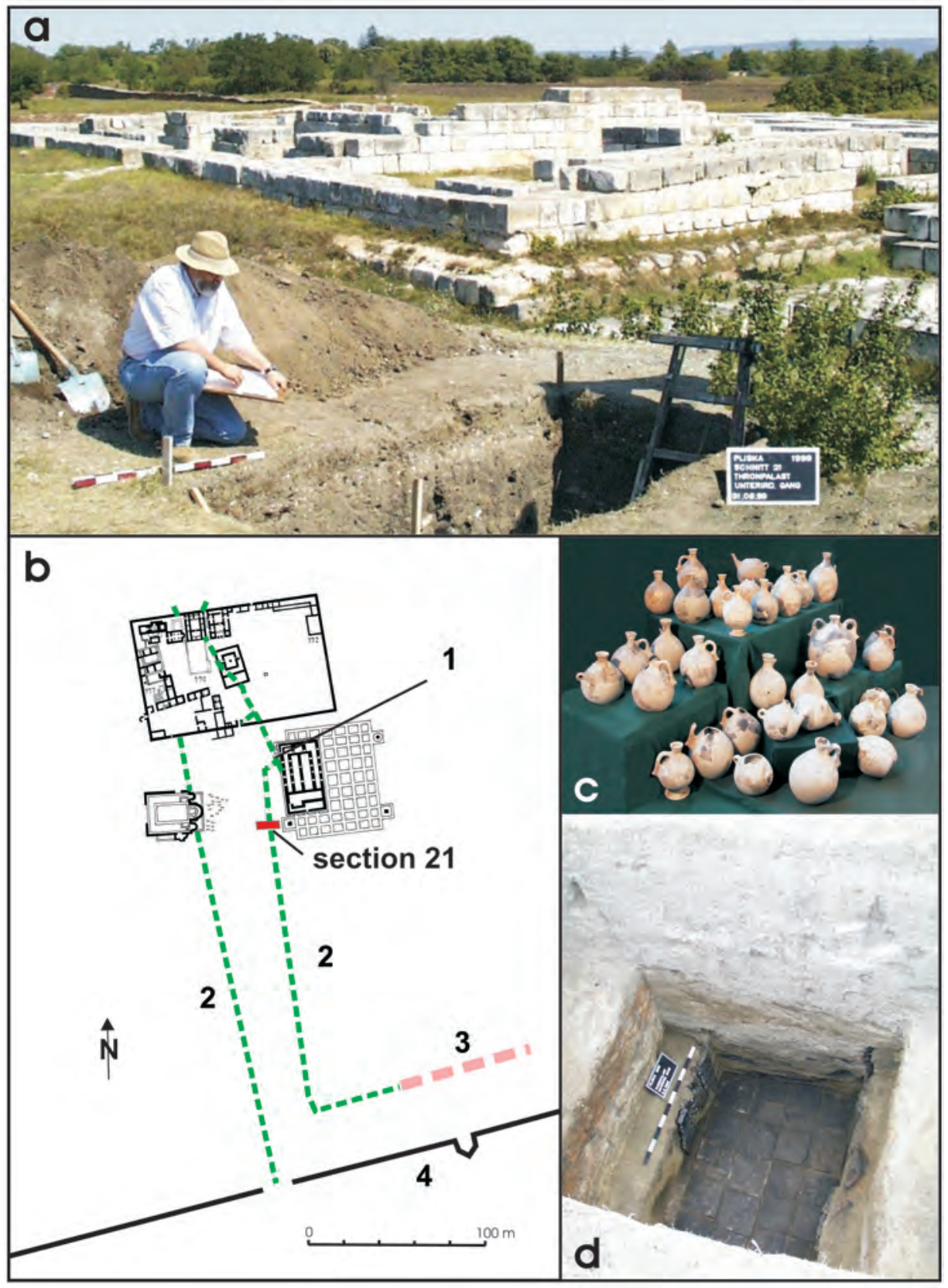

a - excavation of one of the secret passages in the Inner town of Pliska, 1999, section 21; b - the passage (2) connects the "Krum palace" (1) and the earth-and-stone fortification (3) uncovered by S. Pletneva; c - set of vessels of the yellow pottery type found in the secret passage (excavation R. Rašev); $d$ - brick pavement and burnt timber constructions in the secret passage 


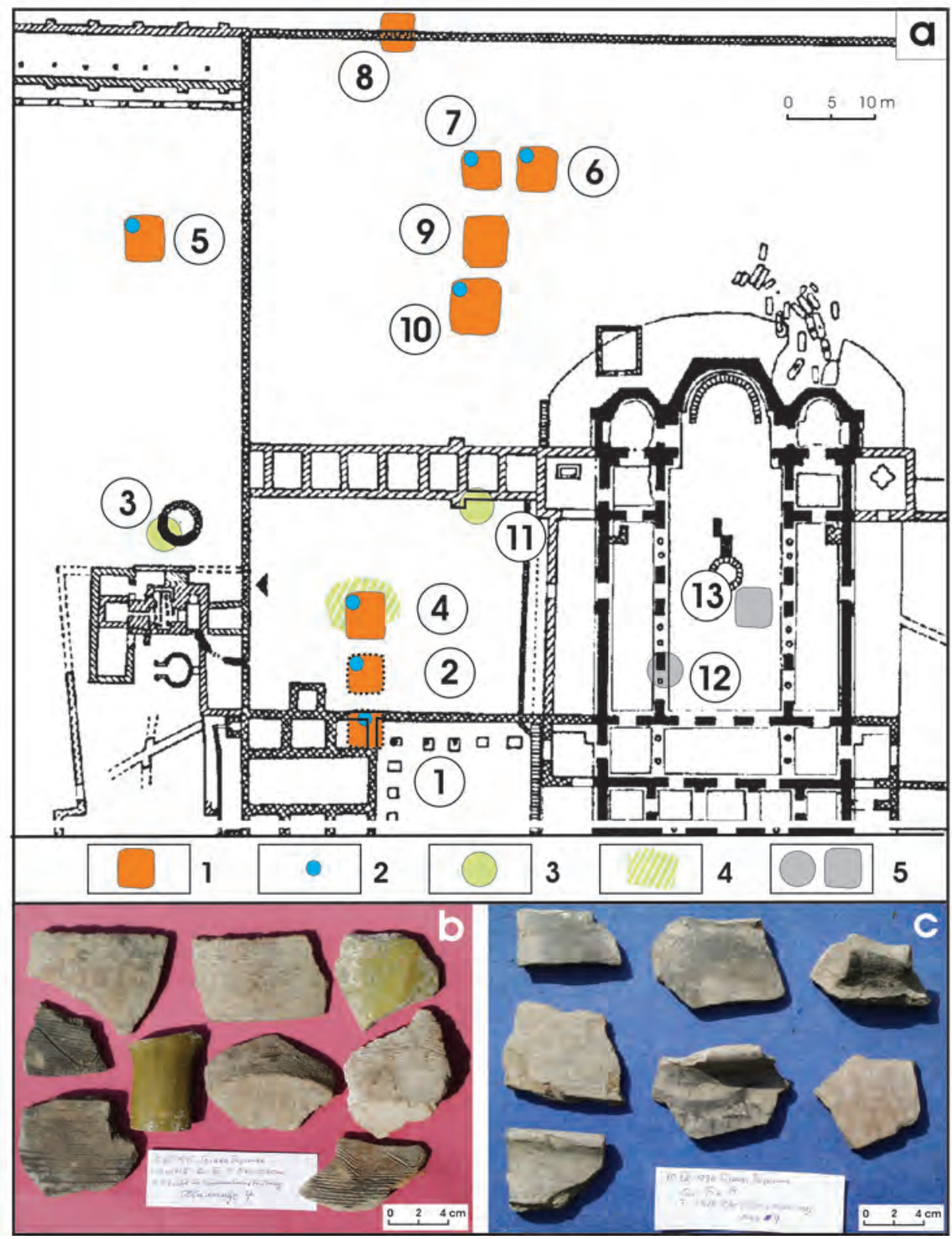

a - area of the Great Basilica with excavated settlement features (numbering in circles); key: Grubenhäuser (1) with ovens (2) and detected flat settlement features (3) and contemporaneous occupation layers (4); ambiguous structures (5); b - glazed and non-glazed ceramics (between late ninth and eleventh century) found on the floor of grubenhaus No. 4 (excavated by the author in 1977); c - earlier variations of ceramics with a high component of grey ware (eighth-early ninth century) associated with flat settlement structures and similar rests of occupation layers that were later cut by grubenhäuser 


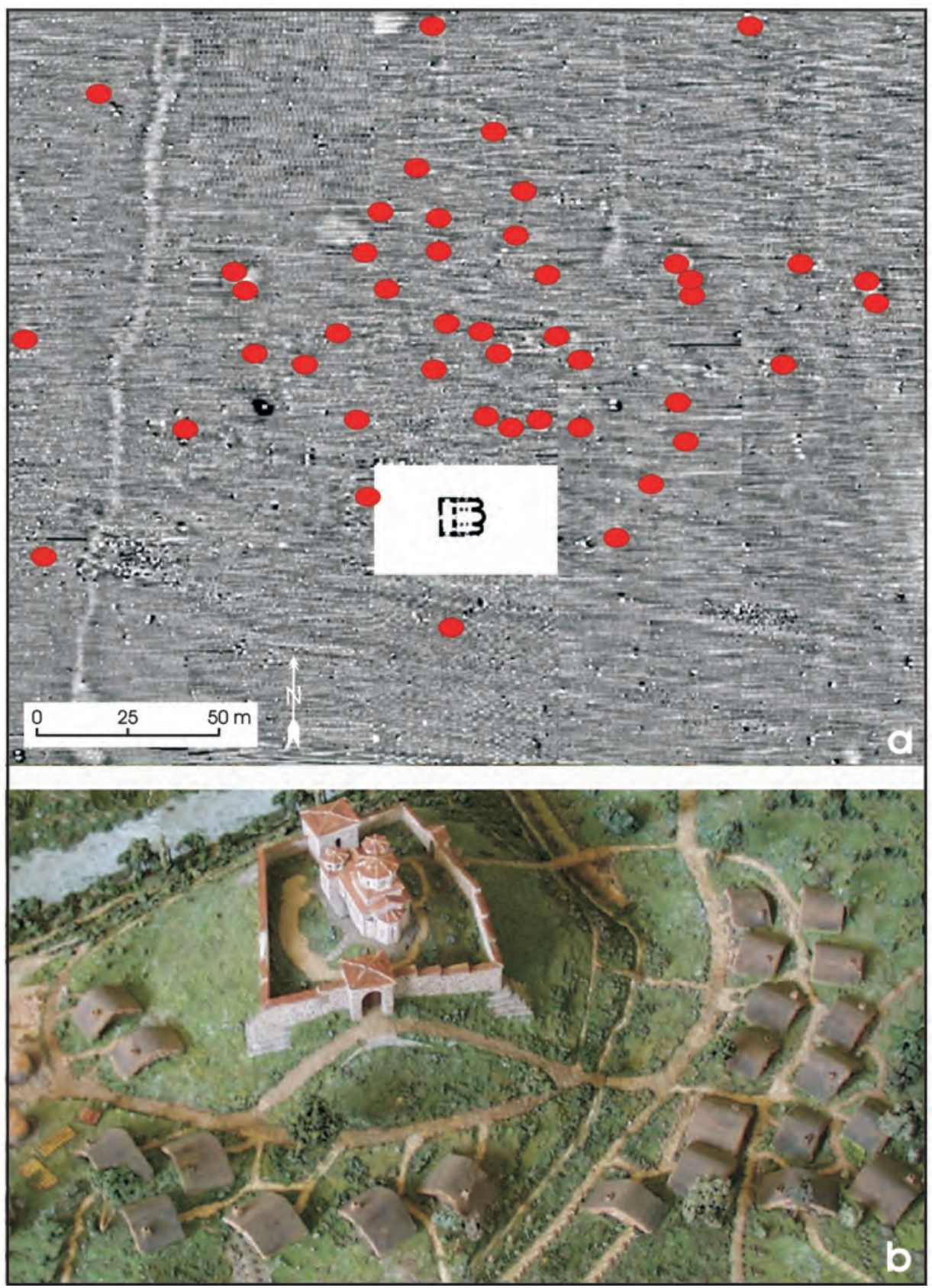

a - geophysical mapping of an area around the church No. 5. The marked in red anomalies indicate the positions of sunken structures, most probably grubenhäuser; $b$ - reconstruction of a similar situation with grubenhäuser around the fourteenth century church of Vinitsa (excavation: T. Totev) 


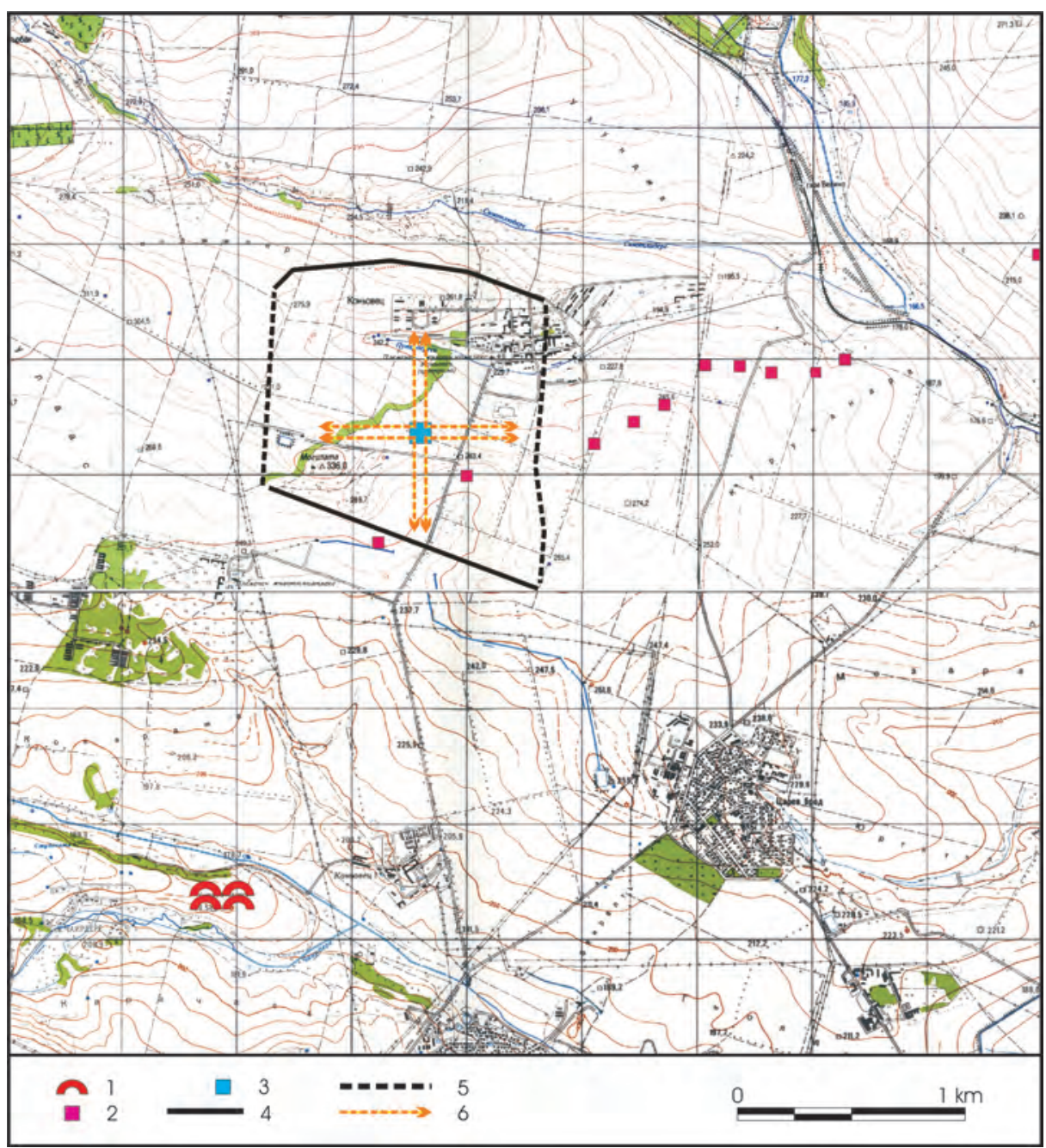

Early medieval fortification of Kabiyuk, North Bulgaria. Topographic situation; key: 1 - burial mound, 2 - assemblies of standing stones (Devtašlari), 3 - area of geomagnetic prospecting, 4 - well-preserved rampart line, 5 - badly preserved rampart line, 6 - alignment of detected building structures 


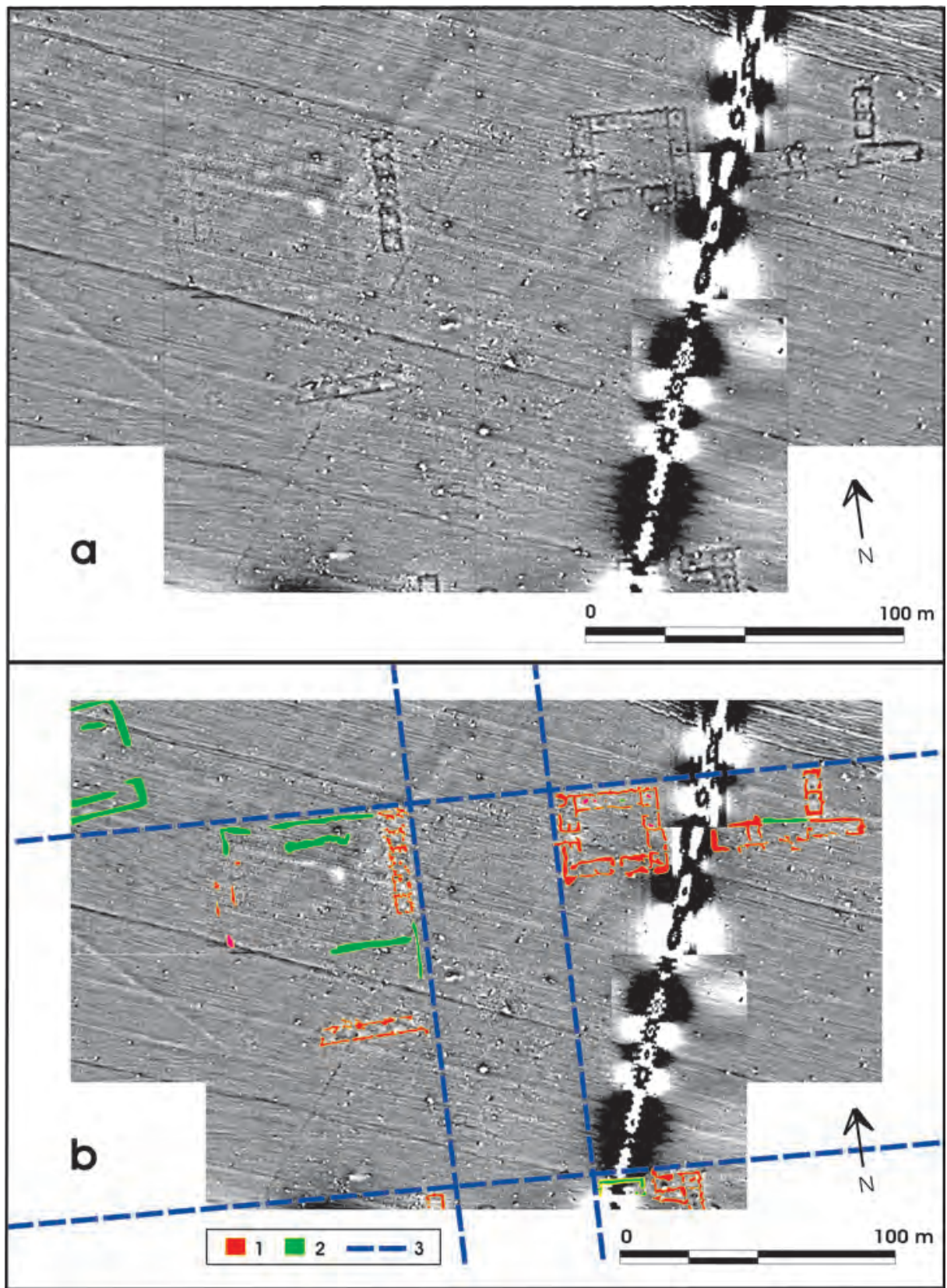

Kabiyuk. Geomagnetic prospecting 2003; a - mapping of magnetometer survey results with three-channel fuxgate gradiometer Foerster Ferex 4.032, dynamism of measured values: $-5 /+5 \mathrm{nT}$ in 256 degree grayscale (black-and-white, linear), sensitivity: $0.1 \mathrm{nT}$, grid: $0.25 / 0.50 \mathrm{~m}$; b - interpretation of the measurement results; key: 1 - clearly recognizable features, 2 - vague features, 3 - alignment of detected building structures 


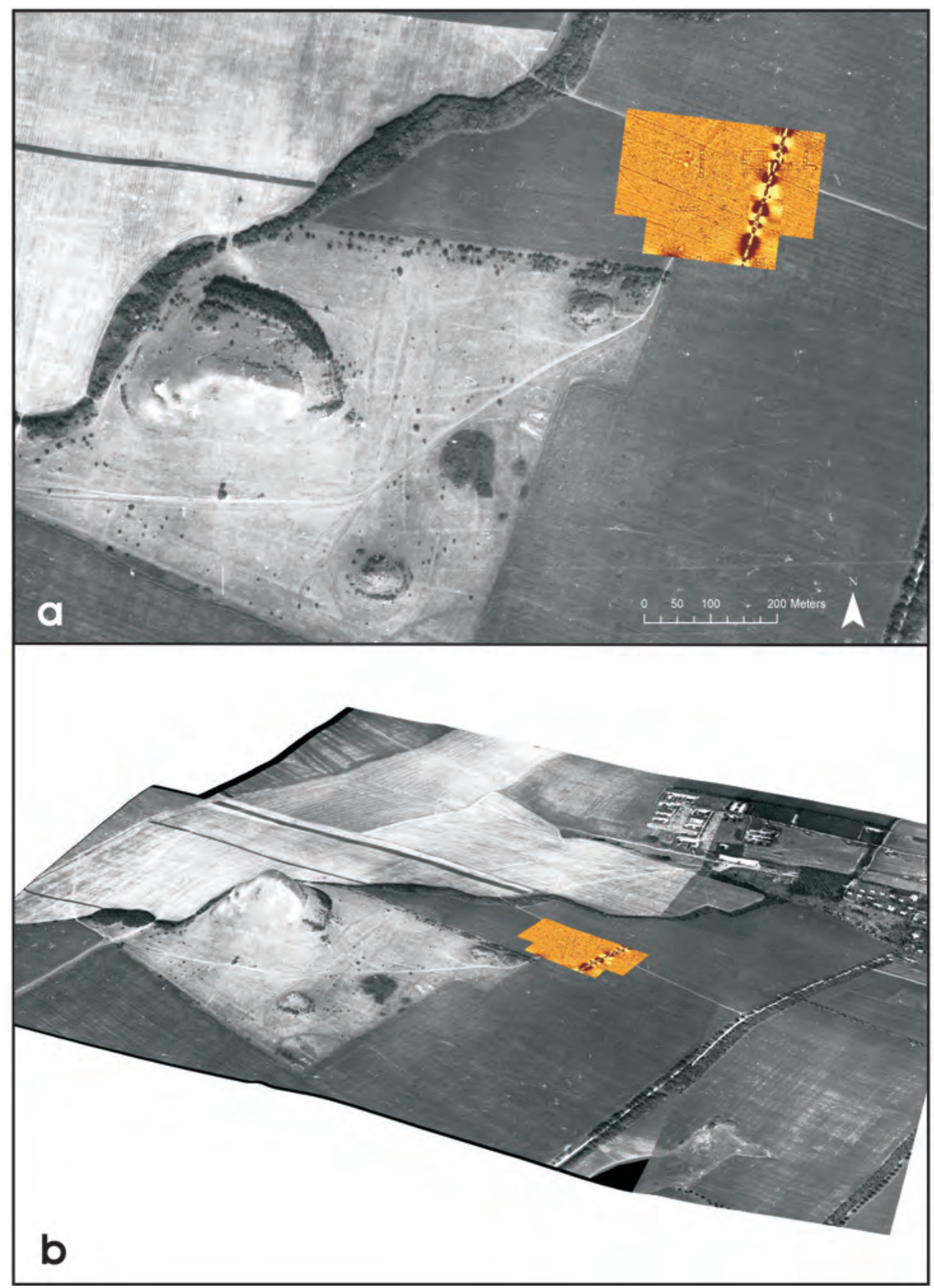

Kabiyuk. Geomagnetic measurement area and the surrounding topographic situation; a - orthogonal aerial photo; $b$ - 3D view with aerial photo overlay, triple vertical exaggeration. Data basis: Topographic map with contour lines 1:5000 and orthogonal aerial photo 


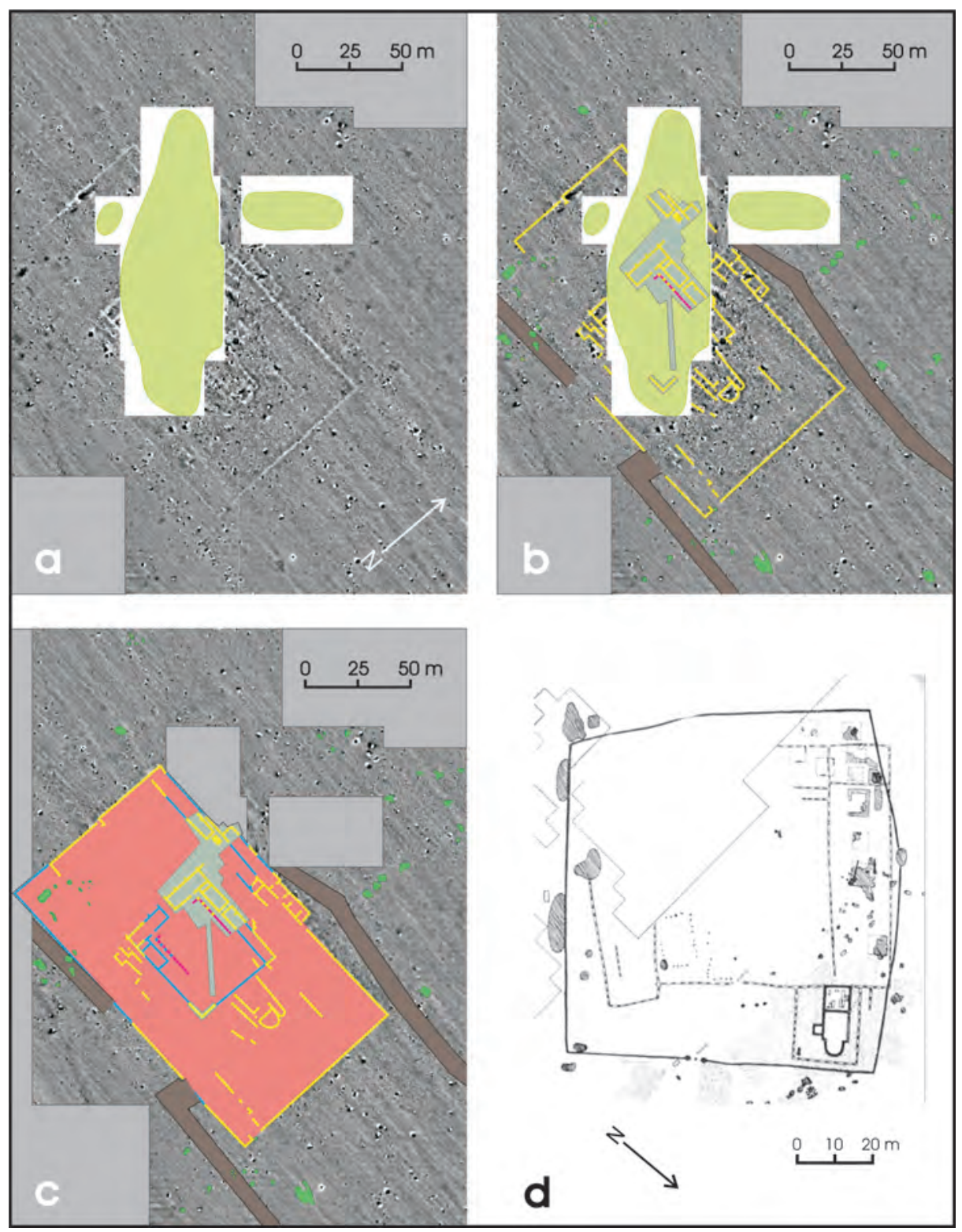

Early medieval building compound at the Strumba locality near Shumen, North Bulgaria, German-Bulgarian investigations 2002; a - geomagnetic prospecting: light green - areas in parts excavated or covered with spoil material; $b$ - building structures excavated by Pavlina Petrova (yellow on gray areas): red line - colonnade of the interior courtyard quadrangle. Interpreting geomagnetic anomalies: yellow - detected stone walls, green - sunken features (probably grubenhäuser), brown - probable access paths; c - reconstruction of the building compound's ground plan: blue - interpolated stone walls; d - the so-called Great Moravian "curtis" or noble courtyard of Břeclav-Pohansko, Czechia, ninth century 


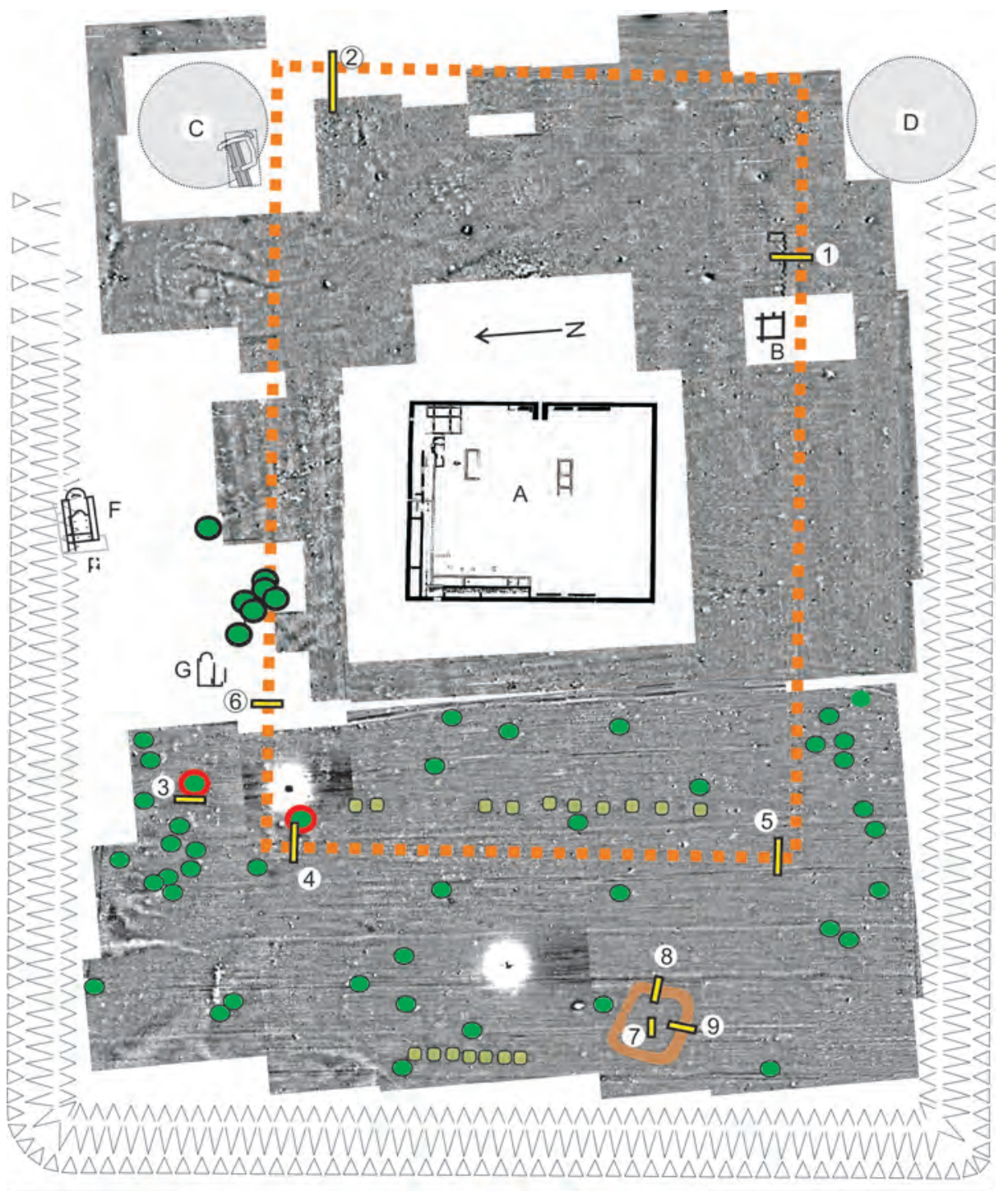

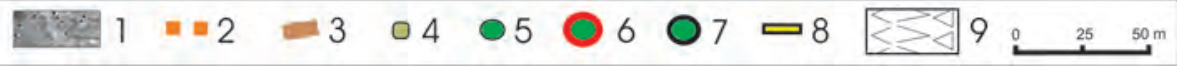

Palace camp (aule) of khan Omurtag near Tsar Krum village (Shumen district): German-Bulgarian investigations 2002-2003; key: A - inner stone wall enclosure (ninth century), B - stone building; C - northern mound (excavation trench: T. Balabanov), D - southern mound, F - early Byzantine basilica, G - early medieval church (A, B, F, G excavation areas of Zv. Dremsizova \& V. Antonova); key: 1 - geomagnetic prospecting area, 2 - double palisade enclosure (discovered by geomagnetics and confirmed archaeologically 2002-2003), 3 - rectangular ditch structure, 4 - geomagnetic anomalies (row structures), 5 - grubenhaus expected (geomagnetics), 6 - grubenhaus excavated in 2003, 7 - grubenhaus excavated by Zv. Dremsizova \& V. Antonova,

8 - excavation trenches No. 1-9 (2002-2003), 9 - outer rampart and ditch fortification 